\title{
Towards the Origin of Microblade Technology in Northeastern Asia
}

\author{
S. G. Keates, A. V. Postnov, Y. V. Kuzmin
}

For citation: Keates S. G., Postnov A. V., Kuzmin Y. V. Towards the Origin of Microblade Technology in Northeastern Asia. Vestnik of Saint Petersburg University. History, 2019, vol. 64, iss. 2, pp. 390-414. https://doi.org/10.21638/11701/spbu02.2019.203

Microblade technology is one of the most remarkable phenomena in the Upper Paleolithic of northern Eurasia, primarily the northern and eastern regions of Asia. Here we present an overview of the most recent developments in attempting to understand the emergence and spread of this technology, based on data known for Siberia and the Russian Far East, Mongolia, China, Korea, and Japan. The main assumptions for selection of the earliest microblade

Susan G. Keates - D. Philos. in Archaeology, Professor, Center for East Asian Prehistory, Heinrichstraße 74, Düsseldorf, 40239, Germany; anthres15@yahoo.com

Сюзан Г. Китс - д-р филос., проф., Центр изучения древней истории Восточной Азии, ФРГ, 40239, Дюссельдорф, Генрихштрассе, 74; anthres15@yahoo.com

Aleksander V. Postnov - PhD in History, Senior Researcher, Institute of Archaeology \& Ethnography, Siberian Branch of the Russian Academy of Sciences, Lavrentiev Ave. 17, Novosibirsk 630090, Russian Federation; postnov@yandex.ru

Александр Вадимович Постнов - канд. ист. наук, ст. науч. сотр., Институт археологии и этнографии Сибирского отделения Российской Академии наук, Российская Федерация, 630090, Новосибирск, пр. Лаврентьева, 17; postnov@yandex.ru

Yaroslav V. Kuzmin - Doctor in Geography, Leading Researcher, Sobolev Institute of Geology \& Mineralogy, Siberian Branch of the Russian Academy of Sciences, Koptyug Ave. 3, Novosibirsk 630090, Russian Federation; Leading Researcher, Laboratory of Mesozoic and Cenozoic Continental Ecosystems, Tomsk State University, Lenin St. 36, Tomsk 634050, Russian Federation; kuzmin@fulbrightmail.org

Ярослав Всеволодович Кузьмин - д-р геогр. наук, вед. науч. сотр., Институт геологии и минералогии Сибирского отделения Российской Академии наук, Российская Федерация, 630090, Новосибирск, пр. Коптюга, 3; вед. науч. сотр., Лаборатория континентальных экосистем мезозоя и кайнозоя, Томский государственный университет, Российская Федерация, 634050, Томск, пр. Ленина, 36; kuzmin@fulbrightmail.org

The article was prepared with the support of Tomsk State University grant program; State assignment number 0330-2016-2018; the Russian Science Foundation (RNF), grant number 14-50-00036.

Статья подготовлена при поддержке грантами Программы повышения конкурентоспособности Томского государственного университета; Государственного задания № 0330-2016-2018; Российского научного фонда (РНФ), грант № 14-50-00036.

We are grateful to Drs. V. N. Zenin, G.-K. Lee, E. P. Rybin, M. Yi, T. Tsutsumi, S. A. Gladyshev, E. V. Akimova, and I. I. Razgildeeva, and Mr. A. D. Stepanov for providing additional information on the earliest microblade complexes in northern and eastern Asia, and for discussion of the relevant issues. We also thank Dr. Vladimir V. Pitulko for the invitation to participate in this Special Issue.

Мы благодарны В. Н. Зенину, Г. К. Ли, Е. П. Рыбину, М.Йи, Т. Цуцуми, С. А. Гладышеву, Е. В. Акимовой, И.И. Разгильдеевой и А.Д. Степанову за предоставление дополнительной информации о самых ранних микроблезовых комплексах в Северной и Восточной Азии, а также за обсуждение актуальных вопросов. Мы также благодарим В.В.Питулько за приглашение принять участие в этом специальном выпуске.

() Санкт-Петербургский государственный университет, 2019 
complexes are: 1) the presence of three artifact types: wedge-shaped microcores; microblades; and retouched (utilized) microblades; 2) a reliable chronology based on critical evaluation of radiocarbon dates; and 3) the stratigraphic integrity of artifacts. The pressure flaking was a technique to make microblades, and this is important issue which was often not taken into account previously. Based on these criteria, the oldest microblade-bearing complexes for each of the regions listed above were selected. Using these data, we can conclude that the earliest evidence of microblade technology is known from the Korean Peninsula where it is dated to ca. 25,500-24,200 BP. In other regions (China, Siberia, Russian Far East and Japan), the first microblade assemblages are dated to ca. 21,100-19,400 BP. As a result of our analysis, two possible explanations for the emergence of microblade technology in northern and eastern Asia can be considered: 1) invention and diffusion from a single core area; and 2) independent creation in several places and subsequent expansion. Currently, we cannot solve this issue, but generate some suggestions which may bring us closer toward identifying its origin and spread. Factual data as presented in this paper can be used as a primary source for future research.

Keywords: Upper Paleolithic, microblade technology, lithic analysis, chronology, spatiotemporal patterns, Asia.

\section{К происхождению микропластинчатой технологии в Северо-Восточной Азии}

\section{С.Г.Китс, А. В.Постнов, Я. В. Кузвмин}

Для цитирования: Keates S. G., Postnov A. V., Kuzmin Y. V. Towards the Origin of Microblade Technology in Northeastern Asia // Вестник Санкт-Петербургского университета. История. 2019. T.64. Вып. 2. С. 390-414. https://doi.org/10.21638/11701/spbu02.2019.203

Микропластинчатая технология является одним из самых выразительных явлений в верхнем палеолите Северной Евразии, в основном в северных и восточных регионах Азии. В работе представлен обзор новейшей информации для попытки понять появление и распространение этой технологии с опорой на данные по Сибири и Дальнему Востоку России, Монголии, Китаю, Корее и Японии. Основными критериями для выбора самых ранних микропластинчатых комплексов являются: 1) присутствие трех типов артефактов: клиновидных микронуклеусов, микропластин и ретушированных (утилизованных) микропластин; 2) надежная хронология, основанная на критической оценке радиоуглеродных дат; 3) стратиграфическая целостность комплексов артефактов. На этих основаниях выбраны самые древние комплексы с микропластинами для каждого из перечисленных регионов. Анализ данных позволяет заключить, что самое раннее свидетельство микропластинчатой технологии известно на Корейском полуострове, где оно датировано около 25 500-24 200 радиоуглеродных лет назад (л. н.). В других регионах (Китай, Сибирь, Дальний Восток России и Япония) первые микропластинчатые комплексы датируются около 21 100-19 400 л. н. В результате можно рассматривать два допустимых объяснения появления микропластинчатой технологии в Северной и Восточной Азии: 1) изобретение и проникновение из единственного очага; 2) независимое появление в нескольких местах и последующее распространение. В настоящее время данная проблема неразрешима, однако могут быть предложены некоторые соображения, приближающие к пониманию особенностей культурного развития региона, причин появления и распространения микропластинчатой технологии. Фактические данные, собранные в работе, представляют собой основу для последующих исследований в этом направлении.

Ключевые слова: верхний палеолит, микропластинчатая технология, анализ каменного материала, хронология, пространственно-временно́й анализ, Северо-Восточная Азия. 


\section{Introduction}

The origin of the Upper Paleolithic in Eurasia is among the most important issues in Old World prehistory ${ }^{1}$. As a part of Upper Paleolithic studies, microblade technology is one of the most remarkable phenomena ${ }^{2}$, the origin of which is still not well known ${ }^{3}$. Recent discoveries of Upper Paleolithic sites and excavations in Siberia and East Asia ${ }^{4}$ show a more complex picture of the development of lithic technology compared to what was known 20 years ago.

Several volumes have appeared in the last 25 years regarding the emergence and diffusion of microblade technology in northern Eurasia ${ }^{5}$. The latest developments and new data call for an evaluation of the existing evidence on the origin and expansion of microblade technology in the northeast Asian region (Fig. 1). We argue that only the combined presence of microblade cores, microblades, and backed microblades in an assemblage represents confirmation for intentional microblade manufacture. We take into account the most recent research results from the northern and eastern parts of Asia, and also consider the current status of the identification of pressure flaking, an essential technique in the manufacture of microblades ${ }^{6}$.

The aim of this paper is to present a critical analysis of the earliest microblade complexes in Siberia and the Russian Far East (both in Russia), Mongolia, China, Korea, and Japan (Fig. 1) in the context of the spatiotemporal patterns of the origin and spread of this technology in the northern and eastern regions of Asia.

\section{Material and Methods}

\subsection{Main assumptions}

In this study, we suggest that microblade technology in northern and eastern Asia emerged from the use of flat-faced core technology. An important component of this technology was the application of pressure flaking to produce microblades. At some Upper Paleolithic sites in Siberia tortsovy (narrow-faced) cores for making small irregular bladelets appear to be preforms (i.e., background) for the development of the wedge-

1 The early Upper Paleolithic beyond Western Europe / eds P. J. Brantingham, S. L. Kuhn, K. W. Kerry. Berkeley; Los Angeles, 2004. P. 1-15.

2 Origin and spread of microblade technology in Northern Asia and North America / eds Y. V. Kuzmin, S. G. Keates, C. Shen. Burnaby, 2007. P. 1-24.

${ }^{3}$ Inizan M.-L. Pressure débitage in the Old World: Forerunners, researchers, geopolitics - handing on the baton // The emergence of pressure blade making / ed. by P.M.Desrosiers. New York, 2012. P.1115; Gómez Coutouly Y. A. The emergence of pressure knapping microblade technology in Northeast Asia // Radiocarbon. 2018. Vol.60, iss. 3. P. 821-824.

${ }^{4}$ Emergence and diversity of modern human behavior in Paleolithic Asia / eds Y. Kaifu, M. Izuho, T. Goebel, H. Sato, A. Ono. College Station TX, 2015. P. 1-16.

5 The origin and dispersal of microblade industry in Northern Eurasia / ed. by Kimura H. Sapporo, 1993. P.1-45; Origin and spread of microblade technology in Northern Asia and North America; The emergence of pressure blade making / ed. by P. M. Desrosiers. New York, 2012. P. 1-65.

6 Takakura J. Emergence and development of the pressure microblade production: a view from the Upper Paleolithic of northern Japan // The emergence of pressure blade making / ed. by P.M. Desrosiers. New York, 2012. P.285-290; Gómez Coutouly Y.A. The emergence of pressure knapping microblade technology in Northeast Asia // Radiocarbon. 2018. Vol.60, iss. 3. P. 821-824. 


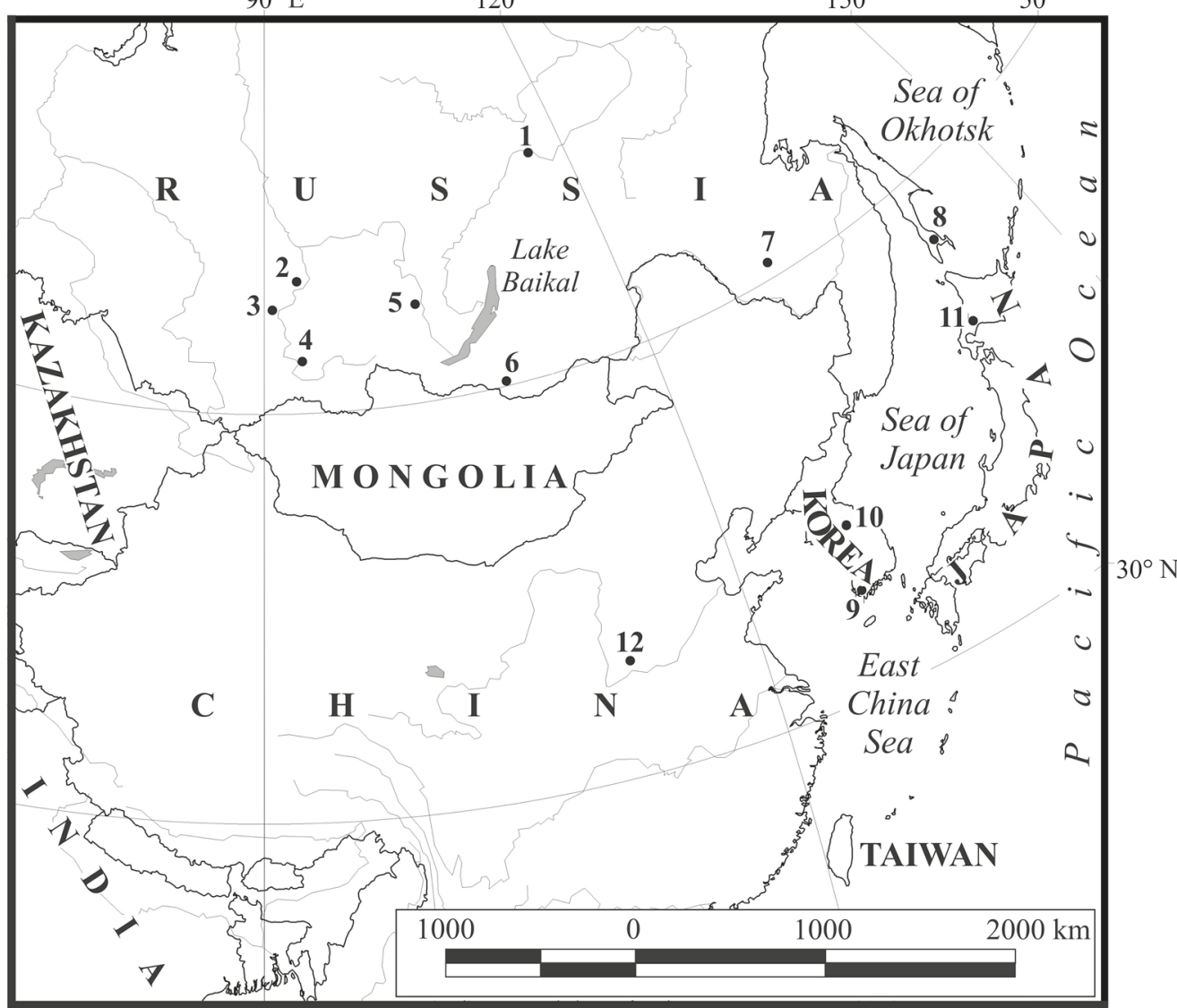

Fig. 1. The position of early microblade sites mentioned in the text (see also Table 1).

1 - Khayrgas; 2 - Listvenka; 3 - Tarachikha; 4 - Maininskaya; 5 - Krasny Yar; 6 - Studenoe 2; 7 - Ust'-Ul'ma 1; 8 - Ogonki 5; 9 - Sinbuk; 10 - Jangheung-ri; 11 - Kashiwadai 1; 12 Xiachuan (created by authors)

shaped core technique ${ }^{7}$. The narrow-faced core is a core worked on its narrow side; it has also been described as an edge-faceted or end core ${ }^{8}$. It is crucial to understand that the narrow-faced core must have a volumetric appearance in order to allow the production of multiple blades from the same narrow front (face). In this case, numerous blades can be detached, by either percussion (narrow-faced core sensu stricto) or pressure flaking (microblade core). The former core type emerged in the Initial Upper Paleolithic in northern Asia at least at ca. 43,000 radiocarbon years ago (hereafter. - B. P.) ${ }^{9}$.

7 Abramova Z. A. Klinovidnye nukleusy v paleolite Severnoi Azii // Paleolit i neolit. Leningrad, 1986. P. 11-14.

8 Vasil'ev S. A., Bozinski G., Bredli B. A., Vishniatskii L. B., Giria E. V., Gribchenko Iu. N., Zheltova M. N., Tikhonov A.N. Chetyrekh"iazychnyi (russko-anglo-franko-nemetskii) slovar'-spravochnik po arkheologii paleolita. St. Petersburg, 2007. P. 156.

9 Rybin E.P. Middle and Upper Paleolithic interactions and the emergence of modern behavior in Southern Siberia and Mongolia // Emergence and diversity of modern human behavior in Paleolithic Asia. College Station, 2015. P. 470-475. 
According to the studies by M.-L. Inizan and coauthors ${ }^{10}$, a fine-grained stone is needed for the successful application of the pressure flaking technique, which is important for achieving the standardization of microblade manufacture. The "Very straight and regular parallel arrises" - and, one should add, the narrow scars found on microblades - identify cores worked by pressure from other nuclei ${ }^{11}$. Other distinguishing marks include, for example, edges and arrises that are parallel and usually straight on microblades ${ }^{12}$. The analysis of obsidian microblades identified fracture wings under the microscope that can differentiate between direct percussion and pressure percussion ${ }^{13}$. In this respect, when publishing microblade cores, it would be helpful if authors included clear, detailed photographs of areas that were pressure flaked.

In order to properly examine the earliest microblade complexes in northern and eastern Asia, we chose the following criteria. As the main criterion, and a novel approach, we used the presence of three artifact types: 1) wedge-shaped microcores (as the most common of microblade nuclei);2) microblades; and 3) retouched (utilized) microblades. A similar view was expressed earlier ${ }^{14}$. This can ensure that only those artifacts are recognized as microblades that were not made accidentally but intentionally, and were used as such. The existence of this trio represents solid evidence for microblade technology. This kind of caution is necessary because in the early Upper Paleolithic, percussion was employed to detach blades ${ }^{15}$. Thus, without microblade cores and evidence of microblades since ca. 40,000-45,000 BP many small blades (bladelets) and blade fragments were produced by use of percussion, and it would be a mistake to regard these small blades as indicators of microblade technology. The second criterion is the secure age determination based on critical analysis of radiocarbon $\left({ }^{14} \mathrm{C}\right)$ dates ${ }^{16}$. We refer to ${ }^{14} \mathrm{C}$-dated sites only because ${ }^{14} \mathrm{C}$ is the most reliable dating method for the time range under consideration. The third criterion is the stratigraphic integrity of artifacts. Only those assemblages found in an in situ context are taken into account here.

\subsection{Definition of microblade technology}

We use the following terms of microblade technology and its elements. A microblade generally refers to a small and narrow blade produced mostly from conical or wedgeshaped microcores ${ }^{17}$. B. Kipfer ${ }^{18}$ defines a microblade as "a small, narrow stone blade, ranging from less than 5 to $11 \mathrm{~mm}(0.1-0.4$ inches) wide and about $15-45 \mathrm{~mm}(0.6-$

10 Inizan M.-L., Roche H., Tixier J. Technology of knapped stone. Meudon, 1992. P. 1-32.

11 Ibid. P. 63.

12 Ibid. P. 63-64.

13 Takakura J. Emergence and development of the pressure microblade production: a view from the Upper Paleolithic of northern Japan. P. 285-291.

14 Abramova Z. A. Klinovidnye nukleusy v paleolite Severnoi Azii. P. 11-13.

15 Ibid. P. 11-14.

16 Kuzmin Y. V., Keates S. G.: 1) Dates are not just data: Paleolithic settlement patterns in Siberia derived from radiocarbon records // American Antiquity. 2005. Vol.70, iss.4. P.773-775; 2) Dynamics of Siberian Paleolithic complexes (based on analysis of radiocarbon records): the 2012 state-of-the-art // Radiocarbon. 2013. Vol. 55, iss. 2-3. P. 1314-1317.

17 Darvill T. The concise Oxford dictionary of archaeology. Oxford, 2003. P. 1-506; The new Penguin dictionary of archaeology / ed. by P. Bahn. London, 2004. P. 1-537.

18 Kipfer B. A. Dictionary of artifacts. Singapore, 2007. P. 195. 
1.7 inches) long". T. Akazawa and coauthors ${ }^{19}$ determine microblade dimensions as with a length more than twice the width, while the width is smaller than $12 \mathrm{~mm}$.

Some author ${ }^{20}$ also refer to microblades as "microbladelets" and "bladelets". However, unlike microblades, bladelets can be produced from any blade cores, including narrow-faced ones, while microblades were usually made on either wedge-shaped, prismatic, or conical cores by pressure flaking ${ }^{21}$. Here we distinguish also between microblades and microliths; the latter is a more general category determined as "any of various very small stone tools varying in size from 1 to $5 \mathrm{~cm}(0.4-2$ inches) - mainly thin blades or blade fragments with sharp cutting edges, usually geometric in shape... using the microburin technique"22. In China, microliths also include some small lithic artifacts ${ }^{23}$.

J. Flenniken ${ }^{24}$ established the use of the pressure blade technique for making microblades in the Dyuktai culture of Yakutia as part of greater northern Asia. It is now obvious that people who invented the microblade technology almost always employed pressure blade flaking ${ }^{25}$. While this technique (more strictly, pressure retouch ${ }^{26}$ ) had appeared a long time before microblade technology and was known in the Middle Stone Age of South Africa ${ }^{27}$, it was not in use in northern and eastern Asia until microblade production emerged there.

\section{Regional perspectives}

\subsection{Siberia}

The first summaries on microblade technology for Siberia were published in the $1980 \mathrm{~s}^{28}$. Z. A. Abramova established four stages of the Upper Paleolithic in Siberia; the distinct feature of stages 1 (end of Karginian interstage, corresponds to MIS 3 isotope

${ }_{19}$ Akazawa T., Oda S., Yamanaka I. The Japanese Palaeolithic: A techno-typological study. Tokyo, 1980. P.74.

${ }^{20}$ Akazawa T., Oda S., Yamanaka I. The Japanese Palaeolithic: A techno-typological study. P.74-75; Inizan M.-L., Roche H., Tixier J. Technology of knapped stone. P. 65; Vasilev S. A., Bosinski G., Bradley B. A., Vishniatskii L. B., Giria E. V., Gribchenko Iu. N., Zheltova M. N., Tikhonov A. N. Chetyrekh"iazychnyi (russkoanglo-franko-nemetskii) slovar'-spravochnik po arkheologii paleolita. P. 147.

${ }^{21}$ Morlan R.E. Wedge-shaped core technology in northern North America // Arctic Anthropology. 1970. Vol. 7, iss. 2. P. 17-20.

${ }^{22}$ Kipfer B. A. Dictionary of artifacts. P. 196; Inizan M.-L., Roche H., Tixier J. Technology of knapped stone. P. 69-70.

${ }^{23}$ Chen C., Wang X.-Q. Upper Paleolithic microblade industries in North China and their relationships with Northeast Asia and North America // Arctic Anthropology. 1989. Vol. 26, iss. 2. P. 128.

${ }^{24}$ Flenniken J. J. The Paleolithic Dyuktai pressure blade technique of Siberia // Arctic Anthropology. 1987. Vol.24, iss. 2. P. 117-120.

${ }^{25}$ Inizan M.-L. Pressure débitage in the Old World: Forerunners, researchers, geopolitics - handing on the baton. P.11-15; Takakura J. Emergence and development of the pressure microblade production: a view from the Upper Paleolithic of northern Japan. P.285-291; Gómez Coutouly Y.A. Migrations and interactions in prehistoric Beringia: the evolution of Yakutian lithic technology // Antiquity. 2016. Vol.90, iss. 349. P.9-15.

${ }^{26}$ Inizan M.-L. Pressure débitage in the Old World: Forerunners, researchers, geopolitics - handing on the baton. P.11-14.

${ }_{27}$ Mourre V., Villa P., Henshilwood C.S. Early use of pressure flaking on lithic artifacts at Blombos Cave, South Africa // Science. 2010. Vol.330, iss. 6004. P. 659-660.

${ }_{28}$ Abramova Z. A. Klinovidnye nukleusy v paleolite Severnoi Azii. P.11-14; Abramova Z. A. Paleolit Severnoi Azii // Paleolit Kavkaza i Severnoi Azii. Leningrad, 1989. P. 145-150. 
stage) and 2 (the beginning of the Sartan glaciation, correlates with the early part of the Last Glacial Maximum [LGM], or early MIS 2) is the absence of wedge-shaped microcores $^{29}$. Stage 3 of the Siberian Upper Paleolithic (second part of the Sartan glaciation, corresponds to the late LGM, or late MIS 2) includes sites where wedge-shaped microcores appear and become widespread, and is associated with the microblade technique necessary to equip slotted tools with insets. The individual sites and cultural complexes are: Mogochino; Afontova Culture (sites of Afontova Gora 2 and 3; Kokorevo 2; Tashtyk 1 and 2; Maininskaya; and Kantegir); Kokorevo Culture (sites of Kokorevo 1; and Novoselovo 6 and 7); Golubaya 1; upper layers of Ust-Kova and Krasny Yar; Sosnovy Bor (Layer 5); Makarovo 2; and Verkhne-Troitskaya, Ezhantsy, and Dyuktai Cave ${ }^{30}$.

The Dyuktai Culture of Yakutia was always connected with the microblade technol$\mathrm{ogy}^{31}$. However, the chronology of this cultural complex was a topic of intense discussion until recently ${ }^{32}$. It was proposed ${ }^{33}$ that the earliest ${ }^{14} \mathrm{C}$ dates from the Dyuktai Culture sites, dated to ca. 23,000-35,000 BP according to another view ${ }^{34}$, were too old, and that no microblade complexes of a similar age existed in Siberia. Later, it was suggested that the beginning of the Dyuktai Culture can be dated to ca. 17,000/18,000-10,000/11,000 BP, and possibly older, beginning at ca. 22,000/23,000 $\mathrm{BP}^{35}$.

Recent progress with ${ }^{14} \mathrm{C}$ dating of the Khayrgas site in central Yakutia ${ }^{36}$ (see Fig. 1), with its layers 6-7 associated with the Dyuktai Culture ${ }^{37}$ (Fig. 2, A), allowed researchers to establish the beginning of this complex to at least ca. 20,700 BP. Layer 7 of the Khayrgas site contains a few wedge-shaped cores and microblades, and more items directly related to microblade technology are found in Layer 6 dated to ca. 16,000 BP (Table 1). Thus, we can tentatively accept that the earliest evidence of microblade production in Yakutia is now dated to ca. 20,700 BP. It is clear that more data are needed to resolve the issue of the beginning of the Dyuktai Culture in Yakutia.

In the Yenisei River basin (see Fig. 1), some sites can be associated with the early microblade technology (Fig. 2, B-D). At the Maininskaya site (Layer A-3), several wedgeshaped cores and some microblades (the exact number is not indicated) were found

${ }^{29}$ Abramova Z.A. Klinovidnye nukleusy v paleolite Severnoi Azii. P. 240-243.

30 Ibid.

${ }^{31}$ Mochanov Y.A.: 1) Paleolithic finds in Siberia (resume of studies) // Beringia in Cenozoic era / ed. by V.I. Kontrimavichus. New Delhi, 1984, P. 694-700;2) The earliest stages of settlement by people of Northeast Asia. Anchorage, AK, 2009. P. 1-286; Abramova Z. A. O vozraste paleolita Aldana // Sovetskaia arkheologiia. 1979. No. 4. P. 5-12; Flenniken J. J. The Paleolithic Dyuktai pressure blade technique of Siberia. P.117-120; Gómez Coutouly Y.A. Migrations and interactions in prehistoric Beringia: the evolution of Yakutian lithic technology. P.9-14.

32 Abramova Z.A. O vozraste paleolita Aldana. P.9-12; Yi S., Clark G. The "Dyuktai culture" and New World origins // Current Anthropology. 1985. Vol.26, iss.1. P.1-12; Kuzmin Y.V., Orlova L.A. Radiocarbon chronology of the Siberian Paleolithic // Journal of World Prehistory. 1998. Vol.12, iss. 1. P. 22-33; Pitulko V. V., Pavlova E. Y. Geoarchaeology and radiocarbon chronology of Stone Age Northeast Asia. College Station, TX, 2016. P. 112-130.

33 Abramova Z. A. O vozraste paleolita Aldana. P. 10-14.

34 Mochanov Y. A. The earliest stages of settlement by people of Northeast Asia. P. 264-265.

35 Pitulko V. V., Pavlova E. Y. Geoarchaeology and radiocarbon chronology of Stone Age Northeast Asia. P. 125-130.

${ }^{36}$ Kuzmin Y.V., Kosintsev P.A., Stepanov A.D., Boeskorov G. G., Cruz R.J. Chronology and faunal remains of the Khayrgas Cave (Eastern Siberia, Russia) // Radiocarbon. 2017. Vol.59, iss. 2. P. 575-580.

37 Stepanov A.D., Kirillin A.S., Vorobeva S.A., Soloveva E.N., Efimov N.N. Peshchera Khaiyrgas na Srednei Lene (rezultaty issledovanii 1998-1999 gg.) // Drevnie kul'tury Severo-Vostochnoi Azii. Astroarkheologiia. Paleoinformatika, 2003. P.98-100. 


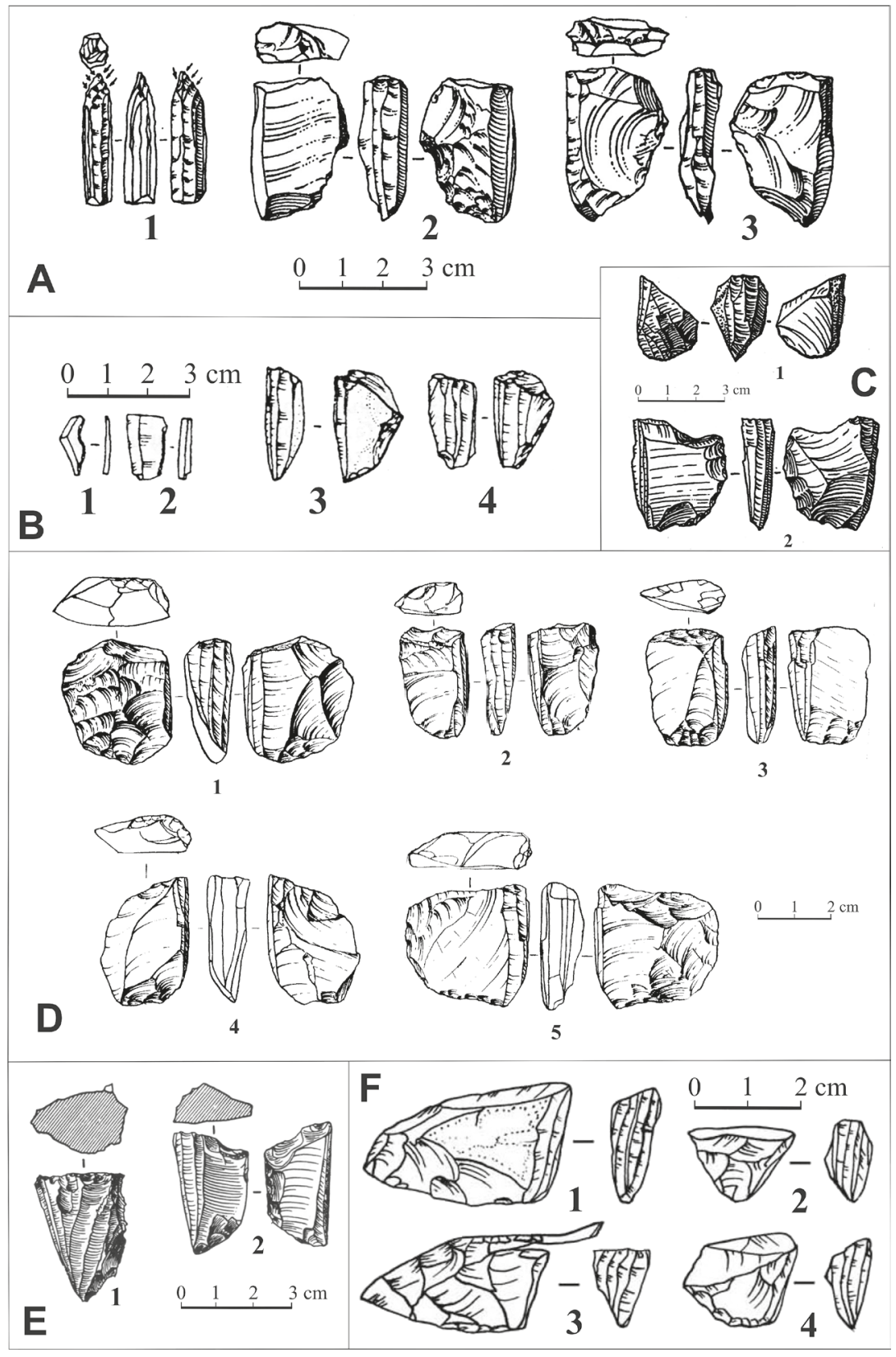

Fig. 2. Wedge-shaped and other cores, and microblades from the early microblade complexes of Siberia:

A - Khayrgas site: 1 - pencil-like core (Layer 6); 2 - wedge-shaped core (Layer 6); 3 - wedge-shaped core (Layer 7) [Stepanov et al., 2003]; B - Mainiskaya site, Layer A-3: 1-2 - retouched microblades; 3-4 - wedge-shaped cores [Vasilev, 1996]; C Tarachikha site, Layer 1: 1-2 - wedge-shaped cores [Lisitsyn, 2000]; D — Listvenka site, Layer 15A: 1-4 - wedge-shaped microcores; 5 - wedge-shaped core [Akimova et al., 2005]; E - Krasny Yar, Layer 2: 1-2 - wedge-shaped cores [Abramova, 1965]; F - Studenoe 2, Layer 4/5: 1-4 - wedge-shaped cores [Konstantinov, 2001] 
$\left(\right.$ Tab. 1) ${ }^{38}$. The latest chronological data show the age of this stratum as ca. $19,300 \mathrm{BP}^{39}$. At the Tarachikha site, the microblade complex can be associated with ${ }^{14} \mathrm{C}$ dates of ca. $18,930 \mathrm{BP}$ and ca. 19,850 $\mathrm{BP}^{40}$; however, no information exists about the direct association between these values and the microblade-bearing layer ${ }^{41}$. At the Listvenka site, Layer 15A contains five wedge-shaped cores and numerous microblades (Table 1); the ${ }^{14} \mathrm{C}$ date of this component is ca. $17,100 \mathrm{BP}^{42}$.

In the Angara River basin, the Krasny Yar (a.k.a. Krasnyi Iar) site has the earliest evidence of microblade technology (Figs 1 and 2, E; Table 1). It has been studied several times, and a ${ }^{14} \mathrm{C}$ date of ca. $19,100 \mathrm{BP}$ was obtained for Layer $2^{43}$. Despite a disagreement about the numbering of the cultural layers ${ }^{44}$, the association between the ${ }^{14} \mathrm{C}$ value, wedge-shaped cores and microblades looks secure.

In the Transbaikal region, the Studenoe 2 site (see Fig. 1) contains the earliest microblade complex (Fig. 2F; Fig. 3A). Layer 5, dated to ca. 17,200 BP, has seven wedge-shaped cores and more than 150 microblades (Table 1). In Layer $4 / 5$ directly above it, artifacts related to the manufacture of microblades are also found. The chronology of this component is to some extent controversial, with a wide range of ${ }^{14} \mathrm{C}$ values: from ca. $14,490 \mathrm{BP}$ to ca. $18,300 \mathrm{BP}^{45}$. While the youngest ${ }^{14} \mathrm{C}$ date may well be an outlier, the oldest ${ }^{14} \mathrm{C}$ value is accepted by some scholars ${ }^{46}$. However, this contradicts the site's stratigraphy, and the most reliable age estimate for Layer 4/5 is ca. 16,200-17,200 BP.

\subsection{The Russian Far East}

In the middle part of the Amur River basin, the Ust'-Ulma 1 site (Fig. 1) contains the earliest representation of microblade technology in the region. Two wedge-shaped cores were found in the lowermost component, Layer $3^{47}$. In Layer $2 \mathrm{~b}$ immediately above Layer 3 , there are 18 wedge-shaped cores and one prismatic core, and two microblades (Tab. 1; Fig. 3, B). The ${ }^{14} \mathrm{C}$ age of Layer 3 is undetermined; Layer $2 \mathrm{~b}$ is dated to ca. 19,400 BP.

38 Vasilev S. A. Pozdnii paleolit verkhnego Eniseia (po materialam mnogosloinykh stoianok raiona Mainy). St. Petersburg, 1996. P.200-215.

39 Vasilev S. A., Yamskikh A. F., Yamskikh G. Yu., Kuzmin Y.V., Jull A. J. T. Novye dannye po khronologii i paleosrede mnogosloinykh stoianok Maininskogo raiona na Verkhnem Enisee // Aktualnye voprosy evraziiskogo paleolitovedeniia / eds A. P. Derevianko, M. V. Shunkov. Novosibirsk, 2005. P. 25-30.

${ }^{40}$ Kuzmin Y.V., Orlova L.A., Zenin V.N., Lbova L. V., Dementiev V.N. Radiouglerodnoe datirovanie paleolita Sibiri i Dalnego Vostoka Rossii: materialy k katalogu ${ }^{14} \mathrm{C}$ dat (po sostoianiiu na konets $2010 \mathrm{~g}$.) // Stratum plus. 2011. No.1. P. 186.

${ }^{41}$ Lisitsyn N. F. Pozdnii paleolit Chulymo-Eniseiskogo mezhdurechia. St. Petersburg, 2000. P. 137.

42 Akimova E. V., Drozdov N.I., Laukhin S.A., Chekha V.P., Orlova L.A., Koltsova V. G., Sanko A. F., Shpakova E. G. Paleolit Eniseia. Listvenka. Krasnoiarsk, 2005. P. 154.

43 Abramova Z. A. Krasnyi Iar - a new Palaeolithic site on the Angara // Arctic Anthropology. 1965. Vol. 3, iss. 1. P. 122-126.

44 Abramova Z. A. Krasnyi Iar - Krasnyi Iar - a new Palaeolithic site on the Angara. Arctic Anthropology, 1965. Vol.3, iss. 1. P.122-128. Versus: Medvedev G.I. Archaeological investigations of the stratified Palaeolithic site of Krasnyi Iar on the Angara in 1964-1965. Arctic Anthropology, 1969. Vol. 6, iss. 1. P.30-44.

${ }^{45}$ Kuzmin Y. V., Jull A.J.T., Razgildeeva I.I. Chronology of the Upper-Paleolithic site Studenoe 2 (Transbaikal, Siberia): case study of the multi-hearth dwelling in horizon 4/5 // Current Research in the Pleistocene. 2004. Vol.21. P. 6-7.

${ }^{46}$ Buvit I., Waters M.R., Konstantinov M. V., Konstantinov A. V. Geoarchaeological investigations at Studenoe, an Upper Paleolithic site in the Transbaikal region, Russia // Geoarchaeology. 2003. Vol. 18, iss. 6. P. 649-655.

${ }^{47}$ Derevianko A.P., Zenin V.N. Paleolit Selemdzhi. Novosibirsk, 1995. P. 105-114. 


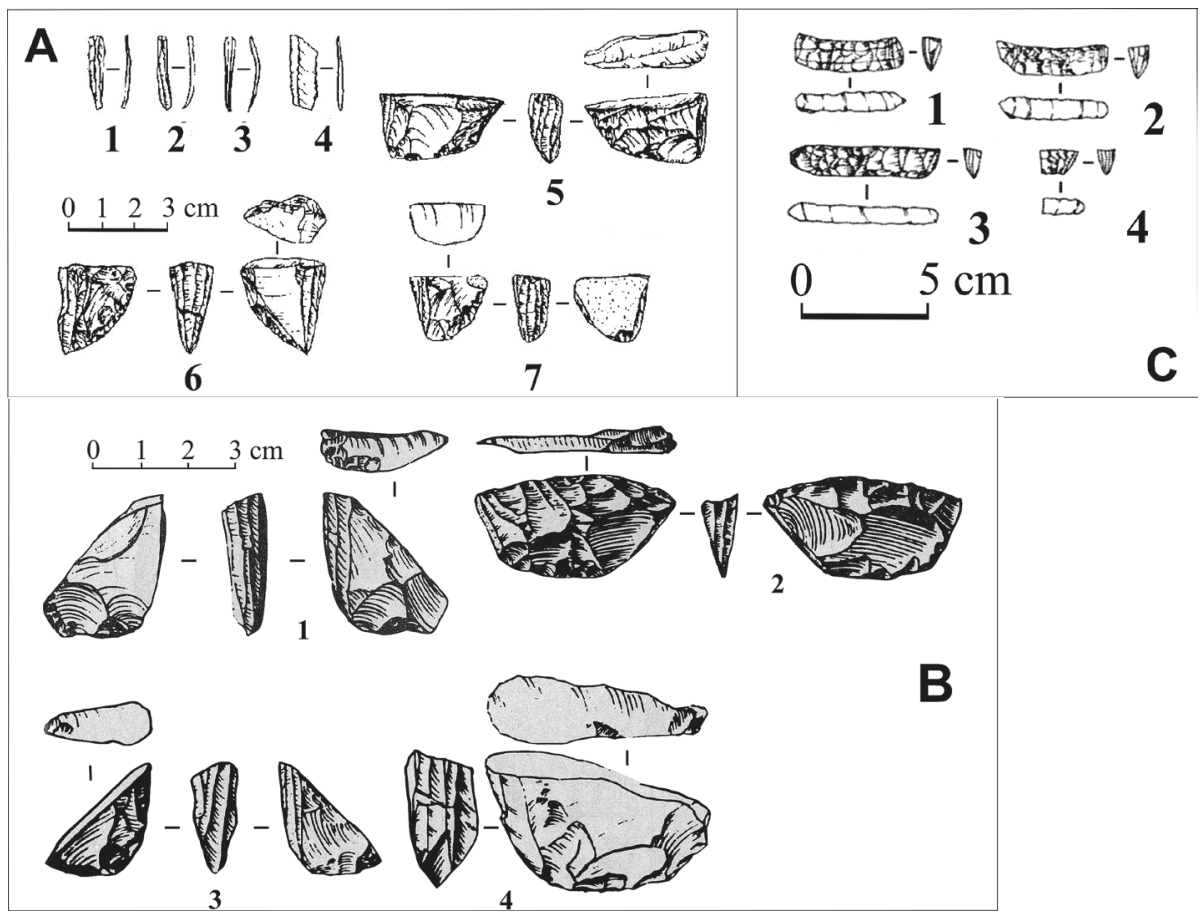

Fig. 3. Wedge-shaped cores and microblades from the early microblade complexes of Siberia and the Russian Far East:

A - Studenoe 2, Layer 5: 1-4 microblades; 5-7 - wedge-shaped cores [Konstantinov, 2001]; B - Ust'-Ul'ma 1, Layer 2b: 1-4 - wedge-shaped cores [Derevianko, Zenin, 2005]; C - Ogonki 5, Horizon 3: 1-4 - wedge-shaped cores [Vasilevsky, 2003]

Another example of an early microblade complex in the Russian Far East is the Ogonki 5 site on Sakhalin Island (Figs 1 and 3, C). It has numerous wedge-shaped cores and microblades in Horizon $3^{48}$ (see Table 1). The ${ }^{14} \mathrm{C}$ age range of Horizon 3 is ca. 19,400$18,900 \mathrm{BP}$.

\subsection{China}

The earliest reliable evidence of microblade technology in China can be found in its northern part $^{49}$. The well-known Xiachuan site complex in Shanxi Province (see Fig. 1), with 16 "microlithic" localities has yielded between $204^{50}$ and $219^{51}$ microblade cores,

48 Vasilevsky A. A. Periodization and classification of the Upper Paleolithic of Sakhalin and Hokkaido in the light of the research conducted at the Ogonki-5 site // Archaeology, Ethnology \& Anthropology of Eurasia. 2003. No. 3 (15). P. 51-60.

${ }^{49} \mathrm{Lu}$ L.D. The microblade tradition in China: regional chronologies and significance in the transition to Neolithic // Asian Perspectives. 1998. Vol.37, iss. 1. P. 84-90.

50 Wang J., Wang X., Chen Z. Xiachuan culture // Kaogu Xuebao. 1978. No. 3. P.259-280; Tang C. The Upper Palaeolithic of North China: the Xiachuan culture // Journal of East Asian Archaeology. 2000. Vol. 2. P. 37-45.

${ }^{51}$ Chen C., Wang X.-Q. Upper Paleolithic microblade industries in North China and their relationships with Northeast Asia and North America // Arctic Anthropology. 1989. Vol. 26, iss. 2. P. 134. Figs 5 and 6. 
including 15 wedge-shaped cores and 186 microblades from Layer $2^{52}$ (see Table 1). The ${ }^{14} \mathrm{C}$ dates for Cultural Layer 2 range in age from about $23,220 \mathrm{BP}$ to $15,900 \mathrm{BP}^{53}$ and cluster around ca. 20,700-16,400 BP. The oldest dates are ca. 23,220 BP and 21,090 BP 54 . For the $21,090 \pm 1000 \mathrm{BP}$ date (ZK-384), the context "microlith culture layer" is specifically noted 55 . However, the dated samples are from four localities "...rather than from a sequential profile of cultural deposits." 56 , and the "...ages are problematic owing to poor stratigraphic control of the samples." ${ }^{27}$. While we here provisionally accept the ca. 21,100 BP date for Xiachuan $^{58}$, the poor stratigraphic and relatively thick layer context from which the dating samples were collected, leave some doubts about the chronology of this site.

The existence of Pleistocene microblade technology south of the Yangtze River is still unresolved. T. Qu and coauthors ${ }^{59}$ do not mention any microblade sites in southern China, and L. D. $\mathrm{Lu}^{60}$ refers to microblades from Guang dong Province dated to the midHolocene. On the other hand, the presence of microblades in the Yangtze Phase in Jiangxi Province is indicated at ca. 24,500-17,000 $\mathrm{BP}^{61}$.

\subsection{Korea}

At the Sinbuk site on the southern tip of the Korean Peninsula (Fig. 1), about 160 microblade cores were found, including five wedge-shaped cores, and also more than 300 microblades $^{62}$ (see Table 1; Fig. 4, A). The ${ }^{14} \mathrm{C}$ dates from Sinbuk can be combined in two clusters: ca. 25,500-23,900 BP and 21,800-21,000 $\mathrm{BP}^{63}$. The existence of a third

52 Chen C., Wang X.-Q. Upper Paleolithic microblade industries in North China and their relationships with Northeast Asia and North America; Tang C. The Upper Palaeolithic of North China: the Xiachuan culture // Journal of East Asian Archaeology.

53 The Institute of Archaeology, Chinese Academy of Social Sciences (CASS). Radiocarbon dates in Chinese archaeology, 1965-1991. Beijing, 1991. P.39-41; The Laboratory, Institute of Archaeology, Chinese Academy of Social Sciences (CASS). Report on radio-carbon dates (V) // Kaogu. 1978. No.4. P.280-282.

54 The Institute of Archaeology, Chinese Academy of Social Sciences (CASS). Radiocarbon dates in Chinese archaeology, 1965-1991. 1991. P. 40-41.

55 The Laboratory, Institute of Archaeology, Chinese Academy of Social Sciences (CASS). Report on radio-carbon dates (V). P. 281.

56 Chen C., Wang X.-Q. Upper Paleolithic microblade industries in North China and their relationships with Northeast Asia and North America. P. 135.

57 Nian X., Gao X., Xie F., Mei H., Zhou L. Chronology of the Youfang site and its implications for the emergence of microblade technology in North China // Quaternary International. 2014. Vol.347. P. 113-118; see also: Chen C., Wang X.-Q. Upper Paleolithic microblade industries in North China and their relationships with Northeast Asia and North America. P. 135; An Z. Carbon-14 dating and its problems of the Late Paleolithic in China // Acta Anthropologica Sinica. 1983. Vol.2, iss. 4. P.342-350.

58 Yi M., Gao X., Li F., Chen F. Rethinking the origin of microblade technology: a chronological and ecological perspective // Quaternary International. 2016. Vol.400. P. 136.

${ }_{59}$ Qu T., Bar-Yosef O., Wang Y. The Chinese Upper Paleolithic: geography, chronology, and technotypology // Journal of Archaeological Research. 2013. Vol. 21, iss. 1. P. 40-43.

${ }^{60} \mathrm{Lu}$ L. D. The microblade tradition in China: regional chronologies and significance in the transition to Neolithic // Asian Perspectives. P. 85

61 MacNeish R.S. A Paleolithic-Neolithic sequence from South China Jiangxi Province, PRC // Interdisciplinary perspectives on the origins of the Japanese. Kyoto, 1999. P. 233-250.

62 The Sinbuk Upper Palaeolithic site in Jangheung county, Jeollanam Province, Korea / Chosun University Museum. Gwangju, 2008. P. 1-168.

63 Seong C. Evaluating radiocarbon dates and Late Paleolithic chronology in Korea // Arctic Anthropology. 2011. Vol. 48, iss. 1. P. 93-110. 
Table 1. The earliest sites in northern and eastern Asia with presence of microblade technology

\begin{tabular}{|c|c|c|c|c|c|}
\hline $\begin{array}{l}\text { Region, site, cultural } \\
\text { layer and thickness }\end{array}$ & $\begin{array}{l}\text { Wedge- } \\
\text { shaped } \\
\text { cores }\end{array}$ & $\begin{array}{l}\text { Other } \\
\text { microblade } \\
\text { cores }\end{array}$ & Microblades & $\begin{array}{l}\text { Retouched } \\
\text { microblades }^{\mathrm{a}}\end{array}$ & ${ }^{14} \mathrm{C}$ age, $\mathrm{BP}$ \\
\hline \multicolumn{6}{|c|}{ Siberia } \\
\hline $\begin{array}{l}\text { Khayrgas Cave, Layer } 7 \\
(0.45-0.60 \mathrm{~m})\end{array}$ & 2 & - & 1 & - & ca. $20,700-21,500$ \\
\hline $\begin{array}{l}\text { Khayrgas Cave, Layer } 6 \\
(0.40-0.50 \mathrm{~m})\end{array}$ & 5 & $2^{b}$ & 25 & 3 & ca. 16,000 \\
\hline $\begin{array}{l}\text { Maininskaya, Layer A-3 } \\
(0.30 \mathrm{~m})\end{array}$ & 12 & $10^{c}$ & $778^{d}$ & 5 & ca. 19,300 \\
\hline $\begin{array}{l}\text { Tarachikha, Layer } 1 \\
(0.30 \mathrm{~m})\end{array}$ & 2 & - & 46 & 12 & $\begin{array}{c}\text { ca. } 18,900- \\
19,900^{\mathrm{e}}\end{array}$ \\
\hline $\begin{array}{l}\text { Listvenka, Layer 15A } \\
(0.02-0.03 \mathrm{~m})\end{array}$ & 5 & - & 59 & 1 & ca. 17,100 \\
\hline $\begin{array}{l}\text { Krasny Yar, Layer } 2^{\mathrm{f}} \\
(0.10 \mathrm{~m})\end{array}$ & $3^{g}$ & $?$ & $?^{\mathrm{h}}$ & $?$ & ca. 19,100 \\
\hline $\begin{array}{l}\text { Studenoe 2, Layer } \\
4 / 5(0.10 \mathrm{~m})\end{array}$ & 5 & $1^{\mathrm{i}}$ & 48 & 2 & ca. $16,200-17,200$ \\
\hline $\begin{array}{l}\text { Studenoe 2, Layer } 5 \\
(0.04-0.07 \mathrm{~m})\end{array}$ & 7 & - & 157 & - & ca. 17,200 \\
\hline \multicolumn{6}{|c|}{ Russian Far East } \\
\hline $\begin{array}{l}\text { Ust'-Ul'ma 1, Layer 2b } \\
(0.30-0.40 \mathrm{~m})\end{array}$ & 18 & $1^{\mathrm{i}}$ & 2 & - & ca. 19,400 \\
\hline $\begin{array}{l}\text { Ogonki 5, Horizon } \\
3(0.40-0.70 \mathrm{~m})\end{array}$ & 66 & - & 339 & - & ca. $18,900-19,400$ \\
\hline \multicolumn{6}{|c|}{ Korean Peninsula } \\
\hline $\begin{array}{l}\text { Sinbuk, Paleolithic } \\
\text { layer (ca. } 0.20 \mathrm{~m})\end{array}$ & 6 & ca. $160^{j}$ & $>300^{\mathrm{k}}$ & - & ca. $18,500-25,500$ \\
\hline $\begin{array}{l}\text { Jangheung-ri, Layer } 1 \\
(0.50-0.60 \mathrm{~m})\end{array}$ & 1 & 4 & 34 & 6 & ca. $24,200-24,400$ \\
\hline \multicolumn{6}{|c|}{ Japanese Islands } \\
\hline $\begin{array}{l}\text { Kashiwadai 1, Layer } \\
4(0.60 \mathrm{~m})\end{array}$ & 5 & - & 638 & 137 & ca. $19,800-20,800$ \\
\hline \multicolumn{6}{|c|}{ Northern China } \\
\hline $\begin{array}{l}\text { Xiachuan, Layer } 2^{1} \\
(1.00-1.50 \mathrm{~m})\end{array}$ & 15 & $204^{\mathrm{m}}$ & 186 & $?$ & $\begin{array}{l}\text { ca. } 15,900- \\
23,220^{\mathrm{n}}\end{array}$ \\
\hline
\end{tabular}

a Included in the total number of microblades. ${ }^{b}$ Pencil-like cores. ${ }^{c}$ These are "untypical" wedgeshaped cores. ${ }^{\mathrm{d}}$ Including bladelets. ${ }^{\mathrm{e}}$ Exact layer number is not indicated. ${ }^{\mathrm{f}}$ Main cultural layer. ${ }^{\mathrm{g}}$ Minimal number; the exact number is not indicated. Sixteen "Gobi" (i. e. wedge-shaped) cores are mentioned in Horizon VI by G. I. Medvedev, most closely related to the "main cultural layer" of Z. A. Abramova. ${ }^{h}$ Numerous microblades are mentioned by Z. A. Abramova. At least ten microblades are illustrated by G. I. Medvedev. ${ }^{i}$ Prismatic core. ${ }^{j}$ Exact number of cores is not indicated, these include one boatshaped core. ${ }^{\mathrm{k}}$ G.-K. Lee, personal communication, August 2016. ${ }^{1}$ Note that Layer 2 is numbered as Layer 1 in paper by Wang et al. (1978). ${ }^{\mathrm{m}}$ Two hundred and nineteen microblade cores according to the paper by Chen and Wang (1989). Other core types from Xiachuan are: 100 conical, 51 semi-conical, 19 boat-shaped, 10 cylindrical, and 24 funnel-shaped. ${ }^{n}$ The dated sites are: Shunwangping, Xiachuan, and Xiaobaihua; in some sources the Shanshanyan locality is also referred to. 

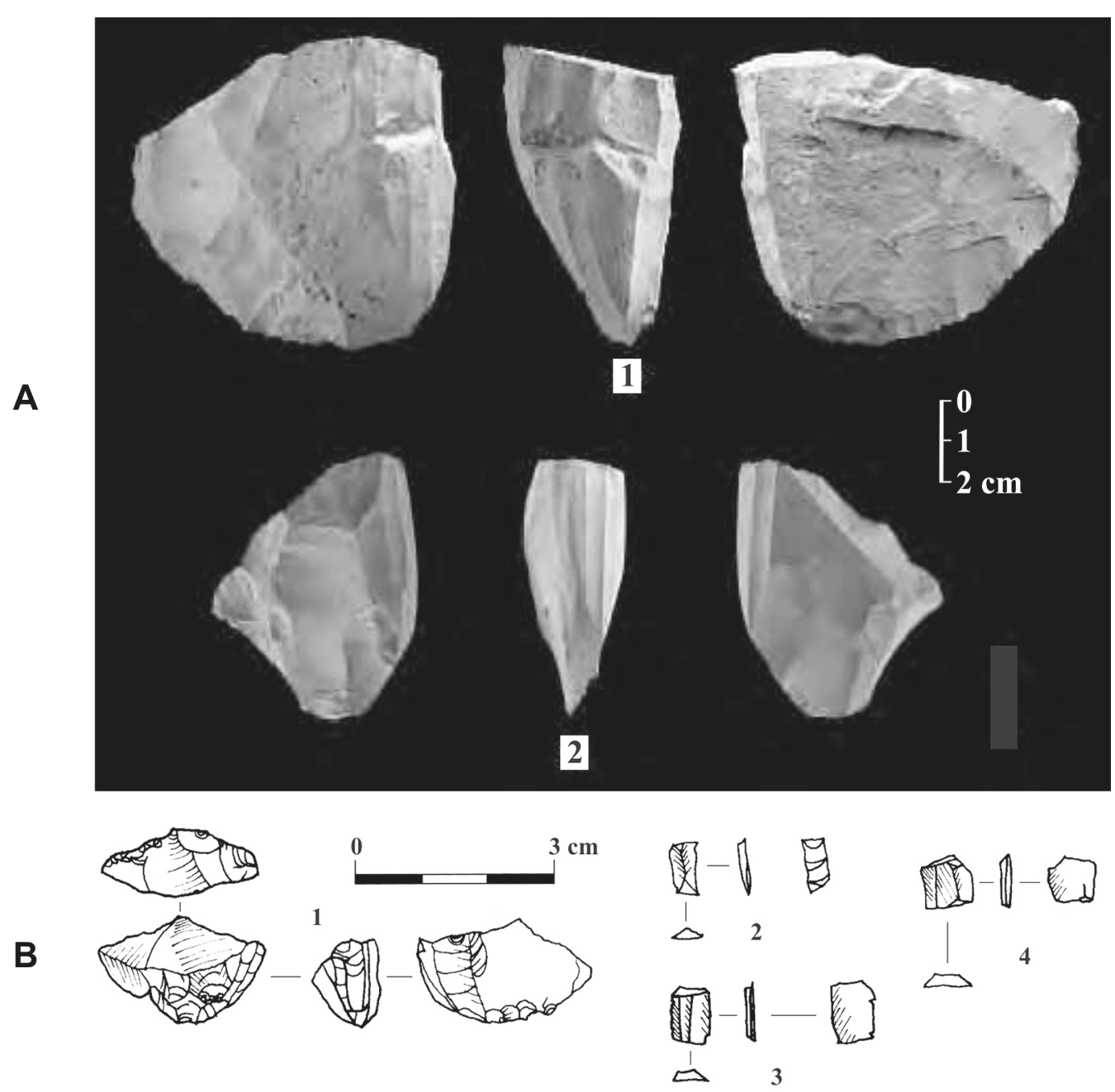

Fig. 4. Wedge-shaped cores and microblades from the early microblade complexes of Korea:

A - Sinbuk site: 1-2 - wedge-shaped cores [The Sinbuk Upper Palaeolithic site in Jangheung county, Jeollanam Province, Korea... 2008]. B - Jangheung-ri site: 1 - wedge-shaped core; 2-4 microblades [The Janghung-ri Palaeolithic site... 2001]

cluster, at ca. $18,500 \mathrm{BP}$, is also possible ${ }^{64}$. The relatively wide spread of ${ }^{14} \mathrm{C}$ dates at Sinbuk ${ }^{65}$ should not prevent us from accepting the oldest values considering that the dates were produced on charcoal from hearths ${ }^{66}$. Also, the phenomenon of a wide range of ${ }^{14} \mathrm{C}$ ages at Paleolithic sites in northern Asia is well-known, indicating more than one occupation ${ }^{67}$. P. 106.

${ }^{64}$ See discussion: Seong C. Evaluating radiocarbon dates and Late Paleolithic chronology in Korea.

65 Ibid. P. 107; Seong C. Diversity of lithic assemblages and evolution of Late Palaeolithic culture in Korea // Asian Perspectives. 2015. Vol.54, iss. 1. P.94-109.

66 Seong C. Evaluating radiocarbon dates and Late Paleolithic chronology in Korea. P. 106.

67 See: Kuzmin Y. V., Keates S. G. Dates are not just data: Paleolithic settlement patterns in Siberia derived from radiocarbon records. P.780. 
A site in central Korea, Jangheung-ri, yielded five microblade cores and 34 microblades ${ }^{68}$ (see Table 1; Figs 1 and 4B). The two ${ }^{14} \mathrm{C}$ dates for Jangheung-ri are ca. 24,400 BP and $24,200 \mathrm{BP}^{69}$.

\subsection{Japan}

The Kashiwadai 1 site on Hokkaido Island (Fig. 1) has yielded five wedge-shaped cores, 638 microblades, including 137 retouched microblades from Layer $4^{70}$ (see Table 1; Fig. 5). The ${ }^{14} \mathrm{C}$ dates for this layer are ca. 20,800-19,800 $\mathrm{BP}^{71}$. According to some authors ${ }^{72}$, the dates cluster around 20,500 BP. In other parts of the Japanese Islands, microblade technology sites are significantly younger, beginning at ca. 16,000-15,000 $\mathrm{BP}^{73}$.

\subsection{Other potentially early microblade sites}

Beside the complexes described above, there are other sites in northern and eastern Asia which have a certain potential to be considered. However, the ambiguities surrounding their age and artifact typology prevent us from accepting them at face value. Below, we briefly discuss these sites.

In northern Mongolia, the Tolbor 15 site yielded one boat-shaped microcore and one wedge-shaped microblade core from Layer 5 (Archaeological Horizon 5), $0.2 \mathrm{~m}$ thick, dated to ca. 32,200-28,500 $\mathrm{BP}^{74}$. However, directly above this, there is Layer 4 (thickness of $0.25 \mathrm{~m}$ ), a stratum with numerous microblades ${ }^{14} \mathrm{C}$-dated to ca. $14,800-14,700 \mathrm{BP}$. Because the boundary between layers 5 and 4 is irregular due to erosion ${ }^{75}$, the possibility that microblade cores and microblades were redeposited from the upper layer to the lower one should be considered. The mixture of sediments at the Tolbor 15 site, including underlying layers 7 and 6, is evident from two ${ }^{14} \mathrm{C}$ values for layers 6-7, 15,750 $\pm 80 \mathrm{BP}$ (Beta263741) and 19,520 $\pm 280 \mathrm{BP}$ (AA-93138), which are much younger than accepted ages of ca. 33,200-29,120 BP; it is also noted that Layer 5 is re-deposited ${ }^{76}$. The presence of animal burrows, especially in layers 5 and $4^{77}$, could also have facilitated movement of artifacts ${ }^{78}$.

68 The Janghung-ri Palaeolithic site / ed. by Choi B. K. Chuncheon, 2001. P. 1-143.

69 The Janghung-ri Palaeolithic site. P.123-126; Seong C. Evaluating radiocarbon dates and Late Paleolithic chronology in Korea. P. 106-107.

70 Kashiwadai 1 iseki / eds J. Fukui, K. Koshida. Sapporo, 1999. P.1-312; Sato H., Tsutsumi T. The Japanese microblade industries: technology, raw material procurement, and adaptations // Origin and spread of microblade technology in Northern Asia and North America. Burnaby, 2007. P. 17-29.

${ }^{71}$ Ono A., Sato H., Tsutsumi T., Kudo Y. Radiocarbon dates and archaeology of the Late Pleistocene in the Japanese Islands // Radiocarbon. 2002. Vol. 44, iss. 2. P. 477-484.

72 Takakura J. Emergence and development of the pressure microblade production: a view from the Upper Paleolithic of northern Japan. P. 293.

${ }^{73}$ Sato H., Tsutsumi T. The Japanese microblade industries: technology, raw material procurement, and adaptations. P. 40-43.

74 Gladyshev S. A., Tabarev A. V. Mikroplastinchatoe rasshcheplenie v rannem verkhnem paleolite Mongolii // Stratum plus. 2018. No. 1. P.339-345.

75 Gladyshev S., Tabarev A., Olsen J. W. Origin and evolution of the Late Paleolithic microindustry in northern Mongolia // Current Research in the Pleistocene. 2010. Vol.27. P.37. Fig. 1.

${ }^{76}$ Khatsenovich A. M. Rannie etapy verkhnego paleolita Severnoi Mongolii. Diss. ... kand. ist. nauk. Novosibirsk, 2018. P. 1-287.

77 Gladyshev S. A., Tabarev A. V. Mikroplastinchatoe rasshcheplenie v rannem verkhnem paleolite Mongolii. P. 346-351; Khatsenovich A. M. Rannie etapy verkhnego paleolita Severnoi Mongolii. P. 77.

${ }^{78}$ Rybin E. P., Khatsenovich A.M., Gunchinsuren B., Olsen J. W., Zwyns N. The impact of the LGM on the development of the Upper Paleolithic in Mongolia // Quaternary International. 2016. Vol. 425. P. 69-80. 


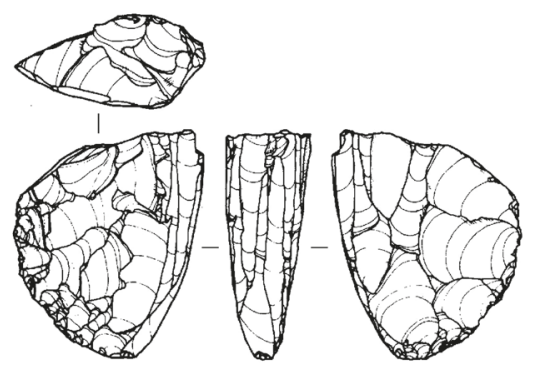

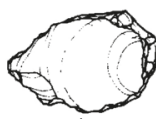
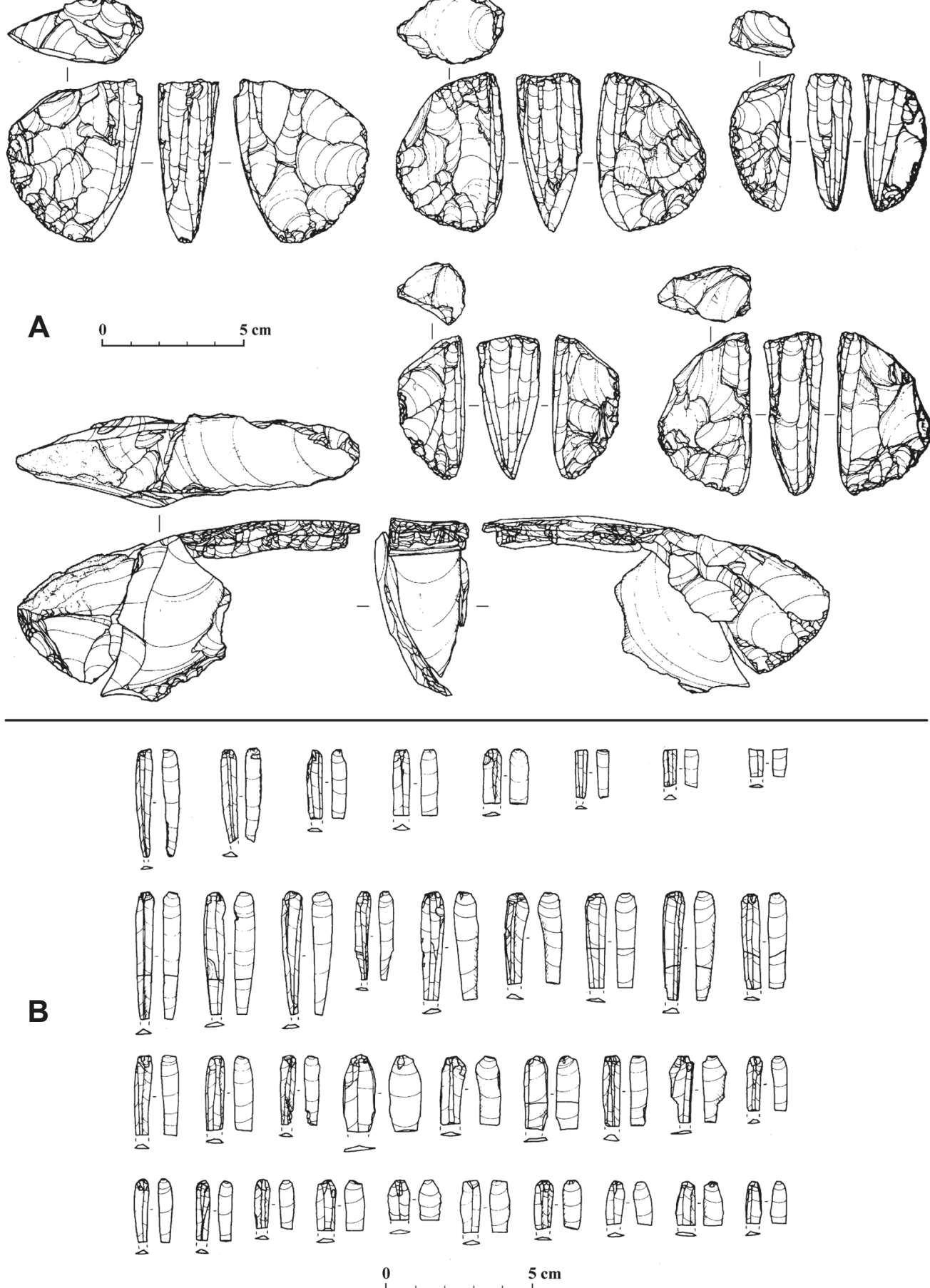

Fig. 5. Microblade cores (A) and microblades (B) from the Kashiwadai 1 site [Kashiwadai 1, 1999] 
In northern China, other, potentially early microblade sites include Chaisi, Shanxi Province (Locality 77:01, Dingcun site complex), with six microblade cores (wedgeshaped, conical and boat-shaped) and 53 microblades found in a cultural layer 0.3-0.6 m thick ${ }^{79}$. A single ${ }^{14} \mathrm{C}$ value on shell dates the site to ca. $25,650 \mathrm{BP}^{80}$. However, there are doubts about the stratigraphic integrity of the materials ${ }^{81}$.

The lower cultural layer of the Xishi site in Henan Province has yielded three microblade cores and 82 microblades $^{82}$. The artifacts, including blade cores and blades, were found at the base of the ca. $3 \mathrm{~m}$ thick Malan loess in a $0.20 \mathrm{~m}$ thick context ${ }^{83}$ and ${ }^{14} \mathrm{C}$-dated to ca. $22,100 \mathrm{BP}^{84}$. Judging from the illustration ${ }^{85}$, we cannot be certain if the specimen is a true wedge-shaped core.

At Longwangchan Locality 1 in Shaanxi Province, lithic artifacts including "microliths" were recovered from the $2.5-3.4$ m thick layers $4-6$ with a ${ }^{14} \mathrm{C}$ date range of ca. $24,145-20,710 \mathrm{BP}^{86}$. The optically stimulated luminescent (OSL) dates are in the range of ca. 44,300-21,400 years ago ${ }^{87}$, while another paper reports OSL ages of ca. 28,80021,400 years ago ${ }^{88}$. The ${ }^{14} \mathrm{C}$ date distribution is not always consistent with depth ${ }^{89}$, and there is inversion in the ${ }^{14} \mathrm{C}$ date sequence of Layer 6 and the OSL chronology ${ }^{90}$. Further, OSL dates from some Chinese Paleolithic sites such as Longwangchan and Shuidonggou 1 and 2 cannot be shown to fit the independently established ${ }^{14} \mathrm{C}$ chronology ${ }^{91}$. Frequencies of individual categories and specific layer origin are not provided ${ }^{92}$. According to M. Yi

79 Wang J., Tao F., Wang Y. Preliminary report on investigation and excavation of Dingcun Palaeolithic sites // Journal of Chinese Antiquity. 1994. No. 3. P. 1-66.

80 The Institute of Archaeology, Chinese Academy of Social Sciences (CASS). 1991. P. 33.

81 An Z. Radiocarbon dating and the Neolithic period of China // Kaogu. 1984. No. 3. P.271-273; Wang J., Tao F., Wang Y. Preliminary report on investigation and excavation of Dingcun Palaeolithic sites. Journal of Chinese Antiquity. P. 1-25.

82 Yi M., Gao X., Li F., Chen F. Rethinking the origin of microblade technology: a chronological and ecological perspective. P. 130-135.

83 Wang Y., Qu T. New evidence and perspectives on the Upper Paleolithic of the Central Plain in China // Quaternary International. 2014. Vol.347. P. 179.

${ }^{84}$ Wang Y. P. New evidence of modern human behavior in Paleolithic Central China // Emergence and diversity of modern human behavior in Paleolithic Asia / eds Y. Kaifu, M. Izuho, T. Goebel, H. Sato, A. Ono. College Station, TX, 2015. P.250-253.

85 Yi M., Gao X., Li F., Chen F. Rethinking the origin of microblade technology: a chronological and ecological perspective. P. 36. Fig. 3.5.

86 Zhang J.-F., Wang X.-Q., Qiu W.-L., Shelach G., Hu G., Fu X., Zhuang M.-G., Zhou L.-P. The Paleolithic site of Longwangchan in the middle Yellow River, China: chronology, paleoenvironment and implications // Journal of Archaeological Science. 2011. Vol.38, iss. 7. P. 1539.

87 Ibid. P. 1540.

${ }^{88}$ Yi M., Gao X., Li F., Chen F. Rethinking the origin of microblade technology: a chronological and ecological perspective. P. 135-136.

89 Zhang J.-F., Wang X.-Q., Qiu W.-L., Shelach G., Hu G., Fu X., Zhuang M.-G., Zhou L.-P. The Paleolithic site of Longwangchan in the middle Yellow River, China: chronology, paleoenvironment and implications. P. 1541.

90 Ibid. P. 1541, 1543. Table 1-2.

${ }^{91}$ Keates S. G., Kuzmin Y.V. Shuidonggou localities 1 and 2 in northern China: archaeology and chronology of the Initial Upper Palaeolithic in north-east Asia // Antiquity. 2015. Vol. 89, iss. 345. P. 714-719.

${ }_{92}$ Zhang J.-F., Wang X.-Q., Qiu W.-L., Shelach G., Hu G., Fu X., Zhuang M.-G., Zhou L.-P. The Paleolithic site of Longwangchan in the middle Yellow River, China: chronology, paleoenvironment and implications. P. 1540-1543; Yi M., Gao X., Li F., Chen F. Rethinking the origin of microblade technology: a chronological and ecological perspective. P. 135-136. 
(pers. comm. July 2015), a few microblade cores were found. At least four microblade cores, classified only as "microlithic cores" were recorded: these are conical and cylindrical93.

While there is a claim that the Youfang site (Hebei Province) is the earliest microblade complex in northern China ${ }^{94}$, the ages of ca. 29,000-26,000 years ago are based on OSL dating of the thick $(1.9-3.1 \mathrm{~m})$ cultural layer. Other OSL dating results ${ }^{95}$ determined the age of the Youfang site as ca. 16,000-14,000 years ago. With regard to the Youfang chronology and their preferred use of OSL dating, it is contended that "charcoal from archaeological sites is readily contaminated..." ${ }^{\prime 6}$ citing several references ${ }^{97}$. In fact, the samples used for the ${ }^{14} \mathrm{C}$ dates in these papers derived from disturbed and fluvial contexts; the results of ${ }^{14} \mathrm{C}$-dated charcoal are described as "reliable"

Concerning the Siberian sites of Ust'-Karakol 1 and Anui $2^{99}$, it is not certain if pressure flaking was used on the not fine-grained stone material available. At other Siberian sites, Kamenka $\mathrm{B}^{100}$, Barun-Alan ${ }^{101}$, and Malta ${ }^{102}$, there are no wedge-shaped cores. A caution was expressed about the absence of true wedge-shaped cores at the Malta and Buret sites, as well as other sites in Western Siberia and Central Asia, which contain small blades (bladelets) produced from flat-faced cores ${ }^{103}$. In our opinion, there are no early microblade assemblages dated to before ca. 20,000 BP in most of Siberia, including the Altai Mountains, the Angara River basin and Transbaikal, unlike views expressed earlier ${ }^{104}$.

93 Zhang J.-F., Wang X.-Q., Qiu W.-L., Shelach G., Hu G., Fu X., Zhuang M.-G., Zhou L.-P. The Paleolithic site of Longwangchan in the middle Yellow River, China: chronology, paleoenvironment and implications. P. 1540, Fig. 3.

94 Nian X., Gao X., Xie F., Mei H., Zhou L. Chronology of the Youfang site and its implications for the emergence of microblade technology in North China // Quaternary International. 2014. Vol. 347. P. 113-121.

95 Nagatomo T., Shitaoka Y., Namioka H., Sagawa M., Wei Q. OSL dating of the strata at Paleolithic sites in the Nihewan Basin, China // Acta Anthropologica Sinica. 2009. Vol.28, iss. 3. P. 276-280.

96 Nian X., Gao X., Xie F., Mei H., Zhou L. Chronology of the Youfang site and its implications for the emergence of microblade technology in North China. P. 116.

97 Gillespie R., Brook B. Is there a Pleistocene archaeological site at Cuddie Springs? // Archaeology in Oceania. 2006. Vol.41, iss. 1. P.1-11; Blong R. J., Gillespie R. Fluvially transported charcoal gives erroneous ${ }^{14} \mathrm{C}$ ages for recent deposits // Nature. 1978. Vol.271, iss. 5647. P.739-741; El-Daoushy F., Eriksson M. G. Radiometric dating of recent lake sediments from a highly eroded area in semiarid Tanzania // Journal of Paleolimnology. 1998. Vol. 19, iss. 4. P. 377-384.

98 Gillespie R., Brook B. Is there a Pleistocene archaeological site at Cuddie Springs? P. 6.

99 Derevianko A. P., Shunkov M. V., Agadzhanian A. K., Baryshnikov G. F., Malaeva E. M., Ulianov V.A., Kulik N. A., Postnov A. A., Anoikin A. A. Prirodnaia sreda i chelovek v paleolite Gornogo Altaia. Novosibirsk, 2003. P.1-448; Derevianko A.P., Volkov P. V. Evolution of lithic reduction technology in the course of the Middle to Upper Paleolithic transition in the Altai Mountains // Archaeology, Ethnology \& Anthropology of Eurasia. 2004. No. 2(18). P. 21-35.

100 Lbova L. V. Paleolit severnoi zony Zapadnogo Zabaikal'ia. Ulan-Ude, 2000. P. 1-237.

101 Tashak V.I., Antonova Y.E. Paleoenvironment and peculiarities of stone industry development on Barun-Alan-1 site (Western Transbaikal) // Quaternary International. 2015. Vol.355. P. 126-133.

102 Kimura $H$. The blade industry of the Malta site // Archaeology, Ethnology \& Anthropology of Eurasia. 2003. No. 1 (13). P.11-33.

103 Abramova Z. A. Klinovidnye nukleusy v paleolite Severnoi Azii. P. 14-16.

104 See: Derevianko A.P., Shunkov M.V., Agadzhanian A.K., Baryshnikov G.F., Malaeva E.M., Ulianov V.A., Kulik N.A., Postnov A.A., Anoikin A.A. Prirodnaia sreda i chelovek v paleolite Gornogo Altaia. P.224-235; Derevianko A.P., Volkov P. V. Evolution of lithic reduction technology in the course of the Middle to Upper Paleolithic transition in the Altai Mountains. P.31-35; Keates S. G. Microblade technology in Siberia and neighbouring regions: an overview // Origin and spread of microblade technology in Northern Asia and North America. Burnaby, 2007. P. 125-146; Kuzmin Y. V. Geoarchaeological aspects of the origin and spread of microblade technology in Northern and Central Asia // Origin and spread of 


\section{Discussion}

The following spatiotemporal patterns in northern and eastern Asia can now be proposed (see Table 1, Fig. 6). The earliest evidence of microblade technology is known from the two microblade complexes on the Korean Peninsula, Shinbuk and Jangheung-ri, and can be placed at ca. 25,500-24,200 BP.

After examining the spatiotemporal features of the earliest microblade assemblages in northern and eastern Asia, we suggest two possible scenarios for the emergence of microblade technology: 1) invention and diffusion from a single core area; and 2) independent creation in several places and expansion from them.

The early dates from Korea and the later ages for other early microblade technology sites (in Siberia, the Russian Far East, China and Japan) suggest that an origin of this technology in the northeast Asian region may point to a single 'core area' (i.e., Korea). The increasing regularity (standardization) and higher lithic numbers at the later sites would appear to support this scenario, that is, progressive sophistication of knapping technology to manufacture increasingly more refined and numerous specimens. Several scholars are in favor of a single core area, with the Altai Mountains as the place of origin for microblade technology ${ }^{105}$.

In northern and eastern Asia, pressure flaking may have its origin in regions where narrow-faced core technology developed, and these are Siberia, Mongolia, Korea, and Ja$\operatorname{pan}^{106}$. Tortsovy cores (i. e., a kind of narrow-faced core) have not been identified in China. It therefore seems possible that microblade technology was invented in several places. We can provisionally suggest at least three centers of origin: Korea, Yakutia (as part of Siberia), and Hokkaido (Fig. 6).

At least one of these centers (most probably, Korea) may be responsible for the appearance of microblade technology in North China. This is supported by the non-existence of blades in North China before the emergence of microblades ${ }^{107}$. The proposed early

microblade technology in Northern Asia and North America. Burnaby, 2007. P.115-124; Yi M., Gao X., Li F., Chen F. Rethinking the origin of microblade technology: a chronological and ecological perspective. P.135-136; Terry K., Buvit I., Kontsantinov M. V. Emergence of a microlithic complex in the Transbaikal Region of southern Siberia // Quaternary International. 2016. Vol.425. P. 88-99; Buvit I., Izuho M., Terry K., Konstantinov M. V., Konstantinov A.V. Radiocarbon dates, microblades and Late Pleistocene human migrations in the Transbaikal, Russia and the Paleo-Sakhalin-Hokkaido-Kuril Peninsula // Quaternary International. 2016. Vol. 425. P. 100-119.

105 Derevianko A.P., Volkov P. V. Evolution of lithic reduction technology in the course of the Middle to Upper Paleolithic transition in the Altai Mountains. P.31-35; Yi M., Gao X., Li F., Chen F. Rethinking the origin of microblade technology: a chronological and ecological perspective. Quaternary International, 2016, vol.400, pp.130-139; Terry K., Buvit I., Kontsantinov M. V. Emergence of a microlithic complex in the Transbaikal Region of southern Siberia. P.92-99; Buvit I., Izuho M., Terry K., Konstantinov M. V., Konstantinov A.V. Radiocarbon dates, microblades and Late Pleistocene human migrations in the Transbaikal, Russia and the Paleo-Sakhalin-Hokkaido-Kuril Peninsula. P. 105-119.

106 Rybin E. P. Middle and Upper Paleolithic interactions and the emergence of modern behavior in Southern Siberia and Mongolia // Emergence and diversity of modern human behavior in Paleolithic Asia. College Station TX, 2015. P.470-480; Lee G.-K.: 1) Characteristics of Paleolithic industry in southwestern Korea during MIS 3 and MIS 2 // Quaternary International. 2012. Vol.248. P. 12-20;2) The characteristics of Upper Paleolithic industry in Korea // Emergence and diversity of modern human behavior in Paleolithic Asia. College Station, 2015. P.270-280; Ono A., Yamada M. The Upper Palaeolithic of the Japanese Islands: an overview // Archeometriai Mühely. 2012. Vol.9, iss. 4. P.219-226.

107 Yi M., Gao X., Li F., Chen F. Rethinking the origin of microblade technology: a chronological and ecological perspective. P. 133-136. 
presence of blade technology at the Shuidonggou 1 and 2 sites at ca. 36,300-29,800 BP 108 requires further chronological research because the current evidence for this age is questionable $\mathrm{e}^{109}$.

For the mainland Russian Far East with the oldest microblade assemblage dated to ca. 19,400 BP, it is plausible to suggest that the Korean 'center' was responsible for the appearance of microblade technology in the Amur River basin (Ust'-Ul'ma 1 site; see Fig. 6) because contacts existed in the Upper Paleolithic between Korea and the Russian Far East as testified by the exchange of obsidian ${ }^{110}$.

The Siberian region of Yakutia with its relatively old microblade assemblage at the Khayrgas site (dated to ca. 20,700 BP) could have served as a core area for the southern Siberian regions of Transbaikal, and the Angara and Yenisei River basins (Fig. 6).

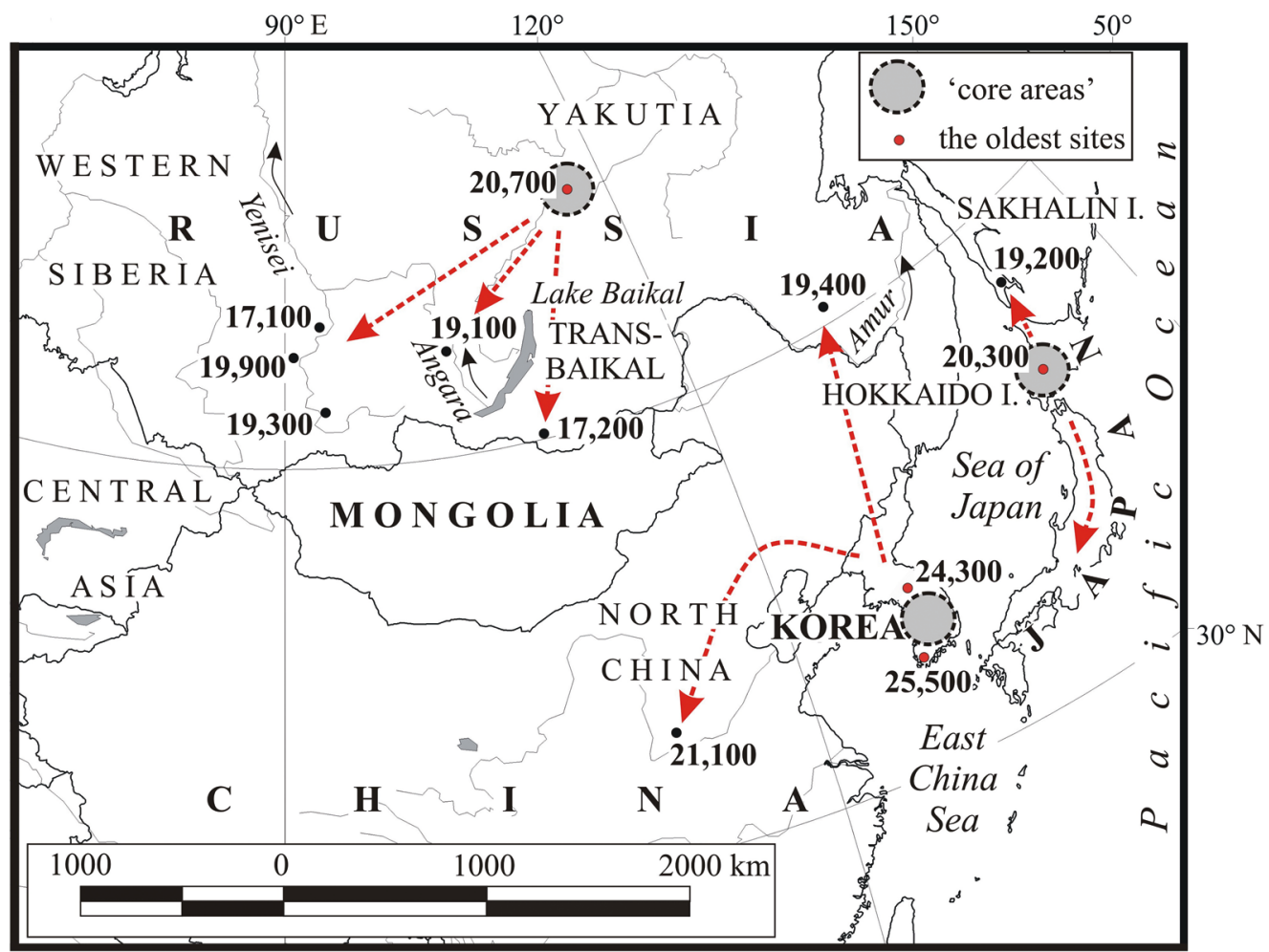

Fig. 6. Spatiotemporal patterns of the earliest microblade complexes in northern and eastern Asia, and possible ways of spread of microblade technology from three 'core areas'. Numbers correspond to the uncalibrated ${ }^{14} \mathrm{C}$ dates for each key site (see Table 1 ) (created by authors)

${ }^{108}$ Li F., Gao X., Chen F., Pei S., Zhang Y., Zhang X., Liu D., Zhang S., Guan Y., Wang H., Kuhn S.L. The development of Upper Palaeolithic China: new results from the Shuidonggou site // Antiquity. 2013. Vol. 87, iss. 336. P. 368-381.

109 See: Keates S. G., Kuzmin Y. V. Shuidonggou localities 1 and 2 in northern China: archaeology and chronology of the Initial Upper Palaeolithic in north-east Asia // Antiquity. 2015. Vol. 89, iss. 345. P.716-720; Li F., Kuhn S. L., Gao X. A response to Keates and Kuzmin // Antiquity. 2015. Vol. 89, iss. 345. P. 722-723.

${ }^{110}$ Kuzmin Y. V. Obsidian as a commodity to investigate human migrations in the Upper Paleolithic, Neolithic, and Paleometal of Northeast Asia // Quaternary International. 2017. Vol.442. P. 5-10. 
The ca. 20,700 BP old microblade technology at the Kashiwadai 1 site on Hokkaido is older than the microblade assemblages from Honshu Island (ca. 14,250 BP) and Kyushu Island (ca. 16,000 BP) ${ }^{111}$. The Kashiwadai 1 wedge-shaped cores and microblades are very standardized and advanced. For Sakhalin Island (Ogonki 5 site), Hokkaido is the most probable source area for the introduction of microblade technology (Fig. 6). The exchange of raw material (obsidian) is known to have existed between these regions since ca. $19,200 \mathrm{BP}^{112}$.

The proposal that microblade technology was introduced to Hokkaido from the Altai and possibly Transbaikal via Mongolia, and to Transbaikal from Hokkaido via Sakhalin and the Russian Far East ${ }^{113}$, ignores the evidence from the Korean Peninsula. It can also not account for the lack of sites between Hokkaido and Mongolia because of the absence of microblade complexes south of Hokkaido within the Japanese archipelago (Kyushu and Honshu islands) where around 13,670 Paleolithic sites are known ${ }^{114}$. There is also no reliable evidence for human migration from Hokkaido Island to the Transbaikal via Sakhalin Island and mainland Russian Far East ${ }^{115}$.

With regard to misinterpretations and misrepresentations of our views in terms of the age and origin of microblade technology, three recent cases deserve attention. O. BarYosef ${ }^{116}$ states that "...the early pottery examples from Japan and from eastern Siberia are found in the context of microblade industries, the origin of which is currently attributed to northern China", with reference to our volume ${ }^{117}$. However, this book ${ }^{118}$ does not contain any information about northern China as the place for the origin of microblade complexes, and Bar-Yosef's opinion is a plain misrepresentation ${ }^{119}$.

It is stated that "...the Lake Baikal region of Siberia was the cradle of microblade technology..." ${ }^{120}$, citing our work ${ }^{121}$. There are no claims in these publications that Lake Baikal

111 Sato H., Tsutsumi T. The Japanese microblade industries: technology, raw material procurement, and adaptations. P. 17-25; Iwase A. A functional analysis of the LGM microblade assemblage in Hokkaido, northern Japan: A case study of Kashiwadai 1 // Quaternary International. 2016. Vol. 425. P. 140-152.

112 Kuzmin Y.V. Obsidian as a commodity to investigate human migrations in the Upper Paleolithic, Neolithic, and Paleometal of Northeast Asia. P.7-10.

113 Buvit I., Izuho M., Terry K., Konstantinov M. V., Konstantinov A. V. Radiocarbon dates, microblades and Late Pleistocene human migrations in the Transbaikal, Russia and the Paleo-Sakhalin-Hokkaido-Kuril Peninsula. P. 106-119.

114 Palaeolithic sites in the Japanese Islands: A database / Japanese Palaeolithic Research Association. Tokyo, 2010. P. 1-312.

${ }^{115}$ Kuzmin Y.V. Comment on "Radiocarbon dates, microblades and Late Pleistocene human migrations in the Transbaikal, Russia and the Paleo-Sakhalin-Hokkaido-Kuril Peninsula" by Buvit I., Izuho M., Terry K., Konstantinov M. V. and Konstantinov A. V. (Quaternary International, 425, 100-119) // Quaternary International. 2017. Vol. 436. P. 171-172.

116 See: Taylor R. E., Bar-Yosef O. Radiocarbon dating: An archaeological perspective. Walnut Creek, CA, 2014. P. 196.

117 Origin and spread of microblade technology in Northern Asia and North America / eds Y. V. Kuzmin, S. G. Keates, C. Shen. Burnaby, 2007. P. 1-222.

118 Ibid.

119 See also: Kuzmin Y.V. Radiocarbon and Archaeology - Long-Term Alliance: Review of R. E. Taylor, O. Bar-Yosef. Radiocarbon Dating: An Archaeological Perspective. $2^{\text {nd }}$ ed. Walnut Greek, 2014 // Radiocarbon. 2016. Vol.58, iss. 3. P.iii-vi.

${ }^{120}$ Nian X., Gao X., Xie F., Mei H., Zhou L. Chronology of the Youfang site and its implications for the emergence of microblade technology in North China. P. 113.

${ }^{121}$ Kuzmin Y.V. Geoarchaeological aspects of the origin and spread of microblade technology in Northern and Central Asia. P.115-124; Keates S. G. Microblade technology in Siberia and neighbouring 
was a possible place for the origin of microblade technique ${ }^{122}$. X. Nian and coauthors ${ }^{123}$ do not cite the right reference for S.G. Keates ${ }^{124}$, instead referring to another paper ${ }^{125}$ which is not relevant to the issue of the origin of microblade technology. In contrast to this, it was stated that "...it is possible to conclude that the earliest evidence of microblade technology is now known from the Altai Mountains region of southern Siberia, dated to c. 35,000 BP..." ${ }^{126}$. We have no idea how Nian and coauthors ${ }^{127}$ arrived at these opposite conclusions.

Although Buvit et al. (2016) assume that the earliest microblades in the Altai are dated to more than 41,000 calendar years ${ }^{128}$, citing our work ${ }^{129}$ as one of the sources, it does not reflect what was actually published ${ }^{130}$.

\section{Conclusions}

After a critical review of the earliest microblade complexes in northern and eastern Asia, it seems clear that we cannot solve the issue of the appearance of microblade technology, but only come closer toward identifying its origin and spread. It is certain that there are strengths and weaknesses for each of the major scenarios for the emergence of the regional microblade assemblages.

In some cases, migration may explain the occurrence of microblades at sites dated after the initial or oldest finds in Korea. Thus, a "single origin scenario" would reflect the spatiotemporal patterns of the spread of the technology. However, there are large geographic gaps where no microblade sites have been reported. This prevents us from creating a more detailed picture of microblade origin(s). Alternatively, a "multiple origin scenario" could be the mechanism responsible for the emergence of microblade technology at ca.

regions: an overview // Origin and spread of microblade technology in Northern Asia and North America. P. $125-145$.

122 Keates S. G. Microblade technology in Siberia and neighbouring regions: an overview. Origin and spread of microblade technology in Northern Asia and North America / eds Y. V.Kuzmin, S. G. Keates, C. Shen. Burnaby, B.C. (Canada), Archaeology Press. 2007. P.125-146; Kuzmin Y. V. Geoarchaeological aspects of the origin and spread of microblade technology in Northern and Central Asia. Origin and spread of microblade technology in Northern Asia and North America / eds Y. V. Kuzmin, S. G. Keates, C. Shen. Burnaby, B. C. (Canada). Archaeology Press. 2007. P. 115-124..

${ }^{123}$ Nian X., Gao X., Xie F., Mei H., Zhou L. Chronology of the Youfang site and its implications for the emergence of microblade technology in North China. P. 114.

124 Keates S. G. Microblade technology in Siberia and neighbouring regions. P. 125-144.

125 Keates S. G., Hodgins G.W.L., Kuzmin Y.V., Orlova, L.A. First direct dating of a presumed Pleistocene hominid from China: AMS radiocarbon age of a femur from the Ordos Plateau // Journal of Human Evolution. 2007. Vol. 53, iss. 1. P.1-4.

126 Kuzmin Y.V. Geoarchaeological aspects of the origin and spread of microblade technology in Northern and Central Asia. P. 123.

127 Nian X., Gao X., Xie F., Mei H., Zhou L. Chronology of the Youfang site and its implications for the emergence of microblade technology in North China. P. 115.

128 Buvit I., Izuho M., Terry K., Konstantinov M. V., Konstantinov A. V. Radiocarbon dates, microblades and Late Pleistocene human migrations in the Transbaikal, Russia and the Paleo-Sakhalin-Hokkaido-Kuril Peninsula. P. 100.

129 Keates S. G. Microblade technology in Siberia and neighbouring regions: an overview // Origin and spread of microblade technology in Northern Asia and North America. P. 125-144.

130 See details: Kuzmin Y. V. Comment on "Radiocarbon dates, microblades and Late Pleistocene human migrations in the Transbaikal, Russia and the Paleo-Sakhalin-Hokkaido-Kuril Peninsula" by Buvit I., Izuho M., Terry K., Konstantinov M. V. and Konstantinov A. V. (Quaternary International, 425, 100-119) // Quaternary International, 2017. Vol.436. P.170-172. 
25,500 BP and later, at ca. 24,300-20,300 BP. The inhabitants of the earliest microblade sites, i. e. in Korea, may have invented the technology independently. A major problem in resolving this is the lack of any microblade-containing localities between the earliest 'core areas' in the geographically distant regions (Fig. 6).

The continuation of research in the northern and eastern regions of Asia will bring new knowledge on the Upper Paleolithic allowing a more detailed examination of the issue. The selection of sites presented in this paper (see Table 1) can be used as a basic source for future research.

\section{References}

Abramova Z. A. Krasnyi Iar - a new Palaeolithic site on the Angara. Arctic Anthropology, 1965, vol.3, issue 1 , pp. 122-128.

Abramova Z. A. O vozraste paleolita Aldana. Sovetskaia Arkheologiya, 1979, no. 4, pp. 5-14. (In Russian).

Abramova Z. A. Klinovidnye nukleusy v paleolite Severnoi. Paleolit i neolit. Ed. by V. P. Lyubin. Leningrad, Nauka, 1986, pp.11-16. (In Russian).

Abramova Z. A. Paleolit Severnoi Azii. Paleolit Kavkaza i Severnoi Azii. Ed. by P. I. Boriskovsky. Leningrad, Nauka, 1989, pp. 145-243. (In Russian).

Akazawa T., Oda S., Yamanaka I. The Japanese Palaeolithic: A techno-typological study. Tokyo, Rippu Shobo, 1980, $243 \mathrm{p}$.

Akimova E. V., Drozdov N.I., Laukhin S.A., Chekha V.P., Orlova L.A., Koltsova V.G., Sanko A.F., Shpakova E. G. Paleolit Yeniseia. Listvenka. Krasnoiarsk, Univers Press, 2005, 184 p. (In Russian).

An Z. Carbon-14 dating and its problems of the Late Paleolithic in China. Acta Anthropologica Sinica, 1983, vol. 2, iss. 4, pp. 342-351. (In Chinese with English abstract).

An Z. Radiocarbon dating and the Neolithic period of China. Kaogu, 1984, no. 3, pp. 271-277. (In Chinese with English title).

Blong R. J., Gillespie R. Fluvially transported charcoal gives erroneous ${ }^{14} \mathrm{C}$ ages for recent deposits. Nature, 1978, vol.271, iss. 5647, pp. 739-741.

Buvit I., Izuho M., Terry K., Konstantinov M. V., Konstantinov A.V. Radiocarbon dates, microblades and Late Pleistocene human migrations in the Transbaikal, Russia and the Paleo-Sakhalin-Hokkaido-Kuril Peninsula. Quaternary International, 2016, vol.425, pp. 100-119.

Buvit I., Waters M. R., Konstantinov M. V., Konstantinov A. V. Geoarchaeological investigations at Studenoe, an Upper Paleolithic site in the Transbaikal region, Russia. Geoarchaeology, 2003, vol.18, iss.6, pp. 649-673.

Chen C., Wang X.-Q. Upper Paleolithic microblade industries in North China and their relationships with Northeast Asia and North America. Arctic Anthropology, 1989, vol. 26, iss. 2, pp. 127-156.

Darvill T. The concise Oxford dictionary of archaeology. Oxford, Oxford University Press, 2003, 506 p.

Derevianko A.P., Shunkov M.V., Agadjanian A.K., Baryshnikov G.F., Malaeva E. M., Ulianov V.A., Kulik N.A., Postnov A.V., Anoikin A.A. Prirodnaia sreda $i$ chelovek v paleolite Gornogo Altaia. Novosibirsk, Institute of Archaeology \& Ethnography, 2003, 448 p. (In Russian).

Derevianko A.P., Volkov P. V. Evolution of lithic reduction technology in the course of the Middle to Upper Paleolithic transition in the Altai Mountains. Archaeology, Ethnology \& Anthropology of Eurasia, 2004, no. 2(18), pp. 21-35.

Derevianko A.P., Zenin V.N. Paleolit Selemdzhi. Novosibirsk, Institute of Archaeology \& Ethnography, 1995, 160 p. (In Russian).

El-Daoushy F., Eriksson M. G. Radiometric dating of recent lake sediments from a highly eroded area in semiarid Tanzania. Journal of Paleolimnology, 1998, vol. 19, iss. 4, pp.377-384.

Flenniken J. J. The Paleolithic Dyuktai pressure blade technique of Siberia. Arctic Anthropology, 1987, vol. 24, iss. 2, pp. 117-132.

Gillespie R., Brook B. Is there a Pleistocene archaeological site at Cuddie Springs? Archaeology in Oceania, 2006, vol. 41, iss. 1, pp. 1-11.

Gladyshev S., Tabarev A., Olsen J. W. Origin and evolution of the Late Paleolithic microindustry in northern Mongolia. Current Research in the Pleistocene, 2010, vol.27, pp.38-40. 
Gladyshev S.A., Tabarev A.V. Mikroplastinchatoe rascheplenie v rannem verkhnem paleolite Mongolii. Stratum plus, 2018, no. 1, pp.339-351. (In Russian).

Gómez Coutouly Y. A. Migrations and interactions in prehistoric Beringia: the evolution of Yakutian lithic technology. Antiquity, 2016, vol. 90, iss. 349, pp.9-31.

Gómez Coutouly Y.A. The emergence of pressure knapping microblade technology in Northeast Asia. Radiocarbon, 2018, vol.60, iss. 3, pp. 821-855.

Inizan M.-L. Pressure débitage in the Old World: Forerunners, researchers, geopolitics - handing on the baton. The emergence of pressure blade making. Ed. by P. M. Desrosiers. New York, Springer Publ., 2012, pp. 11-42.

Inizan M.-L., Roche H., Tixier J. Technology of knapped stone. Meudon, CREP Publ., 1992, 127 p.

Iwase A. A functional analysis of the LGM microblade assemblage in Hokkaido, northern Japan: A case study of Kashiwadai 1. Quaternary International, 2016, vol. 425, pp. 140-157.

Keates S. G. Microblade technology in Siberia and neighbouring regions: an overview. Origin and spread of microblade technology in Northern Asia and North America. Eds Ya. V. Kuzmin, S. G. Keates, C. Shen. Burnaby, B. C. (Canada), Archaeology Press, 2007, pp. 125-146.

Keates S. G., Hodgins G. W. L., Kuzmin Y.V., Orlova, L. A. First direct dating of a presumed Pleistocene hominid from China: AMS radiocarbon age of a femur from the Ordos Plateau. Journal of Human Evolution, 2007, vol.53, iss. 1, pp.1-5.

Keates S. G., Kuzmin Y. V. Shuidonggou localities 1 and 2 in northern China: archaeology and chronology of the Initial Upper Palaeolithic in north-east Asia. Antiquity, 2015, vol. 89, iss. 345, pp. 714-720.

Khatsenovich A. M. Rannie etapy verkhnego paleolita Severnoi Mongolii. Unpublished Candidate of Sciences Dissertation. Novosibirsk, Institute of Archaeology and Ethnography, 2018. 287 p. (In Russian).

Kimura H. The blade industry of the Malta site. Archaeology, Ethnology \& Anthropology of Eurasia, 2003, no. 1 (13), pp. 11-33.

Kipfer B. A. Dictionary of artifacts. Singapore, Blackwell Publ., 2007, 349 p.

Konstantinov A. V. Drevnie zhilishcha Zabaikal'ia (paleolit, mezolit). Novosibirsk, Nauka, 2001, 224 p. (In Russian).

Kuzmin Y. V. Geoarchaeological aspects of the origin and spread of microblade technology in Northern and Central Asia. Origin and spread of microblade technology in Northern Asia and North America. Eds Y. V. Kuzmin, S. G. Keates, C. Shen. Burnaby, B. C. (Canada), Archaeology Press, 2007, pp. 115-124.

Kuzmin Y.V. Radiocarbon and Archaeology - Long-Term Alliance: Review of R.E. Taylor, O. Bar-Yosef. Radiocarbon Dating: An Archaeological Perspective. $2^{\text {nd }}$ ed. Walnut Greek, Left Coast Press., 2014. Radiocarbon, 2016, vol. 58, iss. 3, pp.iii-vii.

Kuzmin Y. V. Obsidian as a commodity to investigate human migrations in the Upper Paleolithic, Neolithic, and Paleometal of Northeast Asia. Quaternary International, 2017, vol. 442, pp. 5-11.

Kuzmin Y.V. Comment on "Radiocarbon dates, microblades and Late Pleistocene human migrations in the Transbaikal, Russia and the Paleo-Sakhalin-Hokkaido-Kuril Peninsula" by Buvit I., Izuho M., Terry K., Konstantinov M.V.and Konstantinov A.V.(Quaternary International, 425, 100-119). Quaternary International, 2017, vol.436, pp.170-172.

Kuzmin Y. V., Jull A. J. T., Razgildeeva I. I. Chronology of the Upper-Paleolithic site Studenoe 2 (Transbaikal, Siberia): case study of the multi-hearth dwelling in horizon 4/5. Current Research in the Pleistocene, 2004, vol.21, pp. 6-7.

Kuzmin Y.V., Keates S. G. Dates are not just data: Paleolithic settlement patterns in Siberia derived from radiocarbon records. American Antiquity, 2005, vol.70, iss. 4, pp. 773-789.

Kuzmin Y.V., Keates S. G. Dynamics of Siberian Paleolithic complexes (based on analysis of radiocarbon records): the 2012 state-of-the-art. Radiocarbon, 2013, vol. 55, iss. 2-3, pp. 1314-1321.

Kuzmin Y. V., Kosintsev P. A., Stepanov A. D., Boeskorov G. G., Cruz R. J. Chronology and faunal remains of the Khayrgas Cave (Eastern Siberia, Russia). Radiocarbon, 2017, vol.59, iss. 2, pp. 575-582.

Kuzmin Y. V., Orlova L. A. Radiocarbon chronology of the Siberian Paleolithic. Journal of World Prehistory, 1998, vol. 12, iss. 1, pp. 1-53.

Kuzmin Y. V., Orlova L. A., Zenin V.N., Lbova L. V., Dementiev V.N. Radiouglerodnoe datirovanie paleolita Sibiri i Dalnego Vostoka Rossii: materialy k katalogu ${ }^{14} \mathrm{C}$ dat (po sostoianiiu na konets 2010 g.). Stratum plus, 2011, no. 1, pp. 171-200. (In Russian).

Lbova L. V. Paleolit severnoi zony Zapadnogo Zabaikal'ia. Ulan-Ude, Buryat Scientific Center, 2000, 237 p. (In Russian).

Lee G.-K. Characteristics of Paleolithic industry in southwestern Korea during MIS 3 and MIS 2. Quaternary International, 2012, vol.248, pp. 12-21. 
Lee G.-K. The characteristics of Upper Paleolithic industry in Korea. Emergence and diversity of modern human behavior in Paleolithic Asia. Eds Y. Kaifu, M. Izuho, T. Goebel, H. Sato, A. Ono. College Station, TX, Texas A\&M University Press, 2015, pp. 270-286.

Li F., Gao X., Chen F., Pei S., Zhang Y., Zhang X., Liu D., Zhang S., Guan Y., Wang H., Kuhn S.L. The development of Upper Palaeolithic China: new results from the Shuidonggou site. Antiquity, 2013, vol. 87, iss. 336, pp.368-383.

Li F., Kuhn S. L., Gao X. A response to Keates and Kuzmin. Antiquity, 2015, vol. 89, iss. 345, pp.721-723.

Lisitsyn N.F. Pozdny paleolit Chulymo-Yeniseiskogo mezhdurech'ia. St. Petersburg, Peterburgskoe Vostokovedenie, 2000, 232 p. (In Russian).

Lu L.D. The microblade tradition in China: regional chronologies and significance in the transition to Neolithic. Asian Perspectives, 1998, vol. 37, iss. 1, pp. 84-112.

MacNeish R. S. A Paleolithic-Neolithic sequence from South China Jiangxi Province, PRC. Interdisciplinary perspectives on the origins of the Japanese. Ed. by K. Omoto. Kyoto, International Research Center for Japanese Studies, 1999, pp. 233-255.

Medvedev G. I. Archaeological investigations of the stratified Palaeolithic site of Krasnyi Iar on the Angara in 1964-1965. Arctic Anthropology, 1969, vol. 6, iss. 1, pp. 30-44.

Mochanov Y.A. Paleolithic finds in Siberia (resume of studies). Beringia in Cenozoic era. Ed. by V. I. Kontrimavichus. New Delhi, Amerind, 1984, pp. 694-724.

Mochanov Y. A. The earliest stages of settlement by people of Northeast Asia. Anchorage, AK, Shared Beringian Heritage Program, 2009, 286 p.

Morlan R. E. Wedge-shaped core technology in northern North America. Arctic Anthropology, 1970, vol. 7 , iss. 2, pp. 17-37.

Mourre V., Villa P., Henshilwood C. S. Early use of pressure flaking on lithic artifacts at Blombos Cave, South Africa. Science, 2010, vol.330, iss. 6004, pp. 659-662.

Nagatomo T., Shitaoka Y., Namioka H., Sagawa M., Wei Q. OSL dating of the strata at Paleolithic sites in the Nihewan Basin, China. Acta Anthropologica Sinica, 2009, vol. 28, iss. 3, pp. 276-284. (In Chinese with English abstract).

Nian X., Gao X., Xie F., Mei H., Zhou L. Chronology of the Youfang site and its implications for the emergence of microblade technology in North China. Quaternary International, 2014, vol.347, pp. 113-121.

Ono A., Sato H., Tsutsumi T., Kudo Y. Radiocarbon dates and archaeology of the Late Pleistocene in the Japanese Islands. Radiocarbon, 2002, vol. 44, iss. 2, pp. 477-494.

Ono A., Yamada M. The Upper Palaeolithic of the Japanese Islands: an overview. Archeometriai Mühely, 2012, vol.9, iss. 4, pp. 219-228.

Pitulko V. V., Pavlova E. Y. Geoarchaeology and radiocarbon chronology of Stone Age Northeast Asia. College Station, TX, Texas A\&M University Press, 2016, 222 p.

Qu T., Bar-Yosef O., Wang Y. The Chinese Upper Paleolithic: geography, chronology, and techno-typology. Journal of Archaeological Research, 2012, vol.21, iss. 1, pp. 1-73.

Razgildeeva I. I. Planigrafiia paleoliticheskogo kompleksa zapadnogo Zabaikal'ia. Arkheologicheskie Vesti, 2013, no. 19, pp. 12-25. (In Russian).

Razgildeeva I. I. Planigrafiia shestiochazhnogo kompleksa pozdnepaleoliticheskogo poseleniia Studenoe-2 v Zabaikalie. Stratum plus, 2016, no. 1, pp. 243-263. (In Russian).

Rybin E. P. Middle and Upper Paleolithic interactions and the emergence of modern behavior in Southern Siberia and Mongolia. Emergence and diversity of modern human behavior in Paleolithic Asia. Eds Y. Kaifu, M. Izuho, T. Goebel, H. Sato, A. Ono. College Station, TX, Texas A\&M University Press, 2015, pp. 470-489.

Rybin E. P., Khatsenovich A.M., Gunchinsuren B., Olsen J.W., Zwyns N. The impact of the LGM on the development of the Upper Paleolithic in Mongolia. Quaternary International, 2016, vol. 425, pp. 69-87.

Sato H., Tsutsumi T. The Japanese microblade industries: technology, raw material procurement, and adaptations. Origin and spread of microblade technology in Northern Asia and North America. Eds Y. V. Kuzmin, S. G. Keates, C. Shen. Burnaby, B. C. (Canada), Archaeology Press, 2007, pp. 17-43.

Seong C. Evaluating radiocarbon dates and Late Paleolithic chronology in Korea. Arctic Anthropology, 2011, vol. 48 , iss. 1, pp. 93-112.

Seong C. Diversity of lithic assemblages and evolution of Late Palaeolithic culture in Korea. Asian Perspectives, 2015, vol. 54, iss. 1, pp. 94-112.

Stepanov A.D, Kirillin A.S., Vorobiev S. A., Solovieva E.N., Efimov N. N. Peshchera Khayrgas na Srednei Lene (rezultaty issledovanyi 1998-1999 gg.). Drevnie kul'tury Severo-Vostochnoi Azii. Astroarkheologiia. Paleoinformatika. Ed. by A. N. Alekseev. Novosibirsk, Nauka, 2003, pp.98-113. (In Russian). 
Takakura J. Emergence and development of the pressure microblade production: a view from the Upper Paleolithic of northern Japan. The emergence of pressure blade making. Ed. by P. M. Desrosiers. New York, Springer Publ., 2012, pp. 285-306.

Tang C. The Upper Palaeolithic of North China: the Xiachuan culture. Journal of East Asian Archaeology, 2000, vol.2, pp. 37-49.

Tashak V.I., Antonova Y.E. Paleoenvironment and peculiarities of stone industry development on BarunAlan-1 site (Western Transbaikal). Quaternary International, 2015, vol.355, pp. 126-133.

Taylor R. E., Bar-Yosef O. Radiocarbon dating: An archaeological perspective. Walnut Creek, CA, Left Coast Press, 2014, $403 \mathrm{p}$.

Terry K., Buvit I., Kontsantinov M.V. Emergence of a microlithic complex in the Transbaikal Region of southern Siberia. Quaternary International, 2016, vol. 425, pp. 88-99.

The Institute of Archaeology, Chinese Academy of Social Sciences (CASS). Radiocarbon dates in Chinese archaeology, 1965-1991. Beijing, Cultural Relics Publishing House, 1991, 487 p. (In Chinese with English abstract).

The Laboratory, Institute of Archaeology, Chinese Academy of Social Sciences (CASS). Report on radiocarbon dates (V). Kaogu, 1978, no. 4, pp. 280-287. (In Chinese with English title).

Vasilev S. A. Pozdny paleolit verkhnego Yeniseia (po materialam mnogosloinykh stoianok raiona Mainy). St. Petersburg, Peterburgskoe Vostokovedenie, 1996, 225 p. (In Russian).

Vasilev S. A., Yamskikh A.F., Yamskikh G. Y., Kuzmin Y.V., Jull A.J.T. Novye dannye po khronologii i paleosrede mngosloinykh stoyanok Maininskogo reiona na Verkhnem Yenisee. Aktualnye voprosy evraziiskogo paleolitovedeniia. Eds A.P.Derevianko, M. V.Shunkov. Novosibirsk, Institute of Archaeology \& Ethnography Press, 2005, pp. 25-35. (In Russian).

Vasilev S.A., Bozinski G., Bredli B.A., Vishniatski L.B., Giria E.Y., Gribchenko Y.N., Zheltova M.N., Tikhonov A. N. Chetyrekh"iazychnyi (russko-anglo-franko-nemetskii) slovar'-spravochnik po arkheologii paleolita. St. Petersburg, Peterburgskoe Vostokovedenie, 2007, 264 p. (In Russian).

Vasilevsky A. A. Periodization and classification of the Upper Paleolithic of Sakhalin and Hokkaido in the light of the research conducted at the Ogonki-5 site. Archaeology, Ethnology \& Anthropology of Eurasia, 2003, no. 3 (15), pp. 51-69.

Wang J., Tao F., Wang Y. Preliminary report on investigation and excavation of Dingcun Palaeolithic sites. Journal of Chinese Antiquity, 1994, no. 3, pp. 1-75. (In Chinese with English title).

Wang J., Wang X., Chen Z. Xiachuan culture. Kaogu Xuebao, 1978, no.3, pp.259-288. (In Chinese with English title).

Wang Y., Qu T. New evidence and perspectives on the Upper Paleolithic of the Central Plain in China. Quaternary International, 2014, vol.347, pp. 176-182.

Wang Y.P. New evidence of modern human behavior in Paleolithic Central China. Emergence and diversity of modern human behavior in Paleolithic Asia. Eds Y. Kaifu, M. Izuho, T. Goebel, H. Sato, A. Ono. College Station, TX, Texas A\&M University Press, 2015, pp. 250-258.

Yi S, Clark G. The "Dyuktai culture" and New World origins. Current Anthropology, 1985, vol.26, iss. 1, pp. 1-20.

Yi M., Gao X., Li F., Chen F. Rethinking the origin of microblade technology: a chronological and ecological perspective. Quaternary International, 2016, vol. 400, pp. 130-139.

Zhang J.-F., Wang X.-Q., Qiu W.-L., Shelach G., Hu G., Fu X., Zhuang M.-G., Zhou L.-P. The Paleolithic site of Longwangchan in the middle Yellow River, China: chronology, paleoenvironment and implications. Journal of Archaeological Science, 2011, vol. 38, iss. 7, pp. 1537-1550.

\footnotetext{
Статья поступила в редакцию 17 марта 2018 г. Рекомендована в печать 12 марта 2019 г.

Received: March 17, 2018

Accepted: March 12, 2019
} 


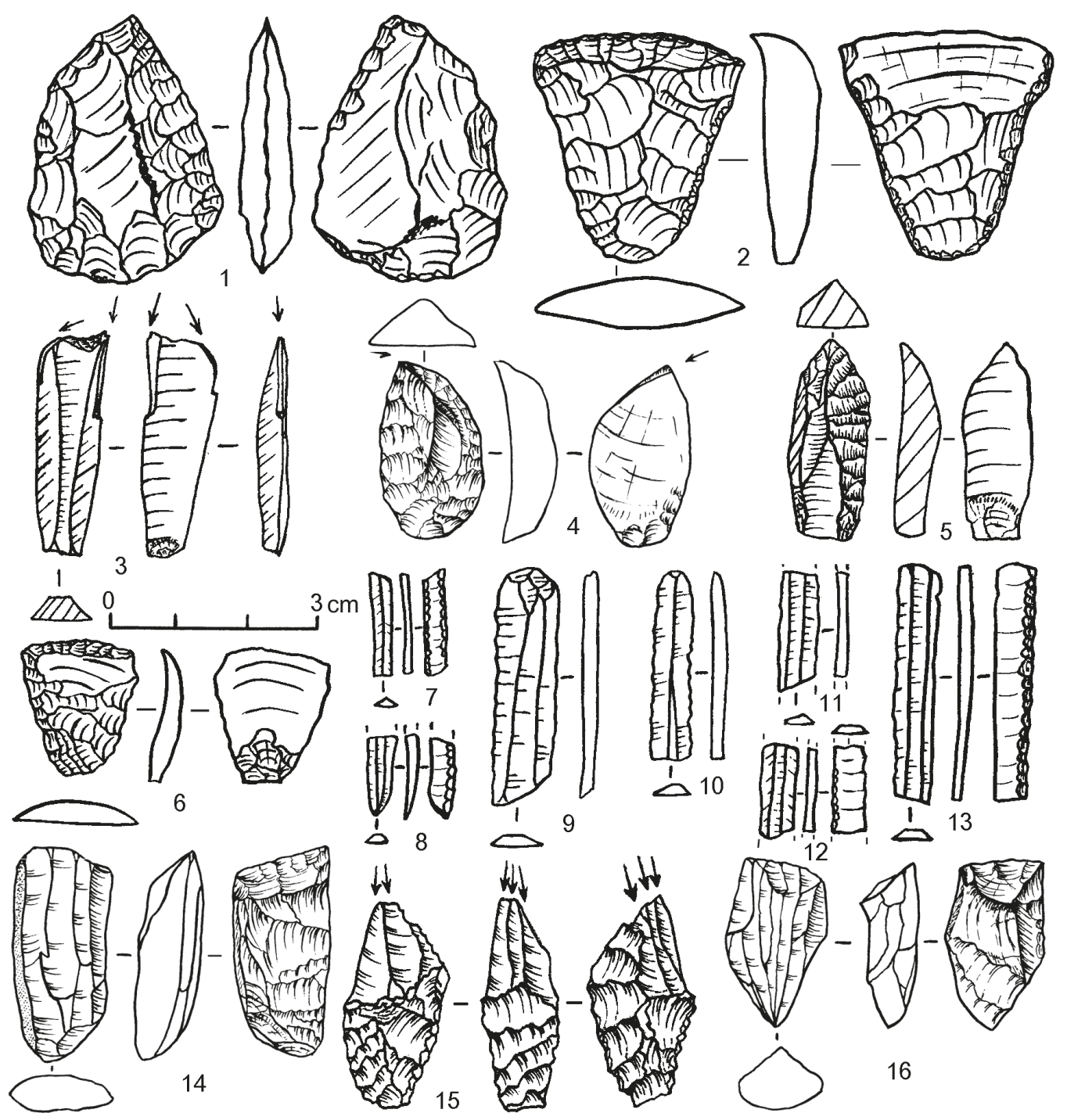

Fig. 3. Stone tools assemblage of the Middle Neolithic Kolyma sites (1-16):

1 - biface; 2, 6 - scrapers; 3 - corner burin; 4, 5 - gravers; 7-13 - microblades; $14,16-$ microblade cores; 15 - multifaceted burin (created by S. Slobodin)

Charcoal from the hearth was AMS dated to $4790 \pm 50$ (Beta-140689). The lack of any complex dwelling structures indicates that the Neolithic population was using light aboveground tents with a wooden pole frame and a skin covering, similar to the ones used by the local Even reindeer hunters to this day.

This complex is complemented by tools from the sites Nemichan and Migai, such as small leaf-shaped and triangular arrow points (some are notched and have a pointed stem); endscrapers on flakes with dorsal retouch, and on a blade with an angled working edge; conical and prismatic cores, dihedral, angle and multifaceted burins, burins on microblades, bifacially retouched oval, a ground/polished implement (see Figs 1,2). 
The raw materials include local chert, quartz crystal, and obsidian from Chukotka. Decorations consist of round flat disks-pendants. A charred bone from Migai was dated to $4470 \pm 25$ and $4190 \pm 30$ (UGAMS 20282-83).

The archaeological record of the Okhotsk-Kolyma uplands alpine tundra and woodlands indicates that the area was actively inhabited ${ }^{22}$. The geographic conditions of the uplands determined the characteristics of the deep-rooted hunting specialization of the tribes living here. Reindeer were the main prey species. Since there were no large rivers that would be obstacles for migrating reindeer herds, a different hunting technique developed here compared to that practiced by the Chukotka and Yakutia Neolithic hunters, who would dispatch reindeer at river crossings or moose in taiga ${ }^{23}$.

Despite the major role played by hunting, it does not appear to have been the only subsistence activity of the Neolithic population of Okhotsk-Kolyma uplands. Shallow headwaters of the Okhotsk watershed rivers, where chum and pink salmon migrate up to spawn, were more convenient places to fish than the river mouths since it was easier to dam the shallow stream and fish with a leister or create traps, as the local population does to this day.

The collections from sites of this region (Khurendzha-II, III, V, VI, VIII, Neel-Ustye, Kheta (upper level), Neel II, IV, Urtychuk II, III, IX, X, Elikchan Lake, and Burlakich) include prismatic, conical, and flattened cores; microblades, microblade insets retouched along one or both edges; awls on microblades and flakes; arrow points - stemmed on trilateral blade and flat triangular with straight and notched base, bifacially flaked oval and slightly pointed or subrectangular knives; large bifacial knives and spear points, truncated-lanceolate in shape; end and side scrapers of flakes, partially or fully retouched; multifaceted, dihedral burins on blades with retouched edges, and angle burins on blades; burins on microblades, beak-like burins on flakes; and a small polished adze.

Technologically and typologically, the sites in Okhotsk-Kolyma Uplands share many common traits with the Middle Neolithic cultures of Yakutia and Chukotka, but also exhibit significant originality in the types of implements. A striking feature here is the presence of flat oval ground pendants with a hole and disks up to $4 \mathrm{~cm}$ in diameter with a hole in the center made from white agalmatolite.

The timing of existence of the Khurendzha complex on the Okhotsk-Kolyma uplands is dated with assays from Khurendzha VIII $-5210 \pm 170$ (LE-3901), Khurendzha V $4530 \pm 150$ (MAG-1261), and Neel-Ustye - $4150 \pm 120$ (LE-3988), $4220 \pm 100$ (LE-4653), $4880 \pm 170$ (LE-4654), $4970 \pm 70$ (Beta-140692). Thus, the Khurendzha complex had been developing from the end of the $4^{\text {th }}$ to the end of the $3^{\text {rd }}$ millennium $\mathrm{BC}$, during the Middle Neolithic of Yakutia and Chukotka, and as such could very well have been an ASTt ancestor.

One more representative complex of chert tools, including microblades, primary spalls, beak-like burin spalls, multifaceted burins and cores, similar to the ASTt ones, was found in the Upper Kolyma region, at the Ust-Tenkeli site. The cores have one platform; the face of the core, from which microblades were removed, is located on one of the wide surfaces. The platform is tilted back significantly. The cores are 2.4 to $3.1 \mathrm{~cm}$ tall, 1.1 to

22 Slobodin S. The Upper Kolyma and Continental Priokhot'e during the Neolithic and Early Metal Periods.

${ }^{23}$ Okladnikov A.P., Mazin L.I. Pisanitsy basseina reki Aldan. Novosibirsk, 1979; Dikov N. N. Early Cultures of Northeastern Asia. 
$2 \mathrm{~cm}$ wide, 0.6 to $1.4 \mathrm{~cm}$ thick. One of the cores is made of quartz crystal. The complex may have been older that the Middle Neolithic, but similarities between it and ASTt in the core manufacturing technique are obvious.

In the middle Neolithic of the Northern Okhotsk Sea coast we see a more widespread, compared to the Early Holocene ${ }^{24}$, entry of the hunters from the interior into the coastal areas of the Okhotsk Sea. This evidence is so far scarce.

A collection of microblades and triangular points was obtained from Kukhtuy I and III sites at the mouth of the Kukhtuy River on the Okhotsk coast ${ }^{25}$. Excavations at Kukhtuy III exposed a Neolithic level, containing charcoal C14 dated to $4700 \pm 100$ (Le-995). This indicates the earliest evidence of a maritime adaptation in the Neolithic populations of the Okhotsk Sea coast.

Other evidence of continental tribes' entry onto the Northern Okhotsk Sea coast is known from the sites Malkachan 1-4, Iretskaya (Yama Bay coast in the Shelikhov Gulf), Oksa V, Vesyolaya VII, Dukcha, Alevina, Kolchakovskaya (Tauy Bay) and Gizhiga ${ }^{26}$. There, researchers have found microblades, prismatic microcores, dihedral and multifaceted burins, small triangular points, and a preform of a rectangular in cross-section adze. These artifacts have much in common with the Middle Neolithic tools from the Okhotsk-Kolyma Uplands.

The route of the continental hunters towards the Okhotsk Sea coast was along river valleys, as exemplified by the site Ola I, located $50 \mathrm{~km}$ away from the coast, in the Ola River valley. The site, located on a massive remnant of the bedrock at the mouth of a large tributary, with a great view of a large portion of the valley floor, contained microblades (some of them retouched along the edges) and small slightly notched triangular points ${ }^{27}$.

Neolithic materials from the Okhotsk-Kolyma highlands and the continental Priokhot'e region are important in the discussion of the origins of maritime cultures of the Northern Priokhot'e. Without doubt, continental tribes, which reached the Okhotsk coast in antiquity and explored the coastal ecosystems, played an important role in this process. Since the end of the first millennium BC in the Northern Priokhot'e region, the non-microblade Tokareva maritime culture had formed. The interaction between continental cultures with the developing maritime cultures in Priokhot'e and Chukotka remains unclear due to the scarcity of Neolithic sites in coastal areas.

The Middle Neolithic of the Kolyma region is characterized by the emergence of new tools, but at the same time many elements of the Early Neolithic material culture were preserved. Obtaining microblades from prismatic cores remained a widely used technique; scrapers, burins and blade inserts continued to be used, but their percentage in the toolkit gradually decreases to $10-11 \%$ of all finds. The stability of the types in the stone toolkit indicates that the subsistence style of the ancient Kolyma inhabitants did not differ significantly from the style shaped by the new environmental conditions in the Early Neolithic. Hunting remained the main subsistence activity of the population, as evidenced by the arrow points and environmental conditions of the sites, with a smaller role played by fish-

${ }^{24}$ Slobodin S. B., Anderson P. M., Glushkova O. Yu., Lozhkin A. V. Western Beringia. P. 239-298.

${ }_{25}$ Mochanov Yu. A. Drevneishie etapy zaseleniia chelovekom Severo-Vostochnoi Azii. Novosibirsk, 1977. P. 87.

${ }^{26}$ Slobodin S. The Upper Kolyma and Continental Priokhot'e during the Neolithic and Early Metal Periods. P. 9, 27-32.

27 Ibid. 
ing and small animal trapping. According to ethnographic data, the native people from Kolyma practiced hare hunting on a great scale (more than 12,000 animals per winter) in the recent past ${ }^{28}$.

During this time, the Kolyma inhabitants had developed regional networks for raw material trading, as evidenced by their use of obsidian from Krasnoye Lake (Chukotka) ${ }^{29}$.

In West Chukotka, Middle Neolithic material found at Yagodnaya site and Cape Sinitsina on Malyi Anui River included retouched microblades, stemmed points on microblades, bifacially flaked lanceolate projectile points, dihedral and multifaceted burins, scrapers, and cord ceramics ${ }^{30}$. At the Yagodnaya site, artifacts were accompanied by small fragments of reindeer bone.

The following spread of the Middle Neolithic to the Central Chukotka is observed in the Ust-Belskiy burial materials, at Anadyr River, although in general the site dates to the Late Neolithic ${ }^{31}$. First of all, these are: a stepped adze from burial 11, typical of the Belkachi culture in Yakutia ${ }^{32}$, as well as flat triangular points with asymmetric base and flattened prismatic cores, which are also present in the Middle Neolithic sites of the Kolyma region ${ }^{33}$.

The large number of microblades in the burial, which is not characteristic of the Late Neolithic Northeast Asian cultures, led Dikov to distinguish two components, early and late, in the Ust-Belskaya culture. To date the lower boundary of the early Ust-Belskaya culture complex to the beginning of the $2^{\text {nd }}$ millennium BC, Dikov ${ }^{34}$ relied on these Middle Neolithic finds, although, based on the presence of cord impressions ceramics ${ }^{35}$, they could be dated to the $3^{\text {rd }}$ millennium BC. The same ceramic was found at the Kameshki and Chikayevo sites on the Anadyr River, where it was associated with cores and microblades $^{36}$. In the Ust-Belskiy burial, there are also ground burins ${ }^{37}$, similar to the burins found in ASTt of Alaska ${ }^{38}$ and Eastern Arctic ${ }^{39}$. Thus, we should distinguish a Middle Neolithic complex of tools and ceramics (including some material from Ust-Belaya, Chikayeva and Kameshki sites) in the Anadyr River Valley. Dikov's note ${ }^{40}$ regarding the

${ }^{28}$ Khersonskiy S. O zverinykh promyslakh v Okhotskoi okruge Primorskogo Kraia // Zapiski Amurskogo otdela RGO. Khabarovsk, 1898. Vol.IV, no. I. P. 1-26.

${ }^{29}$ Yoshitany A., Slobodin S., Tomoda T., Vorobey I.E, Yano T. Studies on the obsidian fragments from the Late Palaeo-, Meso- and Neolithic Sites in the Northeastern Part of Far East of Russia // Memoir of The Museum of Archaeology of Kokugakuin Univ. Shibuta, Tokyo, 2013. No. 29. P. 1-21.

${ }^{30}$ Kiryak M. A. Arkheologiia zapadnoi Chukotki.

31 Dikov N. N. Early Cultures of Northeastern Asia.

32 Mochanov Yu. A. Mnogosloinaia stoianka Bel'kachi I i periodizatsiia kamennogo veka Iakutii.

33 Slobodin S. The Upper Kolyma and Continental Priokhot'e during the Neolithic and Early Metal Periods; Kashin V.A. Neolit Srednei Kolymy: sbornik trudov.

${ }^{34}$ Dikov N. N. Early Cultures of Northeastern Asia. P. 113.

${ }_{35}$ Dikov N.N. Archaeological Sites of Kamchatka, Chukotka, and the Upper Kolyma. Anchorage, 2003. Plate 100.

36 Ibid. Plate $95-98$.

37 Ibid. Plate 98 (17).

38 Giddings J.L. The archeology of Cape Denbigh. Providence, 1964. P.237; Anderson D.D. The Denbigh Flint Complex in Northwest Alaska: A Spatial Analysis // Alaska Journal of Anthropology. 2005. Vol.3, no. 2. P.90;

39 Sorensen M. Technology and tradition in the Eastern Arctic, 2500 BC-AD 1200: a dynamic technological investigation of lithic assemblages from the Palaeo-Eskimo traditions of Greenland. Copenhagen, 2012.

40 Dikov N. N. Early Cultures of Northeastern Asia. P. 104. 
spread of the cord ceramics into the Anadyr River Basin indicates that he was also inclined to support this model.

On the Chukchi Peninsula, Dikov identified as Middle Neolithic such sites as Naulyngytgyn II and III, Igelkhveyem VIII, XV, and XIV, Tymkyrylen I and II, Tyerkemkyn and others containing ceramics, microblades, and prismatic and conical cores ${ }^{41}$. A radiocarbon sample from Terkemkyn dates the site to $4580 \pm 40$ BP (LE-2661) ${ }^{42}$.

The material discussed here provide evidence for the development of a powerful cultural formation with a high potential in Northeast Asia at the end of the Atlantic and the beginning of the Subboreal periods of the Holocene (its warm phase at 6000-5000 BP). The center of this formation's origin was Yakutia, where at the time the Belkachi Middle Neolithic culture existed. Its local variants spread to the east of the Verkhoyanskiy Range.

Technologically, inhabitants of that time used a sophisticated microblade and inset technology, had a mobile toolkit, which included a wide range of various small chert and bone tools, and demonstrated a high level of adaptability and survival in the harsh Arctic conditions. They explored all types of landscapes, including coastal regions of the Okhotsk Sea. They possessed energy sufficient to transmit a strong cultural signal (most likely by way of direct migration) through the Bering Strait to Alaska, where they gave rise to the Arctic Small Tool tradition, which later spread through the entire American Arctic.

\section{ASTt in Alaska}

Many researchers posit that the Neolithic traditions of Kolyma and Chukotka spread into Alaska and North Canada around 5000 years ago, where they gave rise to the Arctic Small Tool tradition ${ }^{43}$. Genetic data also point to Asian origins of the ancient inhabitants of Arctic Alaska, Canada and Greenland ${ }^{44}$.

Originally, ASTt material was distinguished as the Denbigh Flint Complex (culture; DFC) by J. L. Giddings in 1948 when he was studying a specialized tool complex found in the lowest culture-bearing sediments at Iyatayet, on Cape Denbigh in the Norton Sound (Northwest Alaska) ${ }^{45}$. In a thin, intermittent cultural layer, covered with the ceramics and other artifacts from the 2500-year-old Norton culture, he found a complex consisting of only stone tools, noticeably small in size (on average, $4 \mathrm{~cm}$ long), meticulously covered by tiny, uniform, parallel or oblique-parallel pressure flaking. The toolkit included microcores, microblades, unihedral and polyhedral burins, flake knives (beak-like), gravers with polished blades, flat bifacially flaked triangular and leaf-shaped projectile points for arrows, darts and harpoons, asymmetrical lanceolate insets, end scrapers on flakes, and others.

41 Dikov N.N. Asia at the Juncture with America in Antiquity. P. 33-83.

42 Ibid. P. 38-40.

43 Powers W. R., Jordan R. H. Human biogeography and climate change in Siberia and Arctic North America in the fourth and fifth millennia BP // Philosophical Transactions of Royal Society of London. Series A, Mathematical and Physical Sciences. 1990. Vol.330, no. 1615. P.665-670; Hoffecker J.F. A Prehistory of the north: human settlement of the higher latitudes. New Brunswick, NJ, 2005. P. 125-129; Mochanov Yu. A. Mnogosloinaia stoianka Bel'kachi I i periodizatsiia kamennogo veka Iakutii; Dumond D. E. The Eskimo and Aleuts; McGhee R. Ancient People of the Arctic. Vancouver, 1996.

44 Raghavan M., DeGiorgio M., Albrechtsen A. et al. The Genetic Prehistory of the New World Arctic // Science. 2014. No. 345, iss. 6200. P. 1255832; Rasmussen M. et al. Ancient human genome sequence of an extinct Palaeo-Eskimo // Nature, 2010. Vol.463. P.757-762.

45 Giddings J. L. The archeology of Cape Denbigh. P. 191-270. 
No bone tools were found at the site, but their use was indirectly indicated by the stone tools, which were mostly insets to be used in bone tools. In addition, the site was located near the sea, and the discovery of small seal bones in the same layer as the tools suggested that the inhabitants had the harpoon technology and hunted marine mammals. Small flat triangular points were identified as harpoon end-blades ${ }^{46}$. Large numbers of smaller lanceolate projectile points at ASTt sites implies that these hunters used bow-andarrow technology ${ }^{47}$.

The history of dating the DFC is a complicated one. Based on the Iyatayet stratigraphy and the artifact provenance, Beringia geologist D. Hopkins and Giddings suggested, in their book, that the complex could be $8500-12,000$ years old ${ }^{48}$. They had technological and typological basis to think so: Denbigh microblades and wedge cores were compared to the Campus site materials, which were dated to the Late Pleistocene - early Holocene ${ }^{49}$, while the microcores of Greenland's Suqqaq complexes and ASTt cores from the Matcharak Lake site are even today described as "wedge-shaped," manufactured using the Yubetshu and Horoko techniques ${ }^{50}$.

When the C-14 results showed that Denbigh is no more than $4000-5000$ years old ${ }^{51}$, Hopkins and Giddings tried to correct this information in the book, but were told that the book was already in press and the text could not be changed (D. Hopkins, pers. comm., 1999). Nonetheless, Giddings did not immediately accept the radiocarbon dates he obtained pointing out that the real age of the Denbigh complex had not yet been established ${ }^{52}$ and drawing parallels between the Denbigh microblades and the Trail Creek Complex dated to around $6000{ }^{14} \mathrm{C}$ years ${ }^{53}$, although the association of this date with the artifacts is doubtful ${ }^{54}$. Hopkins, based on the C-14 dates, believed that «...the age of DFC is more than 4200 and less than 5000 years ${ }^{55}$. In reality, as we now know, Denbigh Flint complex is even younger.

Ten years after the DFC was discovered at Iyatayet, in the late 1950s, W. Irving noted typological similarities between the sites in the Brooks Range (Imaigenik) and the south side of the Alaskan Range (Susitna River valley) with the characteristic Denbigh toolkit items, and combined these sites into the Arctic Small Tool tradition (ASTt) ${ }^{56}$. Irving em-

${ }^{46}$ Giddings J.L. The archeology of Cape Denbigh. P. 233.

${ }^{47}$ Ibid. P. 232.

${ }^{48}$ Hopkins D.M., Giddings J.L. Geological background of the Iyatayet archaeological Site, Cape Denbigh, Alaska // Smithsonian Miscellaneous Collection. Vol.121, no. 11. Washington D. C., 1953. P. 29.

49 Giddings J. L. The archeology of Cape Denbigh. P. 203, 206; Nelson N. C. Notes on cultural relations between Asia and America // American Antiquity. 1937. Vol.2, no. 2. P.267-272.

50 Tremayne A. H. The Design of Arctic Small Tool Tradition Toolkits: An Example from Matcharak Lake, Alaska // North American Archaeologist. 2015. Vol.36. P. 1-31; Sorensen M. Technology and tradition in the Eastern Arctic, 2500 BC-AD 1200. P. 120.

51 Giddings J. L. The archeology of Cape Denbigh. P. 244-250.

52 Giddings J.L. The Denbigh Flint Complex is Not Yet Dated // American Antiquity. 1955. Vol.20, no. 4. P. 375-376.

53 Giddings J. L. The archeology of Cape Denbigh. P.252, 270.

${ }^{54}$ Larsen H. Trail Creek: Final Report on the Excavation of Two Caves on Seward Peninsula, Alaska // Acta Arctica. Vol. XV. Copenhagen, 1968. P.71; Slaughter D. C. Radiocarbon dating the Arctic Small Tool tradition in Alaska // Alaska Journal of Anthropology. 2005. Vol. 3, no. 2. P. 117-134.

55 Giddings J. L. The archeology of Cape Denbigh. P. 248.

${ }^{56}$ Irving W. N.: 1) Evidence of early tundra cultures in northern Alaska // Anthropological Papers of the University of Alaska. 1953. Vol. 1, no.2. P. 55-85; 2) An archaeological survey of the Susitna Valley // Anthropological Papers University of the Alaska. 1957. Vol. 6, no. 1. P.37-52. 
phasized that the ASTt name signaled a difference between the Northern Alaskan sites of the Denbigh complex from the microblade complexes of the Northern Microblade Tradition (Campus and Pointed Mountain) ${ }^{57}$ in the taiga zones of the Central and Southern Alaska and Yukon ${ }^{58}$.

At the same time, in the Canadian Arctic and Greenland, researchers examined a number of sites, grouped into Independence I, Pre-Dorset, Saqqaq cultures, which revealed typologico-technological and chronological similarities with the Alaskan sites ${ }^{59}$.

Irving finished formulating the idea of the ASTt tradition and culture in 1962 after excavating the Punyik Point site (Etivlik Lake) in the central Brooks Range, where he found a typical Denbigh toolkit. He noticed similarities between the tool complexes in the sites in Northern Alaska, Northern Canada and Greenland dating to 4500-2500 years ago and included them into the $\mathrm{ASTt}^{60}$. He noted that "no single trait is known with certainty to be peculiar to this tradition" ${ }^{\prime \prime}$. Such defining characteristics were determined later ${ }^{62}$. Observing that all ASTt sites were located above the tree line in the Arctic (except those in the Susitna River Valley and Alaska Peninsula), he emphasized the differences between coastal and inland sites, where the main prey focus was different (marine mammals vs. reindeer $)^{63}$. Like Giddings, he thought that ASTt may have been as old as 6000 years $^{64}$.

Archaeologists started actively using the term ASTt, defined by Irving ${ }^{65}$, for materials similar to the Denbigh Complex, dating to 2000-5000 years ago throughout the North American Arctic and even in the more southern regions, down to the Alaska Peninsula and the Aleutians ${ }^{66}$.

As early as 1959, MacNeish ${ }^{67}$ included ASTt in the list of ten traditions (cultures) that he distinguished in the Yukon, remarking that the Northern Microblade tradition overlaps with ASTt, many sites of which stretched "from the Seward Peninsula in western

57 MacNeish R.S.: 1) Pointed Mountain Site near Fort Liard, Northwest Territories, Canada // American Antiquity. 1953. Vol. 19, no.3. P. 234-253; 2) The Engigstciak Site on the Yukon Arctic Coast // Anthropological Papers of the University of Alaska. 1956. Vol. 4, no. 2. P.91-111.

${ }^{58}$ Irving W. N. An archaeological survey of the Susitna Valley. P. 47.

59 Giddings J. L. A Flint Site in Northernmost Manitoba // American Antiquity. 1956. Vol.11, no. 3. P. 255-268; Harp E.Jr. Prehistory in the Dismal Lake area, N.W.T., Canada // Arctic. 1958. Vol.1, no. 4. P.219-249; Knuth E. The Paleo-Eskimo Culture of Northeast Greenland Elucidated by Three New Sites // American Antiquity. 1954. Vol.19, no.4. P.367-381; Maxwell M.S. Prehistory of the Eastern Arctic. Orlando, 1985.

${ }^{60}$ Irving W.N. A provisional comparison of some Alaskan and Asian stone industries // Prehistoric cultural relations between the Arctic and temperate zone of North America. Arctic Institute of N. America. Technical paper. No. 11. 1962. P. 55-68.

61 Ibid. P. 56.

${ }^{62}$ Dumond D. E. The Eskimo and Aleuts; Anderson D. D. Onion Portage: the archaeology of a stratified Site from the Kobuk River, Northwest Alaska // Anthropological Papers University of the Alaska. 1988. Vol. 22, no. 1-2. P. 1-163.

${ }^{63}$ Irving W. N. A provisional comparison of some Alaskan and Asian stone industries. P. 56.

64 Ibid. P. 57.

${ }^{65}$ Irving W. N. An archaeological survey of the Susitna Valley. P. 37-52.

${ }^{66}$ Dumond D.E.: 1) The Eskimo and Aleuts; 2) Western Arctic Small Tool // Encyclopedia of Prehistory. Vol.2. Arctic and Subarctic. Boston, 2001. P.213-224; Helmer J. W. Arctic Small Tool Tradition // Archaeology of Prehistoric Native America. New York; London, 1998. P. 28-31; Odess D. The Arctic Small Tool Tradition // Encyclopedia of the Arctic. Routledge; New York, 2005. P. 146-147.

${ }^{67}$ MacNeish R.S. Men out of Asia: as seen from the Northwest Yukon // Anthropological Papers University of the Alaska. 1959. Vol.7, no. 2. P. 41-70. 
Alaska to the Independence culture in Greenland"68. He identified Engigstciak and Firth River complexes as ASTt and combined them into the New Mountain phase ${ }^{69}$. Griffin, who studied Arctic ceramics, stated that the culture of ASTt inhabitants, who adapted to the coastal and tundra areas of the East Arctic "did not penetrate as a complex through the boreal forest zone" ${ }^{\prime 70}$. In general, the spread of ASTt from southwestern Alaska to Greenland is accepted ${ }^{71}$.

In his summary monograph about the archaeology of Cape Denbigh, Giddings traced general connections of the DFC across Alaska, including the Aleutian Islands (Chaluka site) as well as Canada and Greenland (Independence I) based on the presence of microblades and small retouched tools in the site's collection ${ }^{72}$. Attempting to solve the question of the Denbigh complex origins, Giddings noted that he "doubt[s] strongly that the DFC is to be derived from any well-known aspect of the Siberian Neolithic...", but at the same time wrote that the "Mesolithic diffusion out of the Old World appears to have sent Denbigh-like waves along the coasts and northern interior of America"73. Since the Neolithic cultures of Northeast Asia were not well-known, and the research into the Paleolithic was only at its infancy, this was a rather adequate position. Concluding the description of Iyatayat's DFC, Giddings wrote that "...the microblade and burin technology, as it was practiced in the DFC, spread to Alaska from Asia about $4000 \mathrm{BC}$ "74. Similarly to Giddings, Irving did not see any connections between ASTt and the Baikal Region Neolithic cultures and wrote that the Chukotka's complexes known at the time were "too recent to be considered among its [ASTt] antecedents" 75 .

New Northeast Asian Neolithic material obtained in the 1960s by Mochanov and Dikov, and later by Kiryak, Slobodin, Kashin and others ${ }^{76}$, reveals technical and typological analogies between the ASTt complexes and the Middle and Late Holocene complexes of Yakutia, Chikotka, and Alaska in more detail. This allowed scholars to talk about the spread of Asian Neolithic cultures through the Bering Strait to Alaska and regard them as ancestral to the North American Holocene cultures ${ }^{77}$, although some research-

${ }^{68}$ MacNeish R.S. Recent finds in the Yukon Territory of Canada // Prehistoric cultural relations between the Arctic and temperate zone of North America. AINA, Technical paper No. 11. 1962. P. 25.

69 Ibid. P. 22; MacNeish R. S. The Engigstciak Site on the Yukon Arctic Coast. P.95-99.

${ }^{70}$ Griffin J.B. A discussion of Prehistoric Similarities and Connections Between the Arctic and Temperate Zones of North America // Prehistoric Cultural Relations Between the Arctic and Temperate Zones of North America. Arctic Institute of N. America. Technical paper No. 11. 1962. P. 159.

71 Dumond D.E. The Eskimo and Aleuts. P.91.

${ }_{72}$ Giddings J. L. The archeology of Cape Denbigh. P.252-254.

73 Ibid. P. 266.

${ }_{74}$ Ibid. P. 270.

75 Irving W. N. A provisional comparison of some Alaskan and Asian stone industries. P.57.

${ }^{76}$ Mochanov Yu.A. Mnogosloinaia stoianka Bel'kachi I i periodizatsiia kamennogo veka Iakutii; Dikov N. N. Early Cultures of Northeastern Asia; Kiryak M. A. Arkheologiia zapadnoi Chukotki; Slobodin S. The Upper Kolyma and Continental Priokhot'e during the Neolithic and Early Metal Periods; Kashin V. A. Neolit Srednei Kolymy: sbornik trudov.

77 Griffin J.B. A discussion of Prehistoric Similarities and Connections Between the Arctic and Temperate Zones of North America. P.154-163; Mochanov Yu.A., Fedoseeva S. A. Main Periods in the Ancient History of North East Asia. P. 669-693; Powers W. R., Jordan R. H. Human biogeography and climate change in Siberia and Arctic North America in the fourth and fifth millennia BP. P. 665-670; Hoffecker J. F. A Prehistory of the north: human settlement of the higher latitudes. P. 125-129; Dikov N. N. Drevnie kostry Kamchatki i Chukotki. Magadan, 1969. P.69-72. 
ers proposed that ASTt originated from the Paleolithic American Paleoarctic Tradi$\operatorname{tion}^{78}$.

ASTt is at the center of solving the question of development of the maritime adaptation and the formation of the Early Maritime Traditions in northern Alaska since ASTt sites yielded the first evidence of seal hunting ${ }^{79}$. However, the specifics of the marine adaptation of ASTt population are still not known: it could have been either summer rookery hunting or winter (spring) ice hunting, or it could have included open-sea hunting in boats.

The existence of a harpoon complex at the maritime Alaskan ASTt sites is for now hypothesized, based on singular finds of marine animal bones, the typology of the stone tools (end blades), and ethnographic parallels ${ }^{80}$. The possibility of hunting sea animals in their haul-out sites cannot be excluded; such hunting does not require a developed harpoon technology or boats. At the same time, if the Alaskan ASTt cultures originated from Northeast Asian Neolithic cultures, they would have had to cross the Bering Strait, presumably in boats. In addition, data from the East Arctic ASTt sites indicate that a completely developed maritime adaptation (with boats and harpoons) existed by around 4300 years ago, i. e. concurrent with the earliest stages of $\mathrm{ASTt}^{81}$. This supposes a similar level of maritime adaptation for ASTt in Alaska, which seems to have been the core territory of this culture, taking into account its incredibly fast (almost instantaneous, judging from available radiocarbon dates) spread into the entire Arctic of North America.

Some material from Western Canada is older or contemporaneous with the known North Alaskan sites ${ }^{82}$, although this data needs to be verified. Technological evolution could not have been that fast, especially in such a complicated industry as maritime hunting, which means there was a developmental stage of this maritime culture in the Bering Strait area, which has not been identified yet.

It has also been suggested that the ancestors of the ASTt people, identified as continental Neolithic cultures of reindeer hunters from Northeast Asia, crossed the Bering Strait around 5000 years ago (Middle Holocene) over ice ${ }^{83}$. Paleoecological studies have shown

78 Anderson D. D. Onion Portage: the archaeology of a stratified Site from the Kobuk River, Northwest Alaska. P.1-163; Maxwell M.S. Archaeology of the Arctic and Subarctic Zones // Annual Review of Anthropology. 1980. No. 9. P. 161-185.

${ }^{79}$ Dumond D.E. Coastal adaptation and cultural change in Alaskan Eskimo prehistory. Prehistoric Maritime Adaptations of the Circumpolar Zone. Paris, 1975. P.168-180; Ackerman R. E. Early Maritime Traditions in the Bering, Chukchi and East Siberian Seas // Arctic Anthropology. 1998. Vol. 35, no. 1. P. 247262; Giddings J. L., Anderson D. D. Beach Ridge archeology of Cape Krusenstern. Washington D. C., 1986.

80 Giddings J. L. The archeology of Cape Denbigh. P. 241.

81 Gronnow B. An archaeological reconstruction of Saqqaq bows, darts, harpoons, and lances // Inuit Studies. 2012. Vol.36, no. 1. P.23-48; Savelle J.M., Dyke A.S. Variability in Palaeoeskimo Occupation on South-Western Victoria Island, Arctic Canada: Causes and Consequences // World Archaeology. 2002. Vol.33, no.3, P. 508-522; Mobjerg T. New Adaptive Strategies in the Saqqaq Culture of Greenland, c. 16001400 bc // World Archaeology. 1999. Vol.30, no.3. P.452-465; Maxwell M.S. Archaeology of the Arctic and Subarctic Zones. P. 161-185; McGhee R. Paleoeskimo occupations of Central and High Arctic Canada // Memoirs of the Society for American Archaeology. 1976. Vol.31. P. 15-39.

82 Savelle J.M., Dyke A.S. Variability in Palaeoeskimo Occupation on South-Western Victoria Island, Arctic Canada: Causes and Consequences. P. 508-522.

83 Mochanov Yu.A., Fedoseeva S. A. Main Periods in the Ancient History of North East Asia in the Cenozoic Era. P. 669-693; McGhee R. Ancient People of the Arctic. 
that around 5000-4000 years ago, i. e. by the time ASTt had spread to Alaska, environmental conditions (flora, fauna, and climate) similar to the modern ones were established ${ }^{84}$.

Looking at Alaskan ASTt as a result of Neolithic (mid- to late-Holocene) migration of a population from Northeast Asia, we need to define the timing and available evidence for the formation of maritime adaptation in the Asian section of the Pacific Ocean, where such adaptations are identified starting with mid-Holocene at Primorye (Boysman Site) ${ }^{85}$.

Reliable evidence of a profoundly specialized maritime adaptation on the Asian side of the Bering Strait comes from the Unenen and Chertov Ovrag sites, identified as belonging to the Old Wailing culture and dated to ca. $3300 \mathrm{BP}^{86}$, which is significantly younger than the oldest ASTt sites of Alaska and Greenland. Of course, it is clear that this culture was not a "tabula rasa" in terms of its origins. The high level of specialization in maritime subsistence activities at Unenen (hunting whales from boats, harpoon complex, whalebone dwellings) suggests an earlier time for the beginning stages of its formation, approximately 5000-4000 years ago. The stone toolkit of the site bears definite Neolithic traits, pointing to its connection with continental Neolithic cultures of Chukotka. Their emergence on the shores of the Okhotsk, Bering and Chukchi Seas defines the beginning of a maritime adaptation, i.e. a specialized subsistence complex focused on hunting not only terrestrial but also maritime animals. The development of a maritime hunting complex contributed to the emergence of boats and the ability of the ASTt ancestors to cross the Bering Strait, which separates Chukotka and Alaska by no more than $100 \mathrm{~km}$, with islands midway.

Within the entire range of ASTt distribution, researchers currently distinguish Western ASTt, in Alaska ${ }^{87}$, and Eastern ASTt, in Arctic Canada and Greenland ${ }^{88}$. In addition to certain differences in stone tools between the Western and Eastern ASTt toolkits, one significant feature is the presence in Eastern ASTt materials of many well-preserved bone tools: harpoons, lances, inset projectiles, needles, etc.

Based on ca. $100 \mathrm{C}-14$ dates $^{89}$, the age of Alaskan ASTt is currently determined to be $4500-2200$ years $^{90}$, although many dates need to be verified. The legitimacy of both the oldest (over 4000 years) and the youngest (less than 3000 years) dates is questioned ${ }^{91}$.

${ }^{84}$ Anderson P. M., Brubaker L.B. Vegetation History of Northcentral Alaska: A Mapped Summary of Late-Quaternary Pollen Data // Quaternary Science Reviews. 1994. No. 13. P. 71-92.

${ }^{85}$ Popov A. N. Burial Assemblages of Boisman-2 - a Stratified Site in Southern Primorye. Archaeology, Ethnology and Anthropology of Eurasia. 2008. Vol. 34, no. 2. P. 68-76.

86 Dikov N. N. Early Cultures of Northeastern Asia; Gusev S. V. Raskopki poseleniia Unenen na Vostochnoi Chukotke (drevnekitoboinaia kul'tura) v 2007-2014 gg. // Arkheologiia Arktiki. 2014. No. 2. P. 205-212.

87 Dumond D. E. Western Arctic Small Tool. P.213-224; Odess D. The Arctic Small Tool Tradition. P. 146-147.

88 Park R. Eastern Arctic Small Tool // Encyclopedia of Prehistory. Vol. 2. Arctic and Subarctic. Boston, 2001. P. 27-45; Helmer J. W. Arctic Small Tool Tradition. P. 28-31; Odess D.: 1) An Early Arctic Small Tool Tradition Structure from Northwestern Alaska // Inuit Studies. 2003. Vol. 27, no. 1-2. P. 13-28; 2) The Arctic Small Tool Tradition. P.146-147; 3) The Arctic Small Tool Tradition Fifty Years On // Alaska Journal of Anthropology. 2005. Vol.3, no. 2. P. 5-16.

${ }^{89}$ Slaughter D. C. Radiocarbon dating the Arctic Small Tool tradition in Alaska. P. 117-134;

90 Giddings J.L. The archeology of Cape Denbigh. P.244-248; Dumond D.E. The Eskimo and Aleuts; McGhee R. Ancient People of the Arctic; Powers W. R., Jordan R. H. Human biogeography and climate change in Siberia and Arctic North America in the fourth and fifth millennia BP. P.665-670; Kunz M.L.: 1) The Mosquito Lake Site (PSM-049). Pipeline Archaeology. Fairbanks, 1977. P.747-982; 2) The Denbigh Flint Complex at Punyjk Point, Etivlik Lake, Alaska // Alaska Journal of Anthropology. 2005. Vol. 3, no. 2. P. 101-116.

${ }_{91}$ Reuther J.D., Gerlach S.C. Testing the "DICARB Problem": A Case Study from North Alaska // Radiocarbon. 2005. Vol.47, no.3. P.359-366; Tremayne A. H., Rasic J. T. The Denbigh Flint complex of northern Alaska // The Oxford handbook of the prehistoric Arctic. Oxford, 2016. P.349-370. 
The issue of the age of Alaskan ASTt and the timing of the migration of its ancestors from Asia remains open since C-14 AMS dates from western Canada (Victoria Island) show, that people were already living there 4500 years ago ${ }^{92}$, which is practically the same age as the oldest securely dated materials from Alaska ${ }^{93}$.

\section{Western ASTt}

Regarding the Western ASTt materials (i.e. Alaska), it is important to note that some researchers follow the ASTt concept suggested by Giddings and Anderson, in which they changed William Irving's original definition of ASTt (1957), by including in it not only the DFC, but also cultures which followed: Choris, Norton and Ipiutak (3000-950 years old) ${ }^{94}$. This scheme did not gain traction with Alaskan archaeologists ${ }^{95}$. Without taking this peculiarity into account, blind comparisons of stone tool complexes with the ASTt definition of Giddings and Anderson leads some researchers ${ }^{96}$ to erroneous constructions and conclusions ${ }^{97}$.

In addition, D. Anderson working at Onion Portage, a well-stratified site with a series of C-14 dates, distinguished Proto-Denbigh, Classic Denbigh, and Late Denbigh stages $^{98}$. Later D. Anderson concluded that this segmentation does not demonstrate some evolution of the Denbigh Complex ${ }^{99}$ (pers. comm. 2002). No such evolution is seen by other researchers ${ }^{100}$.

Within the Western ASTt distribution, researchers distinguish a Northern and a Southern sub-traditions ${ }^{101}$.

Northern Sub-tradition of the Western ASTt is represented by the regional complex Denbigh ASTt, located in the Arctic part of Alaska from the Norton Sound (where Iyatayet site was found) and Seward Peninsula in western Alaska to the Canadian border and lower reaches of the Mackenzie River delta in the Northwest Territories, including the entire Brooks Range, British Mountains, and the Yukon Territory.

A total of around 150 ASTt sites have been discovered. They are located near lakes, in mountain passes, on coastal spits, and in river valleys. Often, there are concentrations

92 Savelle J.M., Dyke A.S. Variability in Palaeoeskimo Occupation on South-Western Victoria Island, Arctic Canada: Causes and Consequences. P. 508-522.

93 Tremayne A. H. The Design of Arctic Small Tool Tradition Toolkits. P. 1-31.

94 Giddings J.L., Anderson D. D. Beach Ridge archeology of Cape Krusenstern.

95 Odess D. The Arctic Small Tool Tradition Fifty Years On. P. 6; Tremayne A. H., Brown W. A. Mid to Late Holocene Population Trends, Culture Change and Marine Resource Intensification in Western Alaska // Arctic. 2017. Vol.70, no.4, P.365-380; Dumond D. E. Denbigh Flint Complex // Archaeology of Prehistoric Native America. New York, NY; London, 1998. P. 207-208.

96 Orekhov A. A. Severnaia Pacifika v golotsene (problemy primorskoi adaptatsii). Avtoref. dis. ... dokt. ist. nauk. St. Petersburg, 2001. P. 13-15.

${ }_{97}$ On discussion, see: Slobodin S. B.: 1) K voprosu o vydelenii protoeskimosskikh kul'tur v Beringii // II Dikovskie chteniia: Materialy nauchno-prakticheskoi konferentsii. Magadan, 2002. P.372-379;2) Neolit Severo-Vostoka Azii i tradiciya Arktik Smol Tul Severnoi Ameriki // III Dikovskie chteniya: materialy nauchno-prakticheskoi konferentsii. Magadan, 2004. P. 343-355.

98 Anderson D. D. Onion Portage: the archaeology of a stratified Site from the Kobuk River, Northwest Alaska. P. 1-163.

${ }^{99}$ Anderson D. D. The Denbigh Flint Complex in Northwest Alaska... P. 81-100.

100 Tremayne A. H., Rasic J. T. The Denbigh Flint complex of northern Alaska // The Oxford handbook of the prehistoric Arctic. Oxford, 2016. P.349-370.

101 Dumond D. E.: 1) Denbigh Flint Complex. P. 207-208;2) Archaeology on the Alaska Peninsula: the Naknek Region, 1960-1975 // Anthropological papers No. 21. Eugene, 1981. 
of sites in some locations, up to several dozen. Many were visited over a long period of time, like Onion Portage ${ }^{102}$. However, only about 30 sites have secure C-14 dates ${ }^{103}$, ranging from 4700 to 2500 years. The most fully studied sites are Iyatayet (4500-3290 BP) at Norton Sound (recent studies have shown the age of $3717 \pm 39 \mathrm{BP}$ on charcoal from a hearth $)^{104}$, Mosquito Lake (3515-2135 BP) ${ }^{105}$, Punyik Point (4660-2260 BP $)^{106}$, Kurupa Lake (3540-3450 BP $)^{107}$, Matcharak Lake (4200-3430 BP) ${ }^{108}$, Croxton $(4420-2219 \text { BP })^{109}$ at the Brooks Range, Cape Espenberg (4100-3880 BP ${ }^{110}$; Kuzitrin Lake (4770-3750 BP) at Seward Peninsula ${ }^{111}$, Onion Portage (3950-3530 BP) at the Kobuk River ${ }^{112}$, Imaigenik $(3330 \mathrm{BP})^{113}$; Engigstciak ${ }^{114}$, Walakpa, Coffin, Prudhoe Bay sites ${ }^{115}$ and others.

Most of these sites in Alaska are located above the Arctic Circle and in the nearby regions, so they are often characterized by a poorly preserved thin cultural layer disturbed by cryoturbation and solifluction, which often destroy stratigraphy and inverts radiocarbon dates. At coastal sites, archaeologists have dated driftwood and marine mammal bone, which requires applying reservoir effect corrections. This raises questions regarding the "outlier" radiocarbon dates, both the oldest, over 4500 years for lyatayet and Kuzitrin Lake, otherwise dated to 4200-4300 years old, and the youngest (2135-2260 years old) for Mosquito Lake, Croxton, and Punyik Point. Revising the age of the available organic samples from these sites using the AMS method in several cases yielded dates 1000-1500 years older, around 3300-3600 years ago ${ }^{116}$. Thus, the most likely age for these complexes of the

102 Anderson D. D. Onion Portage: the archaeology of a stratified Site from the Kobuk River, Northwest Alaska.

103 Slaughter D.C. Radiocarbon dating the Arctic Small Tool tradition in Alaska. P.117-134; Tremayne A.H., Brown W.A. Mid to Late Holocene Population Trends, Culture Change and Marine Resource Intensification in Western Alaska // Arctic. 2017. Vol.70, no. 4. P.365-380.

104 Giddings J.L. The archeology of Cape Denbigh. P.244-248; Tremayne A., Darwent Ch.M., Darwent J., Rasic J. T. Iyatayet revisited: Report on Renewed Investigations of a Stratified Middle-to-Late Holocene Coastal Campsite in Norton Sound, Alaska // Arctic anthropology. 2018. Vol. 55, no. 1. P. 1-23.

105 Kunz M. L. The Mosquito Lake Site (PSM-049). Pipeline Archaeology. Fairbanks, 1977. P.747-982.

106 Irving W.N. Punyik Point and the Arctic Small Tool Tradition. Ph.D. dissertation. University of Wisconsin, Madison, 1964.

107 Schoenberg K. M. The archeology of Kurupa Lake. Research / Resources management report ARE-

10, U.S. Department of the Interior, National Park Service, Anchorage, 1985.

108 Tremayne A. H. An Analysis of Denbigh Flint Complex Burin Technology from Matcharak Lake, Alaska // Alaska Journal of Anthropology. 2010. Vol. 8, no. 1. P. 73-85.

109 Reuther J.D., Gerlach S. C. Testing the "DICARB Problem": A Case Study from North Alaska // Radiocarbon. 2005. Vol.47, no. 3. P.359-366.

110 Tremayne A.H., Brown W.A. Mid to Late Holocene Population Trends, Culture Change and

Marine Resource Intensification in Western Alaska // Arctic. 2017. Vol. 70, no. 4. P.365-380.

111 Harritt R. Paleo-Eskimo Beginnings in North America: A New Discovery at Kuzitrin Lake, Alaska

// Inuit Studies. 1998. Vol.22, no. 1. P.59-81.

112 Anderson D. D. Onion Portage: the archaeology of a stratified Site from the Kobuk River, Northwest Alaska. P. 1-163.

113 Wilson A. The Imaigenik Site: Irving's Arctic Small Tool Prior to Punyik // Paper presented at the $36^{\text {th }}$ Annual Alaska Anthropological Association Meeting, Anchorage, Alaska, 2008.

114 MacNeish R. S. Men out of Asia: as seen from the Northwest Yukon. P.41-70.

115 Slaughter D.C. Radiocarbon dating the Arctic Small Tool tradition in Alaska. P.117-134;

Lobdell J. E. North Alaskan Pingos: Ephemeral Refugia in Prehistory // Arctic Anthropology. 1995. Vol.32, no. 1. P. 62-81.

116 Reuther J.D., Gerlach S.C. Testing the "DICARB Problem": A Case Study from North Alaska // Radiocarbon. 2005. Vol.47, no.3. P.359-366; Tremayne A. H., Rasic J. T. The Denbigh Flint complex of northern Alaska // The Oxford handbook of the prehistoric Arctic. Oxford, 2016. P. 349-370; Tremayne A. H., 
Northern Sub-tradition of the Western ASTt is approximately 4300 to 3300 years B.P. (3500-4500 cal B. P.).

The sites can be divided into winter sites, with semisubterranean houses, and seasonal sites, used briefly and containing above-ground shelters surrounded by stones (sometimes just a few) on the perimeter. There is little evidence regarding the appearance and structure of dwellings of the Northern sub-tradition of the Western ASTt; this information comes only from a few continental sites, but it enables to distinguish two types of dwellings: winter and summer ones.

Summer dwellings are light portable tent-like structures, with a frame made of poles covered with skins whose edges were held by rocks. The tent rings, oval or sub-rectangular in form, measure about 3-4 meters in diameter. Some of the dwellings were only surrounded by a few stones, as at Lake Matcharak ${ }^{117}$ or Kuzitrin Lake ${ }^{118}$. At other sites, the dwelling perimeter was contoured quite regularly, with 20-22 pebbles, as at KIR-124 at Kurupa Lake ${ }^{119}$. Some dwellings have sophisticated stone components with "axial" or "midpassage" structures typical of the Early ASTt in Canada and Greenland ${ }^{120}$. Hearths have not been found in summer dwellings, which means they were likely placed outside the dwellings in other parts of the sites.

Winter ASTt dwellings are identified as semi-subterranean (up to $0.5 \mathrm{~m}$ deep) sod houses, oval or sub-rectangular in form, with a central stone fireplace ${ }^{121}$. A unique characteristic of the houses at Onion Portage and Punyik Point are a "mid-passage" and an excavated entrance tunnel ${ }^{122}$. Inside the dwellings researchers have noticed the presence of fire-cracked rocks ${ }^{123}$, presumably used for boiling water.

ASTt stone toolkit includes a large number of thin microblades, microblade cores, bifacially retouched thin projectile points, triangular and lanceolate; side inserts with asymmetrical lanceolate form and an angled base; small end scrapers, burins with multiple rejuvenations; very typical flake knives; burin spalls with ground edges; awls and drills; and retouched adzes with ground edges (Fig. 4). All tools are meticulously covered by tiny, uniform pressure flaking, unifacially or bifacially. Stone points are flaked with narrow parallel, oblique-parallel retouch, fully covering the widest parts of the tools from one edge to the other, giving them a thin lens-like cross-section.

ASTt microblade cores are a special type different from the typical conical or prismatic ones found in the Neolithic sites of Northeast Asia (blocky microblade cores). They

Brown W. A. Mid to Late Holocene Population Trends, Culture Change and Marine Resource Intensification in Western Alaska // Arctic. 2017. Vol. 70, no. 4. P.365-380.

117 Tremayne A. H. An analysis of faunal remains from a Denbigh Flint Complex camp at Matcharak lake, Alaska // Arctic Anthropology. 2011. Vol.48, no. 1. P.35-53.

118 Harritt R.: 1) Eskimo Prehistory on the Seward Peninsula, Alaska. Research Report AR 21. Anchorage, 1994. P. 214; 2) Paleo-Eskimo Beginnings in North America: A New Discovery at Kuzitrin Lake, Alaska // Inuit Studies. 1998. Vol. 22, no. 1. P.59-81.

119 Schoenberg K. M. The archeology of Kurupa Lake. P. 85, 145-146.

120 Odess D. An Early Arctic Small Tool Tradition Structure from Northwestern Alaska. P. 17.

121 Anderson D. D. Onion Portage: the archaeology of a stratified Site from the Kobuk River, Northwest Alaska. P. 101; Irving W. N. Punyik Point and the Arctic Small Tool Tradition. Ph.D. dissertation. University of Wisconsin, Madison, 1964.

122 Ibid; Anderson D. D. The Denbigh Flint Complex in Northwest Alaska... P. 81-100.

123 Anderson D. D. Onion Portage: the archaeology of a stratified Site from the Kobuk River, Northwest Alaska. P. 101; Kunz M. The Denbigh Flint Complex at Punyjk Point, Etivlik Lake, Alaska // Alaska Journal of Anthropology. 2005. Vol.3, no. 2. P. 110. 
have been described as pyramid-like or polyhedral. When drawn or photographed, they often have an unusual projection, which makes their identification difficult. They can be described as short frontal cores with a wide face, and a platform significantly sloping back so that the platform and the face of the core form an acute angle. The platforms, along with the sides, are usually flaked. Microblades, removed from these cores, were used as inserts and were often retouched along one side; many show use-wear.

Flake knives are slightly convex in cross-section, retouched from the dorsal side unifacially and from the ventral side, with flat retouch only along the cutting edge. The base is narrower than the rest of the knife, while the edge has a sub-rectangular or pointed shape. Scrapers on flakes and blade-like flakes are usually almost completely retouched, except for the lowest part, near the scraping edge; some have distinguishable handles.

Supposedly, the flat triangular projectile points with notches at the base served as harpoon tips ${ }^{124}$. In Alaska, they have only been found at coastal sites ${ }^{125}$, although in the Kolyma region and in Chukotka, such projectile points are quite common at strictly interior sites where harpoons are absent ${ }^{126}$.

Lanceolate projectile point bases vary from pointed to flat or obliquely truncated bases. Many of these tools indicate the presence of the bow and arrow technology ${ }^{127}$. Its presence was also suggested by smoothers with a narrow groove (5-7 mm wide), similar to the diameter of arrows, from Iyatayet ${ }^{128}$ and Onion Portage ${ }^{129}$, and finally confirmed by the discovery of bow parts and multiple arrow shafts from Qeqertasussuk in Greenland ${ }^{130}$. Side blade inserts have an asymmetrically lanceolate shape with a somewhat asymmetric lens-like cross-section. One of the most characteristic Denbigh tools is a "mitten-shaped" burin on a blade-like flake, dihedral and angle burin rejuvenated by spalling multiple times.

Organic tools are rare at the DFC sites. At Punyuk Point, there is a thin arrow point, perhaps slotted, and a digging tool made from caribou antler ${ }^{131}$. At Trail Creek, antler and bone "arrow points" (some of them slotted) and a decorated slotted bone handle or arrow point were found ${ }^{132}$, and Engigstciak yielded a slotted bone foreshaft, bone fish gorges, awls, and antler flakers ${ }^{133}$. However, DFC materials are mixed at these sites with younger levels, and the association of these tools remains unclear. Small stone tools of the ASTt complex imply the presence of various slotted shafts, harpoons, and spears. An example

124 Giddings J. L. The archeology of Cape Denbigh. P. 233.

125 Anderson D. D. The Denbigh Flint Complex in Northwest Alaska... P. 84.

126 Dikov N. N. Early Cultures of Northeastern Asia. P. 112; Kiryak M. A. Arkheologiia zapadnoi Chukotki. P. 186, 193, 194; Slobodin S. The Upper Kolyma and Continental Priokhote during the Neolithic and Early Metal Periods. P. 32, 45, 67, 150, 160; Kashin V.A. Neolit Srednei Kolymy: sbornik trudov. P. 171-174, 216

127 Giddings J. L. The archeology of Cape Denbigh. P. 232.

128 Ibid. P. 238-239, Pl. 73/11.

129 Anderson D. D. Onion Portage: the archaeology of a stratified Site from the Kobuk River, Northwest Alaska. P.96. Fig. 92.

${ }^{130}$ Gronnow B. Qeqertasussuk - the archaeology of a frozen Saqqaq site in Disko Bugt, West Greenland // Threads of Arctic prehistory: Papers in honour of William E. Taylor. Quebec. 1994. P. 202-240; Gronnow B. An archaeological reconstruction of Saqqaq bows, darts, harpoons, and lances. P. 23-48.

${ }^{131}$ Irving W. N. Punyik Point and the Arctic Small Tool Tradition; Dumond D. E. Western Arctic Small Tool. P.213-224.

${ }^{132}$ Larsen H. Trail Creek: Final Report on the Excavation of Two Caves on Seward Peninsula, Alaska. P. 49.

${ }^{133}$ MacNeish R. S. Recent finds in the Yukon Territory of Canada. P. 22. 


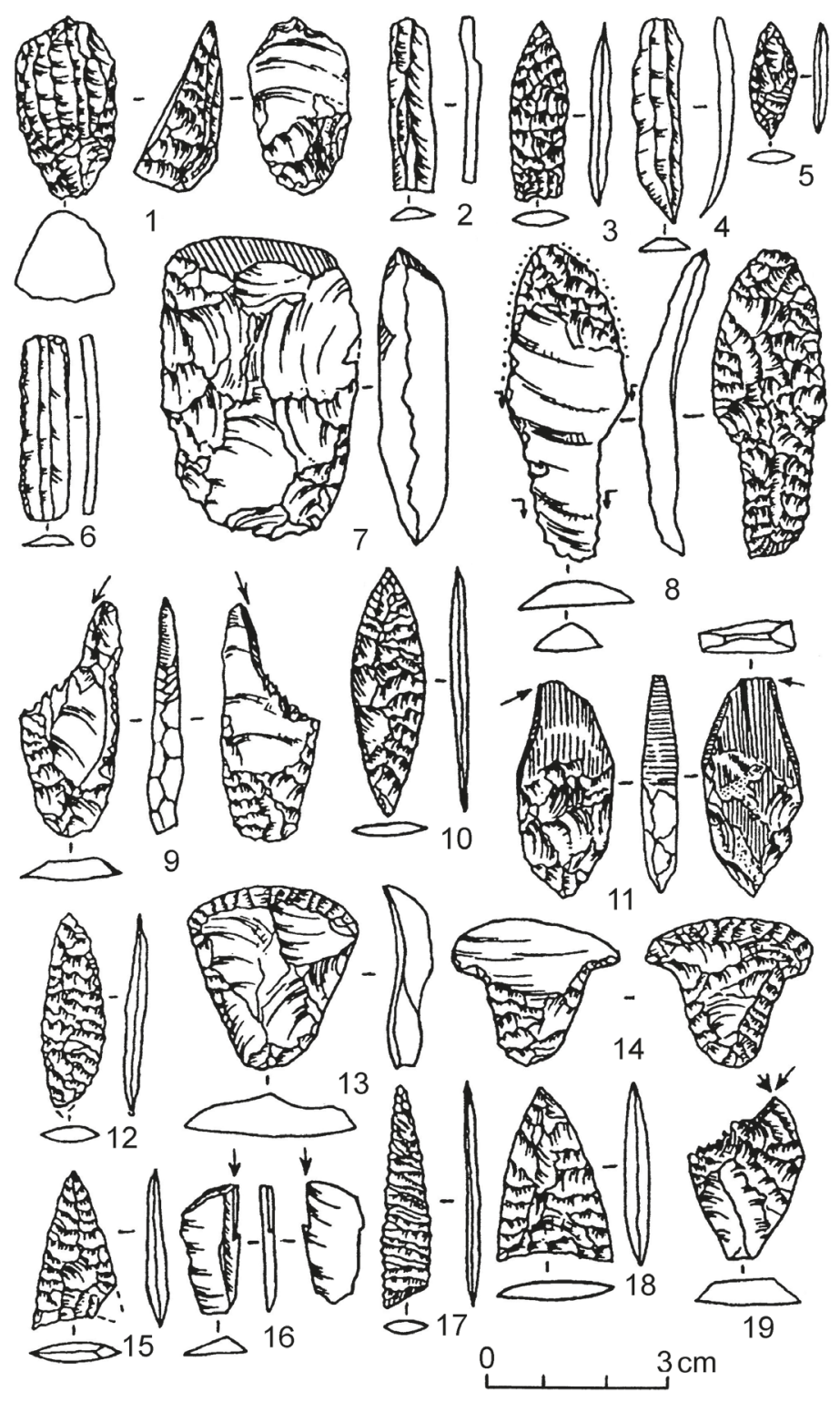

Fig. 4. Stone tools assemblage of the ASTt tradition (1-19):

1 - microblade core; 2, 4, 6 - microblades; $3,15,18$ - points; 5, 10, 12, 17 - side inserts; 7 - adze; 8 - flake knife; 9, 19 - "mittenshaped" burins; 13,14 - scrapers; 16 - corner burin (Nos. 1-6, 9, $10,13,15,16,18,19-$ are from Punyik Point Site; nos. 8, 12 - are from Kurupa Lake Site; no. 11 - from Margaret Bay Site; no. 17 from Sell-033 Site, all drawn by S. Slobodin from the collections; nos. 7 and $14-$ are redrawn by S. Slobodin, respectively, after D. Dumomd [1987] and after D. Anderson [1988]) 
of organic ASTt tool set was recently obtained from the Matcharak Lake site ${ }^{134}$ : several dozen bone and antler tools, including barbs of a leister prong, projectile points, composite fish hooks, a pressure flaker for flint-knapping, a hammer from antler, and a decorated foreshaft from a rib bone.

The economic/subsistence basis for ASTt entailed exploring environmental resources from the home area. A home area encompassing various landscape zones guaranteed greater stability of their subsistence during the lean years. Faunal remains from interior and coastal ASTt sites are very rare and come only from a few ASTt sites, making it difficult to reconstruct their subsistence in detail ${ }^{135}$. Considering the environmental conditions of the ASTt site locations and the few faunal remains of animals and fish found there, researchers conclude that the ASTt inhabitants survived on both continental and maritime (coastal) resources, hunting seasonal terrestrial and maritime animals and fishing based on the regional and local ecological opportunities, using spears, bow and arrows, harpoon, terrestrial traps, and fish traps in streams and lakes ${ }^{136}$.

In the continental/interior ASTt sites in Arctic Alaska people, undoubtedly, relied mostly on caribou, especially during their mass migrations in the fall and spring through the Brooks Range, which continues to this day ${ }^{137}$. Evidence for this comes from caribou remains from Engigstciak ${ }^{138}$, Punyik Point ${ }^{139}$, Imaigenik ${ }^{140}$, Onion Portage ${ }^{141}$ and Matcharak Lake ${ }^{142}$.

Fish bones and scales have been found at lakeside sites (Punyik Point, Matcharak Lake), indicating that fishing supported human diets. Near the mountains, people hunted Dall sheep, whose bones were found at Matcharak Lake and Engigstciak. In the summer, while waiting for the caribou, ASTt inhabitants could have hunted Arctic ground squirrels, which are abundant in the Brooks Range ${ }^{143}$. In the boreal forest, they also hunted wapiti, whose remains were identified at Engigstciak ${ }^{144}$.

Comprehensive data regarding ASTt subsistence and settlement pattern of this area were recently received from the Lake Matcharak site (Upper Noatak drainage) ${ }^{145}$, charac-

134 Tremayne A. H. An Analysis of Faunal Remains from a Denbigh Flint Complex Camp at Matcharak Lake, Alaska // Arctic Anthropology, 2011. Vol. 48, no. 1. P. 35-53.

135 Odess D. The Arctic Small Tool Tradition Fifty Years On. P. 5-16; Dumond D. E. Western Arctic Small Tool. P.213-224.

136 Giddings J.L. The archeology of Cape Denbigh. P.239-242; Dumond D. E. The Eskimo and Aleuts. P. 79-90; Anderson D. D. Onion Portage: the archaeology of a stratified Site from the Kobuk River, Northwest Alaska. P. 148-149.

${ }^{137}$ Hemming J.E. The Distribution and movement patterns of caribou in Alaska. Alaska Department of Fish and Game. Game Technical Bulletin July 1971. No.1; Nicholson K.L., Arthur S. M., Horne J.S., Garton E. O., Del Vecchio P. A. Modeling Caribou Movements: Seasonal Ranges and Migration Routes of the Central Arctic Herd // PLoS ONE. 2016. no. 11(4): e0150333. doi:10.1371/journal.pone.0150333

138 MacNeish R. S. The Engigstciak Site on the Yukon Arctic Coast. P.91-111.

139 Irving W.N. Punyik Point and the Arctic Small Tool Tradition.

140 Irving W.N. Evidence of early tundra cultures in northern Alaska. P. 55-85; Wilson A. The Imaigenik Site: Irving's Arctic Small Tool Prior to Punyik // Paper presented at the $36^{\text {th }}$ Annual Alaska Anthropological Association Meeting. Anchorage, Alaska, 2008.

${ }^{141}$ Anderson D. D. Onion Portage: the archaeology of a stratified Site from the Kobuk River, Northwest Alaska. P. 1-163.

142 Tremayne A. H. An Analysis of Faunal Remains from a Denbigh Flint Complex Camp at Matcharak Lake, Alaska. P. 44-45.

143 Odess D. The Arctic Small Tool Tradition Fifty Years On. P.5-16.

144 MacNeish R.S. The Engigstciak Site on the Yukon Arctic Coast. P.91-111.

145 Tremayne A. H. An Analysis of Faunal Remains from a Denbigh Flint Complex Camp at Matcharak Lake, Alaska. P. 35-53. 
terized by great faunal preservation. The site is located in the mountains near modern migration routes of caribou to their winter range ${ }^{146}$. Excavations yielded over 80,000 bones, $90 \%$ of which were caribou bones. Small portions of the collection come from faunal remains of other mammals (Dall sheep, ground squirrel, marmot, snowshoe hare and porcupine), birds (ptarmigan and ducks), and fish (burbot, grayling, lake trout, pike).

Faunal analysis indicates that people lived here from spring to late fall ${ }^{147}$, although if the fall hunting resulted in stored reindeer meet, they could have spent part of the winter there as well. Ethnographic data show that a family of six needed 64 reindeer for the winter period (eight months) ${ }^{148}$. If dogs were present, that number would have been significantly larger, although fish stockpiles were also used to feed dogs.

Coastal ASTt inhabitants - at Iyatayet, Coffin, Walakpa, Cape Espenberg (KTZ325) - according to the faunal remains and stone tool types, had a mixed subsistence style, hunting both maritime animals (mostly seals and, perhaps, walruses) and the terrestrial ones (caribou and, perhaps Muskox) $)^{149}$. The lack of semisubterranean houses appears to indicate that these were seasonal settlements.

Assuming that people based their subsistence on the most accessible and productive resources, it is obvious to suggest that people started to (or continued to, after crossing the Bering Strait) engage in maritime hunting, perhaps using boat (kayaks) and harpoon technology. Triangular projectiles with notched bases are considered to be part of the harpoon technology ${ }^{150}$, although harpoons are not necessary or even suitable for haulout hunting on the shore. However, it is possible that spring hunting took place from the ice edge and required harpoon equipment.

The most accessible animals on the coast are those that haul out to rookeries on the shore. Even using the simple equipment (spears) without specialized harpoon toolkit and boats, people could have plenty of food for their daily needs, in addition to creating a significant stockpile for future (important during late fall and winter). In this respect, seals are the most accessible and could have been hunted not only on the shores but also on the ice in spring. The Cape Espenberg (KTZ-325) radiocarbon date of 4,100 \pm 40 years indicates a very early maritime adaptation within ASTt ${ }^{151}$.

In light of the general consensus that the ASTt and ceramic industry in Alaska originated from the Northeast Asian Neolithic cultures ${ }^{152}$, it is unclear why ceramics are absent

${ }^{146}$ Hemming J.E. The Distribution and movement patterns of caribou in Alaska. Alaska Department of Fish and Game. Game Technical Bulletin July 1971. No. 1.

147 Tremayne A. H. An Analysis of Faunal Remains from a Denbigh Flint Complex Camp at Matcharak Lake, Alaska. P. 49.

${ }_{148}$ D'yachkov A.E. Anadyrskii krai [The Anadyr Region]. Magadan, 1992. P. 205.

149 Giddings J.L. The archeology of Cape Denbigh. P.241-242; Tremayne A. H. An Analysis of Faunal Remains from a Denbigh Flint Complex Camp at Matcharak Lake, Alaska. P. 35-53.

150 Giddings J. L. The archeology of Cape Denbigh. P. 233-236.

151 Tremayne A.H. New Evidence for the Timing of Arctic Small Tool Tradition Coastal Settlement in Northwest Alaska // Alaska Journal of Anthropology. 2015. Vol.13, no.1. P.1-18; Tremayne A.H., Brown W. A. Mid to Late Holocene Population Trends, Culture Change and Marine Resource Intensification in Western Alaska // Arctic. 2017. Vol. 70, no. 4. P.365-380.

152 Griffin J. B. A discussion of Prehistoric Similarities and Connections Between the Arctic and Temperate Zones of North America. P. 154-163; Dumond D. E. The Eskimo and Aleuts. P.91-93; Powers W. R., Jordan R. H. Human biogeography and climate change in Siberia and Arctic North America in the fourth and fifth millennia BP. P. 665-670; Hoffecker J. F. A Prehistory of the north: human settlement of the higher latitudes. P. 227-228; Mochanov Yu. A. Mnogosloinaia stoianka Bel'kachi I i periodizatsiia kamennogo veka Iakutii; Dumond D. E., Bland R. L. Holocene Prehistory of the Northernmoust north Pacific // JWP. 1995. Vol. 9, no. 4. P. 401-451. 
from the ASTt sites, while this artifact type is one of the chief characteristics of the Northeast Asian Neolithic ${ }^{153}$. Powers and Jordan suggested that the Alaskan ASTt could be "... an aceramic variant of the Belkachi culture"154.

Some Alaska sites contain ceramics associated with ASTt, such as Coffin, Walakpa (Linear, Check stamp), Engigstciak, Firth River, Punyik Point (Cord-marked) ${ }^{155}$; the mixed character of these complexes casts doubt on the association of ceramics with the rest of the ASTt materials ${ }^{156}$. For example, Griffin, after studying the Engigstciak and Firth River ceramics identified it as Norton ${ }^{157}$.

The Southern ASTt sub-tradition, uncharacteristically for its original definition ${ }^{158}$, demonstrates a distribution of the DFC south of the Bering Strait in the interior boreal forest, but has been found only at a few sites on the Alaska Peninsula, Kenai Peninsula and the Aleutian Islands ${ }^{159}$. This distribution process was probably discrete in character. In the vast territory of the Yukon-Kuskokwim Lowland, from the Norton Sound with the Iyatayet site to the Alaska Peninsula, almost no ASTt sites are known, and the routes (continental or coastal) through which it spread south have not been discovered.

According to the C-14 dates, approximately 4220 years ago representatives of ASTt appear in this part of Alaska at Chugachik Island, not far from the Kenai Peninsula in the Kachemak Bay, as evidenced at SEL-033 ${ }^{160}$. This is almost contemporaneous with the earliest DFC dates from the Arctic Alaskan sites, which brings us back to the question of the timing and routes of ASTt distribution in Alaska. In order to get to Kachemak Bay ASTt groups would have needed a certain amount of time to cross the area from Northwest Alaska through the Yukon-Kuskokwim delta on land or along the coast, using boats. If

153 Griffin J.B. A discussion of Prehistoric Similarities and Connections Between the Arctic and Temperate Zones of North America. P. 154-163; Dikov N. N. Early Cultures of Northeastern Asia; Mochanov Yu. A. Mnogosloinaia stoianka Bel'kachi I i periodizatsiia kamennogo veka Iakutii; Kiryak M. A. Arkheologiia zapadnoi Chukotki; Slobodin S. The Upper Kolyma and Continental Priokhot'e during the Neolithic and Early Metal Periods; Pitulko V. V. Golotsenovyi kamennyi vek Severo-Vostochnoi Azii // Estestvennaia istoriia Rossiiskoi Vostochnoi Arktiki v pleistotsene i golotsene. Moskow, 2003. P. 99-145.

154 Powers W. R., Jordan R. H. Human biogeography and climate change in Siberia and Arctic North America in the fourth and fifth millennia BP. P. 666.

${ }_{155}$ MacNeish R.S. Recent finds in the Yukon Territory of Canada. P. 22; Slaughter D. C. Radiocarbon dating the Arctic Small Tool tradition in Alaska. P.117-134; Stanford D.E. Evidence of Paleo-Eskimos on the North Coast of Alaska. Paper presented at the 36th annual meeting of the Society for American Archaeology. Norman, 1971; Stanford D. Walakpa Site Alaska: It's Place in the Birnirk and Thule Cultures // Smithsonian Contributions to Anthropology. No. 20. 1975. P.16; Ackerman R.E. The Neolithic-Bronze age cultures of Asia and the Norton phase of Alaskan prehistory // Arctic Anthropology. 1982. Vol. 19, no. 2. P. 14. Stimmell C. Going to pot: a technological overview of North American Arctic ceramics // Threads of Arctic prehistory: papers in honour of W. E. Taylor Jr. Ottawa, Quebec. 1994. P.35-56.

156 Anderson S.L., Tushingham S., Buonasera T. Y. Aquatic adaptations and the adoption of Arctic pottery technology: results of residue analysis. Anthropology faculty publications and presentations, no. $125,2017,87 \mathrm{p}$.

157 Griffin J.B. A discussion of Prehistoric Similarities and Connections Between the Arctic and Temperate Zones of North America. P. 161.

${ }^{158}$ Irving W.N. A provisional comparison of some Alaskan and Asian stone industries // Prehistoric cultural relations between the Arctic and temperate zone of North America. Arctic Institute of N. America, 1962. P. 56-59.

159 Dumond D. E. The Eskimo and Aleuts. P.79-86; Dumond D. E. The Alaska Small Tool tradition in Southern Alaska. P. 67-78.

160 Workman W. B., Zollars P. The Dispersal of the Arctic Small Tool Tradition into Southern Alaska: Dates and Data from the Kenai Peninsula, Southcentral Alaska // Anthropological Papers of the University of Alaska. 2002. Vol. 2, no. 1. P.39-49. 
the reason for movement of (and exploration of new territories by) groups with an "appropriating" subsistence approach was resource depression of their range, then it would have taken them considerable time to cross these rich territories. Thus, the beginnings of the ASTt movement to the south and east from the Bering Strait should be extended back significantly.

The toolkit from Chugachik Island site demonstrates full consistency with the main ASTt tool types. Even with no faunal remains present, it is clear that the island inhabitants' subsistence activities were focused on hunting marine animals at sea. They most likely had boats. Some rare finds of small stone tools on Kodiak Island presumably indicate the spread of ASTt to the island ${ }^{161}$.

The well-studied Alaska Peninsula sites, located approximately $20-60 \mathrm{~km}$ from the Bering Sea coast, along the shores of small salmon rivers Brooks and Ugashik, which enter Bristol Bay of the Bering Sea, are slightly younger. At these sites, researchers distinguish the Ugashik Hilltop Phase dated to 3900-3600 BP, and Brooks River Gravels Phase (Naknek drainage) dated to 3600-3100 BP, corresponding to the Gravels phase ${ }^{162}$. Located on the terraces of shallow salmon streams, the sites confirm active use of fish resources (summer and fall salmon runs) by their inhabitants. This group might have had a diverse subsistence strategy since the hunting character of the toolkit indicates active use of terrestrial resources, facilitated by the Alaska Peninsula landscape favorable for caribou herds.

Contemporaneous with the last stage of the Gravels phase ASTt, an "island" or "coastal" variant of ASTt started developing on Unalaska Island in the Aleutian Islands (Margaret Bay Site). Its unique trait, in addition to the small chert tools similar to the ASTt assemblages, is a strong maritime adaptation represented by a developed sea mammal hunting strategy from boats in open water and from the ice, with such artifacts as a harpoon complex, stone lamps, netsinkers, composite hooks, and labrets, which indicates their connection with the ancient Aleut culture ${ }^{163}$.

The toolkit at all these sites, although somewhat unique, in general matches the ASTt complex and includes: small lanceolate points with a narrower base (almost a stem); wide flat bifacially flaked insets for knives; meticulously worked end and side scrapers; small retouched adzes with polished edges; burins; burin spalls with polished edges; microblades. Unlike the northern ASTt sites (Denbigh complex), the southern sites of this tradition contain somewhat larger implements, have fewer microblades, not well shaped, and burins on microblades. Microblades were obtained from amorphous subprismatic cores and sometimes are absent altogether.

The sites are located in river valleys and next to lakes rich in fish during the salmon runs. Small hunting stone toolkit indicates that caribou hunting continued to be an important activity on the southern ASTt sites, but fishing and perhaps maritime hunting at Margaret Bay (Unalaska Island), and at SEL-033 were much more important for the inhabitants' subsistence needs than at the Denbigh Flint complex sites. Marine mammal bones, fish bones, and numerous salmon teeth support this conclusion. Inhabitants of these sites had long-term settlements with winter dwellings.

161 Steffian A. F., Saltonstall P. G. Tools but not Toolkits: Traces of the Arctic Small Tool Tradition in the Kodiak Archipelago // Alaska Journal of Anthropology. 2005. Vol. 3, no. 2. P. 17-49.

162 Dumond D. E. The Alaska Small Tool tradition in Southern Alaska. P. 67-78.

163 Knecht R.A., Davis R.S., Carver G.A. The Margaret Bay Site and Eastern Aleutian Prehistory // Recent Archaeology in the Aleut Zone of Alaska, 2001. University of Oregon Anthropological Papers. No.58. P.35-69. 
At the Brooks River site, around 100 of such dwellings presumably existed. Excavations show that they were sub-rectangular in shape, measured about $4 \times 4 \mathrm{~m}$, and were $0.5 \mathrm{~m}$ deep, with a stone hearth (some hearths have a square shape and are constructed of flat stone slabs) in the center of the dwelling and an angled exit passage way. The frame of the dwelling was likely wooden, with posts at the base, and was probably covered with sod $^{164}$. Numerous salmon and trout bones and teeth, found in the houses, indicate that they were inhabited in summer and winter. It was noted that the shape of Gravels phase ASTt dwellings resembles the dwellings of the Norton tradition, which follows ASTt ${ }^{165}$.

Margaret Bay site dwellings were semi-subterranean (about $1 \mathrm{~m}$ deep), oval in shape, approximately $6 \mathrm{~m}$ in diameter with stone walls, stone hearth boxes and other domestic objects $^{166}$.

East ASTt is found in the Arctic region of Canada (north of the treeline, Arctic Archipelago) and Greenland, and represents the earliest human settlement period of this part of the world. Humans reached this area after the ice shield had retreated, no later than 4,500 years ago.

Although some sites in the East Arctic date to around 5000 BP (for example Pre-Dorset ObPj- 6 at Victoria Island dated to $5245 \pm 42$ [AA-40853] and TkAt-4 [Sojourn] at Ellesmere Island dated $4685 \pm 70$ (S-2423) or even 4900), they still require confirmation ${ }^{167}$. Researchers posit that Central and East Arctic was inhabited from Alaska around $4500 \mathrm{BP}^{168}$.

Eastern ASTt consists of the following regional and chronological complexes: Independence I (High Arctic, Greenland, 4500-3600 years ago), Pre-Dorset (Central and East Arctic, 4500-2700 years ago) and Saqqaq (Greenland, 3900-2700 years ago).

Knuth, who described the Independence I Culture, Meldgaard, who described Saqqaq, and Collins, who described Pre-Dorset, noted the similarity between these cultures and Western ASTt ${ }^{169}$. Ross suggested that Independence I and Pre-Dorset are

164 Dumond D. E. Western Arctic Small Tool. P. 213-224.

165 Maschner H. D., Jordan J. W. The Russell Creek Manifestation of the Arctic Small Tool Tradition on the Western Alaska Peninsula // Archaeology in the Aleut Zone of Alaska: Some Recent Research. University of Oregon Anthropological Papers. 2001. No. 58. P. 151-171.

${ }^{166}$ Knecht R.A., Davis R.S., Carver G.A. The Margaret Bay Site and Eastern Aleutian Prehistory // Recent Archaeology in the Aleut Zone of Alaska, 2001. University of Oregon Anthropological Papers. No. 58. P.35-69.

167 Ross J.M. Peopling of the Eastern Canadian Arctic // Human Colonization of the Arctic: The interaction between early migration and the paleoenvironment. London; Cambridge, 2017. P.341-364; Sutherland P. D. Continuity and change in the Paleo-Eskimo prehistory of Northern Ellesmere Island // The Paleo-Eskimo Cultures of Greenland, New Perspectives in Greenlandic Archaeology. Copenhagen, 1996. Publ. No. 1. P.271-294; Hood B. C. Theory on ice: the discourse of eastern Canadian Arctic Paleo-Eskimo archaeology // Acta Borealia. 1998. No.2. P.3-58; Milne B., Park R. Pre-Dorset Culture // The Oxford handbook of the prehistoric Arctic. Oxford, 2016. P. 807-806.

168 Maxwell M. S. Prehistory of the Eastern Arctic. Orlando, Florida, 1985; Dumond D. E. The Eskimo and Aleuts; McGhee R. Ancient People of the Arctic; Rasmussen M. et al. Ancient human genome sequence of an extinct Palaeo-Eskimo // Nature. 2010. Vol. 463. P.757-762; Odess D.: 1) The Arctic Small Tool Tradition. P. 146-147; 2) The Arctic Small Tool Tradition Fifty Years On. P.5-16; Dyke A. S., Savelle J. M. Paleoeskimo Demography and Sea-Level History, Kent Peninsula and King William Island, Central Northwest Passage, Arctic Canada //Arctic. Vol. 62, no. 4. 2009. P.371-392.

169 Knuth E. An outline of archaeology of Peary Land // Arctic. 1952. Vol. 5, no. 1. P. 17-32; Giddings J. L. The archeology of Cape Denbigh. P.258-261; Meldgaard J.A. Paleo-Eskimo Culture in West Greenland // American Antiquity. 1952. Vol.17, no.3. P. 222-230; Collins H. B. Archaeological research in the North American Arctic // Arctic. 1954. Vol. 7. P.296-306. 
regional variations representing the same culture ${ }^{170}$. Together with Western ASTt they were referred to as the Paleoeskimo culture ${ }^{171}$, a concept put forward 100 years ago by H.P. Steensby ${ }^{172}$.

The most characteristic complexes of this tradition are known today in Canada, at such sites as Lake View, Cape Storm Beaches, Kettle Lake, Camp View (Ellesmere Island); Closure, Mittimatalik, LdFa-1, 12, LeDx-42, Mosquito Ridge, Kapuivik, Parry Hill, Annawak, Shaymarc (Baffin Island); Port Refuge, Gneiss, Far Site, Icy Bay, Hind, Rocky Point (Devon Island); Buchanan, Wellington Bay (Victoria Island); Kaleruserk (Igloolik Island); Crane (Mackenzie Delta), Stanwell Fletcher Lake (Somerset Island); Bettison Point (Prince of Wales Island); Umingmak, Shoran Lake (Banks Island); Engigstciak, Dismal, Bloody Falls (Northwest Territories); Saglek Bay (Quebec). In Greenland, they include Qeqertasussuk, Deltaterrasserne, Saqqaq, Niivertussannguaq, Nipisat, Qajaa, Sermermiut, Tuapassuit, Tupersui, Nuussuaq, Pearylandville, Midternaes and others ${ }^{173}$.

These complexes later gave the basis for the development of the Dorset culture (2600-700 (500) BP). Dorset is often viewed within the Eastern ASTt as the last stage of the Paleoeskimo culture, dating ASTt to 4500-1000 (500) BP ${ }^{174}$. Not all researchers agree with this scheme; some archaeologists limit the ASTt timeframe to the existence of Denbigh, Independence I, Saqqaq and Pre-Dorset, i. e. to 4500-2500 years ago ${ }^{175}$.

The archaeological record shows that the exploration of this territory was rather quick and intensive despite the low population numbers in the Arctic during that time, according to the general consensus. In the Canadian Arctic, around 1900 sites have been found ${ }^{176}$ (but the area has yet to be extensively covered by archaeologists), and in Greenland, just in the very north, at Peary Land, archaeologists have found 51 sites with remains of 244 dwellings ${ }^{177}$. East Greenland's Saqqaq sites provide evidence of the first people in

170 Ross J.M. Peopling of the Eastern Canadian Arctic // Human Colonization of the Arctic: The Interaction Between Early Migration and the Paleoenvironment. London; Cambridge, 2017. P.341-364.

${ }^{171}$ Knuth E. The Paleo-Eskimo Culture of Northeast Greenland Elucidated by Three New Sites // American Antiquity. 1954. Vol.19, no.4. P.367-381; Meldgaard J.A. Paleo-Eskimo Culture in West Greenland // American Antiquity. 1952. Vol. 17, no.3, P. 222-230; Odess D. The Arctic Small Tool Tradition. P. 146-147; Jensen J. F., Odgaard U., Funder S., Plumet P. First people in Greenland // Human Colonization of the Arctic: the interaction between early migration and the Paleoenvironment. London, Cambridge, 2017. P. 367-404; Ross J. M. Peopling of the Eastern Canadian Arctic // Human Colonization of the Arctic: The Interaction Between Early Migration and the Paleoenvironment. London, Cambridge, 2017. P.341-364.

172 Steensby H.P. An Anthropogeographical study of the origin of the Eskimo Culture // Meddelelser om Gronland, 1916. Vol. 53. P. 170-174.

173 Maxwell M. S. Pre-Dorset and Dorset Prehistory of Canada // Handbook of North American Indians: Arctic. Vol.5. Washington, 1984. P.359-368; Maxwell M.S. Prehistory of the Eastern Arctic. Orlando, Florida, 1985; Park R. Eastern Arctic Small Tool. P.27-45; Gronnow B. Qeqertasussuk - the archaeology of a frozen Saqqaq site in Disko Bugt, West Greenland. P.202-240; Jensen J.F., Odgaard U., Funder S., Plumet P. First people in Greenland // Human Colonization of the Arctic: the interaction between early migration and the Paleoenvironment. London; Cambridge, 2017. P. 367-404.

${ }_{174}$ Helmer J. W. Arctic Small Tool Tradition. P. 28-31; McChee R. Dorset Culture. Archaeology of Prehistoric Native America. New York, NY; London, 1998. P. 216-217.

175 Dumond D. E. The Eskimo and Aleuts; Park R. Eastern Arctic Small Tool. P. 27-45.

176 Ross J.M. Peopling of the Eastern Canadian Arctic // Human Colonization of the Arctic: The Interaction Between Early Migration and the Paleoenvironment. London; Cambridge, 2017. P.341-364.

177 Jensen J. F., Odgaard U., Funder S., Plumet P. First people in Greenland // Human Colonization of the Arctic: the interaction between early migration and the Paleoenvironment. London; Cambridge, 2017. P. 367-404. 
Greenland using kayak-like vessels ${ }^{178}$, so the migration may have to some extent relied on sailing in open waters during the warm months.

The Eastern ASTt toolkit in general, is compared by the researchers to the Denbigh Complex and consists of similar small tools with elaborate flaking (Fig. 5); it also has unique characteristics, for example, much better preservation of organic tools (bone, antler, and wood). It contains microblades, which were removed from the microblade cores of the same shape as those in the Denbigh Complex; burins (mitten-shape) and burins spalls removed from them, which were used as chisel tips to work on bone, antler, and wooden implements; end and side scrapers of various shape, including those with a side notch; retouched and polished burin spalls; awls; stemmed and lanceolate knives and spear points; flat triangular projectile tips, which were supposedly used to arm harpoons; and adzes with a slightly ground/polished edge ${ }^{179}$.

During Pre-Dorset, people started using ground slate spearheads and insets ${ }^{180}$, which were widely used during the following period (Dorset). We should note that there is a significant typological similarity between several Denbigh tools, described as «flake knives» ${ }^{181}$ and tools described in the Eastern ASTt as side scrapers ${ }^{182}$.

Eastern ASTt sites contain a wide array of organic tools, which practically never preserve in the West ASTt sites. These tools include bone harpoons, leister prongs, serrated single- and double-row dart points, pressure flakers, sewing needles, bone and wood handles for burins and spalls, and bow fragments ${ }^{183}$.

During the early stages of ASTt development (Independence I complex), serrated harpoons emerged, with a tanged base, flat wide hitch, non-toggling, with a space at the end for a stone end blade. At Qeqertasussuk researchers discovered over 50 toggling and tanged heads of harpoons ${ }^{184}$. Later (Saqqaq and Pre-Dorset), in addition to the barbed harpoons, toggle harpoons, serrated, with an open socket for foreshaft, some with a groove for a stone side or end blade were developed ${ }^{185}$.

In the continental regions, ASTt inhabitants hunted muskox, caribou, and to a lesser extent, arctic fox, hare, and polar bear. On the coast, they took seals, at the edge of the ice or at breathing holes, and walruses at their rookeries. Fragments of kayak-like watercraft ${ }^{186}$ indicate that in the summer people hunted marine animals, perhaps even whales, in open waters. Leisters point to fishing activities, and perhaps bird hunting. Plant foods were not

178 Gronnow B. Qeqertasussuk - the archaeology of a frozen Saqqaq site in Disko Bugt, West Greenland. P. 202-240.

179 Sorensen M. Technology and tradition in the Eastern Arctic, 2500 BC-AD 1200...

${ }^{180}$ Maxwell M. S. Prehistory of the Eastern Arctic. Orlando, Florida, 1985. Fig. 5.4 - OO, QQ.

181 Giddings J. L. The archeology of Cape Denbigh. Pl. 69, 15, 19.

${ }_{182}$ Maxwell M. S. Prehistory of the Eastern Arctic. Orlando, Florida, 1985. Fig. 4.3; 4.7; 5.4; 5.14.

183 Gronnow B. Qeqertasussuk - the archaeology of a frozen Saqqaq site in Disko Bugt, West Greenland. P. 205-220.

${ }^{184}$ Gronnow B. A. The backbone of the Saqqaq culture: Study of the Nonmaterial Dimensions of the Early Arctic Small Tool Tradition // Arctic Anthropology. 2012b. Vol.49, no.2. P.61-62; Park R. Eastern Arctic Small Tool. P. 27-45.

185 Maxwell M. S. Pre-Dorset and Dorset Prehistory of Canada. P. 359-368; Maxwell M. S. Prehistory of the Eastern Arctic. Orlando, 1985; Gronnow B. Qeqertasussuk - the archaeology of a frozen Saqqaq site in Disko Bugt, West Greenland. P. 202-240.

${ }^{186}$ Gronnow B. Qeqertasussuk - the archaeology of a frozen Saqqaq site in Disko Bugt, West Greenland. P. 216-222. 


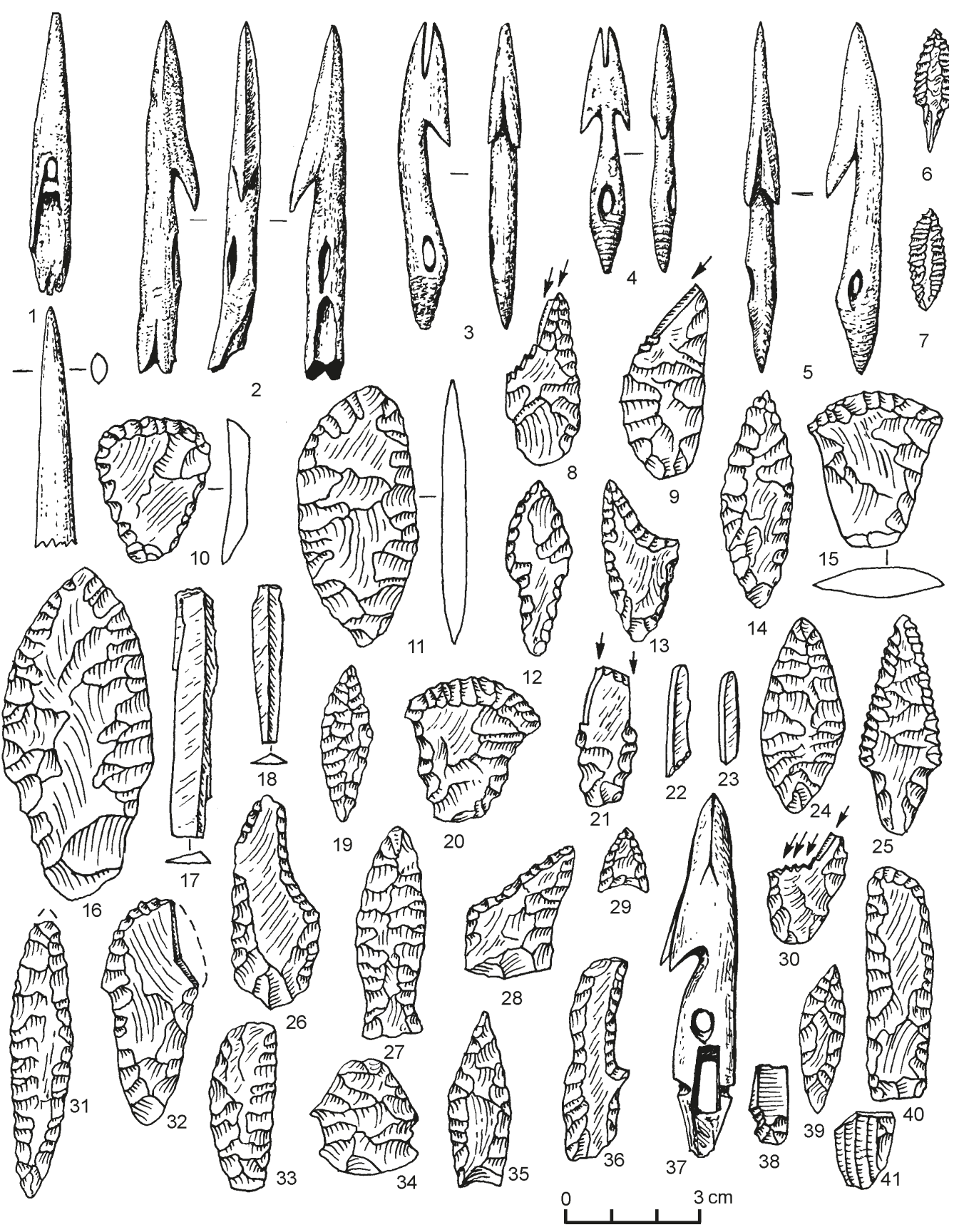

Fig. 5. Stone and osseous (bone and antler) tool assemblage of Eastern tradition ASTt (1-41):

$1-5,37$ - osseon tools; $6,12,14,16,19,24,25,27,29,35$ - points; $7,31,33,39$ - side inserts; 8, 9, 30 - "mitten-shaped" burins; 10, 15, 20, 38 - scrapers; 11, 28, 32, 36, 40 - knives; 13, 26 - side scrapers; 17, 18 - microblades; 21 - corner burin; 22; 23 - burin spalls; 34 - side-notched knife; 41 - microblade cores ([Redrawing after: 1-5 - [Gronnow, 1994]; 6-40 - [Maxwell, 1985]) 
a significant part of people's diet here. Meat was stored for the winter in stone-lined pits covered with stone plates ${ }^{187}$.

Due to the nomadic lifestyle, people lived in mobile small single-family dwellings, with skins over the driftwood frame. According to the remains of such dwellings, their edges were held down by gravel, small cobbles, or, in winter, snow blocks. The dwellings contained stone "midpassages" and a central hearth, which separated the dwelling into a residential area and a work area. Box hearth was constructed from vertically set flat stone plates, with stone boxes at either side for various practical needs (fuel storage, meat thawing) ${ }^{188}$. Researchers suppose that the Eastern ASTt dwellings were lit by stone lamps ${ }^{189}$, although there is some doubt regarding their existence in that area ${ }^{190}$. Several dwellings, housing up to six families, commonly formed a settlement ${ }^{191}$.

\section{Conclusion}

The archaeological record shows, that the unique continental Belkachi culture of taiga hunters, which formed in the Lena River drainage around $5200 \mathrm{BP}$ and whose roots appear to have been traced to the Transbaikalia ${ }^{192}$, quickly spread to the east of the Verkhoyansk Range through the Kolyma region and Chukotka ${ }^{193}$, all the way to the Bering Strait. The accumulated cultural energy allowed it to preserve its basic traits along the entire route, although, under the external or internal factors, certain aspects of it had changed, forming local Kolyma and Chukotka variants with their own unique characteristics.

The cultural impulse accumulated by this tradition allowed the Belkachi groups to transmit it across the narrow Bering Strait, separating Asia and North America, to Alaska, where it formed as a distinctive AST tradition with microblade cores, microblades, and a set of small chert insert tools ${ }^{194}$. Archaeological and genetic data suggest that this event dates to no later than $5000 \mathrm{BP}^{195}$. Crossing the Bering Strait implies that they had boats, although the strait could have been crossed over ice.

On the American continent, the population of this tradition spread from Alaska to its entire Arctic region all the way to Greenland, just as fast, over a few hundred years. They settled in regions, which had not previously seen humans, and developed specific territo-

187 Meldgaard M. Ancient Harp Seal Hunters of Disko Bay // Subsistence and Settlement at the Saqqaq Culture Site Qeqertasussuk (2400-1400 BC), West Greenland. Meddelelser om Gronland, Man and Society, 2004. Vol. 30. P. 196-200.

188 McGhee R. Ancient People of the Arctic.

189 Park R. Eastern Arctic Small Tool. P. 27-45.

190 Jensen J. F., Odgaard U., Funder S., Plumet P. First people in Greenland // Human Colonization of the Arctic: the interaction between early migration and the Paleoenvironment. London; Cambridge, 2017. P. 367-404.

191 Ross J.M. Peopling of the Eastern Canadian Arctic // Human Colonization of the Arctic: The Interaction Between Early Migration and the Paleoenvironment. London; Cambridge, 2017. P. 341-364.

192 Mochanov Yu. A. Mnogosloinaia stoianka Bel'kachi I i periodizatsiia kamennogo veka Iakutii.

${ }^{193}$ Dikov N. N. Early Cultures of Northeastern Asia; Kiryak M. A. Arkheologiia zapadnoi Chukotki; Slobodin S. The Upper Kolyma and Continental Priokhot'e during the Neolithic and Early Metal Periods; Kashin V.A. Neolit Srednei Kolymy: sbornik trudov.

194 Giddings J.L. The archeology of Cape Denbigh; Irving W.N. A provisional comparison of some Alaskan and Asian stone industries. P. 55-68.

${ }^{195}$ Harritt R. Paleo-Eskimo Beginnings in North America: A New Discovery at Kuzitrin Lake, Alaska // Inuit Studies. 1998. Vol.22, no.1. P.59-81; Rasmussen M. et al. Ancient human genome sequence of an extinct Palaeo-Eskimo // Nature. 2010. Vol. 463. P.757-762. 
rial complexes: Denbigh, Gravels, Pre-Dorset, Independence I, Saqqaq. These complexes demonstrate a superb adaptation of the inhabitants to interior and marine subsistence situations, with a developed harpoon complex and marine mammal hunting from boats in the open seas. The development of the classic ASTt concluded around 3000-2500 BP ${ }^{196}$, but some of its features were preserved in the succeeding cultures, Choris and Norton in Alaska $^{197}$, and Dorset in Canada and Greenland ${ }^{198}$.

\section{References}

Ackerman R.E. The Neolithic-Bronze age cultures of Asia and the Norton phase of Alaskan prehistory. Arctic Anthropology, 1982, vol. 19, no. 2, pp.11-38.

Ackerman R. E. Early Maritime Traditions in the Bering, Chukchi and East Siberian Seas. Arctic Anthropology, 1998, vol. 35, no. 1, pp. 247-262.

Ackerman R. E. Late Tundra. Encyclopedia of Prehistory. Vol. 2. Arctic and Subarctic. Boston, 2001, pp. 111115.

Anderson D. D. Onion Portage: the archaeology of a stratified Site from the Kobuk River, Northwest Alaska. Anthropological Papers University of the Alaska, 1988, vol. 22, no. 1-2, pp.1-163.

Anderson D.D. The Denbigh Flint Complex in Northwest Alaska: A Spatial Analysis. Alaska Journal of Anthropology, 2005, vol. 3, no. 2, pp. 81-100.

Anderson P. M., Brubaker L. B. Vegetation History of Northcentral Alaska: A Mapped Summary of LateQuaternary Pollen Data. Quaternary Science Reviews, 1994, no. 13, pp.71-92.

Anderson S.L., Tushingham S., Buonasera T.Y. Aquatic Adaptations and the Adoption of Arctic Pottery Technology: Results of Residue Analysis. Anthropology Faculty Publications and Presentations, 2017, no. $125,87 \mathrm{p}$.

Collins H. B. Archaeological research in the North American Arctic. Arctic, 1954, vol. 7, pp. 296-306.

Dikov N. N. Drevnie kostry Kamchatki i Chukotki. Magadan, Kniznoe izdatel'stvovo, 1969, 256 p. (In Russian)

Dikov N. N. Asia at the Juncture with America in Antiquity. Anchorage, the U.S. Department of the Interior, National Park Service, 1997, 248 p.

Dikov N.N. Archaeological Sites of Kamchatka, Chukotka, and the Upper Kolyma. Anchorage, the U.S. Department of the Interior, National Park Service, 2003, 394 p.

Dikov N. N. Early Cultures of Northeastern Asia. Anchorage, the U.S. Department of the Interior, National Park Service, 2004, $331 \mathrm{p}$.

Dixon E. J. Quest for the origin of the first Americans. Albuquerque, University of New Mexico Press, 1993, $156 \mathrm{p}$.

Dumond D.E. Coastal adaptation and cultural change in Alaskan Eskimo prehistory. Prehistoric Maritime Adaptations of the Circumpolar Zone. Paris, Mouton, 1975, pp. 168-180.

Dumond D. E. Archaeology on the Alaska Peninsula: the Naknek Region, 1960-1975. University of Oregon Anthropological papers, no. 21, Eugene, 1981, 277 p.

Dumond D.E. The Eskimo and Aleuts. London, ACLS Humanities E-Book, 1987, 180 p.

Dumond D. E. Denbigh Flint Complex. Archaeology of Prehistoric Native America. New York, NY; London, 1998, pp. 207-208.

Dumond D. E. Western Arctic Small Tool. Encyclopedia of Prehistory. Volume 2. Arctic and Subarctic. Boston, Springer US, 2001, pp. 213-224.

Dumond D.E. The Alaska Small Tool tradition in Southern Alaska. Alaska Journal of Anthropology, 2005, vol. 3, no. 2, pp. 67-78.

Dumond D.E., Bland R.L. Holocene Prehistory of the Northernmoust north Pacific. Journal of World Prehistory, 1995, vol. 9, no. 4, pp. 401-451.

196 Dumond D. E. The Alaska Small Tool tradition in Southern Alaska // Alaska Journal of Anthropology. 2005. Vol.3, no. 2. P.67-78; Tremayne A.H., Brown W.A. Mid to Late Holocene Population Trends, Culture Change and Marine Resource Intensification in Western Alaska // Arctic. 2017. Vol.70, no. 4. P. 365-380; Odess D. The Arctic Small Tool Tradition Fifty Years On. P. 5-16.

197 Giddings J. L. The archeology of Cape Denbigh; Dumond D. E. The Eskimo and Aleuts.

198 Maxwell M. S. Prehistory of the Eastern Arctic. Orlando, Florida, 1985. 
Dyke A.S. An outline of North American deglaciation with emphasis on central and northern Canada. Quaternary Glaciations, Extent and Chronology. Amsterdam, Elsevier Science, 2004, vol. 2b, pp. 373425.

Dyke A.S., Savelle J. M. Paleoeskimo Demography and Sea-Level History, Kent Peninsula and King William Island, Central Northwest Passage, Arctic Canada. Arctic, 2009, vol. 62, no. 4, pp. 371-392.

D'yachkov A. E. Anadyrskii krai. Magadan, Kniznoe izdatel'stvo, 1992, pp. 161-267. (In Russian)

Esdale J.E. A Current Synthesis of the Northern Archaic. Arctic Anthropology, 2008, vol.45, no. 2, pp. 3-38.

Everstov S. I. Novye archeologicheskie pamyatniki Indigirki i Alazei. Novoe v arkheologii Iakutii. Iakutsk, 1980, pp. 66-74. (In Russian)

Giddings J. L. The Denbigh Flint Complex is Not Yet Dated. American Antiquity, 1955, vol. 20, no. 4, pp. 375376.

Giddings J. L. A Flint Site in Northernmost Manitoba. American Antiquity, 1956, vol. 11, no. 3, pp. 255-268.

Giddings J. L. The archeology of Cape Denbigh. Providence, R. I., Brown University Press, 1964, 331 p.

Giddings J. L., Anderson D. D. Beach Ridge archeology of Cape Krusenstern. Washington, GPO, 1986, 386 p.

Goebel T., Powers R., Bigelow N. The Nenana complex of Alaska and Clovis origins. Clovis: origins and adaptations. Corvallis, Center for the Study of the First Americans, 1991, pp.49-79.

Goebel T., Waters M. R., O'Rourke D. H. The Late Pleistocene Dispersal of Modern Humans in the Americas. Science, 2008, vol.319, no. 5869, pp. 1497-1502.

Griffin J.B. A discussion of Prehistoric Similarities and Connections Between the Arctic and Temperate Zones of North America. Prehistoric Cultural Relations Between the Arctic and Temperate Zones of North America. Arctic Institute of North America, 1962, pp. 154-163.

Grønnow B. Qeqertasussuk - the archaeology of a frozen Saqqaq site in Disko Bugt, West Greenland. Threads of Arctic prehistory: Papers in honour of William E. Taylor. Quebec, Canadian Museum of Civilization, 1994, pp. 202-240.

Grønnow B. An archaeological reconstruction of Saqqaq bows, darts, harpoons, and lances. Inuit Studies, 2012, vol. 36, no. 1, pp. 23-48.

Grønnow B. A. The backbone of the Saqqaq culture: Study of the Nonmaterial Dimensions of the Early Arctic Small Tool Tradition. Arctic Anthropology, 2012, vol.49, no. 2, pp. 58-71.

Gusev S. V. Raskopki poseleniia Unenen na Vostochnoi Chukotke (drevnekitoboinaia kul'tura) v 20072014 gg. Archeologiya Arktiki, 2014, no. 2, pp. 205-212. (In Russian)

Harp E. Jr. Prehistory in the Dismal Lake area, N. W. T., Canada. Arctic, 1958, vol. 1, no. 4, pp. 219-249.

Harritt R. Eskimo Prehistory on the Seward Peninsula, Alaska. Research Report AR 21. Anchorage, the U.S. Department of the Interior, National Park Service, 1994, 572 p.

Harritt R. Paleo-Eskimo Beginnings in North America: A New Discovery at Kuzitrin Lake, Alaska. Inuit Studies, 1998, vol.22, no. 1, pp.59-81.

Helmer J. W. Pre-Dorset. Archaeology of Prehistoric Native America. New York; London, Routledge, 1998, pp. 683-686.

Helmer J.W. Arctic Small Tool Tradition. Archaeology of Prehistoric Native America. New York; London, Routledge, 1998, pp. 28-31.

Hemming J. E. The Distribution and movement patterns of caribou in Alaska. Alaska Department of Fish and Game. Game Technical Bulletin, July 1971, no. 1, 60 p.

Hoffecker J.F. A Prehistory of the north: human settlement of the higher latitudes. New Brunswick, Rutgers University Press, 2005, 227 p.

Holmes Ch. E. Tanana River Valley Archaeology Circa 14,000 to 9000 B. P. Arctic Anthropology, 2001, vol.38, no. 2, pp. 154-170.

Hood B.C. Theory on ice: the discourse of eastern Canadian Arctic Paleo-Eskimo archaeology. Acta Borealia, 1998, no. 2, pp. 3-58.

Hopkins D.M., Giddings J.L. Geological background of the Iyatayet archaeological Site, Cape Denbigh, Alaska. Smithsonian miscellaneous collection, vol. 121, no. 11. Washington, The Smithsonian Institution, $1953,33 \mathrm{p}$.

Irving W. N. Evidence of early tundra cultures in northern Alaska. Anthropological Papers of the University of Alaska, 1953, vol. 1, no. 2, pp. 55-85.

Irving W. N. An archaeological survey of the Susitna Valley. Anthropological Papers University of the Alaska, 1957, vol. 6, no. 1, pp. 37-52.

Irving W.N. A provisional comparison of some Alaskan and Asian stone industries. Prehistoric cultural relations between the Arctic and temperate zone of North America. Arctic Institute of N. America. Technical paper, 1962, no. 11, pp. 55-68. 
Irving W.N. Punyik Point and the Arctic Small Tool Tradition. Ph.D. dissertation. Madison, University of Wisconsin, 1964, $356 \mathrm{p}$.

Jensen J. F., Odgaard U., Funder S., Plumet P. First people in Greenland. Human Colonization of the Arctic: the interaction between early migration and the Paleoenvironment. London, Cambridge, 2017, pp. 367-404.

Kashin V. A. Neolit Srednei Kolymy: sbornik trudov. Novosibirsk, Nauka, 2013, 224 p. (In Russian)

Khersonskiy S. O zverinykh promyslakh v Okhotskoi okruge Primorskogo Kraya. Zapiski Amurskogo otdela $R G O$. Khabarovsk, 1898, vol. IV, no. I, pp.1-26. (In Russian)

Khlobystin L. P. The archaeology of Northernmost Eurasia. Washington, 2005. 236 p.

Kiryak M. A. Arkheologiia zapadnoi Chukotki. Moscow, Nauka, 1993, 224 p. (In Russian)

Kistenev S. P. Kamennyi vek basseina Nizhnei Kolymy. Avtoref. dis. ... kand. ist. nauk. Yakutsk, 1990, 22 p. (In Russian)

Kistenev S. P. Novye arkheologicheskie pamiatniki v basseine Kolymy. Novoe v arkheologii Iakutii. Iakutsk, 1980, pp. 74-87. (In Russian)

Knecht R.A., Davis R.S., Carver G.A. The Margaret Bay Site and Eastern Aleutian Prehistory. Recent Archaeology in the Aleut Zone of Alaska. University of Oregon Anthropological Papers, no. 58, pp. 35-69.

Knuth E. An outline of archaeology of Peary Land. Arctic, 1952, vol. 5, no. 1, pp. 17-32.

Knuth E. The Paleo-Eskimo culture of Northeast Greenland elucidated by three new sites. American Antiquity, 1954, vol. 19, no. 4, pp. 367-381.

Kunz M. L. The Mosquito Lake Site (PSM-049). Pipeline Archaeology. Fairbanks, University of Alaska, 1977, pp. 747-982.

Kunz M. The Denbigh Flint Complex at Punyjk Point, Etivlik Lake, Alaska. Alaska Journal of Anthropology, 2005, vol.3, no.2, pp. 101-116.

Larsen H. Trail Creek: Final Report on the Excavation of Two Caves on Seward Peninsula, Alaska. Acta Arctica. Vol. XV. Copenhagen, Munksgaard, 1968, 99 p.

Lobdell J.E. North Alaskan Pingos: Ephemeral Refugia in Prehistory. Arctic Anthropology, 1995, vol.32, no. 1, pp. 62-81.

MacNeish R.S. Pointed Mountain Site near Fort Liard, Northwest Territories, Canada. American Antiquity, 1953, vol. 19, no. 3, pp. 234-253.

MacNeish R.S. The Engigstciak Site on the Yukon Arctic Coast. Anthropological Papers of the University of Alaska, 1956, vol.4, no. 2, pp.91-111.

MacNeish R. S. Men out of Asia: as seen from the Northwest Yukon. Anthropological Papers University of the Alaska, 1959, vol. 7, no. 2, pp.41-70.

MacNeish R.S. Recent finds in the Yukon Territory of Canada. Prehistoric cultural relations between the Arctic and temperate zone of North America. AINA, Technical paper, 1962, no. 11, pp. 20-26.

Maschner H. D., Jordan J.W. The Russell Creek Manifestation of the Arctic Small Tool Tradition on the Western Alaska Peninsula. Archaeology in the Aleut Zone of Alaska: Some Recent Research. University of Oregon Anthropological Papers, 2001, no. 58, pp. 151-171.

Maxwell M.S. Archaeology of the Arctic and Subarctic Zones. Annual Review of Anthropology, 1980, no. 9, pp. 161-185.

Maxwell M.S. Pre-Dorset and Dorset Prehistory of Canada. Handbook of North American Indians: Arctic, vol. 5. Washington, The Smithsonian Institution, 1984, pp.359-368.

Maxwell M. S. Prehistory of the Eastern Arctic. Orlando, Academic Press, 1985, 327 p.

McGhee R. Paleoeskimo occupations of Central and High Arctic Canada. Memoirs of the Society for American Archaeology, 1976, vol.31, pp. 15-39.

McGhee R. Ancient People of the Arctic. Vancouver, UBC Press, 1996, 224 p.

McChee R. Dorset Culture. Archaeology of Prehistoric Native America. New York; London, Routledge, 1998, pp. 216-217.

Meldgaard J. A. Paleo-Eskimo Culture in West Greenland. American Antiquity, 1952, vol. 17, no. 3, pp. 222230.

Meldgaard M. Ancient Harp Seal Hunters of Disko Bay. Subsistence and Settlement at the Saqqaq Culture Site Qeqertasussuk (2400-1400 BC), West Greenland. Meddelelser om Gronland. Man and Society, 2004, vol.30, pp. 196-200.

Milne B., Park R. Pre-Dorset Culture. The Oxford handbook of the prehistoric Arctic. Oxford, Oxford University Press, 2016, pp. 806-807.

Mobjerg T. New Adaptive Strategies in the Saqqaq Culture of Greenland, c. 1600-1400 bc. World Archaeology, 1999, vol. 30, no. 3, pp. 452-465.

Mochanov Yu. A. Mnogosloinaia stoianka Bel"achi I i periodizatsiia kamennogo veka Iakutii. Moscow, Nauka, 1969, 254 p. (In Russian) 
Mochanov Yu. A. Drevneishie etapy zaseleniia chelovekom Severo-Vostochnoi Azii. Novosibirsk, Nauka, 1977, 264 p. (In Russian)

Mochanov Yu. A., Fedoseeva S. A. Main Periods in the Ancient History of North East Asia. Beringia in the Cenozoic Era. Rotterdam, New Delphi, 1986, pp. 669-693.

Nelson N. C. Notes on cultural relations between Asia and America. American Antiquity, 1937, vol.2, no. 2, pp. 267-272.

Odess D. An Early Arctic Small Tool Tradition Structure from Northwestern Alaska. Inuit Studies, 2003, vol. 27, no. 1-2, pp. 13-28.

Odess D. The Arctic Small Tool Tradition. Encyclopedia of the Arctic. New York, Routledge, 2005, pp. 146147.

Odess D. The Arctic Small Tool Tradition Fifty Years On. Alaska Journal of Anthropology, 2005b, vol. 3, no. 2, pp. 5-16.

Okladnikov A. P., Mazin L. I. Pisanitsy basseina reki Aldan. Novosibirsk, Nauka, 1979, 152 p. (In Russian)

Orekhov A. A. Severnaia Pacifika v golotsene (problemy primorskoi adaptatsii). Avtoref. dis. ... dokt. ist. nauk. St. Petersburg, 2001, 48 p. (In Russian)

Park R. Eastern Arctic Small Tool. Encyclopedia of Prehistory. vol. 2. Arctic and Subarctic. Boston, Springer US, 2001, pp. 27-45.

Pitulko V. V. Holocene stone age of Northeastern Asia. Encyclopedia of Prehistory. Vol. 2. Arctic and Subarctic. Boston, Springer US, 2001, pp. 46-58.

Pitulko V. V. Golocenovyi kamennyi vek Severo-Vostochnoi Azii. Estestvennaia istoriia Rossiiskoi Vostochnoi Arktiki v pleistotsene i golotsene. Moscow, Geos, 2003, pp.99-145. (In Russian)

Pitulko V.V., Pavlova E. Y. Geoarchaeology and Radiocarbon Chronology of the Stone Age of the North-East Asia. St. Petersburg, Nauka, 2010, 264 p. (In Russian)

Popov A.N. Burial Assemblages of Boisman-2 - a Stratified Site in Southern Primor'ye. Archaeology, Ethnology and Anthropology of Eurasia, 2008, vol.34, no. 2, pp.68-76.

Powers W. R., Jordan R. H. Human biogeography and climate change in Siberia and Arctic North America in the fourth and fifth millennia BP. Philosophical Transactions of Royal Society of London. Series A, Mathematical and Physical Sciences, 1990, vol. 330, no. 1615, pp. 665-670.

Raghavan M., DeGiorgio M., Albrechtsen A., et al. The Genetic Prehistory of the New World Arctic. Science, 2014, no, 345, iss. 6200, p. 1255832.

Rasmussen M. et al. Ancient human genome sequence of an extinct Palaeo-Eskimo. Nature, 2010, vol.463, pp. 757-762.

Reuther J.D., Gerlach S.C. Testing the "DICARB Problem": A Case Study from North Alaska. Radiocarbon, 2005, vol.47, no. 3, pp. 359-366.

Ross J.M. Peopling of the Eastern Canadian Arctic. Human Colonization of the Arctic: The Interaction Between Early Migration and the Paleoenvironment. London, Cambridge, 2017, pp.341-364.

Savelle J.M., Dyke A.S. Variability in Palaeoeskimo Occupation on South-Western Victoria Island, Arctic Canada: Causes and Consequences. World Archaeology, 2002, vol.33, no. 3, pp. 508-522.

Schoenberg K. M. The archeology of Kurupa Lake. Research / Resources management report ARE-10. Anchorage, U.S. Department of the Interior, National Park Service, 1985, 434 p.

Slaughter D. C. Radiocarbon dating the Arctic Small Tool tradition in Alaska. Alaska Journal of Anthropology, 2005, vol.3, no. 2, pp. 117-134.

Slobodin S. B. K voprosu o vydelenii protoeskimosskih kul'tur v Beringii. II Dikhovskie chteniia: Materialy nauchno-prakticheskoi konferentsii. Magadan, 2002, pp. 372-379. (In Russian)

Slobodin S. B. Neolit Severo-Vostoka Azii i traditsiia Arktik Smol Tul Severnoi Ameriki. III Dikhovskie chteniia: materialy nauchno-prakticheskoi konferentsii. Magadan, 2004, pp. 343-355. (In Russian)

Slobodin S. The Upper Kolyma and Continental Priokhote during the Neolithic and Early Metal Periods. Anchorage, NPS, 2015, $210 \mathrm{p}$.

Slobodin S. B., Anderson P. M., Glushkova O. Yu., Lozhkin A. V. Western Beringia. Human Colonization of the Arctic: the Interaction Between Early Migration and the Paleoenvironment. London, Cambridge, 2017, pp. 239-298.

Sorensen M. Technology and tradition in the Eastern Arctic, 2500 BC-AD 1200: a dynamic technological investigation of lithic assemblages from the Palaeo-Eskimo traditions of Greenland. Copenhagen, Museum Tusculanum Press, University of Copenhagen, 2012, 420 p.

Stanford D.E. Evidence of Paleo-Eskimos on the North Coast of Alaska. Paper presented at the $36^{\text {th }}$ annual meeting of the Society for American Archaeology, Norman, Oklahoma, 1971, 26 p.

Stanford D. Walakpa Site Alaska: It's Place in the Birnirk and Thule Cultures. Smithsonian contributions to Anthropology, no. 20, 1975, 226 p. 
Steensby H.P. An Anthropogeographical study of the origin of the Eskimo Culture. Meddelelser om Gronland, 1916, vol. 53, 228 p.

Steffian A. F., Saltonstall P. G. Tools but not Toolkits: Traces of the Arctic Small Tool Tradition in the Kodiak Archipelago. Alaska Journal of Anthropology, 2005, vol. 3, no. 2, pp. 17-49.

Stimmell C. Going to Pot: A Technological Overview of North American Arctic Ceramics. Threads of Arctic Prehistory: Papers in Honour of William E. Taylor Jr. Eds David Morrison and Jean-Luc Pilon. Quebec, Canadian Museum of Civilization, 1994, pp. 35-56.

Sutherland P.D. Continuity and change in the Paleo-Eskimo prehistory of Northern Ellesmere Island. The Paleo-Eskimo Cultures of Greenland, New Perspectives in Greenlandic Archaeology. Copenhagen, Danish Polar Center, 1996, Publ. no. 1, pp. 271-294.

Tremayne A.H. An Analysis of Denbigh Flint Complex Burin Technology from Matcharak Lake, Alaska. Alaska Journal of Anthropology, 2010, vol. 8, no. 1, pp.73-85.

Tremayne A.H. An analysis of faunal remains from a Denbigh Flint Complex camp at Matcharak Lake, Alaska. Arctic Anthropology, 2011, vol. 48, no. 1, pp. 35-53.

Tremayne A.H. The design of Arctic Small Tool tradition toolkits: An example from Matcharak Lake, Alaska. North American Archaeologist, 2015, vol.36, pp. 1-31.

Tremayne A. H. New Evidence for the Timing of Arctic Small Tool Tradition Coastal Settlement in Northwest Alaska. Alaska Journal of Anthropology, 2015, vol. 13, no. 1, pp. 1-18.

Tremayne A.H., Brown W. A. Mid to Late Holocene population trends, culture change and marine resource intensification in Western Alaska. Arctic, 2017, vol.70, no. 4, pp. 365-380.

Tremayne, A.H., Rasic, J.T. The Denbigh Flint complex of northern Alaska. The Oxford handbook of the prehistoric Arctic. Oxford, Oxford University Press, 2016, pp. 349-370.

Tremayne A., Darwent Ch. M., Darwent J., Rasic J. T. Iyatayet Revisited: A Report on Renewed Investigations of a Stratified Middle-to-Late Holocene Coastal Campsite in Norton Sound, Alaska. Arctic Anthropology, 2018, vol.55, no. 1, pp. 1-23.

Wilson A. The Imaigenik Site: Irving's Arctic Small Tool Prior to Punyik. Paper presented at the 36th Annual Alaska Anthropological Association Meeting, Anchorage, Alaska, 2008.

Workman W. B., Zollars P. The Dispersal of the Arctic Small Tool Tradition into Southern Alaska: Dates and Data from the Kenai Peninsula, Southcentral Alaska. Anthropological Papers of the University of Alaska, 2002, vol. 2, no. 1, pp. 39-49.

Yesner D.R. Human dispersal into interior Alaska: antecedent conditions, mode of colonization, and adaptations. Quaternary Science Reviews, 2001, vol.20, no. 1-3, pp.315-337.

Yoshitany A., Slobodin S., Tomoda T., Vorobey I.E, Yano T. Studies on the obsidian fragments from the Late Palaeo-, Meso- and Neolithic sites in the Northeastern Part of Far East of Russia. Memoir of the Museum of Archaeology of Kokugakuin Univ. Shibuta, Tokyo, 2013, no. 29, pp. 1-21.

Статья поступила в редакцию 17 июня 2018 г.

Рекомендована в печать 12 марта 2019 г.

Received: June 17, 2018

Accepted: March 12, 2019 


\title{
The Most Ancient Ceramics of Baikal Siberia in the Context of the Traditions of Ceramics of East Asia
}

\author{
V.M. Vetrov ${ }^{\dagger}$, E. M.Ineshin
}

For citation: Vetrov V. M., Ineshin E. M. The Most Ancient Ceramics of Baikal Siberia in the Context of the Traditions of Ceramics of East Asia. Vestnik of Saint Petersburg University. History, 2019, vol. 64, issue 2, pp. 453-473. https://doi.org/10.21638/11701/spbu02.2019.205

Here we discuss research questions that arised in Siberian and the Russian Far Eastern archaeology due to discovery of the ancientmost ceramics. Usually study of ceramics and stone implements do not intercept. Lithic industries even if followed by ceramics are being discussed as Upper Paleolithic materials. Here we present previously unpublished data from Ust-Karenga archaeological complex along with the context of lithic industry. Description of the ancient ceramics is given in the context of archaeological materials from adjacent territories that contemporary to Ust-Karenga finds. Real links between these materials are established based on radiocarbon dating, mineralogy and micro element compositions of rocks used to manufacture diverse stone tools. Autors argue that the emergence of ceramic production took place in South China between 17,000-14,000 years ago. Then it spread northeast reaching Vitim and Chikoy basins when ceramic tradition holders started moving because of the late glacial environmental changes. Presumably, this might take place at around 13,000 years ago. New adaptation models such as fishing, food storage and necessity to use resources of vast had been challenged. This is in line with paleoathropological evidence and with the results of paleogenetics studies that indicate the southeastern origin of the mtDNA genome found for the bearers of the ancient ceramic tradition revealed in Siberia. Based on comprehensive evaluation of both lithic and ceramic component of archaeological context, authors see the necessity to revise the approach in search for cultural definition and principals of periodization in the Stone Age archaeology of Northern Asia.

Keywords: wedge-shaped cores, Siberia, late Pleistocene, glaciation, microblades, adaptation, three in one principle, ancient ceramics.

\section{Древнейшая керамика Байкальской Сибири в контексте традиций керамики Восточной Азии}

В.М.Ветров, Е. М. Инешин

Для цитирования: Vetrov V.M., Ineshin E.M. The Most Ancient Ceramics of Baikal Siberia in the Context of the Traditions of Ceramics of East Asia // Вестник Санкт-Петербургского университета. История. 2019. Т.64. Вып. 2. С. 453-473. https://doi.org/10.21638/11701/spbu02.2019.205

Evgeny M. Ineshin - PhD in History, Head of the Laboratory of Archeology, the Pedagogical Institute of the Irkutsk State University, 9, Sukhbaatar, Irkutsk, 664011, Russian Federation; ineshin.evgen@yandex.ru

Евгений Матвеевич Инешин - канд. ист. наук, зав. лаборатории археологии, Педагогический институт Иркутского государственного университета, Российская Федерация, 664011, Иркутск, Сухэ-Батора, 9; ineshin.evgen@yandex.ru

(c) Санкт-Петербургский государственный университет, 2019 
В статье рассмотрен круг вопросов археологии Сибири и Дальнего Востока России, появившихся в связи с открытием и постепенным вводом в научный оборот данных, относящихся к древнейшим свидетельствам керамического производства. Отмечено, что по настоящее время их значение не в полной мере оценено научным сообществом. Так, анализ керамики и каменного инвентаря до сих пор проводится раздельно, при этом каменные индустрии, сопровождающие ранние находки керамики, воспринимаются исследователями исключительно в качестве верхнепалеолитических. В статье представлены неопубликованные данные о керамических сосудах из Усть-Каренгского археологического комплекса и сопровождающем их каменном инвентаре. Древнейшая керамика Усть-Каренгского археологического комплекса описана в контексте одновозрастных археологических памятников прилегающих территорий. На основании данных радиоуглеродного датирования, изучения минералогического и элементного составов изделий из камня удалось выявить реальные связи, существовавшие между археологическими объектами в прошлом. В результате, сформулировано предположение о происхождении собственно керамического производства и о путях переноса данной традиции в бассейн Витима и Чикоя, а также и о ее носителях. Предполагается, что традиция керамического производства, сформировавшаяся около 17000-14000 л. н. в южных районах Китая, распространилась на рубеже 13000 лет назад в районы Северо-Востока Азии. Природно-климатическим фоном этого процесса служили условия позднего ледниковья, в контексте которых у местного населения формировались новые адаптационные механизмы (новый способ создания запасов пищевых ресурсов - рыболовство и высокая мобильность, необходимая для освоения обширных пространств небольшими группами охотников-собирателей). Данное предположение подтверждается как палеоантропологическими материалами, так и результатами изучения митохондриальной ДНК древнего населения региона. Носители традиции древнейшего керамического производства имеют юго-восточное происхождение. С позиций комплексной оценки каменного и керамического инвентаря в палеоэкологическом контексте сделан вывод о необходимости пересмотра подхода к выделению культур и принципов периодизации каменного века Северной Азии.

Ключевые слова: клиновидные нуклеусы, Сибирь, поздний плейстоцен, оледенения, микропластины, адаптации, принцип «три в одном», древняя керамика.

In the territory of modern Russia, the oldest ceramics was discovered in the early 1970s almost simultaneously in several places - in Primorye and the Amur River region (Hummi, Gassia, Ustinovka, Osipovka) ${ }^{1}$, in Transbaikal region (in the Chikoy river valley at Studenoe 1 sites) ${ }^{2}$ and in the Vitim river valley (Ust-Karenga XII, XIV, XVI, Yumurchen-VIII) ${ }^{3}$. At present, 18 reliable archaeological sites with ancient ceramics are known, which are provided with 77 radiocarbon dates ${ }^{4}$ (Fig. 1). Its discovery in Russia was preceded by similar finds in Japan, where about 100 archaeological sites with the evidence

${ }^{1}$ Zhushchikhovskaia I. S. Drevneishaia keramika: puti tekhnologicheskoi innovatsii // Vestnik DVO RAN. Arkheologiia. 2011. No. 1. P. 101-110.

${ }^{2}$ Razgildeeva I.I., Dai K., Ianshina O.V. Novye dannye o vozraste drevneishikh keramicheskikh kompleksov zapadnogo Zabaikal'ia // Evraziia v Kainozoe. Stratigrafiia, paleoekologiia, kul'tury. 2013. Iss. 2. P. 168-178; Tsydenova N., Andreeva D., Zech W. Early pottery in Transbaikal Siberia: New data from Krasnaya Gorka // Quaternary International. 2017. Vol.441. P. 81-90.

3 Kuzmin Y., Vetrov V. The earliest Neolithic complex in Siberia: the Ust-Karenga 12 site and its significance for the Neolithization process in Eurasia // Documenta Praehistorica. 2007. No. 24. P. 9-12.

4 Sato H., Natsuki D. Human behavioral responses to environmental conditions and the emergence of the worlds oldest pottery in East and Northeast Asia: An overview // Quaternary International. 2017. Vol. 441. P. 12-28. 
of technology of the most ancient ceramic have been discovered by now ${ }^{1}$. Subsequently, traces of ancient pottery are found in China (Xianjendong, Yuchanyan, Miaoyan) and in South Korea (e.g., Kozanni, Tomsandon, Kumenri) (Fig. 1). Reliable dates on ceramic complexes were obtained in the late 1980s and in the 1990s on organic materials from cultural layers (charcoal and bone), and with the development of AMS dating technology, they were largely confirmed by direct dating of organic residues included in ceramic paste and carbon deposits on dishware surface.

The most complete up-to-date radiocarbon data set is presented by Sato and Natsuki who made important and reasonable conclusions when discussing the question of spatio-temporal patterns observed in the Far East on the ancient pottery ware sites ${ }^{5}$, and we find it to be fully appropriate and reliable. Partly, these data are also used by Kuzmin ${ }^{6}$, however in that version they are not so detailed, and thus we follow mostly Sato and Natsuki $^{7}$ in further discussions.

Surprisingly, the discovery of the most ancient ceramics did not lead to careful consideration of the phenomenon of ancient ceramics in the professional community. In general, it was mostly expressed in validation of dates, re-dating of the materials in search of older periods and debate of their reliability ${ }^{8}$. Some of the researchers, including those who found the first contexts with really old ceramics, questioned their own findings, and thus the very fact of the existence of the ancient pottery ware was rejected ${ }^{9}$. For instance, the discovery of ancient ceramics in cultural horizons dated by the end of the Pleistocene by the radiocarbon method of coal from the centers of the settlements Studenoe-1 and Ust-Menza in Transbaikalia was first ignored by the discoverer, then presented as a kind of error in the method of dating or a specific feature of the object's stratigraphy. As a rule, researchers give a description of ancient ceramics with no connection to the analysis of stone and bone implements, or the latter are discussed superficially ${ }^{10}$.

There was also no understanding of the phenomenon of early ceramics in the context of validation of the criteria for definition of the boundaries for some of the taxons used in the archaeological periodization based on European materials when applied to the ar-

${ }^{5}$ Sato H., Natsuki D. Human behavioral responses to environmental conditions and the emergence of the worlds oldest pottery in East and Northeast Asia: An overview. P. 12-28.

${ }^{6}$ Kuzmin Y. V. The origins of pottery in East Asia and neighboring regions: An analysis based on radiocarbon data // Quaternary International. 2017. Vol. 441B. P. 29-35.

7 Sato H., Natsuki D. Human behavioral responses to environmental conditions and the emergence of the worlds oldest pottery in East and Northeast Asia: An overview.

8 Zhushchikhovskaia I.S. Drevneishaia keramika: puti tekhnologicheskoi innovatsii. P.101-110; Razgildeeva I. I., Dai K., Ianshina O. V. Novye dannye o vozraste drevneishikh keramicheskikh kompleksov zapadnogo Zabaikal'ia. P.168-178; Mylnikova L.N., Nesterov S.P. Fiziko-khimicheskoe issledovanie keramiki pamiatnika Kosanni: k probleme proiskhozhdeniia goncharstva // Neolit i neolitizatsiia basseina Iaponskogo moria: chelovek i istoricheskii landshaft: Vladivostok, 2008. P. 161-165.

9 Konstantinov M. V.: 1) Kamennyi vek vostochnogo regiona Baikalskoi. Ulan-Ude; Chita, 1994; 2) "I opyt, syn oshibok trudnykh" (problemy opredeleniia vozrasta drevnikh poselenii Zabaikal'ia) // Drevnee Zabaikale: kul'tura i priroda. Chita, 2009. P. 35-42.

${ }^{10}$ Kuzmin Y. V. The origins of pottery in East Asia and neighboring regions: An analysis based on radiocarbon data // Quaternary International. 2017. Vol.441B. P. 29-35; Razgildeeva I. I., Dai K., Ianshina O. V. Novye dannye o vozraste drevneishikh keramicheskikh kompleksov zapadnogo Zabaikal'ia // Evraziia v Kainozoe. Stratigrafiia, paleoekologiia, kul'tury. 2013. Iss. 2. P. 168-178; Tsydenova N., Andreeva D., Zech W. Early pottery in Transbaikal Siberia: New data from Krasnaya Gorka // Quaternary International. 2017. Vol.441. P. 81-90; Sato H., Natsuki D. Human behavioral responses to environmental conditions and the emergence of the worlds oldest pottery in East and Northeast Asia: An overview. P. 12-28. 


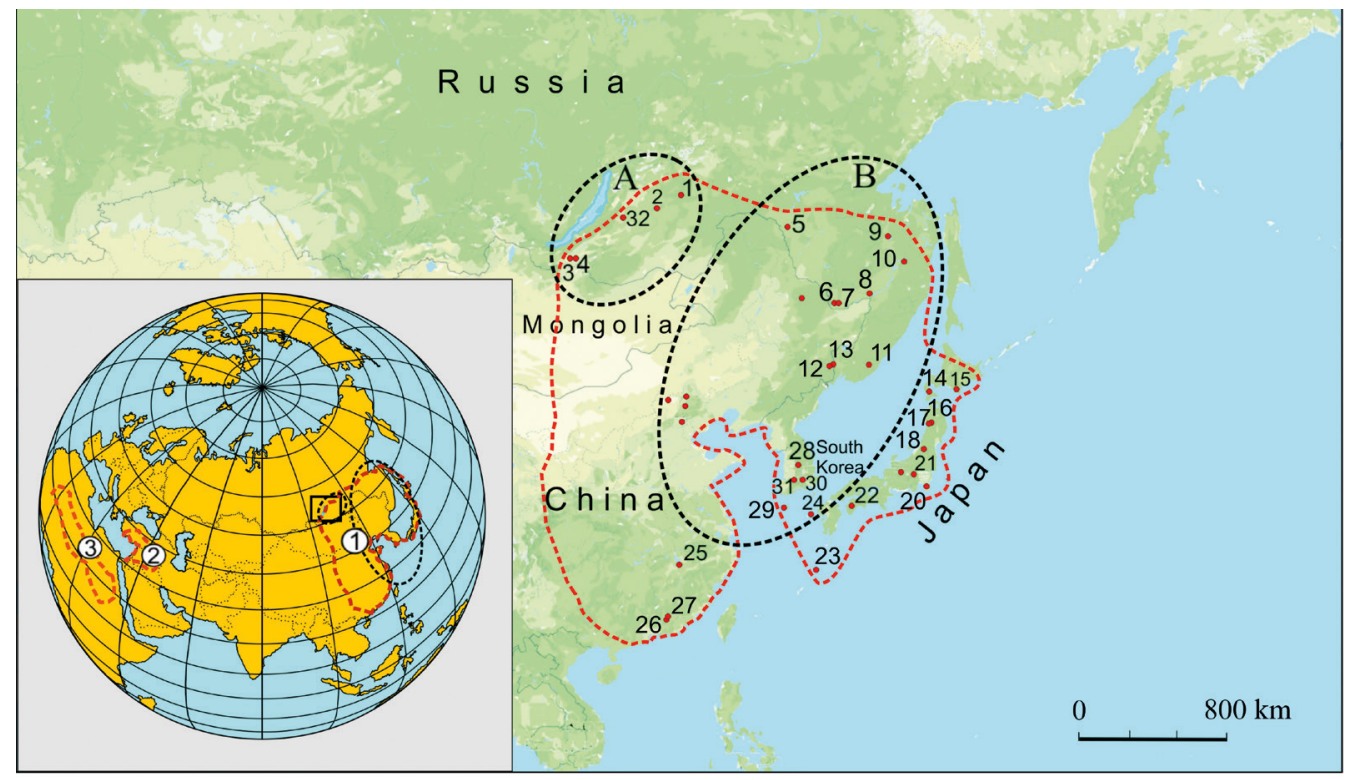

Fig. 1. Map of archaeological sites with ancient ceramics in East Asia:

1 - Ust'-Karenga 2, 14, 16; 2 - Ust'-Umyrchen 8; 3 - Studenoe 1; 4 - Ust'-Menza 1; 5 Gromatukha; 6 - Goncharka 1, Osinovaya rechka, Gasha; 7 - Novotroitskoe; 9 - Yamikhta; 10 - Khummi; 14 - Odai-Yamamoto I; 17 - Kiwada; 18 - Takihata; 19 - Kubodera-minami, Tako-minamihara, Jin., Unoki-minami; 20 - Kuzuharazawa IV, 2-Seiko-sanso, Gotenyama 2N, Shoanfujisawa campus, Tsukimino-kamino loc. 2, Nozawa; 21 - Gotenyama 2N; 22 - Kamikuroiwa; 23 - Sankakuyama; 24 - Fukui cave, Senpukuji; 25 - Xianrendong; 26 - Zengpiyan; 27 Yuchanyan; 28 - Osanni; 29 - Gosanri; 30 - Tonsamdon; 31 - Posanni; 32 - Krasnaya Gorka; 33 - Nanzhuangtou; 34 - Donghulin; 35 - Zhuannian; 36 - Yujigou.

Red dashed line marks the area of the Far Eastern province of the ancient ceramics, within which continental (A) and coastal zone (B) are distinguished and indicated by black dashed contours. Low left corner: worlwide distribution of the ancient ceramics - East Asian province (1), West Asian, or Near Eastern center (2), and North African province (3) (illustration by E. Ineshin)

chaeology of Asia. The fact of ancient ceramics has not been appreciated in terms of understanding human adaptations at the end of the Pleistocene in North Asia. If in Europe the emergence of ceramics is appraised as a marker of the Neolithic and related changes in the economic and ideological spheres, then how, in light of the new evidence on the ancient ceramics dating, can we assess the end of the Pleistocene in the East of Asian? Was its ceramics Paleolithic, Mesolithic? Pleistocene Neolithic? How to evaluate, in the light of the latest datings of the oldest ceramics in southeastern China, the late Paleolithic in North Asia? What did the manufacture of ceramics mean in terms of primitive economy? Cooking? Stockpiling and canning? What was the original shape of ceramic vessels and what were their changes associated with? What do the earliest forms of ornaments reflect? And so on. All these questions remain outside the scope of discussion.

Among known archaeological sites with ancient ceramics, the Ust-Karenga archaeological complex stands quite apart ${ }^{11}$. It is the largest and most studied of the objects with

11 Vetrov V.M. Drevneishie sledy keramicheskogo proizvodstva v Vostochnoi Azii // Antropogen. Paleontropologiia, geoarkheologiia, etnologiia Azii. Irkutsk, 2008. P. 28-34. 


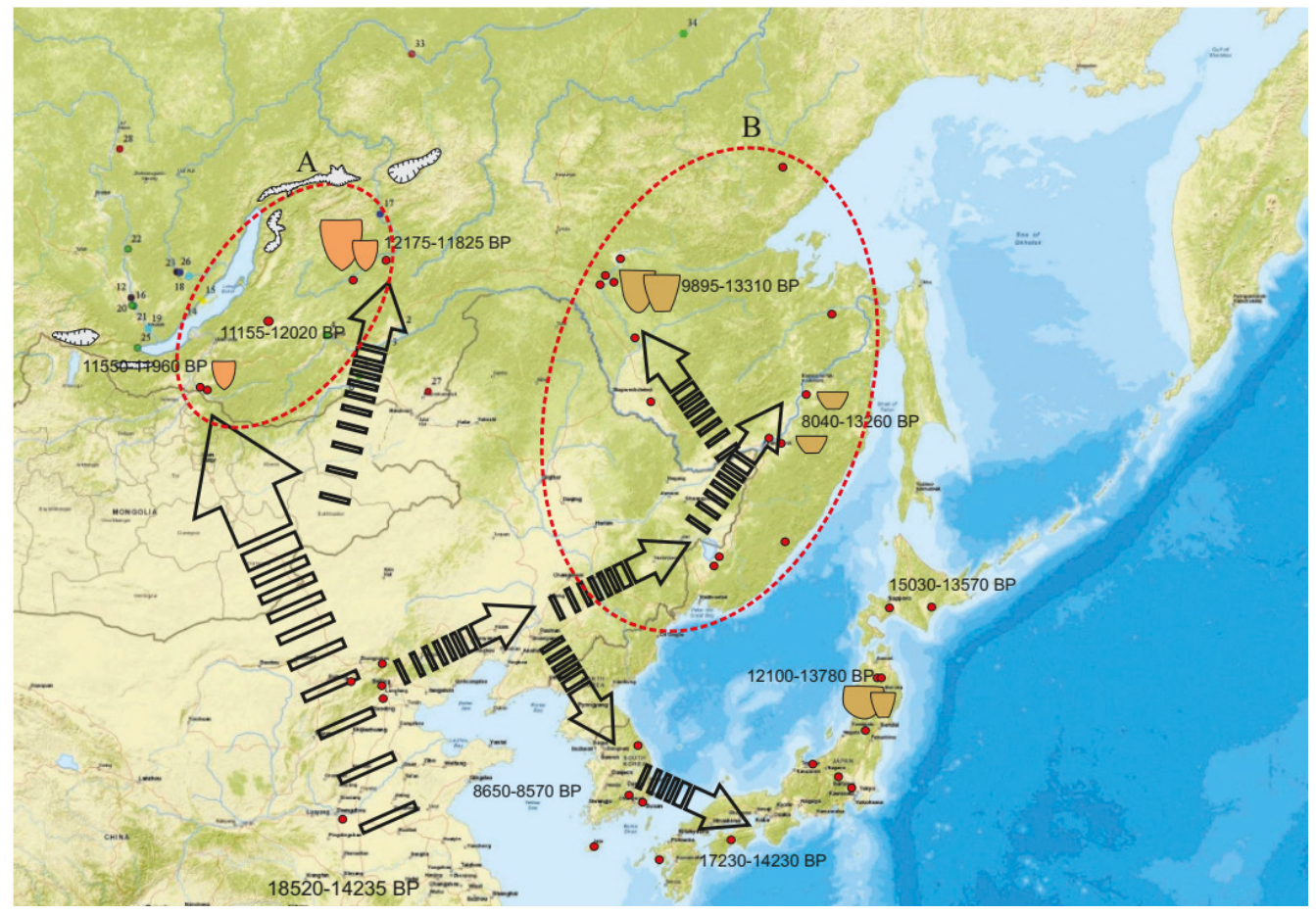

Fig. 2. East Asian center of the emergence and development of the ceramics production, and possible directions of its spread into coastal continental zone, respectively.

A - continental zone of the most ancient ceramics production; B - coastal zone of the most ancient ceramics production (map by E.M. Ineshin)

the oldest ceramics on Vitim (Ust-Yumurchen VIII, Ust-Oktorokon). The peculiarity of archaeological monuments with the oldest ceramics on Vitim are their layering and proximity to other archaeological objects which are synchronous to them, being also multilayered, but with no ceramics in the collection. There have been established connections between a part of archaeological objects with ceramics and without it, which are reliably documented by the observed facts of the transfer of rare types of stone raw materials, and are confirmed by the analytical results of various methods ${ }^{12}$. Following A. A.Zinoviev $^{13}$, by connections we mean "matter or energy transfer" hereafter. In the Ust-Karenga archaeological complex, ancient ceramics was recorded in various cultural horizons included in alluvial and subaerial deposits formed over a long chronological interval of 11,240-6,890 years ago (Fig. 2), which was not observed at any other archaeological site in East Asia (uncalibrated radiocarbon ages are used hereafter).

Practically, this is the only archaeological site where the oldest ceramics is fixed in a multi-layered position, which makes it possible to follow both the development of manufacturing technology, changes in the shape of vessels, functional use and ornamentation

12 Vetrov V.M., Ineshin E.M., Revenko A. G., Sekerin A.P. Artefakty iz ekzoticheskikh vidov syria na arkheologicheskikh pamiatnikakh Vitimskogo basseina // Baikalskaia Sibir' v drevnosti. 2000. Iss. 2, part 1. P.98-117.

13 Zinovev A. A. Na puti k sverkhobshchestvu. Moscow, 2000. P. 260. 
through time, and changes in the stone inventory accompanying ceramics as well. After $6890 \pm 80{ }^{14} \mathrm{C}$ BP, the oldest type of ceramics was replaced by another type, and changes occurred in sets of stone implements, expressed in the transition to another way of flaking system for blade cores (from wedge-shaped to prismatic) with the simultaneous switch to different raw material ${ }^{14}$. The final dating of ceramics of the most ancient type is of particular importance to us, as it enables, on well-documented grounds, to include the materials from human burial on Lower Dzhilinda (Sivakon) into a circle of objects that are synchronous to ancient ceramic production. In turn, this circumstance allows to proceed to a discussion of the issues of anthropology and paleogenetics of the ancient potters of Asia. This is the only case so far that makes it possible to include some new information in the analysis.

It is conceivable that ancient ceramics was also present in Studenoe 1 and Ust-Menza 1 stratified sites, but the very fact of finding it was ignored due to the methodology used by the excavators, and thus such finds had not been even mapped. Currently, there are only brief descriptions published tardily, on the two cultural horizons of these objects, including the dating of cultural remains, data on the form and technology of manufacturing the oldest vessels from the Chikoy valley ${ }^{15}$.

The remains of ceramic vessels of the most ancient type (as a rule, their upper parts), were recorded in separate loci at the Ust-Karenga archaeological complex, precisely at locality III, XII, XIV and XVI. Ceramic-bearing layer of these stratified sites recognized as 'combined cultural horizon 7' was detected on the vast area. Its end points are at a distance of $1500 \mathrm{~m}$ from each other, and thus, presumably, the area covered by the horizon 7 between localities XII, XIV, and XVI counts to $1,7 \times 10^{5} \mathrm{~m}^{2}$, of which only $822 \mathrm{~m}^{2}$ of which have been excavated. These local points do not constitute a single settlement with a common structure, and the allocation of so-called the $7^{\text {th }}$ cultural horizon with ancient ceramics at each of the localities is, to some extent, a simplification based on the general position of the horizon with cultural remains in the top of alluvial bedded river sands covered by thin-layered fine grained lacustine sands. The difference in elevation between separate localities that contain horizon 7 exceeds $3 \mathrm{~m}$ in height, yet this level is termed 'the $7^{\text {th }}$ cultural horizon (combined horizon)'. At Ust-Karenga XII site, cultural remains are also recorded below the level 7, in 8 and $8 \mathrm{~A}$ horizons occurring in the alluvial deposits that underlie it. However, no ceramics belongs to them so far, which is probably due to the small area of excavation ${ }^{16}$. It should be noted that in terms of lithic technology (knapping technology and tool typology) there is no difference between the $7^{\text {th }}$ cultural horizon, on the one hand, and 8 and $8 \mathrm{~A}$ horizons, on the other.

So far, only two horizons of those which yielded the oldest ceramics are characterised by radiocarbon dates on charcoal samples from the hearth and on organic residues respectively. The Horizon 7 at Ust-Karenga XII dates to $11,240 \pm 180{ }^{14} \mathrm{C}$ years BP, and the $5^{\text {th }}$ cultural horizon at Ust-Karenga III dates to $6890 \pm 80{ }^{14} \mathrm{C}$ years BP. Additionally, two more dates were obtained on organic component of ceramic paste from Ust-Karenga

14 Vetrov V.M. Drevneishie sledy keramicheskogo proizvodstva v Vostochnoi Azii. P. 28-34.

15 Razgildeeva I. I., Dai K., Ianshina O. V. Novye dannye o vozraste drevneishikh keramicheskikh kompleksov zapadnogo Zabaikal'ia. P. 168-178.

${ }_{16}$ Hommel P.N., Schwenninger J.-L., Ineshin E.M., Vetrov V.M. Testing times: an evaluation of the radiocarbon chronology for early ceramic vessel production at Ust'-Karenga // Izvestiia laboratorii drevnikh tekhnologii. 2017. Vol. 13, no. 1. P.31-46. 
XII. These are $11065 \pm 70(\mathrm{AA}-38101)$ and $10600 \pm 110(\mathrm{AA}-21378)^{17}$ that come from the $7^{\text {th }}$ (combined) cultural horizon. Finally, OSL dating performed on quartz grains extracted from the ceramic paste produced the age of 11240 years ago.

Research done on previously received radiocarbon dates on charcoal samples that come from the hearth fill allowed to recognize problems in methodological approach used for sampling. Because of that, older dating results are considered erroneous, and we therefore use the chronology based on the newest AMS ${ }^{14} \mathrm{C}$ dating results performed on organic inclusions extracted from the ceramic paste. These dates have a good relationship with the dating of catastrophic geological event, which is well recognizable in the regional stratigraphic record. This is the formation of Muya dammed lake that left well-expressed signature at Ust-Karenga archaeological complex. Its lithostratigraphic sequence contains a deposit of fine grained thin-bedded sand which is up to $1,4 \mathrm{~m}$ thick. This sand deposit overlays culture-bearing deposits, namely horizons 8 and $8 \mathrm{~A}$, and combined horizon 7 .

Lacustrine genesis of these deposits is reliably established by pollen and diatom record that indicates formation of diatomic associations in the cold environment of stagnant deep-water reservoir. Radiocarbon dates obtained by D. Kunikita on organic inclusions sampled from ceramic fragments of three different ceramic vessels that come from three different locations at Ust-Karenga site complex indicate that the human habitation and ceramic production took place at about 12000 years ago - $11870 \pm 40$ (TKA-19744, locality XVI), $11825 \pm 45$ (TKA-19745, locality XII, vessel 1), and $12175 \pm 40$ (TKA-19743, locality XII, vessel 2$)^{18}$.

These ages pre-date the formation of Muya dammed lake, which is reliably dated to $11770 \pm 40$ (Beta-432243). This date is received by dating the larchwood sample obtained from the burried forest horizon in the central part of the former lake ( the external part of the larchwood stem was sampled within the latest growth zone of the last five year-rings, which makes the dating result solid). Thus, time of the formation of the combined culture-bearing horizon (horizon 7) in different areas can be estimated as 350 years at least.

Year-ring structures observed on the samples of the buried larchwood forest indicate extremely cold and dry conditions with low-water stage of the river development that lasted for 200 years prior to the formation of Muya dammed lake and thus precisely demonstrate environmental conditions at the time of the formation of the combined horizon 7.

In general, the geological age of the ceramics and cultural remains from different horizons of the Ust-Karenga complex is supported by 24 age determinations, 21 of which are radiocarbon dates and three produced by OSL dating ${ }^{19}$. This is a large data set, but for years all kinds of errors and/or misinterpretations have occurred ${ }^{20}$, and then this needs to be discussed extensively. At present, we can agree with the above given chronology that is based on direct dating of the early ceramics of the horizon 7 at Ust-Karenga and which is

${ }^{17}$ Kuzmin Y., Vetrov V. The earliest Neolithic complex in Siberia: the Ust-Karenga 12 site and its significance for the Neolithization process in Eurasia. P. 9-20.

18 Sato H., Natsuki D. Human behavioral responses to environmental conditions and the emergence of the worlds oldest pottery in East and Northeast Asia: An overview. P. 12-28.

${ }^{19}$ Hommel P. N., Schwenninger J.-L., Ineshin E.M., Vetrov V.M. Testing times: an evaluation of the radiocarbon chronology for early ceramic vessel production at Ust'-Karenga. P. 31-46.

${ }^{20}$ Kuzmin Y. V.: 1) The origins of pottery in East Asia and neighboring regions: An analysis based on radiocarbon data. P. 29-35; 2) Proiskhozhdenie keramiki v Evrazii: sovremennoe sostoianie voprosa // Rossiiskii arkheologicheskii ezhegodnik. No. 3. 2013. P. 8-26. 
in agreement with geochronological data and history of sedimentation revealed for this site as demonstrated (see above).

In the Ust-Karenga archeological complex, the type of the most ancient ceramics appears to be of well-developed form as it is found among the materials yielded by the combined $7^{\text {th }}$ cultural horizon as well as by the finds from the overlying cultural horizons 6 through 3. In cultural horizons 3 and 4, finds of the ancient ceramic type are few and can be considered as potentially redeposited because the stratigraphy of these finds is not absolutely clear.

The cultural remains of the most ancient $7^{\text {th }}$ horizon are sealed within thin $(1-3 \mathrm{~cm}$ thick) layer of alluvial sand of dark color within the area where finds are concentrated, with inclusions of small charcoals, possibly washed out from the eroded hearth. As a rule, in the center of such concentrations there is a hearth with no construction, with small fragments of burned bone and products of combustion in the form of a carbonaceous-ash mass eroded from the hearth and distributed across the habitation area. Outside it, the alluvial layer does not contain carbonaceous inclusions, is not colored, and in the cross-section is visually practically indistinguishable from the alluvial thin-bedded sands of different (lacustrine) genesis that overlay it. This is eloquently indicated by the state of the ancient pollen from the cultural-stratum layer itself and the overlying sediments. According to the conclusion of a palynologist N. V. Kulagina, pollen grains from the lake alluvial sands overlapping the $7^{\text {th }}$ cultural horizon are damaged, do not have an integral form; pollen contains grains clearly redeposited from much more ancient sediments of Tertiary age. This can be explained only by the deposition of pollen grains under conditions of dammed lake, high water stand and erosion of older sediments along the sides of the valley with subsequent re-deposition of the pollen grains contained in them.

This indicates a sharp change in depositional regimes in the Ust-Karenga part of the Vitim valley caused by catastrophic geological events and the emergence of a giant dammed lake in the river valley that also penetrated into its tributaries ${ }^{21}$. This event is reliably documented by the buried forest (Sukhakit "stump" horizon) in the proposed center of the formation of a dammed lake reservoir in the Muya-Kuandin depression $340 \mathrm{~km}$ downstream in the Vitim river from the Karenga river mouth. Radiocarbon dating performed on burried trees sampled by each five year rings produced ages of $11780 \pm 40$ years ago (Beta-432243), which is consistent with the age of cultural remains of the $7^{\text {th }}$ combined cultural horizon. The thickness of the lake alluvium, which overlaps the $7^{\text {th }}$ combined cultural horizon, varies from site to site and changes from 0.4 to $1.4 \mathrm{~m}$. In fact, that facilitated good preservation of cultural remains and spatial structure of human settlements, close to the in situ state. However, this was not favourable for the preservation of bones, of which only small burnt fish bones and fragments of mammal bones were preserved. Cultural remains of the $6^{\text {th }}, 5^{\text {th }}, 4^{\text {th }}$, and $3^{\text {rd }}$ horizons belong to subaerial deposits, formed after the emptying of the dammed lake about $10260 \pm 220$ (Ri-202), when this surface came out of the accumulation mode of bottom sediments of the lake and river type ${ }^{22}, 18$. According to geologists, this giant dammed lake, whose maximum area and volume belonged to

21 Kulchitskii A.A., Skovitina T.M., Ufimtsev G.F. Plotinnye ozera v dnishchakh riftov Vostochnoi Sibiri: svidetel'stva iz proshlogo i veroiatnost' v budushchem // Geografiia i prirodnye resursy. 1997. No. 1. P.61-65; Margold M., Jansson K.N. Glacial geomorphology and glacial lakes of central Transbaikalia, Siberia, Russia // Journal of Maps. 2011. Vol. 7 (1). P. 18-30.

22 Vetrov V. M. Drevneishie sledy keramicheskogo proizvodstva v Vostochnoi Azii. P. 28-34. 
Muya-Kuandin depression ${ }^{23}$, existed for about 1500 years $^{24}$. This explains the absence of cultural remains in the lake alluvium at the Karenga river mouth and the reappearance in this area of the carriers of the oldest ceramics' culture at level 6, with a significant time gap. The time gap is the interval between the dates on the seventh cultural horizon of $11825 \pm 45$ (TKA-19745) and horizon 6, which is somewhat older than the $6890 \pm 80$ (LE-1961) as can be concluded by dating the fifth cultural horizon.

At present, the combined collection of the Ust-Karenga archaeological complex includes 1330 fragments of the oldest type of ceramics that belong to 35 vessels. This makes it possible to reconstruct both the shape and the manufacturing technology and the main decoration patterns. In fact, this is the largest number of fragments of the oldest ceramics obtained from any archaeological site in Russia. The degree of completeness of representation of each vessel enables to restore ornamental compositions for 24 vessels, in addition to their shape, which is more than $68 \%$ of the total number of ceramics (Fig. 3). This significantly increases the information value of this source.

In the planigraphy of the sites of Ust-Karenga complex, concentrations of pottery ware fragments are always confined to accumulations of the stone waste material near the hearth, which form oval concentrations of cultural remains with typical dimensions of $4 \times 5 \mathrm{~m}$ with inclusions of small charcoal pieces in matrix sediments. Among the forms of the pottery ware, there are two groups: large vessels of a simple open ovoidal shape with a pointed bottom with a volume of 8 to 10 liters, and smaller vessels of the same simple open expressive ovoidal shape with a pointed bottom of a volume from 1 to 1.5 liters. Almost no vessel has any traces of soot, while some large vessels bear the evidence of repair attempted by means of drilling holes on both sides of the crack and stitching the parts, most probably with organic fibers. The latter may support the assumption that at least large vessels were used for storage of dry bulk or thick viscous products such as fat, pickled fish, or as containers for products of plant origin (Fig. 4).

Given the size of the vessels and their technical parameters, it is difficult to assume that their owners travelled long with them. It is logical to suppose that the manufacture and use of vessels occurred directly on the habitation site and was confined to sites with a relatively permanent occupation, where pottery ware was used as containers for storing food supplies. Vessels of the same size, decoration and manufacture technique were found in the $3^{\text {rd }}$ cultural horizon of the location of Ust-Yumurchen VIII in Vitim river valley near proposed margin of Muya dammed lake, about $180 \mathrm{~km}$ upstream from Ust-Karenga group of archaeological sites. Few fragments of the same pottery ware were found at Oktokoron site $25 \mathrm{~km}$ upstream in the Vitim river valley. A similar form of vessels and dimensions were discovered from the $8^{\text {th }}$ cultural horizon of Studenoe 1 settlement and in the $8^{\text {th }}$ cultural horizon of Ust-Menza 1 site in Chikoy river valley ${ }^{25}$, albeit nothing is known about their decoration pattern.

In the Ust-Karenga archeological complex, vessels were made by the zonal-paste method with the initial formation of the bottom part in the form of a funnel with a point-

${ }^{23}$ Margold M., Jansson K. N. Glacial geomorphology and glacial lakes of central Transbaikalia, Siberia, Russia. P. 18-30.

${ }^{24}$ Kulchitskii A.A., Skovitina T.M., Ufimtsev G.F. Plotinnye ozera v dnishchakh riftov Vostochnoi Sibiri: svidetel'stva iz proshlogo i veroiatnost' v budushchem. P. 61-65.

${ }_{25}$ Razgildeeva I. I., Kunikita D., Yanshina O. V. Novye dannye o vozraste drevneishikh keramicheskikh kompleksov zapadnogo Zabaikal'ia. P. 168-178. 


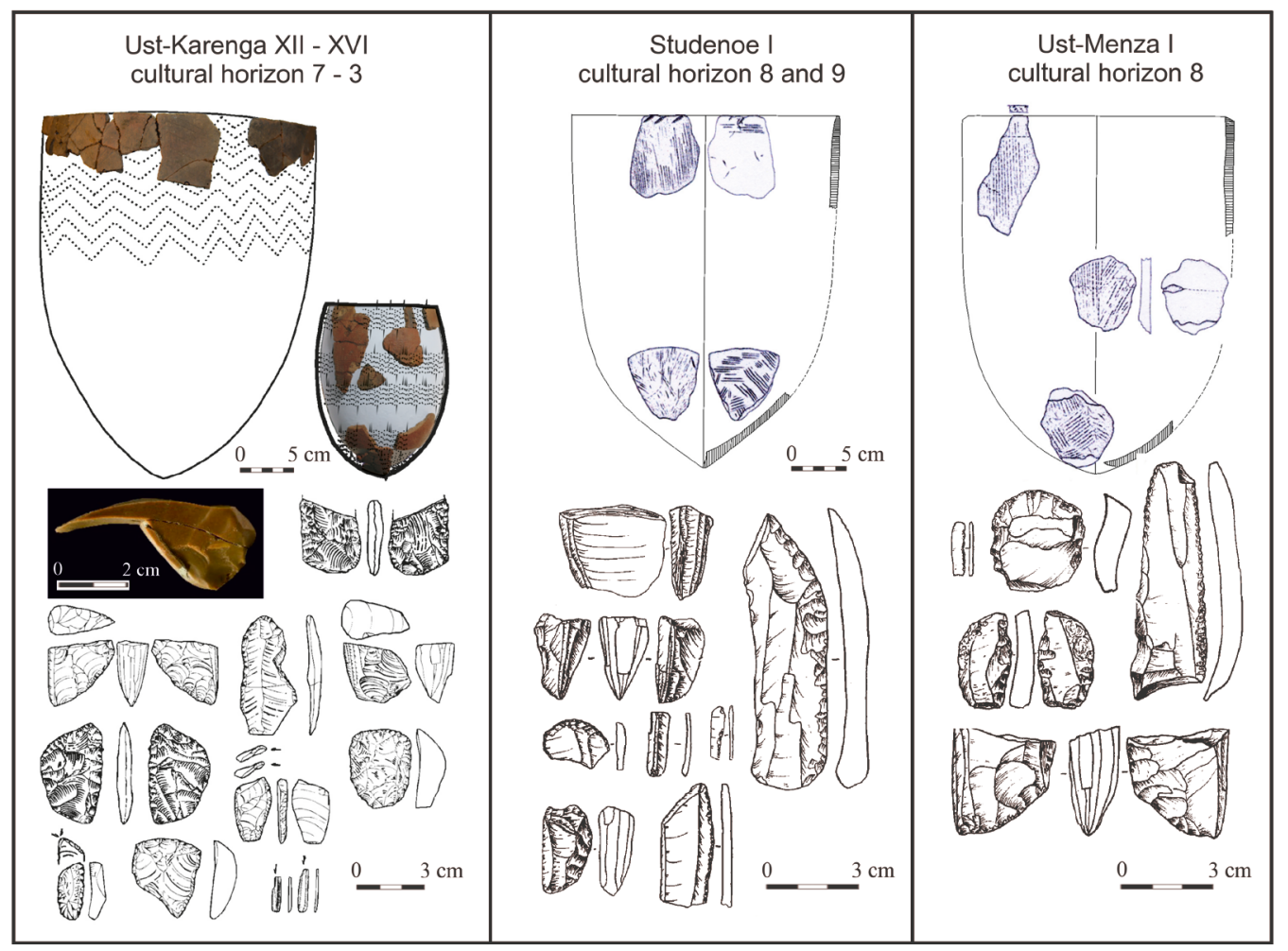

Fig. 3. Ceramics and lithic material from pottery-bearing archaeological contexts of different archaeological objects, left to right: Ust-Karenga XII-XVI, cultural horizons 7 to 3 [Vetrov, 2008]; Studenoe I, cultural horizons 8 and 9, and Ust-Menza I, cultural horizon 8 (modified from [Konstantinov, 1994] (lithic material) and [Razgil'deeva, Kunikita, Yanshina, 2013] (ceramics))

ed end. All vessels of the combined collection have a pointed bottom, a wide mouth, and slightly convex walls that form a simple ovoidal truncated shape. The rim diameter $\mathrm{s}$ is a little smaller (by 5-10 $\mathrm{mm}$ ) than the maximum diameter of the body, which causes a certain closure of the shape. As already mentioned, the volume of vessels varies from 1.5 to 9 liters, which indicates different functions as well as a possible degree of mobility of owners of vessels of such volume. The walls of the vessels are thin, with stable thickness which never exceeds $5 \mathrm{~mm}$. The paste is dense with the addition of granitic subsoil and organic residues visible on scraps and cleavages in the form of traces of burnt grass fragments of sedge grass plants, and, rarely, animal hair. Thin patches of the future vessel stuck to each other with a slight baselap, after which they were probably molded by extrusion, as is evidenced by the position of particles of organic residues and grains of granitic subsoil on breaks and in cleavages.

After the main body of the vessel was made, it was dried. Then a rim, made in the form of a narrow coil, would be attached, and the external surface was smoothed with liquid clay. The inner surface of the vessels was also rubbed with a solution of liquid clay using a bundle of sedge grass plants. This operation leaves characteristic marks in the form of horizontal scratches and grass imprints on the surfaces of the vessel walls. After that, 

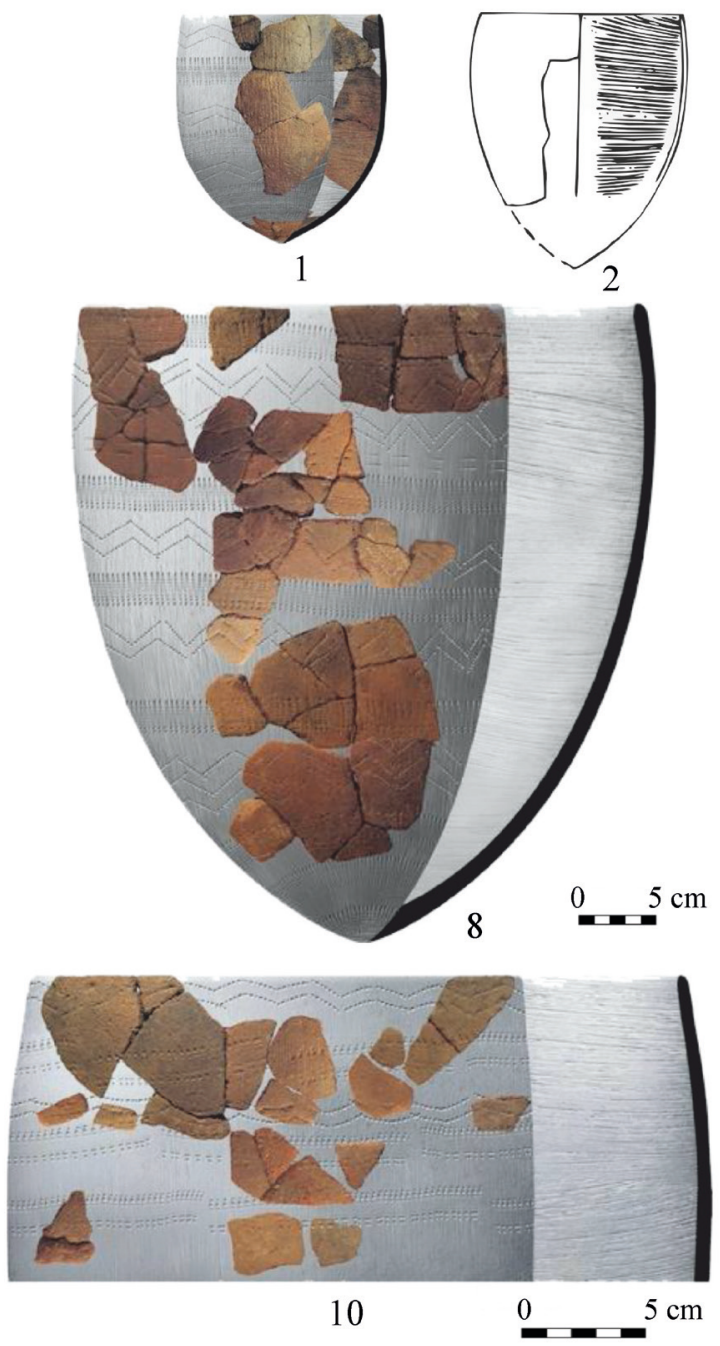
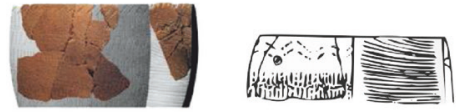

3

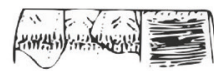

5

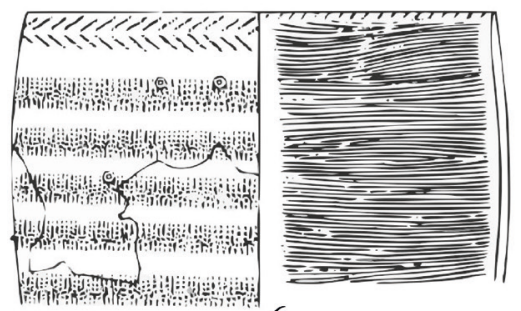

6
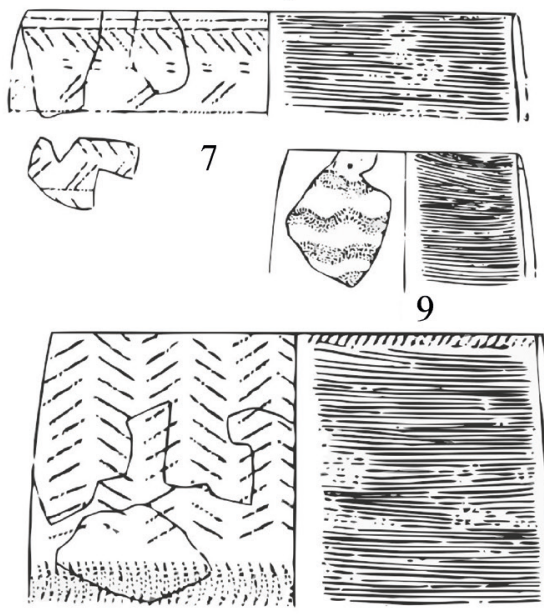

11
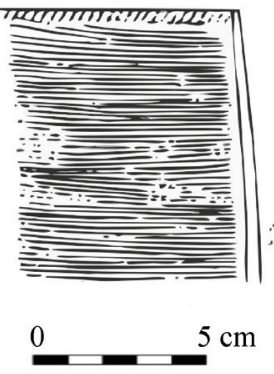

Fig. 4. The most ancient ceramics from Ust-Karenga geoarchaeological complex, combined cultural horizon 7, and cultural horizons 6, 5, 4. General shape of the vessels and ornamental compositions (drawing by E. M. Ineshin)

decoration was applied to the wet external surface with an indented stamp in the form of a small scapula with a denticulate edge. When stamped on clay, it produces a comb stamp. The ornamentation, as already noted, was applied with a comb stamp in the form of horizontal rows of zigzag lines, in which the starting and ending points of the indented stamp imprint had a slightly larger impression depth. This is well-known "stepping comb" ornamentation (see Fig. 4) extremely wide spread in the northern Eurasia ${ }^{26}$.

The ornamentation could be supplemented with horizontal dashed lines or horizontal zigzag rows of the same stamp. In some cases, it was supplemented by inclined depressions of the tip of the same denticular stamp made around the rim either from the outside

${ }^{26}$ Vetrov V.M. Drevneishie sledy keramicheskogo proizvodstva v Vostochnoi Azii. P. 28-34. 
or from the inside (see Fig. 3, 4). The analysis of the micro-traces and peculiarities of the stamp made it possible to conclude that one vessel was ornamented by the same tool but in a different technique of making prints. After all, the vessels were baked in a fire at sufficiently high temperatures, which produced high-quality thin-walled vessels with pointed bottom and the outer walls of a light brown color. Often, the decoration covered the entire body of the vessel from the rim to the bottom (see Fig. 3, 4). Of the total volume of reconstructed vessels, only one copy had no decoration.

Regarding the origin of this type of ornament, its stable repeatability, it can be assumed that an indented stamp and its type ("stepping comb") imitated a line of stitches, fastening parts of leather or bark parts of containers that served as the prototype of ceramic vessels. Ethnographic objects like bast baskets, panniers, pouches and other items of the same function are common among taiga hunters and reindeer herders of Siberia. Interestingly, they all have a characteristic feature as tack welds connecting various parts of the object usually play a decorative role and provide additional aesthetic properties. In that sense, decoration patterns observed on pottery could have been inherited from traditional containers of all kinds made of organic materials, which were already in use. However, in ceramics they received additional quality, such as waterproof walls, the possibility of being placed in a fire or on coals for the purpose of cooking, and the ability to have safely sealed container.

Based on actualistic approach, one can put forward a hypothesis about the formation in the mountain-steppe regions of the Baikal-Patom Highland and the Vitim Plateau an economic model with a base camp-site and a number of temporary camps. At the base sites, a part of the population lived permanently, while mobile groups of hunter-gatherers could organize temporary/seasonal camps for harvesting different kinds of supply to support the inhabitants of the base site. It could take tens and even hundreds of kilometers to travel between base site and temporary/seasonal camps.

Only in this case, we can find a noncontradictory explanation for the presence in the same region (the Vitim river basin) contemporaneous archaeological sites with and without ceramics. They are found at a considerable distance from each other, but clearly have some connections, which is seen, in addition to shared tradition of manufacture of stone tool production, by use of rare, or exotic, rocks as raw material (graphite, jasper, volcanic pumices, quartz crystal) transported from original source areas to archaeological $\operatorname{sites}^{27}$ (Fig. 5). The genesis and geographic location of such areas indicates its compact local distribution, which does not go further than the first tens of kilometers. Consequently, its exploitation and movement in space over long distances could only be carried out by human teams, within which there was an idea of the beneficial use of these minerals and the position of their sources, transmitted over generations. It can also serve as another, though indirect, confirmation of the stability of the ancient population, within which not only specific ceramic traditions survived and allowed to maintain production of the ancient type of pottery ware, but also as the confirmation that the knowledge of stone processing and the choice of specific lithic raw material for certain types of the artifacts were transmitted.

27 Vetrov V.M., Ineshin E.M., Revenko A.G., Sekerin A.P. Artefakty iz ekzoticheskikh vidov syr'ia na arkheologicheskikh pamiatnikakh Vitimskogo basseina. P.98-117; Demonterova E.I., Ivanov A.V., Ineshin E. M., Tetenkin A. V. K voprosu o mobil'nosti drevnego naseleniia severa Baikal'skoi Sibiri v kontse pleistotsena // Stratum plus. 2014. No. 1. P. 165-180. 


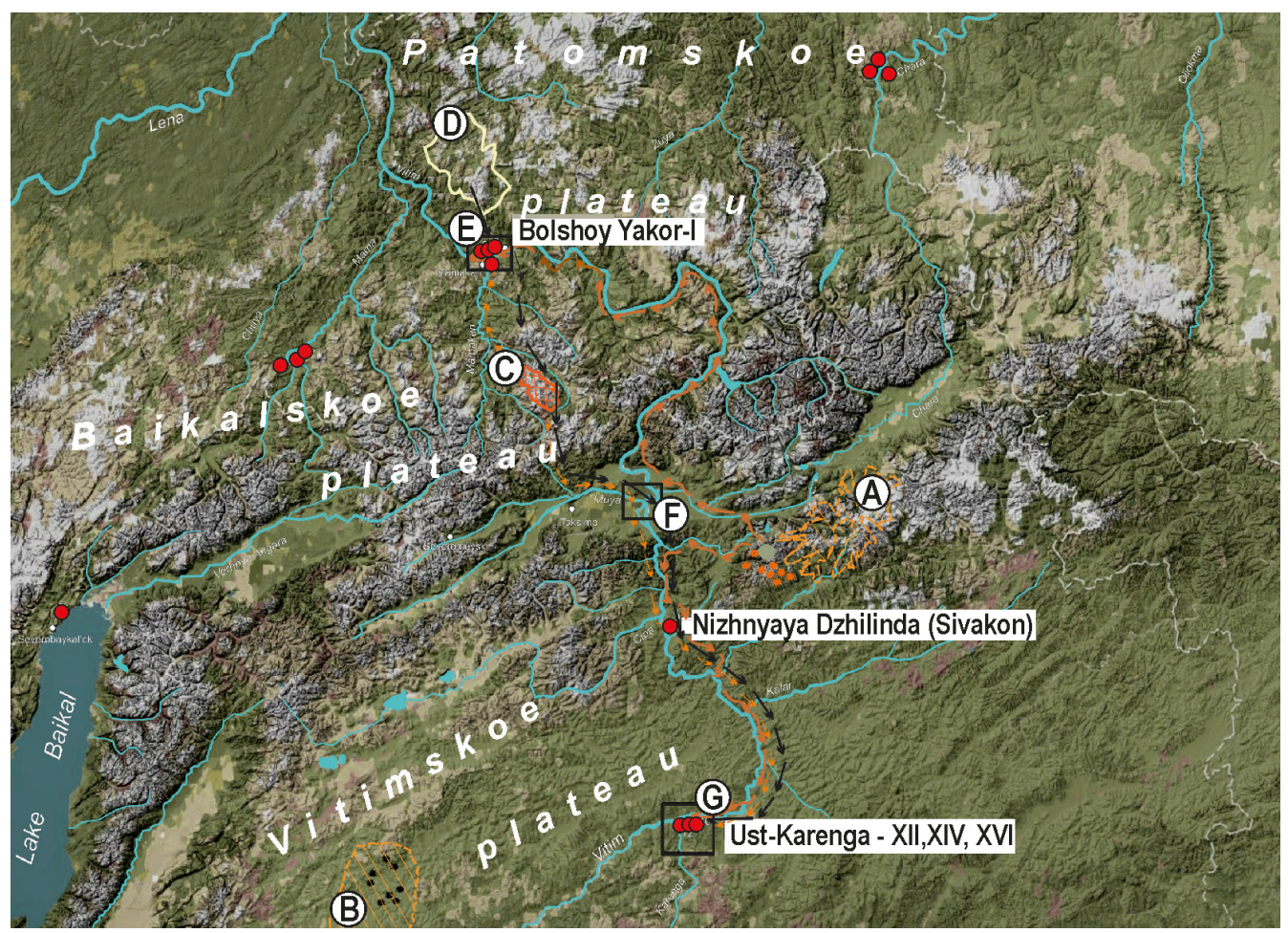

Fig. 5. Long-distance transportation of exotic lithic raw materials in Baikal-Patom highlands and Vitim plateau.

A - Udokan volcanic plateau, Trakhit volcano pumic stone source; C - Kelyan suit, brownish jasper source; D - Takhtygin field of graphite rock, raw material source; E - Bolshoi Yakor complex of archaeological objects (Bolshoi Yakor I, Kovrizhka II, Invflidnyi III); G - Ust-Karenga geoarchaeological complex (map by E. M.Ineshin)

Comparing the ancient ceramics of the Ust-Karenga archaeological complex with the materials of the well-known archaeological sites of Japan, China, South Korea, Primorye and the Amur River region, we can note its high quality both in manufacture technology (quality of the ceramic paste, consistency in the size of vessels, variable shape) and richness of decorations. Such characteristics are not observed in any other archaeological site with the oldest ceramics in East Asia.

Unfortunately, due to the fragmentary preservation of the vessels in other archaeological complexes in East Asia, we cannot fully compare the oldest ceramics of the Ust-Karenga complex with other sites (by shape, size, ornamentation, and functional use). Very provisionally, it can be stated that if compared to the finds from coastal territories including Amur regions, simple pointed-bottom ovoidal forms of vessels dominate the ceramics of the sites of the inland region (namely, Ust-Karenga III, XII, XIV, XVI, Ust-Yurmuren VIII, Octorocon 1, Studenoe 1, Ust-Menza 1) (see Fig. 5). In the coastal and Amur areas of this center of the most ancient pottery, vessels with flat or, rarely, with convex/rounded bottom are more common (see Fig. 2).

It can also be noted that from the point of view of the landscape and environmental conditions observed in the locations of sites with the most ancient ceramics in the 
Vitim and Chikoy, they occupy niches with the same environmental properties. This inland region was characterized by the presence of local mountain glaciers from 15,000 to 9,000 years ago with near-glacial mosaic plant-faunal complexes that were exploited by the ancient population ${ }^{28}$. On Vitim, this was further complicated by the emergence and long existence of a dammed lake, whose area was nearly a half of lake Baikal one ${ }^{29}$. Such large water mass had a significant impact not only on the plant and animal communities that inhabited their surroundings, but also on the activities of the ancient population and their adaptations to the local environments. In some cases, subsistence practice of the inland hunters that involved the formation and development of the tradition of the use of pottery had, in a certain sense, common features with that of the coastal regions of China, Korea, and the Japanese islands. In particular, this is the exploitation of fish resources as indicated by the high content of nitrogen isotopes in the bone tissues of the ancient inhabitants of the region and sufficiently large amount of fish remains in the composition of the faunal collections of archaeological sites.

The description of the physical appearance of the ceramics-bearing culture of the inland East Asia would not be complete without the information on their stone industry. It has to be stressed that it fully preserves the major characteristics of the features of the socalled "final Paleolithic" tradition based on the use of both bifacial tools and microblades. Its elements are observed, in general, from the Yenisei in the west to the Pacific coast, including the Japan Islands and Sakhalin, in the east. By meridian, their presence is noted in East Siberian materials up to the coast of the Arctic Ocean in the north to the regions of China in the south (see Fig. 1).

The main features of this tradition are the production of bifacial tools which were easy to carry on. As for the function, these were knives, large side scrapers, and possibly large points used to equip thrusting spears. If necessary, all these items could be easily turned into the preforms of narrow faced cores (end cores) to produce microblades to be used as side blades for composite osseous tools, such as spear points and knives. Given the logic of the function, this principle could be described as "three in one". Such tools were often made of high-quality lithic raw materials.

The second important feature of this tradition, derived from the first one, is the high development and wide use of side-blade technology seen in composite tools in which both osseous and lithic materials are combined (see Fig. 3$)^{30}$. The wedge-shaped cores including the micro-cores of the same type are the most important marker of that tradition. More precisely, these are end cores whose platforms are prepared by a single longitudinal removal or by a series of removals taken off from the laterals (see Fig. 4). A specific complex of tools for bone processing presented by different burins (transversal and angle burins) constitutes another peculiar feature of this tradition.

Knapping technology based on wedge-shaped cores made of fragmented bifacial tools is not concluded with that but includes additionally core preparation procedures which al-

${ }^{28}$ Ineshin E.M. Dinamika razvitiia lednikovykh obstanovok i zaselenie chelovekom BaikaloPatomskogo nagoria v pleistotsene - rannem golotsene // Izvestiia laboratorii drevnikh tekhnologii. Irkutsk, 2003. Iss. 1. P. 50-57.

${ }^{29}$ Kulchitskii A.A., Skovitina T.M., Ufimtsev G.F. Plotinnye ozera v dnishchakh riftov Vostochnoi Sibiri: svidetelstva iz proshlogo i veroiatnost' v budushchem. P. 61-65; Margold M., Jansson K. N. Glacial geomorphology and glacial lakes of central Transbaikalia, Siberia, Russia. P. 18-30.

30 Ineshin E.M., Tetenkin A. V. Chelovek i prirodnaia sreda severa Baikal'skoi Sibiri v pozdnem pleistotsene. Mestonakhozhdenie Bol'shoi Iakor' I. Novosibirsk, 2010. 
low repeating of the same steps of knapping to produce microblades. After $\sim 10000$ years ago, at a time of the late Ust-Karenga ceramic tradition, wedge-shape core technology was supplemented by prismatic blade technology with microblades being taken off the whole perimeter of the core front, or from the most part of it. Starting from cultural horizon 6 of Ust-Karenga site microprismatic knapping dominates in the lithic contexts, but that does not exclude using the wedge-shape cores at the same time. Among osseous tools, bone parts of inset tools, fish spears of diverse size and shape, and needles should be mentioned.

For the most of the researchers, knapping technology based on wedge-shaped core serves as a clear signature of the late Upper Paleolithic which unequivocally does not have any ceramics ${ }^{31}$. This point of view is absolutely prevalent and does not even require supporting citation, which would be endless, and thus we leave it aside as it needs separate lengthy discussion. In brief, these technological principles are described as common in archaeological materials assigned to the so-called Duktay paleolitic culture spread in Yakutia, or, according to other? Opinions, recognized in the materials of Selemdzha culture in the Amur River region ${ }^{32}$. It is also seen in the archaeological materials of Verkholensk culture in the Baikal region ${ }^{33}$. In any case, this is a clearly wide-spread cultural phenomenon.

The Ust-Karenga archaeological complex enables to raise the question of the emergence and the early development of the tradition of ancient ceramics in greater details than it is possible for the above-mentioned materials. In the Vitim river basin, there are archaeological sites which are contemporaneous to ceramic-bearing cultural layers of Ust-Karenga sites, but with no ceramics in cultural contexts. Similar to Ust-Karenga complex, these are stratified sites whose cultural materials are included in alluvial deposits. These sites are located at a distance of $600-750 \mathrm{~km}$ from Ust-Karenga. At one of the most studied monuments of this circle (Bolshoi Yakor I, cultural horizon 21), bone remains are well preserved, which made it possible to obtain additional data on hunting preference and seasonality, and estimate their occupation length, and thus suggest their place and role in adaptation strategy used by their inhabitants.

The chronology of the major sites of the Vitim valley is well supported by radiocarbon data. These are, first of all, Bolshoi Yakor I, Invalidniy III, Kovrizhka II and III (see Fig. 2) ${ }^{34}$. For a number of cultural horizons on the reference site of Bolshoi Yakor I, it was possible to obtain seasonality data based on determining the season by animal teeth, analyzing the tooth growth structures.

It was found that human activity which resulted in the formation of cultural horizons with no ceramics, but contemporary to the cultural horizons of Ust-Karenga that yielded ancient ceramics, took place in a short period of time. This is either late fall (October and

${ }^{31}$ Medvedev G. I. Khoziaistvennyi uklad mezoliticheskogo naseleniia Ust'-Beloi Priangaria // Mezolit Verkhnego Priangaria. Irkutsk, 1971. P. 111-126; Mochanov Iu. A. Drevneishie etapy zaseleniia chelovekom Severo-Vostochnoi Azii. Novosibirsk, 1977.

32 Derevianko A. P., Volkov P. V, Li Kh. Selemdzhinskaia pozdnepaleoliticheskaia kul'tura. Novosibirsk, 1998.

${ }_{33}$ Medvedev G. I. Khoziaistvennyi uklad mezoliticheskogo naseleniia Ust'-Beloi Priangaria. P. 111126; Aksenov M. P.: 1) Issledovaniia doneoliticheskikh kompleksov na Verkhnei Lene // Baikal'skaia Sibir' v drevnosti. Irkutsk, 1995. P.45-60; 2) Arkheologicheskaia stratigrafiia i posloinoe opisanie inventaria Verkholenskoi gory 1 // Mezolit verkhnego Priangaria. Pamiatniki Irkutskogo raiona. Irkutsk, 1980. P.4593.

${ }^{34}$ Ineshin E.M., Tetenkin A.V. Chelovek i prirodnaia sreda severa Baikal'skoi Sibiri v pozdnem pleistotsene. Mestonakhozhdenie Bol'shoi Yakor' I. P. 52-55. 
November) or late spring (April and May). The composition of stone and bone equipment of cultural horizons varies depending on the season of the year ${ }^{35}$. The estimated time period of the existence of the camps is presumed to have varied from a single day to several weeks, which was typical of hunting camps on the migration routes of herd animals. Based on this, the cultural horizons of the Bolshoi Yakor I and that of the Invalidniy III site were identified as temporary hunting camps on the path of seasonal migration of herd animals (see Fig. 5).

The study of animal bone remains resulted from hunting and food utilization of the hunting prey by the inhabitants of the site demonstrated that only small mammals and fish were fully consumed. In larger animals, only little transportable body parts with low food value, such as heads, lower parts of legs, and, apparently, liver ${ }^{36}$ was used on the spot. The most valuable body parts were clearly taken outside the sites, possibly as a food supply for the group members who stayed in the base camps ${ }^{37}$, and then transported to such locations. Archaeological contexts of the Ust-Karenga complex that are regarded as cultural horizons 7, 6, 5, and 4 could be perceived as an example of that.

However, the question of the origin and roots of the East Asian ceramics tradition remains open. If radiocarbon dates were put on the map on condition that the old dates for pottery ware from Xianrendong Cave (Jiangxi Province, southern China) ${ }^{38}$ are correct, it could be concluded that the emergence of the ceramic tradition may have taken place in the south and then spread northward. To a certain degree, this is in agreement with dualistic hypothesis of the introduction of the oldest pottery as recently proposed by Jordan et al. ${ }^{39}$ This is very provisional estimate but indeed the question of the origins of the ceramics requires true interdisciplinary approach, and thus it should involve various data including physical anthropology and paleogenetics, first of all, because technological knowledge could be transmitted from people to people, and therefore, most probably could have been transferred within relatively close population group. Inter-group knowledge transmission is also possible, but this requires some mediators to facilitate this exchange.

The physical appearance of the bearers of the early ceramic tradition remains almost totally unknown. Fossil human remains of this time are known very little, and they are poorly studied. Remains of Dzhilinda man, whose burial was excavated at the site of Lower Dzhilinda (Sivakon) at distance of $1280 \mathrm{~km}$ away from the Ust-Karenga archaeological complex $^{40}$ (see Fig. 5) help to fill the gap and give clues both for anthropology and for genetics.

35 Ineshin E.M., Tetenkin A.V. Chelovek i prirodnaia sreda severa Baikal'skoi Sibiri v pozdnem pleistotsene. Mestonakhozhdenie Bol'shoi Yakor' I. P. 233.

${ }^{36}$ Ineshin E.M. Dinamika razvitiia lednikovykh obstanovok i zaselenie chelovekom BaikaloPatomskogo nagoria v pleistotsene - rannem golotsene. P. 50-57.

${ }^{37}$ Ineshin E. M., Tetenkin A.V. Chelovek i prirodnaia sreda severa Baikal'skoi Sibiri v pozdnem pleistotsene. Mestonakhozhdenie Bol'shoi Yakor' I. P. 235, 242-246.

38 Wu X., Zhang C., Goldberg P., Cohen D., Pan Y., Arpin T., Bar-Yosef O. Early Pottery at 20,000 Years Ago in Xianrendong Cave, China // Science. 2012. Vol. 336, iss. 6089. P. 1696-1700.

39 Jordan P., Gibbs K., Hommel P., Piezonka H., Silva F., Steele J. Modelling the diffusion of pottery technologies across Afro-Eurasia: emerging insights and future research // Antiquity. 2016. Vol. 90, iss. 351. P. 590-603.

40 Vetrov V.M, Zadonin O. V., Ineshin E.M. Mnogosloinoe mestonakhozhdenie Nizh. Dzhilinda (Sivakon) - 1 v Bambuiskoi kotlovine // Kul'tury i pamiatniki epokhi kamnia i rannego metalla Zabaikal'ia. Novosibirsk, 1993. P.98-112. 
Several radiocarbon dates run on the human bone samples from this burial (both conventional and AMS $\left.{ }^{14} \mathrm{C}\right)$ produced ages between $7230 \pm 40(\mathrm{GIN}-4051)$ and $7630 \pm 30$ (Beta-432255). This interval corresponds to the late stage of the ancient pottery ware tradition with stepping comb decoration. Although pottery fragments of the ancient type were not found exactly in the burial, lithic artifacts made of exotic rocks were discovered, which is typical in general for the Early Neolithic burials in Asia. The same exotic raw materials come from Ust-Karenga where they are present in cultural horizon 7 (combined horizon). These are jasper-like rocks of dark gray to deep black color found in horizons 5 and 6 as well. In addition, a prismatic core made of dark brown jasper was excavated from the burial. Exactly the same jasper was found in various horizons of the Bolshoi Yakor I site (cultural horizon 3B), as well as in the cultural layers of Invalidniy III and

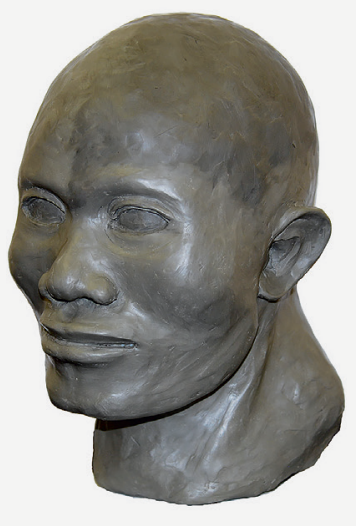

Fig. 6. Low Dzhilinda I (Sivakon site) man (plastic reconstruction by D. V. Pezhemskiy) Kovrizhka I sites ${ }^{41}$. Indirectly, these observations provide some grounds to draw a connection between human fossils unearthed at Low Dzhilinda and population groups that produced ceramics of the most ancient type.

Thanks to the plastic reconstruction of the Dzhilinda man based on the M. M. Gerasimov's method ${ }^{42}$ performed by anthropologist D. V. Pezhemsky, the physical appearance together with the results of cranioscopic study allowed D. V. Pezhemsky to suggest South Asian origin of that individual (Fig. 6) ${ }^{43}$. The genetics study of the bone remains of Dzhilinda Man by the research team led by M. Götherström (Götherström, personal communication: preliminary conclusions reported to the author) enabled to identify Y-chromosome which belongs to Y-chromosome Hg C2bla.

This demonstrates South Asian origin of this individual seen both in male and female lineages as it is confirmed by the identification of mtDNA haplogroup (C5c) and thus indicates South Asian origin of the bearers of the ancient pottery ware tradition. Replication of the result (i.e., the same direction of the gene flow both in mtDNA and in Y-chromosome) could be interpreted as the evidence of certain isolation of this population group from other inhabitants of the area. The results of the study performed on mitochondrial genome of the Dzhilinda man do not contradict this ${ }^{44}$. It's possible to hypothesize that this group either tended to avoid other inhabitants, or the territory was very scarcely populated.

Additionally, it is found that bone tissues of the Dzhilinda individual contain nitrogene isotopes in relatively high numbers $(\mathrm{d} 15 \mathrm{~N}=+12,2 \%$ ), which indicates high amount of fish in the diet of the ancient population of the Vitim river basin. This observation

41 Vetrov V.M. Ritualnyi kompleks v uste r. Karenga (dolina r.Vitim) i nekotorye problemy neolita Vostochnoi Sibiri // Izvesti laboratorii drevnikh tekhnologii. 2008. Iss. 6. P. 28-43.

${ }^{42}$ Gerasimov M. M. Vosstanovlenie litsa po cherepu: (sovremennyi i iskopaemyi chelovek). Moscow, 1955.

43 Pezhemskii D. V., Rykushina G. V. Chelovek iz Nizhnei Dzhilindy (predvaritel'noe soobshchenie) // Vestnik antropologii. 1998. Iss. 5. P.115-135.

${ }^{44}$ Kılınç G. M., Kashuba N., Yaka R. et al. Investigating Holocene human population history in North Asia using ancient mitogenomes // Scientific Reports, 2018. Vol. 8 (1). P. 8969. 
is also supported by findings of fish bones in cultural horizon 7 (combined horizon) at Ust-Karenga site complex ${ }^{45}$.

In sum, the combination of these data does not contradict the assumption that the ancient ceramics tradition in the Vitim basin, whose evidence is found at Ust-Karenga XII, XIV, and XVI localities and in the Chikoy river where it is yielded by several site, namely Studenoe 1 (cultural horizon 8) and Ust-Menza 1 (cultural horizon 8), appears to have been the result of transmitting of knowledge in the south-north direction (see Fig. 2), or it could have been the result of human migration. The possible initial area of distribution of the most ancient pottery can be recognized as the territory limited by Xianrendong - Yuchanyan - Baozitou sites in southeast China (see Fig. 1, 2) ${ }^{46}$.

Recently, with the expanding of archaeological investigations in the north-eastern Asia, new archaeological sites produced an evidence for the oldest ceramic production. For example, the Krasnaya Gorka site on the Bolshoe Eravninsky Lake on the southeast face of the Vitim Plateau, $390 \mathrm{~km}$ from the Ust-Karenga archaeological complex, was discovered $^{47}$ and partially investigated (see Fig. 1). According to the published data, ceramics dates to $11150 \pm 50$ (AAR-21437) - $12010 \pm 60$ (Poz-68-608). It also has a number of key indicators in shape and size of the vessels, some details of the manufacturing technology, and thus it is very similar to the oldest ceramics of Ust-Karenga, being contemporaneous to it, too. The lithic material of the site has practically the same technical and typological indicators similar to the stone industry of the Ust-Karenga archaeological complex (bifacial techniques in different variants, from bifacial tools to biface core preforms, transversal burins, large side scrapers, microblades ${ }^{48}$.

These findings show that as scientific research steps forward, the number of archaeological objects with traces of ancient pottery should increase. Assessing the situation with the oldest ceramics in Eastern Asia and the Eurasian continent as a whole, it is necessary to emphasize that its invention and then distribution worldwide greatly expanded the adaptive capabilities of ancient humans. Presumably, it emerged and reached significant heights in the east of Eurasia, and only then reached the Middle East and North Africa. There are no direct data that would allow asserting that the very idea of ceramics, having arisen in the east, then spread to the west. Perhaps, in the Middle East region or in North Africa, the idea of making ceramics was formed independently of the East Asian Center, but the current state of knowledge suggests that the East was, at least, its ancestral home. From there, from the East, and in subsequent epochs, well-known useful innovations spread over the world repeatedly: not only ceramics, but also porcelain, compass, gunpowder, paper, and other technologies.

45 Stock J. T., Bazaliiskii V. I., Goriunova O. I., Savelev N. A, Weber A. W. Skeletal Morphology, Climatic Adaptation, and Habitual Behavior among Mid-Holocene Cis-Baikal Populations // Prehistoric HanterGetherers of the Baikal Region, Siberia: bioarchaeological studies of past life ways. Philadelphia, 2010. P. 180-191.

46 Sato H., Natsuki D. Human behavioral responses to environmental condition and the emergence of the world's oldest pottery in East and Northeast Asia: An overview. P. 12-28.

47 Tsydenova N., Andreeva D., Zech W. Early pottery in Transbaikal Siberia: New data from Krasnaya Gorka. P. 81-90.

${ }^{48}$ Ineshin E. M., Tetenkin A. V. Chelovek i prirodnaia sreda severa Baikalskoi Sibiri v pozdnem pleistotsene. Mestonakhozhdenie Bol'shoi Yakor' I. P. 85. 


\section{Conclusions}

Several important conclusions based on Ust-karenga materials discussed in the broad context of archaeological, anthropological, genetics and environmental data can be drawn, such as

1. The East Asian center of the origin and development of the oldest ceramics is the oldest center of the origin of ceramic production. Archaeological sites whose contexts contain the oldest pottery ware belong to coastal (e. g., Hummi, Gassia, Goncharka, Gromatuha, Osipovka, Chernigovka 1, Ustinovka 3) and to the inland zone (that is, Ust-Karenga XII, XIV, XVI, Ust-Yurmchen VIII, Ust-Menza 1, Studenoe 1, Krasnaya Gorka).

2. The appearance and existence of the oldest ceramics in these zones reflect the specific adaptations of the ancient Asian population necessary for further development of the hunter-gatherer economy, which was expressed in the development of a flexible form of organization of human groups. It can be assumed that their groups were divided into relatively settled groups and moving "harvesters". The latter carried out the harvesting of food supplies and exotic rocks of stone raw materials in areas adjacent to mountains, still partially covered by mountain-valley glaciers with subalpine plant stations rich in food resources. Food stocks and raw materials, often in the form of various artifacts, were transported to the sites (e. g., jasper, quartz crystal, pumice-stone, graphite, red ochre).

3. Hunting species used by these people were mainly herd animals migrating from winter habitats to summer ones, such as reindeer, red deer, elk, horse, bison, but also arctic fox, hare, ptarmigan, waterfowl, wolf and brown bear. Fish catching also played an important role. Perch, pike, and sturgeon were more common. Presumably, by this time fishing traps of wicker twigs or a bark had already been known.

4. Ceramic vessels, in most cases, served as containers for food storage, but they also were used as cookware to process raw meat. In some cases, ceramic vessels were repaired after they had cracked, by tight stitching the fragments with some organic fibers through drilled holes. Further use of repaired vessels for processes which would involve heating (e.g., cooking) was impossible. This means that in some cases vessels were of high value as its replacement was impossible, for whatever reason. Thus, from the point of view of the activity approach, they denote the stationary, relatively long-term camps of ancient hunters, where the permanent inhabitants were few mobile members of the collectives. In terms of lithic technology, there is no difference between base camps with ceramics (Ust-Karenga XII, XIV and XVI, horizons 3, 4, 5, 6; Ust-Yumurchen-VIII, mountain 4; Studenoe-1, mountains 8-9; Ust-Menza-1, mountains 8) and temporary seasonal sites used by hunting groups sent to harvest, which had no ceramics in their contexts (Bolshoi Yakor I, Kovrizhka II, III, and IV, Invalidniy III). Bifacial technology and production of microblades for insert tools seem to have been the main characteristics of lithic industry of these sites. Bifacial tools (large side scrapers and knives) were at the same time the preforms for end-cores for microblades. This tool kit based on "three in one" principle is easy to carry and gives all necessary options for long-distance travels. Bifacial processing and compact forms of bifacial implements are in this context ideal adaption that perfectly suits hunting on seasonally migrating animal species in the conditions of tundra-steppes and mountain alpinoid tundra-steppes with mosaic taiga forest.

5. Migrating groups of hunter-harvesters transported not only hunting products (fillet parts of animal corpses), but also high-quality lithic raw materials in the form of 
finished products, such as bifaces or extremely rarely rock nodules. Sources of raw materials were located along the path of movement of groups of hunter-harvesters who exploited the migration routes of large animals. Thus, the pattern of spatial distribution of exotic lithic raw materials in the region becomes a map of seasonal migrations of hunters in the past following migrations of the prey species. Importantly, they had been able to transmit through time the knowledge of the location of high-quality lithic raw materials as well the tradition of ceramic production. Probably, this may indicate genetically homogeneous population.

6. According to the most recent data from paleogenetics and anthropology of the ancient population revealed for the territory of Baikal region of Siberia and Yakutia, the bearers of the tradition of making and using the most ancient ceramics had roots in southern regions of Asia (see Fig. 6). This is also confirmed by anthropological and genetic analysis of Dzhilinda man discovered in the Vitim river basin.

This study, once again, demonstrates that "European" approach to Asian archaeological materials is not really productive and often leads to a deadlock. It seems that the academic community of various scholarly schools in South Korea, China, Russia, and Japan faces the great challenge of developing an adequate nomenclature for describing and understanding the very specific ancient history of the Asian continent.

\section{References}

Aksenov M. P. Arkheologicheskaia stratigrafiia i posloynoe opisanie inventaia Verkholenskoy Gory 1. Mezolit Verkhnego Priangar'ya. Pamyatniki Irkutskogo rayona. Irkutsk, IGU, 1980, pp. 45-93. (In Russian)

Aksenov M. P. Issledovaniia doneoliticheskikh kompleksov na Verkhney Lene. Baikal'skaia Sibir'v drevnosti. Irkutsk, IGPI, 1995, pp.45-60. (In Russian)

Gerasimov M. M. Vosstanovlenie litsa po cherepu: (sovremennyi i iskopaemyi chelovek). Moscow, Izdatel'stvo Akademii Nauk SSSR, 1955, 585 p. (In Russian)

Demonterova E. I., Ivanov A. V., Ineshin E. M., Teten'kin A. V. K voprosu o mobil'nosti drevnego naseleniia severa Baikal'skoi Sibiri v kontse pleystotsena. Stratum plus, 2014, no. 1, pp. 165-180. (In Russian)

Derevianko A. P., Volkov P. V, Li K. Selemdzhinskaia pozdnepaleoliticheskaia kul'tura. Novosibirsk, IAET SO RAN, 1998, 335 p. (In Russian)

Hommel P.N., Schwenninger J.-L., Ineshin E.M., Vetrov V.M. Testing times: an evaluation of the radiocarbon chronology for early ceramic vessel production at Ust'-Karenga. Izvestiia laboratorii drevnikh tekhnologiy, 2017, vol. 13, no. 1, pp.31-46.

Ineshin E.M. Dinamika razvitiia lednikovykh obstanovok i zaselenie chelovekom Baikalo-Patomskogo nagoria $\mathrm{v}$ pleistotsene - rannem golotsene. Izvestiia laboratorii drevnikh tekhnologii. Iss. 1. Irkutsk, Izdatel'stvo IrGTU, 2003, pp. 50-57. (In Russian)

Ineshin E. M., Teten'kin A. V. Chelovek i prirodnaia sreda severa Baykal'skoy Sibiri v pozdnem pleystotsene. Mestonakhozhdenie Bol'shoy Yakor' I. Novosibirsk, Nauka, 2010, 270 p. (In Russian)

Jordan P., Gibbs K., Hommel P., Piezonka H., Silva, F., Steele, J. Modelling the diffusion of pottery technologies across Afro-Eurasia: emerging insights and future research. Antiquity, 2016, vol.90, iss. 351, pp. 590-603.

Kılınç G. M., Kashuba N., Yaka R., Sümer A.P., Yüncü E., Shergin D., Ivanov G., Kichigin D., Pestereva K., Volkov D., Mandryka P., Kharinskii A., Tishkin A., Ineshin E., Kovychev E., Stepanov A., Alekseev A., Fedoseeva S., Some M., Jakobsson M., Krzewińska M., Storå J., Götherström A. Investigating Holocene human population history in North Asia using ancient mitogenomes. Scientific Reports, 2018, vol. 8 (1), pp. 8969.

Konstantinov M.V. Kamennyi vek vostochnogo regiona Baikal'skoi Azii. Ulan-Ude; Chita, Institut obshchestvennykh nauk BNTS SO RAN, 1994, 163 p. (In Russian) 
Konstantinov M.V. "I opyt, syn oshibok trudnykh” (problemy opredeleniia vozrasta drevnikh poselenii Zabaikal'ia). Drevnee Zabaikal'e: kul'tura i priroda. Ed. by M. V. Konstantinov. Chita, 2009, pp. 35-42. (In Russian)

Kul'chitskiy A.A., Skovitina T.M., Ufimtsev G.F. Plotinnye ozera v dnishchakh riftov Vostochnoi Sibiri: svidetel'stva iz proshlogo i veroyatnost' v budushchem. Geografiia i prirodnye resursy, 1997, no. 1, pp. 61-65. (In Russian)

Kuzmin Y. V. The origins of pottery in East Asia and neighboring regions: An analysis based on radiocarbon data. Quaternary International. 2017, vol. 441B, pp. 29-35.

Kuzmin Y.V. Proiskhozhdenie keramiki v Evrazii: sovremennoe sostoianie voprosa. Rossiiskii arkheologicheskii ezhegodnik, 2013, no. 3, pp. 8-26. (In Russian)

Kuzmin Y., Vetrov V. The earliest Neolithic complex in Siberia: the Ust-Karenga 12 site and its significance for the Neolithization process in Eurasia. Documenta Praehistorica, 2007, no. 24, pp. 9-20.

Margold M., Jansson K. N. Glacial geomorphology and glacial lakes of central Transbaikalia, Siberia, Russia. Journal of Maps, 2011, vol. 7 (1), pp. 18-30.

Medvedev G. I. Khoziaistvennyi uklad mezoliticheskogo naseleniia Ust'-Beloy Priangar'ia. Mezolit Verkhnego Priangar'ia. Irkutsk, Irkutsk State University Publishing House, 1971, pp. 111-126. (In Russian)

Mochanov Y. A. Drevneishie etapy zaseleniia chelovekom Severo-Vostochnoy Azii. Novosibirsk, Nauka, 1977, 264 p. (In Russian)

Myl'nikova L. N., Nesterov S. P. Fiziko-khimicheskoe issledovanie keramiki pamiatnika Kosanni: k probleme proiskhozhdeniia goncharstva. Neolit i neolitizatsiia basseina Iaponskogo moria: chelovek $i$ istoricheskii landshaft: Materialy mezhdunarodnoi arkheologicheskoi konferentsii, posviashchennoi 100-letiiu so dnia rozhdeniia A.P. Okladnikova. Vladivostok, Dal'nevostochnyi Universitet, 2008, pp. 161-165. (In Russian)

Pezhemskiy D. V., Rykushina G. V Chelovek iz Nizhney Dzhilindy (predvaritel'noe soobshchenie). Vestnik antropologii, 1998, iss. 5, pp.115-135. (In Russian)

Razgil'deeva I.I., Kunikita D., Yanshina O.V. Novye dannye o vozraste drevneyshikh keramicheskikh kompleksov zapadnogo Zabaykal'ia. Eurasia in Cenozoic Era. Stratigraphy, paleoecology, cultures, 2013, iss. 2, pp. 168-178. (In Russian)

Sato H., Natsuki D. Human behavioral responses to environmental condition and the emergence of the worlds oldest pottery in East and Northeast Asia: An overview. Quaternary International, 2017, vol. 441, pp. 12-28.

Stock J.T., Bazaliiskii V.I., Goriunova O.I., Savel'ev N.A., Weber A.W. Skeletal Morphology, Climatic Adaptation, and Habitual Behavior among Mid-Holocene Cis-Baikal Populations. Prehistoric HanterGetherers of the Baikal Region, Siberia: bioarchaeological studies of past life ways. Philadelphia, 2010, pp. 180-191.

Tsydenova N., Andreeva D., Zech W. Early pottery in Transbaikal Siberia: New data from Krasnaya Gorka. Quaternary International, 2017, vol.441, pp. 81-90.

Wu X., Zhang C., Goldberg P., Cohen D., Pan Y., Arpin T., Bar-Yosef O. Early Pottery at 20,000 Years Ago in Xianrendong Cave, China. Science, 2012, vol. 336, iss. 6089, pp. 1696-1700.

Vetrov V.M. Drevneishie sledy keramicheskogo proizvodstva v Vostochnoi Azii. Antropogen. Paleontropologiya, geoarkheologiia, etnologiia Azii. Ed. by G. I. Medvedev. Irkutsk, Ottisk, 2008, pp. 28 34. (In Russian)

Vetrov V. M. Ritual'nyi kompleks v ust'e r. Karenga (dolina r.Vitim) i nekotorye problemy neolita Vostochnoi Sibiri. Izvestiia laboratorii drevnikh tekhnologii, 2008, iss. 6, pp. 28-43. (In Russian)

Vetrov V.M., Ineshin E.M., Revenko A.G., Sekerin A.P. Artefakty iz ekzoticheskikh vidov syr'ia na arkheologicheskikh pamiatnikakh Vitimskogo basseina. Baikal'skaia Sibir'v drevnosti, 2000, iss.2, part 1, pp.98-117. (In Russian)

Vetrov V. M., Zadonin O. V., Ineshin E. M. Mnogosloinoe mestonakhozhdenie Nizh. Dzhilinda (Sivakon) $1 \mathrm{v}$ Bambuyskoy kotlovina. Kul'tury i pamyatniki epokhi kamnia i rannego metalla Zabaykal'ia. Novosibirsk, Nauka, 1993, pp.98-112. (In Russian)

Zinov'ev A. A. Na puti k sverkhobshchestvu. Moscow, Tsentrpoligraf, 2000, 260 p. (In Russian)

Zhushchikhovskaya I.S. Drevneishaia keramika: puti tekhnologicheskoi innovatsii. Vestnik DVO RAN. Arkheologiia, 2011, no. 1, pp.101-110. (In Russian)

Статья поступила в редакцию 17 мата 2018 г. Рекомендована в печать 12 марта 2019 г.

Received: March 17, 2018

Accepted: March 12, 2019 


\title{
The Indigenous Watercraft of Northern Eurasia
}

\author{
W. W. Fitzhugh, H. T. Luukkanen
}

For citation: Fitzhugh W. W., Luukkanen H. T. The Indigenous Watercraft of Northern Eurasia. Vestnik of Saint Petersburg University. History, 2019, vol.64, issue 2, pp. 474-498.

https://doi.org/10.21638/11701/spbu02.2019.206

Hear we overview the indigenous watercraft from northern Europe to Bering Strait and the Far East. Our purpose has been to document the types of boats, their history, and how they were made and used by the cultures of this vast region. Data have been gleaned from diverse sources, including archaeological finds, ethnographic descriptions, museum collections, photographs, historical documents, and reports of early trans-Siberian travelers. Because of space limitations, the summary provided here is devoted to bark boat traditions, with limited discussion of skin boats because the latter are better known in existing literature. Our work has been facilitated by Valentina V. Antropova, whose 1961 survey of Soviet/Russian watercraft guided much of our work. We describe four major canoe traditions, each coinciding with major river systems: Ob-Pechora, Yenesei, Lena, and Amur. Within each river system there may be several sub-types, e. g. Amur I and Amur II. Except in rock art, the history of bark boat development is very shallow as very few bark canoes have been preserved archaeologically. Paddles, however, indicate the presence of bark canoes as early as 8000 years ago. Some rock art depicts log canoes rather than bark or skin boats. Wooden planked boats replaced bark

Harri T. Luukkanen - independent researcher, Hiihtomäentie, 33B, 19, 00800 Helsinki, Finland; Harri.Luukkanen@gmail.com

Харри Т. Луукканен - независимый исследователь, Финляндия, Хельсинки, 00800; Хиихтомаенти, 33Б 19; Harri.Luukkanen@gmail.com

William W. Fitzhugh - PhD in Anthropology, Senior Scientist, Smithsonian Institution's Arctic Studies Center and curator of North American archaeology, $10^{\text {th }}$ St. \& Constitution Ave, NW Washington, D.C., 20560, USA; Fitzhugh@si.edu

Вильям В. Фиихью - д-р философии (антропология), ст. науч. сотр., Центр Арктических исследований Смитсоновского Института, фонд археологии Северной Америки. США, округ Колумбия, Вашингтон, 20560, 10-я ул. и пр. Конституции; Fitzhugh@si.edu

Our work on North Eurasian watercraft has been facilitated by so many individuals and organizations that it is impossible to adequately convey our appreciation in the space allowed here. Over the past decade, Harri Luukkanen has consulted hundreds of individuals and scores of museums, libraries, and archives ranging from Western Europe to the Far East. Harri conducted most of the basic research and initial drafting of the book manuscript, while Fitzhugh worked around the edges, elaborating, re-writing, and filling in anthropological and archaeological knowledge. In addition to the large number of partners unmentioned here, we can at least thank our families and spouses, a score of Smithsonian's Arctic Studies Center interns, and Marcia Bakry and Dan Cole for drawings and maps.

Работе над нашей статьей о судостроении аборигенов Северной Евразии способствовало так много людей и организаций, что невозможно передать нашу благодарность несколькими словами. За последнее десятилетие Х. Луукканен проконсультировался с множеством сотрудников различных музеев, библиотек и архивов от Западной Европы до Дальнего Востока. Х. Луукканен провел большую часть базовых исследований и подготовку для первоначального составления рукописи, в то время как В. Фицхью занимался работой с антропологическими и археологическими данными. В дополнение к большому количеству партнеров, не упомянутых здесь, мы можем, по крайней мере, поблагодарить наши семьи и стажеров Смитсоновского центра арктических исследований, а также Марсию Бакри и Дана Коула за рисунки и карты.

() Санкт-Петербургский государственный университет, 2019 
canoes in northwestern Eurasia during the late Iron Age but persisted in the Amur into the $20^{\text {th }}$ century. Canoes appear to have dispersed from South Siberia during the early Holocene and developed distinctive features in their respective river systems. Some Ket Yenesei canoe styles may be prototypes of Kootenai Indian canoes of interior British Columbia.

Keywords: indigenous watercraft, bark canoe, boat history, archaeology, canoe types, construction, functions

\section{Аборигенное судостроение Северной Евразии}

\section{В. В. Фиихью, Х. Т. Луукканен}

Для цитирования: Fitzhugh W. W., Luukkanen H. T. The Indigenous Watercraft of Northern Eurasia // Вестник Санкт-Петербургского университета. История. 2019. Т. 64. Вып. 2. С. 474-498. https://doi.org/10.21638/11701/spbu02.2019.206

Настоящая работа содержит обзор источников по аборигенному судостроению от Северной Европы до пролива Беринга и Дальнего Востока. Цель исследования состоит в документации типов лодок, их истории, а также процессов их изготовления и использования в культурах этой обширной территории. Представленные данные собраны из разнообразных источников, включая археологические находки, этнографические описания, музейные коллекции, фотографии, исторические документы и записки первых путешественников, посетивших Сибирь. В настоящей работе мы уделяем большее внимание традиции строительства лодок из древесной коры, в меньшей степени обсуждая лодки с кожаным покрытием, поскольку последние известны гораздо лучше. Данная работа восходит к труду В.В.Антроповой, чье исследование лодок народов СССР/ России, опубликованное в 1961 г., послужило для нас руководством. Мы описываем четыре основных наиболее важных традиции строительства каное, совпадающие с основными речными системами Северной Евразии: Обско-Печорской, Енисейской, Ленской и Амурской. В пределах каждой из них могут быть выделены некоторые подтипы, например Амур I и Амур II. За исключением наскальных изображений, история развития традиций строительства лодок из древесной коры малоизвестна, поскольку они представлены всего несколькими археологическими находками. Находки весел тем не менее указывают на существование лодок из коры по крайней мере 8000 л. н. Некоторые наскальные рисунки изображают лодки-долбленки, а не лодки, крытые корой или кожей. В Северо-Западной Евразии деревянные лодки из досок замещают лодки из коры в позднем железном веке, но продолжают существовать на Амуре в ХХ столетии. Представляется, что каное распространяются из Южной Сибири в раннем голоцене и приобретают своеобразные черты в различных речных системах. Некоторые стили каное енисейских кетов могли быть прототипами каное индейцев Коутенай во внутриматериковых районах Британской Колумбии.

Ключевые слова: аборигенный водный транспорт, каноэ из коры, история лодки, археология, типы каноэ, конструкция, функции.

In 1964, the Smithsonian Institution published Bark Canoes and Skin Boats of North America authored by Edwin Tappan Adney and Howard I. Chapelle. By that time, the Smithsonian had been collecting Native American artifacts and watercraft for more than a century. Yet, except for a report by Otis Mason and Meriden Hill ${ }^{1}$ and a description of

1 This paper is a condensation of a book the authors have prepared titled Bark Canoes and Skin Boats of the Eurasian North, to be published in 2019 by Smithsonian Books and Random House (Mason Otis T., 
building a Chippewa birch-bark canoe by Robert Ritzenthaler ${ }^{2}$, anthropological literature on indigenous North American watercraft was largely anecdotal. For the first time, Adney and Chapelle had provided scholars and general readers with a comprehensive study of canoes and kayaks in North American collections that included detailed descriptions, ethnographic data, photographs and drawings, and information on use, decoration, and ritual. Despite its monographic style, the book became so popular that it remained in print ever since. The opportunity to prepare a comparable work prompted the present authors to undertake a sequel for the Eurasian continent. Bark and Skin Boats of the Eurasian North describes the history, use, and types of bark and skin boats utilized by the traditional cultures of northern Eurasia. The book serves as an historical atlas of traditional boats among more than forty tribes and peoples from northern Europe to Central Asia and the Far East.

\section{The Tappan Adney Legacy}

Tappan Adney was a renaissance individual - artist, naturalist, woodsman, linguist, and scholar. At age 19, while Adney was vacationing in Woodstock, New Brunswick, a Maliseet Indian named Peter Joe taught him how to make a bark canoe. Soon Adney became fascinated with American Indians, Indian lore, and, in particular, their canoes and canoe traditions. His early curiosity about Indian watercraft developed into a lifetime spent documenting canoes and kayaks in museums and Native communities across North America $^{3}$. He documented manufacturing techniques, raw materials, and vessel performance; he interviewed and photographed Native Americans making canoes and used this information to build scale models and make nautical-style drawings of canoe lines, and sketches of construction details. Late in life, he sold his models and willed his voluminous archives to the Mariner Museum in Newport News, Virginia (Fig. 1). Following Adney's death in 1950, Howard Chapelle, a marine architect and curator of naval history at the Smithsonian National Museum of American History, organized Adney's materials into a monographic study. Its ethnographic descriptions and photographs provided a window onto a long-neglected and mostly vanished part of North American Native life, and its construction drawings enabled recreational boat-builders to make authentic replicas for the first time.

While the history of European plank boats has been discussed by many authors ${ }^{4}$, there has been relatively little synoptic literature on traditional watercraft covering the entire region of northern Eurasia. Rudolf Trebitsch ${ }^{5}$ wrote on the origin and distribution

Meriden S. Hill. Pointed Bark Canoes of the Kutenai and Amur. Report of the U.S. National Museum for 1899. Washington, 1901. P. 525-537).

2 Ritzenthaler R.E. The Building of a Chippewa Indian Birch-Bark Canoe // Bulletin of the Public Museum of the City of Milwaukee. Vol. 19(2). 1950. P.59-98.

3 Adney T.E., Chapelle H. Bark Canoes and Skin Boats of North America. Washington, 1983. P.4; Jennings J. The Art and Obsession of Tappan Adney. Toronto, 2004.

${ }^{4}$ Johnstone P. The Seacraft of Prehistory. Cambridge, 1980; McGrail S. Ancient Boats in NorthWest Europe: The Archaeology of Water Transport to AD 1500. New York, 1998; Crumlin-Pedersen O. Archaeology and the Sea in Scandinavia and Britain: A Personal Account. Maritime Culture of the North 3. Roskilde, 2010.

${ }^{5}$ Trebitsch $R$. Fellboote und Schwimsäcke und ihre geographische Verbreitung in der Vergangenheit und Gegenwart // Archiv für Anthropologie. Neue Folge, Bd. XI. 1912. S. 61-84. 


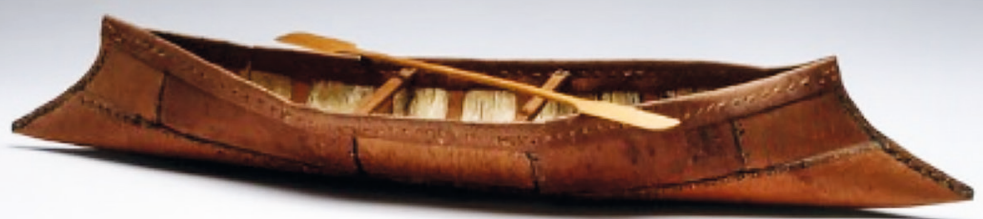

Fig. 1. Yakut Canoe Model. Adney made this model based on Otis Mason's 1901 publication of a model Yakut canoe (MAE 701-51) collected by Alexander Fedorovich von Middendorf in the Lena River valley in 1846. The MAE model was loaned to the Smithsonian to facilitate Mason's comparative study of North American canoes (Mariner's Museum photo MP48)

skin boats in Europe; H.H. Brindley ${ }^{6}$ reported on boats of Siberia based on reports of early explorers and navigators; and Scandinavian skin boats have been discussed by Westerdahl ${ }^{7}$. There is also an early global summary of skin and bark boats ${ }^{8}$ and on bark boats of East Africa ${ }^{9}$. Three years before Adney's and Chapelle's book appeared, Valentina V. Antropova ${ }^{10}$, a researcher in the Ethnography Department of the Peter the Great Museum of Anthropology and Ethnography, also known as the Kunstkamera in St. Petersburg, published a chapter titled "Boats" in the Kunstkamera's 1961 Historical-Ethnographical Atlas of Siberia. Antropova's paper described northern Russia's indigenous bark canoes, dugouts, planked boats, kayaks, and large skin boats for each major ethnographic group and offered a typological classification of the different boat types. Antropova recognized that because Siberia lacked Europe's Roman literature, her primary sources would be ethnographic and historical.

\section{North Eurasian Boat Types}

In her "frame boat" class, Antropova identified three birch-bark canoe types, which she named after the river systems where they had been found. The Yenisey type has a pointed, overhanging bow and stern. The Lena type has a rounded, upturned bow and stern projection, a partially enclosed cockpit, and gunwales that do not extend the full

${ }^{6}$ Brindley H. H. Notes on the Boats of Siberia // Mariner's Mirror. 1919. No. 5(4). P.66-72; No. 5(5). P. 130-142; No. 5(6). P. 184-187.

7 Westerdahl Ch.: 1) Sewn Boats of the North: A Preliminary Catalogue with Introductory Comments. Part I // International Journal of Nautical Archaeology and Underwater Exploration. No. 14(1), 1985. P. 33$62 ; 2)$ Sewn Boats of the North: A Preliminary Catalogue with Introductory Comments. Pt. II // International Journal of Nautical Archaeology and Underwater Exploration. No. 14(2), 1985. P. 119-142

${ }^{8}$ Nishimura Sh. A Study of Ancient Ships of Japan. Pt. 4: Skin Boats. Tokyo, 1931.

9 Arnold B. Les pirogues kapepe, l'espace nautique du bassin de la rivière Malagarasi (Tanzanie) et quelques observations sur les pirogues en écorce d'Afrique orientale. Le Locle, 2014.

${ }_{10}$ Antropova V. V. Boats // Historical-Ethnographic Atlas of Siberia / eds M. G. Levin, L. P. Potapov. Moscow, 1961. 


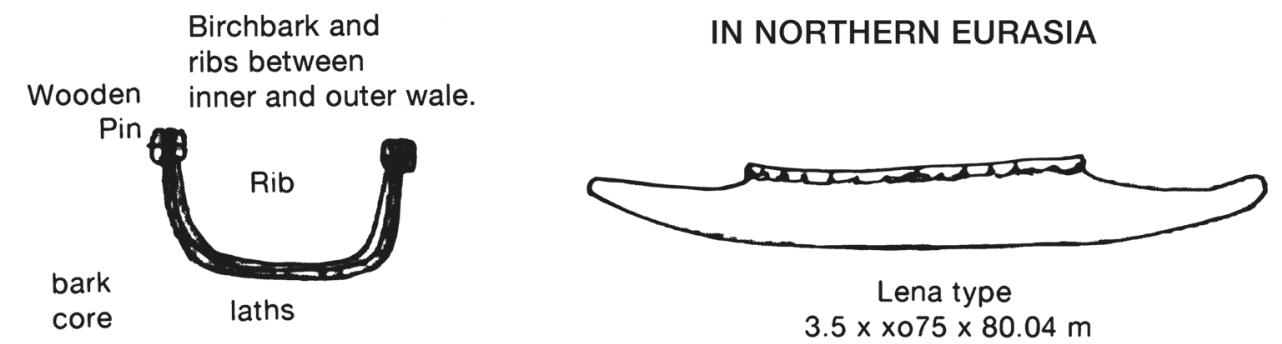

\section{MAJOR BIRCH BARK CANOES \\ IN NORTHERN EURASIA}

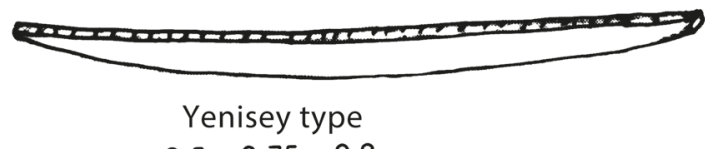

$3.5 \times 0.75 \times 0.3$
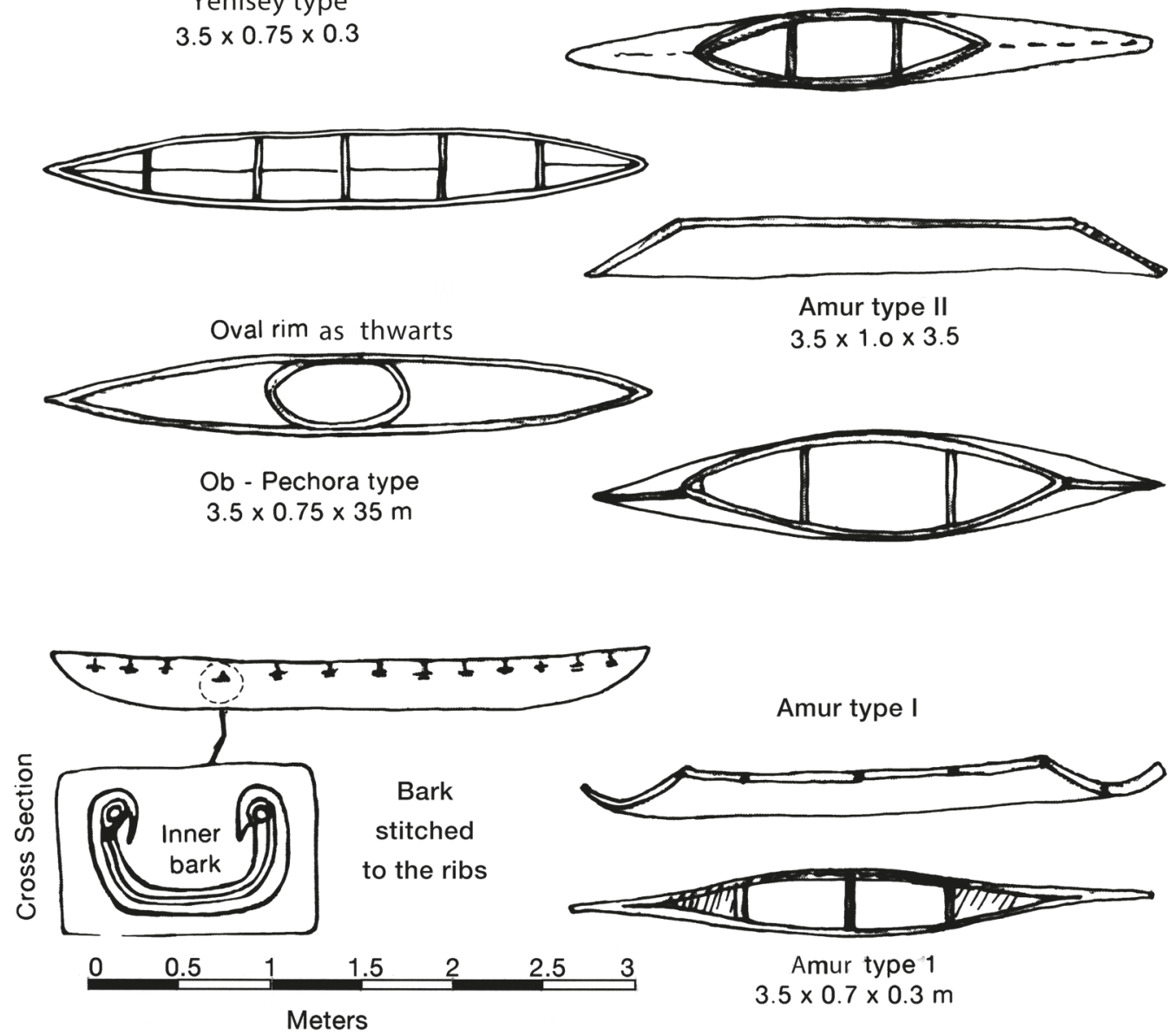
Bakry)

Fig. 2. Canoe types of the Russian North and Far East (drawing by Harri Luukkanen and Marcia

length of the boat. The Amur type has bow and stern projections, a narrow beam, and sometimes partially covered bow and stern decks. Birch bark was the preferred material for all three types. Antropova's skin boat classification has two types. The large, open skin 
boat is defined by a keel running down the middle of the vessel's bottom to which ribs that curve upward to the gunwales are attached. Although adding weight, the keel adds longitudinal strength needed for use in rough maritime regions. This large, open-top, skin-covered bidara was used by Chukchi and Pacific coastal groups in northeastern Siberia for long-distance travel, trade, and hunting whales and walrus. It was called angyapik by the Chukchi and Yupik Eskimo, umiak by the Alaskan and Canadian Inuit, and angyaq by Kodiak Alutiit. The second type is the smaller, fully-decked, skin-covered kayak used on both sides of Bering Strait and throughout Arctic North America as a hunting craft propelled by single, double, or occasionally in the Aleutian Islands, by three paddlers, said to have been an innovation to accommodate a Russian trade boss.

Although Antropova was primarily concerned with the description and geographic distribution by ethnic group, like Trebitsch, she also had ideas about boat history. She commented on the widespread distribution of the bark canoe, which was replaced in Western Siberia and the Okhotsk region first by expanded log boats and later, following Russian contact with Native groups in the $17^{\text {th }}$ to $19^{\text {th }}$ centuries, by plank boats. Based on linguistic data, she speculated that the birch-bark canoe probably originated in the taiga forest zone of southern Siberia. She also commented on the northeastern Siberian distribution and probable origin of skin-covered bidarkas and kayaks, which she identified as the most specialized and ancient of all known Russian indigenous boats, among interior reindeer hunters. Citing Rudenko ${ }^{11}$ and Arutiunov's and Sergeev's ${ }^{12}$ finds at Ekven, she noted that models of boats similar to ethnographic skin-covered umiaks and kayaks were recovered from Old Bering Sea and Punuk archaeological sites in coastal Chukotka dating ca. 1,500-800 and 1,200 years ago, respectively. She also remarked that $16^{\text {th }}$-century exploration literature contains illustrations of kayak-like boats used by Nenets maritime hunters and their neighbors in the Barents and Kara Seas ${ }^{13}$.

The classification system used in our survey largely follows Antropova's taxonomy but recognizes five rather than three bark canoe types (Fig. 2). We follow Antropova's Yenisey and Lena types, split her Amur type into two sub-types (Amur I and II), and identify a new Ob-Pechora type. In addition, our study of keeled skin boats recognizes more variation in the open and closed types than Antropova's. We classify the kayak group into several ethnic-based sub-types, including Yukagir, Eskimo-Chukchi, Koryak, and Kuril/ Ainu. Our open skin boat classification follows Antropova's two types: the Eskimo-Chukchi type of Chukotka and the Koryak-Kerek type of northern Kamchatka.

\section{Description of Canoe Types}

Bark canoes were used by all aboriginal peoples living in Northern Eurasia's boreal forest. The era of birch-bark canoe lasted until the $18^{\text {th }}$ century in most of Eurasia and a century or two longer in parts of eastern Siberia and the Far East. Canoe type areas usually follow the large river basins of the Pechora-Ob, Yenisey, Lena, and Amur River homelands

${ }_{11}$ Rudenko S. I. Early Harpoon Heads of the Asiatic Eskimo // Sovietskaia Etnografiia. Moscow, 1947. No. 2. P.33-56.

12 Arutiunov S. A., Sergeev D. A. Problems of Ethnic History in the Bering Sea: The Ekven Cemetery. Transl. by R. L. Bland. Anchorage, Alaska, 2006.

${ }^{13}$ Belyavsky F. O. A Trip to the Arctic Sea. St. Petersburg, 1833 (see: 2007 Khanty-Mansiysk: FGUK State Historical Museum). 
of the people who used these boats. Each river drainage area had its own typical canoe design, and these types often were shared across linguistic and ethnic borders. The close linguistic and cultural relations among the various groups living along a single river system facilitated sharing, and their canoe traditions tended to cluster in a similar fashion.

The Yenisey type has strong double gunwales that sandwich both the horizontal lath planking strips and the vertical ribs, a technique still used in modern wood canoe construction today. The Lena type with more or less vertical bow and stern profiles was used by Evenk and Sakha peoples living around the eastern portions of the Vitim and Olekma rivers, eastern tributaries of the Lena. In addition to this type, people living in the Lena basin also used canoe types known from the Yenisey and Amur systems due to population migrations and adoption of neighboring canoe technology.

Amur canoes occur in two main forms. Amur I has long projecting bow and stern extensions resembling "beaks" that turn upward at their ends, while Amur II is a short canoe with straight, pointed extensions at the waterline. The longer Amur I type typically had a beam of 70 centimeters, a strong bottom construction using as many as five bark layers glued together, and an interior keel running from end to end. Wooden blocks were sewn into the bark sheets to support the gunwales at the bow and stern. Because its hull design resisted flexing, the Amur I type could be made very long - as demonstrated by a 15-meter-long bark canoe found on the Maya River, a tributary of the Aldan. The Amur II-type canoe, originally described by Otis Mason as a "sturgeon-nose" canoe because its ends or "beaks" resembled a sturgeon's snout, was short, had rather weak gunwales, and could carry only a single person. Beyond the Amur, the Amur II type was known in the upper (southern) Lena River locations where Evenk people of Amur origin resided. Most Amur basin people were Tungus-related, and all made similar bark canoes.

Our proposed Ob-Pechora type bark canoe originated in Southern Siberia, where it was used by Samoyed and shared with Ob-Ugrian peoples; from there, it diffused throughout Western Siberia between the Pechora and the Yenisey Rivers. Evidence for this canoe type comes from several sources: Kamas canoe construction on the Yenisey River documented in G. F. Miller's 1730-1740 "Description of Siberian Peoples"14; a drawing of a Mansi or Khanty boat in Obdorsk made by Tobias Königsfeld in $1728^{15}$; a Khanty model in the Swedish Ethnographic Museum collected by F. R. Martin on the Tobol River in 1895; a bark canoe model from the Amgun River (MAE 5333); and Samoyed oral evidence from Narym ${ }^{16}$.

The Ob-Pechora type occurred in the middle Ob-Irtysh-Tobol area occupied mainly by the Samoyed (Nenets, Selkup, and Kamas-Koibal) and Ob-Ugrian (Khanty and Mansi) peoples. This canoe type was found among Turkic Tatars in the south Siberian taiga and was shared with western Ural peoples in the Mezen-Pechora taiga of northeastern Europe. Its main differences from the Yenisey type are: (1) presence of an oval rim instead of transverse thwarts, known among the Eastern Khanty; (2) a single rather than a double gunwale strake; (3) passing the bark over, rather than between, the gunwales; and (4) a

14 Vermeulen H.S. Ethnography and Empire. G. F.Müller and the Description of Siberian Peoples // Before Boas. The Genesis of Ethnography and Ethnology in the German Enlightenment. London, 2016. P. 131-218.

${ }^{15}$ De Lisle N., Königsfeld T. Extract de Voyage un Sibirie M. DeLisle \& Journal de M. Königsfeld en 1740 // Francois Antoine (1768), Histoire générale des voyages, voyage de Sibiria. Paris, 1768.

16 Pelikh G. I. Proiskhozhdenie selkupov. Tomsk, 1972. 
different method for fastening the gunwales. The latter involved lashing the gunwales together fifty centimeters from their ends, thus creating a narrow top profile for bow and stern. In the $\mathrm{Ob}$ canoe, the gunwale ends were not pinched together but were fastened to separate pieces of bent wood. The rounded ends provided more cargo space and buoyancy and reduced taking on wave water. On the middle $\mathrm{Ob}$, Khanty canoe builders doubled the birch-bark bottom by inserting an additional bark layer inside the outer shell. In other features, the Yenisey and Ob-Pechora canoes were similar.

Despite the great distances and multiple ethnic groups occupying the region from the Yenisey to the Pechora, the similarities between the canoes of this region probably results from two factors: migration history of the past 1,000 years, and the intense interactions of long-distance traders during the Russian fur-trade era. The Khanty, Nenets, and Mansi were constantly trading and warring with one another across the Ural passes. Until circa 1470, many Mansi lived on the European side and held lands reaching as far west as the Dvina River ${ }^{17}$, where their traders were in contact with Karelian groups. This could account for the similarity in canoe styles between the $\mathrm{Ob}$ and the Mezen-Pechora taiga. Archaeological, linguistic, and DNA data ${ }^{18}$ suggest that the eastern Saami peoples who once lived along the southern White Sea coast had contacts with groups living in the CisUrals $^{19}$. It is likely that the Saami birch-bark canoe types as they are known today from oral descriptions and remains found in northern Sweden, were also similar to Mansi or Samoyed canoes known from the White Sea.

Here, as in other areas of Eurasia, Antropova's and our studies indicate that geographic proximity along a single river system generally was a more important factor than either language or ethnicity in determining the geography of boat types. This principle confounds the typological changes usually seen across cultural-historic and ethnolinguistic borders. In his study of northeastern European paddle types, Grigori Burov ${ }^{20}$ found that he could date different types of paddles to a certain millennium, beginning as early as 8700 BP. In this case, chronology rather than culture seems to have been the dominant factor determining a paddle form. By contrast, from the $19^{\text {th }}$ century ethnographic data, Otis Mason ${ }^{21}$ found that the shapes of paddles from different Amur cultures were good indicators for the ethnic groups who made them. Similarly, style shifts in Eskimo kayak and paddle types from Alaska to Greenland show strong correlation with ethnic and language areas ${ }^{22}$.

Recent research at the 8500 BCE Mesolithic site at Star Carr by Peter Rowley-Conwy ${ }^{23}$ reviewed the scant information on bark canoes in North European prehistory. Noting

17 Sokolova Z.P. The Mansi. Moscow, 1983.

18 Tambets K. et al. The Western and Eastern Roots of the Saami - The Story of Genetic 'Outliers' Told by Mitochondrial DNA and Y Chromosomes // American Journal of Human Genetics. No. 74(4). 2004. P. 661-682.

19 Foss M. E. Kul'turnye sviazi severa Vostochnoi Evropy vo II tysiacheletiiu do nashei ehry // Sovetskaia Etnografiia. 1948. No. 4. P.23-35.

${ }^{20}$ Burov G. M. On Mesolithic Means of Water Transportation in Northeastern Europe // Mesolithic Miscellany. No. 17. 1996. P.5-15.

${ }^{21}$ Mason O., Meriden Sh. Pointed Bark Canoes of the Kutenai and Amur. Report of the U. S. National Museum for 1899. Washington, DC, 1901. P. 525-537.

${ }^{22}$ Rousellot J.-L. Watercraft in the North Pacific: A Comparative View // Anthropology of the North Pacific Rim. Washington, 1994. P.243-258; Golden H. Kayaks of Alaska. Portland, 2015.

${ }^{23}$ Rowley-Conwy P. To the Upper Lake: Star Carr Revisited - by Birchbark Canoe // Economic Zooarchaeology: Studies in Hunting, Herding, and Early Agriculture. Chapter 23. Oxford, 2017. 
finds of birch resin and bark sheets in water-logged Mesolithic sites, Rowley-Conwy believes birch-bark canoes were the usual vehicles for exploiting post-glacial wetland environments. Undoubtedly, the same could be said for post-glacial northern Eurasia, where 8700 year old paddles indicate water transport.

\section{Geography of Bark Canoes Types}

When we began our canoe project, we thought that careful comparison of boat types would enable us to make a rough synthesis of Northern Eurasian boat history by using a combination of construction form controlled for both spatial and chronological dimensions (Figs 3, 4). This approach, which is the normal basis for archaeological reconstruction, had a practical disadvantage due to the limited knowledge of canoe history, even for the past 500 years. This type of historical data does exist for plank boat development in the Mediterranean and Western Europe for the past 2,000 years ${ }^{24}$. Reconstructing such a data matrix was the goal of early attempts at a global evolutionary framework of boat development based on ethnographic data, as seen, for example, in James Hornell's ${ }^{25} \mathrm{Wa}$ ter Transport: Origins and Early Evolution. Hornell encountered many of the same problems we faced, including insufficient archaeological and historical data. In the case of bark canoes and skin boats, we are limited to a few centuries of historical documentation, ethnographic boat models, rare archaeological finds, and rock art images of problematic interpretation. Our birch-bark canoe data matrix, which includes only data from the end of the $18^{\text {th }}$ century onward, is not a reliable database for understanding 10,000 years of canoe form and construction. Although a sporadic 8,700-year development is known for paddles, they tell us little more than the size of the canoes. Nevertheless, one thing is clear: the movements of people hunting, fishing, trading, warring, and migrating in the taiga zone have been hugely successful in spreading bark canoe technology into all corners of Eurasia and throughout Northern North America.

We must remark on an exception in the general absence of data for Europe west of the Ob River. The Saami bark canoe, although being closest to Europe's technological heartland, lasted longer than bark canoes in other areas of northeastern Europe and Scandinavia. There is some evidence that the birch-bark canoe survived as a rarity until the early 1800s in Swedish Lapland, where oral literature and archaeological sites reveal evidence of bark canoes ${ }^{26}$. Remains of an undated birch bark canoe of Saami or Karelian origin have been found in the Lake Saimaa region of eastern Finland, although not enough was preserved to determine its type classification ${ }^{27}$. In Europe, the use of the birch-bark canoe faded early because of the appearance of the expanded log boat, which replaced it in

24 McGrail S. Ancient Boats in North-West Europe: The Archaeology of Water Transport to AD 1500. New York, 1998; Christensen A. E. Ships and Navigation // Vikings: the North Atlantic Saga. Washington, 2000. P.86-97; Crumlin-Pedersen O. Archaeology and the Sea in Scandinavia and Britain: A Personal Account. Maritime Culture of the North 3. Roskilde, Denmark, 2010.

25 Hornell J. Water Transport: Origins and Early Evolution. Newton, 1970.

26 Westerdahl Ch. Sewn Boats of the North: A Preliminary Catalogue with Introductory Comments. Pt. I // International Journal of Nautical Archaeology and Underwater Exploration. No. 14 (1), 1985a. P. 3362; Westerdahl Ch. Sewn Boats of the North: A Preliminary Catalogue with Introductory Comments. Pt. II // International Journal of Nautical Archaeology and Underwater Exploration. No. 14 (2), 1985. P. $119-42$.

27 Itkonen T.I. Suomen Ruuhet: 1-, 2-, 3-Ja Monipuiset Sekä Lautaruuhet Kivikaudesta Vuoteen 1940. Forssa, 1942. P. 48. 
Users: Samoyed, Khanty, Mansi, Users: Samoyed, Ket, Evenki Users: Yukaghir, Evenk, Lamut, Sakha Users: Nanai, Negidal, Nivkh

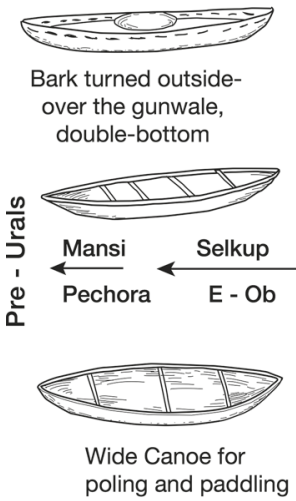

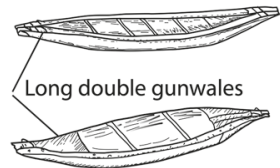

Half - decked, Covered with Bark or Skin

Evenki,

E- Yenisey

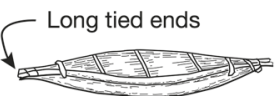

Big Variation in size, Canoes made for 1-6 persons

(C) H. Luukhanen May 9, 2014

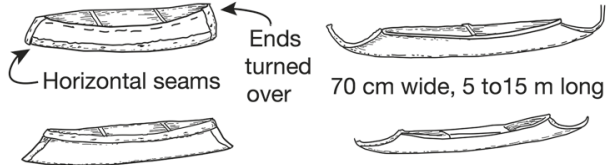

Half - decked

Covered with Bark or Skin

Half-decked, vertical or dull ends Evenki, Sakha $\leftarrow$ E - Lena

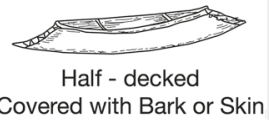

Evenki, Sakha

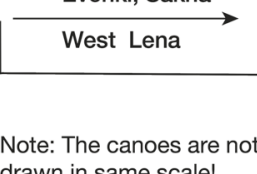
drawn in same scale! $\stackrel{\text { Amur - Evenk }}{\longrightarrow}$

Canoe size veriation Very large: Beam 0.5-0.5-1.5m Length $4-10 \mathrm{~cm}$

Fig. 3. Geography of canoe types across northern Eurasia (drawing by Harri Luukkanen and Marcia Bakry)
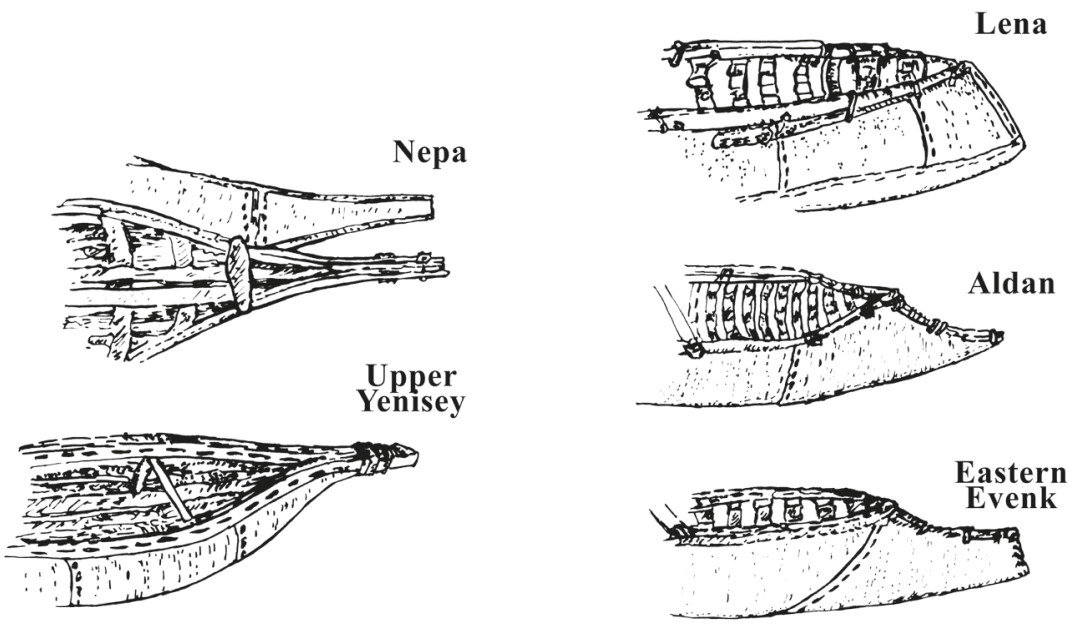

Fig. 4. Canoe construction variation in Central and Southern Siberia (drawing by Harri Luukkanen)

the taiga during the Late Medieval period and may have superseded the skin boat in the tundra zone. This phenomenon may have taken place when the Saami-Karelian people invented or adopted expanded log boats to which planks could be attached, providing higher sides to keep out water ${ }^{28}$.

The canoes of the eastern $\mathrm{Ob}$ and western Yenisey River basins conform to a single type, within which there is significant diversity owing to the complex history of the peo-

${ }^{28}$ Luukkanen H. On the Diffusion of Bark Canoes, Skin Boats and Expanded Log Boats in the Eurasian North // A Circumpolar Reappraisal: The Legacy of Gutorm Gjessing (1906-1979). BAR International Series, 2154. Oxford, 2010. P. 189-217. 
ples in this area, many of whom arrived from the south and east. We know from written documents ${ }^{29}$ that Mansi hunters (known then as Yugra) on the Ural slopes and in the Mezen-Pechora River basin were bark canoe builders, but the descriptions are vague. The Eastern Khanty peoples, who lived as hunters and fishermen, seem to have built birchbark canoes in the Narym region until the early $1700 s^{30}$; some Western Khanty hunters, including the Tara near Omsk, may have used them in the taiga forest country until $1886^{31}$. Little is known about these canoes because the appearance of iron following contacts with Russian traders resulted in the Mansi and Khanty switching to expanded log boats with planked sides earlier than the Samoyed.

The coming of new boat technology was part of a wave of social, economic, and political change that occurred when the Russian fur trade expanded into Western Siberia. Trade and European technology, including guns, iron, axes and other useful goods, exacerbated longstanding regional hostilities and often led to interethnic competition. From the $15^{\text {th }}$ through the $17^{\text {th }}$ centuries, northeastern Europe and Western Siberia experienced recurring intertribal warfare, and watercraft played a major role in skirmishes, raids, and all-out battles ${ }^{32}$. Pressure from population movements from the south and east also contributed to conflicts. The arrival of Ugrian peoples east of the Ob River brought hostilities. According to Khanty accounts of the Ob River wars between the Ural Samoyed and the Ugrian peoples circa 1500-1700, Khanty Ugrians using expanded log boats prevailed partly because their archers, who were armed with crossbows, could shoot holes in the Samoyed's bark canoes ${ }^{33}$. The Khanty had replaced their bark canoes with log boats in some parts of the upper Ob before the 1700s. The Selkup (Ostyak Samoyed) also built bark canoes in the Western Siberian taiga. The Selkup bark canoe that Kai Donner collected at the Ket River in 1911-1914 shows Yenisey-type construction, which also appeared in the eastern $\mathrm{Ob}$ basin. Distinctive features of these canoes are use of bird-cherry wood, double layering of the birch-bark bottom, partial decking, and the use of a bent-wood oval insert instead of straight crossways thwarts.

Antropova ${ }^{34}$ assumed - and we concur - that the most recent dispersal of the bark canoe probably occurred in late Iron Age (ca. $500 \mathrm{BCE}$ to $1 \mathrm{CE}$ ) or even later, and probably was centered on Southern Samoyed territory around the headwaters of the Ob, Yenisey, and Lena rivers. Later, there were many other, smaller, shifts in canoe types that resulted in their modern distribution. Various Samoyed groups used bark canoes which would have been known to other people who entered their lands, including Ket and other upper Yenisey groups. Turkic Tatars, the Southern Samoyed's neighbors to the south, may have

${ }^{29}$ Georgi G. J. Beschreibung aller Nationen des Russischen Reichs (Dscription of all Nations of the Russian Empire). St. Petersburg, 1776.

30 Ides E. Y. Three Years Travel over Land from Moscow to China. London, 1706.

31 Granö J. Suomalaisten elämästäSiperiasta. A Letter to Finland from Tomsk, Siberia // The Morning Paper (Newspaper). Finland, August 29, 1886. Available: http://www.migrationinstitute.fi/files/pdf/ suomalaiset_siperiassa/pastori_granon_kirjeita.pdf (accessed: 01.02.2019).

32 Golovnev A. V. Wars and Chiefs Among the Samoyeds and Ugrians of Western Siberia // HunterGatherers in the Modern World: Conflict, Resistance, and Self-Determination. New York; Oxford, 2000. P. 125-49.

${ }^{33}$ Starcev G. Die Ostjaken: Sozial-Ethnographische Skizze. Aus dem Russischen Übertragen von Katharina Oestreich-Geib. München, 1988. S. 5. (First published in 1928 as Study on Vakh River Ostyak, Moskva).

${ }^{34}$ Antropova V. V. Boats. 
adopted the bark canoe from them, as suggested by the Tatars calling the birch-bark canoe a "Samoyed" boat ${ }^{35}$.

Moving east, we leave the canoe traditions of the Ob-Yenisey region and come to the huge Lena River basin and its dominant people, the Sakha, formerly known as Yakut. The Sakha have a mixed bark canoe history owing to their appearance in the Lena valley in the 1300s, arriving from the Baikal region to the south. According to Antropova ${ }^{36}$, the Sakha called their Lena canoe a "Tungus" boat, while linguistic data suggest a western bark canoe heritage related to the Yenisey River $\mathrm{Ket}^{37}$. Sakha groups also settled along the upper Aldan River, where they traded with Chinese and Manchu people by crossing the Stanovoy Mountains to the Zeya River and were introduced to beaked Amur-type canoes.

Environmental conditions partly dictated the origins of these peoples and the directions of their migration routes. The Ob, Yenisey, and Lena rivers were major north-south transport corridors. No less important were the east-west routes created by the Arctic Ocean coast and the east-west-running tributaries of the large rivers, whose headwaters nearly link up between the major river drainages. Travel across these routes was a routine matter by sledge in the winter and by canoe during the rest of the year. In these Central Siberian regions few mountains intervened. Finally, the open Buryat Steppe of north-central Asia south of the Yenisey and Lena headwaters enabled easy movement for horse-based pastoralists and the armies of Central Asian empires and states.

The major dynamic driving population migrations and other movements in Central Siberia, however, was the tumultuous history of cultural interactions channeled by these geographic corridors. During the past 2,000 years, many events resulted in population movements and demographic disruptions. The two most important were the expansion of Turkic-speaking peoples from the Altai Mountain region beginning in the $7^{\text {th }}$ century and the Mongol expansion from the same area in the $13^{\text {th }}$ century. The Turkic expansion reached as far west as the Black Sea and north into the Lena valley, displacing some peoples into the Arctic and assimilating others. The Mongol wars and incursions caused similar disruptions as people were expelled from their homelands. These migrations and displacements were not a new phenomena; they were preceded by similar events linked to the expansion of militarism and pastoral nomadism stimulated by horse domestication in the late Bronze Age and by intensified equestrian conquest in the Iron Age. These movements undoubtedly influenced canoe history, resulting in both demographic movements, such as those of the Ket, the Evenk, and the Sakha, and cultural exchanges, seen in, for instance, the sharing of Lena traditions with Yenisey peoples and in similarities between the Lena and Amur versions of the birch bark canoe seen in the partially-covered decks of the Chuni Western Evenk canoes from the Niblet River (Krasnoyarsk Krai Museum photo 028-009-2107).

The easternmost birch bark canoe users were the Yukagir, who were in the late $19^{\text {th }}$ century a remnant of a much larger people living on the upper and lower Kolyma River in northeastern Siberia, where they speared reindeer at river crossings from bark canoes, skin kayaks, or log boats. They originally lived east of the Yenisey, north of Lake Baikal

${ }^{35}$ Belgibaev E.A. Chelkantsy Landshaft i Cul'tura // Iazyki korennykh narodov Sibiri. Chelkan Collection. Novosibirsk, 2004. P. 102-126.

${ }^{36}$ Antropova V. V. Boats.

37 Sieroszewski W. The Yakut: An Experiment in Ethnographic Research. The Economic Bases of the Way of Life. Moscow, 1993. 
and next to the Samoyed and migrated (perhaps a millennium ago) from there down the Lena River ${ }^{38}$. During this journey they would have been in contact with the Tungus-Evenk, Even, and Sakha. The Yukagir, who were still making birch bark canoes along the upper Kolyma River in 1827, probably acquired their boat traditions from contact with the Samoyed around Lake Baikal.

South of the Yukagir were the Evenk, who inhabited a large swath of territories in the upper Amur, Lena, and Yenisey drainages of Eastern Siberia. As might be expected from their large distribution, the Evenk have an equally complicated bark canoe history that includes many boat types. The origin of the western Tungus-Evenk peoples, who entered Yenisey lands from the south and east, is unclear, but they probably learned to build Yenisey bark canoes by contact with the Ket, the Assan, and other Yeniseyan peoples along the Angara River ${ }^{39}$.

While these reconstructions are speculative and based largely on linguistic and oral history, Western Evenk bark canoes in the Lower and Stony (Podkamennaya) Tunguska rivers belong to the Yenisey type. The border between the Yenisey and the Lena canoe regions ran along the Vitim and Olekma rivers, where both types were known. West of the Vitim, around Lake Baikal and along the Kirenga and Lena headwaters, the Yenisey type was dominant, whereas along the Lena River proper, east of the Vitim confluence, the Lena canoe was prevalent ${ }^{40}$. East of the Yenisey River, various Evenk hunting peoples were the main users of birch bark canoes, and they kept this tradition alive until the early 1900s, when they adopted expanded log boats.

Canoe sizes varied considerably in these large river basins. Some bark canoes were very large, but most were small, usually only two or three meters long, and were built for one or two persons so the canoe could be easily carried over portages. Some boats were made narrow and fast to transport hunters, while others were wide and slow, serving as freighters. The largest birch-bark canoe we know of in Northern Eurasia was an archaeological find built by Evenk hunters along the Maya River, the easternmost Lena tributary; it is 15 meters long and was found at Ust-Maya village in 2001, probably having been made less than 20 years earlier ${ }^{41}$. The canoe has not survived, but it was identified as being a 70-centimeter-wide Amur Type I beaked canoe.

In the Far East, the birch-bark canoe persisted into the $20^{\text {th }}$ century. In old Manchuria, in the basin of the Amur (Heilongjiang) River and along its many tributaries in Russian, Chinese, and Outer Mongolian territory, Tungus-related peoples such as the Manchu, Nanay, and Negidal once constructed similar versions of the beaked Amur canoe. Most were small single-person vessels used for hunting and fishing. Drawings document some canoes from the Chinese Qing (Manchu) dynasty.

\section{Elm and Larch Bark Canoes}

Canoes made of other bark than birch represent a line of canoe development about which much less is known. Archaeological finds and documented descriptions across

38 Ushnitsky V.V. The Whole Truth about the Tungus and Their History (Vsya Pravda o Tungusakh i ikh Istorii). Available at: http://merkit.livejournal.com (accessed: 01.02.2019).

39 Forsyth J. History of the Peoples of Siberia: Russian's Northern Asian Colony 1581-1990. Cambridge, 1994.

40 Antropova V. V. Boats.

${ }^{41}$ Abakumov S. On Orels Track // From the History of Ulusov of Yakutia. 2001. P. 1-6. 
Northern Eurasia identify canoes made of elm, larch, pine, spruce, and aspen. These boats may have had more limited use in time and distance - for instance, for a single crossing of a river - or when birch bark was not available.

The "alternative path" theory for non-birch-bark canoes was suggested by a unique archaeological find on the Viskan (Byslätt) River in Swedish Västergötland, which may be the only elm-bark canoe known in Europe. This fragmented canoe was discovered eroding from a riverbank in 1934 and was between three and five meters long, with slender ribs of hazel branches fastened into the gunwales with wooden pegs; remains of leather were also present. Maria Lindberg ${ }^{42}$ reexamined this find, which was radiocarbon-dated to the late Bronze Age, circa 900 to 800 BCE. No birch bark canoes (and only a handful of conventional log boats) are known in southern Sweden.

Another example of canoes made from other types of bark comes from the old city of Novgorod in northwestern Russia. Here archaeologists found the remains of three composite canoes beneath the walls of the Vladimir Tower, which dates to $1044 \mathrm{CE}$. Study of the best-preserved canoe revealed a thin, expanded log hull measuring 675 by 90 by 55 centimeters covered with glued-on aspen-bark panels ${ }^{43}$. The Vladimir Tower boats may be the most extraordinary small boats in Europe since the canoes combine all the known technologies of their day. Each vessel was a thin-hulled log boat with sewn planks supported by wooden ribs and covered by an outer layer of aspen bark and an inner layer of hide. Their elaborate construction suggests they may have had a special use.

\section{The Ainu Yachip Birch-Bark Canoe}

Adney and Chappelle ${ }^{44}$ described North American Indian elm- and pine-bark canoes in addition to birch-bark ones, and some Northern Eurasian groups, too, used bark other than birch. Information about elm-bark canoes in Eurasia is scarce, except in Hokkaido, where it was used extensively for impromptu boats and other purposes by the Ainu. Nishimura ${ }^{45}$ noted that the basic Ainu boat, a dugout craft known as a chip, closely resembled dugouts of the ancient Evenk-related Japanese. Besides log chips, the Ainu used builtup versions called mochips, hollowed-out tree trunks to which planks were stitched on either side ${ }^{46}$. Ainu log and planked boats existed on Sakhalin Island into the $19^{\text {th }}$ century; Chepelev ${ }^{47}$ studied them and other wooden boats of the Far East. Nishimura documented the Ainu elm-bark canoes that preceded and then persisted alongside log and plank boats following their introduction from mainland Asian via Japanese, Korean, and Manchurian influences.

${ }^{42}$ Lindberg M. The Byslätt Bronze Age Boat: A Swedish Bark Canoe. Master's thesis, Marine Archaeology Programme, University of Southern Denmark, 2012.

43 Troianovskiy S. V., Petrov M. I. The XI Century Boat from Novgorod // Soviet Archaeology. Vol. 2. 1969. P. $1-7$.

44 Adney T. E., Chapelle H. Bark Canoes and Skin Boats of North America. $2^{\text {nd }}$ ed. Washington, 1983.

45 Nishimura Sh. A Study of Ancient Ships of Japan. Pt. 4: Skin Boats. Tokyo, 1931.

${ }^{46}$ Ohtsuka K. Iiaomanochip: Reviving of Boat-Building and Trading Tradition // Ainu: Spirit World of a Northern People. Washington, 1999. P.374-380.

${ }^{47}$ Chepelev V.R. Traditional Means of Waterway Transportation among Aboriginal Peoples of the Lower Amur Region and Sakhalin // Study of Maritime Archaeology. St. Petersburg, 2004. Iss. 5. P. 141-161. 
The Hokkaido History Museum has examples of even simpler bark canoes made of elm bark. This craft has no rib framework; rather, it is structured by a square arrangement, at the top of the boat, of robust sticks attached to a bentwood gunwale-like oval hoop to which bark sheets are fastened at several points. A mat of parallel sticks serves as a flooring to protect the bark bottom. This is the simplest type of bark boat of any we have seen in northern Eurasia and can be imagined as the type of craft that was an early prototype in the evolution of the frame canoe. Its serviceability depends on using elm bark, which is much thicker than any other northern tree bark. Our research also turned up an unusual source of data for Ainu boats: carvings of miniature boats on Ainu ikupasuy prayer sticks. These images are quite common and usually accompany images of large fish and marine mammals. We searched for images of sea-going bark canoes and skin boats among hundreds of $19^{\text {th }}$ and early $20^{\text {th }}$ century ikupasuys, but found none, only images of log and plank boats.

Although elm was unavailable in Northern Siberia, larch was a suitable - if uncommon - alternative to birch. The first academic explorer of Siberia, D. G. Messerschmidt, a German traveling in 1723 on behalf of the RAS, journeyed from New Mangazeya (later renamed Turukhansk) on the Yenisey to the Lower Tunguska River, where he met small groups of Evenk and commented on their bark canoes, some of which he measured and weighed. The Evenk apparently were using larch-bark canoes alongside birch-bark ones; Messerschmidt recorded Evenk larch-bark canoes between the Uchami and Taimura Rivers that were similar in both use and size to those of birch bark; he records one as being 360 by 90 by 30 centimeters.

In 1914, the Dolgan people in Sloika near the Golchikha trading post in western Taimyr used larch-bark canoes, as recorded in an account written by Maud Dorian Haviland ${ }^{48}$. She and an English companion on an ornithology expedition tried to cross a flooded river with their Dolgan guides in larch bark canoes. The Dolgan and Nganasan used similar small boats for hunting birds on Taimyr lakes, where birch bark is not available. Her report shows that larch canoes were common even in the northernmost tundra of the Russian High Arctic for spearing wild reindeer in rivers and for crossing lakes and rivers with tame reindeer during seasonal migrations. These boats, less than three meters long, were small and light - designed for a single person - and could be carried on a reindeer sledge.

\section{Open Skin Boats and Kayaks}

In addition to hosting bark canoes, Northern Eurasia has an extensive history as a skin boat using region; nearly all major groups in the tundra zone used skin boats at some point in their past, although the intensity and purposes differed as it did in the case of bark canoes. Skin boats were used by Siberian Eskimo, Chukchi, and Koryak peoples and had a wider distribution along the Arctic and Pacific coasts in the past than known from recent history. Open skin boats and kayaks have been reported from most coastal areas of Northern Eurasia, the Sea of Okhotsk, and even parts of the Far East. European, Siberian, and Central Asian peoples inhabiting inland regions also used open skin boats, half-decked canoe-kayaks, and bowl-shaped vessels covered with seal, reindeer, or moose hide.

${ }^{48}$ Haviland M.D. A Summer on the Yenisey. London, 1971. 
In Northern Europe, the Saami people may have an early history of skin boat use, as suggested by Stone Age petroglyphs and folk legends. For many years, Nordic archaeologists interpreted petroglyph images dated between 2,000 to 6,000 years old as depictions of skin boats based on their high sides and profiles similar to Eskimo umiaks. However, because heavy ground stone axes and woodworking gouges have been unearthed in the same areas as the petroglyphs, archaeologists today tend to interpret these images as log boats or expanded log boats with sewn plank additions. Nevertheless, some probably do show skin boats, especially in areas where people once hunted seal and walrus among the broken spring sea ice, where hunters would not have been able to use heavy log boats. There are oral history accounts of Saami skårne-väntse skin boats in Swedish Lapland as well as legends relating to how people used skin boats to cross rivers with their reindeer and to hunt sea mammals along the coast ${ }^{49}$. Although there is no detailed knowledge of Saami skin boats, one archaeological find from Tiisteenjoki village on the Lapua River, along the western Finnish coast, dates to circa $3200 \mathrm{BP}^{50}$. According to Mulk and Bayliss-Smith (2006), skin boats may have been used on the northern Norwegian coast until circa 300 to $600 \mathrm{CE}$, when "Viking" lapstrake boats began to replace them. In interior regions, small skin boats survived in villages of the Vapsten Lapp people in Sweden until the first half of the $19^{\text {th }}$ century ${ }^{51}$.

The Karelians, possibly the closest relatives of the Saami owing to mixing and assimilation, arrived on the Kola Peninsula in the 1200s. They later became skin boat users, especially in the White Sea region. Kalevala runes collected between 1600 and 1850 describe boats covered with "fish" (i. e., seal) skin in several regions inhabited by the Finns, Karelians, and Ingrians from the Gulf of Bothnia and the White Sea coast.

Russian Pomors, who arrived on the White Sea coast in the $13^{\text {th }}$ century and pushed the Saami, Karelians, and Ingrians farther north, used light canvas-covered plank boats to hunt seal amid spring sea ice until circa 1900 . This fact does not necessarily imply a prior history of skin-covered frame boats; rather, the Pomors may have used skins as a practical way to waterproof their leak-prone sewn or nailed plank boats. Pomor plank boats were six to eight meters in length, and it is likely that their construction incorporated elements of previous Saami and Karelian technology, including seal-skin waterproofing over planks. The boat traditions of the Maritime Pomors are well documented, as is their large-scale sealing industry, which employed thousands of people and hundreds of boats for hundreds of years. Further research may show that both skin boats and sealing or whaling have a deep history in Northern Scandinavia and northwestern Russia. The many river estuaries from Kola to Taimyr, where beluga whales were hunted, have rock engravings whose shapes suggest skin boats.

Fig. 5 shows the types of open skin boats and skin-covered kayaks that existed in most areas of Northern Eurasia. Two major points can be made about their diversity: first, the overriding conclusion is that open skin boats have been used widely along the continent's northern and northeastern coasts, from Europe to the Amur River and the Sea of Okhotsk

49 Westerdahl Ch. Sewn Boats of the North: A Preliminary Catalogue with Introductory Comments. Part I // International Journal of Nautical Archaeology and Underwater Exploration. No. 14(1). 1985. P. 3362; Sewn Boats of the North: A Preliminary Catalogue with Introductory Comments. Pt. II // International Journal of Nautical Archaeology and Underwater Exploration. No. 14(2). 1985. P. 119-142.

50 Itkonen T.I. Suomen Ruuhet: 1-, 2-, 3-Ja Monipuiset Sekä Lautaruuhet Kivikaudesta Vuoteen 1940.

51 Whitaker I. The Scottish Kayaks Reconsidered // Antiquity. No. 51(201). 1977. P.41-45. 
SCANDINAVIA / WHITE SEA

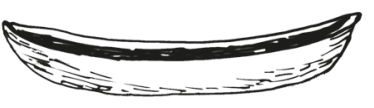

NOVGOROD - RUSSIAN 1300

Plank, Bark, Skin

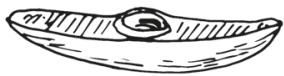

NENETS - KHANTY 1833

Skin decked log boat

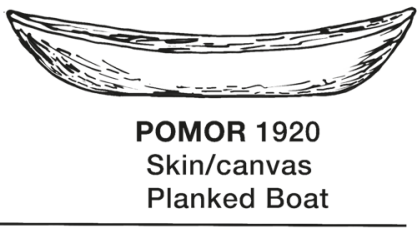

Skin/canvas

Planked Boat

WEST/CENTRAL SIBERIA

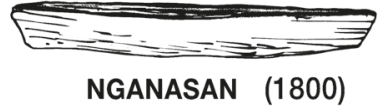

Skin -Covered log Boat

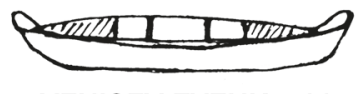

YENISEY EVENK 1927

Skined-decked canoe

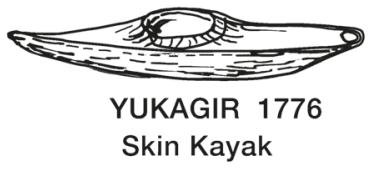

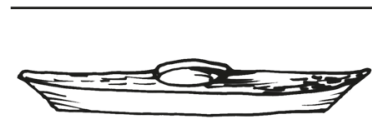

REINDEER CHUKCHI 1900

Skin Kayak

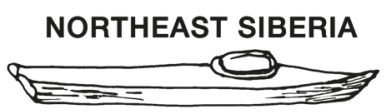

SIBERIAN YUPIK 1905

Skin Kayak

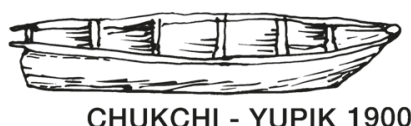

Skin Boat

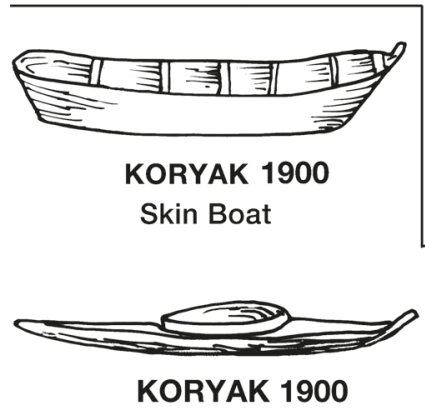

Skin Kayak

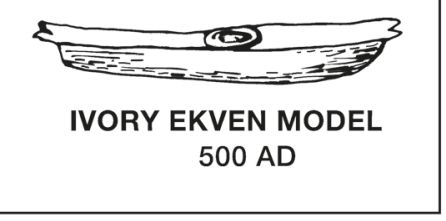

KURIL / KAMCHATKA

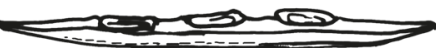

ALEUT KODIAK / KURIL 1840

Skin Kayak

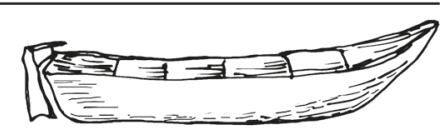

KEREK 1750

Skin Boat

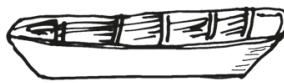

KURIL-KAMCHATKA 1900

Skin Boat

FAR EAST / AMUR

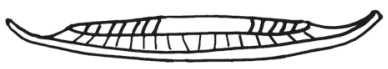

NANAI-GOLDI 1900

Skin-decked Bark Canoe

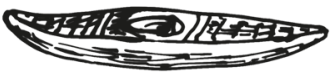

UDEGE 2005

Log Boat, Skin cover

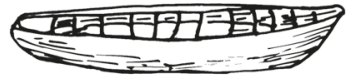

NIVKH-SAKHALIN 1931

Skin Boat Bakry)

Fig. 5. Skin Boats of Northern Eurasia and the Far East (drawing by Harri Luukkanen and Marcia

wherever sea ice was seasonally present. Second, skin-covered kayaks and canoe-kayaks built for individual use in a cold marine or tundra environment were also widely distributed throughout these territories and were used for sea mammal hunting along the coast and for reindeer hunting on lakes and rivers. Inland versions were usually covered with reindeer or moose hide rather than seal skin. Although archaeological evidence is needed for confirmation, historical sources documenting Stephen Burough's voyages to the Kara 
Sea in 1556-1557 $7^{52}$ and Pierre Martin de la Martinière's voyage ca. $1753(1706)^{53}$ indicate that before 1500, skin boats and kayaks were used along the entire Arctic Ocean coast and were not restricted to the historically-known Eskimo territories around Chukotka and Bering Strait. The widespread distribution of these watercraft raises the obvious question of their age and place of origin.

We know little about skin boats in Western Siberia, although the Samoyed along the Arctic Ocean coast, who had long been sea mammal hunters and fishermen, reportedly used such boats. Until the late 1800s, the Nenets (Yurak Samoyed) hunted and fished in the Ob River estuary and off the Yamal Peninsula in decked composite kayaks (log boat hulls decked with seal skins). They may also have used open boats (about which we do not have details). For the Tundra Nenets, farther north, seal and walrus hunting was an important seasonal activity. In the Ob River estuary, the Tundra Nenets shared their hunting grounds, skills, and boats with the Sea Khanty, who - according to accounts written by polar travelers like Alexdander Schrenk (1848) and Timotheus Klingstedt (1769) - hunted beluga in the lower part of the river and in Ob Bay.

East of the Ob estuary are the maritime territories of the Enets (Yenisey Samoyed). Johan Balak ${ }^{54}$ documented their skin boats when he described the journey of the polar explorer and sailor Olivier Brunel, who met Samoyed paddling skin boats on the open sea near the Taz Peninsula 1576. The Nganasan of the Yenisey estuary used small open skin boats for hunting ducks on lakes and spearing reindeer at water crossings ${ }^{55}$.

Our study leads us to believe that before AD 1500 skin boats were used from the Barents Sea to the Anadyr River in Chukotka. This zone included the western regions inhabited by the Nenets, Enets, Nganasan, and Yukagir. Nenets, Sihirtia, and Mansi peoples, all of whom lived along the Barents Sea coast, may have provided connections between the Western Scandinavian pre-Saami skin boat users, while the Yukagir east of Taimyr carried this connection to the Siberian Eskimo and the Pacific tribes as far south as the Sea of Okhotsk. Evidence for the use of skin boats by the Enets and Nganasan, like the case for skin boats in the Sea of Okhotsk, the Kuril Islands, and southern Kamchatka Peninsula, is scant compared to the rich records for their use on the Chukchi Peninsula and in the Bering Strait region.

According to Antropova's classification, Siberian Yupik and Chukchi open skin boats were identical, while the Koryak boats had a different design and construction. Building a large open skin boat or kayak in the treeless tundra required lengthy preparation, including procuring wood for the frame and skins for the cover and gaining the cooperation of several builders and skin sewers. Furthermore, skin boats needed special care and maintenance; on long trips they had to be dried frequently to prevent stretching of the skins and leakage, and their skins and lashings needed constant adjustment and rapid repair when they were torn or punctured.

52 Burough St. The Voyage of the Foresaid M. Stephen Burough, An. 1557 // The Principal Navigations, Voyages, Traffiques, and Discoveries of the English Nation. Cambridge, 2014. P.363-375.

53 Martinière P. M. de la. A New Voyage to the North. London, 1706.

${ }^{54}$ Balak J. Journey into Siberia and to the River Ob, 1581. Available: www.vostlit.info/Texts/rus16/ Merkator/brief_balak_20_02_1581.htm (accessed: 01.02.2019).

55 Simchenko Y. B.: 1) Nganasans // Materialy K Serii "Narody i Kul'tury. No. XXIII. 1976. P.35-37;

2) The Culture of Reindeer Hunters of Northern Eurasia. Moscow, 1976; Popov A. A. The Nganasans // The Peoples of Siberia. Chicago, 1964. 
The close connection between the Siberian Yupik and the Chukchi since the 1600s may have resulted in transfer of the Eskimo kayak and open skin boat designs to the Chukchi. Although the Siberian Eskimo ceased building kayaks in the late 1800s and switched exclusively to the large open angyapit, Chukchi inland and maritime groups continued to use kayaks for hunting on rivers and lakes into the early $20^{\text {th }}$ century. Compared to the longer and more slender Chukchi and Eskimo type, the Koryak kayak was short and wide; it survived as a hunting boat in Penzhina Bay, in the northern Sea of Okhotsk, until the 1920s. The Tungus-Even people adopted this kayak, as well as the large open Koryak skin boat, when they came to Koryak lands on the Okhotsk coast. In all, only a few Chukchi and Koryak kayaks have survived in museums, and only a single Siberian Yupik kayak is known because their use had been replaced by angyapit which were more suitable for whale and walrus hunting.

Another maritime culture, the Itelmen (or Kamchadal) of Kamchatka, employed open skin boats of both the baidar and kayak types. Like the Yukagir, they have a long history in a large and rich land, but introduced diseases and attacks by other Native groups and by Russians entering their lands decimated them. The Itelmen used large skin boats for sea hunting and fishing until the 1800s, and we have some knowledge of their decked kayaks, which they may have shared with the Kushi (Kuril Ainu) and possibly the Hokkaido Ainu. The Nivkh, residing on the Sea of Okhotsk coast and Sakhalin Island, were probably also part of this skin boat maritime culture, but they stopped using such craft before they could be documented. A photograph taken on southern Sakhalin Island, then in Japanese hands, shows two large open skin boats ${ }^{56}$, but their construction details are not clear enough in the photograph to allow detailed description.

We have found a drawing of a two-horned Yukagir decked skin kayak in Georgi's 1776 description of Siberian peoples that has been overlooked in canoe literature (Fig. 6). This kayak, from east of the Lena delta, is very similar to the miniature ivory kayak models excavated from the ca. 500 years CE. Old Bering Sea culture site at Ekven, on Chukotka's East Cape (Fig. 7). Both models show gunwales protruding from bow and stern. The form of the two-horned Yukagir boat suggests design continuity with this ancient Eskimo-Chukchi boat, for these horns are a diagnostic feature of modern angyapik/ umiak construction.

A new find demonstrating likely evidence of skin boats comes from an engraved whalebone artifact found at the Un'en'en site near Nunligran, Chukotka. The artifact came from the floor of a house excavated by Sergei Gusev, radiocarbon-dated to ca. 1,000 BCE and shows engraved images of hunters harpooning large whales ${ }^{57}$ (Gusev pers. comm.). Given the treeless Chukotka coastal environment, it is reasonable to suppose that skin boats are represented. The find is controversial because identical images are only known from Punuk and Thule sites in Alaska and Okhotsk culture dating $1000 \mathrm{calCE}$, making the Un'en'en find 1500 years older than the appearance of whaling harpoons and skin boat models at Ekven. Nevertheless, it is of comparable age to harpoon cradles and kayak fittings indicating skin boats were present at 3000 year old Choris sites in Alaska.

Beyond the sea coast, the Evenk and Mongol peoples had a skin boat culture as well. Skin boats have been documented in the lower Yenisey and upper Lena basins, and in

${ }^{56}$ Nishimura Sh. A Study of Ancient Ships of Japan. Fig. 60.

57 Witze A. Whaling Scene Found in a 3000-Year-Old Picture // Nature News. Available: https://www. nature.com/news/2008/080331/full/news.2008.714/box/1.html (accessed: 01.02.2019). 


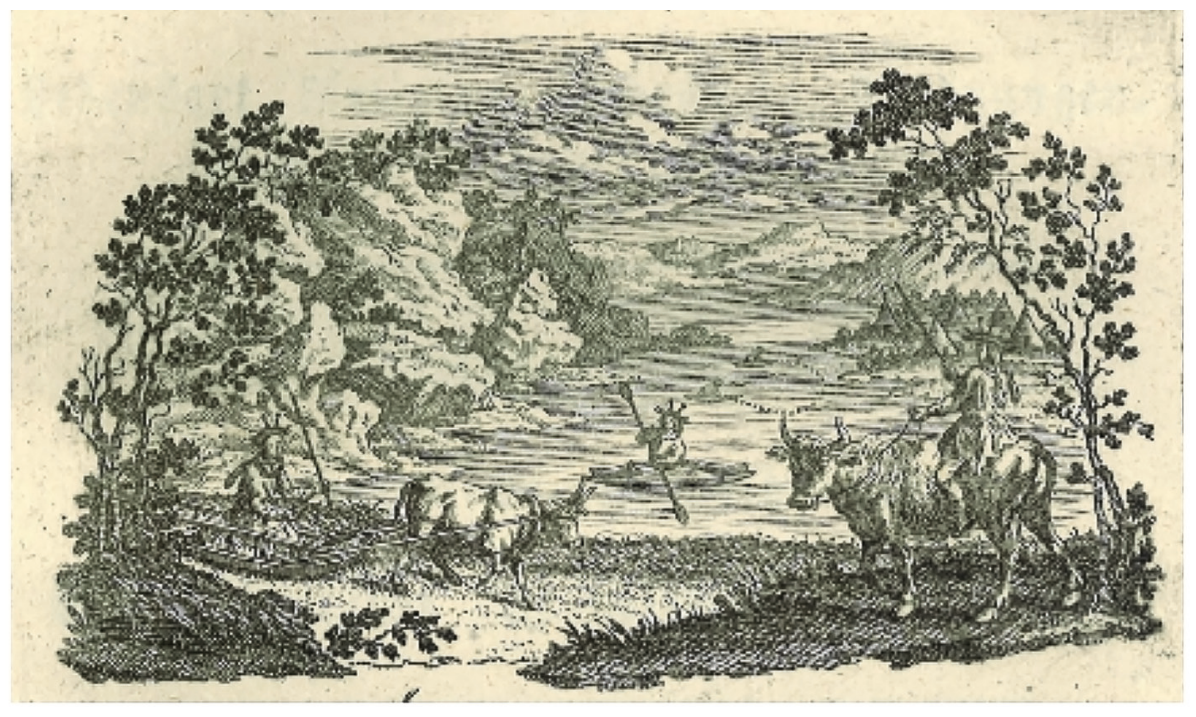

Fig. 6. Yukagir Historical Scene with Two-Pronged Kayaks. Johan Gottleib Georgi (1776) included this illustration in his discussion of the Yukaghir, although it may represent Sakha. The romanticized scene shows conical tents, domesticated cattle, and people with tri-pointed headgear paddling and fishing in skin kayak-like boats. These boats have the same type of bifurcated bow and stern seen in modern Inuit umiaks and ritual boat carvings from the 1,500-year-old Ekven Old Bering Sea Eskimo site near East Cape, Chukotka [Georgi, 1776: 271]

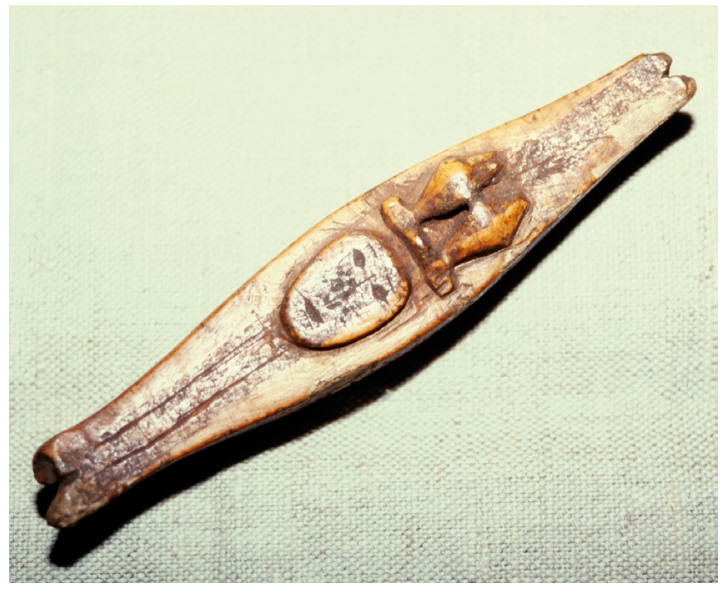

Fig. 7. Spirit Boat from Ekven. This ivory Old Bering Sea model from a Grave 10/11 at Ekven, near East Cape, Chokotka, and a second example from the same site, are the earliest examples Eskimo skin boats. The model shares features of both a kayak (covered deck, cockpit, float gear) and an open skin boat (gunwale extensions, side profile). The human-face and whales on the deck suggest this is a spirit boat with a symbolic, not realistic, function. (Photo: E. V. Anishtchenko [Arutiunov, Sergeev, 1975, pl. 48]) 
Amur-Manchuria and northern Mongolia a similar skin boat culture has a deep history. Most interesting from an evolutionary perspective is the skin boat type we call a canoe-kayak, which has a self-supporting structure and fore and aft decks. It was known among the Chuni-Evenk people who resided between the Angara and Stony Tunguska rivers. Their canoe-kayak was constructed with thin, closely spaced stringers and ribs and was partially decked with reindeer skins or birch bark. The Chuni-Evenk may have originally come here from the Amur region, for a similar construction is seen in the Amur II-type canoe, which also has bow and stern half decks covered with deerskins or birch bark. As suggested by Otis Mason, the decked canoe of the Kootenai Indians of British Columbia suggests possible ancestry with the Amur decked canoe.

Manchu or mixed Evenk and Tungus-Mongol heritage could explain the presence of skin boats in the Far East - including, perhaps, the Korean Peninsula and Japan, whose skin boat history is documented in Chinese records. These records ${ }^{58}$ describe the ethnographic and probably ancient use of rafts buoyed by hides filled with straw or wool and air by horse people of the steppe, especially the Mongols and their neighbors ${ }^{59}$. Since ancient times, Central Asian people have used open coracle-like, wicker-framed skin boats for crossing rivers, and modern Tibetans still use yak-skin boats for fishing and downriver transport of people and freight. Air-filled skins also supported rafts used for downriver cargo transport on the Yellow River and other large rivers in China. Construction and use of these rafts in the rivers of the Far East differed completely from the framed skin boat traditions in Northern Eurasia, and none of these Far East boats could be used for propelled travel. These Far East and Central Asian coracle-type boats probably once existed throughout the steppe, forest, and tundra zones of Eurasia as the Paleolithic prototype for the more highly engineered boats including bark canoes and skin boats. Even in the $20^{\text {th }}$ century people caught without time or tools to fabricate a canoe made simple coracles out of alder or birch withies covered with caribou skins to cross rivers. Examples of this living tradition can be seen in the impromptu bark boats of the Ainu, used for crossing rivers that consist of little more than a folded piece of elm bark supported by a light framework of gunnel-like sticks.

\section{Summary: East Meets West}

Our summary ends with a question: why is the history of bark and skin boats in the northern region of the Eurasian Far East so different from that in the continent's northwestern extremes around the Baltic and White Sea? To put it another way: why have so few of these highly serviceable craft been documented during the past 1,000 years in Fennoscandia, with virtually none persisting into the recent historical era, while in the Far East bark boats dominated the interior waterways into the $20^{\text {th }}$ century?

Part of the answer lies in the types of available records. Written records exist in Fennoscandia only from medieval times, and archaeological finds consist mostly of paddles. Here, bark and skin boats were mostly replaced during the Iron Age, and few excavated boats have been found dating to the succeeding 1,500 years. In Eastern Siberia and along its Arctic and Subarctic coasts, bark canoe and skin boat use continued into mod-

${ }^{58}$ Nishimura Sh. A Study of Ancient Ships of Japan.

59 Sinor D. On Water-Transport in Central Eurasia // Ural-Altaische Jahrbücher. 1961. Vol.33. P. 156179. 
ern times, and both types of craft have been studied and documented, although few are known archaeologically. A wealth of data no doubt exists in Chinese and Manchurian literature dating back to the Iron Age, but this information is not accessible to researchers lacking Chinese or Manchurian language.

However, factors other than archival data are also involved. In Northern Europe, planked boats built with iron nails on a keel rather than a log base were introduced 2,000 years ago, stimulated by developments in the Mediterranean ${ }^{60}$. In northern Europe, lapstrake boats with overlapping planks with sewn seams and then in Viking times with nails, produced strong, light boats of all sizes following a single basic hull design. The smaller versions, for one or a few people, were more durable, and therefore safer, than bark or skin boats and quickly replaced them. Once iron tools and nails became accessible to local builders, plank log boats and clinker boats supplanted birch- and larch-bark canoes, first in the Baltic region by 1500, and soon afterward replaced skin boats along the Arctic coast of western Eurasia.

Unlike in Northern Europe, in the quieter waters of the Amur basin bark canoes continued in regular use into the $20^{\text {th }}$ century for hunting, fishing, and travel. Efficiency and Native economies were the dominant factors in their preservation. Birch bark was readily accessible and could be fashioned into a hunting or fishing craft with just a few days' work. Their persistence in the Far East resulted from social, economic, and political factors related to the maintenance of traditional lifeways, economies, and settlement patterns, and especially the absence of industrialization and commerce once away from the coast and the main Amur artery. As in Europe, boats with nailed or stitched planks also began to supplant bark canoes in the flat-water parts of the Amur system, but these changes did not reach peoples of the northern interior until the $19^{\text {th }}$ century. Where hunters had to navigate rapids and portage between lakes and tributaries, the bark canoe - easy to build, requiring few tools or nails, and extremely light, with no cost for materials - remained the boat of choice into the $20^{\text {th }}$ century.

Bark canoes have been an influential factor connecting peoples from Northern Europe to Chukotka and the Far East. They probably spread throughout the northern parts of the continent even before the final retreat of Ice Age glaciers more than 10,000 years ago and must have entered North America with the first Asian immigrants. Life in the taiga and boreal forests, with their extensive swamps and waterways, was impossible without the bark canoe. Its success continued until canvas, fiberglass, and aluminum replaced bark and wooden frames. Yet even with improved materials, following the same basic design style, canoes remain an integral part of modern life in the forest zone, even far south of the northern forests.

Skin boats and kayaks had the same level of importance for northern coastal peoples as canoes had for boreal peoples. From a construction point of view, the skin boat must have evolved from what people learned earlier in the forest zone from bark canoe building. The skin boat was the only feasible means of travel, migration, hunting and fishing in the rough, ice-infested waters of the northern marine environment. Extensive studies of the Eskimo-type kayak have been made across its range from Northeast Asia to Alaska and Greenland by Rousellot, Zimmerly, Golden, Heath, Kankaanpää, and others, and many theories of its origin have been proposed, but none with definitive proof. It is

${ }^{60}$ Crumlin-Pedersen O. Archaeology and the Sea in Scandinavia and Britain: A Personal Account // Maritime Culture of the North 3. Roskilde, 2010. 
unclear whether a single skin boat technology was shared throughout the Eurasian Arctic, but there is no doubt that after its refinement by Eskimo cultures in the Bering Sea it spread as a single tradition throughout the North American Arctic and Greenland. This technology represents one of the finest examples of nautical design (especially as seen among the Aleut/Unangan) known in the preindustrial world.

Today, bark canoe craftsmen like Henri Vaillancourt (www.birchbarkcanoe.net; see also John McPhee's The Survival of the Bark Canoe) ${ }^{61}$ and a host of skin boat-builders and researchers produce, describe, and promote the use of bark canoes and skin boats of indigenous design. The success of Tappan Adney and Howard Chapelle's North American compendium attests to the undying interest among scholars, enthusiasts, and canoe/ kayak-builders who celebrate the ingenuity of northern craftsmen and the profound influence their boats had on human history. This revolutionary technology, originally inspired and made possible by the birch tree and animal skin, turned rivers and oceans into highways, made possible the discovery and exploitation of new lands, and connected peoples and cultures long before conveyances other than human feet existed. Two facts guarantee the legacy of Northern Eurasian canoes and skin boats: the settlement of the Americas and the continuing use of canoes and kayaks today. Together they are a fitting legacy for a craft that changed the world.

\section{References}

Abakumov S. On Orels Track. From the History of Ulusov of Yakutia, 2001, pp. 1-6.

Adney T.E., Chapelle H. Bark Canoes and Skin Boats of North America. 2 ${ }^{\text {nd }}$ ed. Washington, D.C., Smithsonian Institution Press, 1983, 242 p.

Antropova V. V. Boats. Historical-Ethnographic Atlas of Siberia. Eds M. G. Levin, L. P. Potapov. Moscow, Nauka, 1961, 497 p.

Arnold B. Les pirogues kapepe, l'espace nautique du bassin de la rivière Malagarasi (Tanzanie) et quelques observations sur les pirogues en écorce d'Afrique orientale. Le Locle, Editions G d'Encre, 2014, 68 p.

Arutiunov S. A., Sergeev D. A. Problems of Ethnic History in the Bering Sea: The Ekven Cemetery. Translated by Richard L. Bland. Anchorage, Alaska, Shared Bering Heritage Program, 2006, 262 p.

Belgibaev E. A. Chelkantsy Landshaft i Cul'tura (Chelkantsy: Landscape and Culture). Iazyki korennykh narodov Sibiri. Chelkan Collection. Novosibirsk, Barnaul, Altai State University Press, 2004, pp. 102126. (In Russian)

Belyavsky F. O. A Trip to the Arctic Sea. St. Petersburg: Lazarevs' Institute of Foreign Languages, 1833,259 p.

Brindley H. H. Notes on the Boats of Siberia. Mariner's Mirror, 1919, no. 5(4), pp.66-72; no. 5(5), pp. 130142 ; no. 5(6), pp. 184-187.

Burov G. M. On Mesolithic Means of Water Transportation in Northeastern Europe. Mesolithic Miscellany, 1996, vol. 17, no. 1, pp. 5-15.

Burough St. The Voyage of the Foresaid M. Stephen Burough, An. 1557. The Principal Navigations, Voyages, Traffiques, and Discoveries of the English Nation. Ed. by R. Hakluyt. Cambridge, Cambridge University Press, 2014, pp.363-375.

Christensen A.E. Ships and Navigation. Vikings: the North Atlantic Saga. Eds W. Fitzhugh, E.I. Ward. Washington, D. C., Smithsonian Institution Press, 2000, pp. 86-97.

Chepelev V.R. Traditional Means of Waterway Transportation among Aboriginal Peoples of the Lower Amur Region and Sakhalin. Study of Maritime Archaeology. St. Petersburg, Russian Academy of Sciences, 2004, no. 5, pp. 141-161.

Crumlin-Pedersen O. Archaeology and the Sea in Scandinavia and Britain: A Personal Account. Maritime Culture of the North 3. Roskilde, Viking Ship Museum, 2010, 184 p.

De Lisle N., Königsfeld T. Extract de Voyage un Sibirie M. DeLisle \& Journal de M. Königsfeld en 1740. Francois Antoine (1768), Histoire générale des voyages, voyage de Sibiria. Paris, Chez Didot, pp. 525-527.

61 McPhee J. The Survival of the Bark Canoe. New York, 1975. 
Forsyth J. History of the Peoples of Siberia: Russian's Northern Asian Colony 1581-1990. Cambridge, Cambridge University Press, 1994, 445 p.

Foss M.E. Kul'turnye sviazi severa Vostochnoi Evropy vo II tysiacheletii do nashei ehry. Sovetskaia Etnografiia, 1948, vol. 4, pp. 23-35.

Georgi G. J. Beschreibung aller Nationen des Russischen Reichs (Dscription of all Nations of the Russian Empire). St. Petersburg, C. W. Müller, 1776, 530 p.

Golden H. Kayaks of Alaska. White Horse Grocery Press, 2015, 560 p.

Golovnev A. V. Wars and Chiefs Among the Samoyeds and Ugrians of Western Siberia. Hunter-Gatherers in the Modern World: Conflict, Resistance, and Self-Determination. Eds P.P. Schweitzer, M. Biesele, R. K. Hitchcock. New York, Oxford, Bergham Books, 2000, pp. 125-149.

Haviland M. D. A Summer on the Yenisey. London, Ayer Publishing, 1971, 328 pp.

Hornell J. Water Transport: Origins and Early Evolution. Newton Abbot, David \& Charles, 1970, 377 pp.

Itkonen T. I. Suomen Ruuhet: 1-, 2-, 3-Ja Monipuiset Sekä Lautaruuhet Kivikaudesta Vuoteen 1940. Forssa, Kansantieteellinen Arkisto, 1942, 172 p.

Ides E. Y. Three Years Travel over Land from Moscow to China. Ed. by N. Witsen. London, W. Freeman, 1706, $210 \mathrm{p}$.

Jennings J. The Art and Obsession of Tappan Adney. Toronto, Firefly Books, 2004, 152 p.

Johnstone P. The Seacraft of Prehistory. Ed. by Sean McGrail. Cambridge, Harvard University Press, 1980, $260 \mathrm{p}$.

Kankaanpää J. Kajakki. Typologinen Ja Etnohistoriallinen Tutkielma (The Kayak: A Study in Typology and Ethnohistory). Master's thesis, University of Helsinki. Helsingin Yliopiston Kansatieteen Laitoksen Tutkimuksia 15, 1989, $72 \mathrm{p}$.

Klingstädt T. M. Historische Nachricht von den Samojeden und den Lapplä̈dern. St. Petersburg, Hartknoch, $1769,72 \mathrm{p}$.

Lindberg M. The Byslätt Bronze Age Boat: A Swedish Bark Canoe. Master's thesis, Marine Archaeology Programme, University of Southern Denmark, 2012.

Luukkanen H. On the Diffusion of Bark Canoes, Skin Boats and Expanded Log Boats in the Eurasian North. A Circumpolar Reappraisal: The Legacy of Gutorm Gjessing (1906-1979). Ed. by Ch. Westerdahl. BAR International Series 2154. Oxford, Archaeopress, 2010, pp. 189-217.

Martinière P. M. de la. A New Voyage to the North. London, T. Hodgson and A. Barker, 1706, 153 p.

Mason O., Meriden S.H. 1901. Pointed Bark Canoes of the Kutenai and Amur. Report of the U. S. National Museum for 1899, Washington, DC, Government Printing Office, 1706, pp. 525-537.

McGrail S. Ancient Boats in North-West Europe: The Archaeology of Water Transport to AD 1500. New York, Addison Wesley Longman, 1998, $324 \mathrm{p}$.

McPhee J. The Survival of the Bark Canoe. New York, Farrar, Strauss and Giroux, 1975, 160 p.

Mulk I-M., Bayliss-Smith T. The Representation of Sámi Cultural Identity in the Cultural Landscapes of Northern Sweden: the Use and Misuse of Archaeological Evidence. The Archaeology and Anthropology of Landscape. Eds P. J. Ucko, J. Layton. London, Routledge, 1998, pp. 358-396.

Nishimura Sh. A Study of Ancient Ships of Japan. Part 4: Skin Boats. Tokyo, Society of Naval Architects, 1931, $249 \mathrm{p}$.

Ohtsuka K. Iiaomanochip: Reviving of Boat-Building and Trading Tradition. Ainu: Spirit World of a Northern People. Eds W.W.Fitzhugh, C.Dubreuil. Washington D.C., Arctic Studies Center, Smithsonian Institution, 1999, p. 374-380.

Pelikh G. I. Proiskhozhdenie selkupov. Tomsk, Tomsk State University Press, 1972. 424 p. (In Russian)

Popov A.A. The Nganasans. The Peoples of Siberia. Eds M. G. Levin, L.P. Potapov. Transl. by E. Dunn. Chicago, University of Chicago Press, 1964, pp. 571-586.

Ritzenthaler R. E. The Building of a Chippewa Indian Birch-Bark Canoe. Bulletin of the Public Museum of the City of Milwaukee, no. 19(2), 1950, pp.59-98.

Rousellot J.-L. Watercraft in the North Pacific: A Comparative View. Anthropology of the North Pacific Rim. Eds W. Fitzhugh, V. Chaussonnet. Washington, D. C., Smithsonian Institution Press, 1994, pp. 243-258.

Rowley-Conwy P. To the Upper Lake: Star Carr Revisited - by Birchbark Canoe. Economic Zooarchaeology: Studies in Hunting, Herding, and Early Agriculture. Eds P. Rowley-Conwy, D. Serjeantson, P. Halstead. Chapter 23. Oxford, Oxbow Books, 2017, pp. 197-207.

Rudenko S.I. Early Harpoon Heads of the Asiatic Eskimo. Sovietskaia Etnografiia. Moscow, Izdatel'stvo Akademii nauk SSSR, 1947, vol. 2, pp. 33-56.

Schrenk L. Reisen und Forschungen im Amur-Lande. Bd.3: Die Völker des Amur-Landes. St. Petersburg, Russian Academy of Science, 1881, 310 p. 
Sieroszewski W. The Yakut: An Experiment in Ethnographic Research. The Economic Bases of the Way of Life. Moscow, Nauka, 1993, 713 p.

Simchenko Y. B. Nganasans. Materialy k Serii "Narody i Kul'tury. Vol. XXIII. 1976, pp. 35-37. (In Russian)

Simchenko Y. B. The Culture of Reindeer Hunters of Northern Eurasia. Moscow, Nauka, 1976.

Sinor D. On Water-Transport in Central Eurasia. Ural-Altaische Jahrbücher, 1961, no. 33, pp. 156-179.

Sokolova Z. P. The Mansi. Moscow, Nauka, 1983, 322 p. (In Russian)

Starcev G. Die Ostjaken: Sozial-Ethnographische Skizze. Aus dem Russischen Übertragen von K. OestreichGeib. Transl. by K. Oestreich-Geib. München, Veröffentlichungen der Congregatio Ob-Ugrica, 1988, $103 \mathrm{~S}$.

Tambets K. et al. The Western and Eastern Roots of the Saami-The Story of Genetic 'Outliers' Told by Mitochondrial DNA and Y Chromosomes. American Journal of Human Genetics, 2004, vol. 74, iss. 4, pp. 661-682.

Trebitsch R. Fellboote und Schwimsäcke und Ihre Geographische Verbreitung in der Vergangenheit und Gegenwart. Archiv für Anthropologie. Neue Folge, Bd. XI., Braunschweig, Friendrich Vieweg \& Sohn, 1912, pp. 61-84.

Troyanovskiy S. V., Petrov M.I. The XI Century Boat from Novgorod. Soviet Archaeology, 1969, vol.2, pp. 1-7.

Vermeulen H. S. Ethnography and Empire. G. F. Müller and the Description of Siberian Peoples. Before Boas. The Genesis of Ethnography and Ethnology in the German Enlightenment. Ed. by Han F. Vermeulen, Lincoln and London, University of Nebraska Press, 2016, pp. 131-218.

Westerdahl Ch. Sewn Boats of the North: A Preliminary Catalogue with Introductory Comments. Part I. International Journal of Nautical Archaeology and Underwater Exploration, 1985, no. 14(1), pp.33-62.

Westerdahl Ch. Sewn Boats of the North: A Preliminary Catalogue with Introductory Comments. Part II. International Journal of Nautical Archaeology and Underwater Exploration, 1985, no. 14(2), pp.119142.

Whitaker I. The Scottish Kayaks Reconsidered. Antiquity, 1977, vol.51(201), pp. 41-45.

Статья поступила в редакцию 1 июня 2018 г. Рекомендована в печать 12 марта 2019 г.

Received: June 1, 2018

Accepted: March 12, 2019 


\title{
Aleut Mortuary Practices. Re-Interpretation of Established Aleut Burial Customs
}

\author{
B. Frohlich, D. R. Hunt, J. Birna
}

For citation: Frohlich B., Hunt D.R., Birna J. Aleut Mortuary Practices. Re-Interpretation of Established Aleut Burial Customs. Vestnik of Saint Petersburg University. History, 2019, vol. 64, issue 2, pp. 499-524. https://doi.org/10.21638/11701/spbu02.2019.207

The Unangan/Aleut people have lived in the Aleutian Islands for more than 9,000 years. About 250 years ago this unique and successful balance between nature and man was disturbed to such a degree, that the Unangan people almost became extinct. Russian fur hunters and traders (promyshlenniks) killed, annihilated, raped, introduced new diseases (leprosy, smallpox, syphilis and consumption (tuberculosis)), and forcefully displaced Unangan people for the purpose of promoting their fur business. This resulted in major declines in the Unangan population size. It is estimated that an original population of more than 15,000 people in 1741 (time of arrival of Russians in the Aleutian Islands) to less than 2000 in 1800 . This drastic reduction in the population size and increasing Russian control did not result in a thoroughly eradication of the Unangans' culture and spiritual belief. Also, it is doubtful that the Russian Orthodox Church had much control over the Unangans' spiritual activities, as previously suggested by the church's records. Our research, based on the historical record, archaeological excavations and particularly on the reconstruction of the traditional mortuary practices, strongly support our present hypothesis that the Unangans' devotion to their

Bruno Frohlich - M.S., PhD in Biological Anthropology, Visiting Professor, Dartmouth College, Hanover, New Hampshire, 03765, USA, and Research Associate, National Museum of Natural History, Smithsonian Institution, $10^{\text {th }}$ St. Constitution Ave., NW, Washington D.C., 20013-7012, USA; FROHLICH@si.edu

Бруно Фролик - магистр, д-р философии (физическая антропология), приглашенный професcop, Дартмутский колледж, США, Нью-Хэмпшир, Гановер, 03765; научный сотрудник, Национальный музей естественной истории, Смитсоновский институт, США, Округ Колумбия, Вашингтон, 20013-7012, 10-я ул. и пр. Конституции; FROHLICH@si.edu

David R. Hunt - M.A., PhD in Biological/Forensic Anthropology, Collection Manager, National Museum of Natural History, Smithsonian Institution, $10^{\text {th }}$ St. Constitution Ave., NW, Washington DC, 20013-7012, USA; HuntD@si.edu

Дэвид Р. Хант - магистр, д-р философии (физическая антропология и судебная медицинская экспертиза), куратор коллекций отдела антропологии Национального музея естественной истории, Смитсоновский институт, США, Округ Колумбия, Вашингтон, 20013-7012, 10-я ул. и пр. Конституции; HuntD@si.edu

Jonsdottir Birna - M. A., MD in Radiology; Domus Medica, Egilsgata, 3, 101, Reykjavik; Iceland; birna@rd.is

Йонсдоттер Бирна - магистр, д-р медицины (радиология), Датский центр медицинских исследований, Исландия, Рейкьявик, 101, Медика Игилсгата, 3; birna@rd.is.

This publication has respectfully been dedicated to the late Professor William S. Laughlin, and to the great people of Nikolski, the Aleutian Islands.

Авторы с благодарностью посвящают данную работу светлой памяти профессора Уильяма С. Лафлина и замечательным жителям села Никольское и Алеутских островов.

(C) Санкт-Петербургский государственный университет, 2019 
traditional spirituality was well established and operational at any given time, including: - after the arrival of the promyshlenniks (1741), - after the establishment of the Russian American Company (1799), - after the introduction of the Russian Orthodox Church (ca. 1800), - after the sale of Russian America to the USA in 1867, - and most likely well into the $20 \mathrm{t}^{\mathrm{h}}$ century.

Keywords: Aleutian Islands, mortuary practices, spirituality, mummification, reconstruction, Chaluka.

\section{Алеутские погребальные практики:}

\section{переосмысление сложившейся алеутской погребальной обрядности}

\section{Б. Фролек, Д. Р. Хант, Й. Бирна}

Для цитирования: Frohlich B., Hunt D. R., Birna J. Aleut Mortuary Practices. Re-Interpretation of Established Aleut Burial Customs // Вестник Санкт-Петербургского университета. История. 2019. Т. 64. Вып. 2. С.499-524. https://doi.org/10.21638/11701/spbu02.2019.207

Коренное население Алеутских островов (народ унанган, более известный как алеуты) на своих территориях проживало на протяжении более 9000 лет. Около 250 лет назад этот уникальный баланс между природой и человеком оказался в значительной степени нарушен, в результате чего коренные обитатели островов практически исчезли. Численность унанганского населения резко сократилась в результате недружественной деятельности российских промышленников (убийства, насилие, распространение инфекционных заболеваний, таких как оспа, проказа, сифилис, туберкулез) и насильственного переселения алеутов с целью повышения эффективности и доходности пушного промысла. Считается, что население островов, составлявшее на момент прихода русских в 1741 г. около 15000 человек, к 1800 г. насчитывало менее двух тысяч. Резкое сокращение численности народонаселения и управление различными сторонами его жизни, осуществлявшееся российской администрацией, все же не привели к полному уничтожению культуры унанганов и особенностей их духовной жизни. Русская Православная церковь осуществляла христианизацию местного населения, однако имеются сомнения в том, что воздействие этого процесса на духовность унанганов было существенным (в то же время, подобные утверждения встречаются в церковных архивах). Выводы нашего исследования, основанные на исторических данных, результатах археологических раскопок, и, в особенности, на реконструкции погребальной обрядности, подтверждают ранее высказанную авторами гипотезу о том, что приверженность унанганцев их традиционной духовности была хорошо выражена и последовательно практиковалась во все времена на протяжении последних 250 лет - после прихода промышленников (1741), после создания Русско-Американской Компании (1799), после появления русской православной миссии (около 1800) и после продажи Русской Америки Североамериканским Соединенным Штатам в 1867 г. Скорее всего, традиция не прекращалась и в ХХ столетии.

Ключевые слова: Алеутские острова, погребальный обряд, духовность, мумификация, реконструкция, Чалука.

\section{Introduction}

The Unangan/Aleut people have lived in the Aleutian Islands for more than 9,000 years. About 250 years ago, this unique balance between nature and man was disturbed to such a degree that the Unangan people were almost annihilated. The Russian 
conquest of the Aleutian Islands and other geographical areas in what we today know as the State of Alaska was powered by relentless greed and demand for fur products. In less than 60 years the uncontrolled activities of promyshlenniks (fur hunters) resulted in an eighty-five percent reduction of the Unangan population. Additionally, the delicate ecological balance between man and his environment was severely disturbed by the excessive overexploitation of marine mammals.

Russian records, including those of Ivan Veniaminov ${ }^{1}$, tend to emphasize the success of Russian political, physical, cultural, social and spiritual power resulting in an almost complete conversion of the Unangan people to Russian traditions. Until recently it has been unclear how effective the Russians and later the Americans were in converting the Unangan people from their traditional way of living and especially in making them abolish their traditional spirituality. Needless to say that little is found in the ethnographic records, which for the most part derives from Russian hunters, administrators and clergy. Granted, a rich and wonderful amount of information is found in many sources including those of Ivan Veniaminov ${ }^{2}$ and George Steller ${ }^{3}$ (1793), but all tend to ignore the possibility that the Russians did not have full control over the Unangan people 4 .

The archaeological record is helping us to understand the historical record and the extent to which such records can be trusted. Burial records are especially important. Without burial records we significantly limit our ability to reconstruct historical and pre-historical events.

Our work on burial practices is based on the study of existing records, as well as on modern research on human remains still in our collections (as of 2002).

We use only nondestructive and noninvasive methods. Thus, technologies such as $\mathrm{x}$-ray, photography, and computed tomography (CT) are used to explore and study the remains. If tissue sampling is required and permitted, CT scanning allows directed removal of minute samples for analytical purposes.

Our data, interpretations, and results have been combined with records from archaeological surveys, excavations and the ethnographical record. Not only does combining all available resources allow us to obtain a much better understanding of Unangan burial practices, but it also enables to evaluate the various records in terms of accuracy.

We hypothesize that Unangan traditions and spirituality continued long after the arrival of the Russians in 1741 and the Americans in 1867. Indeed, traditional Unangan burial practices and the practice of Unangan spirituality most likely continued well into the $20^{\text {th }}$ century. It was not significantly replaced by Russian and American traditions and culture until more efficient travel and communication procedures became available with the arrival of fossil fueled ships, radio communication, organized education, and with easier opportunities for the Unangan people to travel and communicate with the "outside world".

1 Veniaminov I. Notes on the Islands of the Unalaska Division. 80, vol. 3. St. Petersburg. 1840. (cited by: Hrdlicka A. The Aleutian and Commander Islands and their Inhabitants. The Wistar Institute of Anatomy and Biology. Philadelphia, 1945. Reprinted by the Limestone Press, 1984).

2 Veniaminov I. Notes on the Islands of the Unalaska Division.

3 Steller George W. Reise von Kamtschatka nach Amerika mit dem Commandeur-Kapitan Bering. St. Petersburg, 1793. (cited by: Jochelson W. History, Ethnology and Anthropology of the Aleut. The Carnegie Institution Washington. Washington, 1933. P. 18).

${ }^{4}$ Berreman G.D. Aleut Shamanism in the twentieth Century? An Assessment of Evidence // To the Aleutian and Beyond. The Anthropology of William S. Laughlin / eds B. Frohlich, A. B. Harper, R. Gilberg. Copenhagen, 2002. P. 25-50. (Publications of The National Museum. Ethnographical Series, Vol. 20). 


\section{Unangan Mortuary Practices}

The very sparse knowledge available today about Unangan mortuary practices is based on recorded observation by Russian explorers, hunters (promyshlenniks), administrators and clergy men, a few late $19^{\text {th }}$ - and early $20^{\text {th }}$ - century excavations, and the more recent collection of burial artifacts and human remains from settlement excavations, caves and rock shelters ${ }^{5}$.

Much of the records describe burials, probably less than 1,000 years old. Unfortunately little is known about the first approximately 8,000 years of Unangan burial practices. This is a product of logistic problems in identifying ancient burials, which for years have been exposed to a very austere environment.

\section{Excavations and Collections. 1870-1945}

Unangan mortuary practices have been studied by many scholars. Alfonse L. Pinart $(1872)^{6}$ explored caves in the Shumagin island group and on Amoknak Island, Unalaska ${ }^{7}$. William Dall, during a geographical and hydrographic survey of the Aleutian Islands between 1871 and 1873, located several settlement sites and burial caves on

${ }^{5}$ Aigner J.S., Veltre D. W. The Distribution and Pattern of Umqan Burial on Southwest Umnak Island // Arctic Anthropology. Vol.XIII (2). 1976. P.113-127; Aigner J. S., Veltre D. W., Fullem B., Veltre M. An Infant Umqan Burial from Southwest Umnak Island // Arctic Anthropology. Vol. XIII (2). 1976. P. 128-131; Cook J. A Voyage to the Pacific Ocean Undertaken, by the Command of His Majesty, for making Discoveries in the Northern Hemisphere. G. Nicol, Bookseller to His Majesty, in the Strand; and T. Cadell, in the Strand, London, 1785. P.519; Coxe W. Account of the Russian Discoveries Between Asia and America to Which Are Added the Conquest of Siberia and the History of the Transactions and Commerce Between Russia and China. $4^{\text {th }}$ enl. London, 1780. P. 154-155, 173; Dall W.: 1) Notes on the Pre-Historic Remains in the Aleutian Islands // Proceedings of the California Academy of Sciences IV (1868-1872). San Francisco, 1873. P. 284-286; 2) On Succession in the Shell-Heaps of the Aleutian Islands // Contributions to North American Ethnology. Washington, 1877. P. 62-71, 84; 3) On the Remains of Later Pre-Historic Man obtained from Caves in the Catherina Archipelago, Alaska Territory, and especially from the Caves of the Aleutian Islands. Smithsonian Institution. Washington City, 1878. P. 5-8; Hrdlička A.: 1) Exploration of Mummy Caves in the Aleutian Islands. Part I. Previous Knowledge of such Caves. Vol. 52. January. 1941. P. 5-23; 2) Exploration of Mummy Caves in the Aleutian Islands. Part II. Further Exploration. Vol.52. January 1941. P. 113-130; 3) The Aleutian and Commander Islands and their Inhabitants. The Wistar Institute of Anatomy and Biology. Philadelphia, 1945. P.178-194; Jochelson W. Archaeological Investigations in the Aleutian Islands. The Carnegie Institution of Washington. Washington, 1925. P.44-52; Laughlin W.: 1) Aleuts: Survivors of the Bering Land Bridge. Holt, Rinehart and Winston. New York, 1980. P. 89, 96-103; 2) Aleut Mummies: Their Significance for Longevity and Culture // Cultures of the Bering Sea Region: Papers from an International Symposium. IREX, New York, 1983. P. 41-44; Laughlin W., Gordon H. The Lamellar Flake Manufacturing Site on Anangula Island in the Aleutians // American Antiquity. 1954. Vol. XX (1). P.28-29; McCartney A. Prehistory of the Aleutian Region // Arctic. Handbook of North American Indians. Vol. V. Washington, 1984. P. 131; Sarychev G. Account of a Voyage of Discovery to the North-East of Siberia, the Frozen Ocean, and the North-East Sea. London, 1807. P.77-78; Sauer M. An Account of a Geographical and Astronomical Expedition to the Northern Parts of Russia for Ascertaining the Degrees of Latitude and Longitude of the Mouth of the River Kovima; of the whole coast of the Tshutski, to East Cape; and of the Islands in the Eastern Ocean, stretching to the American Coast. London, 1802. P.161; Veniaminov I. Notes on the Islands of the Unalaska Division; Weyer E. M.: 1) An Aleutian Burial // Anthropological Papers of the American Museum of Natural History XXXI(III). The American Museum of Natural History/ New York City, 1929. P.228238; 2) Archaeological material from the village site at Hot Springs, Port Moller, Alaska // Anthropological Papers of the American Museum of Natural History of Natural History, XXXI(IV). The American Museum of Natural History. New York City, 1930. P.260-263.

${ }^{6}$ Pinart A. Catalogue des collections rapporte de Exposees dans le Museed' Histoire. Paris, 1872.

7 Hrdlička A.: 1) Exploration of Mummy Caves in the Aleutian Islands. Part I. Previous Knowledge of such Caves. Original Explorations. The Scientific Monthly, vol.52. January 1941. P. 8-9; 2) The Aleutian 
Unalaska, Atka, Adak, Amchitka and Attu islands and in 1874 secured the accession of 12 bundles of human mummified remains from the Warm Cave on Kagamil Island ${ }^{8}$. The mummies were collected by Captain E. Hennig of the Alaska Commercial Company in 18749. Between January 1909 and June 1910 Waldemar Jochelson excavated 13 ancient village sites and five caves on Attu, Atka, Umnak and Unalaska islands ${ }^{10}$. Aleš Hrdlička ${ }^{11}$ completed three expeditions to the Aleutian and Commander islands. In 1936, Hrdlička surveyed and excavated settlement sites and burials on Amoknak Island (Unalaska Island), Atka, Kiska, and Kagamil islands. The following year (1937) Hrdlička continued his work on Unalaska Island (Cernovski, Split Rock, Veselov [Wislow Island], Kashega Bay [Split Rock Island], and Amoknak Island); Umnak Island (Chaluka); Atka Island (Nazan Bay); Amlia Island; Adak Island (Bay of Waterfall, Bay of Islands); Attu Island (Chichagof Harbor); Agatu Island (McDonald Bay); Tanaga and Ilak islands (caves); and Ship Rock Island (rock shelters). Hrdlička's last expedition to the Aleutian Islands took place in 1938. Hrdlička and his team, which included William Laughlin, visited Unalaska (Amoknak Island, Cernovski, Kashega Island); Ship Rock Island; Umnak Island (eastern coast survey, excavating Chaluka/Nikolski); Amlia Island; Kanaga Island (Kanaga Harbor); Ilak Island; Amchitka Island (Constantine Harbor); and Kagamil Island (Fig. 1).

\section{5 to Present (2002)}

The post WWII period did not see excavation of burial grounds in the same magnitude as those carried out by Dall, Jochelson and Hrdlička. As early as 1948, William Laughlin, on the US Coast Guard Cutter 'Northland', visited the Warm Cave on Kagamil Island, but found it 'empty'12; apparently Hrdlička had done a complete 'excavation' a few years earlier (in 1938). Later, between 1973 and 1975, William Laughlin and his students excavated a few burials on Chaluka (Nikolski) and on Anangula Island, and Aigner and Veltre $^{13}$ (1976) excavated two Umqan burial structures on the southern part of Umnak Island.

and Commander Islands and their Inhabitants. The Wistar Institute of Anatomy and Biology. Philadelphia, 1945. P. 403; Jochelson W. Archaeological Investigations in the Aleutian Islands. Washington, 1925. P. 21.

${ }^{8}$ Hrdlička A. Exploration of Mummy Caves in the Aleutian Islands. Part I; Hunt D. Aleutian Remains at the Smithsonian Institution // To the Aleutian and Beyond. The Anthropology of William S.Laughlin / eds B. Frohlich, A. B.Harper, R. Gilberg. Copenhagen, 2002. P.139-140. (Publications of The National Museum. Ethnographical Series, Vol.20).

${ }^{9}$ Dall W. On the Remains of Later Pre-Historic Man obtained from Caves in the Catherina Archipelago, Alaska Territory, and especially from the Caves of the Aleutian Islands. Washington, 1878; Hrdlička A.: 1) Exploration of Mummy Caves in the Aleutian Islands. P. 9; 2) The Aleutian and Commander Islands and their Inhabitants. P. 186, 414-415; Jochelson W. Archaeological Investigations in the Aleutian Islands. The Carnegie Institution of Washington. P. 44-45; Laughlin W. Aleuts: Survivors of the Bering Land Bridge. New York, 1980. P. 99-101.

10 Jochelson W.: 1) Archaeological Investigations in the Aleutian Islands; 2) History, Ethnology and Anthropology of the Aleut. The Carnegie Institution Washington, Washington, 1933; Korsun S.A., Taksami N. Ch., Ushakov N. V. Treasures of the Kunstkamera. Aleuts: How they were seen by V. Iokhel'son. Photo-Laboratory. St. Petersburg, 2001.

11 Hrdlička A. The Aleutian and Commander Islands and their Inhabitants.

12 Thomas C. W. Ice is where you find it. Bloomington, 1951.

13 Aigner J. S., Veltre D. W. The Distribution and Pattern of Umqan Burial on Southwest Umnak Island. P. 113-127. 


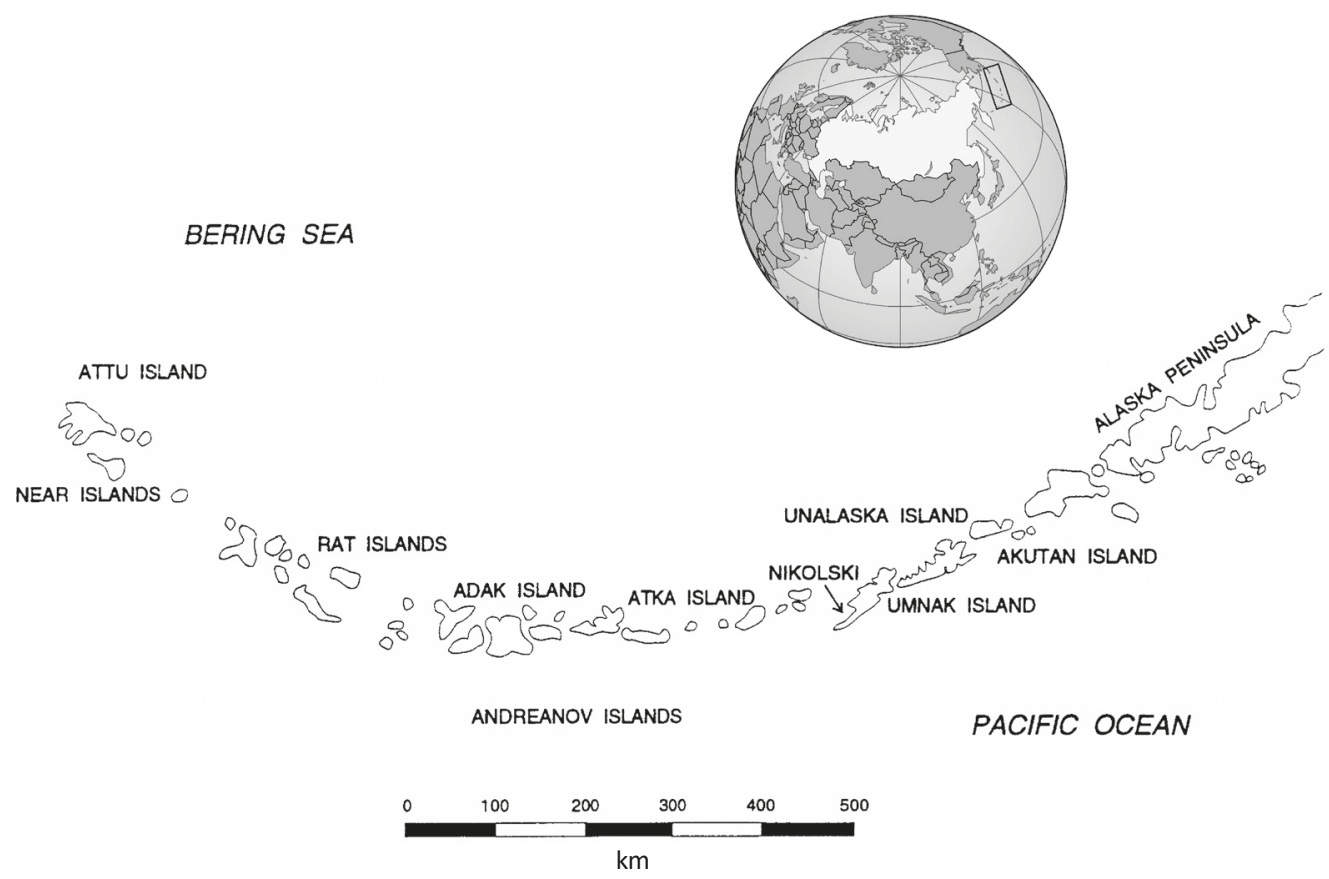

Fig. 1. Aleutian Islands, Alaska. The island chain stretches for about 1,500 km (950 miles) from Port Moller on the Alaska Peninsula to Cape Wrangell on the western end of Attu Island (after [Frohlich et al., 2002, p. 90])

Around 1950, the focus of research shifted from the collection of human remains to the analysis of collections including human remains and what such information could teach us about the Unangan people.

Such analyses have strongly supported the figures of an original Unangan population of about 16,000 people, with a temporal continuity of about 9,000 years ${ }^{14}$. Similarly, the uniqueness of the Unangan people and the importance of such data in the interpretation of population movements/migrations, adaptation, demography, paleopathology and much more, is attested in many publications, including: Harper and Laughlin ${ }^{15}$; Harper ${ }^{16}$;

${ }^{14}$ Dumond D.E., Knecht R. An Early Blade Site in the Eastern Aleutians // University of Oregon Anthropological Papers. 2001. Vol. 58. P.9-34; Harper A. B.: 1) Secular Change and Isolate Divergence in the Aleutian Population System. Ph.D dissertation. University of Connecticut. Storrs, 1975; 2) Life Expectancy and Population Adaptation: The Aleut Centenarian Approach // The First Americans: Origins, Affinities, and Adaptations. New York, 1979. P.309-337; Knecht R.A., Davis R. S. A Prehistoric Sequence for the Eastern Aleutians // University of Oregon Anthropological Papers. 2001. Vol.58. P.269-288; Knecht R. A., Davis R. S., Carver G. A. The Margaret Bay Site and Eastern Aleutian Prehistory // University of Oregon Anthropological Papers. 2001. Vol.58. P.269-288; Laughlin W. S.: 1) Ecology and Population Structure in the Arctic // The Structure of Human Populations. Oxford, 1972; 2) Aleuts, Ecosystem, Holocene History and Siberian Origin // Science. 1975. Vol. 189 (4202). P. 507-515; 3) Aleuts: Survivors of the Bering Land Bridge.

15 Harper A. B., Laughlin W.S. Inquiries into the Peopling of the New World: Development of Ideas and Recent Advances // A History of American Physical Anthropology, 1930-1980. New York, 1982. P.281304.

16 Harper A. B., Laughlin W.S. Anthropologist's Anthropologist, 1919-2001// To the Aleutian and Beyond. The Anthropology of William S. Laughlin / eds B. Frohlich, A. B. Harper, R. Gilberg. Copenhagen, 2002. P.7-23. (Publications of The National Museum. Ethnographical Series, Vol. 20). 
Frohlich and Pedersen ${ }^{17}$; Frohlich, Harper and Gilberg ${ }^{18}$; Laughlin $^{19}$; Laughlin and Harp$\mathrm{er}^{20}$; Harper and Laughlin ${ }^{21}$; Laughlin and Jørgensen ${ }^{22}$; Laughlin et al. ${ }^{23}$; Turner ${ }^{24}$ and Zimmerman ${ }^{25}$.

\section{Ethnographic Data. A Review}

The Unangans' attitude toward the dead is based on respect rather than fear ${ }^{26}$. The Unangans preserved all deceased members of their communities from new-born to elderly and of both $\operatorname{sexes}^{27}$. This importance of preserving every individual meant that bodies were buried in their clothing and encased in wrappings of animal tissues and woven matting to keep the remains protected ${ }^{28}$. Cave and rock shelter burials, like those found on Ship Rock Island, contained naked adult bodies of both sexes wrapped in gut robes ${ }^{29}$. Deceased babies and infants wore their bird skin caps, a tradition most often observed in infant burials in mummy caves of the Islands of Four Mountains ${ }^{30}$. Whole kayaks, paddles, and related hunting equipment were included in the burials of 'kayak hunters' ${ }^{31}$.

17 Frohlich B., Pedersen P.O. Secular Changes Within Arctic and Sub-Arctic Populations: A Study of 632 Mandibles from The Aleutian Islands, Alaska and Greenland // Arctic Medical Research. 1992. Vol.51. P. $173-188$.

18 To the Aleutian and Beyond. The Anthropology of William S. Laughlin. Publications of The National Museum. Ethnographical Series. Eds B. Frohlich, A. B. Harper and R. Gilberg. Vol. 20. Copenhagen, 2002.

${ }^{19}$ Laughlin W.S.: 1) Human Migration and Permanent Occupation in the Bering Sea Area // The Bering Land Bridge. Stanford, 1967; 2) Holocene History of Nikolski Bay; Eskimo and Aleut Evolution // Folk. 1974/1975. Vol. 16-17; 3) Aleuts, Ecosystem, Holocene History and Siberian Origin // Science. 1975. Vol. 189(4202). P. 507-515; 4) Holocene History of Nikolski Bay, Alaska, and Aleut Evolution // Beringia in Cenozoic. Vladivostok, 1976. P.492-508; 5) Aleuts: Survivors of the Bering Land Bridge; 6) Aleut Mummies: Their Significance for Longevity and Culture // Cultures of the Bering Sea Region: Papers from an International Symposium. New York, 1983.

20 The First Americans: Origins, Affinities, and Adaptation. Eds W. S. Laughlin, A. B. Harper. New York, 1979.

${ }^{21}$ Harper A. B., Laughlin W. S. Inquiries into the Peopling of the New World: Development of Ideas and Recent Advances, 1982. P.281-304.

${ }^{22}$ Laughlin W. S., Jørgensen J. B. Isolate Variation in Greenlandic Eskimo Crania // Acta Genetica et Statistica Medica. 1956. Vol.6.

${ }^{23}$ Laughlin W. S., Jørgensen J. B., Frohlich B. Aleuts and Eskimos: Survivors of the Bering Land Bridge // The First Americans: Origins, Affinities, and Adaptation. New York, 1979.

24 Turner C. G. 1) The First Americans: The Dental Evidence // National Geographic Research. 1986. Vol.2(1). P. 37-46; 2) The Dentition of Arctic peoples. New York, 1991.

${ }^{25}$ Zimmermann M.R. Alaskan and Aleutian Mummies // Mummies, Disease, and Ancient Cultures. Cambridge, 1998. P. 138-253.

${ }^{26}$ Jochelson W. Archaeological Investigations in the Aleutian Islands. P. 41-42.

27 Laughlin W. S. Aleut Mummies: Their Significance for Longevity and Culture. P. 41.

${ }^{28}$ Sauer M. An Account of a Geographical and Astronomical Expedition to the Northern Parts of Russia for Ascertaining the Degrees of Latitude and Longitude of the Mouth of the River Kovima; of the whole coast of the Tshutski, to East Cape; and of the Islands in the Eastern Ocean, stretching to the American Coast. London, 1802. P. 161; Hrdlička A. Exploration of Mummy Caves in the Aleutian Islands. P. 129.

${ }^{29}$ Hrdlička A. The Aleutian and Commander Islands and their Inhabitants. P. 417.

30 Ibid. P. 80, 420, 422, 471.

31 Dall W. H.: 1) Notes on the Pre-Historic Remains in the Aleutian Islands. P. 286; 3) On the Remains of Later Pre-Historic Man obtained from Caves in the Catherina Archipelago, Alaska Territory, and especially from the Caves of the Aleutian Islands. P. 21; Hrdlička A. 1) Exploration of Mummy Caves in the Aleutian Islands. Pt. I. P. 15; 2) Exploration of Mummy Caves in the Aleutian Islands. Pt. II. P. 129; 3) The Aleutian and Commander Islands and their Inhabitants. P. 412, 433; Sauer M. An Account of a Geographical and Astronomical Expedition to the Northern Parts of Russia for Ascertaining the Degrees of Latitude and 
The bodies were preserved so that they, over time, would be accessible for visits, offerings, and consultation. Mummification was an important religious observance aimed at preserving the spiritual life of the person, following physiological death ${ }^{32}$.

The preservation of the deceased person could take place within the household where it was prepared, kept for up to several months, and then deposited in a cave, rock shelter, or pit burial ${ }^{33}$. It has been suggested that they were placed in distant and inaccessible caves so that the body was well protected, allowing only the most courageous members of the society to visit and view the body ${ }^{34}$. However, according to Hrdlička ${ }^{35}$, some caves were easily accessible to the villages that used them.

Coxe $^{36}$ and Dall ${ }^{37}$ postulated that only wealthy and important members of the society were artificially mummified.

Dismemberment was the opposite of preservation and was supposed to release the resident power in the body so that it could not harm living Aleuts ${ }^{38}$. Dismemberment appears to have been practiced by the Unangans to some extent on non-Unangan bodies during the massacre of the Russian Medvedev's party in 1764 in Nikolski ${ }^{39}$. More recently, a Nikolski Unangan named Iliodor Sokolnikoff dismembered a man who had attacked him while he was building a baidarki (Aleut kayak). The dismemberment was not carried out in anger but strictly for the purpose of protecting oneself from the malevolent power that otherwise would have remained in the body of the slain enemy ${ }^{40}$.

Additional information can be found in Aleš Hrdlička ${ }^{41}$ publication: The Aleutians and Commander Islands, William Laughlin's ${ }^{42}$ publication Aleuts: Survivors of the Bering Land Bridge, and in Frohlich, Harper and Gilberg ${ }^{43}$.

Longitude of the Mouth of the River Kovima; of the whole coast of the Tshutski, to East Cape; and of the Islands in the Eastern Ocean, stretching to the American Coast. P. 161.

32 Jochelson W. Archaeological Investigations in the Aleutian Islands. The Carnegie Institution of Washington. P.41; Laughlin W. S. Aleuts: Survivors of the Bering Land Bridge. P.96-106; Laughlin W. S. Aleut Mummies: Their Significance for Longevity and Culture. P.41; Veniaminov I. Notes on the Islands of the Unalaska Division.

${ }^{33}$ Laughlin W. S. Aleut Mummies: Their Significance for Longevity and Culture. P. 42-43.

34 Weyer E.M. An Aleutian Burial // Anthropological Papers of the American Museum of Natural History. Vol. 31, Pt. 3. New York, 1929. P. 226.

${ }^{35}$ Hrdlicka A. 1) Exploration of Mummy Caves in the Aleutian Islands. Pt. I. P. 21;2) The Aleutian and Commander Islands and their Inhabitants. The Wistar Institute of Anatomy and Biology. P. 409.

${ }^{36}$ Coxe W. Account of the Russian Discoveries Between Asia and America to Which Are Added the Conquest of Siberia and the History of the Transactions and Commerce Between Russia and China. P. 173.

37 Dall W.H. On the Remains of Later Pre-Historic Man obtained from Caves in the Catherina Archipelago, Alaska Territory, and especially from the Caves of the Aleutian Islands. Smithsonian Institution. P. 5-6.

${ }^{38}$ Laughlin W. S. Aleut Mummies: Their Significance for Longevity and Culture. P. 44-46.

39 Laughlin W.S. Massacre at Chaluka // Polar Record. Vol.22, no. 138. Cambridge, 1984. P.316; Laughlin W. S., Harper A.B., Laughlin S. B. Massacre: Fate of the Medvedev Promyshlenniks in an Aleut Village, 1764 AD. Paper presented at the $55^{\text {th }}$ Annual Meeting, Society for American Archaeologist, 1990.

40 Laughlin W. S. Aleut Mummies: Their Significance for Longevity and Culture. P. 45.

${ }^{41}$ Hrdlička A. The Aleutian and Commander Islands and their Inhabitants. The Wistar Institute of Anatomy and Biology.

42 Laughlin W. S. Aleuts: Survivors of the Bering Land Bridge.

43 To the Aleutian and Beyond. The Anthropology of William S.Laughlin. Publications of The National Museum. Ethnographical Series. Eds B. Frohlich, A. Harper, R. Gilberg. Vol. 20. Danish National Museum. Copenhagen, 2002. 


\section{Burial Types. A Review}

Unangan burial practices fall into three main categories: (1) cave and rock-shelter burials, (2) house burials and charnel houses, and (3) pit burials. All three categories yield various sub-categories displaying a diversity of methods and procedures presumably related to the individual's function and social status within the Unangan community, the number of surviving relatives, the availability of suitable burial locations, and the interaction between the spirits and the living ${ }^{44}$.

\section{Cave and Rock-Shelter Burials}

Cave and rock-shelter burials have been described ${ }^{45}$ and have, in general, been associated with the practice of artificial mummification ${ }^{46}$.

Cave and shelter burials are defined as burials where the body is placed on the ground, suspended from a wall or ceiling in a protected area, or placed in a container making it suitable to keep within the household. In some cases, the mummified body was placed in a wood frame or box and hanged from a supporting system of wood so that it could be observed easily by visitors ${ }^{47}$. In some cases, stonewalls were constructed around the body and covered with soil and turf ${ }^{48}$.

Common for all recorded shelter and cave burials is that they are located in isolated areas most often separated from settlements by a body of water (salt) and, in general, protected from the environment (Fig. 2). The accessibility was relatively easy with a nearby boat landing.

${ }^{44}$ Laughlin W. S. Personal Communication. University of Connecticut. Storrs, CT, 1992.

45 Dall W.H.: 1) Notes on the Pre-Historic Remains in the Aleutian Islands // Proceedings of the California Academy of Sciences IV (1868-1872). The California Academy of Sciences. San Francisco, 1873. P. 283-287. P. 286; 2) On the Remains of Later Pre-Historic Man obtained from Caves in the Catherina Archipelago, Alaska Territory, and especially from the Caves of the Aleutian Islands. P. 5-11; Hrdlička A. The Aleutian and Commander Islands and their Inhabitants. The Wistar Institute of Anatomy and Biology. P. 412-417; Jochelson W. Archaeological Investigations in the Aleutian Islands. The Carnegie Institution of Washington. P.45-49; Laughlin W. S.: 1) Aleuts: Survivors of the Bering Land Bridge. P. 99; 2) Aleut Mummies: Their Significance for Longevity and Culture // Cultures of the Bering Sea Region: Papers from an International Symposium. P. 43-44.

46 Dall W. H.: 1) Notes on the Pre-Historic Remains in the Aleutian Islands. P. 286; 2) On the Remains of Later Pre-Historic Man obtained from Caves in the Catherina Archipelago, Alaska Territory, and especially from the Caves of the Aleutian Islands. Smithsonian Institution. P. 6; Hrdlička A. The Aleutian and Commander Islands and their Inhabitants. The Wistar Institute of Anatomy and Biology. P. 182-195; Jochelson W. Archaeological Investigations in the Aleutian Islands. The Carnegie Institution of Washington. P. 42-45; Laughlin W. S.: 1) Aleuts: Survivors of the Bering Land Bridge. P.99-101;2) Aleut Mummies: Their Significance for Longevity and Culture. P. 42-44; Sauer M. An Account of a Geographical and Astronomical Expedition to the Northern Parts of Russia for Ascertaining the Degrees of Latitude and Longitude of the Mouth of the River Kovima; of the whole coast of the Tshutski, to East Cape; and of the Islands in the Eastern Ocean, stretching to the American Coast. P.161; Zimmermann M. R. Alaskan and Aleutian Mummies // Mummies, Disease, and Ancient Cultures. Cambridge, 1998. P. 147-152.

47 Coxe W. Account of the Russian Discoveries Between Asia and America to Which Are Added the Conquest of Siberia and the History of the Transactions and Commerce Between Russia and China. P. 154-155, 173; Laughlin W.S. Aleut Mummies: Their Significance for Longevity and Culture. P.43-44; Veniaminov I. Notes on the Islands of the Unalaska Division. P. 184.

48 Coxe W. Account of the Russian Discoveries Between Asia and America to Which Are Added the Conquest of Siberia and the History of the Transactions and Commerce Between Russia and China. P. 173; Dall W. H. On the Remains of Later Pre-Historic Man obtained from Caves in the Catherina Archipelago, Alaska Territory, and especially from the Caves of the Aleutian Islands. P. 5. 


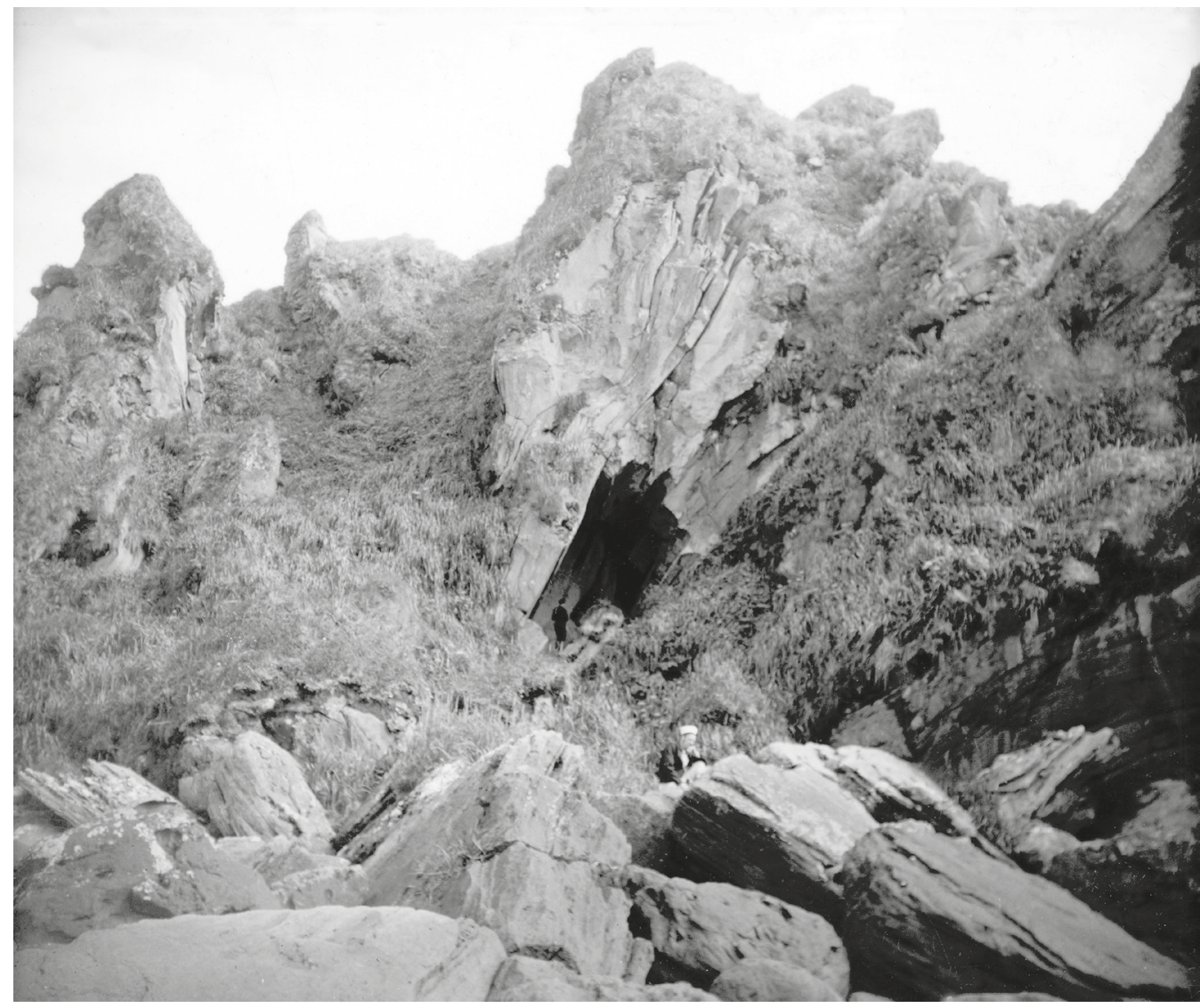

Fig. 2. The "Warm Cave" on the southwestern end of Kagamil Island in the "Islands of the Four Mountains' [Frohlich et al., 2002, p. 91]

\section{House Burials and Charnel Houses}

At times the body of a deceased person was placed within the household until a suitable and permanent resting place could be either located or constructed ${ }^{49}$. In some instances, the deceased was interred in the household dwelling (Barabara), either in a grave dug into the floor or in a covered niche within the wall structure ${ }^{50}$. At other times, an entire house was used for the disposal of deceased individuals, thus turning such structures into "charnel houses".

49 Dall W.H. On the Remains of Later Pre-Historic Man obtained from Caves in the Catherina Archipelago, Alaska Territory, and especially from the Caves of the Aleutian Islands. P. 6-7; Laughlin W. S. Aleut Mummies: Their Significance for Longevity and Culture. P. 42-43.

${ }^{50}$ Dall W. H.: 1) Notes on the Pre-Historic Remains in the Aleutian Islands. P. 284; 2) On Succession in the Shell-Heaps of then Aleutian Islands. P. 84; 3) On the Remains of Later Pre-Historic Man obtained from Caves in the Catherina Archipelago, Alaska Territory, and especially from the Caves of the Aleutian Islands. P. 7; Laughlin W.S. Aleut Mummies: Their Significance for Longevity and Culture. P. 41-42. 


\section{House Burials}

House burials have been described by Jochelson ${ }^{51}$ and may constitute a major part of the burials recovered by Hrdlička on Attu, Agattu, Umnak and Unalaska islands in 1936,1937 , and $1938^{52}$. Unfortunately, the lack of excavation records prevents us from separating these structures into house or pit burials.

\section{Pit Burials}

Pit burials have been identified outside house structures and within, or in close vicinity of a village site. Unfortunately, very few controlled and well-documented excavations have been conducted in areas where such burials are present. We do know that these burials are quite common ${ }^{53}$. For example, the occupational site at Chaluka, in present-day Nikolski, on Umnak Island, has yielded numerous burials that, in certain cases, could have been located within and outside proven house structures ${ }^{54}$.

The construction of a water line in Nikolski Village in May and June of 1974 crossed the Chaluka mound and yielded 11 burials of which none could be positively associated with known house structures. However, the fact that the Chaluka mound originally was and still is an occupational site strongly supports previous observations that some Unangan burials were located within or near houses. Such houses (barabaras) could be dwellings of living Unangan or structures constructed chiefly for the purpose of disposing of the deceased ${ }^{55}$.

Umqan burials are pit burials located behind a village, most often positioned on a hill, and are therefore often exposed to strong erosion. Umqans are unique by being located on hillsides and with man-made trenches surrounding the burial pits ${ }^{56}$ (Fig. 3).

\section{Uncommon Cases}

The variety of burials found within each of the three main categories includes a small number of unusual burials, most of them found within the Chaluka settlement (Nikolski Village $)^{57}$. For example, the following unusual cases have been reported: burials above and

${ }^{51}$ Jochelson W. Archaeological Investigations in the Aleutian Islands. P. 49-52.

52 Hrdlička A. The Aleutian and Commander Islands and their Inhabitants. The Wistar Institute of Anatomy and Biology. P. 211-402, 420-423.

53 Aigner J.S., Veltre D. W. The Distribution and Pattern of Umqan, 1976. Burial on Southwest Umnak Island // Arctic Anthropology. Vol. XIII (2). Madison, 1976. P. 127; Hrdlička A. The Aleutian and Commander Islands and their Inhabitants. The Wistar Institute of Anatomy and Biology. P.364-381, 411-412; Jochelson W. Archaeological Investigations in the Aleutian Islands. P. 49-53; Laughlin W. S. Aleut Mummies: Their Significance for Longevity and Culture. P. 41-42.

${ }^{54}$ Hrdlička A. The Aleutian and Commander Islands and their Inhabitants. The Wistar Institute of Anatomy and Biology. P.411; Jochelson W. Archaeological Investigations in the Aleutian Islands. P. 4952; Laughlin W.S. Aleut Mummies: Their Significance for Longevity and Culture. P.41-42; Weyer E. M. Archaeological material from the village site at Hot Springs, Port Moller, Alaska. Anthropological Papers of the American Museum of Natural History. Vol.31, pt. 4. The American Museum of Natural History. New York City, 1930. P.261-263..

55 Laughlin W. S. Personal Communication. University of Connecticut. Storrs, CT, 1992.

56 Frohlich, B., Laughlin S. B. Unangan Mortuary Practices and the Umqan Burials on Anangula Island, Aleutian Islands, Alaska. To the Aleutian and Beyond. P. 89-119.

57 Frohlich B. Aleut Settlement Distribution on Adak, Kagalaska and Attu Islands, Alaska. 


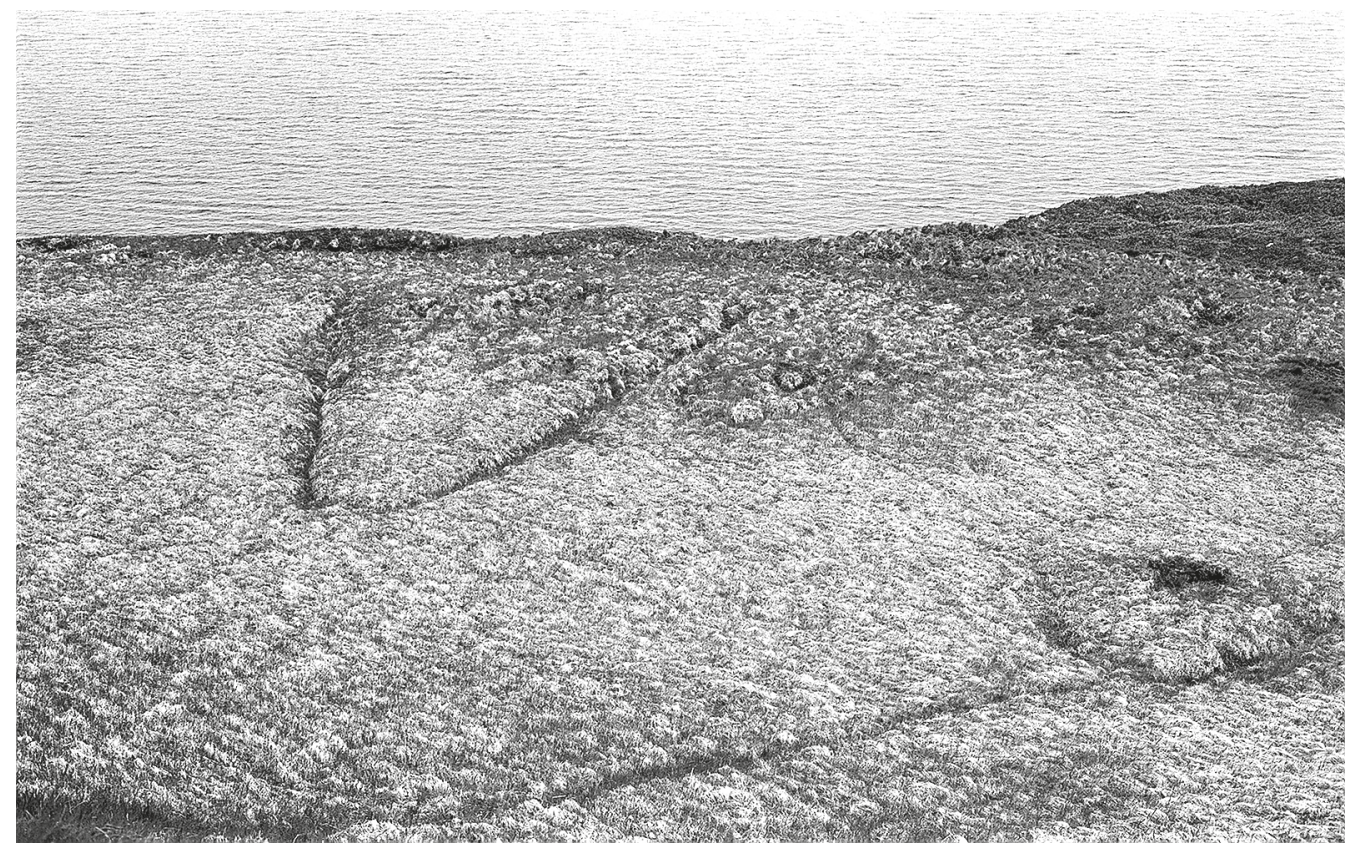

Fig. 3. "Umqan" on Anangula Island. Burials are located within the "V trench" [Frohlich et al., 2002, p. 96]

below the same whale scapula ${ }^{58}$; burials in slab-stone boxes ${ }^{59}$; burials in stone boxes (so far identified and excavated only on hills near the Chaluka mound); and the use of smaller houses for single burials, essentially a conical chamber built of logs or posts and covered with sod ${ }^{60}$. Such traditions fall within the aforementioned three main categories and attest to the great variability found within Unangan mortuary practices.

Controlled and well-documented archaeological excavations of Unangan burial structures are limited and have focused on a few Umqan excavations ${ }^{61}$.

\section{Mortuary Practices}

The purpose of studying burials is to reconstruct mortuary practices. The knowledge of mortuary practices combined with other archaeological records, such as historical and

${ }^{58}$ Hrdlička A. The Aleutian and Commander Islands and their Inhabitants. The Wistar Institute of Anatomy and Biology. P. 368.

59 Laughlin W. S. Aleut Mummies: Their Significance for Longevity and Culture. P. 42.

${ }^{60}$ Laughlin W.S.: 1) Ibid.; 2) Personal Communication. University of Connecticut. Storrs, CT, 1992.

${ }^{61}$ Aigner J.S., Veltre D.W. The Distribution and Pattern of Umqan, 1976. Burial on Southwest Umnak Island. P.113-127; Aigner S. J, Veltre D. W., Fullem B, Veltre M. An Infant Umqan Burial from Southwest Umnak Island // Arctic Anthropology Vol. XIII (2). Madison, 1976. P. 128-131; Frohlich B. The Evidence from Umqan burials on change within the Aleut population // Abstract. American Journal of Physical Anthropology. Vol.41. The Wistar Institute of Anatomy and Biology, Philadelphia, 1974. P. 480; Frohlich B.S., Laughlin B. Unangan Mortuary practices and the Umqan Burials on Anangula Island, Aleutian Islands, Alaska // To the Aleutian and Beyond. The Anthropology of William S. Laughlin / eds B. Frohlich, A. B. Harper, R. Gilberg. Copenhagen, 2002. P. 89-119. (Publications of The National Museum. Ethnographical Series, Vol.20). 
ethnographical records, creates a larger body of information allowing the development of inferential arguments.

The archaeological record does not specifically lead to a complete understanding of the intricate spiritual world, as the Unangan people see it. Neither do ethnographical records derived from explorers, hunters, traders, and the Russian Orthodox clergy. We do not have any records or knowledge of ethnographers or of any scientists actually living with and recording Unangan traditions without, at the same time being part of a foreign system, imposing new traditions and beliefs. Thus, our reconstruction of Unangan spirituality and how its relation to burial practices, or vice versa becomes a process of reasoning based on decent and reliable 'evidence.' Our evidence is the accumulative volume of information consisting of the archaeological, ethnographical, historical, and physical anthropological records. The evidence helps us to understand Unangan burial practices, how the Unangan relate to death, and how this relationship is reflected in the various ways the biologically deceased body is treated, respected, feared, and/or ignored.

We argue that (1) Russian control over the Unangan people was never as absolute as indicated by Russian priests and administrators, (2) the early attempt to convert all Unangans to the Russian Orthodox Church failed, and (3) the study of Unangan burial data suggests that traditional Unangan mortuary practices continued well into the $20^{\text {th }}$ century. The result is that some present Unangan people, especially the 'elders', may possess direct knowledge, and interest in traditional behavior and especially traditional Unangan spirituality.

\section{Russian jurisdiction over the Unangan}

At the time when the Russian American Company was established in 1799, Russian fur hunters and traders (promyshlenniks) had successfully eliminated the greater part of the marine mammals and sea otters in the waters off the Aleutian Islands.

The Russians gradually started to move their interest further toward the American northwest coast ${ }^{62}$. In less than 60 years, beginning in 1741 when Vitus Bering and Alexei Cherikov first discovered the Aleutian Islands, the number of Unangan people decreased from an estimated 15,000 individuals to about 5,000. Svetlana Fedorova ${ }^{63}$ reported over 8,000 natives in 1799 , a number which includes all native groups in Russian America. In 1880 , the number of Unangans had decreased to a little more than $2,000^{64}$.

The decrease in the Unangan population is a product of several factors. The introduction of diseases such as leprosy, smallpox, syphilis and possibly consumption (tuberculosis) certainly is partially to blame ${ }^{65}$. It is also likely that the Unangan population by its early exposure to smallpox, developed biological resistance or immunity against such diseases over time. Thus smallpox may not have been the 'big killer' although epidemics were reported by Ivan Veniaminov in 1807, 1808, 1830 and 1838, which killed mostly

${ }^{62}$ Fedorova S. G. The Russian Population in Alaska and California. Late $18^{\text {th }}$ Century -1867 . The Limestone Press, Kingston, Ontario, 1973. P. 105-106, 178.

63 Ibid. P. 275-279.

${ }^{64}$ Ibid. P. 278-279.

${ }^{65}$ Jónsdóttir B. CT Scanning of Aleutian Mummies // To the Aleutian and Beyond. To the Aleutian and Beyond. The Anthropology of William S. Laughlin / eds B. Frohlich, A. B. Harper, R. Gilberg. Copenhagen, 2002. P.155-167. (Publications of The National Museum. Ethnographical Series, Vol.20); Ortner D.J. Identification of Pathological Conditions in Human Skeletal Remains. New York, 2003. 
young and healthy men ${ }^{66}$. The presence of immunity against such diseases and/or survival is supported by the finds of smallpox lesions in some Unangan skeletal material ${ }^{67}$, which suggests that the person(s) lived with the disease for some time, survived and could have died from other causes.

Primarily, the decrease in population size is due to the deliberate attempts by Russian promyshlenniks to kill, annihilate, rape and forcefully relocate Unangan hunters in order to benefit the Russian fur business. Even with the introduction of advanced Russian technology, the hunting techniques applied and developed by the Unangan for thousands of years were most likely still far superior. The Russians capitalized on these skills by removing Unangan hunters from their homes, forcing them to act as hunters, significantly enhancing their own fur trade. Such events undoubtedly increased the mortal effect of Russian introduced diseases, by, among other things, eradicating the traditional Unangan family support system.

\section{The Introduction and Influence of the Russian Orthodox Church}

The Russians designated the first small chapel in Nikolski between 1795 and $1799^{68}$. Chapels were built in Unalaska in 1808 and in Atka in 1806. Churches were established in Nikolski in 1826, in Unalaska in 1825, and in Atka in $1826^{69}$. In general, few Russian priests arrived in Russian America before 1820. A total of four priests are recorded to have been in Russian America around 1840, a number, which had increased to about 11 by 1860, not including about 16 deacons, sextons and sacristans $\mathrm{s}^{70}$.

With the exception of the eminent priest Ivan Veniaminov, who resided in Unalaska between 1824 and $1834^{71}$, it appears that the effect of the Russian Orthodox church was limited ${ }^{72}$. If the church was effective to any degree in converting Unangan people and other native American population groups, such effectiveness would have been evident only at administrative centers including Kodiak, Sitka (Novo-Arkhangel'sk), Unalaska and to a lesser extent Nikolski and Atka.

The number of Russians in 'Alaska', including traders, administrators and church officials ranges from 225 (in 1799) to the maximum recorded number of 823 (in 1839). However, the average number is around 600. The majority settled and lived in Kodiak and Sitka. In 1860, for example, 519 out of 595 Russian settlers, or $87 \%$, lived in Sitka and in Kodiak $^{73}$. It is unlikely that about 75 individuals, mostly consisting of promyshlenniks, could have had any major cultural and spiritual impact on native populations ranging from Attu island in the West to the interior of the Alaska mainland, and from the north slope and down south to Fort Ross in northern California. The records tell us that Unangan people were converted in great numbers, but referring to Gerry Berreman's paper on Aleut Shamanism ${ }^{74}$ this could easily be misleading: 'Those whose task it has been to obliterate

\footnotetext{
66 Veniaminov I. Notes on the Islands of the Unalaska Division. P. 257-258.

67 Ortner D. J. Identification of Pathological Conditions in Human Skeletal Remains. P.334-336.

${ }^{68}$ Laughlin W.S. Aleuts: Survivors of the Bering Land Bridge. P. 79.

69 Veniaminov I. Notes on the Islands of the Unalaska Division. P. 233-239.

${ }^{70}$ Fedorova S. G. The Russian Population in Alaska and California. P. 261-262.

71 Veniaminov I. Notes on the Islands of the Unalaska Division.

72 Fedorova S. G. The Russian Population in Alaska and California. P.261-267.

${ }^{73}$ Ibid. P. 273, 275-279.

${ }^{74}$ Berreman G. D. Aleut Shamanism in the twentieth Century? An Assessment of Evidence. P. 25-50.
} 
traditional religion have an even greater investment in denying all traces of its persistence than do those they sought to convert who, by their words and behavior, expose the clerics' imperfect accomplishment of their goal'75.

We argue that traditional Unangan spirituality continued after the arrival of Russian promyshlenniks in 1741, after the establishment of the Russian American Company in 1799, after the sale of Russian America to USA in 1867, and most likely into the 20th century.

\section{Biological and Archaeological Evidence}

We are using data from previous studies on Unangan human remains to support our ideas and hypotheses. Some of the skeletal remains are presently curated in the Department of Anthropology at the National Museum of Natural History in Washington, DC and have been collected from Ship Rock, Chernovsky, Kashega, Unalaska, Unga, Chaluka, and Okee $\mathrm{Bay}^{76}$.

Recently we have focused on the study of 36 mummified bodies from the Warm Cave on Kagamil Island ${ }^{77}$. The study included detailed descriptions of exterior surfaces and extensive study of the interior using nondestructive and noninvasive analytical methods such as computed tomography and traditional $\mathrm{x}$-ray technologies ${ }^{78}$.

The antiquity of the Unangan mummies from the Warm Cave on Kagamil Island has been debated for a long time. Our research has suggested that some of the bundles and 'packs' containing human remains may be much younger than previously believed. We base this on a variety of observations, including (1) descriptions of find locations by William Dall ${ }^{79}$ and Aleš Hrdlička ${ }^{80}$, the preservation and especially the weathering of the wrapping material, (2) the study of diseases and anomalies found in the skeletal remains and in the mummified soft tissue, and (3) the archaeological and ethnographical records.

Captain Hennig collected 12 mummies from the Warm Cave in $1874^{81}$. Hennig removed only 12 bundles, and it is believed that he collected the best preserved material leaving many less desirable items. A majority of the 12 mummies are in fair to good condition, but not exceptionally well preserved. Indeed, some of them appear to have been seriously damaged, perhaps by foxes.

75 Ibid. P. 29.

76 Frohlich B. The Aleut-Eskimo Mandible. PhD Dissertation. University of Connecticut, Storrs, 1979; Frohlich B., Pedersen P. O. Secular Changes Within Arctic and Sub-Arctic Populations: A Study of 632 Mandibles from The Aleutian Islands, Alaska and Greenland // Arctic Medical Research. Vol. 51: Nordic Council for Arctic Medical Research. Oulu, 1992. P. 173-188; Hunt D. Aleutian Remains at the Smithsonian Institution. P. 137-153.

77 Hunt D. Aleutian Remains at the Smithsonian Institution. P. 137-153; Jónsdóttir B. CT Scanning of Aleutian Mummies. P. 155-167.

78 Jónsdóttir B. CT Scanning of Aleutian Mummies. P. 155-167.

79 Dall W.H.: 1) Notes on the Pre-Historic Remains in the Aleutian Islands. P. 283-287; 2) On the Remains of Later Pre-Historic Man obtained from Caves in the Catherina Archipelago, Alaska Territory, and especially from the Caves of the Aleutian Islands.

${ }^{80}$ Hrdlička A.: 1) Exploration of Mummy Caves in the Aleutian Islands. Pt. I; 2) The Aleutian and Commander Islands and their Inhabitants. The Wistar Institute of Anatomy and Biology.

81 Dall W.H. On the Remains of Later Pre-Historic Man obtained from Caves in the Catherina Archipelago, Alaska Territory, and especially from the Caves of the Aleutian Islands; Hrdlička A. Exploration of Mummy Caves in the Aleutian Islands. Pt. I. P. 9. 
Based on the description of the caves, it is likely that Aleš Hrdlička visited the same cave in 1936 and removed everything which was left to collect. Of the material Hrdlička collected, 29 bundles of mummified remains are still intact and preserved in their original condition $^{82}$. Some of the bundles and backpacks are in excellent condition and display no damage or any decay caused by weathering. Indeed, one bundle appears to be almost new (Fig. 4). We argued that if Hennig and Hrdlička collected human remains from the same cave, then some of the mummies Hrdlička collected more than 60 years after Hennig had visited the cave must have been placed in the Warm Cave by the Unangan after Hennig's visit but before 1936.

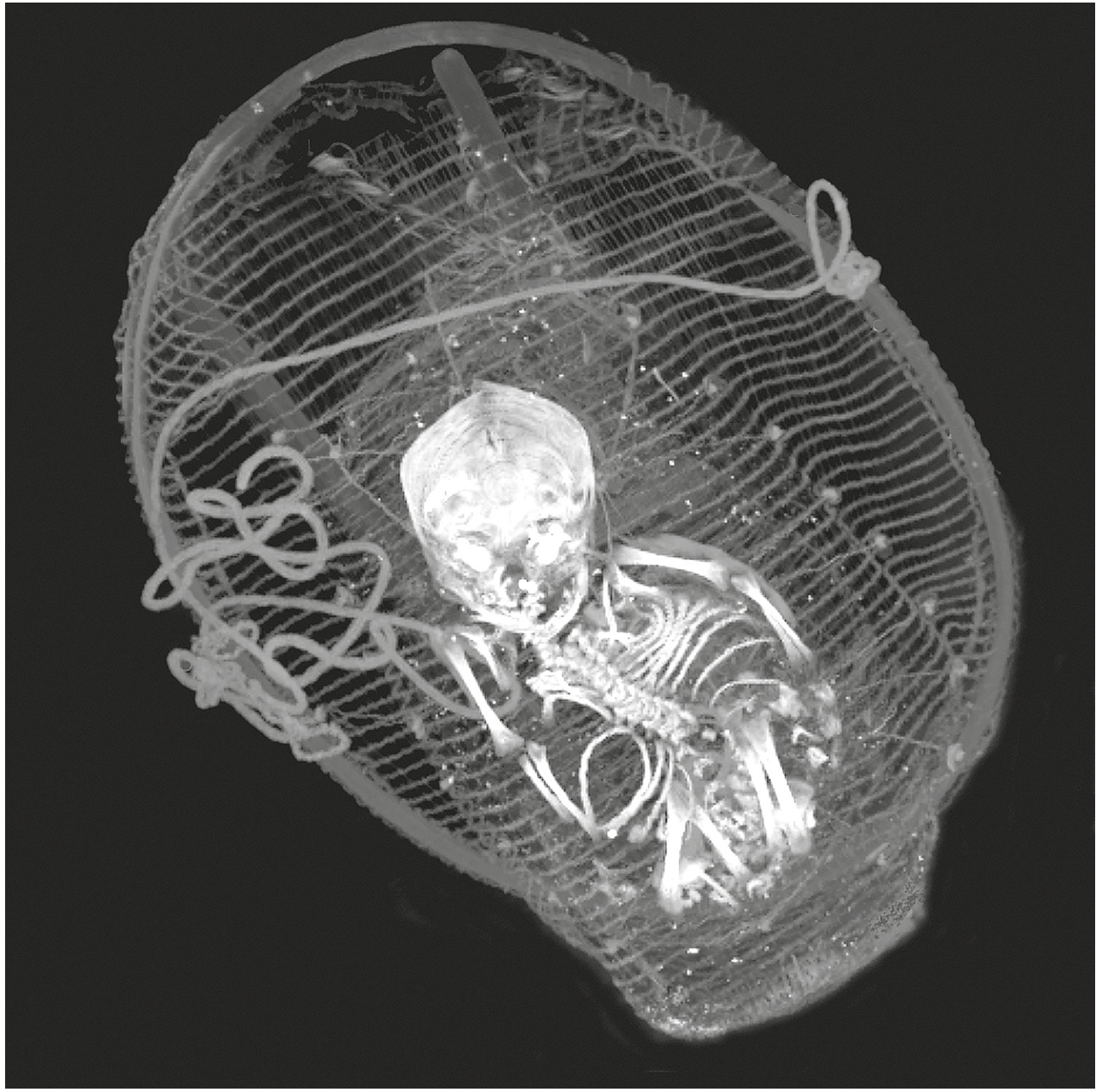

Fig. 4. Three dimensional reconstruction of infant placed within a backpack structure. Body is protected by several layers of marine mammal furs, bird skins and grass mattings. The reconstruction is based on about 900 slices of CT (computed tomography) data [Frohlich et al., 2002, p. 110]

${ }^{82}$ Hunt D. Aleutian Remains at the Smithsonian Institution. P. 137-153; Jónsdóttir B. CT Scanning of Aleutian Mummies. P. 155-167. 
There is still some doubt about the identity of the cave Captain Hennig visited. Hrdlička visited a third, but empty cave during his journey to Kagamil in 1937 or 1938, but no other information is available ${ }^{83}$. If this cave is the one visited by Captain Hennig in 1874, then somebody else must have emptied it before Hrdlička visited it and found it empty. Based on the descriptions available today, it appears that Captain Hennig collected his 12 mummies from the same cave (the Warm Cave) Hrdlička visited and collected from in $1936^{84}$

Several of the adult mummies, including the poorly preserved that were macerated include pathological anomalies such as leprosy ${ }^{85}$, syphilis (Ousley, personal communication, July 2002), and smallpox ${ }^{86}$. If such diseases were present in the Unangan population before the Russians arrived, we should find similar frequencies of such anomalies in the skeletal population from Chaluka/Nikolski, about $26 \mathrm{~km}$ (16 miles) east of Kagamil Island. We did not. The Chaluka burials are all dated to pre-Russian period, and none of them displays any potential introduced diseases, such as smallpox, leprosy, syphilis, etc. Because of the clear evidence that post-Russian diseases are present in the mummified burials, the obvious conclusion must be that at least some of the mummified burials can be dated to post-Russian period.

Nikolski is one of the areas where a few Russians may have intermittingly settled. A small Russian Orthodox chapel was constructed between 1795 and $1799^{87}$, and a church was established in 1826. It is likely that most of the burials found in the ancient Chaluka mound and depicting Unangan burial practices are pre-Russian, thus preceding the arrival of the Russians around 1800. Out of 98 skeletons from Chaluka, Okee Bay and one other site on southeastern Umnak Island, one case of possible syphilis has been identified. In contrast, a minimum of five cases, including syphilis $(\mathrm{n}=3)$, smallpox $(\mathrm{n}=1)$, and leprosy $(n=1)$ have been identified in the Kagamil material $(n=200+/-)^{88}$.

We conclude that most of the remains found in the Warm and Cold caves on Kagamil Island can be dated to after the arrival of the Russians and that some of the diseases we find in the Kagamil mummy material is a product of bacterial or viral transmission from the Russians to the Unangan people.

The research on the Unangan skeletal remains is not completed, however. Only part of the collection has been analyzed, and, at this time, no data collection will be conducted before prior approval has been obtained from the Unangan people. We are processing already available data and comparing the results with other Arctic and Sub-Arctic populations. For example, studies of skeletal data in pre-contact and post-contact Eskimo groups from western Greenland demonstrate significant differences in especially non-metric frequencies when comparing the two groups ${ }^{89}$. This change has been attributed to cultural and genetic changes caused by the arrival to western Greenland of Europeans and espe-

${ }^{83}$ Hrdlička A. Exploration of Mummy Caves in the Aleutian Islands. Pt. I. P. 21.

${ }^{84}$ Hunt D. Aleutian Remains at the Smithsonian Institution. P. 145-148.

85 Jónsdóttir B. CT Scanning of Aleutian Mummies. P. 155-167.

86 Ortner D. J. Identification of Pathological Conditions in Human Skeletal Remains.

87 Laughlin W. S. Aleuts: Survivors of the Bering Land Bridge. P. 79.

88 Jónsdóttir B. CT Scanning of Aleutian Mummies. P. 155-167; Ortner D.J. Identification of Pathological Conditions in Human Skeletal Remains; Ousley S. Personal Communication. Department of Anthropology, Smithsonian Institution. Washington, 2002.

${ }^{89}$ Frohlich B., Pedersen P. O. Secular Changes Within Arctic and Sub-Arctic Populations: A Study of 632 Mandibles from The Aleutian Islands, Alaska and Greenland. P. 184-186. 
cially Danes in the $18^{\text {th }}$ century ${ }^{90}$. Presently, similar analyses are being planned on skeletal material from Kagamil and Umnak islands, supported by data collected in $1978^{91}$.

Samples for radiocarbon dating were collected several years back from some of the Kagamil mummies. It is unknown if the collected samples are human bone, wood, fur, or other kind of associated material. The dates range from about 1,600 BP to about $600 \mathrm{BP}$ with the majority of the samples between 1,100 BP and $900 \mathrm{BP}$. We are unaware if these dates have been calibrated (including marine reservoir effect), and we have not yet established the amount and kind of preservation and conservation chemicals added to the bundles over time since the arrival at the museum 65 years ago. In fact we have little knowledge of any potential factors, which could have altered the carbon dates. New and additional samples will be collected and submitted for processing when adequate permissions have been received from the Unangan people. Apparently, some of the samples previously collected for dating purposes were obtained from some of the excellent bundles collected by Hrdlička in 1936. Knowing the effect of the Aleutian weather on any object, we seriously question the 1,000 year antiquity of an object, appearing as if it has been produced more recently and never exposed to the harsh Aleutian environment. We hope that new dating of the bundles and backpacks can solve some of these questions.

Traditional way of life, including traditional spirituality was not abandoned before the Unangan people were significantly exposed to western civilization including organized education, improved housing, nutrition, and access to better information and communication. The question is at what time this major exposure took place. We have used the photographic record to evaluate at what time the change from using the traditional Unangan house (barabara) to modern European/American house structures occured. Up to at least 1910, a majority of Unangan people still lived in the traditional barabaras, although some improvements had been added, such as doors and perhaps a few glass windows replacing the top entrance described by Cook $^{92}$ and McCartney and Veltre ${ }^{93}$. Between Waldemar Jochelson's visit to Umnak in 1909/1910 and Aleš Hrdlička’s first visit in 1936, the Unangan community in Nikolski had been transferred from a population living in barabaras to a population living in wood framed American-styled housing (Figs 5 and 6). During the same period, communications between the islands and other communication centers were greatly improved by the gradual switch from wind and steam powered shipping to diesel powered shipping, and with the increasing availability of wireless communication, health-care and a methodical educational services.

Some Unangan children became educated outside the islands and, in general, there appeared to be a move of Unangans from the Aleutian Islands to other geographical locations in the U.S. It is inferred that this is the time when the majority of the Unangan people adopted western traditions and the Russian Orthodox teaching, and by then

${ }^{90}$ Frohlich B. The Aleut-Eskimo Mandible. P. 40, 168; Frohlich B., Pedersen P.O. Secular Changes Within Arctic and Sub-Arctic Populations: A Study of 632 Mandibles from The Aleutian Islands, Alaska and Greenland. P. 184-186.

91 Ibid. P. 174-178.

92 Cook J. A Voyage to the Pacific Ocean Undertaken, by the Command of His Majesty, for making Discoveries in the Northern Hemisphere. G. Nicol, Bookseller to His Majesty, in the Strand; and T.Cadell, in the Strand. London, 1785.

${ }_{93}$ McCartney A.P., Veltre D.W. Longhouses of the Eastern Aleutian Islands, Alaska // To the Aleutian and Beyond. The Anthropology of William S. Laughlin / eds B. Frohlich, A. B. Harper, R. Gilberg. Copenhagen, 2002. P. 250-253. (Publications of The National Museum. Ethnographical Series, Vol. 20). 


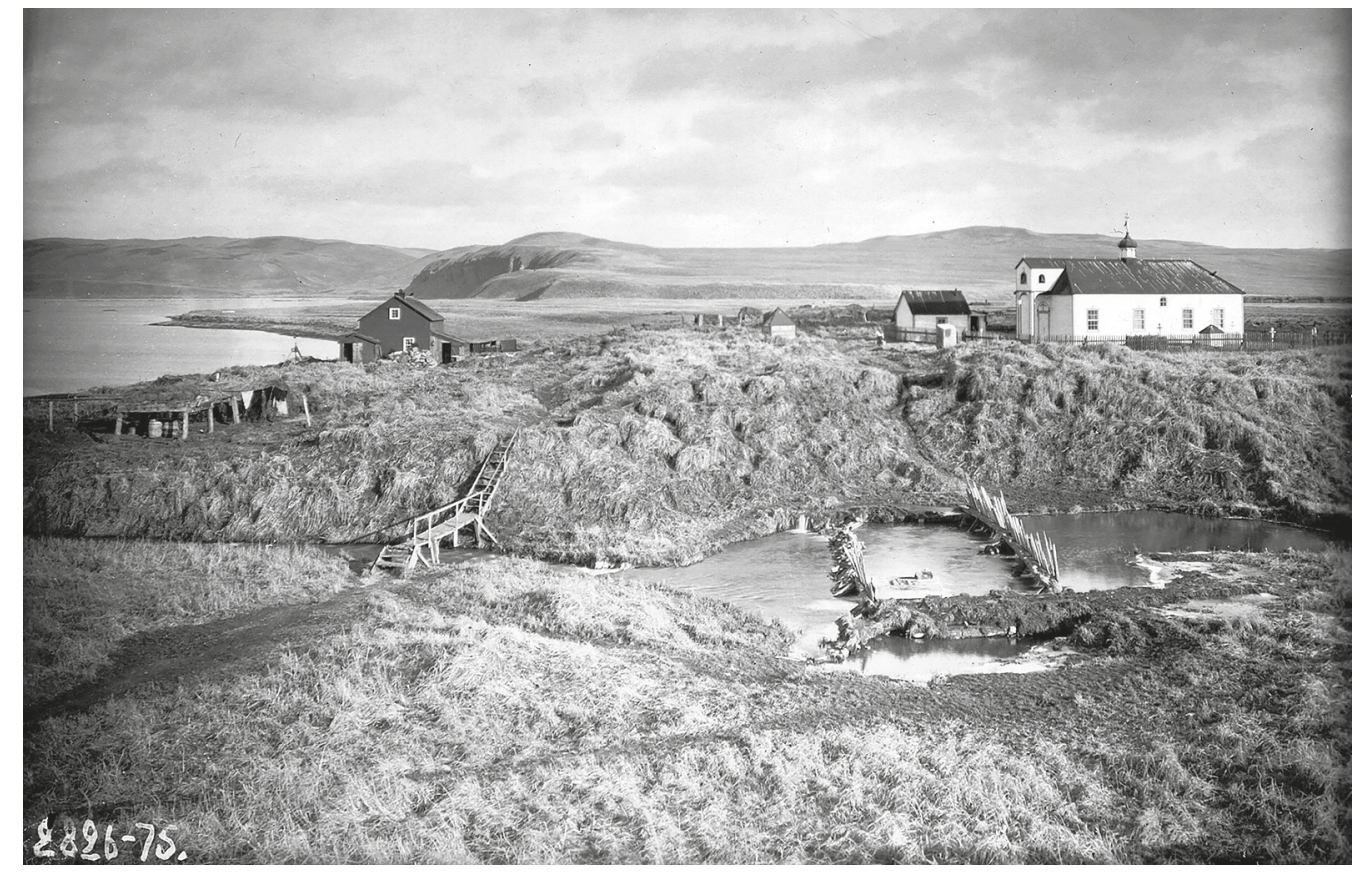

Fig. 5. Nikolski Village viewed from the Chaluka settlement, ca. 1909-1910 [Frohlich et al., 2002, p.111]

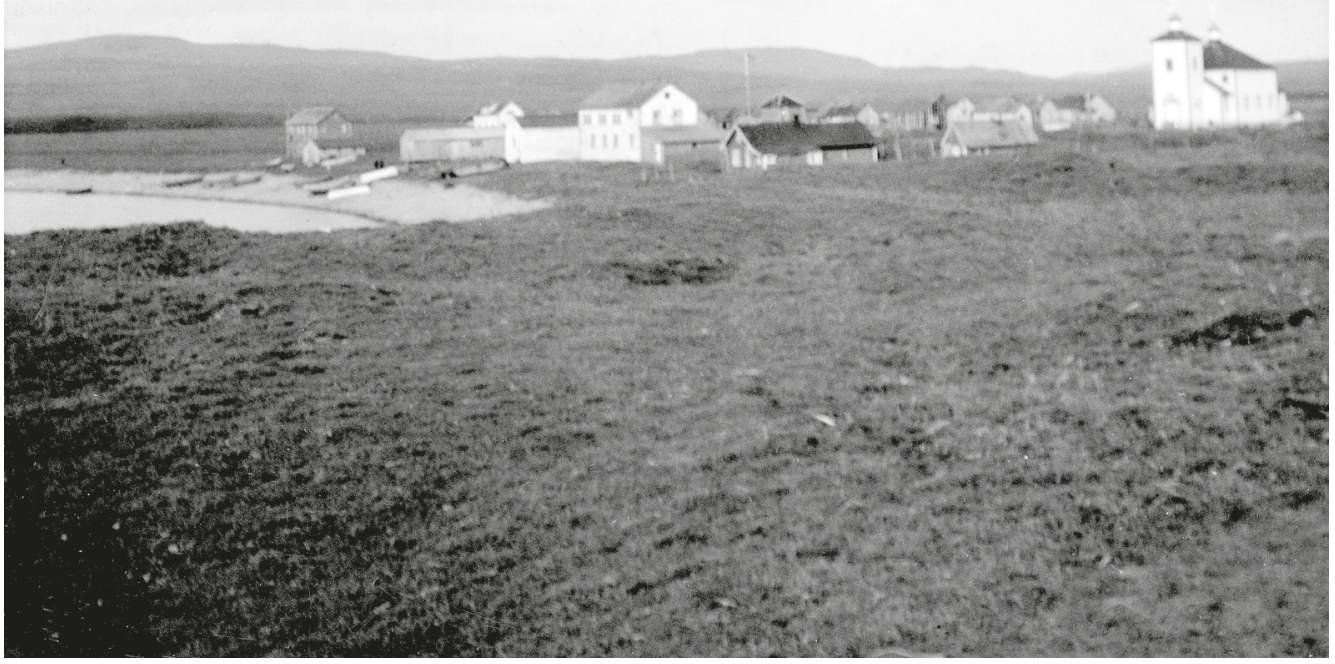

Fig. 6. Nikolski Village viewed from the western part of the Chaluka settlement, ca. 1936 [Frohlich et al., 2002, p. 111] 
abandoning their traditional way of life and traditional Unangan spirituality. It is also the time when Unangan completed the migration from traditional settlements to a few centralized villages and when the Aleutian Island Chain started to become the home for fewer and fewer Unangans.

\section{Unangan Mortuary Practices and Traditional Unangan Spirituality}

Traditional Unangan spirituality is complex and based on criteria that are closely related to the individual's understanding of the spiritual world, and works in great harmony with the Unangans' 9,000 years of successful adaptation to a very rich natural environment. While much still has to be learned about Unangan spirituality and the extent if its relation to mortuary practices, it is possible to infer a model which appears to be compatible with our finds.

Much of our knowledge about traditional spirituality derives from living with the Unangan people in Nikolski for a total of more than nine months, talking to elders, discussing burial practices and helping them with processing the finds of unmarked preRussian burials, especially on Chaluka and at Sandy Beach (excavations and reburials). We also obtained valuable information from elders in Unalaska during a short visit in August, 2000 at which time an early version of our model was presented and discussed.

The following reconstruction of Unangan mortuary practices and its connection to Unangan spirituality is based on data and information as discussed above, but is strictly hypothetical and tentative:

(1) According to traditional Unangan spirituality, at the time of biological death the human soul leaves the body and goes to 'another world'. When the soul has left the body, the body is less important and cannot create any potential problems for the living Unangan. In fact, the Unangans are not afraid of the body after the soul has left. The 'soul/spirit-free' body is placed in a permanent burial structure, which can be within the settlement or in a pit burial (Umqan) adjacent to the settlement. Why some bodies are interred within or externally to the settlement is presently unknown.

(2) In situations where there are unsolved problems between the deceased and the living, the soul may not leave the body. In such cases, the body and soul become a potential danger to the living, and for that reason the problems, which caused this situation must be resolved before the soul can go to 'another world'. Problems are resolved by communicating with the soul.

(3) Because the soul and, possibly, the body could become dangerous to the living, the body is left in an isolated location, separated from the settlements by a body of salt water. The access to the location has to be relatively easy so that everybody, including children and older people, can visit and communicate with the bodytrapped souls. The caves on Kagamil Island and the shelters on Ship Rock Island and other islands fulfill these requirements: separation and easy access.

(4) When the soul is satisfied, it leaves the body and goes to 'another world'; and the body can now be buried in a pit burial within the settlement or in an Umqan. The process can take a short or long time, possibly up to a year or longer. 
(5) Similar situations appear with deceased infants and young children. In such cases, the mother may not have had enough time to establish adequate spiritual contact with the deceased infant/child. Thus, when the infant/child dies, the soul is confused and cannot depart the body. Since this unfortunate situation is not caused by an external problem developed during their lifetime, the deceased child's or infant's soul is not necessarily dangerous to the living person. The mother can keep the body and the soul within the household and communicate with it until the soul can leave the body and go to 'another world'. For practical reasons the body may be eviscerated, and the body's cavities are filled with cut grass $^{94}$.

Bird skins, furs from marine and terrestrial mammals, and grass matting are used to keep the body safe and protected. In some cases, the body is wrapped into a bundle that can be hanged from the wall or ceiling in the barabara, placed in a backpack like structure, which can be carried by the mother at any time, or placed in a wood dish, enhancing her communication with the infant's soul.

This procedure may be supported by observations by Martin Sauer in 1790 and Gawrila Sarychev in 1791-1792 describing the way in which the Aleuts disposed of their dead children: 'A mother will keep a dead child thus embalmed in their hut for some months, constantly wiping it dry; and they bury it when it begins to smell, or when they get reconciled to parting with it ${ }^{95}$, and ... 'but little children for whom such a frame can be made firmer and closer, are kept sometimes a whole year and even longer, until another comes into the world to supply its place ${ }^{96}$.

An image, by Wladimir Jochelson in 1910, and now located at the Peter The Great Museum of Anthropology and Ethnography (Kunstkamera), St. Petersburg, Russian Federation, show an Unangan woman (Chaluka, Nikolski) with a baby in a backpack (Fig. 7). The baby's position suggests that something else is taking up space in the backpack. At the national Museum of Natural History (Smithsonian Institution) we have several such similar backpacks collected from the Kagamil Warm Cave by Hennig in 1874 and Hrdlička in 1936, 1937 and 1938 (see [Frohlich, Laughlin, 2002, p.92-93] for more details and images). All of the backpacks include the remains of a deceased infant, in some cases artificially mummified. We argue that the woman photographed by Jochelson in 1910 carries a backpack with her deceased baby and her new baby on top (see Fig. 7).

Nondestructive and noninvasive CT scanning has improved our knowledge about the mummy bundles and mummy backpacks. Bird and mammal skins can be identified by studying the CT images, and the presence of beads, labrets, wood tools, stitching, and major construction features can be viewed and studied in Jónsdóttir's article in Frohlich, Harper and Gilberg ${ }^{97}$.

94 Jónsdóttir B. CT Scanning of Aleutian Mummies. P. 159, 162; Frohlich B., Laughlin S. B. Unangan Mortuary practices and the Umqan Burials on Anangula Island, Aleutian Islands, Alaska. To the Aleutian and Beyond. P. 114.

95 Sauer M. An Account of a Geographical and Astronomical Expedition to the Northern Parts of Russia for Ascertaining the Degrees of Latitude and Longitude of the Mouth of the River Kovima; of the whole coast of the Tshutski, to East Cape; and of the Islands in the Eastern Ocean, stretching to the American Coast. T. Cadell, Jun., and W. Davies, in the Strand, London, 1802. P. 161.

96 Sarychev G. Account of a Voyage of Discovery to the North-East of Siberia, the Frozen Ocean, and the North-East Sea. London, 1807. P.77-78.

97 Jónsdóttir B. CT Scanning of Aleutian Mummies. P. 155-165. 


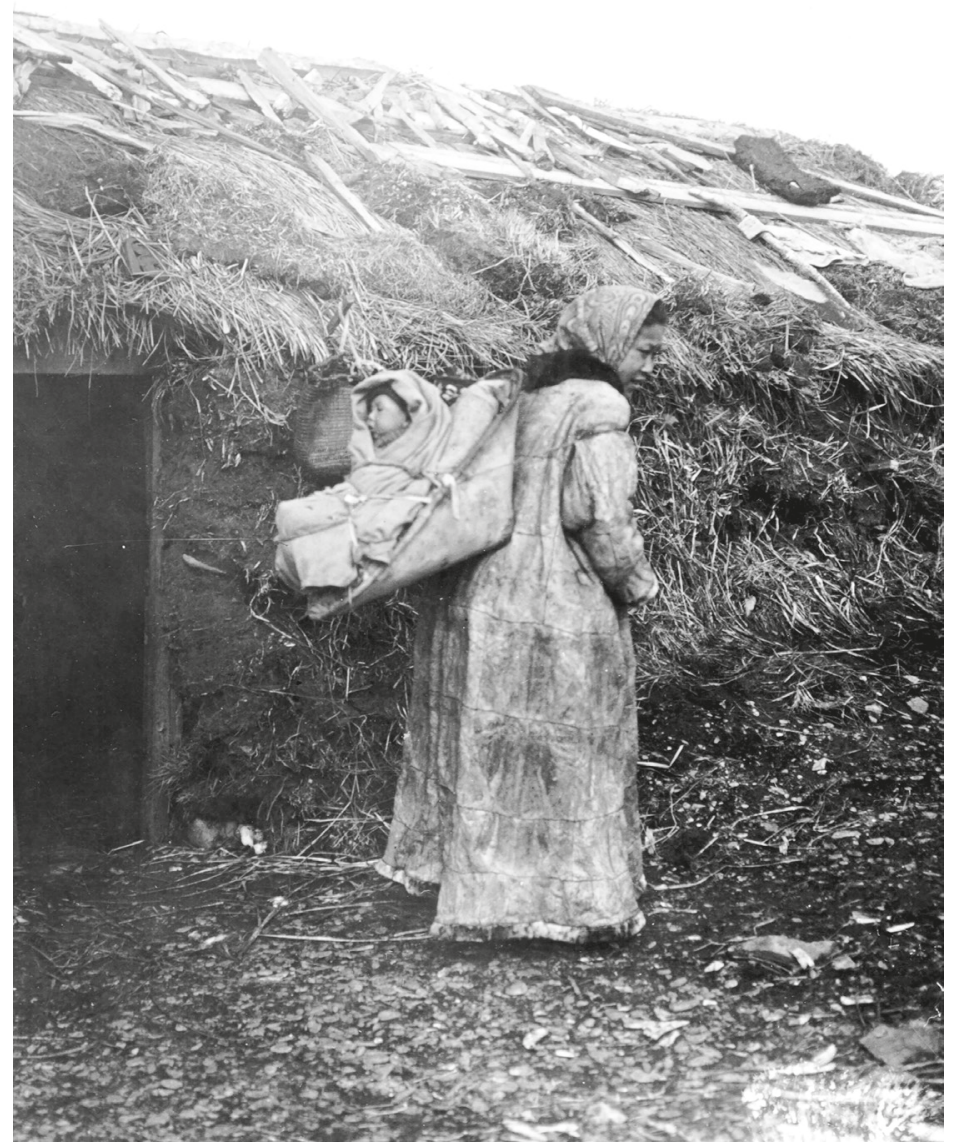

Fig. 7. Nikolski woman at the entrance to a barabara on Chaluka. Backpack is carried on back and supported and held in place by a string around the upper part of the woman's body. Shown backpack is similar to those found in the Warm Cave on Kagamil Island containing bodies of deceased infants [Frohlich et al., 2002, p. 114]

The backpacks are re-used over time, but the most important packing material and the lines securing the deceased body to the pack are new. For decorative purposes, some of the fittings on the backpack are new as well. Marine mammal skins, used as outer layers for both adults and sub-adults, are re-used. This is seen in the presence of older and unused stitch holes, which may have had another practical function, when the skin was used for something else at an earlier time.

When the soul has left the infant's body, the body is removed from the bundle or backpack and placed in a pit burial within the settlement or in an Umqan. Aigner et al. ${ }^{98}$

98 Aigner S. J, Veltre D. W., Fullem B, Veltre M. An Infant Umqan Burial from Southwest Umnak Island. P. 128-129. 
reports the find of an infant bundle in an Umqan burial including bird skin, beads, and a supporting wood piece, all features of which are much similar to what we identify on the CT images of the Kagamil mummy backpacks. It appears that this infant burial could represent a case where the mother was satisfied with the communication, and the child was placed in an Umqan for a final resting place. Additionally, Russian artifacts have been found in Umqan burials ${ }^{99}$ suggesting continuity of the construction of Umqan burials after 1741.

The use of caves and rock shelters as temporary resting places for bodies explains the low number of mummies identified so far. Thus, the cave and shelter burials are temporary burials. Bodies are mummified both naturally and artificially. Mummified infant burials are often kept in the house structure (barabara) where the mother can communicate with the deceased infant; a system is further developed by enable the mother to carry the deceased infant in a backpack while doing walking around. Thus, the total number of similar burials (caves, shelters, etc.) does not represent a 'normal population/distribution' but a selective one of which the applied use is temporary. Therefore, the sample size will never be 'high'. This becomes even more significant when we take into account the possible and most likely extensive and unrecorded looting of rock shelters and caves during the last hundred year, at which time the presence of non-Unangan people in the Aleutian Islands has increased considerably.

Unangan mortuary practices, as evaluated from archaeological and ethnographical records, are products of a belief system based on traditional Unangan spirituality. Most likely, such practices and traditions continued into the $20^{\text {th }}$ century.

Finally, the archaeological and anthropological records are important factors in reconstructing biological and social histories of any population. Such records should be studied in details, but in full collaboration with descendants of the people being studied, and in a manner which is nondestructive, noninvasive and respectable.

\section{References}

Aigner J. S., Veltre D. W. The Distribution and Pattern of Umqan, 1976. Burial on Southwest Umnak Island. Arctic Anthropology. Vol. XIII (2). Madison, Wisconsin, 1976, pp. 113-127.

Aigner S. J, Veltre D. W., Fullem B, Veltre M. An Infant Umqan Burial from Southwest mUmnak Island. Arctic Anthropology. Vol. XIII (2). Madison, Wisconsin, 1976, pp. 128-131.

Berreman G. D. Aleut Shamanism in the twentieth Century? An Assessment of Evidence. To the Aleutians and Beyond. The Anthropology of William S.Laughlin. Eds B. Frohlich, A. B. Harper, R. Gilberg. Copenhagen, Danish National Museum, 2002, pp. 25-50. (Publications of The National Museum. Ethnographical Series, Vol. 20).

Black R. Geology of Umnak Island, Eastern Aleutian Islands as related to the Aleuts. Arctic and Alpine Research, 1976, vol. 8(1), pp.7-35.

Black R., Laughlin W.S. Anangula: A Geological Interpretation of the Oldest Archaeological Site in the Aleutians. Science, vol. 143(3612), 1964, pp. 1321-1322.

Cook J. A Voyage to the Pacific Ocean Undertaken, by the Command of His Majesty, for making Discoveries in the Northern Hemisphere. G. Nicol, Bookseller to His Majesty, in the Strand; and T.Cadell, in the Strand. London, 1785, $421 \mathrm{p}$.

Coxe W. Account of the Russian Discoveries Between Asia and America to Which Are Added the Conquest of Siberia and the History of the Transactions and Commerce Between Russia and China. $4^{\text {th }}$ enl. Ed. London, Cadell and Davies, 1780, $344 \mathrm{p}$.

\footnotetext{
${ }^{99}$ Ibid. P. 129.
} 
Dall W. H. Notes on the Pre-Historic Remains in the Aleutian Islands. Proceedings of the California Academy of Sciences IV (1868-1872). San Francisco, The California Academy of Sciences, 1873, pp. 283-287.

Dall W.H. On Succession in the Shell-Heaps of the Aleutian Islands. Contributions to North American Ethnology. Washington, Department of the Interior, 1877, pp.41-106.

Dall W.H. On the Remains of Later Pre-Historic Man obtained from Caves in the Catherina Archipelago, Alaska Territory, and especially from the Caves of the Aleutian Islands. Smithsonian Institution, Washington City, 1878, 68 p.

Dove C.J., Peurach S.C. Microscopic Analysis of Feather and Hair Fragments Associated with Human Mummified Remains from Kagamiln Island, Alaska. To the Aleutians and Beyond. The Anthropology of William S. Laughlin. Eds B. Frohlich, A. B. Harper, R. Gilberg. Copenhagen, Danish National Museum, 2002, pp. 51-61. (Publications of The National Museum. Ethnographical Series, Vol. 20).

Dumond D. E., Knecht R. An Early Blade Site in the Eastern Aleutians. Recent Archaeology in the Aleut Zone of Alaska. Ed by D. E. Dumond. University of Oregon Anthropological Papers. Eugene, Oregon, 2001. Vol. 58, pp.9-34.

Fedorova S. G. The Russian Population in Alaska and California. Late 18th Century - 1867. Kingston, Ontario, The Limestone Press, 1973. 376 p.

Frohlich B. The Evidence from Umqan burials on change within the Aleut population. American Journal of Physical Anthropology, 1974, vol. 41, no. 3, p. 480.

Frohlich B. The Aleut-Eskimo Mandible. Ph.D. Dissertation. University of Connecticut, Storrs. USA, 1979. $267 \mathrm{p}$.

Frohlich B. Aleut Settlement Distribution on Adak, Kagalaska and Attu Islands, Alaska. To the Aleutians and Beyond. The Anthropology of William S.Laughlin. Eds B. Frohlich, A. B.Harper, R. Gilberg. Copenhagen, Danish National Museum, 2002, pp. 63-88. (Publications of The National Museum. Ethnographical Series, Vol.20).

Frohlich, B., Laughlin S.B. Unangan Mortuary practices and the Umqan Burials on Anangula Island, Aleutian Islands, Alaska. To the Aleutians and Beyond. The Anthropology of William S. Laughlin. Eds B. Frohlich, A. B. Harper, R. Gilberg. Copenhagen, 2002, pp. 89-119. (Publications of The National Museum. Ethnographical Series, Vol.20).

Frohlich B., Pedersen P.O. Secular Changes Within Arctic and Sub-Arctic Populations: A Study of 632 Mandibles from The Aleutian Islands, Alaska and Greenland. Arctic Medical Research. Vol.51. Oulu, Nordic Council for Arctic Medical Research, 1992, pp. 173-188.

Harper A. B. Secular Change and Isolate Divergence in the Aleutian Population System. Ph.D Dissertation, University of Connecticut. Storrs, 1975, 225 p.

Harper A.B. Life Expectancy and Population Adaptation: The Aleut Centenarian Approach. The First Americans: Origins, Affinities, and Adaptations. Eds W.S. Laughlin, A. B. Harper. New York, Gustav Fisher, 1979, pp.309-327.

Harper A.B., Laughlin W.S. Anthropologist's Anthropologist, 1919-2001. To the Aleutians and Beyond. The Anthropology of William S. Laughlin. Eds B. Frohlich, A. B. Harper, R. Gilberg. Copenhagen, 2002, pp.7-23. (Publications of The National Museum. Ethnographical Series, Vol.20).

Harper A. B., Laughlin W. S. Inquiries into the Peopling of the New World: Development of Ideas and Recent Advances. A History of American Physical Anthropology, 1930-1980. Ed. by F. Spencer. New York, Academic Press, 1982, pp. 281-304.

Hrdlička A. Exploration of Mummy Caves in the Aleutian Islands. Part I. Previous Knowledge of such Caves. Original Explorations. The Scientific Monthly, vol. 52, January, 1941, pp.5-23.

Hrdlička A. Exploration of Mummy Caves in the Aleutian Islands. Part II. Further Exploration. The Scientific Monthly, vol.52, 1941, January, pp. 113-130.

Hrdlička A. The Aleutian and Commander Islands and their Inhabitants. Philadelphia, The Wistar Institute of Anatomy and Biology, 1945, $630 \mathrm{p}$.

Hunt D. Aleutian Remains at the Smithsonian Institution. To the Aleutians and Beyond. The Anthropology of William S. Laughlin. Eds B. Frohlich, A. B. Harper, R. Gilberg. Copenhagen, 2002, pp. 137-153. (Publications of The National Museum. Ethnographical Series, Vol. 20).

Jochelson W. Archaeological Investigations in the Aleutian Islands. Washington, The Carnegie Institution of Washington, 1925, $145 \mathrm{p}$.

Jochelson W. History, Ethnology and Anthropology of the Aleut. Washington, The Carnegie Institution of Washington, 1933. $104 \mathrm{p}$. 
Jónsdóttir B. CT Scanning of Aleutian Mummies. To the Aleutians and Beyond. The Anthropology of William S. Laughlin. Eds B. Frohlich, A. B. Harper, R. Gilberg. Copenhagen, 2002, pp. 155-167. (Publications of The National Museum. Ethnographical Series, Vol.20).

Korsun S.A., Taksami N.Ch., Ushakov N.V. Treasures of the Kunstkamera. Aleuts: How they were seen by V.Iokhel'son. Photo-Laboratory. St. Petersburg, Peter the Great Museum of Anthropology and Ethnography (Kunstkamera), 2001. 100 p.

Knecht R. A. Archaeological Site Surveys of Unalaska Island 1998-2000. Report on file, Office of History and Archaeology, Alaska Division of Parks and Outdoor Recreation, Anchorage, Alaska, 2001. 19 p.

Knecht R. A., Davis D. S. A Prehistoric Sequence for the Eastern Aleutians. Recent Archaeology in the Aleut Zone of Alaska. Ed. by D. E. Dumond. University of Oregon Anthropological Papers. Vol.58. Eugene, Oregon, 2001, pp. 269-288.

Knecht R.A., Davis R.S., Carver G. A. The Margaret Bay Site and Eastern Aleutian Prehistory. Recent Archaeology in the Aleut Zone of Alaska. Ed by D. E. Dumond. University of Oregon Anthropological Papers. Vol. 58. Eugene, Oregon, 2001, pp. 269-288.

Laughlin W.S. Human Migration and Permanent Occupation in the Bering Sea Area. The Bering Land Bridge. Ed. by D. Hopkins. Stanford, Stanford University Press, 1967, pp. 409-460.

Laughlin W. S. Ecology and Population Structure in the Arctic. The Structure of Human Populations. Eds G. A. Harrison, A. J. Boyce. Oxford, Clarendon Press, 1972, pp. 379-392.

Laughlin W.S. Holocene History of Nikolski Bay; Eskimo and Aleut Evolution. Folk, vol. 16-17, 1974-1975, pp. 95-116.

Laughlin W. S. Aleuts, Ecosystem, Holocene History and Siberian Origin. Science, vol. 189(4202). American Association for the Advancement of Science, 1975, pp. 507-515.

Laughlin W.S. Holocene History of Nikolski Bay, Alaska, and Aleut Evolution, Beringia. Cenozoic, Theses of the reports of All Union Symposium, The Bering Land Bridge and Its Role for the History of Holarctic Floras and Faunas in the Late Cenozoic, Khabarovsk, May, 1973. Ed. by V.L. Kontrimavichus. Khabarovsk, 1976, pp. 492-508. (In Russian).

Laughlin W. S. Aleuts: Survivors of the Bering Land Bridge. Holt, Rinehart and Winston, New York, 1980. $151 \mathrm{p}$.

Laughlin W.S. Aleut Mummies: Their Significance for Longevity and Culture. Cultures of the Bering Sea Region: Papers from an International Symposium. Eds H. N. Michael, J. W. VanStone. IREX, International Research and Exchange Board, New York, 1983, pp. 41-61.

Laughlin W.S. Massacre at Chaluka. Polar Record, vol.22, no. 138. Cambridge University Press, Cambridge, England, 1984, pp.314-318.

Laughlin W. S. Personal Communication. University of Connecticut. Storrs, CT, 1992.

Laughlin W.S., Marsh G.H. The Lamellar Flake Manufacturing Site on Anangula Island in the Aleutians. American Antiquity, vol. 20, no. 1 July 1954, pp.27-39.

Laughlin W. S., Jørgensen J. B. Isolate Variation in Greenlandic Eskimo Crania. Acta Genetica et Statistica Medica, 1956, vol. 6, p. 312.

Laughlin W.S., Harper A.B. (eds.) The First Americans: Origins, Affinities, and Adaptation. New York, Gustav Fisher, 1979, 340 p.

Laughlin W. S., Jørgensen J. B., Frohlich B. Aleuts and Eskimos: Survivors of the Bering Land Bridge. The First Americans: Origins, Affinities, and Adaptation. Eds W.S. Laughlin, A. Harper. New York, Gustav Fisher, 1979, pp. 91-104.

McCartney A.P. Prehistory of the Aleutian Region. Handbook of North American Indians Ed. by W. C. Sturtevant. Vol. V: Arctic. Washington, Smithsonian Institution 1984, pp. 119-135.

McCartney A.P., Veltre D.W. Longhouses of the Eastern Aleutian Islands, Alaska. To the Aleutians and Beyond. The Anthropology of William S. Laughlin. Eds B. Frohlich, A. B. Harper, R. Gilberg. Copenhagen, 2002, pp. 249-265. (Publications of The National Museum. Ethnographical Series, Vol.20).

Ortner D. J. Identification of Pathological Conditions in Human Skeletal Remains. New York, Academic Press, 2003, 645 p.

Ousley S. Personal Communication. Department of Anthropology. Washington, Smithsonian Institution, 2002.

Steller G.W. Reise von Kamtschatka nach Amerika mit dem Commandeur-Captän Bering. St. Petersburg, Johann Zacharias Logan, 1793, 133 p.

Thomas C. W. Ice is where you find it. Bloomington, Bobbs-Merrill Company, 1951, 378 p.

Turner C.G. The First Americans: The Dental Evidence. National Geographic Research, 1986, vol.2(1), pp.37-46. 
Turner C. G. The Dentition of Arctic peoples. New York, Garland, 1991. 281 p.

Weyer E. M. An Aleutian Burial. Anthropological Papers of the American Museum of Natural History. New York, The American Museum of Natural History, 1929, vol.31, part 3, pp. 225-238.

Weyer E. M. Archaeological material from the village site at Hot Springs, Port Moller, Alaska. Anthropological Papers of the American Museum of Natural History. New York City, The American Museum of Natural History, 1930, vol. 31, part 4, pp. 241-279.

Zimmermann M.R. Alaskan and Aleutian Mummies. Mummies, Disease, and Ancient Cultures. Eds A. Cockburn, E. Cockburn, T. A. Reyman. Cambridge, Cambridge University Press, 1998, pp. 138-253.

Статья поступила в редакцию 30 мая 2018 г. Рекомендована в печать 12 марта 2019 г.

Received: May 30, 2018

Accepted: March 12, 2019 


\title{
The Eastern Frontier of the Gravettian in the Kostenki-Borshchevo Palaeolithic Locality, the Don Basin, Russia
}

\author{
S. N. Lisitsyn
}

For citation: Lisitsyn S.N. The Eastern Frontier of the Gravettian in the Kostenki-Borshchevo Palaeolithic Locality, the Don Basin, Russia. Vestnik of Saint Petersburg University. History, 2019, vol. 64, iss. 2, pp. 525-554. https://doi.org/10.21638/11701/spbu02.2019.208

The Gravettian cultural phenomenon refers to the middle phase of the European Upper Palaeolithic periodization (30-20 ky BP (uncal)). The previous pattern of the Gravettian in the Kostenki-Borshchevo area of the Middle Don basin yielded a two-phase periodization. The early phase was thought to be presented by Kostenki 8/II dating back to $27 \mathrm{ky} \mathrm{BP}$ (uncal). The second phase comprised the Kostenki-Avdeevo culture (the Eastern Gravettian) sites: Kostenki 1/I, Kostenki 13, 18, Kostenki 14/I (23-21 ky BP (uncal)) and five typologically particular assemblages altogether being in accordance with the late Gravettian. New data on the archaeology and absolute chronology obtained in the recent excavations enabled to clarify the Gravettian sequence as well as to integrate the local assemblages into general European taxonomy. The main advance was achieved in the defining of the middle Gravettian phase newly dated 25-24 ky BP (uncal) (sites Kostenki 4, Borshchevo 5 and probably Kostenki 9). This cultural complex was associated with the Pavlovian being determined by tools typology and in particular by the series of stone items treated with polishing. It was specified that along with the Kostenki-Avdeyevo culture the latest phase comprised Kostenki 21/III as the local final Gmelin type Gravettian formerly conjoined together with Anosovka assemblage (Kostenki 11/II). The latter was attributed to the non-Gravettian/proto-Magdalenian. Thus, the Gravettian technocomplex in the basin of the Don acquired a three-part sequence of the early (27-25 ky BP (uncal)), middle (25-24 ky BP (uncal)) and late (23-21 ky BP (uncal)) phases which corresponds to the periodization in Central Europe.

Keywords: the Middle Upper Paleolithic, the Gravettian, material culture, periodization, cultural attribution.

Sergey N. Lisitsyn - $\mathrm{PhD}$ in History, Senior researcher, Institute for the History of Material Culture, Russian Academy of Sciences, 18, Dvortsovaya nab., St. Petersburg, 191186, Russian Federation; serglis@rambler.ru

Сергей Николаевич Лисицын - канд. ист. наук, ст. науч. сотрудник, Институт истории материальной культуры РАН, Российская Федерация, 191186, Санкт-Петербург Дворцовая наб., 18; serglis@rambler.ru

The research was carried out withint the Government Research Project No. 0184-2018-0012. It was also supported by the Russian Foundation for Basic Research project No. 18-00-00837 granted to K. N. Gavrilov.

Работа выполнена в рамках реализации ФНИ ГАН по теме государственного заказа № 01842018-0012 «Древнейшие обитатели России и сопредельных стран: пути и время расселения, эволюция культуры и общества, адаптация к природной среде», а также при поддержке РФФИ, проект № 18-00-00837 КОМФИ «Культурная география верхнего палеолита центральных районов Русской равнины: восточный граветт и эпиграветт» (рук. К.Н. Гаврилов).

(C) Санкт-Петербургский государственный университет, 2019 


\title{
Восточный фронтир граветта в Костёнковско-Борщёвском районе сосредоточения палеолитических стоянок на Дону, Россия
}

\author{
С. Н. Лисицььн
}

Для цитирования: Lisitsyn S. N. The Eastern Frontier of the Gravettian in the Kostenki-Borshchevo Palaeolithic Locality, the Don Basin, Russia // Вестник Санкт-Петербургского университета. История. 2019. Т. 64. Вып. 2. С. 525-554. https://doi.org/10.21638/11701/spbu02.2019.208

Граветт как культурный феномен в европейской периодизации верхнего палеолита, относится к его средней стадии, или 30-20 тыс. л. н. в некалиброванных значениях радиоуглеродного возраста (т. л. н.). Граветтийские памятники, исследованные в КостёнковскоБорщевском районе на Среднем Дону, благодаря сочетанию культурного разнообразия комплексов с концентрированным расположением в пределах локального участка Дона, исключительно важны для изучения данной эпохи. В настоящей работе предпринята попытка ревизии периодизации местного граветта по этапам и культурным группам в свете появления новых материалов и новых 14С-датировок. Прежние обобщения по граветту Костёнковско-Борщёвского палеолитического района фокусировались на наиболее ярких комплексах, таких как памятники костёнковско-авдеевской культуры (восточный граветт). Структура местного граветта имела двучастную периодизацию. Ранняя фаза соответствовала комплексу Костёнок 8/II с датировкой 27 т. л. н. Вторая фаза включала памятники восточного граветта: Костёнки 1/I, Костёнки 13 и 18, Костёнки 14/I (23-21 т.л.н.) и еще пять обособленных комплексов, отнесенных к позднему граветту. Археологические и радиометрические данные, полученные новейшими раскопками, позволили уточнить периодизацию граветта, а также показать соотношение локальных комплексов с европейским контекстом. Главным достижением можно считать выявление фазы среднего граветта с новыми датами 25-24 т. л. н. (стоянки Костёнки 4, Борщёво 5 и, вероятно, Костёнки 9). На основании типологии орудий и специфики каменных изделий, обработанных шлифовкой, данный культурный комплекс атрибутирован как павловьен. Установлено, что наряду с костенковско-авдеевской культурой к позднейшей фазе граветта принадлежит гмелинский вариант комплекса Костенки 21/ III, который ранее соотносили с аносовским комплексом Костенок 11/II. Последний был атрибутирован как неграветтийский/протомадленский.Таким образом, технокомплекс граветта на Дону имеет трехчастную структуру, включающую фазы: раннюю (27-25 т. л.н.), среднюю (25-24 т. л. н.), и позднюю (23-21 т. л. н.), которые соответствуют периодизации граветта в Центральной Европе.

Ключевые слова: верхний палеолит, граветт, материальная культура, периодизация, культурная атрибуция.

\section{Introduction}

The Gravettian is a cultural phenomenon in the Upper Paleolithic that refers to its middle stage (30-20 ky BP (uncal)). Territorial and chronological groups of sites comprising the Gravettian technocomplex are quite different in terms of the material culture variability. However, a number of common features can be enumerated:

1) The preference of flint raw materials of exceptionally high quality.

2) Pronounced lamellar character of the stone industry. Most of the tools are made on large and medium blades, while microliths employ regular microblades.

3) Extensive use of abrupt edge retouching. 
4) Distinctive bone and ivory inventory, superior in its diversity to the instruments of other traditions.

5) Realistic zoomorphic and anthropomorphic figurines, the most typical being female full-figured Venuses.

6) No clear variation in seasonal or functional specialization of sites combined with complexity of dwelling areas.

7) Important role of the mammoth in hunting.

For a long time, the Gravettian studies had been focused on interpretating the sites of the Kostenki-Avdeevo type. Thus, a number of similar terms almost identical in meaning appeared: "Willendorf-Kostenki culture", "Kostenki culture", "Eastern Gravettian". Kostenki-Avdeevo sites-lay the foundation for the concept of cultural unity of the Central and Eastern European population, established on the Gravettian basis at the middle stage of the Upper Paleolithic. G. P. Grigoriev introduced a concise term for the aforementioned period - "the Gravettian episode"1.

Discussion on the status of this community, which encompassed modern Austria, Moravia, southern Poland, as well as the basins of the Dnieper, Don and Oka, has never yielded a definite understanding of its internal cultural variability and periodization. There exists an even greater range of opinions concerning the interpretation of external archaeological connections and the assessment of the Gravettian dynamics ${ }^{2}$. Among the sites that preceded the glacier maximum there are those on the Russian Plain which belong to the Gravettian technocomplex, but cannot be classified as part of the Eastern Gravettian in a strict sense. For instance, Molodovo 5/VII on the Dniester, Khotylevo 2 and Pushkari 1 on the Desna, Gagarino on the upper Don, a number of sites with Gravettian layers in Kostenki-Borshchevo region (hereafter referred to as KBR) on the middle Don. In recent years, similar sites have been discovered on the Russian Plain: Borshchevo 5, Troyanovo 4, Ozerovo, etc. ${ }^{3}$

\section{Periodization}

Many researchers have made attempts to systematize the Gravettian sites of the Russian plain. Kh. A. Amirkhanov introduced a classification of the main gravettoid complexes according to the degree of typological proximity ${ }^{4}$. The sites are paired based on the basis of the leading tool types (shouldered points, leaf-shaped points and Kostenki type knives) and divided into Kostenki-Avdeevo, Khotylevo-Gagarino, Kostenki-Borshchevo

${ }^{1}$ Grigorev G. P. Edinstvo Evropy v pervyi raz: gravettiiskii epizod // Vzaimodeistvie drevnikh kul'tur i tsivilizatsii i ritmy kul'turogeneza. St. Petersburg, 1994. P. 12-14.

2 Bulochnikova E. V. Vchera i segodnia poniatiia "vostochnyi gravet'en" // Vostochnyi gravett. Moscow, 1998. P. 67-73.

${ }^{3}$ Lisitsyn S. N. Khronostratigrafiia i arkheologiia stoianki Borshchevo 5 po dannym raskopok 20022003 gg. // Kostenki i ranniaia pora verkhnego paleolita Evrazii: obshchee i lokalnoe. Voronezh, 2004. P.66-79; Zalizniak L.L., Stepanchuk V.M., Vetrov D. O., Tovkailo M.T., Ozerov P.I. Gravetska stoianka Troianove 4 pid Novomirgorodom // Kam'iana doba Ukraini. Vip. 10. Kiiv, 2007. P. 102-125; Zalizniak L. L., Vetrov D. O. Nova gravetska stoianka Ozerove na Kirovogradshchini // Kam’iana doba Ukraini. Vip. 10. Kiiv, 2007. P. 56-62; Demidenko Yu. E. Gravett Bol'shogo Severnogo Prichernomoria v kontekste verkhnego paleolita Vostochnoi Evropy // Stratum plus. 2018. No. 1. P. 265-284.

4 Amirkhanov Kh.A. Vostochnyi gravett ili gravettoidnye industrii Tsentral'noi i Vostochnoi Evropy // Vostochnyi Gravett. Moscow, 1998. P. 15-34. 
and Kostenki-Aleksandrovka groups. However, only Kostenki-Avdeevo sites are considered monocultural in a strict sense. The excessive variability of the inventory of the rest of the gravettoid complexes, even in regard to the leading tools types, does not make it possible to develop a cultural periodization within the East-European community, which even G. P. Grigoryev refused to work out at the time ${ }^{5}$.

D. Yu. Nuzhnyi developed a two-stage periodization of the Ukranian Gravettian sites by splitting them into the early stage of 30-26 ky BP (uncal) (Mezhigirtsy, Molodovo 5/IXX, Oselivka 1/III-II, Voronovitsa 1/II) and the late stage of 25-22 ky BP (uncal) (Molodovo 5/VIII-VII, Korman 4/VII-VI, Molodovo 1/I, Voronovitsa 1/VI, and Babin 1). D. Yu. Nuzhny determined a distinction between the local complexes and the Kostenki-Avdeevo and Gagarino ones, while also drawing similarities between the Ukranian and the Pavlovian sites of Moravia and Khotylevo 2 on the Desna ${ }^{6}$ at the late stage. Yu. E. Demidenko ${ }^{7}$ also confirms a continuity gap between the two periods of penetration of the early and late Gravettian from Central to Eastern Europe.

M. V.Anikovich proposed that two variations of Eastern Gravettian could have been developing in parallel: "Willendorf-Kostenki-Zaraisk" and "Pavlovo-Khotylevo-Gagarino" within the rough approximation of 24-16 ky BP (uncal). Apart from that, he substantiated the coexistence of the Kostenki-Avdeevo archaeological culture with the Anosovka-Gmelinskaia culture in the KBR (Kostenki 11/II, Kostenki 21/III, Kostenki 5/III) ${ }^{8}$. Kostenki 4/I, Kostenki 9 and Borshchevo 5/I belong to late gravettoid sites with pronounced Aurignacian features. According to M. V. Anikovich, Kostenki 8/II and Kostenki 4/II stand apart from other Gravettian complexes.

A. A. Sinitsyn made an attempt to assess the Gravettian systematics comprehensively, on the basis of the dominant elements that determine cultural identification. Kostenki 4/II, Kostenki 21/III, Borshchevo 5/I were recognized as the most definite Gravettian, according to accepted European practice (differentiation of blade blanks, presence of the Gravettian points and backed bladelets). Kostenki 11/2 least of all corresponded to the given criteria due to the presence of knives similar to those of Federmesser culture (Anosovka knives). According to A. A. Sinitsyn, there is no cultural continuity between the second layer of Kostenki 8 as the earliest Gravettian complex of a Western European or Mediterranean appearance (28-27 ky BP (uncal)) and the late Gravettian. A. A. Sinitsyn excluded Kostenki-Avdeevo from the Gravettian sites since here specific Kostenki tools (shouldered points, Kostenki type knives) are prevalent over the generally Gravettian ones ${ }^{9}$. Thus, according to Sinitsyn, the Gravettian on the Middle Don is represented discretely - as a single early manifestation (Kostenki 8/II), followed by three local varia-

${ }^{5}$ Grigorev G. P. Otnoshenie vostochnogo gravetena k Zapadu // Vostochnyi gravett. Moscow, 1998. P. 73-80.

${ }^{6}$ Nuzhnyi D. Y. The industrial variability of the eastern Gravettian assemblages of Ukraine // Quartär. 2009. N 56. P. 159-174.

7 Demidenko Yu.E. Gravett Bol'shogo Severnogo Prichernomoria v kontekste verkhnego paleolita Vostochnoi Evropy.

8 Anikovich M. V. Dnepro-Donskaia istoriko-kul'turnaia oblast' okhotnikov na mamontov: ot "vostochnogo gravetta" k "vostochnomu epigravettu" // Vostochnyi gravett. Moscow, 1998. P.35-66; Anikovich M. V., Popov V. V., Platonova N. I. Paleolit Kostenkovsko-Borshchevskogo raiona v kontekste verkhnego paleolita Evropy. St. Petersburg, 2008. P. 175.

9 Sinitsyn A.A. Gravett Kostenok v kontekste gravetta Vostochnoi Evropy // Problemy zaseleniia severo-zapada Vostochnoi Evropy v verkhnem i finalnom paleolite (kul'turno-istoricheskie protsessy). St. Petersburg, 2013. P. 4-32. 
tions of the late Gravettian. As a result, the researcher rejects the concept of the Gravettian episode as a unifying event in the cultural history of Central and Eastern Europe since the concept is meaningless without respective eponymous complexes.

K.N. Gavrilov denotes both common and distinguishing features of the Gravettian complexes of Central and Eastern Europe. In particular, he draws attention to the proximity of the needle-shaped micropoints of the Kostenki 8/II complex to microblades with pointed ends, ventrally retouched along the edge opposite to the backed one, found in the $10^{\text {th }}$ layer of Molodovo 5 and at the Dolní Vestonice I and II sites, as well as at the early Gravettian complexes of the Swabian Jura. In the Kostenki 8/II inventory, he emphasizes the presence of both Pavlovian elements (asymmetric trapezia) and Aurignacian ones (carinated scrapers, twisted profile segments).

According to Gavrilov, the sites' unity is combined with their internal cultural variability: in this case the Eastern Gravettian implies the Eastern European Gravettian in a broad sense. The researcher concludes that it is possible to "assume that the Eastern Gravettian was formed on the Russian Plain due to complex processes in the indigenous population culture combined with the influence or reciprocal contacts with the culture/ population of Central Europe"10.

Thus, the KBR Gravettian sites are essential in understanding the European specifics of the Upper Paleolithic due to an unusual combination of their cultural diversity with a concentrated location within the local area of the Don ${ }^{11}$.

\section{The discussion on cultural differentiation of the Gravettian}

Kostenki-Avdeevo culture has always been considered the meaningful core of the KBR Gravettian episode, while the rest of the complexes have been compared to it depending on the degree of their cultural proximity. Apparently, it is the inflexibility of such a construction that led to the fact that no detailed periodization has yet been created for the Kostenki Gravettian, given a fairly large number of artefacts.

This paper attempts to revise the KBR Gravettian classification in the light of new materials and new 14C-datings, which allows us to propose a periodization scheme. Classification of the KBR Gravettian stone industries by culturally separate groups is generally well established, although it needs some adjustment. From my point of view, five separate cultural units can be distinguished.

\section{Telmanskaia complex (Kostenki 8/II)}

The complex is represented by a single site - Kostenki 8/II (Telmanskaia site). The second cultural layer was identified in 1950 by A. N. Rogachev and studied in the 1950$1970 \mathrm{~s}$ on an area of $530 \mathrm{~m}^{212}$. The finds were discovered in a reduced humified soil with

${ }^{10}$ Gavrilov K. N. Migratsiia, diffuziia, razvitie? K voprosu o proiskhozhdenii vostochnogo gravetta na Russkoi ravnine // Stratum Plus. 2016. No. 1. P. 45.

${ }^{11}$ Lisitsyn S.N. O variabelnosti gravettiiskogo epizoda nakanune poslednego lednikovogo maksimuma: vzgliad iz Kostenok // Verkhnii paleolit Severnoi Evrazii i Ameriki: pamiatniki, kul'tury, traditsii. Ser. "Archaeologica Petropolitana". St. Petersburg, 2014. P. 179-186.

${ }_{12}$ Rogachev A.N. Mnogosloinye stoianki Kostenkovsko-Borshevskogo raiona na Donu i problema razvitiia kul'tury v epokhu verkhnego paleolita na Russkoi ravnine // Materialy i issledovaniia po arkheologii 
ferruginous and carbonate mineralization. Three clusters of finds could be identified. Two of them are of a round shape and have a hearth in the center, while the third one is oval and has three hearth structures (Fig. 1: A). These clusters are considered to be remnants of light ground dwellings ${ }^{13}$. Drawing on the analysis of the flint inventory ( $\left.\mathrm{n}>23,000\right)$, L. M.Litovchenko (Chelidze) proposed to single out a separate Kostenki-Telmanskaia archaeological culture ${ }^{14}$. Recent research has proceeded with the study of the second cultural layer of this site. Another cluster of finds with two hearths was discovered on an area of $56 \mathrm{~m}^{2}$, yielding a new collection of artefacts $(\mathrm{n}>4000)^{15}$.

Kostenki 8/II inventory has a pronounced microlithoid character: the instruments are made on regular thin blades and microblades (Fig. 1: B). Backed points are prevalent, as well as burins of all types, including multiple burins, which could have been used as cores for microblades. Scrapers are few in number and are represented mainly by simple end scrapers on blades; there are several carinated ones, as well. Among common tools, there are miniature narrow microgravettes, which are intensely backed and have one or both asymmetrical ends ventrally retouched (needle-shaped points). No leaf-shaped points were found. This complex is peculiar due to the presence of 9 trapezia and 14 segments on microblades (see Fig. 1: B, 3-6, 35-36). Bone tools are represented by awls and lissoirs made of ribs and ivory. Among adornments, the following were found: cylindrical beads made of small bones ornamented by parallel cuts, round double-eyed plaques and various pendants of mammoth tusk.

Artefacts similar ro Kostenki 8/II can be found among the early European Gravettian sites: Grotta Paglicci (layer 23a) in Italy, Geissenklösterle (layer Ic) in Germany, Abri Pataud (layer 5) in France, Willendorf 2 sites (layer 5) in Austria and Molodovo 5 (layers 9,10 ) in Ukraine. Their $14 \mathrm{C}$ age is defined as $31-27 \mathrm{ky} \mathrm{BP}$ (uncal) ${ }^{16}$. According to M. V. Anikovich, layer II of Kostenki 8 was similar to the scarce artefacts found in layer IV of Kostenki 11 and to the Northern point of the same site, so they could be united into a separate Anosovka-Telman archaeological culture ${ }^{17}$. I believe the available data is insufficient for such unification, in terms of both stratigraphic and typological context.

SSSR. 1957. No. 59. P. 47-56; Paleolit Kostenkovsko-Borshchevskogo raiona na Donu. 1879-1979: nekotorye itogi polevykh issledovanii / eds N. D. Praslov, A. N. Rogachev. Leningrad, 1982. P. 101-108.

13 Paleolit Kostenkovsko-Borshchevskogo raiona na Donu... P. 101.

${ }^{14}$ Chelidze L.M. Telmanskaia stoianka i nekotorye voprosy razvitiia verkhnepaleoliticheskoi kul'tury v Vostochnoi Evrope. Avtoref. dis. ... kand. ist. nauk. Leningrad, 1968; Litovchenko L.M. Telmanskaia paleoliticheskaia stoianka (II kul'turnyi sloi) // Sovetskaia arkheologiia. 1969. No. 3. P. 123.

${ }^{15}$ Dudin A.E., Pustovalov A. Yu., Platonova N.I. Vtoroi kulturnyi sloi stoianki Kostenki-8 (Telmanskaia): struktura, ob”ekty mikrostratigrafii // Vestnik NGU. Seriia: Istoriia, filologiia. 2016. Vol. 15. No.3: Arkheologiia i etnografiia. P. 41-52.

${ }^{16}$ Moreau L. Le Gravettien ancient d'Europe centrale revisité: mise au point et perspectives // Lanthropologie. 2012. Vol.116. P.609-638; Sinitsyn A.A. Gravett Kostenok v kontekste gravetta Vostochnoi Evropy // Problemy zaseleniia severo-zapada Vostochnoi Evropy v verkhnem i final'nom paleolite (kul'turno-istoricheskie protsessy). St. Petersburg, 2013. P. 13; Gavrilov K. N. Migratsiia, diffuziia, razvitie? K voprosu o proiskhozhdenii vostochnogo gravetta na Russkoi ravnine // Stratum plus. 2016. No. 1. P. 29-50; Demidenko Yu.E. Gravett Bol'shogo Severnogo Prichernomoria v kontekste verkhnego paleolita Vostochnoi Evropy // Stratum plus. 2018. No. 1. P. 265-284.

${ }_{17}$ Anikovich M. V., Popov V.V., Platonova N.I. Paleolit Kostenkovsko-Borshchevskogo raiona v kontekste verkhnego paleolita Evropy. St. Petersburg, 2008. P. 128. 


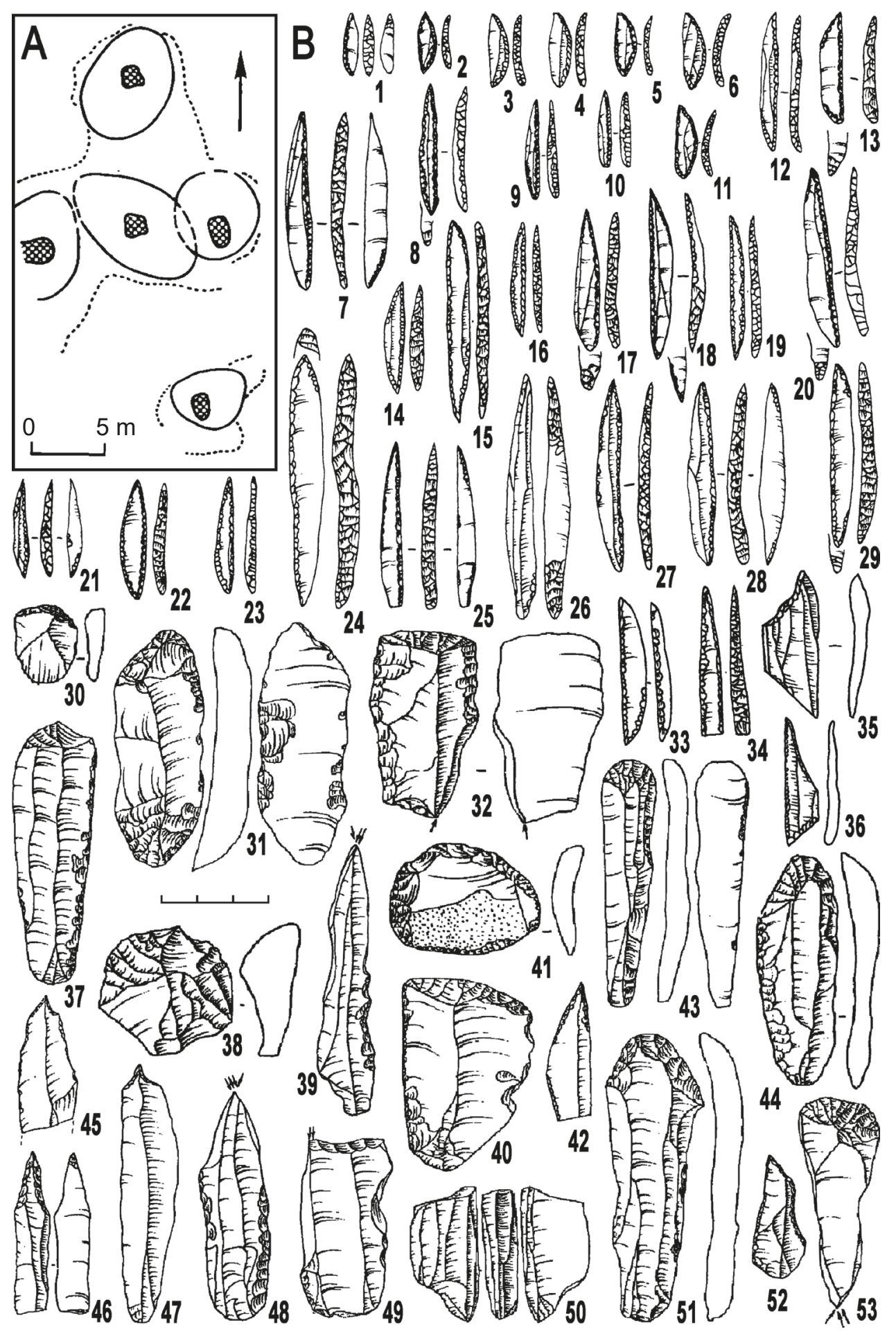

Fig. 1. Kostenki 8, cultural layer II:

A - contours of dwellings (from: [Sergin, 1988]); B — the stone assemblage [Sinitsyn, 2013] 


\section{Aleksandrovka complex (Kostenki 4, Borshchevo 5/I, Kostenki 9)}

Kostenki 4 (Aleksandrovka) is a two-layer site with both cultural layers (and horizons, according to A.N. Rogachev) containing backed points. In 1927, the site was discovered by S.N.Zamyatnin and was further studied by A. N. Rogachev. The finds were deposited in the loess loam sediments on the first terrace. On the area of over $900 \mathrm{~m}^{2}$ the remains of a settlement consisted of two (northern and southern) long-drawn objects with a number of hearths along the central axis parallel to each other were discovered. Two round objects with a firepit in the center were adjacent to the northern object and partially overlapping it. Subsequently, A.N. Rogachev attributed them to the dwellings (western and eastern) of the upper horizon (Fig. 2: A-B). Long objects with multiple hearths were, in turn, associated with the dwellings of the lower horizon. Both layers of Kosteki 4 with dwellings of various types merged along the strike ${ }^{18}$.

A. N. Rogachev divided the finds into horizons years after the completion of the excavation, therefore their purity is relative. It is evident when comparing published data. Given the varying size of the collections of the upper $(\mathrm{n} \sim 14,500)$ and lower $(\mathrm{n} \sim 60,000)$ cultural layers, the anomalous ratio of individual tool types is striking. For instance, the number of burins in a smaller inventory of the upper layer $(n=260)$ is half as much as their number in the lower layer $(\mathrm{n}=158)$. On the contrary, the number of scrapers in the upper layer $(n=76)$, is three times lower compared to the lower one $(n=212)$. All hammer-stones and pestle-stones $(n=43)$, microblades and micropoints $(n=404)$, as well as cores on flakes $(\mathrm{n} \sim 179)$ are attributed to the upper layer, while blades and points on blades with a vertically retouched backed edge $(n=2604)$, as well as chisel tools $(\mathrm{n}=1210)-$ to the lower layer.

The peculiarity of the toolkit in each of the Kostenki 4 layers is determined by variations in specific tool types. According to A. N. Rogachev, the upper layer includes micropoints with one straight backed edge and another semi-convex edge and ends ventrally retouched (see Fig. 2: B, 1-4). He compared these tools with the needle-shaped points from the second cultural layer of Kostenki 8. The second layer of Kostenki 4 includes the Gravettian points, "awl-shaped points" with a dorsally retouched sharp tip and bitruncated backed bladelets. Among the latter, there is a series $(n=25)$ of denticulated items (see Fig. 2: B, 17). It is evident that backed tools are clearly divided into cultural layers by the blank size (microblades and blades) and the end retouching techniques (ventral and dorsal).

In regard to a series of leaf-shaped points of the upper layer $(n=191)$, A. N. Rogachev specified a particular group of tools, in which the haft element was designed as a dihedral burin ("Aleksandrovka points" - see Fig. 2: B, 6, 11). Two of them are traced back as drawing knives ${ }^{19}$. M.N. Zheltova ${ }^{20}$ determined that no more than ten artefacts could be attributed to the classical points of this type, not taking debitage into account. Concurrently, they are morphologically heterogeneous and multifunctional. At least two items were associated with the lower but not upper cultural layer of the site.

${ }_{18}$ Rogachev A.N. Aleksandrovskoe poselenie drevnekamennogo veka u sela Kostenki na Donu // Materialy i issledovaniia po arkheologii SSSR. 1955. No. 45. P. 19-24.

19 Semenov S. A. Pervobytnaia tekhnika (opyt izucheniia drevneishikh orudii i izdelii po sledam raboty) // Materialy i issledovaniia po arkheologii SSSR. 1957. No. 54. P. 135.

${ }_{20}$ Zheltova M. N. Ostriia aleksandrovskogo tipa: kontekst, morfologiia, funktsiia // Paleolit i Mezolit Vostochnoi Evropy. Sbornik statei v chest' 60-letiia Kh. A. Amirkhanova. Moscow, 2011. P. 226-234. 


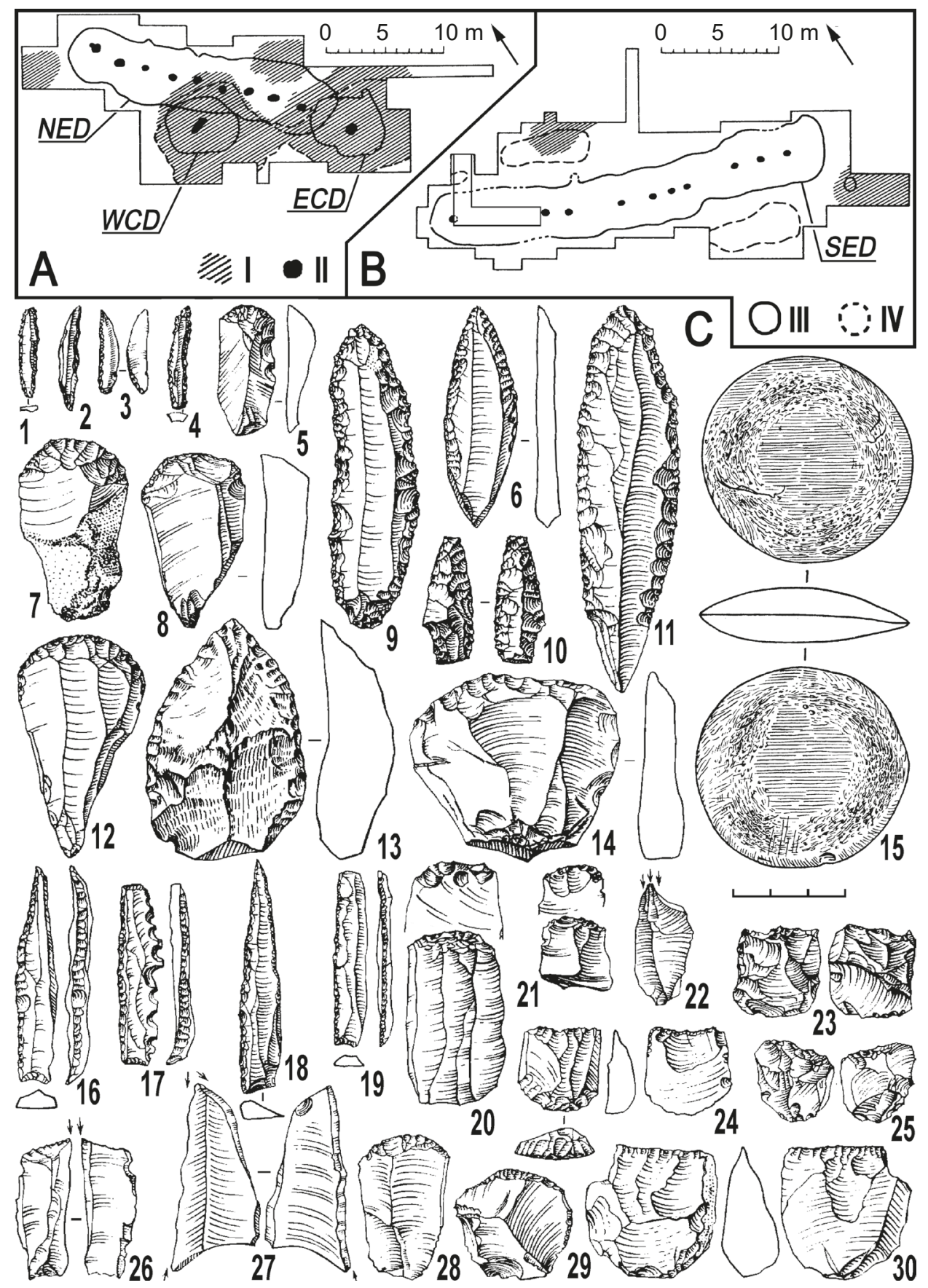

Fig. 2. Kostenki 4:

A - NED - north elongate dwelling (the lower cultural layer), WCD and ECD - west and east circular dwellings (the upper cultural layer); B - SED - south elongate dwelling (the lower cultural layer). I - extensions of the upper cultural layer; II - hearths; III - contours of dwellings; IV - finds accumulations; C - the stone assemblage: 1-15 - from the upper cultural layer; 16-30 - from the lower cultural layer [Rogachev, 1955] 
Stone inventory of upper layer of Kostenki 4 can be distinguished from the lower one by the presence of bifacial points $(n=4)$. Possibly the most impressive item is a massive laurel-leaf biface $20 \mathrm{~cm}$ in length ${ }^{21}$. The other three are small subtriangular fragments of points or knives bearing typical cutting edge polishing traces. One of them is considered a shouldered point, however, its shape and retouching technique have little in common with the Eastern Gravettian points (see Fig. 2: B, 10).

It should be noted that by their proportions the Kostenki 4 points belong to thick bifaces, for example, contrary to the same Kostenki-Streletsky points, which show typical features of thin bifaces ${ }^{22}$. The morphologically perfect "solutrean" point of the Aleksandrovka site is represented by a single item, which indicates that bifaces as a whole are an alien element in that stone industry. It could be possibly explained by the fact that the site is located on the same cape as a Bronze Age settlement. Ceramics from this settlement is also included in the Kostenki 4 collection. Massive bifaces are most characteristic of the Aeneolithic or the Bronze Age. Faunal assemblage of Kostenki 4 includes bones of the Holocene animals (wild boar, corsac fox, beaver, red deer), embedded into the Paleolithic horizon as a result of later intrusions ${ }^{23}$. Other peculiar features of the composition of the finds in Kostenki 4, for example, the extraordinary variety of stone raw materials noted by A.N. Rogachev, can also be explained by the stratigraphic proximity of cultural items of the Bronze Age and the Palaeolithic ${ }^{24}$.

Finally, Kostenki 4/I materials can be distinguished by the presence of a series of polished objects made of soft stone. These include grinding slabs, quartzite grindstones, slate biconvex discs (see Fig. 2: B, 15), rectangular billets, "polyhedral" wands and bullet-shaped points. They are found mainly within round dwellings or nearby, in the northern oblong dwelling. One fragment of a polished tool and 17 slate flakes, possibly connected to the manufacturing of such tools, were found in the southern oblong dwelling, in which, as previously believed, only the lower layer artefacts were found ${ }^{25}$.

Osseous inventory of Kostenki 4 includes awls, lissoirs, wands, points, a mammoth ivory disc. The adornments are represented by double-headed beads, an ivory ornamented fibula with a perforated head, a pendant made on tubular bone pieces and marl pendants. Works of art include four ornamented ivory items, including a schematic anthropomorphic figurine with a dotted pattern, seven schematic zoomorphic marl figurines, an animal head and a fragment of limestone face figurine. Most of these artefacts belong to the upper cultural layer ${ }^{26}$.

Description of the Kostenki 4 materials shows that the probable intrusion of the Bronze Age artefacts, as well as the composition of the collection made a certain impact on A.N.Rogachev's interpretation of the results of his own work at the Aleksandrovka

${ }^{21}$ Rogachev A. N. Aleksandrovskoe poselenie drevnekamennogo veka u sela Kostenki na Donu. P. 52.

${ }^{22}$ Girya E. Yu. Tekhnologicheskii analiz kamennykh industrii. Metodika mikro-makroanaliza drevnikh orudii truda. St. Petersburg, 1997. P. 158.

${ }^{23}$ Zheltova M.N., Burova N.D. Sopostavlenie zhilykh kompleksov Kostenok 4 na osnove izucheniia osteologicheskikh kollektsii // Stratum plus. 2014. No. 1. P. 111-145.

${ }_{24}$ Rogachev A. N. Aleksandrovskoe poselenie drevnekamennogo veka u sela Kostenki na Donu. P. 37.

25 Zheltova M. N.: 1) Mesto kamennykh industrii Kostenok $4 \mathrm{v}$ kontekste verkhnego paleolita Evropy // Problemy zaseleniia severo-zapada Vostochnoi Evropy v verkhnem i final'nom paleolite (kul'turnoistoricheskie protsessy). St. Petersburg, 2013. P.86-109; 2) Kostenki 4: opyt rekonstruktsii uchastka kul'turnogo sloia // Arkheologicheskie vesti. 2014. No. 20. P. 55-68.

${ }^{26}$ Rogachev A. N. Aleksandrovskoe poselenie drevnekamennogo veka u sela Kostenki na Donu. P. $78-$ $88,146-148$. 
site $^{27}$. It is evident that dividing the collection into two typologically opposite groups of inventory based on certain culture-determining categories (micro- and macroblanks, core types, hammer-stones and pestle-stones, points and bifaces, chisels, etc.) is outdated.

Ultimately, separating these two cultural layers is possible not through a classification of finds, but through understanding how these artefact types are connected to various types of dwellings - long, with multiple hearths, and round, with a single firepit. As M.N.Zheltova demonstrates in her work ${ }^{28}$, neither does establishing such a connection result in a conclusive distinction, nor does it allow to associate one or the other inventory with only one type of dwelling. It is important to note that round dwellings with a single hearth are widespread throughout the Stone Age, while the elongated ones are unique in their size or design. The dimensions of the long southern $(32 \times 5.5 \mathrm{~m})$ and long northern $(23 \times 5.5 \mathrm{~m})$ dwellings of Kostenki 4 imply the need to install supports for the roof. However, A.N. Rogachev recorded only four sufficiently deep $(15-30 \mathrm{~cm})$ holes in the floor of the southern dwelling, which would have been suitable for supporting pillars ${ }^{29}$; there were no such holes found in the northern dwelling. Both in the elongated and round dwellings, numerous shallow holes were found near the hearth zone and were quite similar. Apparently, understanding the problems associated with the reconstruction of the oblong dwellings, the researcher of this site suggested that they consisted of three joint sections, each with its own roof. Nonetheless, by studying planigraphy, M.N.Zheltova ${ }^{30}$ drew a conclusion that the eastern round dwelling of the upper layer was either another section of the northern oblong one or built on its ruins. Thus, the only western round dwelling stands out from the group of dwellings, due to the fact that it is located sideways, outside the central axis of the long northern dwelling (see Fig. 2: A).

I believe it would be more reasonable to regard the Aleksandrovka site as a settlement structure with traces of multiple visits. In the field practice of the Stone Age, determining contours of constructions within settlements with multiple hearths poses a challenge. For instance, in the case of Magdalenian settlements, which were thoroughly excavated, it is extremely difficult to separate such palimpsests containing remains of several light dwellings at once ${ }^{31}$. Partial overlapping of dwellings results in complex structures with multiple hearths. Such dwelling sites stretch along the edge of a coastal terrace for dozens of meters,

${ }^{27}$ Rogachev A. N.: 1) Paleoliticheskoe poselenie Kostenki IV // Kratkie soobshcheniia instituta istorii materialnoi kul'tury. 1940. Iss. IV. P. 36-41;2) Aleksandrovskoe poselenie drevnekamennogo veka u sela Kostenki na Donu. P. 152-155.

28 Zheltova M. N.: 1) Mesto kamennykh industrii Kostenok 4 v kontekste verkhnego paleolita Evropy // Problemy zaseleniia severo-zapada Vostochnoi Evropy v verkhnem i final'nom paleolite (kul'turnoistoricheskie protsessy). P. 86-109; 2) Kostenki 4: opyt rekonstruktsii uchastka kul'turnogo sloia. P. 55-68; 3) Zheltova M. N. Planigraficheskii analiz zhilykh kompleksov stoianki Kostenki 4. Avtoref. dis. ... kand. ist. nauk. St. Petersburg, 2015; 4) Problema khronologicheskogo i kul'turnogo edinstva materialov nekotorykh kostenkovskikh stoianok i vozmozhnye metody ee resheniia // Estestvennonauchnye metody v izuchenii i sokhranenii pamiatnikov Kostenkovsko-Borshchevskogo arkheologicheskogo raiona. Voronezh, 2017. P. 124-139.

29 Rogachev A. N. Aleksandrovskoe poselenie drevnekamennogo veka u sela Kostenki na Donu. P. 89115 .

30 Zheltova M.N. Kostenki-4: vzaimoraspolozhenie ob"ektov v prostranstve i vremeni (analiz kul'turnogo sloia) // Arkheologiia, etnografiia i antropologiia Evrazii. 2009. No. 2(38). P. 19-27.

${ }^{31}$ Leesch D., Bullinger J. Identifying dwellings in Upper Palaeolithic open-air sites: the Magdalenian site at Monruz and its contribution to analysing palimpsests // A mind set on flint. Studies in honour of Dick Stapert (Groningen Archaeological Studies 16) / eds M.Niekus, R. Barton, M.Street, T. Terberger. Groningen, 2012. P. 165-181. 
which is consistent with the idea that the KBR Gravettian settlements are connected to the coastal terrains associated with the flood activity of the Don in the Pleistocene ${ }^{32}$.

The case of Kostenki 4 is not unique: according to I. I. Razgildeeva ${ }^{33}$, the Palaeolithic site of Studenoe 2 in the Transbaikal region demonstrates a similar overlapping of dwellings together with an adjacent household zone. Similar to Kostenki 4, a construction stretching parallel to the river bank was found. Previously it had been considered as an elongated dwelling space with 6 hearths ${ }^{34}$. However, a planigraphic analysis showed that the artefact assemblages were associated with separate hearths that had various asynchronous $14 \mathrm{C}$-datings.

Thus, stratigraphically and planigraphically merged cultural items of Kostenki 4 belong to a settlement, which contains artefacts of multiple habitation periods of a single culturally unified population. In 1959, at the northern point of the site, excavation led by N.K. Anisyutkin revealed a horizon of finds with materials from the "lower" cultural layer of Kostenki 4, which included tools characteristic of the "upper" layer: micropoints, microblades with fine retouching and secondary end cores ${ }^{35}$. Types of tools characteristic of both cultural layers of the Aleksandrovka site were identified in the inventory of Borschevo $5 / \mathrm{I}$ and Kostenki $9^{36}$, where they were also combined together.

Borshchevo 5/I. The site of Borshchevo 5 (studied by the author since 1998) belongs to the ravine cape of the second terrace. The upper Gravettian layer of Borshchevo 5 has bedding levels (Ia and Ib), corresponding to two paleosoils, which are located in the loess loam strata. Layer Ib is deposited in situ, while the overlying Ia shows signs of dislocation along the slope. Approximately $140 \mathrm{~m}^{2}$ were uncovered. A circular accumulation of finds was discovered in the central area of the cape. With a diameter of $5.5 \mathrm{~m}$, it has the remains of an open hearth in the center, which can be interpreted as the remnants of a light dwelling (Fig. 3: A).

The stone inventory of the upper cultural layer $(n>3000)$ is represented by finds from horizons Ia and Ib, which are comparable in volume. Almost all the artefacts are concentrated within the dwelling, with only single finds outside of it. The composition of the finds of both horizons is identical down to the percentage of the main tool types ${ }^{37}$. The industry is lamellar, but not microlithoid (Fig. 3: B). Among the secondary treated tools, the following types are prevalent: backed microblades with untreated or transversely ventrally retouched ends, as well as micropoints. The latter are represented by microgravettes and flechettes with a trimmed haft or - less often - tip (see Fig. 3: B, 8-10, 14, 19).

${ }^{32}$ Lisitsyn S. N. Epokha gravetta v Kostenkakh: kulturnaia istoriia i paleolandshaft // Puti evoliutsionnoi geografii. Moscow, 2016. P. 687-692.

33 Razgildeeva I.I. Planigrafiia shestiochazhnogo kompleksa pozdnepaleoliticheskogo poseleniia Studenoe-2 v Zabaikale // Stratum plus. 2016. No. 1. P. 243-263.

${ }^{34}$ Konstantinov A. M. Drevnie zhilishcha Zabaikal'ia (paleolit, mezolit). Novosibirsk, 2001. P. 96-110.

35 Anisiutkin N. K. Severnyi punkt stoianki Kostenki 4 i kul'turno-khronologicheskaia interpretatsiia pamiatnika // Kostenki i ranniaia pora verkhnego paleolita Evrazii: obshchee i lokal'noe . Materialy mezhdunarodnoi konferentsii, posviashchennoi 125-letiiu otkrytiia paleolita v Kostenkakh. St. Petersburg, 2006. P. 101-113.

36 Lisitsyn S.N.: 1) Gravettiiskii kompleks stoianki Borshchevo 5 v Kostenkovsko-Borshchevskom raione na Donu // Paleolit i Mezolit Vostochnoi Evropy. Moscow, 2011. P. 204-225; 2) The late Gravettian of Borshevo 5 in the context of the Kostenki-Borshevo sites (Don basin, Russia) // Quaternary International. Vol.359-360. P.372-383.

37 Lisitsyn S.N. The late Gravettian of Borshchevo 5 in the context of the Kostenki-Borshevo sites (Don Basin, Russia). P. 372-383. 

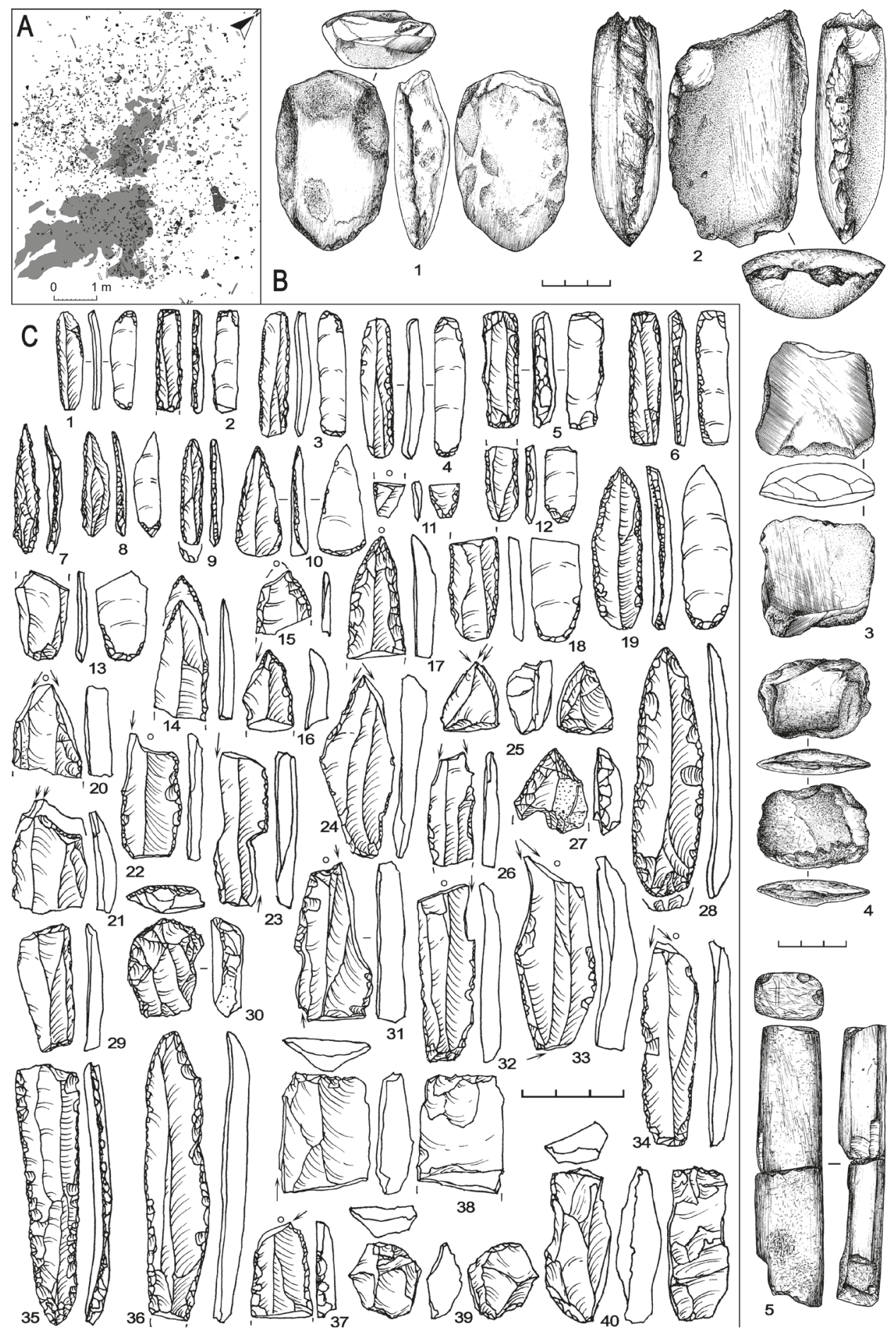

Fig. 3. Borshchevo 5, the upper cultural layer:

$\mathrm{A}-$ accumulation of finds in the dwelling; $\mathrm{B}-$ the polished pieces; $\mathrm{C}-$ the stone assemblage (drawing by the author) 
Burins, mainly angular and dihedral ones, are predominant over scrapers. Among other numerous tool types are chisels and massive leaf-shaped points on blades with a retouched contour, sometimes combined with burins.

The complex is peculiar due to the presence of 5 artefacts treated with grinding. An axe and an adze with hammered chopping edge (see Fig. 3: B, 2-3) were made of silicified dolomite. A heavily damaged biconvex disc (Fig. 3: B, 4) and a wand, quadrangular in cross-section and, judging by the traces, used as an anvil with two applied parts (see Fig. 3: B, 5) were made of slate. Another artefact, made of a concave-convex quartzite oval pebble, was treated with pecking and polished (see Fig. 3: B, 1). Ground tools are generally similar to those found in Kostenki 4. Ivory tools are scarce: mattocks made of a mammoth rib and tusk, simple awls. Bullet-shaped points were also made of a tusk, as well as lissoirs, double-headed beads, two daggers and an anthropomorphic figurine, which is morphologically similar to the Kostenki 4 one ${ }^{38}$.

Kostenki 9. Kostenki 9 site, discovered by P.P.Efimenko in 1937, belongs to the cape of the second terrace of the Don, not particularly prominent in the relief. In 1959, A. N. Rogachev discovered a lens of cultural remains with a closed eastern contour which were concentrated around a cindery hearth in the center (fig. 4: A). It was interpreted as an aboveground dwelling with a diameter of 5-6 m. In 2006-2007, A. V.Popov and A. Yu. Pustovalov uncovered another lens of a cultural layer, belonging to the upper part of loess loam and obtained a small collection of artefacts, including a polished slate disc fully analogous to the finds from Kostenki 4 and Borshchevo 5 (Fig. 4: B, 24) ${ }^{39}$.

The main collection of the 1937 and 1959 excavations ( $\mathrm{n}$ 3000) is published. Almost all of the tools of Kostenki 9 are made on blades and microblades (see Fig. 4: B), with the exception of a few scrapers on lamellar flakes. The main burin types are angular and dihedral, to a lesser extent the ones on truncation. A series of chisels is found in the collection. Large leaf-shaped points with a marginal retouch along the contour stand out in the assemblage. Backed points are microgravettes made on microblades with a ventrally retouched haft, as well as flechettes similar to the Borshchevo ones. Backed microblades have the shape of elongated rectangles, predominantly with a ventral trimming on the ends.

Apart from the flint artefacts, the assemblage includes fragments of slate tools with polishing traces, two cone-shaped slate wands, subquadrangular in cross-section polished over the entire surface (see Fig. 4: B, 19-22), as well as a marl zooomorphic piece of unclear morphology (see Fig. 4: B, 23). Osseous tools are scarse: a lissoir made of a mammoth $\mathrm{rib}$ and two fragmented ivory wands ${ }^{40}$.

Cultural remains of Kostenki 9 are typologically similar to Borshchevo 5 and Kostenki 4, which allows us to assume that they belong to the same culture. Another similar trait is the presence of artefacts made of soft stone and treated by polishing (especially biconvex discs). The absence of the Eastern Gravettian markers, that is a series of shouldered points and Kostenki type knives, is also indicative of this.

I believe it is justified to compare sites like Borshchevo 5/I, Kostenki 9 and Kostenki 4/I-II with the Pavlovian culture of the Central Europe, and in particular with the most

38 Lisitsyn S. N. Gravettiiskaia statuetka iz bivnia mamonta so stoianki Borshchevo-5 // V (XXI) Vserossiiskii arkheologicheskii s"ezd. Barnaul, 2017. P. 627-628.

39 The author is grateful to A. Yu. Pustovalov for the opportunity to study materials from the test pits of 2006-2007.

${ }^{40}$ Litouchanka L.M. Paleolitichnaia staianka Biruchy Log (Kastsenki IX) // Vestsi AN BSSR. Ser. gramad. navuk. 1966. № 3. P. 110-115. 

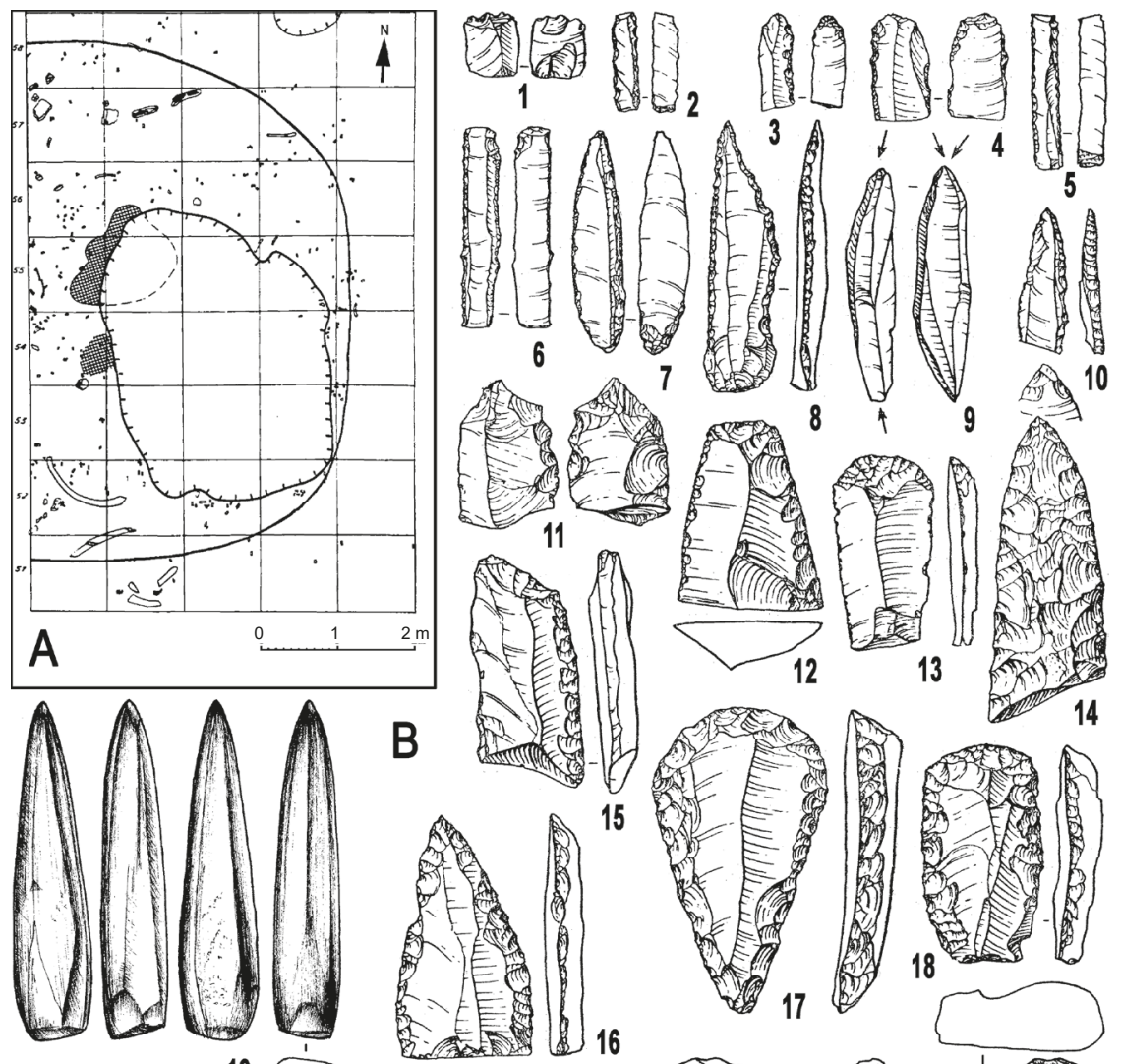

15
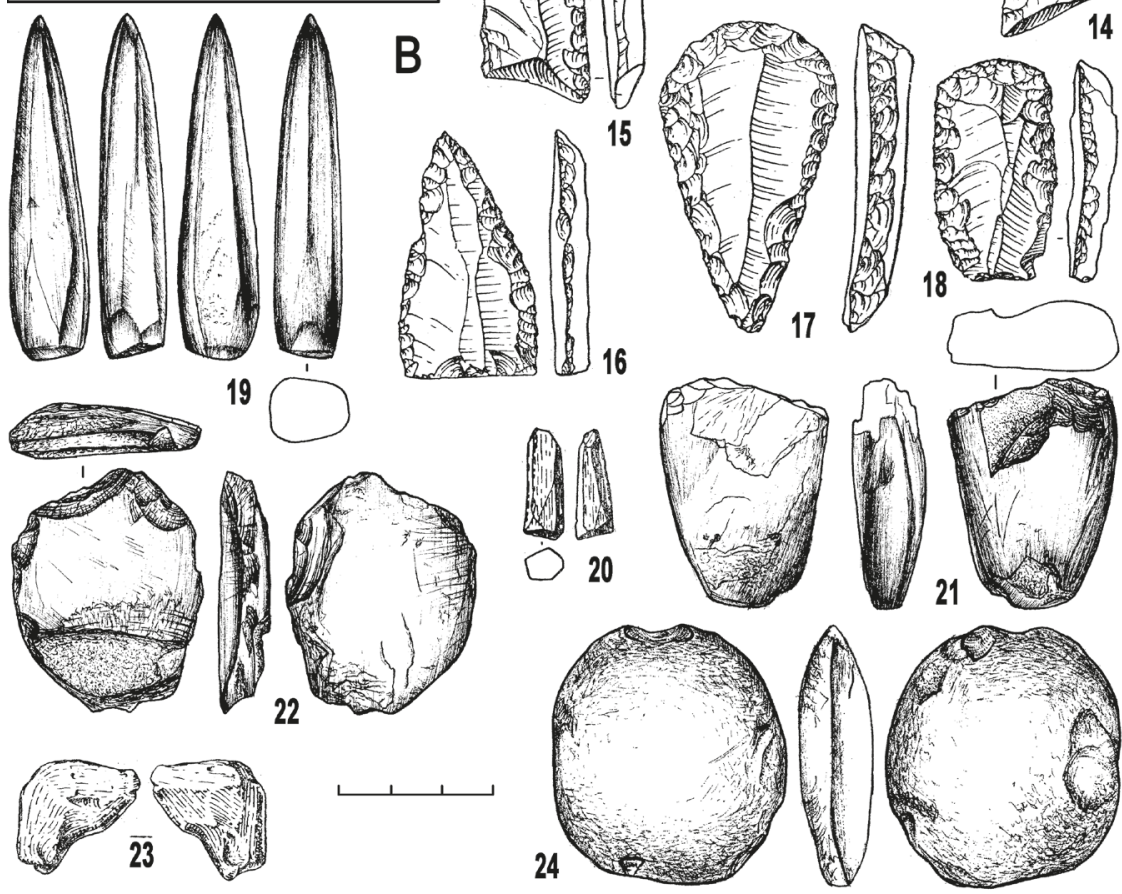

Fig. 4. Kostenki 9:

A - the dwelling in the excavations of A.N. Rogachev, 1959; B - the stone assemblage [Paleolit Kostenkovsko-Borshchevskogo raiona na Donu..., 1982 with additions]

chronologically recent complex that dates to 25,000-22,000 years BP, i. e. with the upper cultural layer of Milovice 1 site in Moravia ${ }^{41}$.

${ }^{41}$ Milovice, site of the mammoth people below the Pavlov hills: the question of mammoth bone structures // Studies in Anthropology, Palaeoethnology and Quaternary Geology. Vol. 27, ns 19. Brno, 2009. P. 161-211. 
Milovice has a full range of artefacts characteristic of Borshchevo 5/I, Kostenki 4 and Kostenki 9, given its greater typological variety. Other late Pavlovian sites (26,000$25,000 \mathrm{ky} \mathrm{BP}$ (uncal)), which are closer geographically, albeit not so remarkable, can also provide analogies to the Milovice finds. Among these are the Gravettian layer of the Kašov site in Slovakia ${ }^{42}$ and the Jakšice 2 site in Poland ${ }^{43}, 3-4$ layers of the Grub-Kranwetberg site in Austria ${ }^{44}$ and, possibly, other undated sites of the late Pavlovian ${ }^{45}$.

Polishing in production of stone tools is specific to the Aleksandrovka cultural complex, and some similarities in that respect can be drawn only with the Pavlovian sites ${ }^{46}$. Generally speaking, production of polished tools is a differentiating factor of the Moravian Gravettian sites (Pavlov, Dolní Vestonice, Przhedmost, Trenčianske Bohuslavice), which distinguishes Pavlovian sites from the rest of the Gravettian complexes. Pavlov $1^{47}$ has the most exhaustive collection of such tools. Upon obtaining new 14C-datings the eponymous Pavlovian site is considered a settlement of recurrent habitation - from the late Aurignacian (31-30 ky BP (uncal)) to the early (28-27 ky BP (uncal)) and middle Gravettian (26-25 ky BP (uncal) $)^{48}$ inclusively. In this case, the existence of sites with polished tools in the KBR (25-24 ky BP (uncal)) indicates the expansion of the developed Pavlovian to the Russian Plain in the period immediately preceding the late Gravettian migration of the Willendorf-Kostenki population from the Danube (23-21 ky BP (uncal)).

\section{Kostenki-Avdeevo (Willendorf-Kostenki) complex (Kostenki 1/I, Kostenki 13, Kostenki 14/I, Kostenki 18)}

All three sites belong to the strata of the second terrace of the Pokrovsky ravine. Traces of long-term settlement were examined, that is, remains of hearths, pits, and dwellings. Apart from that, a child's burial was found in Kostenki 18. The upper cultural layer of Kostenki 1 (Polyakov's site) remains the most abundant of the studied settlements, which have been studied for over 80 years ${ }^{49}$ on a total area exceeding a $1000 \mathrm{~m}^{2}$. There were found the remains of two oval dwelling complexes, parallel to each other, each consisting of numerous hearths located along the central line, as well as pits and dugouts along the outer contour (Fig. 5: A). The material culture of the Kostenki-Adeevo sites has been

42 Novak M. Gravettian occupation in the lower layer of Kašov I // The Gravettian along the Danube. Brno, 2004. P.217-242. (Dolnověstonické studie, 11).

43 A Gravettian site in southern Poland: Jaksice II. Krakow, 2015. P. 33-52.

44 Nigst P. N., Antl-Weiser W. Les structures d'occupation gravettiennes en Europe centrale: le cas de Grub/Kranawetberg, Autriche // L'Anthropologie. 2012. Vol. 116, iss. 5. P. 639-664.

45 Svoboda J. A. The Gravettian on the Middle Danube // PALEO. 2007. No. 19. P.203-220; Polanska M., Hromadova B. Réflexion autour des industries gravettiennes "post-pavloviennes" de Slovaquie occidentale et de Moravie (25,500/24,500-22,000 BP non calibré) // Forgotten times and spaces: New perspectives in paleoanthropological, paleoetnological and archeological studies. Brno, 2015. P. 132-154.

46 Zheltova M. N., Lisitsyn S.N. Shlifovannye izdeliia iz kamnia v paleolite Kostenok // V (XXI) Vserossiiskii arkheologicheskii sieezd. Barnaul, 2017. P.368-369.

47 Skrlda P. The Pavlovian lithic technologies // Pavlov I - Northwest, The Dolní Věstonice Studies. Vol. 4 / ed. J.Svoboda. Brno, 1997. P.313-372.

48 Svoboda J., Novak M., Sazelova S., Demek J. Pavlov I: A large Gravettian site in space and time // Quaternary International, 2016. Vol.406, pt. A. P. 95-105.

49 Efimenko P. P. Kostenki I. Moscow; Leningrad, 1958; Paleolit Kostenkovsko-Borshchevskogo raiona na Donu... P. 42-62; Anikovich M. V., Popov V. V., Platonova N.I. Paleolit Kostenkovsko-Borshchevskogo raiona v kontekste verkhnego paleolita Evropy. St. Petersburg, 2008. P. 176-192. 


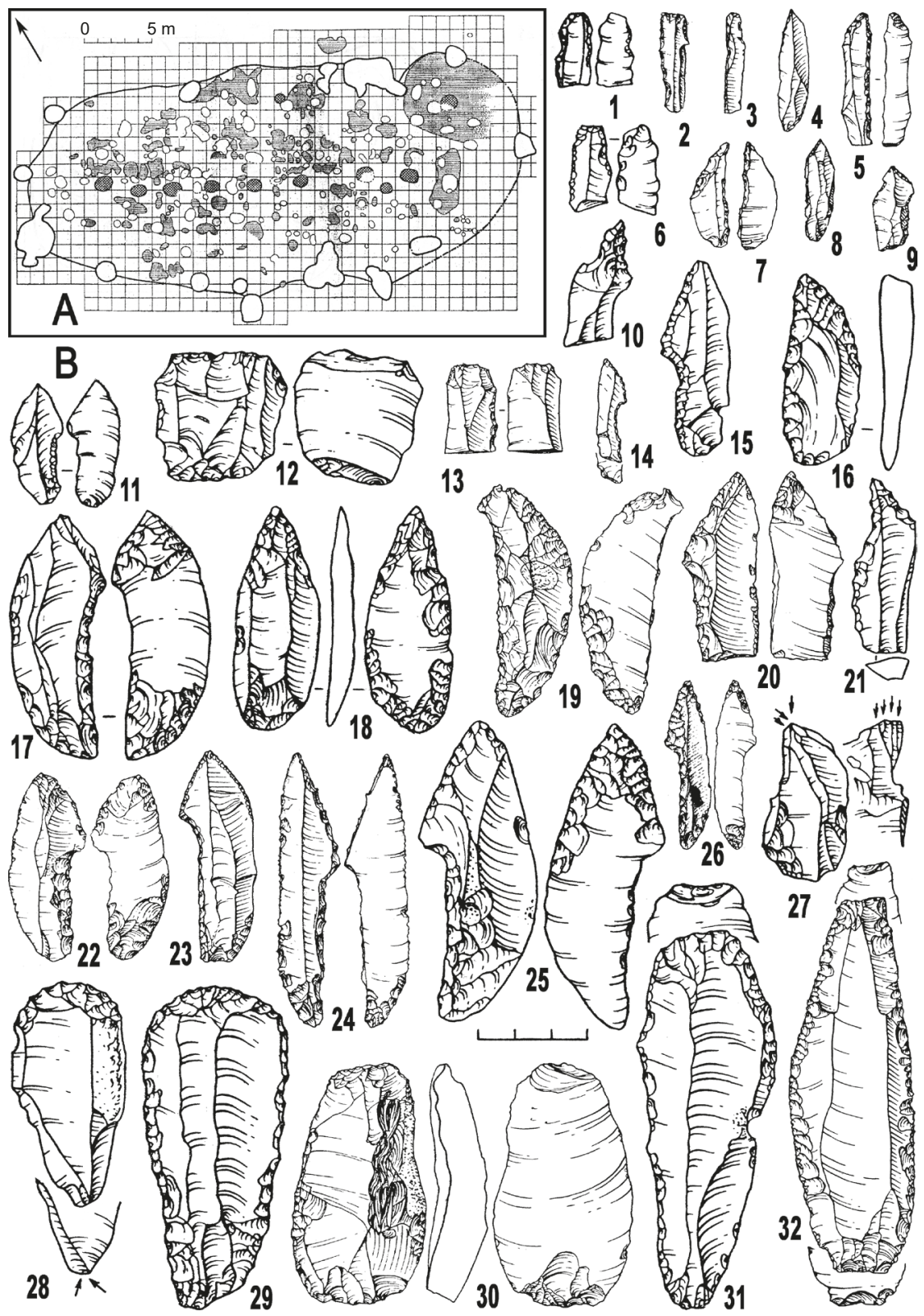

Fig. 5. Kostenki 1, the upper cultural layer:

A - the first dwelling complex [Efimenko, 1958]; B — stone assemblage [Paleolit Kostenkovsko-Borshchevskogo raiona na Donu..., 1982]

described in sufficient detail. Therefore, we can confine ourselves to a brief description of the main parameters of the inventory (see Fig. 5: B).

Tools were made on lamellar blanks, varying from massive ones to miniature microblades. The toolkit can be distinguished by the combination of three tool types: shouldered points, in which the side notch equals $2 / 3$ of the length (both larger and smaller 
types), Kostenki type knives, and backed microblades - rectangles with transversely retouched ends (dorsally and less frequently ventrally) ${ }^{50}$. Bone and ivory inventory is extremely abundant and manifold.

The most characteristic are rib spatulas with anthropomorphic heads, ivory mattocks, various points. Adornments are represented by ornamented diadems, pendants, fibulas ${ }^{51}$. Objects of art include canonical female figurines made of ivory and marl, as well as zoomorphic figurines.

\section{Anosovka complex \\ (Kostenki 11/II, Kostenki 21/III - dwelling complexes)}

Kostenki 11 site (Anosovka 2) was discovered by A. N. Rogachev in 1951. It has been intermittently excavated to the present day due to research of Mezin type bone dwellings in the upper cultural layer ${ }^{52}$. The site is located on the ravine cape of the second terrace.

The second cultural layer has been predominantly examined by testpitting. It is deposited in the middle part of the loess loam and lies in separate clusters. Remains of two dwellings were partially studied (Fig. 6: A). The remains of the southern dwelling are an oval lens of $12 \times 6.5 \mathrm{~m}$ filled with bone char and ash. Inside the dwelling two deepened firepits and $\sim 13,500$ artefacts were discovered. The northern dwelling was $6 \times 7 \mathrm{~m}$ in size, but, in contrast to the southern one, did not contain ash-carbon mass. The collection from the northern dwelling (partially excavated) amounts to $\sim 3000$ items. The total number of artefacts from Kostenki 11/II comprises 20,000 items, with 1000 tools having a secondary treatment ${ }^{53}$. Blades with a truncated dorsally retouched end, with a frequent contour retouching along the edges, are prevalent in the toolkit (Fig. 6: B, 37-40). Predominance of burins on retouched truncation is a particular feature of this complex. Scrapers are small in numbers and inexpressive; there are also individual cases of treated two-side leafshaped points and scrapers of different morphology.

A series of small backed lanceolate points with either dorsal straight or arcuate truncations on one and less often both ends (Anosovka points) gives a peculiarity to the complex. Another peculiarity is the small tool size (up to $\sim 3 \mathrm{~cm}$ ) and the blank type: they are made on shortened sub-triangular bladelets and lamellar flakes (Fig. 6: B, 1-17). Their

50 Lisitsyn S.N. Mikroplastinchatyi inventar' verkhnego sloia Kostenok 1 i nekotorye problemy razvitiia mikroorudii v verkhnem paleolite Russkoi ravniny Evropy // Vostochnyi Gravett. Moscow, 1998. P. 299-308.

${ }^{51}$ Gromadova B. Ispolzovanie syria iz kosti, bivnia i roga na stoiankakh kostenkovsko-avdeevskoi kul'tury (vostochnyi gravett). Avtoref. dis. ... kand. ist. nauk. Moscow, 2012.

52 Rogachev A. N.: 1) Mnogosloinye stoianki Kostenkovsko-Borshevskogo raiona na Donu i problema razvitiia kul'tury v epokhu verkhnego paleolita na Russkoi ravnine. P.9-134; 2) Anosovka II - novaia mnogosloinaia stoianka v Kostenkakh // Kratkie soobshcheniia Instituta arkheologii. 1961. Iss. 82. P. 8696; Paleolit Kostenkovsko-Borshchevskogo raiona na Donu... P. 125-128; Popov V. V., Pustovalov A. Yu. Poselenie 2-go kul'turnogo sloia stoianki Kostenki 11 (Anosovka 2) // Arkheologicheskie pamiatniki basseina Dona. Voronezh, 2004. P.3-8; Fediunin I. V. Kamennyi inventar' pervogo kulturnogo sloia stoianki Kostenki $11 \mathrm{v}$ svete novykh issledovanii i nekotorye problemy verkhnego paleolita Kostenkovsko-Borshchevskogo raiona // Arkheologicheskie vesti. 2017, iss.23. P. 19-32.

53 Popov V. V.: 1) Analiz kremnevogo inventaria stoianki Kostenki 11 (II kul'turnyi sloi) // Drevnie pamiatniki na territorii Vostochnoi Evropy. Izvestiia VGPI.Vol.227. Voronezh, 1983. P.5-13; 2) Razvitie pozdnepaleoliticheskoi kul'tury Vostochnoi Evropy po materialam mnogosloinoi stoianki Kostenki 11. Avtoref. dis. ... kand. ist. nauk. Leningrad, 1989; Popov V. V., Pustovalov A. Yu. Poselenie 2-go kul'turnogo sloia stoianki Kostenki 11 (Anosovka 2). P.3-8. 


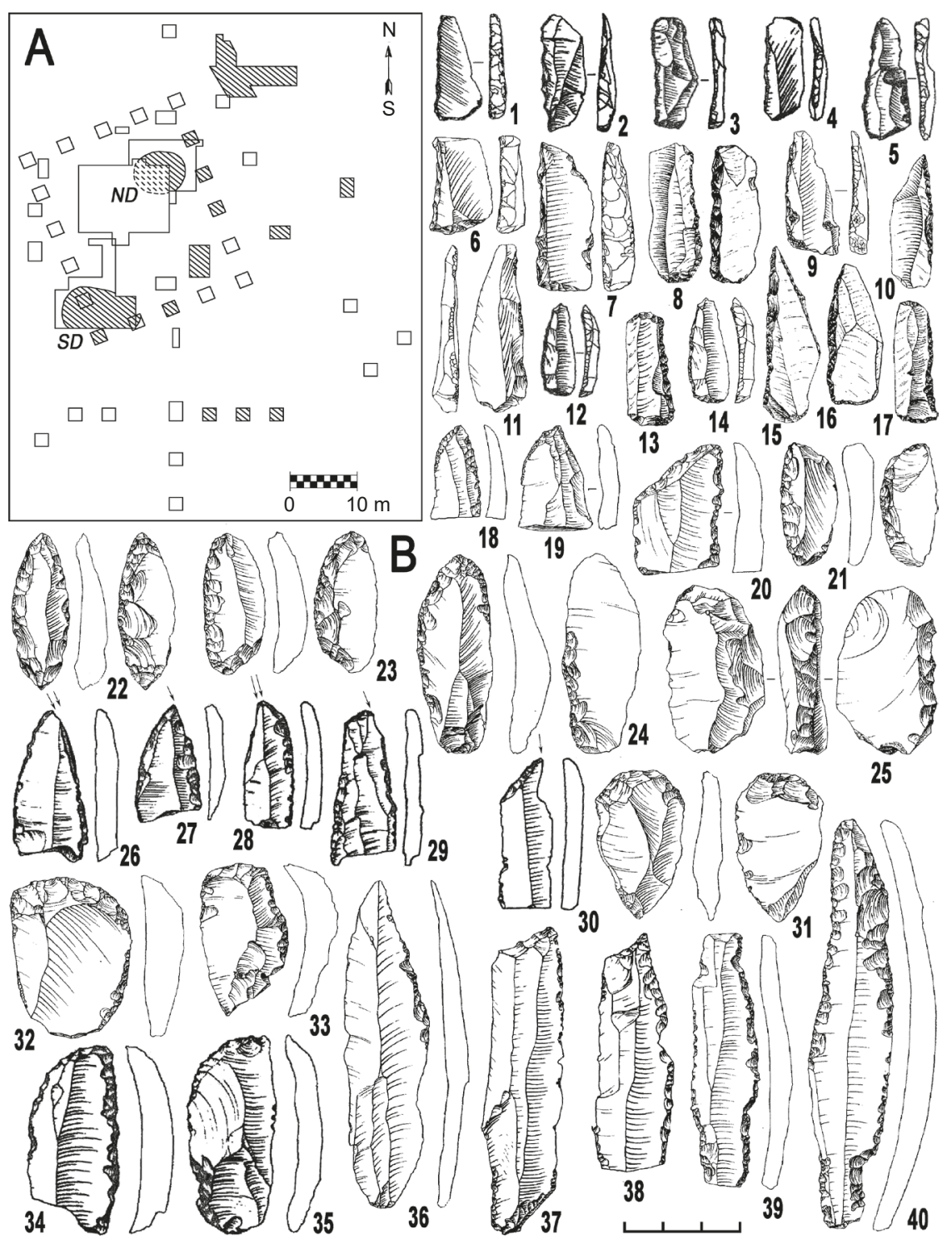

Fig. 6. Kostenki 11, the second cultural layer:

A - the excavations and testpits scheme. Areas of the cultural reamains spread are hatched. ND - the north dwelling, SD - the south dwelling; B - the stone assemblage [Sinitsyn, 2013; Popov \& Pustovalov, 2004]

dimensions are caused not by the blank standardization, but by an intense edge backing combined with truncation of the point ends. Actually, such tools should be attributed to geometric microliths.

Bone artefacts are represented by two points with heads which resemble animal faces. Kostenki 11/II complex also features a number of art objects, namely, a series of miniature marl figurines (over 100 items) with a flattened base, some of which are quite recognizable (mammoth, woolly rhinocerous, bison). 
The complex does not have comprehensive analogies in the Gravettian industries, but in some aspects, it is similar to various East European sites. Zoomorphic marl figurines in KBR sites resemble Kostenki 1/I, Kostenki 4, Kostenki $9^{54}$, while backed tools and tools with truncated ends remind of Kostenki 21/III, as well as Pushkari 1 and Klyussi in the Desna region ${ }^{55}$. A specific feature of Kostenki 11/II inventory is the lack of signs indicating microblade blank production combined with mass production of microliths. By this criterion, Anosovka complex is similar to the Byki 1 and Byki 7/I-Ia sites in the Seym area with their triangular microliths (the beginning of the late stage of the Upper Palaeolithic, $17000-15000$ yr uncal BP). It should be noted that N. B. Akhmetgaleyeva ${ }^{56}$ attributes this industry not to the Gravettian, but to the Magdalenian cultural cluster. According to the combination of features, the inventory of Anosovka corresponds most fully to materials of Kostenki 21/III. However, surprisingly, these parallels are limited only to some local areas of the latter site and are not represented in others.

Kostenki 21 (Gmelinskaia encampment) is a site discovered by N. D. Praslov in 1956 on the first terrace of the Don. Total area uncovered in 1950-70s. exceeds $500 \mathrm{~m}^{2}$. Within the terrace composed of loess-like loams, three cultural layers were revealed, of which the best studied one is the lower one, connected to the Gravettian ${ }^{57}$.

Judging by separate finds clusters, six household complexes (I-VI) were determined, spread over $\sim 200 \mathrm{~m}$ along the riverside (Fig. 7: A). Four of them are thought to be remains of dwellings. Both complex I and the southern complex II are interpreted as production centers for flint knapping and tool manufacturing. These complexes are interspaced with cultural layer sections having relatively sparse finds. The inventory of Anosovka type is associated exclusively with dwelling features (Fig. 7: B).

Remains of dwellings are represented by lenses of ash mass clusters, stone artefacts, bones and ocher ${ }^{58}$. In the plan, they have a circular-oval shape and occupy an area of $10-16 \mathrm{~mm}^{2}$. Three of them had deepened hearths. Near one of the dwellings (the northern complex), limestone tiles contoured the remains of a structure from the eastern and southern sides. The stone tool collection found in the dwellings $(\mathrm{n} \sim 2700)$ amounts to 271 tools. The most numerous and expressive types are backed vertically retouched points and blades (Anosovka points), as well as knife-shaped blades with transverse and oblique truncated ends (see Fig. 7: B, 1-6). These are followed by burins, including burins on retouched truncation and multiple ones, in addition to scrapers. Osseous inventory is represented by fragments of three points and adornments such as oval pendants made of

${ }^{54}$ Abramova Z.A. Izobrazheniia zhivotnykh s paleoliticheskoi stoianki Aleksandrovka // Kratkie soobshcheniia Instituta arkheologii. 1961. Iss. 82. P.97-103; Rogachev A.N. Anosovka II - novaia mnogosloinaia stoianka v Kostenkakh. P. 86-96; Anikovich M. V. K probleme sinkhronizatsii nekotorykh pozdnepaleoliticheskikh pamiatnikov Kostenkovsko-Borshchevskogo raiona // Kratkie soobshcheniia Instituta arkheologii. 1983. Iss. 173. P. 16-31.

55 Sinitsyn A. A. K probleme kul'turnoi prinadlezhnosti Pushkarei $1 / /$ Problemy arkheologii epokhi kamnia: k 70-letiiu Valentiny Ivanovny Beliaevoi: sbornik nauchnykh statei. St. Petersburg, 2014. P.234244. (Trudy istoricheskogo fakul'teta Sankt-Peterbgskogo universiteta. Vol. 18).

56 Akhmetgaleeva N.B. Kamennyi vek Poseimia: verkhnepaleoliticheskaia stoianka Byki 7. Kursk, 2015. P. 181-184.

57 Praslov N.D. Gmelinskaia stoianka v Kostenkakh // Kratkie soobshcheniia Instituta arkheologii. 1964. Iss. 97. P. 59-63; Paleolit Kostenkovsko-Borshchevskogo raiona na Donu... P. 198-209.

58 Ivanova M. A. Zhiloi kompleks Gmelinskoi pozdnepaleoliticheskoi stoianki v Kostenkakh // Kratkie soobshcheniia Instituta arkheologii. 1981. Iss. 165. P. 37-42. 
mammoth tusk. Overall, the inventory is identical to the finds of Kostenki 11/II, except for the absence of marl figurines.

Artefacts found in manufacturing complexes of Kostenki 21/III differ dramatically both from the toolkit found at the site of dwelling and from Kostenki 11/II inventory by the knapping technique, as well as the tools types (see Fig. 7: B). The collection has pronounced Gravettian features given a large number of microblades and tools on microblades, with shouldered points and numerous ivory and bone tools. According to M. N. Ivanova and N. D. Praslov ${ }^{59}$, such differences can be explained by specifics of activity taking place in dwellings and on tool production areas.

M.V.Anikovich and V.V.Popov united the finds of the second cultural layer of Kostenki 11 with those of the lower layer on the Gmelinskaia site, and with the scarce inventory of Kostenki 5/III under the term of Anosovka-Gmelinskaia archeological culture, proposing an alternative interpretation of the typological differences between sites. They believe such differences could be caused by the seasonal character of habitatation - a winter settlement on Kostenki 11/II and a summer settlement on Kostenki 21/III ${ }^{60}$. From my point of view, such explanation is unsubstantiated since it is based solely on the presence of bone coal in the dwellings of Kostenki 11/II in contrast to Kostenki 21/ III, where charcoal prevailed.

It should be noted that in Kostenki 21/III the finds clusters of two different cultures were found in alternating deposition. Their appearance is not connected to the presence or absence of various household structures of habitation or seasonal character of settlement. Palimpsest cultural layers with separate clusters, left by single- or multi-cultural population groups, are quite common for the Neolithic-Mesolithic sites. The same is true for the KBR at sites of the first terrace of the Don (Kostenki 4, Kostenki 21, Borshchevo 1 and 2). Thus, artefacts of the lower layer of the Gmelinskaia site should be divided into two cultural complexes - Anosovka ("dwellings") and Gmelinskaia ("manufacturing features"). Therefore, each of these groups becomes typologically accurate and can be described within a specific cultural and archaeological context.

\section{Gmelinskaia complex (Kostenki 21/III - production areas)}

Kostenki 21/III production complexes are characterized by a large area (40 and $\sim 80 \mathrm{~m}^{2}$ respectively). These are long lenses of a cultural layer with ash spots and high concentration of finds. At least one open hearth was documented in complex I, while in complex II no hearths were found. Stone tool collections amount to $\mathrm{n} \sim 7,500$ for complex I and $\mathrm{n} \sim 24,000$ for complex II. The number of artefacts with secondary treatment is quite significant $(\mathrm{n}>1000)$.

In production complexes, as opposed to the dwelling sites, the main tool blanks were regular blades and microblades ( $>50 \%$ of all the items). There are predominantly dihedral burins or burins on retouched truncation found in the collection. Backed points are

59 Ivanova M.A.: 1) Zhiloi kompleks Gmelinskoi pozdnepaleoliticheskoi stoianki v Kostenkakh; 2) Struktura Gmelinskogo paleoliticheskogo poseleniia (po rezultatam planigraficheskogo i tipologicheskogo analiza kremnevogo inventaria). Avtoref. dis. ... kand. ist. nauk. Leningrad, 1985; Paleolit KostenkovskoBorshchevskogo raiona na Donu... P. 209.

${ }^{60}$ Anikovich M. V., Popov V.V., Platonova N.I. Paleolit Kostenkovsko-Borshchevskogo raiona v kontekste verkhnego paleolita Evropy. S. 205-206. 


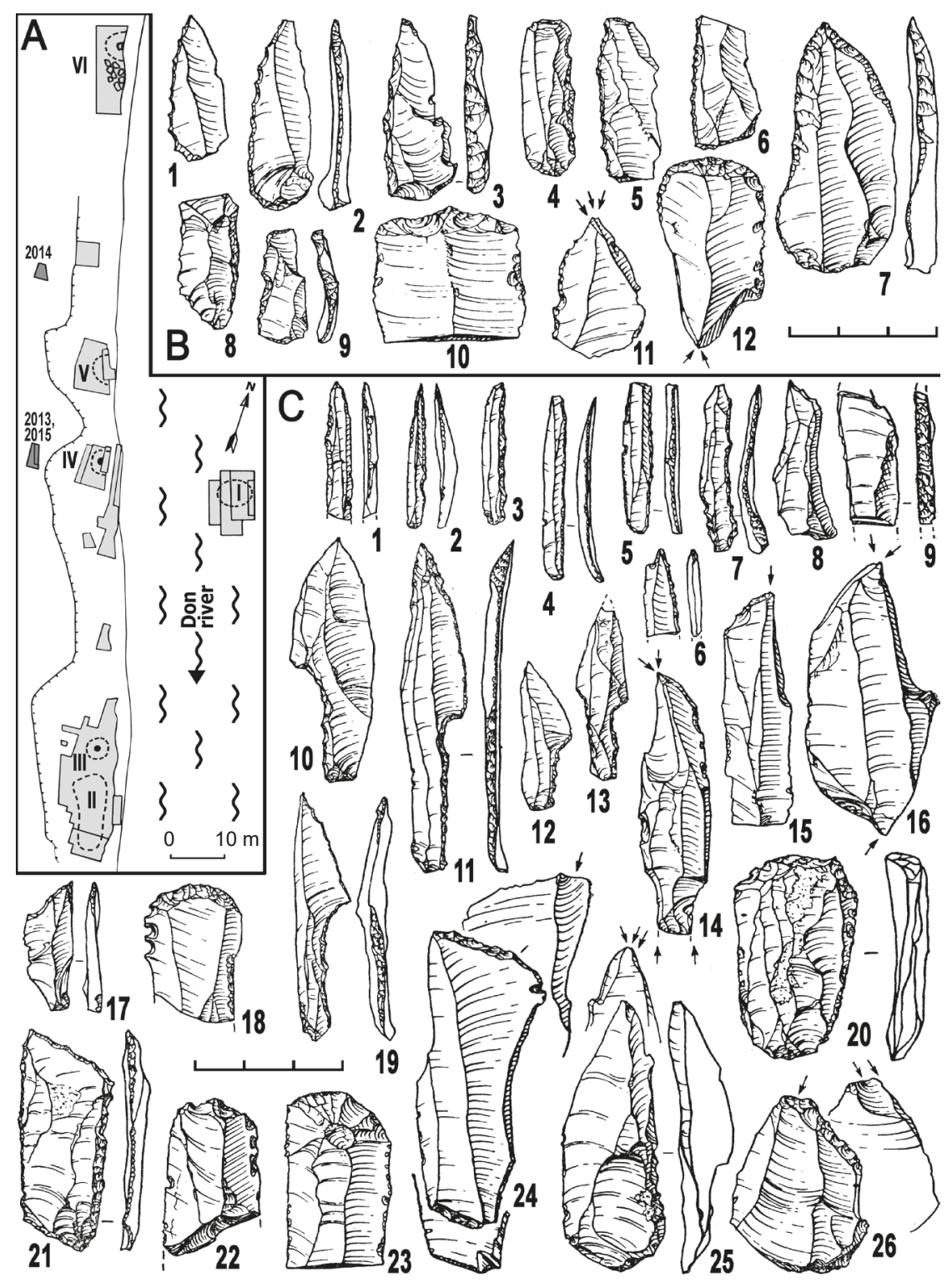

Fig. 7. Kostenki 21, the lower cultural layer: A - excavations and testpits scheme (I and II — «manufacturing» complexes; III through VI — «dwelling» complexes); B — stone assemblage of the complex IV; C - stone assemblage of the complex II (modified from: Paleolit Kostenkovsko-Borshchevskogo raiona na Donu... 1982)

miniature and are of a microlithoid appearance. Backed microblades have a sharpened or natural end (see Fig. 7: B, 1-7). Shouldered points $(n>100)$ make up an expressive category. In contrast to the Kostenki-Avdeevo points, the notch does not exceed half of the blank length (see Fig. 7: B, 10-13, 19). Bone tools vary - they comprise a series of ivory points, awls, an eyed needle, several flounder-shaped pendants and a pendant made of a reindeer canine tooth. Rare items include an ivory "shaft straightener" with a fir-tree ornament, 
as well as an item that is interpreted as a handle. Apart from that, there are two unique engravings of zoomorphic images on stone discs ${ }^{61}$.

During the recent work of A. A. Bessudnov, the remains of two more lenses with flint inventory corresponding to the toolkit of "production centers" were found on Kostenki 21. In my opinion, a wide distribution of Gmelinskaia type finds, including those in the newly unearthed areas, confirms that they are not simply functional, but bear an independent cultural character ${ }^{62}$.

Parallels to the Gmelinskaia complex can be drawn at Gagarino site on the upper Don $^{63}$. The Gmelinskaia complex is similar to the industry of Gagarino due to a pronounced microlithoid character of flint tools, the use of blades and their fragments to make tools, a combination of burins on retouched truncation and dihedral burins of similar morphology, besides a series of shouldered points on microblades with the notch taking up half of the blank length.

The same features unite Kostenki 21/III and Khotylevo 2 on the Desna. The Gagarino site has even more common features with the latter one: Kostenki type knives, bone and ivory tools and art objects, including typical female figurines ${ }^{64}$. Differences between the Gmelinskaia and Khotylevo-Gagarino toolkits are mostly negative. For instance, the Kostenki 21/III site has practically no ventral retouching on tools. Some tool types characteristic of the Eastern Gravettian are absent from the toolkit. This difference is also reinforced by the absence of specific bone and ivory items and typical design elements.

Nevertheless, the Gmelinskaia complex is closer to the classic sites of the Eastern Gravettian than any other Gravettian complexes in Kostenki, which are not immediately connected to the Kostenki-Avdeevo culture. In the Gmelinskaia industry, distinguishing feautures are miniature shouldered points, having prototypes in the Eastern Gravettian. In this regard, the Gmelinskaia complex can be seen as a borderline that separates the Gravettian sensu lato from the Epigravettian.

\section{Stratigraphy and geomorphological correlation}

The KBR Gravettian sites are associated with the so-called loess-like loam uppermost bed, which completes the local Pleistocene sedimentation column. The only exception could be Kostenki 8/II horizon, enclosed in the horizon of a reduced upper humus stratum, directly covered by loess-like loam. The upper humus stratum is usually compared with the Bryansk paleosoil, and in the KBR it is considered isochronous to $32-28 \mathrm{ky} \mathrm{BP}$ (uncal).

However, according to the latest research of Kostenki 8, younger datings of 23.3 and $25.6 \mathrm{ky}$ BP (uncal) were obtained for the second cultural layer. Therefore, cautious doubts

${ }_{61}$ Paleolit Kostenkovsko-Borshchevskogo raiona na Donu... P. 208-209.

62 Bessudnov A. A. Issledovaniia III kul'turnogo sloia Kostenok $21 \mathrm{v}$ khode spasatel'nykh rabot 20132014 gg. // Novye materialy i metody arkheologicheskogo issledovaniia. Materialy III Mezhdunarodnoi konferentsii molodykh uchenykh. Moscow, 2015. P. 10-12.

63 Tarasov L. M. Gagarinskaia stoianka i ee mesto v paleolite. Moscow, 1979.

${ }^{64}$ Gavrilov K.N.: 1) Tipologiia kamennykh orudii i kulturnaia prinadlezhnost' Khotylevskoi verkhnepaleoliticheskoi stoianki // Problemy kamennogo veka Russkoi ravniny. Moscow, 2004. P.262284; 2) Verkhnepaleoliticheskaia stoianka Khotylevo 2. Moscow, 2008; 3) Migratsiia, diffuziia, razvitie? K voprosu o proiskhozhdenii vostochnogo gravetta na Russkoi ravnine. P. 29-50. 
are being voiced concerning the orthodox view on the age of the enclosing horizon ${ }^{65}$. I believe the "humus content" can be explained by the presence of washed-out hearth structures containing charcoal and ash, and not by association with this very stratum. Regardless, it can be argued that the majority of the KBR Gravettian settlements existed during the cold cycle of loess sedimentation corresponding to the final phase of the middle Weichselian glaciation.

Buried soils may be used as additional stratigraphic markers to divide the loess-like bed into parts. Episodes of soil formation, which are associated with the Gravettian cultural layers, have been repeatedly recorded. In particular, up to four ephemeral fossil soils can be distinguished in the Kostenki 14 loess member, of which the two lower ones are associated with Gravettian finds ${ }^{66}$. Two levels of soil formation were recorded on Borshchevo 5, and both contain Gravettian artefacts. At least one distinct paleosoil (the Gmelin one) can be distinguished at the level of the Gravettian layer bedding on Kostenki 1, Kostenki 21 and, possibly, on Kostenki $11^{67}$.

\section{Chronology and periodization}

Over a hundred datings have been obtained on samples from the KBR Gravettian cultural layers. Almost half of them comes from the upper cultural layer of Kostenki 1. Datings on bone samples are prevalent. Existing 14C datings, in average uncalibrated values, determine the period of existence of the KBR Gravettian from 27,000 (Kostenki 8/II) to 21,000 yr BP (Kostenki 21/III). Effectively, in a series of datings, they vary for almost each site, providing an opportunity to demonstrate one's chronological preferences and choose a specific timepoint accordingly. The most reliable method for development of the Kostenki Gravettian periodization is to examine certain complexes in comparison to the Gravettian sites of other regions and see if they mutually correlate. In accordance with common European ideas on periodization of the Upper Paleolithic, the KBR Gravettian can be divided into the early period of 27,000-25,000 yr uncal BP, the middle one of $25,000-24,000 \mathrm{yr}$ uncal BP, and the late one of 23,000-21,000 yr uncal BP. Given a common archaeological context of the identified KBR Gravettian cultural groups with the sites of Eastern and Central Europe, as well as the compliance of datings, we can determine the cultural and chronological succession of these complexes (Table 1).

${ }^{65}$ Dudin A.E., Pustovalov A. Yu., Platonova N.I. Vtoroi kul'turnyi sloi stoianki Kostenki-8 (Telmanskaia): struktura, ob"ekty mikrostratigrafii. P. 41-52.

66 Sedov S.N., Khokhlova O.S., Sinitsyn A.A., Korkka M.A., Rusakov A.V., Ortega B., Solleiro E., Rozanova M. S., Kuznetsova A.M., Kazdym A.A. Pozdnepleistotsenovye paleopochvennye serii kak instrument lokalnoi paleogeograficheskoi rekonstruktsii (na primere razreza Kostenki 14) // Pochvovedenie. 2010. No.8. P.938-955; Sinitsyn A.A. Kostenki 14 (Markina gora) - opornaia kolonka kul'turnykh i geologicheskikh otlozhenii paleolita Vostochnoi Evropy dlia perioda 27-42 tys.l.n. // Drevnie kul'tury Vostochnoi Evropy: etalonnye pamiatniki i opornye kompleksy v kontekste sovremennykh arkheologicheskikh issledovanii. Zamiatninskii sbornik. Iss. 4. St. Petersburg, 2015. P. 40-59.

67 Paleolit Kostenkovsko-Borshchevskogo raiona na Donu... P. 116; Popov V. V., Pustovalov A. Yu. Poselenie 2-go kulturnogo sloia stoianki Kostenki 11 (Anosovka 2). P.3-8; Hoffecker J. F., Holliday V.T., Anikovich M.V., Dudin A.E., Platonova N.I., Popov V.V., Levkovskaya G.M., Kuz'mina I.E., Syromyatnikova E. V., Burova N.D., Goldberg P., Macphail R.I., Forman S.L., Carter B. J., Crawford L. J. Kostenki 1 and the early Upper Paleolithic of Eastern Europe // Journal of Archaeological Science: Reports. 2016. Vol. 5. P. 307-326. 
Table 1. The periodisation and chronology of the Gravettian assemblages in the Kostenki-Borshchevo locality

\begin{tabular}{|c|c|c|c|c|}
\hline $\begin{array}{c}\text { Periodization } \\
\text { (14C uncal.) } \\
\text { and } \\
\text { chronology }\end{array}$ & \begin{tabular}{|c|} 
Cultural \\
attribution
\end{tabular} & Sites / Layers & $\begin{array}{c}\text { Dates } \\
(14 \mathrm{C} \text { uncal. BP })\end{array}$ & Related sites \\
\hline $\begin{array}{l}\text { Early } \\
\text { Gravettian } \\
\text { (27-25 ky BP } \\
\text { (uncal)) }\end{array}$ & $\begin{array}{l}\text { Telman- } \\
\text { skaia } \\
\text { complex }\end{array}$ & Kostenki 8/II & $\begin{array}{l}27700 \pm 750\left(^{\text {GrN-10509) }}\right)^{\mathrm{a}} \\
27670 \pm 270 \text { (OxA-30198) }^{\mathrm{b}} \\
27620 \pm 270 \text { (OxA-30197) }^{\mathrm{b}} \\
25640 \pm 210 \text { (CURL-15797) }^{\mathrm{c}} \\
24500 \pm 450 \text { (GIN-7999) }^{\mathrm{d}} \\
23340 \pm 150 \text { (CURL-15816) }^{\mathrm{c}} \\
23020 \pm 320 \text { (OxA-7109) }^{\mathrm{d}} \\
21900 \pm 450 \text { (GrA-9283) }^{\mathrm{e}}\end{array}$ & $\begin{array}{l}\text { Grotta Paglicci /23a } \\
\text { Geißenklösterle /Ic } \\
\text { Abri Pataud /5 }\end{array}$ \\
\hline \multirow{3}{*}{$\begin{array}{l}\text { Middle } \\
\text { Gravettian } \\
(25-24 \text { ky BP } \\
\text { (uncal)) }\end{array}$} & \multirow{3}{*}{$\begin{array}{l}\text { Aleksan- } \\
\text { drovka } \\
\text { complex } \\
\text { (Pavlovian) } \\
\end{array}$} & Kostenki 4/I-II & $\begin{array}{l}25290 \pm 210\left(\text { OxA-30194) layer I/II }{ }^{\mathrm{b}}\right. \\
24790 \pm 190(\text { OxA-30193) layer I/II } \\
24710 \pm 200(\text { OxA-30196) layer I/II } \\
23000 \pm 300\left(\text { БИН7994) layer I }{ }^{\mathrm{d}}\right. \\
22800 \pm 120\left(\text { ГИН7995) layer I } \mathrm{I}^{\mathrm{d}}\right. \\
20290 \pm 150(\text { OxA8310) layer I/II } \\
14210 \pm 70(\text { OxA-30195) layer I/II } \\
\end{array}$ & \multirow[t]{3}{*}{$\begin{array}{l}\text { Pavlov } 1 \\
\text { Milovice } \\
\text { Jaksice } 2\end{array}$} \\
\hline & & Kostenki 9 & - & \\
\hline & & Borshchevo 5/I & $\begin{array}{l}25110 \pm 200\left(\text { OxА-30200) layer Ia }{ }^{\mathrm{b}}\right. \\
24720 \pm 190(\text { ОхА-30199) layer Ia } \\
22500 \pm 700(\text { ГИН-10239) } \\
20000 \pm 300(\text { ЛЕ-6947) } \\
17400 \pm 2000(\text { ЛЕ-5571) } \\
14060 \pm 110(\text { ЛЕ-6809) } \\
\end{array}$ & \\
\hline \multirow{5}{*}{$\begin{array}{l}\text { Late } \\
\text { Gravettian } \\
(23-21 \text { ky BP } \\
\text { (uncal)) }\end{array}$} & \multirow{4}{*}{\begin{tabular}{|l|} 
Kostenki- \\
Avdeevo \\
complex \\
(East \\
Gravettian) \\
\end{tabular}} & Kostenki 1/I & \begin{tabular}{|l|} 
\\
mainly concentrated $23-22 \mathrm{kyr}^{\mathrm{h}}$ \\
\end{tabular} & \multirow[b]{3}{*}{ Kraków Spadzista } \\
\hline & & Kostenki 13 & $\ldots$ & \\
\hline & & Kostenki 18 & 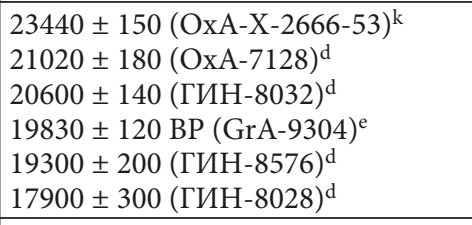 & \\
\hline & & Kostenki 14/I & 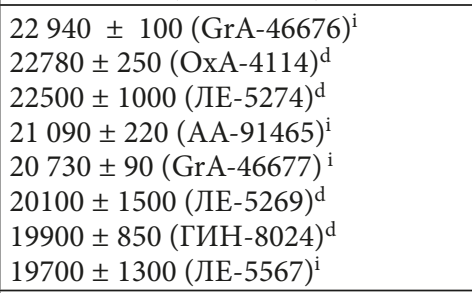 & \multirow[t]{2}{*}{$\begin{array}{l}\text { Avdeevo } \\
\text { Zaraisk } \\
\text { Berdyzh }\end{array}$} \\
\hline & $\begin{array}{l}\text { Gmelin- } \\
\text { skaia com- } \\
\text { plex }\end{array}$ & $\begin{array}{l}\text { Kostenki 21/ } \\
\text { III «production } \\
\text { centers» }\end{array}$ & \multirow{2}{*}{$\begin{array}{l}22860 \pm 320(\mathrm{GrN}-24968)^{\mathrm{f}} \\
22270 \pm 150(\mathrm{GrN}-7363)^{\mathrm{a}} \\
22230 \pm 100(\mathrm{GrN}-14669)^{\mathrm{f}} \\
21780 \pm 90(\text { ГИН-9668) } \\
21260 \pm 340(\mathrm{GrN}-10513)^{\mathrm{a}} \\
16960 \pm 300(\text { ЛЕ-1043) }\end{array}$} & \\
\hline \multirow{2}{*}{$\begin{array}{l}\text { Epi- } \\
\text { Gravettian } \\
(\leq 21 \mathrm{ky} \mathrm{BP} \\
\text { (uncal)) }\end{array}$} & \multirow{2}{*}{$\begin{array}{l}\text { Anosovka } \\
\text { complex }\end{array}$} & \begin{tabular}{|l|}
$\begin{array}{l}\text { Kostenki 21/III } \\
\text { "dwellings" }\end{array}$ \\
\end{tabular} & & \multirow[t]{2}{*}{ Pushkari 1} \\
\hline & & Kostenki 11/II & $\begin{array}{l}21800 \pm 200(\text { ГИН-2531) } \\
15200 \pm 300(\text { ТА }-34)^{\mathrm{a}}\end{array}$ & \\
\hline
\end{tabular}


${ }^{a}$ Paleolit Kostenkovsko-Borshchevskogo raiona na Donu. 1879-1979: nekotorye itogi polevykh issledovanii / ed. by N. D. Praslov, A. N. Rogachev. Leningrad, 1982.

${ }^{\mathrm{b}}$ Reynolds N., Lisitsyn S. N., Sablin M. V., Barton N., Higham T.F. G. Chronology of the European Russian Gravettian: new radiocarbon dating results and interpretation // Quartär. Vol.62. 2015. P. 121-132.

${ }^{c}$ Dudin A.E., Pustovalov A.Iu., Platonova N.I. Vtoroi kul'turnyi sloi stoianki Kostenki-8 (Telmanskaia): struktura, ob"ekty mikrostratigrafii // Vestnik NGU. Seriia. Istoriia, filologiia. Vol. 15, no. 3. Arkheologiia i etnografiia. Novosibirsk, 2016. P.41-52.

d Sinitsyn A.A., Praslov N.D., Svezhentsev Yu. S., Sulerzhitskii L.D. Radiouglerodnaia khronologiia paleolita Vostochnoi Evropy // Radiouglerodnaia khronologiia paleolita Vostochnoi Evropy i Severnoi Azii: problemy i perspektivy / eds A. A. Sinitsyn, N. D. Praslov. St. Petersburg, 1997. P.21-66.

e Sinitsyn A. A. Les sépultures de Kostenki: chronologie, attribution culturelle, rite funéraire // La Spiritualité: Actes du colloque de la commission 8 de l'UISPP (Paléolithique supérieur), Liège, 10-12 décembre 2003. Études et Recherches Archéologiques de l'Université de Liège / ed. by M. Otte. Liège, 2004. P. 237-244.

${ }^{\mathrm{f}}$ Zheltova M.N. Kostenkovskie stoianki pervoi nadpoimennoi terrasy: varianty adaptatsii k okruzhaiushchei srede verkhnego pleistotsena // Problemy biologicheskoi i kul'turnoi adaptatsii chelovecheskikh populiatsii: sbornik statei, posviashchennyi 100-letiiu so dnia rozhdeniia M. M. Gerasimova. Vol. 1. Arkheologiia. Adaptatsionnye strategii drevnego naseleniia Severnoi Evrazii: syre i priemy obrabotki / ed. by G. A. Khlopachev. St. Petersburg, 2008. P. 48-52.

g Lisitsyn S. N. Khronostratigrafiia i arkheologiia stoianki Borshchevo 5 po dannym raskopok 2002-2003 gg. // Kostenki i ranniaia pora verkhnego paleolita Evrazii: obshchee i lokalnoe. Materialy Mezhdunarodnoi konferentsii. Kostenki, 23-26 avgusta, 2004 / eds M. V. Anikovich, N. I. Platonova. Voronezh, 2004. P. 66-79.

h Anikovich M. V., Popov V. V., Platonova N.I. Paleolit Kostenkovsko-Borshchevskogo raiona v kontekste verkhnego paleolita Evropy / ed. by M. V. Anikovich. St. Petersburg, 2008.

${ }^{\mathrm{i}}$ Sinitsyn A. A. Preryvistost i preemstvennost v paleolite Kostenok // Verkhnedonskoi arkheologicheskii sbornik. Iss. 6 / ed. by A. N. Bessudnov. Lipetsk, 2014. P. 66-76

j Sinitsyn A. A. K probleme kul'turnoi prinadlezhnosti Pushkarei 1 // Problemy arkheologii epokhi kamnia: k 70-letiiu Valentiny Ivanovny Beliaevoi: sbornik nauchnykh statei. St. Petersburg, 2014. P. 234-244. (Trudy istoricheskogo fakul'teta Sankt-Peterbgskogo universiteta. Vol. 18)

${ }^{\mathrm{k}}$ Reynolds N., Dinnis R., Bessudnov A., Devièse T., Higham T. The Kostënki 18 child burial and the cultural and funerary landscape of Mid Upper Palaeolithic European Russia // Antiquity. 2017. Vol.91, iss. 360. P. 1435-1450.

\section{Conclusion}

Archaeological unity of the Gravettian sites is synstadial in character, which is expressed by common features of inventory and technological basis, and, potentially, by the type of economic adaptation caused by cooling and aridization of the climate. It seems the reasons behind cultural diversity of the KBR Gravettian should be attributed to favorable environmental conditions of this local area to arrange encampment settlements ${ }^{68}$.

Taking into account European archealogical context, cultural differentiation of the Kostenki Gravettian takes form of a relatively orderly periodization. Cultural complexes can be distinguished by distinct features of material culture. They are linked to different

${ }^{68}$ Lisitsyn S.N. Epokha gravetta v Kostenkakh: kul'turnaia istoriia i paleolandshaft // Puti evoliutsionnoi geografii: materialy Vserossiiskoi nauchnoi konferentsii, posviashchennoi pamiati professora A. A. Velichko. Moscow, 2016. P. 687-692. 
chronological episodes and have corresponding analogies among the sites of Eastern and Central Europe.

The first manifestation of the Gravettian 27,000-25,000 yr uncal BP was marked by the emergence of a population group with the Kostenki 8/II industry type in the basin of the Don river. The second wave of settlers (25,000-24,000 yr uncal BP), associated with the Pavlovian, shaped the Aleksandrovka complex belonging to the middle Gravettian. The Gravettian succession in the KBR is completed by the Kostenki-Avdeevo complex $(23,000-22,000 \mathrm{yr}$ uncal BP). It is possible that the peak of cooling after 21,000 yr uncal BP led to the emergence of local industries of Anosovka and Gmelin type. The latter largely inherits Gravettian traditions, while Anosovka type belongs to a different line of cultural development.

People of the Gravettian era occupied the Don basin in waves, settling in the tundra-steppe landscape zone, which on the eve of the glacial maximum united the territories of Central and Eastern Europe into a single ecosystem. At the same time, no signs of mixing or hybridization of various generations of the KBR Gravettian may indicate that the waves of these populations followed each other consequently, which leaves open the question if there were any direct contacts between them.

\section{References}

Abramova Z. A. Izobrazheniia zhivotnykh s paleoliticheskoi stoianki Aleksandrovka. Kratkie soobshcheniia Instituta arkheologii, 1961, iss. 82, pp.97-103. (In Russian)

Akhmetgaleeva N.B. Kamennyi vek Poseimia. Verkhnepaleoliticheskaia stoianka Byki 7. Kursk, Mechta, 2015, 254 p. (In Russian)

Amirkhanov Kh.A. Vostochnyi gravett ili gravettoidnye industrii Tsentral'noi i Vostochnoi Evropy. Vostochnyi Gravett. Ed. by Kh. A. Amirkhanov. Moscow, Nauchnyi mir, 1998, pp. 15-34. (In Russian)

Anikovich M.V. K probleme sinkhronizatsii nekotorykh pozdnepaleoliticheskikh pamiatnikov Kostenkovsko-Borshchevskogo raiona. Kratkie soobshcheniia Instituta arkheologii, 1983, iss. 173, pp. 16-31. (In Russian)

Anikovich M. V. Dnepro-Donskaia istoriko-kul'turnaia oblast' okhotnikov na mamontov. ot "vostochnogo gravetta" k "vostochnomu epigravettu". Vostochyi gravett. Ed. by Kh. A. Amirkhanov. Moscow, Nauchnyi mir, 1998, pp. 35-66. (In Russian)

Anikovich M.V., Popov V.V., Platonova N.I. Paleolit Kostenkovsko-Borshchevskogo raiona $v$ kontekste verkhnego paleolita Evropy. Ed. by M. V. Anikovich. St. Petersburg, Nestor-Istoriia Publ., 2008, 304 p. (In Russian)

Anisiutkin N.K. Severnyi punkt stoianki Kostenki 4 i kul'turno-khronologicheskaia interpretatsiia pamiatnika. Kostenki $i$ ranniaia pora verkhnego paleolita Evrazii: obshchee i lokalnoe. Materialy mezhdunarodnoi konferentsii "Kostenki i ranniaia pora verkhnego paleolita Evrazii. obshchee i lokalnoe", posviashchennoi 125-letiiu otkrytiia paleolita v Kostenkakh. Ed. by M. V. Anikovich. St. Petersburg, Nestor-Istoriia Publ., 2006, pp. 101-113. (In Russian)

Bessudnov A. A. Issledovaniia III kul'turnogo sloia Kostenok 21 v khode spasatel'nykh rabot 2013-2014 gg. Novye materialy i metody arkheologicheskogo issledovaniia. Materialy III Mezhdunarodnoi konferentsii molodykh uchenykh. Moscow, Institut arkheologii RAN, 2015, pp. 10-12. (In Russian)

Bulochnikova E.V. Vchera i segodnia poniatiia "vostochnyi gravet’en". Vostochyi gravett. Ed. by Kh. A. Amirkhanov. Moscow, Nauchnyi mir Publ., 1998, pp. 67-73. (In Russian)

Chelidze L. M. Telmanskaia stoianka i nekotorye voprosy razvitiia verkhnepaleoliticheskoi kul'tury $v$ Vostochnoi Evrope. Avtoref. dis. ... kand. ist. nauk. Leningrad. 1968, 20 p. (In Russian)

Demidenko Yu. E. Gravett Bol'shogo Severnogo Prichernomoria v kontekste verkhnego paleolita Vostochnoi Evropy. Stratum plus, 2018, no. 1, pp. 265-284. (In Russian)

Dudin A.E., Pustovalov A.Yu., Platonova N.I. Vtoroi kul'turnyi sloi stoianki Kostenki-8 (Telmanskaia). struktura, ob"ekty mikrostratigrafii. Vestnik NGU. Istoriia, filologiia, 2016, vol. 15, no. 3: Arkheologiia i etnografiia, pp. 41-52. (In Russian)

Efimenko P. P. Kostenki I. Moscow, Leningrad. Akademiia nauk Publ., 1958, 483 p. (In Russian) 
Fediunin I. V. Kamennyi inventar' pervogo kul'turnogo sloia stoianki Kostenki 11 v svete novykh issledovanii i nekotorye problemy verkhnego paleolita Kostenkovsko-Borshchevskogo raiona. Arkheologicheskie Vesti, 2017, iss. 23. St. Petersburg, pp. 19-32. (In Russian)

Gavrilov K. N. Tipologiia kamennykh orudii i kul'turnaia prinadlezhnost Khotylevskoi verkhnepaleoliticheskoi stoianki. Problemy kamennogo veka Russkoi ravniny. Ed. by Kh. A. Amirkhanov. Moscow, Nauchnyi mir, 2004. P. 262-284. (In Russian)

Gavrilov K.N. Verkhnepaleoliticheskaia stoianka Khotylevo 2. Moscow, Taus. 2008. 242 p. (In Russian)

Gavrilov K. N. Migratsiia, diffuziia. razvitie? K voprosu o proiskhozhdenii vostochnogo gravetta na Russkoi ravnine. Stratum Plus, 2016, no. 1, pp. 29-50. (In Russian)

Girya E. Yu. Tekhnologicheskii analiz kamennykh industrii. Metodika mikro-makroanaliza drevnikh orudii truda. Vol. 2 (44). Arkheologicheskie izyskaniia. Ed. by V. E. Shchelinskii. St. Petersburg, Akadem Print, 1997, 198 p. (In Russian)

Grigorev G. P. Edinstvo Evropy v pervyi raz. Gravettiiskii epizod. Vzaimodeistvie drevnikh kultur i tsivilizatsii i ritmy kul'turogeneza. Materialy metodologicheskogo seminara. Pamiati G. N. Kurochkina. Ed. by V.M. Masson. St. Petersburg, Institutt istorii materialnoi kul'tury RAN, 1994, pp. 12-14. (In Russian)

Grigorev G. P. Otnoshenie vostochnogo gravetena k Zapadu. Vostochnyi gravett. Ed. by Kh.A. Amirkhanov. Moscow, Nauchnyi mir, 1998, pp. 73-80. (In Russian)

Gromadova B. Ispolzovanie syria iz kosti, bivnia i roga na stoiankakh kostenkovsko-avdeevskoi kul'tury (vostochnyi gravett). Avtoref. dis. ... kand. ist. nauk. Moscow, 2012, 26 p. (In Russian)

Hoffecker J. F., Holliday V. T., Anikovich M. V., Dudin A. E., Platonova N. I., Popov V. V., Levkovskaya G. M., Kuz'mina I.E., Syromyatnikova E.V., Burova N.D., Goldberg P., Macphail R.I., Forman S.L., Carter B. J., Crawford L. J. Kostenki 1 and the early Upper Paleolithic of Eastern Europe. Journal of Archaeological Science: Reports, 2016, vol. 5, p. 307-326.

Ivanova M.A. Zhiloi kompleks Gmelinskoi pozdnepaleoliticheskoi stoianki v Kostenkakh. Kratkie soobshcheniia Instituta arkheologii, 1981, iss. 165, pp. 37-42. (In Russian)

Ivanova M.A. Struktura Gmelinskogo paleoliticheskogo poseleniia (po rezultatam planigraficheskogo $i$ tipologicheskogo analiza kremnevogo inventaria). Avtoref. dis. ... kand. ist. nauk. Leningrad, 1985. 18 p. (In Russian)

Konstantinov A. M. Drevnie zhilishcha Zabaikal'ia (paleolit, mezolit). Novosibirsk, Nauka, 2001, 222 p. (In Russian)

Leesch D., Bullinger J. Identifying dwellings in Upper Palaeolithic open-air sites: the Magdalenian site at Monruz and its contribution to analysing palimpsests. A mind set on flint. Studies in honour of Dick Stapert (Groningen Archaeological Studies 16). Eds M. Niekus, R. Barton, M. Street, T. Terberger. Groningen, 2012, pp. 165-181.

Lisitsyn S. N. Mikroplastinchatyi inventar' verkhnego sloia Kostenok 1 i nekotorye problemy razvitiia mikroorudii v verkhnem paleolite Russkoi ravniny Evropy. Vostochnyi Gravett. Ed. by Kh. A. Amirkhanov. Moscow, Nauchnyi mir, 1998, pp. 299-308. (In Russian)

Lisitsyn S. N. Khronostratigrafiia i arkheologiia stoianki Borshchevo 5 po dannym raskopok 2002-2003 gg. Kostenki i ranniaia pora verkhnego paleolita Evrazii: obshchee i lokalnoe. Materialy Mezhdunarodnoi konferentsii, Kostenki 23-26 avgusta, 2004. Eds M. V.Anikovich, N.I.Platonova. Voronezh, Istoki, 2004, pp. 66-79. (In Russian)

Lisitsyn S.N. Gravettiiskii kompleks stoianki Borshchevo 5 v Kostenkovsko-Borshchevskom raione na Donu. Paleolit i Mezolit Vostochnoi Evropy. Sbornik statei v chest' 60-letiia Kh. A. Amirkhanova. Ed. by K. N. Gavrilov. Moscow, Taus, 2011, pp. 204-225. (In Russian)

Lisitsyn S. N. O variabelnosti gravettiiskogo epizoda nakanune poslednego lednikovogo maksimuma: vzgliad iz Kostenok. Verkhnii paleolit Severnoi Evrazii i Ameriki. pamiatniki, kultury, traditsii Ser. "Archaeologica Petropolitana”. Eds S. A. Vasilev, E. S. Tkach. St. Petersburg. Peterburgskoe vostokovedenie, 2014, pp. 179-186. (In Russian)

Lisitsyn S. N. The late Gravettian of Borshevo 5 in the context of the Kostenki-Borshevo sites (Don basin, Russia). Quaternary International, 2015, vol.359-360, pp.372-383.

Lisitsyn S. N. Epokha gravetta v Kostenkakh. Kul'turnaia istoriia i paleolandshaft. Puti evoliutsionnoi geografii. Materialy Vserossiiskoi nauchnoi konferentsii, posviashchennoi pamiati professora A. A. Velichko. Ed. by A. V.Panin. Moscow, Institut geografii RAN, 2016, pp. 687-692. (In Russian)

Lisitsyn S. N. Gravettiiskaia statuetka iz bivnia mamonta so stoianki Borshchevo-5. V (XXI) Vserossiiskii arkheologicheskii s"ezd. Sbornik nauchnykh trudov. Eds A.P.Derevianko, A. A. Tishkin. Barnaul, Altaiskii gosudarstvennyi universitet, 2017, pp. 627-628. (In Russian)

Litouchanka L. M. Paleolitichnaia staianka Biruchy Log (Kastsenki IX). Vestsi AN BSSR. Ser. gramad. navuk, 1966, no. 3, pp. 110-115 (In Belorussian). 
Litovchenko L. M. Telmanskaia paleoliticheskaia stoianka (II kul'turnyi sloi). Sovetskaia arkheologiia, 1969, no. 3, pp. 110-123. (In Russian)

Moreau L. Le Gravettien ancient d'Europe centrale revisité: mise au point et perspectives. L'anthropologie, 2012, vol. 116, iss. 5, pp. 609-638.

Nigst P.N., Antl-Weiser W. Les structures d'occupation gravettiennes en Europe centrale: le cas de Grub/ Kranawetberg, Autriche. L'Anthropologie, 2012, vol.116, iss. 5, pp.639-664.

Novak M. Gravettian occupation in the lower layer of Kašov I. The Gravettian along the Danube. Dolnověstonické studie, 11 . Brno, 2004, pp. 217-242.

Nuzhnyi D.Y. The industrial variability of the eastern Gravettian assemblages of Ukraine. Quartär, 2009, no. 56, pp. 159-174.

Polanska M., Hromadova B. Réflexion autour des industries gravettiennes "post-pavloviennes" de Slovaquie occidentale et de Moravie (25,500/24,500-22,000 BP non calibré). Forgotten times and spaces: New perspectives in paleoanthropological, paleoetnological and archeological studies. Brno, 2015, pp. 132-154.

Popov V. V. Analiz kremnevogo inventaria stoianki Kostenki 11 (II kul'turnyi sloi). Drevnie pamiatniki na territorii Vostochnoi Evropy. Izvestiia VGPI. Vol.227. Ed. by A. T. Siniuk. Voronezh, 1983, pp.5-13. (In Russian)

Popov V. V. Razvitie pozdnepaleoliticheskoi kul'tury Vostochnoi Evropy po materialam mnogosloinoi stoianki Kostenki 11. Avtoref. dis. ... kand. ist. nauk. Leningrad. LGU, 1989, 23 p. (In Russian)

Popov V. V., Pustovalov A. Yu. Poselenie 2-go kul'turnogo sloia stoianki Kostenki 11 (Anosovka 2). Arkheologicheskie pamiatniki basseina Dona. Mezhvuzovskii sbornik nauchnykh trudov. Ed. by A.S. Siniuk. Voronezh, VGPU. 2004, pp.3-8. (In Russian)

Praslov N. D. Gmelinskaia stoianka v Kostenkakh. Kratkie soobshcheniia Instituta arkheologii, 1964, iss. 97, pp. 59-63. (In Russian)

Razgildeeva I. I. Planigrafiia shestiochazhnogo kompleksa pozdnepaleoliticheskogo poseleniia Studenoe-2 v Zabaikal'e. Stratum plus, 2016, no. 1, pp. 243-263. (In Russian)

Reynolds N., Lisitsyn S. N., Sablin M. V., Barton N., Higham T.F. G. Chronology of the European Russian Gravettian: new radiocarbon dating results and interpretation. Quartär, 2015, vol.62, pp. 121-132.

Reynolds N., Dinnis R., Bessudnov A., Devièse T., Higham T. The Kostënki 18 child burial and the cultural and funerary landscape of Mid Upper Palaeolithic European Russia. Antiquity, 2017, vol.91(360), pp. 1435-1450.

Rogachev A.N. Paleoliticheskoe poselenie Kostenki IV. Kratkie soobshcheniia Instituta istorii materialnoi kul'tury. Moscow; Leningrad, Izdatel'stvo Akademii nauk SSSR, 1940, iss. IV, pp. 36-41. (In Russian)

Rogachev A.N. Aleksandrovskoe poselenie drevnekamennogo veka u sela Kostenki na Donu. Materialy $i$ issledovaniia po arkheologii SSSR. Moscow; Leningrad, Izdatel'stvo Akademii nauk SSSR 1955, no. 45. 164 p. (In Russian)

Rogachev A. N. Mnogosloinye stoianki Kostenkovsko-Borshevskogo raiona na Donu i problema razvitiia kul'tury v epokhu verkhnego paleolita na Russkoi ravnine. Materialy $i$ issledovaniia po arkheologii SSSR. Moscow; Leningrad, Izdatel'stvo Akademii nauk SSSR, 1957, no. 59, pp.9-134. (In Russian)

Rogachev A. N. Anosovka II — novaia mnogosloinaia stoianka v Kostenkakh. Kratkie soobshcheniia instituta arkheologii, 1961, iss. 82, pp. 86-96. (In Russian)

Sedov S. N., Khokhlova O. S., Sinitsyn A. A., Korkka M. A., Rusakov A. V., Ortega B, Solleiro E., Rozanova M. S., Kuznetsova A.M., Kazdym A.A. Pozdnepleistotsenovye paleopochvennye serii kak instrument lokalnoi paleogeograficheskoi rekonstruktsii (na primere razreza Kostenki 14). Pochvovedenie. 2010, no. 8, pp.938-955. (In Russian)

Semenov S. A. Pervobytnaia tekhnika (opyt izucheniia drevneishikh orudii i izdelii po sledam raboty). Materialy $i$ issledovaniia po arkheologii SSSR. Moscow; Leningrad, Izdatel'stvo Akademii nauk SSSR, 1957, no. 54, 240 p. (In Russian)

Sergin V.Ia. Klassifikatsiia paleoliticheskikh poselenii s zhilishchami na territorii SSSR. Sovetskaia arkheologiia, 1988, no. 3, pp. 5-20. (In Russian)

Sinitsyn A. A. Les sépultures de Kostenki: chronologie, attribution culturelle, rite funéraire. La Spiritualité: Actes du colloque de la commission 8 de l'UISPP (Paléolithique supérieur), Liège, 10-12 décembre 2003. Études et Recherches Archéologiques de l'Université de Liège. Ed. by M. Otte. Liège, 2004, pp. 237-244.

Sinitsyn A. A. Gravett Kostenok v kontekste gravetta Vostochnoi Evropy. Problemy zaseleniia severo-zapada Vostochnoi Evropy v verkhnem i final'nom paleolite (kul'turno-istoricheskie protsessy). Ed. by G. V.Sinitsyna. St. Petersburg, Institut istorii materialnoi kul'tury RAN, 2013, pp.4-32. (In Russian) 
Sinitsyn A.A. K probleme kul'turnoi prinadlezhnosti Pushkarei 1. Problemy arkheologii epokhi kamnia: k 70-letiiu Valentiny Ivanovny Beliaevoi: sbornik nauchnykh statei. St. Petersburg, 2014, pp. 234-244. (Trudy istoricheskogo fakul'teta Sankt-Peterbgskogo universiteta. Vol. 18).

Sinitsyn A. A. Preryvistost i preemstvennost v paleolite Kostenok. Verkhnedonskoi arkheologicheskii sbornik, iss. 6. Ed. by A.N. Bessudnov. Lipetsk, VPO LGPU, 2014, pp. 66-76. (In Russian)

Sinitsyn A. A. Kostenki 14 (Markina gora) - opornaia kolonka kul'turnykh i geologicheskikh otlozhenii paleolita Vostochnoi Evropy dlia perioda 27-42 tys.1.n. Drevnie kul'tury Vostochnoi Evropy. Etalonnye pamiatniki i opornye kompleksy v kontekste sovremennykh arkheologicheskikh issledovanii. Zamiatninskii sbornik. Ed. by G. A. Khlopochev. St. Petersburg, MAE RAN, iss. 4, 2015, pp. 40-59. (In Russian)

Sinitsyn A. A., Praslov N. D., Svezhentsev Yu. S., Sulerzhitskii L. D. Radiouglerodnaia khronologiia paleolita Vostochnoi Evropy. Radiouglerodnaia khronologiia paleolita Vostochnoi Evropy i Severnoi Azii. Problemy $i$ perspektivy. Eds A. A. Sinitsyn, N. D. Praslov. St. Petersburg, Akadem-Print, 1997, pp.21-66. (In Russian)

Skrlda P. The Pavlovian lithic technologies. Pavlov I - Northwest, The Dolní Věstonice Studies 4. Ed. by J. Svoboda. Brno, 1997, pp. 313-372.

Svoboda J.A. The Gravettian on the Middle Danube. PALEO, 2007, no. 19, pp. 203-220.

Svoboda J., Novak M., Sazelova S., Demek J. Pavlov I: A large Gravettian site in space and time. Quaternary International, 2016, vol.406, part A, pp.95-105.

Tarasov L. M. Gagarinskaia stoianka i ee mesto v paleolite Evropy. Moscow, Nauka, 1979, 167 p. (In Russian)

Zalizniak L. L., Stepanchuk V. M., Vetrov D. O., Tovkailo M. T., Ozerov P. I. Gravetska stoianka Troianove 4 pid Novomirgorodom. Kam'iana doba Ukraini. Ed. by L. L.Zalizniak. Kiiv, 2007, iss. 10, pp. 102-125 (In Ukrainan).

Zalizniak L.L., Vetrov D.O. Nova gravetska stoianka Ozerove na Kirovogradshchini. Kam’iana doba Ukraini. Ed. by L. L.Zalizniak. Kiiv, 2011, iss. 10, pp. 56-62 (In Ukrainan).

Zheltova M.N. Kostenkovskie stoianki pervoi nadpoimennoi terrasy. varianty adaptatsii k okruzhaiushchei srede verkhnego pleistotsena. Problemy biologicheskoi i kul'turnoi adaptatsii chelovecheskikh populiatsii. Sbornik statei, posviashchennyi 100-letiiu so dnia rozhdeniia M. M. Gerasimova. Vol. 1: Arkheologiia. Adaptatsionnye strategii drevnego naseleniia Severnoi Evrazii. syre i priemy obrabotki. Ed. by G. A. Khlopachev. St. Petersburg, MAE RAN, Nauka Publ., 2008, pp.48-52. (In Russian)

Zheltova M.N. Kostenki-4. vzaimoraspolozhenie ob"ektov v prostranstve i vremeni (analiz kul'turnogo sloia). Arkheologiia, etnografiia i antropologiia Evrazii. Novosibirsk, 2009, no. 2 (38), pp.19-27. (In Russian)

Zheltova M. N. Ostriia aleksandrovskogo tipa. kontekst, morfologiia, funktsiia. Paleolit i Mezolit Vostochnoi Evropy. Sbornik statei v chest' 60-letiia Kh. A. Amirkhanova. Ed. by K. N. Gavrilov. Moscow, Taus Publ., 2011, pp. 226-234. (In Russian)

Zheltova M.N. Mesto kamennykh industrii Kostenok $4 \mathrm{v}$ kontekste verkhnego paleolita Evropy. Problemy zaseleniia severo-zapada Vostochnoi Evropy $v$ verkhnem i final'nom paleolite (kul'turno-istoricheskie protsessy). Ed. by G. V. Sinitsyna. St. Petersburg, Institut istorii materialnoi kul'tury RAN, 2013, pp. 86109. (In Russian)

Zheltova M.N. Kostenki 4. opyt rekonstruktsii uchastka kul'turnogo sloia. Arkheologicheskie vesti, 2014, no. 20, pp. 55-68. (In Russian)

Zheltova M.N. Planigraficheskii analiz zhilykh kompleksov stoianki Kostenki 4. Avtoref. dis. ... kand. ist. nauk. St. Petersburg, 2015, 22 p. (In Russian)

Zheltova M. N. Problema khronologicheskogo i kul'turnogo edinstva materialov nekotorykh kostenkovskikh stoianok i vozmozhnye metody ee resheniia. Estestvennonauchnye metody $v$ izuchenii $i$ sokhranenii pamiatnikov Kostenkovsko-Borshchevskogo arkheologicheskogo raiona. Ed. by V.N.Kovalevskii. Voronezh, Voronezhskii gosudarstvennyi universitet, 2017, pp. 124-139. (In Russian)

Zheltova M.N., Burova N.D. Sopostavlenie zhilykh kompleksov Kostenok 4 na osnove izucheniia osteologicheskikh kollektsii. Stratum plus, 2014, no. 1, pp.111-145. (In Russian)

Zheltova M.N., Lisitsyn S.N. Shlifovannye izdeliia iz kamnia v paleolite Kostenok. V (XXI) Vserossiiskii arkheologicheskii s"ezd. Sbornik nauchnykh trudov. Eds A.P.Derevianko, A.A.Tishkin. Barnaul, FGBOU VO Altaiskii gos. universitet, 2017, pp. 368-369. (In Russian)

Статья поступила в редакцию 30 апреля 2018 г. Рекомендована в печать 12 марта 2019 г.

Received: April 30, 2018

Accepted: March 12, 2019 


\section{Mammoth-hunter Camps in the Scandinavian North Sea Sector during the Late Weichselian?}

\section{O. Grøn}

For citation: Grøn O. Mammoth-hunter Camps in the Scandinavian North Sea Sector during the Late Weichselian? Vestnik of Saint Petersburg University. History, 2019, vol. 64, issue 2, pp. 555-583. https://doi.org/10.21638/11701/spbu02.2019.209

Until recently, the general view of archaeologists was that southern Scandinavia was uninhabited during the last ice age, the Weichselian glaciation. It was thought that humans arriving from south would have met a wall of ice if they tried to penetrate into the area. Recent climate reconstructions and glaciological data, combined with recent faunal finds from the adjacent North Sea sector, promote the idea of a much more moderate and prosperous landscape with large, now submerged, plains accessible. Then this paper argues that large parts of the South Scandinavian North Sea sector were actually inhabitable during most of this glacial period, with extensive ice-free coastal zones even during the Last Glacial Maximum. It is difficult to believe that humans, already well-documented in the adjacent land areas, should not have known to inhabit and exploit such a rich resource zone. In addition to the paleoenvironmental data, ethnoarchaeological evidence is used to document that it was no problem for humans to kill large animals such as mammoths as some researchers have maintained. Furthermore, findings from excavations of mammoth-hunter sites, are used to argue that the large quantities of megafaunal remains fished up from the North Sea in recent years should be seriously considered as representing settlement material associated with mammoth-hunter camps dating from the second half of the Weichsel Glacial Stage. The central question is whether these North Sea faunal remains represent sites similar to the mammoth-hunter camps known from other parts of Europe and from Siberia? If that is the case, the Cultural Heritage management is confronted with a hitherto unrecognised problem.

Keywords: mammoth hunters, mammoth bone remains, Upper Paleolithic, ethoarchaeology, Scandinavia, North Sea, late Weichselian.

Ole Grøn - PhD, research scientist, University of Geosciences and Natural Resource Management, University of Copenhagen, Østervoldgade, 10, DK 1250, Copenhagen K, Denmark; olegron111@gmail.com

Оле Грюн - д-р философии (археология), науч. сотр., Копенгагенский университет, Дания, DK 1250, Копенгаген К, Остервольдгаде, 10; olegron111@gmail.com

Anders Fischer, Vladimir Pitulko, Jane Richter, Pål Nymoen, Jan Michael Burdukievicz, Luc Amkreutz, Marcel J.L.T.Niekus, Marine Dunsmore and Stefan Wenzel are all thanked for comments and suggestions relating to various versions of this manuscript. Nic Flemming is thanked for adding his own observations to the review of published information on the collection of mammoth faunal remains from the North Sea

Автор выражает благодарность за комментарии и предложения, касающиеся различных версий этой рукописи Андерсу Фишеру, Владимиру Питулько, Джейн Рихтер, Полу Нимоену, Яну Майклу Бурдукиевич, Люку Амкройц, Марселю Ж. Л. Ниекус, Марин Дунсморе и Стефану Вензелю. Отдельная благодарность Нику Флеммингу за предоставление своих наблюдений в обзор опубликованной информации о сборе останков мамонтовой фауны из Северного моря.

(C) Санкт-Петербургский государственный университет, 2019 


\section{Лагеря охотников на мамонтов в Скандинавском секторе Северного моря во время последнего вислинского оледенения?}

О. Грюн

Для цитирования: Grøn O. Mammoth-hunter Camps in the Scandinavian North Sea Sector during the Late Weichselian? // Вестник Санкт-Петербургского университета. История. 2019. Т. 64. Вып. 2. С. 555-583. https://doi.org/10.21638/11701/spbu02.2019.209

До недавних пор в археологическом сообществе было распространено мнение о том, что Южная Скандинавия в последнюю (вислинскую) ледниковую эпоху оставалась незаселенной человеком. Так, считалось, что двигавшиеся с юга группы людей при попытке проникнуть на эту территорию столкнулись бы с ледяной стеной. Последние реконструкции климата в совокупности с гляциологическими данными и новыми фаунистическими находками в прилегающем секторе Северного моря дают основания предполагать более умеренный и благоприятный ландшафт с обширными равнинными участками, ныне затопленными. Таким образом, показано, что значительные области южно-скандинавского сектора Северного моря были обитаемы на протяжении значительной части ледниковой эпохи, в течение которой даже во время последнего ледникового максимума существовали обширные безледные прибрежные зоны. С трудом можно допустить, что люди, присутствие которых на прилегающих сухопутных территориях несомненно, не могли бы заселить и использовать столь богатую ресурсами зону. В дополнение к палеогеографическим данным для доказательства данного тезиса в работе использованы этноархеологические свидетельства, показывающие, что охота даже на таких крупных животных, как мамонты, не представляла собой проблемы для древнего человека. Данные, полученные в результате раскопок стоянок охотников на мамонтов, привлечены для обоснования того, что массовые находки костных остатков мегафауны, в большом количестве собранные в последние годы в результате тралового лова рыбы в Северном море, могут рассматриваться в качестве материалов поселенческих структур, относящихся ко второй половине поздней стадии вислинского оледенения. Главный вопрос состоит в том, являются ли фаунистические остатки, поднятые в Северном море, остатками материалов со стоянок, подобных лагерям охотников на мамонтов, известных в других частях Европы и в Сибири. Если это так, то возникает ранее неизвестная проблема администрирования объектов культурного наследия.

Ключевые слова: охотники на мамонтов, костные остатки мамонтов, верхний палеолит, этноархеология, Скандинавия, Северное море, поздняя стадия вислинского оледенения.

\section{Introduction - the setting (1)}

Until recently, the Scandinavian North Sea sector was not seen as a relevant area for maritime archaeological investigations of Stone Age remains. Despite the recovery of tree stumps and a range of Mesolithic artefacts ${ }^{1}$, erosion and redeposition of sediment in this

${ }^{1}$ Fischer A. Submerged Stone Age - Danish examples and North Sea potential // Submarine prehistoric archaeology of the North Sea. Research priorities and collaboration with industry. CBA Research Report 141. English Heritage/Council for British Archaeology. 2004. P.23-36; Koijmans L. Mesolithic Bone and Antler Implements from the North Sea and from the Netherlands // Berichten van de Rijksdienst voor het Oudheidkundig Bodemonderzoek. Jaargang 20-21. 1971. P.27-73; Reid C. Submerged Forest. Cambridge, 1913. 
dynamic environment were thought to have effectively erased any cultural deposits, leaving only heavily abraded artefacts as remnants of former cultural contexts ${ }^{2}$.

An increasing general focus on submerged Stone Age archaeology, inspired to some degree by significant industrial development of off-shore technology, has recently prompted a systematic appraisal of the potential for locating and investigating submerged Stone Age sites from glacial periods when the sea level was significantly lower than it is today. It is a well-established fact that significant parts of the continental shelf were inhabited during various Stone Age epochs. As far as the English Channel is concerned, for instance, a settlement on land now partly located below present sea level has recently been shown to date back almost a million years in Happisburgh in eastern England ${ }^{3}$.

\section{1.a. The environmental setting}

A central problem relating to the understanding of Stone Age settlement during prehistoric glacial periods is that a rather primitive form of modelling has generally been applied to environmental-cultural interactions in archaeological studies. The edges of prehistoric ice sheets have been perceived as simple walls of ice that blocked human access to 'glaciated' areas covering northern land surfaces ${ }^{4}$. Very little attention has been paid to the importance of land/sea interfaces, including the quite common broad ice-free corridors running between the 'outer coast' and the 'inland ice margin', as recognised in modern glaciology 5 .

${ }^{2}$ Coles B. Doggerland: a Speculative Survey // Proceedings of the Prehistoric Society. Vol.64. 1998. P. 45-81.

3 Ashton N., Lewis S. G., De Groote I., Duffy S. M., Bates M., Bates R., Hoare P., Lewis M., Parfitt S. A., Peglar S., Williams C., Stringer C. Hominin Footprints from Early Pleistocene Deposits at Happisburgh, UK // PLOS ONE. February 2014. Vol. 9, iss. 2, 13 p.; Bailey G., Sakellariou D. et al. SPLASHCOS: Submerged Prehistoric Archaeology and Landscapes of the Continental Shelf // Antiquity. Vol. 086, iss. 334. December 2012; Bicket A. Submerged Prehistory: Marine ALSF Research in Context. Marine ALSF Science Monograph Series No. 5. (Ed. J. Gardiner). MEPF 10/P150. 2011.; Dix J., Quinn R., Westley K. Re-assessment of the archaeological potential of continental shelves // English Heritage ALSF project No. 3362. University of Southampton, 2008; Flemming N. Research Infrastructure for Systematic Study of the Prehistoric Archaeology of the European Submerged Continental Shelf // Submerged Prehistory. Oxford, 2011. P. 287-297; Grøn O., Froberg Mortensen L. Stone Age in the Danish North Sea Sector // Maritime Archaeology Newsletter from Denmark. No.26, Summer 2011. P.3-8; Parfitt S. A., Ashton N. M., Lewis S. G., Abel R. L., Russell Coope G., Field M.H., Gale R., Hoare P.G., Larkin N.R., Lewis M.D., Karloukovski V., Maher B.A., Peglar S.M., Preece R. C., Whittaker J. E., Stringer C. B. Early Pleistocene human occupation at the edge of the boreal zone in northwest Europe // Nature. Vol.466, iss. 7303, 8 Jul. 2010. P. 229-233; Peeters H. North Sea Prehistory Research and Management Framework (NSPRMF). Amersfoort, 2009; Arch-Manche: Archaeology, Art and Coastal Heritage - tools to support management and climate change planning across the Channel Regional Sea: Technical Report // Arch-Manche Technical Report / Eds J. Satchel, L. Tidbury. September. 2014. P. 40; Tizzard L., Bicket A., De Loecker D. Seabed Prehistory. Investigating the Palaeogeography and Early Middle Palaeolithic Archaeology in the Southern North Sea. Wessex Archaeology Report 35. 2015.

${ }^{4}$ Bordes F. The Old Stone Age. Toronto, 1972. P.9-10, 213; Coles J. M., Higgs E. S. The Archaeology of Early Man. London, 1975. P. 18, 419; Honoré P. Das Buch der Altsteinzeit - oder der Streit um die Vorfahren. Wien, 1967. P. 101, 399, 406, 430.

${ }^{5}$ Barron E., van Andel T.H., Pollard D. Glacial Environments II: Reconstructing the Climate of Europe in the Last Glaciation // Neanderthals and modern humans in the European landscape during the last glaciation: archaeological results of the Stage 3 Project. University of Cambridge, 2003. P.57-78; Kelly M. A., Long A. J. The dimensions of the Greenland Ice Sheet since the Last Glacial Maximum // PAGES News. Vol. 17, no. 2, June 2009. P. 60-61; Lambeck K., Purcell A., Zhao J., Svensson N.-O. The Scandinavian Ice Sheet: from MIS 4 to the end of the Last Glacial Maximum // BOREAS. Vol.39, no. 2. 2010. P.410-435; 


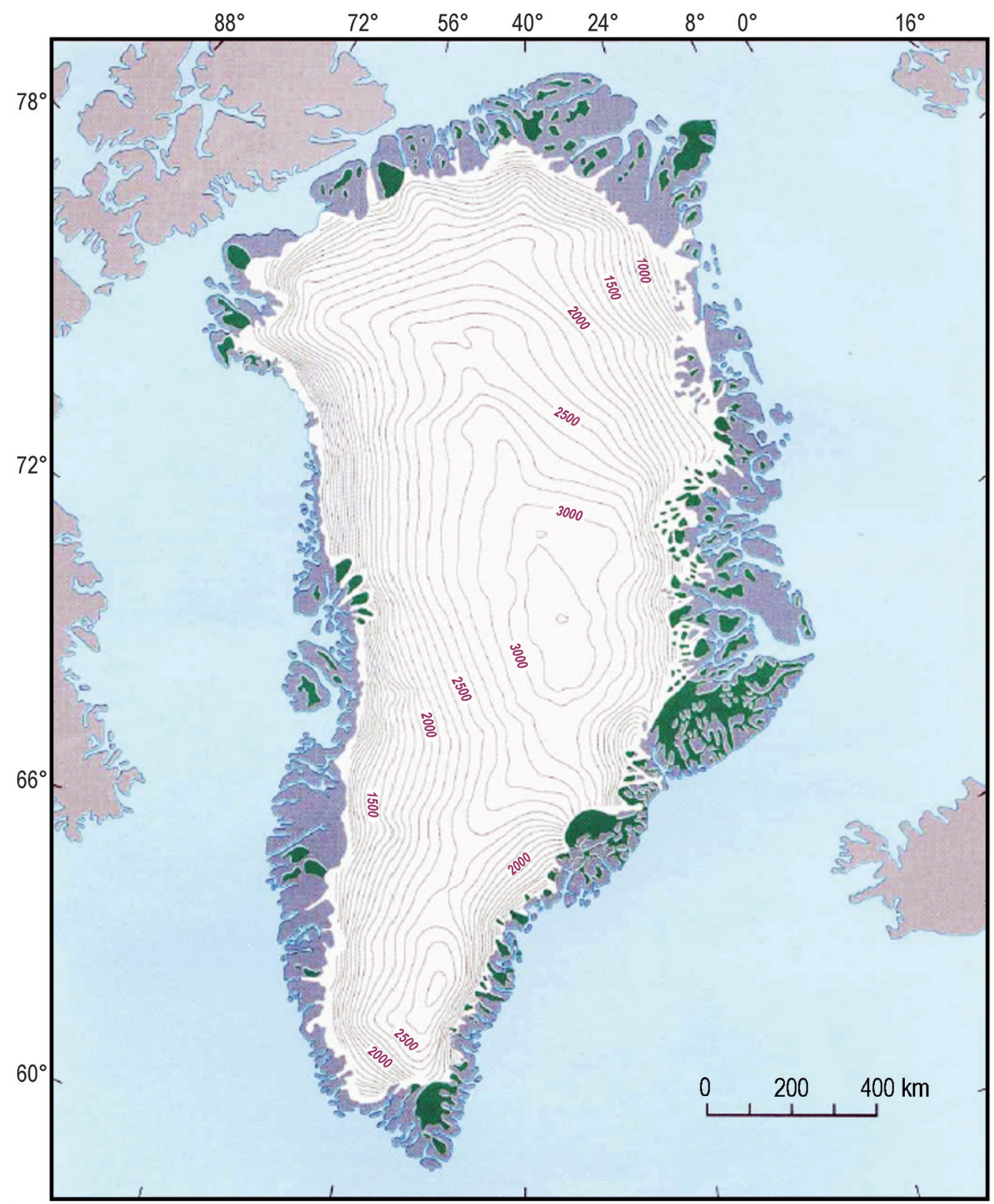

Fig. 1. The permanent ice sheet on Greenland consists of a number of glaciers flowing from the interior out towards the coast. In some areas these glaciers reach fjords where they break up to form icebergs. In other areas the ice melts or evaporates before it reaches the coast. The outer coast does not have permanent ice cover [Weidick, 1995]

Mackintosh A., Colledge N., Domack E., Dunbar R., Leventer A., White D., Pollard D., DeConto R., Fink D., Zwartz D., Gore D., Lavoie C. Retreat of the Antarctic ice sheet during the last glacial termination // Nature Geoscience. Vol. 4. 2011, March. P. 195-202; Påsse T., Andersson L. Shore-level displacement in Fennoscandia calculated from empirical data // GFF. Vol.127 (2005). P.253-268; Weidick A., Bennike O. Quaternary glaciation history and glaciology of Jakobshavn Isbræ and the Disko Bugt region, West Greenland: a review. Copenhagen, 2007. P. 12, 48-49. 
There are numerous past and present examples of glaciated areas with ice-free outer coasts, such as modern Greenland (Fig. 1) and the Antarctic during the Last Glacial Maximum, as well as several other similar prehistoric situations ${ }^{6}$. In other cases, the ice sheet extends or extended beyond the coastline and into the sea as shelf ice ${ }^{7}$.

A complex set of factors controls the configuration of glacial coasts: precipitation, melting of and evaporation from the ice sheet, altitude of the snow line, rate of growth of the ice sheet, sea temperature, presence/absence of permanent sea ice and so on ${ }^{8}$. Permanent sea ice will, due to its insulating effect, reduce the impact of the relatively warm seawater (warmer than $\mathrm{c} .-1.8^{\circ} \mathrm{C}$ ) on a land-based ice sheet and deflect the sun's rays more efficiently than open water, thereby reducing the sun's heating effect on the sea ${ }^{9}$. The potential for formation of permanent sea ice will depend on a series of factors, such as the depth and bathymetry of the seabed, currents, wind conditions, etc. ${ }^{10}$ Recent reconstructions of the Weichselian landscape show extensive ice-free coastal and inland zones for the Scandinavian North Sea margin which, in the southernmost zone, persist throughout the entire glaciation. The Norwegian coast may have been ice-covered through most of the later Weichselian, but its ice/land/sea configuration during this period is difficult to reconstruct in detail ${ }^{11}$.

${ }^{6}$ Long A. J., Roberts D. H., Wright M. R. Isolation basin stratigraphy and Holocene relative sea-level change on Arvepinsen Ejland, Disko Bugt, West Greenland // Journal of Quaternary Science. Vol. 14(4). 1999. P.323-345; Mackintosh A., Colledge N., Domack E., Dunbar R., Leventer A., White D., Pollard D., DeConto R., Fink D., Zwartz D., Gore D., Lavoie C. Retreat of the Antarctic ice sheet during the last glacial termination // Nature Geoscience. Vol.4, March 2011. P. 195-202; Weidick A., Bennike O. Quaternary glaciation history and glaciology of Jakobshavn Isbræ and the Disko Bugt region, West Greenland: a review. Copenhagen, 2007. P. 12.

7 Lemke P., Ren J., Alley R. B., Allison I., Carrasco J., Flato G., Fujii Y., Kaser G., Mote P., Thomas R. H., Zhang T. Observations: Changes in Snow, Ice and Frozen Ground // Climate Change 2007: The Physical Science Basis. Contribution of Working Group I to the Fourth Assessment Report of the Intergovernmental Panel on Climate Change. 2007. P. 341; Sejrup H.P., Larsen E., Haflidason H., Berstad I. M., Hjelstuen B. O., Jonsdottir H., King E.L., Landvik J., Longva O., Nygård A., Ottesen D., Raunholm S., Rise L., Stalsberg K. Configuration, history and impact of the Norwegian Channel Ice Stream // Boreas. 2003. Vol. 32. P. 18-36.

8 Dansgaard W., White J.W.C., Johnsen S. J. The abrupt termination of the Younger Dryas climate event // Nature. Vol.339. 15 June. 1989. P.532-534; Lemke P., Ren J., Alley R. B., Allison I., Carrasco J., Flato G., Fujii Y., Kaser G., Mote P., Thomas R. H., Zhang T. Observations: Changes in Snow, Ice and Frozen Ground. P.341; Weidick A., Bennike O. Quaternary glaciation history and glaciology of Jakobshavn Isbræ and the Disko Bugt region, West Greenland: a review. Copenhagen, 2007. P.28-64.

9 Armand L.K., Leventer A. Palaeo Sea Ice Distribution - Reconstruction and Palaeoclimatic Significance // Sea Ice. An Introduction to its Physics, Chemistry, Biology and Geology. Oxford, 2003. P. 333-372; Gildor H., Tziperman E. Sea ice as the glacial cycles' climate switch: Role of seasonal and orbiting forcing // Paleoceanography. Vol. 15(6). 2000. P. 605-615; Golden K. M. Climate Change and the Mathematics of Transport in Sea Ice // Notices of the American Mathematical Society. Vol.56(5). 2009. P. 562-584

10 Leventer A. Particulate Flux from Sea Ice in Polar Waters // Sea Ice. An Introduction to its Physics, Chemistry, Biology and Geology. Oxford, 2003. P. 303-332; Morison J., Kwok R., Peralta-Ferritz C., Alkire M., Rigor I., Steele M. Changing Arctic Ocean freshwater pathways // Nature. Vol. 481.5 January. 2012. P. 66-70; Nghiem S. V., Clemente-Colón P., Rigor I. G., Hall D. K., Neumann G. Seafloor control on sea ice // Deep-Sea Research II. Vol.77-80. 2012. P. 52-61.

11 Barron E., van Andel T. H., Pollard D. Glacial Environments II: Reconstructing the Climate of Europe in the Last Glaciation. (Eds.) Tjeerd H.van Andel and William Davies // Neanderthals and modern humans in the European landscape during the last glaciation: archaeological results of the Stage 3 Project. McDonald Institute for Archaeological Research, University of Cambridge, 2003. P.57-78; Lambeck K., Purcell A., Zhao J., Svensson N.-O. The Scandinavian Ice Sheet: from MIS 4 to the end of the Last Glacial Maximum // BOREAS. Vol.39, no. 2. 2010. P. 410-435; Mangerud J. Ice sheet limits in Norway and on the Norwegian continental shelf // Quaternary Glaciations - Extent and Chronology. Vol. 1. 2004. P.271-294; 
In addition to abandoning simplistic ideas about the principles of interaction between human cultures and prehistoric glacial landscapes, we must also accept the existence of greater climatic and environmental complexity and dynamics during these glacial periods. The Greenland ice cores (DYE-3, GRIP, GISP2, NGRIP and NEEM) have revolutionised our ideas of climate dynamics ${ }^{12}$. Given the early date demonstrated for Happisburgh ${ }^{13}$, we should be aware of the possible existence in northern Europe of submerged sites during the glacial periods, with their low sea levels and relatively high coastal temperatures, as far back as a million years ago.

A further important argument for the existence of deep coastal Stone Age sites is that, apart from tropical rainforests, shallow marine coasts represent the most productive biotope in existence ${ }^{14}$, and they are therefore especially attractive to humans.

\section{1.b. Cultural factors}

Based on studies of the historical territorial development of Australian hunter-gatherer groups, Peter Sutton suggests that the more successful of these groups managed, over time, to extend and move their territories out to the highly productive seashore ${ }^{15}$. Information about very successful coastal hunter-gatherer groups, such as the Northwest Coast Indians, the coastal Nivkh/Gilyak of the Amur River estuary and the Ainu of Sakhalin and Hokkaido, also seems to support the general idea that highly productive marine coasts ${ }^{16}$ hold a particular attraction for humans and represent a special potential for human cultural development ${ }^{17}$. A growing understanding of the importance of coastal resources in the Palaeolithic, including the Late Palaeolithic of northern Europe, is reflected in the more recent literature ${ }^{18}$.

Påsse T., Andersson L. Shore-level displacement in Fennoscandia calculated from empirical data // GFF. Vol. 127. 2005. P.253-268.

12 Austin W. E. N., Hibbert F. D., Rasmussen S. O., Peters C., Abbot P. M., Bryant C. L. The synchronization of palaeoclimatic events in the North Atlantic region during Greenland Stadial 3 (ca 27.5 to $23.3 \mathrm{kyr}$ b2k) // Quaternary Science Reviews. Vol. 36. 2012. P. 154-164.

13 Ashton N., Lewis S. G., De Groote I., Duffy S. M., Bates M., Bates R., Hoare P., Lewis M., Parfitt S. A., Peglar S., Williams C., Stringer C. Hominin Footprints from Early Pleistocene Deposits at Happisburgh, UK // PLOS ONE. February 2014. Vol.9, iss.2. 13 p.

14 Odum E. P., Barrett G. W. Fundamentals of Ecology. Belmont, 2005.

15 Sutton P. The Pulsating Hearth: Large Scale Cultural and Demographic Processes in Aboriginal Australia // Hunter-Gatherer Demography. Past and Present. University of Sydney, 1990. P.71-80.

16 Odum E. P., Barrett G. W. Fundamentals of Ecology. Belmont, 2005.

17 Black L. The Nivkh (Gilyak) of Sakhalin and the Lower Amur // Arctic Anthropology. Vol. 10(1). 1973. P. 1-110; Ohnuki-Tierney E. The Ainu of the Northwest Coast of Southern Sakhalin. New York, 1974; Shternberg L.I. The Socal Organisation of the Gilyak // Anthropological Papers of The American Museum of Natural History. No. 82, 1999; Northwest Coast / ed. by W. Suttles. Washington, 1990; Watanabe H. The Ainu Ecosystem. Environment and Group Structure. Seattle, 1973.

18 Bjerck H. B. Tidligmesolittsk tid (TM) og Fosnatradisjon 9500-8000 BC. // Ormen Lange Nyhamnia. NTNU Vitenskapsmuseets arkeologiske undersøkelser. Trondheim, 2008. P. 552-570; Bjerck H. B. Colonising seascapes: comparative perspectives on the development of maritime relations in the Pleistocene/Holocene transition in north-west Europe // Mesolithic Horizons. Oxford, 2009. P. 16-23; Bradley B., Stanford $D$. The North Atlantic ice-edge corridor: a possible Palaeolithic route to the New World // World Archaeology. Vol.36(4). 2004. P. 459-478; Cortés-Sánchez M., Morales-Muñiz A., Simón-Vallejo M.D., Lozano-Francisco M.C., Vera-Peláez J.L., Finlayson C., Rodriguez-Vidal J., Delgado-Huertas A., Jiménez-Espejo F. J., Martínez-Ruiz F., Martínez-Aguirre M. A., Pascual-Granged A. J., Bergadà-Zapata M. M., Gibaja-Bao J.F., Riquelme-Cantal J. A., López-Sáez J. A., Rodrigo-Gámez M., Sakai S., Sugisaki S., Finlayson G., Fa D. A., Bicho N. Earliest Known Use of Marine Resources by Neanderthals // PLoS one. Vol. 6(9): e24026. 2011. Available: 
Territorial manoeuvring over time at clan level, or direct migration, either locally or over greater distances, are both well-known phenomena in hunter-gatherer societies ${ }^{19}$. This introduces the interesting possibility that deeper submerged coastlines may have been densely populated by cultural groups that differed markedly from those we can observe in today's terrestrial situations.

The author has had the opportunity to study the Siberian Evenk and has recorded a rather high level of curiosity-driven long-distance travel by them. This concurs with Parry's observations of the Inuit living in the Melville Peninsula area ${ }^{20}$. Long-distance pre-contact trading expeditions to areas more than a thousand kilometres from their homes appear to have been a well-known phenomenon among the Indians of the Canadian Plains as well as those of the North American Southwest. Travel and related exchange activities must be seen as something in which hunter-gatherers liked to engage ${ }^{21}$.

https://journals.plos.org/plosone/article?id=10.1371/journal.pone.0024026 (accessed: 04.02.2019); Fischer A., Mortensen M. F., Henriksen P. S., Mathiassen D. R., Olsen J. Dating the Trollesgave site and the Bromme culture - chronological fix-points for the Lateglacial settlement of Southern Scandinavia // Journal of Archaeological Science. 2013. Vol. 40 P. 1-12; E18 Brunlanesprosjektet. Arkeologiske undersøkelser i Larvik kommune, Vestfold fylke. Årsrapport 2007. Oslo, 2008. P. 42-51, 59-61; E18 Brunlanesprosjektet. Arkeologiske undersøkelser i Larvik og Porsgrunn kommuner, Vestfold og Telemark fylker. Årsrapport 2008 / ed. by L. Jaksland. Oslo, 2009. P.19-27, 30-31; Parfitt S. A., Barendregt R. W., Breds M., Collins M.J., Coope G.R., Durbridge P., Field M.H., Lee J.R., Lister A.M., Mutch R., Penkman K.E.H., Preece R. C., Rose J., Stringer C. B., Symmons R., Whittaker J.E., Wymer J.J., Stuart A. J. The earliest record of human activity in northern Europe // Nature. 2005. Vol.438, no. 7070, 15 December. P. 1008-1012; Parfitt S. A., Ashton N. M., Lewis S. G., Abel R. L., Russell Coope G., Field M.H., Gale R., Hoare P. G., Larkin N. R., Lewis M. D., Karloukovski V., Maher B. A., Peglar S. M., Preece R. C., Whittaker J. E., Stringer C. B. Early Pleistocene human occupation at the edge of the boreal zone in northwest Europe // Nature. 2010. Vol.466, no. 7303, 8 July. P. 229233; Ramos J., Domíguez-Bella S., Cantillo J.J., Soriguer M., Pérez M., Hernando J., Vijande E., Zabala C., Clemente I., Bernal D. Marine resources exploitation by Palaeolithic hunter-fisher-gatherers and Neolithic tribal societies in the historical region of the Strait of Gibraltar // Quaternary International. 2011. Vol.239. P. 104-113; Richards M. P., Jacobi R., Cook J., Pettitt P. B., Stringer C. B. Isotope evidence for the intensive use of marine foods by Late Upper Palaeolithic humans // Journal of Human Evolution. 2005. Vol. 49. P. 390-394; Shackleton J. C., van Andel T. Prehistoric Shore Environments, Shellfish Availability, and Shellfish Gathering at Frantchi, Greece // Geoarchaeology. 1986. Vol.1, no.2. P.127-143; Wikell R., Molin F., Pettersson M. The archipelago of Eastern Middle Sweden - Mesolithic settlement in comparison with C14 and shoreline dating // Chronology and Evolution within the Mesolithic of North-West Europe. 2009. P. 417-434.

19 Alden Smith E., Hill K., Marlowe F. W., Nolin D., Wiessner P., Gurven M., Bowles S., Mulder M. B., Hertz T., Bell A. Wealth Transmission and Inequality among Hunter-Gatherers // Current Anthropology. 2010. Vol. 51 (1), February. P. 19-34; Grøn O., Turov M., Klokkernes T. Settling in the landscape - settling the land: Ideological aspects of territoriality in a Siberian hunter-gatherer society // Archaeology of Settlements and Landscape in the North Umeå University. 2008. P. 57-80; Layton R. Political and Territorial Structures Among Hunter-Gatherers // Man. New Series. 1986. Vol.21(1), March. P. 18-33; Pettipas L. Aboriginal Migrations. A History of Movements in Southern Manitoba. Manitoba, 1996; Raghavan M. et al. Upper Palaeolithic Siberian genome reveals dual ancestry of Native Americans // Nature. 2014. Vol.505, no. 7481, 2 January. P. 87-94; Reich D., Patterson N., Campbell D., Tandon A., Mazieres S. et al. Reconstructing Native American population history // Nature. 2012. Vol.488, no. 7411, 16 August. P. 370-376.

20 Parry W.E. Journal of a Second Voyage for the Discovery of a North-West Passage from the Atlantic to the Pacific; Performed in the Years 1821-22-23 in his Majesty's ships Fury and Hecla, under the Orders of Captain William Edward Parry, R. N., F. R.S., and Commander of the Expedition. London, 1824. P.175, 185, 196-199, 252, 296, 303-305, 512-513.

${ }^{21}$ Brown J.S.H. History of the Canadian Plains Until 1870 // Handbook of North American Indians. Vol. 13 - Plains. Washington, 2001. P.300-312; Clark J. G.D. Prehistoric Europe. The Economic Basis. London, 1952. P. 241-256; Fitzgerald R. T., Jones T.L., Schroth A. Ancient long-distance trade in Western North America: new AMS radiocarbon dates from Southern California // Journal of Archaeological Science. Vol. 32. 2005. P. 423-434; Grindon A. J., Davison A. Irish Cepaea nemoralis Land Snails Have a Cryptic Franco-Iberian Origin That Is Most Easily Explained by the Movements of Mesolithic Humans // PLoS ONE 
Whereas the southernmost parts of the Scandinavian North Sea coastal areas and their hinterlands were apparently without ice cover throughout the entire Weichselian glaciation, and the Danish North Sea zone was only partly glaciated during the relatively short Late Glacial Maximum, it is possible that larger parts of the Norwegian North Sea coast were glaciated even though there were most probably significant ice-free refugia ${ }^{22}$. This does not imply, however, that it would have been a problem for humans to move around and subsist here. With an ice sheet extending all the way to the sea, there should be a good basis for solid sea ice in winter, which is traditionally the travelling season in northern coastal areas. 'The Sea Ice is Our Highway' is for instance the title of a contribution to the Arctic Marine Shipping Assessment from the Inuit Circumpolar Council of Canada (2008). The Inuit have demonstrated that a winter economy based on fishing and hunting through and on sea ice can be quite an attractive option ${ }^{23}$.

On the other hand, if there was a generally unglaciated land/sea interface, transportation along the North Sea Coast without boats would also be an obvious possibility. The presence or absence of people along the Scandinavian North Sea coast seems therefore mainly to have been a question of the nature of the available resources.

\section{Evidence for a mammoth fauna at the ice/land/sea interface in the Scandinavian North Sea sector during the Weichselian glaciation}

The huge quantities of faunal remains trawled up by Dutch fishermen from the North Sea, including the Danish North Sea sector, show that an actual mammoth fauna existed here for extensive periods during the second half of the Weichselian glaciation ${ }^{24}$. In turn,

8(6): e65792. 2013. Available: https://journals.plos.org/plosone/article?id=10.1371/journal.pone.0065792 (accessed: 04.02.2019); Klassen L. Jade und Kupfer. Untersuchungen zum Neolithisierungsprozess im westlichen Ostseeraum unter besonderer Berücksichtigung der Kulturentwicklung Europas 5500-3500 BC. Aarhus, 2009. P. 24-148; Ray A. J. Some Thoughts about the Reasons for Spatial Dynamism in the Early Fur Trade. 1580-1800 // Three Hundred Prairie Years: Henry Kelsey's "Inland Country of Good Report”. University of Regina, 1993. P. 114, 121; Reimer R. Reassessing the role of Mount Edziza obsidian in northwestern North America // Journal of Archaeological Science: Reports 2 (2015). P.418-426; Swagerty W.R. Indian Trade in the Trans-Mississippi West to 1870 // Handbook of North American Indians Vol.4 - History of Indian - White Relations. Washington, 1988. P.351-374; Sulgosłowska Z. Mesolithic mobility and contacts on areas of the Baltic Sea watershed, the Sudety, and Carpathian Mountains // Journal of Anthropological Archaeology. 2006. Vol.25. P. 193-203.

${ }^{22}$ Barron E., van Andel T.H., Pollard D. Glacial Environments II: Reconstructing the Climate of Europe in the Last Glaciation // Neanderthals and modern humans in the European landscape during the last glaciation: archaeological results of the Stage 3 Project. Cambridge, 2003. P.57-78; Lambeck K., Purcell A., Zhao J., Svensson N.-O. The Scandinavian Ice Sheet: from MIS 4 to the end of the Last Glacial Maximum // BOREAS. 2010. Vol. 39, no. 2. P. 410-435; Mangerud J. Ice sheet limits in Norway and on the Norwegian continental shelf // Quaternary Glaciations - Extent and Chronology. Vol. 1 Europe, Elsevier. Amsterdam, 2004. P. 271-294; Parducci L., Jørgensen T., Tollefsrud M. M., Elverland E., Alm T., Fontana S. L., Bennett K.D., Haile J. Matetovici I., Suyama Y., Edwards M.E. Andersen K., Rasmussen M., Boessenkool S., Coissac E., Brochmann C., Taberlet P., Houmark-Nielsen M., Krog Larsen N., Orlando L., Gilbert T.P., Kjor K. H., Greve Alsos I., Willerslev E. Glacial Survival of Boreal Trees in Northern Scandinavia // Science. 2012. Vol.335, 2 March. 2014. P. 1083-1087; Påsse T., Andersson L. Shore-level displacement in Fennoscandia calculated from empirical data // GFF. 2005. Vol. 127. P.253-268.

${ }^{23}$ Birket-Smith K. The Chugach Eskimo // Nationalmuseets Skrifter, Ecnografisk Række, VI, Copenhagen, 1953.

${ }^{24}$ Glimmerveen J., Mol D., Post K., Reumer J. W. F., van der Plicht H., de Vos J., van Reenen G., Pals J.P. Submarine prehistoric archaeology of the North Sea. Research priorities and collaboration with industry // CBA Research Report 141, English Heritage/Council for British Archaeology. 2004. P. 43-52. 


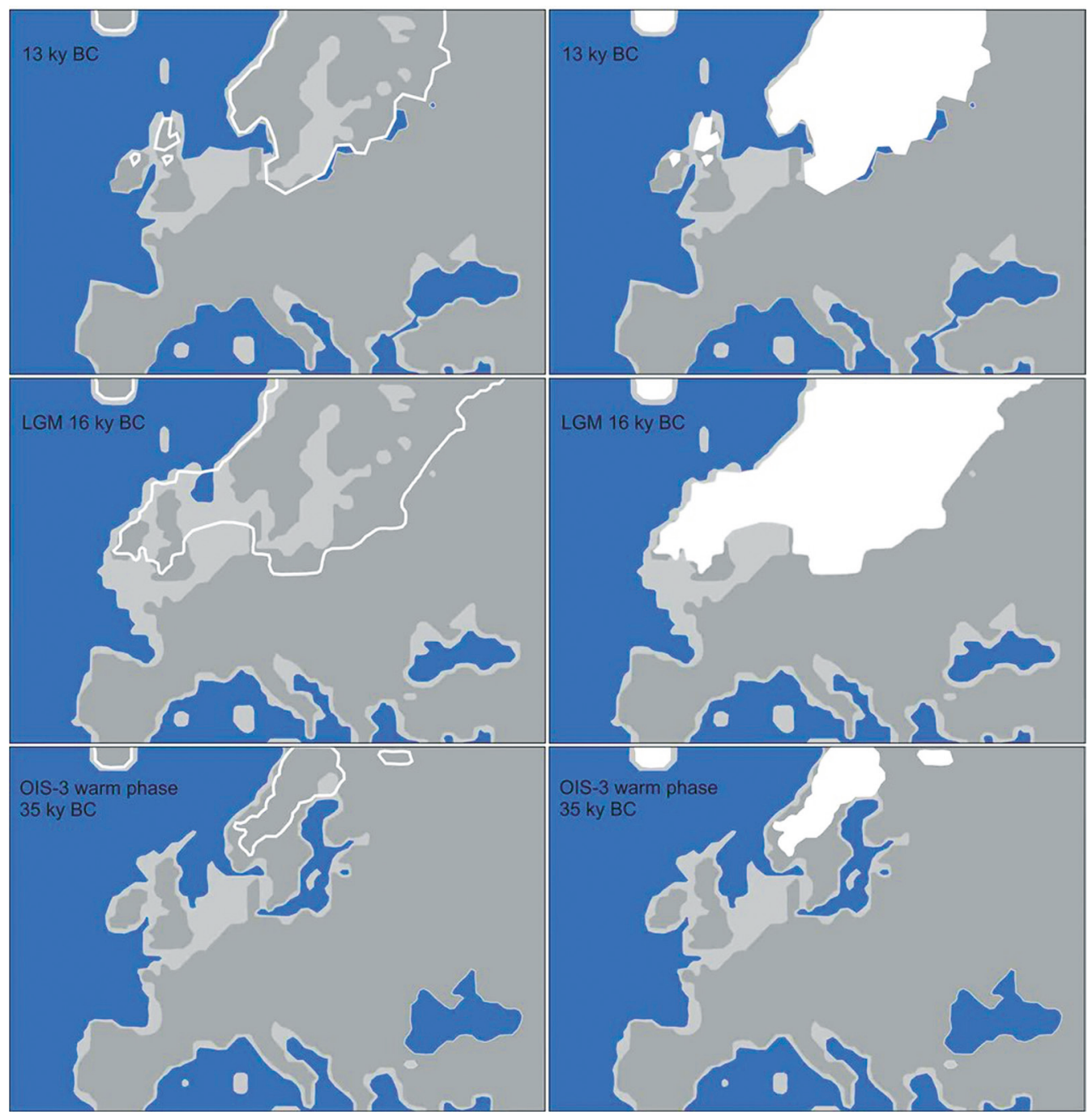

Fig. 2. Sketch maps showing the distribution of land, sea and ice during three phases of the last glaciation (the Weichselian $-117 \mathrm{ky}-11.6 \mathrm{ky} \mathrm{BP}$ ). Right: Ice sheets shown as white areas. Left: Ice sheets shown as transparent areas with white outlines to give a better impression of the present-day areas they covered. Water: blue; land today: dark grey; additional land during the different phases: light grey. Top: 15 ky BP. Middle: Last Glacial Maximum - LGM - 18 ky BP. Bottom: OIS-3 warm phase 37 ky BP. Based on [Barron et al., 2003; Clark et al., 2012; Sejrup et al., 2000; Sejrup et al., 2003; and Svendsen et al., 2004]

this demonstrates the existence here of extensive and highly productive ice-free coastal landscapes. Regardless of the debate about the type of vegetation upon which the mammoth fauna depended, and also helped to maintain, there is no doubt that the existence of extensive open landscapes was a precondition for their presence in this area ${ }^{25}$.

${ }^{25}$ Kozhevnikov J.P., Ukraintseva V. V. Pleistocene tundra-steppe: arguments pro and con // Mammoths and the Mammoth Fauna: Studies of an Extinct Ecosystem. Proceedings of the First International Mammoth 
Mammoth remains have been recovered from the Dutch and British North Sea sectors for the past 150 years and are heavily represented in Dutch natural history muse$u^{u m s} s^{26}$ (Fig. 3). Over a period of about 40 years, enormous quantities of palaeontological remains, including bones of mammoth, deer, woolly rhinoceros, wolf, bear, musk-ox, sabre-toothed tiger and other species, were recovered from the sea by Dutch fishermen using beam trawls. This is a type of trawl that, until the technology was recently improved, scraped through the upper $30-40 \mathrm{~cm}$ of the seabed with a heavy metal chain. The consumers of this by-catch were palaeontological collectors around the world. The material was sorted into categories for sale, which is legally permitted, as the material was allegedly found outside the territorial limit of 24 nautical miles ${ }^{27}$. There was a requirement to report bone artefacts to the archaeological authorities, and this rule was complied with. A qualified estimate is that, during this 40-year-period, about 10-20 tonnes of diverse palaeontological remains were landed each year by trawlers at the various ports.

The items acquired by palaeontological collectors have, in some cases, been analysed and presented in scientific publication ${ }^{28}$, while bones that were sold commercially have probably not been recorded or published. Most of the faunal remains have been found across a wide area straddling the Dutch-UK maritime boundary in the central-southern part of the North Sea, although some have been recovered further north in the UK, German and Danish sectors.

Radiocarbon dates have been published for several items, with an apparent focus on material from the Brown Bank. The time interval indicated by the 13 dates for mammoth, two for musk-ox and one each for giant deer and hyena, is 45-34 ky BP. The nine dates for reindeer span the interval from $45 \mathrm{ky}-30 \mathrm{ky} \mathrm{BP}^{29}$. The mammoth fauna recovered from the Eurogeul shipping lane and the Yangtze harbour in the Rotterdam area, and especially its later part in the Dutch Yangtze Harbour study, has also been dated to the Weichselian glaciation ${ }^{30}$.

Conference St. Petersburg, Russia, October 16-21, 1995. DEINSEA 6. 1999. P.199-210; Putshkov P.V. The impact of mammoths on their biome: clash of two paradigms // Advances in Mammoth Research. Proceedings of the Second International Mammoth Conference, Rotterdam, May 16-20 1999. DEINSEA 9. 2003. P.365-379; Willerslev et al. Fifty thousand years of Arctic vegetation and megafaunal diet // Nature. 2014. Vol. 506, no. 7486, 6 February. P. 47-51.

${ }^{26}$ Mol D., Post K., Reumer J. W. F., van der Pflicht J., de Vos J., van Geel B., van Reenen G., Pals J.P., Glimmerveen J. The Eurogeul - first report of the palaeontologica, palynological and archaeological investigations of this part of the North Sea // Quaternary International. 2006. Vol.142-143. P.178-185; Interdisciplinary Archaeological Research Programme Maasvlakte 2, Rotterdam, Part 2. BOORrapporten 566 / eds J. M. Moree, M. M. Sier. 2015. P.357; Peeters H. North Sea Prehistory Research and Management Framework (NSPRMF). Amersfoort, 2009; Glimmerveen J., Mol D., Post K., Reumer J.W.F., van der Plicht H., de Vos J., van Reenen G., Pals J.P. Submarine prehistoric archaeology of the North Sea. Research priorities and collaboration with industry // CBA Research Report 141, English Heritage/Council for British Archaeology. 2004. P. 43-52.

27 Dromgoole S. Underwater Cultural Heritage and International Law. Cambridge, 2013. P. 28-64.

${ }_{28}$ Mol D., de Vos J., Bakker R., van Geel B., Glimmerveen J., van der Plicht H., Post K. Mammoeten, neushoorns en andere dieren van de Noordzeebodem. Veen Magazines. Diemen, 2008.

${ }^{29}$ Glimmerveen J., Mol D., Post K., Reumer J. W. F., van der Plicht H., de Vos J., van Reenen G., Pals J.P. Submarine prehistoric archaeology of the North Sea. Research priorities and collaboration with industry // CBA Research Report 141, English Heritage/Council for British Archaeology. 2004. P. 43-52.

${ }^{30} \mathrm{Mol}$ D., Post K., Reumer J. W. F., van der Pflicht J., de Vos J., van Geel B., van Reenen G., Pals J.P., Glimmerveen J. The Eurogeul - first report of the palaeontologica, palynological and archaeological investigations of this part of the North Sea // Quaternary International. 2006. Vol.142-143. P. 178-185; 


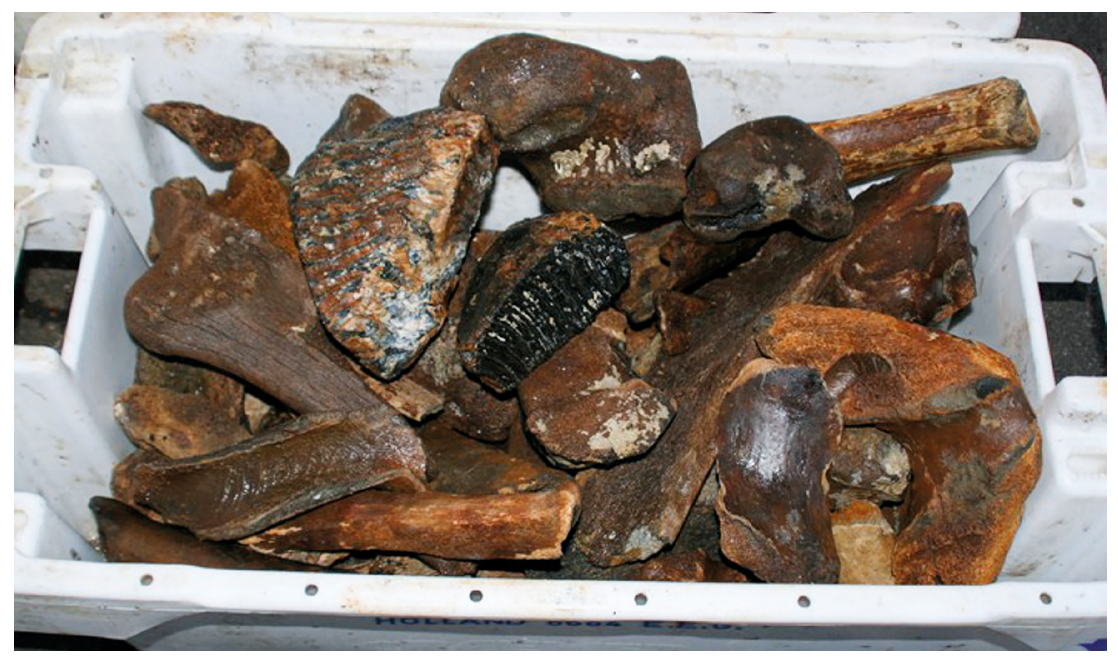

Fig. 3. Example of megafaunal remains trawled up from the North Sea (photo by Jan Meulmeester)

The key questions are: What do these remains of the mammoth fauna represent? Are they from animals that died of natural causes - possibly in so-called 'mammoth cemeteries' - due to natural catastrophes, or were they the prey of prehistoric hunters? Why were they preserved? Unburied bones, including those of the order Proboscidea, i.e. elephants and mammoths that are left unburied on the ground, normally do not survive for long $^{31}$.To what extent do these remains represent material associated with prehistoric settlements where their chances of preservation were significantly improved by, for instance, deposition in pits or other forms of burial? The ability of prehistoric hunter-gatherers to kill prehistoric elephants, including mammoths, has been questioned ${ }^{32}$. This aspect must therefore be investigated as a basis for further discussion.

\section{Ethno-archaeological evidence for human hunting of Elephant/ Mammoth family}

The ethnographic record demonstrates that hunter-gatherers are able to kill Proboscidea. The pygmies of the Congo and Cameroon jungle had no apparent problems in killing elephants with their fire-hardened wooden spears (in a few cases apparently

Interdisciplinary Archaeological Research Programme Maasvlakte 2, Rotterdam. Pt. 2. BOORrapporten 566 / eds J. M. Moree, M. M. Sier. 2015. P. 370, 382.

31 Bell L.S., Skinner M. F., Jones S. J. The speed of post mortem change to the human skeleton and its taphonomic significance // Forensic Science International. 1996. Vol. 82. P. 129-140; Haynes G. Longitudinal Studies of African Elephant Death and Bone Deposits // Journal of Archaeological Science. 1988. Vol.15. P. 131-157; Trueman C.N.G., Behrensmeyer A.K., Tuross N., Weiner S. Mineralogical and compositional changes in bones exposed on soil surfaces in Amboseli National Park, Kenya: diagenetic mechanisms and the role of sediment pore fluids // Journal of Archaeological Science. 2004. Vol.31. P.721-739.

32 Binford L.R. Human Ancestors; Changing Views of Their Behavior // Journal of Anthropological Archaeology. Vol. 4. 1985. P. 292-327; Bosch M. D. Human-Mammoth dynamics in the mid-Upper Paleolithic of the Middle Danube region // Quaternary International. 2012. Vol.276-277. P.170-182; Soffer O. The Upper Paleolithic of the Central Russian Plain. New York, 1985. P. 477. 
tipped with poison) or sometimes with harpoons. These large animals were targeted in their soft underbellies, just behind the ribs, or had their Achilles tendons cut. The aim of the former was to puncture the animal's bladder. Wounds inflicted in this way would leave few traces on the skeleton, and they enabled a single hunter to kill an elephant. The animal would die within a couple of days of the attack, in many cases far away from where it had been speared ${ }^{33}$. Cutting an elephant's Achilles tendons required a group of four to five pygmy hunters, but was also an efficient hunting method, which left the elephant to die where it had been attacked. According to Wæhle, the older pygmies in his study area were also acquainted with pygmy use of spear-falls and self-shot mechanisms, while the younger pygmies were not ${ }^{34}$ (Wæhle personal communication).

According to Schebesta, some Asian Semang (the Ple from Ulu Sengoh/Perak) apparently also hunted elephants for food using foot-traps or spear-falls, even though most of the groups in this area had a food taboo relating to the animals ${ }^{35}$. The Indian Kadar of Cochin trapped elephants for use as presents but did not eat their flesh because of a similar food taboo ${ }^{36}$.

All in all, it seems that hunting Proboscidea apparently posed no problems for either recent pygmy hunter-gatherers or a number of other cultural groups.

\section{Archaeological evidence for human hunting of Elephant/Mammoth family}

The body of archaeological evidence for human hunting of Proboscidea is presently increasing rather rapidly due to a new research focus on this theme. New mammoth sites with evidence for hunting have been found and old sites and finds have been re-examined, resulting in new observations and identifications of traces indicating hunting and butchering.

\subsection{Associated hunting weapons and remains of Proboscidea that indicate hunting}

A fire-hardened wooden (ebony) spear from the Upper Acheulian, found between the ribs of the skeleton of a straight-tusked elephant at Lehringen in Germany, demonstrates that, as has been pointed out by Jacob-Friesen and Movius, spear-hunting techniques like those of pygmy groups/tribes were practised during the Palaeolithic ${ }^{37}$. A clum-

33 Putnam A.E. Eight Years with Congo Pigmies. London, 1955. P.91-96; Turnbull C. M. The Mbuti Pygmies: An Ethnographic Survey // Anthropological Papers of the American Museum of Natural History. Vol. 50, pt. 3. New York 1965. P. 206-207; Zwilling E. A. Unvergessenes Kamerun. Zehn Jahre Wanderungen und Jagden 1928-1938. Berlin, 1941.

34 Turnbull C.M.: 1) The Mbuti Pygmies: An Ethnographic Survey // Anthropological Papers of the American Museum of Natural History, Vol. 50, pt. 3. New York 1965. P. 208; 2) The Mbuti Pygmies. Change and Adaptation. New York, 1983. P. 19-20.

35 Schebesta P. Die Negritos Asiens. II Bd. Etnographie der Negrito. 1. Halbband, Wirtschaft und Soziologie. Mödling, 1954. S. 58.

36 Ehrenfels U.R. Kadar of Cochin. Madras University Anthropological Series, no. I. University of Madras, 1952. P. 17, 57, 71, 110, 112, 180-181.

37 Jacob-Friesen K. H. Grosswildjäger des Eiszeitalters in Niedersachsen. Kosmos, Heft 11. November, 1949. P.408-412; Movius Jr. H.L. A Wooden Spear of Third Interglacial Age from Lower Saxony 
sily-made, roughly-pointed artefact, fashioned from the split long bone of a deer, was found in the more or less articulated skeleton of an enormous forest elephant (calculated head height $4.2 \mathrm{~m}$ ) that had partly sunk into the muddy shore sediments of a prehistoric lake at Neumark-Gröbern, Germany. Clearly associated with this skeleton were also 26 Palaeolithic flint flakes ${ }^{38}$. The authors doubt whether this irregular bone point would have been able to penetrate the $2-3 \mathrm{~cm}$ thick 'leather hide' of the elephant. However, it should be borne in mind that the animal's belly is much less well protected than the rest of its body, making this the ideal point of attack. The tip of what appears to have been a wooden spear of yew, not fire-hardened, was found at Clacton-on-Sea, in a Clactonian flint artefact context, in deposits containing faunal remains that included forest elephant (Elephas antiquus) $^{39}$. An interesting note in Nature (1888) mentions the discovery near Southall, west of London, of a mammoth skeleton surrounded by flint artefacts, including hand axes:

Several implements were found in Norwood Lane, in close proximity to the remains, and a well-formed spear-head, nearly 5 inches in length, of exactly the same shape as the spear-heads of obsidian until recently in use among the natives of the Admiral Islands, and other savages, was discovered in actual contact with the bones; smaller spear-head flakes, less symmetrically worked, were also found at this spot. They are symmetrically formed for easy insertion into the shafts by thinning out the butt ends, similar to those found abundantly by the author at the workshop floor, Acton, and described by him in his recently published work, "Palaeolithic Man in North-West Middlesex" ${ }^{40}$.

\subsection{Projectile impacts and butchering traces}

The increasing number of records of spear, lance and other projectile points, or evidence of the impact of such weapons, found on prehistoric mammoth/elephant skeletons, demonstrates that Proboscidea were hunted by humans during the Palaeolithic. The YMAM site, near the Yana Palaeolithic Site (RHS), in Arctic Siberia, is an accumulation of mammoth bones representing a minimum of 31 individuals, over a period extending from 31,200 to $25,100 \mathrm{BP}$. Of the four projectile impacts recorded there, three had struck three right scapulae and the fourth - a pelvis ${ }^{41}$. At Kostienki I, dated to around $21,000 \mathrm{BP}$, a mammoth rib was found with a tip fragment from a flint point embedded in $\mathrm{it}^{42}$. At Lugovskoe, western Siberia, the skeleton of an adult female mammoth, dating from around $13,500 \mathrm{BP}$, had a penetrating injury to a thoracic vertebra caused by what

// Southwestern Journal of Anthropology. 1950. Vol.6, no.2. P.139-142; Thieme H. Lower Palaeolithic hunting spears from Germany // Nature. 1997. Vol. 385, no. 6619, 27 February. P. 807-810.

${ }_{38}$ Mania D., Thomae M., Litt T., Weber T. Neumark-Grobern. Beitrage zur Jagd des mittelpalaolithischen Menschen. Berlin, 1990. P. 117-121, 215-235.

39 Oakley K.P., Andrews P., Keeley L.H., Clark J.D. A Reappraisal of the Clacton Spearpoint // Proceedings of the Prehistoric Society. 1977. Vol. 43. P.13-30.

40 Brown J. A. Discovery of Elephas Primigenius associated with flint implements at Southall // Nature. 1888. Vol.38, iss.977, July 19. P. 283-284.

${ }^{41}$ Nikolskiy P. A., Pitulko V. V. Evidence from the Yana Palaeolithic site, Arctic Siberia, yields clues to the riddle of mammoth hunting // Journal of Archaeological Science. 2013. Vol.40. P. 4189-4197.

42 Praslov N. Outils de chasse du Paleolithique de Kostenki // Anthropologie et Prehistoire. 2000. Vol.111. P.37; Sinitsyn A.A., Praslov N.D., Svezhentsev Yu.S., Sulerzhitskii L.D. Radiouglerodnaia khronologiia paleolita Vostochnoi Evropy // Radiouglerodnaia khronologiia paleolita Vostochnoi Evropy i Severnoi Azii. Problemy i perspektivy. St. Petersburg, 1997. P.21-66. 
appears to have been a point with two slots for quartzite inserts ${ }^{43}$. In 2011, a concentration of faunal remains, including those of at least five mammoths, was found at the Orto-Stan site on the Buor-Khaya Peninsula, Siberia. Two well-preserved pelvic bones of mammoth showed clear projectile impacts and one of these had clear traces of the removal of the head of the femur with a chopping tool. In addition, a right innominate bone of a horse had distinct cutmarks made by a lithic tool. The three bones with impacts resulting from human activity are dated to 28,790-27,080 $\mathrm{BP}^{44}$. By the Maksunuokha river in Siberia, the Nikita site consists of a redeposited concentration of faunal remains that includes at least 11 individuals. Several mammoth ribs show clear butchering marks, and some have lithic tool fragments embedded in them. The site has been radiocarbon dated to $12,050-11,960 \mathrm{BP}$ and contains ivory debitage, spearhead preforms and actual lithic artefacts including teardrop bifaces ${ }^{45}$. On the Ilin-Syalakh river, in the Yana-Indighirka interfluve, a smaller concentration of mammoth remains, the ISYLAKI-034 site, includes several mammoth ribs with clear human impact traces that can be interpreted as either butchering marks or projectile impacts. A mammoth mandible from this site gave a date of 22,700 $\mathrm{BC}^{46}$. At the Valea Morilor Palaeolithic site, Moldova, a mammoth ulna showed evidence of having been pierced by a pointed weapon ${ }^{47}$. At the Gontsy Palaeolithic site in the Ukraine, a bladelet was found lodged in a mammoth ib $^{48}$. At the Manis Mastodons site, on Washington's Olympic Peninsula, a mastodon skeleton had a point made from a mastodon bone embedded in a 12th, 13th or (most likely) 14th rib; the point has been dated to $13,800 \mathrm{BP}^{49}$.

\subsection{Configurations of Proboscidea remains indicating butchering}

Several Palaeolithic sites have also been found to contain varying concentrations of Proboscidea remains, where the configuration of these bones, their relation to human artefacts, or to bones of other hunted species, cutmarks, bone breakage patterns, the surface conditions and/or the sorting of various skeletal parts etc., strongly indicate that these assemblages represent hunted and butchered animals. Examples include: Dolní Vĕstonice I-II, Pavlov I and Milovice G and IV, the Czech Republic; Geissenklösterlee, Hohle Fels,

${ }^{43}$ Zenin V. N., LeshchinskiyS. V., Zolotarev K. V., Grootes P. M., Nadeau M.-J. Lugovskoe: geoarchaeology and culture of a Paleolithic site // Archaeology, Ethnology and Anthropology of Eurasia. 2006. Vol. 25. P. 4153.

44 Pitulko V. V., Yakshina I., Strauss J., Schirrmeister L., Knzuetsova T., Nikolskiy P., Pavlova E. Y. A MIS 3 kill-butchery mammoth site on Buor-Khaya Peninsula, Eastern Laptev Sea, Russian Arctic // Scientific Annals, School of Geology, Aristotle University of Thessaloniki, Greece, VI ${ }^{\text {th }}$ International Conference on Mammoths and their Relatives, Grevena - Siatista. Special Vol. 102. Thessaloniki, 2014. P. 158-159.

45 Ibid. P. 155.

46 Ibid.

47 Obada T., van der Plicht J., Markova A., Prepelitsa A. Preliminary results of studies of the Valea Morilor Upper Palaeolithic site (Chişinău, Republic of Moldova): A new camp of mammoth hunters // Quaternary International. 2012. Vol.276-277. P.227-241.

48 Iakovleva L., Djindjian F. New data on Mammoth bone settlements of Eastern Europe in the light of the new excavations of the Gontsy site (Ukraine) // Quaternary International. 2005. Vol. 126-128. P. 195207.

49 Lawler A. Pre-Clovis Mastodon Hunters Make a Point. Science Vol.334, 21 October, 2011; Waters M.R., Stafford T.W.jr., McDonald H.G., Gustafson C., Rasmussen M., Cappellini E., Olsen J.V., Szklarczyk D., Jensen L. J., Gilbert T.P., Willerslev E. Pre-Clovis Mastodon Hunting 13,800 Years Ago at the Manis Site, Washington // Science. 2011. Vol.334, 21 October. P. 351-353. 
Krems Wachtberg and the Neumark-Gröbern sites, Germany; Valea Morilor, the Republic of Moldova; the Maastricht-Belvédère Sites (B, C, G, N) and the Veldwezelt-Hezerwater sites (WFL, TL, MLMB), the Netherlands and Belgium; Krakow-Spadzista Street (B), Poland; Yudinovo (pavilion), Kostienki I and YMAM, Russia; Ambrona, Spain; Mezhirich and Gontsy, the Ukraine; La Sena and Lovewell, USA (Nebraska and Kansas) ${ }^{50}$.

Several concentrations of Proboscidea remains have been proclaimed so-called 'mammoth cemeteries' in the sense of 'natural death sites' where single individuals or herds of Proboscidea were caught in natural traps under circumstances that provided good conditions for the preservation of their remains. They are thought to have drowned while crossing rivers, lakes or swamps, to have been covered by falling/sliding earth, stone or other debris or to have fallen into 'permafrost wells' (pot holes, sink holes) that can form as part of subsoil ice veins in permafrost areas, or to have drowned in flash floods ${ }^{51}$.

${ }^{50}$ Fladerer F. A., Salcher-Jedrasiak T. A., Händel M. Hearth-side bone assemblages within the 27 ka BP Krems-Wachtberg settlement: Fired ribs and the mammoth bone-grease hypothesis // Quaternary International - in press - (2012); Germonpré M., Sablin M., Khlopachev G. A., Grigorieva G. V. Possible evidence of mammoth hunting during the Epigravettian at Yudinovo, Russian Plain // Journal of Anthropological Archaeology. 2008. Vol.27. P. 475-492; Hoffecker J. F., Kuz'mina I. E., Syromyatnikova E. V., Anikovich M. V., Sinitsyn A.A. Popov V. V., Holliday V.T. Evidence for kill-butchery events of early Upper Paleolithic age at Kostenki, Russia // Journal of Archaeological Science. 2010. Vol.37. P.1073-1089; Holen S.R. Taphonomy of two last glacial maximum mammoth sites in the central Great Plains of North America: A preliminary report on La Sena and Lovewell // Quaternary International. 2006. Vol.142-143. P. 30-43; Iakovleva L., Djindjian F., Maschenko E. N., Kronik S., Moigne A.-M. The late Upper Palaeolithic site of Gontsy (Ukraine): A reference for the reconstruction of the hunter-gatherer system based on a mammoth economy // Quaternary International. 2012. Vol.255. P. 86-93; Kozlowski J. Mammoth bone accumulations and dwelling structures: discussing some arguments around Krakow-Spadzista B site // Perceived Landscapes and Built Environments. The Cultural Geography of Late Paleolithic Eurasia, BAR International Series. 2003. Vol.1122. P.59-64; Mania D., Thomae M., Litt T., Weber T. NeumarkGrobern. Beitrage zur Jagd des mittelpalaolithischen Menschen. Berlin, 1990. S. 36, 113-114, 117-121, 125-126, 215-235; Münzel S. C. Seasonal hunting of mammoth in the Ach-Valley of the Swabian Jura // The World of Elephants. Proceedings of the $1^{\text {st }}$ International Congress, Rome, 16-20 october, 2001. P.318-322; Nikolskiy P. A., Pitulko V. V. Evidence from the Yana Palaeolithic site, Arctic Siberia, yields clues to the riddle of mammoth hunting // Journal of Archaeological Science. 2013. Vol.40. P.4189-4197; Obada T., van der Plicht J., Markova A., Prepelitsa A. Preliminary results of studies of the Valea Morilor Upper Palaeolithic site (Chişinău, Republic of Moldova): A new camp of mammoth hunters // Quaternary International. 2012. Vol.276-277. P.227-241; Pidoplichko l.G. Upper Palaeolithic Dwellings of Mammoth Bones in the Ukraine // BAR International Series. Oxford, 1998. Vol.712. P. 87-105, 157; Sinitsyn A. A., Stephanova K. N. Models of Landscape use in the Upper Palaeolithic. Geomorphic Processes and Geoarchaeology // From Landscape Archaeology to Archaeotourism. International conference, August 20-24. 2012, Moscow Smolensk, Russia. Extended Abstracts. P.257-260; Svoboda J., Péan S., Wojtal P. Mammoth bone deposits and subsistence practices during Mid-Upper Palaeolithic in Central Europe: three cases from Moravia and Poland // Quaternary International. 2005. Vol. 126-128. P. 209-221; Svoboda J., Bocheński Z. M., Čulíková V., Dohnalová A., Hladilová S., Hložek M., Horáček I., Ivanov M., Králík M., Novák M., Pryor A. J. E., Sázelová S., Stevens R.E., Wilczyński, Wojtal P. Paleolithic Hunting in a Southern Moravian Landscape: The Case of Milovice IV, Czech Republic // Geoarchaeology: An International Journal. 2011, Vol.26, no. 6. P. 838-866; Villa P., Soto E., Santonja M., Pérez-Gonzáles A., Mora R., Parcerisas J., Sesé C. New data from Ambrona: closing the hunting versus scavenging debate // Quaternary International. 2005. Vol.126-128. P.223-250; Warrimont J.P.L.M.N. de. Prospecting Middle Palaeolithic open-air sites in the Dutch-Belgian border area near Maastricht // PalArch's Journal of Archaeology of Northwest Europe 1. 2007. Vol.3. P. 40-89; Wojtal P., Sobczyk K. Taphonomy of the Gravettian site - Kraków Spadzista Street (B) // DEINSEA.2003. Vol.9. P.557-562; Wojtal P., Wilczyński J., Bocheński Z.M., Svoboda J.A. The scene of spectacular feasts: Animal remains from Pavlov I south-east, the Czech Republic // Quaternary International. 2012. Vol.252. P. 122141.

51 Vereshchagin N.K.: 1) The mammoth "cemeteries" of North-East Siberia // Polar Record. 1974. Vol. 17, no. 106. P. 3-12; 2) Berelekh mammoth graveyard (in Russian) // Trudy Zoologicheskogo instituta. 
In an attempt to distinguish between assemblages of mammoth/elephant remains resulting from hunting by humans and natural causes of death, Germonpré compares two archaeological sites likely to belong to the first category, Yudinovo ('pavilion' - complexes 3 and 4) and Krakow-Spadzista Street, with concentrations of remains as high as one individual per 1.4-1.9 $\mathrm{m}^{2}$, with two modern African natural death sites where densities are markedly lower, ranging from one elephant individual per 6-35 $\mathrm{m}^{2}$. The individuals found at the latter sites tend also to be significantly younger than those in the assemblages resulting from (presumed) human activities: At least $85 \%$ of the individuals at the two African natural death sites were less than 12 years of age when they died, whereas the average age of the individuals from the archaeological sites was considerably greater ${ }^{52}$. Account should be taken of the fact that the two natural death sites in Africa were both in places where elephants tend to sink into the mire. Consequently, young, weaker individuals would be more exposed to danger than older, stronger ones. Natural death sites representing herds that were covered by landslides can, on the other hand, be expected to have a different age profile. However, distinguishing between different site types, based on the age-at-death profiles of the animals involved appears more complicated than stated by Klein. Moreover, in addition to the fact that different types of natural death sites must be expected to produce different age-at-death profiles, the potential coexistence of various well-established hunting strategies further complicates the matter. This is demonstrated by Bosch's study of five mammoth bone assemblages in cultural deposits at four archaeological sites in the Middle Danube region ${ }^{53}$. Detailed studies of the presence/absence of small foot bones, sorting of specific skeletal parts and the degradation of bone surfaces appear to yield more reliable information about which category a bone assemblage belongs to ${ }^{54}$.

The classic 'mammoth cemetery' in the North Yakutian locality of Berelekh was investigated extensively by Vereshchagin in 1970-1972. The excavation uncovered the remains of 140 mammoth individuals deposited in a palaeochannel. They are presumed to have died in small groups along the upper reaches of the proto-Berelekh river, killed either by winter blizzards or by drowning in spring or autumn when crossing the ice or by one or more flash-flood events. The use of 'powerful jets of water' in the excavation may have resulted in the loss of Palaeolithic artefacts. The recovery of only 39 tusks is taken to reflect that some tusks were salvaged from the site by Palaeolithic hunters. The central

1977. Vol.72. P.5-50; Vereshchagin N. K., Tomirdiaro S. V. Taphonomic research in permafrost regions: a survey of past and present studies in the former Soviet Union // Mammoths and the Mammoth Fauna: Studies of an Extinct Ecosystem. DEINSEA.1999. Vol.6. P.187-198; Nikolskiy P.A., Basilyan A.E., Sulerzhitskya L.D., Pitulko V. V. Prelude to the extinction: Revision of the Achchagyi-Allaikha and Berelyokh mass accumulations of mammoth // Quaternary International. 2010. Vol.219. P. 16-25.

52 Corfield T.F. Elephant mortality in Tsavo National Park // East African Wildlife Journal 11. 1973. P.339-368; Germonpré M., Sablin M., Khlopachev G. A., Grigorieva G. V. Possible evidence of mammoth hunting during the Epigravettian at Yudinovo, Russian Plain // Journal of Anthropological Archaeology. 2008. Vol.27. P.475-492; Haynes G. Mammoths, Mastodonts, and Elephants. Biology, Behavior, and the Fossil Record. Cambridge, 1991. Tables 4.6-4.7.

53 Bosch M.D. Human-Mammoth dynamics in the mid-Upper Paleolithic of the Middle Danube region // Quaternary International. 2012. Vol.276-277. P.170-182; Klein R. G. Age (Mortality) Profiles as a Means of Distinguishing Hunted Species from Scavenged Ones in Stone Age Archeological Sites // Paleobiology. 1982. Vol. 8, no. 2 (Spring, 19132). P. 151-158.

54 Germonpré M., Sablin M., Khlopachev G.A., Grigorieva G.V. Possible evidence of mammoth hunting during the Epigravettian at Yudinovo, Russian Plain // Journal of Anthropological Archaeology. 2008. Vol. 27. P. 475-492. 
question here is whether the dating of the bone bed to the interval 13,700-11,900 years $\mathrm{BP}$ is matched by the local presence of hunters. The Palaeolithic cultural deposits recorded $150 \mathrm{~m}$ downstream from the bone bed are dated to c. 12,000-11,500 years BP. However, unstratified finds of bone artefacts found in the area have yielded dates of 11,800 , 12,200 and 18,920 years BP respectively, indicating that human presence locally may not have been restricted to the period represented by the cultural deposits first recorded in the area ${ }^{55}$. The fact that natural disasters, such as those suggested by Vereshchagin, may have resulted in the deposition in a palaeochannel of concentrations of mammoth skeletons of this magnitude within such a restricted area is intriguing.

Another important and extensively investigated mammoth mass death site is that at Sevsk, on the central Russian Plain, $600 \mathrm{~km}$ south of Moscow, which was excavated in 1988-91. The site, which is interpreted as resulting from a number of mammoths being caught by landslides, consisted of two spatially-connected lenses of alluvial sand and clay, $20 \mathrm{~m}$ long, 6-7 m wide and 30-50 cm thick. The lower lens contained all the articulated skeletons from a minimum of 33 individuals, as well as sixteen pieces of worked flint directly associated with the concentration of bones, which show no cutmarks, while the upper lens only contained isolated bones ${ }^{56}$. The age and sex distribution of the materials resemble those of modern elephant family groups and is very similar to the situation at Berelekh. The presence of articulated skeletons and small foot bones is taken as indicating that these mammoths died in situ. The dating interval for the bones from the lower bone-bearing lens is quite narrow: c. 13,950 years BP, whereas a tusk from the upper bone-bearing lens has been dated to 13,680 years $\mathrm{BP}^{57}$. It seems strange, however, that a group of 33 mammoths, including quite a number of strong, adult individuals, could be caught and killed by a landslide that deposited little more than $30-50 \mathrm{~cm}$ of sand, at the most. The bottom of the lower sand lens, as presented in the published section, seems to show local pit/depression features related to the visible skeletons (Fig. 4) ${ }^{58}$. The dimensions of the lower lens, $6-7 \times 20 \mathrm{~m}$, correspond to c. $4 \mathrm{~m}^{2}$ per mammoth individual. This is not much more than the area occupied by individual elephants pressed against each other and is very different from the spatial situations observed when screening a large number of photos of elephant herds where the animals are generally seen to be several metres apart. It is difficult to find scientific data on the maximum density of these herds. The minimum indoor space per elephant recommended by the Association of Zoos and Aquariums (AZA) is, however, $56 \mathrm{~m}^{2}$ for males, $37 \mathrm{~m}^{2}$ females and $56 \mathrm{~m}^{2}$ for females with calves $^{59}$.

${ }^{55}$ Pitulko V. V. The Berelekh Quest: A Review of Forty Years of Research in the Mammoth Graveyard in Northeast Siberia // Geoarchaeology. 2011. Vol.26, no. 1. P. 5-32; Pitulko V. V., Basilyan A. E., Pavlova E. Y. The Berelekh Mammoth "Graveyard": New Chronological and Stratigraphical Data from the 2009 Field Season // Geoarchaeology. 2014. Vol.29. P.277-299; Vereshchagin N.K.: 1) The mammoth 'cemeteries' of North-East Siberia // Polar Record. 1974. Vol.17, no.106. P.3-12; Berelekh mammoth graveyard (in Russian) // Trudy Zoologicheskogo instituta. 1977. Vol. 72. P. 5-50.

${ }_{56}$ Maschenko E.N., Gablina S.S., Tesakov A.S., Simakova A.N. The Sevsk woolly mammoth (Mammuthus primigenius) site in Russia: Taphonomic, biological and behavioral interpretations // Quaternary International. 2006. Vol.142-143. P. 147-165, fig. 2B.

57 Ibid. P. 147-165.

58 Ibid. Fig. 2B.

59 Associations of Zoos \& Aquariums: AZA Standards for Elephant Management and Care. Approved March 2011. 


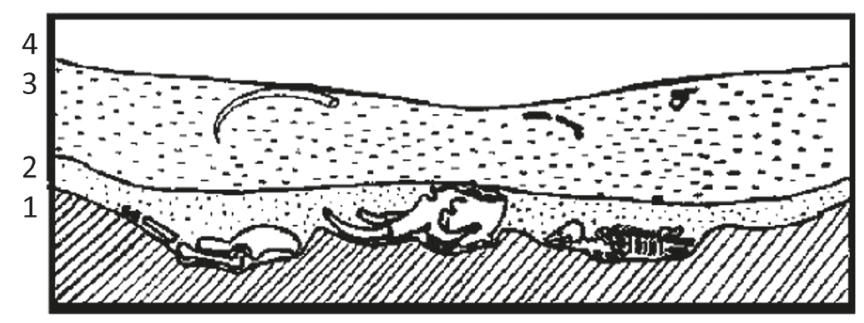

Fig. 4. Vertical section through the excavation at Sevsk:

1 - Alluvial sand deposits underlying the bone-bearing lenticular layer; 2 - The lower bone-bearing lenticular layer, 30-50 cm thick, containing well-preserved bones, skeletons and skeletal fragments; 3 - The upper part of the bonebearing lenticular layer with isolated bones does not contain any complete skeletons or skeletal fragments; 4 - Deposits overlaying the bone-bearing layer [Maschenko, 2006, fig. 2B]

A third possible "mammoth cemetery" is the north Siberian site of Achchagyi-Allaikha, located $125 \mathrm{~km}$ to the east of the Berelokh locality. The site was discovered in the early 1970s in the side of the Achchagyi-Allaikha channel. It was partially excavated in 1982, with further investigation in 2003-04. All the faunal remains recovered so far represent material redeposited from one or more layers located higher up in the channel side. The distribution of the material is restricted to a $30-40 \mathrm{~m}$ zone along the channel. The mammoth remains include small bones, but no intact tusks, complete skulls or lower jaws and only a few isolated teeth. This situation probably reflects the easy accessibility of the site, and extraction of tusks, teeth and occasionally also large bones is known to have taken place (at times through large-scale excavation) with the involvement of local people from the Chokurdal settlement located $20 \mathrm{~km}$ away. A MNI (minimum number of individuals) of 21 individuals from the most recent campaign may overlap to some degree with the MNI of 14 individuals recovered in the first excavation. In terms of age and gender, the remains recovered during the most recent campaign match the composition of family groups of modern elephants. The material is coeval with Berelekh, with radiocarbon dates covering the interval from 12,500 to 12,300 years BP. Even though a few stone tools (two bifaces and a flake) were found during the 1982 excavation, prehistoric human activity at the site is thought to have been restricted to scavenging for tusks. As for the cause of death of these mammoths, it is suggested that early spring flooding (possibly aggravated by ice drift) was responsible ${ }^{60}$. Again, it is rather difficult to understand how flooding could have led to the formation of such a small, spatially restricted concentration of bones.

It is worth noting that several Russian researchers have, in recent years, become increasingly accepting of the general idea of humans as central agents in the creation of mammoth bone concentrations ${ }^{61}$.

${ }^{60}$ Nikolskiy P. A., Basilyan A.E., Sulerzhitskya L.D., Pitulko V.V. Prelude to the extinction: Revision of the Achchagyi-Allaikha and Berelyokh mass accumulations of mammoth // Quaternary International. 2010. Vol.219. P. 16-25.

${ }^{61}$ Pitulko V. V., Nikolskiy P. A., Basilyan A. E., Pavlova E. Y. Dating mass accumulations of mammoth across Arctic Eurasia // The Quaternary in all of its variety. Basic issues, results, and major trends of further 
Based on evidence from the Gontsy site, Iakovleva et al. ${ }^{62}$ describe the typical position of a mammoth-hunter base camp from the end of the Weichselian glaciation - around $15,000-14,000 \mathrm{BP}$ - in the landscape, as well as the spatial 'modules' that appear to make up such sites. They are generally located on promontories bordered by ravines cut into the slopes of river valleys and generally consist of:

A. An area with mammoth-bone huts and associated pits (up to ten pits around each hut) and other related structures, separated by zones of working areas with hearths.

B. Dump areas with remains of hearth debris and flint debitage.

C. Butchering areas used specifically for small and medium-sized mammals (reindeer, carnivores and rodents)

D. A mammoth 'bone bed' typically located in a palaeo-ravine not far from the other settlement modules. This can contain bones of other mammals, hearths and artefacts of bone and flint apparently reflecting exploitation of the bone bed. The content of the latter shows an under-representation of the scapulae, pelvises, skulls, tusks, long bones and jaws typically found in mammoth-bone huts.

It must of course be expected that other, less visible, types of site were employed by the same cultures responsible for these highly visible localities and that there was considerable variation over time in this site organisation pattern. What is interesting, however, is the concept of a separate bone bed being an integral part of these massive settlements, serving as a storage facility for larger, more or less articulated, parts of mammoths (reflected in the presence of ribs, vertebrae and distal leg bones). The meat was for consumption and the extremely fat-rich Proboscidea bones were used for fuel - a widely recognised practice in the mammoth-hunter cultures of the last glaciation ${ }^{63}$.

Even in an Arctic climate, the bodies of larger animals left unprotected on the surface must be assumed to have become unsuitable for human consumption within a few days, as a result of chemical-bacterial degradation, in addition to the more useful parts being removed by scavengers ${ }^{64}$. In general, the actual bones would disappear rather quickly due to the actions and effects of rodents, fungi, sun and rain. Even a relatively rapid loess deposition of several centimetres per year, forming 'dunes' around the dead bodies, as suggested by Vereshchagin, is unlikely to have preserved the skeletons ${ }^{65}$.

research. Proceedings of the VII All-Russian Quaternary Conference (Apatity, September 12-17, 2011), Vol. 2. The Geological Institute KSC RAS. 2011. P. 146-149.

${ }^{62}$ Iakovleva L., Djindjian F., Maschenko E. N., Kronik S., Moigne A.-M. The late Upper Palaeolithic site of Gontsy (Ukraine): A reference for the reconstruction of the hunter-gatherer system based on a mammoth economy // Quaternary International. 2012. Vol.255. P. 86-93.

63 Iakovleva L., Djindjian F., Maschenko E. N., Kronik S., Moigne A.-M. The late Upper Palaeolithic site of Gontsy (Ukraine): A reference for the reconstruction of the hunter-gatherer system based on a mammoth economy // Quaternary International. 2012. Vol.255. P. 86-93; Marquer L., Otto T., Nespoulet R., Chiotti L. A new approach to study the fuel used in hearths by hunter-gatherers at the Upper Palaeolithic site of Abri Pataud (Dordogne, France) // Journal of Archaeological Science. 2010. Vol.37. P. 2735-2746; Praslov N.D., Stanko V. N., Abramova Z. A., Sapozhnikov I. V., Brozijak I. A. The steppes in the Late Palaeolithic // Antiquity. 1989. Vol.63(241). P. 784-792; Soffer O. The Upper Paleolithic of the Central Russian Plain. New York, 1985. P. 258-259.

${ }^{64}$ Haynes G. Longitudinal Studies of African Elephant Death and Bone Deposits // Journal of Archaeological Science. 1988. Vol. 15. P. 131-157.

65 Vereshchagin N. K. The mammoth "cemeteries" of North-East Siberia // Polar Record. 1974. Vol. 17, no. 106. P. 3-12. 
The assumption is that these bone beds, in many cases representing permafrost-based meat stores in the vicinity of base camps, containing large chunks of Proboscidea meat deposited in palaeo-ravines and palaeochannels and covered by insulating sediment, combined with burning of the bones following subsequent processing and consumption of this meat, can explain the good preservation of the material, as well as the very restricted appearance of cutmarks on the large quantities of preserved Proboscidea bones. In this respect, it is interesting that the ravine containing the bone bed at Gontsy was apparently rapidly filled with up to $75 \mathrm{~cm}$ of sand and silt. The absence of evidence of gnawing by carnivores or weathering indicates that its contents were not left exposed to the open air ${ }^{66}$. This may not be a natural but a cultural phenomenon.

The bone beds at Dolní Vĕstonice I and II showed some degree of sorting of articulated rib elements, vertebrae and groups of carpals/tarsals, whereas in the bone bed at Gontsy these skeletal elements in some cases appeared in 'anatomical groups', interpreted as representing parts of individual animals ${ }^{67}$. These observations support the interpretation of the bone beds as storage facilities.

The Sevsk bone bed, which includes ribs, vertebrae and carpals/tarsals, as well as skulls and tusks that do not normally appear in settlement bone beds, could hypothetically represent a storage facility for entire mammoth individuals.

\section{Back to the North Sea - discussion}

The above discussion demonstrates the massive extent of human hunting of Proboscidea during the Late Weichselian glaciation and suggests that a major proportion of the preserved bones and tusks from these animals may owe its preservation to artificial deposition in permafrost-based storage facilities or use as structural materials for dwellings and other constructions. For example, at Kostienki I, the tusks used to support the roofs over the dwelling pits were, following their collapse, protected by the fill within these pits $^{68}$.

In a discussion of the actual significance and origin of the abundant mammoth remains recovered from the Danish, German, British and Dutch North Sea sectors, the possibility that a significant proportion of these represent bones and tusks preserved because they were associated with settlements and/or kill-site storage facilities, based on an updated understanding of land-based Eurasian mammoth and mammoth-hunter sites, seems much more plausible than hitherto assumed. In principle, the majority of the Proboscidea remains trawled up from the North Sea may represent human settlement material.

A general problem that apparently prevents proper archaeological interpretation of the mammoth faunal remains from the North Sea, as well as a large proportion of the east-

${ }^{66}$ Iakovleva L., Djindjian F., Maschenko E. N., Kronik S., Moigne A.-M. The late Upper Palaeolithic site of Gontsy (Ukraine): A reference for the reconstruction of the hunter-gatherer system based on a mammoth economy // Quaternary International. 2012. Vol.255. P. 86-93.

67 Ibid; Svoboda J., Péan S., Wojtal P. Mammoth bone deposits and subsistence practices during MidUpper Palaeolithic in Central Europe: three cases from Moravia and Poland // Quaternary International. 2005. Vol. 126-128. P. 209-221; Wojtal P., Sobczyk K. Taphonomy of the Gravettian site - Kraków Spadzista Street (B) // DEINSEA. 2003. Vol. 126-128. P. 557-562.

68 Praslov N.D., Rogachev A. N. (eds.) Palaeolithic of the Kostenko-Borshchevo area on the river Don. 1879-1979: Results of field investigations (in Russian). Leningrad, 1982. P. 45, 48-49. 
ern "Mammoth-cemeteries", is that they have long been regarded primarily as zoological phenomena. Their full archaeological potential has only recently begun to become clear.

Many modern elephant populations are known to embark on seasonal or periodic long-distance migrations within their 'home ranges'. The home range of a population extends over an area of about 1000 to $9000 \mathrm{~km}^{2}$ and is often centred on a significant river or lake basin. A rough estimate of the size of similar home-range populations in an undisturbed 'pre-agricultural' environment is of the order of 500 animals. Movement is in herds of varying size, from a few individuals to several hundred animals, organised in a hierarchy of families, bond groups and clans ${ }^{69}$. Isotope studies indicate that prehistoric elephant species also exhibited migratory behaviour ${ }^{70}$, most likely of the same kind as today's elephants.

The fact that no classic mammoth-hunter camps have so far been identified in Scandinavia may well be due to these being located on the major prehistoric rivers here, which are today all found below sea level.

Scandinavia's now submerged North Sea coastal zones and hinterlands of glacial and other colder periods may well represent an important research potential with respect to both local cultural developments and the environmental settings in which these took place. It is important to bear in mind that we should not only be aware of the potential for submerged settlements from the Weichselian glaciation, but also from earlier glacial periods. The immediate expectation is, however, that it may be possible to obtain information on actual tangible submerged mammoth hunter sites dating from the later Weichselian period, which are located in the southern part of the Scandinavian North Sea sector, where mammoth fauna remains, including parts of Proboscidea, are known to have been found.

In order to enter this field of research in a meaningful way, we need new and cost-effective methodologies for the mapping, management and investigation of submerged Stone Age landscapes as alternatives to our present relatively inefficient early-phase approaches that are mainly based on topographical modelling which ignores the significant dynamics of the vegetation and fauna ${ }^{71}$.

${ }^{69}$ Jachmann H. Direct Counts of Elephants From the Ground (Chapter 6) // Studying Elephants. AWF Technical Handbook Series. Nairobi, Kenya. 1996. P. 49-56; Smit I. P. L., Grant C. C., Whyte I. J. Landscapescale sexual segregation in the dry season distribution and resource utilization of elephants in Kruger National Park, South Africa // Biodiversity Research. 2007. Vol.13. P. 225-236; Thomas B., Holland J.D., Minot E. Seasonal home ranges of elephants (Loxodonta africana) and their movements between Sabi Sand Reserve and Kruger National Park // African Journal of Ecology (earlier: East African Wildlife Journal). 2011. Vol.50, iss. 4. P.131-139; Western D., Lindsay W. K. Seasonal herd Dynamics of a Savanna Elephant Population. African Journal of Ecology (earlier: East African Wildlife Journal). 1984. Vol. 22, iss. 4. P.229244; Whyte I. J. Studying Elephant Movements (Chapter 8) // Studying Elephants. AWF Technical Handbook Series. Nairobi, Kenya. 1996. P.75-89; Wittemyer G. W., Getz W. M., Vollrath F., Douglas-Hamilton I. Social dominance, seasonal movements, and spatial segregation in African elephants: a contribution to conservation behaviour // Behavioral Ecology and Sociobiology. 2007. Vol. 61, no. 12 (October). P. 1919-1931.

${ }^{70}$ Hoppe K.A. Late Pleistocene mammoth herd structure, migration patterns, and Clovis hunting strategies inferred from isotopic analyses of multiple death assemblages // Paleobiology. 2004. Vol.30(1). P. 129-145; Hoppe K.A., Koch P.L., Carlson R.W., Webb S.D. Tracking mammoths and mastodons: Reconstruction of migratory behavior using strontium isotope ratios // Geology. 2012. Vol.27, no. 5. P. 439442; Sharp Z. D., Atudorei V., Panarello H. O., Fernández J., Douthitt C. Hydrogen isotope systematics of hair: archeological and forensic applications // Journal of Archaeological Science. 2003. Vol. 30. P. 1709-1716.

${ }^{71}$ Bicket A. Submerged Prehistory: Marine ALSF Research in Context. Marine ALSF Science Monograph Series No. 5. (Ed. J. Gardiner). MEPF 10/P150. 2011; Submarine prehistoric archaeology of the North Sea. Research priorities and collaboration with industry // CBA Research Report 141. English Heritage/Council for British Archaeology / ed. by N. Flemming. 2004; Grøn O. Some problems with modelling 
Before the first systematic excavations in Baltic waters documented well-preserved submerged Mesolithic settlement surfaces and associated waste accumulations ${ }^{72}$, there was a robust and widespread view that no settlement deposits could have survived the wave action inherent in marine transgressions. Large areas will of course have been damaged by erosion, for example the central parts of many sounds and belts, but this is not necessarily the general case. Even though the North Sea is more dynamic than the Baltic, we must also expect preserved pockets to be here, in locations protected by bathymetric features. Many of the faunal remains that have been fished up are so well preserved that it is obvious they have not been exposed to dynamic sediment processes.

\section{References}

Alden Smith E., Hill K., Marlowe F. W., Nolin D., Wiessner P., Gurven M., Bowles S., Mulder M. B., Hertz T., Bell A. Wealth Transmission and Inequality among Hunter-Gatherers. Current Anthropology. Vol. 51 (1), feb. 2010, pp. 19-34.

Andersen S. H. Tybrind Vig. Submerged Mesolithic settlements in Denmark. Jutland Archaeological Society Publications., Højbjerg, Aarhus University Press, 2013, vol. 77.

Armand L. K., Leventer A. Palaeo Sea Ice Distribution - Reconstruction and Palaeoclimatic Significance. Sea Ice. An Introduction to its Physics, Chemistry, Biology and Geology. Eds D. N. Thomas \& G. S. Dieckmann. Oxford, Blackwell Publishing, 2003, pp. 333-372.

Austin W.E. N., Hibbert F. D., Rasmussen S. O., Peters C., Abbot P. M., Bryant C. L. The synchronization of palaeoclimatic events in the North Atlantic region during Greenland Stadial 3 (ca 27.5 to $23.3 \mathrm{kyr}$ b2k). Quaternary Science Reviews, 2012, vol. 36, pp. 154-164.

Tjeerd H. van Andel, Davies W. Neanderthals and modern humans in the European landscape during the last glaciation: archaeological results of the Stage 3 Project. Glacial Environments II: Reconstructing the Climate of Europe in the Last Glaciation. Eds E. Barron, T. H. van Andel, D. Pollard. University of Cambridge, McDonald Institute for Archaeological Research, 2003, pp. 57-78.

Bell L. S., Skinner M. F., Jones S. J. The speed of post mortem change to the human skeleton and its taphonomic significance. Forensic Science International, 1996, vol. 82, pp. 129-140.

Bicket A. Submerged Prehistory: Marine ALSF Research in Context. Marine ALSF Science Monograph Series No. 5. (Ed. J. Gardiner). MEPF 10/P150. 2011.

Binford L. R. Human Ancestors; Changing Views of Their Behavior. Journal of Anthropological Archaeology, 1985, vol. 4, pp. 292-327.

Birket-Smith K. The Chugach Eskimo. Copenhagen, Nationalmuseets Publikationsfond, 1953. 252 p.

Bjerck H. B. Tidligmesolittsk tid (TM) og Fosnatradisjon 9500-8000 BC. Ormen Lange Nyhamnia. NTNU Vitenskapsmuseets arkeologiske undersøkelser. Eds H. B. Bjerck, L. I. Åstveit, J. Gundersen, S. Normann. Trondheim, Tapir Akademisk Forlag, 2008, pp. 552-570.

the positions of prehistoric hunter-gatherer settlements on the basis of landscape topography. Journal of Archaeological Science: Reports. Vol.20. 2018. P. 192-199; Grøn O., Boldreel L. O. Chirping for LargeScale Maritime Archaeological Survey. A Strategy Developed from a Practical Experience-Based Approach // Journal of Archaeology. 2014. Vol. Article ID 147390. 2014; Grøn O., Dell'Anno A., Hermand J.-P. Investigations of deep, submerged Stone Age settlements covered by sea-floor sediments: preliminary methodological considerations // IEEEXplore. 2013. P.1-4; Grøn O., Boldreel L.O., Hermand J.-P., Rasmussen H., Dell'Anno A., Cvikel D., Galili E., Madsen B., Nørmark E. Detecting human-knapped flint with marine high-resolution reflection seismics. A preliminary study of new possibilities for sub-sea mapping of submerged Stone Age sites // Underwater Technology. 2018. Vol.35(1); Hermand J.-P., Grøn O., Asch M., Ren Q.-Y. Modelling flint acoustics for detection of submerged Stone Age sites // Proc. OCEANS'11 MTS/ IEEE Kona Conf. (Oceans of Opportunity: International cooperation and partnership across the Pacific). Institute of Electrical and Electronics Engineers, IEEE. Sept. 2011; Hermand J.-P., Tayong R. Geoacoustic characterization of Stone Age cultural layers: Preliminary FE modelling // IEEEXplore. 2013. P. 1-6.

72 Andersen S. H. Tybrind Vig. Submerged Mesolithic settlements in Denmark // Jutland Archaeological Society Publications. 2013. Vol.77; Skaarup J., Grøn O. Møllegabet II. A submerged Mesolithic settlement in southern Denmark. BAR International Series 1328. Oxford, 2004. 
Bjerck H. B. Colonising seascapes: comparative perspectives on the development of maritime relations in the Pleistocene/Holocene transition in north-west Europe. Mesolithic Horizons. Eds S. McCartan, R. Schulting, G. Warren, P. Woodman. Oxford, Oxbow, 2009, pp. 16-23.

Black L. The Nivkh (Gilyak) of Sakhalin and the Lower Amur. Arctic Anthropology, 1973, vol.10(1), pp. $1-110$.

Bordes F. The Old Stone Age. Toronto, World University Library, New York, McGraw-Hill Book Company, 1972.

Bosch M.D. Human-Mammoth dynamics in the mid-Upper Paleolithic of the Middle Danube region. Quaternary International, 2012, vol. 276-277, pp. 170-182.

Bradley B., Stanford D. The North Atlantic ice-edge corridor: a possible Palaeolithic route to the New World. World Archaeology, 2004, vol.36(4), pp. 459-478.

Brown J.A. Discovery of Elephas Primigenius associated with flint implements at Southall. Nature, 1888, July 19 , pp. 283-284.

DeMaille R. J., Sturtevant W. C. Handbook of North American Indians. Plains. Vol. 13. Washington, Smithsonian Institution, 2001, pp.300-312.

Clark J. G. D. Prehistoric Europe. The Economic Basis. London, Methuen \& Co., 1952.

Clark C. D., Hughes A. L. C., Greenwood S. L., Jordan C., Sejrup H. P. Pattern and timing of retreat of the last British-Irish Ice Sheet. Quaternary Science Reviews, 2012, vol. 44, pp. 112-146.

Coles B. Doggerland: a Speculative Survey. Proceedings of the Prehistoric Society, 1988, vol.64, pp. 45-81.

Coles J. M., Higgs E. S. The Archaeology of Early Man. Harmondsworth, Penguin Books Ltd., 1975.

Corfield T. F. Elephant mortality in Tsavo National Park. East African Wildlife Journal, 1973, vol. 11, pp. 339368.

Dansgaard W., White J.W.C., Johnsen S. J. The abrupt termination of the Younger Dryas climate event. Nature, vol. 339, 15 june, 1989, pp. 532-534.

Dromgoole S. Underwater Cultural Heritage and International Law. Cambridge, Cambridge University Press, 2013, $440 \mathrm{p}$.

Ehrenfels U. R. Kadar of Cochin. Madras, University of Madras, 1952, 319 p.

Fischer A. Submerged Stone Age - Danish examples and North Sea potential. Submarine prehistoric archaeology of the North Sea. Research priorities and collaboration with industry. Ed. by Nic Flemming. CBA Research Report 141. English Heritage/Council for British Archaeology, 2004, pp. 23-36.

Fischer A., Mortensen M. F., Henriksen P. S., Mathiassen D. R., Olsen J. Dating the Trollesgave site and the Bromme culture - chronological fix-points for the Lateglacial settlement of Southern Scandinavia. Journal of Archaeological Science, 2013, vol. 40, pp. 1-12.

Fischer A., Clemmesen L. B., Donahue R., Heinemeier J., Lykke-Andersen H., Lysdal P., Mortensen M.F., Olsen J., Vang Petersen P. Late Palaeolithic Nørre Lyngby - a northern outpost close to the west coast of Europe. Quartär, 2013, vol.60, pp.137-162.

Fitzgerald R. T., Jones T.L., Schroth A. Ancient long-distance trade in Western North America: new AMS radiocarbon dates from Southern California. Journal of Archaeological Science, 2005, vol. 32, pp. 423434.

Flemming N. (ed.) Submarine prehistoric archaeology of the North Sea. Research priorities and collaboration with industry. CBA Research Report 141. English Heritage/Council for British Archaeology, 2004.

Flemming N. Research Infrastructure for Systematic Study of the Prehistoric Archaeology of the European Submerged Continental Shelf. Submerged Prehistory. Eds. J. Benjamin, C. Bonsall, C. Pickard, A. Fischer. Oxford; Oakville, Oxbow, 2011, pp. 287-297.

Germonpré M., Sablin M., Khlopachev G. A., Grigorieva G. V. Possible evidence of mammoth hunting during the Epigravettian at Yudinovo, Russian Plain. Journal of Anthropological Archaeology, 2008, vol.27, pp. 475-492.

Gildor H., Tziperman E. Sea ice as the glacial cycles' climate switch: Role of seasonal and orbiting forcing. Paleoceanography, 2000, vol. 15(6), pp. 605-615.

Flemming N. Submarine prehistoric archaeology of the North Sea. Research priorities and collaboration with industry. Eds J. Glimmerveen, D. Mol, K. Post, J. W. F. Reumer, H. van der Plicht, J. de Vos, G. van Reenen, J.P.Pals. CBA Research Report 141, English Heritage/Council for British Archaeology, 2204, pp. 43-52.

Golden K. M. Climate Change and the Mathematics of Transport in Sea Ice. Notices of the American Mathematical Society, 2009, vol. 56(5), pp. 562-584.

Grindon A. J., Davison A. Irish Cepaea nemoralis Land Snails Have a Cryptic Franco-Iberian Origin That Is Most Easily Explained by the Movements of Mesolithic Humans. PLoS ONE, 2013, vol. 8(6), e65792. https://doi.org/10.1371/journal.pone.0065792. 
Grøn O. Our grandfather sent the elk — some problems for hunter-gatherer predictive modelling. Quartär 2012, vol. 59, pp. 175-188.

Grøn O. Some problems with modelling the positions of prehistoric hunter-gatherer settlements on the basis of landscape topography. Journal of Archaeological Science: Reports, 2018, vol. 20, pp. 192-199.

Grøn O., Turov M., Klokkernes T. Settling in the landscape - settling the land: Ideological aspects of territoriality in a Siberian hunter-gatherer society. Archaeology of Settlements and Landscape in the North. Ed. by Anders Olofsson. Umeå, Umeå University, 2008, pp. 57-80.

Grøn O., Froberg M.L. Stone Age in the Danish North Sea Sector. Maritime Archaeology Newsletter from Denmark, 2011, no. 26 (summer), pp. 3-8.

Grøn O., Dell'Anno A., Hermand J.-P. Investigations of deep, submerged Stone Age settlements covered by sea-floor sediments: preliminary methodological considerations. MTS/IEEE OCEANS - Bergen. Bergen, 2013, pp. 1-4. https://doi.org/10.1109/OCEANS-Bergen.2013.6608026

Grøn O., Boldreel L. O. Chirping for Large-Scale Maritime Archaeological Survey. A Strategy Developed from a Practical Experience-Based Approach. Journal of Archaeology, vol.2014, Article ID 147390, 11 p. http://dx.doi.org/10.1155/2014/147390

Grøn O., Boldreel L.O., Hermand J.-P., Rasmussen H., Dell'Anno A., Cvikel D., Galili E., Madsen B., Nørmark E. Detecting human-knapped flint with marine high-resolution reflection seismics. A preliminary study of new possibilities for sub-sea mapping of submerged Stone Age sites. Underwater Technology, 2018, vol. 35, no. 2, pp. 35-49.

Haynes G. Longitudinal Studies of African Elephant Death and Bone Deposits. Journal of Archaeological Science, 1988, vol. 15, pp. 131-157.

Haynes G. Mammoths, Mastodonts, and Elephants. Biology, Behavior, and the Fossil Record. Cambridge University Press, Cambridge, 1991, $413 \mathrm{p}$.

Hermand J.-P., Grøn O., Asch M., Ren Q.-Y. Modelling flint acoustics for detection of submerged Stone Age sites. Proc. OCEANS'11 MTS/IEEE Kona Conf. (Oceans of Opportunity: International cooperation and partnership across the Pacific), Institute of Electrical and Electronics Engineers, IEEE, Sept. 2011/ 0-933957-39-8 @2011 MTS.

Hermand J.-P., Tayong R. Geoacoustic characterization of Stone Age cultural layers: Preliminary FE modelling. IEEEXplore, 2013, pp. 1-6. https://doi.org/10.1109/OCEANS-Bergen.2013.6608184.

Hoppe K. A. Late Pleistocene mammoth herd structure, migration patterns, and Clovis hunting strategies inferred from isotopic analyses of multiple death assemblages. Paleobiology, 2004, vol.30(1), pp. 129145.

Hoppe K. A., Koch P.L., Carlson R. W., Webb S. D. Tracking mammoths and mastodons: Reconstruction of migratory behavior using strontium isotope ratios. Geology, 2012, vol.27, no. 5, pp.439-442.

Jachmann H. Direct Counts of Elephants From the Ground (Chapter 6). Ed. by K. Kangwana. Studying Elephants. Nairobi, Kenya AWF Technical Handbook Series, 1996, pp. 49-56.

Hoffecker J. F., Kuz'mina I.E., Syromyatnikova E. V., Anikovich M.V., Sinitsyn A.A.Popov V.V., Holliday V.T. Evidence for kill-butchery events of early Upper Paleolithic age at Kostenki, Russia. Journal of Archaeological Science, 2010, vol. 37, pp. 1073-1089.

Holen S. R. Taphonomy of two last glacial maximum mammoth sites in the central Great Plains of North America: A preliminary report on La Sena and Lovewell. Quaternary International, 2006, pp. 30-43.

Honoré P. Das Buch der Altsteinzeit - oder der Streit um die Vorfahren. Düsseldorf, Wien, Econ-Verlag, 1967, 468 s.

Iakovleva L., Djindjian F. New data on Mammoth bone settlements of Eastern Europe in the light of the new excavations of the Gontsy site (Ukraine). Quaternary International, vol. 126-128, 2005, pp. 195-207.

Iakovleva L., Djindjian F., Maschenko E. N., Kronik S., Moigne A.-M. The late Upper Palaeolithic site of Gontsy (Ukraine): A reference for the reconstruction of the hunter-gatherer system based on a mammoth economy. Quaternary International, 2012, vol. 255, pp. 86-93.

Jacob-Friesen K. H. Grosswildjäger des Eiszeitalters in Niedersachsen. Kosmos, Heft 11, November 1949, pp. 408-412.

Kelly M. A., Long A. J. The dimensions of the Greenland Ice Sheet since the Last Glacial Maximum. PAGES News, 2009, vol. 17, no. 2, pp.60-61.

Klassen L. Jade und Kupfer. Untersuchungen zum Neolithisierungsprozess im westlichen Ostseeraum unter besonderer Berücksichtigung der Kulturentwicklung Europas 5500-3500 BC., Aarhus, Jutland Archaeological Society, Moesgard Museum, 2009.

Klein R.G. Age (Mortality) Profiles as a Means of Distinguishing Hunted Species from Scavenged Ones in Stone Age Archeological Sites. Paleobiology, 1982, vol. 8, no. 2 (Spring, 19132), pp. 151-158. 
Koijmans L. Mesolithic Bone and Antler Implements from the North Sea and from the Netherlands. Berichten van de Rijksdienst voor het Oudheidkundig Bodemonderzoek, 1971, Jaargang 20-21, pp. 27-73.

Kozhevnikov J. P., Ukraintseva V.V. Pleistocene tundra-steppe: arguments pro and con. Mammoths and the Mammoth Fauna: Studies of an Extinct Ecosystem. Proceedings of the First International Mammoth Conference St. Petersburg, Russia, October 16-21, 1995. DEINSEA. Eds G. Haynes, J. Klimowicz, J. W. F. Reumer. 1999, vol. 6, pp. 199-210.

Kozlowski J. Mammoth bone accumulations and dwelling structures: discussing some arguments around Krakow-Spadzista B site. Perceived Landscapes and Built Environments. The Cultural Geography of Late Paleolithic Eurasia, BAR International Series. Eds S. A. Vasil’ev, O. Soffer, J. Kozlowski. 2003, vol. 1122, pp.59-64.

Lambeck K., Purcell A., Zhao J., Svensson N.-O. The Scandinavian Ice Sheet: from MIS 4 to the end of the Last Glacial Maximum. BOREAS, 2010 vol. 39, no. 2, 2010, pp. 410-435.

Lawler A. Pre-Clovis Mastodon Hunters Make a Point. Science, 2011, vol.334, 21 October, p. 302.

Layton R. Political and Territorial Structures Among Hunter-Gatherers. Man, New Series, 1986, vol.21(1), mar, pp. 18-33.

Leventer A. Particulate Flux from Sea Ice in Polar Waters. (Eds.) D. N. Thomas \& G. S. Dieckmann, Sea Ice. An Introduction to its Physics, Chemistry, Biology and Geology. Oxford, Blackwell Publishing, 2003, pp. 303-332.

Long A. J., Roberts D.H., Wright M.R. Isolation basin stratigraphy and Holocene relative sea-level change on Arvepinsen Ejland, Disko Bugt, West Greenland. Journal of Quaternary Science, 1999, vol. 14(4), pp.323-345.

Lemke P., Ren J., Alley R. B., Allison I., Carrasco J., Flato G., Fujii Y., Kaser G., Mote P., Thomas R.H., Zhang T. Observations: Changes in Snow, Ice and Frozen Ground. Climate Change 2007: The Physical Science Basis. Contribution of Working Group I to the Fourth Assessment Report of the Intergovernmental Panel on Climate Change. Eds S. Solomon, D. Qin, M. Manning, Z. Chen, M. Marquis, K. B. Averyt, M. Tignor, H. L. Miller. New York; Cambridge, Cambridge University Press, 2007, pp.337-383.

Mackintosh A., Colledge N., Domack E., Dunbar R., Leventer A., White D., Pollard D., DeConto R., Fink D., Zwartz D., Gore D., Lavoie C. Retreat of the Antarctic ice sheet during the last glacial termination. Nature Geoscience, 2011, vol. 4, March, pp. 195-202.

Mangerud J. Ice sheet limits in Norway and on the Norwegian continental shelf. Quaternary Glaciations Extent and Chronology. Eds J. Ehlers, J., P. Gibbard. Vol. 1. Amsterdam, Elsevier, 2004, pp. 271-294.

Mania D., Thomae M., Litt T., Weber T. Neumark-Grobern. Beitrage zur Jagd des mittelpalaolithischen Menschen. Berlin, Deutscher Verlag der Wissenschaften, 1990.

Marquer L., Otto T., Nespoulet R., Chiotti L. A new approach to study the fuel used in hearths by huntergatherers at the Upper Palaeolithic site of Abri Pataud (Dordogne, France). Journal of Archaeological Science, 2010, vol.37, pp. 2735-2746.

Maschenko E. N., Gablina S.S., Tesakov A.S., Simakova A.N. The Sevsk woolly mammoth (Mammuthus primigenius) site in Russia: Taphonomic, biological and behavioral interpretations. Quaternary International, 2006, vol. 142-143, pp. 147-165.

Mol D., Post K., Reumer J. W. F., van der Pflicht J., de Vos J., van Geel B., van Reenen G., Pals J. P., Glimmerveen J. The Eurogeul - first report of the palaeontologica, palynological and archaeological investigations of this part of the North Sea. Quaternary International, 2006, vol. 142-143, pp. 178-185.

Mol D., de Vos J., Bakker R., van Geel B., Glimmerveen J., van der Plicht H., Post K. Mammoeten, neushoorns en andere dieren van de Noordzeebodem. Diemen, Veen Magazines, 2008, 233 p.

Morison J., Kwok R., Peralta-Ferritz C., Alkire M., Rigor I., Steele M. Changing Arctic Ocean freshwater pathways. Nature, 2012, vol. 481, 5 January, pp. 66-70.

Movius Jr. H. L. A Wooden Spear of Third Interglacial Age from Lower Saxony. Southwestern Journal of Anthropology, 1950, vol. 6, no. 2, pp. 139-142.

Münzel, S.C., 2001a. Seasonal hunting of mammoth in the Ach-valley of the Swa-bian Jura. The World of Elephants. Proceedings of the 1st International Congress. Eds G. Cavarretta, P. Gioia, M. Mussi, M. R. Palombo. Rom, Consiglio Nazionale delle Ricerche, 2001, pp.318-322.

Nghiem S. V., Clemente-Colón P., Rigor I. G., Hall D. K., Neumann G. Seafloor control on sea ice. Deep-Sea Research II, 2012, vol.77-80, pp. 52-61.

Nikolskiy P. A., Basilian A.E., Sulerzhitskia LD., Pitulko V. V. Prelude to the extinction: Revision of the Achchagyi-Allaikha and Berelyokh mass accumulations of mammoth. Quaternary International, 2010, vol. 219, pp. 16-25. 
Nikolskiy P. A., Pitulko V. V. Evidence from the Yana Palaeolithic site, Arctic Siberia, yields clues to the riddle of mammoth hunting. Journal of Archaeological Science, 2013, vol.40, pp.4189-4197. https://doi. org/10.1016/j.jas.2013.05.020.

Oakley K. P., Andrews P., Keeley L. H., Clark J. D. A Reappraisal of the Clacton Spearpoint. Proceedings of the Prehistoric Society, 1977, vol.43, pp. 13-30.

Obada T., van der Plicht J., Markova A., Prepelitsa A. Preliminary results of studies of the Valea Morilor Upper Palaeolithic site (Chişinău, Republic of Moldova): A new camp of mammoth hunters. Quaternary International, 2012, vol. 276-277, pp. 227-241.

Odum E. P., Barrett G. W. Fundamentals of Ecology. Belmont, Thomson Brooks/Cole, 2005, 598 p.

Ohnuki-Tierney E. The Ainu of the Northwest Coast of Southern Sakhalin. New York, Holt, Rinehart and Winston, 1974, $127 \mathrm{p}$.

Parry W.E. Journal of a Second Voyage for the Discovery of a North-West Passage from the Atlantic to the Pacific; Performed in the Years 1821-22-23 in his Majesty's ships Fury and Hecla, under the Orders of Captain William Edward Parry, R. N., F. R. S., and Commander of the Expedition. London, John Murray, $1824,571 \mathrm{p}$.

Parducci L., Jørgensen T., Tollefsrud M. M., Elverland E., Alm T., Fontana S. L., Bennett K. D., Haile J., Matetovici I., Suyama Y., Edwards M.E. Andersen K., Rasmussen M., Boessenkool S., Coissac E., Brochmann C., Taberlet P., Houmark-Nielsen M., Krog Larsen N., Orlando L., Gilbert T. P., Kjær K. H., Greve Alsos I., Willerslev E. Glacial Survival of Boreal Trees in Northern Scandinavia. Science, 2012, vol. 335, 2 March, pp. 1083-1087.

Parfitt S.A., Barendregt R.W., Breds M., Collins M.J., Coope G. R., Durbridge P., Field M.H., Lee J.R., Lister A. M., Mutch R., Penkman K.E.H., Preece R. C., Rose J., Stringer C. B., Symmons R., Whittaker J.E., Wymer J. J., Stuart A. J. The earliest record of human activity in northern Europe. Nature, 2005, vol. 438, 15 December, pp. 1008-1012.

Parfitt S. A., Ashton N. M., Lewis S. G., Abel R. L., Russell Coope G., Field M.H., Gale R., Hoare P. G., Larkin N. R., Lewis M. D., Karloukovski V., Maher B. A., Peglar S. M., Preece R. C., Whittaker J.E., Stringer C. B. Early Pleistocene human occupation at the edge of the boreal zone in northwest Europe. $\mathrm{Na}$ ture 2010, vol. 466, 8 July, pp. 229-233.

Peeters H., Murphy P., Flemming N. North Sea Prehistory Research and Management Framework (NSPRMF) 2009. Amersfoort, Rijksdienst voor het Cultureel Erfgoed Ministerie van Onderwijs, Cultuur en Wetenschap, 2009.

Pettipas L. Aboriginal Migrations. A History of Movements in Southern Manitoba. Manitoba, Manitoba Museum of Man and Nature, 1996, 223 p.

Pidoplichko L. G. Upper Palaeolithic Dwellings of Mammoth Bones in the Ukraine. BAR International Series 712. Oxford, British Archaeological Reports Oxford Ltd, 1998, 328 p.

Pitulko V.V. The Berelekh Quest: A Review of Forty Years of Research in the Mammoth Graveyard in Northeast Siberia. Geoarchaeology, 2010, vol. 26, no. 1, pp. 5-32.

Pitulko V.V., Nikolskiy P. A., Basilyan A. E., Pavlova E. Y. Dating mass accumulations of mammoth across Arctic Eurasia. The Quaternary in all of its variety. Basic issues, results, and major trends of further research. Proceedings of the VII All-Russian Quaternary Conference (Apatity, September 12-17, 2011). Eds P. Korsakova, V. V. Kolka, L. D. Chistyakova. 2011, vol. 2, pp. 146-149.

Pitulko V.V., Yakshina I., Strauss J., Schirrmeister L., Knzuetsova T., Nikolskiy P., Pavlova E. Y. A MIS 3 kill-butchery mammoth site on Buor-Khaya Peninsula, Eastern Laptev Sea, Russian Arctic. Scientific Annals, School of Geology, Aristotle University of Thessaloniki, Greece, VIth International Conference on Mammoths and their Relatives, Grevena - Siatista. Thessaloniki, 2014, special volume 102, pp. 158-159.

Pitulko V.V., Pavlova E. Y., Basilyan A.E. A MIS 3 kill-butchery mammoth site on Buor-Khaya Peninsula, Eastern Laptev Sea, Russian Arctic. Scientific Annals, School of Geology, Aristotle University of Thessaloniki, Greece, VIth International Conference on Mammoths and their Relatives, Grevena - Siatista, Thessaloniki, 2014, special volume 102, p. 155.

Pitulko V.V., Basilyan A.E., Pavlova E. Y. 2 The Berelekh Mammoth "Graveyard”: New Chronological and Stratigraphical Data from the 2009 Field Season. Geoarchaeology, 2014, vol. 29, pp. 277-299.

Praslov N. Outils de chasse du Paleolithique de Kostenki. Anthropologie et Prehistoire 2000, vol. 111, p. 37.

Praslov N. D., Stanko V.N., Abramova Z. A., Sapozhnikov I. V., Brozijak I. A. The steppes in the Late Palaeolithic. Antiquity, 1989, vol. 63 (241), pp. 784-792.

Putnam A. E. Eight Years with Congo Pigmies. London, Hutchinson, 1955. 192 p. 
Putshkov P.V. The impact of mammoths on their biome: clash of two paradigms. Advances in Mammoth Research. Proceedings of the Second International Mammoth Conference, Rotterdam, May 16-20, 1999. DEINSEA 9. Eds J. W. F. Reumer, J. de Vos, D. Mol. 2003, pp. 365-379.

Påsse T., Andersson L. Shore-level displacement in Fennoscandia calculated from empirical data. GFF, 2005, vol. 127, pp. 253-268.

Raghavan M. et al. Upper Palaeolithic Siberian genome reveals dual ancestry of Native Americans. Nature, 2014, vol. 505, 2 January, pp. 87-94.

Ramos J., Domíguez-Bella S., Cantillo J. J., Soriguer M., Pérez M., Hernando J., Vijande E., Zabala C., Clemente I., Bernal D. Marine resources exploitation by Palaeolithic hunter-fisher-gatherers and Neolithic tribal societies in the historical region of the Strait of Gibraltar. Quaternary International, 2011, vol. 239, pp. 104-113.

Ray A. J. Some Thoughts about the Reasons for Spatial Dynamism in the Early Fur Trade. 1580-1800. Three Hundred Prairie Years: Henry Kelsey's "Inland Country of Good Report". Ed. by Henry Epp. Regina, Canadian Plains Research Center, University of Regina, 1993, pp. 113-123.

Reich D., Patterson N., Campbell D., Tandon A., Mazieres S. et al. Reconstructing Native American population history. Nature, 2012, vol.488, 16 august, pp.370-376.

Reid C. Submerged Forest. Cambridge, Cambridge University Press, 1913, 138 p.

Reimer R. Reassessing the role of Mount Edziza obsidian in northwestern North America. Journal of Archaeological Science: Reports, 2015, vol.2, pp. 418-426.

Richards M. P., Jacobi R., Cook J., Pettitt P. B., Stringer C. B. Isotope evidence for the intensive use of marine foods by Late Upper Palaeolithic humans. Journal of Human Evolution, 2005, vol. 49, pp. 390-394.

Schebesta P. Die Negritos Asiens. Band II: Etnographie der Negrito. Halbband 1: Wirtschaft und Soziologie. St.Gabriel Verlag, Mödling bei Wien, 1954, 336 p.

Sejrup H. P., Larsen E., Landviken J., King E. L., Haflidason H., Nesje A. Quaternary gaciations in southern Fennoscandia: evidence from southwestern Norway and the northern North Sea region. Quaternary Science Review, 2000, vol. 19, pp. 667-685.

Sejrup H.P., Larsen E., Haflidason H., Berstad I. M., Hjelstuen B. O., Jonsdottir H., King E. L., Landvik J., Longva O., Nygård A., Ottesen D., Raunholm S., Rise L., Stalsberg K. Configuration, history and impact of the Norwegian Channel Ice Stream. Boreas, 2003, vol.32, pp. 18-36.

Shackleton J. C., van Andel T. Prehistoric Shore Environments, Shellfish Availability, and Shellfish Gathering at Frantchi, Greece. Geoarchaeology, 1986, vol. 1, no. 2, pp. 127-143.

Sharp Z.D., Atudorei V., Panarello H.O., Fernández J., Douthitt C. Hydrogen isotope systematics of hair: archeological and forensic applications. Journal of Archaeological Science, 2003, vol. 30, pp. 1709-1716.

Shternberg L.I. The Social Organisation of the Gilyak. Bruce Grant, Swarthmore College, Anthropological Papers of The American Museum of Natural History, 1999, no. 82, 336 p.

Sinitsyn A. A., Praslov N. D., Svezhentsev Yu. S., Sulerzhitskii L. D. Radiouglerodnaia khronologiia paleolita Vostochnoi Evropy. Radiouglerodnaia khronologiia paleolita Vostochnoi Evropy i Severnoi Azii. Problemyi i perspektivy. Eds A. A. Sinitsyn, N. D. Praslov. St. Petersburg, IIMK RAN, 1997, pp.21-66. (In Russian)

Skaarup J., Grøn O. Møllegabet II. A submerged Mesolithic settlement in southern Denmark. BAR International Series 1328. Oxford, Archaeopress, 2004, 199 p.

Smit I. P. L., Grant C. C., Whyte I. J. Landscape-scale sexual segregation in the dry season distribution and resource utilization of elephants in Kruger National Park, South Africa. Biodiversity Research, 2007, vol. 13, pp. 225-236.

Soffer O. The Upper Paleolithic of the Central Russian Plain. New York, Academic Press, 1985, 539 p.

Sulgosłowska Z. Mesolithic mobility and contacts on areas of the Baltic Sea watershed, the Sudety, and Carpathian Mountains. Journal of Anthropological Archaeology, 2006, vol. 25, pp. 193-203.

Sutton P. The Pulsating Hearth: Large Scale Cultural and Demographic Processes in Aboriginal Australia. Hunter-Gatherer Demography. Past and Present. Eds B. Meehan, N. White. Sydney, University of Sydney, 1990, pp. 71-80.

Svendsen J.I., Alexanderson H., Astakhov V.I.Demidov I., Dowdeswell J.A., Funder S., Gataullin V., Henriksen M., Hjort C., Houmark-Nielsen M., Hubberten H. W., Ingólfsson Ó., Jakobsson M., Kjær K. H., Larsen E., Lokrantz H., Lunkka J.P., Lyså A., Mangerud J., Matiouchkov A., Murray A., Möller P., Niessen F., Nikolskaya O., Polyak L., Saarnisto M., Siegert C., Siegert M. J., Spielhagen R. F., Stein R. Late Quaternary ice sheet history of northern Eurasia. Quaternary Science Reviews, 2004, vol.23, pp. 1229-1271. 
Svoboda J., Péan S., Wojtal P. Mammoth bone deposits and subsistence practices during Mid-Upper Palaeolithic in Central Europe: three cases from Moravia and Poland. Quaternary International, 2005, vol. 126-128, pp. 209-221.

Svoboda J., Bocheński Z.M., Čulíková V., Dohnalová A., Hladilová S., Hložek M., Horáček I., Ivanov M., Králík M., Novák M., Pryor A. J.E., Sázelová S., Stevens R. E., Wilczyński Wojtal P. Paleolithic Hunting in a Southern Moravian Landscape: The Case of Milovice IV, Czech Republic. Geoarchaeology: An International Journal, 2011, vol.26, no. 6, pp. 838-866.

Swagerty W. R. Indian Trade in the Trans-Mississippi West to 1870. Handbook of North American Indians Vol. 4: History of Indian - White Relations. Eds W. E. Washburn \& W. C. Sturtevant. Washington, Smithsonian Institution, 1988, pp. 351-374.

Thieme H. Lower Palaeolithic hunting spears from Germany. Nature, 1997, vol.385, iss.6619, pp. 807-810.

Thomas B., Holland J. D., Minot E. Seasonal home ranges of elephants (Loxodonta africana) and their movements between Sabi Sand Reserve and Kruger National Park. African Journal of Ecology, 2011, vol. 50, iss. 4 , pp. 131-139.

Trueman C.N. G., Behrensmeyer A. K., Tuross N., Weiner S. Mineralogical and compositional changes in bones exposed on soil surfaces in Amboseli National Park, Kenya: diagenetic mechanisms and the role of sediment pore fluids. Journal of Archaeological Science, 2004, vol.31, pp.721-739.

Turnbull C. M. The Forest People. New York, Simon \& Schuster, 1961, 330 p.

Turnbull C.M. The Mbuti Pygmies: An Ethnographic Survey. Vol.50, part 3. New York, Anthropological Papers of the American Museum of Natural History, 1965, pp. 141-282.

Turnbull C. M. The Mbuti Pygmies. Change and Adaptation. New York, Holt, Rinehart and Winston, 1983, $161 \mathrm{p}$.

Tizzard L., Bicket A., De Loecker D. Seabed Prehistory. Investigating the Palaeogeography and Early Middle Palaeolithic Archaeology in the Southern North Sea. Salisbury, Wessex Archaeology, 2015, 152 p.

Vereshchagin N.K. The mammoth 'cemeteries' of North-East Siberia. Polar Record, 1974, vol.17, no. 106, pp. 3-12.

Vereshchagin N. K. Berelekh mammoth graveyard. Trudy Zoologicheskogo Instituta, 1977, vol.72, pp.5-50. (In Russian)

Vereshchagin N. K., Tomirdiaro S. V. Taphonomic research in permafrost regions: a survey of past and present studies in the former Soviet Union. Mammoths and the Mammoth Fauna: Studies of an Extinct Ecosystem. DEINSEA. Eds G. Haynes, J. Klimowicz, J. W. F. Reumer. 1999, vol. 6, pp. 187-198.

Villa P., Soto E., Santonja M., Pérez-Gonzáles A., Mora R., Parcerisas J., Sesé C. New data from Ambrona: closing the hunting versus scavenging debate. Quaternary International, 2005, vol. 126-128, pp. 223250.

de Warrimont J.P.L.M.N. Prospecting Middle Palaeolithic open-air sites in the Dutch-Belgian border area near Maastricht. PalArch's Journal of Archaeology of Northwest Europe, 2007, vol. 1, iss. 3, pp. 40-89.

Watanabe H. The Ainu Ecosystem. Environment and Group Structure. Seattle, University of Washington Press, 1973, $170 \mathrm{p}$.

Waters M.R., Stafford T.W.jr., McDonald H.G., Gustafson C., Rasmussen M., Cappellini E., Olsen J.V., Szklarczyk D., Jensen L. J., Gilbert T. P., Willerslev E. Pre-Clovis Mastodon Hunting 13,800 Years Ago at the Manis Site, Washington. Science 2011, vol.334, 21 October, pp. 351-353.

Weidick A. Satellite Image Atlas of Glaciers of the World. Greenland. United States Geological Survey. Professional Paper 1386-C. Washington, United States Government Printing Office, 1995, 141 p.

Weidick A., Bennike O. Quaternary glaciation history and glaciology of Jakobshavn Isbroe and the Disko Bugt region, West Greenland: a review. Copenhagen, Geological Survey of Denmark and Greenland Bulletin $14,2007,78 \mathrm{p}$.

Western D., Lindsay W. K. Seasonal herd Dynamics of a Savanna Elephant Population. African Journal of Ecology, 1984, vol.22, iss. 4, pp. 229-44.

Whyte I. J. Studying Elephant Movements. Whyte I. J. Studying Elephants. Ed. by K. F. Kangwana, Nairobi, AWF Technical Handbook Series, 1996, pp. 75-89.

Wikell R., Molin F., Pettersson M. The archipelago of Eastern Middle Sweden - Mesolithic settlement in comparison with $\mathrm{C} 14$ and shoreline dating. Chronology and Evolution within the Mesolithic of NorthWest Europe. Eds P. Crombé, M. van Strydonck, J. Sergant, M. Boudin, M. Bats. 2009, pp.417-34.

Willerslev E., Davison J., Moora M., Zobel M., Coissac E., Edwards M.E., Lorenzen E. D., Vestergard M., Gussarova G., Haile J., Craine J., Gielly L., Boessenkool S., Epp L. S., Pearman P. B., Cheddadi R., Murray D., Brathen K. A., Yoccoz N., Binney H., Cruaud C., Wincker P., Goslar T., Alsos I. G., Bellemain E., Brysting A. K., Elven R., Sonstebo J.H., Murton J., Sher A., Rasmussen M., Ronn R., Mourier T., Cooper A., Austin J., Moller P., Froese D., Zazula G., Pompanon F., Rioux D., Niderkorn V., Tikhonov A., 
Savvinov G., Roberts R.G., MacPhee R.D.E., Gilbert M.T.P., Kjar K., Orlando L., Brochmann C., Taberlet P., 2014. Fifty thousand years of Arctic vegetation and megafaunal diet. Nature, 2014, vol.506, 6 February, pp. 47-51.

Wittemyer G. W., Getz W. M., Vollrath F., Douglas-Hamilton I. Social dominance, seasonal movements, and spatial segregation in African elephants: a contribution to conservation behaviour. Behavioral Ecology and Sociobiology, 2007, vol.61, no. 12 (October), pp. 1919-1931.

Wojtal P., Sobczyk K. Taphonomy of the Gravettian site - Kraków Spadzista Street (B). DEINSEA, 2003, vol. 9, pp. 557-562.

Wojtal P., Wilczyński J., Bocheński Z.M., Svoboda J.A. The scene of spectacular feasts: Animal remains from Pavlov I south-east, the Czech Republic. Quaternary International, 2012, vol. 252, pp. 122-141.

Zenin V.N., Leshchinskiy S. V., Zolotarev K. V., Grootes P. M., Nadeau M.-J. Lugovskoe: geoarchaeology and culture of a Paleolithic site. Archaeology, Ethnology and Anthropology of Eurasia, 2006, vol.25, pp. 41-53.

Zwilling E. A. Unvergessenes Kamerun. Zehn Jahre Wanderungen und Jagden 1928-1938. Berlin, Verlag von Paul Parey, 1941, 384 S.

Статья поступила в редакцию 30 мая 2018 г. Рекомендована в печать 12 марта 2019 г.

Received: May 30, 2018

Accepted: March 12, 2019 


\title{
About the Genuine Author of the Magical Hypothesis of Art Origins
}

\author{
L. B. Vishnyatsky
}

For citation: Vishnyatsky L. B. About the Genuine Author of the Magical Hypothesis of Art Origins. Vestnik of Saint Petersburg University. History, 2019, vol. 64, issue 2, pp. 584-598.

https://doi.org/10.21638/11701/spbu02.2019.210

The paper deals with the history of formation of the "magical hypothesis" of art origins, which replaced the "art for art's sake" one at the turn of the last century and dominated the field till the middle 1960's. The birth of the magical hypothesis is usually dated to 1903, when Salomon Reinach published his "Lart et la magie". However, contrary to the traditionally held view, the magical hypothesis was first formulated and substantiated not by S. Reinach but by the Russian journalist and popular science writer L. K. Popoff. In 1880 he published a book entitled "From the prehistoric life of man". One of its chapters was devoted to the question of functions of the drawn and sculptured animal images dated to "l'age du renne". Popoff used ethnographic evidence to suggest that these images were "inspired by belief in the existence of a material relation between a being and its image and in the possibility of acting on the first through the second". Though he presented his ideas and arguments also in French (1890) and English (1891), his hypothesis, born before its time, went unnoticed and received no recognition. The author gives account of Popoff's works devoted to the problem of art origins and assesses the degree of their novelty in comparison with works of his West European predecessors (E. Tylor) and contemporaries. Some consideration is given to the question as to whether S. Reinach had known of the hypothesis of his Russian forerunner. In addition, the paper includes a biographical essay containing little known facts of Popoff's life.

Keywords: Paleolithic, art origins, history of science, S. Reinach, L. K. Popoff.

\section{О подлинном авторе магической гипотезы происхождения искусства}

\section{Л.Б. Вищняцุкий}

Для цитирования: Vishnyatsky L. B. About the Genuine Author of the Magical Hypothesis of Art Origins // Вестник Санкт-Петербургского университета. История. 2019. Т. 64. Вып. 2. С. 584-598. https://doi.org/10.21638/11701/spbu02.2019.210

Работа посвящена истории становления «магической гипотезы» происхождения искусства. Магическая гипотеза, сменив игровую (гипотеза «искусства для искусства») в самом начале прошлого века, господствовала в науке до середины 1960-х годов и не утра-

Leonid B. Vishnyatsky - Doctor in History, Leading Researcher, Institute for the History of material Culture of the Russian Academy of Sciences, 18, Dvortsovaya nab., St. Petersburg, 191186, Russian Federation; lvishn@yandex.ru

Леонид Борисович Вищняцкий - д-р ист. наук, вед. науч. сотр., Институт истории материальной культуры РАН, Российская Федерация, 191186, Санкт-Петербург, Дворцовая наб., 18; lvishn@yandex.ru

(c) Санкт-Петербургский государственный университет, 2019 
тила влияния по сей день. Ее основоположником считается французский искусствовед и филолог Саломон Рейнак, статья которого «Искусство и магия», вышедшая в 1903 г., оказала огромное влияние на современников и во многом предопределила ход разработки проблемы на последующие полстолетия с лишним. Однако в действительности, вопреки традиционной точке зрения, первым, кто сформулировал и обосновал магическую гипотезу происхождения искусства, был не Рейнак, а петербургский журналист и популяризатор науки Л. К. Попов (1851-1917). В 1880 г. он опубликовал научно-популярную книгу «Из первобытной жизни человека». Один из ее разделов был посвящен проблеме назначения рисованных и скульптурных изображений животных, находимых в культурных слоях стоянок «века оленя». Спроецировав этнографические данные на археологические находки, Попов пришел к выводу, что эти изображения служили для их создателей средством, с помощью которого можно было «действовать на оригинал», «приобрести над ним некоторую власть». Хотя впоследствии Попов представил свои идеи и аргументы также на французском (1890) и английском (1891) языках, его гипотеза, опередившая время, осталась незамеченной и неоцененной современниками. В статье дается характеристика работ Попова, посвящённых проблеме происхождения искусства, оценивается степень их оригинальности и новизны в сравнении с работами Э. Тайлора и других западноевропейских исследователей второй половины XIX в. Кратко рассматривается вопрос о том, знал ли Рейнак о гипотезе его русского предшественника. В статью включен также биографический очерк, содержащий малоизвестные сведения о жизни Л.К. Попова.

Ключевые слова: палеолит, происхождение искусства, история науки, С.Рейнак, Л.К.Попов.

Preface. The beginning of the study of the Paleolithic art dates back to the mid $19^{\text {th }}$ century. From the time of the discovery of its artifacts and the first news coverage of them in 1864 up to our days numerous attempts to define the functions of the ancient drawings (images) and explain their origin have been made. Among these, the magical hypothesis can be considered the most successful one in terms of its influence on the minds of the scholars, the duration of heated debates and the number of advocates. It is based on the idea that the Paleolithic art (in general or a substantial part of it) is derived from the magical rituals, and was presumably created to accompany these rituals and cater for them. It is often associated with the hunting magic and procreative magic, although other variants are also possible (protective magic, healing magic etc). The magical hypothesis, which replaced the preceding "game" hypothesis of "art for art's sake" in the early $20^{\text {th }}$ century had dominated the academic research up to the mid $1960 \mathrm{~s}^{1}$ and is still relevant now. It is generally believed that it owes its origin to the French archeologist, historian and philologist Salomon Reinach, whose article "Lart et la Magie", published in 1903, exerted great impact on his contemporaries and to a large extent predetermined the study of this topic in the course of the following fifty years or more.

In his article, Reinach not only articulated and substantiated the thesis about the link between the ancient images and magical rituals, but took pains to prove and emphasize his reputation of the founder of the new hypothesis. The publications in press, which might have given an incompetent reader an idea that Reinach had been outstripped in this matter by another French archeologist Louis Capitan, urged him to do that. The point

${ }^{1}$ About its development in that period see: Frolov B.A. Zarubezhnaia literatura o soderzhanii paleoliticheskogo iskusstva (1952-1964 gg.) // Sovetskaia arkheologia. 1966. No. 1. P.297-305. 
is that before the publication of "Lart et la Magie" Reinach in his two-page review (of a short work of Gustave Chauvet), which came out in two different sources in February and April of the same 1903, had written in passing, but quite clearly about the magical nature of the Paleolithic images. However, in the same year in May "Dr Capitan at the meeting of the Academy of inscriptions ${ }^{2}$ touched upon totemism and magic with regard to the cave drawings. Apparently, he did this, referring to my article" ("dans une séance de l'Académie des Inscriptions, M.le docteur Capitan a parlé de totémisme et de magie à propos des peintures des cavernes; mais il l'a fait en se référant à mon article") - clarifies Reinach in one of the footnotes on the first page of "Lart et la Magie". "In some proceedings of that meeting (for example, in Petit Temps $s^{3}$ from May 20) the facts were delivered in such a way that it could form the impression that it was me, who picked up the ideas, initially developed by Dr. Capitan, who undoubtedly regrets this even more than I do. This note aims at the elimination of any possible misunderstandings which may occur." ("Certains comptes-rendus de cette séance (par exemple dans le Petit Temps du 20 mai) ont résumé les choses de telle façon qu'on pourrait me soupçonner d'exprimer ici des idées qui appartiennent à M. Cipitan, ce qu'il regretterait sans doute encore plus que moi. La présente note a pour objet déviter tout malentendu à cet égard") 4 .

The note of Reinach, which Capitan refers to, states, in particular, that dark corridors of the caves, "decorated with the images of animals are equivalent, mutatis mutandis, to catacombs and some church crypts; they, undoubtedly, served for the performance of religious rites. These rites, presumably, originated from the same concept as the images of animals and in my opinion are related to the sphere of sympathetic magic. The clan lived on meat products; imitating the animals, which served as the staple food, the people believed that it helped to increase their number and encouraged the reproduction in the same manner as the wild tribes of Australia believed that they were able to encourage the reproduction of kangaroos, performing the kangaroo dance. $\langle\ldots\rangle$ The idea that art is a game is nothing more than a modern prejudice: in fact it originated as a ritual and even magical act. When we talk now about the 'magic of art' we do not realize how close to the truth we are". ("décorés de représentations d'animaux, sont l'équivalent, mutatis mutandis, des catacombes et de certaines cryptes d'églises; on s'y réunissait, sans doute, pour célébrer des rites religieux. Ces rites devaient être inspirés par la même idée que la figuration des animaux, $\langle\ldots\rangle$ qui me semble relever de la magie sympathique. Le clan vivait de chair; en représentant les animaux dont il se nourrissait, il croyait en accroître le nombre, en favoriser la multiplication, comme les sauvages de l'Australie croient favoriser celle des kangourous en se livrant à la danse des kangourous. $<\ldots>$ L'idée que l'art est un jeu peut nêtre qu'un préjugé moderne; à l'origine, c'est une opération rituelle ou magique. Quand nous parlons aujourd'hui de 'la magie de l'art', nous ne savons pas combien nous avons raison") $)^{5}$. Capitan undoubtedly just repeated some of these ideas of Reinach in his talk. He definitely was not the author of the magical hypothesis. However, Reinach was not its author either. Certainly, it gained popularity due to his works, but it was another

2 Academy of the inscriptions and belles-lettres (l'Académie des inscriptions et belles-lettres).

3 Le Petit Temps - the newspaper, published in Paris from 1893 up to 1917(?)

4 Reinach S. Lart et la magie. A propos des peintures et des gravures de l'âge du Renne // L'Anthropologie. 1903. Vol. 14. P. 257.

${ }_{5}$ Reinach S. Gustave Chauvet. Notes sur l'art primitif. Angoulème, Coquemard, 1903 // Revue Archéologique. Quatrième Série. 1903. Vol. 1. P.290-291. 
person, a Russian journalist and interpreter of science Lazar Konstantinovich Popoff, who for the first time clearly articulated and substantiated the idea of the magical nature of the Paleolithic drawings, having applied ethnographic data to the archeological materials. It is also worthy of note that he had done this long before Reinach, twenty five years earlier, to be precise.

L. K. Popoff: biography. Few facts are currently known about Popoff. Meanwhile, he played an important role in the intellectual and social life of Russia, in particular, of St. Petersburg. He wrote a number of books, as well as hundreds of articles, notes and reviews in the journals and newspapers. His name and pen name (El'pe) are mentioned in the letters and diaries of L.N.Tolstoi, A.P.Chekhov, G. I. Uspenskii and V. V. Rozanov. In his works, Popov touched upon different subjects related to botany, zoology, anthropology, physics, chemistry, healthy lifestyle, gardening,

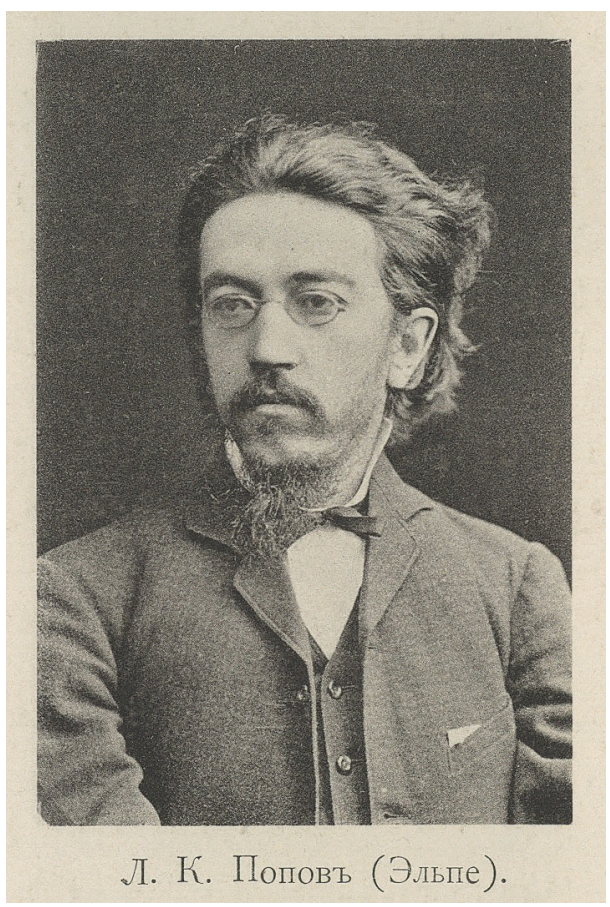

Fig. 1. Portrait of L. K. Popov [Bogdanov, 1889] housekeeping and the like 6 . Moreover, he edited numerous translations, such as "The Life of Animals" by Brehm, and was a full member of the Russian Physico-chemical Society and the Imperial Society of Devotees of Natural Science, Anthropology and Ethnography.

Post-revolutionary encyclopedias and biographical dictionaries either do not mention Popoff at all or give brief references, entirely borrowed from the "Brockhaus and Efron Encyclopedic Dictionary". This scanty information can be amplified by the sources of the late $19^{\text {th }}-$ early $20^{\text {th }}$ centuries, in the first place by the "Materials on the history of the scientific and applied activities in Russia" by A. Bogdanov ${ }^{7}$, as well as by the anniversary and memorial publications in journals and newspapers ${ }^{8}$.

L. K. Popoff was born on February 22 (March 7), 1851 in the city of Mariupol in the family of a trader Konstantin Kiriakovich Popoff (apparently, of Greek origin). The family was quite wealthy; in particular, it owned an estate with a big garden on the bank of a legendary river Kalka. Father and son spent a lot of time in the garden, and the former "without realizing it, encouraged the child to study nature, setting a positive example for him". According to some references in Popoff's books the above-mentioned interest was

${ }^{6}$ One of his books for general public has been reprinted recently. (El'pe. Obikhodnaia retseptura. Moscow, 1993).

7 Bogdanov A. Materialy dlia istorii nauchnoi i prikladnoi deiatel'nosti v Rossii po zoologii i soprikasaiushchimsia s neiu otrasliam znaniia preimushchestvenno za poslednee tridtsatipiatiletie (18501888). Vol. 2. Moscow, 1889.

8 Anonymous author. L.K. Popoff (Elpe). K 25-ti-letiiu literaturnoi deiatel'nosti // Novoe vremia (illiustrirovannoe prilozhenie). 1897. No.7491. P.7; Vakulovskii N.N. L. K. Popov (Elpe) // Nauchnoe obozrenie. 1897. Kn. 4; Afanasev N. L. K. Popoff (nekrolog) // Novoe vremia. 1917. No. 14887. P. 5.

9 Anonumous author. L. K. Popov (Elpe). K 25-letiiu literaturnoi deiatel'nosti. P. 7. 
also inspired by the trips to foreign countries he made with his parents. Thus, he claimed that the shoulder blade of the bull from Laugerie Basse bears the image of a porpoise (not a whale, as many scientists believed) on the grounds of his personal encounter with one of these animals, "whose body was brought to Dordona by the waves and cast ashore between Castillon and Libourne. The fishermen, who had killed it with fish gaffs, dragged it from city to city to demonstrate"10.

Popoff's father wanted him to pursue a career in business but at the same time respected his inclinations, and when his son, having studied for five years at Moscow Commercial School, dropped out of it one year before graduation ("because of the eye disease") ${ }^{11}$ and left first for Kharkov and later for Petersburg to engage in natural sciences, gave him all the necessary support and assistance. In 1868-1869, Popoff, as an auditor, attended the lectures (on physics, botany and zoology) at Petersburg University and the Imperial Medical and Surgical Academy (on physiology and anatomy). During that period, he joined the circle of young people with revolutionary views and was forced to leave for Switzerland ${ }^{12}$. He spent two years there (from the end of 1869 till the end of 1871) and also in Germany, where he attended lectures (in particular, of Ernst Haeskel and Carl Vogt) at the universities of Bern, Zurich, Geneva and Jena. At the end of 1871, Popoff came back to Petersburg, where he probably remained ever since, not counting the summer months, regularly spent in his father's garden "engaged in experiments and microscope observations" 13 .

"I don't know whether it is good or bad", mentions Popoff in his autobiography written, presumably at the request of A. Bogdanov and referred to in the "Materials", authored by the latter, - "but no lecturer seems to have ever engrossed my attention and I, as a matter of fact, have never had supervisors; I studied what I wanted and in the way I wanted, always dwelling on the topics, which interested me, regardless of any conclusions or instructions of others. It does not come as a surprise that under these circumstances I did not become an expert in any particular science (and was not in the least eager to do so), and although I have always directed my efforts mostly to the study of biology, I also took an intense interest in other natural sciences. The tendency to summarize books and lectures and make notes of the interesting phenomena of flora and fauna, which I observed with my own eyes, formed my writing habit and gave an impetus to the popularization of knowledge" 14 .

These efforts turned out to be successful, and since mid 1870s Popoff had become a regular author writing for some Petersburg periodicals, including the collection "Nature", and frequently published in 1876-1877. He also worked for the journal "People and Nature" (1878-1879) ${ }^{15}$, wrote news items on science for the "Russian Speech" for a number of years and published his works in the "Voice", "Observer" and "Scientific Review". Since 1883, he had worked for the "New Time", where he ran a column "Letters on Science" for many years. His name sometimes was referred to as one of the editors of specialized

10 Popoff L. K. Iz pervobytnoi zhizni cheloveka. St. Petersburg, 1880. P. 169.

11 According to one of the biographers, the school inoculated him with the feeling of "deep aversion to the so-called science of commerce" (Vakulovskii N. N. L. K. Popov (Elpe). P. 146).

12 Afanas'ev N. L. K. Popoff. P. 5.

13 Bogdanov A. Materialy dlia istorii nauchnoi i prikladnoi deiatel'nosti v Rossii po zoologii i soprikasaiushchimsia s neiu otrasliam znaniia preimushchestvenno za poslednee tridtsatipiatiletie (18501888). (No pagination).

14 Ibid.

${ }^{15}$ He published his materials in this journal under the pen-name "Chronicler". 
periodicals, such as "The Herald of Wine Production" (see the "Directory of Sankt-Petersburg" of 1894", edited by P. O. Iablonskii).

Popoff's interest in archeology and ancient history first became evident in 1876, when he published his review of J.Lubbock's "Origin of Civilization", and reached its height at the turn of the 1870s-1880s when he wrote and published his main works on this topic (a book, five articles and a review). Apart from an expert knowledge of literature, the author demonstrated remarkable originality and freedom of judgment and opinion. If it was timely, he easily entered into indirect polemics with the academic authorities and his arguments seem to have been no less significant than the ideas contested by him. In the mid 1880s Popoff published a series of articles on physical anthropology and ethnography in the "New Time", and in 1898 placed two more articles in the same periodical, in which he gave an account of his encounters with N. N. Miklukho-Maclay and expressed concerns about the academic heritage of the famous scientist and traveler.

In the directory "All Petersburg" for 1894 Popoff was featured as a hereditary "honorary citizen". Annual directories informed that since 1894 at the latest and up to his death in 1917 he had lived on Pushkinskaia street in house № 6 not far from Nikolaievsky (Moscow) railway station and a stone's through from Nevsky avenue. The house, like many old buildings in this part of the city, is extant now. Popoff's family consisted of his wife and son Leonid. He outlived them both and, according to the obituary, "at the end of his life was totally alone"16.

Popoff's hypothesis. The popular science book by Popoff "From the prehistoric life of man", which contained the main principles of the magical hypothesis ${ }^{17}$, was released in 1880. Foreign authors who worked on the same topic later on, apparently, knew nothing about it - anyway none of the foreign language publications on Paleolithic art and the history of archeology available to me mention it or refer to it. Among Russian archeologists B. A. Frolov was the first to pay attention to this work by Popoff and to rightly point out that the "magical" concept in Popoff's book "is presented much more clearly than in the work by Reinach in 1903"18. Later on, the book was briefly mentioned by A. A. Formozov $^{19}$ and A.K. Filippov ${ }^{20}$, with the former casting doubt on the positive comment of B. A. Frolov and claiming that he "was not inclined to see that essay [meaning the book of Popoff. $-L . V$.] as an independent attempt to investigate the topic as it had been argued earlier"21.

The skeptical attitude of A.A. Formozov probably arises from the fact - which he emphasizes - that Popoff used few sources in his book, and the text abounds in the lengthy quotes from the works by J. Lubbock, K. Vogt, E. Tylor and P. Broca. Though it

16 Afanas'ev N. L. K. Popoff. P. 5.

17 Popoff L. K. Iz pervobytnoi zhizni cheloveka. P. 163-176.

18 Frolov B.A. Otkrytie i priznanie naskal'nykh izobrazhenii lednikovoi epokhi. Istoriia odnogo kollektivnogo otkrytiia // Nauchnoe otkrytie i ego vospriiatie / eds S. R. Mikulinskii, M. G. Iaroshevskii. Moscow, 1971. P.220-221. See also: Frolov B.A.: 1) Chisla v grafike paleolita. Novosibirsk, 1974. P.14; 2) Pervobytnaia grafika Evropy. Moscow, 1992. P.32.

19 Formozov A. A.: 1) Nachalo izucheniia kamennogo veka v Rossii. Moscow, 1983. P.24; 2) Stranitsy istorii russkoi arkheologii. Moscow, 1986. P. 186.

${ }^{20}$ Filippov A. K. Khaos i garmoniia v iskusstve paleolita. St. Petersburg, 2004. P. 65.

${ }^{21}$ Formozov A. A. Nachalo izucheniia kamennogo veka v Rossii. P. 24. 
is true that Popoff "to a great extent depended on the above-mentioned sources"22, the interpretations of the facts he came up with sometimes were absolutely original. One of the most vivid examples of this is the section of his book focused on the "art of troglodytes". Here Popoff first disputed the "game" hypothesis of the origin of art, generally accepted at the time, and, second, did something nobody had done before, including the authors he so profusely quoted: he applied the data about the "magic of the savages" to the archeological findings, such as the drawings and figurines of animals of the "era of deer" and came to the most unexpected for his time conclusions about the purpose of these images.

While the well-established experts both in Russia and abroad unanimously claimed that art "could not have been generated by anything other than imagination, contemplation and leisure"23 and disinterested tendency to imitate nature, and that its development was the "manifestation of a particular spiritual need" 24 , an unknown amateur, without batting an eyelid, stated the opposite. "We have no good grounds for thinking that for these troglodytes every work of art served only as a drawing ${ }^{25}$ and had no other purpose but aesthetic pleasure", writes Popoff starting his analysis ${ }^{26}$, on completion of which he asserts confidently that "for the savages an image is a tool, which can influence the original object, inflict damage on it or to some extent help get control over it" 27 , and, consequently, "the motivation behind artistic activity is not to 'imitate animate nature by means of art' but to conquer the nature"28.

Between the presupposition and final conclusion there is a chain of coherent arguments, alternated with the ethnographic examples. His main ideas were the following: 1) at an early stage of the development of human mind, it could hardly distinguish between such concepts as shadow, soul and image. "From the point of view of some savage there is an inherent connection between a human being and his 'shadow' or 'image', thus the damage inflicted on the image or shadow of a person can cause harm to their owner"29. 2) As the 'savages' believed that animals also have soul, it "can be easily assumed that from the point of view of a savage between the animal and its image there allegedly existed the same inherent connection as in the case with human beings. Consequently, the very possession of the image of an animal.... meant having some kind of power over it"30. 3) Prehistoric man "who always struggled with the animal world around him, had many motives for his desire to obtain this power. Finally, he finds the method to do it: he transfers the shadow - the second soul of the animal - to an ivory plate; outlining the image he saw in the shadow $\langle\ldots\rangle$ This is the starting point of the primitive art $\langle\ldots\rangle$ Hence the tendency to create the artificial images of objects, hence the art of drawing. The idea

${ }^{22}$ Formozov A. A. Nachalo izucheniia kamennogo veka v Rossii. P. 24.

${ }^{23}$ Piette E. 1873. Sur la grotte de Gourdan, sur la lacune que plusieurs auteurs placent entre lâge du renne et celui de la pierre polie, et sur l'art paléolithique dans ses rapports avec l'art gaulois // Bulletins de la Société d’anthropologie de Paris. 1873. T. 8. P. 413; Piette E. La grotte de Gourdan pendant lâge du renne // Matériaux pour l'histoire primitive et naturelle de l'homme. T.5. P.74.

24 Uvarov A. S. Arkheologiia Rossii. I. Kamennyi period. Moscow, 1881. P. 243.

${ }^{25}$ Hereafter the italics are used by the author of the quote.

${ }^{26}$ Popoff L.K. Iz pervobytnoi zhizni cheloveka. P. 163.

27 Ibid. P. 174.

28 Ibid. P. 176.

29 Ibid. P. 164.

${ }^{30}$ Ibid. P. 165. 
behind the first drawing of a living creature was not the imitation, but possession" 31 . All the above-mentioned statements, according to Popoff, "can be applied to the prehistoric sculpture as well" 32 . 4) Like "the Indians of northern America, the prehistoric man, contemporaneous with the reindeer, might have made the drawings of the animal in order to succeed in hunting. May be this can account for the fact that the drawings of troglodytes are mostly focused on the animals they hunted for. Among these, the most precious for the prehistoric man animals were represented most frequently, with the reindeer being one of them"33.

In the first two paragraphs, Popoff echoes the ideas of Edward Tylor, who wrote fifteen years before, that "man, in a low stage of culture, very commonly believes that between the object and the image of it there is a real connexion $\langle\ldots\rangle$ and that it is accordingly possible to communicate an impression to the original through the copy" 34 . These words and the numerous ethnographical examples offered to confirm them encouraged Annette Laming-Emperaire ${ }^{35}$ to claim that Tylor "had allegedly made attempts to explain the prehistoric drawings", but "his hypothesis went almost unnoticed the time" 36 . B. A. Frolov supported Laming-Emperaire ${ }^{37}$. He wrote about the hypothesis of Tylor ${ }^{38}$, "restated by Popoff - regarding the specific purpose of the Paleolithic images, similar to those, familiar to ethnography" 39 , and called this hypothesis the "the idea of Popoff-Tylor" 40 . However, all this is hardly true. When Tylor writes about magic, he doesn't touch upon prehistoric times and archeological findings. When he does mention them, it has nothing to do with magic; he also makes no attempts to examine the drawings of the "age of unpolished stone" in the context of ethnographical data, which is so important for his book. He indeed mentions the artifacts, discovered by H. Christy and E. Lartet a year before the publication of the book, but only briefly in order to pay tribute to the people who, having "very rude" tools in their disposal, managed to decorate "their works in bone not only with hatched and waved patterns but also with carvings of animals done with consid-

31 Ibid. P. 166-167.

32 Ibid. P. 167.

33 Ibid. P. 167-168.

34 Tylor E.B. Researches into the early history of mankind and the development of civilization. London, 1865. P. 118.

35 In the Russian literature, there are different versions of her name: [Lamin], [Lamin'] and [Laming]. It is symbolical that the French researcher, whose works (together with the works by M. Raphael and A. Leroi-Gourhan) announced the beginning the era of structuralism in the study of Paleolithic art and put a stop to the dominance of the magical hypothesis, was born a week after the death of the author of this hypothesis - L. K. Popoff, with her being born in the same city where he had lived and passed away - in Petrograd. Before the revolution her father had worked as an administrator of the Russian-French Chamber of Commerce (this is mentioned in the handbooks "All Petersburg" and "All Petrograd" for 1913-1917). Immediately after the revolution, the family with a baby daughter left Russia and returned to France via Finland and England (Curtis G. The Cave Painters: Probing the Mysteries of the World's First Artists. New York, 2012. P. 137).

36 Laming-Emperaire A. La signification de l'art rupestre Paléolithique. Méthode et applications. Paris, 1962. P. 65.

37 Frolov B.A.: 1) Otkrytie i priznanie naskal'nykh izobrazhenii lednikovoi epokhi. Istoriia odnogo kollektivnogo otkrytiia. P. 220; 2) Pervobytnaia grafika Evropy. P. 31.

38 In his article of 1971 B. A. Frolov spells his name as Talor, in the book of 1992 — as Tylor.

39 Frolov B.A. Otkrytie i priznanie naskal'nykh izobrazhenii lednikovoi epokhi. Istoriia odnogo kollektivnogo otkrytiia. P. 221.

40 Ibid. P. 222. 
erable skill and taste" ${ }^{21}$. Tylor did not go any further, so the most significant statements of Popoff (represented in paragraphs 3 and 4 ) are absolutely original.

Apart from Tylor, there are other specialists who are thought to have been the forerunners of Popoff and Reinach, but as far as the works released before 1880 are concerned, this topic was touched upon only in occasional statements or references, mentioned in passing, in which only with a large element of wishful thinking something more definite could be seen. There were references to pendants-amulets worn out of superstition" ${ }^{42}$ "to guarantee successful hunting or to protect the infants from the evil spirits" 43 , to the symbolic status function of so-called (military) leaders' wands ${ }^{44}$ etc. The idea of the social meaning of art and of possible practical usage of ornaments was in the air, but had not gained traction for a long time. Probably, of all foreign scholars it was a British art historian Andrew Lang who clearly articulated and briefly outlined it for the first time. However, this happened after the publication of Popoff's book. ${ }^{45}$

The future of the hypothesis. As it has already been mentioned, foreign scholars were not familiar with the book of Popoff. In Russia, his hypothesis had also fallen into oblivion until B.A. Frolov remembered about it. Even the fundamental historiographic collections by Russian authors focused on the Paleolithic art and its origin do not say a word about it. This fact might be excusable for such an archivist and "expert in Moscow studies" as I. I. Fomin, who had compiled the first review of the data, related to this topic ${ }^{46}$, in Russia before the revolution, but the absence of Popoff's name in the works of professional historians of art and archeologists is really surprising. However, Popoff himself must have realized that his ideas about the origins of art were at least not trivial and made efforts to "promote" them.

In 1881, Popoff published an article entitled "The origins of painting (the issue from an anthropologist's perspective)" ${ }^{37}$. The study went unnoticed by Russian historiographers, including B. A. Frolov and A. A. Formozov. However, it only repeated the materials which had been featured in the book a year before and was a far cry from the further

41 Tylor E. B. Researches into the early history... P. 196.

42 Bourgeois L., Delaunay A. Notice sur la Grotte de la Chaisse // Revue Archéologique. 1865. T.12. P. 92.

43 Broka P. Vezerskie troglodity // Priroda: populiarnyi estestvenno-istoricheskii sbornik. 1873. Book 2. P. 235, 247 (cited from Frolov B. A. Pervobytnaia grafika Evropy. P. 31).

44 Piette E. Sur la grotte de Gourdan... P.414-416; Bernardin R.J. Les archives et les monnaies préhistoriques // La Revue savoisienne. 1876. P. 12.

45 The drawings of the savages "have a practical purpose, and do not spring from... the innate love of imitation for its own sake", stated Lang. Probably, "we inherit the love, the disinterested love, of imitative art from very remote ancestors, whose habits of imitation had a direct, interested, and practical purpose". He proceeds: "The member of Parliament who mimics the crowing of a cock during debate, or the street boy who beguiles his leisure by barking like a dog, has a disinterested pleasure in the exercise of his skill; but... the first men who imitated the voices of dogs, and cocks, and other animals, did not do so merely for fun, but with the practical purpose of indicating to their companions the approach of these creatures. Such were the rude beginnings of human language; and whether that theory is correct or not, there are certainly practical reasons which impel the savage to attempt imitative art" (Lang A. The art of savages. II. Representation // The magazine of art. 1882. Vol.5. P.303).

${ }^{46}$ Fomin I. I. Iskusstvo paleoliticheskogo perioda v Evrope. Moscow, 1912.

47 Popoff L. K. Proiskhozhdenie zhivopisi (opyt resheniia voprosa s antropologicheskoi tochki zreniia) // Popov L. K. Populiarnye ocherki po estestvoznaniiu. St. Petersburg, 1881. 
development of the hypothesis. The publications in French ${ }^{48}$ and English ${ }^{49}$, which followed ten years later, also did not evolve it. The French text represented a slightly abridged version of the Russian article of 1881, and two English articles, translated from French and published in the same periodical two and a half years apart, are absolutely identical, varying only in the title and some footnotes.

I haven't found any references to these articles in English, in Russian or foreign scholarly literature, probably due to the fact that these identical texts released in a popular science periodical were disregarded by the specialists. The French version of the publication proved to be slightly more successful. Henry Balfour, a respectable British archeologist and the first curator of Pitt-Rivers museum in Oxford, spotted it straight away and added Popoff's article from "Revue scientifique" to the recommended literature list in his book "The Evolution of Decorative Art" 50 . Other researchers, however, even if they had read the work of this obscure Russian author, were not eager to reveal this. Only recently it has been rescued from oblivion and attracted some attention abroad ${ }^{51}$.

Popoff and Reinach. Coming back to Reinach: was he aware of Popoff's article? B. A. Frolov believed that he definitely was not ${ }^{52}$. In my opinion, it is not entirely evident. First, the book by Balfour was certainly familiar to Reinach, as he referred to it in his works ${ }^{53}$. Second, and what is even more important, he often referred to the articles from "Revue Scientifique" as well. Taking into consideration that it was one of the most influential academic periodicals in France and Western Europe at that time, such an authority as Reinach must at least have looked through it. What is more, he published his works there ${ }^{54}$. Of course, there is a possibility that he could have missed Popoff's article, but it is more likely that he did come across it, but attached no importance to it and forgot all about it afterwards. It appears that in 1890, Reinach was not ready to take the idea about the magical nature and practical application of Paleolithic images seriously. He was quite satisfied with the conventional concepts of the ancient art as a game and its purely aesthetical nature. For example, he echoed them in $1889^{55}$, giving an account of the collections of Saint-Germain-en-Laye museum ${ }^{56}$.

The fallacy or at least insufficiency and limitation of such views became clear to Reinach only after the authenticity and antiquity of the cave painting had been recognized. His "Lart et la Magie" is actually a rehash of "Mea Culpa d'un sceptique" by Emile Cartailhac. Popoff, on the other hand, was writing his book when little was known about Altamira,

48 Popoff L. Lorigine de la peinture // Revue scientifique. 1890. T. XLVI.

49 Popoff L. The origin of painting // Popular Science Monthly. 1891. Vol. 40. P. 100-107; Popoff L. The origin of art // Popular Science Monthly. 1894. Vol. 44. P. 827-833.

${ }^{50}$ Balfour H. The evolution of decorative art. New York, 1893. P. 131.

51 Palacio-Pérez E. The origins of the concept of 'Palaeolithic art': theoretical roots of an idea // Journal of Archaeological Method and Theory. 2013. Vol.20, no. 4. P.682-714.

${ }^{52}$ Frolov B.A. Otkrytie i priznanie naskalnykh izobrazhenii lednikovoi epokhi. Istoriia odnogo kollektivnogo otkrytiia. P.221.

${ }^{53}$ For example: Reinach S. Repertoire de l'art Quaternaire. Paris, 1913. P.XXI.

${ }^{54}$ Reinach S. Phénomènes généraux du totémisme animal // Revue Scientifique. 1900. T. 14. P.449457.

55 Reinach S. Antiquités nationales. Description raisonnée du Musée de Saint-Germain-en-Laye. Vol. 1. Epoque des alluvions et cavernes. Paris, 1889. See: Richard N. De l'art ludique a l'art magique. Interprétations de l'art pariétal au XIX siècle // Bulletin de la Socété préhistorique française. 1993. T.90, no. 1. P. 62.

${ }^{56}$ At present National archeological museum (Musée d’archéologie nationale). 
and published his article in French when Altamira was generally believed to be a forgery. The magical hypothesis of Popoff was developed only for explanatory reasons and only for the mobile art pieces, while Reinach as a matter of fact applied the same idea to the interpretation of the cave drawings. The very arrangement of these drawings - usually bright and colorful, on the walls and dome-ceilings of the hard-to-reach completely dark underground chambers and corridors - raised doubts that they had been created entirely for aesthetic reasons and suggested the idea of some mysterious rituals related to them. Reinach came to the conclusion that these were magical rituals, and magic he associated with religion. "Religion and art originated together" - he argued - "and remained inseparably linked throughout the centuries" 57 .

In contrast to Reinach who advocated the view that the purpose of Paleolithic art was rooted both in magic and religion, Popoff even does not mention religion in the context of his study of the images belonging to the "age of deer". Moreover, the word "magic" cannot be found in the sections of his book featuring these images, although it was magic which the author had in mind. In the French article, and, respectively, in its version in English, the word "magic" occurs already, although rarely (twice to be precise). Obviously, Popoff mostly dwelt on the idea of the practical meaning of ancient images and the utilitarian purpose of art in general. In his review of the Russian translation of "Anthropology" by E. Tylor, he applies this idea to dance ${ }^{58}$. However, as art was developing, its objectives also underwent changes: "At first people interpreted the objects of art as a form of life, later on they attempted to find life in them, and up to now we all look at any work of art with the same feeling" 59 .

Popoff as a biologist. In addition to the elaboration of the original hypothesis of the origin of art, it is necessary to give credit to Popoff for other achievements in the sphere of science. They also proved to be ahead of their time and remained forgotten for a century. These achievements have nothing to do with archeology, but are worthy of note and should be briefly mentioned here. His research interests were mostly focused on biology; Popoff actively engaged in the popularization of biological knowledge and at the same time came up with a number of ideas. If these ideas had been presented by a researcher with academic/university background and published in special academic journals, they would have definitely attracted the attention of professional scientists, may be not immediately, but not a century later, either.

In his book "Life as motion" (1882) Popoff suggested an original hypothesis of the origin of life on Earth and the appearance of plant cells. According to a historian of biology A. A. Shcherbakova, of all the statements of Russian scientists related to these subjects, "the ideas of L. K. Popoff seem to be the most comprehensive and coherent. Actually, from

57 Reinach S. Istoriia iskusstv. ("Apollon"). Moscow; Leningrad, 1938. P. 14. Reinach was not the first specialist to link Paleolithic drawings to religion. For example, a British historian of art William Conway had stated this view before him. Conway believed that all the animals portrayed on the cave walls might have been totems, and if so, it means that "palaeolithic man possessed germs of religious emotion such as underlay the ancient religious systems of the Egyptians, the Chaldeans, and even the Hebrews and Greeks" (Conway W. M. Dawn of art in the ancient world. London, 1891. P. 31).

58 Popoff L. K. Obzor nauchnoi i uchebnoi literatury // Russkaia rech'. 1882. Vol. 4. P. 340.

59 Popoff L.K. Iz pervobytnoi zhizni cheloveka. P. 175-176. 
the point of view of the modern science, they also cannot be challenged" 60 . Nevertheless, as Shcherbakova writes in a footnote, "this work of Popoff seems to have been overlooked by the biologists: I have not come across its analysis in the Russian scientific books" 61 . We can also add that even after the publication of Shcherbakova's book, this work of Popoff remained unnoticed ${ }^{62}$. Only 50 years later the contribution of Popoff to biology was appreciated by A.P. Pilipenko, a researcher from Kiev. According to him, "the views of Popoff are of paramount importance for the history of the origin of life" 63 , and his research work is one of the most significant studies of the 19 century in this field. "It gives a detailed, consistent account of different concepts, including the idea of the heterotrophy of the first living organisms, which, according to the historians of science, date back to the 1920s and are attributed to A.I Oparin" 64 .

A.P. Pilipenko also claimed that it was Popoff who coined the term "molecular biology", which in the historico-biological literature is usually believed to date back to the 1940s. In reality, the term had appeared at least sixty years before that. The text of the above-mentioned book "Life as motion" initially (in 1881) was released in a series of articles under the common title "The principles of molecular biology". Taking into consideration that these articles were published in the "Russian speech", a journal which had already been on the brink of closure by that time, there was little chance for the professionals interested in the topic to find them. This was one of the reasons why "The principles" created little stir in the academic circles. Another reason was that "the scientists at that time were not ready to accept the molecular-biological and evolutionary-chemical approaches to the perception of life"65. "The terminological breakthrough of L. K. Popoff", states A. P. Pilipenko, "confirms that he was one of the first scientists who realized that the process of the formation of the new science had started"66.

Interesting parallels can be drawn between the academic interests and the fate of the ideas of Popoff and K.S. Merezhkovskii, the hero of another recent archeological and biological article of mine. Both Popoff and Merezhkovskii, apart from archeology, made contribution to biological science, both were ahead of their time, the achievements of both were underestimated and received recognition only decades later (or have just received it). Even the life histories of these two seemingly different men - a rover Merezhkovskii, who never stopped travelling, and indulged in all possible vices and passions, and a loving son ${ }^{67}$, husband and father Popoff, who spent the second half of his life in

${ }^{60}$ Shcherbakova A. A. Istoriia tsitologii rastenii v Rossii v XIX veke. Moscow, 1961. P. 150; see also: Bazilevskaia N. A., Belokon' I. P., Shcherbakova A. A. Kratkaia istoriia botaniki. Moscow, 1968. P. 145-146.

${ }^{61}$ Shcherbakova A. A. Istoriia tsitologii rastenii v Rossii v XIX veke. P. 150.

62 To some extent the pejorative and obviously unfair feedback on the works of Popoff given by B. E. Raikov in the last volume of his fundamental thesis "Russian biologists-evolutionists before Darwin" can account for this. Raikov stigmatized Popoff as a "dubious writer" "whose pen was smooth but shallow, and who had no idea of both natural science and the popularization of knowledge" (Raikov B. E. Russkie biologievoliutsionisty do Darvina. Materialy k istorii evoliutsionnoi idei v Rossii. Vol. 4. Moscow; Leningrad, 1959. P. 135).

63 Pilipenko O. Bilia vitokiv molekuliarnoï biologiï. Do 130-richchia publikatsiï traktatu «Osnovi molekuliarnoï biologiï» ta 160-richchia vid dnia narodzhennia iogo avtora L.K. Popova // Visnik Natsionalnoï akademiï nauk Ukraïni. 2011. No. 11. P. 65.

64 Ibid. P. 68.

65 Ibid. P. 62.

66 Ibid. P. 69.

${ }^{67}$ His first book ("From the prehistoric life of man") Popoff dedicated to his father. 
one and the same apartment, having confined himself to the neighborhood of Nevskii avenue, have some similarities. Both studied at St. Petersburg University, both passed away at the age of 66 with no one around them.

Instead of conclusion. Some of Popoff's works were published under a pen-name El'pe, (abbreviation consisting of the initial letters of the author's name and surname). At present time, this fact has given rise to a misunderstanding which should be elucidated. The "Literary Encyclopedia of Russian Emigrants" states that after the revolution Popoff allegedly left for Germany and published in 1922 in Berlin his story "Forelock, not a tale but a true story from the life of Petersburg dogs" ${ }^{\prime \prime}$. The real author of the story was L. Piankov, whose pen-name was also El'pe ${ }^{69}$, which caused the mix-up. After the revolution, Piankov, whose works had been published in the "Bulletin of Vitebsk", really moved abroad and started publishing in the émigré periodicals in Bulgaria ${ }^{70}$, and later on in Germany ${ }^{71}$.

The mistake made by the authors of the "Literary Encyclopedia of Russian Emigrants", unfortunately, misleads some of those few specialists who refer to Popoff today ${ }^{72}$. This mistake also accounts for the fact that Wikipedia and some other internet sources do not indicate the date of Popoff's death (leaving a question mark there), although it is not at all a secret. Popoff died at 8 a.m. on October 2 (15) 1917. This was confirmed by the newspaper "New Time", which published the obituary on the front page ${ }^{73}$. Popoff was laid to rest on October 4 at the cemetery of the Voskresenskii (Resurrection) Novodevichii monastery (section 32) next to the grave of his son.

The Voskresenskii monastery, overtaken by the same terrible misfortune as other religious buildings under the Soviets, has been restored recently and demonstrates shining domes again. As for the graveyard, which used to be elitist once, and due to this fact was badly damaged during the first months after the revolution, it fell into neglect and has remained in this state ever since. The remote sections of it, including section 32, represent an extremely depressing sight. Despite its small size, my efforts to find the grave of Popoff among other broken tombs proved to be futile.

\section{References}

Alekseev A.D. Literatura russkogo zarubezh'ia. Knigi 1917-1940. Materialy k bibliografii. St. Petersburg, Nauka, 1993, 202 p. (in Russian)

Anonim. L.K. Popoff (El'pe). K 25-ti-letiiu literaturnoi deiatel'nosti. Novoe vremia (illiustrirovannoe prilozhenie), 1897, no.7491, p.7. (in Russian)

Afanas'ev N. L. K. Popov (nekrolog). Novoe vremia, 1917, no. 14887, p. 5. (in Russian)

Balfour H. The evolution of decorative art. New York, Macmillan and Co., 1893, 131 p.

\footnotetext{
${ }^{68}$ Mukhachev Iu. V. Literaturnoe zarubezh'e Rossii: Entsiklopedicheskii spravochnik. Moscow, 2006. P. 587.

69 See: Masanov I. F. Slovar psevdonimov russkikh pisatelei, uchenykh i obshchestvennykh deiatelei. Vol.3. Moscow, 1958. P. 269.

70 Petkova G. Khronika literaturnoi zhizni russkogo zarubezh'ia. Bolgariia (1919-1940) // Literaturovedcheskii zhurnal. 2003. No.17. P.386.

71 Alekseev A.D. Literatura russkogo zarubezhia. Knigi 1917-1940. Materialy k bibliografii. St. Petersburg, 1993. P. 192. Probably, Piankov was the author of the caricatures of Stalin, signed by El'pe, which were published in the Russian language newspapers of Nazi Germany ("New word", "New Life", "Call") during the war.

72 For example: Pilipenko O. Bilia vitokiv molekuliarnoï biologii. P. 63.

73 Afanas'ev N. L. K. Popoff.
} 
Bazilevskaia N. A., Belokon' I. P., Shcherbakova A. A. Kratkaia istoriia botaniki. Moscow, Nauka, 1968, 312 p. (in Russian)

Bernardin R. J. Les archives et les monnaies préhistoriques. La Revue savoisienne, 1876, pp.11-13.

Bourgeois L., Delaunay A. Notice sur la Grotte de la Chaisse. Revue Archéologique, 1865, vol. 12, pp. 90-94.

Broka P. Vezerskie troglodity. Priroda: populiarnyi estestvenno-istoricheskii sbornik, 1873, book 2. (in Russian)

Conway W. M. Dawn of art in the ancient world. London, Percival and Co., 1891, 189 p.

Curtis G. The Cave Painters: Probing the Mysteries of the World's First Artists. New York, Random House, $2012,288 \mathrm{p}$.

Filippov A. K. Khaos i garmoniia v iskusstve paleolita. St. Petersburg, Sokhranenie Prirody i Kul'turnogo Naslediia, 2004, 222 p. (in Russian)

Fomin I. I. Iskusstvo paleoliticheskogo perioda v Evrope. Moscow, Pechatnia A. I. Snegirevoi, 1912, 90 p. (in Russian)

Formozov A. A. Nachalo izucheniia kamennogo veka v Rossii. Moscow, Nauka, 1883, 128 p. (in Russian)

Formozov A. A. Stranitsy istorii russkoi arkheologii. Moscow, Nauka, 1986, 237 p. (in Russian)

Frolov B. A. Zarubezhnaia literatura o soderzhanii paleoliticheskogo iskusstva (1952-1964 gg.). Sovetskaia arkheologiia, 1966, no. 1, pp.297-305. (in Russian)

Frolov B. A. Otkrytie i priznanie naskal'nykh izobrazhenii lednikovoi epokhi. Istoriia odnogo kollektivnogo otkrytiia. Nauchnoe otkrytie i ego vospriiatie. Eds S. R. Mikulinskii and M. G. Iaroshevskii. Moscow, Nauka, 1971, pp. 194-235. (in Russian)

Frolov B. A. Chisla v grafike paleolita. Novosibirsk, Nauka, 1974, 237 p. (in Russian)

Frolov B. A. Pervobytnaia grafika Evropy. Moscow. Nauka, 1992, 200 p. (in Russian)

Laming-Emperaire A. La signification de l'art rupestre Paléolithique. Méthode et applications. Paris. Editions A. et J. Picard et $C^{\text {ie }}, 1962,424$ p.

Lang A. The art of savages. II. Representation. The magazine of art, 1882, vol. 5, pp. 303-307.

Masanov I. F. Slovar' psevdonimov russkikh pisatelei, uchenykh i obshchestvennykh deiatelei. Vol.3. Moscow, Vsesoiuznaya Knizhnaya Palata Publ., 1958, 416 p. (in Russian)

Mukhachev Iu. V. (comp.). Literaturnoe zarubezhe Rossii: Entsiklopedicheskii spravochnik. Moscow, Parad, 2006, 680 p. (in Russian)

Palacio-Pérez E. The origins of the concept of 'Palaeolithic art': theoretical roots of an idea. Journal of Archaeological Method and Theory, 2013, vol. 20, no. 4, pp. 682-714.

Petkova G. Khronika literaturnoi zhizni russkogo zarubezh'ia. Bolgariia (1919-1940). Literaturovedcheskii zhurnal, 2003, no. 17, pp.369-451. (in Russian)

Piette E. Sur la grotte de Gourdan, sur la lacune que plusieurs auteurs placent entre lâge du renne et celui de la pierre polie, et sur l'art paléolithique dans ses rapports avec l'art gaulois. Bulletins de la Société d'anthropologie de Paris, 1873, vol. 8, pp. 384-425.

Piette E. La grotte de Gourdan pendant l'âge du renne. Matériaux pour l'histoire primitive et naturelle de l'homme, 1874, vol. 5, pp. 53-79.

Pilipenko O. Bilia vitokiv molekuliarnoï biologiï. Do 130-richchia publikatsiï traktatu «Osnovi molekuliarnoï biologiï» ta 160-richchia vid dnia narodzhennia iogo avtora L. K. Popova. Visnik Natsional'noï akademiï nauk Ukraïni, 2011, no. 11, pp.61-71. (in Ukrainian)

Popoff L. K. Iz pervobytnoi zhizni cheloveka. St. Petersburg, Tipografiia Ministerstva putei soobshcheniia (A. Benke), 1880, 275 p. (in Russian)

Popoff L.K. Proiskhozhdenie zhivopisi (opyt resheniia voprosa s antropologicheskoi tochki zreniia). Popov L. K. Populiarnye ocherki po estestvoznaniiu. St. Petersburg, Knizhnyi Magazin A. Tsinzerlinga, 1881, pp.159-178. (in Russian)

Popoff L. K. Obzor nauchnoi i uchebnoi literatury. Russkaia rech', 1882, book 4, pp. 327-346. (in Russian)

Popoff L. Lorigine de la peinture. Revue scientifique, 1890, vol. 46, pp. 399-403.

Popoff L. The origin of painting. Popular Science Monthly, 1891, vol. 40, pp. 100-107.

Popoff L. The origin of art. Popular Science Monthly, 1894, vol.44, pp. 827-833.

Raikov B. E. Russkie biologi-evoliutsionisty do Darvina. Materialy $k$ istorii evoliutsionnoi idei v Rossii. Vol. 4. Moscow; Leningrad, Academy of Science of the USSR Press, 1959, 678 p. (in Russian)

Reinach S. Antiquités nationales. Description raisonnée du Musée de Saint-Germain-en-Laye. Vol. 1: Epoque des alluvions et cavernes. Paris, Firmin-Didot, 1889, 322 p.

Reinach S. Phénomènes généraux du totémisme animal. Revue scientifique, 1900, $4^{\text {ème }}$ série, vol. 14, pp. 449457.

Reinach S. Gustave Chauvet. Notes sur l'art primitif. Angoulème, Coquemard, 1903. Revue archéologique, 1903, vol. 1, pp. 290-291. 
Reinach S. L'art et la magie. A propos des peintures et des gravures de lâge du Renne. L'Anthropologie, 1903, vol. 14, pp. 257-266.

Reinach S. Repertoire de l'art Quaternaire. Paris, Ernest Leroux, 1913, 203 p.

Reinach S. Istoriia iskusstv (“Apollon"). Moscow; Leningrad, Gosstroiizdat, 1938, 368 p. (in Russian)

Richard N. De l'art ludique a l'art magique. Interprétations de l'art pariétal au XIX siècle. Bulletin de la Socété préhistorique française, 1993, vol. 90, no. 1, pp.60-68.

Shcherbakova A. A. Istoriia tsitologii rastenii v Rossii v XIX veke. Moscow, Academy of Sciences of the USSR Press, 1961, 186 p. (in Russian)

Tylor E. B. Researches into the early history of mankind and the development of civilization. London, John Murray, 1865, $388 \mathrm{p}$.

Uvarov A.S. Arkheologiia Rossii. Vol. I. Kamennyi period. Moscow, Sinodal'naia tipografiia, 1881, 439 p. (in Russian)

Vakulovskii N. N. L. K. Popov (El'pe). Nauchnoe obozrenie, 1897, book 4, pp. 146-148. (in Russian)

Статья поступила в редакцию 5 мая 2018 г.

Рекомендована в печать 12 марта 2019 г.

Received: May 5, 2018

Accepted: March 12, 2019 


\title{
Первые горняки Донбасса
}

\author{
А. В. Колесник
}

Для цитирования: Колесник А. В. Первые горняки Донбасса // Вестник Санкт-Петербургского университета. История. 2019. Т. 64. Вып. 2. С. 599-620.

https://doi.org/10.21638/11701/spbu02.2019.211

Неравномерное распределение минеральных ресурсов на Земле способствовало экономической специализации отдельных районов и приводило к зарождению обмена в первобытном обществе. Донбасс - особая геологическая структура на юге ДнепроДонского междуречья с обильными залежами качественного кремневого сырья верхнемелового генезиса. Эти минеральные сырьевые источники обнажаются на многих участках современной дневной поверхности, преимущественно в Северо-Западном и Южном Донбассе. Богатая минеральная база обусловила формирование Донбасса в неолитическую эпоху в качестве крупного европейского центра по добыче и переработке минеральных ресурсов. Именно в это время у местных племен появляется первый опыт горных работ, связанный со сбором и извлечением из материнской породы необходимых для нужд хозяйства кремневых конкреций. К неолитическому времени относятся простые карьеры по добыче кремня в Северо-Западном Донбассе. Они располагаются на береговых склонах рек и балок или на склонах меловых гор. Карьеры находились на месте выхода на дневную поверхность наиболее продуктивных участков кремневых жил (Андреевка, Красное, Балка Редкодуб). Энеолитом датируются штольневые выработки по добыче кремня в Южном Донбассе. Эти выработки (Широкино) имели вид системы широких и низких, соединенных между собой горизонтальных камер. Видимо, в неолите и энеолите формируются основные признаки горного дела в виде знаний о геологическом строении местности и свойствах минералов, технические приемы по добыче и переработке сырья. Эти навыки горных работ каменного века и энеолита явились прологом дальнейшего поступательного прогресса горного дела в Донецком регионе. В статье рассматривается традиция горного дела Донбасса в неолите и энеолите. Рядом с местами добычи кремня, как правило, возникали мастерские по первичной переработке этого минерала. Горные выработки шахтного типа появились в Донбассе только в позднем бронзовом веке в связи с добычей медной руды и бытовали вместе с крупными карьерами.

Ключевые слова: неолит, энеолит, Донбасс, горное дело, добыча и обработка кремня, карьеры, штольни.

\section{The First Miners of the Donbass}

\section{A. V. Kolesnik}

For citation: Kolesnik A. V. The First Miners of the Donbass. Vestnik of Saint Petersburg University. History, 2019, vol. 64, iss. 2, pp. 599-620. https://doi.org/10.21638/11701/spbu02.2019.211 (In Russian)

Александр Викторович Колесник - д-р ист. наук, проф., Донецкий национальный университет, Украина, 283001, Донецк, Университетская ул., 24; akolesnik2007@mail.ru

Alexander V. Kolesnik - Doctor in History, Professor, Donetsk State University, Universitetskaya ul., 24, 283001, Donetsk, Ukraine; akolesnik2007@mail.ru

(C) Санкт-Петербургский государственный университет, 2019 
Irregular distribution of mineral resources in space promoted economic specialization of certain areas and resulted in the emergence of exchange in the primitive society. The Donets Ba$\sin$ (Donbass) is a special geological structure in the south of the Dnieper-Don interfluve with plentiful deposits of flint raw materials of the Upper Cretaceous genesis. These mineral raw sources can be seen on many sites of modern outcrops, mainly in the Northwest and Southern Donbass. The rich mineral base predetermined the formation of the Donbas during the Neolithic era as a large European center for production and processing of mineral resources. It was during that period that local tribes gained their first experience in mining in the form of collecting and extraction of flint concretions from the mother rock, which were necessary for household needs. Simple pits for flint extraction in the Northwest Donbass date to the Neolithic. They were located on the banks of rivers and gullies, or on the slopes of cretaceous mountains. There were pits at the sites of outcrops of the most productive sites of flint veins (Andreyevka, Krasnoye, Balka Redkodub). Shafts for extraction of flint in the Southern Donbas are dated back to the Chalcolithic. These workings (Shirokino) were the system of wide and low horizontal cameras connected with each other. Probably, mining as the knowledge of a geological structure of the area and properties of minerals, techniques of production and processing of raw materials, skills necessary for such work, was shaped in the Neolithic and the Chalcolithic. The first skills of mining of the Stone Age and the Chalcolithic were a prelude to further progress of mining in the Donetsk region. The article examines the tradition of mining of Donbass in the Neolithic and the Chalcolithic. As a rule, next to the places of flint extraction, there were workshops for primary processing of this mineral. In Donbass, mine-like workings emerged only in the Late Bronze Age, in connection with the extraction of copper ore, and existed along with large pits.

Keywords: the Neolithic, the Chalcolithic, Donbass, mining, production and processing of flint, open-cast mines, adits.

Геологическая история Донбасса обусловила наличие здесь мощных отложений каменноугольной и меловой эпох. Строение Кряжа и характер осадочных толщ обусловлены многочисленными фазами тектонического движения с различной по размаху амплитудой перемещения. Особо интенсивно накапливались осадки в каменноугольный период. Решающее значение в формировании Донецкой складчатой структуры имело поднятие Украинского кристаллического щита и опускание Днепровско-Донецкой впадины в палеогене. В результате этих процессов в меловой период сформировался относительно небольшой возвышенный участок суши, окаймленный мелководными морскими бассейнами. В меловой период Кряж был окружен мелководными морскими бассейнами, на дне которых накапливались обильные и разнообразные органико-минералогические остатки. Отложения мелового возраста окаймляют Донецкий кряж с юга, севера и северозапада. Кряж и его меловое обрамление практически полностью совпадают с территорией Большого Донбасса. Суммарная толщина верхнемеловых пород может достигать нескольких сот метров. Как правило, меловые породы погружены на большую глубину и обнажаются в современном рельефе (или подходят близко к поверхности) на относительно ограниченных участках местности в районах поднятий, сбросов, дислокаций. В целом ландшафтная оболочка современного Донбасса содержит многочисленные геологические источники кремня, связанные преимущественно с отложениями верхнего мела.

Основной породой, содержащей конкреционный и плитчатый кремень, является писчий мел. В коренном залегании кремневые жилы обнажаются преимуще- 
ственно в Бахмутско-Торецкой котловине, на правом коренном берегу р. Северского Донца, в долине р. Крынки, на отдельных участках долин рек Миус и Тузлов, в устье р. Северского Донца при впадении последнего в р. Дон, в среднем течении р. Оскол. При этом встречаются многокилометровые обнажения мела без кремневых включений или с кремнями, непригодными для производства орудий труда. Кремнесодержащие породы верхнемелового возраста обнажаются по берегам рек и балок, чаще всего образуя участки с сильно расчлененным рельефом. Крутые склоны меловых скал и останцев содержат обильные россыпи кремневого сырья, отпрепарированного естественной эрозией.

Целью настоящей работы является краткий очерк истории древнего горного дела Донбасса в контексте истории горного дела советской и постсоветской традиции, характеристика основных памятников горных работ в Донбассе в неолите и энеолите, а также краткий анализ каменных инструментов из мастерских, сопровождающих горные выработки. Очерк снабжен кратким словарем, который позволяет уточнить содержание используемых терминов и понятий.

Открытие и изучение основных памятников древнего горного дела Донбасса почти полностью осуществлялось в общем русле изучения древнего горного дела в рамках советской археологии.

Как известно, толчком к изучению древнейших памятников горного дела Западной Европы послужили знаковые открытия шахт каменного века в 60-70-е гг. XIX в. в Бельгии - в местности Спиенна ${ }^{1}$, в Англии - в Сисбури ${ }^{2}$ и Грем-Грейвсе ${ }^{3}$, во Франции - в местности Мюр-де-Барре 4 . Почти одновременно возник интерес к древним каменоломням индейцев Северной Америки. Детально изучались каменоломни и мастерские для наконечников стрел во Флориде ${ }^{5}$ и в Индиане ${ }^{6}$, обсидиановые копи - в Йеллоустонском парке ${ }^{7}$, каменоломни Кремневой Гряды - в Огайо ${ }^{8}$. Подробные обзоры истории изучения горного дела каменного века Европы, индейцев Америки и аборигенов Австралии (до 70-х гг. XX в.) в русскоязычной литературе содержатся в историографических очерках Т. Мирсаатова $^{9}$, М. Р. Касымова ${ }^{10}$, Н. Н. Гуриной ${ }^{11}$, Л. Я. Крижевской ${ }^{12}$ и др.

${ }^{1}$ Cornet F. L., Briart A. Sur lâge des silex ouvrés de Spiennes // Bull. Acad. r. Belg. T. 25. 1868. P. $26-$ 138.

${ }^{2}$ Fox Lane A.H. Further remarks on the hill forts of Sussex: being an account of excavations in the Forts at Cissbury and Highdown // Archeologia. Vol. 42, no. 1. 1869. P. 53-76.

${ }^{3}$ Greenwell W. On the opening of Grim's graves in Norfolk // The Journal of the Ethnological Society of London. Vol. 2, no. 4. 1870. P. 419-430.

${ }^{4}$ Boule M. Découverte fe puits prehitoiques d;extraction du silex // Matériaux pour l'hisotire et naturalle de l'homme, T.1. Paris, 1884. P.65-75.

5 Walker S. T. Preliminary exploration among the Indian mounds in southern Florida // Annual Report of the Smithsonian Institution for 1879. Washington, 1880. P.392-413.

${ }^{6}$ Homsher G. W. Remains on White Water river, Indiana // Annual Report of the Board of Regents of the Smithsonian Institute, 1882. Washington, 1884. P.728-752.

${ }^{7}$ Holmes W. H. An ancient quarry in Indian Territory. Washington, 1894.

8 Smith Ch. M. Sketch of Flint Ridge, Licking Country, Ohio // Annual Report of the Board of Regents of the Smithsonian Institute for the year 1884. Washington, 1885. P. 851-873.

9 Мирсаатов Т. М. Древние шахты Учтута. Ташкент, 1973. С. 82-104.

10 Касымов М. Р. Кремнеобрабатывающие мастерские и шахты каменного века Средней Азии. Ташкент: Фан, 1972. С. 116-126.

11 Гурина Н. Н. Древние кремнедобывающие шахты. Л., 1976.

12 Крижевская Л.Я. Кремнеобрабатывающая неолитическая мастерская и поселение на северовостоке Башкирии // Материалы и исследования по археологии СССР. № 79. 1960. С. 239-280. 
Очевидные успехи в изучении древнего горного дела в западной науке не могли остаться незамеченными в среде российских историков, хотя специально проблема не изучалась. Длительное время, до конца 50-х гг. XX в., интерес к европейским шахтам и карьерам каменного века носил в основном умозрительный характер и выражался в различных обзорах. Одним из первых российских исследователей обратил внимание на проблему добычи каменного сырья В.А.Городцов $^{13}$. Он же обсуждал значение европейских неолитических шахт по добыче кремня ${ }^{14}$. Необходимость добычи кремня неолитическим населением бассейна Северского Донца была понятна Н. В. Сибилеву, который хорошо знал месторождения кремня на правом берегу реки ${ }^{15}$. Неоднократно возвращался к этой теме Д. Н. Лев. В его публикациях рассматривались конструкции шахт Западной Европы, типы горных инструментов, хранящиеся в различных музеях, проблемы обмена в первобытное время ${ }^{16}$. Под близким углом зрения интересовались проблемой М. Фосс и Л. Ельницкий ${ }^{17}$, которые исходя из общей оценки неолитической эпохи не сомневались в существовании древних шахт в Восточной Европе. Такие же прогнозы делались и в отношении кремневых шахт в Средней Азии ${ }^{18}$. Процесс производства каменных орудий труда и в связи с этим вопросы добычи сырья в Поднестровье и в Башкирии затрагивались в работах Т.С.Пассек ${ }^{19}$, Л.Я.Крижевской ${ }^{20}$ и в других статьях.

В 50-60-е гг. XX в. в советской археологической науке начался качественно новый этап изучения горного дела каменного века. Последовала серия блестящих полевых открытий памятников древнего горного дела в различных уголках СССР, прежде всего в Средней Азии, где центром притяжения исследований стали раскопки Учтутских шахт и мастерских (Узбекистан), которые стартовали в 1958 г. и продолжались до 1967 г. Наиболее масштабные работы проводились в 1963-1964, 1966-1967 гг. Материалы исследований подробно изложены в двух итоговых монографиях ${ }^{21}$. В начале 60-х гг. детально обследуются Верхневолжские открытые выработки 22 . Одновременно (1962) начинаются масштабные исследования шахтных полей в Западной Белоруссии в бассейне р. Рось ${ }^{23}$. Крупные

13 Городиов В.А. Результаты археологических исследований в Изюмском уезде Харьковской губернии 1901 г. // Труды ХІІ Археологического съезда, Т. I. M., 1905. С. 174-225.

14 Городияв В. А. Археология. Каменный век. Т. 1. М., 1923. С/3410343.

15 Сибилев Н. В. Древности Изюмщины. Изюм, 1926. Вып. II.

16 Лев Д. Н. К вопросу о происхождении древнейших кремневых шахт // Советская этнография. 1934. № 1-2. С. 123-127.

17 Фосс М.Е., Ельнииякий Л. О. О добывании камня и древнейших каменоломенных орудиях на севере Восточной Европы // Материалы и исследования по археологии СССР. 1941. № 2. С. 189.

18 Литвинский В.А. Древнейшие страницы истории горного дела Таджикистана и других республик Средней Азии // Тр. Института истории, археологии и этнографии АН Таджикской ССР. Сталинабад, 1954. Вып. 19. С. 12.

19 Пассек Т. С. Трипольские поселения на Днестре // Краткие сообщения Института истории материальной культуры. Вып. XXXII. 1950. С. 47-56.

20 Крижевская Л. Я. Кремнеобрабатывающая неолитическая мастерская и поселение на северовостоке Башкирии.

21 Касымов М.Р. Кремнеобрабатывающие мастерские и шахты каменного века Средней Азии; Мирсаатов Т. М. Древние шахты Учтута.

22 Гурина Н.Н. К вопросу о макролитах Верхней Волги // Краткие сообщения Института археологии. Вып. 92. 1962. С.24-28.

23 Гурина Н.Н. Новые данные о древних шахтах по добыче кремня на Западе Белоруссии // Краткие сообщения Института археологии. Вып. 100. 1965. С. 85-89. 
штольневые выработки изучаются С. Н. Бибиковым на горе Белой в районе г. Каменец-Подольск в первой половине 60-х гг. ${ }^{24}$. На Западной Украине, в Ровенской области, И. К. Свешников находит необычные кремневые копи энеолитического времени ${ }^{25}$.

В круг этих исследований прочно вписываются работы Д.С.Цвейбель в Южном Донбассе. В 1965-1966 гг. ею был раскопан уникальный горный комплекс в балке Широкой на правом берегу р. Крынки ${ }^{26}$. Параллельно проводились разведочные работы в районе г. Изюм, а также в с. Красном в Северо-Западном Донбассе с целью поиска памятников неолитического горного дела. Хронография поиска памятников древнего горного дела Донбасса детально проанализирована автором в отдельной статье 27 .

В ключевой монографии, посвященной древним кремендобывающим шахтам, Н.Н.Гурина подвела итоги работ в СССР в данном направлении за неполных два десятилетия ${ }^{28}$. В этой работе помимо детальной публикации белорусских шахт содержится сводка всех известных на то время памятников, предлагается классификация мест добычи и обработки сырья.

Работы 70-90-х гг. осуществлялись на базе сложившихся региональных научных центров. В 80-е гг. в Ивано-Франковской области исследователями В. М.Коноплей и Б.В.Василенко выявлен богатейший микрорайон древнего горного дела ${ }^{29}$. В 1985 г. В.М. Конопля изучил серию неглубоких копей по добыче кремня в Ровенской области ${ }^{30}$. В 90-е гг. в Донбассе поиски привели к обнаружению нескольких небольших выработок на Северском Донце и в Бахмутско-Торецкой котловине ${ }^{31}$. Несколько простых выработок были исследованы в Западной Украине, в бассейне p. Большая Высь ${ }^{32}$. Продолжились работы в Западной Беларуси ${ }^{33}$. Таким образом, исследование памятников горного дела неолита и меднокаменного века Донбасса является составной частью общей традиции изучения древнего горного дела в советской и постсоветской археологической науке.

${ }^{24}$ Бибиков С. Н. Древние кремневые выработки в Среднем Поднестровье // Sbornik Narodnigo Muzea v Praze. Acta Muzei Nationalis Pracae. Vol.XX, no. 1/2. Praga, 1966. P. 3-7.

${ }_{25}$ Свешников И.К. Кремневые копи у с. Городок Ровенской области // Краткие сообщения Института истории материальной культуры. 1969. Вып. 117. С. 114-121.

${ }^{26}$ Цвейбель Д.С. Древние каменные выработки у с. Широкое в Донбассе // Советская археология. № 1. 1970. С.227-233.

27 Колесник А.В. Очерк истории изучения памятников кремнедобычи и кремнеобработки каменного века - эпохи палеометалла Большого Донбасса // Археологический альманах. 2013. № 30. C. 5-21.

28 Гурина Н.Н. Древние кремнедобывающие шахты.

29 Василенко Б. А. Видобування і обробка кременю на Правобережжі Верхнього Подніпров’я в енеоліті // Пролеми історіі та археологіi населення Укранськоі РСР. Киів, 1989. С. 38-39.

30 Конопля В.M. Лендельская культура // Археология Прикарпатья, Волыни и Закавказья. Энеолит, бронза и раннее железо. Киев, 1990. С. 4-17.

31 Дегерменджи С.M. О возможных следах древней разработки кремня у с. Закотное в Подонцовье // Археологический альманах. 2000. № 9. С. 179-184; Kolesnik A. Neolithic - Chalcolithic flint exploitation in Donbas (South-East of the Ukraine) // Stone Age - Mining Age. Der Anschnitt. Montanhistorische Zeitschrift. Bd. 19. Bochum, 2006. P. 129-134.

32 Цвек Е.В., Мовчан И.И. Энеолитический производственный комплекс по добыче и обработке кремня на реке Большая Высь // На пошану Софії Станіславівни Березанської: Збірка наукових праць. Киев, 2005. С. 66-76.

33 Charniausky M. M. Ancient flint mines in Belarus // Archaeologia Polona. Vol.33. Warsaw, 1995. P. 263-269. 


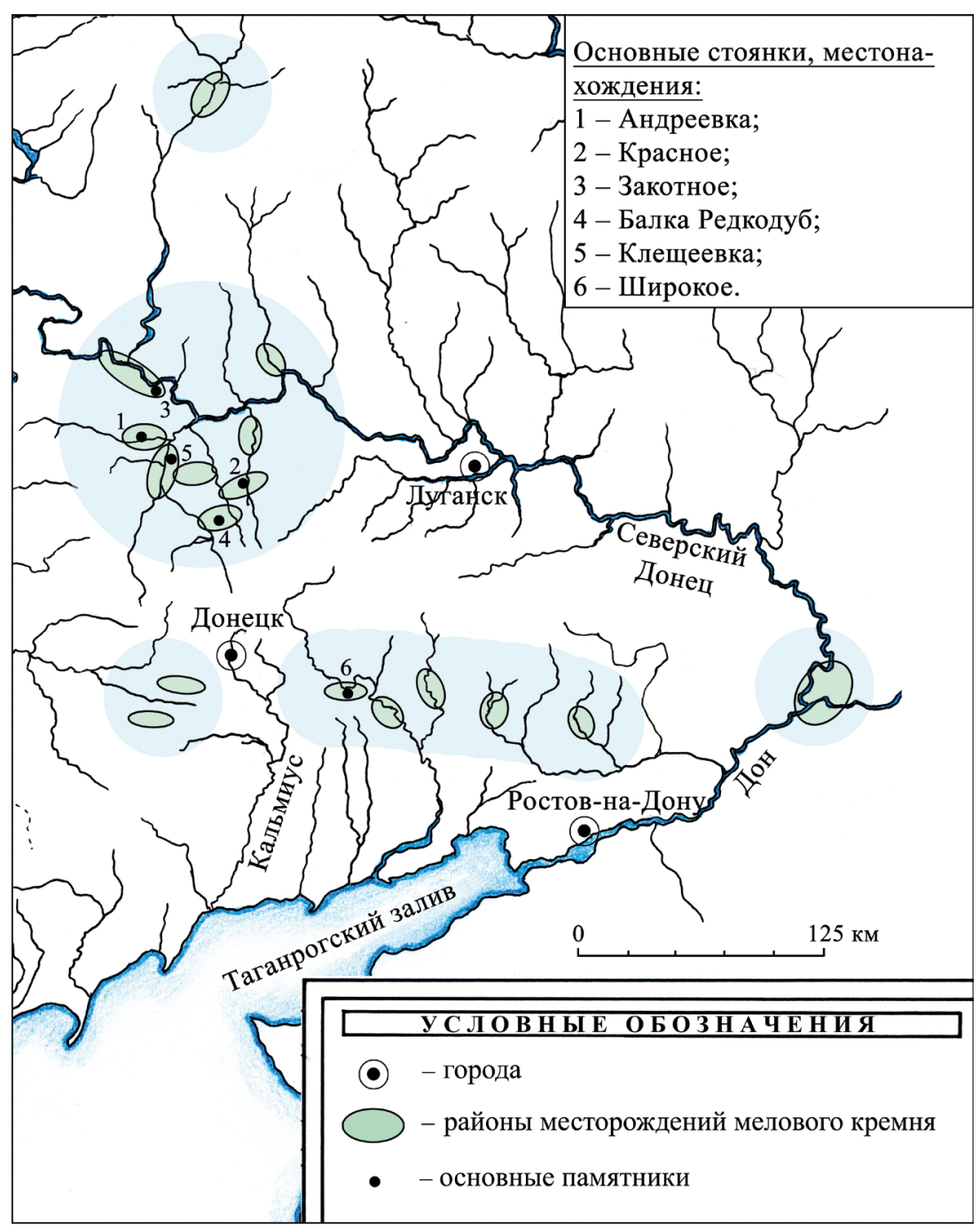

Puc. 1. Карта распространения отложений верхнего мела и памятники горного дела Донбасса эпохи неолита и энеолита (рис. А. В. Колесника)

Суммарно в Донецком регионе к неолиту может быть отнесено всего пять памятников горного дела. Это небольшие карьеры на меловых склонах. Основанием для их неолитической датировки является сопровождающий археологический материал.

1. Андреевка (рис.1). Наивысшей точкой мелового плато в месте впадения p. Сухой Торец в р. Казенный Торец на границе городов Славянск и Краматорск в Северо-Западном Донбассе является гора Карачун. К западу от карьера меловой склон прорезан короткой глубокой каньонообразной балкой. В устье этой балки находится пос. Андреевка Славянского горсовета. На правом склоне балки местами обнажаются участки скального мела. Археологический памятник на данном участке был обнаружен нами вместе с С. М. Дегерменджи в 1990 г. Памятник связан 
с пониженным участком балки ${ }^{34}$. Нижняя часть поверхности склона усеяна расщепленным кремнем. Полоса артефактов протянулась в пойму реки вплоть до поселка. Немногочисленные кремни встречаются и на левом берегу балки. Большинство заготовок нуклеусов относятся к неолитическим типам. Отдельные заготовки крупных конических призматических нуклеусов можно датировать поздним неолитом или энеолитом. Встречаются также заготовки неоэнеолитических бифасиальных наконечников. Весь кремень имеет тонкую фарфоровидную патину и по сохранности не разделяется на хронологические группы. На одном из участков правого склона балки обнажается крупный скальный выступ. В нижней части этого выступа с крутым склоном находится неглубокий, сильно разрушенный склоновой эрозией карьер овальной формы. Его размеры: $20 \times 15$ м. В верхней части выемки сохранился участок скальной стены искусственного происхождения. В нижней части карьер оконтурен полуовальным отвалом из рыхлого мела. Высота отвалов менее 1 м. Внутри выемки находятся куски мела, низкосортные отбракованные ветвистые конкреции кремня. Расщепленные кремни встречаются за пределами выемки и частично на поверхности отвалов. Основная концентрация расщепленного кремня отмечена в 30 м к северу от карьера.

2. Красное (см. рис. 1). Красненский горный комплекс впервые археологически был Д. С.Цвейбель локализован еще в середине 60-х гг. прошлого века. Детальная съемка памятников была осуществлена в 1998 г. Комплекс включает 17 мастерских и несколько карьеров по добыче кремня. На наиболее приподнятых участках (гора Баба) в окрестностях с. Красное Артемовского района Донецкой области мел обнажается в виде скал высотой 40-50 м. Массовые обнажения мела отмечены вдоль левого берега балки Долгой и на левом берегу р. Ступки. Высота горы Баба над поймой балка Долгой - более 70 м. Основная площадь меловых склонов выглядит как гравитационные осыпи.

В районе села содержатся месторождения кремня двух сортов. Первый из них это обычный серый и темно-серый стекловидный меловой кремень в форме конкреций. Он залегает в меловой толще и находится в эрозионном состоянии. Вторая разновидность - пестро-цветный кремень с белыми, бурыми и коричневыми прожилками - встречается в виде крупных плитчатых блоков. Этот кремень залегает стратиграфически выше и обнажается на поверхности террас, расположенных на коре выветривания меловых пород. Пестро-цветной кремень проявляется всего в двух местах и на обоих источниках отмечены энеолитические мастерские. Они уверенно датируются по специфическим нуклеусам и бифасам.

Мастерские вдоль берегов р. Ступки связаны с эрозионными источниками кремня, мастерские в балке Долгой - как с эрозионными источниками, так и с кремнем из карьеров. Все небольшие карьерные разработки связаны с добычей серого стекловидного конкреционного кремня. Выработки располагаются на левом высоком берегу балки. На этом участке местности плато обрывается крутым меловым уступом высотой от 50 до 70 м. Край мелового массива сильно расчленен промоинами на небольшие горы и холмообразные мысы с крутыми склонами. Верхняя часть южного склона горы представляет собой скалистое обнажение цельного мела, нижняя часть скрыта осыпями. В средней части склона этой возвышенности

${ }^{34}$ Kolesnik A. Neolithic - Chalcolithic flint exploitation in Donbas (South-East of the Ukraine). P. 129-134. 
выделяется множество довольно крупных, до 40 м в длину, горизонтально ориентированных углублений. Эти выемки окружены сильно оплывшими отвалами, которые часто стыкуются между собой.

Второе скопление меловых выработок приурочено к крутостенным холмистым мысам в 1,2 км к северо-западу - западу от моста. Здесь выделяются минимум семь отдельно отстоящих карьеров, расположенных на скалистых вершинах и в верхней части склонов меловых холмов. Общие размеры этого участка около 0,5 км.

Можно говорить о горных выработках двух разновидностей. Карьеры первого вида - крупные углубления длиной до 60 м и шириной до 35 м, глубина колеблется от 2 до 4 м. Таких крупных карьеров по крайней мере три. Они окружены отвалами нестрогих очертаний, которые частично оконтуривают выемку, частично образуют сползающие в ямы кучи рыхлого мелового щебня. И выемки, и отвалы сильно оплыли и заросли травой. Крупные карьеры, как правило, располагаются на вершинах меловых возвышенностей (рис. 2: 2). В некоторых местах видно, что углубление карьера был остановлено на уровне кремневой жилы. Карьеры второй разновидности приурочены к верхним участкам меловых склонов и чаще всего встречаются недалеко от края плато. Они врезаны в наклонную поверхность меловой скалы и имеют вид открытых с одной стороны выработок. Размеры этих разработок небольшие - до $10 \mathrm{M}$.

Топография маленьких карьеров определила их современный вид. В результате склоновой эрозии от таких выработок сохранились небольшие полуцирки с одной скальной стеной и сильно размытыми боковыми отвалами. В меловой стене иногда видны торчащие кремневые конкреции, но все следы работы по выборке каменного сырья из меловой толщи полностью уничтожены временем.

3. Закотное (см. рис. 1). Специфическая выработка по добыче кремня на месте микроструктурных террас меловой породы в первичном залегании предполагается С.М.Дегерменджи у с. Закотное в Краснолиманского района Донецкой области ${ }^{35}$. Здесь на правом берегу Северского Донца естественная слоистость меловой толщи, обусловленная различной плотностью пород, способствовала образованию при эрозии открытых участков горных пород в долинах рек ступенеобразных склоновых участков. Разборка породы при добыче кремня осуществлялась по уже сформированным пластам, поэтому расположенный на склоне карьер в общих чертах сохранял террасовидный рельеф склона, но дополнял его выемками и отвалами рыхлой горной породы, которые по размерам и форме существенно отличаются от естественных гравитационных осыпей. Именно такую ситуацию зафиксировал С. М.Дегерменджи в небольшой западине (приблизительно $4 \times 2$ м), расположенной на склоне коренного берега Северского Донца в 160 м от поймы. Склон в основании сложен мелоподобным мергелем в коренном залегании и покрыт плащом осыпи. Площадка в пределах западины предварительно была обследована геофизическим методом. После расчистки выявлена выемка размерами до $8 \mathrm{~m}^{2}$ с серией ступенчатых врезов (см. рис. 2: 1). Выявленные террасы не производят впечатления естественных структурных террас, так как различны по высоте и несколько не совпадают со слоистостью горной породы. В стенках уступов сохранились «гнезда»

35 Дегерменджи С.М. О возможных следах древней разработки кремня у с. Закотное в Подонцовье. С. 179-184. 

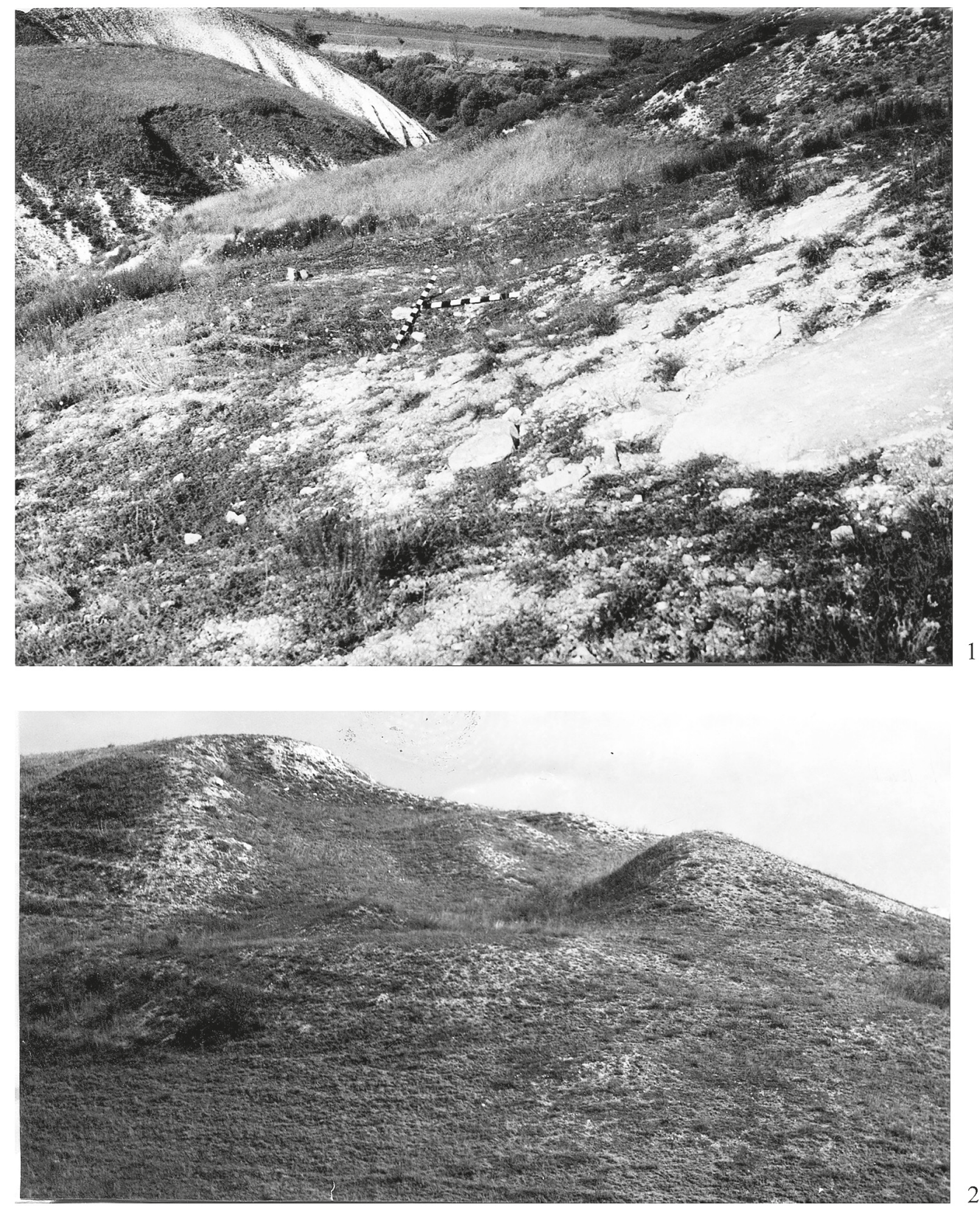

Puc. 2. Неолитические карьеры по добыче кремня в Донбассе:

1 - Закотное, 2 - Красное (по [Дегеменджи, 2000; Kolesnik, 2006])

от кремневых конкреций, однако общая сохранность поверхности ступенек не способствовала сохранению здесь каких-либо следов горных инструментов. Нижняя ступенька врезана в породу несколько глубже естественного склона. Судя по оставшимся «гнездам», из мелоподобного мергеля извлекались относительно небольшие кремневые конкреции размерами до 10 см. 
4. Балка Редкодуб (см. рис. 1). В верховьях балки Редкодуб (Константиновский район Донецкой области) автором выявлена самая крупная в Донбассе кремнеобрабатывающая мастерская площадного типа. Балка стекает с водораздела, на поверхности которого местами обнажаются меловые породы. Основной рукав балки прорезает плато на глубину до 25 м. В истоках рукава на правом берегу мел обнажается в виде скал и крутых осыпей; выше по склону и на плато кора выветривания меловых пород залегает непосредственно под маломощной современной почвой. Мел содержит большое количество кремня в виде мелких и средних по размеру конкреций. На пахотном поле и на лугу встречается огромное количество расщепленного кремня. Поверхность горизонтального обнажения коры выветривания мела на данном участке составляет приблизительно $500 \times 400$ м. Таковы же и размеры основной мастерской.

Преобладающее количество находок относится к неолиту. Небольшая часть материала, возможно, имеет энеолитический или более ранний, чем неолит, возраст. Имеются доказательства преднамеренной добычи части кремневого сырья из меловых недр простым горным способом. На самом высоком крае террасы, на правом берегу балки, в 1991 г. автором выявлен небольшой округлый в плане карьер. Он имеет диаметр около 15 м и глубину до 5 м. Карьер сохранился в виде полуцирка, обращенного в сторону балки. По бокам карьера со стороны склона сохранились небольшие, до 1 м высотой, отвалы. Они сильно оплыли вниз. Продукты расщепления относительно крупных конкреций рассеяны на крае плато в непосредственной близости вокруг этого карьера. Кремневые отщепы и заготовки орудий залегают также на склоне карьера со стороны плато и на верхних участках осыпей.

5. Клещеевка (см. рис. 1). Местонахождение выявлено автором в 1998 г. ${ }^{36} \mathrm{Ha}$ ходится на левом берегу небольшого отвершка балки на юго-восточной окраине п. Клещеевка Артемовского района Донецкой области. Отвершек балки врезан в склон коренной террасы, состоящей из мела. Глубина вреза - до 30-40 м. В верхней части склона обнажается плотная меловая порода с прослоями кремневых конкреций, низ склона скрыт осыпью. В скальном мелу отмечены карстовые образования в виде горизонтальных щелей, вертикальных трещин и небольших горизонтальных туннелей с широким сводом и узким дном. Одна из таких карстовых полостей имеет щелевидную форму. В верхней части полости сохранились явные следы извлечения кремневых конкреций из материнского ложа. Эти следы имеют вид насечек шириной 4-5 см. Следы от инструмента концентрируются главным образом, на своде, преимущественно вокруг «гнезд» от кремневых конкреций. Искусственная разработка верхней части щели привела к расширению свода. Судя по «гнездам», из потолка извлекались конкреции размерами до 20 см. Одна из оставшихся в мелу конкреций разбита при попытке ее извлечения. В рыхлом заполнении полости (меловая крошка) найдены конкреция со следами формирования ударной площадки и несколько отщепов. Эта, по сути, разведочная выработка иллюстрирует начальный этап одного из способов разработки недр горизонтальными штреками. На поверхности террасы над тестовой выработкой расположена небольшая неолитическая кремнеобрабатывающая мастерская.

${ }^{36}$ Колесник А.В., Ковль Ю.Г. Новый памятник кремнедобычи у п. Клещиевка в Донбассе // Матеріали археологічної конференції «Етнічна історія та культура населення степу та лісостепу Євразії (від кам’яного віку по раннього середньовіччя)». Дніпропетровськ, 1999. С. 19-20. 
Помимо перечисленных выработок в литературе упоминаются карьеры по добыче кремня у с. Красно-Поповка на Луганщине ${ }^{37}$. Сведения о древних копях на меловой горе в с. Яремовка под Изюмом ${ }^{38}$ имеют чисто историографическое значение. Предположения о шахте по добыче кремня на горе Кременец в Изюме носили характер рабочей версии. Данные о местах добычи кремня в с. Волобуево на Харьковщине ${ }^{39}$, со ссылкой на разведки Ю. В. Буйнова, также не подтвердились. Во время обследования предполагаемого места древних выработок в 2004 г. нами вместе с сотрудницей Харьковского исторического музея И. А. Снежко установлено, что на окраине села на правом берегу реки обнажаются гривы плитчатого известняка, россыпи которого были приняты за устья шахт. Сам известняк кремня не содержит. В срезе берегового обрыва видны заполненные смытым обломочным материалом глубокие промоины, которые, видимо, были приняты за шахтные колодцы. На поверхности террасы найдено невыразительное мезо-неолитическое местонахождение с небольшим количеством подъемного материала. Следует отметить также глубокие провалы на поверхности меловых останцев у с. Рай-Стародубовка (правый берег р. Северский Донец), которые в ходе разведок принимались нами за устья шахт, но в реальности имеют карстовый генезис. Таково происхождение и узких глубоких вертикальные структур, вскрытых меловым карьером на западной окраине г. Славянска, в меловом карьере в г. Краматорске и в других местах.

Типология неолитических горных комплексов разработана Н.Н.Гуриной ${ }^{40}$. В ее схеме места добычи сырья делятся на открытые выработки (места сборов каменного сырья на поверхности и ямы) и подземные (горизонтальные разработки штольни - и вертикальные разработки - шахты). На этом фоне классификация неолитических выработок Донбасса выглядит упрощенной, так как фактически представлена одна разновидность выработок - небольшие карьеры на склоне или в высшей точке мелового склона. Геометрия склона определяла форму отвала рыхлой породы и врезки по продуктивной кремневой жиле. Как правило, в верхней точке склона отвал рыхлой породы оконтуривал небольшую выемку со стороны плато (балка Редкодуб), на крутом склоне отвал сбрасывался вниз и окружал выемку полукольцом (п. Андреевка, Закотное). На склонах врезка по продуктивному слою неизбежно приобретала ступенеобразный характер. Несмотря на небольшие отличия речь идет фактически об одном типе карьеров.

С точки зрения типологических отличий открытые выработки Донбасса по добыче кремневого сырья можно разделить на следующие типы:

- карьеры различной конфигурации на склонах и поверхности плато или меловых останцев (Красное, Редкодуб);

- ступенеобразные каръеры на склоне меловой возвышенности (с. Закотное, Андреевка);

37 Гаврилюк Н. А., Ветров В. С. Конспект лекций по дисциплине «Методика полевой археологии» (для студентов специальности «История»). Луганск, 2003. С. 22.

38 Сібільов М. В. Підсумки досліджень палеолітичних і неолітичних стоянок басейну р. Донця // Наукові Записки Інституту історії і археології України. Київ, 1946. Кн. 2. С. 29-37.

39 Березанская С. С., Цвек Е. В., Клочко В. И., Ляшко С.Н. Ремесло эпохи энеолита - бронзы на Украине. Киев, 1996.

40 Гурина Н.Н. Древние кремнедобывающие шахты. 
- тестовая выработка в естественной подземной полости карстового происхождения (с. Клещеевка).

К энеолиту уверенно может быть отнесен только один горный комплекс, расположенный в Южном Донбассе.

6. Широкое (см. рис. 1). Горный комплекс у с. Широкое, предположительно, функционировал в неолите - энеолите, но энеолитическая датировка самих подземных полостей более доказательна благодаря сохранившимся следам металлических инструментов. Комплекс состоит из горных выработок и расположенных поблизости мастерских. Выработки находятся на правом берегу р. Крынки в балке Широкой Амвросиевского района Донецкой области ${ }^{41}$. Памятник исследовался Д. С. Цвейбель в 1965-1966 гг. Уникальность широкинских выработок объясняется, прежде всего, особенностями строения геологического тела, в недра которого по наиболее насыщенной кремневой жиле были врублены подземные полости. Меловые горы на правом берегу р. Крынки являются частью системы верхнемеловых отложений. Южная полоса этих отложений тянется по Крынке приблизительно 30 км. Среди них преобладают отложения мелоподобного мергеля с белым известняком в основании. Последний содержит кремень в виде конкреционных жил. В результате эрозии склоны правого коренного берега реки приобрели расчлененный рельеф. Одна из сопок в устье балки Широкой, на ее левом берегу, получила название Белая гора (высота до 60 м). Вдоль южного склона возвышенности со стороны балки протянулся уступ, сложенный относительно более плотной породой. К моменту археологического обследования уступ был сильно разрушен эрозией и частично скрыт осыпью, В районе пещерного комплекса он сохранился более или менее отчетливо и повторял общий контур южного склона сопки. Высота уступа достигала до 3 м. Белая гора была разделена небольшой промоиной на два участка - западный и восточный. Древние выработки находились на обоих участках. Все они были приурочены к стене-уступу. На западном участке Д. С. Цвейбель нашла множественные обвалившиеся пещеры и два навеса-карниза длиной 12 и 20 м. Наиболее полно сохранились «пещеры 1 и 2».

В районе искусственных навесов отмечены три жилы кремня, в районе углубленных выработок - две, на уровне потолка и пола пещер. Расстояние между жилами не превышало $1 \mathrm{~m}$.

Подземные полости представляют собой относительно небольшие углубленные и расширенные ниши вдоль уступа, соединенные между собой небольшими «окнами». Конфигурация выработок восстанавливается по северным, углубленным в материковую толщу стенкам. Южные стенки, обращенные наружу, сохранились очень плохо. В результате эрозии и гравитационной деформации привходовые участки во многих случаях разрушились почти полностью. Из конструктивных элементов выработок в привходовой части сохранилось только несколько мощных целиков - опорных монолитов, поддерживающих свод на входе (рис.3). Целики отесаны с трех сторон со стороны камеры.

«Пещера 1» состоит их нескольких соединенных вместе камер. Как видно, наращивание объемов подземной полости происходило не вглубь скалы, а параллельно стене уступа путем разработки новой углубленной ниши, которая сливалась

${ }^{41}$ Цвейбель Д. С. Древние каменные выработки у с. Широкое в Донбассе. 

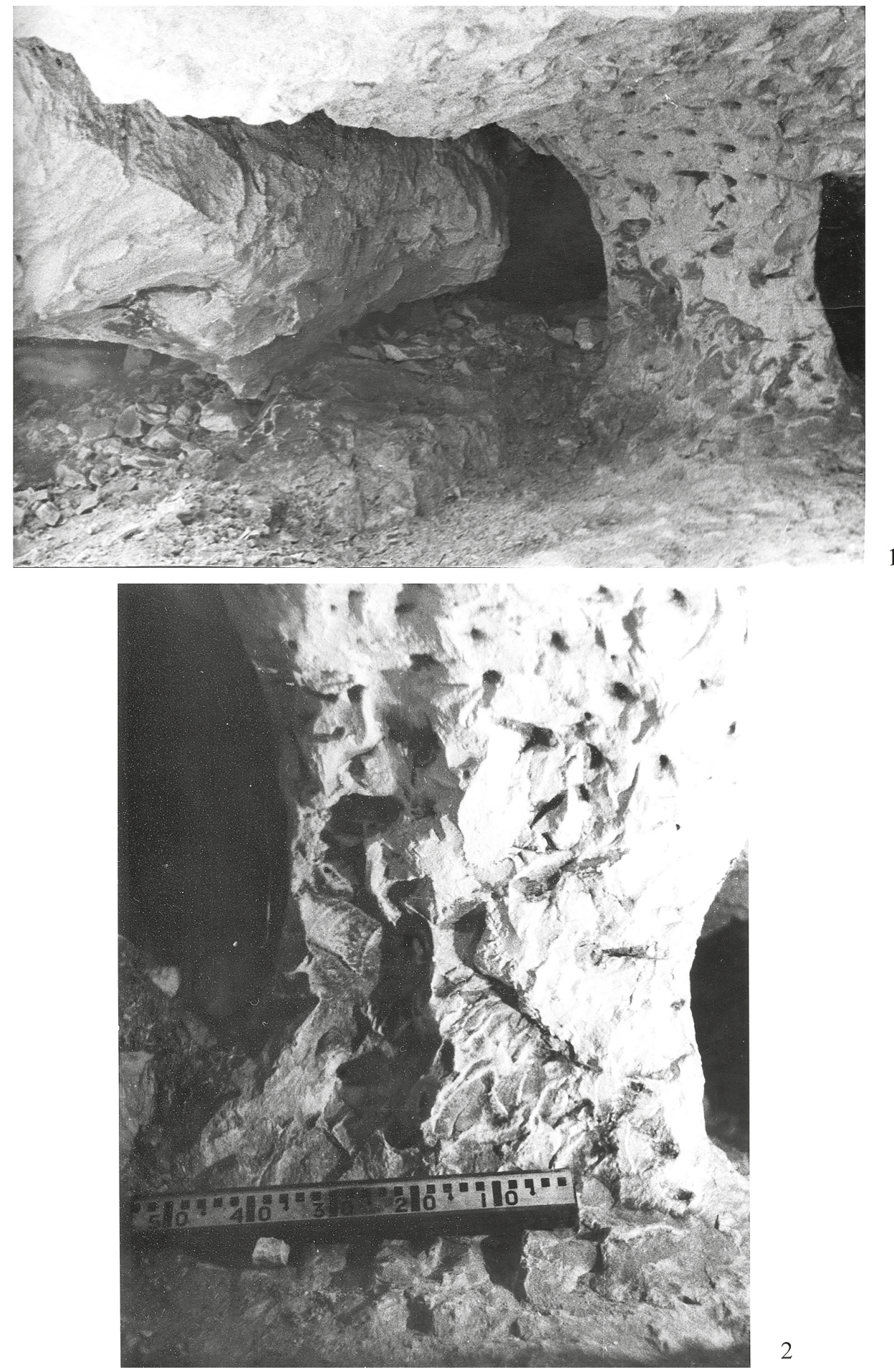

Puc. 3. Широкинский горный комплекс. Вид подземных полостей (1-2) (по [Колесник, Коваль, 1997, рис. 3]) 
с уже существующей соседней полостью. В результате образовывалась объединенная вместе цепочка камер, из которых каждая имела один или более самостоятельных выходов на дневную поверхность. Общая протяженность «пещеры 1» - 24,4 м. Отдельные камеры имеют ширину соответственно 5,2, 4,4 и 2,0 м. Высота камер существенно уменьшается к задней стенке - от 1 до 30-40 см. Эти низкие щелевидные подбои образуют волнистую в плане линию. Переходы между камерами имеют арочный вид. «Кремень извлекался главным образом из потолка, в котором видны торчащие обломки желваков» ${ }^{42}$. Основная часть заполнений камер образовалась еще в древности из рыхлой известняковой крошки.

«Пещера 2» представляет собой сохранившуюся часть крупной подземной выработки сложной конфигурации. Крупный обвал в новейшее время «произошел в глубине пещеры 2 - часть свода упала и почти загораживает путь внутрь» ${ }^{43}$. Размеры исследованной части - 10,4-4,4 м. В глубине расчищены два хода - длиной 2,5 и 7,0 м. С северо-запада к «пещере 2» примыкал крупный разрушенный подземный комплекс длиной до 35 м. Он полностью обвалился и был недоступен для изучения.

Отчетливые следы орудий сохранились на стенах и потолке «пещеры 1». Они детально описаны Д. С. Цвейбель в рукописи 1965 г. Выделяются следы трех видов: «тонкие ровные углубления 3-7 см длиной, поставленные прямо или наискось... более широкие и несколько изогнутые следы... и довольно глубокие почти прямоугольные следы длиной 6-7 см, весьма густо примыкающие друг к другу» ${ }^{44}$. Фотографии из архива Д. С. Цвейбель дают ясное представление об этих последних следах - они явно оставлены нешироким металлическим теслом или клиновидным топором. Ширина следов стандартная - около 6 см. В одном случае лезвие инструмента в плане прямое (рис. 4, A), в другом - слегка выпуклое (рис. 4, В). Широкие короткие медные топоры-тесла датируются в широких пределах энеолита - раннего бронзового века ${ }^{45}$.

С типологической точки зрения ${ }^{46}$ в Широкинском комплексе следует различать два технологически и генетически связанных между собой типа горных выработок (эволюция выработок (рис. 5):

- подбои-карнизы вдоль обнажающейся по склону кремневой жилы с горизонтальным простиранием;

- штольневые выработки вдоль склона - подземные выработки в виде относительно небольших камер, идущих цепочкой вдоль крутого склона меловой горы по кремневой жиле.

Наиболее сложный шахтный способ добычи кремня в регионе пока не известен.

\section{2 Там же. С. 229.}

43 Цвейбель Д. С. Отчет об археологической практике студентов 1 курса истфака Донецкого госуниверситета у с. Широкое в 1965 г. Рукопись // Архив Музея археологии и этнографии ДонНУ. Донецк, 1965. С. 4.

44 Там же. С. 6.

45 Черных Л.А. О типологических особенностях металлического инвентаря из памятников ранней бронзы Северного Причерноморья (тесла, долота) // Археологический альманах. 1997. № 6. C. 97-124.

${ }^{46}$ Kolesnik A. Neolithic - Chalcolithic flint exploitation in Donbas (South-East of the Ukraine) // Stone Age - Mining Age. Der Anschnitt. 

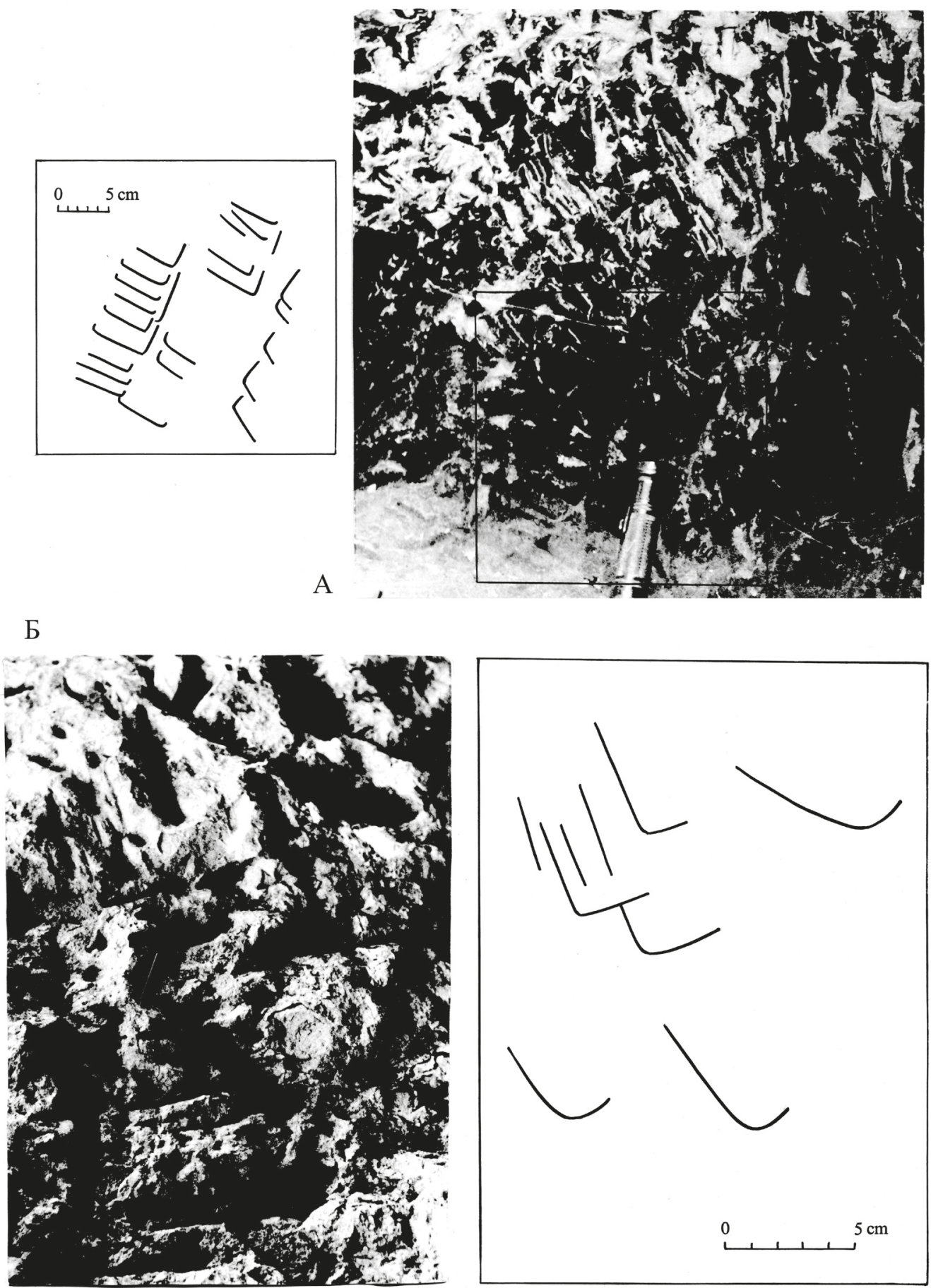

Puc. 4. Широкинский горный комплекс. Следы инструментов на стенах (А) и сводах подземных выработок (Б) (по [Колесник, Коваль, 1997, рис. 5]) 

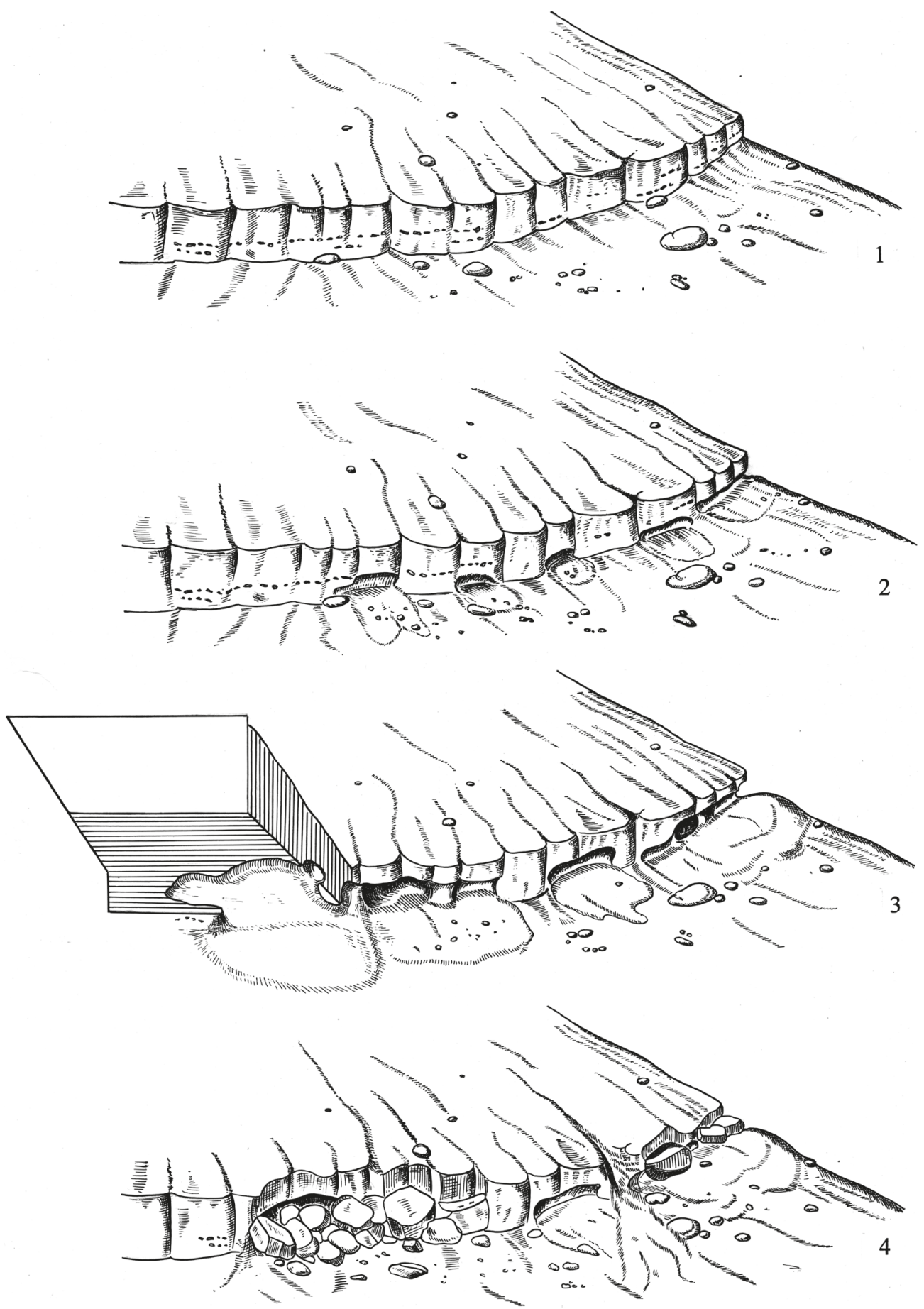

Puc.5. Широкинский горный комплекс. Реконструкция этапов функционирования горных выработок:

1 - инициальный этап; 2 - начальный этап горных работ; 3 - конечный этап горных работ; 4 - этап постгенетической деструкции (по [Колесник, Коваль, 1997, рис. 2]) 
А.А.Бритюк декларирует также вариант простейших горных работ, который «предусматривает изъятие кремневых конкреций, залегающих неглубоко в земле», со ссылкой на материалы энеолитических поселений Груша и Георгиевка в бассейне р. Ольховой на Луганщине ${ }^{47}$. Однако в публикации самих материалов указаний на такой тип горных работ нет.

Практически все горные выработки Донбасса эпохи неолита и энеолита сопровождаются мастерскими по первичной переработке добытого кремневого сырья. Немногочисленные горные инструменты, вероятно, связанные с разработкой недр Донбасса в неолите и энеолите с целью добычи кремневого сырья, проанализированы нами в отдельной работе ${ }^{48}$. Они представлены различными ударными инструментами из рога, меди и камня. Важным дополнением к этому горному инструментарию были различные простейшие каменные отбойники, серийно представленные на мастерских, расположенных вблизи от горных выработок Донбасса в составе единых горных комплексов по добыче и первичной переработки кремня. Этот класс простейших инструментов в одинаковой степени характерен для неолитических и энеолитических мастерских. В подавляющем большинстве случаев в качестве отбойников использовались небольшие конкреции и куски кремня из того же месторождения, что и кремневое сырье для нуклеусов и орудий.

Каменные отбойники уверенно диагностируются по характеру износа. Фиксированное положение отбойников при работе приводило к образованию локальных зон забитости. В пределах таких зон формировались особые поверхности, состоящие из разрушенного множественными трещинами материала отбойника. При ударе отбойником по обрабатываемому кремневому предмету возникал волновой эффект, направленный в обе стороны. За счет кинетической энергии отбойника удар обеспечивал образование планируемой трещины в статичном предмете, однако контрударный эффект неизбежно приводил к микротрещинам на поверхности самого отбойника. Наложение конусов трещин вело к разрушению ударной поверхности, образованию своеобразного амортизационного слоя, при этом понижалась твердость ударной части кремневого отбойника. Возникающую характерную забитость в русскоязычной литературе принято называть «звездчатой».

Шероховатая и более мягкая, чем материал отбойника, поверхность амортизировала удар и обеспечивала сцепку между инструментом и предметом обработки. Поэтому при оценке рабочих качеств отбойника следует учитывать не твердость самого материала отбойника, а физические свойства зоны забитости. При работе активная зона отбойника постепенно выкрашивается и возобновляется. Такие свойства отсутствуют у простого куска кремня, поэтому не исключено предварительное создание зон забитости на отбойнике. В меньшей степени нуждались в подготовке специальной поверхности кварцевые и кварцитовые гальки, так как естественная зернистость и вязкость этих минералов была удовлетворительной для ударной техники скола. Расположение зон забитости на теле отбойника дает основание для выделения отдельных групп инструментов. Функциональные зоны располагаются на полюсах и ребрах отбойников, т.е. на наиболее выступающих участках.

47 Бритюк А. А. Кремнеобрабатывающие мастерские у с. Житловка в Донбассе // Матеріали та дослідження з археології Східної України. Луганськ: Шлях, 2004. Вип. 3. С. 99.

48 Колесник А.В. Из истории горного дела Донбасса // Тр. ист. фак-та СПбГУ. Т. 18: Проблемы археологии эпохи камня. К 70-летию В. И. Беляевой. СПб., 2014. С. 281-292. 
При работе с каменным отбойником используется кинетическая энергия падающего отбойника, который опускается до соприкосновения с предметом обработки (т.е. удара) под собственным весом. Физическая работа мастера связана с ритмическим подъемом инструмента на заданную высоту и его коррекцией (удерживанием) при ударе. Дополнительный разгон при движении вниз в основном не требовался. Сила удара регулируется весом отбойника, который легко подобрать из окружающих кусков породы. Среди отбойников выделяются кластеры изделий весом 50-100, 200-350 и 500-600 г при отсутствии резкой границы межу ними. Они могли применяться для различных операций (дробление, оббивка, ударная ретушь) при обработке предметов разной величины. Основное количество отбойников, происходящих из мастерских, имеют вес до 350 г. Наиболее крупные отбойники (весом около 500 г) встречаются исключительно на мастерских вблизи горных выработок.

Сломанный кремневый отбойник легко заменялся новым. Этот класс инструментов был одним из наиболее рентабельных. На неолитических и энеолитических мастерских, расположенных непосредственно возле горных выработок Донбасса, собрано значительное количество различных отбойников из кремня (в основном) и кварцита. Среди них выделяются следующие классы изделий.

Округлые не обработанные отбойники из конкреций кремня. Это самая распространенная разновидность отбойников (рис. 6: 1-2). Практически каждый геологический источник кремня содержит множество округлых, гантелеобразных, цилиндрических и пальцевидных мелких конкреций, из которых можно было выбрать нужный предмет. Предпочтение отдавалось шаровидным и яйцевидным конкрециям величиной 7-8 см.

Округлые отбойники со следами обработки. Многие отбойники имеют следы грубой оббивки - им специально придавался кубовидный контур с обязательным участком естественной сферической поверхности (рис.6: 3-4). Принадлежность к отбойникам этих кубовидных предметов определяется наличием участков со специфической забитостью. Иногда в качестве отбойников использовались полностью освобожденные от корки кубовидные изделия, которые невозможно отличить от кубовидных нуклеусов. Они встречаются только на мастерских.

Отбойники из отщепов или плоских кусков кремня. У таких, как правило, небольших по размеру, отбойников следы забитости концентрируются на узких выступающих ребрах. Редким экземпляром представлен специально сформированный дисковидный отбойник со следами интенсивной забитости по окружности. Вероятно использование этих инструментов в качестве грубых ретушеров.

Отбойники из кремневых нуклеусов или их заготовок в небольшом количестве систематически встречаются на мастерских у горных выработок (рис. 6: 5-7). Отбойники из сработанных нуклеусов встречаются также на поселениях в силу своей массивности. Следы сработанности концентрируются в районе выпуклого основания нуклеуса или вдоль кромки отбивной площадки. Уникальные отбойники их крупных удлиненных бифасиальных заготовок отмечены в комплексе Красное 15. Не исключено, что эти отбойники, по форме напоминающие отбойники из комля лосиного рога, специально готовились по технологиям обработки двусторонних заготовок нуклеусов и копий. 

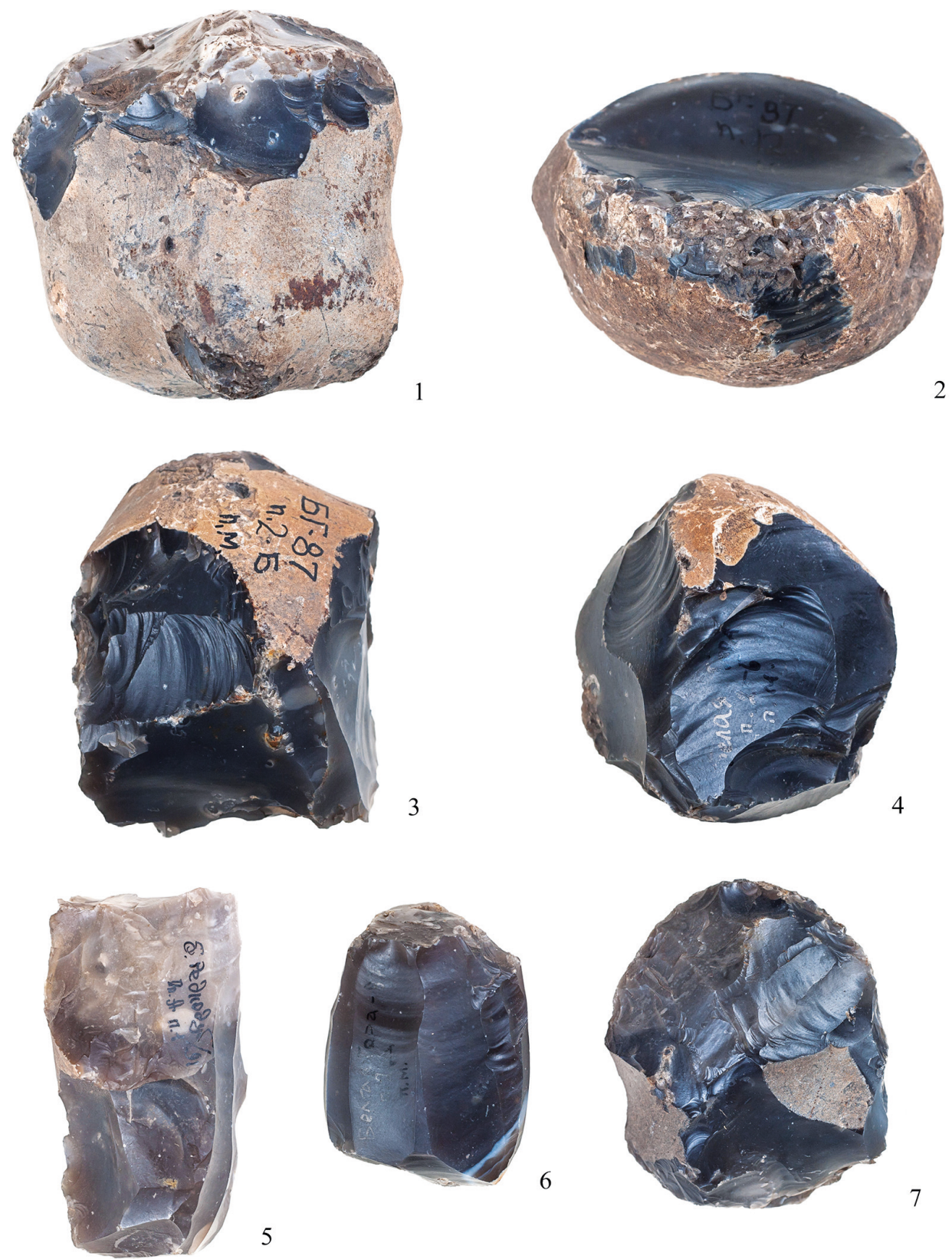

5

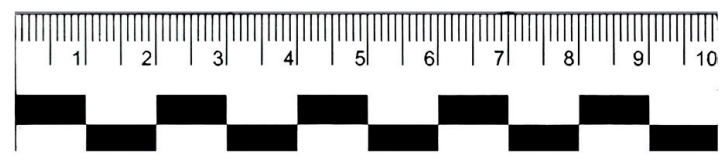

Puc. 6. Каменные отбойники из неолитических и энеолитических мастерских Донбасса, расположенные возле горных выработок:

1-2 - округлые отбойники; 3-4 - кубовидные отбойники; 5-7 - отбойники из нуклеусов (фото В. Лемянского) 
Очевидно, при массовой потребности в отбойниках на мастерских в районе добычи кремня их не только отбирали, но и специально готовили (рис. 6: 2-4); имела место калибровка размеров и, видимо, веса.

\section{Краткий словарь терминов, связанных с горным делом}

Горный комплекс - часть производственного центра, горные выработки по добыче кремня. Могут иметь вид открытых карьеров, штолен, подбоев и сложно организованных шахт со своей внутренней типологией. Выработки связаны в основном с плотными карбонатными породами.

Производственный иентр - в аспекте кремнеобработки, это комплекс, состоящий из связанных в единый производственный цикл участков добычи кремня горным способом (искусственной выемкой) и мест его последующей переработки до определенной технологической глубины. Места добычи и обработки кремня в большинстве случаев образуют крупные сложные по внутренней организации взаимосвязанные соседние структуры.

Инициальная (тестовая) выработка - незначительные по масштабам выработки, связанные с поиском кремневой жилы, опробованием возможности ведения горных работ, качества каменного сырья. На практике это неглубокие ямы, «слепые» штольни в шахтах, слегка расширенные естественные карстовые полости, промоины и др.

Подбои-карнизы вдоль обнажающейся по склону кремневой жилы с горизонтальным простиранием (Широкое) реализуют самый простой горный способ выемки кремневого сырья из скальной породы.

Карьеры различной конфигурации (Красное, Редкодуб) наблюдаются в местах неглубокого залегания кремненосного слоя. Отвалы рыхлой породы имеют различную форму. Иногда дно карьера имеет ступенеобразный рельеф в связи со слоистым строением скальной породы.

Ступенеобразные карьеры на склоне меловой возвышенности (Закотное, Андреевка) возникали на склонах со структурными террасами в месте обнажения кремневых жил. Как правило, продуктивная жила залегает в основании ступеньки, уходя в материк. Отвал накапливается в нижней части карьера и опоясывает его полукругом. Горные выработки этого типа приурочены к естественным крутым склонам рек и максимально полно используют преимущества такого рельефа.

Штольневые выработки вдоль склона - подземные выработки в виде относительно небольших камер, идущих цепочкой вдоль крутого склона меловой горы по кремневой жиле (Широкое). Низкие широкие субгоризонтальные камеры с «окнами»-входами соединены между собой. Полости располагались под кремневой жилой, т. е. выемка конкреций осуществлялась из потолка подземной комнаты. Для предотвращения обвала в камерах оставлялись столбы-целики. Основной объем полостей завален отработанной рыхлой породой.

\section{Выводы}

Обзор памятников горного дела Донбасса неолита и энеолита позволяет сделать следующие выводы. 
1. Древнее горное дело Донбасса - важная составная часть горного дела Восточной Европы. Традиция изучения этих памятников была общей и базируется в основном на советской археологической науке.

2. В неолите в пределах Большого Донбасса формируется крупный центр кремнеобрабатывающего производства. Этот центр имел сложноорганизованную структуру и состоял из нескольких районов в пределах Северо-Западного, Южного и Юго-Восточного Донбасса. Эти центры маркируются многочисленными мастерскими по первичному расщеплению кремня и, по крайней мере в Северо-Западном и Южном Донбассе, горными выработками по добыче кремневого сырья. Добыча кремня осуществлялась в простых карьерах на месте обнажения меловых пород (Красное, Закотное, Андреевка, Балка Редкодуб).

3. В энеолите в регионе наблюдается дальнейшее развитие горного дела, связанного с добычей кремня, в Южном Донбассе появляется более сложные по организации штольневые выработки (с. Широкое).

\section{References}

Berezanskaya S. S., Tsvek E. V., Klochko V.I., Lyashko S. N. Remeslo epokhi eneolita - bronzy na Ukraine. Kiev, Naukova dumka Print., 1996, vip. 3. 189 p. (In Russian)

Bibikov S. N. Drevnie kremnievye vyrabotki v Srednem Podnestrov'e. Sbornik Narodnigo Muzea v Praze. Acta Muzei Nationalis Pracae, vol. XX, no 1/2. Praga, Nákladem Muzea, 1966, pp.3-7. (In Russian)

Brityuk A. A. Kremneobrabatyvaiushchie masterskie u s. Zhitlovka v Donbasse. Materiali ta doslidzhennia $z$ arkheologii Skhidnoi Ukraini. Vip. 3. Lugansk, Shliakh Print., 2004, pp.99-113. (In Russian)

Boule M. Découverte fe puits prehitoiques d'extraction du silex. Matériaux pour l'hisotire et naturalle de l'homme. T. 1. Paris, Ch. Reinwald, libraire, 1884, pp. 65-75.

Cornet F.L., Briart A. Sur l'âge des silex ouvrés de Spiennes. Bulletins de l'Académie royale des sciences, des lettres et des beaux-arts de Belgique. Bruxselles, M. Hayez, Imprimeur de l'academie Royale de Belgique, 1868, t. 25, pp. 26-138.

Charniausky M. M. Ancient flint mines in Belarus. Archaeologia Polona. Vol.33. Warsaw, The Institute of Archaeology and Ethnology, Polish Academy of Sciences, 1995, pp. 263-269.

Chernykh L.A. O tipologicheskikh osobennostiakh metallicheskogo inventaria iz pamiatnikov rannei bronzy Severnogo Prichernomor'ia (tesla. dolota). Arkheologicheskii al'manakh, 1997, no. 6, pp.97124. (In Russian)

Degermendzhi S. M. O vozmozhnykh sledakh drevnei razrabotki kremniiaa u s. Zakotnoe v Podontsovye. Arkheologicheskiy al'manakh, 2000, no. 9, pp. 179-184. (In Russian)

Foss M.E., Elnitskiy L.O. O dobyvanii kamnia i drevneishikh kamenolomennykh orudiiakh na severe Vostochnoi Evropy. Materialy i issledovania po arkheologii SSSR. Moscow; Leningrad, Izdatel'stvo Akademii nauk SSSR, 1941, no. 2, pp. 182-192. (In Russian)

Fox Lane A.H. Further remarks on the hill forts of Sussex: being an account of excavations in the Forts at Cissbury and Highdown. Archeologia, 1869, vol. 42, no. 1, pp. 53-76.

Gavrilyuk N.A., Vetrov V.S. Konspekt lektsii po distsipline "Metodika polevoi arkheologii" (dlia studentov spetsial'nosti "Istoriia"). Lugansk, Western-Ukraine University Print., 2003, 84 p. (In Russian)

Gorodtsov V. A. Rezultaty arkheologicheskikh issledovanii v Iziumskom uezde Khar'kovskoi gubernii $1901 \mathrm{~g}$. Trudy XII Arkheologicheskogo S"ezda. Vol.I. Moscow, Tovarishchestvo tipografii A.I.Mamontova, 1905, pp. 174- 225. (In Russian)

Gorodtsov V. A. Arkheologiia. Kamennyy vek. Vol. 1. Moscow, Kniga po trebovaniiu, 1923, 404 p. (In Russian)

Gurina N. N. K voprosu o makrolitakh Verkhney Volgi. Kratkie soobshenia Instituta arkheologii. Moscow, Izdatel'stvo Akademii nauk SSSR, 1962, vol.92. pp. 24-28. (In Russian)

Gurina N. N. Novyye dannyye o drevnikh shakhtakh po dobyche kremnya na Zapade Belorussii. Kratkie soobshenia Instituta arkheologii. Moscow, Nauka, 1965, vol. 100, pp. 85-89. (In Russian)

Gurina N.N. Drevniye kremnedobyvayushchiye shakhty. Leningrad, Nauka, 1976, 176 p. (In Russian)

Greenwell W. On the opening of Grim's graves in Norfolk. The Journal of the Ethnological Society of London. London, Royal Anthropological Institute of Great Britain and Ireland, 1870, Vol.2, no. 4, pp. 419-430.

Holmes W. H. An ancient quarry in Indian Territory. Washington, Government printing office, 1894, 19 p. 
Homsher G.W. Remains on White Water river, Indiana. Annual Report of the Board of Regents of the Smithsonian Institute, 1882. Washington, Government printing office, 1884, pp. 728-752.

Kasymov M. R. Kremneobrabatyvaiushchie masterskie i shakhty kamennogo veka Srednei Azii. Tashkent, Fan Print., 1972, 160 p. (In Russian)

Kolesnik A. Neolithic - Chalcolithic flint exploitation in Donbas (South-East of the Ukraine). Stone Age Mining Age. Der Anschnitt. Montanhistorische Zeitschrift. Bd. 19. Bochum, Deutsches Bergbau-Museum Bochum Print, 2006, pp. 129-134.

Kolesnik A.V. Ocherk istorii izucheniia pamiatnikov kremnedobychi i kremneobrabotki kamennogo veka - epokhi paleometalla Bol'shogo Donbassa. Arkheologicheskii al'manakh, 2013, no.30, pp. 5-21. (In Russian)

Kolesnik A. V. Iz istorii gornogo dela Donbassa. Problemy arkheologii epokhi kamnia. Trudy istoricheskogo fakulteta Sankt-Peterburgskogo gosudarstvennogo universiteta. Vol. 18: K 70-letiiu Valentiny Ivanovny Beliaevoi. St. Petersburg, St. Petersburg University Print., 2014, pp. 281-292. (In Russian)

Kolesnik A. V., Koval Yu. G. Novyi pamiatnik kremnedobychi u p. Kleshchievka v Donbasse. Materiali arkheologichnoi konferentsii "Etnichna istoriia ta kul'tura naselennia stepu ta lisostepu Evrazii (vid kam'ianogo viku po rannogo serednovichchia)". Dnipropetrovsk, Dnipropetrovsk University Print., 1999, pp. 19-20. (In Russian)

Konoplya V.M. Lendel'skaia kul'tura. Arkheologiia Prikarpat'ia. Volyni i Zakavkazia. Eneolit, bronza i rannee zhelezo. Kiev, Naukova Dumka Print, 1990, pp.4-17. (In Russian)

Krizhevskaya L. Ya. Kremneobrabatyvaiushchaia neoliticheskaia masterskaia i poselenie na severo-vostoke Bashkirii. Materialy i issledovania po arkheologii SSSR. Moscow, Izdatel'stvo Akademii nauk SSSR, 1960, no.79, pp. 239-280. (In Russian)

Lev D. N. K voprosu o proiskhozhdenii drevneishikh kremnevykh shakht. Sovetskaia etnjgrafia. Moscow, Izdatel'stvo Akademii nauk SSSR, 1934, no. 1-2, pp. 123-127. (In Russian)

Litvinskiy V. A. Drevneyishie stranitsy istorii gornogo dela Tadzhikistana i drugikh respublik Srednei Azii. Trudy instituta istorii AN Tadzhikistana. Stalinabad, Izdatel'stvo Akademii nauk Tadzhikskoi SSR, 1954, vol. 19, 46 p. (In Russian)

Mirsaatov T. M. Drevnie shakhty Uchtuta. Tashkent, Fan Print., 1973, 108 p. (In Russian)

Mirsaatov T. M. Gornye razrabotki v epokhu kamnia. Tashkent, Fan Print., 1977, 144 p. (In Russian)

Sibilev N. V. Drevnosti Iziumshchiny. Izium, tipografiia Pechatnoe delo, 1926, iss. 2, 20 p. (In Russian)

Sibilov M.V. Pidsumki doslidzhen paleolitichnikh i neolitichnikh stoyanok baseynu r. Dontsya. Naukovi Zapiski Institutu istorii i arkheologii Ukraini. Vol.2. Kiev, Print of the Academy of Science of the Ukraine SSR, 1946, pp. 29-37. (In Ukrainian)

Smith Ch. M. Sketch of Flint Ridge, Licking Country, Ohio. Annual Report of the Board of Regents of the Smithsonian Institute for the year 1884. Washington, Government printing office, 1885, pp. 851-873.

Sveshnikov I. K. Kremnevye kopi u s. Gorodok Rovenskow oblasti. Kratkie soobshenia Instituta istorii material'noi kul'tury. Iss. 117. Moscow, Nauka, 1969, pp. 114-121. (In Russian)

Passek T.S. Tripolskie poseleniia na Dnestre. Kratkie soobshenia Instituta istorii material'noi kul'tury. Vyp. XXXII. Moscow, Leningrad, Izdatel'stvo Akademii Nauk SSSR, 1950, pp. 47-56. (In Russian)

Tsvek E. V., Movchan I. I. Eneoliticheskii proizvodstvennyi kompleks po dobyche i obrabotke kremnia na reke Bol'shaia Vys'. Na poshanu Sofii Stanislavivni Berezanskoï: Zbirka naukovikh prats. Kiev, Shlyakh Print., 2005, pp.66-76. (In Russian)

Tsveybel D.S. Drevnie kamennye vyrabotki u s. Shirokoye v Donbasse. Sovetskaia arkheologiya. Moscow, Nauka, 1970, no. 1, pp. 227-233. (In Russian)

Vasilenko B. A. Vidobuvannia i obrobka kremenyu na Pravoberezhzhi Verkhnogo Podniprov'ya v eneoliti. Prolemi istorii ta arkheologii naselennya Ukranskoi RSR. Kiev, Naukova dumka Print, 1989, pp. 38-39. (In Ukrainian)

Walker S. T. Preliminary exploration among the Indian mounds in southern Florida. Annual Report of the Smithsonian Institution for 1879. Washington, Government printing office, 1880, pp.392-413.

Статья поступила в редакцию 29 мая 2018 г.

Рекомендована в печать 12 марта 2019 г.

Received: May 29, 2018

Accepted: March 12, 2019 


\title{
Модели распространения культур шнуровой керамики в Верхнем Подвинье
}

\author{
E. C. Tкач
}

Для цитирования: Ткач E. С. Модели распространения культур шнуровой керамики в Верхнем Подвинье // Вестник Санкт-Петербургского университета. История. 2019. Т.64. Вып. 2. С. 621638. https://doi.org/10.21638/11701/spbu02.2019.212

Памятники культур шнуровой керамики (КШК) выявлены на территории Центральной, Северной и Восточной Европы. Их бытование относят к III тыс. до н. э. Обсуждаются две гипотезы, объясняющие характер их распространения: первая предполагает прямую миграцию населения - носителей данной традиции, а вторая - диффузное культурное влияние. Новейшие данные палеогенетики подтверждают миграционную гипотезу. В области течения верховьев реки Западная Двина в России материалы КШК встречаются в двух регионах - Ловатско-Двинском междуречье (юг Псковской и север Смоленской областей) и по берегам оз. Белая Струга в Палкинском районе Псковской области. В анализе материалов использованы артефакты КШК из поселений верховьев р. Западной Двины, важные для культурной диагоностики: керамические сосуды со шнуровой орнаментацией, характерные для шнуровых культур А-кубки и амфоры, кремневые треугольные наконечники. Кроме того, изучены каменные сверленые топоры, известные между этими регионами в качестве случайных находок. В результате удалось выявить две модели распространения культур шнуровой керамики. Первая согласуется с миграционной моделью и представлена материалами А-горизонта культур шнуровой керамики - это кубки с елочным орнаментом А-типа, амфоры, каменные сверленые топоры А-типа. Они имеют аналогии на территории Эстонии, Литвы, Латвии, Беларуси, Украины, а также Центральной Европы, и датируются первой половиной III тыс. до н.э. Вторая модель предполагает культурную диффузию; согласно ей, появление элементов КШК в регионе верховьев р. Западной Двины России связано с обменными отношениями и культурным влиянием. Появление «импортных» изделий свидетельствует о наличии обмена между населением Ловатско-Двинского междуречья и Верхнего Поднепровья. Обмен с территорией Прибалтики подтверждается наличием изделий из балтийского янтаря. Распространение лоскутной техники изготовления посуды и орнаментация сосудов с помощью оттисков шнура свидетельствуют о сильном влиянии КШК на материальную культуру населения Ловатско-Двинского междуречья в течение III тыс. до н. э. Таким образом, перечисленные элементы могут

Евгения Сергеевна Ткач - канд. ист. наук, мл. науч. сотрудник, Институт истории материальной культуры РАН, Россия, 191186, Санкт-Петербург, Дворцовая наб., 18; jenij90@mail.ru

Evgeniia S. Tkach - PhD in History, Junior fellow, Institute for the History of Material Culture Russian Academy of Science, Dvortsovaya nab., 18, Saint-Petersburg, 191198, Russia; jenij90@mail.ru

Исследование проведено в рамках выполнения программы ФНИ ГАН № 0184-2019-0002 «Первые люди на Севере России: Арктика и Субарктика в позднем плейстоцене и раннем голоцене».

The research was conducted in the framework of the Federal Scientific Research of the State Academy of Sciences № 0184-2019-0002 "First people in the North of Russia: Arctic and Subarctic in the Late Pleistocene and Early Holocene".

(c) Санкт-Петербургский государственный университет, 2019 
быть результатом культурной диффузии и необязательно связаны со сменой населения региона в указанное время.

Ключевые слова: культуры шнуровой керамики, Верхнее Подвинье, миграция, диффузия.

\section{Models of the Corded Ware Culture Distribution in the Upper Western Dzvina River}

E. S. Tkach

For citation: Tkach E.S. Models of the Corded Ware Culture Distribution in the Upper Western Dzvina River. Vestnik of Saint Petersburg University. History, 2019, vol. 64, iss. 2, pp. 621-638. https://doi.org/10.21638/11701/spbu02.2019.212 (In Russian)

Artefacts of Corded Ware cultures (CWC) dating to the $3^{\text {rd }}$ millennium BC have been identified in the territory of the most part of Europe. There are two hypotheses explaining their spread in the area. The first of them suggests direct migration of human groups representing this culture, while the other presupposes the model of cultural diffusion. On the territory of the Upper Western Dzvina River, CWC materials are distinguished in two regions - in the Lovat'-Dvina interfluve and along the shores of the lake Belaya Struga in Pskov region. This paper analyses culturally important CWC artefacts (which serve as cultural markers) unearthed from the cultural deposits, such as ceramics with cord ornamentation and triangular flint arrowheads. Additionally, stone battle-axes collected in between of these regions were studied. It is possible to identify two models of CWC distribution. The first one is a migration model which is presented by the materials of CWC A-horizon. These are A-type beakers with "herringbone" ornamentation, amphoras, and A-type battle-axes. They are analogous to CWC materials in the territory of Central Europe and Baltic Coast. A-horizon dates to the first half of the 3rd millennium BC. The second model suggests cultural diffusion. According to it, elements of the CWC might have emerged due to exchange/trade connections and cultural influence (imported products indicates the long-distance exchange network with the Middle Dnieper culture population). Connections with the Baltic Coast areindicated by the presence of Baltic amber. The spread of the patchwork technique in ceramics and cord ornamentation show a strong cultural influence on the local Neolithic materials from the main area of distribution of CWC.

Keywords: Corded Ware cultures, Upper Western Dzvina River, migration, diffusion.

\section{Введение}

Одним из наиболее значительных событий на рубеже эпох камня и бронзы на территории Европы является возникновение и распространение культур шнуровой керамики (далее - КШК). Именно с этими археологическими культурами связывалось распространение индоевропейских языков ${ }^{1}$. Палеогенетические исследования последних лет, проводимые несколькими группами исследователей, подтверждают высказывавшиеся ранее предположения о миграции нового населения из степной зоны - территории распространения ямной культурно-исторической общности ${ }^{2}$.

${ }^{1}$ Kossina G. Ursprung und Verbreitung der Germanen in vor- und frühgeschichtlicher Zeit. Leipzig, 1928; Gimbutas M. The Prehistory of Eastern Europe. Mesolithic, Neolithic and Copper Age cultures in Russia and the Baltic area. Cambridge, 1956. Pt. 1.

2 Haak W. et al. Massive migration from the steppe was a source for Indo-European languages in Europe // Nature. No. 522. 2015. P.207-211; Allentoft M. E. et al. Population genomics of Bronze Age Eurasia // Nature. No. 522. 2015. P. 167-172. 
Материалы КШК обнаружены на территории Центральной, Северной и Восточной Европы и датируются III тыс. до н.э. Примечательной особенностью КШК является характер их распространения: они заполняют не сплошную территорию, а имеют дискретное распределение. Между областями, занятыми носителями традиций КШК, существуют пустые пространства, на которых не обнаружено материалов, относящихся к КШК. Объяснить это явление только слабой изученностью данных территорий затруднительно. При этом существуют различные, порой взаимоисключающие, представления о механизмах распространения КШК и взаимодействия носителей этой традиции с аборигенным населением ${ }^{3}$.

На территории верховьев реки Западная Двина (юг Смоленской и вся Псковская области) на данный момент не выявлено погребальных памятников, которые можно было бы соотнести с кругом КШК. Это может свидетельствовать как о плохой изученности территории, так и об отсутствии прямой миграции носителей традиций КШК. В связи с этим представляет особый интерес материал, обнаруженный на поселениях (керамические сосуды и каменный инвентарь), а также случайные находки. В числе последних существенное место занимают каменные сверленые топоры, распространение которых связывается с КШК.

В рассматриваемом регионе можно выделить две группы памятников, где обнаружены материалы КШК. Первая группа представлена поселениями, расположенными в Ловатско-Двинском междуречье: Усвяты IV, Удвяты I, Наумово, Сертея II. Памятники являются многослойными, в них найдены материалы различных культур неолитического времени (IV-II тыс. до н. э.). Вторая группа включает в себя несколько местонахождений на берегу оз. Белая Струга в Палкинском районе Псковской области. Материал представлен керамическими сосудами КШК А-горизонта, а также медным шилом и обломком каменного топора. Расстояние между Ловатско-Двинским междуречьем и Палкинским районом составляет около 300 км. Между этими двумя регионами было обнаружено большое количество (более 70) каменных сверленых топоров (все - случайные находки), что может служить одним из косвенных показателей физического присутствия носителей традиций КШК. Для определения характера появления материалов КШК в указанном регионе требуется рассмотреть основные модели их распространения в европейской части в целом.

\section{Модели распространения КШК в Европе}

Существующие представления о происхождении и причинах локальных особенностей КШК крайне разнообразны ${ }^{4}$. Согласно первой модели, распростране-

${ }^{3}$ Furholt M. Upending a 'Totality': Re-evaluating Corded Ware Variability in Late Neolithic Europe // Proceedings of the Prehistoric Society. Vol. 80. Cambridge, 2014. P. 67-86; Кривальиевич Н.Н. К проблеме распространения традиций культур шнуровой керамики в междуречье Припяти и Западной Двины // Культурные процессы в циркумбалтийском пространстве в раннем и среднем голоцене. СПб., 2017. С.213-220; Kholkina M. A. Some aspects of Corded ware on Rosson river (NarvaLuga klint bay // Estonian Journal of Archaeology. 2017. No.21 (2). P. 148-160.

${ }^{4}$ Gimbutas M. The Prehistory of Eastern Europe. Mesolithic, Neolithic and Copper Age cultures in Russia and the Baltic area. Pt. 1; Мерперт Н.Я. Древнеямная культурно-историческая область и вопросы формирования культур шнуровой керамики // Восточная Европа в эпоху камня и бронзы. М., 1976. С. 103-127; Крийска А., Нордквист К., Герасимов Д. В. Эстонский вариант шнуровой керамики 
ние КШК связывается с массовыми миграциями. «Миграции - это переселение, передвижение населения, перенос культуры ее носителями с одной территории на другую» ${ }^{5}$. Данная точка зрения в ее крайнем варианте представлена в исследованиях Г. Коссинны и М. Гимбутас.

Согласно второй модели, основное внимание уделяется культурному влиянию и обменным отношениям ${ }^{6}$, что согласуется с течением диффузионизма. «Диффузия - это распространение культурных элементов из одного очага (одной культуры) на соседние и более далекие, распространение некого культурного явления или комплекса явлений из одного центра на другие территории» 7 .

Первая, миграционная модель была принята большинством исследователей в XX в. Миграции населения имели вид военных экспедиций и походов (из Северной Германии - по Г. Коссинне, из южных степей - по М. Гимбутас). Теорию расселения из одного центра поддерживал П.М.Долуханов ${ }^{8}$. По В.С. Титову, расселение КШК можно отнести к первому типу миграций, когда местная культура совершенно или почти не ощущается ${ }^{9}$. Многие исследователи принимают модель инфильтрации ${ }^{10}$.

В середине XX в. широкое распространение получила идея так называемого общеевропейского (А) горизонта. Основоположниками этой гипотезы были П. Глоб 11 и К. Струве ${ }^{12}$. Для А-горизонта характерны определенные типы (А) кубков, амфор и каменных топоров. Этот материал обнаружен на большей части распространения КШК в первой половине III тыс. до н.э. Согласно данной гипотезе, образованию КШК предшествовало распространение единого культурного пласта, оставленного небольшой группой подвижных скотоводческих племен. Племена распространились за короткое время на значительную территорию. В результате смешения носителей традиций А-горизонта с местными племенами возникли КШК.Само распространение происходило из единого центра.

// V (XXI) Всероссийский археологический съезд. Сб. науч. тр. Барнаул, 2017. С.557-558; Kristiansen K. Prehistoric Migrations - the Case of the Single Grave and Corded Ware Cultures // Journal of Danish Archaeology. Vol. 8. Odense, 1989. P. 211-225.

${ }^{5}$ Клейн Л. С. Теоретический словарь археологии. Донецк, 2014. С. 119.

6 Жульников А. М. Обмен янтарем в Северной Европе в III тыс. до н. э. как фактор социального взаимодействия // Проблемы биологической и культурной адаптации человеческих популяций. Т. 1. СПб., 2008. C.134-145; Heron C., Craig O., Luquin A., Steele V.J., Thompson A., Piličiauskas G. Cooking fish and drinking milk? Patterns in pottery use in the southeastern Baltic, 3300-2400 cal BC // Journal of Archaeological Science. 2015. Vol. 63. P. 33-43.

7 Клейн Л. С. Теоретический словарь археологии. С. 61.

8 Долуханов П.М. Истоки миграций (моделирование демографических процессов по археологическим и экологическим данным) // Проблемы археологии. Вып. 2. Л., 1978. С. 42.

9 Титов С.В. К изучению миграций бронзового века // Археология Старого и Нового Света. M., 1982. C. 99 .

${ }^{10}$ Neustupný E. Prehistoric migrations by infiltration // Archeologické rozhledy. XXXIV. Praha, 1982. P.283; Kurzawa J. Zagadnienie najwcześniejszych faz kultury ceramiki sznurowej na nizinie Wielkokopolsko-Kujawskiej. Problem tła genetycznego społeczności kultury pucharów lejkowatych. Poznań, 2001. S. 275; Girininkas A. Migraciniai procesai Rytu Pabaltijyje velyvajame neolite. Virvelinès keramikos kultūra // Lietuvos archeologija. T.23. Vilnius, 2002. P.92; Бондарь Н.Н. Культуры шнуровой керамики и их роль в древней истории Европы: автореф. дис. ... д-ра ист. наук. Киев, 1981. С. 41.

${ }_{11}$ Glob P. V. Stugier over den Juske Enkeltgravskultur. København, 1945.

12 Struve K.W. Die Einzelgrabkultur in Schleswig-Holstein und ihre kontinentalen Beziehungen. Neumünster, 1955. 
С идеей наличия А-горизонта также соглашался А. Я. Брюсов, который писал о многократном разнонаправленном (веерообразном) движении племен КШК ${ }^{13}$. Эту идею поддерживал Х. А. Моора ${ }^{14}$. По мнению Е. Фогта, миграция КШК имела характер однократного движения ${ }^{15}$. В 1968 г. в своей книге, посвященной КШК и культуре шаровидных амфор, Т. Сулимирский очагом зарождения КШК считает территорию междуречья Днепра и Одера, откуда идет распространение «маленькими группами в различных направлениях» ${ }^{16}$.

Вышеприведенные модели распространения традиций КШК зачастую использовались во второй половине ХХ в. для объяснения характера расселения их носителей в Европе. Однако в то же самое время некоторые исследователи стали приводить контраргументы. Г. Чайлд, не отрицая роли миграции на первых этапах, полагал, что КШК возникли в результате усвоения местными племенами производящей экономики и некоторых видов металлического оружия ${ }^{17}$.

Гипотеза наличия единого А-горизонта подвергалась критическому анализу ряда исследователей, которые усматривали ее недееспособность. В частности, К.Штрам обращал внимание на редкое сочетание всех элементов общеевропейского горизонта в одном памятнике, погребальном или поселенческом ${ }^{18}$. Такого же мнения придерживалась Р. Римантене ${ }^{19}$. Под сомнение существование А-горизонта КШК ставила С. С. Березанская, указывающая на единичные экземпляры общеевропейского горизонта в материалах КШК Восточной Европы. Она считала, что это может быть связано с культурным обменом ${ }^{20}$.

При изучении КШК на территории к западу от Вислы исследователями была предложена иная модель ее распространения. КШК рассматриваются в рамках культурного пространства с определенным набором общих и локальных признаков, а также стилей. Они соединены между собой межрегиональными культурными связями и «шнуровой коммуникационной системой» ${ }^{21}$. Эти отличительные черты, стили и идеи могли возникать в разное время и на различных территориях, где выделены КШК.

О возможной разновременности материалов А-горизонта также писали такие исследователи, как, например, Я. Чебрешук и М.Шмит (ими изучались территории Понеманья, Подвинья, Верхнего Поднепровья, а также Верхнего Поволжья). Отвергая наличие А-горизонта, присутствие черт разных культур они объясняли раз-

13 Брюсов А. Я. Об экспансии «культур с боевыми топорами» в конце III тыс. до н. э. // Советская археология. 1961. № 3. С. 22.

14 Моора Х. А. О древней территории расселения балтийских племен // Советская Археология. 1958. № 2. C. 13.

${ }^{15}$ Fogt E. Die Herkunft der Michelsberger Kultur // Acta Archaeologica. 1953. Vol. XXIV. S. 159.

16 Sulimirski T. Corded Ware and Globular Amphorae North-East of the Carpathians. London, 1968. P. 85.

17 Чайлд Г. У истоков европейской цивилизации. М., 1952. С. 244-245.

18 Strahm Chr. Die Dynamik der schnurkeramischen Entwicklung in der Schweiz und in Südwestdeutschland // Die kontinentaleuropäischen Gruppen der Kultur mit Schnurkeramik. Schnurkeramik Symposium. Praehistorica XIX. Praha, 1992. S. 174.

19 Rimantiene R. The Neolithic of the Eastern Baltic // Journal of World Prehistory. 1992. Vol. 6, no. 1. P. 116.

20 Березанская С.С. О так называемом общеевропейском горизонте культур шнуровой керамики Украины и Белоруссии // Советская археология. 1971. № 4. С. 48.

${ }^{21}$ Кривальцевич Н.Н. К проблеме распространения традиций культур шнуровой керамики в междуречье Припяти и Западной Двины. С. 214. 
ницей в их хронологии 22 . Следовательно, исключается необходимость обращения к явлению миграции как обязательному фактору в генезисе местных ответвлений «лесных» КШК. Интерпретация появления простых шнуровых узоров в качестве однозначного свидетельства присутствия носителей традиций КШК является необоснованной и должна быть подтверждена рядом других аргументов. По их мнению, в III - начале II тыс. до н. э. происходило поддержание постоянных, длительных во временном отношении межкультурных контактов ${ }^{23}$. Работы последних лет аргументированно опровергают теорию о наличии единого горизонта материалов ${ }^{24}$.

В последние годы набирает популярность метод исследования древней ДНК. Несколько групп ученых в Германии, Дании, Финляндии, Эстонии изучают древнюю ДНК в шнуровых культурах. Сейчас изучено более 70 образцов древней ДНК носителей КШК, и результат их анализа позволяет немного иначе посмотреть на распространение древнего населения в III тыс. до н.э. Со шнуровыми культурами связывается гаплогруппа Rla1, с ямными - R1b1. Полученные данные вновь ставят вопрос о происхождении культур шнуровой керамики из регионов ямной культурной области ${ }^{25}$. Но существует множество проблем в соотношении археологического материала и полученных данных по гаплогруппам. Так, результаты, полученные по образцам ямной культуры, происходящими из территории степной части России (Самарская область), имеют наиболее полное сходство с материалами Германии, в то время как более близкие им материалы ямной культуры Венгрии (которые должны бы демонстрировать тот же уровень сходства) указывают на различное развитие ${ }^{26}$.

Столь же большое внимание уделяется изотопным исследованиям, в том числе и КШК Германии. Наиболее интересным результатом, по мнению авторов работ, является корреляция между полом, мобильностью населения и диетой ${ }^{27}$. Она может быть интерпретирована как результат стабильной системы женской экзогамии, которая включала в себя различные группы ${ }^{28}$.

22 Чебрешук Я., Шмит М. К исследованию среднеевропейских факторов процесса культурных перемен в лесной зоне Восточной Европы в III тыс. до н.э. // Гістарычна-археалагічны зборниік. Вып. 18. Мінск, 2003. С. 48.

${ }^{23}$ Czebreczuk J., Szmyt M. Chronology of Central-European Influences within the Western Part of the Forest Zone during the 3-d Millenium BC // Проблемы хронологии и этнокультурных взаимодействий в неолите Евразии. СПб, 2004. С. 177.

${ }^{24}$ Furholt M. Upending a 'Totality': Re-evaluating Corded Ware Variability in Late Neolithic Europe // Proceedings of the Prehistoric Society, 80. P. 67-86.

${ }^{25}$ Haak W., et al. Massive migration from the steppe was a source for Indo-European languages in Europe. P. 207-211; Allentoft M. E. et al. Population genomics of Bronze Age Eurasia. P. 167-172.

${ }^{26}$ Клейн Л.С.: 1) Ямная, буджакская и ДНК // Внешние и внутренние связи степных (скотоводческих) культур Восточной Европы в энеолите и бронзовом веке (V-II тыс. до н.э.). СПб., 2016. С. 7; 2) Ямная, не ямная (обзор современных работ о курганных погребениях Подунавья) // Stratum Plus. 2017. № 2. C. 361-376.

27 Sjögren K.-G., Price T., Kristiansen K. Diet and Mobility in the Corded Ware of Central // PLoS ONE. 2016. Vol.1, no.5. URL: http://journals.plos.org/plosone/article?id=10.1371/journal.pone.0155083 (дата обращения: 22.12.2017).

${ }_{28}$ Meyer C., Brandt G., Haak W., Gansmeier R. A., Meller H., Alt K.W. The Eulau eulogy: Bioarchaeological interpretation of lethal violence in Corded Ware multiple burials from Saxony-Anhalt, Germany // Journal of Anthropological Archaeology. 2009. Vol. 28. P. 412-423. 
Наиболее близко к территории Северо-Запада России расположены две культуры КШК - фатьяновская и приморская (жуцевская). Представляет отдельный интерес проблема их возникновения.

Фатьяновская культура распространена на территории лесной и лесостепной зон России (занимает территорию Верхнего Поволжья и бассейны волжских притоков - p. Оки и низовий р. Камы). Появление данной культуры различными исследователями связывалось с прямыми миграциями с территории Центральной и/ или Южной Европы ${ }^{29}$. Фатьяновская культура датируется серединой III - первой половиной II тыс. до н. э.

Иной вариант генезиса демонстрирует приморская (жуцевская) культура, известная на территории Прибалтики. Здесь появление КШК связывается с процессом инфильтрации небольших групп в местную культуру. Эти небольшие группы не теряли свою идентичность и специфические особенности в течение нескольких поколений ${ }^{30}$. В процессе формирования приморской (жуцевской) культуры участвовала не только пришлая КШК, по предположению Р. Римантене, приморская культура «появилась в результате смешения нарвской, неманской культур, культур шаровидных амфор и КШК. Данные изменения произошли довольно быстро»³. Открытия последних лет подтверждают наличие материалов культур шаровидных амфор (далее - КША) в окрестности Вислинского залива ${ }^{32}$. Повторное изучение материалов с территории Литвы (поселения Швентойи, Нида) позволяет говорить о том, что приморская (жуцевская) культура образовалась под первоначальным влиянием КША на местную культуру, а затем - КШК. Хронологические рамки бытования культуры определяются от 3200 до 2400 лет до н. э. ${ }^{33}$

\section{КШК верховьев реки Западная Двина}

Для выявления элементов КШК в неолитических культурах верховьев Западной Двины были выделены диагностичные артефакты. Среди керамических сосудов это посуда с оттисками шнура в качестве орнаментации, посуда в форме кубков и амфор и характерные для А-горизонта широкогорлые горшки. Каменный инвентарь КШК характеризуется кремневыми треугольными наконечниками стрел с выемкой в основании или без нее, а также каменными топорами со сверлиной.

Ловатско-Двинское междуречье - регион, где до настоящего времени не выявлено комплексов КШК, которые можно было бы считать гомогенными. В то же время присутствие элементов КШК в материалах исследованных археологических памятников было замечено с начала их изучения ${ }^{34}$. Как неоднократно отмечалось,

29 Крайнов Д. А. Древнейшая культура Волго-Окского междуречья. М., 1972.

${ }^{30}$ Loze I. The Early Corded Ware culture in the territory of Latvia // Early Corded Ware Culture. The A-Horizont - fiction or fact? International Symposium in Jutland, 2-7 may 1994. Esbjerg, 1997. P. 143; Neustupný E. Prehistoric migrations by infiltration. P. 281.

31 Rimantiene R. The Neolithic of the Eastern Baltic. P. 127.

32 Зальиман Э. Б. К проблеме происхождения приморской культуры (по материалам раскопок поселений Прибрежное и Ушаково-3) // Вестник Балтийского федерального ун-та им. И.Канта. Сер.: Гуманитарные и общественные науки. 2016. № 1. С. 32.

${ }^{33}$ Heron C., Craig O., Luquin A., Steele V.J., Thompson A., Piličiauskas G. Cooking fish and drinking milk? Patterns in pottery use in the southeastern Baltic, 3300-2400 cal BC. P. 34.

${ }_{34}$ Микляев А. М. Памятники Усвятского микрорегиона. Псковская область // Археологический сборник. 1969. Вып. 11. С. 18-40. 
этот регион расположен в контактной зоне культурных миров Центральной, Северной и Восточной Европы, через него распространялись культурные влияния от носителей традиций культур воронковидных кубков и шаровидных амфор, а также от носителей традиций культур гребенчато-ямочной и ромбо-ямочной керамики.

В результате исследований Северо-Западной археологической экспедиции Государственного Эрмитажа под руководством А. М. Микляева в 1962-1992 гг. была выявлена серия культур от поздней поры верхнего палеолита до эпохи длинных курганов $^{35}$. А.М.Микляев и А.Н. Мазуркевич выделили в археологическом материале четыре так называемые фазы развития керамики, маркирующие «реально происшедшие изменения в технологии, формах и орнаментации глиняной посуды различных культур» ${ }^{36}$. Фазы j, k, l, т относятся к среднему, позднему неолиту и началу бронзового века. Фазу ј они соотносили с жижицкой археологической культурой, а фазы k, l, m - с северо-белорусской культурой. А. М. Микляев отмечал, что керамические сосуды с оттисками шнура встречаются среди материалов усвятской культуры среднего неолита. Она датируется IV-III тыс. до н. э. (3488-3096 лет до н. э. - для первого и 3078-2208 лет до н. э. - для второго этапов соответственно) ${ }^{37}$.

Жижицкая культура была выделена на основании археологического материала, обнаруженного в «переходном» горизонте поселения Наумово в Псковской области. Обоснованность выделения данной культуры позднее была подтверждена обнаружением схожих «переходных» горизонтов на других свайных памятниках Подвинья. По образцам древесины из данного слоя были получены следующие даты: 2476-2142 лет до н. э. (ТА-469), 2470-2064 лет до н.э. (ТА-462), 2471-2026 лет до н.э. $\left(\right.$ ТА-467) ${ }^{38}$.

Выше слоев, содержащих культурные остатки, относящиеся к жижицкой культуре, залегают слои северо-белорусской культуры. Они обнаружены в слоях А на большинстве свайных поселений Псковской и Смоленской областей и имеют даты 2291-1901 лет до н. э. (ТА-816), 2279-1916 лет до н. э. (ЛЕ-1004) (кв. Ф-VII), 21981772 лет до н.э. (ТА-756) . $^{39}$

Северо-белорусскую культуру А. М. Микляев относил к кругу шнуровых культур, связывая ее возникновение с влиянием КШК Прибалтики ${ }^{40}$. Данный вывод основывался на присутствии схожих орнаментальных и морфологических признаков у керамических сосудов памятников двух территорий: Ловатско-Двинского междуречья и Верхнего Подвинья.

${ }_{35}$ Микляев А. М., Короткевич Б. С., Мазуркевич А. Н. Древности каменного - железного веков в Двинско-Ловатском междуречье (опыт археолого-палеогеографической периодизации) // Археологические культуры Евразии и проблемы их интеграции. СПб., 1991. С. 5-8.

${ }^{36}$ Микляев А.М. Каменный - железный века в междуречье Западной Двины и Ловати // Петербургский археологический вестник. СПб., 1994. Вып. 9. С.7-10.

${ }_{37}$ Мазуркевич А.Н., Зайцева Г.И., Кулькова М.А., Долбунова Е. В., Семениов А.А., Ришко С.А. Абсолютная хронология неолитических древностей Днепро-Двинского междуречья VII-III тыс. до н.э. С. 321.

38 Зайцева Г. И., Васильев С. С., Дергачев В.А., Мазуркевич А.Н., Семенов А. А. Новые исследования памятников бассейна Западной Двины и Ловати: распределение радиоуглеродных дат, корреляция с изменением природных процессов, применение математической статистики // Древности Подвинья: исторический аспект. СПб., 2003. С. 140-154.

39 Мазуркевич А.Н., Зайцева Г.И., Кулькова М.А., Долбунова Е. В., Семенцов А.А., Ришко С.А. Абсолютная хронология неолитических древностей Днепро-Двинского междуречья VII-III тыс. до н.э. С. 337.

40 Микляев А. М. Каменный - железный век в междуречье Западной Двины и Ловати. С. 26. 


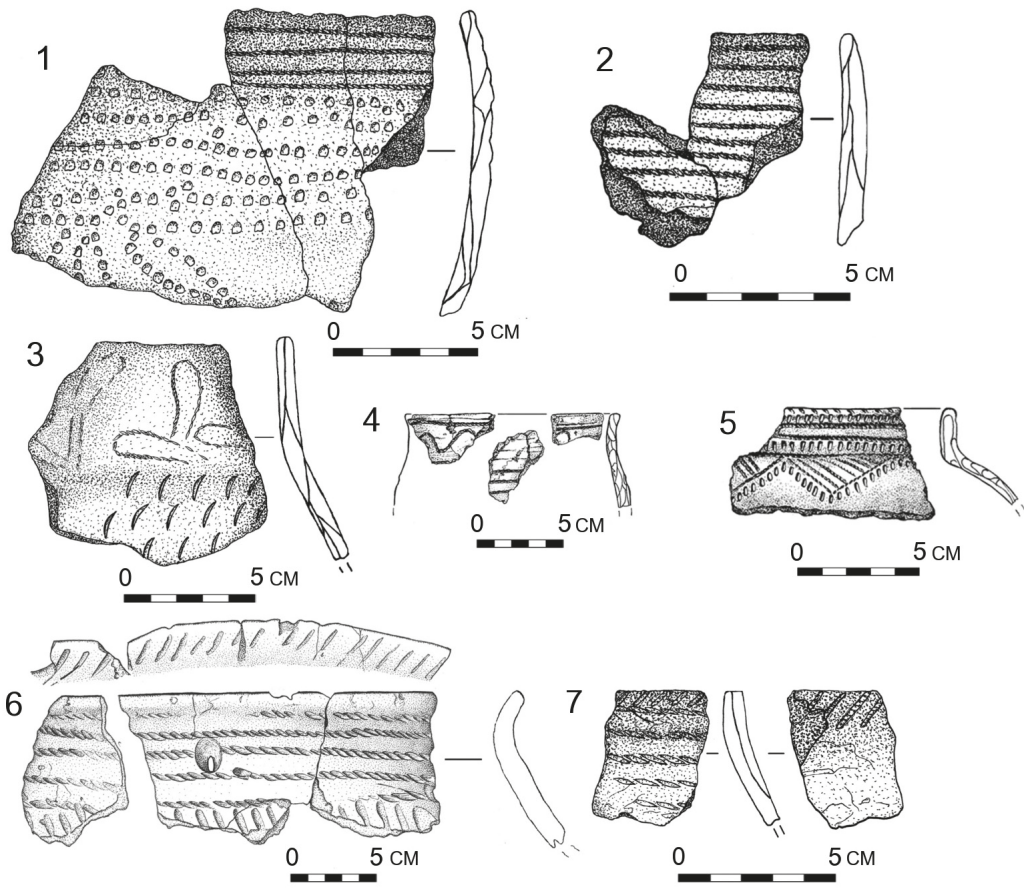

8
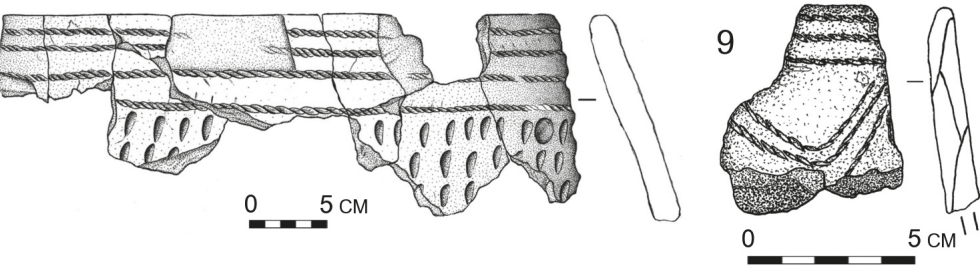

Puc. 1. Фрагменты керамических сосудов со шнуровой орнаментацией из памятников Ловатско-Двинского междуречья:

1, 2, 6-9 - поселение Наумово; 3 - поселение Усвяты IV; 4, 5 - поселение Сертея II (4, 5, 8 - рис. К. В.Дубровиной; 1, 2, 3, 6, 7, 9 - рис. Е. С. Ткач)

При изучении материалов из поселений Ловатско-Двинского междуречья было установлено, что влияние КШК в Ловатско-Двинском междуречье прослеживается как в керамическом (рис. 1), так и в каменном инвентаре.

Среди керамического материала были выделены фрагменты серии сосудов «гибридного» типа ${ }^{41}$. Они отличаются сочетанием в одном сосуде (фрагменте) признаков двух основных керамических традиций - местной и пришлой шнуровой. Это сочетание присутствует на посуде всех изученных памятников. Данные сосуды зачастую изготовлены в ленточно-лоскутной технике с примесью дресвы и, реже, ракушки в формовочном тесте. Примесь ракушки является характерной для мест-

41 Ткач E.C. Керамические сосуды со шнуровой орнаментацией: типология, проблемы хронологии // Археология озерных поселений IV-II тыс. до н. э.: хронология культур и природноклиматические ритмы. СПб., 2014. С.281-286. 
ной усвятской культуры, в то время как примесь дресвы и песка - для культур шнуровой керамики. В большинстве случаев на внутренних стенках сосудов присутствуют «расчесы», хотя для культуры среднего неолита характерным является лощение. В «гибридной» группе встречается посуда в виде кубков и амфор, характерных для КШК. В то же время продолжают обнаруживаться и широкогорлые сосуды с округлым дном. Одним из главных показателей влияния КШК является присутствие шнуровой орнаментации, она разнообразна - встречаются как простые, так и сложные мотивы. К числу последних можно отнести волны, петли, ромбы, висящие треугольники и пр.

Вторая группа керамики представлена сосудами, которые заметно отличаются от таковых в культурах среднего и позднего неолита Ловатско-Двинского междуречья. Отличия прослеживаются в технологии изготовления, морфологии сосудов, а также в их орнаментации. Они изготовлены в лоскутной технике, в составе формовочного теста присутствует примесь дресвы и/или шамота, сами сосуды имеют формы кубков и амфор. Орнаментация представлена шнуровыми оттисками, расположенными горизонтально по отношению к тулову сосуда под венчиком или в виде висящих треугольников и волн. Таким образом, эти сосуды обладают достаточно полным набором признаков керамики КШК и лишены набора признаков, характерных для местной керамики. Очевидно, что такие сосуды в археологическом смысле являются «импортом»: они либо поступили с территорий других культур, либо сделаны на месте в соответствии с нормами другой культуры.

Влияние КШК на материальную культуру Ловатско-Двинского междуречья также проявляется в каменном инвентаре, прежде всего в оформлении наконечников стрел. Они имеют треугольные очертания. Аналогии им прослеживаются среди наконечников стрел ряда шнуровых культур: среднеднепровской, приморской (жуцевской), КШК Понеманья и Эстонии. Кроме того, на поселении Сертея II был обнаружен каменный сверленый топор, а на поселении Наумово - обломок топора. Таким образом, распространение элементов КШК на рассматриваемой нами территории фиксируется на протяжении середины и второй половины III тыс. до н.э.

Местонахождения по берегам озер Белая Струга и Щадрицкое были обнаружены в ходе археологических разведок в 1957 г. А.Н. Щегловым ${ }^{42}$. Озеро Белая Струга и примыкающие к нему с запада озеро Черное и с востока озеро Щадрицкое расположены в слабохолмистой моренной местности. Сами озера ледникового происхождения и имеют пологие берега с песчаными дюнами.

Исследователем были выявлены три местонахождения. Первое расположено на большой дюне северного берега оз. Щадрицкое. Среди обнаруженного материала - кремневые сколы и керамические сосуды. Три их них могут быть сопоставлены с КШК. Они представлены лишь верхними частями (венчиками). Один сосуд орнамента не имеет, на двух других имеются оттиски полого штампа. Сосуды изготовлены в ленточной технике с примесью мелкотолченой (1-3 мм) дресвы. Внутренняя поверхность сосудов заглажена.

Второе местонахождение расположено в устье озера Белая Струга (на южном мысу восточного берега). А.Н.Щеглов полагал, что, возможно, «стоянка первона-

42 Щеглов А.Н. Стоянки озера Белая Струга // Архив Псковского государственного музеязаповедника. Оп. 2. 1959 г. О/ф 34485/2. Л. 1-6. 
1

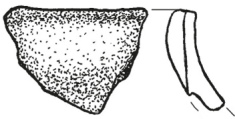

2
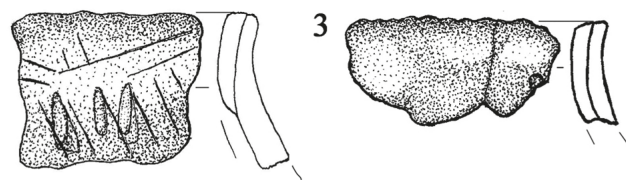

4

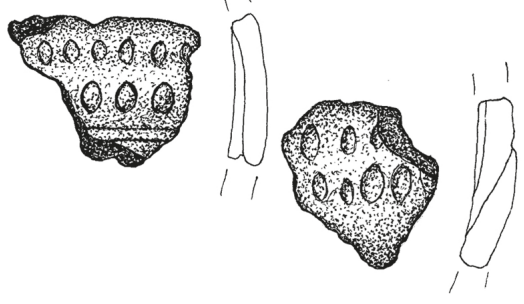

6
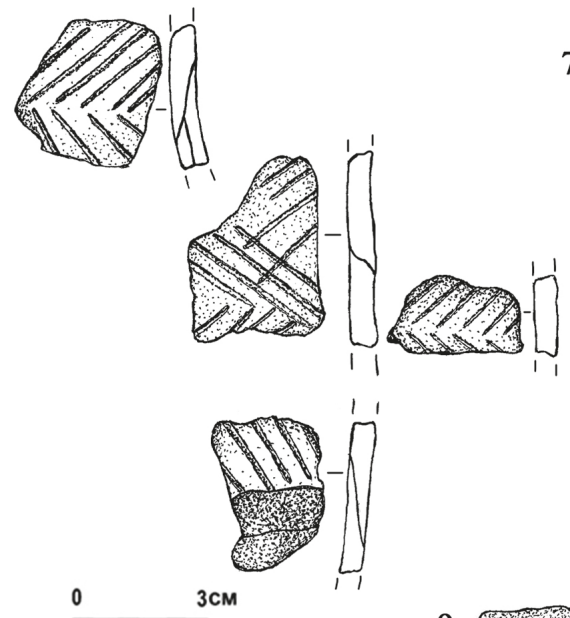

0

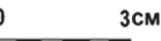

9

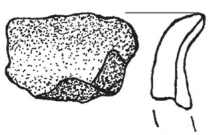

7

5
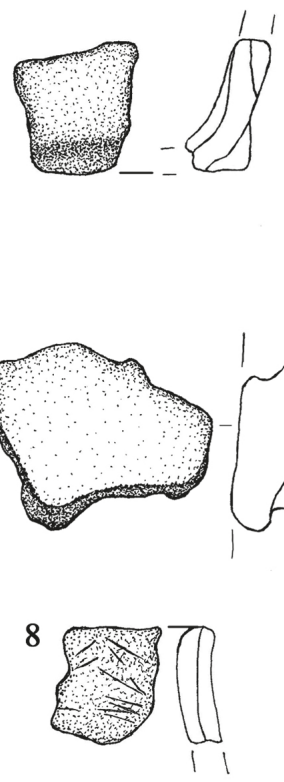

11
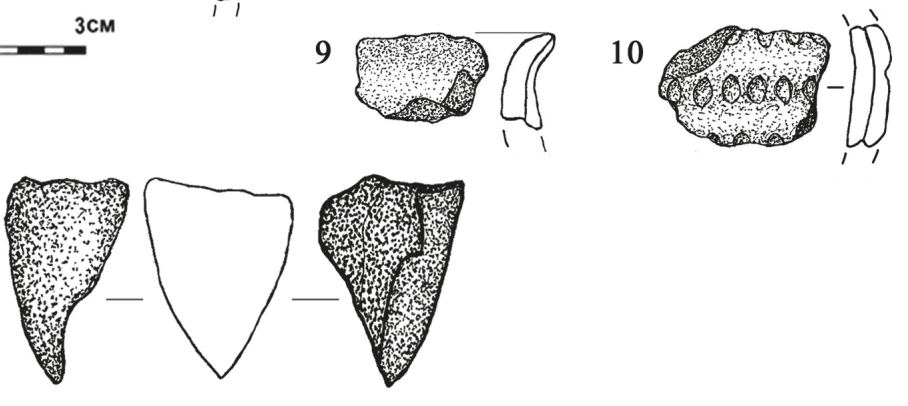

Puc. 2. Материалы местонахождения № 2, оз. Белая Струга, Палкинский р-н Псковской обл.:

1-10 - фрагменты керамических сосудов; 11 - фрагмент каменного сверленого топора (рис. Е. С. Ткач)

чально располагалась на небольшом островке» ${ }^{43}$. Здесь сосредоточено наибольшее количество материалов, которые относятся с КШК.

43 Щеглов А.Н. Стоянки озера Белая Струга // Архив Псковского государственного музеязаповедника. Л.3. 
Выделенные керамические материалы представлены девятью сосудами, которые могут быть разделены на две группы (рис.2). Первая включает в себя тонкостенные сосуды (4-5 мм) с примесью мелко- (1 мм) и крупнотолченой дресвы (3 мм) (см. рис. 2: 1-6, 8-10). Поверхность данных сосудов заглажена с внутренней и внешней сторон. С внешней стороны также прослеживаются следы штриховки, которая могла выступать, в том числе, в качестве орнаментации. Керамика изготовлена в ленточной технике. Все сосуды профилированы. Невозможно восстановить целые формы, однако можно предположить наличие двух форм - амфор и кубков. Также к данной группе относится фрагмент плоского донца, который изготовлен в лоскутной технике (см. рис. 2: 5). Часть сосудов этой группы не имеет орнамента. На четырех сосудах присутствует орнаментация ямочными вдавлениями, гребенчатым или полым штампами.

Вторая группа сосудов включает в себя фрагмент толстостенного (19 мм) сосуда (см. рис. 2: 7), который изготовлен в лоскутной технике. В качестве примеси в формовочное тесто этого сосуда использовалась мелкая дресва (2-3 мм).

Отдельный интерес представляют обнаруженные здесь изделия из камня и металла. Это обломок каменного топора, изготовленного из диорита (см. рис. 2: 11), и фрагмент бронзового четырехгранного шила ${ }^{44}$.

Третий пункт расположен напротив местонахождения 2, т. е. на северном мысу восточного залива озера Белая Струга. А. Н. Щеглов на основе концентрации материалов разделил стоянку на три участка. Материалы КШК обнаружены в средней и восточной частях местонахождения. Здесь керамические сосуды представлены в первую очередь сосудом в виде кубка, который характерен для КШК Центральной Европы. Он изготовлен в лоскутной технике, в формовочном тесте присутствует примеси песка и органики. Толщина стенок составляет 4 мм. Поверхность сосуда была тщательно заглажена с внутренней и внешней сторон. Орнаментация представлена нарезками, расположенными мотивом «елочки».

Кроме того, были выделены сосуды, схожие с посудой, обнаруженной на местонахождении 2. Среди них следует указать: 1) профилированные тонкостенные сосуды с примесью дресвы в формовочном тесте, изготовленные в лоскутной технике (один из этих сосудов орнаментирован ямочными вдавлениями, остальные - без орнамента, однако на их внешних поверхностях присутствуют следы штриховки); 2) фрагмент толстостенного сосуда (16 мм) без орнамента, изготовленный в ленточной технике; в качестве примеси в его тесте использовалась крупная (4-5 мм) дресва.

На данный момент отсутствуют абсолютные даты по упомянутым стоянкам. Ближайшим памятником со схожими материалами является поселение Россонь $9^{45}$ на территории Ленинградской области (Нарвско-Лужское междуречье), которое датировано первой половиной III тыс. до н. э. На территории Карельского перешейка и в Эстонии обнаружены поселения КШК, керамические сосуды из которых также схожи с посудой, обнаруженной на местонахождениях по берегам озера Белая Струга ${ }^{46}$.

44 Мазуркевич А.Н. Находки каменного века с северных территорий Псковской области // Археология и история Пскова и Псковской земли. Псков, 2008. С. 186-194.

45 Kholkina M. A. Some aspects of Corded ware on Rosson river (Narva-Luga klint bay). P. 153.

${ }^{46}$ Крийска А., Нордквист К., Герамисов Д.В., Санделл С. Новые исследования памятников со шнуровой керамикой в Нарвско-Лужском междуречье, в пограничье России и Эстонии // Тверской археологический сборник. 2015. Вып. 10. С. 195-203. 


\section{Каменные боевые топоры Верхнего Подвинья}

Для оценки связей местных неолитических культур с кругом КШК особое значение имеют каменные топоры со сверлиной. Они являются одним из самых ярких атрибутов КШК. Ранее многие исследователи (Г. Коссинна, М. Гимбутас и др.) относили их к числу боевого оружия. Всего изучено 68 целых топоров и 14 фрагментов. Материал хранится в фондах краеведческих музеев Псковской области, часть находится в Государственном Эрмитаже.

Каменные топоры изучаемой совокупности были разделены на 9 типов, которые соотносятся с типами Я. Махника ${ }^{47}$. Его типология является наиболее разработанной для каменных сверленых топоров КШК. Так, тип 1 классификации топоров из территории Верхнего Подвинья идентичен типу 1 в типологии Я. Махника.

Всего для территории Верхнего Подвинья были выделены следующие типы ${ }^{48}$ :

1) топоры ромбической формы, четырехугольные в сечении, часто с прямым обухом;

2) широкие топоры с размытыми ромбическими контурами;

3) топоры, напоминающие в профиль ладьевидные с овальным, реже прямым поперечным сечением и обухом в виде цилиндра;

4) топоры, лезвие которых слегка асимметрично, с несколько вытянутой спинкой и прямоугольным поперечным сечением;

5) топоры с клиновидным профилем;

6) топоры, лезвие которых слегка асимметрично, а поперечное сечение прямоугольное и подквадратное;

7) топор, в профиль ладьевидный, но с зауженным обухом и резко сужающимися к лезвию краями;

8) обушковые топоры;

9) ладьевидные топоры типа А.

Аналогии выделенным типам прослеживаются среди материалов Малой Польши $^{49}$, Понеманья ${ }^{50}$, Прибалтики ${ }^{51}$, а также среди материалов среднеднепровской ${ }^{52}$ и фатьяновской ${ }^{53}$ культур.

\section{Характер появления носителей традиций КШК на территории Северо-Запада России}

В Ловатско-Двинском междуречье в течение III тыс. до н. э. было выделено три этапа распространения элементов КШК (рис. 3$)^{54}$. Степень их проявления посте-

${ }^{47}$ Machnik J. Studia nad kulturą ceramiki sznurowej w Małopolsce. Wrocław-Warszawa-Kraków, 1966.

48 Ткач E.C. О подходах и возможностях исследования каменных боевых топоров эпохи неолита - бронзы // Археологические вести. 2015. Вып. 21. С. 52-64.

49 Włodarczak P. Kultura ceramiki sznurowej na Wyżynie Małopolskiej. Kraków, 2006.

50 Лакіза В. Л. Старажитнасці позняга неаліту і ранняга перыяду бронзавага веку Беларускага Панямонн. Мінск, 2008.

51 Rimantiene R. Lietuvos TSR Archeologijos Atlasas. Vilnius, 1974. T. 1.

52 Крывальиэвіч М. М. Могільнік сярэдзіны III - пачатку II тыс. до н. э. на Верхнім Дняпры Прорва 1. Мінск, 2006.

${ }^{53}$ Крайнов Д. А. Древнейшая культура Волго-Окского междуречья. М., 1972.

54 Ткач E.C. Распространение традиций культур шнуровой керамики в верховьях Западной Двины в III тыс. до н. э. // Самарский научный вестник. 2017. № 3 (20). С. 163-171. 


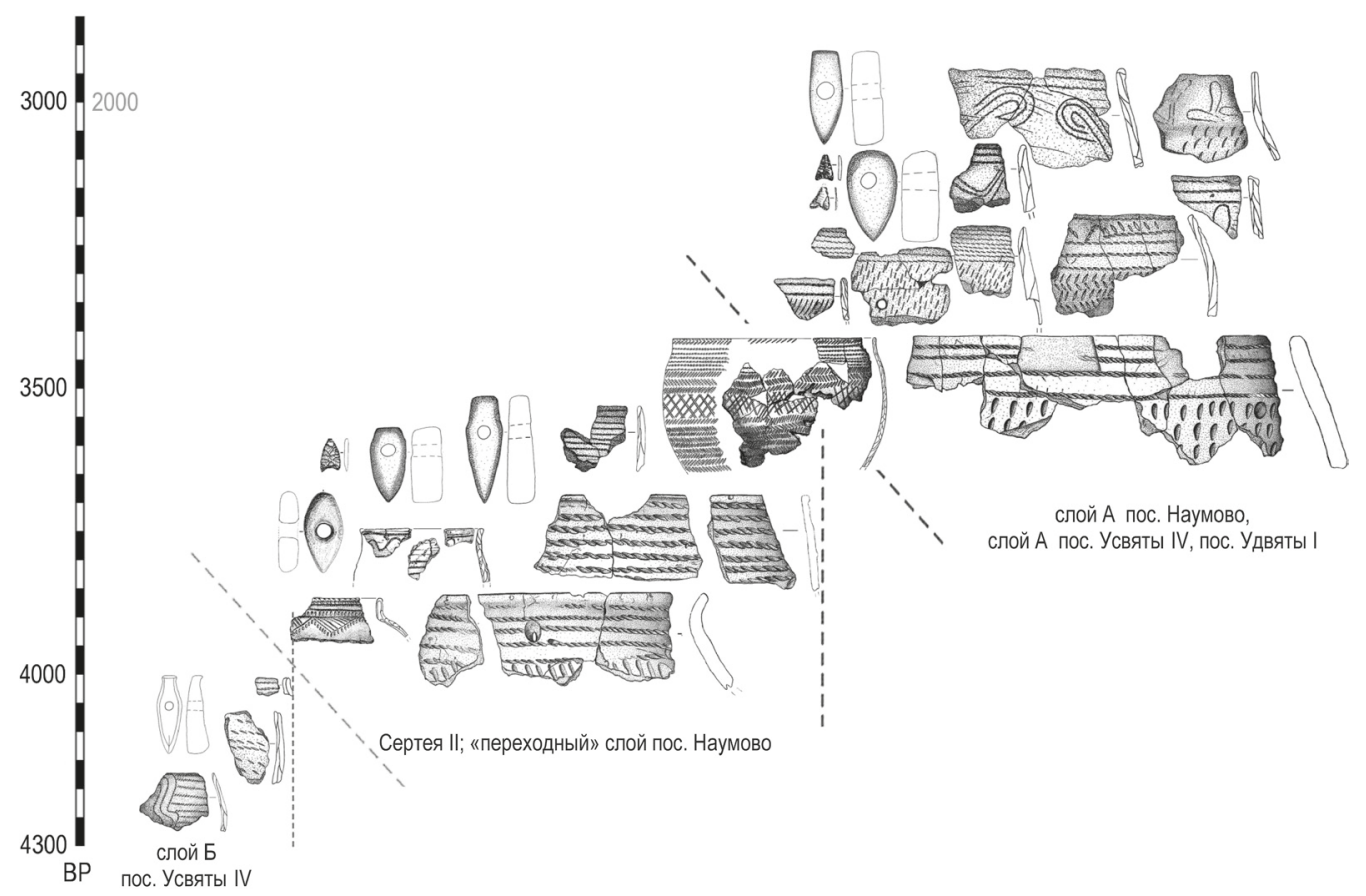

Puc. 3. Этапы появления и развития элементов культур шнуровой керамики на территории Ловатско-Двинского междуречья (рис. Е. С. Ткач)

пенно нарастает от первой половины III тыс. до н.э. к концу III тыс. до н. э., когда фиксируется смешение нескольких культурный традиций.

Первый этап выделен на основании редких находок фрагментов сосудов с оттисками шнура в слое Б поселения Усвяты IV и единичными находками топоров со сверлиной А-типа. Данный этап относится ко времени развития так называемого А-горизонта КШК, который приходится на первую половину III тыс. до н.э. Появление элементов КШК в течение второй четверти III тыс. до н. э. на территории Верхнего Подвинья может быть связано с территорией Центральной Европы.

Второй этап представлен материалами, найденными в «переходном» слое поселения Наумово и материалами поселения Сертея II. Данный этап характеризуется смешением двух культурных традиций - местной и пришлой. Он датируется серединой III тыс. до н. э. Аналогии материалам этого этапа находятся среди инвентаря приморской (жуцевской $)^{55}$, среднеднепровской ${ }^{56}$ культур и культур шнуровой керамики Польши ${ }^{57}$. Для данного этапа можно говорить о развитии обменных отношений (появление «импортов» и янтарных изделий). В это же время влияние КШК на материальную культуру населения Ловатско-Двинского междуречья становится заметным, что находит отражение в распространении «гибридных» сосудов.

55 Тимофеев В. И. Памятники культуры шнуровой керамики восточной части Калининградской области (по материалам исследований 1970-1980-х гг.) // Древности Подвинья: исторический аспект. СПб., 2003. С. 119-134.

56 Крьвальиэвіч М. М. Курган сярэднедняпроўскай культуры на возеры Камарын каля Рагачова // Гістарычна-археалагічны зборнік. Вып. 19. 2004. С. 34-57.

57 Kempisty A., Włodarczak P. Cemetery of Corded Ware culture in Żerniki Górne. Warszaw, 2000. 
Третий этап распространения КШК в Ловатско-Двинском междуречье выявляется по материалам слоя А поселения Наумово, слоя А поселения Усвяты IV, поселения Удвяты I. Он датируется второй половиной III тыс. до н. э. В это время в регионе фиксируется сильное влияние со стороны приморской (жуцевской) культуры ${ }^{58}$. Сходство по орнаментальным мотивам также прослеживается с керамическими сосудами среднеднепровской ${ }^{59}$ и катакомбной ${ }^{60}$ культур. Данная волна распространения элементов КШК может быть связана с обменными взаимоотношениями. Это подтверждается увеличением числа янтарных изделий и дальнейшими изменениями в керамическом материале.

Появление материалов А-горизонта КШК в Палкинском районе Псковской области можно интерпретировать только в соответствии с прямой миграцией носителей традиций КШК. Аналогии выделенному комплексу присутствуют среди материалов А-горизонта КШК Центральной Европы и Прибалтики, это в первую очередь поселение Россонь $9^{61}$. Аналогичные материалы обнаружены на территории Прибалтики ${ }^{62}$ и Эстонии ${ }^{63}$. Везде на указанных территориях материал А-горизонта связывается с миграцией.

Каменные сверленые топоры найдены в большом количестве, что может свидетельствовать о физическом присутствии носителей традиций КШК в указанном регионе. Среди проанализированных каменных сверленых топоров также были обнаружены топоры А-типа.

\section{Выводы}

Таким образом, можно выделить две модели распространения КШК на территории верховьев Западной Двины. Первая представляет собой прямую миграцию носителей традиций КШК. Она подтверждается обнаружением материалов А-горизонта КШК (сверленые топоры, кубки, амфоры). О прямой миграции также свидетельствует обнаружение большого количества иных типов сверленых топоров, которые имеют прямые аналогии среди топоров КШК Малой Польши. Появление носителей традиций КШК приходится на первую половину III тыс. до н. э.

Согласно второй модели, появление элементов КШК на изучаемой территории связано с обменными отношениями и культурным влиянием. Появление «импортных» изделий свидетельствует о наличии обмена между населением Ловатско-Двинского междуречья и среднеднепровской культуры. Обмен с территорией Прибалтики подтверждается наличием изделий из балтийского янтаря ${ }^{64}$. Распро-

58 Butrimas A. Akmens amžius Zemaiču aukštumoje. Daktariskès neolito gyvenviete. Katalogas. Vilnius: LTSR Istorijos ir etnografijos muziejus, 1982.

59 Чарняўскі Макс. М. Керамічны комплекс стаянкі Асавец 7 // Гістарычна-археалагічны зборниік. 2006. Вып. 21. С. 37-46.

60 Ивашов М. В. Памятники катакомбного времени на Верхнем Дону: дисс. ... канд. ист. наук. Воронеж, 2015.

${ }^{61}$ Kholkina M. A. Some aspects of Corded ware on Rosson river (Narva-Luga klint bay). P. 148-160.

${ }^{62}$ Loze I. The Early Corded Ware culture in the territory of Latvia. P. 142.

${ }^{63}$ Kriiska A. Corded Ware Culture sites in North-Eastern Estonia // De temporibus antiquissimis ad honorem Lembit Jaanits (Muinasaja teadus, 8). Tallinn, 2000. P. 59-79.

64 Щедринский А.М., Вамплер Т.П., Мазуркевич А.Н. Янтарь и янтареподобные смолы в культуре строителей свайных поселений Верхнего Подвинья // Сообщения Государственного Эрмитажа. 2004. Вып. LXII. C. 74-80. 
странение лоскутной техники изготовления посуды и орнаментация с помощью оттисков шнура свидетельствуют о сильном влиянии КШК на материальную культуру населения Ловатско-Двинского междуречья. Однако в регионе не прослеживается резкой смены населения, здесь отсутствуют памятники с только шнуровыми материалами. Таким образом, появление и распространение КШК в указанном регионе в середине III тыс. до н. э. можно связывать с диффузионистской моделью.

\section{References}

Allentoft M.E. et al. Population genomics of Bronze Age Eurasia. Nature, 2015, no. 522, pp. 167-172.

Berezanskaya S. S. O tak nazuvaemom obshcheevropeuskom gorizonte kul'tur shnurovoi keramiki Ukrainu i Belorussii. Sovetskaia archeologia, 1971, no.4, pp.36-47. (In Russian)

Bondar N. N. Ku'lturu shnorovoi kemamiki i ikh rol'v drevnei istorii Evropu. Avtoref. ... doctora ist. nauk. Kiev, 1981, 53 p. (In Russian)

Brusov A. Ya. Ob ekspansii "kul'tur s boevumi toporami» v kontse III tys. do n.e. Sovetskaia archeologia, 1961, no. 3, pp. 13-33. (In Russian)

Butrimas A. Akmens amzĭus Zémaiciù aukstumoje. Daktariskés neolito gyvenviete: Katalogas. Vilnius, LTSR Istorijos ir etnografijos muziejus, 1982, $79 \mathrm{p}$.

Chaild G. U istokov evropeiskoi tsivilizatsii. Moscow, Print inostr. literatury, 1952, 468 p. (In Russian)

Charnjay̆ski Maks. M. Keramichny kompleks stajanki Asavec 7. Gistarychna-arhealagichny zborniik, 2006, vol.21, pp. 37-46. (In Belorussian)

Chebreshuk Ya., Shmit M. K issledovaniiu sredneevropeiskikh faktorov protsessa kul'turnykh peremen v lesnoi zone Vostochnoi Evropy v III tys. do n.e. Gistarychna-arhealagichny zborniik, 2003, vol.18, pp. 34-51. (In Belorussian)

Czebreczuk J., Szmyt M. Chronology of Central-European Influences within the Western Part of the Forest Zone during the 3-d Millenium BC. Problemy khronologii i etnokul'turnukh vzaimodeistvii v neolite Evrazii. St. Petersburg, IIMK RAN, 2004, pp. 168-181. (In Russian)

Doluchanov P. M. Istoki migratsii (modelirovanie demograficheskikh protsessov po arkheologicheskim i ekologicheskim dannym). Problemy archeologii, 1978, vol.2, pp. 38-43. (In Russian)

Fogt E. Die Herkunft der Michelsberger Kultur. Acta Archaeologica, 1953, vol. XXIV, pp. 147-164.

Furholt M. Upending a "Totality": Re-evaluating Corded Ware Variability in Late Neolithic Europe. Proceedings of the Prehistoric Society, 2014, vol. 80, pp.67-86.

Gimbutas M. The Prehistory of Eastern Europe. Mesolithic, Neolithic and Copper Age cultures in Russia and the Baltic area. Part 1. Cambridge, published by the Peabody museum, 1956, $241 \mathrm{p}$.

Girininkas A. Migraciniai procesai Rytu Pabaltijyje velyvajame neolite. Virvelinés keramikos kultūra. Lietuvos archeologija. Vilnius, Lietuvos TSR Mokslų akademijos istorijos institutas, 2002, vol.22, pp. 73-92.

Glob P. V. Stugier over den Juske Enkeltgravskultur. København, Gyldendal, 1945, 283 s.

Haak W. et al. Massive migration from the steppe was a source for Indo-European languages in Europe. Nature, 2015, no. 522, pp. 207-211.

Heron C., Craig O., Luquin A., Steele V.J., Thompson A., Piličiauskas G. Cooking fish and drinking milk? Patterns in pottery use in the southeastern Baltic, 3300-2400 cal BC. Journal of Archaeological Science, 2015, no. 63, pp. 33-43.

Ivashov M. V. Pamiatniki katakombnogo vremeni na Verchnem Donu. Diss. ... kand. ist. nauk. Voronezh, 2017, 312 p. (In Russian)

Kempisty A., Włodarczak P. Cemetery of Corded Ware culture in Żerniki Górne. Warszaw, Institute of Archaeology Warsaw University, 2000, 180 s.

Kholkina M. A. Some aspects of Corded ware on Rosson river (Narva-Luga klint bay). Estonian Journal of Archaeology, 2017, no. 21 (2), pp. 148-160.

Kleyn L.S. Iamnaia, budzhakskaia i DNK. Vneshnie i vnutrennie sviazi stepnykh (skotovodcheskikh) kul'tur Vostochnoi Evropy v neolite i bronzovom veke (V-II tys. do n.e.). Ed. by V. A. Alekshin. St. Petersburg, Gosudarstvennyi Hermitazh, 2016, pp. 6-13. (In Russian)

Kleyn L.S. Iamnaia, ne iamnaia (obzor sovremennych rabot o kurgannykh porgebeniakh Podunav'ia). Stratum Plus, 2017, no. 2, pp.361-376. (In Russian)

Kleyn L. S. Teoteticheskii slovar' archeologii. Donetsk, Donetsk university Press, 2014, 279 p. (In Russian) 
Kossina G. Ursprung und Verbreitung der Germanen in vor- und frühgeschichtlicher Zeit. Leipzig, Verlag von Curt Kabitzsch, 1928, 320 s.

Kraynov D. A. Drevneishaia kul'tura Volgo-Okskogo mezhdurech'ia. Moscow, Nauka, 1972, 274 p. (In Russian) Kriiska A. Corded Ware Culture sites in North-Eastern Estonia. De temporibus antiquissimis ad honorem Lembit Jaanits (Muinasaja teadus, 8). Tallinn, Ajaloo Instituudi valjaanne, 2000, pp. 59-79.

Kriiska A., Nordkvist K., Gerasimov D. V., Sandell S. Novye issledovaniia pamiatnikov so shnurovoi keramikoi v Narvsko-Luzhskom mezhdurech'e, v pogranich'e Rossii i Estonii. Tverskoi arheologicheskii sbornik, 2015, vol.10, pp. 195-203. (In Russian)

Krijska A., Nordkvist K., Gerasimov D. V. Estonskii variant shnurovoi keramiki. V (XXI) Vserossiiskii arkheologicheskii s"ezd. Sbornik nauchnykh trudov. Barnaul, Altai State University Press, 2017, pp.557558. (In Russian)

Kristiansen K. Prehistoric Migrations - the Case of the Single Grave and Corded Ware Cultures. Journal of Danish Archaeology, 1989, vol. 8, pp.211-225.

Kryvaltsevich M.M. Kurgan sjarjednednjaproy̆skaj kul'tury na vozery Kamaryn kalja Ragachova. Gistarychna-arhealagichny zbornik, 2004, vol. 19, pp. 34-57. (In Belorussian)

Kryvaltchevich M. M. Mogil'nik sjarjedziny III - pachatku II tys. do n.e. na Verhnem Dnepre - Prorva 1. Minsk, Instytut gistoryi NAN Belarusi, 2006, 202 p. (In Belorussian)

Kryvaltsevich N.N. K probleme rasprostraneniia traditsii kul'tur shnurovoi keramiki v mezhdurech'e Pripiati i Zapadnoi Dviny. Kul'turnye protsessy v cirkumbaltiiskom prostranstve $v$ rannem $i$ srednem golotsene. Ed. by D. V. Gerasimov. St. Petersburg, MAE RAN, 2017, p. 214. (In Russian)

Kurzawa J. Zagadnienie najwcześniejszych faz kultury ceramiki sznurowej na nizinie WielkokopolskoKujawskiej. Problem tła genetycznego społeczności kultury pucharów lejkowatych. Poznań, Uniwersytet im. A. Mickiewicza, 2001, $382 \mathrm{s.}$

Lakiza V. L. Starazhitnasci poznjaga nealitu i rannjaga peryjadu bronzavaga veku Belaruskaga Panjamonnja. Minsk, Belaruskaja navuka, 2008, 343 p. (In Belorussian)

Loze I. The Early Corded Ware culture in the territory of Latvia. Early Corded Ware Culture. The A-Horizont - fiction or fact? International Symposium in Jutland, 2nd-7th may 1994. Esbjerg, Esbjerg museum, 1997, pp.135-145.

Machnik J. Studia nad kultura ceramiki sznurowej w Małopolsce. Wrocław; Warszawa; Kraków, Inst. Historii kultury materialnej Polskiej akad. nauk, 1966, 266 s.

Mazurkevich A. N. Nakhodki kamennogo veka s severnykh territorii Pskovskoi oblasti. Arheologiia i istoriia Pskova i Pskovskoi zemli. Ed. by I. K. Labutina. Pskov, IA RAN, 2008, pp. 186-194. (In Russian)

Mazurkevich A. N., Zajceva G.I., Kul'kova M.A., Dolbunova E. V., Semencov A. A., Rishko S. A. Absoliutnaia khronologiia neoliticheskikh drevnostei Dnepro-Dvinskogo mezhdurech'ia VII-III tys. do n.e. Radiouglerodnaia khronologiia epokhi neolita Vostochnoi Evropy VII-III tys. do n. e. Ed. by A. N. Mazurkevich. Smolensk, Svitok, 2016, pp. 317-355. (In Russian)

Merpert N. Ja. Drevneiamnaia kul'turno-istoricheskaia oblast' i voprosy formirovaniia kul'tur shnurovoi keramiki. Vostochnaia Evropa v epokhu kamnia i bronzy. Moscow, Nauka, 1976, pp. 103-127. (In Russian)

Meyer C., Brandt G., Haak W., Gansmeier R. A., Meller H., Alt K. W. The Eulau eulogy: Bioarchaeological interpretation of lethal violence in Corded Ware multiple burials from Saxony-Anhalt, Germany. Journal of Anthropological Archaeology, 2009, vol.28, pp. 412-423.

Mikliaev A.M. Kamennyi - zheleznyi vek v mezhdureche Zapadnoi Dviny i Lovati. Peterburgskii arheologicheskii vestnik. St. Petersburg, Gosudarstvenniy Hermitazh, 1994, vol. 9, pp. 7-39. (In Russian)

Mikliaev A. M. Pamiatniki Usviatskogo mikroregiona. Pskovskaia oblast'. Arheologicheskii sbornik, 1969, vol. 11, pp. 18-40. (In Russian)

Mikliaev A. M., Korotkevich B.S., Mazurkevich A. N. Drevnosti kamennogo-zheleznogo vekov v DvinskoLovatskom mezhdurech'e (opyt arheologo-paleogeograficheskoi periodizatsii). Arheologicheskie kultury Evrazii i problemy ikh integratsii, 1991, pp. 5-8. (In Russian)

Moora H. A. O drevnei territorii rasseleniia baltiiskikh plemen. Sovetskaia arheologiia, 1958, no. 2, pp.9-33. (In Russian)

Neustupný E. Prehistoric migrations by infiltration. Archeologické rozhledy, 1982, vol.XXXIV, pp. 278-293. Rimantienè R. Lietuvos TSR Archeologijos Atlasas. T. I. Vilnius, Mintis, 1974, 240 s.

Rimantiene R. The Neolithic of the Eastern Baltic. Journal of World Prehistory, 1992, vol. 6, no. 1, pp. 97-143.

Shhedrinskii A.M., Vampler T.P., Mazurkevich A.N. Iantar' i iantarepodobnye smoly v kul'ture stroitelei svainykh poselenii Verhnego Podvin'ia. Soobshcheniia Gosudarstvennogo Ermitazha, 2004, vol. LXII, pp. 74-80. (In Russian) 
Strahm Chr. Die Dynamik der schnurkeramischen Entwicklung in der Schweiz und in Südwestdeutschland. Die kontinentaleuropäischen Gruppen der Kultur mit Schnurkeramik. Schnurkeramik Symposium. Phara-Stirin, 1990. Praehistorica XIX, Praha, 1992, ss. 163-177.

Struve K. W. Die Einzelgrabkultur in Schleswig-Holstein und ihre kontinentalen Beziehungen. Neumünster, Wachholtz, 1955, 215 S.

Sulimirski T. Corded Ware and Globular Amphorae North-East of the Carpathians. London, Athlone, 1968, $283 \mathrm{p}$.

Timofeev V.I. Pamiatniki kul'tury shnurovoi keramiki vostochnoi chasti Kaliningradskoi oblasti (po materialam issledovanii 1970-1980-h gg.). Drevnosti Podvin'ia: istoricheskii aspect. Ed. by G. V. Vilinbahov. St. Petersburg, Gosudarstvennyi Hermitazh, 2003, pp. 119-134. (In Russian)

Titov S. V. K izucheniju migratsii bronzovogo veka. Arheologiia Starogo i Novogo Sveta. Ed. by V. I. Guljaev. Moscow, Nauka, 1982, pp. 89-145. (In Russian)

Tkach E.S. Keramicheskie sosudy so shnurovoi ornamentatsiei: tipologiia, problemy khronologii. Arheologiia ozernykh poselenii IV-II tys. do n.e.: khronologiia kul'tur i prirodno-klimaticheskie ritmy. Ed. by A. N. Mazurkevich. St. Petersburg, Gosudarstvennyi Hermitazh, 2014, pp. 281-286. (In Russian)

Tkach E. S. O podkhodakh i vozmozhnostiakh issledovaniia kamennykh boevykh toporov epokhi neolita bronzy. Arheologicheskie Vesti, 2015, vol.21, pp. 52-64. (In Russian)

Tkach E. S. Rasprostranenie traditsii kul'tur shnurovoi keramiki v verhov'iakh Zapadnoi Dviny v III tys. do n. e. Samarskii nauchnyi vestnik, 2017, no. 3(20), pp. 163-171. (In Russian)

Włodarczak P. Kul’tura ceramiki sznurowej na Wyżynie Małopolskiej. Kraków, Instytut archeologii i etnologii Polskiej Akademii Nauk, 2006. 346 s.

Zaitseva G.I., Vasil'ev S.S., Dergachev B.A., Mazurkevich A.N., Semenov A.A. Novye issledovaniia pamiatnikov basseina Zapadnoi Dvinu i Lovati: raspredelenie radiouglerodnykh dat, korreliatsiia s izmeneniiami prirodnykh protsessov, primenenie matematicheskoi statistiki. Drevnosti Podvin'ia: istoricheskii aspect. Ed. By G.V.Vilinbachov. St. Petersburg, Gosudarstvennyi Hermitazh, 2003, pp. 140-154. (In Russian)

Zaltsman E.B. K probleme proiskhozhdeniia promorskoi kul'tury (po materialam raskopok poselenii Pribrezhnoe I Ushakovo-3). Vesnik Baltiiskogo federal'nogo universiteta im. I. Kanta. Ser.: Gumanitarnue i obshchestvennye nauki, 2016, no. 1, pp. 6-38. (In Russian).

Zhulnikov A.M. Obmen iantarem v Severnoi Evrope v III tys. do n.e. kak factor sotsial'nogo vzaimodeistviia. Problemy biologicheskoi i kul'turnoi adaptatsii chelovecheskikh populiatsii. Vol.1. Ed. by G. A. Khlopachev. St. Petersburg, MAE RAN, 2008, pp. 134-145. (In Russian)

Статья поступила в редакцию 7 мая 2018 г.

Рекомендована в печать 12 марта 2019 г.

Received: May 7, 2018

Accepted: March 12, 2019 


\title{
Quartz Assemblage from the Early Mesolithic Helvetinhaudanpuro Settlement Site in Eastern Central Finland
}

\author{
T. Rostedt, A. Kriiska
}

For citation: Rostedt T., Kriiska A. Quartz Assemblage from the Early Mesolithic Helvetinhaudanpuro Settlement Site in Eastern Central Finland. Vestnik of Saint Petersburg University. History, 2019, vol. 64, issue 2, pp. 639-665. https://doi.org/10.21638/11701/spbu02.2019.213

Research of the occupation in the eastern shores of the Baltic Sea areas has been vivid over the last centuries and it has had different perspectives and thematic ranges. In this paper we present a overview of the history of Stone Age quartz research in Finland and general quartz working techniques and, above all, some results considering analysis of the quartz material from the Early Mesolithic settlement site of Helvetinhaudanpuro in Finland. It is surprising how little in archaeology has been paid attention to the changes in the variations of lithic technologies when groups of people moved from one area to another. If there were not any possibilities to use familiar stone materials as a technological starting point, adaptation to new materials was essential. In the lithic material of Helvetinhaudanpuro we detected characteristics connected to adaptation from flint to the local quartz. The shift in raw materials took place within a few hundred years and appears to coincide with the change in social networks related to the break in connections with previous habitation areas. The quartz techniques seen in Helvetinhaudanpuro are similar to those from other Finnish Mesolithic sites; bipolar technique dominates, but platform percussion has also been in use to some extent. There are some aspects in this material that are unusual, even special, and more compatible to flint than quartz technology: Helvetinhaudanpuro-type points, inserts and possible use of pressure flaking in some cases. These tool shapes and technical achievement indicate a deeper socio-cultural background and are a distinctive link between flint and quartz knapping technology.

Keywords: Early Mesolithic, Finland, quartz, lithic techniques.

Tapani Rostedt - MA, freelance archaeologist, Peltokatu, 18, 20540, Turku, Finland; tapaniro@hotmail.com

Тапани Ростедm - независимый исследователь (археология), Финляндия, 20540, Турку, ул. Пелтокату, 18; tapaniro@hotmail.com

Aivar Kriiska - PhD, Professor, Institute of History and Archaeology, University of Tartu, Jakobi 2, 51014, Tartu, Estonia; aivar.kriiska@ut.ee

Айвар Крийска - д-р философии (археология), проф. лабораторной археологии, Институт истории и археологии, Университет Тарту, Эстония, 51014, Тарту, ул. Якоби, 2; aivar.kriiska@ut.ee

This research was supported by the research project of the Estonian Research Council 'Estonia in Circum-Baltic space: archaeology of economic, social, and cultural processes' (IUT20-7) and "Natural selection and migrations in shaping human genetic diversity in East European Plain. An ancient DNA study" (PRG243).

Данное исследование выполнено при поддержке Научного совета Эстонии, проекты «Эстония в циркум-балтийском пространстве: археология экономических, социальных и культурных процессов» (IUT20-7) и «Естественный отбор и миграции в формировании генетического разнообразия населения Восточно-Европейской равнины. Исследование древнего ДНК» (PRG243)

(c) Санкт-Петербургский государственный университет, 2019 


\title{
Кварцевая индустрия из раннемезолитического поселения Хельветинхауданпуро на востоке центральной Финляндии
}

\author{
T. Ростедm, А. Крийска
}

Для цитирования: Rostedt T., Kriiska A. Quartz Assemblage from the Early Mesolithic Helvetinhaudanpuro Settlement Site in Eastern Central Finland // Вестник Санкт-Петербургского университета. История. 2019. Т. 64. Вып. 2. С. 639-665. https://doi.org/10.21638/11701/spbu02.2019.213

Изучение первичного заселения восточных берегов Балтийского моря на протяжении последних столетий осуществлялось весьма активно. Были исследованы различные аспекты и этапы этого процесса. В статье приведен обзор истории изучения вопросов использования кварца в каменном веке Финляндии, общих методов обработки этого материала, а также представлены результаты анализа кварцевого материала раннемезолитического поселения Хельветинхауданпуро в Финляндии. История изучения проблематики использования кварца показывает, как мало в археологии уделялось внимания вариациям каменных технологий при перемещении групп людей из одного района в другой. При невозможности использования известного каменного сырья и знакомой технологии возникала необходимость в приспособлении к новому материалу. В каменном материале Хельветинхауданпуро мы выделили характеристики, указывающие на адаптацию технологий обработки кремня к местному сырью - кварцу. Переход к другому виду сырья осуществлялся в течение нескольких сотен лет и, веротятно, совпал с социальными изменениями, обусловленными разрывом контактов с предыдущими районами обитания. Техники обработки кварца, наблюдаемые в Хельветинхауданпуро, очень похожи на техники других мезолитических стоянок Финляндии. Среди них доминировала биполярная, но в некоторой степени использовалась и площадочная техника. В находках на этой территории отмечаются уникальные особенности, более характерные для кремневых, чем для кварцевых технологий, среди них - острия типа хельветинхауданпуро и вкладыши, а в некоторых случаях, вероятно, использовалась отжимная техника расщепления. Эти формы орудий и технические достижения, возможно, имеют более глубокие социальные и культурные причины и являются отличительной чертой, связывающей технологии расщепления кремня и кварца.

Ключевые слова: ранний мезолит, Финляндия, кварц, техники обработки камня.

\section{Introduction}

The earliest inhabitants of Finland appear to have easily adopted quartz as a raw material for manufacturing small tools. Since Finland do not have natural sources of flint, it was necessary for the settlers to find a substitute for this material. It is possible that the fast transition to utilise quartz was also influenced by previous contacts with the material that had been used before arriving in Finland. However, the proportion of quartz in Early Mesolithic settlement sites within the "flint zone" remains extremely low. For instance, quartz makes up only $0.7 \%$ of the lithics found in the Early Mesolithic site of Pulli in Estonia ${ }^{1}$.

This early period of change in lithic raw materials is observable, among other things, in the characteristic features of the Finnish quartz percussion techniques.

Considering the abundance of quartz artefacts from Finnish Stone Age and Bronze Age settlement sites, it seems strange that during more than a hundred years of research,

${ }^{1}$ Jussila T., Kriiska A., Rostedt T. The Mesolithic Settlement in NE Savo, Finland and the earliest Settlement in the Eastern Baltic Sea // Acta Archaeologica. 2007. Vol. 78, iss. 2, fig. 12. 


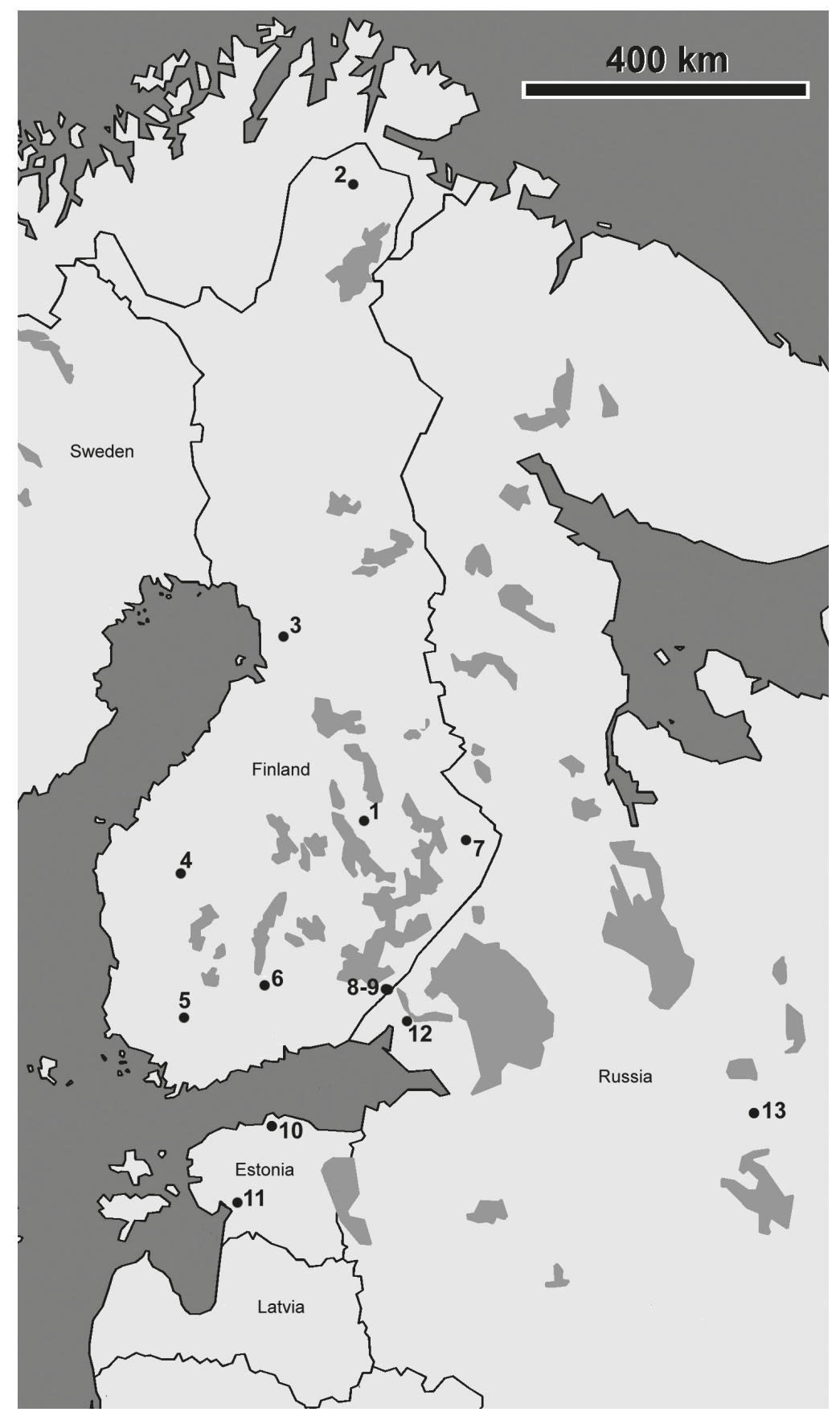

Fig. 1. Sites mentioned in the text. Finland:

1 - Juankoski Helvetinhaudanpuro; 2 - Utsjoki Sujala; 3 - Yli-Ii Kierikinsaari; 4 - Alavus Ojalankangas; 5 - Urjala Palomäki; 6 - Lahti Ristola; 7 - Eno Jokivarsi 1; 8-9 - Lappeenranta Saarenoja 2 and Muilamäki, Estonia; 10 - Kunda Lammasmägi; 11 - Pulli, Russia; 12 - Veshevo 2 and 13 - Lotova Gora (Map based on [Jussila et al., 2007, fig. 1] and Tapani Rostedt) 
only relatively little attention has been paid to this mineral. From the 2000 onward, there has been an increasing interest in the technological characteristics of quartz knapping. In Finland, the new pioneers of quartz technology include, first and foremost, Tuija Rankama and Jarmo Kankaanpää. They continue the inspection of quartz from where Ville Luho and Ari Siiriäinen decades ago concluded. Their persistent research and analysis of quartz technology awoke the field from a long slumber, and new articles on the topic are published by various researchers almost annually ${ }^{2}$.

For a long time, quartz was a relatively underappreciated lithic material. Experimental studies have shown that the fracture properties of quartz are not even close to those of flint and therefore flint knapping techniques cannot be directly applied to quartz ${ }^{3}$. The fracture properties of quartz, and especially its tendency to shatter when struck, no doubt create challenges for research, but we believe that general trends can still be observed. Formal percussion techniques have usually been the main subject in quartz technology studies. These rely on the assumption that mobility and the low availability of well-flaking lithics have caused simplification of earlier percussion techniques ${ }^{4}$. Generally, research on quartz knapping techniques has been rather moderate in the last decades and new interpretations regarding knapping traditions have not appeared.

This article sets three main aims: 1 ) to give an overview of the history of quartz research in Finland; 2) to discuss general techniques used when working with quartz, and above all 3) to present the results of analysis of the quartz material from the Early Mesolithic settlement site of Helvetinhaudanpuro in Juankoski. Notably, it is possible to observe some distinctive features in the quartz percussion technique in the Helvetinhaudanpuro material, a fact that might give a reason to look for similarities in other assemblages in the

${ }^{2}$ Rankama T. Ala-Jalve. Spatial, technological, and behavioral analyses of the lithic assemblage from a Stone Age Early Metal Age site in Utsjoki, Finnish Lapland // British Archaeological Reports, International Series. Vol.681. Oxford, 1997; Takala H. The Ristola Site in Lahti and the Earliest Postglacial Settlement of South Finland. Jyväskylä, 2003; Kankaanpää J. \& Rankama T. Early Mesolithic Pioneers in Northern Finnish Lappland // Pioneer Settlements and Colonization Processes in the Barents Region // Vuollerim Papers on Hunter-Gatherer Archaeology. Vol. 1 / ed. by H. Knutsson. Vuollerim 6000 År: Vuollerim, 2005. P. 109-161; Jussila T., Kriiska A., Rostedt T. The Mesolithic Settlement in NE Savo, Finland and the earliest Settlement in the Eastern Baltic Sea // Acta Archaeologica. 2007. Vol. 78, iss. 2. P. 143-162; Rankama T., Kankaanpää J. Eastern arrivals in post-glacial Lappland: The Sujala site 10000 cal BP // Antiquity. 2008. Vol. 82. P. 884-900; Tallavaara M., Manninen M. A., Hertell E. \& Rankama T. How flakes shatter. A critical evaluation of Quartz fracture analysis // Journal of Archaeological Science. 2010. Vol.37. P.2442-2448; Hertell E., Tallavaara M. High Mobility or Gift Exchange: early Mesolithic chipped lithics in Southern Finland // Mesolithic interfaces: Variability in lithic technologies in eastern Fennoscandia / ed. by T. Rankama. Saarijärvi, 2011. P. 11-41; Jussila T., Kriiska A., Rostedt T. Saarenoja 2 - An Early Mesolithic Site in South-Eastern Finland: Preliminary Results and Interpretations of Studies Conducted in 2000 and 2008-10 // Fennoscandia archaeological. 2012. Vol. XXIX. P. 3-27; Manninen M. A. Culture, Behavior and the 8200 cal BP Cold Event. Organisational Change and Culture-environmental Dynamics in Late Mesolithic Northern Fennoscandia. Vol.4. Helsinki. 2014; Manninen M.A., Knuttson K. Lithic raw material diversification as an adaptive strategy - Technology, mobility and site structure in Late Mesolithic northern mosts Europe // Journal of Athropological Archaeology. 2014. Vol.33. P. 84-98.

${ }^{3}$ Luho V. Die Askola-Kultur. Die frühmesolitische Steinzeit in Finnland. (Suomen Muinaismuistoyhdistyksen Aikakauskirja. Vol.57. Helsinki. 1956. P.116-117; Siiriäinen A. Problems of the East Fennoscandian Mesolithic. Finskt Museum 1977. Helsinki, 1981. P. 14-15; see also: Rankama T. Ala-Jalve. Spatial, technological, and behavioral analyses of the lithic assemblage from a Stone Age Early Metal Age site in Utsjoki, Finnish Lapland. (British Archaeological Reports, International Series. Vol. 681). Oxford, 1997.

${ }^{4}$ See e.g. Knutsson H., Knutsson K., Molin F., Zetterlund P. From flint to quartz: Organisation of lithic technology in relation to raw material availability during the pioneer process of Scandinavia // Quaternary International. 2016. Vol. 424. P.32-57. 
future. Based on a thorough analysis and comparative studies of the lithics from different settlement sites, it appears that the percussion techniques used by the pioneer settlers, who arrived in what is now modern-day Finland, initially incorporated 'memories' of previous stone-working techniques into quartz knapping. Later, the percussion techniques were simplified to an extent, but the function of tools remained the same for some time. Thus, the manufacturing technique was simplified due to the percussion properties of quartz, while simultaneously the tools became more multifunctional.

Previously, conducting long-term analysis was more complicated because the quartzes found in multi-period settlement sites did not necessarily represent only one period of occupation. Over the last decade the situation has changed for the better because more studies have been conducted on Early Mesolithic sites that were in use for a relatively short period of time. At the same time, reference material for specific time periods in Finland has increased, and the results are more accurate $\mathrm{e}^{5}$. The relatively short occupation period at Helvetinhaudanpuro adds credibility to the quartz assemblage from the site.

\section{History of quartz studies in Finland}

In the early days of lithic technological studies in Europe in the $19^{\text {th }}$ century, research was driven by general developments in archaeology: the birth of periodization, typology, and borrowing from the natural sciences. The creation of Palaeolithic periodization was of utmost importance: the evolution of lithic technology from fewer complexes to more complex types and to knapping techniques requiring the production of a core. The focus in lithic technology was on flint. Quartz was different, marginalised, and had almost no effect on the general study of lithic. It did not play a notable role even in areas such as Finland, where quartz was basically the only lithic raw material used for making small tools.

The fact that quartz was underappreciated in the early days of archaeology in Finland can be confirmed by the lack of systematic collection of the material during excavations. More attention to finding, collecting and studying quartz was paid from 1910 onward. Although Julius Ailio ${ }^{6}$ [1909] described quartz material to some extent in his dissertation, Sakari Pälsi is considered the forerunner of quartz studies in Finland ${ }^{7}$. He studied the

${ }^{5}$ Jussila T., Kriiska A., Rostedt T.: 1) Varhaismesoliittisesta asutuksesta Koillis-Savossa - alustavia tuloksia Juankosken Akonpohjan Helvetinhaudanpuron asuinpaikan kiviaineistosta // Arkeologia ja kulttuuri. Uutta kivikauden tutkimuksessa. Arkeologipäivät. 2005. Hamina, 2006. P. 50-61; 2) The mesolithic Settlement in NE Savo, Finland and the earliest Settlement in the Eastern Baltic Sea // Acta Archaeologica. 2007. Vol. 78, iss. 2. P. 143-162; 3) Saarenoja 2 - An Early Mesolithic Site in South-Eastern Finland: Preliminary Results and Interpretations of Studies Conducted in 2000 and 2008-10 // Fennoscandia archaeological. 2012. Vol. XXIX. P. 3-27; Kankaanpää J., Rankama T. Spatial Patterns of the Early Mesolithic Sujala Site. Utsjoki, Finnish Lappland // Mesolithic interfaces: Variability in lithic technologies in eastern Fennoscandia. Saarijärvi, 2011. P. 42-63; Rankama T., Kankaanpää J. Fast or slow pioneers? A view from Northern Lappland. Lateglacial and Postglacial Pioneers in Northern Europe // British Archaeological Reports, International Series. Vol. 2599. Oxford, 2014. P. 147-160; Kriiska A., Rostedt T., Jussila T. The Development of Early Mesolithic Social Networks During the Settlement of Virgin Lands in the Eastern Baltic Sea Region- Interpreted through Comparison of Two Sites in Finland // Comparative Perspectives on Past Colonisation, Maritime Interaction and Cultural Integration (New Directions in Anthropological Archaeology) / eds L. Melheim, H. Glørstad and Z. Glørstad. South Yorkshire, 2016. P. 19-40.

${ }^{6}$ Ailio J. Die Steinzeitliche Wohnplatzfunde in Finland I-II. Helsingfors, Kommission bei der Akademischen Buchhandlung, 1909.

${ }^{7}$ Luho V. Die Askola-Kultur. Die frühmesolitische Steinzeit in Finnland. (Suomen Muinaismuistoyhdistyksen Aikakauskirja. Vol.57). Helsinki, 1956. P. 16; Luho V. Die Suomusjärvi-Kultur. Die mittel- und 
shapes and retouches of the quartz assemblage from the Palomäki Stone Age settlement site in Urjala ${ }^{8}$. Aarne Europaeus (Äyräpää) ${ }^{9}$ published similar descriptions of quartz tools from the assemblage of the Stone Age settlement site of Ojalankangas in Alavus. He recognised that quartz had been an important raw material, at least in Western and Northern Finland.

Quartz did not receive much recognition again after the works of Pälsi and Europaeus until the studies by Ville Luho in the $1940 \mathrm{~s}^{10}$. Luho researched the earliest occupation of Finland and quartz technology, comparing the physical characteristics of the latter to those seen in flint technology. He assumed that the similarity in forms of quartz tools with flint tools was a sufficient reason to adapt the Central European Paleolithic typology to Finnish material. In his opinion, quartz tools were made by applying flint knapping techniques. Therefore, artefact types correspond and are comparable to those made from flint. According to Luho ${ }^{11}$, the differences in quartz technology concerned mainly the low quality of retouched blades and unpredictability of the material to fragmentation. Based on differences in quartz working techniques, he divided the Finnish Mesolithic into the Askola culture which was followed by the Suomusjärvi culture. He emphasized the large size of blades and blade cores found in the Askola culture, which prompted him to differentiate between the Askola and Suomusjärvi cultures ${ }^{12}$ on the basis of this old technological trait. Luho considered the quartz technology of the Neolithic Comb Ware culture a continuation of the Suomusjärvi tradition, without any major changes in technology or population ${ }^{13}$.

Luho's method of analysing quartz technology by comparing it directly to flint technology was later criticised. In his Master's thesis, Ari Siiriäinen ${ }^{14}$ studied the quartz assemblage from the Neolithic Asbestos Ceramic culture Yli-Ii settlement site. His intention was to find taxonomic differences in the material from the site dating to ca. 2000-1500 BC. In his work, Siiriäinen stressed how the fracture properties of quartz differ from those of flint. Since Luho had failed to do this, Siiriäinen considered his typology erroneous ${ }^{15}$. According to Siiriäinen, the uncritical application of typological terms derived from flint technology to characterize quartzes inevitably leads to incorrect conclusions. He believed

spätmesolitische zeit in Finnland // Suomen Muinaismuistoyhdistyksen Aikakauskirja. Vol.66. Helsinki, 1967. P. 10.

8 Pälsi S. Palomäen kivikautinen asuinpaikka Urjalassa // Suomen Museo 1913. Helsinki, 1913. P. 75-76.

9 Europaeus A. Ojalankankaan kivikauden löytöpaikka Alavudella // Suomen Museo 1916. Helsinki, 1919. P. 73-82; see also: Luho. 1956. P.16-17.

10 Ibid. P. 17.

11 Luho V. Die Askola-Kultur. Die frühmesolitische Steinzeit in Finnland // Suomen Muinaismuistoyhdistyksen Aikakauskirja. Vol. 57). Helsinki, 1956. P. 18; Luho V. Die Suomusjärvi-Kultur. Die mittel- und spätmesolitische zeit in Finnland. (Suomen Muinaismuistoyhdistyksen Aikakauskirja. Vol.66). Helsinki, 1967. P. 120.

${ }^{12}$ Luho V. Die Askola-Kultur. Die frühmesolitische Steinzeit in Finnland // Suomen Muinaismuistoyhdistyksen Aikakauskirja. Vol.57. Helsinki, 1956. P.116-117; Luho V. Die Suomusjärvi-Kultur. Die mittel- und spätmesolitische zeit in Finnland // Suomen Muinaismuistoyhdistyksen Aikakauskirja. Vol.66. Helsinki. 1967. P. 24.

${ }^{13}$ Luho V. Die Suomusjärvi-Kultur. Die mittel- und spätmesolitische zeit in Finnland // Suomen Muinaismuistoyhdistyksen Aikakauskirja. Vol. 66. Helsinki, 1967. P. 120.

14 Siiriäinen A. Yli-Iin Kierikin Asbestikeraamisen asuinpaikan kvartsiesineet. Lähdekriittinen tutkimus. Unpublished Master's thesis. University of Helsinki. Helsinki, 1968.

15 Siiriäinen A. Problems of the East Fennoscandian Mesolithic // Finskt Museum 1977. Helsinki, 1981. P. 6-14. 
that quartz and flint assemblages are not comparable in general because the introduction of quartz as a raw material caused the adaptation of new techniques which differed greatly from previous ones ${ }^{16}$. Based on quartz technology, Siiriäinen attributed the earliest occupation in Finland to the Suomusjärvi cultural area, which, in his opinion, uniformly influenced both Finland and neighbouring areas in the East during the Mesolithic period ${ }^{17}$.

The favourable strategies of prehistoric people related to lithic raw materials did not gain much international attention until the $1980 \mathrm{~s}^{18}$. Although research on the effect of properties of raw materials became particularly common in technological studies in North America, examination of quartz in Finland was world-class too at the time. In 1977, Ari Siiriäinen published an article in the journal Finskt Museum, in which he demonstrated how the quality and availability of raw materials used for crafting tools affected the overall composition of the archaeological assemblage in the River Rockshelter settlement site in Kenya (Eastern Africa). Siiriäinen did not, however, generalize his results but considered them as a starting point and encouraged further research into the connection between the properties of raw materials and the composition of the material culture in different areas and time periods. The availability and quality of raw materials is generally considered important, if not crucial, in lithic studies, and therefore this issue is still relevant and important.

Quartz was also explored thereupon by other archaeologists. Heikki Matiskainen dealt with quartz to some degree when studying the Suomusjärvi culture and material ${ }^{19}$. Hans-Peter Schulz ${ }^{20}$, on the other hand, studied Mesolithic quartz technologies in more detail. In his opinion, primary production was quite uniform. A hard or soft hammer was used on pieces of vein quartz, the bipolar technique was applied to a hard surface, and the platform percussion technique - on a striking platform. Pure platform technique was

16 Ibid. P. 14-15; Knutsson K. Garaselet-Lappviken-Rastklippan. Introduktion till en diskurssion om Norrlands Äldsta Bebyggelse // Tor. 1993. Vol.25. P. 12.

17 Siiriäinen A. Problems of the East Fennoscandian Mesolithic // Finskt Museum 1977. Helsinki, 1981. P. 18; Pankrušev G. A. Karjalan mesoliittinen ja neoliittinen kausi. Mesoliittinen kausi. Helsinki / eds P. Maaranen, M. Lavento, 1994. Vol. 1. P.67.

18 Bleed P. The Optimal Design of Hunting Weapons: Maintainability or Reliability // American Antiquity. 1986. Vol.51, iss.4; Bamforth D. B. Technological efficiency and tool curation // American Antiquity. 1986. Vol.51, iss. 1. P.38-50; Parry W. J., Kelly R. L. Expedient Core Technology and Sedentism. The Organization of Core Technology / eds J.K. Johnson, C. A. Morrow. Boulder, 1987. P. 285-304; Gero J.M. Assessing social information in material objects: how well do lithics measure up? // Time, energy and stone tools / ed. by R. Torrence. Cambridge, 1989. P.92-105; Hayden B. Practical and Prestige Technologies: The Evolution of Material Systems // Journal of Archaeological Method and Theory. 1998. Vol. 5, iss. 1. P. 1-55; Nelson M. C. The Study of Technological Organization // Archaeological Method and Theory. Vol.3, iss. 1. 1991. P. 57-100; Andrefsky W. Jr. Raw-material availability and the organization of technology // American Antiquity. 1994. Vol.59, iss. 1. P.21-34; Kuhn S. L. Mousterian lithic technology. Princeton, 1995; Brantingham P. J. et al. Raw Material Quality and Prepared Core Technologies in Northeast Asia // Journal of Archaeological Science. 2000. Vol.27. P. 255-271.

19 Matiskainen H.: 1) Beiträge zur Kentnisse der mesolitischen Schrägschneidepfeile und Mikrolithen aus Quarz. Studia praehistorica Fennica C F Meinander septuagenario dedicata // Iskos. Vol. 6. 1986. P.7798; 2) The Palaeoenvironment of Askola, Southern Finland. Mesolithic Settlement and Subsistence 100006000 b.p. // Iskos. 1989. Vol. 8.97 p.

${ }^{20}$ Schulz H.-P.: 1) On the Mesolithic Quarz Industry in Finland. Fenno-Ugri et Slavi. Papers presented by the participants in the Finnish-Soviet Archaeological Symposium 'Studies in the Material Culture of the Peoples of eastern and Northern Europe' 10-16 May 1988 in the National Museum of Finland // Iskos. Vol.9. 1988. P.7-23; 2) Pioneerit pohjoisessa. Suomen varhaismesoliittinen asutus arkeologisen aineiston valossa // Suomen Museo 1996. Helsinki, 1996. P.5-45. 
used, too. Schulz has also found evidence for bipolar blade percussion. According to him, Mesolithic quartz technology involves features from flint knapping technology. Although there are differences in the initial production phases of quartz and flint technologies, there are also similarities. Techniques used to shape the tools after initial reduction resemble those used for working flint, and therefore applying terminology from flint knapping is justified. Nevertheless, typology should still be based primarily on knapping technology and not just on appearance ${ }^{21}$.

When considering technology as part of a complex interdependent system, we are able to refer to stone tools to answer broader questions regarding production and use of artefacts. According to Margaret Nelson ${ }^{22}$, the most important result of the study of technological systems is the focus on the variables that influence the technology. In this way, the attention is shifted from the shape, production techniques or use of lithics, or from the picture these can produce of the activities occurring at the settlement site to the variables that cause change. The main objective of the study of technological systems has been to discover how changes in technology reflect broader changes in human behaviour ${ }^{23}$.

Inspired by the study of technological systems, recent research in Finnish lithic technology also deals with essential questions regarding stone working, artefact use and locating activity at settlement sites ${ }^{24}$.

\section{Quartz working techniques}

Knapping techniques are skills and capabilities mastered and used by a specific person. In archaeological lithic technological studies, technology usually refers to stone working customs. Lithic technological studies are often determined by research approaches; theoretical and philosophical principles, sometimes referred to as generalisations ${ }^{25}$.

Techniques and lithic raw material are interdependent because the characteristics of rocks influence their use and behaviour when being worked ${ }^{26}{ }^{26}$. The crystal structure

${ }^{21}$ Ibid. P.18; Callahan E. et al. Kulturhistoriska kommentarer till det säregna sönderfallet vid bearbetning av kvarts // Tor. 1992. Vol.24. P. 32.

22 Nelson M. C. The Study of Technological Organization // Archaeological Method and Theory. 1991. Vol. 3, iss. 1. P. 57-100.

${ }^{23}$ Kelly R. L. The three sides of a biface // American Antiquity. 1988. Vol. 53. P.717-734.

${ }^{24}$ Räihälä O. Suomussalmen Salonsaari kivikautinen leiripaikka Kiantajärven rannalla // Kirjoitelmia arkeologian alalta. Kentältä poimittua 4. Museoviraston arkeologian osaston julkaisuja. Vol. 7. Helsinki, 1997. P. 5-23; Rankama T. Ala-Jalve. Spatial, technological, and behavioral analyses of the lithic assemblage from a Stone Age Early Metal Age site in Utsjoki, Finnish Lapland // British Archaeological Reports, International Series. Vol.681. Oxford, 1997; Rankama T. Analyses of the Quartz Assemblages of Houses 34 and 35 at Kauvonkangas in Tervola // Huts and Houses. Stone Age and Early Metal Age Buildings in Finland / Ed. by H. Ranta. Helsinki, 2002. P.79-108; Manninen M. A. Chaîne opératoire-analyysi ja kvartsi. Esimerkkinä kvartsiniskentäpaikka Utsjoki Leakšagoađejohka 3, Master's thesis. E-thesis, University of Helsinki, 2004. Available: http://urn.fi/URN:NBN:file 200319462003 (accessed: 18.04.2018); Manninen M. A., Tallavaara M., Hertell E. Subneolithic bifaces and flint assemblages in Finland. Outlining the history of research and future questions. Uniting Sea. Stone Age societies in the Baltic Sea region // Papers in Archaeology. Vol. 33. Uppsala, 2003. P. 161-179; Hertell E., Manninen M.A. Rävåsens kvartsmaterial // Finskt Museum 2002. Helsinki, 2005. P. 84-100; Pesonen P., Tallavaara M. Esihistoriallinen leiripaikka Lohjan Hossanmäellä- kvartseja ja yllättäviä ajoituksia // Suomen Museo 2005. Helsinki, 2006. P. 5-26.

25 Trigger B. G. A History of Archaeological Thought. Cambridge, 1989.

${ }^{26}$ Rajala U. Kvartsiteknologian tutkiminen ja luokittelu Turun Niuskalan Kotirinteen kiukaiskeraamisen asuinpaikan vuosien 1983 ja 1984 kvartsilöydöt. Unpublished Master’s thesis, University of Turku. Turku, 1995. 
of rock affects its fracture properties and ability to flake; in microcrystalline rocks the crystals cause the rock to fragment when external constructive forces surpass the resolution of the crystals. Different rocks have different crystal structures, which influence the controllability during knapping. Quartz and other minerals in the same group are generally comprised of silicone dioxide $\mathrm{SiO}_{2}{ }^{27}$. In addition to common quartz and its colour variants, the quartz group includes silicone dioxides that are stable in room temperature, such as flint, calchedony, agate, jasper and opal.

Quartz and other lithic raw materials utilized in prehistory occur naturally in bedrock as veins or nodules. The lithic raw material most probably would have been collected either by digging or by taking advantage of vein quartz deposits. To determine the collection method used, one can analyse the quality of quartz, and look for the presence of an erosion surface, a sign of moraine quartz.

Quartz is hard but brittle. The relative hardness of quartz is 7 on the Mohs' 10-point hardness scale. Due to its structure, quartz behaves differently from flint when worked; a flint flake will usually remain intact, whereas a quartz flake will shatter into many fragments. An experimental study conducted by Swedish researchers in the 1980s and 1990s found that fragmentation is a not as random as was previously thought, but follows certain rules of fracture mechanics ${ }^{28}$. In addition, the internal flaws of quartz influence its working properties just as its brittleness causes fragmentation. These internal flaws cause fragmentation along pre-existing planes of fracture lines, making it difficult to predict and control the shape and size of flakes ${ }^{29}$. The problem is not nearly as severe with flint and therefore predictability with flint is much better. It seems, however, that there is some predictability in quartz knapping when reduction sequences are not conducted too rapidly, and the material is checked periodically during different reduction sequences.

Distinguishing knapping methods and percussion techniques is intriguing because different techniques are suitable for producing different types of tools. By using bifacial reduction, it is possible to produce flakes suitable for use as blanks for tools, and to work retouched tools. Platform percussion is suited for making both blanks and shaping and sharpening tools such as scrapers. With bipolar percussion, however, it is possible to produce mostly flake blanks used to manufacture other tools. In North American scholarship, this technique is considered especially well-suited for working small-sized pieces of raw material. Due to this, bipolar percussion is considered to have been the method employed when there was a need to utilize raw material as economically as possible ${ }^{30}$.

In principal quartz knapping, there are two basic techniques - platform percussion and bipolar percussion. Bifacial reduction is rare in quartz knapping and will therefore not be described in detail here. In platform percussion, the core is usually an artefact with one

27 Eskola P. Kidetieteen, mineralogian ja geologian alkeet. Porvoo, 1957. P. 65.

28 Callahan E., Forsberg L., Knutsson K., Lindgren C. Frakturbilder. Kulturhistoriska kommentarer till det säregna sönderfallet vid bearbetning av kvarts // Tor. 1992. Vol.24. P. 27-63; Siiriäinen A. Quartz, Chert and Obsidian. A Comparison of Raw Materials in a Late Stone Age Aggregate in Kenya // Finskt Museum 1974. Helsinki, 1977. P. 15-16.

29 Siiriäinen A. Quartz, Chert and Obsidian. A Comparison of Raw Materials in a Late Stone Age Aggregate in Kenya // Finskt Museum 1974. Helsinki, 1977. P. 15-16.

30 Andrefsky W. Jr. Lithics. Macroscopic approaches to analysis. (Cambridge Manuals in Archaeology). 1998. P. 119-120, 149; Tallavaara M. Vihiä teknologisista strategioista. Tutkimus Rääkkylän Vihin kampakeraamisen ajan asuinpaikan piikivi- ja kvartsiaineistoista. Master's thesis. E-thesis, University of Helsinki, 2007. P. 24. Available: http://urn.fi/URN:NBN:fi-fe20072153 (accessed: 15.03.2018). 
or more flat surfaces, for which the force needed for flake detachment is adapted. Techniques used were percussion, striking or pressure ${ }^{31}$. In platform percussion, the core is held in one hand, supported by the thighs, for example, and flakes or blades are detached using a percussion stone or some other percussion tool. The strikes are directed diagonally towards the edge of the platform, causing the detachment of a flake that has retained a piece of the platform. It is typical that flakes produced with platform percussion do not have sharp, but rather upright angles between the surface of the platform and the dorsal side of the flake. Other distinctive features of platform percussion are bulbs of percussion, eraillure scars and arrises ${ }^{32}$.

In platform percussion, an anvil can be used as a support. In this case, the quartz is placed on an anvil. When striking the core, the pressure of percussion is directed towards the edge of the platform and not directly from above to the anvil. The technique is still considered platform percussion as long as the aforementioned characteristics can be detected. Platform-on-anvil reduction is sometimes considered a fusion between platform percussion and bipolar percussion. If the raw material has been reduced to a very small size by later reduction sequences, then bipolar percussion techniques can often be applied in addition ${ }^{33}$. The bipolar blade production mentioned by Schulz can technically be placed within this category ${ }^{34}$.

The anvil is also used as a support in bipolar percussion. In this case, the quartz core is placed on an anvil and struck directly from above, causing the percussion force to move towards the anvil. The percussion force enters the core from two sides: from the direction of the percussion and from the anvil. With hard blows the stress in quartz is broken, causing the flaking to follow the cracks in the material. As a result of bipolar percussion, flakes detach from both ends of the core. One of the main characteristics of the technique is the presence of radiating fissures on the both ends of the core. Contrary to platform percussion, the bipolar technique does not generally have a proper remnant of a platform or a defined bulb of percussion, but the eraillure scars in the core and flakes can be well defined. Flakes created using the bipolar technique can be thinner and therefore more practical in certain circumstances than those created with the platform percussion technique ${ }^{35}$.

31 Tallavaara M. Vihiä teknologisista strategioista. Tutkimus Rääkkylän Vihin kampakeraamisen ajan asuinpaikan piikivi- ja kvartsiaineistoista. Master's thesis. E-thesis, University of Helsinki, 2007. P. 73. Available: http://urn.fi/URN:NBN:fi-fe20072153 (accessed: 15.03.2018).

32 Crabtree D.E. An introduction to the technology of stone tools. (Occasional papers of the museum, number 28). Pocatello (Idaho), 1972. P.11; Knutsson K. Making and using stone tools. The analysis of the lithic assemblages from the Middle Neolithic sites with flint in Västerbotten, northern Sweden. (Aun. Vol. 11). 1988. P.37.

33 Knutsson K. Making and using stone tools. The analysis of the lithic assemblages from the Middle Neolithic sites with flint in Västerbotten, northern Sweden. (Aun. Vol.11). 1988. P. 148-149; Olofsson A. Early Colonization of Northern Norrland: Technology, Chronology, and Culture. Pioneer Settlement in the Mesolithic of Northern Sweden. (Archaeology and Environment. Vol. 16). Umeå, 2003. P. 5

34 Schulz H.-P. On the Mesolithic Quarz Industry in Finland // Fenno-Ugri et Slavi. Papers presented by the participants in the Finnish-Soviet Archaeological Symposium "Studies in the Material Culture of the Peoples of eastern and Northern Europe" 10-16 May 1988 in the National Museum of Finland. (Iskos. Vol.9). P.7-23; Olofsson A. Early Colonization of Northern Norrland: Technology, Chronology, and Culture. Pioneer Settlement in the Mesolithic of Northern Sweden. (Archaeology and Environment. Vol. 16). Umeå, 2003. P. 71-72.

${ }_{35}$ Crabtree D. E. An introduction to the technology of stone tools // Occasional papers of the museum, number 28. Pocatello (Idaho), 1972. P. 10-11; Callahan E. An evaluation of the lithic technology in middle Sweden during the Mesolithic and Neolithic. (Aun. Vol.8). Uppsala, 1987. P.61; Rankama T. Ala-Jalve. 
To guarantee better controllability during knapping and flake detachment, indirect percussion can be applied. When using this method, a punch made from a bone, stone or dense wood is placed on a desired location on the platform and struck with a hammerstone. Tools fashioned in this way are finer than those manufactured with the basic technique because the naturally occurring cracks in quartz can be utilized more efficiently. The resulting flakes are smaller and more consistent than those made with the basic technique ${ }^{36}$.

If the core is not supported well during knapping, it eventually begins to bend. If force is applied in this situation, it will not go right through the core as intended. As a result, flakes are shorter than planned. If the item is supported securely, it will be easier to take advantage of materials fracture properties ${ }^{37}$. An anvil and stones with defined edges can be used as supports to stabilise cores during flaking ${ }^{38}$.

The pressure technique can also be applied as an aid when shaping and strengthening blades. For this, a bone, antler or wooden tool is used to press out small pieces from the edge. The force to be used is determined by the size of the pieces to be removed. In situations requiring more force, the shoulder or chest can be used along with long tools. Flakes resulting from the use of pressure technique are often very consistent and thin compared to those made with the basic technique.

\section{Helvetinhaudanpuro settlement site}

The Helvetinhaudanpuro site is located on top of a high and gently sloping fossilized 7-10 $\mathrm{m}$ wide ancient shore escarpment ${ }^{39}$. According to the shore displacement chronology of Lake Saimaa, the water level was near the top edge of the escarpment (112 m a.s.1.) about $8500 \mathrm{cal} \mathrm{BC}$ and at the foot of the escarpment (108 m a. s. 1.) about $8400 \mathrm{cal} \mathrm{BC}$ during the Ancylus Lake Phase of the Baltic Sea basin. At this location, the highest shoreline of ancient Lake Saimaa lies some $160 \mathrm{~m}$ further down the gentle slope at an elevation of $99 \mathrm{~m}$ a.s.l., where the water level stood c. $4800-4000 \mathrm{cal} \mathrm{BC}$. Today, the nearest body of water is Lake Akonjärvi, part of the present Saimaa Lake system located $1.5 \mathrm{~km}$ west of the site at an elevation of $82 \mathrm{~m}$ a.s.l. The water of this lake has been at the present level since the beginning of the ancient Lake Saimaa transgression phase, soon after the isolation of the Saimaa lake complex from the early Litorina Sea c. $7000 \mathrm{cal} \mathrm{BC}^{40}$.

Spatial, technological, and behavioral analyses of the lithic assemblage from a Stone Age Early Metal Age site in Utsjoki, Finnish Lapland // British Archaeological Reports, International Series. Oxford, 1997. Vol.681. P.73; Tallavaara M. Vihiä teknologisista strategioista. Tutkimus Rääkkylän Vihin kampakeraamisen ajan asuinpaikan piikivi- ja kvartsiaineistoista. Master's thesis. E-thesis, University of Helsinki, 2007. P.43-44. Available: http://urn.fi/URN:NBN:fi-fe20072153 (accessed: 15.03.2018).

36 Crabtree D. E. An introduction to the technology of stone tools // Occasional papers of the museum. Number 28. Pocatello (Idaho), 1972. P. 12-13.

37 Whittaker J. C. Flintknapping. Making and understanding stone tools. Austin, 1994. P. 151.

38 Pelegrin J. Blade-Making Techniques from the Old World: Insights and Applications to Mesoamerican Obsidian Lithic Technology // Mesoamerican Lithic Technology: Experimentation and interpretation / Ed. by K. Hirth. Salt Lake City, 2003. P. 65

39 Jussila T., Kriiska A., Rostedt T. The mesolithic Settlement in NE Savo, Finland and the earliest Settlement in the Eastern Baltic Sea // Acta Archaeologica. 2007. Vol. 78, iss. 2. P. 143-162.

40 Saarnisto M. The late Weichselian and Flandrian History of the Saimaa Lake Complex // Commentationes physico-mathematicae. Vol.37. 1970. P. 3-7; ${ }^{14} \mathrm{C}$-dates calibrated // Jussila T. Saimaan kalliomaalausten ajoitus rannansiirtymiskronologian perusteella. Saimaan ja Päijänteen alueen kalliomaalausten si- 


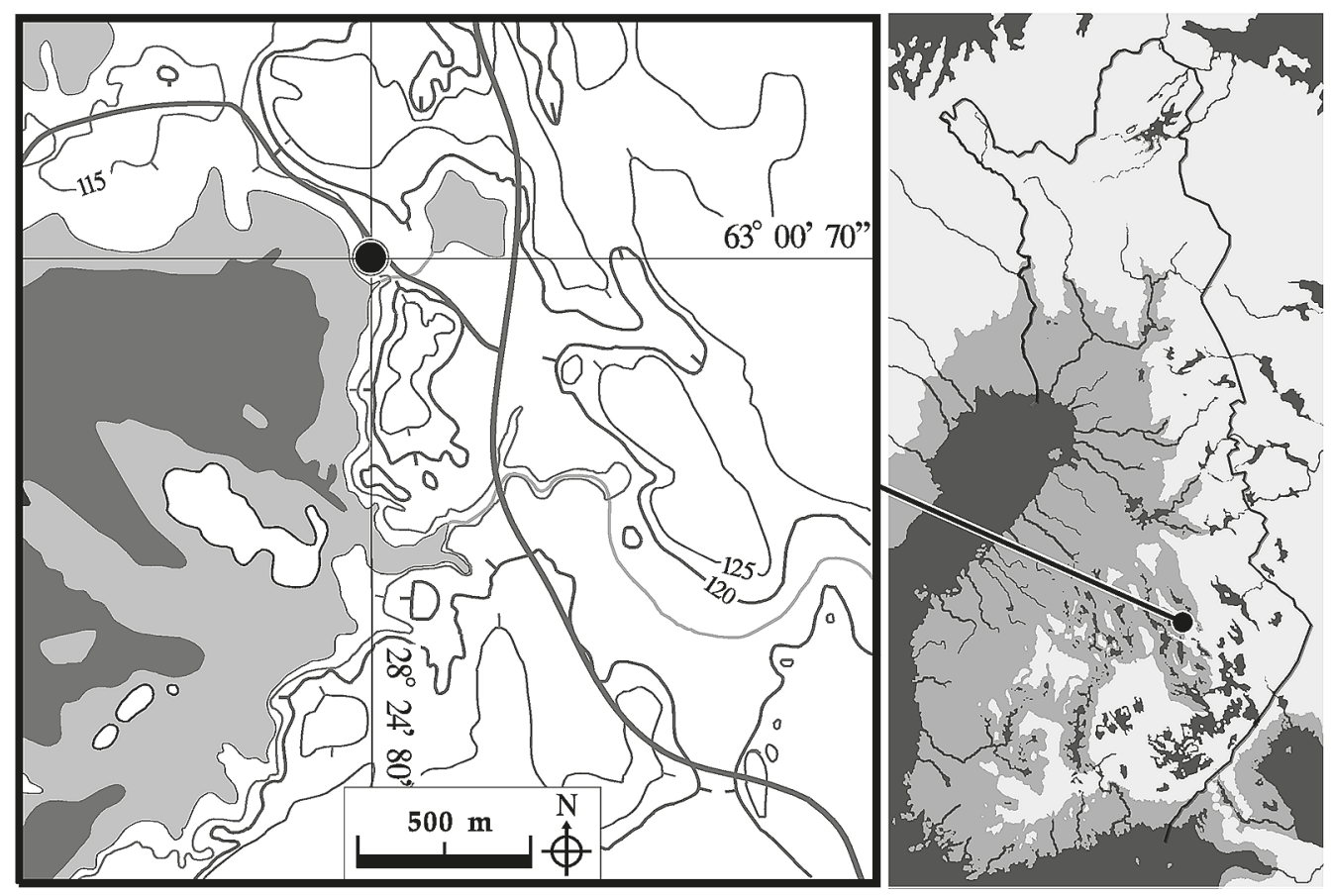

Fig. 2. Location of Helvetinhaudanpuro site. Light grey indicates water level $8500 \mathrm{cal} \mathrm{BC}$, darker grey is present water level (map by [Jussila et al., 2007, fig. 2])

The site was situated along the Ancylus Lake opening to the southwest and was located on the northwestern side of a small river mouth at the base of a 600-1000 m wide bay sheltered by an archipelago. The site lies on a c. $25 \mathrm{~m}$ wide terrace between the ancient shore escarpment and a gently rising slope (Figs 2 and 3). The terrain rises in all directions except southwest and west as seen from the site. When the site was occupied, the water directly in front of it was moderately deep, but on the north-western side the shore became shallow.

The site lies on the edge of a glacifluvial esker where the deposited sand of the esker turns into till. The soil at the site is quite loose equigranular sand; at the root of the escarpment it turns into fine sand and further downhill to silty till. To the north of the site the esker expands into a glacifluvial delta with kettle holes. 200 meters northeast of the site is a kettle hole c. $200 \mathrm{~m}$ in diameter with a maximum depth of some five to six meters. In this depression, there was a pond that is now almost completely paludified. From this pond, an ancient riverbed with steep banks runs directly to the south-eastern edge of the site where a small but fairly deep river discharged into the Ancylus Lake. On the opposite side of the ancient riverbed the terrain becomes somewhat more uneven, and on the upper slopes there are also outcrops of bedrock. Farther towards the southeast the soil is sandy till with a stony topsoil that has so far yielded no traces of prehistoric activities. Northwest of the site the topsoil becomes stonier, while the site area and its immediate surroundings are totally stone free. The fossilized erosion escarpment gradually disappears towards the jainti ja syntyaika. (Kalliomaalausraportteja. Vol. 1) / eds P. Kivikäs, T. Jussila, R. Kupiainen. Jyväskylä, 1999. P. 113-133. 


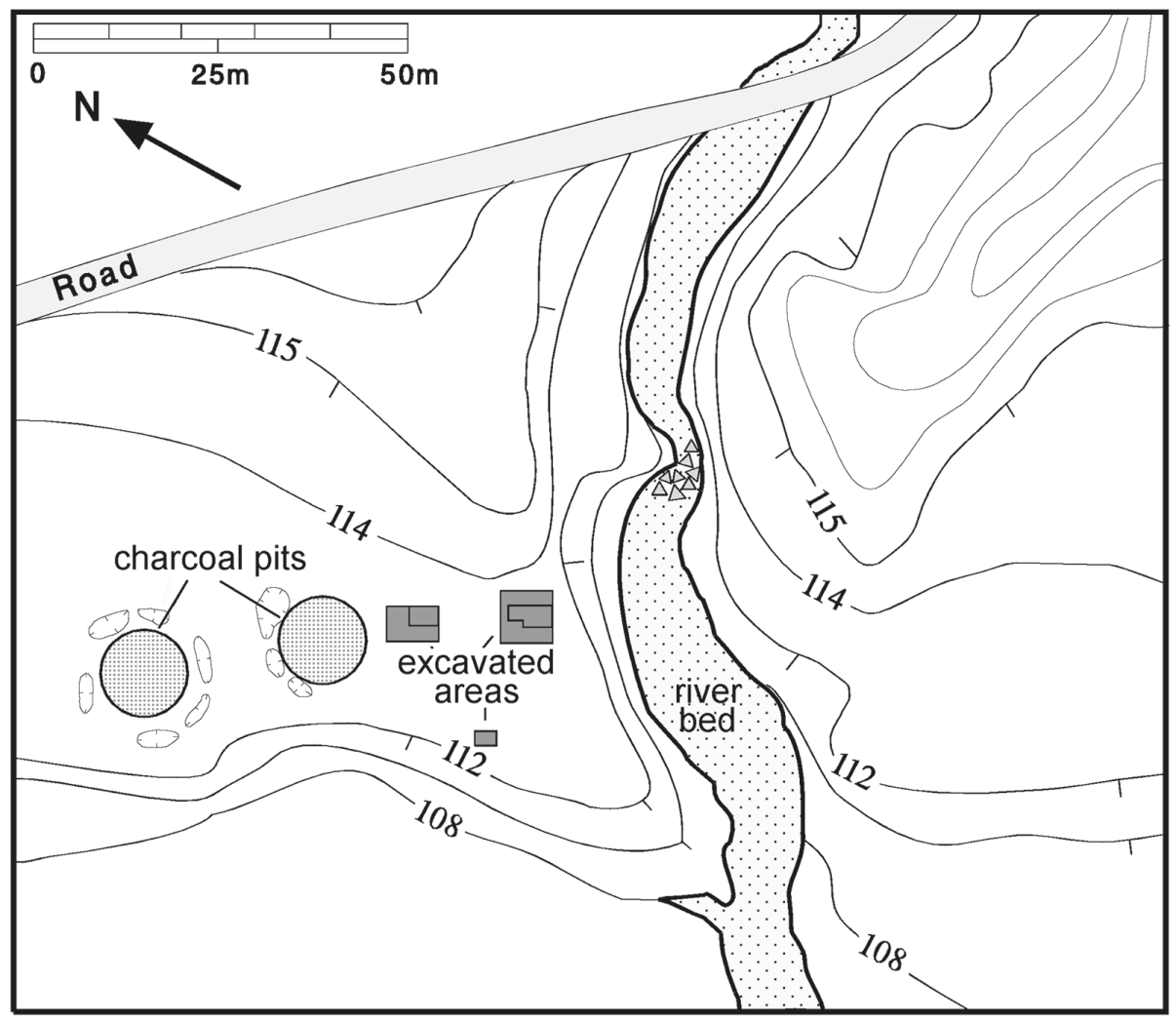

Fig. 3. General map of Helvetinhaudanpuro (map by [Jussila et al., 2007])

northwest as the floor of the ancient lakebed in front of it gradually rises and blends into the gentle slope.

Archaeologist Timo Jussila discovered the fossilized Ancylus escarpment mentioned above in 2000 and visited the location several times during years 2000-2002, digging a number of random test pits at the edge of the escarpment without noticing any traces of prehistoric activity. In the autumn of 2003, the topsoil at the location was partly exposed as a result of logging operations, and when visiting the site again, Jussila observed several quartz flakes and tools indicating the presence of a Stone Age site. The site was not at the edge of the escarpment, as is usual, but about 15-20 metres away from it. Later, during excavations, a number of quartz flakes were found in a test pit on the opposite side of the riverbed. The north-western part of the site was partially destroyed by two $19^{\text {th }}$ century charcoal-pits (Fig. 3).

In the summer of 2004, a small excavation area of $15 \mathrm{~m}^{2}$ was opened up on the spot where the highest concentrations of quartz were observed in patches of revealed mineral soil ${ }^{41}$. In the summer of 2005 , the excavation area was expanded to $48 \mathrm{~m}^{2}$, of which $33 \mathrm{~m}^{2}$ was excavated that year. A small test area of $6 \mathrm{~m}^{2}$ was excavated at the edge of the escarp-

${ }^{41}$ Jussila T., Kriiska A., Rostedt T. Varhaismesoliittisesta asutuksesta Koillis-Savossa - alustavia tuloksia Juankosken Akonpohjan Helvetinhaudanpuron asuinpaikan kiviaineistosta // Arkeologia ja kulttuuri. Uutta kivikauden tutkimuksessa. Arkeologipäivät 2005. Hamina, 2006. P. 50-61. 
ment. The finds from this second area were few and consisted of small quartz flakes. A third area of $7 \mathrm{~m}^{2}$ was opened up 10 meters northwest of the main area, where a small chunk of flint was found in a scarification patch. This area was excavated only to a depth of $5 \mathrm{~cm}$ into the mineral soil, forming a "seed" for forthcoming excavations. Fieldwork continued in 2006, revealing, among other things, some traces of a semi-subterranean rectangular house. The overall size of the site is assumed to be roughly $80 \times 25 \mathrm{~m}^{42}$.

The main excavation area was characterized by a fairly thin podsol soil profile typical of the coniferous forest zone. Distinct coloured cultural layers were not discernible. Ten thousand years of podsolization processes in the loose and sandy soil had eradicated most of the visible traces of original anthropogenic dirt and sooty soil from the surface layers of the topsoil. A weakly outlined but deep pocket of dirty soil in the north-eastern corner of the main excavation area also contained a concentration of small quartz flakes. The find layer was generally $30-35 \mathrm{~cm}$ thick and was located directly below the organic surface layer. In a limited area towards the middle of the main excavation, the find layer reached a depth of 40-45 cm, and in the previously mentioned spot in the north-eastern corner - a depth of $70 \mathrm{~cm}$.

There are two radiocarbon dates from the site, both made from burnt fragment of elk bone: $9200 \pm 75$ BP (Hela-918) - 95\% probability 8606-8285 cal BC and 9275 460 (Hela1406) - $95 \%$ probability $8697-8311$ cal BC (calibrated by OxCal v4.3 $3^{43}$ and the IntCal13 atmospheric calibration curve ${ }^{44}$ ), which corresponds well to the age determination given by shore displacement chronology.

\section{The quartz material from Helvetinhaudanpuro}

The quartz material collected between 2004 and 2006 has been published in previous $\operatorname{articles}^{45}$. Therefore, the focus of this paper is on the description of some special characteristics of the quartz assemblage.

The quartz found at the settlement site varies in colour and quality. The assemblages from Helvetinhaudanpuro sites contain milky as well as almost translucent material. Additionally, different shades of grey and 'smoky' quartz are present. The bulk of the quartz found at the site derives from nodules. Only a small percentage could be interpreted as

${ }^{42}$ Kriiska A., Rostedt T., Jussila T. The Development of Early Mesolithic Social Networks During the Settlement of Virgin Lands in the Eastern Baltic Sea Region- Interpreted through Comparison of Two Sites in Finland // Comparative Perspectives on Past Colonisation, Maritime Interaction and Cultural Integration. (New Directions in Anthropological Archaeology) / eds L. Melheim, H. Glørstad, Z. Glørstad. South Yorkshire, 2016. P. 23.

${ }^{43}$ Bronk Ramsey C. OxCal (computer program). Version 4.23. The Manual. Available: http://c14.arch. ox.ac.uk/oxcal/OxCal.html (accessed: 19.05.2018).

${ }^{44}$ Reimer P. J. et al. IntCal13 and Marine13 radiocarbon age calibration curves 0-50,000 years cal BP // Radiocarbon. 2013. Vol.55, iss. 4. P.1111-1150.

${ }^{45}$ Jussila T., Kriiska A., Rostedt T. Varhaismesoliittisesta asutuksesta Koillis-Savossa - alustavia tuloksia Juankosken Akonpohjan Helvetinhaudanpuron asuinpaikan kiviaineistosta // Arkeologia ja kulttuuri. Uutta kivikauden tutkimuksessa. Arkeologipäivät 2005. Hamina, 2006; Jussila T., Kriiska A., Rostedt T. The mesolithic Settlement in NE Savo, Finland and the earliest Settlement in the Eastern Baltic Sea // Acta Archaeologica. 2007. Vol. 78, iss. 2. P. 143-162; Kriiska A., Rostedt T., Jussila T. The Development of Early Mesolithic Social Networks During the Settlement of Virgin Lands in the Eastern Baltic Sea RegionInterpreted through Comparison of Two Sites in Finland // Comparative Perspectives on Past Colonisation, Maritime Interaction and Cultural Integration. (New Directions in Anthropological Archaeology) / eds L. Melheim, H. Glørstad, Z. Glørstad. South Yorkshire, 2016. P. 19-40. 
vein quartz. There is a simple explanation for this. Namely, we found an abundance of natural quartz nodules close to the settlement site, on the other side of the creek, which would have been easy to transport to the site. The quartz had a rough macrocrystalline structure and was mostly opaque in colour, although some nearly clear and greyish flakes were also detected.

The total amount of quartz found at the site is quite large, consisting of 23981 pieces (Table 1). The material contained mostly flakes (23 506 pieces, $98 \%$ of all quartz material including microdebitage) from which we were able to separate blades (1906 pieces, 8.1\%). We also separated cores (296 pieces, $1.2 \%$ ) and formal tools (179 pieces, $0.7 \%$ ) from the total quartz assemblage.

Table 1. Quartz artefacts from the Helvetinhaudanpuro site

\begin{tabular}{|l|c|c|l|}
\hline Total & 23981 & $99.7 \%$ & of all lithic material \\
\hline Flakes & 23506 & $98.0 \%$ & of total quartz artefacts \\
\hline Blades & 1906 & $8.1 \%$ & of quartz flakes \\
\hline Cores & 296 & $1.2 \%$ & of total quartz artefacts \\
\hline Tools & 179 & $0.7 \%$ & of total quartz artefacts \\
\hline \multicolumn{3}{|l|}{} \\
\hline Identified techniques & 6003 & $25.0 \%$ & of total quartz artefacts \\
\hline Bipolar & 4198 & $69.9 \%$ & of identified techniques in quartz artefacts \\
\hline Platform & 1805 & $30.1 \%$ & of identified techniques in quartz artefacts \\
\hline Flakes & 3348 & $55.8 \%$ & of identified techniques in quartz artefacts \\
\hline Bipolar flakes & 2051 & $61.3 \%$ & of identified quartz flakes \\
\hline Platform flakes & 1297 & $38.7 \%$ & of identified quartz flakes \\
\hline Blades & 2203 & $36.7 \%$ & of identified techniques in quartz artefacts \\
\hline Bipolar blades & 1883 & $85.5 \%$ & of identified quartz blades \\
\hline Platform blades & 320 & $14.5 \%$ & of identified quartz blades \\
\hline Cores & 296 & $4.9 \%$ & of identified techniques in quartz artefacts \\
\hline Bipolar cores & 179 & $53.3 \%$ & of identified quartz cores \\
\hline Platform cores & 157 & $46.7 \%$ & of identified quartz cores \\
\hline Tools, identified & 116 & $1.9 \%$ & of identified techniques in quartz artefacts \\
\hline Bipolar tools & 85 & $73.3 \%$ & of identified quartz tools \\
\hline Platform tools & 31 & $26.7 \%$ & of identified quartz tools \\
\hline Tools, unidentified & 63 & $35.2 \%$ & of quartz tools \\
\hline
\end{tabular}

The fracture properties of quartz make it prone to fragmentation, posing challenges in attempting to determine the reduction technique. It was possible to determine the reduction technique in 6003 items ( $25 \%$ of all quartz artefacts) from Helvetinhaudanpuro. Out of these, 4198 (69.9\%) were manufactured using the bipolar technique (Fig. 4 : 1-3) and 1805 (30.1\%) using the platform technique (Fig. 4: 4-6).

While studying the quartzes, we discovered some exceptional features in items manufactured using the platform technique. First, among the complete long blades we found some pieces without an eraillure scar. The lack of an eraillure scar is possible, but rare when using the basic platform technique in quartz. These unusually shaped flakes and blades are also relatively straight and quite thin for quartz flakes. These features suggest perhaps 

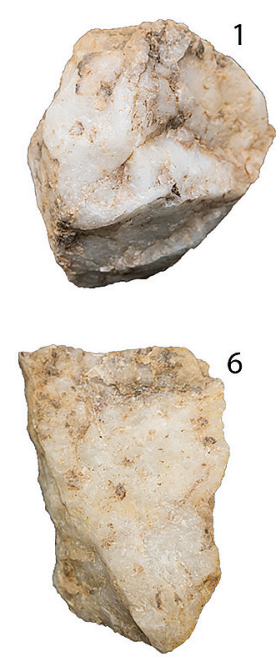
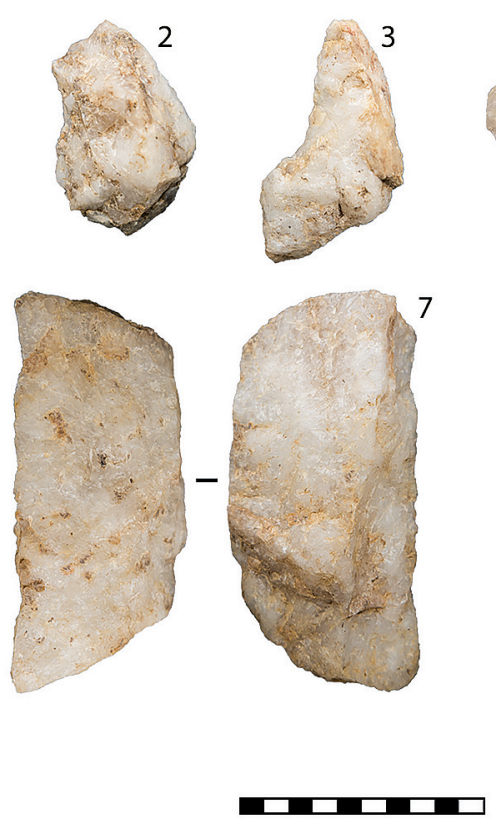

Fig. 4. Some examples of quartz artefacts in Helvetinhaudanpuro:

Bipolar core (1); bipolar flake $(2,3)$; platform core (4); platform flake $(5,6)$; pressure flake $(7$, 8, 10); pressure blade (9) (1 - KM 35473:107, 2 - KM 34661:240, 3 - KM 35473:963, 4 - KM 35473:893, 5 - KM 34661:52, 6 - KM 35473:888, 7 - KM 34661:193, 8 - KM 34661:49b, 9 - KM 35473:440, 10 - KM 34661:225) (photos by Aivar Kriiska, technical realization Kristel Roog)

the difference in percussion, probably even the use of pressure flaking (Fig. 4: 7-10). The signs of pressure flaking in flint and other rock types include regular shape as well as the almost complete absence of compression waves, eraillure scars and bulbs of percussion ${ }^{46}$. These traits are usually hard to detect in quartz, and therefore it is particularly complicated to distinguish direct percussion from indirect percussion in this material. It is difficult, however, to explain the manufacturing of the Helvetinhaudapuro blades in any other way.

Signs of possible pressure flaking were detected only in 41 artefacts $(0,02 \%$ from qurtz artefacts), out of which 24 (59\%) were flakes, 5 (12\%) blades and 12 (29\%) cores. As mentioned, identification of pressure flaking in fragmentary quartz material is complicated and somewhat questionable. Therefore, these figures include only complete or almost complete blades and flakes, which were manufactured using platform percussion. Thus, the actual number of tools produced with pressure flaking is probably larger than the numbers presented above.

The blades, flakes and cores, in which we could detect probable pressure flaking, were relatively large compared to the rest of the material. Their length varied between $3.1-17 \mathrm{~cm}$, width - between $1.1-14,5 \mathrm{~cm}$, and thickness - between $0.5-10.8 \mathrm{~cm}$. The

46 Sørensen M., Rankama T., Kankaanpää J., Knutsson K., Knutsson H., Melvold S., Eriksen B. V., Glørstad H. The First Eastern Migrations of People and Knowledge into Scandinavia: Evidence from Studies of Mesolithic Technology, $9^{\text {th }}-8^{\text {th }}$ Millennium BC // Norwegian Archaeological Review. 2013. Vol. 46, iss. 1. P. 19-56. 

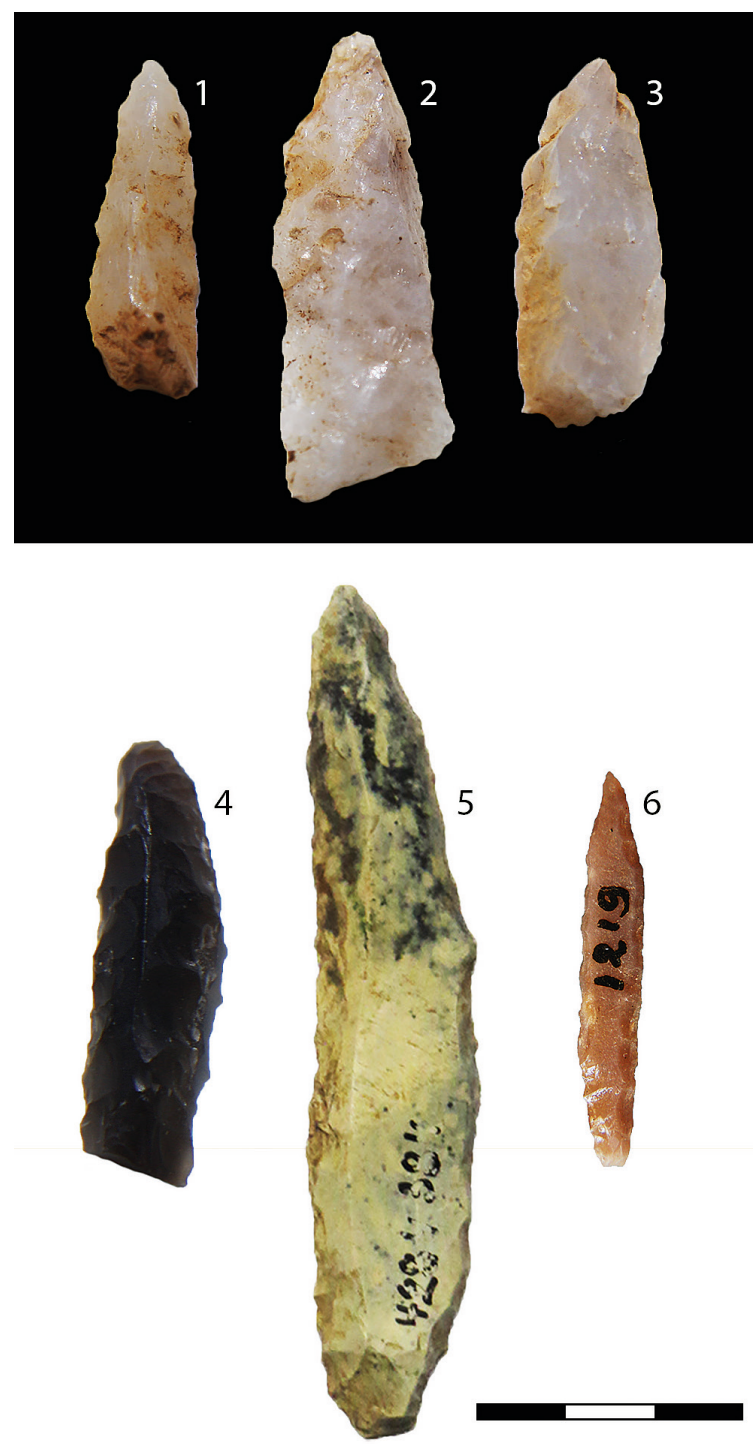

Fig. 5. Narrow retuched quartz and flint points from Helvetinhaudanpuro (1-4), Kunda Lammasmägi (Estonia) (5) and Lotova Gora (Russia) (6) (KM 36024:3305, KM 36024:3310, KM 36024:3319, KM 36024:1, AI 4284:384, 1219) (photos by Aivar Kriiska and Jarmo Kankanpää, technical realization Kristel Roog)

average length was $8,6 \mathrm{~cm}$, width $-6.4 \mathrm{~cm}$, and thickness $-3.2 \mathrm{~cm}$. A large number of cores (10 out of 41) probably explains at least partially the exceptional width and thickness in this material.

It is very difficult to distinguish whether these flakes were made by percussion technique or by, for instance, conical flaking. For clarity, it must be mentioned that in this 
study the conical core pressure blade concept is separated from the subsequent Mesolithic blade concept using keeled cores (often called 'handle cores') ${ }^{47}$.

Another feature detected in the Helvetinhaudanpuro quartz assemblage that also hints to flint technology are the narrow retouched points (Fig. 5: 1-3). There are three of these in total. The points were manufactured from blades or blade fragments, with dimensions ranging between $1.9-3.0 \mathrm{~cm}$ in length, maximum width being between $0.5-1.4 \mathrm{~cm}$, and maximum thickness between $0.4-0.7 \mathrm{~cm}$. The shape of the blade was utilized, and one or two edges exhibit extreme retouching on the dorsal surface. The shape and retouch is quite unusual for quartz. However, flint counterparts have been found in Early Mesolithic settlement sites in the Eastern and Northern European forest zone. In fact, among the lithic material from Helvetinhaudanpuro, there is one flint point (measuring $2.8 \times 0.7 \times 0.5 \mathrm{~cm}$ ) that has been fashioned in the same way as the quartz points (Fig. 5: 4).

Specific groups of artefacts related to the percussion of the quartz is in Helvetinhaudanpuro are 19 anvil stones (see Table 2 and Fig. 6) and three hammerstones. The anvils are relatively soft stones ( 5 on the Mohs' hardness scale) with indentations of different size on one or several sides. The largest of these stones has dimensions of $32.0 \times 21.5 \times 12.0 \mathrm{~cm}$. Most probably, anvil stones were used for bipolar percussion of quartz, but one cannot rule out the possibility of using them in some cases in pressure flaking as platforms, around which a construction withstanding heavier pressure was built.
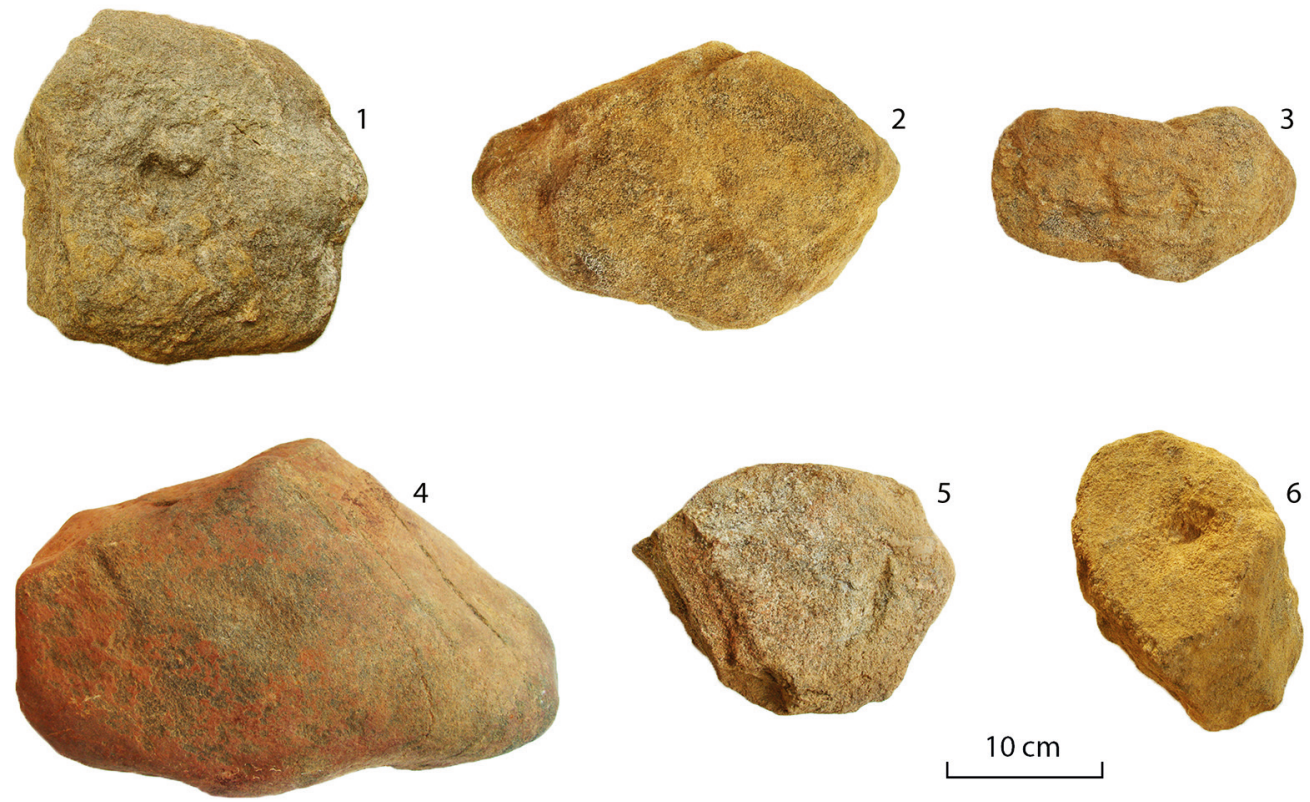

Fig. 6. Anvil stones found from Helvetinhaudanpuro:

1 - KM 36024:2030; 2 - KM 36024:2584; 3 - KM 36024:2029; 4 - KM 36024:2086; 5 - KM 36024:2437; 6 - KM 36024:2583 (photos by Tapani Rostedt and Aivar Kriiska, technical realization Kristel Roog)

47 Sørensen M., Rankama T., Kankaanpää J., Knutsson K., Knutsson H., Melvold S., Eriksen B. V., Glørstad H. The First Eastern Migrations of People and Knowledge into Scandinavia... P. 19-56. 
Table 2. Anvil stones from the Helvetinhaudanpuro site

\begin{tabular}{|c|c|c|c|c|c|c|c|c|c|}
\hline No & $\begin{array}{c}\text { Number of } \\
\text { museum } \\
(\mathrm{KM})\end{array}$ & 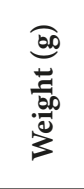 & 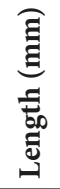 & 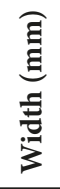 & 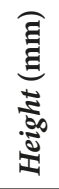 & 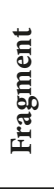 & 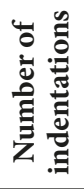 & $\begin{array}{c}\text { Dimension of } \\
\text { indentations }(\mathrm{mm})\end{array}$ & $\begin{array}{c}\text { Smaller } \\
\text { use marks }\end{array}$ \\
\hline 1 & $34661: 244$ & 2950 & 197 & 148 & 60 & $\mathrm{x}$ & 6 & $24-45 \times 18-30 \times 2-8$ & $\mathrm{x}$ \\
\hline 2 & 35473: 521 & 483,2 & 120 & 75 & 65 & $\mathrm{x}$ & 4 & $27-9 \times 17 \times 2-5$ & \\
\hline 3 & 35473: 899 & 538,8 & 142 & 110 & 25 & $\mathrm{x}$ & 2 & $23-26 \times 23-26 \times 4$ & $\mathrm{x}$ \\
\hline 4 & 35473: 1009 & 1060 & 142 & 90 & 60 & & 2 & $30-32 \times 24-26 \times 3-5$ & $\mathrm{x}$ \\
\hline 5 & 35473: 1076 & 7200 & 258 & 178 & 105 & & 2 & $40-45 \times 35-40 \times 2$ & $\mathrm{x}$ \\
\hline 6 & 36024: 586 & 168 & 93 & 60 & 23 & $\mathrm{x}$ & 0 & & $\mathrm{x}$ \\
\hline 7 & 36024: 665 & 3,5 & 23 & 22 & 6 & $\mathrm{x}$ & 1 & $25 \times 25 \times 2$ & \\
\hline 8 & 36024: 2029 & 1390 & 180 & 108 & 60 & & 6 & $26-42 \times 15-33 \times 3-7$ & \\
\hline 9 & 36024: 2030 & 3762 & 210 & 200 & 50 & & 11 & $20-43 \times 20-43 \times 2-8$ & $\mathrm{x}$ \\
\hline 10 & 36024: 2031 & 253 & 87 & 60 & 34 & $\mathrm{x}$ & 1 & $13 \times 9 \times 2$ & $\mathrm{x}$ \\
\hline 11 & 36024: 2033 & 1655 & 180 & 126 & 45 & & 2 & $33-51 \times 22-26 \times 3-5$ & $\mathrm{x}$ \\
\hline 12 & 36024: 2034 & 4021 & 237 & 126 & 104 & & 1 & $47 \times 40 \times 4$ & $\mathrm{x}$ \\
\hline 13 & 36024: 2035 & 745 & 105 & 98 & 70 & & 8 & $28-42 \times 24-28 \times 4-7$ & $\mathrm{x}$ \\
\hline 14 & 36024: 2086 & 9300 & 320 & 215 & 120 & & 1 & $59 \times 47 \times 4$ & $\mathrm{x}$ \\
\hline 15 & 36024: 2437 & 638 & 109 & 81 & 56 & & 2 & $16-25 \times 12-17 \times 2-4$ & $\mathrm{x}$ \\
\hline 16 & 36024: 2582 & 842 & 85 & 79 & 71 & & 6 & $19-42 \times 14-36 \times 3-8$ & $\mathrm{x}$ \\
\hline 17 & 36024: 2583 & 1546 & 146 & 97 & 68 & & 8 & $24-41 \times 24-41 \times 4-8$ & $\mathrm{x}$ \\
\hline 18 & 36024: 2584 & 5450 & 200 & 145 & 97 & & 10 & $18-36 \times 9-30 \times 3-5$ & $\mathrm{x}$ \\
\hline 19 & 36024: 3253 & 2600 & 177 & 165 & 53 & & 1 & $20 \times 20 \times 2$ & \\
\hline
\end{tabular}

\section{Discussion and conclusion}

Human curiosity and creativity, the ability to create 'friendly model environments in hostile environments', and first and foremost, the ability to decide whether to be innovative or conservative makes every one of us a unique creature. Nevertheless, it is difficult to imagine a society that can function by itself without having any impact on its surroundings. Shelter, clothing, nourishment and overall life style are largely dependent on the environment. In fact, the challenges of and adaptations to the environment are reflected in one way or another in almost every aspect of human society ${ }^{48}$. Anyhow, humans do not just passively adapt to their environments, but they also shape them. People from different cultures shaped and took advantage of their environments in a variety of ways. These differences can be seen in both technology and the way in which people experience their surroundings. Relying solely on ecological models of human-environ-

48 Nuñez M., Okkonen J. Environmental Background for the Rise and Fall of Villages and Megastructures in North Ostrobotnia 4000-2000 cal BC // Dig it all. Papers dedicated to Ari Siiriäinen / ed. by M. Huurre, Jyväskylä, 1999. P.112; Rankama T. The colonization of northernmost Finnish Lappland and the inland areas of Finnmark // Mesolithic on the Move / eds L. Larsson, H. Kindgren, K. Knutsson, D. Loeffler and A. Åkerlund. Oxford, 2003. P.43-44. 
ment relationships is always questionable, because archaeologists create these models based on their own cultural experiences, unconsciously or not ${ }^{49}$.

To create an accurate image of society, it is necessary to study, for instance, how economic and technological changes impact the social structures of societies. In this way, society is seen as a complex entity with constant and daily conflicts in between challenges and needs. Personal challenges, ancestral customs and social norms created by society become the influencers. Thus, society is not viewed as a coherent unit, but rather as a loose alliance where every individual has a function and needs. Through compromise and adaptation, together they create the society and its image to the outside world ${ }^{50}$.

The reasons for temporal-geographic shifts and changes within society should be looked for not only in ecological explanations but also in internal sociocultural actors. Both approaches can be studied independently, but for better results, it is beneficial to everyone to compare the interdependence of the two. In this way, it is possible to avoid the overuse of environmental determinism, in which the natural environment is seen as the main factor that shapes culture.

In the Helvetinhaudanpuro material, we detected characteristics connected to adaptation to the local raw material - quartz - but the material also contained technical achievements and tool shapes which indicate a deeper socio-cultural background. Technology is a vital research tool when attempting to understand the persistence of occupation and social connections in cases where the raw materials change. In Finland, we are only at the beginning of understanding the earliest occupation, currently concentrating on collecting and describing the empirical evidence, but we should also keep in mind the long-term goal of studying the diversity of the society. The Helvetinhaudanpuro material has strong explanatory potential for studying the beginning of the local habitation.

The area of Finland was first inhabited after the last Ice Age, according to the newest data, approximately soon after $9000 \mathrm{cal} \mathrm{BC}^{51}$. The peopling of Finland was part of the rapid colonisation of the Eastern and Northern European forest zone, extending from the Baltic Sea all the way to the Urals. In the early phases of colonisation, close contact with the homeland continued, and through wide social networks, raw materials, particularly flint, were also exchanged. For instance, flint makes up almost half of the lithics at the Saarenoja 2 settlement site in Southern Finland, the only Early Mesolithic site in this micro region with a relatively short occupation period (c. $8700 \mathrm{cal} \mathrm{BC})$ that has been extensively excavated to date ${ }^{52}$.

49 Uleberg E. Cultural Landscapes in Stone Age Research // The Mesolithic of Central Scandinavia / ed by J. Boaz. Oslo. 1999. P. 41; Welinder S. Människor och landskap. (Aun, vol. 15). Uppsala, 1992. P. 63.

50 Tilley C. Conceptual Frameworks for the explanation of Sosio-cultural Change // Pattern of the Past / eds I. Hodder I, G. Isaac, N. Hammond. Cambridge. 1981. P. 368.

${ }_{51}$ Pesonen P., Hertell E., Simponen L., Mannermaa K., Manninen M. A., Rostedt T., Taipale, N., Tallavaara M. Postglacial pioneer settlement in the Lake Sarvinki area, eastern Finland. Lateglacial and Postglacial Pioneers in Northern Europe // British Archaeological Reports, International Series. Vol.2599. Oxford, 2014. P. 174-190; Kriiska A., Rostedt T., Jussila T. The Development of Early Mesolithic Social Networks During the Settlement of Virgin Lands in the Eastern Baltic Sea Region-Interpreted through Comparison of Two Sites in Finland // Comparative Perspectives on Past Colonisation, Maritime Interaction and Cultural Integration (New Directions in Anthropological Archaeology). South Yorkshire, 2016. P. 34.

52 Kriiska A., Rostedt T., Jussila T. The Development of Early Mesolithic Social Networks During the Settlement of Virgin Lands in the Eastern Baltic Sea Region- Interpreted through Comparison of Two Sites in Finland // Comparative Perspectives on Past Colonisation, Maritime Interaction and Cultural Integration. (New Directions in Anthropological Archaeology). South Yorkshire, 2016. P. 25. 
Flint does not occur naturally in Finland and therefore quartz usually became the substitute for it in southernmost Finland. The shift in raw materials took place within a few hundred years and appears to have coincided with the change in social networks related to the break in connections with the homeland ${ }^{53}$. Helvetinhaudanpuro belongs to the second phase of early colonisation of Finland, for which one of the characteristics is the use of local materials. Foreign raw materials, in particular flint, make up a marginal amount of the material excavated $(0.07 \%$ of the total lithic assemblage). There is no reason to doubt that the first settlers of Helvetinhaudanpuro had already been using quartz before arriving at the site. Some of the signs indicating that people were already familiar with quartz are the overall mastery of quartz reduction and several carefully crafted quartz objects that would not have been of such high quality if the population was just experimenting with quartz knapping ${ }^{54}$.

The quartz techniques seen in Helvetinhaudanpuro are very similar to those from other Finnish Mesolithic sites - bipolar technique dominates, but platform percussion was also used to some extent ${ }^{55}$. However, some items are unusual, even special, and more comparable to flint than quartz material.

In both materials, tools are dominated by scrapers, but what connects the two technologically and morphologically events are the Helvetinhaudanpuro points. To our knowledge, no quartz counterparts have been found to date in other parts of Finland. Similar points from flint have been found in Saarenoja 2 (see Fig. 5: 5) and Lahti Ristola in Finland, in Kunda Lammasmägi (see Fig. 5: 5) and Pulli in Estonia, as well as in Veschevo 2 on the Karelian Isthmus and Lotova Gora (information from Tuija Rankama and Jarmo Kankaanpää) (see Fig. 5: 6) on the Vologda region in Russia. ${ }^{56}$

The second characteristic of the Helvetinhaudanpuro assemblage is the possible use of pressure flaking in quartz knapping. The abnormally straight blades and flakes lacking eraillure scars as well as some cores are an indicator of pressure flaking, but proving this hypothesis requires further research and experimental knapping. If indeed we have evidence of pressure flaking, then this assemblage is unique with no precedents in Finland or the Eastern Baltic.

Pressure flaking is generally associated with other lithics than quartz. Pressure flaking was used with the intention of producing an abundance of tools or blanks ${ }^{57}$. Pressure

53 Ibid. P. 34.

${ }^{54}$ Knutsson H., Knutsson K., Molin F., Zetterlund P. From flint to quartz: Organisation of lithic technology in relation to raw material availability during the pioneer process of Scandinavia // Quaternary International. 2016. Vol. 424. P. 32-57.

55 Jussila T., Kriiska A., Rostedt T. The mesolithic Settlement in NE Savo, Finland and the earliest Settlement in the Eastern Baltic Sea // Acta Archaeologica. 2007. Vol.78, iss. 2. P. 143-162; and the literature mentioned there.

56 Jussila T., Kriiska A., Rostedt T. Saarenoja 2 - An Early Mesolithic Site in South-Eastern Finland: Preliminary Results and Interpretations of Studies Conducted in 2000 and 2008-10 // Fennoscandia archaeological. 2012. Vol. XXIX. P. 3-27; Takala H. The Ristola Site in Lahti and the Earliest Postglacial Settlement of South Finland. Jyväskylä, 2003.

57 Sørensen M. Teknologiske traditioner I Maglemosekulturen. En diakron analyse av Maglemosekulturens flækkeindustri // Stenalderstudier. Tidlig Mesolitiske jægere og samlere i Sydskandinavien / ed. by E. B. V. Århus. Jutland Archaeological Society. 2006. P. 19-77; Sørensen M. The Arrival and Development of Pressure Blade Technology in Southern Scandinavia // The Emergence of Pressure Blade Making. From Origin to Modern Experimentation / ed. by P. M. Desrosiers. New York, 2012. P.237-260; Sulgostowska Z. The Earliest Mesolithic Settlement in North-Eastern Poland // The Earliest Settlement in Scandinavia. Acta Archaeologica Lundensia. Series in 8, no. 24. Stockholm, 1996. P. 297-305; Sulgostowska Z. Final Palaeolithic 
flaking is not commonly seen in the early colonisation wave in Finland, but there is evidence of its use in the lithic material from the Early Mesolithic Sujala in Utsjoki ${ }^{58}$, Jokivarsi 1 in Eno and Saarenoja 2 in Lappeenranta ${ }^{59}$ settlement sites. The raw material used in Sujala was metamorphic sand stone, whereas flint was the raw material used at the Jokivarsi in Eno, Ristola in Lahti and Saarenoja 2 in Lappeenranta settlement sites.

Pressure flaking in itself is an unusual lithic reduction method. Experimental archaeological studies have shown that adopting the technique does not take very long. In fact, the technique is learned faster than freehand percussion. Once the tools and constructions required had been manufactured, detaching blades from the core by applying pressure was actually a relatively simple process ${ }^{60}$.

The dating of pressure flaking varies in Eurasia. The technique is considered to have originated in Paleolithic Mongolia more than 20,000 years ago ${ }^{61}$. The oldest dates from Europe derive from the Eastern European Forest zone from where the technique seems to have spread to the west ${ }^{62}$. The earliest evidence near Finland dates to the Early Mesolithic, c. $9000 \mathrm{cal} \mathrm{BC}$ or slightly later. It coincides with the earliest Mesolithic colonisation of the Eastern and Northern European Forest zone (the Pulli period, c.9000-8500 cal $\mathrm{BC}$ ) and with the subsequent period when local cultures (e.g. Butovo, Kunda, Veretye) had already been developed. Pressure flaking was in use during the Mesolithic in both Russia and the Eastern Baltic ${ }^{63}$.

Masovian Cycle and Mesolithic Kunda Culture Relations // Tanged points cultures in Europe. Read at the international Archaeological Symposium, Lublin, September 13-16, 1993. Lublin, 1999. P. 85-93.

${ }_{58}$ Rankama T., Kankaanpää J. Eastern arrivals in post-glacial Lappland: The Sujala site 10000 cal BP // Antiquity. 2008. Vol. 82. P. 884-900.

${ }_{59}$ Jussila T., Kriiska A., Rostedt T. Saarenoja 2 - An Early Mesolithic Site in South-Eastern Finland: Preliminary Results and Interpretations of Studies Conducted in 2000 and 2008-10 // Fennoscandia archaeological. 2012. Vol. XXIX. P. 15.

60 Pelegrin J. Prehistoric lithic technology: some aspects of research // Archaeological Review from Cambridge. 1990. Vol.9, iss. 1. P.116-125; Sørensen M. The Arrival and Development of Pressure Blade Technology in Southern Scandinavia // The Emergence of Pressure Blade Making. From Origin to Modern Experimentation / ed. by P. M. Desrosiers. New York. 2012. P.250; Sørensen M. et al. The First Eastern Migrations of People and Knowledge into Scandinavia: Evidence from Studies of Mesolithic Technology, $9^{\text {th }}-8^{\text {th }}$ Millennium BC // Norwegian Archaeological Review. 2013. Vol. 46, iss. 1. P. 23.

${ }^{61}$ Inizan M.-L. Pressure débitage in the old world: forerunners, researchers, geopolitics - handing on the Baton // The Emergence of Pressure Blade Making. From Origin to Modern Experimentation. New York, 2012. P. 11-43; Darmark K. Surface Pressure Flaking in Eurasia: Mapping the Innovation, Diffusion and Evolution of a Technological Element in the Production of Projectile Points // The Emergence of Pressure Blade Making. From Origin to Modern Experimentation. New York, 2012. P.261-284.

62 Sørensen M., Rankama T., Kankaanpää J., Knutsson K., Knutsson H., Melvold S., Eriksen B. V., Glørstad H. The First Eastern Migrations of People and Knowledge into Scandinavia: Evidence from Studies of Mesolithic Technology, 9th-8th Millennium BC // Norwegian Archaeological Review. 2013. Vol. 46, iss. 1. P. 19-56.

${ }^{63}$ Oshibkina $S$. V. Tanged point industries in the northwest Russia. // Tanged points cultures in Europe. Read at the international Archaeological Symposium, Lublin, September 13-16, 1993. Lublin, 1999. P.325-336; Koltsov L. V., Zhilin M. G. Tanged point cultures in the upper Volga basin. Tanged points cultures in Europe Lublin, 1999. P.346-360; Zhilin M. G. Early Mesolithic communication networks in the East European forest zone // Mesolithic on the Move. Oxford, 2003. P.688-693; Zhilin M. G. The terminal Paleolithic - Early Mesolithic of the Upper Volga and colonization of the north-west of eastern Europe // Pioneer settlement and colonization Processes in the Barents Region. Vuollerim papers on Hunter-Gatherer Archaeology. Vol. 1. Vuollerim, 2005. P. 163-179; Kriiska A., Lõhmus M. Archaeological fieldwork on Kivisaare Stone Age burial ground and settlement site // Archaeological fieldwork in Estonia 2004. Tallinn, 2005. P. 31-43. 
Pressure flaking is one of many techniques and formal similarities that connected these areas in the Early Mesolithic. The similarities in lithic technology also include the conical core pressure blade concept, flint arrowheads with a tang and retouch on the ventral side of edge, flint edge burins on blades, flint chisels etc. ${ }^{64}$

The same wide distribution area is seen in bone tools and technology, particularly with regard to arrowheads ${ }^{65}$. The acidic nature of the soil in Finland causes rapid deterioration of organic materials and therefore only burned bones usually survive. Because of this problem, only two tools have been found that can be securely assigned to the Early Mesolithic based on typology: a tip fragment of an arrowhead with a biconical head and several fragments of slotted point from Lappeenranta Muilamäki. Flint inserts associated with slotted points have been found in many locations: Saarenoja 2 (ca. 10\% of all flint tools from the site), Muilamäki, Helvetinhaudanpuro, Lahti Ristola and Eno Jokivarsi 1 settlement sites ${ }^{66}$. There is at least one quartz insert from Helvetinhaudanpuro (NM 36024:3316, bipolar flake measuring $2.7 \times 0.5 \times 0.2 \mathrm{~cm}$ ).

To sum up, the quartz assemblage from the Helvetinhaudanpuro settlement site, dating approximately to $8500 \mathrm{cal} \mathrm{BC}$, is a unique link between flint and quartz knapping technology. The material is diverse and representative, and due to the short occupation sequence this site is an exceptional location for studying the early period of change in raw materials in Finland.

The majority of the quartz artefacts from the site are analogous to the 'normal' and previously described quartz material from Finnish Mesolithic sites younger than Helvetinhaudanpuro. Nevertheless, the assemblage contains retouched points and insert from quartz that seem to connect the material more to flint than quartz and through this to older settlements in Finland and wider areas in Eastern and Northern Europe. It appears that pressure techniques usually associated with flint knapping were adopted for use in quartz knapping at the Helvetinhaudapuro site, at least for a while. This is a very unusual feature in quartz reduction, and in fact, the first possible evidence from Finland, Russian Karelia and Estonia for this technological 'memory' from the initial colonisation period in the Early Mesolithic.

\section{References}

Ailio J. Die Steinzeitliche Wohnplatzfunde in Finland I-II. Helsingfors, Kommission bei der Akademischen Buchhandlung, 1909, 394 p.

${ }^{64}$ Ostrauskas T. Mesolithic Kunda Culture. A glimpse from Lithuania // De temporibus antiquissimis ad honorem Lembit Jaanits (Muinasaja teadus, vol.8). Tallinn, 2000. P.67-180; Jussila T., Kriiska A., Rostedt T. Saarenoja 2 - An Early Mesolithic Site in South-Eastern Finland: Preliminary Results and Interpretations of Studies Conducted in 2000 and 2008-10 // Fennoscandia archaeological. 2012. Vol. XXIX. P. 3-27; Sørensen M. et al. The First Eastern Migrations of People and Knowledge into Scandinavia: Evidence from Studies of Mesolithic Technology, 9th-8th Millennium BC // Norwegian Archaeological Review. 2013. Vol. 46, iss. 1. P. 19-56.

65 Ibid. P. 19-56; Zhilin M. Early Mesolithic bone arrowheads from the Volga-Oka interfluve, Central Russia // Fennoscandia archaeological. 2015. Vol.XXXII. P.35-54.

${ }^{66}$ Kriiska A., Rostedt T., Jussila T. The Development of Early Mesolithic Social Networks During the Settlement of Virgin Lands in the Eastern Baltic Sea Region- Interpreted through Comparison of Two Sites in Finland // Comparative Perspectives on Past Colonisation, Maritime Interaction and Cultural Integration (New Directions in Anthropological Archaeology) / eds L. Melheim, H. Glørstad, Z. Glørstad. South Yorkshire, 2016. P. 27. 
Andrefsky W. Jr. Raw-material availability and the organization of technology. American Antiquity, 1994, vol. 59, iss. 1, pp. 21-34.

Andrefsky W. Jr. Lithics. Macroscopic approaches to analysis (Cambridge Manuals in Archaeology). Cambridge, 1998, 326 p.

Bamforth D. B. Technological efficiency and tool curation. American Antiquity, 1986, vol.51, iss. 1, pp.3850.

Bleed P. The Optimal Design of Hunting Weapons: Maintainability or Reliability. American Antiquit, 1986, vol. 51, iss. 4, pp. 737-747.

Brantingham P. J., Olsen J.W., Rech J.A. and Krivoshapkin A.I. Raw Material Quality and Prepared Core Technologies in Northeast Asia. Journal of Archaeological Science, 2000, vol. 27, pp. 255-271.

Callahan E. An evaluation of the lithic technology in middle Sweden during the Mesolithic and Neolithic (Aun, vol. 8). Uppsala, Societas Archaeologica Upsaliensis, 1987, 72 p.

Callahan E., Forsberg L., Knutsson K., Lindgren C. Frakturbilder. Kulturhistoriska kommentarer till det säregna sönderfallet vid bearbetning av kvarts. Tor, 1992, vol. 24, pp. 27-63.

Crabtree D. E. An introduction to the technology of stone tools (Occasional papers of the museum, number 28). Pocatello, Idaho, Idaho State University, 1972. 98 p.

Darmark K. Surface Pressure Flaking in Eurasia: Mapping the Innovation, Diffusion and Evolution of a Technological Element in the Production of Projectile Points. The Emergence of Pressure Blade Making. From Origin to Modern Experimentation. Ed. by P. M. Desrosiers. New York, 2012, pp. 261-284.

Eskola P. Kidetieteen, mineralogian ja geologian alkeet. Porvoo, Werner Söderström Osakeyhtiö, 1957. 337 p.

Europaeus A. Ojalankankaan kivikauden löytöpaikka Alavudella. Suomen Museo 1916. Helsinki, 1919, pp. 73-82.

Gero J.M. Assessing social information in material objects: how well do lithics measure up? Time, energy and stone tools. Ed. by R. Torrence. Cambridge, Cambridge University Press, 1989, pp. 92-105.

Hayden B. Practical and Prestige Technologies: The Evolution of Material Systems. Journal of Archaeological Method and Theory, 1998, vol. 5, iss. 1, pp.1-55.

Hertell E., Manninen M. A. Rävåsens kvartsmaterial. Finskt Museum 2002. Helsinki, 2005, pp. 84-100.

Hertell E., Tallavaara M. High Mobility or Gift Exchange: early Mesolithic chipped lithics in Southern Finland. Mesolithic interfaces: Variability in lithic technologies in eastern Fennoscandia. Ed. by T. Rankama. Saarijärvi, The Archaeological Society of Finland, 2011, pp.11-41.

Inizan M.-L. Pressure débitage in the old world: forerunners, researchers, geopolitics - handing on the Baton. The Emergence of Pressure Blade Making. From Origin to Modern Experimentation. Ed. by P. M. Desrosiers. New York, 2012, pp. 11-43.

Jussila T. Saimaan kalliomaalausten ajoitus rannansiirtymiskronologian perusteella. Saimaan ja Päijänteen alueen kalliomaalausten sijainti ja syntyaika. (Kalliomaalausraportteja 1). Ed. by P. Kivikäs, T. Jussila, R. Kupiainen. Jyväskylä, Kivikäs - muinaistaidekeskus, 1999, pp. 113-133.

Jussila T., Kriiska A., Rostedt T. Varhaismesoliittisesta asutuksesta Koillis-Savossa - alustavia tuloksia Juankosken Akonpohjan Helvetinhaudanpuron asuinpaikan kiviaineistosta. Arkeologia ja kulttuuri. Uutta kivikauden tutkimuksessa. Arkeologipäivät 2005. Ed. by T. Mökkönen \& P. Pesonen. Hamina, Suomen Arkeologinen Seura, 2006, pp. 50-61.

Jussila T., Kriiska A., Rostedt T. The mesolithic Settlement in NE Savo, Finland and the earliest Settlement in the Eastern Baltic Sea. Acta Archaeologica 2007, vol. 78, iss. 2, pp. 143-162.

Jussila T., Kriiska A., Rostedt T. Saarenoja 2 - An Early Mesolithic Site in South-Eastern Finland: Preliminary Results and Interpretations of Studies Conducted in 2000 and 2008-10. Fennoscandia archaeologica, 2012, vol.XXIX, pp.3-27.

Kankaanpää J.\& Rankama T. Early Mesolithic Pioneers in Northern Finnish Lappland. Pioneer Settlements and Colonization Processes in the Barents Region. (Vuollerim Papers on Hunter-Gatherer Archaeology 1). Ed. by H. Knutsson. Vuollerim, Vuollerim 6000 År, 2005, pp. 109-161.

Kankaanpää J., Rankama T. Spatial Patterns of the Early Mesolithic Sujala Site, Utsjoki, Finnish Lappland. Mesolithic interfaces: Variability in lithic technologies in eastern Fennoscandia. Ed. by T. Rankama. Saarijärvi, The Archaeological Society of Finland, 2011, pp. 42-63.

Kelly R. L. The three sides of a biface. American Antiquity, 1988, vol.53, pp.717-734.

Koltsov L. V., Zhilin M. G. Tanged point cultures in the upper Volga basin. Tanged points cultures in Europe. Eds S. K. Kozlowski, J. Gurba, L. L. Zalisnyak. Lublin, Maria Curie-Skłodowska, 1999, pp. 346-360.

Knutsson K. Making and using stone tools. The analysis of the lithic assemblages from the Middle Neolithic sites with flint in Västerbotten, northern Sweden. (Aun, vol. 11). Uppsala, Societas Archaeologica Upsaliensis, 1988, $206 \mathrm{p}$. 
Knutsson K. Garaselet-Lappviken-Rastklippan. Introduktion till en diskurssion om Norrlands Äldsta Bebyggelse. Tor, 1993, vol. 25, pp. 5-51.

Knutsson H., Knutsson K., Molin F., Zetterlund P. From flint to quartz: Organisation of lithic technology in relation to raw material availability during the pioneer process of Scandinavia. Quaternary International, 2016, vol.424, pp. 32-57.

Kriiska A., Lõhmus M. Archaeological fieldwork on Kivisaare Stone Age burial ground and settlement site. Archaeological fieldwork in Estonia 2004. Tallinn, Muinsuskaitseamet, 2005, pp. 31-43.

Kriiska A., Rostedt T., Jussila T. The Development of Early Mesolithic Social Networks During the Settlement of Virgin Lands in the Eastern Baltic Sea Region- Interpreted through Comparison of Two Sites in Finland. Comparative Perspectives on Past Colonisation, Maritime Interaction and Cultural Integration. (New Directions in Anthropological Archaeology). Eds L. Melheim, H. Glørstad, Z. Glørstad. South Yorkshire, Equinox publishing, 2016, pp. 19-40.

Kuhn S. L. Mousterian lithic technology. Princeton, Princeton University Press, 1995, 209 p.

Luho V. Die Askola-Kultur. Die frühmesolitische Steinzeit in Finnland. Suomen Muinaismuistoyhdistyksen Aikakauskirja. Vol.57. Helsinki, Suomen Muinaismuistoyhdistys, 1956, 167 p.

Luho V. Die Suomusjärvi-Kultur. Die mittel- und spätmesolitische zeit in Finnland. Suomen Muinaismuistoyhdistyksen Aikakauskirja. Vol.66). Helsinki, Suomen Muinaismuistoyhdistys, 1967, $124 \mathrm{p}$.

Manninen M. A., Tallavaara M., Hertell E. Subneolithic bifaces and flint assemblages in Finland. Outlining the history of research and future questions. Uniting Sea. Stone Age societies in the Baltic Sea region. (Papers in Archaeology, vol.33). Eds C. Samuelsson, N. Ytterberg Occasional. Uppsala, Uppsala Universitet, 2003, pp. 161-179.

Manninen M.A. Culture, Behavior and the 8200 cal BP Cold Event. Organisational Change and Culture-environmental Dynamics in Late Mesolithic Northern Fennoscandia. (Monographs of the Archaeological Society of Finland, vol. 4.) Helsinki, Archaeological society of Finland, 2014, 87 p.

Manninen M.A., Knuttson K. Lithic raw material diversification as an adaptive strategy - Technology, mobility and site structure in Late Mesolithic northernmosts Europe. Journal of Athropological Archaeology, 2014, vol. 33, pp. 84-98.

Matiskainen H. Beiträge zur Kentnisse der mesolitischen Schrägschneidepfeile und Mikrolithen aus Quarz. Studia praehistorica Fennica C F Meinander septuagenario dedicata. ISKOS, vol. 6. Ed. by T. Edgren. Helsinki, Suomen muinaismuistoyhdistys, 1986, pp.77-98.

Matiskainen H. The Palaeoenvironment of Askola, Southern Finland. Mesolithic Settlement and Subsistence 10000-6000 b.p. (ISKOS, vol. 8). Helsinki, Suomen muinaismuistoyhdistys, 1989, 97 p.

Nelson M. C. The Study of Technological Organization. Archaeological Method and Theory, vol. 3, iss. 1. Ed. by M. B. Schiffer. Arizona, University of Arizona Press, 1991, pp. 57-100.

Nuñez M., Okkonen J. Environmental Background for the Rise and Fall of Villages and Megastructures in North Ostrobotnia 4000-2000 cal BC. Dig it all. Papers dedicated to Ari Siiriäinen. Ed. by M. Huurre. Jyväskylä, Finnish Antiquarian Society and Archaeological Society of Finland, 1999, pp. 105-115.

Olofsson A. Early Colonization of Northern Norrland: Technology, Chronology, and Culture. Pioneer Settlement in the Mesolithic of Northern Sweden. (Archaeology and Environment 16). Umeå, Umeå University Department of Archaeology and Sami Studies, 2003, 159 p.

Oshibkina S. V. Tanged point industries in the northwest Russia. Tanged points cultures in Europe. Read at the international Archaeological Symposium, Lublin, September 13-16, 1993. Eds S. Kozlowski, J. Gurba, L. I.Zalisnyak. Lublin, Maria-Curie Sklodowska University Press, 1999, pp. 325-336.

Ostrauskas T. Mesolithic Kunda Culture. A glimpse from Lithuania. De temporibus antiquissimis ad honorem Lembit Jaanits. Vol. 8: Muinasaja teadus. Eds V.Lang, A. Kriiska. Tallinn, Ajaloo Instituut, 2000, pp. 67-180.

Pankrušev G. A. Karjalan mesolittinen ja neolitttinen kausi. Vol. 1. Helsinki, Mesoliittinen kausi,1994, 122 p.

Parry W. J., Kelly R. L. Expedient Core Technology and Sedentism. The Organization of Core Technology. Eds J. K. Johnson, C. A. Morrow. Boulder, Westview Press, 1987, pp. 285-304.

Pelegrin J. Prehistoric lithic technology: some aspects of research. Archaeological Review from Cambridge, 1990, vol. 9, issue. 1, pp. 116-125.

Pelegrin J. Blade-Making Techniques from the Old World: Insights and Applications to Mesoamerican Obsidian Lithic Technology. Mesoamerican Lithic Technology: Experimentation and interpretation. Ed. by K. Hirth. Salt Lake City, University of Utah Press, 2003, pp. 55-71.

Pesonen P., Tallavaara M. Esihistoriallinen leiripaikka Lohjan Hossanmäellä- kvartseja ja yllättäviä ajoituksia. Suomen Museo 2005. Helsinki, 2006, pp.5-26. 
Pesonen P., Hertell E., Simponen L., Mannermaa K., Manninen M. A., Rostedt T., Taipale, N., Tallavaara M. Postglacial pioneer settlement in the Lake Sarvinki area, eastern Finland. Lateglacial and Postglacial Pioneers in Northern Europe. (British Archaeological Reports, International Series, vol.2599). Eds F. Riede, M. Tallavaara. Oxford, Archaeopress, 2014, pp. 174-190.

Pälsi S. Palomäen kivikautinen asuinpaikka Urjalassa. Suomen Museo 1913. Helsinki, 1913, pp. 63-79.

Rajala U. Kvartsiteknologian tutkiminen ja luokittelu Turun Niuskalan Kotirinteen kiukaiskeraamisen asuinpaikan vuosien 1983 ja 1984 kvartsilöydöt. Unpublished Master's thesis, University of Turku. Turku, $1995,129 \mathrm{p}$.

Rankama T. Ala-Jalve. Spatial, technological, and behavioral analyses of the lithic assemblage from a Stone Age Early Metal Age site in Utsjoki, Finnish Lapland. British Archaeological Reports International Series. Vol.681. Oxford, Archaeopress, 1997, 146 p.

Rankama T. Analyses of the Quartz Assemblages of Houses 34 and 35 at Kauvonkangas in Tervola. Huts and Houses. Stone Age and Early Metal Age Buildings in Finland. Ed. by H. Ranta. Helsinki, National Board of Antiquities, 2002, pp. 79-108.

Rankama T. The colonization of northernmost Finnish Lappland and the inland areas of Finnmark. Mesolithic on the Move. Papers presented at the Sixth International Conference on the Mesolithic in Europe, Stockholm 2000. Eds L. Larsson, H. Kindgren, K. Knutsson, D. Loeffler, A. Åkerlund. Oxford, Oxbow Books, 2003, pp. 414-430.

Rankama T., Kankaanpää J. Eastern arrivals in post-glacial Lappland: The Sujala site 10000 cal BP. Antiquity, 2008, vol. 82, pp. 884-900.

Rankama T., Kankaanpää J. Fast or slow pioneers? A view from Northern Lappland. Lateglacial and Postglacial Pioneers in Northern Europe. British Archaeological Reports, International Series. Vol. 2599. Eds F. Riede, M. Tallavaara. Oxford, Archaeopress, 2014, pp.147-160.

Räihälä O. Suomussalmen Salonsaari kivikautinen leiripaikka Kiantajärven rannalla. Kirjoitelmia arkeologian alalta. Kentältä poimittua 4. Museoviraston arkeologian osaston julkaisuja, vol. 7. Helsinki, Museovirasto, 1997, pp.5-23.

Reimer P. J., Bard E., Bayliss A., Beck J. W., Blackwell P. G., Bronk Ramsey C., Grootes P. M., Guilderson T. P., Haflidason H., Hajdas I., Hatte C., Heaton T. J., Hoffmann D. L., Hogg A. G., Hughen K. A., Kaiser K. F., Kromer B., Manning S. W., Niu M., Reimer R. W., Richards D. A., Scott E. M., Southon J. R., Staff R. A., Turney C.S.M., van der Plicht J. IntCal13 and Marine13 radiocarbon age calibration curves 0-50,000 years cal BP. Radiocarbon, 2013, vol. 55, issue. 4, pp. 1111-1150.

Saarnisto M. The late Weichselian and Flandrian History of the Saimaa Lake Complex. Commentationes physico-mathematicae, 1970, vol.37, pp.3-7.

Schulz H.-P. On the Mesolithic Quarz Industry in Finland. Fenno-Ugri et Slavi. Papers presented by the participants in the Finnish-Soviet Archaeological Symposium 'Studies in the Material Culture of the Peoples of eastern and Northern Europe' 10-16 May 1988 in the National Museum of Finland. (Iskos, vol.9). Ed. by T. Edgren. Helsinki, The Finnish Antiquarian Society, 1988, pp.7-23.

Schulz H.-P. Pioneerit pohjoisessa. Suomen varhaismesoliittinen asutus arkeologisen aineiston valossa. Suomen Museo 1996. Helsinki, 1996. 5-45.

Siiriäinen A. Yli-Iin Kierikin Asbestikeraamisen asuinpaikan kvartsiesineet. Lähdekriittinen tutkimus. Unpublished Master's thesis, University of Helsinki, Helsinki, 1968, 123 p.

Siiriäinen A. Quartz, Chert and Obsidian. A Comparison of Raw Materials in a Late Stone Age Aggregate in Kenya. Finskt Museum 1974. Helsinki, 1977, pp. 15-29.

Siiriäinen A. Problems of the East Fennoscandian Mesolithic. Finskt Museum 1977, Helsinki, 1981, pp. 5-31.

Sulgostowska Z. The Earliest Mesolithic Settlement in North-Eastern Poland. The Earliest Settlement in Scandinavia. (Acta Archaeologica Lundensia Series in 8, No 24). Ed. By L. Larsson. Stockholm, Almqvist \& Wiksell International, 1996, pp. 297-305.

Sulgostowska Z. Final Palaeolithic Masovian Cycle and Mesolithic Kunda Culture Relations. Tanged points cultures in Europe. Read at the international Archaeological Symposium, Lublin, September 13-16, 1993. Eds S. Kozlowski, J.Gurba, L.I.Zalisnyak. Lublin, Maria-Curie Sklodowska University Press, 1999, pp. 85-93.

Sørensen M. Teknologiske traditioner I Maglemosekulturen. En diakron analyse av Maglemosekulturens flækkeindustri. Stenalderstudier. Tidlig Mesolitiske jogere og samlere i Sydskandinavien. Ed. by E. B. V. Århus. Jutland Archaeological Society, 2006, 19-77.

Sørensen M. The Arrival and Development of Pressure Blade Technology in Southern Scandinavia. The Emergence of Pressure Blade Making. From Origin to Modern Experimentation. Ed. by P. M. Desrosiers. New York, 2012, pp. 237-260. 
Sørensen M., Rankama T., Kankaanpää J., Knutsson K., Knutsson H., Melvold S., Eriksen B. V., Glørstad H. The First Eastern Migrations of People and Knowledge into Scandinavia: Evidence from Studies of Mesolithic Technology, 9th-8th Millennium BC. Norwegian Archaeological Review, 2013, vol. 46, iss. 1, pp. 19-56.

Takala H. The Ristola Site in Lahti and the Earliest Postglacial Settlement of South Finland. Jyväskylä, Lahti City Museum, 2003, 205 p.

Tallavaara M., Manninen M. A., Hertell E. \& Rankama T. How flakes shatter. A critical evaluation of Quartz fracture analysis. Journal of Archaeological Science, 2010, vol. 37, 2442-2448.

Tilley C. Conceptual Frameworks for the explanation of Sosio-cultural Change. Pattern of the Past. Eds I. Hodder I, G. Isaac, N. Hammond. Cambridge, Cambridge University Press, 1981, pp.363-386.

Trigger B. G. A History of Archaeological Thought. Cambridge, Cambridge University Press, 1989, 500 p.

Uleberg E. Cultural Landscapes in Stone Age Research. The Mesolithic of Central Scandinavia. (Universitetets Oldsaksamlings Skrifter Ny Rekke nr. 22). Ed by J. Boaz. Oslo, Universitetets Oldsaksamling, 1999, pp. 39-45.

Welinder S. Människor och landskap. (Aun, vol.15). Uppsala, Societas Archaeologica Upsaliensis, 1992. $141 \mathrm{p}$.

Whittaker J. C. Flintknapping. Making and understanding stone tools. Austin, University of Texas Press,1994, $352 \mathrm{p}$

Zhilin M.G. Early Mesolithic communication networks in the East European forest zone. Mesolithic on the Move. Papers presented at the Sixth International Conference on the Mesolithic in Europe, Stockholm 2000. Eds L. Larsson, H. Kindgren, K. Knutsson, D. Loeffler, A. Åkerlund. Oxford, Oxbow Books, 2003, pp. 688-693.

Zhilin M. G. The terminal Paleolithic - Early Mesolithic of the Upper Volga and colonization of the northwest of eastern Europe. Pioneer settlement and colonization Processes in the Barents Region. (Vuollerim papers on Hunter-Gatherer Archaeology, vol. 1). Ed. by H. Knutsson. Vuollerim 6000 År: Vuollerim, 2005, pp. 163-179.

Zhilin M. Early Mesolithic bone arrowheads from the Volga-Oka interfluve, Central Russia. Fennoscandia archaeologica, 2015, vol. XXXII, pp. 35-54.

Статья поступила в редакцию 19 апреля 2018 г. Рекомендована в печать 12 марта 2019 г.

Received: April 19, 2018

Accepted: March 12, 2019 


\title{
Мезолитические стоянки Кильдинского пролива и проблема заселения Кольского полуострова в каменном веке
}

\author{
А. И. Мурашкин, Е. М. Колпаков
}

Для цитирования: Мурашкин А.И., Колпаков Е.М. Мезолитические стоянки Кильдинского пролива и проблема заселения Кольского полуострова в каменном веке // Вестник СанктПетербургского университета. История. 2019. Т. 64. Вып. 2. С. 666-682.

https://doi.org/10.21638/11701/spbu02.2019.214

Пути и время инициального заселения Северной Фенноскандии относятся к самым актуальным темам арктической археологии. В последнее десятилетие Кольская археологическая экспедиция Института истории материальной культуры РАН (КолАЭ ИИМК РАН) провела раскопки мезолитических стоянок Гусиный 4-7 на южном берегу Кильдинского пролива Баренцева моря. Стоянки расположены на древних морских террасах на высотах от 27-30 до 35 м н. у. м. На стоянке Гусиный 6 раскопом 16 м² исследовано квадратное слабо углубленное жилище размером $3 \times 3$ м, в нем обнаружены изделия из кварца, окремненного песчаника и кремня, в том числе серия черешковых наконечников «аренсбургского» облика и топоров на отщепах. По характеру инвентаря стоянка Гусиный 6 относится к кругу памятников фазы I по Б. Ульсену (Комса - по П. Вудману). Фаза I датируется 10000-9000 ВР и отражает первоначальное заселение Северной Фенноскандии вдоль норвежского побережья. Исследованная площадь на стоянках Гуси-

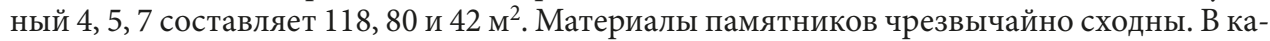
честве сырья использовался кремень, окремненный песчаник и кварц. Технологический контекст индустрии указывает на то, что расщепление на стоянках было направлено на получение пластин в технике отжима или удара через посредник. Набор орудий на стоянках ограничен. Большой серией представлены пластины с ретушью (зачастую намеренно фрагментированные), концевые скребки на пластинах, резцы на углу сломанной пластины. В коллекции стоянки Гусиный 5 имеется черешковый наконечник, оформленный пологой ретушью на вентральной поверхности. Ближайшие аналогии стоянкам Гусиный 4, 5 и 7 находятся в материалах стоянки Суяла (Северная Финляндия) и среди других памятников с так называемой восточной пластинчатой технологией, которая распространяется в Северной Фенноскандии после 9000 лн. Вероятно, она является свидетельством миграции населения из лесной зоны Восточной Европы.

Антон Игоревич Мурашкин - ст. преподаватель, Санкт-Петербургский государственный университет, Российская Федерация, 199034, Санкт-Петербург, Университетская наб., 7-9; a.murashkin@spbu.ru

Anton I. Murashkin - Senior Lecturer, St. Petersburg State University, 7-9, Universitetskaya nab., St. Petersburg, 199034, Russian Federation; a.murashkin@spbu.ru

Евгений Михайлович Колпаков - канд. ист. наук, ст. науч. сотр., Институт истории материальной культуры РАН, 191186, Российская Федерация, Санкт-Петербург, Дворцовая наб., 18; eugenkolp@yandex.ru

Evgeny M. Kolpakov - $\mathrm{PhD}$ in History, Senior Researcher, Institute of the History of Material Culture of the Russian Academy of Sciences, Dvortsovaya nab., 18, St. Petersburg, 191186, Russia; eugenkolp@yandex. $\mathrm{ru}$

(c) Санкт-Петербургский государственный университет, 2019 
Ключевые слова: Кольский полуостров, Северная Фенноскандия, мезолит, заселение, культура Комса.

\section{Mesolithic Sites of the Kildinsky Strait and the Problem of Settling the Kola Peninsula in the Stone Age}

\section{A. I. Murashkin, E. M. Kolpakov}

For citation: Murashkin A. I., Kolpakov E. M. Mesolithic Sites of the Kildinsky Strait and the Problem of Settling the Kola Peninsula in the Stone Age. Vestnik of Saint Petersburg University. History, 2019, vol. 64, iss. 2, pp. 666-682. https://doi.org/10.21638/11701/spbu02.2019.214 (In Russian)

The routes and the time of the initial colonization of Northern Fennoscandia are among the most actively discussed topics of the Arctic archeology. In the last decade the KolAE IHMC RAS excavated four Mesolithic sites of Gusiny 4-7 on the southern coast of Kildin Strait, Barents Sea. The sites are located on ancient marine terraces at the elevations from 27-30 to $35 \mathrm{~m}$ asl. Remnants of a shallow square dwelling structure $3 \times 3 \mathrm{~m}$ was investigated on Gusiny 6. The assemblage consists of quartz, silicified sandstone and chert items. There is set of tanged "Ahrensburgian» and single-edged points and flake-axes. Lithic assemblage of Gusiny 6 belongs to the phase I according to B. Olsen. The sites of that phase were dated back to 10000-9000 BP and represent the initial colonization of Northern Fennoscandia along the Norwegian coast. The excavated area of Gusiny 4, 5, 7 sites was 118,80 and $42 \mathrm{~m}^{2}$ respectively. Their assemblages are very similar and consist of chert, silicified sandstone and quartz artefacts. Technological context indicates that knapping process was aimed to blade-production in pressure technique or indirect percussion. Tools are normally restricted to retouched blades and lower amount of end-scrapers. Other types are represented by few items. There is a tanged point on blade modified with semi-abrupt and invasive retouch on ventral face. The closest analogy to the sites Gusiny 4, 5 and 7 are sites with the so-called "eastern" blade technology, which have spread in Northern Fennoscandia after 9000 BP. It is probably an evidence of migration from the forest zone of Eastern Europe.

Keywords: Kola peninsula, Northern Fennoscandia, Mesolithic, colonization, Komsa culture.

\section{Введение}

Начиная с 1920-х гг. вопросы о путях и времени заселения Северной Фенноскандии относятся к самым актуальным темам арктической археологии. Дискуссия началась после открытия А.Нуммедалем памятников каменного века в Западной и Северной Норвегии, отнесенных к культурам Фосна и Комса. Первоначально наибольшее распространение получила точка зрения о продвижении людей через Русскую равнину в конце верхнего палеолита или в раннем мезолите с востока: из южных областей России, Сибири, Монголии, Китая. Основой для таких утверждений служил архаичный, «макролитический», облик каменного инвентаря, аналогии которому находили среди изделий европейского среднего и даже нижнего палеолита ${ }^{1}$. Одновременно были высказаны предположения о происхождении

${ }^{1}$ Bøe I., Nummedal A. Le Finnmarkien: les origins de la civilization dans l'extrême-nord de l'Europe. Oslo, 1936. P. 183; Gjessing G. Yngre steinalder i Nord-Norge. Oslo, 1942. P.373-378. 
культур Фосна и Комса от финальнопалеолитических культур Северной Европы и о продвижении населения вдоль побережья Норвегии ${ }^{2}$.

В русскоязычной литературе можно найти такие же взаимоисключающие мнения. Так, Б. Ф. Земляков после открытия стоянок «арктического палеолита» на полуостровах Средний и Рыбачий скептически отзывался о возможности проникновения населения через западное побережье Скандинавии и указывал на сходство кварцевого инвентаря этих памятников с северо-карельскими ${ }^{3}$. Н. Н. Гурина, видимо, вслед за А.Я.Брюсовым, в своих ранних работах рассматривала мезолитические стоянки северо-западной части полуострова как явление случайное, не имевшее продолжения. Она подчеркивала, что между мезолитом и неолитом Кольского полуострова отсутствует преемственность, а полноценное заселение региона относится лишь к позднему неолиту или эпохе раннего металла и происходит не ранее 1500 л. до н.э. с территории северо-восточной Карелии 4 . К 1980-м гг. точка зрения Н.Н. Гуриной существенно изменилась. В.Я.Шумкин поддержал точку зрения К. Однера о заселении Севера Фенноскандии, и в частности восточной ее части, по западному побережью Скандинавии. На это указывало распространение наиболее ранних мезолитических памятников в северо-западной части Кольского полуострова, их сходство (если не тождество) с памятниками культуры Комса, отсутствие ранних памятников в других районах ${ }^{5}$. Н.Н. Гурина предполагала, что заселение шло двумя путями: первоначально - с северо-западного направления, но для южной части полуострова можно говорить об инфильтрации населения с территории Карелии 6 .

В середине 1980-х гг. полевые исследования мезолитических памятников в Мурманской области прервались. Выходившие на протяжении 15-20 лет публикации или вводили в оборот накопленные ранее материалы ${ }^{7}$, или повторяли уже известные факты ${ }^{8}$. В эти годы в Скандинавии и Финляндии полевые работы не останавливались, а в Норвегии даже интенсифицировались: здесь были проведены широкомасштабные спасательные раскопки 9 . В результате была многократно

${ }^{2}$ Историю дискуссии см.: Odner K. Komsakulturen i Nesseby og Sor-Varanger. Tromsø Museums Skrifter. Vol. XII. Troms $\emptyset$, 1966. P. 135-136.

3 Земляков Б. Ф.: 1) Археологические исследования на побережье Арктического океана // Тр. Советской секции Ассоциации по изучению четвертичного периода. Вып. 3. 1937. С. 85-86, 94; 2) Арктический палеолит на севере СССР // Советская археология. Вып. 5. 1940. С. 130.

${ }^{4}$ Гурина Н.Н. Неолитические поселения северного побережья Кольского полуострова // Поселения эпохи неолита и раннего металла на Севере Европейской части СССР. Материалы и исследования по археологии СССР. № 20. М.; Л., 1951. С. 166-167.

${ }^{5}$ Шумкин В.Я.: 1) Мезолит Кольского полуострова // Советская археология. 1986. № 2. С.29$31 ; 2)$ Ранний каменный век западной части Европейской Арктики (мезолит северной Скандинавии) // Древности Северо-Запада России (славяно-финно-угорское взаимодействие, русские города Балтики). СПб., 1993. С. 56-58.

6 Гурина Н.Н. История культуры древнего населения Кольского полуострова. СПб., 1997. С. 132; Археология СССР. Мезолит СССР. М., 1989. С. 26.

7 Шаяхметова Л.Г. Пост-II - мезолитическая стоянка на северо-восточном побережье Баренцева моря // Древности Русского Севера. Вып. 1. Вологда, 1996. С. 43-52.

${ }^{8}$ Сорокин А.Н., Ошибкина С. В., Трусов А. В. На переломе эпох. М., 2009. С. 256-263.

9 Hesjedal A., Damm C., Olsen B., Storli I. Arkeologi pa Slettnes. Dokumentasjon av 11.000 ars bosetning. Tromsø museum skrifter,vol. XXVI. Tromsø, 1996; Hesjedal A., Ramstad M., Niemi A. R. Undersokelsene pa Melkoya. Melkoyaprosjektet - kulturhistoriske registreringer og utgravninger 2001 og 2002. Tromura (Kulturvitenskap). Vol.36. Tromsø, 2009; Bjerck H., Astveit L. I., Meling T., Gundersen J., Jørgensen G., 
увеличена источниковая база, получены естественнонаучные данные, на основе которых были сделаны новые палеогеографические реконструкции, и положено начало целой волне новых исследовательских проектов. Характерные тенденции современных исследований - изучение технологии расщепления каменного сырья как культуроопределяющего признака ${ }^{10}$ и широкое использование АМСдатировок для установления хронологии памятников. Дискуссия о путях заселения Северной Фенноскандии возобновилась после раскопок стоянки Суяла в Северной Финляндии и повторного анализа или раскопок ряда сходных памятников в Северной Норвегии ${ }^{11}$. Для них характерны следующие признаки: технология расщепления, направленная на получение пластин с помощью отжима или удара мягким отбойником, преднамеренная фрагментация пластин и использование ретушированных фрагментов в качестве вкладышей (?), использование пологой ретуши на вентральной поверхности для оформления орудий, прежде всего черешковых и листовидных наконечников. Первоначально памятники с этой индустрией были неудачно обозначены как «пост-свидерские», спустя несколько лет распространился нейтральный термин «памятники с “восточной” пластинчатой технологией», намекающий на аналогии этим памятникам в лесной зоне Восточной Европы, прежде всего в Бутовской культуре.

В настоящий момент многие исследователи поддерживает идею о проникновении около 8300-8200 л. до н. э. населения из лесной зоны Русской равнины в Северную Фенноскандию через территорию Карелии и Финляндии ${ }^{12}$. Однако до недавнего времени проблемой в доказательствах восточного пути заселения Северной Фенноскандии оставалось отсутствие информации о подобных памятниках в Мурманской области и Северной Карелии.

Normann S. Ormen Lange Nyhamna. NTNU Vitenskapsmuseets arkeologiske undersøkelser. Trondheim, 2008.

10 Berg-Hansen I. M. Continuity and change in Late Glacial and Postglacial social networks: knowledge transmission and blade production methods in Ahrensburgian and Early Mesolithic North West Europe // The Early Settlement of Northern Europe: The Technology of Early Settlement in Northern Europe: Transmission of Knowledge and Culture. Vol. 2. Sheffield, 2018. P. 63-98.

${ }^{11}$ Kankaanpaa J., Rankama T. Fast or Slow Pioneers? A View from Northern Lapland // Lateglacial and Postglacial Pioneers in Northern Europe. BAR International Series, Edition: 2599. Oxford, 2014. P. 147-159; Rankama T., Kankaanpaa J. From Russia with Love: Eastern Intruders in the North Norwegian Mesolithic // Early Economy and Settlement in Northern Europe: Pioneering, Resource Use, Coping with Change. The Early Settlement of Northern Europe. Vol.3. Sheffield, 2018. P. 139-167; Sørensen M., Rankama T., Kankaanpaä J., Knutsson K., Knutsson H., Melvold S., Eriksen B. V., Glørstad H. The Frst Eastern Migrations of People and Knowledge into Scandinavia: Evidence from Studies of Mesolithic Technology, $9^{\text {th }}-8^{\text {th }}$ Millennium BC // Norwegian Archaeological Review. 2013. Vol.46(1). P. 19-56.

12 Sorensen M., Rankama T., Kankaanpaa J., Knutsson K., Knutsson H., Melvold S., Eriksen B. V., Glorstad H. The First Eastern Migrations of People and Knowledge into Scandinavia: Evidence from Studies of Mesolithic Technology, $9^{\text {th }}-8^{\text {th }}$ Millennium BC // Norwegian Archaeological Review. 2013. Vol. 46, no. 1. P. 19-56; Damlien H. Eastern pioneers in westernmost territories? Current perspectives onMesolithic hunter-gatherer large-scale interaction and migration within Northern Eurasia // Quaternary International. 2014. Vol. 419. P. 5-16; Damlien H., Solheim S. The Pioneer Settlement of Eastern Norway // Early Economy and Settlement in Northern Europe - Pioneering, Resource Use, Coping with Change. Sheffield, 2018. P.335-367; Kleppe J. I. Desolate landscapes or shifting landscapes? Late glacial/early post-glacial settlement of northernmost Norway in the light of new data from eastern Finnmark // Lateglacial and Postglacial Pioneers in Northern Europe. BAR International Series 2599. Oxford, 2014. P. 121-145; Tarasov A. Filling a gap in the migration route? Initial peopling of Lake Onega in the light of new radiocarbon datings // Norwegian Archaeological Review. Vol.51, iss.1-2. 2018. P.178-189. 
В 2014-2016 гг. КолАЭ ИИМК РАН провела раскопки четырех мезолитических стоянок (Гусиный 4-7) на северном побережье Кольского полуострова (Мурманская область РФ), три из которых по характеру инвентаря относятся к числу памятников с так называемой восточной пластинчатой технологией, четвертый - к кругу памятников фазы I мезолита Северной Норвегии по Б. Ульсену ${ }^{13}$, или периода Комса по П. Вудману ${ }^{14}$.

\section{Мезолитические стоянки Кильдинского пролива}

В 2004-2005 и 2007 гг. КолАЭ ИИМК РАН впервые было проведено археологическое обследование острова Кильдин и прилегающего участка северного побережья Кольского полуострова ${ }^{15}$. В 2014-2016 гг. полевые работы продолжились. В результате на берегах Кильдинского пролива обнаружено 69 археологических памятников, среди которых 9 относятся к мезолитическому времени. На четырех расположенных на южном (материковом) берегу Кильдинского пролива, у ручья Гусиный - стоянках Гусиный 4-7, были проведены раскопки (рис. 1).

Гусиный 4. Стоянка расположена в 650 м к западу от устья ручья Гусиный на мысовидной площадке третьей морской террасы высотой 28 м БСВ, ограниченной с востока озером Заскальным, с запада - заболоченным понижением. С севера стоянка прикрыта скальным возвышением, с юга ограничена скалой, возвышающейся над площадкой на 30 м. Площадь стоянки составляет $60 \times 40$ м. В 2014-2015 гг. на стоянке было заложено 4 раскопа. В раскопах 1, 3 и $4(4 \times 5$ м, $2 \times 2$ м, $3 \times 4$ м соответственно) были обнаружены немногочисленные находки мезолитического облика, залегающие в дюнном песке с горизонтами погребенных дневных поверхностей (горизонтами почвообразования), которых могло быть до трех. Раскопом 2 (83 кв. м) был исследован средневековый курган диаметром 6,5 м и высотой до 0,7 м, а также овальное $(7 \times 5$ м) скопление находок мезолитического времени, залегавшее ниже насыпи, в слое песка под погребенным дерном.

В юго-восточном углу раскопа 1 было расчищено округлое кострище диаметром 1,15 м, около которого наблюдалась концентрация находок. Небольшое скопление древесных угольков размером $1,1 \times 0,65$ м, разрушенное лисьей норой, было зафиксировано в раскопе 4. Других объектов в мезолитическом культурном слое стоянки не выявлено. Основная масса находок, среди которых представлены только каменные артефакты, обнаружена в раскопе 2 (795 экз.); всего на стоянке найдено 873 предмета (табл. 1).

Гусиный 5. Стоянка расположена в 650 м к югу от устья ручья Гусиный, на его левом коренном берегу, на слегка наклонной в северном направлении площадке третьей морской террасы высотой 30-32 м БСВ. По выдувам и обнажениям выявлено три участка распространения находок. Закладке раскопа предшествовал

13 Olsen B. Bosetning og samfunn i Finnmarks forhistorie. Oslo, 1994. P.29-30.

14 Woodman P.C. The Komsa Culture: a re-examination of its position in the Stone Age of Finnmark // Acta Archaeologica Vol. 63. 1993. P. 57-76.

15 Шумкин В.Я., Мурашкин А.И., Колпаков Е. М. Археологические памятники острова Кильдин и прилегающего участка побережья Кольского полуострова // Первобытная и средневековая история и культура Европейского Севера: проблемы изучения и научной реконструкции. Соловки, 2006. C. $106-111$. 


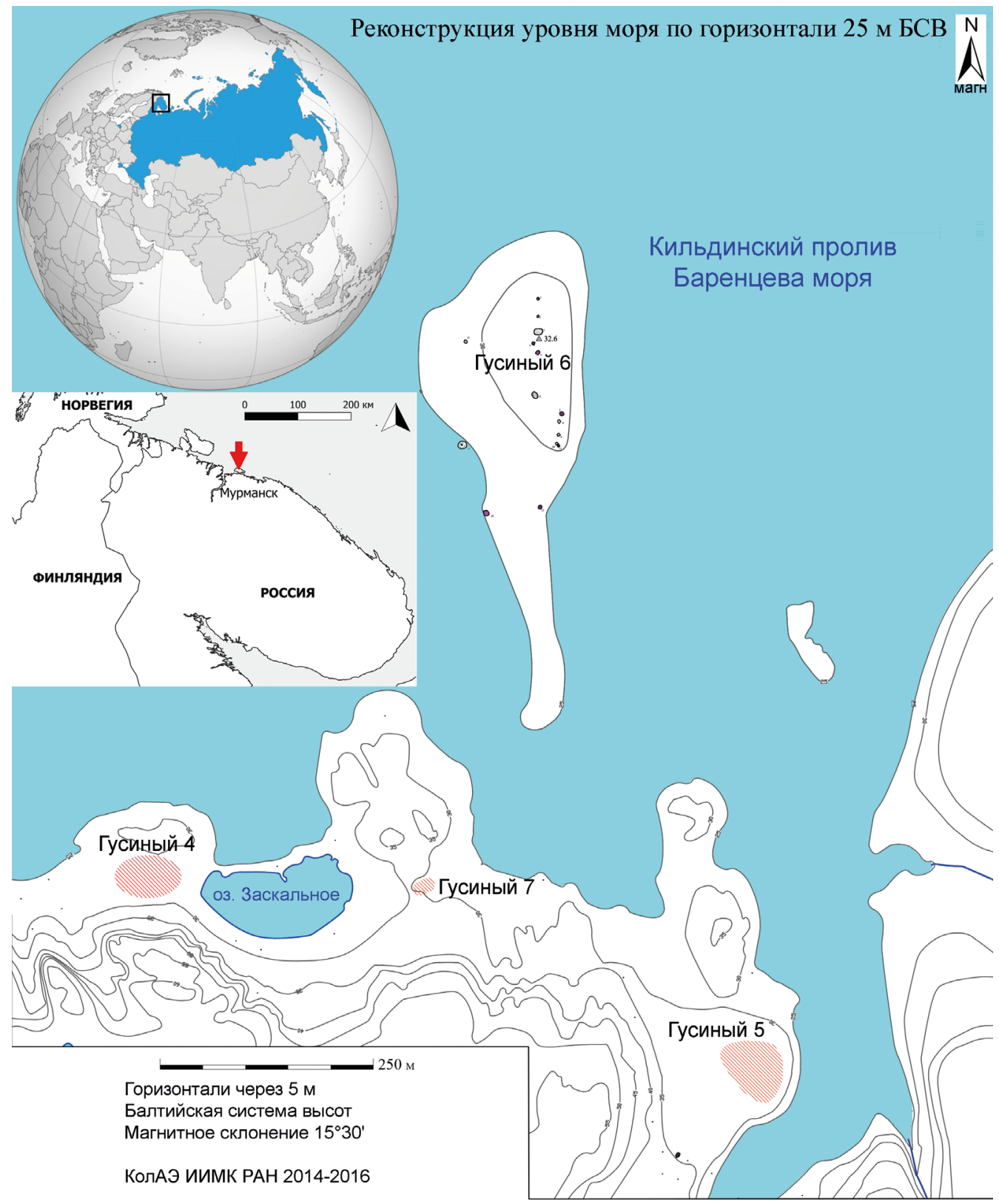

Puc. 1. План расположения стоянок Гусиный 4-7. Реконструирован уровень моря +25 м н. у. м. (рис. Е. М. Колпаков)

сбор подъемного материала с трехмерной фиксацией находок во всех трех пунктах. Раскоп площадью $80 \mathrm{~m}^{2}$ был заложен на участке 3 . Никаких объектов в раскопе не выявлено. Находки, представленные каменными изделиями, образуют отчетливое овальное скопление размером $6 \times 5$ м. Южная, восточная и северо-восточная границы скопления совершенно отчетливы, к северу и северо-западу концентрация 
находок падает постепенно за пределами раскопа. Общее количество находок составляет 965 экз. (табл. 1). Большинство кварцевых артефактов собрано в скоплении 1, лишь 14 из них - в пределах раскопа.

Таблица 1. Гусиный 6, жилище 8. Каменный инвентарь

\begin{tabular}{|c|c|c|c|c|c|}
\hline \multicolumn{2}{|c|}{ Артефакты } & \multicolumn{3}{|c|}{ Сырье } & \multirow[b]{2}{*}{ Итого } \\
\hline $\begin{array}{c}\text { Технологический } \\
\text { контекст }\end{array}$ & Наименование & Кварц & Кремень & $\begin{array}{c}\text { Окремненный } \\
\text { песчаник }\end{array}$ & \\
\hline \multirow{6}{*}{$\begin{array}{l}\text { Продукты } \\
\text { расщепления }\end{array}$} & Галька с оббивкой & 8 & & 3 & 11 \\
\hline & Нуклеус & 41 & 2 & 9 & 52 \\
\hline & Осколок & & & 2 & 2 \\
\hline & Пластина & 39 & 12 & 20 & 71 \\
\hline & Отщеп & 2250 & 151 & 1131 & 3532 \\
\hline & Микродебитаж & 9367 & 95 & 791 & 10253 \\
\hline \multirow{12}{*}{ Орудия } & $\begin{array}{l}\text { Отщеп с ретушью (из них } \\
\text { со следами утилизации) }\end{array}$ & $174(8)$ & $17(2)$ & $11(-)$ & $202(10)$ \\
\hline & Пластина с ретушью & 7 & 4 & 1 & 12 \\
\hline & Наконечник & 12 & 2 & 1 & 15 \\
\hline & Острие & 2 & 1 & & 3 \\
\hline & Проколка & 4 & 1 & & 5 \\
\hline & Скребок & 46 & 3 & & 49 \\
\hline & Скребло & & & 1 & 1 \\
\hline & Скобель & 19 & 2 & & 21 \\
\hline & Нож & 3 & & & 3 \\
\hline & Комбинированное орудие & 3 & & & 3 \\
\hline & Резец & & 2 & & 2 \\
\hline & Топор & & 1 & 6 & 7 \\
\hline \multicolumn{2}{|l|}{ ВСЕГО } & 11975 & 293 & 1976 & 14244 \\
\hline
\end{tabular}

Гусиный 7. Стоянка находится в 400 м к западу от левого берега ручья Гусиный, на площадке третьей морской террасы высотой 29-30 м БСВ, ограниченной с севера и юга скальными возвышениями, с востока и запада - понижениями к озерам Девичьему и Заскальному. На памятнике было заложено два раскопа: первый, площадью 30 м², - около выдува, на котором обнаружены артефакты мезолитического облика; второй, площадью $12 \mathrm{~m}^{2}$, - на расположенном в 10 м к юго-западу выложенном камнями крупном очаге, датированном XVII-XVIII вв. В восточной части раскопа 1 мезолитические находки залегали ниже погребенной почвы, в такой же стратиграфической ситуации, как на стоянке Гусиный 4. В раскопе 2 каменные артефакты залегали ниже камней очага. Никаких мезолитических объектов в обоих раскопах не выявлено, находки продолжались за пределами раскопов во всех направлениях. Всего на памятнике было обнаружено 247 каменных изделий (см. табл. 1).

Гусиный 6. Поселение расположено на вершине широкого мыса (30-32 м БСВ) между бухтами Ручьи и Каренкол, в 330 м к северо-западу от устья р. Гусиный (см. рис. 1). Здесь зафиксировано 15 объектов, из которых три квадратные западины размером до $3 \times 3$ м, глубиной до 0,2 м, по всей видимости, являются мезолитиче- 
скими жилищами. Остальные - обкладки чумов, каменные и каменно-земляные насыпи, кольцевые выкладки из валунов - относятся к периоду от раннего железного века до Нового времени. В 2015-2016 гг. раскопом $4 \times 4$ м было исследовано жилище 8.

Визуально объект воспринимался как квадратная в плане оплывшая западина, размером не более $4 \times 4$ м по верхним краям, плавно понижающаяся к своему центру до глубины 25 см. Под дерном, или фактически сразу с поверхности, залегает светло-серый песок мощностью 5-15 см. Ниже начинается светло-коричневый песок. В нем вокруг центральной части западины проходит «канавка» шириной до 1 м и максимальной глубиной от поверхности до 25 см, заполненная серым, до черного в нижней части, песком. Заполнение «канавки» на ощупь производит впечатление слегка жирного. Именно из него происходят немногочисленные мелкие древесные угольки. В плане «канавка» близка по форме к квадрату с разрывом в северной части и с длиной стороны по внешней границе 2,1 м. Каменные артефакты (14 244 экз.) (табл. 2) залегают от поверхности и до верхней части ( 10 cм) светло-коричневого песка. Наибольшая плотность артефактов наблюдается в районе «канавки», образуя в плане прямоугольник: 2,6×2 м по внешней стороне и $\sim 1,4 \times 1$ м - по внутренней, с двумя «хвостами» длиной до 1 м и шириной 0,5-1 м, отходящими от «прямоугольника» на север и на юг. По внешней границе это скопление артефактов частично ограничено крупными валунами. Под некоторыми из них обнаружены артефакты, но только под той стороной камней, которая обращена к центру сооружения.

\section{Характеристика каменного инвентаря}

По результатам предварительного анализа четыре исследованных памятника относятся к двум индустриям, различающимся по выбору сырья, технологии расщепления и орудийному набору.

Гусиный 6. На памятнике обнаружено 14244 предмета, из которых 11974 изготовлено из кварца (84\%), 1976 - из окремненного песчаника $(14 \%)^{16}, 293$ из окремненной породы, здесь и далее условно обозначенной как «кремень» (2\%) (табл. 2). К начальной стадии расщепления относятся гальки из кварца (8 экз.) и окремненного песчаника (3 экз.) с 2-4 негативами сколов. Среди 52 нуклеусов представлены: дисковидные, призматические одно- и двуплощадочные, многоплощадочные ситуационного расщепления, биполярные. Для нуклеусов из кварца (41 экз.) и песчаника (9 экз.) не характерна подправка ударной площадки. У большинства из них имеется плоская, оформленная одним сколом, площадка; ретушированных площадок нет; у некоторых нуклеусов начальной стадии расщепления ударные площадки покрыты галечной коркой. Только у трех кварцевых нуклеусов отмечена подправка ударных площадок несколькими сколами. Ни у одного из нуклеусов из окремненного песчаника не отмечено подправки ударной площадки. У двух кремневых полностью истощенных призматических двуплощадочных нуклеусов имеется подправка ударных площадок, у одного - редуцирование карниза.

16 Определение условное; цвет породы варьирует от темно- до светло-серого, зернистость может быть ярко выражена, характерна слоистость; бо́льшая часть изделий имеет пористую, выветренную поверхность. 
Чешуйки и отщепы составляют 10253 и 3532 экз. По всей видимости, первичное расщепление кварца и окремненного песчаника проводилось на стоянке; об этом свидетельствует большой процент сколов с галечной коркой (18 и 14 \% соответственно), их крупные размеры, большой процент первичных отщепов. Среди кремневых отщепов имеются технические - сколы подправки ударной площадки нуклеуса («таблетки»), сколы оживления плоскости расщепления. Общее количество пластин - 93 экз. (46 - из кварца, 16 - из кремня, 21 - из окремненного песчаника); примерно треть пластин из кварца и окремненного песчаника имеет галечную корку и около половины - треугольное сечение. Подавляющее большинство пластин массивные, укороченных пропорций, с нерегулярной огранкой - по всей видимости, они были получены случайно.

Таким образом, расщепление всех видов сырья на памятнике было направлено на получение отщепов. Только кремневые артефакты демонстрируют признаки подправки нуклеусов, что было связано не со стремлением получать пластины, а направлено на продление их «жизни» для экономии ценного сырья.

Предметов со вторичной обработкой в коллекции 323 экз., из них отщепов с ретушью - 202 экз. Зачастую производилось минимальное ретуширование изделий, поэтому четкое разделение отщепов с ретушью и орудий затруднено. Такой характер обработки в целом характерен для мезолитических памятников Кольского полуострова. Пластин с ретушью - 12 экз. (7 - из кварца, 4 - из кремня, 1 - из окремненного песчаника). У всех пластин ретушь зафиксирована только на дорсальной поверхности; наиболее характерна крутая ретушь.

Среди орудий наибольшее число составляют изготовленные на отщепах скребки (46 - из кварца, 3 - из кремня) и скобели (19 - из кварца, 2 - из кремня). Представлены одно-, дву- и трехлезвийные изделия. В коллекции имеется одно скребло из окремненного песчаника, изготовленное на массивном отщепе крупной ретушью. Другие орудия представлены остриями (3), проколками (5), резцами (2), комбинированными (2 - скребок-нож, 1 - скребок-скобель).

Коллекция включает 15 наконечников стрел и их фрагментов: 12 - из кварца, 2 - из кремня, 1 - из окремненного песчаника. Из них 13 - черешковые (рис. 2: 3-6). Почти все они изготовлены на пластинчатых отщепах. Чаще всего крутой ретушью на дорсальной поверхности оформлен только расположенный в проксимальной части скола черешок. Изредка используется противолежащая ретушь или крутая ретушь на вентральной поверхности. Во всех случаях обработка минимальна - черешок оформлен несколькими фасетками. Обработка пера отмечается только у двух изделий. Кроме того, имеется поперечнолезвийный кварцевый и подтреугольный кремневый наконечник (рис. 2: 1, 2). В коллекции представлено семь рубящих орудий, изготовленных на крупных отщепах (6 - из окремненного песчаника, 1 - из кремня). У них крутой обивкой и ретушью сформированы боковые грани, лезвием служит необработанный край отщепа (рис. 2: 7-8).

Гусиный 4, 5, 7. В качестве сырья на всех трех стоянках использовался кремень, окремненный песчаник и кварц в различных пропорциях (табл. 2). Среди мезолитических памятников Кольского полуострова данные памятники выделяются большим количеством кремневых пластин и связанных с их изготовлением продуктов расщепления. Сходство инвентаря позволяет охарактеризовать каменную индустрию стоянок Гусиный 4, 5, 7 суммарно. 

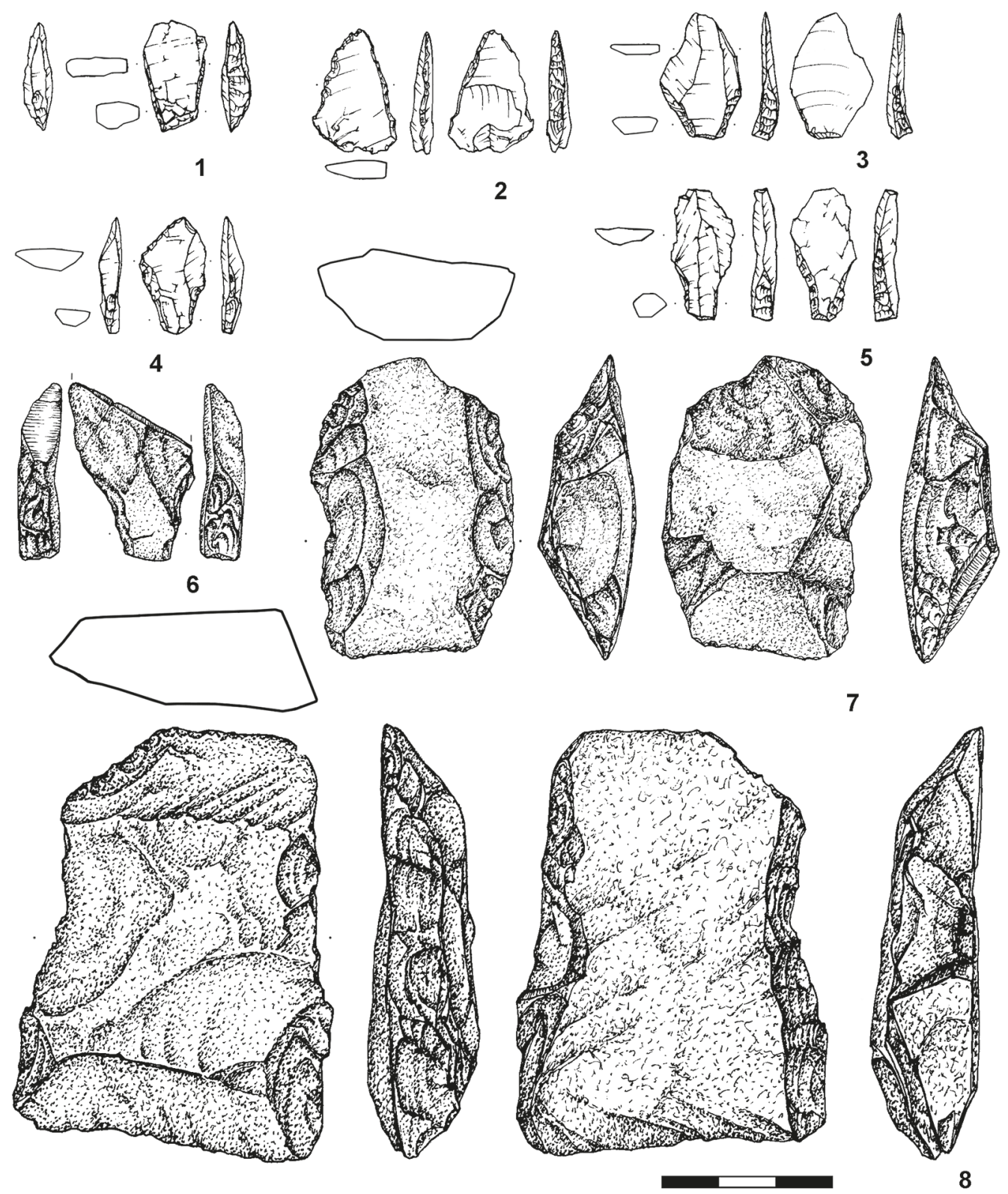

7

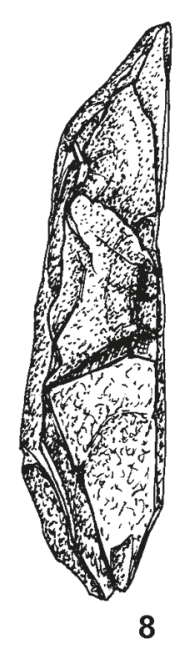

Puc. 2. Инвентарь стоянки Гусиный 6, жилище 8:

1 - поперечнолезвийный наконечник стрелы; 2 - треугольный наконечник стрелы; 3-6 - черешковые наконечники стрел; 7-8 - топоры на отщепах; (1, 3-5 - кварц; 2 - кремень; 6-8 - окремненный песчаник) (рис. А. А. Малютина)

В коллекции имеется два кремневых полностью истощенных призматических одноплощадочных нуклеуса для снятия пластин (рис. 3: 16-17). Их ударные площадки оформлены несколькими сколами и покрыты негативами мелких снятий. Нуклеусов из других пород нет. Среди кремневых отщепов на всех стоянках пред- 
Таблица 2. Гусиный 4, 5 и 7. Каменный инвентарь

\begin{tabular}{|l|c|c|c|c|c|c|c|c|c|c|c|c|c|}
\hline \multirow{2}{*}{$\begin{array}{l}\text { Наимено- } \\
\text { вание }\end{array}$} & \multicolumn{3}{|c|}{ Гусиный } & \multicolumn{5}{c|}{ Гусиный } & \multicolumn{5}{c|}{ Гусиный } \\
\hline & Кр. & О.п. & Кв. & Итого & Кр. & О.п. & Кв. & Итого & Кр. & О. П. & Кв. & Гр. & Итого \\
\hline $\begin{array}{l}\text { Галька } \\
\text { с оббивкой }\end{array}$ & & 1 & & 1 & & 1 & 1 & $\mathbf{2}$ & & & 1 & & $\mathbf{1}$ \\
\hline Нуклеус & 1 & & & $\mathbf{1}$ & 1 & & & 1 & & & & & \\
\hline Чешуйка & 249 & 10 & 12 & $\mathbf{2 7 1}$ & 21 & 113 & 25 & $\mathbf{1 5 9}$ & 18 & 1 & 94 & & $\mathbf{1 1 3}$ \\
\hline Отщеп & 312 & 23 & 41 & $\mathbf{3 7 6}$ & 150 & 289 & 52 & $\mathbf{4 9 1}$ & 20 & 15 & 56 & & $\mathbf{9 1}$ \\
\hline Осколок & 9 & & & $\mathbf{9}$ & 7 & & & 7 & & & 2 & & $\mathbf{2}$ \\
\hline Пластина & 94 & 3 & & $\mathbf{9 7}$ & 145 & 12 & & $\mathbf{1 5 7}$ & 18 & & 1 & & $\mathbf{1 9}$ \\
\hline $\begin{array}{l}\text { Отщеп } \\
\text { С ретушью }\end{array}$ & 22 & & & 22 & 21 & 1 & 3 & $\mathbf{2 5}$ & 6 & & 2 & & $\mathbf{8}$ \\
\hline $\begin{array}{l}\text { Пластина } \\
\text { с ретушью }\end{array}$ & 68 & & & $\mathbf{6 8}$ & 98 & & & $\mathbf{9 8}$ & 9 & & & & $\mathbf{9}$ \\
\hline Скребок & 8 & & & $\mathbf{8}$ & 10 & & 1 & $\mathbf{1 1}$ & 1 & & 1 & & $\mathbf{2}$ \\
\hline Скобель & & & & & 4 & & & 4 & & & & & \\
\hline Резец & 7 & & & $\mathbf{7}$ & 1 & & & 1 & & & & & \\
\hline Проколка & 2 & & & $\mathbf{2}$ & 2 & & & 2 & & & & & \\
\hline Острие & 1 & & & $\mathbf{1}$ & 2 & & & $\mathbf{2}$ & 1 & & & & $\mathbf{1}$ \\
\hline $\begin{array}{l}\text { Комбини- } \\
\text { рованное }\end{array}$ & & & & & 2 & & & 2 & & & & & \\
\hline Наконечник & & & & & 1 & & & 1 & & & & & \\
\hline Отбойник & & & & & & & & & & & & 1 & $\mathbf{1}$ \\
\hline ВСЕГО & 773 & 37 & 53 & 863 & 465 & 416 & 82 & 963 & 73 & 16 & 157 & 1 & 247 \\
\hline
\end{tabular}

ставлены многочисленные технические сколы, связанные с подготовкой и подправкой нуклеусов, в том числе: подправки ударной площадки нуклеусов («таблетки»), подправки фронта расщепления, подправки основания нуклеуса. Среди сколов бо́льшую часть составляют пластины и микропластины: Гусиный $4-97$ экз.; Гусиный $5-157$ экз.; Гусиный $7-18$ экз. Пластины имеют признаки скалывания в технике отжима или удара через посредник: большая ширина при малой толщине, параллельность краев, слабый изгиб, трапециевидное сечение, наличие «губы», фасетированные ударные площадки минимальных размеров, редуцирование карниза, пологий рельеф ударного бугорка и т. д. Самая длинная пластина (с обломанным дистальным концом) достигает 7,5 см при толщине 4 мм. Несомненно, расщепление кремня на стоянках было направлено на получение пластин.

Среди изделий со вторичной обработкой доминируют фрагменты пластин с ретушью (десять из них имеют резцовые сколы): Гусиный $4-68$ экз.; Гусиный 5 - 98 экз.; Гусиный $7-9$ экз.; особенно часто ретушируются медиальные части пластин (см. рис. 3: 3-5, 9, 11-12). Широко представлены фрагменты пластин с ретушью утилизации (см. рис. $3: 10,14)$. Бо́льшую часть орудий составляют скребки (19 экз.). Среди них представлены концевые на пластинах и ногтевидные на отщепах (см. рис. 3: 6, 13, 15). Для концевых характерна обработка крутой ретушью боковых, прилегающих к скребковому лезвию, граней. Четыре скобеля изготовлены на отщепах. Восемь боковых резцов оформлены на углу сломанных пластин. В коллекциях представлены четыре проколки на отщепах и четыре острия на пластинах. 


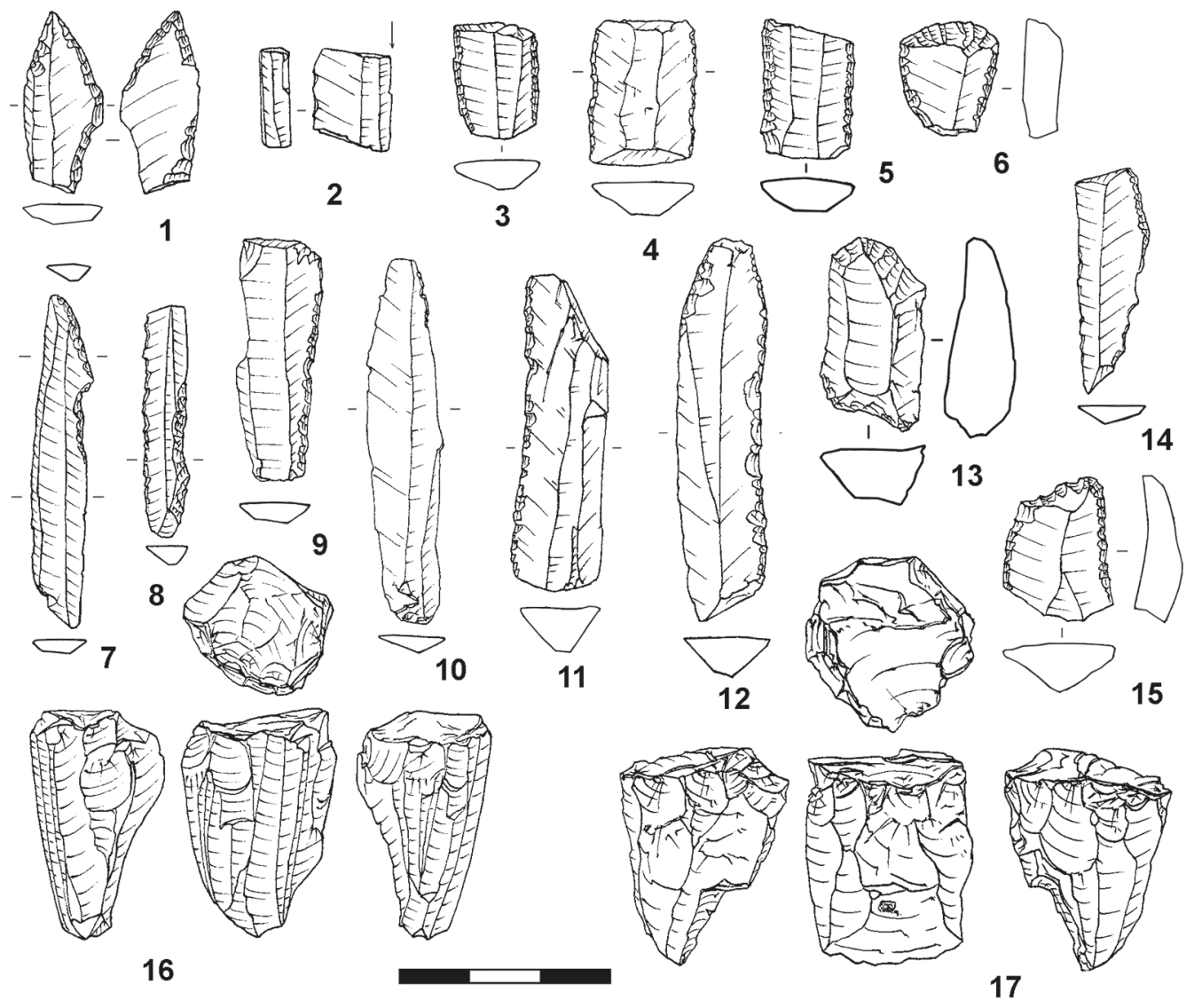

Puc. 3. Инвентарь стоянок Гусиный 4, 5 и 7:

1 - наконечник стрелы; 2 - резец; 3-5, 8-9, 11-12 - ретушированные фрагменты пластин; 6, 13, 15 - скребки; 7 - острие; 10, 14 - пластины с ретушью утилизации; $16-17$ - нуклеусы. 1, 2, 4, 6, 10-12, 17 - Гусиный 5; 3, 5, 9, 13, 15, 16 - Гусиный 4; 7, 8 - Гусиный 7 (все кремень, рис. А.А. Малютина)

Для оформления острий характерно использование крутой ретуши на дорсальной поверхности. Одно из них имеет выделенный ретушью зубец (рис. 3: 7). Два комбинированных орудия представлены скребком-скобелем на отщепе и скребком-проколкой. Черешковый наконечник со стоянки Гусиный 5 изготовлен из пластинчатого отщепа (?) с помощью полукрутой ретуши на дорсальной поверхности и пологой — на вентральной (рис. 3: 1).

Продукты расщепления кварца представлены только отщепами и чешуйками (см. табл. 2). Единственное исключение - пластина из кварца со стоянки Гусиный 7. Предметы со вторичной обработкой на стоянке Гусиный 4 полностью отсутствуют, на стоянках Гусиный 5 и 7 представлены пятью отщепами с ретушью и двумя скребками на отщепах.

Примерно половину инвентаря стоянки Гусиный 5 составляют артефакты из окремненного песчаника; в небольшом количестве они представлены и на двух других памятниках (см. табл. 2). Среди отщепов присутствует большое количество 
крупных массивных сколов, многие из которых имеют галечную корку, покрывающую всю дорсальную поверхность. Очевидно, расщепление галек окремненного песчаника происходило на стоянках. Подобные гальки встречены в русле ручья Гусиный и на многих участках побережья. Также в коллекции имеются пластины из этого материала (Гусиный $4-3$ экз., Гусиный $5-12$ экз.). Они резко отличаются по своим пропорциям от кремневых: гораздо массивнее, с неровными краями, укороченных пропорций. Орудия в коллекциях отсутствуют; имеется единственный отщеп с несколькими фасетками грубой ретуши (Гусиный 5). Единственный предмет из гранита - отбойник из небольшой округлой гальки, на двух сторонах которого имеются отчетливые следы забитости (Гусиный 7).

\section{Культурно-хронологическая атрибуция мезолитических стоянок у ручья Гусиный}

Определение возраста исследованных стоянок возможно на основании результатов радиоуглеродного датирования, приуроченности к древним береговым линиям и типологическим аналогиям. В настоящее время одна 14С-дата получена по древесному углю из кострища в раскопе 1 на стоянке Гусиный $4-8418 \pm 80$ ВР (СПб-1377) (7595-7301, 7217-7201 calBC). Вторая дата получена по древесному углю из скопления на дне «канавки» в жилище 8 на поселении Гусиный $6-8350 \pm 150$ ВР (СПб-2113) (7705-7699, 7682-7041 calBC).

Детальные реконструкции поднятия земной коры и перемещения древних морских береговых линий выполнены для Кольского залива и района г. Полярный ${ }^{17}$, которые находятся в 30 км к западу от р. Гусиный. Считается, что уровень 30 м н. у. м. освободился в период от 9000 до 8500 л.н., а в период до 7000 л. н. на уровне 29-30 м отмечалось длительное стояние уровня моря, соотнесенное с трансгрессией тапес ${ }^{18}$. На северном берегу Кильдинского пролива, в восточной части о. Кильдин, на высоте 24-26 м выявлен террасовый уровень, относящийся к ранней стадии трансгрессии тапес ${ }^{19}$. По всей видимости, террасовый уровень 28-32 м, на котором расположены стоянки Гусиный 4-7, формировался в период 9000-8500 л. н.

Аналогии инвентарю из жилища 8 на стоянке Гусиный 6 обнаруживаются в памятниках, относящихся к культуре Комса, охватывающей Северную Норвегию и северную часть Кольского полуострова. Для раннего периода культуры, за которым П. Вудман предложил закрепить эпонимное название Комса ${ }^{20}$, а Б. Ульсен называет фазой ${ }^{21}$, характерны оформленные крутой ретушью на дорсальной поверхности

${ }^{17}$ Corner G.D., Kolka V. V., Yevzerov V. Y., Møller J.J. Postglacial relative sea-level change and stratigraphy of raised coastal basins on Kola Peninsula, northwest Russia // Global and Planetary Change. Vol. 31. 2001. Р. 155-177; Толстобров Д. С., Толстоброва А. Н., Колька В. В., Корсакова О. П. Постледниковое поднятие земной коры в северо-западной части Кольского региона // Вестник Мурманского гос. техн. ун-та. 2015. Т. 18, № 2. С. 295-306.

18 Толстобров Д. С., Толстоброва А. Н., Колька В. В., Корсакова О. П. Постледниковое поднятие земной коры в северо-западной части Кольского региона. С. 302.

${ }_{19}$ Митяев М.В., Корсун С.А., Стрелков П.П., Матишов Г.Г. Древние береговые линии Восточного Кильдина // Докл. Академии Наук. 2008. Т. 423, № 4. С. 546-550.

20 Woodman P.C. The Komsa culture. A re-examination of its position in the Stone Age of Finnmark // Acta Archaeologica. 1993. Vol.63. P.57-76.

${ }^{21}$ Olsen B. Bosetning og samfunn i Finnmarks forhistorie. Oslo, 1994. P. 30 
черешковые наконечники, острия с притупленной спинкой, а также грубые топоры на отщепах. C точки зрения технологического анализа для этого периода характерно использование нерегулярных пластин или отщепов, полученных в результате прямого удара мягким отбойником; основные типы нуклеусов - дисковидные и призматические двуплощадочные 22 . Эта стадия на основании немногочисленных радиоуглеродных определений датируется 10 000-9000 л. н. ${ }^{23}$.

Прямые аналогии материалам стоянок Гусиный 4, 5, 7 находятся в коллекции стоянки Суяла, исследованной в 2004-2006 гг. в Северной Финляндии. Почти все изделия на памятнике $(98,6 \%)$ изготовлены из окремненной породы, которую авторы определяют как слабометаморфизированный песчаник ${ }^{24}$. Из 6341 предмета в коллекции 1739 составляют пластины и их фрагменты и 401 - ретушированные пластины. На основании подробного исследования продуктов расщепления авторы исследования делают вывод о получении пластин в результате отжима или удара через посредник ${ }^{25}$. Сходство стоянок прослеживается не только в сырьевой базе и технологии расщепления (оформление ударных площадок нуклеусов, сколы подправки нуклеусов, параметры пластин) ${ }^{26}$, но и характере инвентаря (важно учитывать, что набор вторично обработанных изделий чрезвычайно неразнообразен). Для всех памятников характерны преднамеренная фрагментация и ретуширование пластин, резцы на углу сломанной пластины, обработка боковых граней концевых скребков на пластинах ${ }^{27}$. Единственный наконечник из стоянки Гусиный 5 идентичен одному из наконечников Суялы ${ }^{28}$.

В настоящее время в Северной Норвегии выявлена серия памятников с инвентарем, сходным с обнаруженным на стоянке Суяла: Фаллегоахтесайегуолба, Мортенснес 2/Р10, Стареньюнни, Саленсхогда, Престестуа 2 и др. Коллекции большинства из них получены в результате сборов на развеянных террасах, только некоторые получены в результате раскопок. Отдельные коллекции имеют смешанный характер (Саленсхогда), когда только часть комплекса относится к технологическому контексту получения и использования отжимных пластин ${ }^{29}$. П. Вудман, кото-

22 Ibid. P. 29-30; Kankaanpaa J., Rankama T. Fast or Slow Pioneers? A View from Northern Lapland // Lateglacial and Postglacial Pioneers in Northern Europe. BAR International Series 2599. Oxford, 2014. P. $151-152$.

${ }^{23}$ Olsen B. Bosetning og samfunn i Finnmarks forhistorie. P.29-31; Bang-Andersen S. Colonizing contrasting landscapes. The pioneer coast settlement and inland utilization in Southern Norway 10,0009500 years before present // Oxford journal of archaeology. 2012. Vol. 31 (2). P. 106-108; Kleppe J. I. Desolate landscapes or shifting landscapes? Late glacial/early post-glacial settlement of northernmost Norway in the light of new data from eastern Finnmark // Lateglacial and Postglacial Pioneers in Northern Europe. BAR International Series 2599. Oxford, 2014. P. 136-137; Bang-Andersen S. Colonizing contrasting landscapes. The pioneer coast settlement and inland utilization in Southern Norway 10,000-9500 years before present // Oxford journal of archaeology. 2012. Vol. 31 (2). Р. 103-120; Бланкхольм П., Хууд Б., Клеп Й. И. Северная Скандинавия. Синтез // Первоначальное заселение Арктики человеком в условиях меняющейся природной среды: Атлас-монография. М., 2014. С. 24-25.

${ }^{24}$ Rankama T., Kankaanpaa J. First evidence of eastern Preboreal pioneers in arctic Finland and Norway // Quartär. International Yearbook for Ice Age and Stone Age Research. 2011. Vol. 58. P. 186.

25 Ibid. P. 187-191.

26 См. например: Ibid. Fig. 7, 9, 11, 16.

27 Ibid. Fig. 11, 17-c, d; 18-d.

28 Ibid. Fig. 19-f.

${ }_{29}$ Rankama T., Kankaanpaa J. From Russia with Love: Eastern Intruders in the North Norwegian Mesolithic // Early Economy and Settlement in Northern Europe: Pioneering, Resource Use, Coping with Change. The Early Settlement of Northern Europe .Vol.3. P. 139-167. 
рый в начале 1990-х гг. анализировал инвентарь некоторых из этих памятников, выделил их в период / фазу Саленсхогда (9000-7500/7000 л.н.) и подчеркивал отличие этой группы памятников от более ранних ${ }^{30}$. На современном этапе многие исследователи подчеркивают сходство памятников типа Суяла с мезолитическими культурами с пластинчатым инвентарем лесной зоны Восточной Европы, прежде всего Бутовской, Веретье, Кунда. Предполагается, что распространение технологии отжима пластин на рубеже фаз I (Комса) и II (Саленсхогда) связано с проникновением в Северную Фенноскандию нового населения из Восточной Европы ${ }^{31}$. Эта миграция по времени совпадает с началом Бореального периода и распространения сосновых лесов в Северную Фенноскандию ${ }^{32}$.

Гипотеза о восточном пути заселения Северной Фенноскандии нуждается в подтверждении, поскольку базируется на анализе нескольких памятников, расположенных в «конечной» точке маршрута. В настоящий момент на территории Кольского полуострова имеется три стоянки, сходные по инвентарю с кругом стоянок типа Суяла. Сведения о других памятниках с подобным инвентарем пока (?) минимальны.

В отчете А.В. Анпилогова о раскопках стоянок Ловозеро II, IIа и III в 1970 г. содержатся фотографии и описания кремневых пластин, чрезвычайно близких по своим параметрам к отжимным пластинам со стоянок типа Суяла ${ }^{33}$. При описании материала стоянки Шуонийоки 2 Н. Н. Гурина упоминает «отчетливо выраженный постсвидерский наконечник стрелы и классической формы конический нуклеус с негативами от очень узких, правильного огранения ножевидных пластин» ${ }^{34}$. С двух стоянок в Лумбовской Губе (воронка Белого моря) также происходят ножевидные пластины «правильного огранения, ширина негативов на которых не превышает 3-4 мм ... Стоянки Лумбовской Губы указывают на связь с юговосточными районами - Припечорском и Вычегодским краем» ${ }^{35}$. В пользу гипотезы восточного пути заселения Кольского полуострова, возможно, говорит возраст четырех памятников Северного Обонежья, датированных около 9000 л. н., в материале которых представлен пластинчатый инвентарь ${ }^{36}$.

\footnotetext{
30 Woodman P. C. The Komsa culture. A re-examination of its position in the Stone Age of Finnmark. P. 57-76.

31 Damlien, H. Eastern pioneers in westernmost territories? Current perspectives on Mesolithic hunter-gatherer large-scale interaction and migration within Northern Eurasia // Quaternary International. 2014. Vol.419. P.5-16; Sorensen M., Rankama T., Kankaanpaa J., Knutsson K., Knutsson H., Melvold S., Eriksen B. V., Glorstad H. The First Eastern Migrations of People and Knowledge into Scandinavia: Evidence from Studies of Mesolithic Technology, $9^{\text {th }}-8^{\text {th }}$ Millennium BC // Norwegian Archaeological Review. 2013. Vol.46, no. 1. P. 19-56; Rankama T., Kankaanpaa J. From Russia with Love: Eastern Intruders in the North Norwegian Mesolithic. P. 139-167.

32 Сапелко Т. В. Северная Скандинавия. Палеогеография Кольского полуострова // Первоначальное заселение Арктики человеком в условиях меняющейся природной среды: Атлас-монография. М., 2014. С. 30-37.

33 Анпилогов А. В. Фотоальбом к отчету о работе Мурманской археологической экспедиции за 1970 год // Архив Мурманского областного краеведческого музея. НВ № 5433/2. Рис. 19, 20, 29.

34 Археология СССР. Мезолит СССР. М., 1989. С. 25

35 Гурина Н. Н. Отчет о полевых работах Кольской археологической экспедиции 1969 г. // Архив ИИМК РАН. 1969. Ф. 35. Д. 25. Л.10-11.

36 Tarasov A. Filling a gap in the migration route? Initial peopling of Lake Onega in the light of new radiocarbon datings.
} 


\section{References}

Bang-Andersen S. Colonizing contrasting landscapes. The pioneer coast settlement and inland utilization in Southern Norway 10,000-9500 years before present. Oxford journal of archaeology, 2012, vol. 31 (2), pp. 103-120.

Berg-Hansen I. M. Continuity and change in Late Glacial and Postglacial social networks: knowledge transmission and blade production methods in Ahrensburgian and Early Mesolithic North West Europe. The Early Settlement of Northern Europe: The Technology of Early Settlement in Northern Europe: Transmission of Knowledge and Culture. Vol.2. Sheffield: Equinox Publishing, 2018, pp. 63-98.

Bjerck H. B., Astveit L. I. Meling T., Gundersen J., Jørgensen G., Normann S. Ormen Lange Nyhamna. NTNU Vitenskapsmuseets arkeologiske undersøkelser. Trondheim: Tapir Akademisk Forlag, 2008, 662 p.

Bøe I., Nummedal A. Le Finnmarkien: les origins de la civilization dans l'extrême-nord de l'Europe. Institutet for sammenlignende Kulturforskning, B 32, Oslo, 1936, 263 s.

Blankkhol'm P., Khuud B., Klep Y. I. Northern Scandinavia. Synthesis. Initial Human Colonization of Arctic in Changing Paleoenvironments: Atlas-monograph. Eds V. M. Kotliakov, A. A. Velichko, S. A. Vasil'yev. Moscow, GEOS Publ., 2014, pp. 24-29. (In Russian)

Corner G. D., Kolka V. V., Yevzerov V.Y., Møller J. J. Postglacial relative sea-level change and stratigraphy of raised coastal basins on Kola Peninsula, northwest Russia. Global and Planetary Change, 2001, vol.31, pp. 155-177.

Damlien H. Eastern pioneers in westernmost territories? Current perspectives on Mesolithic huntergatherer large-scale interaction and migration within Northern Eurasia. Quaternary International, 2014, vol.419, pp. 5-16.

Damlien H., Solheim S. The Pioneer Settlement of Eastern Norway. Early Economy and Settlement in Northern Europe: Pioneering, Resource Use, Coping with Change. The Early Settlement of Northern Europe. Ed by H. P. Blankholm. Vol. 3. Sheffield, Equinox eBooks Publishing, 2018, pp. 335-367.

Gjessing G. Yngre steinalder i Nord-Norge. Institutt for sammenlignende kultuforskning B XXXIX. Oslo, 1942, $525 \mathrm{~s}$.

Gurina N.N. Neoliticheskiye poseleniya severnogo poberezh'ia Kol'skogo poluostrova. Poseleniia epokhi neolita $i$ rannego metalla na Severe Evropeiskoi chasti SSSR. Materialy $i$ issledovaniia po arkheologii SSSR, no. 20. Moscow; Leningrad, Izdatel'stvo AN SSSR, 1951, pp. 143-167. (In Russian)

Gurina N. N. Istoriia kul'tury drevnego naseleniia Kol'skogo poluostrova. St. Petersburg, Tsentr "Peterburgskoe Vostokovedenie", 1997, 240 p. (In Russian)

Hesjedal A., Damm C., Olsen B., Storli I. Arkeologi pa Slettnes. Dokumentasjon av 11.000 ars bosetning. Tromsø museum skrifter. Tromsø, 1996, vol. XXVI, $246 \mathrm{s.}$

Hesjedal A., Ramstad M., Niemi A. R. Undersokelsene pa Melkoya. Melkoyaprosjektet - kulturhistoriske registreringer og utgravninger 2001 og 2002. Tromura (Kulturvitenskap). Tromsø, 2009, vol. 36, $514 \mathrm{~s}$.

Kankaanpaa J., Rankama T. Fast or Slow Pioneers? A View from Northern Lapland. Lateglacial and Postglacial Pioneers in Northern Europe. BAR International Series 2599. Eds F. Riede, M. Tallavaara. Oxford, Archaeopress, 2014, pp. 147-159.

Kleppe J.I. Desolate landscapes or shifting landscapes? Late glacial/early post-glacial settlement of northernmost Norway in the light of new data from eastern Finnmark. Lateglacial and Postglacial Pioneers in Northern Europe. BAR International Series 2599. Oxford, Archaeopress, 2014, pp. 121-145.

Mitiaev M. V., Korsun S.A., Strelkov P.P., Matishov G. G. Drevnie beregovye linii Vostochnogo Kil'dina. Doklady Akademii Nauk, 2008, vol. 423, iss. 4, pp. 546-550. (In Russian)

Odner K. Komsakulturen i Nesseby og Sor-Varanger. Tromsø Museums Skrifter. Tromsø, Universitetsforlaget, 1966, vol.XII, $164 \mathrm{p}$.

Olsen B. Bosetning og samfunn i Finnmarks forhistorie. Oslo, Universitetsforlaget, 1994, 158 p.

Rankama T., Kankaanpaa J. First evidence of eastern Preboreal pioneers in arctic Finland and Norway. Quartär. International Yearbook for Ice Age and Stone Age Research, 2011, vol. 58, pp. 183-209.

Rankama T., Kankaanpaa J. From Russia with Love: Eastern Intruders in the North Norwegian Mesolithic. Early Economy and Settlement in Northern Europe: Pioneering, Resource Use, Coping with Change. The Early Settlement of Northern Europe. Ed by H.P. Blankholm. Vol.3. Sheffield, Equinox eBooks Publishing, 2018, pp. 139-167. 
Sapelko T.V. Northern Scandinavia. Paleogeography of the Kola Peninsula. Initial Human Colonization of Arctic in Changing Paleoenvironments: Atlas-monograph. Eds V.M.Kotliakov, A. A. Velichko, S. A. Vasilev. Moscow, GEOS, 2014, pp. 30-37. (In Russian)

Sorensen M., Rankama T., Kankaanpaa J., Knutsson K., Knutsson H., Melvold S., Eriksen B. V., Glorstad H. The First Eastern Migrations of People and Knowledge into Scandinavia: Evidence from Studies of Mesolithic Technology, 9th-8th Millennium BC. Norwegian Archaeological Review, 2013, vol. 46, no. 1, pp. 19-56.

Sorokin A. N., Oshibkina S. V., Trusov A. V. Na perelome epokh. Moscow, Grif i K, 2009, 388 p. (In Russian)

Shaiakhmetova L. G. Post-II - mezoliticheskaia stoianka na severo-vostochnom poberezhe Barentseva moria Drevnosti Russkogo Severa. Iss. 1. Vologda, Ardvisura, 1996, pp. 43-52. (In Russian)

Shumkin V. Ya. Mesolithic of the Kola peninsula. Soviet Archaeology, 1986, iss. 2, pp. 15-33. (In Russian)

Shumkin V. Ya. Rannii kamennyi vek zapadnoi chasti Evropeiskoi Arktiki (mezolit severnoi Skandinavii). Drevnosti Severo-Zapada Rossii (slaviano-finno-ugorskoe vzaimodeistvie, russkie goroda Baltiki). St. Petersburg, Tsentr "Peterburgskoye vostokovedeniye" Publ., 1993, pp. 34-58. (In Russian)

Tarasov A. Filling a gap in the migration route? Initial peopling of Lake Onega in the light of new radiocarbon datings. Norwegian Archaeological Review, 2018, vol.51, iss. 1-2, pp. 178-189.

Tolstobrov D.S., Tolstobrova A.N., Kol'ka V.V., Korsakova O.P. Postlednikovoe podniatie zemnoi kory v severo-zapadnoi chasti Kol'skogo regiona. Vestnik of the Murmansk Technical University, 2015, vol. 18, iss. 2, p. 295-306. (In Russian)

Woodman P.C. The Komsa culture. A re-examination of its position in the Stone Age of Finnmark. Acta Archaeologica, 1993, vol. 63, pp. 57-76.

Zemliakov B.F. Arkheologicheskie issledovaniia na poberezh'ye Arkticheskogo okeana. Trudy Sovetskoi sektsii Assotsiatsii po izucheniiu chetvertichnogo perioda. Iss. 3, Leningrad, Moscow, Izdatel'stvo AN SSSR, 1937, pp. 81-106. (In Russian)

Zemliakov B. F. Arkticheskii paleolit na severe SSSR. Sovetskaia arkheologiia. Issue 5. Moscow, Leningrad, Izdatel'stvo AN SSSR, 1940, pp. 107-143. (In Russian)

Статья поступила в редакцию 24 мая 2018 г.

Рекомендована в печать 12 марта 2019 г.

Received: May 24, 2018

Accepted: March 12, 2019 


\title{
Начало неолитической эпохи на Верхней Волге
}

\author{
Н. А. Цветкова
}

Для цитирования: Цветкова Н. А. Начало неолитической эпохи на Верхней Волге // Вестник Санкт-Петербургского университета. История. 2019. Т. 64. Вып. 2. С. 683-717. https://doi.org/10.21638/11701/spbu02.2019.215

Статья посвящена вопросу перехода от мезолита к неолиту на Верхней Волге. На основании исследования каменной индустрии со стоянок начального неолита только с неорнаментированной/накольчатой керамикой, сопоставления типов орудий начального неолита и финального мезолита региона и изучения распространения сосудов с неорнаментированной/накольчатой орнаментации на Европейской части России автор реконструирует детали культурных процессов в регионе около 7100/7000 некалиброванных л. н. Так, переход к неолиту следует ассоциировать с разовыми контактами между автохтонным населением и носителями навыков изготовления глиняной посуды с разреженной накольчатой орнаментацией. Наиболее вероятно, что первая посуда попала в регион в готовом виде. Отсутствие различий между каменными индустриями финального мезолита и начального неолита не свидетельствует о массовом притоке населения в регион. Отсутствие принципиальных отличий в наборах культуроопределяющих орудий в древностях начального неолита Верхневолжского региона и сопредельных территорий и невозможность обозначить четкие границы ареалов археологических культур этого времени позволяют говорить о единой культурной общности ранней накольчатой керамики. Появление керамики у мезолитического населения Верхней Волги не привело к возникновению местного очага культурогенеза. Попав в мезолитическую среду, традиция изготовления ранней накольчатой посуды не имела длительного продолжения и была прервана притоком населения, обладавшего навыками изготовления посуды с гребенчатой орнаментацией из сложно-рецептурного теста. Эпизод появления и распространения керамики с разреженной накольчатой орнаментацией, не сопровождавшийся существенными изменениями в облике каменного и костяного инвентаря, можно рассматривать как переходное время между мезолитом и неолитом, собственно неолитизация. Переход к неолиту, отмеченный изменением хозяйственного уклада, формированием местного очага производства керамики и распространением техники изготовления тонких бифасов, произошел позднее и был связан со сменой населения на Верхней Волге 6500-6400 л. н.

Ключевые слова: Верхняя Волга, начальный неолит, неолитизация, культурогенез, волго-окская культура, каменный инвентарь, технокомплекс.

Наталия Александровна Цветкова - специалист отдела научной документации, ФГБУК «Российский этнографический музей», Российская Федерация, 191186, Санкт-Петербург, ул. Инженерная, 4/1, n-tsvetkova@yandex.ru; info@ethnomuseum.ru

Nataliia A. Tsvetkova - Fellow of Scientific Documentation Department, The Russian Museum of Ethnography, 4/1, Inzhenernaya ul., 191186, St. Petersburg, Russia; n-tsvetkova@yandex.ru; info@ethnomuseum.ru

(C) Санкт-Петербургский государственный университет, 2019 


\title{
The Emergence of the Neolithic in the Upper Volga
}

\author{
N. A. Tsvetkova
}

For citation: Tsvetkova N.A. The Emergence of the Neolithic in the Upper Volga. Vestnik of Saint Petersburg University. History, 2019, vol. 64, iss. 2, pp. 683-717.

https://doi.org/10.21638/11701/spbu02.2019.215 (In Russian)

The paper examines a phenomenon of neolithisation in the Upper Volga basin. On the basis on: 1) research of the stone assemblages from reference sites with non-ornamented ceramics or pottery with simple puncture impressions; 2) comparison between types of tools in the final Mesolithic and initial Neolithic; 3) mapping of the non-ornamented/notch-ware pottery in European Russia, - the author reconstructs the details of the cultural processes in the region in 7100/7000 uncalibrated years BP. The initial spread of the non-ornamented/puncture-ware ceramics, which was not followed by fundamental changes in the stone and bone inventory, presents a model of the dynamics of cultural processes in the Upper Volga region about $7100 / 7000$ years uncal BP. Locally, the Neolithic transition is linked with the arrival of some puncture-ware pottery makers who penetrated into the area occupied by indigenous Mesolithic population. Most likely, the first vessels were brought into the region by migrants. Te untraceable differences between the Final Mesolithic and the Early Neolithic stone industries may indicate hardly recognizable inflow of newcomers from neighboring territories into the Upper Volga region. Pottery-making tradition, either production of non-ornamented vessels or vessels decorated by simple puncture impressions, was formed in the environment of regional culture. Thus that should be regarded as a particular transition time from the Mesolithic to the Neolithic (i.e. neolithization). The later rise of the Neolithic about 6500-6400 years BP (uncal) was marked by shifts in the economy and by the development of local ceramics accompanied by the emergence of thin biface technique in the stone assemblages. These changes provide evidence of a transition to the Neolithic in the Upper Volga determined by the progressive replacement of populations.

Keywords: the Upper Volga region, Initial Neolithic, neolithisation, cultural genesis, the Volga-Oka culture, stone inventory, techno-complex.

\section{Введение}

Переход к неолиту в лесной зоне отмечен появлением в материальной культуре керамических сосудов. В Верхневолжском регионе, в который входят территории от истоков Волги вместе с Валдайским поозерьем до впадения Оки в Волгу, это событие произошло около 7100-7000 л. н. (здесь и далее используются некалиброванные значения радиоуглеродного возраста, л. н.). Начальный этап неолита в регионе соотносится с ранним этапом верхневолжской археологической культуры. Его основной особенностью является неорнаментированная и тычково-накольчатая керамика. Процесс перехода от мезолита к неолиту на Верхней Волге воспринимается сейчас как трансформация бутовской мезолитической культуры в ранненеолитическую верхневолжскую с участием пришлого населения, владевшего навыками изготовления глиняной посуды ${ }^{1}$.

${ }^{1}$ Костылева Е.Л. Основные вопросы неолитизации центра Русской равнины (особенности неолитизации лесной зоны) // Неолит - энеолит юга и севера Восточной Европы (новые материалы, исследования, проблемы неолитизации регионов). СПб., 2003. С. 213-218. 
Каменный инвентарь раннего этапа верхневолжской культуры характеризуют материалы стоянок Окаёмово 5; 18/III; Озерки 5/III; Беливо 2; Альба; Давыдковская и Шадрино IV.Для него характерны:

1) использование отщепа в качестве основной заготовки;

2) сокращение количества пластин по сравнению с финальным мезолитом;

3) преобладание пластин с нерегулярной огранкой;

4) наличие разнообразных по формам нуклеусов;

5) изготовление стрел и режущих орудий на пластинах;

6) единичные костяные орудия с пазом и микропластинки-вкладыши в большинстве своем с приостренным краем, изредка - с притупленным краем и концом, и скошенные острия;

7) наконечники стрел с выделенным черешком и изделия иволистной формы с подработкой пера и насада или с ретушью по периметру заготовки, наконечники с двусторонней краевой ретушью;

8) разнообразные по формам скребки, составляющие наиболее многочисленную категорию орудий;

9) угловые резцы на сломе, преимущественно из отщепов, но встречаются и на пластинах;

10) единичные срединные резцы и иные типы резцов;

11) рубящие орудия, в изготовлении которых сочетаются оббивка и шлифовка;

12) различные ножи, скобели, сверла, проколки, комбинированные орудия, пластины и отщепы с регулярной и с нерегулярной ретушью ${ }^{2}$.

Такая весьма общая характеристика каменной индустрии начального этапа неолита Верхней Волги до недавнего времени считалась достаточной для этой эпохи. Это связано с тем, что в свое время была обоснована культурная преемственность ранненеолитического населения от мезолитического (бутовская культура). Детально охарактеризованная каменная индустрия бутовской культуры на позднем этапе ее развития позволяла получить полное представление и о ранней верхневолжской ${ }^{3}$.

Положение дел изменилось после того, как на основе результатов технологического анализа была выявлена неоднородность ранней верхневолжской неорнаментированной/тычково-накольчатой керамики по сравнению с более поздней, ложношнуровой/с гребенчатыми оттисками среднего и позднего этапов развития культуры ${ }^{4}$. Сейчас установлено, что верхневолжские гончары использовали тесто сложносоставных рецептов в вариантах «глина + шамот + органика» и «глина + шамот + органика + дресва». При этом использование шамота рассматривается в качестве маркера верхневолжской культуры. А. А. Бобринский показал, что возникновение сложных технологических традиций (многокомпонентные примеси в формовочных массах) на начальных этапах становления гончарства было обусловлено

2 Энговатова А.В., Жилин М.Г., Спиридонова Е.А. Хронология верхневолжской ранненеолитической культуры (по материалам многослойных памятников Волго-Окского междуречья) // Российская археология. 1998. № 2. С. 18; Кольиов Л. В., Жилин М. Г. Мезолит Волго-Окского междуречья. Памятники бутовской культуры. М., 1999. С. 82.

3 Жилин М. Г.Некоторые вопросы перехода от мезолита к неолитуна Верхней Волге // Проблемы изучения эпохи первобытности и раннего средневековья лесной зоны Восточной Европы. Иваново, 1994. Вып. 1. С. 19-31; Кольцов Л. В., Жилин М. Г. Мезолит Волго-Окского междуречья... С. 82.

4 Цетлин Ю. Б. Периодизация истории населения Верхнего Поволжья в эпоху раннего неолита (по данным изучения керамики) // Тверской археологический сборник. 1996. Вып. 2. С. 155-163. 
контактированием между собой носителей навыков изготовления посуды с однокомпонентными примесями в формовочных массах ${ }^{5}$. Появление примеси дресвы в поздней верхневолжской посуде объясняется контактами верхневолжского населения с носителями традиций изготовления керамики с ямочно-гребенчатым орнаментом. В ранней верхневолжской посуде, декорированной тычками/наколами либо неорнаментированной, в качестве примеси использовалась органика. Данное обстоятельство принято за основу для обособления волго-окской культуры, выделенной Ю. Б. Цетлиным, в качестве самостоятельной историко-культурной единицы, хронологически предшествовавшей верхневолжской культуре 6 .

Концепция волго-окской культуры подверглась серьезной критике. По мнению Е.Л.Костылевой, А.В.Уткина и А.В.Энговатовой, «для начальной стадии гончарства, когда технологические приемы еще только складывались и не были устойчивыми, нет нужды связывать появление той или иной примеси в глиняной посуде с инокультурным влиянием. Подобное возможно лишь в условиях устойчивых, давно сложившихся технологических традиций. Поэтому нам представляется некорректной попытка выделить ранний этап верхневолжской культуры в особую автохтонную волго-окскую культуру... Тем более что выделение новой археологической культуры требует более солидного обоснования, нежели данные по технологии производства керамики» ${ }^{7}$.

Исследования последних лет подтвердили разнородность компонентов верхневолжской культуры. Технико-типологический анализ ее каменной индустрии позволил выделить две качественно отличные друг от друга по технологии группы каменного инвентаря, каждая из которых сопровождается разнокультурной, по Ю.Б. Цетлину, керамикой. Для первой и более ранней индустрии (от 7100-7000 до 6600-6500 л. н.) характерны высокая роль пластины и прием минимальной модификации заготовок при вторичной обработке. Данная черта ярко выражена в облике наконечников стрел с подработкой острия пера и насада/черешка или с контурной ретушью, занимающей менее 3/4 поверхности пластины-заготовки. Этот инвентарь соответствует I этапу развития верхневолжской культуры (волго-окской - по Ю. Б. Цетлину) и сопровождается ранней керамикой с разреженной тычково-накольчатой орнаментацией. Вторая группа изделий происходит со стоянок развитой и поздней верхневолжской культуры (6600/6500 - 6000/5900 л. н.) и характеризуется использованием отщепа в качестве основной заготовки и приема сплошного ретуширования острий (наконечников стрел, копий, дротиков) и ножей, а также появлением техники производства тонких бифасов. Ее сопровождает керамика с ложношнуровым и с гребенчатым орнаментом ${ }^{8}$.

Каменный инвентарь базовых памятников волго-окской культуры Залесье 1, Усть-Валдайка, Языково 1, Сомино 2, Ивановское III, V, VII, Сахтыш I, II, VIII, Косячево 1, 2, Завьялка 1, Малая Ламна 1, Стрелка 1, Боринка 2, Волосово, Коренец,

${ }^{5}$ Бобринский А. А. Гончарство Восточной Европы. М., 1978. С.71-72.

6 Цетлин Ю. Б. Неолит центра Русской равнины. Орнаментация керамики и методика периодизации культур. Тула, 2008. С. 37.

7 Костылева Е.Л., Уткин А.В., Энговатова А.В. Неолитические комплексы стоянки Ивановское VII // Мезолитические и неолитические культуры Верхнего Поволжья (по материалам стоянки Ивановское VII). М., 2002. С. 41.

8 Цветкова Н.А. Ранний неолит бассейна Верхней Волги (по результатам изучения каменной индустрии) // Краткие сообщения Института археологии. 2012. Вып. 227. С. 271-280. 
Тереньково III, Жабки 3, Беливо 2, Давыдковская 9 так и не был охарактеризован. В данной работе приводится детальная характеристика каменной индустрии начального этапа неолита Верхней Волги. На основании полученных данных анализируется правомерность обособления древностей этого времени в самостоятельную археологическую культуру.

\section{Источники}

В качестве источников для настоящего исследования использованы коллекции каменных изделий из девяти стоянок, в культурных слоях которых раннего неолита присутствовала только неорнаментированная/тычково-накольчатая керамика. Такой особенностью обладают памятники, приуроченные к отложениям субаквального и субаэрального генезиса («на песке»): Котчище I и Нилова Пустынь в Тверской обл., Алексеевское I и Шадрино IV в Ивановской обл., Давыдковская в Московской обл. и торфяниковые поселения Замостье 2/4a - $6385 \pm 150$ (СПБ719), $6485 \pm 150$ (SPb-728), $6720 \pm 150$ (СПБ-725), $6975 \pm 100$ (СПБ -721), $7030 \pm$ 100 (СПБ-723) и $7105 \pm 150$ (СПБ-722) и Окаёмово 18/III - (6800 \pm 60 (ГИН-8416) в Московской обл., Сахтыш ІІа/Іг - (6411 1150 (СПБ-1452); $6753 \pm 150$ (СПБ1453); $6874 \pm 150$ (СПБ-1450); $6920 \pm 150$ (СПБ-1451); $7065 \pm 150$ (СПБ-1448); $7088 \pm$ 150 (СПБ-1449); $7037 \pm 27$ (KIA- 39309); $7018 \pm 45$ (KIA-39308); $6860 \pm 31$ (KIA-39301); $6847 \pm 31$ (KIA-39300); $7356 \pm 30$ (KIA-39310); $7072 \pm 36$ (KIA-39311); $6395 \pm 28$ (KIA39312); $6371 \pm 30$ (KIA- 39313); $6740 \pm 90$ (Ki-14556); $6690 \pm 90$ (Ki-14554); $6410 \pm 90$ (Кі-14557); $6290 \pm 90$ (ГИН- 12985); $6960 \pm 40$ (ГИН-12986); $7220 \pm 70$ (ГИН-12984); и Становое 4/II (раскоп 21998 г.), (7030 100 (ГИН-8378) в Ивановской обл, $7030 \pm$ 100 (ГИН-8378) (рис. 1).

Среди исследователей распространено мнение о наличии в культурных слоях этих стоянок примеси финальномезолитических материалов ${ }^{10}$. Как доказательство приводятся примеры налегания материалов раннего неолита на мезолитические находки на торфяниковых памятниках без разделения, за редким исключением, стерильными прослойками. Доказать наличие такой примеси практически невозможно, поскольку различия между каменными индустриями финального мезолита и раннего неолита малозаметны и надежно устанавливаются только на основании сравнительной статистики коллекций. Убедительным доказательством хронологической позиции памятника служат находки ранней керамики в культурном слое.

К раскрытию заявленной проблематики не могут быть привлечены материалы таких ранних памятников, как Окаёмово 5, Озерки 5/III, Беливо 2 и Альба I, материалы из которых, наряду с прочими, были использованы для характеристики инвентаря первого этапа развития верхневолжской культуры. Из ранненеолитического слоя поселения Окаёмово 5 происходят всего 17 предметов. Морфологически выраженных орудий среди них нет. В культурном слое III поселения Озерки 5 присутствует ложношнуровая керамика, которую Е. Л. Костылева относит к развитому

9 Цетлин Ю. Б.: 1) Периодизация истории населения Верхнего Поволжья в эпоху раннего неолита (по данным изучения керамики); 2) Неолит центра Русской равнины. Орнаментация керамики и методика периодизации культур.

10 Костылева Е.Л. Основные вопросы неолитизации центра Русской равнины (особенности неолитизации лесной зоны). СПб., 2003. С. 213. 


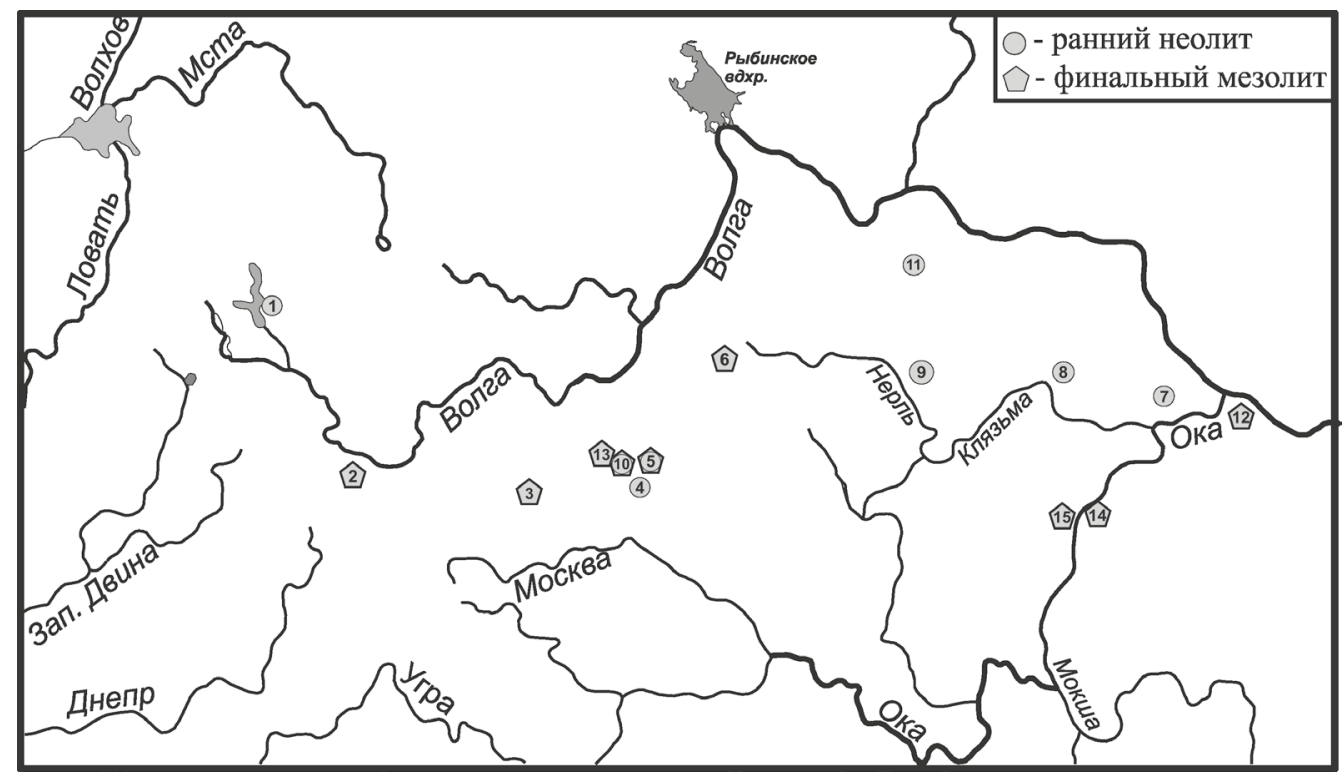

Puc.1. Карта-схема расположения памятников финального мезолита раннего неолита Верхневолжского региона:

1 - Котчище I; Нилова Пустынь; 2 - Озерки 5/IV; 3 - Берендеево III; 4 - Давыдковская; 5 - Замостье 2, верхний мезолитический слой; Замостье 2/4a; 6 - Ивановское VII/IIa; 7 - Шадрино IV; 8 - Алексеевское I; 9 - Сахтыш IІа/ІІг; 10 - Окаёмово 4/III, 5, 18a, 18/III; 11 - Становое 4/II; 12 - Безводное 10; 13 - Нушполы 11; 14 - Новошино; 15 - Елин Бор (составлено автором)

этапу верхневолжской культуры ${ }^{11}$. Материалы стоянок Беливо 2 и Альба I не введены в научный оборот. Из ранненеолитического горизонта Альбы в значительном количестве происходит керамика льяловской культуры, а для стоянки Беливо 2 отмечена мезолитическая примесь ${ }^{12}$.

\section{Обзор материалов}

Массив изученного материала составляет 7521 артефактов из коллекций с девяти стоянок (табл.1). Начальный этап неолита Верхней Волги характеризуется использованием преимущественно кремня различного цвета и качества, происходящего из отложений каменноугольного возраста. Среди него легко отличим сиреневый старицкий кремень, выходы которого известны в Тверском Поволжье. Изделия из него найдены на стоянках Котчище I, Нилова Пустынь, Окаёмово 18/III, Шадрино IV. Минимальный процент изделий на стоянках изготовлен из приносного высококачественного мелового сырья. Например, на стоянке Давыдковская ис-

11 Костылева Е. Л. Ранненеолитическая керамика Верхнего Поволжья // Тверской археологический сборник. 1994. Вып. 1. С. 55.

12 Сорокин А.Н. Мезолит Оки. Проблема культурных различий // Труды Отдела охранных раскопок. М., 2006. Т. 5; Археологическая Карта России: Московская область. М., 1995. Ч.2. С. 20. 
Таблица 1. Распределение категорий каменных изделий на стоянках начального неолита Верхней Волги

\begin{tabular}{|c|c|c|c|c|c|c|c|c|c|c|}
\hline Категории инвентаря & 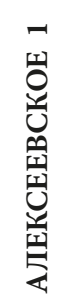 & 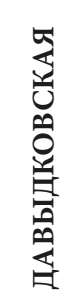 & 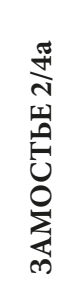 & 息 & 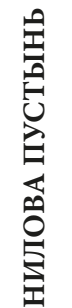 & $\begin{array}{l}\text { 目 } \\
0 \\
0 \\
0 \\
\sum_{:=1}^{\infty} \\
0 \\
0\end{array}$ & $\begin{array}{l}\text { 是 } \\
\text { 罗 } \\
\text { 慁 } \\
\text { 空 }\end{array}$ & 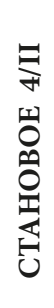 & 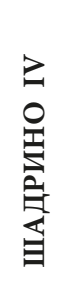 & 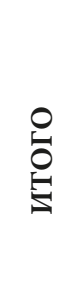 \\
\hline Пренуклеусы & - & 3 & - & - & - & 1 & - & - & - & 4 \\
\hline Нуклеусы & 2 & 10 & 1 & 3 & - & 3 & - & 2 & 3 & 24 \\
\hline HK & 6 & 1 & 4 & 7 & 1 & - & 5 & - & 3 & 27 \\
\hline Отщепы и их фрагменты & 133 & 2267 & 1808 & 1510 & 114 & 62 & 12 & 15 & 113 & 6034 \\
\hline Пластины и их фрагменты & 23 & 554 & 165 & 128 & 3 & 19 & - & 1 & 80 & 973 \\
\hline Абразивы & - & - & - & - & - & 3 & 2 & 1 & - & 6 \\
\hline Грузила & - & - & - & - & - & - & 2 & - & - & 2 \\
\hline Отбойники & - & 2 & - & 1 & - & - & 4 & - & - & 7 \\
\hline Пилы & 1 & - & - & - & - & - & 1 & - & - & 2 \\
\hline Ретушеры & - & 2 & - & 1 & - & - & - & - & - & 3 \\
\hline $\begin{array}{l}\text { Наконечники стрел и их } \\
\text { фрагменты }\end{array}$ & 1 & 3 & 5 & 5 & 1 & 3 & - & - & 1 & 19 \\
\hline $\begin{array}{l}\text { Наконечники копий/ } \\
\text { дротиков }\end{array}$ & - & - & 1 & 2 & - & - & - & - & - & 3 \\
\hline Проколки & 3 & 5 & 27 & 6 & - & 2 & - & - & - & 43 \\
\hline Деревообрабатывающие & 4 & 4 & 3 & 1 & & 1 & 3 & 2 & 1 & 19 \\
\hline $\begin{array}{l}\text { Заготовки } \\
\text { деревообрабатывающих }\end{array}$ & 1 & 1 & & 1 & - & - & 2 & 1 & - & 6 \\
\hline Резцы & 2 & 11 & 1 & 6 & - & 5 & - & - & 3 & 28 \\
\hline Скребки & 5 & 53 & 27 & 34 & 1 & 5 & 2 & 3 & 16 & 146 \\
\hline Вкладыши & 5 & 4 & 9 & - & - & 2 & & 1 & 6 & 27 \\
\hline $\begin{array}{l}\text { Пластины с регулярной } \\
\text { ретушью }\end{array}$ & 3 & 3 & 24 & 14 & - & 1 & - & - & 10 & 55 \\
\hline $\begin{array}{l}\text { Отщепы с регулярной } \\
\text { ретушью }\end{array}$ & 5 & 1 & 4 & - & 2 & 1 & - & - & 1 & 14 \\
\hline Комбинированные орудия & 1 & - & 2 & 1 & - & 4 & - & - & 1 & 9 \\
\hline Неопределимые орудия & 1 & - & - & - & - & - & - & - & - & 1 \\
\hline Фрагменты орудий & - & 2 & - & 1 & - & - & & - & 2 & 5 \\
\hline $\begin{array}{l}\text { Пластины с нерегулярной } \\
\text { ретушью }\end{array}$ & 5 & 1 & - & 1 & - & 1 & - & 1 & 14 & 23 \\
\hline $\begin{array}{l}\text { Отщепы с нерегулярной } \\
\text { ретушью }\end{array}$ & 1 & - & - & - & - & - & 4 & - & 31 & 36 \\
\hline Сырье & 1 & - & - & - & - & - & 3 & 1 & - & 5 \\
\hline ВСЕГО & 203 & 2927 & 2081 & 1722 & 122 & 113 & 40 & 28 & 285 & 7521 \\
\hline
\end{tabular}


пользовался полупрозрачный светло-серый и черный кремень с меловой коркой 13 . Также встречаются орудия из кварцита, сланца, песчаника и др.

\section{Нуклеусы}

Согласно принципу получения сколов-заготовок нуклеусы могут быть призматическими (объемные ядрища кругового скалывания), плоскостными (нехарактерны для раннего неолита Верхней Волги) и бессистемного расщепления (аморфные). Для призматических нуклеусов по соотношению ширины фронта расщепления с остальной частью выделяются неторцовые ядрища (объемные с широким фронтом расщепления), торцовые (объемные с узким фронтом расщепления) и их сочетания. По способу раскалывания выделяются нуклеусы двух видов: параллельные (однонаправленное снятие сколов-заготовок) и конвергентные (разнонаправленное снятие сколов-заготовок), которые имеют разное количество ударных площадок. Так, параллельные нуклеусы могут быть одно- или двухплощадочными, конвергентные - двухплощадочными и многоплощадочными (более двух площадок) ${ }^{14}$. На стоянках начального неолита Верхней Волги преобладают нуклеусы кругового объемного скалывания - неторцовые и торцовые (рис. 2: 6, 7, 11, 12, 15-18, 20-24, 26; табл. 2).

\section{Таблица 2. Типы нуклеусов кругового скалывания со стоянок начального неолита} Верхневолжского бассейна

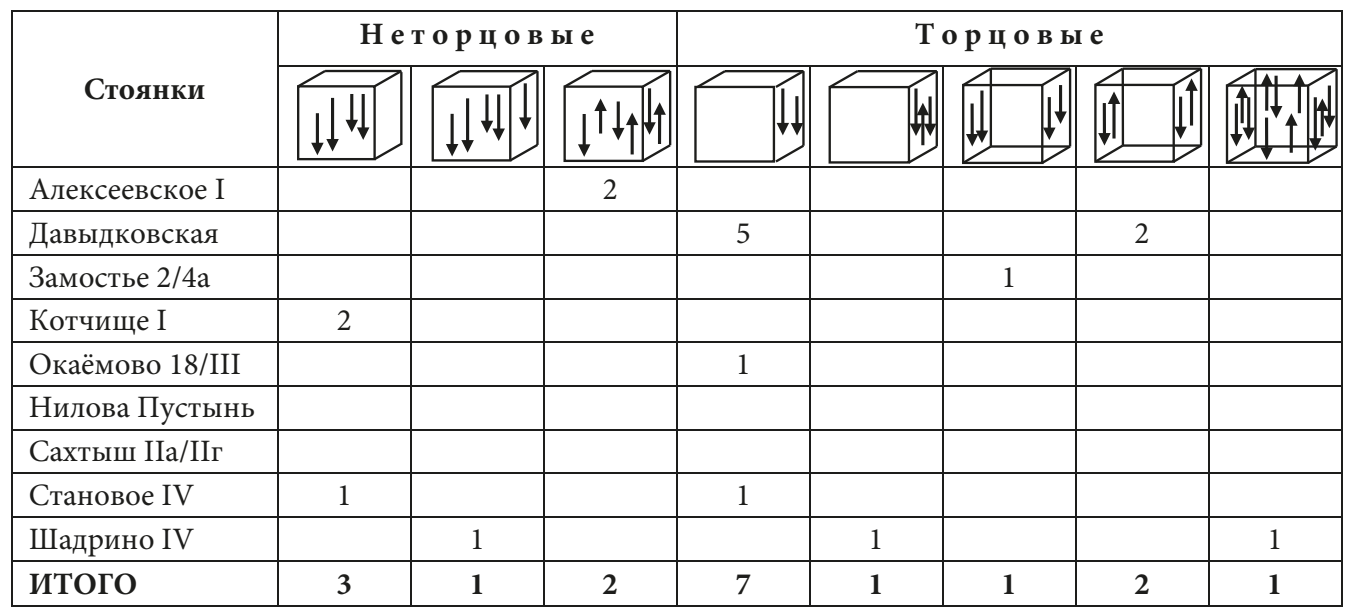

Объемные нуклеусы, сочетающие широкий и узкий фронты (условно-смешанный тип), представлены единственным ядрищем разнонаправленного расщепления со стоянки Шадрино IV для пластин. Его ударные площадки фасетированы, карнизы нередуцированы (рис. 2: 23). Нуклеусы бессистемного расщепления найдены в Окаёмово 18/III - 2 экз., Давыдковской -1 экз.

${ }^{13}$ Сидоров В. В. Давыдковская стоянка на р. Яхроме // Советская археология. 1973. № 2. С. $146-$ 157.

14 Лисищын С.Н. Технология расщепления кремня на финальнопалеолитической стоянкемастерской Аносово I // Тверской археологический сборник. 2002. Вып. 5. С. 38. 


\section{Пластины}

Приведенная ниже характеритика пластин по памятникам учитывает только сколы с субпараллельными краями, длина которых в два и более раза превосходит ширину. К ним относятся изделия с негативами предшествующих продольных пластинчатых снятий на дорсальной поверхности, являющиеся потенциальными заготовками.

Стоянка Алексеевское I - 23 пластины (общее число каменных изделий в коллекции $(\mathrm{N})$ = 205), среди них встречены дистальные (2 экз.), медиальные (18 экз.) и проксимальные части (3 экз.). Из них двугранные - 6 экз., трехгранные - 13 экз., четырехгранные - 4 экз. Найдены четыре целые пластины. Шесть изделий с желвачной коркой. С регулярной огранкой дорсальной поверхности -8 экз., с нерегулярной - 15 экз. Ширина частей пластин - от 7 до 15 мм, в единичном случае - 30 мм. Толщина - от 2 до 4 мм.

Стоянка Давьљковская - 554 пластины ( $\mathrm{n}=3217)$. Отмечено преобладание микропластинок шириной 0,4-1 см (358 экз.), «в основном это мелкие сечения, до 2, 5 см длиной, пластин шириной 1-1,5 cм - 150 шт., и здесь уже преобладают сечения 3-5 см длиной. Широких пластин 46 шт. Значительную часть их составляют короткие вкладыши длиной до 2 см» ${ }^{15}$.

Поселение Замостье 2/4a - 165 пластин ( $\mathrm{n}=311)$, из них 135 экз. - микропластины. Целых пластин и микропластин - 10 и 33 соответственно. Проксимальных частей - 6 экз. (пластины) и 10 экз. (микропластины). Дистальные и медиальные сечения найдены в количестве 14 и 21 экз. соответственно. Микропастинки шириной менее 5 мм составляют группу из 71 экз. ${ }^{16}$

Стоянка Котчище I - 128 пластин ( $\mathrm{n}=1721)$, из них 120 экз. составляют пластины и 8 экз. - микропластины, из которых двугранных - 59 экз., трехгранных - 61 экз., четырехгранных - 5 экз., пятигранных - 3 экз. Изделий с коркой 14 экз. Регулярных пластин - 10 экз. Целых пластин - 11 экз. Ширина пластин колеблется от 6 до 29 см. Наибольшее количество составляют изделия толщиной от 8 до 11 мм и 16-17 мм.

Стоянка Нилова Пустьнь - 3 пластины (n = 122), из которых две - медиальные части и одна целая пластинка. Соотношение ширины к толщине у обоих сечений 15:5. Длина целой пластинки - 23 мм, ширина - 12 мм, толщина - 2 мм.

Стоянка Окаёмово 18/II - 19 пластин (n = 113). Найдено две целые пластины, прочие представлены фрагментами проксимальной части - 3 экз., медиальной -12 экз., дистальной - 5 экз. Большинство из них нерегулярные - 15 экз. Двугранных изделий - 10 экз., трехгранных - 6 экз., четырехгранных - 3 экз. Ширина пластин - 6-32 мм. Преобладают изделий шириной 16-22 мм. Толщина пластин - 2-6 мм.

На поселении Caxmbu IIa/IIг пластины не представлены, а из ранненеолитического комплекса памятника Становое 4/II происходит медиальная часть пластины шириной 12 мм и толщиной 2 мм.

15 Сидоров В.В. Давыдковская стоянка на р. Яхроме. С. 154-155.

16 Лозовская О.В., Лозовский В. М. О каменной индустрии раннего неолита на стоянке Замостье 2 // Методы изучения каменных артефактов. Материалы междунар. конф. Санкт-Петербург, 16-18 ноября 2015 г. СПб., 2015. С. 77. 
В коллекции со стоянки Шадрино IV имеется 80 пластин (n = 306), из них целые - 14 экз., фрагменты - 37 экз. и 29 сечений. Среди целых пластин присутствуют две регулярные пятигранные микропластинки, полученные, вероятно, при помощи отжима. Еще две пластинки представляют собой так называемые петлеобразные сколы. Ширина пластин изменяется от 6 до 9 мм, единичные изделия достигают ширины 16-17 мм.

\section{Орудия для производства орудий ${ }^{17}$}

Абразивы на стоянках начального неолита Верхней Волги представлены шестью фрагментами. В качестве сырья использовался розовый и малиновый кварцит. В Окаёмово 18/III найдены три фрагмента абразивных плиток. Из культурного слоя ІІг поселения Сахтыш ІІа происходят два достаточно крупных фрагмента плит. Оба абразива имеют одинарные зашлифованные рабочие поверхности. У одного из них она очень темного цвета, как будто бы обожжена. Достаточно крупный фрагмент абразивной плиты размером $130 \times 60$ мм найден на поселении Становое 4/II. Кроме того, по одному кварцитовому отщепу со шлифовкой найдено в Окаёмово 18/III и на Сахтыше IIa/ІІг.

Отбойники. Все семь отбойников - гальки размером до 100 мм. Материал розовый или серо-розовый кварцит. Исключения составляют отбойники из кварца (1 экз.) и серого кварцита (1 экз.) со стоянки Сахтыш IІа/ІІг и гранитный отбойник со стоянки Котчище I. На стоянке Давыдковская в качестве отбойников (2 экз.) использовались гальки 50-80 мм с двумя забитыми противоположными концами. В коллекции из раскопок стоянки Давыдковская известны три фрагмента от одного или от нескольких отбойников. Из раскопок прибрежной части поселения Сахтыш 2a/Іг происходят четыре отбойника, два из которых - гальки размерами $110 \times 80$ мм и $65 \times 55$ мм. Первая - плоская, округлой формы с характерными для отбойника «забитостями» по периметру. Вторая - подтреугольной формы с рабочими площадками на противоположных концах и смежной с ними боковой поверхности. Третье орудие - кварцевый желвак размером $65 \times 45$ мм со следами ударов на большей части поверхности. Последний отбойник - галька серого кварцита размером $60 \times 40$ мм с двумя рабочими поверхностями на противоположных концах. Галька серо-розового гранита размером $75 \times 60$ мм со следами работы по периметру имеется в коллекции со стоянки Котчище I. Вполне вероятно, в качестве отбойника могли использовать и кремневый нуклеус бессистемного расщепления, также найденный на стоянке Котчище I. Характерные для работы в качестве отбойника макроследы имеются в большом количестве на киле ядрища. Однако он представлен единственным экземпляром, и относить его к отбойникам без трасологического анализа нельзя.

Сланцевье пиль относятся к данной категории на основании результатов трасологических наблюдений и ряда экспериментов. Два фрагмента пил найдены на стоянке Алексеевское I и в комплексе материалов поселения Сахтыш IIa/IIг. Первый

17 Цветкова Н.А. «Орудия для производства орудий» - изделия из некремневых пород камня (по материалам памятников раннего неолита Верхневолжского региона) // Проблемы изучения эпохи первобытности и раннего средневековья лесной зоны Восточной Европы: к 60-летию А. В. Уткина. Иваново, 2015. Вып. IV. С. 161-164. 
фрагмент пилы представляет собой сланцевую плитку толщиной 5 мм с округлым в сечении рабочим краем. Второй имеет толщину 10 мм и два острых в сечении рабочих края, на каждом из которых шлифовкой сформированы двусторонние фаски.

Чрезвычайно редки находки каменных ретушёров, определяемых типологически. Они выявляются по характерным макроследам утилизации - лункам и царапинам, сконцентрированным на небольшом участке поверхности мелких каменных плиток или галек. На стоянке Давыдковская найден обломок плитки, «густо покрытый лунками (площадь, занимаемая ими, 3 см²)», и плоская галечка, «у которой участки, покрытые лунками, располагаются на слегка выпуклой грани на округлых ребрах, на обеих плоскостях заметны четкие царапины, нанесенные кремнем» ${ }^{18}$. Еще один ретушёр в виде плоской гальки с характерными выбоинами происходит из Котчища I.

\section{Предметы с преднамеренной вторичной обработкой}

\section{Наконечники стрел}

Наконечники стрел со стоянок начального неолита представлены двумя группами изделий. Первую составляют предметы, у которых при формообразовании ретушью модифицировано до $3 / 4$ поверхности заготовки, вторую - со вторичной обработкой, охватывающей $3 / 4$ поверхности заготовки и более.

Все наконечники первой группы изготовлены из пластин и различаются пропорциями, а также наличием или отсутствием выделенного черешка. Так, известны наконечники стрел удлиненных пропорций (соотношение ширины заготовки к ее длине составляет 1: 4 и более). Они представлены тремя орудиями вытянутой листовидной формы. Все наконечники симметричные с подработкой ретушью пера и насада. Первый очень крупный наконечник на трехгранной пластине происходит со стоянки Нилова Пустынь. Орудия таких размеров в Верхневолжском региона более не известны ни на стоянках раннего неолита, ни на памятниках предшествующего периода. Длина наконечника - 90 мм, а ширина - 15 мм. Острие подработано вентральной ретушью, а насад - двусторонней, частично заходящей на перо. На пере также присутствуют несколько фасеток мельчайшей вентральной ретуши (рис. 2: 41). У двух наконечников со стоянок Алексеевское I и Окаёмово 18/III утрачены острия пера. Заготовкой для первого послужила четырехгранная регулярная микропластинка, для второго - трехгранная нерегулярная микропластина. Насады подработаны двусторонней ретушью (рис. 2: 39, 47).

Среди наконечников стрел средних пропорций (соотношение ширины заготовки к ее длине 1:3 или 1:4) есть изделия с выделенным черешком и предметы листовидной формы. Асимметричный наконечник с выделенным черешком и утраченным острием пера найден на стоянке Давыдковская. Черешок подтреугольной формы подработан двусторонней ретушью (рис. 2: 46). На стоянке Окаёмово 18/III найден черешок от наконечника на трехграной регулярной пластине (рис. 2: 49).

Листовидные симметричные наконечники на пластинах происходят из памятников Котчище I (рис. 2: 48) и Окаёмово 18/III. У обоих орудий ретушью подработаны перо и насад (рис. 2: 50).

\footnotetext{
18 Сидоров В. В. Давыдковская стоянка на р. Яхроме. С. 155.
} 
Еще два наконечника листовидной формы изготовлены из отщепов. Первый (со стоянки Котчище I) первоначально был охарактеризован как «крупный удлиненный вкладыш, по форме напоминающий палеолитический граветт, рабочая часть которого образована крутой притупляющей ретушью» ${ }^{19}$. Характер заготовки (отщеп вместо крупной пластины) и отсутствие вентральной подтески, типичной для граветтийской традиции, свидетельствуют о том, что данный наконечник не имеет отношения к верхнему палеолиту. Контекст находки позволяет с уверенностью относить ее к раннему неолиту. Этот наконечник имеет средние пропорции и обработан крутой и отвесной дорсальной контурной ретушью (рис. 2: 40). Заготовкой для второго наконечника средних пропорций из стоянки Давыдковской послужил пластинчатый отщеп. Острие пера утрачено. Округлый насад обработан вентральной полукрутой ретушью, заходящей на перо, и несколькими фасетками дорсальной ретуши (рис. 2: 43). Еще один фрагмент наконечника из того же памятника представлен острием пера с двусторонней подработкой полукрутой дорсальной ретушью и вентральной подтеской.

На поселении Замостье 2/4а найдены пять наконечников стрел: один - с выделенным черешком, четыре - листовидной формы, из которых два - с подработкой двусторонней ретушью пера и насада и два - с краевой дорсальной/вентральной ретушью. Характер заготовки и пропорции не уточняются ${ }^{20}$.

Наконечники стрел со вторичной обработкой от 3/4 поверхности заготовки и более представлены четырьмя орудиями. От наконечника стрелы с двусторонней бифасиальной обработкой из Шадрино IV сохранилось острие пера (рис. 2: 38). Остальные наконечники найдены на стоянке Котчище I. Первый представлен медиальной частью наконечника сильно удлиненных пропорций с полностью ретушированной дорсальной поверхностью и вентральной подтеской (рис. 2: 45). Второй наконечник удлиненных средних пропорций листовидной формы, сплошь ретуширован с дорсальной поверхности и с вентральной подтеской в области насада. Острие пера этого наконечника было сломано и переоформлено в скребковое лезвие (рис. 2: 44). От третьего сохранилась половина с острием пера. Этот наконечник полностью выполнен в бифасильной технике, но не является тонким бифасом.

\section{Наконечники копий/дротиков}

Известны три находки таких орудий. Два наконечника происходят со стоянки Котчище I и один - из Замостье 2/4а. Первый наконечник изготовлен из крупного отщепа, имеет слабо выделенный черешок и обработан сплошной пологой крупнофасеточной дорсальной ретушью. На одном из краев присутствует мелкая крутая ретушь. На вентральной поверхности в области черешка нанесена крутая краевая среднефасеточная ретушь, а по краю (рис. 2: 36) - очень мелкая нерегулярная ретушь утилизации (?). От второго наконечника со сплошной двусторонней ретушью сохранилось острие. Наконечник из Замостье $2 / 4 \mathrm{a}$ - целый (рис. 2: 37). Это листовидное по форме орудие (размеры $65 \times 24 \times 13$ мм), обработанное с обеих сторон

19 Гаврилова И.В. Неолитическая стоянка Котчище на оз. Селигер // Краткие сообщения Института археологии. 1962. Вып. 92. С. 88.

20 Лозовская О.В., Лозовский В.М. О каменной индустрии раннего неолита на стоянке Замостье 2. С. 76. 


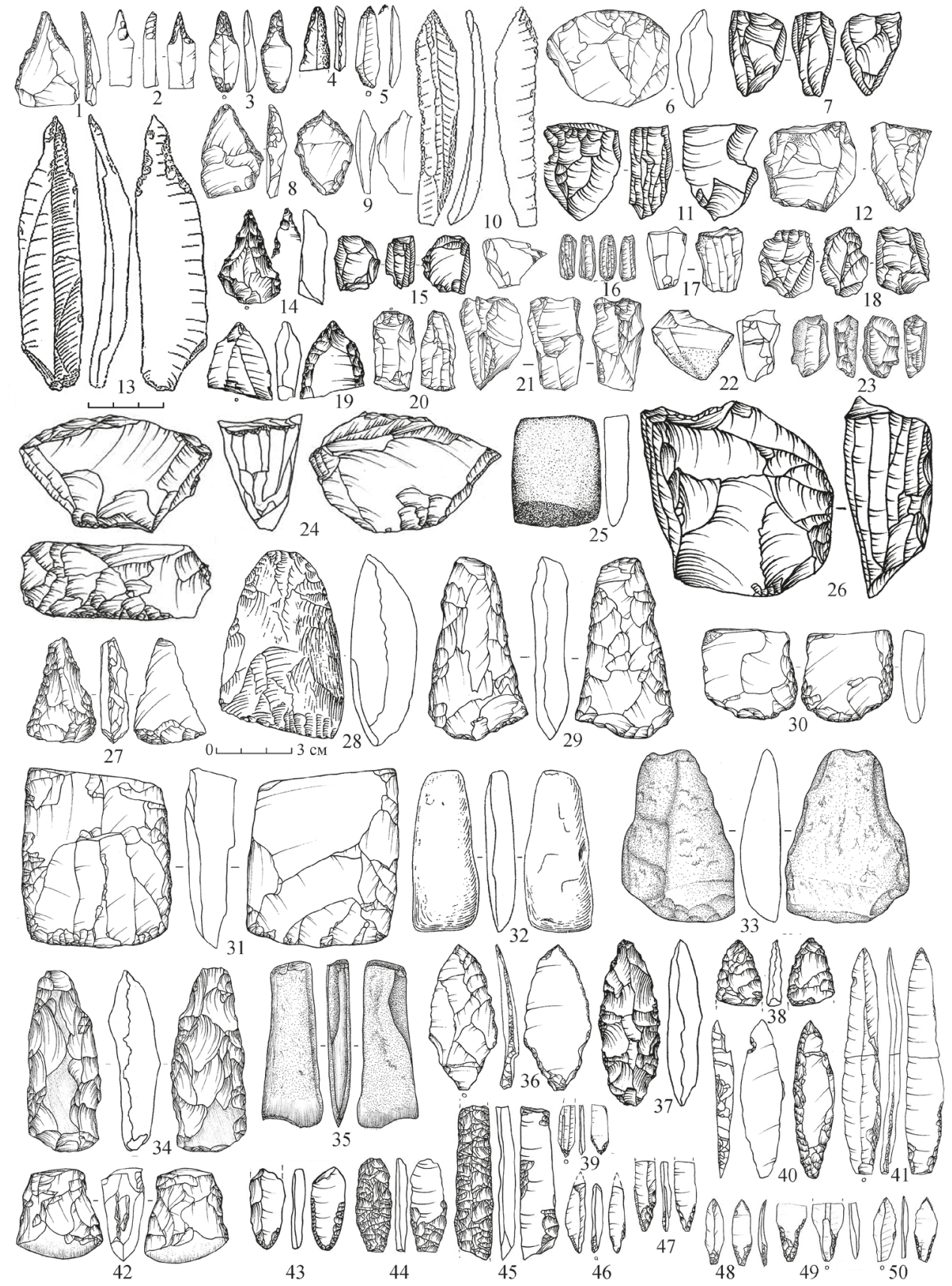

Puc. 2. Каменный инвентарь со стоянок начального неолита Верхней Волги:

$1,3,6,8,9,21,24,27,31,36,40,44,45,48$ - Котчище I; 2, 4, 12, 20, 29, 30, 42, 47 - Алексеевское I (по [Цветкова, 2014]); 5, 39, 49, 50 - Окаёмово 18/III (по [Жилин, 1997]); 7, 10, 13, $15,18,26,28,32,43,46$ - Давыдковская (по [Сидоров, 1973]); 14, 19, 37 - Замостье 2/4а (по [Лозовская, Лозовский, 2015]); 16, 23, 25, 38 - Шадрино IV (по [Цветкова, 2014]); 17, 22, 35 Становое 4/II; 33, 34 - Сахтыш ІІа/ІІг (по [Цветкова, 2013]); 41 - Нилова Пустынь (фр. 1-4, 6, $8,9,12,16,17,20-24,27,29-31,33-36,38,40-42,44,45,47,48$ - рис. автора) 
сплошной крупно-фасеточной ретушью, что вместе с толщиной орудия (13 мм) косвенно указывает на то, что данный предмет находится на конечной стадии изготовления и представляет собой почти готовое изделие (см. рис. 2: 37).

\section{Проколки}

Под проколками понимаются функционально различные по представлениям исследователей орудия (проколки, перфораторы, развертки, сверла, шилья). Устоявшиеся определения для них в литературе отсутствуют. На деле исследователи оперируют терминами «сверло», «шило», «проколка», «перфоратор», «развертка», исходя из собственных представлений об их функциональном назначении. Хорошо известно, что «орудия, имеющие разную форму, использовались для одних и тех же операций и, наоборот, при одинаковой форме имели разные функции» ${ }^{21}$, поэтому судить о функции орудий на основании формы артефакта и по расположению на заготовке макроследов утилизации недопустимо. Исследований, подкрепленных результатами трасологического анализа, для этого вида изделий пока не существует, поэтому корректнее использовать термины «проколки», «перфораторы», «сверла», «шилья», «развёртки» только лишь как синонимы для обозначения группы орудий с прокалывающим кончиком (жальцем) - проколок.

Проколки на стоянках начального неолита Верхневолжского региона представлены орудиями с выделенным и с невыделенным жальцем. Зависимости от типа заготовки (пластина/отщеп) не прослеживается. Тыльные части проколок, как правило, не оформлены.

Проколки с выделенным жальцем найдены на стоянках Алексеевское I (1 экз., см. рис. 2: 2), Давыдковская (1 эк3., см. рис. 2: 13), Замостье 2/4a (2 экз. $\left.{ }^{22}\right)$, Котчище I (3 экз., см. рис. 2: 3, 9). Изделия с невыделенным жальцем происходят из коллекций Алексеевское I (2 экз., см. рис. 2: 4), Давыдковская (4 экз., см. рис. 2: 10), Замостье 2/4a (2 экз., см. рис. 2: 14), Котчище I (3 экз., см. рис. 2: 1, 8), Окаёмово 18/III (2 экз., см. рис. 2: 5).

\section{Деревообрабатывающие орудия}

При изготовлении орудий для обработки дерева использовались карбоновый кремень различного цвета и качества и мягкие породы камня, в основном серый сланец. Отмечен случай использования плитки кварцита. Зависимость морфологии рубящих и технологии их изготовления от типа сырья не установлена ${ }^{23}$.

Деревообрабатывающие орудия, согласно их общему функциональному назначению (рубка и долбление) ${ }^{24}$, подразделяются на орудия с симметричным (топоры) и асимметричным (тёсла) профилем рабочего лезвия. Изделия подчетырехуголь-

${ }^{21}$ Семенов С. А. Развитие техники в каменном веке. Л., 1968. С. 4-5.

22 Всего в слое 4а на поселении Замостье 2 найдены 24 проколки и 3 сверла. Поскольку детальное их описание не представлено, в настоящей статье в статистику включены только проиллюстрированные орудия (в публикации В.М. Лозовского).

23 Цветкова Н.А. Ранненеолитические орудия для обработки дерева в Верхневолжском регионе // Тверской археологический сборник. 2013. Вып. 9. С. 202-217.

24 Семенов С. А. Топор в верхнем палеолите // Краткие сообщения Института истории материальной культуры. 1950. Вып. ХXXI. С. 168-174. 
ной формы, рабочий край (или края) которых сформирован фасетками чешуйчатой ретуши в процессе использованияя ${ }^{25}$, относят к долотовидным орудиям. По общей форме топоры и тесла делят на группы трапециевидных, прямоугольных и треугольных орудий, в каждой из которых согласно способу обработки возможно выделение четырех типов. Первый составляют орудия с двусторонней оббивкой; второй $-c$ оббивкой дорсальной поверхности и вентральной подтеской пологой ретушью; третий - топоры и тесла с оббивкой в сочетании со пришлифовкой; четвертый - шлифованные орудия. Вариантообразующим признаком являются пропорции орудий - удлиненные или средние.

Топоры трапециевидной формы, изготовленные двусторонней оббивкой, найдены на памятниках Алексеевское 1 (см. рис. 2: 29), Давыдковская (2 экз., см. рис. 2: 28) и Окаёмово 18/III (1 экз.). Удиненные пропорции имеет первое орудие, остальные - средние.

Топорик средних пропорций на крупном отщепе с дорсальной оббивкой и вентральной подтеской происходит из комплекса Замостье 2/4a.

Орудия с оббивкой и шлифовкой происходят со стоянок Алексеевское I (2 экз., см. рис. 2: 42), Становое 4/II (1 экз.), Замостье 2/4a (1 экз.), Сахтыш IІа/ІІг (2 экз., см. рис. 2: 33). Все орудия средних пропорций, за исключением одного топорика из Сахтыш ІІа/ІІг, который имеет удлиненные пропорции. Интересен топор со стоянки Алексеевское 1 из серо-зеленого сланца, у которого, в отличие от остальных орудий, рабочее лезвие специально зашлифовано (см. рис. 2: 42).

Полностью шлифованное целое орудие удлиненных пропорций найдено на Становом 4/II. Это достаточно миниатюрное $(65 \times 24 \times 9$ мм $)$ узкое плоское сильно удлиненное толстообушное орудие подтрапециевидной формы с обломанным с одной стороны рабочим лезвием, изготовленное из сланцевой плитки. Шлифовка покрывает не всю поверхность изделия. В некоторых местах сохранилась естественная поверхность сланца (см. рис. 2: 35). Со стоянки Замостье 2/4а происходит фрагмент полностью шлифованного орудия, обушковая часть утрачена.

Топоры подпрямоугольной формы представлены единственным орудием со стоянки Давыдковская. Это толстообушный топорик средних пропорций, изготовленный из отдельности сырья при помощи оббивки и подтески.

Топор треугольной формы также единичен (Котчище I). Это толстообушное орудие средних пропорций, изготовленное из крупного отщепа кремня в технике оббивки в сочетании с подтеской (см. рис. 2: 27).

Тесла трапециевидной формы представлены асимметричной вставкой тесла средних пропорций из поселения Сахтыш ІІа/ІІг. Изделие изготовлено из кварцитовой плитки при помощи оббивки и шлифовки (см. рис. 2: 33). Шлифованное тесло удлиненных пропорций происходит со стоянки Давыдковская (см. рис. 2: 32). На стоянке Шадрино IV найдено прямоугольное шлифованное тесло средних пропорций (см. рис. 2: 25).

Единственное орудие со стоянки Алексеевское 1 относится к долотовидным изделиям (см. рис. 2: 30). Это крупный отщеп с двусторонней крупнофасеточной полукрутой ретушью, образующей рабочее лезвие.

${ }_{25}$ Васильев С. А., Бозински Г., Бредли Б. А., Вишняцикий Л. Б., Гиря Е. Ю., Грибченко Ю. Н., Желтова М. Н., Тихонов А. Н. Четырехъязычный (русско-англо-франко-немецкий) словарь-справочник по археологии палеолита. СПб., 2007. 
Обломки деревообрабатывающих орудий представлены медиальной частью шлифованного предмета (Замостье 2/4a). Известны и заготовки рубящих на разных стадиях изготовления (см. рис. 2: 31 ).

\section{Скребки}

В зависимости от расположения скребкового лезвия на заготовке относительно ее длинной оси выделяются концевые, контурные и боковые скребки. Типообразующим признаком выступает морфология рабочего края. В зависимости от этого выделяются типы: 1 - скребки с дугообразным лезвием; 2 - скребки с прямым лезвием; 3 - скребки с «носиком» (шиповидным выступом на углу рабочего лезвия); 4 - стрельчатые скребки (с треугольным рабочим краем). Симметрия/асимметрия рабочего края (скошенное/нескошенное рабочее лезвие) образуют различия низшего номенклатурного уровня (варинты) ${ }^{26}$.

Со стоянок начального неолита Верхней Волги происходят 116 скребков. Их распределение по группам и типам представлено в табл. 3 (см. рис. 3: 22-41). В нее же включена статистика по аморфным скребкам, несмотря на то что они не являются орудиями с преднамеренной вторичной обработкой. Это изделия случайных форм. Их отличительной чертой является отсутствие намеренно изготовленного скребкового лезвия и использование отщепов, в том числе фрагментированных (отходы производства), в качестве заготовки. То, что обычно у аморфных скребков принимают за скребковое лезвие, является, как правило, нерегулярной ретушью утилизации (?).

Таблица 3. Соотношение групп и типов скребков на стоянках начального неолита Верхневолжского региона

\begin{tabular}{|c|c|c|c|c|c|c|c|c|c|c|c|c|c|c|c|c|c|c|}
\hline \multirow{3}{*}{$\begin{array}{c}\text { Памятники } \\
\text { Группы } \\
\text { ТИПЫ } \\
\end{array}$} & \multirow{2}{*}{\multicolumn{4}{|c|}{$\begin{array}{c}\text { Пластина/ } \\
\text { пластинчатый } \\
\text { отщеп }\end{array}$}} & \multicolumn{12}{|c|}{ Отщеп } & \multirow{3}{*}{ 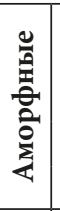 } & \multirow{3}{*}{$\begin{array}{l}0 \\
\stackrel{0}{0} \\
\underline{1}\end{array}$} \\
\hline & & & & & \multicolumn{4}{|c|}{ Концевые } & \multicolumn{4}{|c|}{ Контурные } & \multicolumn{4}{|c|}{ Боковые } & & \\
\hline & 1 & 2 & 3 & 4 & 1 & 2 & 3 & 4 & 1 & 2 & 3 & 4 & 1 & 2 & 3 & 4 & & \\
\hline Алексеевское 1 & 1 & - & - & - & 1 & - & - & - & - & - & - & - & - & - & - & - & - & 2 \\
\hline Давыдковская & 11 & 1 & - & - & 32 & - & - & - & 7 & - & - & - & - & - & - & - & 2 & 53 \\
\hline Котчище I & 3 & 1 & - & 3 & 13 & 4 & - & - & - & - & - & - & 1 & - & - & - & 9 & 34 \\
\hline Нилова Пустынь & 1 & - & - & - & - & - & - & - & - & - & - & - & - & - & - & - & - & 1 \\
\hline Окаёмово 18/III & - & - & - & - & 2 & - & - & 1 & 1 & - & - & - & - & - & - & - & 1 & 5 \\
\hline Сахтыш 2a/IIг & - & - & - & - & - & - & 1 & - & - & 1 & - & - & - & - & - & - & - & 2 \\
\hline Становое 4/II & - & - & - & - & 1 & - & - & - & - & - & - & - & - & - & - & - & 2 & 3 \\
\hline Шадрино IV & 4 & 1 & 1 & - & 7 & - & - & - & 1 & - & - & - & 2 & - & - & - & - & 16 \\
\hline ВСЕГО & 20 & 3 & 1 & 3 & 56 & 4 & 1 & 1 & 9 & 1 & - & - & 3 & - & - & - & 14 & 116 \\
\hline
\end{tabular}

Не имеет аналогов скребок с зубчатой ретушью со стоянки Котчище I (см. рис. 3: 36), который И. В. Гаврилова считала орнаментиром для керамики ${ }^{27}$. Отдель-

26 Цветкова Н.А. Скребки в раннем неолите Верхневолжского региона (сравнительная характеристика) // Тверской археологический сборник. 2015. Вып. 10, т. 1. С. 345-346.

27 Там же. С. 348. 


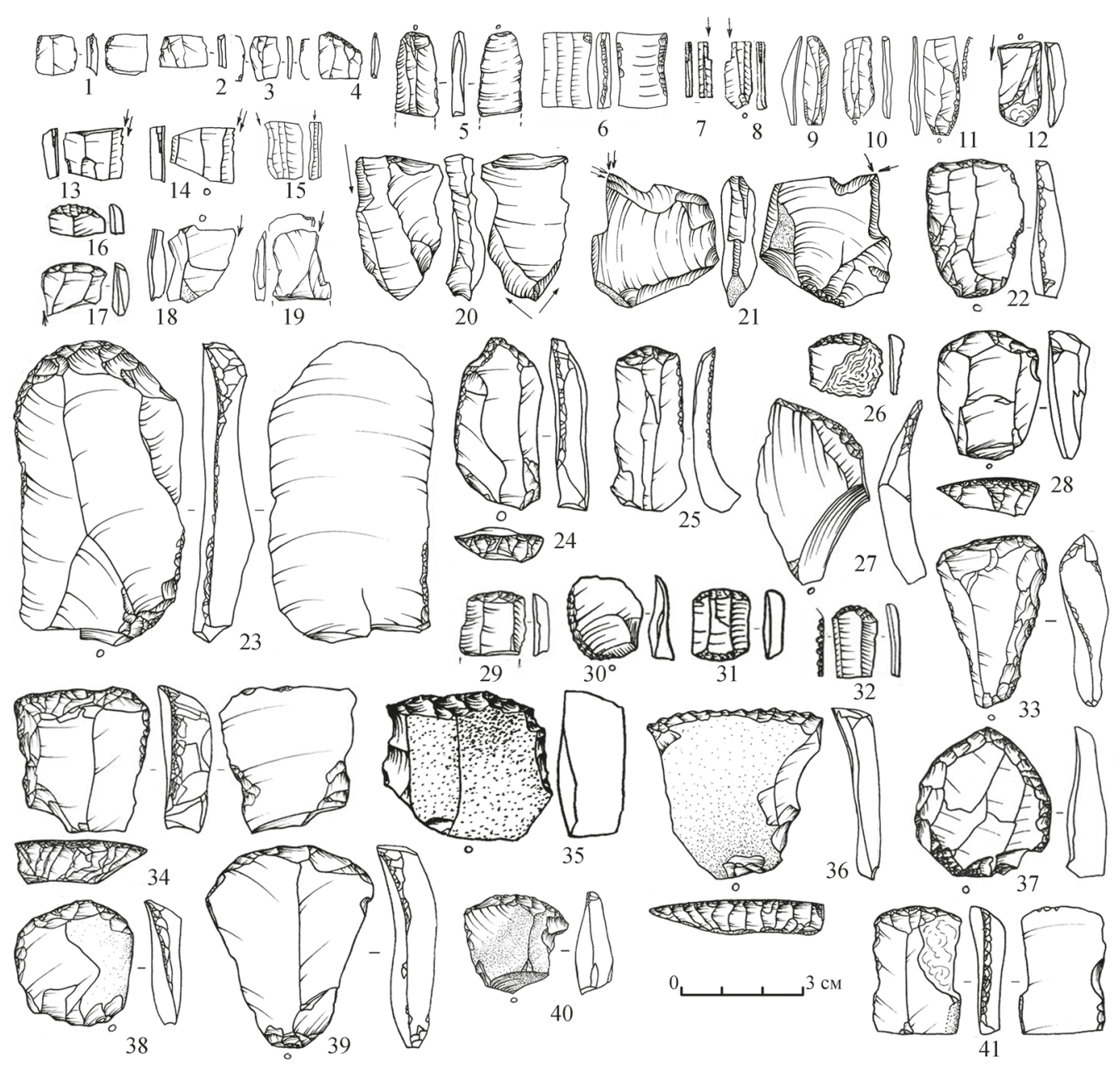

Puc. 3. Каменный инвентарь со стоянок начального неолита Верхней Волги:

1, 2, 4, 17 - Алексеевское 1 (по [Цветкова, 2014]); 3 - Становое 4/II; 5, 19, 12, 22, 24, 25, 27 , 28, 33, 34, 36, 38-41 - Котчище I; 6, 15, 20, 21, 31 - Давыдковская (по [Сидоров, 1973]); 13, 14, 18, 9, 11, 37 - Окаёмово 18/III (по [Жилин, 1997]); 7, 8, 10, 16, 26, 29, 30, 32 - Шадрино IV (по [Цветкова, 2014]); 23 - Нилова Пустынь (по [Цветкова, 2018]); 35 - Замостье 2/4a (по [Лозовская, Лозовский, 2015]) (фр. 1-5, 10, 12, 17, 19, 22-25, 27, 28, 29, 33, 34, 36, 38-41 - рис. автора)

но стоит охарактеризовать скребки со стоянки Замостье 2/4а. Концевые скребки представлены концевыми, боковыми формами; двойными скребками; скребками с обушком (всего 27 экз.). Также найдены четыре микроскребка на отщепах (с узким лезвием). Комбинированных скребков -18 экз. ${ }^{28}$ Более детальных сведений в публикации не представлено. Охарактеризовать согласно представленной классификации можно только опубликованные скребки (7 экз.).

28 Лозовская О.В., Лозовский В.М. О каменной индустрии раннего неолита на стоянке Замостье 2. С. 76. 


\section{Рези,}

По характеру заготовки, определяющей общую форму резца в плане, резцы со стоянок начального этапа неолита подразделяются на две группы. Первую составляют резцы из пластин и пластинчатых отщепов, вторую - резцы из отщепов. Согласно способу формирования резцовой кромки, которая состоит в прямой зависимости от формы резца, выделяются типы:

1) угловые резцы, площадка для снятия резцового скола у которых не подработана и рабочая кромка сформирована прямым ударом (в литературе они известны как угловые на сломе заготовки, см. рис. 3: 12-15, 18);

2) двугранные (срединные) резцы, рабочая кромка которых сформирована ретушированием, а затем - прямым ударом (см. рис. $3: 21$ );

3) ретушные резцы, резцовая кромка которых оформлена сколом, нанесенным на предварительно подготовленную ретушью ударную площадку (см. рис. 3: 19);

4) комбинированные резцы - изделия, сочетающие на одной заготовке разные способы оформления резцовой кромки (см. рис. 3: 20).

Вариантообразующим признаком выступает количество резцовых кромок. Резцовые кромки могут быть расположены по бокам с одного конца заготовки, на противолежащих концах боковых сторон заготовки или на концах боковой стороны заготовки резца ${ }^{29}$.

Таблица 4. Соотношение групп и типов резцов на стоянках начального неолита на Верхней Волге

\begin{tabular}{|c|c|c|c|c|c|c|c|c|c|c|c|c|c|c|}
\hline \multirow{3}{*}{ Памятники } & \multicolumn{6}{|c|}{$\begin{array}{c}\text { На пластине/пластинчатом } \\
\text { отщепе }\end{array}$} & \multicolumn{7}{|c|}{ На отщепе } & \multirow{3}{*}{$\begin{array}{l}0 \\
\stackrel{0}{0} \\
\underline{5}\end{array}$} \\
\hline & \multicolumn{2}{|c|}{ 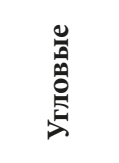 } & \multirow[t]{2}{*}{ 总兽兽 } & \multirow[t]{2}{*}{ D } & \multicolumn{2}{|c|}{ 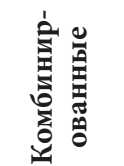 } & \multicolumn{2}{|c|}{ 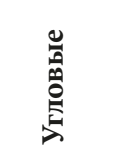 } & \multicolumn{2}{|c|}{ 离葛蒡 } & \multicolumn{2}{|c|}{ 兽 } & \multirow[t]{2}{*}{ 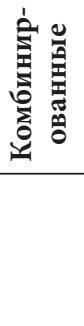 } & \\
\hline & 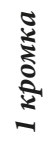 & 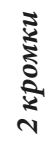 & & & 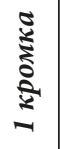 & 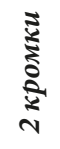 & 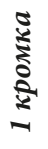 & 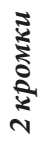 & 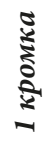 & 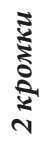 & 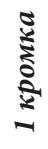 & 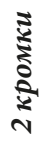 & & \\
\hline Алексеевское 1 & 1 & - & - & - & - & - & - & 1 & - & - & - & - & - & 2 \\
\hline Давыдковская & 3 & 1 & - & - & - & 1 & 3 & 1 & 2 & - & - & - & - & 11 \\
\hline Замостье 2/4a & - & - & - & - & - & - & 1 & - & - & - & - & & & 1 \\
\hline Кочище 1 & 4 & 1 & - & - & - & - & - & - & - & - & 1 & - & - & 6 \\
\hline Нилова Пустынь & - & - & - & - & - & - & - & - & - & & - & - & - & - \\
\hline Окаёмово 18/III & 4 & - & - & - & - & - & 1 & - & - & - & - & - & - & 5 \\
\hline Сахтыш IIa/IIг & - & - & - & - & - & - & - & - & - & - & - & - & - & - \\
\hline Становое 4/II & - & - & - & - & - & - & - & - & - & - & - & - & - & - \\
\hline Шадрино IV & 2 & - & - & - & - & - & \multicolumn{6}{|c|}{ Для одного резца тип неясен } & - & 3 \\
\hline ВСЕГО & 14 & 2 & - & - & - & 1 & 5 & 2 & 2 & - & 1 & - & - & 28 \\
\hline
\end{tabular}

${ }^{29}$ Цветкова Н.А. Резцы в раннем неолите Верхневолжского региона // Известия Самарского научного центра РАН. 2014. Т. 16, № 3. С. 260-265. 
Резец с рабочими кромками, расположенными на боковых сторонах с одного конца заготовки, происходит со стоянки Давыдковская (см. рис. 3: 20). Еще один резец из Котчища 1 имеет две рабочие кромки, расположенные сбоку на противоположных концах пластины.

\section{Вкладыши}

Микропластины-вкладыши со стоянок начального неолита представлены шестью типами из встречающихся в регионе в мезолите - раннем неолите тринадцати ${ }^{30}$ (см. рис. 3: 1-11; табл. 5). Из коллекции со стоянки Замостье 2/4а происходят восемь микропластин с краевой ретушью и одна - с боковыми выемками ${ }^{31}$ (в табл. 5 не включены). Кроме того, со стоянок раннего неолита, где в коллекциях помимо накольчатой присутствует ложношнуровая и гребенчатая керамика II и III этапов верхневолжской культуры, происходят вкладыши с зубчатой ретушью (Сахтыш II); с затупленным крутой ретушью концом и пологой ретушью края/краев (Сахтыш II); с противолежащей ретушью (Плещеево I) ${ }^{32}$.

Таблица 5. Соотношение типов вкладышей на памятниках раннего неолита Верхней Волги

\begin{tabular}{|c|c|c|c|c|c|c|c|}
\hline \multirow[b]{2}{*}{ Стоянки } & \multicolumn{6}{|c|}{ Микропластинки } & \multirow[b]{2}{*}{ ИТОГо } \\
\hline & 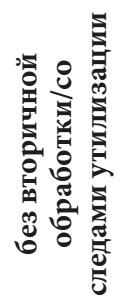 & 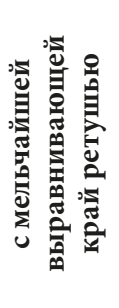 & 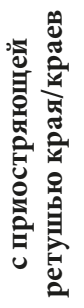 & 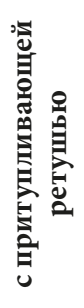 & 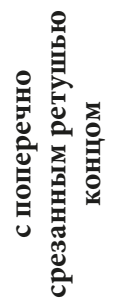 & 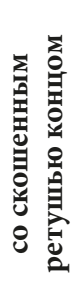 & \\
\hline Алексеевское I & 4 & - & - & - & - & 1 & 5 \\
\hline Давыдковская & 2 & - & 2 & - & - & - & 4 \\
\hline Окаёмово 18/III & & & 1 & & 1 & & 2 \\
\hline Становое 4/II & 1 & - & - & - & - & - & 1 \\
\hline Шадрино IV & 2 & 1 & 1 & 2 & & - & 6 \\
\hline ВСЕГО & 9 & 1 & 4 & 2 & 1 & 1 & 18 \\
\hline
\end{tabular}

\section{Пластины с регулярной ретушью}

На рассматриваемых памятниках региона встречаются различные варианты таких предметов, среди которых наиболее распространены изделия с крутой/полукрутой (притупливающей) ретушью или, напротив, с пологой приостряющей.

Пластины с крутой/полукрутой ретушью по одному краю найдены в следующих памятниках: Алексеевское 1 (3 экз.), Давыдковская (2 экз.), Котчище I (7 экз.),

${ }^{30}$ Цветкова Н.А. Вкладышевое вооружение мезолита - раннего неолита Верхневолжского региона // Stratum plus. 2017. № 1. C. 127-153.

31 Лозовская О.В., Лозовский В.М. О каменной индустрии раннего неолита на стоянке Замостье 2. С. 77.

32 Цветкова Н.А. Вкладышевое вооружение мезолита - раннего неолита Верхневолжского региона. 
Окаёмово 18/III (3 экз.). Все они фрагментированы, и все - с дорсальной ретушью, за исключением одной.

Со стоянки Шадрино IV происходят 10 пластин с крутой/полукрутой и приостряющей ретушью. Количество тех и других в публикации не уточняется ${ }^{33}$.

Пластины с противолежащей ретушью происходят со стоянок Котчище I (3 экз.). У одной пластины на смежном с ретушированным краем конце - подтеска в виде четырех фасеток пологой вентральной ретуши.

Пластины с краевой приостряющей ретушью представлены тремя экз. Со стоянки Давыдковская происходит широкая пластина со сплошной ровной, короткой вентральной ретушью по краям. При исследованиях стоянки Котчище I найдены 2 пластины - с односторонней и двусторонней ретушью. Пластины с выемками представлены двумя экземплярами. Со стоянки Котчище I происходит медиальная часть трехгранной регулярной пластины с мелкофасеточной отвесной краевой ретушью, образующей две неглубокие выемки, и одна пластинка из комплекса Замостье 2/4a. Оттуда же происходят 23 пластины с регулярной ретушью и одна с регулярной бифасиальной. Характер ретуши авторы находок не уточняют. В той же работе упомянута «пилка» — пластинка с зубчатой ретушью ${ }^{34}$.

\section{Отщепь с регулярной ретушью}

Отщепы с приостряющей краевой ретушью происходят со стоянок Окаёмово 18/III (1 экз.) и Давыдковская (1 экз.). У найденных предметов пологой/полукрутой мелкой или среднефасеточной ретушью сформировано ровное острое лезвие. В некоторых случаях ретушь может быть двусторонней. Два отщепа с выемками («скобели») и три - с противолежащей приостряющей ретушью найдены на стоянке Алексеевское 1. Еще один «скобель» известен в Шадрино IV ${ }^{35}$. Из Замостье 2/4а происходят четыре массивных отщепа с одним или двумя грубо ретушированными лезвиями ${ }^{36}$. На стоянке Нилова Пустынь найдено два отщепа с дорсальной ретушью и с противолежащей ретушью ${ }^{37}$.

\section{Комбинированные орудия}

В коллекции со стоянки Котчище I имеется скребок (концевой-боковой по способу организации рабочих участков), он же - резец. Со стоянки Окаёмово 18/III происходят комбинированные изделия, представленные скребком-резцом и двойным боковым скребком-резчиком, а также резцами на сломе ножа и на сломе ско-

33 Крайнов Д. А., Костьлева Е. Л. Ранненеолитическая стоянка Шадрино IV в бассейне р. Лух // Краткие сообщения Института археологии. 1988. Вып. 193. С. 56-65.

34 Лозовская О.В., Лозовский В.М. О каменной индустрии раннего неолита на стоянке Замостье 2. С. 77.

35 Цветкова Н. А. Однослойные памятники раннего неолита Ивановской области // Материалы и исследования по археологии России и Белоруссии. Культурное взаимодействие древних сообществ конца VII-II тыс. до н.э. верховьев Двины и Днепра (технологические и хозяйственные аспекты). СПб., 2014. С. 42-60.

36 Лозовская О.В., Лозовский В.М. О каменной индустрии раннего неолита на стоянке Замостье 2. С. 76.

37 Цветкова Н. А. Ранненеолитическая стоянка Нилова Пустынь (по материалам работ В. И. Тимофеева в Тверской области) // Тверской археологический сборник. 2018. Вып. 11. С.213-219. 
беля ${ }^{38}$. Скребок-резец на дистальной части трехгранной нерегулярной пластины с коркой - из коллекции со стоянки Алексеевское I. Рабочее лезвие скребка сформировано крутой дорсальной ретушью на конце заготовки. Резец угловой на сломе,

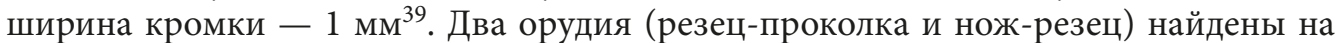
поселении Замостье $2 / 4 \mathrm{a}^{40}$. Из Шадрино IV происходит первичный пластинчатый отщеп с крутой дорсальной нерегулярной ретушью по краю и выемкой на противоположной стороне, сформированной такой же ретушью ${ }^{41}$.

\section{Фрагменты орудий}

Фрагменты орудий, чью функцию невозможно определить, представлены двумя экземплярами со стоянки Сахтыш ІІа/ІІ. Первое изделие - фрагмент расколотой вдоль шлифованной сланцевой плитки, на одном из краев которой присутствует нерегулярная ретушь утилизации. Второе - сформировано двусторонней оббивкой. Из коллекции с поселения Замостье 2/4а происходят отщепы с ретушью и фрагменты орудий из Замостье 2/4а в совокупности 103 экз., статистика для них неизвестна ${ }^{42}$.

\section{Пластины и отщеепы с непреднамеренной вторичной обработкой}

Микропластины-«вкладыши» с нерегулярной ретушью охарактеризованы выше. Пластины с нерегулярной ретушью найдены на стоянках: Алексеевское 1 (5 экз.), Давыдковская (18 экз. $)^{43}$, Котчище I (1 экз.) и Шадрино IV (14 экз.). Отщепы с нерегулярной ретушью найдены при раскопках памятников Алексеевское I (1 экз.) и Шадрино IV (31 экз.). К данной категории относятся и так называемые аморфные скребки (см. «скребки» выше).

\section{Дискуссия}

Резюмируя данные о каменной индустрии начального неолита Верхневолжского региона, следует подчеркнуть нижеследующие ее характеристики.

Наибольшее количество ядрищ на стоянках этого времени - объемного расщепления (призматические). Объемные нуклеусы представлены шестью ядрищами с широким фронтом расщепления (неторцовые) и двенацатью - торцовыми. Нуклеусы условно-смешанного типа (3 экз.) и бессистемного скалывания (3 экз.) немногочисленны (3 и 3 экз., см. табл. 2).

Способы получения сколов-заготовок были различны. Об использовании жесткого отбойника свидетельствуют глубокие неровные негативы сколов на нуклеусах и неподработанные ударные площадки последних. В то же время фасетирование

38 Жилин М. Г. Памятники мезолита и раннего неолита западной части Дубненского торфяника // Древности Залесского края. Сергиев Посад, 1997. С. 167.

39 Цветкова Н. А. Однослойные памятники раннего неолита Ивановской области. С. 46.

40 Лозовская О.В., Лозовский В.M. О каменной индустрии раннего неолита на стоянке Замостье 2. С. 76 .

41 Цветкова Н. А. Однослойные памятники раннего неолита Ивановской области. С. 46.

42 Лозовская О.В., Лозовский В.M. О каменной индустрии раннего неолита на стоянке Замостье 2. С. 77.

43 Сидоров В. В. Давыдковская стоянка на р. Яхроме. С. 155. 
ударных площадок и редукция карнизов нуклеусов могут являться свидетельствами использования мягкого отбойника или посредника. Абразивная подработка карнизов нуклеусов не зафиксирована. Некоторые нуклеусы для микропластин имеют угол скалывания, близкий к 90, что указывает на высокую вероятность использования отжимной техники. Единственный достоверно отжимный (карандашевидный) нуклеус найден на стоянке Шадрино IV (см. рис. 2: 16). Площадки всех призматических нуклеусов сформированы либо единым сколом, либо имеют следы подправки. Карнизы большинства ядрищ не подработаны. Значительная часть нуклеусов сильно истощена.

Процент орудий, изготовленных из пластин, изменяется в широких пределах: от 17,5 до $50 \%$ (Алексеевкое I - $45 \%$ среди всех изделий со вторичной обработкой, Давыдковская - 22,6\%, Замостье 2/4a - 17, $5 \%$, Котчище I - 39\%, Нилова Пустынь - $25 \%$, Окаёмово 18/III - 50\%, Становое 4/II - 14\% и Шадрино IV $36 \%)$. Для сравнения: на стоянках финального мезолита региона значения того же показателя составляют ${ }^{44}$ от 35 до $54 \%$ (Сахтыш 14/Іб - $35 \%$, Окаёмово $18 \mathrm{a}$ - 54\%, Замостье $2-21 \%$, Окаёмово $4-35 \%$, Окаёмово $5-53 \%$, Ивановское VII/IIa, Ивановское $3-31 \%)$.

Изделия-маркеры начального неолита, наконечники стрел с выделенным черешком (2 экз.) или листовидной формы (7 экз.) изготовлены из пластин или микропластин с незначительной модификацией заготовки при помощи ретуши (подправка насада и острия). Пропорции наконечников очень удлиненные (3 экз.) либо средние (6 экз.). Единичны наконечники стрел, выполненные в той же технологической традиции. Заготовкой для них послужили отщеп (Котчище I (см. рис. 2: 40) и пластинчатый отщеп (Давыдковская (см. рис. 2: 43). Наконечник из Котчища I - единственное орудие удлиненных пропорций с контурной ретушью, что объясняется спецификой заготовки (отщеп), потребовавшей большей модификации при изготовлении орудия, нежели только подработка пера и насада. Его стоит рассматривать как индивидуальную форму. К таковым могут быть также отнесены и наконечники-унифасы на пластинах, также найденные при раскопках стоянки Котчище I (см. рис. 2: 44, 45). Наконечники-унифасы известны как в финальном мезолите региона, так и в раннем неолите. Так, например, наконечники-унифасы происходят из ранннеолитического слоя Замостья 2, из той части поселения, где выделение слоя начального неолита из всего ранненеолитического горизонта невозможно.

Фрагмент острия пера наконечника стрелы-бифаса со стоянки Шадрино IV представляет собой, при условии присутствия в коллекции единственного фрагмента ямочно-гребенчатого сосуда, примесь развитого неолита (см. рис. 2: 38$)^{45}$. Наконечник-бифас из Котчище I по характеру вторичной обработки также бесспорно относится к развитому неолиту. Его присутствие объясняется соседним расположением со стоянкой Котчище I поздней стоянки.

Наконечники копий/дротиков редки для начального неолита. Два из них это бифасы со стоянок Котчище I и Замостье 2/4a (см. рис. 2: 37). Третий предмет, с дорсальным сплошным ретушированием и вентральной полукрутой микрорету-

44 Цветкова Н. А. Ранний неолит бассейна Верхней Волги (по результатам изучения каменной индустрии).

45 Цветкова Н. А. Однослойные памятники раннего неолита Ивановской области. С. 48. 
шью, занимающей 3/4 контура, найден в Котчище I (см. рис. 2: 36). Там же найден фрагмент орудия, интерпретируемый как острие пера. По характеру вторичной обработки это развито-неолитическая примесь, связанная с близким расположением позднего памятника. Остальные два изделия-бифаса (с учетом контекста их обнаружения) относятся к раннему неолиту.

Характерными для каменной индустрии начального неолита Верхневолжского региона являются концевые скребки с дугообразным лезвием. Количество таких изделий, изготовленных на отщепах, в 2,5 раза превышает количество скребков на пластинах. Концевые скребки с прямым лезвием, с «носиком», и стрельчатые формы единичны (см. табл.3). Несмотря на то что они не составляют значительных серий, они также в полной мере могут расцениваться как характерные для начального этапа неолита Верхневолжского региона. Микроскребки представлены концевыми формами в коллекциях со стоянок Шадрино IV и Давыдковская (см. рис. 3: 16-17, 26, 29-32). Скрёбла в материалах рассматриваемых памятников неизвестны.

Аморфные скребки - изделия на отщепах и их фрагментах с нерегулярной ретушью, имитирующей скребковое лезвие, составляют $1 / 8$ от общего количества скребков со стоянок начального неолита (см. табл. 3). Таким образом, утверждение о том, что к началу неолита количество аморфных скребков в инвентарях стоянок существенно возрастает ${ }^{46}$, представляется неверным.

Для этого времени характерны угловые резцы с резцовыми кромками, образованными на сломе заготовки. Резцы на пластинах количественно превосходят в два раза резцы на отщепах (см. табл. 4). Как правило, это орудия с одной кромкой. Двухгранные и ретушные резцы единичны. В единственном экземпляре найден комбинированный резец (Давыдковская), сочетающий в себе двухгранный и угловой типы (см. рис. 3: 20). Общее количество изделий, изготовленных из пластин и из отщепов, составляет 17 и 10 экз. соответственно.

Вкладыши на стоянках начального неолита представлены микропластинами девяти разновидностей из возможных тринадцати, выявленных для мезолита раннего неолита Верхней Волги (см. табл. 5). Регресс микропластинчатой техники в начальном неолите, по сравнению с мезолитом, не наблюдается. В каменной индустрий раннего мезолита доля вкладышей составляет от 1,1 до 35 \% среди орудий со вторичной обработкой. В среднем мезолите этот показатель изменяется от 1,1 до $20 \%$, а на памятниках финального мезолита он не превышает 1,3\%. В раннем неолите микропластин-вкладышей - от 0,4 до $13 \%$. Такие показатели свидетельствуют об отсутствии четкой зависимости между возрастом памятника и количеством вкладышей. Следует также учитывать, что микропластины без вторичной обработки - это потенциальные вкладыши.

Вкладышевое вооружение использовалось на Верхней Волге на протяжении всего мезолита и раннего неолита. Некоторые типы орудий, например костяные плоские и игловидные наконечники, оснащенные наборным лезвием, бытовали на протяжении всех рассматриваемых периодов мезолита - неолита. Некоторые из них, такие как наконечники с треугольным пером без шипов и с пазом на стержне, не составляют значительных серий и являются индивидуальными формами. Так, для начального неолита известны пять типов костяных орудий с пазами, три

46 Кольцов Л.В., Жилин М.Г. Мезолит Волго-Окского междуречья. Памятники бутовской культуры М., 1999. С. 64. 
из которых (узкие уплощенные наконечники, однокрылые наконечники с шипом и прямые кинжалы) использовались начиная с пребореала, а один (наконечники с биконической головкой) - с бореала ${ }^{47}$.

Проколки представлены изделиями с выделенным и с невыделенным жальцем. Зависимости от типа заготовки (пластина/отщеп) и формы проколок не прослеживается. Количество проколок, изготовленных из пластин и из отщепов, равное.

Топоры количественно превосходят тёсла в 5 раз. Наиболее распространенными среди обеих категорий являются трапециевидные орудия. Изделия треугольной и прямоугольной формы единичны. Технология изготовления деревообрабатывающих орудий раннего неолита предполагает использование двусторонней оббивки и абразивной обработки с применением разнообразных технических приемов. В их числе следует назвать прием “flake-axe”, когда заготовкой для орудия выступает крупный отщеп, дистальный конец которого, требовавший минимальной обработки, предназначался для лезвия. У такой заготовки подтесывалась вентральная поверхность с боковых сторон, которые предварительно обрабатывались поперечными сколами ${ }^{48}$. Встречено два изделия, изготовленных в такой технике (Котчище I, см. рис. 2: 27, 31).

Сериями представлены пластины и отщепы с регулярной крутой/полукрутой и приостряющей ретушью в различных комбинациях: односторонней, двусторонней, противолежащей.

Комбинированные орудия встречены в сочетаниях «скребок + резец», "резец + нож», «резец + скобель», «резец + проколка». По мнению В. В. Сидорова, для раннего неолита региона характерны так называемые нуклеусы-резцы. В соответствии с технико-морфологическими характеристиками данные изделия являются либо нуклевидными кусками, либо сильно истощенными нуклеусами ${ }^{49}$.

Таким образом, каменную индустрию начального неолита Верхневолжского региона следует характеризовать как пластинчато-отщеповую. Ее оценка по материалам памятников только с неорнаментированной/тычково-накольчатой керамикой существенно уточняет известные представления. В первую очередь это касается роли пластины в индустрии начального неолита. Уже говорилось, что отличительной чертой этого времени среди исследователей считается регресс технологии производства пластин и микропластин. Наблюдения автора показывают, что оценка процентного соотношения пластин, микропластин и изделий из них, по сравнению с отщепами и изделиями из отщепов, в каменных индустриях мезолита и неолита Верхней Волги является в определенном смысле искусственной и связана с неполнотой и неравнозначностью источников ${ }^{50}$, т. е. носит, в основном, источниковедческий характер.

47 Цветкова Н.А. Вкладышевое вооружение мезолита - раннего неолита Верхневолжского региона.

48 Тарасов А.Ю. Адаптация к локальной сырьевой базе, технологическое развитие каменных индустрий и социальное развитие древних обществ: на примере культур Карелии периода неолита - раннего железного века // Адаптация культуры населения Карелии и особенности местной природной среды периодов мезолита - средневековья. Петрозаводск, 2009. Вып. 4. С. 111-134.

49 Цветкова Н. А. Резцы в раннем неолите Верхневолжского региона.

50 Цветкова Н.А. Вкладышевое вооружение мезолита - раннего неолита Верхневолжского региона. 
Во-первых, памятники отличаются друг от друга функциональными особенностями, так как среди них определенно есть охотничьи лагеря, мастерские, поселения, места разделки добычи и т. д. Во-вторых, между ними имеются различия в длительности и периодичности обитания и/или посещения. Кроме того, степень их археологической изученности неравноценна. С другой стороны, процент орудий на пластинах, наличие нуклеусов для пластин и микропластин, количество пластин потенциальных заготовок и высокий процент орудий на пластинах в коллекциях памятников раннего мезолита и начального неолита убедительно свидетельствуют о том, что традиция изготовления орудий на стандартизированной заготовке-пластине просуществовала в регионе 3500 лет, начиная с пребореала. На ее существование никак не повлияли различия в качестве используемого сырья в зависимости от расположения стоянок в разных зонах обеспеченности кремнем ${ }^{51}$.

Микропластинчатая техника на Верхней Волге выходит из употребления вместе с составным вооружением после 6500-6400 л. н. Для этого времени зафиксирована трансформация каменной индустрии из пластинчато-отщеповой в исключительно отщеповую и появление, помимо рубящих орудий, других категорий орудий-бифасов, изготовленных в том числе с применением приема утоньшения ${ }^{52}$. В данном случае можно говорить о последовательном существовании в раннем неолите региона двух различных альтернативных технологических и культурных традиций изготовления орудий. В это же время кардинально меняется и орнаментация керамических сосудов. На смену тычково-накольчатым элементам приходят гребенчатые. В настоящее время по результатам технологического анализа доказано, что носители традиций археологических культур раннего неолита центральной части Европейской России, изготавливавшие посуду с тычково-накольчатыми и гребенчатыми элементами, не родственны между собой ${ }^{53}$. Отказ населения Верхневолжского региона от микропластинчатой техники логичнее объяснять сменой населения, произошедшей на Верхней Волге 6500-6400 л. н., а не потерей навыка изготовления пластин.

Тождество каменных индустрий начального неолита и финального мезолита позволяет раскрыть детали неолитизации Верхневолжского региона. Феномен появления керамики в материальной культуре охотников-рыболовов-собирателей до сих пор до конца не ясен. На территории Европейской части России сегодня известны три наиболее ранних очага гончарства, откуда на Верхневолжский регион распространялись «культурные импульсы» в результате миграций населения. Появление первых глиняных сосудов на Верхней Волге связывается с продвижением в его пределы населения из южных/юго-восточных регионов ${ }^{54}$.

51 Жилин М.Г. Адаптация мезолитических культур Верхнего Поволжья к каменному сырью // Тверской археологический сборник. 1998. Вып. 3. С. 25-30.

52 Энговатова А.В., Жилин М. Г., Спиридонова Е.А. Хронология верхневолжской ранненеолитической культуры (по материалам многослойных памятников Волго-Окского междуречья).

53 Подробно об этом см.: Смирнов А. С. Памятники с накольчатой и гребенчатой орнаментацией в неолите Подесенья // Проблемы изучения раннего неолита лесной полосы Европейской части СССР. Ижевск, 1988. С. 32-43; Иванищева М. В. Хронология памятников раннего неолита Южного Прионежья // Проблемы хронологии и этнокультурных взаимодействий в неолите Евразии. СПб., 2004. С.60-69; Цетлин Ю.Б. О происхождении верхневолжской культуры // Влияние природной среды на развитие древних сообществ. Йошкар-Ола, 2007. С. 197-208.

54 Никитин В.В. Проблемные вопросы неолитизации Волжского бассейна // Человек, адаптация, культура. Тула, 2008. С. 307-313; Вискалин А. В. Культурные процессы на Средней Волге в ран- 
Выводы о перемещениях групп населения, владевшего навыками изготовления посуды, основаны на результатах изучения технологии изготовления и орнаментации керамики. Детальное сравнение каменных индустрий мезолитических и ранненеолитических каменных индустрий по типам орудий для Волго-Окского междуречья до сих пор не проводилось. Считается, что в условиях единых природно-климатических условий и схожих хозяйственных укладов возникает сложность с выявлением различий в каменном инвентаре этих эпох ${ }^{55}$. Однако необходимость такого сравнения очевидна, поскольку разнородность или ее отсутствие в типологическом составе орудийных наборов финального мезолита и раннего неолита может указывать на массовые подвижки населения (миграции) или же на разовые инфильтраты (например, брачные связи, гостевые контакты).

К датированным стоянкам с условно «чистыми» комплексами финального мезолита на Верхней Волге относятся следующие объекты: Безводное 10 (6920 \pm 5380,

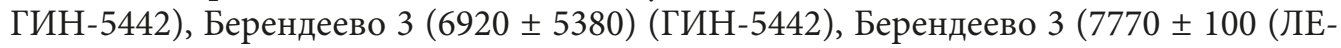
1556), Замостье 2/верх. мез. сл. (7450 \pm 100) (ГИН-6565), $7100 \pm 120$ (ГИН-10066), $7460 \pm 20$ (ЛЕ-10094), $7450 \pm 70$ (ЛЕ-10091), $7440 \pm 60$ (ЛЕ-10092), $7400 \pm 75$ (ЛЕ10260), $7350 \pm 45$ (ЛЕ-10090), $7270 \pm 120$ (ЛЕ-9524), $7050 \pm 60$ (ГИН-10068), $7200 \pm 90$ (ГИН-7988), Ивановское VII/IIa (7530 \pm 150$)$ (ГИН-9361), $7520 \pm 60$ (ГИН-9361), $7490 \pm 120$ (ЛЕ-1260), $7375 \pm 170$ (ЛЕ-1261), $7320 \pm 190$ (ГИН-9369), Нушполы 11 (7310+) (ГИН-6657), Озерки 5/IV (7410 90 (ГИН-6659); $7310 \pm 120$ (ГИН-7218);

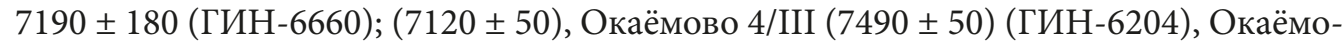
во 5 (7910 \pm 80) (ГИН-6191); $7730 \pm 60$ (ГИН-6192), Окаёмово 18а (7420+50) (ГИН6656a). На основании результатов палинологического анализа материалы стоянок Новошино и Елин Бор/II ${ }^{56}$ (см. рис. 1) относят к началу атлантикума. Сравнение типов орудий, характерных для финального мезолита и раннего неолита региона, показано на рис. 4.

Для первичного расщепления в начальном неолите по сравнению с предшествующим периодом различия не прослеживаются. Сопоставление по типам орудий также показывает отсутствие различий между каменными индустриями финального мезолита и раннего неолита, что можно объяснять культурной преемственностью между населением этих эпох. Новые типы каменных орудий на стоянках с неорнаментированной/тычково-накольчатой керамикой не известны. В.М.Лозовский считал появление струйчатой ретуши ранненеолитическим новшеством $^{57}$. Однако она известна только для орудий из Замостье 2, найденных в слое, где в перемешанном виде залегает ранненеолитическая посуда всех типов. Столь редкое использование данного приема ретуширования говорит о том, что струйчатая ретушь как технический прием не характерна для раннего неолита бассейна Верхней Волги.

Начало неолита на Верхней Волге маркируется появлением глиняной посуды 7100-7000 л. н. без трансформации каменной индустрии. Первая керамика в сово-

ненеолитическую эпоху // Неолитические культуры Восточной Европы: хронология, палеоэкология, традиция. СПб., 2015. С. 26-28.

55 Никитин В. В. Проблемные вопросы неолитизации Волжского бассейна. С. 308.

56 Кольиов Л. В., Жилин М. Г. Мезолит Волго-Окского междуречья. Памятники бутовской культуры М., 1999. С.72.

57 Лозовский В. М., Мазуркевич А. Н. Начальный этап раннего неолита Европейской части России // Российский археологический ежегодник. 2014. № 4. 
купности с пластинчато-отщеповой индустрией существует до 6500-6400 л. н. Очевидно, что каменный инвентарь и керамика этого хронологического отрезка отличаются от более поздних ранненеолитических комплексов Верхневолжского региона (II и III этапы развития верхневолжской культуры). Ю. Б. Цетлин предложил для древностей начального неолита наименование волго-окской археологической куль$m y p \iota^{58}$. Но, скорее, ее нужно рассматривать как бутовскую финально-мезолитическую, на позднем этапе развития которой появляется керамика. Ее нижняя граница определяется появлением керамики около 7100-7000 л. н., а верхняя - появлением техники изготовления тонких бифасов и распространением посуды с ложношнуровой и гребенчатой орнаментацией вместе с исчезновением вкладышевого вооружения около 6500-6400 л. н.

На территориях, сопредельных Верхневолжскому региону, исследователи отмечают появление отщеповых каменных индустрий и появление наконечников стрел/дротиков и ножей-бифасов также около 6500 л. н. вместе с синхронным распространением традиций изготовления сложнорецептурной гребенчатой керамики ${ }^{59}$. Обе категории источников обладают ярким типологическим сходством с древностями Верхней Волги. Исключение составляет карамышевская культура на Верхнем Дону. Для нее характерны отщеповая каменная индустрия и глиняная посуда с накольчатым орнаментом. Однако в связи с отсутствием многослойных четко стратифицированных памятников в верховьях Дона вопрос об облике каменной индустрии карамышевской археологической культуры пока остается открытым ${ }^{60}$.

Таким образом, мы сталкиваемся с ситуацией, когда на обширной территории фиксируются чрезвычайно схожие признаки в каменном инвентаре и в керамике. Их сходство, несмотря на принадлежность к разным археологическим культурам, настолько велико ${ }^{61}$, что четко обозначить границы их ареалов не представляется возможным. В.В.Никитин характеризует взаимоотношения между носителями культур начального неолита лесной и лесостепной части Волжского бассейна как родственные и предлагает рассматривать археологические культуры начального неолита этой территории как части единой историко-культурной общности ${ }^{62}$. Это представляется логичным и целесообразным. Однако возникает вопрос о территориальных границах общности ранней накольчатой керамики, поскольку именно она является маркером начального этапа раннего неолита и за пределами Волжского бассейна ${ }^{63}$.

58 Цетлин Ю. Б. Периодизация истории населения Верхнего Поволжья в эпоху раннего неолита (по данным изучения керамики).

59 Радиоуглеродная хронология эпохи неолита Восточной Европы VII-III тысячелетия до н. э. Смоленск, 2017.

60 Цветкова Н. А. К проблеме определения археологических культур раннего неолита Русской равнины // Археологические источники и культурогенез. Таксоны высокого порядка в системе понятий археологии каменного века. СПб., 2011. С. 133.

61 Никитин В. В. Проблемные вопросы неолитизации Волжского бассейна.

62 Там же. С. 310.

63 Радиоуглеродная хронология эпохи неолита Восточной Европы VII-III тысячелетия до н. э. Смоленск, 2017. 


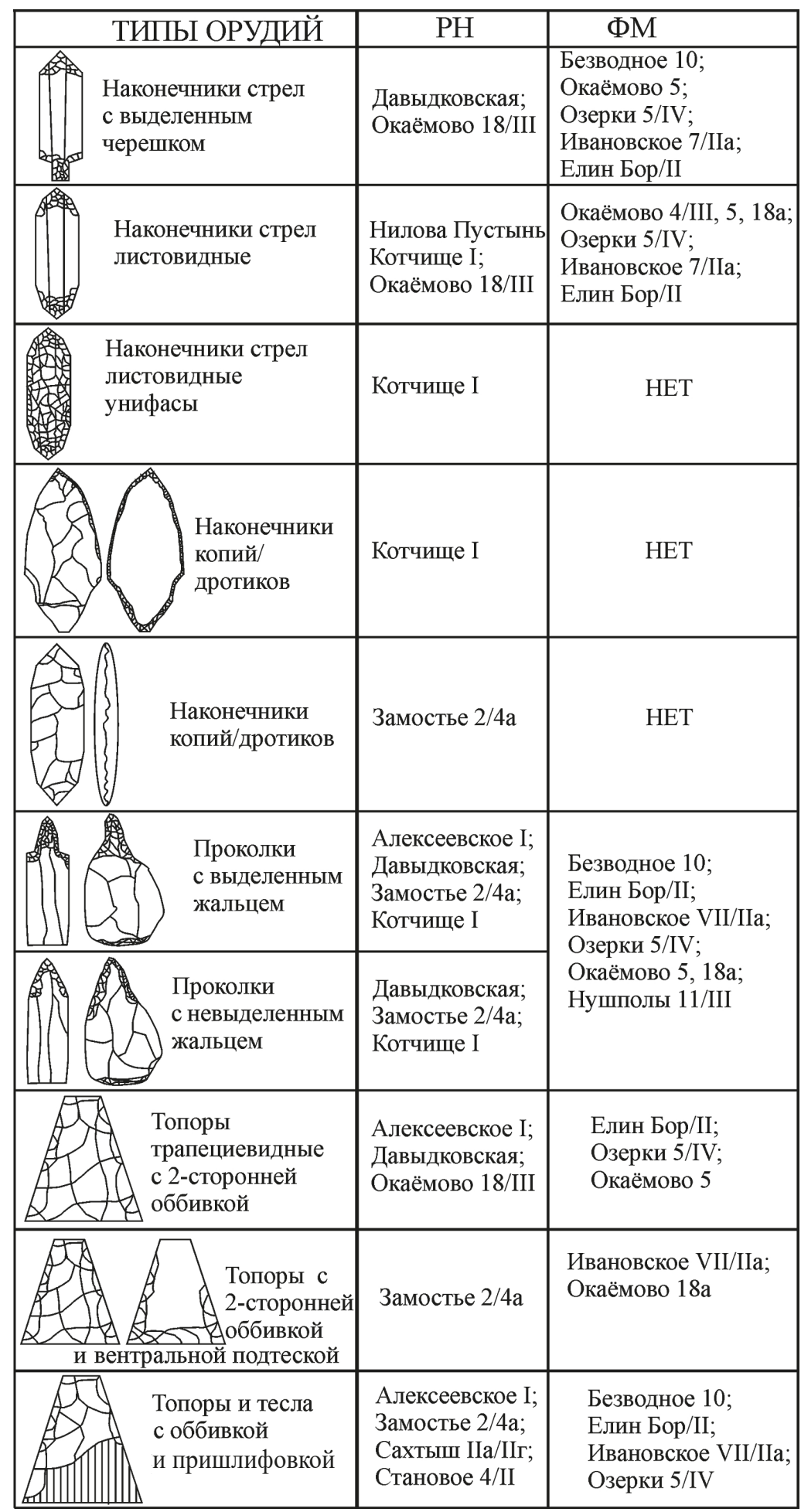

Puc. 4. Сравнительная характеристика типов орудий со стоянок 


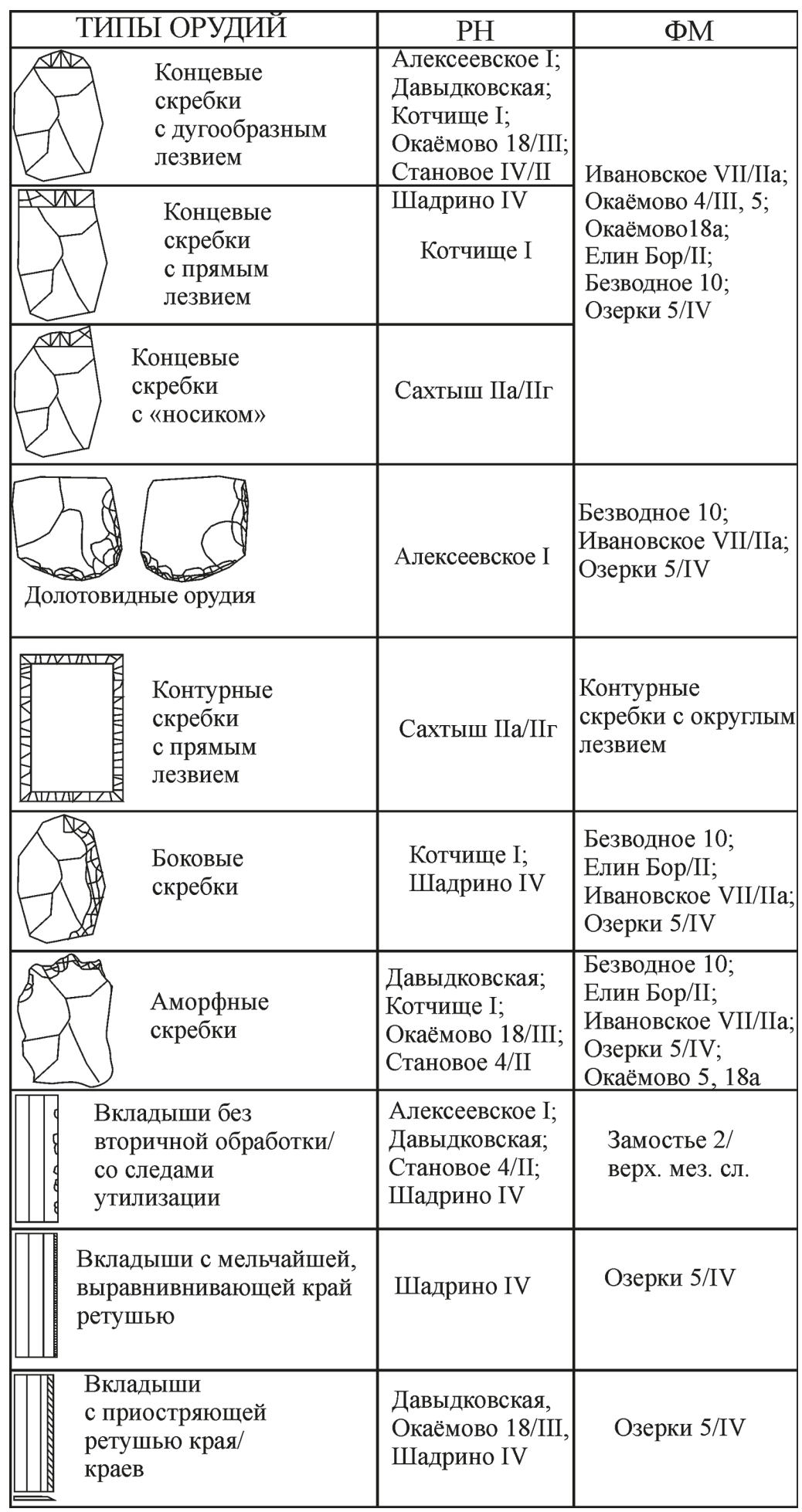

раннего неолита и финального мезолита Верхней Волги (начало) (рис. автора) 


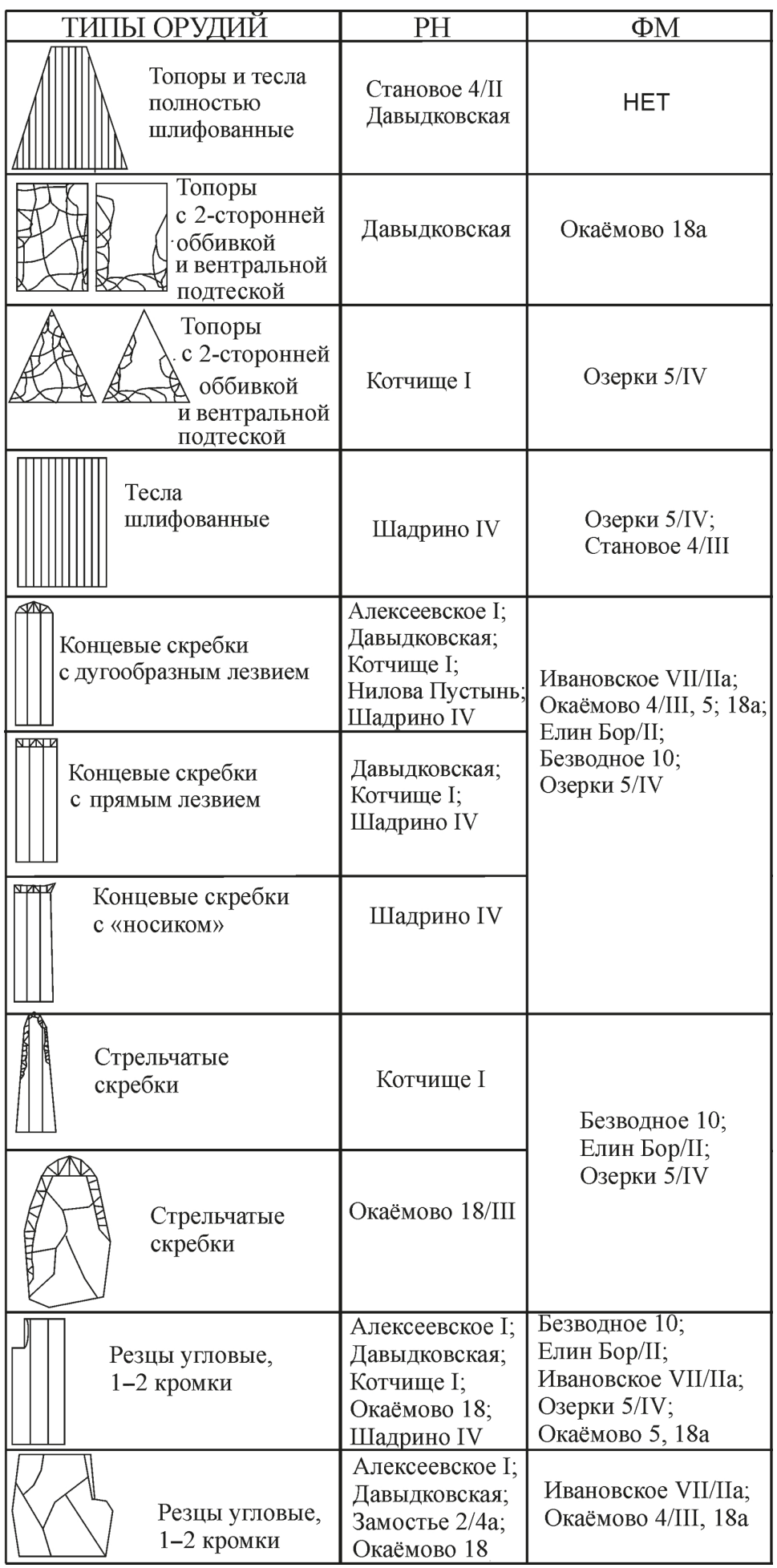

Puc.4. Сравнительная характеристика типов орудий со стоянок 


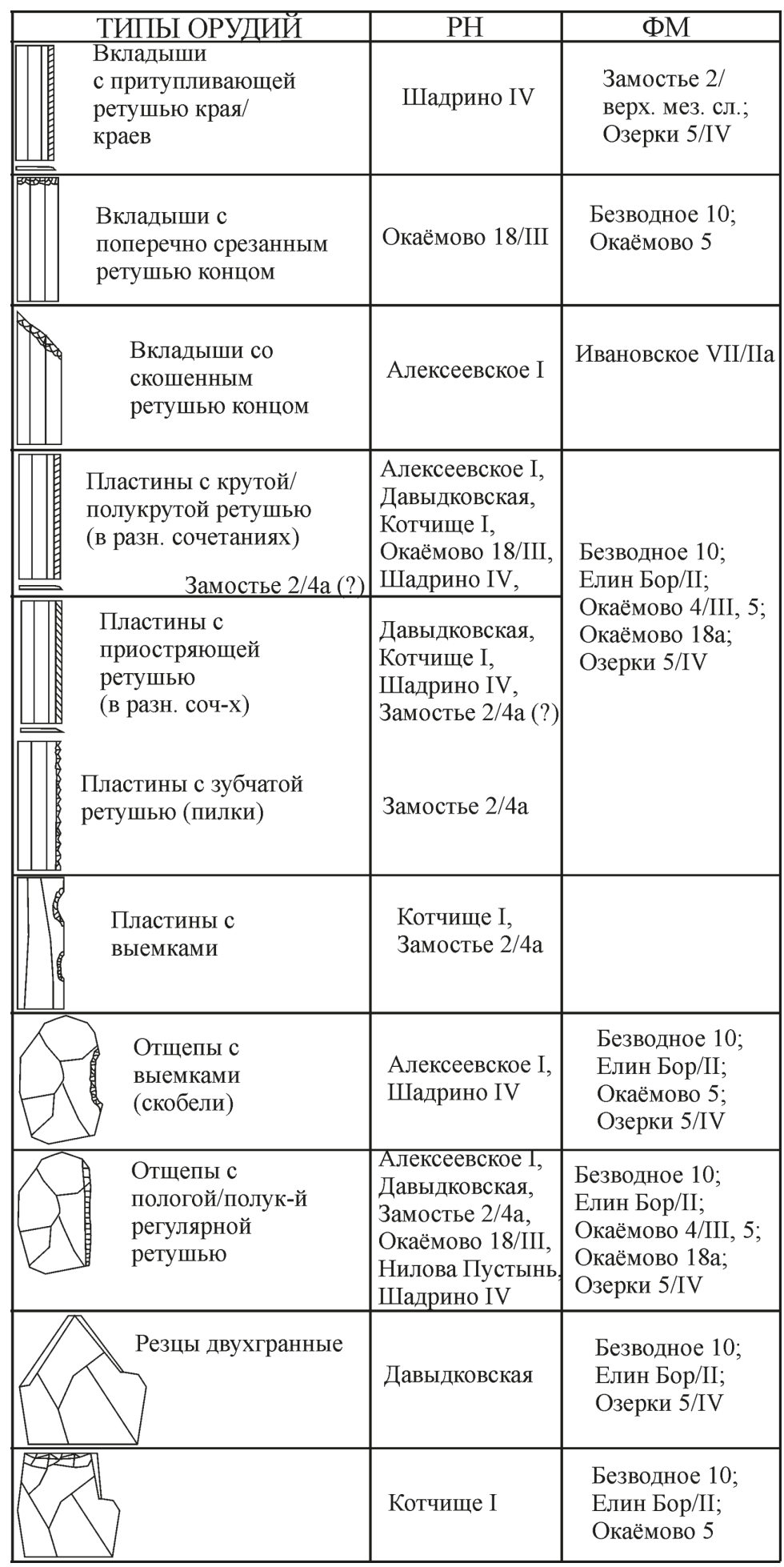

раннего неолита и финального мезолита Верхней Волги (окончание) (рис. автора) 


\section{Выводы}

Переход от мезолита к неолиту на Верхней Волге по данным изучения каменного инвентаря финального мезолита - начального неолита следует ассоциировать с разовыми контактами между автохтонным населением и носителями навыков изготовления глиняной посуды с разреженной тычково-накольчатой орнаментацией. Наиболее вероятно, что первая посуда попала в регион в готовом виде, доказательством чему являются: а) малочисленность сосудов на стоянках; б) находки плоских донцев технологически совершенно вылепленной керамики, не характерной для лесного неолита; в) примесь крупного шамота в ранней посуде, что означает наличие развитой технологии изготовления керамики, основанной на традиции использования «старой» посуды. Поскольку наиболее ранняя посуда появляется на Верхней Волге практически одномоментно без следов ее изготовления на месте, совершенно очевидно, что она являлась импортом.

Отсутствие различий между каменными индустриями финального мезолита и начального неолита на Верхней Волге показывает, что массового притока людей в регион не было. В противном случае в каменной индустрии начального неолита появились бы новые типы орудий и, возможно, технические приемы обработки камня, чего не зафиксировано.

Говоря о культурном статусе материалов начального неолита Верхневолжского региона, следует признать, что волго-окские древности не стоит соотносить с отдельной археологической культурой как с условной единицей деления археологического материала, подразумевающей «совокупность материалов (комплексов и отдельных находок) одного или - чаще - множества памятников, которая, с одной стороны, характеризуется внутренней однородностью, а с другой - заметно отличается по характеру и составу представленных в ней типов артефактов от комплексов, не включаемых в нее» ${ }^{64}$.

Отсутствие принципиальных различий в наборах культуроопределяющих орудий между древностями начального неолита Верхневолжского региона и сопредельных территорий, с одной стороны, и невозможность обозначить четкие границы ареалов археологических культур этого времени - с другой, позволяют рассуждать о единой культурной общности ранней накольчатой керамики. Ее характеризует пластинчато-отщеповый каменный технокомплекс как «совокупность археологических памятников/групп памятников, выделяемых на одной ступени археологической периодизации в определенных пространственно-временных и природных границах» ${ }^{65}$. Известные сегодня археологические культуры следует воспринимать как условные географические подразделения культурного мира носителей традиций изготовления ранней накольчатой керамики. Каждый из них обладает индивидуальными чертами в рамках единых технологических каменной и керамической традиций.

64 Васильев С. А., Бозински Г., Бредли Б. А., Вичняцкий Л. Б., Гиря Е. Ю., Грибченко Ю. Н., Желтова М. Н., Тихонов А. Н. Четырехъязычный (русско-англо-франко-немецкий) словарь-справочник по археологии палеолита. С. 230 .

65 Лисицын С. Н. Технокомплексы рубежа плейстоцена-голоцена в лесной зоне Восточной Европы // Каменный век от Атлантики до Пацифики. Замятнинский сборник. СПб., 2014. Вып. 3. С. 91. 
Попав в мезолитическую среду, традиция изготовления ранней накольчатой посуды не имела в ней длительного продолжения и была прервана притоком населения, обладавшего навыками изготовления посуды с гребенчатой орнаментацией из сложно-рецептурного теста. Эпизоды, характеризующиеся появлением в интервале 7100/7000-6800 л.н. и последующим распространением в период 68006400 л. н. керамики с разреженной тычково-накольчатой орнаментацией ${ }^{66}$, не сопровождавшиеся существенными изменениями в облике каменного и костяного инвентаря, можно рассматривать как переходное время между мезолитом и неолитом, отображающее процесс неолитизации. Переход к неолиту, отмеченный изменением хозяйственного уклада, формированием местного очага производства керамики и распространением техники изготовления тонких бифасов, произошел позднее и был связан со сменой населения на Верхней Волге около 6500-6400 л. н.

\section{References}

Bobrinskii A. A. Goncharstvo Vostochnoi Evropy. Moscow, Nauka, 1978, 272 p. (In Russian)

Gavrilova I. V. Neoliticheskaia stoianka Kotchishche na oz. Seliger. Kratkie soobshcheniia Instituta arkheologii. 1962, iss. 92, pp. 87-90. (In Russian)

Ivanishcheva M. V. Khronologiia pamiatnikov rannego neolita Iuzhnogo Prionezhia. Problemy khronologii i etnokulturnykh vzaimodeistvii v neolite Evrazii (khronologiia neolita, osobennosti kul'tur i neolitizatsiia regionov, vzaimodeistviia neoliticheskikh kul'tur v Vostochnoi i Srednei Evrope). Eds V.I.Timofeev, G. I.Zaitseva. St. Petersburg, IIMK RAN, 2004, pp.60-69. (In Russian)

Koltsov L.V., Zhilin M. G. Mezolit Volgo-Okskogo mezhdurechia. Pamiatniki butovskoi kul'tury. Moscow, Nauka, 1999, 152 p. (In Russian)

Kostyleva E.L. Ranneneoliticheskaia keramika Verkhnego Povolzhia. Tverskoi arkheologicheskii sbornik Ed. by I. N. Chernykh. Iss. 1. Tver', Tverskoi gosudarstvennyi ob’edinennyi muzei, 1994, pp. 53-57. (In Russian)

Kostyleva E.L. Osnovnye voprosy neolitizatsii tsentra Russkoi ravniny (osobennosti neolitizatsii lesnoi zony). Neolit - eneolit iuga i severa Vostochnoi Evropy (novye materialy, issledovaniia, problemy neolitizatsii regionov). Ed. by V. I. Timofeev. St. Petersburg, IIMK RAN, 2003, pp. 213-218. (In Russian)

Kostyleva E.L., Utkin A.V., Engovatova A.V. Neoliticheskie kompleksy stoianki Ivanovskoe VII. Mezoliticheskie i neoliticheskie kul'tury Verkhnego Povolzh'ia (po materialam stoianki Ivanovskoe VII). Moscow, Nauka, 2002, pp.40-63. (In Russian)

Krainov D. A., Kostyleva E.L. Ranneneoliticheskaia stoianka Shadrino IV v basseine r. Lukh. Kratkie soobshcheniia Instituta arkheologii. 1988, iss. 193, pp. 56-65. (In Russian)

Engovatova A.V., Zhilin M.G., Spiridonova E.A. Khronologiia verkhnevolzhskoi ranneneoliticheskoi kul'tury (po materialam mnogosloinykh pamiatnikov Volgo-Okskogo mezhdurechia). Rossiiskaia arkheologiia, 1998, no. 2, pp.11-21. (In Russian)

Lisitsyn S. N. Tekhnologiia rasshchepleniia kremnia na finalnopaleoliticheskoi stoianke-masterskoi Anosovo I. Tverskoi arkheologicheskii sbornik. Ed. by I. N. Chernykh. Iss. 5. Tver', Tverskoi gosudarstvennyi ob"edinennyi muzei, 2002, pp.35-45. (In Russian)

Lisitsyn S. N. Tekhnokompleksy rubezha pleistotsena-golotsena v lesnoi zone Vostochnoi Evropy. Kamennyi vek ot Atlantiki do Patsifiki. Zamiatninskii sbornik. Eds G. A. Khlopachev, S. A. Vasilev. Iss. 3. St. Petersburg, OOO "Izdatelstvo Lema", 2014, pp. 85-109. (In Russian)

Lozovskaia O. V., Lozovskii V.M. O kamennoi industrii rannego neolita na stoianke Zamoste 2. Metody izucheniia kamennykh artefaktov. Materialy mezhdunarodnoi konferentsii. Sankt-Peterburg, 1618 noiabria 2015 g. Eds S. A. Vasilev, V.E. Shchelinskii. St. Petersburg, IIMK RAN, 2015, pp.72-81. (In Russian)

Nikitin V.V. Problemnye voprosy neolitizatsii Volzhskogo basseina. Chelovek, adaptatsiia, kul'tura. Ed. by A. N. Sorokin. Tula, Grif i K, 2008, pp.307-313. (In Russian)

66 Зарецкая, Н.Е., Костылева, Е.Л. Радиоуглеродная хронология начального этапа верхневолжской ранненеолитической культуры // Российская археология. № 1. М., 2008. С. 5-14. 
Semenov S. A. Topor v verkhnem paleolite. Kratkie soobshcheniia Instituta istorii materialnoi kul'tury. 1950, iss. XXXI, pp. 168-173. (In Russian)

Semenov S. A. Razvitie tekhniki v kamennom veke. Leningrad, Nauka, 1968, 376 p. (In Russian)

Sidorov V. V. Davydkovskaia stoianka na r. Iakhrome. Sovetskaia arkheologiia. 1973, no. 2, pp. 146-157. (In Russian)

Smirnov A.S. Pamiatniki s nakolchatoi i grebenchatoi ornamentatsiei v neolite Podesenia. Problemy izucheniia rannego neolita lesnoi polosy Evropeiskoi chasti SSSR. Ed. by L. A. Nagovitsyn. Izhevsk, Institut istorii, iazyka i literatury, 1988, pp. 32-43. (In Russian)

Sorokin A.N. Mezolit Oki. Problema kul'turnykh razlichii. Trudy Otdela Okhrannykh raskopok. Ed. by A. V.Engovatova. Vol. 5. Moscow, IA RAN, 2006, 309 p. (In Russian)

Tarasov A.Yu. Adaptatsiia k lokalnoi syrevoi baze, tekhnologicheskoe razvitie kamennykh industrii i sotsialnoe razvitie drevnikh obshchestv: na primere kul'tur Karelii perioda neolita - rannego zheleznogo veka. Adaptatsiia kul'tury naseleniia Karelii i osobennosti mestnoi prirodnoi sredy periodov mezolita - srednevekovia. Ed. by M.G. Kosmenko. Iss. 4. Petrozavodsk, Karel'skii nauchnyi tsentr RAN, 2009, pp. 111-134. (In Russian)

Tsvetkova N.A. K probleme opredeleniia arkheologicheskikh kul'tur rannego neolita Russkoi ravniny. Arkheologicheskie istochniki i kul'turogenez. Taksony vysokogo poriadka v sisteme poniatii arkheologii kamennogo veka. Tezisy dokladov konferentsii, posviashchennoi 75-letiiu kafedry arkheologii SPbGU, 5-6 dekabria 2011 g. Eds V. I. Beliaeva, A. I. Murashkin. St. Petersburg, St. Petersburg State University Press, 2011, pp. 131-134. (In Russian)

Tsvetkova N.A. Rannii neolit basseina Verkhnei Volgi (po rezultatam izucheniia kamennoi industrii). Kratkie soobshcheniia Instituta arkheologii. 2012, iss.227, pp. 271-280. (In Russian)

Tsvetkova N. A. Ranneneoliticheskie orudiia dlia obrabotki dereva v Verkhnevolzhskom regione. Tverskoi arkheologicheskii sbornik. Ed. by I.N. Chernykh. Iss. 9. Tver', Tverskoi gosudarstvennyi obedinennyi muzei, 2013, pp. 202-217. (In Russian)

Tsvetkova N.A. Reztsy v rannem neolite Verkhnevolzhskogo regiona. Izvestiia Samarskogo nauchnogo tsentra RAN. 2014, vol. 16, no. 3, pp. 260-265. (In Russian)

Tsvetkova N. A. Odnosloinye pamiatniki rannego neolita Ivanovskoi oblasti. Materialy i issledovaniia po arkheologii Rossii i Belorussii. Kul'turnoe vzaimodeistvie drevnikh soobshchestv kon. VII - II tys. do n.e. verkhovev Dviny i Dnepra (tekhnologicheskie i khoziaistvennye aspekty). Ed. by G. N. Poplevko. St. Petersburg, Infiniti, 2014, pp. 42-60. (In Russian)

Tsvetkova N.A. "Orudiia dlia proizvodstva orudii" - izdeliia iz nekremnevykh porod kamnia (po materialam pamiatnikov rannego neolita Verkhnevolzhskogo regiona). Problemy izucheniia epokhi pervobytnosti i rannego srednevekovia lesnoi zony Vostochnoi Evropy: $k$ 60-letiiu A. V. Utkina. Eds E. L. Kostyleva, V. A. Averin. Iss. IV. Ivanovo, Izdatel' Olga Episheva, 2015, pp. 161-164. (In Russian)

Tsvetkova N.A. Skrebki v rannem neolite Verkhnevolzhskogo regiona (sravnitelnaia kharakteristika). Tverskoi arkheologicheskii sbornik. Ed. by I. N. Chernykh. Vol. 1, iss. 10. Tver', Tverskoi gosudarstvennyi obedinennyi muzei, 2015, pp.345-346. (In Russian)

Tsvetkova N.A. Vkladyshevoe vooruzhenie mezolita - rannego neolita Verkhnevolzhskogo regiona. Stratum plus, 2017, no. 1, pp. 127-153. (In Russian)

Tsvetkova N.A. Ranneneoliticheskaia stoianka Nilova Pustyn (po materialam rabot V.I.Timofeeva v Tverskoi oblasti). Tverskoi arkheologicheskii sbornik. Ed. by I.N.Chernykh. Iss. 11. Tver', Tverskoi gosudarstvennyi ob’edinennyi muzei, 2018, pp. 213-219. (In Russian)

Tsetlin Yu. B. Periodizatsiia istorii naseleniia Verkhnego Povolzhia v epokhu rannego neolita (po dannym izucheniia keramiki). Tverskoi arkheologicheskii sbornik. Ed. by I. N. Chernykh. Iss. 2. Tver', Tverskoi gosudarstvennyi ob'edinennyi muzei, 1996, pp.155-163. (In Russian)

Tsetlin Yu. B. O proiskhozhdenii verkhnevolzhskoi kul'tury. Vliianie prirodnoi sredy na razvitie drevnikh soobshchestv (IV Khalikovskie chteniia). Materialy nauchnoi konferentsii, posviashchennoi 50-letiiu Mariiskoi arkheologicheskoi ekspeditsii (Iurino, 5-10 avgusta 2006 g.) Ed. by V. V.Nikitin. Ioshkar-Ola, Mariiskii nauchno-issledovatelskii institut iazyka, literatury i istorii, 2007, pp. 197-208. (In Russian)

Tsetlin Yu. B. Neolit tsentra Russkoi ravniny. Ornamentatsiia keramiki i metodika periodizatsii kul'tur. Tula, Grif i K, 2008, 352 p. (In Russian)

Vasilev S.A., Bozinski G., Bredli B.A., Vishniatskii L.B., Giria E.Iu., Gribchenko Iu. N., Zheltova M.N., Tikhonov A. N. Chetyrekhieiazychnyi (russko-anglo-franko-nemetskii) slovar-spravochnik po arkheologii paleolita. St. Petersburg, Peterburgskoe Vostokovedenie, 2007, 261 p. (In Russian)

Vasileva I. N., Vybornov A. A. Vremia poiavleniia i dinamika rasprostraneniia neoliticheskikh keramicheskikh traditsii v Povolzhe. Povolzhskaia arkheologiia, 2016, no. 3 (17), pp. 104-123. (In Russian) 
Viskalin A.V. Kul'turnye protsessy na Srednei Volge v ranneneoliticheskuiu epokhu. Neoliticheskie kul'tury Vostochnoi Evropy: khronologiia, paleoekologiia, traditsiia. Materialy mezhdunarodnoi nauchnoi konferentsii, posviashchennoi 75-letiiu Viktora Petrovicha Tretiakova. Sankt-Peterburg. 12-16 maia 2015. Eds V. M. Lozovskii, O. V.Lozovskaia, A. A. Vybornov. St. Petersburg, IIMK RAN, 2015, pp. 2628. (In Russian)

Zhilin M.G. Nekotorye voprosy perekhoda ot mezolita k neolitu na Verkhnei Volge. Problemy izucheniia epokhi pervobytnosti i rannego srednevekovia lesnoi zony Vostochnoi Evropy. Ed. by A. V. Utkin. Iss. 1. Ivanovo, Biuro OP Ivobluprstat, 1994, pp. 19-31. (In Russian)

Zhilin M.G. Pamiatniki mezolita i rannego neolita zapadnoi chasti Dubnenskogo torfianika. Drevnosti Zalesskogo kraia. Materialy k mezhdunarodnoi konferentsii "Kamennyi vek Evropeiskikh ravnin: ob"ekty iz organicheskikh materialov i struktura poselenii kak otrazhenie chelovecheskoi kul'tury". 1-5 iiulia 1997. Sergiev Posad. Eds T.N. Manushina, V.M. Mason, V.I. Vishnevskii, V. M.Lozovskii, O. V.Lozovskaia. Sergiev Posad, Sergievo-Posadskii gosudarstvennyi istoriko-khudozhestvennyi muzei-zapovednik, 1997, pp. 164-196. (In Russian)

Zhilin M.G. Adaptatsiia mezoliticheskikh kul'tur Verkhnego Povolzhia k kamennomu syriu. Tverskoi arkheologicheskii sbornik. Ed by I. N. Chernykh. Iss. 3. Tver, Tverskoi gosudarstvennyi ob"edinennyi muzei, 1998, pp. 25-30. (In Russian)

Статья поступила в редакцию 30 мая 2018 г. Рекомендована в печать 12 марта 2019 г.

Received: May 30, 2018

Accepted: March 12, 2019 


\title{
Среднее Зауралье и таежное Приобье в системе связей Западноазиатской металлургической провинции
}

\author{
О. Н. Корочкова
}

Для цитирования: Корочкова О.Н. Среднее Зауралье и таежное Приобье в системе связей Западноазиатской металлургической провинции // Вестник Санкт-Петербургского университета. История. 2019. Т. 64. Вып. 2. С.718-739. https://doi.org/10.21638/11701/spbu02.2019.216

Публикация посвящена различным аспектам становления традиций металлообработки в среде населения таежной периферии Западноазиатской (Евразийской) металлургической провинции эпохи поздней бронзы. Особое внимание уделено проблемам проницаемости и ограничивающих барьеров принципиальных инноваций бронзового века (животноводство, металлопроизводство, транспорт) в среду населения присваивающего образа жизни. Рассмотрены различные модели становления бронзового века в таежном Приобье и на Среднем Урале, обладавших различными природными ресурсами. Начало бронзового века здесь было стимулировано миграциями групп сейминско-турбинского населения и влиянием культур степного пояса. Появление бронзовых орудий не произвело кардинальных перемен в системе жизнеобеспечения таежного мира Сибири. Это был яркий эпизод, активированный мобильными сейминско-турбинскими группами, во многом обусловленный «факторами» Оби и Иртыша - основных транспортных меридиональных магистралей Западной Сибири. После окончания сейминско-турбинского дрейфа вглубь западносибирской тайги местные культуры, по сути, утрачивают ярко выраженные признаки бронзового века. На Среднем Урале археологически зафиксировано две вспышки горно-металлургического производства в дописьменную эпоху, обозначенные коптяковской и иткульской археологическими культурами. Они демонстрируют уникальный для Евразии, в регионе, где не было условий для производства пищи, феномен - развитие прогрессивной металлообработки, в основе которой лежало производство оружия. Исторический пример этих образований показывает, что собственно сырьевой фактор не является решающим в становлении «высоких технологий». Гораздо большее значение имеют образ жизни, востребованность прогрессивных навыков и умений, сложившееся разделение труда, так как производство пищи и металла требуют, помимо соответствующих условий, специализированных профессиональных компетенций и выработанных алгоритмов передачи знаний. Еще один существенный фактор - демографический. В условиях низкой плотности населения, слабой вовлеченности в систему межкультурных связей, утраты эксклюзивности меди после открытия свойств железа, ограниченности возобновляемых ресурсов Средний Урал и вовсе потерял свою привлекательность для освоения и статус производящего центра.

Ольга Николаевна Корочкова - д-р ист. наук, доц., Уральский федеральный университет, Российская Федерация, 620000, Екатеринбург, пр. Мира, 19; Olga.Korochkova@urfu.ru

Olga N. Korochkova - Doctor in History, Associate Professor, Ural Federal University, 19, pr. Mira, Ekaterinburg, 620000, Russian Federation; Olga.Korochkova@urfu.ru

Статья выполнена при поддержке гранта РФФИ, проект № 16-06-00174 и Госзадания № $33.7280 .2017 /$ БЧ.

This research was supported by Russian Foundation for Basic Research, project No. 16-06-00174.

() Санкт-Петербургский государственный университет, 2019 
Ключевые слова: бронзовый век, Урал, Западная Сибирь, Западноазиатская металлургическая провинция, сейминско-турбинский, металлопроизводство.

\title{
Middle Trans-Urals and Taiga Ob' in the System of Relations of the West Asian Metallurgical province
}

\author{
O. N. Korochkova
}

For citation: Korochkova O.N. Middle Trans-Urals and Taiga Ob' in the System of Relations of the West Asian Metallurgical province. Vestnik of Saint Petersburg University. History, 2019, vol. 64, iss. 2, pp. 718-739. https://doi.org/10.21638/11701/spbu02.2019.216 (In Russian)

For years, the history of formation of metalwork traditions among the population of the taiga periphery of West Asian (Eurasian) Metallurgical province of the Late Bronze Age has remained an important research question. The article devotes special attention to the issue of infiltration and the nature of the barriers, which limited the introduction of the principal innovations of the Bronze Age (cattle, metal work, transportation) into the area where appropriating economy dominated local lifestyles. Various cultural models of the Bronze Age in the Ob' river system and in the Middle Urals are being considered. The beginning of the Bronze Age in these regions was stimulated by the cultural impact caused by Seima-Turbino migrations. The introduction of bronze weapons did not significantly affect the indigenous systems of life. Upon the termination of the Seima-Turbino cultural influx, local cultures lost evident features of the Bronze Age. It's confirmed that in the Middle Urals, rich in copper, there was a surge in mining and metal production twice in the pre-literate period, reflected in Koptyak and Itkul archaeological cultures. Their spectacular finds demonstrate that the raw material factor by itself does not determine the emergence of "high technologies". Instead, factors related to demography, e.g. lifestyle, communication, division of labor, and developed algorithms for transmission of knowledge are much more important. The unique phenomenon arising in short-lived formations did not lead to further development. The Middle Urals gradually lost its advantage for human settlements, as well as its the status of the metalworking center, because of scarcity of the population, weak involvement into intercultural relations, and the loss of exclusivity of copper since the discovery of the benefits of the iron.

Keywords: Bronze Age, Urals, West Siberia, West-Asian metallurgy province, Seim-Turbino, metalworking.

Конец III - начало II тыс. до н. э. в Северной Евразии были ознаменованы кардинальными переменами в основных сферах жизнеобеспечения. В степном поясе происходило становление продуктивного хозяйства, основанного на подвижном скотоводстве с преобладанием в стаде крупного рогатого скота ${ }^{1}$. Особое значение имело одомашнивание лошади и развитие колесного транспорта ${ }^{2}$. Перечисленные достижения во многом были обусловлены дальнейшим развитием традиций ме-

${ }^{1}$ Антипина Е.Е., Лебедева Е. Ю. Палеоэкономические реконструкции в археологии: теория и практика археобиологических исследований // Естественнонаучные методы исследований и парадигма современной археологии. М., 2015. С. 105.

2 Кузьмина Е. Е. Кони степей Евразии в эпоху энеолита и бронзы // Кони, колесницы и колесничие степей Евразии. Екатеринбург; Самара; Донецк, 2010. С.5-13; Бочкарев В. С., Кузмина Е. Е., Кузнецов П.Ф., Усачук А.Н. Основные итоги изучения возникновения и распространения колесничества // Кони, колесницы и колесничие степей Евразии. Екатеринбург; Самара; Донецк, 2010. C. 344-345. 
таллообработки и совершенствованием оружия. Заметно возросла плотность населения. Именно эти факторы скорее всего послужили толчком для переоформления культурной карты Северной Евразии. Подстегнутая аридизацией климата повышенная мобильность населения, ориентированного на освоение новых земель и пастбищ, привела к колоссальному расширению зоны культур производящей экономики далеко на восток, а также в подтаежную зону. Усилились процессы глубоких интеграций и межкультурных коммуникаций. На языке археологической систематики данные процессы выразились в феномене культурно-исторических или археологических общностей (абашевско-синташтинская, срубная, андроновская, кротовско-елунинская и др.), который Е.Н. Черных предложил образно именовать «степным синдромом непрерывности культурного полотна» ${ }^{3}$.

Тесные информационные связи во многом были стимулированы потребностью в металлических орудиях, и прежде всего оружия. Металл и доступность к сырью начинают играть ключевую роль в системе коммуникаций. В этой ситуации культуры, локализованные в меднорудных зонах, приобрели качества магистральных образований ${ }^{4}$ и во многом определили стилистику взаимодействий эпохи. Исключительным транскультурным маркером подобных общностей являются металлические орудия как носители самой разнообразной информации о технологии, связях, проницаемости или, напротив, непроницаемости некоторых инновационных барьеров, войне и мире, движении людей, идей, даров.

Именно на этой особенности металлических артефактов основан принцип выделения металлургических провинций эпохи раннего металла $(Э \mathrm{PM})^{5}$, который зарекомендовал себя как универсальный исследовательский подход и инструмент ${ }^{6}$.

Процессы, рассматриваемые в данной работе, адресуют к периферийным таежным районам Западноазиатской (Евразийской) металлургической провинции (рис. 1). Самая обширная по своему территориальному охвату (до 6-7 млн кв. км) провинция складывается в конце III - начале II тыс. до н.э., что, по сути, знаменует начало эпохи бронзы к востоку от Урала. В рамках глобальной периодизации ЭРМ Евразии это время соответствует позднему бронзовому веку․․

Внедрение традиций металлообработки к востоку от Урала происходило по разным сценариям и во многом было сопряжено со становлением производящей экономики: металлургия и металлообработка развивались в тех обществах, которые перешли к продуктивному скотоводству. Исследователи специально отмечают отсутствие достоверных свидетельств земледелия в этих регионах ${ }^{8}$. Вместе с тем археологические материалы, накопленные в результате обширных исследований в таежном Приобье и на Среднем Урале, сообщают о вовлеченности в круг металлоносных

3 Черных Е.Н. Каргалы. Том V. Феномен и парадоксы развития; Каргалы в системе металлургических провинций; Потаенная (сакральная) жизнь архаичных горняков и металлургов. М., 2007. С. 35 .

4 Головнев А. В. Антропология движения. Екатеринбург, 2009. С. 21-22.

5 Черных E.H. Металлургические провинции и периодизация эпохи раннего металла на территории СССР. Российская археология. 1978. № 4. С. 53-82.

6 Рьндина Н. В., Дегтярева А. Д. Энеолит и бронзовый век. М., 2002. С. 40-49.

7 Черных Е.Н. Металлургические провинции на фоне геоэкологических ареалов Евразии // Мегаструктура Евразийского мира. М., 2012. С. 126.

8 Антипина E.E., Лебедева Е.Ю. Палеоэкономические реконструкции в археологии: теория и практика археобиологических исследований // Естественно-научные методы исследований и парадигма современной археологии. М., 2015. С. 99-105. 


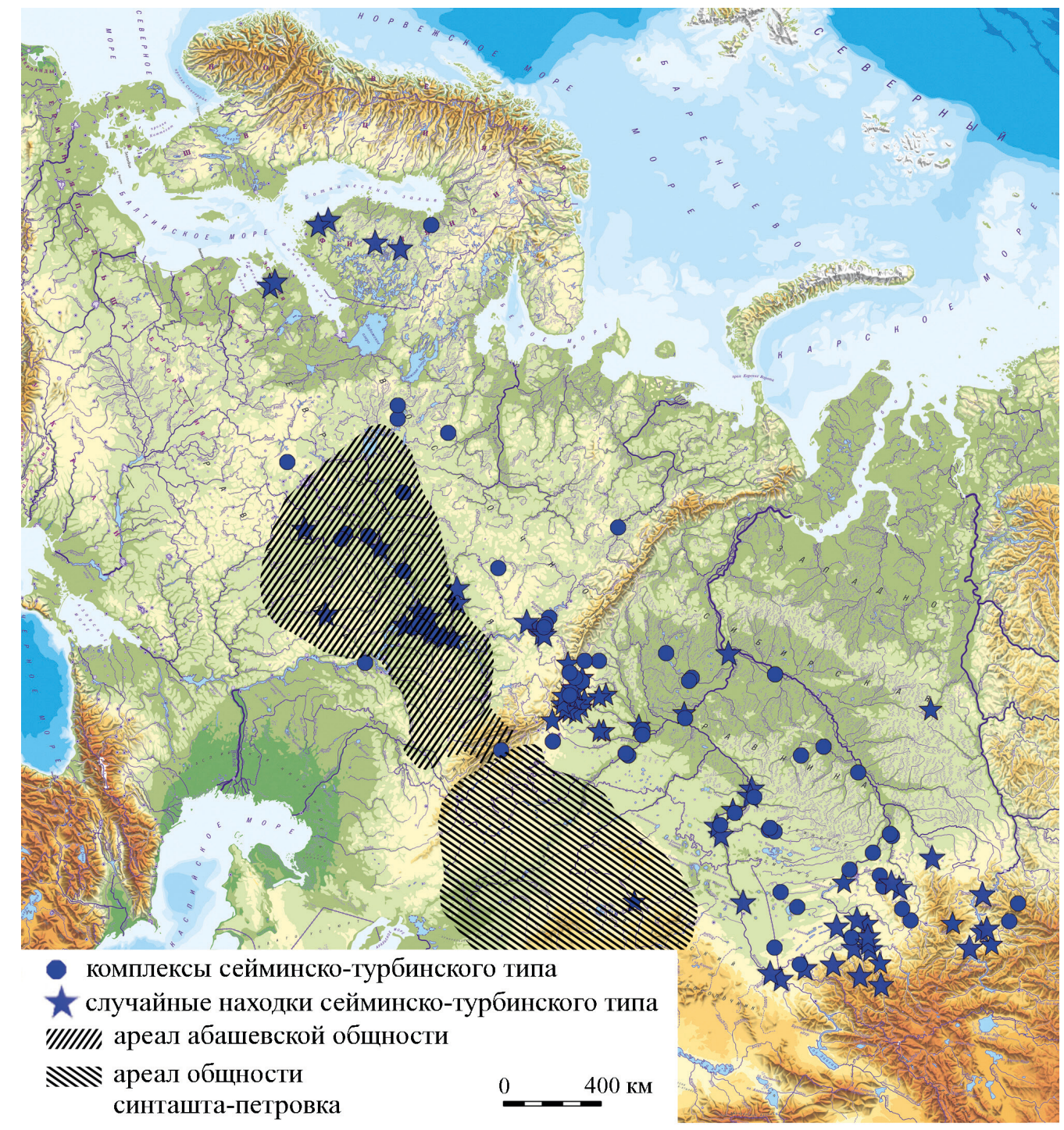

Puc.1. Общности, комплексы, артефакты ранней фазы Западноазиатской (Евразийской) металлургической провинции (рис. автора)

культур и населения, которое проживало на землях, лишенных условий для земледелия и скотоводства. Данное обстоятельство придает особый интерес протекавшим здесь процессам, так как предупреждает о нетипичных и неоднозначных ситуациях, сопровождавших становление и развитие эпохи бронзы в таежном поясе.

Конец III - начало II тыс. до н.э. соответствует суббореальному периоду, для которого характерны продолжительные аридные фазы ${ }^{9}$. В подтаежной зоне Западной Сибири перемены в климате сопровождались обмелением водоемов, умень-

9 Зах В.А., Зимина О.Ю., Рябогина Н.Е., Скочина С.Н., Усачева И.В. Ландшафты голоцена и взаимодействие культур в Тоболо-Ишимском междуречье. Новосибирск, 2008. С. 126-127. 
шением ареала сосновых лесов. На Среднем Урале происходили процессы интенсивного заболачивания озер ${ }^{10}$. Сокращение основных кормовых угодий заметно сказалось на демографической ситуации: к концу III тыс. до н.э. население здесь резко сократилось. В таежном Приобье подобные подвижки в климате не привели к сколько-нибудь значимым переменам в демографии. Карта археологических памятников этого времени ${ }^{11}$ показывает довольно высокую плотность населения, преимущественно в бассейнах малых рек, что вполне объяснимо с точки зрения сложившихся здесь стратегий рыболовства.

Таким образом, становление эпохи бронзы на Урале и в Западной Сибири протекало в разных условиях. В Среднем Приобье, преимущественно на правобережье Оби, это время обозначено памятниками кульеганской культуры ${ }^{12}$, в Кондинской низменности - полымьятскими комплексами ${ }^{13}$, в Нижнем Притоболье - поселениями ташковской культуры ${ }^{14}$. На Среднем Урале количество памятников начальной фазы бронзового века (коптяковской культуры и комплексов карасьеозерского типа) резко диссонирует с западносибирскими (рис. 2). Даже с учетом местонахождений, на которых известны немногочисленные фрагменты керамики, их наберется не более двух-трех десятков против более сотни памятников предшествующего времени. Можно было бы предположить, что часть из них оказалась под водой, так как большинство местных озер подпружены плотинами, а аридность как будто диктовала расположение поселений на более низких гипсометрических отметках. Однако стратиграфия уральских торфяников подтверждает замеченные особенности: в их напластованиях немногочисленность артефактов карасьеозерского и коптяковского типов резко контрастирует с обилием комплексов предшествующего и последующего периодов ${ }^{15}$. Эти обстоятельства отражают скорее всего реальные демографические ситуации.

Традиции металлообработки были привнесены в тайгу пришлыми группами населения. Самые ранние опыты металлообработки относятся к III тыс. до н.э. В так называемых энеолитических комплексах Среднего Урала и Западной Сибири появляются немногочисленные артефакты - миниатюрные металлические предметы (проволока, колечки, пластинки) и остатки литейного дела (тигли, ошлакованная керамика). Изделия, судя по химизму металла, тяготеют к ямному очагу металлообработки ${ }^{16}$. Западный импульс, ассоциируемый с прикамскими гаринскоборскими комплексами, представлен в материалах ранней фазы полымьятского

10 Чаиркина Н. М. Энеолит Среднего Урала. Екатеринбург, 2005. С. 296.

11 Кокшаров С.Ф. Памятники энеолита севера Западной Сибири. Екатеринбург, 2009. Карты $1-7$.

12 Борзунов В.А., Стефанов В. И., Глушков И.Г. Быстрый Кульеган-38 - укрепленное жилище эпохи бронзы в Сургутском Приобье // Археология, этнография и антропология Евразии. 2011. № 2 (46). C. 55-69.

13 Кокшаров С. Ф. Культура населения севера Западной Сибири в бронзовом веке: дис. ... д-ра ист. наук. Новосибирск, 2015. С. 266-300.

14 Ковалева В. Т. Генезис, датировка и этническая специфика ташковской культуры // Археология Урала и Западной Сибири. Екатеринбург, 2005. С. 102-109.

15 Чаиркина Н.М. Торфяниковые памятники Зауралья: анализ и интерпретация: дис. ... д-ра ист. наук. Новосибирск, 2015. С. 209-232.

16 Чаиркина Н. М. Энеолит Среднего Зауралья. Екатеринбург, 2005. С. 209-212. 

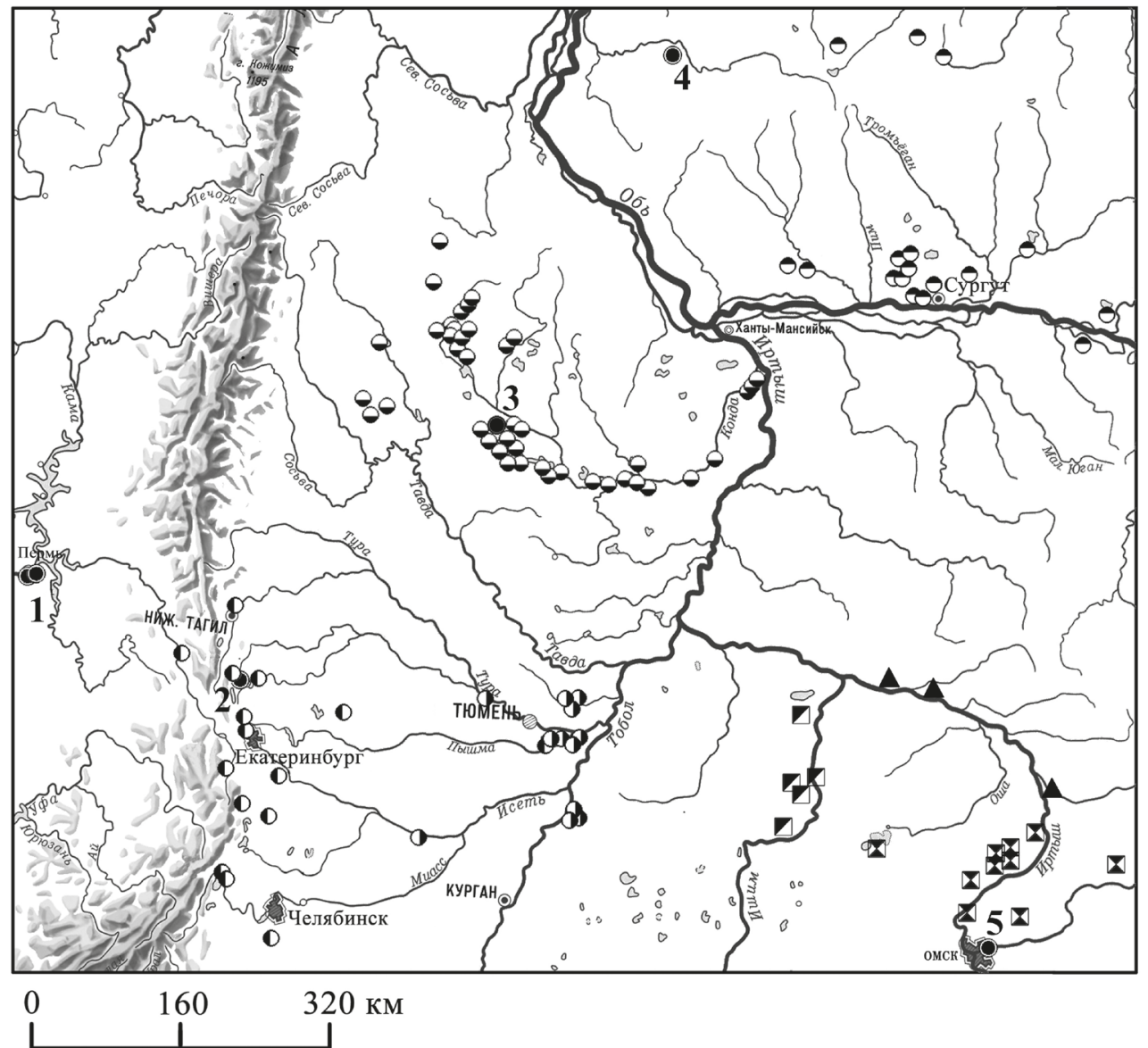

Условные обозначения:

- коптяковские $\theta$ полымьятские 0 некрополи,

- ташковские 0 кульеганские

1 - Турбино; 2 - Шайтанское Озеро II; 3 - Сатыга XVI;

4 - Товкуртлор $3 ; 5$ - Ростовка святилища СТ типа

Puc.2. Археологические памятники ранней фазы бронзового века Среднего Урала и Западной Сибири (по [Корочкова, Спиридонов, 2015, рис. 1])

типа единичными маловыразительными миниатюрными предметами и глиняными матрицами ${ }^{17}$.

Ситуация резко изменилась на рубеже III-II тыс. до н. э., когда в Евразии происходило переоформление культурной карты, связанное с дальними миграциями и процессами колонизации. В рамках Западноазиатской металлургической провинции катализаторами мобильных процессов явились группы населения, оставившие археологические памятники синташтинского и сейминско-турбинского

17 Кокшаров С. Ф. Культура населения севера Западной Сибири в бронзовом веке: дис. ... д-ра ист. наук. Новосибирск, 2015. Рис. 110, 120. 
типов. Уже не раз было отмечено, что сложение этой провинции собственно и стимулировало разнонаправленные и разномасштабные потоки, имевшие встречный характер $^{18}$. Синташтинские древности отражают своего рода западный пучок инноваций, а сейминско-турбинские - восточный. Ярко выраженный встречный характер миграций предполагает сложные модели взаимодействия, а их территориальные устремления подсказывают вероятные «горячие точки» пересечений. Ареал памятников синташтинского типа и генетически связанных с ними петровских приурочен к степной полосе Южного Урала и Северного Казахстана, не простирался восточнее бассейна Ишима и севернее широты современного Челябинска. И если северные границы очерчивались ландшафтно-климатическими «барьерами» (здесь находилась зона, так называемого непродуктивного скотоводства), то на востоке территориальные амбиции были ограничены кротовско-елунинским массивом (см. рис. 1). Явная приуроченность кротовско-елунинских древностей к зоне полиметаллических месторождений Рудного Алтая дает основание полагать, что местная элита контролировала их весьма успешно. Именно в этой среде состоялось эпохальное открытие технологий тонкостенного втульчатого литья и оловянных сплавов, которые являются «визитной карточкой» сейминско-турбинского транскультурного феномена ${ }^{19}$.

Адреса сейминско-турбинских находок и мемориалов определенно сообщают о преимущественно таежном коридоре передвижений, а синташтинские памятники приурочены исключительно к степным ландшафтам (см. рис.1), что как будто исключало точки «рандеву» носителей столь разных традиций. При этом модели мобильности различались кардинально. Степной пояс был охвачен процессами масштабной колонизации, становления здесь полного цикла металлопроизводства (горное дело, выплавка металла из руд, литье) и продуктивного скотоводства, основанного на сезонных перекочевках. Бурный демографический рост сопровождался строительством укрепленных поселений (до 25 тыс. кв. м) с регулярной планировкой, сложной инфраструктурой и большим количеством домов. Усложнение социальной структуры общества и расширение межкультурных контактов сопровождались формированием этнической идентичности, воплощенной в мифоритуальной практике, археологические индикаторы которой наиболее выпукло проявляются в погребальном обряде, костюме, изобразительной деятельности.

Причины миграций сейминско-турбинских кланов не столь очевидны. Учитывая их разнонаправленность, различные способы перемещения (пешие, водные, конные), можно предположить самые разнообразные мотивы мобильности ${ }^{20}$. Но одним из главных стало наличие передового для своего времени вооружения и высокий градус воинской активности. Еще одно весьма существенное обстоятельство - это кардинальные перемены в мировоззрении. Соглашусь с теми исследователями, которые считают, что важны не только сами по себе технологические открытия, но и то, как они меняют отношение к миру. Человек, который научился превращать руду/камень в металл, уже выступает в качестве демиурга и преобразователя. В данном случае перед нами типичный пример обратной связи: если

18 Черных Е.Н. Культуры номадов в мегаструктуре Евразийского мира. Т. 1. М., 2013. С. 222224.

19 Черных Е. Н., Кузьминьх С. В. Древняя металлургия Северной Евразии. М., 1989. С.266-277.

20 Головнев А. В. Антропология движения. Екатеринбург, 2009. С. 146-155. 
в обиходе человека появилось совершенное оружие, то оно будет использовано по назначению. Кроме того, оружие - это демонстрация силы и власти, которые были столь необходимы при освоении новых территорий.

Именно сейминско-турбинские и абашевско-синташтинские миграции, по сути, положили начало бронзовому веку в изучаемых районах ${ }^{21}$. Оставим в стороне степной пояс, так как происходившие здесь процессы получили широкое освещение в работах специалистов, а обратимся к менее изученной таежной зоне Среднего Урала и Среднего Приобья (см. рис. 2). Что их объединяет и отличает? Здесь проживало близкое в культурном отношении население, о чем сообщают прежде всего керамические комплексы. Однако условия жизни отличались кардинально. С точки зрения возобновляемых природных ресурсов западносибирская тайга неизмеримо богаче, стабильнее, нежели соседний Средний Урал. Здесь нет высококачественного каменного сырья, нет меднорудных месторождений, но их отсутствие компенсировалось богатством животного и растительного мира, прежде всего обилием и разнообразием рыбных ресурсов. К началу II тыс. до н. э. в тайге сложилось продуктивное хозяйство на основе рыболовства, охоты и собирательства. Контроль над промысловыми угодьями и территориальные конфликты рано приобрели столь нехарактерную для таежных аборигенов остроту. Одним из убедительных индикаторов напряженной социальной обстановки является феномен фортификаций ${ }^{22}$. Первые укрепленные поселения появляются в тайге Западной Сибири еще в неолите. Причем радиоуглеродные данные неолитического городища Амня I демонстрируют беспрецедентно ранние даты (VI тыс. до н.э.) ${ }^{23}$.

Дальнейший всплеск фортификационного строительства приходится уже на рубеж III - начала II тыс. до н.э. В это время возводятся большие (360-400 кв. м) одиночные бревенчато-земляные дома, окруженные валом и рвом, иногда с дополнительной защитной стеной. По мнению коллег, которое я разделяю, возведение подобных фортификаций свидетельствовало «не только об очередном периоде военной напряженности и междоусобных войн, вызванных ростом населения. Отчасти эти процессы были стимулированы притоком новых групп населения из более южных областей, что стимулировало освоение глубинных территорий тайги, удаленных от крупных водных артерий. ...Центрами общин, закреплявших за собой наиболее богатые рыбные и охотничьи угодья, по-видимому, были эти первобытные “крепости”. Кроме того, такие сооружения олицетворяли собой явный прогресс в местном домостроительстве, стимулированный применением металлических орудий. Впоследствии большие одиночные укрепленные жилища различных форм возводились в западносибирской тайге вплоть до позднего средневековья» ${ }^{24}$.

21 Черных Е.Н. Металлургические провинции и периодизация эпохи раннего металла на территории СССР Советская археология. 1978. № 4. С. 53-82; Бочкарев В. С. Волго-Уральский очаг культурогенеза эпохи поздней бронзы // Социогенез и культурогенез в историческом аспекте. СанктПетербург, 1991. С. 24-27.

22 Борзунов В.А. Западная Сибирь - самый северный ареал укрепленных поселений неолита и первой половины эпохи бронзы // Tp. IV (XX) Всерос. археолог. съезда в Казани. Казань, 2014. C. $218-220$.

23 Стефанов В.И., Борзунов В.А. Неолитическое городище Амня I (по материалам раскопок 1993 и 2000 гг.) // Барсова Гора: Древности таежного Приобья. Екатеринбург; Сургут: Урал. изд-во, 2008. C. $109-110$.

${ }_{24}$ Борзунов В. А. Западная Сибирь - самый северный ареал укрепленных поселений неолита и первой половины эпохи бронзы. С. 219. 
Специально стоит подчеркнуть: в отложениях всех домов-крепостей обнаружены следы металлообработки, а также иные артефакты (изделия из камня, керамика), которые адресуют к культурам, вовлеченным в сферу действия сейминско-турбинского феномена. Тогда же в тайге появляются могильники Сатыга XVI и Товкуртлор 3, которые сообщают о присутствии в западносибирской тайге не только вещей, отлитых из оловянных бронз, но и собственно их носителей ${ }^{25}$. Именно в глубине таежной зоны обнаружены два погребения литейщиков ${ }^{26}$ : одно в составе некрополя Сатыга XVI, другое - местонахождение Сайгатино VI. O правомерности отнесения сайгатинского объекта к разряду погребальных можно спорить, однако ярко выраженная литейная атрибутика в любом случае связывает его с выделившейся профессиональной группой пришлого сейминско-турбинского населения. И еще раз стоит подчеркнуть, отсылая к более развернутым аргументам в монографии, посвященной могильнику Сатыга XVI ${ }^{27}$, ярко выраженную автономность перечисленных культовых памятников, свидетельствующих об определенном дистанцировании этих групп от местного культурного окружения. Столь заметная изолированность, а также ярко выраженный воинский характер захоронений Сатыги XVI, поддерживают версию о некоторой социальной напряженности, что вполне ожидаемо в условиях появления в тайге инокультурных групп, оснащенных бронзовым оружием и ориентированных на совершенно иные модели коммуникаций.

Сформированный на сегодняшний день банк радиоуглеродных данных по эпохе бронзы Среднего Урала и Западной Сибири демонстрирует в целом совпадение хронологических интервалов ${ }^{28}$. Бронзовый век начался в конце III тыс. до н.э. О принадлежности бронзовой эпохе кульеганских, полымьятских, карасьеозерских, коптяковских и ташковских комплексов сообщают прежде всего металлоносные знаки, причем весьма своеобразного свойства. Фиксируются очевидные следы металлопроизводства (тигли, ошлакованная керамика, капли, сплески, литейные формы), а вот собственно металлические орудия единичны. Среди них - пластинчатый нож с рукоятью из слоя с карасьеозерской посудой Горбуновского торфяника ${ }^{29}$,

25 Корочкова О.Н., Стефанов В. И. Сатыга XVI в системе культур эпохи бронзы Зауралья и Западной Сибири // Сатыга XVI: Сейминско-турбинский могильник в таежной зоне Западной Сибири. Екатеринбург, 2011. С. 60-85; Стебанов В.И. Могильник Товкуртлор 3: сейминско-турбинский след в Нижнем Приобье // Российская археология. 2006. № 1. С. 44-58.

26 Корочкова О.Н. Погребение литейщика в Таежном Приобье // Археология Южной Сибири. Кемерово, 2011. С. 129-136.

27 Корочкова О.Н., Стебанов В.И. Сатыга XVI в системе культур эпохи бронзы Зауралья и Западной Сибири // Сатыга XVI: Сейминско-турбинский могильник в таежной зоне Западной Сибири: колл. моногр. Екатеринбург, 2011. С.77-83.

28 Черных Е.Н., Корочкова О.Н., Орловская Л.Б. Проблемы календарной хронологии сейминско-турбинского транскультурного феномена // Археология, этнография и антропология Евразии. 2017. T. 45. № 2. C.45-55; Chairkina N. M., Kuzmin Y. V., Hodgins G. W. Radiocarbon chronology of the mesolithic, neolithic, aeneolithic, and bronze age sites in the Trans-Urals (Russia): a general framework // Radiocarbon, Vol.59, no. 2, 2017. Р. 516; Кокшаров С. Ф., Баранов М. Ю. Следы металлопроизводства бронзового века с поселения Балинское 1 (Ханты-Мансийский автономный округ - Югра). Российская археология. 2017. № 2. С.46-47; Ковалева В. Т. Генезис, датировка и этническая специфика ташковской культуры // Археология Урала и Западной Сибири. Екатеринбург, 2005. С. 106.

29 Чаиркина Н. М., Павлова О.А., Вилисов Е. В. Археологическое исследование VI разреза Горбуновского торфяника в 2009 г. // Уральский исторический вестник. 2014. № 1 (42). С. $112-122$. 
нож-скобель из ташковского комплекса $\mathrm{CAO}^{30}$, определенно имеющие сейминскотурбинский круг аналогий. Немногочисленные литейные формы, найденные на полымьятских и кульеганских поселениях, отчасти соответствуют сейминско-турбинским стандартам, повторяя их, пожалуй, только в одном: среди них есть формы для отливки втульчатых орудий (рис. 3: 1, 4, 5, 6, 17, 22, 23). Однако металлические реплики некоторых орудий неизвестны (рис. 3: 17, 22, 23). Надо сказать, что подобная ситуация не является экстраординарной. На знаменитом поселении Самусь IV, который исследователи склонны считать культовым объектом, найдено беспрецедентное количество литейных форм ${ }^{31}$, однако металлические отливки подобного рода до сих пор не найдены.

Чрезвычайно интересным в этом плане представляется мнение А.Д.Дегтяревой и С.В.Кузьминых, которые детально подошли к проблеме особенностей цветной металлообработки населения ташковской культуры. По их мнению, «...аналитические данные фиксируют лишь стадии подражания обработке металла, владение технологическими параметрами получения меди и бронз освоено еще не в полной мере. Литье в тиглях, в особенности декорированных, вполне возможно, носило скорее сакральный характер, нежели бытовой, производственный» 32 . Полагаю, что это наблюдение имеет принципиальное значение. Таежные аборигены получали бронзовые слитки из соседних производящих центров, а их неудачи при манипулировании с мышьяковыми и оловянными сплавами, которое требовало особых профессиональных навыков, объяснялись скорее всего недостаточной компетентностью. Показательно, что и для кульеганских комплексов характерно изготовление не только сложных и богато орнаментированных тиглей, но также сопел (рис. 4) 33 . Таким образом, аксессуары литейного дела первых металлоносных культур Западной Сибири носят подчеркнутый символический характер, что является универсальной чертой ранних производств.

Магически-ритуальная гипотеза первых литейных опытов среди населения присваивающего образа жизни, проживавшего на территориях, где не было собственных меднорудных месторождений, заслуживает самого пристального внимания. Эту версию поддерживает целый ряд иных аргументов. Особое отношение к металлу демонстрируют культовые памятники ташковской культуры, для которых характерна особая планировочная архитектура и комплекс артефактов ${ }^{34}$.

30 Дегтярева А.Д., Ковалева В.Т., Кузьминых С.В. Особенности цветной металлообработки племен ташковской культуры Нижнего Притоболья // Вестник археологии, антропологии и этнографии. 2014. № 3 (26). Рис. 1, 19.

31 Матющенко В.И. Древняя история населения лесного и лесостепного Приобья (неолит и бронзовый век). Ч. 2 // Из истории Сибири. Вып. 10. Томск, 1973. С. 24-28; Косарев М. Ф. Древние культуры Томско-Нарымского Приобья. М., 1974. Рис. 15.

32 Дегтярева А.Д., Ковалева В.Т., Кузьминых С.В. Особенности цветной металлообработки племен ташковской культуры Нижнего Притоболья. С. 23.

33 Стебанов В.И., Данилова Е.Н. Кульеганские древности Среднего Агана // Ханты-Мансийский округ в зеркале прошлого. Ханты-Мансийск-Томск. С. 95. Рис. 3; Кокщаров С. Ф., Баранов М. Ю. Следы металлопроизводства бронзового века с поселения Балинское 1// Российская археология. 2017. № 2. С. 44, рис. 5.

34 Ковалева В.Т. Взаимодействие культур и этносов по материалам археологии: поселение Ташково II. Екатеринбург: УрГУ, 1997; Ковалева В. Т. Ранний бронзовый век Нижнего Притоболья: ташковская культура // Современные проблемы археологии России. Том 1. Материалы Всерос. археолог. съезда. Новосибирск, 2006. С. 393-395. 


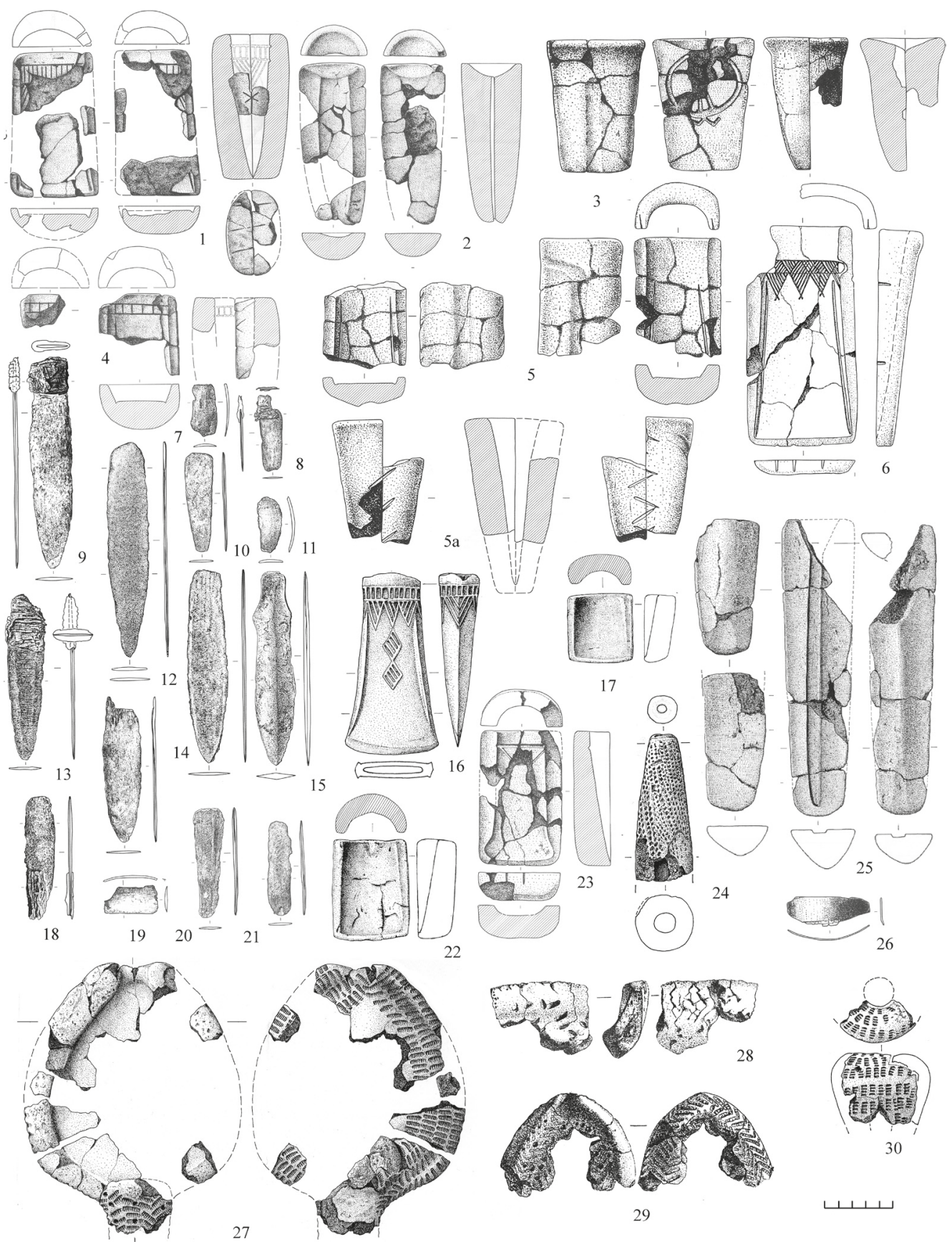

Puc. 3. Металлокомплекс ранней фазы бронзового века таежного Приобья:

1, 2, 4, 7-15, 18-21 - Сатыга XVI; 3, 5, 6 - Сайгатино VI; 16 - Самарово; 17, 22 - Пашкин Бор I; 23 - Волвонча (по [Беспрозванный и др., 2011, рис. 4.1.1, 4.1.2, 4.2.3, 4.2.4 , 5.2, 5.11, 5.15, 5.16, 5.17]); 24, 27, 30 - селище Нёх-Урий 3.2 (по [Стефанов, Данилова, 2013, ил. 3]); 25 - Савкинская Речка I (по [Мызников и др., 2012, рис. 4, 1, 2]); 26 - Товкуртлор 3 (по [Стефанов, 2006, рис. 7, 7]); 28, 29 - поселение ЮАО-ХІІІ (по [Ковалева В.Т. и др., 2000, рис. 52, 4, 5]). (1-6, 17, 22-25, 27-30 - глина; 6 - камень; 7-16, 18-21, 26 - бронза) 


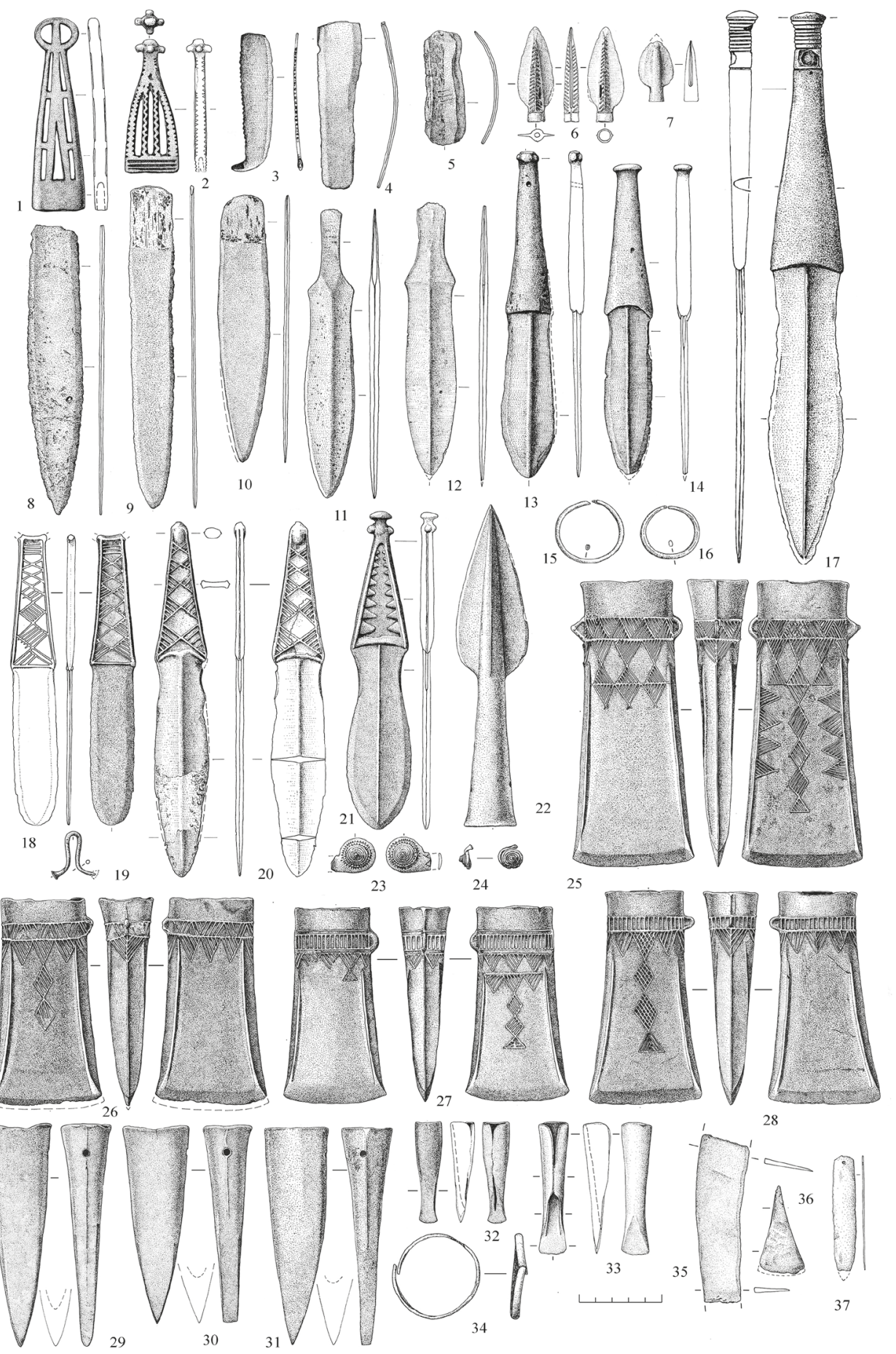

Puc. 4. Металлокомплекс святилища Шайтанское Озеро II:

1-3, 8-11, 17-18, 21 - по [Сериков и др., 2009]; 5, 15, 16, 32, 34 - по [Сериков и др., 2009]; 6, 7, 35 - по [Корочкова, Спиридонов, 2015]; 25-30 - по [Сериков и др., 2009]; 22, 31 - по [Корочкова, Стефанов, 2010]; 12, 31 - по [Корочкова, Стефанов, 2013]; 14 - по [Корочкова, Стефанов, 2013] 
Поселки кольцевой планировки мало соответствуют статусу мест, где протекала обыденная жизнь ${ }^{35}$. Об этом свидетельствуют:

- большое количество жилищ на ограниченной площади;

- отсутствие культурного слоя за пределами и малая мощность культурного слоя внутри «кольца», что указывает на кратковременное или эпизодичнеское использование внутреннего пространства;

- аномально малое для поселений бронзового века представительство фрагментированной посуды и керамики;

- выразительный набор каменного инвентаря, включающий подчас большое количество наконечников стрел;

- специфический керамический комплект, отражающий ядро культуры вне ее связей;

- отсутствие бытовых построек, хозяйственных ям, малочисленность костей животных, птиц, рыбы.

Симптоматично, что практически все артефакты, связанные с архаичным металлопроизводством, обнаружены именно на таких поселениях - Ташково I, ЮАО XIII, Иска, Заводоуковское Х. Химизм ташковского металла определенно указывает на сейминско-турбинский вклад, а также возможные связи со степным синташтинско-петровским очагом металлообработки ${ }^{36}$. Признаки оловянной лигатуры в металлических артефактах таежного Приобья также ориентируют на сейминско-турбинский круг связей.

Известные металлоносные знаки подтверждают смоделированный исследователями магистральный путь распространения сейминско-турбинских новаций преимущественно в таежной среде. Попытаемся развернуть этот вывод с точки зрения накопленных на сегодняшний день археологических данных.

Какой характер носили сейминско-турбинские миграции? Есть основания полагать, что речь идет о продвижении малочисленных групп вооруженного населения ${ }^{37}$, ориентированных не столько на освоение, сколько на открытие новых земель. Движение групп, обладавших уникальным оружием и орудиями, средствами транспорта, означало, что эти люди были знакомы с навыками производящего хозяйства: они знали, как разводить и содержать домашних животных, как плавить металл и делать из него оружие и орудия. Однако все эти навыки не сказались в полной мере на культуре жизнеобеспечения населения, с которым они контактировали, или сказались в разной степени, чему есть целый ряд объяснений. Среда обитания и образ жизни таежного населения, по сути, нивелировали некоторые прогрессивные навыки и умения мигрантов. Сложившаяся к тому времени в тайге система хозяйствования была оптимально адаптирована к местным условиям и степные инновации здесь были не востребованы. И точно так же, как в степном поясе информационные связи циркулировали внутри круга производящих культур ${ }^{38}$, в таежной

35 Корочкова О.Н. Дискуссионные аспекты изучения ташковской культуры // Вестник археологии, антропологии и этнографии. 2012. № 3. С. 28

36 Дегтярева А.Д., Ковалева В.Т., Кузьминых С.В. Особенности цветной металлообработки племен ташковской культуры Нижнего Притоболья. С. 18-19.

37 Черных Е. Н., Кузъминых С. В. Древняя металлургия Северной Евразии. М., 1989. С.269-277.

38 Черных E. Н. Парадигма археологии сквозь призму естественнонаучных методов // Вестник Российской Академии наук. М., 2011. С. 50-52. 
зоне коммуникации поддерживались преимущественно среди населения близкого образа жизни, поэтому достижения мастеров степных металлургических центров не проникали в тайгу.

В отрыве от источников сырья весьма проблематичными становились занятия металлопроизводством. Многочисленные примеры самостоятельных опытов выплавки металла, зафиксированные на памятниках ташковской, кульеганской, полымьятской культур, свидетельствуют о заметных трудностях сибирских аборигенов в овладении навыками работы с легированными сплавами, поиске оптимальных температурных режимов ${ }^{39}$. Ярко выраженный автономный характер погребений литейщиков, а также обряд намеренной порчи литейных форм ${ }^{40}$, указывают на особый, закрытый статус мастеров-литейщиков, принадлежавших к сейминскотурбинским кланам. Показательно, что традиции сейминско-турбинской металлообработки не укоренились в западносибирской тайге и не нашли своего развития в дальнейшем к западу от Урала. Во многом это было продиктовано сырьевым дефицитом, но немаловажное значение имело и другое обстоятельство - неподготовленность местного населения к восприятию подобных инноваций.

Строго говоря, появление бронзовых орудий не произвело кардинальных перемен в системе жизнеобеспечения таежного мира. Это был яркий эпизод, активированный мобильными сейминско-турбинскими группами, во многом обусловленный «факторами» Оби и Иртыша - основных транспортных меридиональных магистралей Западной Сибири. Археологически фиксируется распространение не новых технологий, не нового образа жизни, а передового оружия. Такая же модель реконструируется и на основе сейминско-турбинских памятников западной зоны, среди которых самыми информативными являются большие и малые некрополи: Турбино, Решное, Бор-Ленва, Сейма, Юринский (Усть-Ветлуга). Практика сооружения воинских мемориалов и ярко выраженная манифестация собственной идентичности именно в обрядовой сфере - свидетельства скорее военных агрессивных акций, нежели хозяйственного освоения новых земель. И еще один показательный момент, на который исследователи обратили внимание: тесные интеграции касаются взаимодействий с носителями технологий металлообработки. Так, например, к западу от Урала весьма заметным становится вклад в сейминско-турбинский металлокомплекс абашевских инкорпорантов ${ }^{41}$. А вот присутствие мигрантов в культуре местного населения обнаружить весьма сложно. Об этом прямо сообщают те трудности, с которыми археологи сталкиваются в попытках определения культурного контекста сейминско-турбинских мемориалов.

После окончания проникновения сейминско-турбинских традиций в глубь западносибирской тайги местные культуры, по сути, утрачивают ярко выраженные признаки бронзового века. До сих пор здесь неизвестны какие-либо артефакты, которые свидетельствовали бы о поставках металла из степных центров, где следующий этап бронзового века обозначен археологическими памятниками андроновской общности. Более того, в тайге до сегодняшнего дня неизвестны археологиче-

39 Дегтярева А.Д., Ковалева В.Т., Кузвминых С.В. Особенности цветной металлообработки племен ташковской культуры Нижнего Притоболья. С. 23.

40 Корочкова О.Н. Погребение литейщика в таежном Приобье // Археология Южной Сибири. C. 131 .

41 Черных Е. Н. Культура номадов в мегаструктуре Евразийского мира. Т. 1. М., 2013.С. 284-286. 
ские комплексы, синхронные андроновским, либо эти памятники мало отличаются от комплексов предшествующего времени, либо они до сих пор не идентифицированы среди известных археологических материалов. Свойственный лесным культурам консерватизм при отсутствии инокультурных импульсов создает эффект плавной преемственности. Очередной «культурный слом» обозначился на рубеже II-I тыс. до н. э. миграциями групп северного населения на юг Западной Сибири, для керамики которых характерна так называемая крестовая орнаментация: в перечне археологических образований стали фигурировать памятники атлымского, лозьвинского, белоярского, красноозерского и карьковского типов.

Уровень наших сегодняшних знаний позволяет утверждать, что распространение животноводства, металлопроизводства и колесного транспорта в таежной зоне наталкивалось на культурные и сырьевые барьеры - невостребованность этих инноваций и отсутствие условий для развития собственной металлообработки (в качестве таковых выступают либо собственно сырьевые ресурсы, либо устойчивая система связей по поставке металла).

По иному сценарию развивались процессы внедрения новшеств бронзового века на Среднем Урале - регионе также малопригодном для ведения производящего хозяйства, но обладавшего богатыми меднорудными месторождениями с выходами окисленных руд. Последнее обстоятельство имело особое значение, так как именно окисленные руды соответствовали возможностям металлургии того времени.

Уже не раз обращалось внимание на то, что Урал до недавнего времени представлял собой малообъяснимую лакуну в широтном сейминско-турбинском транскультурном коридоре. Вполне вероятно, что с этим же временем связана находка топора абашевского типа на Горбуновском торфянике ${ }^{42}$. Перечисленные единичные находки воспринимаются как «сейминско-турбинские и абашевско-синташтинские импорты». В той же связи стоит упомянуть и обнаруженные около Нязепетровска остатки литейной мастерской, которые коллеги интерпретируют как следы «абашевской экспедиции». ${ }^{43}$ Таким образом, Средний Урал довольно рано попадает в орбиту интересов первых металлургов.

Однако полноценное включение региона в систему связей металлургической провинции произошло чуть позднее, о чем сообщает феномен местной коптяковской культуры. Самым замечательным памятником этого времени является святилище Шайтанское Озеро II (далее Шайтанка), до открытия которого Средний Урал производил впечатление региона, по каким-то причинам весьма слабо вовлеченного в сферу действия сейминско-турбинского феномена ${ }^{44}$. Сейчас очевидно, что в начале II тыс. до н.э. на Среднем Урале сложился самобытный центр металлообработки, который Д.Г.Савинов предложил именовать коптяковско-сейминским $^{45}$. На сегодняшний день корпус металлических артефактов начальной поры

42 Эдинг Д.Н. Новые находки на Горбуновском торфянике // Материалы и исследования по археологии СССР. 1940. № 1. Табл. II-3.

43 Борзунов В.А., Бельтикова Г.В. Стоянка абашевских металлургов в горно-лесном Зауралье // 120 лет археологии Восточного склона Урала. Первые чтения памяти В. Ф. Генинга. Ч. 2. Екатеринбург, 1999. С. 43-52.

44 Черных Е. Н., Кузвминых С. В. Древняя металлургия Северной Евразии. М., 1989. С. 32.

45 Савинов Д.Г. О двух путях распространения бронзовых изделий сейминского типа на восток // Арии степей Евразии: эпоха бронзы и раннего железа в степях Евразии и на сопредельных территориях. Барнаул, 2014. С. 91-99. 
бронзового века с этой территории приближается к 250 ед., из них $80 \%$ аккумулированы на Шайтанке. Радиоуглеродные даты памятника - 2000-1650 гг. до н. э. соответствуют хронологическому интервалу памятников ранней фазы Западноазиатской (Евразийской) металлургической провинции ${ }^{46}$. От известных некрополей Сейма, Турбино, Ростовка его отличают некоторые весьма заметные особенности.

В металлокомплексе Шайтанки (см. рис.4) нет массивного высокорангового оружия (ножи-кинжалы с фигурными рукоятями и скульптурными навершиями, наконечники копий с вильчатым стержнем и крюком, кельты с ушками-петельками). Кельты и кинжалы, которые составляют основу шайтанского собрания, весьма своеобразны. Кельты снабжены «ложными ушками» (см. рис. 4: 25-28), что, по единодушному мнению специалистов, указывает на более поздний этап бытования подобных предметов, когда исходная конструктивная деталь - петелька - сохраняется в виде имитации, как лишенный функционального назначения атрибут ${ }^{47}$. Среди ножей и кинжалов явно преобладают евразийские формы: речь идет о двулезвийных клинках (см. рис. 4: 11, 12), иногда прилитых к массивным металлическим рукоятям (см. рис. $4: 13,14,17)$. Помимо изделий с прилитыми рукоятями, в коллекции Шайтанки есть два цельнолитых орнаментированных кинжала, на которых имитируются подобные рукояти (см. рис. 4: 18, 20, 21). Вкупе с найденным на Палатках I подобным экземпляром они составляют специфическую группу предметов, неизвестных за пределами Среднего Зауралья. К числу предметов местного происхождения также относятся втульчатые чеканы (см. рис. 4: 29-31). Выполненные по технологии втульчатого литья, они демонстрируют и некоторые особенности рецептуры - отлиты из «чистой меди», что характерно для местной металлообработки. Еще одна весьма примечательная особенность святилища - обилие остатков металлопроизводства (капли, сплески, литейные шишки), около 30 \% от общего количества металлических артефактов.

Металлокомплекс горно-лесного Зауралья, ассоциируемый с местной коптяковской культурой, представляет собой конгломерат различных технологических традиций. Сейминско-турбинский вклад обозначен присутствием изделий, отлитых по технологии «слепой втулки» и пластинчатых ножей (см. рис. 4: 8, 9), а степной, адресующий к традициям, выработанным в среде носителей синташтинских/ петровских традиций, представляют изделия с несомкнутой втулкой (см. рис. 4: 32, 33), двулезвийные кинжалы с нервюрой (см. рис.4: 11, 12), серпы (см. рис. 4: 35), украшения (см. рис. 4: 19, 15, 16, 23, 24, 37). Среднеуральский вклад в металлообработку Западноазиатской металлургической провинции передают изделия оригинальных форм: кельты с ложным ушком, втульчатые чеканы и цельнолитые кинжалы с орнаментированной рукоятью. При этом надо отметить, что они как будто не имели широкого хождения. Из пяти известных на сегодняшний день втульчатых чеканов четыре обнаружены на Шайтанке, а еще один - в лесостепном Притоболье (поселение Высокая Грива в устье р. Суерь) ${ }^{48}$. Кельты с ложными ушками имеют

46 Черных Е.Н., Корочкова О.Н., Орловская Л.Б. Проблемы календарной хронологии сейминско-турбинского транскультурного феномена. С. 51-52.

47 Бочкарев В.С. О функциональном назначении петель-ушек у наконечников копий эпохи поздней бронзы Восточной Европы и Сибири // Культурогенез и древнее металлопроизводство Восточной Европы. СПб., 2010. С. 139-143.

48 Потемкина Т. М. Бронзовый век лесостепного Притоболья. М., 1985. С. 128-130. 
исключительно таежные «адреса» ${ }^{49}$. Кинжалы с орнаментированными рукоятями за пределами Среднего Урала не найдены.

Высокая степень концентрации металлических предметов на территории культового памятника Шайтанское Озеро II подтверждает универсальность практики отчуждения металлических изделий в сакральную сферу на ранней стадии внедрения металла в культуру населения.

Особого акцента заслуживает географический фактор. Коптяковско-сейминский центр металлообработки сложился в среде населения присваивающего образа жизни. Об этом свидетельствует собственно феномен местной коптяковской культуры. Ареал культуры очерчивается не вполне конкретно, ядро ее локализовано на Среднем Урале, но близкие памятники известны в Прикамье ${ }^{50}$ и Притоболье $\mathrm{f}^{51}$. При этом приуральские, среднеуральские и притобольские комплексы отличаются разительно. Основанием для отнесения их к коптяковской культуре является керамическое собрание Шайтанки, которое представляет своего рода обобщенный синтетический комплекс, резко контрастирующий с поселенческими выборками. Для него характерны ярко выраженный архаизм (очевидные параллели с предшествующими энеолитическими традициями), многокомпонентность и специализированность (бо́льшая часть сосудов непригодна для повседневного использования). Так называемые коптяковские комплексы Тюменского Притоболья демонстрируют значительный «алакульский вклад», а в приуральских он не прослеживается вовсе.

Составленная карта памятников коптяковской культуры (рис.5), помимо указаний на чрезвычайно низкую плотность населения, демонстрирует еще одну весьма замечательную особенность - приуроченность их к зоне медно-скарновых месторождений. Безусловных аргументов в непреложности этой связи нет, что во многом объясняется высокой степенью антропогенных разрушений. «Чудские копи», как отмечают геологи, долгое время оставались основным поисковым признаком для горняков Нового времени. Нет в нашем распоряжении и артефактов, которые несомненно свидетельствовали бы о собственно металлургических занятиях носителей коптяковской культуры. Более того, чрезвычайно мало известно и собственно атрибутов литейного дела. В причинах этого еще предстоит разбираться. Некоторые нюансы указывают на вполне вероятное использование окрестных руд для местного центра металлообработки.

В качестве потенциальных источников сырья можно выделить несколько горно-металлургических узлов: Нижнетагильский, Нейво-Рудянский/Калатинский, Пышминско-Ключевской, Гумешевский и Кыштымский. Их локализация в целом совпадает с ядром коптяковской культуры. Помимо того, что в коре выветривания скарновых месторождений образовывались окисленные руды, они были богаты самородной медью. Возможно, именно последнее обстоятельство объясняет отсутствие остатков собственно металлургического производства. Но не исключено, что

49 Корочкова О.Н., Спиридонов И.А., Стефанов В.И. О металлообработке эпохи поздней бронзы горно-лесного Зауралья: кельты кижировского типа // Вестник Кемеровского гос. ун-та. 2015. T.6. С.61-67.

50 Денисов В.П., Мельничук А.Ф., Митряков А.Е. Малоизученный хронологический горизонт Заосиново VII - Непряха VII - Партизаны IV эпохи бронзы Среднего Прикамья // Шестые Берсовские чтения. Екатеринбург, 2011. С.107-116.

51 Зах В. А. Коптяковская культура в Нижнем Притоболье // Вестник археологии, антропологии и этнографии. Тюмень, 2012. № 2 (17). С. 29-40. 


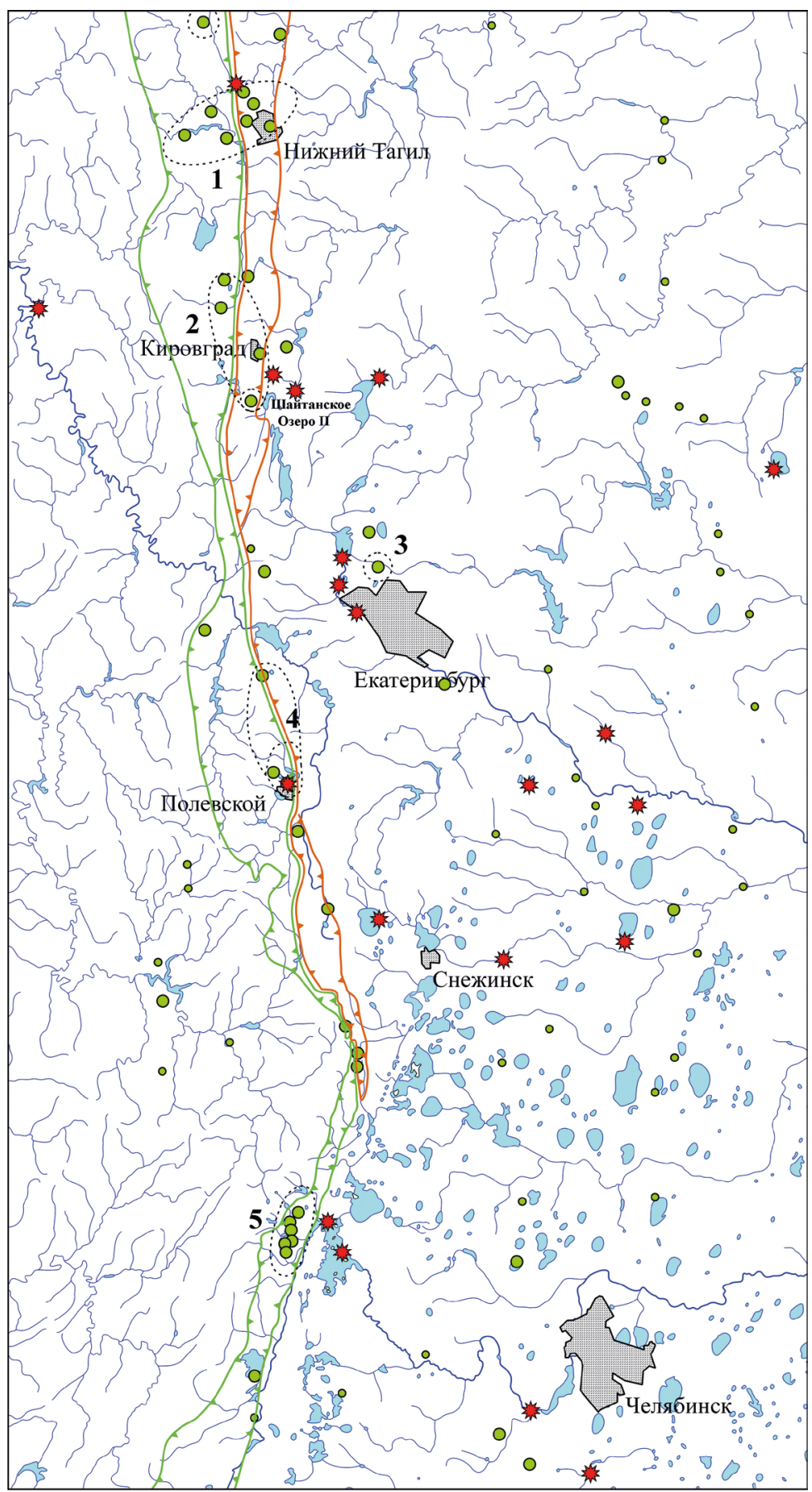

комплексы коптяковской культуры О медно-скарновые месторождения

010 металлогенические зоны Среднего Урала

Горно-металлургические узлы: 1 - Нижнетагильский, 2 - Калатинский,

3 - Пышминско-Ключевской, 4 - Гумешевский, 5- Кыштымский

Puc. 5. Карта археологических комплексов коптяковской культуры и медно-скарновых месторождений Среднего Урала (рис. автора) 
эта особенность имеет иные объяснения. Феномен Каргалов показывает, что занятия металлургов и горняков представляли весьма закрытую сферу деятельности ${ }^{52}$, а некоторые особенности предварительной подготовки сырья (плавка на медный штейн) ${ }^{53}$ объясняют отсутствие шлаков - явных металлургических знаков в местах плавки.

Какова судьба среднеуральского центра металлообработки? Судя по археологическим материалам черкаскульской, бархатовской и межовской культур, отражающих более поздние фазы бронзового века на Среднем Урале, он перешел в латентное состояние. Крайне немногочисленные металлические артефакты свидетельствуют о том, что традиции втульчатого литья не были утрачены. Однако ассортимент изделий был весьма ограничен, популярными стали кельты с пещеркой, прототипы которых адресуют к изделиям с раскованной втулкой, столь характерным для степной металлообработки. Изделия становятся более грацильными.

Несмотря на крайне скупые металлические знаки, есть основания полагать, что традиции металлообработки и использования местных руд на Среднем Урале сохранялись. Об этом сообщает прежде всего феномен иткульского горно-металлургического центра (ГМЦ), функционировавшего в VIII-III вв. до н.э. В ассортименте изделий - кельты, наконечники стрел, копий - прочитываются сейминскотурбинские технологии втульчатого литья, а в рецептуре большинства изделий, выплавленных из «чистой меди», наследие в том числе и коптяковско-сейминского центра ${ }^{54}$. На Урале неизвестны месторождения олова, поэтому местные литейщики недостаток лигатур «восполнили практическим знанием технологии литья и обработки “чистой меди” ${ }^{55}$, что передает технологическое своеобразие иткульского металлопроизводства.

Сложение и функционирование иткульского центра было во многом стимулировано «степным запросом» и сформировавшимся разделением труда, в основе которого лежали взаимовыгодные связи - металл в обмен на скот ${ }^{56}$. По сути, иткульский ГМЦ развивает модель коптяковско-сейминского центра и демонстрирует перспективы и ограничения культивирования высоких технологий в обществах присваивающей экономики, которые определялись степенью интегрированности в круг производящих культур степного пояса.

Таким образом, на Среднем Урале археологически зафиксировано две вспышки горно-металлургического производства в дописьменную эпоху, которые показывают, что собственно сырьевой фактор не является решающим в становлении «высоких технологий». Гораздо большее значение имеют образ жизни, востребованность прогрессивных навыков и умений, сложившееся разделение труда, так как производство пищи и металла требует, помимо соответствующих условий, специализи-

52 Черных E.Н. Каргалы. T. V: феномен и парадоксы развития; Каргалы в системе металлургических провинций; Потаенная (сакральная) жизнь архаичных горняков и металлургов. М., 2007. C. 134-173.

53 Благодарю за консультацию по этому вопросу коллег В. В. Ткачева и С. В. Богданова.

54 Кузьминьх С.В., Дегтярева А.Д. Металлопроизводство иткульской культуры Среднего Урала (по аналитическим данным) // Аналитические исследования лаборатории естественнонаучных методов. Вып. 4. М., 2017. С. 14.

55 Там же. С. 19.

56 Бельтикова Г.В. Среда формирования и памятники Зауральского (иткульского) очага металлургии // Археология Урала и Западной Сибири. Екатеринбург, 2005. С. 162-186. 
рованных профессиональных компетенций и выработанных алгоритмов передачи знаний. Немаловажное значение имеет потребность в изделиях из металла, прежде всего оружия. Еще один существенный фактор - демографический. В условиях низкой плотности населения, слабой вовлеченности в систему межкультурных связей, утраты эксклюзивности меди после открытия свойств железа, ограниченности возобновляемых ресурсов Средний Урал и вовсе потерял свою привлекательность для освоения и статус производящего центра. В позднем железном веке здешние земли заселяли немногочисленные группы охотников и рыболовов.

\section{References}

Antipina E.E., Lebedeva E.Iu. Paleoekonomicheskie rekonstruktsii v arkheologii: teoriia i praktika arkheobiologicheskikh issledovanii. Estestvennonauchnye metody issledovanii paradigma sovremennoi arkheologii. Moscow, Iazyki slavianskoi kul'tury, 2015, pp. 98-105. (In Russian)

Bel'tikova G. V. Sreda formirovaniia i pamiatniki Zaural'skogo (itkul'skogo) ochaga metallurgii. Arkheologiia Urala i Zapadnoi Sibiri. Ekaterinburg, Ural's University Press, 2005, pp. 162-186. (In Russian)

Besprozvannyj E. M., Degtyareva A.D., Korochkova O. N., Kuz'minyh S. V., Stefanov V.I., Kosinskaya L.L. Satyga XVI: Seiminsko-turbinskii mogil'nik v taezhnoi zone Zapadnoi Sibiri. Ekaterinburg, Ural'skii rabochii, 2011, 192 p. (In Russian)

Bochkarev V.S. Volgo-Ural'skii ochag kul'turogeneza epokhi pozdnei bronzy. Sotsiogenez i kul'turogenez $v$ istoricheskom aspekte. Materialy metodologicheskogo seminara IIMK AN SSSR. St. Peterburg, 1991, pp. 24-27. (In Russian)

Bochkarev V.S. O funktsional'nom naznachenii petel'-ushek u nakonechnikov kopii epokhi pozdnei bronzy Vostochnoi Evropy i Sibiri. Kul'turogenez i drevnee metalloproizvodstvo Vostochnoi Evropy. St. Petersburg, Info Ol', 2010, 231 p. (In Russian)

Bochkarev V.P., Kuzmina E.E., Kuznetsov P. F., Usachuk A. N. Osnovnye itogi izucheniia vozniknoveniia i rasprostraneniia kolesnichestva. Koni, kolesnitsy i kolesnichie stepei Evrazii. Ekaterinburg, Samara, Donetsk, 2010, pp.344-347. (In Russian)

Borzunov V. A. Zapadnaia Sibir' - samyi severnyi areal ukreplennykh poselenii neolita i pervoi poloviny epokhi bronzy. Trudy IV (XX) Vserossiiskogo Arkheologicheskogo s"ezda v Kazani. Eds A. G. Sitdikov, N. A.Makarov, A.P.Derevianko. Kazan', Institut arkheologii Akademii nauk Respubliki Tatarstan, Kazanskii (Privolzhskii) Federal'nyi universitet, Institut arkheologii Rossiiskoi akademii nauk, Institut arkheologii i etnografii Sibirskogo otdeleniia Rossiiskoi akademii nauk, Institut istorii material'noi kul'tury Rossiiskoi akademii nauk, 2014, pp. 218-220. (In Russian)

Borzunov V.A., Bel'tikova G.V. Stoianka abashevskikh metallurgov v gorno-lesnom Zaurale. 120 let arkheologii Vostochnogo sklona Urala. Pervye chteniia pamiati Vladimira Fedorovicha Geninga. Pt. 2. Ekaterinburg, Ural's University Press, 1999, pp. 43-52. (In Russian)

Borzunov V. A., Stefanov V. I., Glushkov I. G. Bystryi Kul'egan-38 - ukreplennoe zhilishche epokhi bronzy v Surgutskom Priobe. Arkheologiia, etnografiia i antropologiia Evrazii, 2011, no. 2 (46), pp.55-69. (In Russian)

Chairkina N. M. Eneolit Srednego Urala. Ekaterinburg, UrO RAN, 2005, 312 p. (In Russian)

Chairkina N.M. Torfianikovye pamiatniki Zaural'ia: analiz i interpretatsiia. Diss. ... dok. ist. nauk. Novosibirsk, 2015, 337 p. (In Russian)

Chairkina N.M., Pavlova O.A., Vilisov E.V. Arkheologicheskoe issledovanie VI razreza Gorbunovskogo torfianika v 2009 g. Ural'skii istoricheskii vestnik, 2014, no. 1 (42), pp. 112-122. (In Russian)

Shairkina N.M, Kuzmin Y.V, Hodgins G.W. Radiocarbon chronology of the mesolithic, neolithic, aeneolithic, and bronze age sites in the Trans-Urals (Russia): a general framework. Radiocarbon, 2017, vol. 59, no. 2, pp. 505-518.

Chernykh E.N. Metallurgicheskie provintsii i periodizatsiia epokhi rannego metalla na territorii SSSR. Sovetskaia arkheologiia, 1978, no.4, pp. 53-82. (In Russian)

Chernykh E. N. Kargaly. Tom V: fenomen i paradoksy razvitiia; Kargaly v sisteme metallurgicheskikh provintsii; Potaennaia (sakral'naia) zhizn' arkhaichnykh gorniakov i metallurgov. Moscow, Iazyki slavianskoi kul'tury, 2007, 200 p. (In Russian)

Chernykh E. N. Paradigma arkheologii skvoz' prizmu estestvennonauchnykh metodov. Vestnik Rossiiskoi Akademii nauk. Moscow, 2011, pp. 43-55. (In Russian) 
Chernykh E. N. Metallurgicheskie provintsii na fone geoekologicheskikh arealov Evrazii. Megastruktura Evraziiskogo mira. Ed. by E. N. Chernykh. Moscow, Taus, 2012, pp. 122-127. (In Russian)

Chernykh E.N. Kul'tury nomadov v megastrukture Evraziiskogo mira. T.1. Moscow, Iazyki slavianskoi kul'tury, 2013, 368 p. (In Russian)

Chernykh E.N., Korochkova O.N., Orlovskaia L.B. Problemy kalendarnoi khronologii seiminskoturbinskogo transkul'turnogo fenomena. Arkheologiia, etnografiia i antropologiia Evrazii, 2017, vol. 45, no. 2, pp. 45-55. (In Russian)

Chernykh E. N., Kuz'minykh P. V. Drevniaia metallurgiia Severnoi Evrazii. Moscow, Nauka, 1989, 320 p. (In Russian)

Degtiareva A.D., Kovaleva V.T., Kuz'minykh P.V. Osobennosti tsvetnoi metalloobrabotki plemen tashkovskoi kul'tury Nizhnego Pritobol'ia. Vestnik arkheologii, antropologii i etnografii, 2014, no. 3 (26), pp. 14-24. (In Russian)

Denisov V.P., Mel'nichuk A. F., Mitriakov A.E. Maloizuchennyi khronologicheskii gorizont Zaosinovo VIINepriakha VII-Partizany IV epokhi bronzy Srednego Prikam'ia. Shestye Bersovskie chteniia. Ekaterinburg, Kvadrat, 2011, pp. 107-116. (In Russian)

Eding D. N. Novye nakhodki na Gorbunovskom torfianike. MIA, 1940, no. 1, pp.41-57. (In Russian)

Golovnev A. V. Antropologiia dvizheniia. Ekaterinburg, UrO RAN; Volot, 2009, 496 p. (In Russian)

Koksharov S. F. Pamiatniki eneolita severa Zapadnoi Sibiri. Ekaterinburg, Volot, 2009, 272 p. (In Russian)

Koksharov S. F. Kul'tura naseleniia severa Zapadnoi Sibiri v bronzovom veke. Diss. ... dokt. ist. nauk. Novosibirsk, 2015, 425 p. (In Russian)

Koksharov S.F., Baranov M. Iu. Sledy metalloproizvodstva bronzovogo veka s poseleniia Balinskoe 1 (Khanty-Mansiiskii avtonomnyi okrug - Iugra). Rossiiskaia arkheologiia, 2017, no. 2, pp.39-54. (In Russian)

Korochkova O. N., Stefanov V.I. Kul'tovyj pamyatnik epohi bronzy na Shajtanskom ozere pod Ekaterinburgom (po materialam raskopok 2008 g.). Rossijskaya arheologiya, 2010, no. 4, pp. 120-129. (In Russian)

Korochkova O.N., Stefanov V.I. Kul'tovyj pamyatnik epohi bronzy na SHajtanskom ozere pod Ekaterinburgom (po materialam raskopok 2009-2010 gg.). Rossijskaya arheologiya, 2013, no. 1, pp. 87-96. (In Russian)

Korochkova O.N., Stefanov V.I. Satyga XVI v sisteme kul'tur epokhi bronzy Zaural'ia i Zapadnoi Sibiri. Satyga XVI: Seiminsko-turbinskii mogil'nik v taezhnoi zone Zapadnoi Sibiri. Ekaterinburg, Ural'skii rabochii, 2011, pp.60-85. (In Russian)

Korochkova O.N. Pogrebenie liteishchika v taezhnom Priob'e. Arkheologiia Iuzhnoi Sibiri. Ed by L. N. Ermolenko. Kemerovo, KemGU, 2011, pp. 129-136. (In Russian)

Korochkova O. N. Diskussionnye aspekty izucheniia tashkovskoi kul'tury. Vestnik arkheologii, antropologii i etnografii, 2012, no. 3, pp. 24-33. (In Russian)

Korochkova O.N., Spiridonov I. A. O sud'bakh innovatsii v kul'turakh prisvaivaiushchego mira Urala i Zapadnoi Sibiri. Ural'skii istoricheskii vestnik, 2015, no.3, pp.96-107. (In Russian)

Korochkova O. N., Spiridonov I. A., Stefanov V. I. O metalloobrabotke epokhi pozdnei bronzy gorno-lesnogo Zaural'ia: kel'ty kizhirovskogo tipa. Vestnik Kemerovskogo gosudarstvennogo universiteta, 2015, vol.6, pp. 61-67. (In Russian)

Korochkova O.N., Stefanov V.I. Kul'tovyш pamyatnik epohi bronzy na Shaitanskom ozere pod Ekaterinburgom (po materialam raskopok 2008 g.). Rossiiskaia arheologiia, 2010, no. 4, pp. 120-129. (In Russian)

Korochkova O. N., Stefanov V. I. Kul'tovyi pamyatnik epohi bronzy na Shaitanskom ozere pod Ekaterinburgom (po materialam raskopok 2009-2010 gg.). Rossiiskaia arheologiia, 2013, no. 1, pp. 87-96. (In Russian)

Kosarev M. F. Drevnie kul'tury Tomsko-Narymskogo Priob'ia. Moscow, Nauka, 1974, 220 p. (In Russian)

Kovaleva V.T. Genezis, datirovka i etnicheskaia spetsifika tashkovskoi kul'tury. Arkheologiia Urala $i$ Zapadnoi Sibiri. Ekaterinburg, Ural's University Press, 2005, pp. 102-109. (In Russian)

Kovaleva V.T. Vzaimodeistvie kul'tur i etnosov po materialam arkheologii: poselenie Tashkovo II. Ekaterinburg, Ural's University Press, 1997, 131 p. (In Russian)

Kovaleva V.T. Rannii bronzovyi vek Nizhnego Pritobol'ia: tashkovskaia kul'tura. Sovremennye problemy arkheologii Rossii. Vol. 1: Materialy Vserossiiskogo arkheologicheskogo s"ezda. Novosibirsk. Institut istorii arkheologii i etnografii SO RAN, 2006, pp. 393-395. (In Russian)

Kuz'mina E.E. Koni stepei Evrazii epokhu eneolit i bronzy. Koni, kolesnitsy i kolesnichie stepei Evrazii. Ekaterinburg, Samara, Donetsk, 2010, pp. 5-13. (In Russian)

Kuz'minykh P. V., Degtiareva A. D. Metalloproizvodstvo itkul'skoi kul'tury Srednego Urala (po analiticheskim dannym). Analiticheskie issledovaniia laboratorii estestvennonauchnykh metodov. Eds V.I.Zav'ialov, P. V. Kuz’minykh. M.: Taus', 2017. Vyp. 4, pp. 16-33. (In Russian) 
Matiushchenko V.I. Drevniaia istoriia naseleniia lesnogo i lesostepnogo Priob'ia (neolit i bronzovyi vek). Chast' 2. Samus'skaia kul'tura. Tomsk, Tomsk University Press, 1973, 227 p. (In Russian)

Myznikov S.A., Kosinskaya L.L., Stefanov V.I. Selishche Savkinskaia Rechka 1: novye materialy po bronzovomu veku srednetaezhnogo Priob'ia. Vestnik arkheologii, antropologii i etnografii, 2012, no.3, pp. 60-72. (In Russian)

Potemkina T.M. Bronzovyi vek lesostepnogo Pritobol'ia. Moscow, Nauka, 1985, 376 p. (In Russian)

Ryndina N.V., Degtiareva A.D. Eneolit i bronzovyi vek: Uchebnoe posobie. Moscow, Moscow University Press, 2002, 226 p. (In Russian)

Savinov D. G. O dvukh putiakh rasprostraneniia bronzovykh izdelii seiminskogo tipa na vostok. Arii stepei Evrazii: epokha bronzy i rannego zheleza v stepiakh Evrazii i na sopredel'nykh territoriiakh: sb. pamiati E. E. Kuz'minoi. Eds V. I. Molodin, A. V.Epimakhov. Barnaul, Publ. AltGU, 2014, pp.91-99. (In Russian)

Serikov Y.B., Korochkova O.N., Kuz'minyh S. V., Stefanov V.I. Shaitanskoe Ozero II: novye siuzhety v izuchenii bronzovogo veka Urala. Arheologiia, etnografiia $i$ antropologiia Evrazii. 2009, no.2 (38), pp. 67-78. (In Russian)

Stefanov V. I. Mogil'nik Tovkurtlor 3: seiminsko-turbinskii sled v Nizhnem Priob’e. Rossiiskaia arkheologiia, 2006, no. 1, pp. 44-58. (In Russian)

Stefanov V. I., Borzunov V. A. Neoliticheskoe gorodishche Amnia I (po materialam raskopok 1993 i 2000 gg.). Barsova Gora: Drevnosti taezhnogo Priob'ia. Ekaterinburg; Surgut, Ural, 2008, pp. 93-111. (In Russian)

Stefanov V.I., Danilova E. N. Kul'eganskie drevnosti Srednego Agana. Khanty-Mansiiskii okrug v zerkale proshlogo. Iss. 11. Khanty-Mansiisk, Tomsk, Tomsk University Press, 2013, pp. 84-96. (In Russian)

Zakh V.I. Koptiakovskaia kul'tura v Nizhnem Pritobol'e. Vestnik arkheologii, antropologii i etnografii, 2012, no. 2 (17), pp. 29-40. (In Russian)

Zakh V. A., Zimina O. Iu., Riabogina N. E., Skochina P. N., Usacheva I. V. Landshafty golotsena i vzaimodeistvie kul'tur v Tobolo-Ishimskom mezhdurech'e. Novosibirsk, Nauka, 2008, 212 p. (In Russian)

Статья поступила в редакцию 12 марта 2018 г. Рекомендована в печать 12 марта 2019 г.

Received: March 12, 2018

Accepted: March 12, 2019 


\title{
Западносибирский Север и культурные миры Евразии на рубеже эр
}

\author{
Н. В. Федорова, Ан.В.Гусев
}

Для цитирования: Федорова Н.В., Гусев Ан.В. Западносибирский Север и культурные миры Евразии на рубеже эр // Вестник Санкт-Петербургского университета. История. 2019. Т. 64. Вып. 2. С. 740-761. https://doi.org/10.21638/11701/spbu02.2019.217

В статье рассматривается проблема взаимовлияний и взаимодействий культур вдоль торгового пути Север - Юг (по течению рек Обь - Иртыш): от лесотундры Западной Сибири до кочевых обществ Евразийской степи, центров Причерноморья и государств Средней Азии и Ближнего Востока во время «около рубежа эр». Ставятся вопросы о трансляциях инокультурных элементов в местную среду и о подготовленности лесных и лесотундровых сообществ к восприятию этих влияний, отразившихся в создании копий и подражаний импортным предметам, в чем до сих пор большинство авторов им отказывает. Для этого проводится анализ изделий «дальнего» импорта, а именно: медных/бронзовых котлов на поддонах, бронзовых зеркал и блях «сарматского» круга, серебряных медальонов ближневосточных цивилизаций, стеклянных и фаянсовых бус. Рассматривается материал двух памятников: древнего сакральнопроизводственного центра Усть-Полуй и Горнокнязевского клада (район современного г. Салехард, Северный полярный круг). Массовость и однородность импортных изделий, по мнению авторов, исключает постановку вопроса об опосредованных обменных контактах, но свидетельствует об устоявшихся торговых связях и, возможно, личном участии северного населения в этой торговле. Бытование импортов в местной северной среде, которое отразилось в том числе и в создании копий и подражаний им, недвусмысленно показывает, что эти изделия воспринимались не только как престижные, хотя и как инокультурные, однако осмысливались по-своему, находили место в системе культурных ценностей Севера, становились фактором местной социальной и духовной атрибутики. Таким образом, происходила культурная трансляция новых элементов в среду Севера, к тому времени готовую эти трансляции воспринимать. Отмечается, что к концу I тыс. н.э., когда восстанавливаются нарушенные в его первой половине торговые пути, вновь появляется массовый импорт, в составе которого помимо всего прочего важное место занимают медные котлы, бусы и круглые бляхи. Де-

Наталья Викторовна Федорова - канд. ист. наук, ГКУ ЯНАО «Научный центр изучения Арктики», Российская Федерация, 629008, Салехард, ЯНАО, ул. Республики, 73; mvk-fedorova@mail.ru

Natalia V. Fedorova - Ph.D. in History, Arctic Research Center, 73, ul. Respubliki, Yamal-Nenets Autonomous District, Salekhard, 629008, Russian Federation; mvk-fedorova@mail.ru

Андрей Васильевич Гусев - ст. науч. сотр., ГКУ ЯНАО «Научный центр изучения Арктики», Российская Федерация, 629008, Салехард, ЯНАО, ул. Республики, 73; gusev_av2004@mail.ru

Andrey V. Gusev - Senior Researcher, Arctic Research Center, 73, ul. Respubliki, Yamal-Nenets Autonomous District, Salekhard, 629008, Russian Federation; gusev_av2004@mail.ru

Статья выполнена при поддержке гранта Российского научного фонда (РФФИ), проект № 18-09-40011.

This research was supported by Russian Foundation for Basic Research, project №. № 18-09-40011.

() Санкт-Петербургский государственный университет, 2019 
лается предположение, что круглые зеркала и бляхи с рубежа эр становятся важным элементом статусного костюма.

Ключевые слова: Северный полярный круг, сакрально-производственный центр УстьПолуй, Горнокнязевский клад, культурные взаимодействия, торговые пути, импортные предметы, зеркала и бляхи, бронзовые котлы, стеклянные и фаянсовые бусы.

\section{The North of Western Siberia and the Cultural Worlds of Eurasia at the Turn of the Eras}

\section{N. V.Fedorova, An. V. Gusev}

For citation: Fedorova N.V., Gusev An. V. The North of Western Siberia and the Cultural Worlds of Eurasia at the Turn of the Eras. Vestnik of Saint Petersburg University. History, 2019, vol. 64, iss. 2, pp. 740-761. https://doi.org/10.21638/11701/spbu02.2019.217 (In Russian)

The article studies the problem of the cross-cultural influence and contacts along the NorthSouth trade route: from the West Siberian forest-tundra to the nomadic communities of the Eurasian steppe, the Black Sea centers and the ancient states of the Middle East and Central Asia during the period of "the turn of the eras". The authors raises a question about the translation of the alien cultural elements into the local environment, as well as about the readiness of the forest and the forest-tundra communities to respond to these influences reflected in the numerous replicas and imitations of the imported items. The existence of the imported items in the local northern environment, which was also reflected in the creation of their replicas and imitations, was a distinct demonstration that these items despite their originating from an alien culture, in addition to being perceived as the signs of prestige, were also re-interpreted locally and found their place within the system of the cultural values of the North, where they became a significant factor of the local social and religious attributes.

Keywords: North Polar Circle, sacral-production center Ust-Poluy, Gornoknyasevsk treasure, cultural communications, trade routes, imported items, the copper/bronze pots on drip trays, the bronze mirrors and plaques, the glass and china beads.

Проблема взаимодействия (контактов или даже непосредственных трансляций элементов культуры) с евразийскими культурными мирами рубежа эр для территорий, расположенных у Северного полярного круга в Западной Сибири, до сих пор практически не рассматривалась. И лишь исследования последних лет, главным образом проведенные на сакрально-производственном центре Усть-Полуй (черта современного г. Салехард), позволяют предложить если не окончательное решение, то хотя бы возможность постановки этой проблемы.

Во введении к сборнику, посвященному культурным трансляциям в различные периоды истории, Д.Г.Савинов пишет: «Общество, воспринимающее новые культурные традиции, в плане своего социально-экономического развития должно быть подготовлено к их восприятию; иначе они останутся инородными включениями в чуждую этнокультурную среду» ${ }^{1}$ (курсив наш. - Авт.). Общество культур севера Западной Сибири во вполне определенный период «вдруг» стало готово к таким восприятиям, «инородные» включения перерабатывались, «одомашнивались», становились стимулом для дальнейшего развития. Правда, до сих пор этим

${ }^{1}$ Савинов Д.Г. Введение // Культурные трансляции и исторический процесс (палеолит средневековье). СПб., 1994. С. 3. 
самым культурам в такой подготовленности и прочих сопутствующих процессах по тем или иным причинам отказывают. Весьма характерное мнение столь крупного ученого, как В. А. Шнирельман, пожалуй, наиболее бескомпромиссно: «Окраинные северные районы Евразии с их суровой природной средой и хрупким экологическим равновесием никогда не числились среди наиболее благоприятных для жизни человека областей и лежали далеко от основных центров сложения цивилизации» 2 . В этой цитате сконцентрировано восприятие северных культур частью археологов, историков, этнологов, для которых характерно рассмотрение импортных вещей как показателя «южных» - без расшифровки - связей, причем обычно имеется в виду пресловутый многоступенчатый обмен. Что под этим подразумевается, не вполне ясно, тем более что импорты не анализируются ни с точки зрения их количества и качества, ни с точки зрения взаимодействия с местными культурами. И еще одно высказывание, принадлежащее М.Б. Щукину, также весьма характерно для восприятия нашего региона: вполне правомерно разделив человеческую ойкумену «времени Латена» на семь культурных миров, он делает замечание: «5. Мир угро-финских (в основном) племен Прикамья, Приуралья и Западной Сибири... В дальнейшем мь этого мира почти не будем касаться» ${ }^{3}$ (курсив наш. - Авт.). Почему? А потому, что «Пятый мир в круговорот событий, кажется, еще тоже не

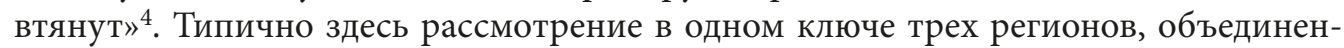
ных понятием «угро-финские племена».

Недалеко ушли в восприятии инокультурных влияний и авторы, предметом исследований которых как раз и служат «культуры пятого мира», т.е., в частности, культуры раннего железного века и времени «около рубежа эр» Западной Сибири. Так, Л.А. Чиндина пишет: «Появление некоторых вещей явно неместного, южного происхождения... отражает только обменные связи (опять же - какие? - Aвm.)» 5 . «Дальние» импорты ею вообще лишь упоминаются. Так, и она, и М.Ф. Косарев пишут, никак, впрочем, не комментируя этот факт, о находке в кладе у с. Пиковка серебряного медальона с изображением парфянского царя Готарза I ${ }^{6}$, и, не перечисляя другие, известные к тому времени импорты парфянского и кушанского происхождения (сакские шлемы, китайские зеркала и переднеазиатский серебряный медальон с изображением богини охотницы из Истяцкого клада, а также серебряный парфянский медальон из Ханты-Мансийского округа), лишь упоминают, казалось бы, еще более важный для понимания культурных взаимодействий факт: «При раскопках на Кижировском городище в низовьях Томи был встречен обломок негативной глиняной титейной формы, воспроизводящей рельефное изображение идущих друг за другом воинов, выполненных в переднеазиатской манере» ${ }^{7}$ (курсив наш. - Авт.).

Собственно, первым влияние импортных предметов на местную культуру, правда применительно к эпохе западносибирского средневековья, отметил

${ }^{2}$ Шнирельман В. А. Освоение Севера: исконные земли или объект колонизации // Актуальные проблемы древне и средневековой истории Сибири. Томск, 1997. С. 72.

${ }^{3}$ Щукин М. Б. Конкретно-историческая природа трансляции культур эпохи Латена // Культурные трансляции и исторический процесс (палеолит - Средневековье). СПб., 1994. С. 100.

4 Там же. С. 102.

5 Чиндина Л. А. Древняя история Среднего Приобья в эпоху железа. Томск, 1984. С. 122.

6 Там же. С. 98; Косарев М. Ф. Древние культуры Томско-Нарымского Приобья. М., 1974. С. 75.

7 Косарев М.Ф. Древние культуры Томско-Нарымского Приобья. С. 63. 
Б. И. Маршак. Еще в 1996 г. он писал: «...вкус к роскоши, стремление выменять или захватить силой оружия, а затем защитить от посягательств драгоценные иноземные вещи, обладание которыми повышало престиж их владельца, меняли сознание и образ жизни... лесных народов, которые... получали... представление об общественной и имущественной иерархии от пришельцев из более развитых стран» 8 (курсив наш. - Авт.).

В последнее время появилось несколько работ, посвященных как импортным бронзовым изделиям времени около рубежа эр, обнаруженным на территории Нижнего/Среднего Приобья, так и их возможным копиям, репликам, дериватам Вроде бы и материала прибавилось, и реплики обозначились, но... импортные вещи - это «отражение того, что происходит вне Западной Сибири - в ареале поставщиков импорта ... импорт позволяет видеть в смене своего источника не изменение в экономической стратегии таежного населения, а отражение перемен в условиях взаимодействия социально-территориальных групп в степной зоне Евразии» ${ }^{10}$ (курсив наш. - Авт.). Ну и, разумеется, все пишущие о населении региона употребляют термин «охотники-рыболовы-собиратели», лишь допуская постепенное развитие пушной охоты как средства добычи эквивалента для обмена.

Новой на данном фоне является позиция В. А. Борзунова, который уже в 2002 г. отмечал резкие и серьезные перемены в местном обществе, приведшие в том числе к строительству городищ с бастионно-башенными конструкциями ${ }^{11}$. Позже при анализе клада Барсова Городка 1/20 он отмечает: «В кулайский период таежные западносибирские общества вступают в стадию развития, отмеченную быстрым расслоением первобытнообщинных отношений и началом социального расслоения. Это происходило в первую очередь потому, что родовая общинная верхушка... стала контролировать всю промысловую и производственную сферу, равно как систему торгово-обменных отношений, и единолично распоряжаться престижными импортными товарами, полученными в обмен на пушнину» ${ }^{12}$.

И только исследования древнего сакрально-производственного центра УстьПолуй позволили иначе увидеть многие факты местной древней истории, в том числе яркие и многозначительные изменения в экономике (появление оленеводства с перспективой перехода к кочевому образу жизни, бронзолитейное производство на привозном сырье, появление железоделательного производства) и социальном строе (новый код культуры, появление воинских доспехов - как реальных, так и парадных, обилие импортов и многое другое).

${ }^{8}$ Маршак Б. И. Сокровища Приобья. С. 6.

9 Ширин Ю.В. Импорт рубежа эр в комплексах Западной Сибири и его значение для хронологии. С. 35-54; Шульга П.И. Вероятные пути эволюции формы «восточных» зеркал-погремушек на территории кулайской общности // I Международная конференция «Археология Арктики». Тез. докл. Екатеринбург, 2017. С. 103-106; Шульга П. И., Оборин Ю. В. Бронзовые диски из Казымского клада и «восточные» зеркала-погремушки // Ханты-Мансийский автономный округ в зеркале прошлого. Томск; Ханты-Мансийск, 2017. Вып. 15. С. 84-123.

10 Ширин Ю.В. Импорт рубежа эр в комплексах Западной Сибири и его значение для хронологии. С. 50.

11 Борзунов В. А. Городища с бастионно-башенными фортификациями раннего железного века в лесном Зауралье // Российская археология. 2002. № 3. С.79-97.

12 Клад кулайской культуры на Барсовой Горе: каталог (из собрания Сургутского краеведческого музея). Екатеринбург; Сургут, 2016. С. 113. 
Удалось в первом приближении наметить основные направления контактов, или, скорее, торговых связей. Так, авторы настоящей статьи при публикации Горнокнязевского клада (I в. до н. э. - II в. н.э.) упоминают следы «по крайней мере следующих достаточно далеких связей: Алтай и Минусинская котловина, или «хуннский след» (медные/бронзовые котлы и «китайские» зеркала), «сарматский след» (плоско-выпуклые зеркала с ручкой и без нее), «сакский след» (шлемы Истяцкого клада и подобные им изображения на местных рисунках-гравировках), «парфянский и кушанский следы» (серебряные медальоны с изображением погрудной фигуры мужчины, медальон с изображением богини охотницы)» ${ }^{13}$. Разумеется, эти условные «следы» лишь намечают основные направления контактов или, как мы постараемся показать ниже, культурных взаимодействий и даже трансляций. Подлинная картина их гораздо сложнее, да и, по нашему мнению, есть разница между контактами (которые могут и не привести в силу различных причин к культурным трансляциям) и собственно трансляциями, т.е. исходя из самого термина, переноса, перемещения неких инокультурных влияний, следов, идей в ткань местной культуры.

Постановка проблемь: на материалах памятников рубежа эр (I-II вв. до н. э. I-II вв. н.э.), исследованных на территории, прилегающей к Северному полярному кругу, а именно сакрально-производственного центра Усть-Полуй и Горнокнязевского клада, а также отдельных находок и целых комплексов с сопредельных низовьям Оби территорий, попытаться представить эти самые культурные трансляции, влияния культур и их отражение в местной культуре. Проще говоря, рассмотреть вопрос о месте этих северных культур в системе торговых путей Евразии.

Памятники. В статье будут в основном рассмотрены материалы двух памятников, расположенных в районе г. Салехарда, т. е. на территории Западной Сибири, примыкающей к Северному полярному кругу: сакрально-производственного центра Усть-Полуй и Горнокнязевского клада (рис. 1).

Усть-Полуй давно и широко известен, исследовался много лет: в 1935-1936 гг., в 1993-1995 и с 2006 по 2015 гг. Материалы исследований неоднократно публиковались ${ }^{14}$. В статье будут рассмотрены материалы из раскопок 1990-2000-х гг. («новые раскопки»).

Анализ морфологии раскопанной за все время части памятника позволил выявить несколько комплексов сакрального и производственного характера; системы, ограждающие территорию центра; два разновременных погребения ${ }^{15}$. Общие датировки памятника и отдельных комплексов ${ }^{16}$ дали возможность говорить о двух основных периодах обустройства сакрально-производственного центра: III-II вв. до н.э. и I в. до н. э. - II в. н. э., при этом, по-видимому, посещения этого центра людьми были непрерывными. При анализе материалов выяснилось, что основные

13 Федорова Н. В., Гусев Ан.В., Подосенова Ю. А. Горнокнязевский клад. Калининград, 2016. С. 56.

14 Чернецов В.Н. Бронза усть-полуйского времени // Материалы и исследования по археологии СССР. М., 1953. № 53. С.121-178; Гусев Ан.В., Федорова Н. В. Древнее святилище Усть-Полуй: конструкции, действия, артефакты. Итоги исследований планиграфии и стратиграфии памятника: 1935-2012 гг. Т. 1.

15 Гусев Ан.В., Федорова Н.В. Морфология древнего сакрально-производственного центра Усть-Полуй // Археология Арктики. Вып. 4. «Усть-Полуй: материалы и исследования». Екатеринбург, 2017. Т. 1. С. 19-61.

16 Там же. С. 62-64. 


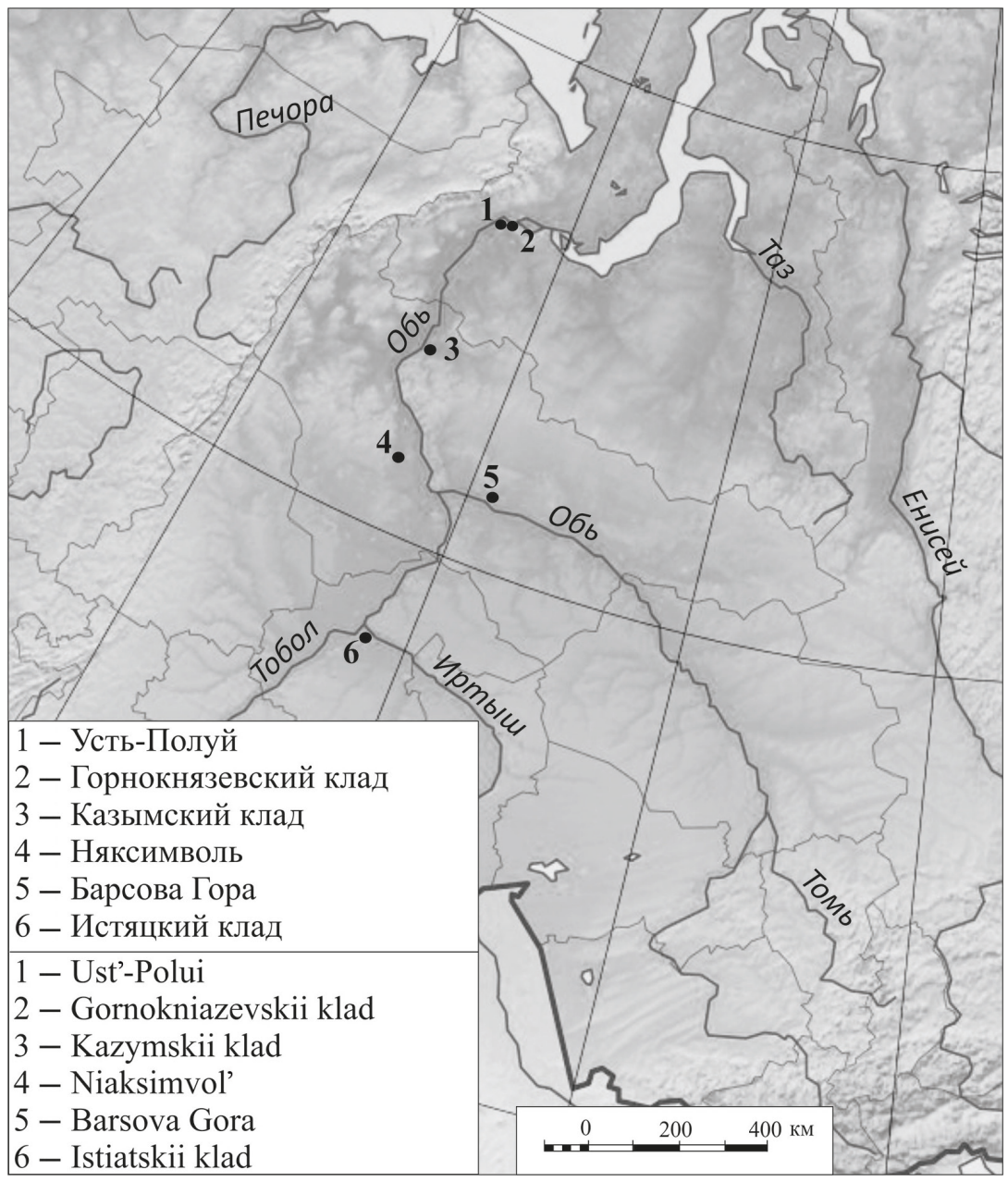

Рuc. 1. Карта памятников Приобья с находками археологических импортов (составлено Н. В. Федоровой, Ан. В. Гусевым)

предметы «дальнего» импорта, как и производственные площадки, относятся ко второму периоду обустройства центра.

Горнокнязевский клад был случайно обнаружен в 2015 г., в 2016 г. - опубликован ${ }^{17}$. Время его комплектации в основном синхронно второму периоду обустройства Усть-Полуя: I в. до н.э. - II в. н.э. Комплекс клада включает 17 бронзовых зеркал и блях; серебряный медальон, вырезанный из блюда или чаши; две серебряные обкладки сосудов (?); два бронзовых котла - все предметы «дальнего» импорта. И лишь одно местное изделие - фрагментированная эполетообразная застежка с изображением четырех голов медведей, уложенных между передними лапами ${ }^{18}$. По словам нашедшего клад и передавшего его в музей г. Салехарда (Ямало-Ненецкий окружной музейно-выставочный комплекс им. И. С. Шемановского,

17 Федорова Н. В., Гусев Ан. В., Подосенова Ю. А. Горнокнязевский клад.

18 Там же. С. 12-40. 
далее - МВК) А. И. Черемина, предметы располагались в небольшой овальной яме на глубине 15-20 см от поверхности. С его слов нами было реконструировано расположение вещей клада. Добавим, что никаких следов археологического памятника в месте находки клада при проведении разведочных работ обнаружено не было. Совершенно очевидно, что комплекс предметов был захоронен (спрятан) его обладателями в необитаемом месте.

\section{Предметы «дальнего» импорта в материалах Усть-Полуя и Горнокнязевского клада}

Под «дальним» импортом имеются в виду предметы, так или иначе доставленные из удаленных географически регионов, не имеющих территориального соприкосновения с севером Западной Сибири, т.е. из первого и шестого миров по классификации М. Б. Щукина: мира античной цивилизации (в нашем случае - передневосточных государств, возникших на руинах державы Александра Македонского: Парфии и Кушанской империи, центров Причерноморья) и мира скифо-сарматских кочевников Евразийских степей ${ }^{19}$, куда включается и территория Алтая-Минусинской котловины. Этот «дальний» импорт состоял из бронзовых/медных котлов на поддонах, бронзовых зеркал и круглых блях, серебряных медальонов, вырезанных из блюд или иных предметов, а также многочисленных стеклянных и фаянсовых бус.

Мы рассмотрим «дальние» импорты, зафиксированные в комплексах двух вышеупомянутых памятников, постараемся выявить разные типы бытования этих предметов - от простого использования готовых импортных вещей до создания копий их и даже подражаний им в местной среде. Последнее, на наш взгляд, знаменует как раз изменения в стратегии местного населения, причем не столько экономической, сколько социальной. И указывает не только и не столько на контакты, но и на культурные трансляции в систему культур таежной и лесотундровой зон Западной Сибири.

Бронзовые импортные артефакты из комплексов Усть-Полуя и Горнокнязевского клада опубликованы, они будут рассмотрены более кратко. Многочисленный корпус бус Усть-Полуя до сих пор не публиковался, ему придется уделить больше внимания. Отдельный сюжет - немногочисленные предметы из серебра, завезенные из государств Ближнего Востока, а также создание подражаний им.

\section{Бронзовые/медные котль на поддонах}

В комплексе Усть-Полуя бронзовые/медные котлы на поддонах присутствуют в виде отдельных, довольно мелких фрагментов, чаще всего стенок. Всего насчитывается 16 фрагментов, в том числе 1 фрагмент рукояти. Из анализа Ю. А.Подосеновой, изучившей сплавы, из которых отливались обнаруженные на Усть-Полуе «бронзовые» артефакты, становится очевидным, что эти фрагменты использовались для переплавки и последующей отливки «местных» изделий ${ }^{20}$. Так, наиболее

19 Щукин М. Б. Конкретно-историческая природа трансляции культур эпохи Латена. С. 99-100.

20 Подосенова Ю.А. Результаты рентгено-флуоресцентного анализа изделий из цветного металла из святилища Усть-Полуй // Археология Арктики. Вып. 4. Усть-Полуй: материалы и исследования. Екатеринбург, 2017. Т. 1. С. 128-129. 

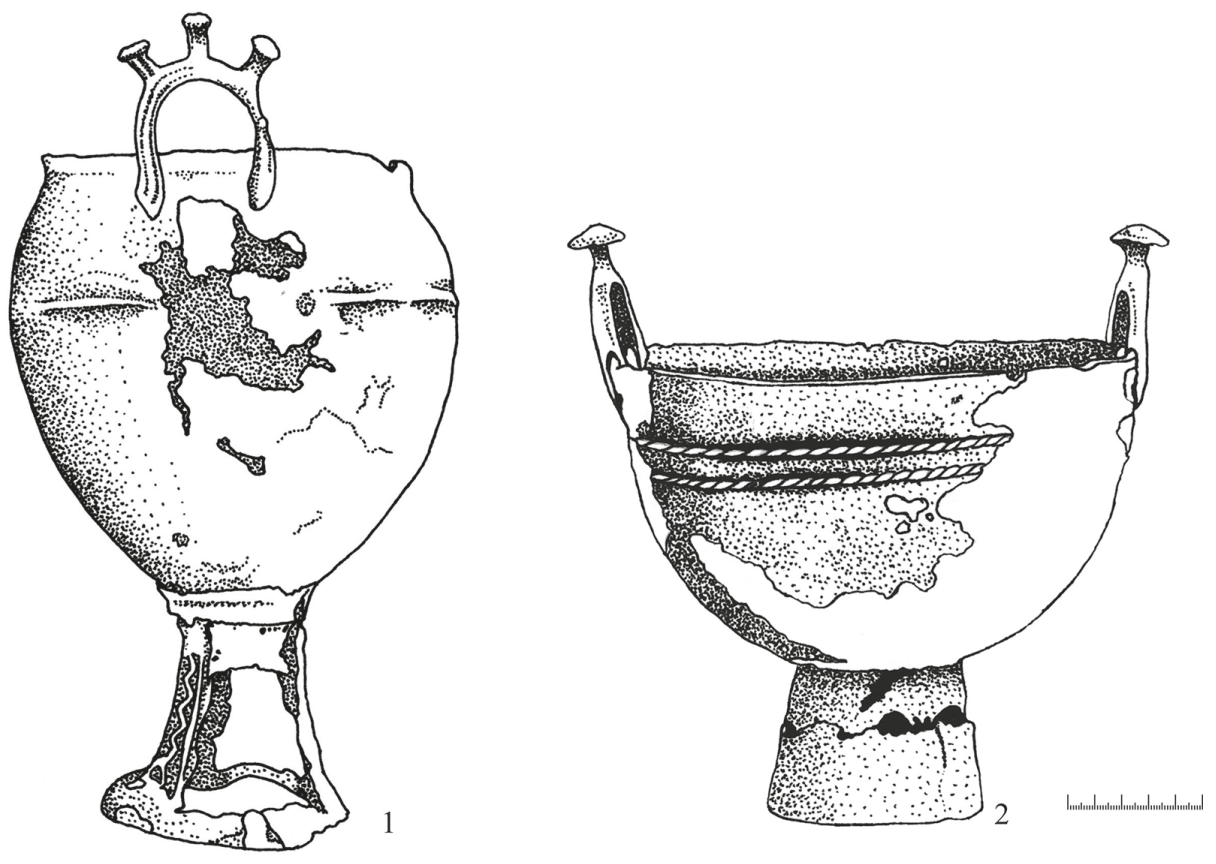

Puc. 2. Горнокнязевский клад. Котлы (бронза) (рис. А. В. Терещенко)

значительные в количественном отношении группы сплавов включают соответственно 23 и 45 предметов, среди которых есть стенки котлов, но кроме того и антропоморфные, зооморфные и орнитоморфные изображения, перстни, бляхи, пронизки и т.д. При раскопках Усть-Полуя нами были зафиксированы места плавок металла, в некоторых из которых, кроме обычных для таких мест сплесков металла, зафиксированы: фрагмент стенки котла и птицевидная отливка. Целых котлов в комплексе Усть-Полуя не обнаружено. Не исключается возможность, что - как и в случае с другими артефактами (например, рукоятками ножей, наконечниками стрел, накладками на лук и т.д.) - на сакральном центре использовался принцип оставления здесь «части вместо целого».

Иную картину дает нам Горнокнязевский клад. Два котла, обнаруженные в его составе, хотя и являются археологически целыми, во-первых, к моменту находки имели многочисленные следы починок, сделанных во время их использования; во-вторых - возможно, именно поэтому ко времени находки оба сохранились во фрагментированном виде ${ }^{21}$ (рис.2). Исследование котлов и починок, проведенное Ю.А.Подосеновой, показало разницу металла, из которого изготовлялось тулово и отдельные детали котлов 22 . Так, если для изготовления тулова применялась либо чистая медь, либо медь с примесью олова, то детали (починки) демонстрируют более сложные сплавы с такими основными элементами, как медь, олово, свинец, мышьяк. Ю.А. Подосенова отмечает, что изготовление котлов на поддонах из свинцовой бронзы, оловянной бронзы и чистой меди характерно для «разных техноло-

21 Федорова Н. В., Гусев Ан. В., Подосенова Ю. А. Горнокнязевский клад. С. 23; 38-39.

22 Там же. С. 60-61. 
гических традиций раннего железного века» ${ }^{23}$. Но где именно производились эти самые починки котлов - в месте изготовления или там, где они использовались, т.е. на севере Западной Сибири? Мы пока не можем с уверенностью ответить на этот вопрос, так как, судя по материалам Усть-Полуя, они могли чиниться и на месте использования, для чего могли применяться фрагменты котлов, зафиксированные в комплексе последнего. С другой стороны, вроде бы место изготовления нового поддона для котла № 1 в виде трех ножек, соединенных кольцом-основанием, на котором расположен орнамент в виде волнистых валиков, и напаянного поверх старого поддона, обычной для таких котлов формы, определяется на основании аналогий как восточные районы евразийских степей - возможно, Алтай или еще более восточные территории.

Бронзовые (медные) котлы на поддонах в конце I тыс. до н.э. - начале I тыс. н.э. имели самое широкое распространение в степной зоне Евразии, именно поэтому выяснение места производства каждого конкретного изделия затруднена. В свое время при публикации Горнокнязевского клада мы подробно касались этих вопросов, поэтому здесь отметим лишь некоторые моменты, важные для нашего сюжета о культурных контактах и трансляциях. Н. А. Боковенко отмечает, что, так как «котлы обычно сопровождали погребальные комплексы кочевой родо-племенной знати, они, по-видимому, представляли определенную вещественную ценность в обществе, о чем свидетельствуют и следы неоднократной починки некоторых из них» ${ }^{24}$ (курсив наш. - Авm.). Не будем приводить многочисленные высказывания различных авторов о местах возможного производства котлов на поддонах, для нас достаточно очертить этот широкий ареал, сузить который в нашем случае вряд ли удастся. Остановимся на нем и на столь же широкой дате, которую мы приняли для котлов из Горнокнязевского клада и которую можно распространить на усть-полуйские фрагменты котлов: от V-IV вв. до н.э. (или скорее III в. до н.э.) и до I-II вв. н.э. и ареала от Минусинской котловины (а с местом изготовления поддона для котла № 1 из Горнокнязевска - и до Монголии и Северного Китая) до неких неизвестных центров в сарматской (или гунно-сарматской) среде. Тем не менее совершенно очевидно, что это достаточно «привычный» импорт - в силу его массовости, особенно если учесть, что многочисленные фрагменты их шли в переплавку, - попавший на север Западной Сибири в результате каких-то налаженных торговых связей.

Странно, но ни сами котлы, ни их фрагменты, предназначенные для переплавки в одновременных комплексах памятников кулайской общности бассейна Средней Оби, в том числе в Сургутском Приобье, почему-то не приводятся в публикациях. И это несмотря на то что их авторы постоянно упоминают, что «цветная металлообработка в кулайское время достигла своего пика» ${ }^{25}$. Обычно отмечаются массовые находки тиглей и их фрагментов, сплесков металла и т.д. В отличие от Ю. П. Чемякина, Л. А. Чиндина задается вопросом о сырьевой базе кулайцев: «...какое сырье использовалось - рудное или готовые сплавы, кто являлся поставщиком

23 Федорова Н. В., Гусев Ан. В., Подосенова Ю. А. Горнокнязевский клад. С. 61

24 Боковенко Н.А. Типология бронзовых котлов сарматского времени в Восточной Европе // Советская археология. 1977. № 4. С. 234-235.

25 Чемякин Ю. П. Барсова Гора. Очерки археологии Сургутского Приобья. Древность. Сургут; Омск, 2008. С. 86. 
сырья?» ${ }^{26}$. Далее она пишет: «По-видимому, в большом количестве в переплавку шли бронзовые котлы. Об этом свидетельствуют многочисленные находки в кулайских памятниках и особенно обломки котлов в местах литейного производства» ${ }^{27}$.

«Привычность» и массовость импортных бронзовых котлов на поддонах в комплексах памятников времени «около рубежа эр» в Нижнем Приобье отразилась не только в самом наличии котлов и их фрагментов, но и - что может быть не менее важным - в создании керамических копий таких котлов. Они появляются в комплексах памятников, в том числе Усть-Полуя, во время конца I тыс. до н. э. начала I тыс. н.э. Форма таких сосудов удивительно похожа на котлы: чашевидное вместилище на высоком, слегка расширенном книзу поддоне ${ }^{28}$. Аналогичные сосуды приблизительно в это время зафиксированы и во многих других памятниках кулайского времени: Шеркалинского могильника, Степановского IV поселения, Саровского городища, Барсовой Горы и других памятников СургутскогоПриобья 29.

При исследованиях Усть-Полуя была зафиксирована связь керамических сосудов на поддонах (имитации бронзовых котлов, фрагменты которых шли в переплавку) и комплексов плавки металла. Так, например, в комплексе 3 рядом с местом плавки были обнаружены три сосуда на поддонах, которые стояли вертикально ${ }^{30}$.

Таким образом, подытоживая все наблюдения, касающиеся бытования или использования бронзовых котлов на поддонах в комплексах Усть-Полуя и Горнокнязевского клада, можно отметить следующее. Во-первых, импорт котлов с юга, из зоны евразийских степей был вполне налаженным, а приток их - постоянным настолько, что фрагменты их служили сырьем для бронзолитейного производства. Во-вторых, эти котлы - как и в степях - служили показателями престижа владельцев/пользователей, что на Усть-Полуе и ряде других памятников вызвало создание их керамических копий. Последнее показывает не просто завоз определенного вида товара в результате «обменных связей», но именно трансляцию элементов чуждой культуры в местную среду.

\section{Бронзовые зеркала и бляхи}

В комплексе Усть-Полуя целых изделий нет, во фрагментах обнаружено 28 изделий, выполненных из различных сплавов, преимущественно из меди с оловом, меди с оловом и свинцом ${ }^{31}$. Так же как в случае с котлами, из сплавов того же состава отливались вещи местных типов: антропоморфные и зооморфные изображения, бронзовая рукоятка железного ножа, поясные накладки и т.д. Фрагменты привозных изделий использовались чаще всего для изготовления различных подвесок: трапециевидных, подпрямоугольных, круглых (21 предмет). Эти подвески

26 Чиндина Л. А. Древняя история Среднего Приобья в эпоху железа. С. 135.

27 Там же. С. 137.

28 Мошинская В.И. Материальная культура и хозяйство Усть-Полуя // Материалы и исследования по археологии СССР. М., 1953. № 35. С. 110, табл. IV, рис. 10.

29 Чиндина Л. А. Древняя история Среднего Приобья в эпоху железа. Рис. 23, 25, 42, 45; Чемякин Ю. П. Барсова Гора. Очерки археологии Сургутского Приобья. Древность. Рис. 73, 74.

30 Гусев Ан.В., Федорова Н.В. Морфология древнего сакрально-производственного центра Усть-Полуй. С. 37.

31 Подосенова Ю.А. Результаты рентгено-флуоресцентного анализа изделий из цветного металла из святилища Усть-Полуй. С. 210-211; 214-227; 230. 
вырезались из цельного изделия. Впоследствии на большинство из них наносились местные рисунки-гравировки ${ }^{32}$.

В комплексе Горнокнязевского клада обнаружено 17 зеркал и круглых блях. Почти все они археологически целые, некоторые собраны из фрагментов, восемь с рукоятками, остальные - без них (рис. 3: 1-2). Очерк с атрибуцией зеркал и связанные с этим проблемы опубликованы ${ }^{33}$. В основном имелись в виду сарматские центры. Особняком и по составу металла, и по аналогиям, стоит самое крупное зеркало с рукояткой-умбоном, которое относят либо к китайским изделиям, либо к изделиям, выполненным по китайским образцам где-то в Сибири или Центральной Азии (рис.3: 3). Сходна с опубликованной нами точка зрения Б. Незабитовской-Вишневской, которая, отмечая распространенность зеркал с длинной треугольной или короткой округлой ручкой в Восточной Европе и Азии, полагает, что самыми близкими горнокнязевским зеркалам были зеркала из Центральной Азии и саргатской культуры ${ }^{34}$.

Все исследователи, изучавшие схему бытования бронзовых зеркал в культурах северо-западной Сибири, отмечают, что они не использовались по назначению в западносибирских комплексах это очевидно, о чем говорит, во-первых, наличие на зеркалах (причем и с лицевой, и с оборотной стороны) местных рисунков-гравировок; во-вторых, явное применение зеркал «вверх ногами», т. е. подвешивание за рукоятку. Надо отметить, что, в отличие от усть-полуйских зеркал и блях, которые употреблялись для изготовления подвесок, горнокнязевские использовались в цельном виде.

Так же как и в случае с созданием копий бронзовых котлов из керамики, копировались бляхи и подвески, причем эти копии создавались как из камня, так и из рога оленя ${ }^{35}$. На круглых бляхах из камня и рога выполнялся такой же концентрический орнамент, как на бронзовых. Реже такие копии изготавливались из бронзы способом отливки в двучастную одностороннюю форму. Подвески, выполненные из рога, изготавливались очень тщательно, многие из них орнаментированы, хотя орнамент и не повторяет тот, который употреблялся на зеркалах. Как применялись подвески, по материалам Усть-Полуя сказать невозможно, но аналогичные бронзовые подвески, вырезанные из зеркал или блях, в погребении 1 (мальчик 6 лет) Барсовского I могильника использовались как накосники ${ }^{36}$.

С точки зрения темы о контактах важно выяснить количество и регион распространения круглых импортных зеркал и блях, а также вырезанных из них подвесок. Как уже упоминалось, в комплексе Усть-Полуя обнаружена 21 подвеска, вырезан-

32 Федорова Н. В. Антропоморфные образы Усть-Полуя: технология, иконография, композиция сцен // Уральский исторический вестник. 2014. № 2. Рис. 1: 1, 2, 4-6, 8-10, 12, 13.

33 Федорова Н. В., Гусев Ан.В., Подосенова Ю. А. Горнокнязевский клад. С. 41-44.

${ }^{34}$ Незабитовска-Вишневска Б. Зеркала из Горнокнязевского клада (Ямало-Ненецкий автономный округ, Россия) - попытка интерпретации // I Международная конференция «Археология Арктики». Екатеринбург, 2017. С. 102.

35 Карманов В. Н. Характеристика каменного инвентаря святилища Усть-Полуй (по материалам раскопок 2006-2015 гг.) // Археология Арктики. Вып.4. «Усть-Полуй: материалы и исследования». Екатеринбург, 2017. Том 1. С. 190-191; Гусев Ан. В. Коллекция изделий из кости и рога по материалам раскопок 1993-1995, 2006-2015 гг. // Археология Арктики. Вып.4. «Усть-Полуй: материалы и исследования». Екатеринбург, 2017. Т. 2. С. 181.

36 Чемякин Ю.П. Барсова Гора. Очерки археологии Сургутского Приобья. Древность. С. 82. Рис. 80-81. 

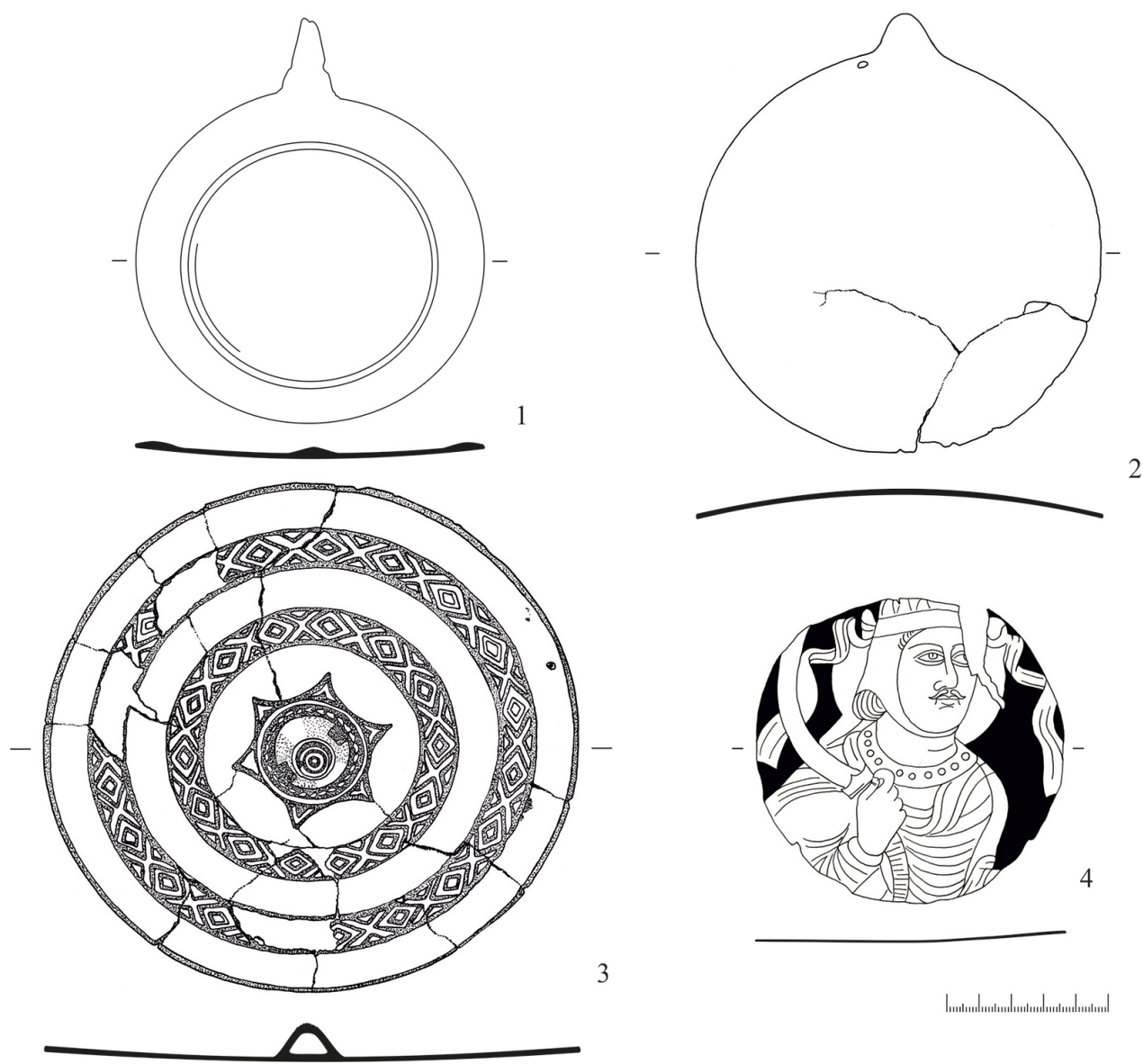

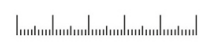

Рuc. 3. Горнокнязевский клад:

1-2 - зеркала с ручками-выступами; 3 - зеркало с выступом-умбоном в центре; $4-$ медальон, вырезанный из блюда или чаши $(1-3-$ бронза; $4-$ серебро, позолота) (рис. А.В. Терещенко)

ная из зеркал или блях. В Горнокнязевском комплексе обнаружено 17 зеркал или блях. В устье Казыма (или бассейнах Сев. Сосьвы) в 1930-е гг. обнаружено 29 зеркал и блях ${ }^{37}$. В 2014 г. (несанкционированные раскопки) в устье Казыма найдено в двух кладах 107 зеркал ${ }^{38}$. По одному зеркалу обнаружено в комплексах у поселка Хурумпауль и поселка Хорьер ${ }^{39}$. На Барсовой Горе (артефакты со святилища Барсов Городок $1 / 9$, могильники кулайского времени, включая находки из несанкционирован-

37 Приступа О.И., Стародумов Д. О., Яковлев Я.А. Окно в бесконечность. Бронзовые зеркала раннего железного века. Ханты-Мансийск, 2002.

38 Бауло А.В. «Старик священного города»: иконография божества в облике медведя по археологическим и этнографическим данным // Археология, этнография и антропология Евразии. 2016. № 2. С. 121; Шульга П. И., Оборин Ю. В. Бронзовые диски из Казымского клада и «восточные» зеркала-погремушки // Ханты-Мансийский автономный округ в зеркале прошлого. Томск; ХантыМансийск, 2017. Вып. 15. С. 84.

39 Бауло А. В. Древняя бронза из этнографических комплексов и случайных сборов. С. 232, 235. 
ных раскопок) - 35 зеркал и блях и 2 подвески ${ }^{40}$. В Шеркалинском могильнике 1 подвеска ${ }^{41}$. В комплексе Истяцкого клада - 29 зеркал или блях. Таким образом, всего обнаружено 220 целых зеркал и блях, 30 подвесок, вырезанных из них. Это очень большое количество, сразу исключающее постановку вопроса о «случайных контактах с югом» или «многоступенчатом обмене». Оно может быть свидетельством только, во-первых, устоявшихся торговых связей, включающих понимание потребностей заказчика, во-вторых, наличия известных обеим сторонам мест, где осуществлялась торговля/производство.

Регион, который очерчивают эти находки: на севере - Северный полярный круг (Усть-Полуй и Горнокнязевский клад), далее к юго-западу - устье р. Казым, памятники по течению Сев. Сосьвы, к востоку - Барсова Гора, на самом юге район г. Тобольска, Истяцкий клад. Надо отметить, что изучен этот регион неравномерно, чтобы не сказать недостаточно, а три комплекса изделий - наиболее массовые - вообще происходят из случайных находок и «несанкционированных» раскопок. За Уралом, в Печорском бассейне, на памятниках гляденовского времени зеркала и подвески из них встречаются, но гораздо реже ${ }^{42}$.

К востоку и юго-востоку от очерченного ареала в той же приблизительно культурной среде бронзовые зеркала и бляхи известны в двух комплексах - Айдашинской пещере и Ишимской коллекции. Зеркала Айдашинской пещеры авторы относят к тагарскому типу ${ }^{43}$, т. е. к другому культурному кругу, чем найденные в вышеописанном ареале. Ишимская коллекция включает 38 зеркал и блях ${ }^{44}$, среди которых как минимум 6 - китайские. Сама коллекция представляет собой очевидный клад, причем довольно разновременный. Зеркал и блях, которые могут быть сопоставлены с бляхами и зеркалами очерченного региона, в ней всего $4^{45}$. В районах Томско-Нарымского Приобья, судя по публикациям, ни «сарматских» зеркал, ни блях с проточенным циркульным орнаментом нет.

Таким образом, районы концентрации бронзовых (саргатских или сарматских, что в данном случае не имеет значения) зеркал четко указывает на существование отлаженного меридионального пути с севера на юг (или с юга на север) вдоль бассейна Нижней- Средней Оби и вдоль Иртыша.

\section{Имитации импортных вещей}

Кроме импортов из «цивилизованных» стран и «кочевых» степных регионов Евразии, в комплексах севера Западной Сибири присутствуют еще и такие странные артефакты, которые иначе как попыткой копирования или даже переработки «импортных» сюжетов не объяснить.

40 Чемякин Ю.П. Барсова Гора. Очерки археологии Сургутского Приобья. Древность. С. 193; Ширин Ю.В., Яковлев Я.А. Мартиролог югорской археологии // Ханты-мансийский автономный округ в зеркале прошлого. Томск; Ханты-Мансийск, 2010. Вып. 8. С. 37-57.

41 Чиндина Л. А. Древняя история Среднего Приобья в эпоху железа. С. 228.

42 См. напр.: Археология Республики Коми. М., 1997. С. 393-394.

43 Молодин В.И., Бобров В.В., Равнушкин В.Н. Айдашинская пещера. Новосибирск, 1980. C. 54-55.

44 Ермолаев А. Ишимская коллекция // Описание коллекций Красноярского музея. Отдел археологический. Красноярск, 1914. Вып. 1. С. 1.

45 Ермолаев А. Ишимская коллекция. Табл. III, IV. 


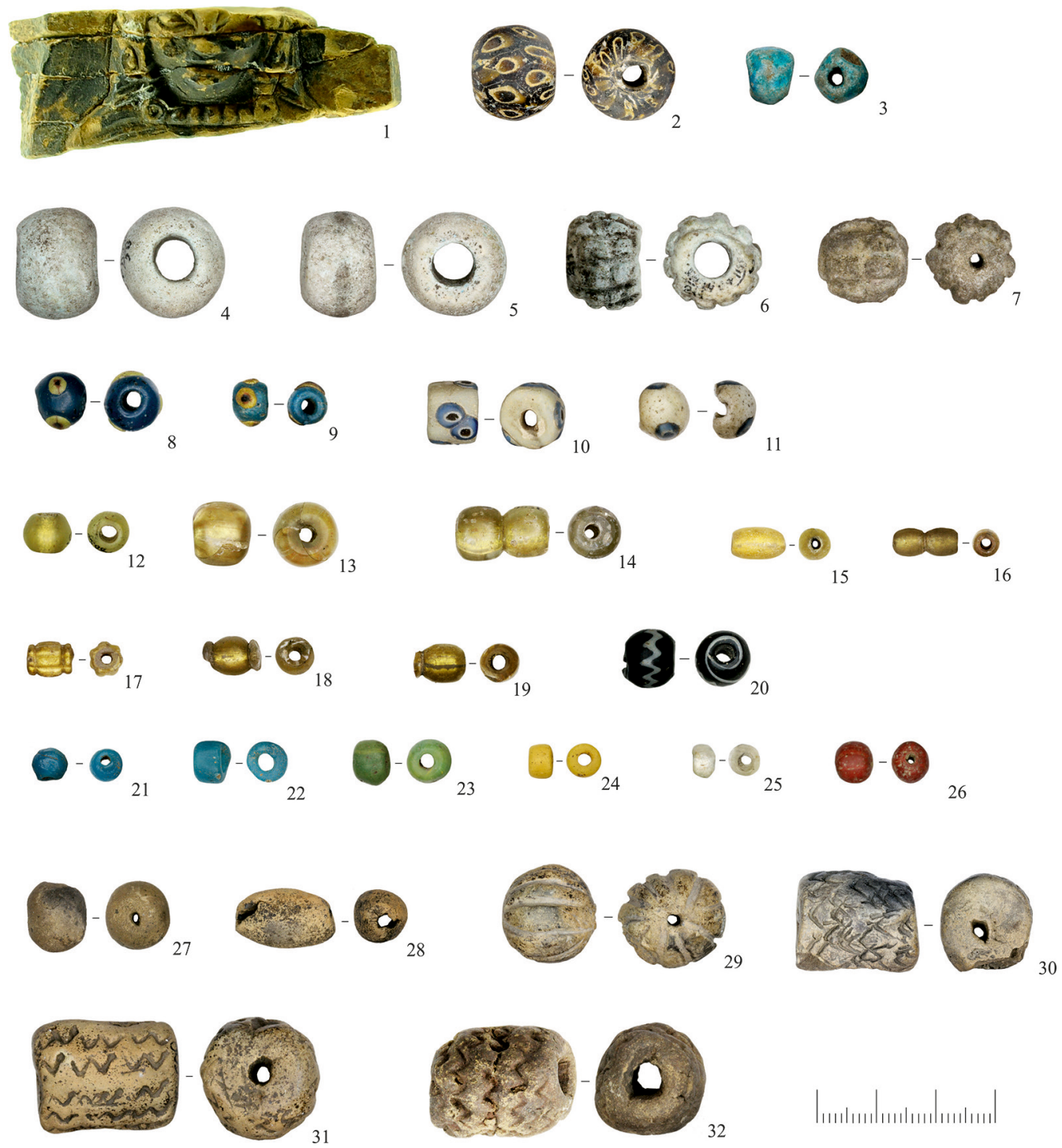

Рuc. 4. Усть-Полуй. Модель с изображением лица; бусы:

1 - сланец; 4-7 - фаянс; 2-3, 8-26 - стекло; 27-32 - керамика (фото Ан. В. Гусева)

В комплексе Усть-Полуя среди прочих зооморфных изображений, в основном передающих местную фауну, зафиксировано два изображения голов или голов и верхней части тулова грифонов ${ }^{46}$. В одном случае это типичный усть-полуйский скребок-лопаточка, выполненный из рога северного оленя, но на рукоятке его вырезаны две головы грифонов, сопоставленные шеями, с мощными открытыми птичьими клювами и львиными ушами. Во втором - бронзовая бляшка с изобра-

46 Федорова Н.В. Зооморфный код Усть-Полуя // Археология Арктики. Вып. 4. «Усть-Полуй: материалы и исследования». Екатеринбург, 2017. Т. 2. С. 231, рис. 13, 6, 7. 
жением двух сопоставленных полуфигур львиноголовых грифонов с трехпалыми лапами и «браслетами» на них.

В комплексе Усть-Полуя есть еще барельеф из глинистого сланца - модель для отливки с изображением лица «парфянского» типа: прическа с кудрями до плеч, полный подбородок, гривна на шее ${ }^{47}$ (рис. 4: 1). Бронзовая литая бляшка, имитирующая серебряные медальоны с портретом парфянского царя, была обнаружена в находках со святилища Барсов Городок 1/9, правда, к сожалению, в ходе несанкционированных раскопок ${ }^{48}$. Ю.В.Ширин, приводя в своей статье изображение бронзовой бляхи с р. Нюролька, пишет о портретных барельефах «парфянского» типа. Отмечая, во-первых, что «таких блях, различных по проработке деталей, известно уже более десятка», во-вторых, что они «сопутствуют в ареале КНК (кулайской общности. - Авт.) зеркалам сарматского типа» ${ }^{49}$. На самом деле подобных блях, действительно, к настоящему времени известно много, но, к сожалению, не все из них опубликованы, в том числе и из уже упомянутого клада или двух кладов с Казыма.

Выше уже упоминалась находка на городище Кижирово обломка негативной глиняной литейной формы, воспроизводящей рельефное изображение идущих друг за другом воинов, выполненных в переднеазиатской манере» ${ }^{50}$. Очевидным представляется использование этой формы именно для производства отливок на памятнике кулайской культуры (общности) по импортным образцам.

Таким образом, анализ изготовления подражаний «импортным» сюжетам или даже переосмыслений/переработки их в местной среде, при всей сложности отдельных атрибуций, в общем и целом указывает то же самое южное направление: сарматы или саргатская культура, Парфия или Кушаны. Восточный «след», который подсказывают бронзовые/медные котлы на поддонах и редкие китайские (или псевдокитайские) зеркала, вполне мог быть реализован через то же южное направление.

\section{Серебряные импортные изделия рубежа эр на севере Западной Сибири}

Серебряных импортных изделий в комплексах северных памятников во время «около рубежа эр» совсем немного. Собственно, нам известны следующие: вырезанный из тонкостенного блюда или чаши медальон с погрудным изображением мужчины из Горнокнязевского клада ${ }^{51}$ (см. рис.3: 4); две серебряные обкладки, возможно, деревянных сосудов $^{52}$; медальон с изображением парфянского царя ${ }^{53}$; очевидно, вырезанный из блюда или чаши медальон с изображением богини-охот-

\footnotetext{
47 См. аналогии: Федорова Н. В., Гусев Ан.В., Подосенова Ю. А. Горнокнязевский клад. С. $35,45$.

48 Ширин Ю. В., Яковлев Я. А. Мартиролог югорской археологии. С. 53. Ил. 72.

49 Ширин Ю.В. Импорт рубежа эр в комплексах Западной Сибири и его значение для хронологии. С. 45 .

50 Косарев М.Ф. Древние культуры Томско-Нарымского Приобья. С. 63.

51 Федорова Н. В., Гусев Ан. В., Подосенова Ю. А. Горнокнязевский клад. С. 20. Рис. 19.

52 Там же. С. 20-21. Рис. 20-21.

53 Зеймаль Е. В. Медальон с изображением парфянского царя // Сокровища Приобья. СПб.,
} 1996. C. $46-47$. 
ницы из комплекса Истяцкого клада ${ }^{54}$; две обкладки фаларов (?) из находок на городище Няксимволь ${ }^{55}$. Вопросы происхождения этих артефактов сложны и заняли бы здесь много места; важно то, что все они атрибутированы как парфянские, кушанские или обобщенно среднеазиатские, что, в конечном итоге, указывает на то же самое южное направление.

\section{Бусы}

Изучение импортных стеклянных бус, обнаруженных в археологических комплексах Среднего и Нижнего Приобья, до сих пор если и производилось, то явно недостаточно. Причин этому несколько: во-первых, их количество не столь велико, как, например, в памятниках более южных, степных районов, во-вторых, бусы в целом малопригодны для решения основного вопроса - датировки объекта, стоящего перед специалистами. Из этого следует в-третьих: если бусы или упоминание о них и попадают в публикации, то, как правило, без соответствующих иллюстраций и атрибуций. Хотя, как всякий «далекий» импорт, они дают много дополнительные основания для выяснения направлений культурных и торговых контактов.

Усть-полуйская коллекция бус представительна и разнообразна по своему составу: всего 230 экземпляров, в основном происходящих из коллекции «новых» раскопок. Поскольку они практически не публиковались, остановимся на них несколько подробнее. При описании хотелось бы подчеркнуть, что коллекция бус Усть-Полуя позволяет зафиксировать резко возросший приток импортов, начавшийся незадолго до рубежа эр, как и в случае с описанными выше металлическими изделиями - зеркалами и котлами.

К наиболее ранним типам бус (имеющим уверенную датировку до рубежа эр) могут быть отнесены два изделия, полученные с разных участков памятника, выполненные из глухого темного стекла (рис. 4: 2). Изделия имеют бочковидную форму и диаметр около 1,5 cм. В составе ядра присутствует керамическая составляющая, а желто-лиловые овальные глазки проникают глубоко внутрь. Отдаленное сходство этих бусин наблюдается с типом 90 по типологии Е. А. Алексеевой, подобные изделия она датировала приблизительно II в. до н. э. ${ }^{56}$. Возможно, еще одна бусина из бирюзового стекла может соотноситься с типом $35^{57}$ (рис. 4: 3). Подобные изделия зафиксированы в разновременных захоронениях из Северного Причерноморья.

Бусы из египетского фаянса представлены 20 экз., целых и фрагментированных. Такие бусы на рубеже эр и в первые века нашей эры завозили в Северное Причерноморье из Египта, оттуда они распространялись по степям Восточной Европы и Азии. Наиболее многочисленны - орнаментированные продольными желобками, образующими волнистые дольки на поверхности. Бусины имеют весьма крупные размеры - до 1,5-2,0 см в диаметре. Пять бусин из Усть-полуйской коллекции принадлежат типу $3 \Gamma^{58}$. Это крупные бусины диаметром 1,6-1,9 см с ши-

54 Зеймаль Е. В. Медальон с изображением богини-охотницы // Там же. С. 48-49.

55 Няксимволь. Томск; Ханты-Мансийск, 2014. С. 45-48.

56 Алексеева Е. М. Античные бусы Северного Причерноморья // Свод археологических источников. М., 1975. Вып. Г1-12, т. І. С. 69, табл. 14: 95.

57 Там же. С. 31, табл. 5: 3.

58 Там же. С. 31, табл. 5: 4, 7-8. 
роким каналом отверстия (рис. 4: 4-5). Глазурь с их поверхности полностью утрачена. Е.А.Алексеева датировала их преимущественно I-II в. н. э., отмечая весьма длительный период их существования. Четыре бусины идентичны изделиям типа 19 - округлой и бочковидной форм с бугристой поверхностью, образованной продольными и поперечными желобками ${ }^{59}$ (рис. 4: 6-7). Производство этих бус велось c III в. до н. э., однако большинство памятников, где они были обнаружены, относилось к І в. н.э.

Многоцветные стеклянные бусы с глазчатым орнаментом представлены 32 экз. Наиболее многочисленны бусы округлой и бочковидной форм, состоящие из основы синего цвета и украшенные слоистыми глазками из темно-синего, красного и желтого стекла - 27 экз. Глазки на них почти всегда выпуклые, число их составляет в среднем от двух до трех (рис. 4: 8-9). Диаметр изделий в среднем составлял 0,7-1,0 см. Визуальное сходство этой части бус имеется с типом 33Ч 60 . Датировка таких глазчатых бус достаточно широка (IV в. до н. э. - II в. н.э.), но наибольшее их распространение пришлось именно на время около рубежа эр.

Глазчатые бусины из белого стекла представлены четырьмя изделиями. Два из них имеют короткую цилиндрическую форму, декорированы черно-бело-голубыми (сиреневыми) глазками (рис. 4: 10). Диаметр бусин 1,0-1,2 см. Еще две округлые бусины имеют слоистые глазки из синего и белого цветов (рис. 4: 11). Наиболее близки этим изделиям бусины тuna $26 Д^{61}$, характерные для комплексов с III в. до н. э. по начало I в. н. э.

Стеклянные бусы с металлической (золотой) прокладкой внутри - 39 экз. Среди них можно выделить несколько типов: 3 бусины с гладкими краями отверстий и ровной поверхностью, диаметром 0,4-0,6 см (рис. 4: 12). Наиболее хронологически ранние такие изделия (тип 1А) известны с III в. до н.э., однако с рубежа эр их производство заметно сокращается, хотя и бытовали они по III-IV вв. н.э. ${ }^{62}$. 27 бусин - шаровидные изделия диаметром около 1,0 cM, представлены и бусины меньшего диаметра ${ }^{63}$ (рис. 4: 13-14). Этот вариант бусин наиболее массово встречался в Северном Причерноморье начиная с I в. н.э. и вплоть до IV в. Три удлиненные бочковидные бусины (тип 2Б) известные только по материалам памятников новой эры ${ }^{64}$ (рис.4: 15-16). Две бусины удлиненной цилиндрической формы (тип 11; рис. 4: 17) с ребристой поверхностью и ребристыми же перетяжками по краям, аналогичные опубликованным Е.А. Алексеевой ${ }^{65}$. Соотносятся с периодом I в. до н.э. - I в. н .э. Три экз. бочковидных бусин с валиками по краям (тип 22), оставшиеся, вероятно, от работы формовочными щипцами (рис.4: 18-19). Такие бусы характерны для I-III вв. н. $э^{66}$. Таким образом, период их бытования достаточно широк: III в. до н. э. - III-IV вв. н. э.

Единственная в коллекции полихромная стеклянная бусина представлена среди находок из раскопа В.С. Адрианова. Изделие имеет округлую форму (диаметр

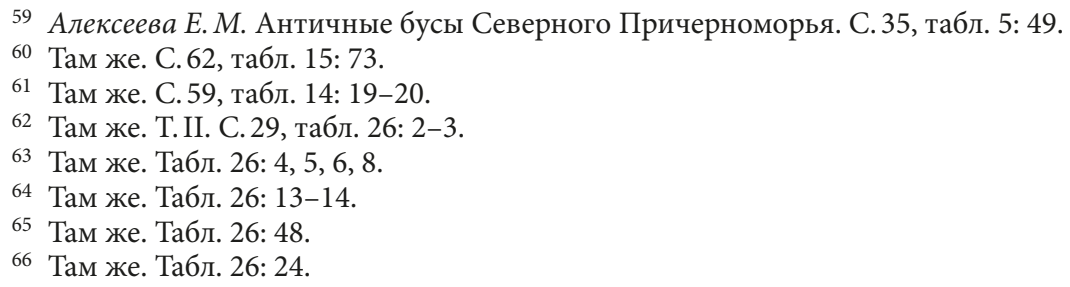


1,2 см) глухой черный цвет и волнисто-поперечный орнамент (рис. 4: 20). Эта бусина схожа с бусами, датированными первыми веками нашей эры ${ }^{67}$.

Одноцвветные бусы из синего и бирюзового (55 ед.), зеленого (22 ед.), прозрачного (21 ед.), желтого (19 ед.), красного (17 ед.) и темного (4) стекла составляют самую многочисленную часть в коллекции (138 ед.). Большинство из них - мелкие, диаметром 0,5-0,7 см, округлой и бочковидной форм (рис. 4: 21-26). Данная группа атрибутируется сложно без проведения технологического и химического анализов ${ }^{68}$, но в общем соотносится с самым широким спектром производственных центров от Северного Причерноморья до Центральной Азии.

Так же как в случае с подвесками и котлами, имеющими в комплексе УстьПолуя местные копии-подражания, зафиксированы и бусы, представляющие собой аналоги стеклянных и фаянсовых изделий, выполненных местными мастерами из глины. Всего в коллекции насчитывается 59 целых и фрагментированных бусин, из них округлых гладких -45 , удлиненно-бочковидной формы -3 , орнаментированных продольными желобками -3 , циллиндрической формы с поперечным орнаментом в виде зигзагов - 8 (рис. 4: 27-32).

Ближайшим памятником, где известно сопоставимое с Усть-Полуем количество бус, является погребение мальчика из Барсовского III могильника - всего более 250 ед. ${ }^{69}$ Многочисленная серия бус обнаружена в захоронениях могильника Барсовский VII, данные по которым представлены лишь в общем виде $\mathrm{e}^{70}$. Из 20 захоронений на могильнике Сырой Аган 13, лишь трем умершим было положено по одной стеклянной бусине с золотой фольгой ${ }^{71}$. В составе клада на городище Барсов городок I/20 оказалась лишь одна глазчатая бусина, да и то, по мнению В. А.Борзунова, более ранняя, чем остальной набор вещей ${ }^{72}$. Прямых аналогий в Устьполуйской коллекции она не имеет. Не менее семи бусин, по своему облику схожих с усть-полуйскими, были обнаружены на месте предполагаемого захоронения в бассейне р. Агана у п. Радужный ${ }^{73}$. Л. А. Чиндина для трех захоронений Шеркалинского могильника отметила наличие 52 бус из них: $34-$ стеклянных и $18-$ керамических ${ }^{74}$. Стеклянные бусы, судя по описанию, аналогичны усть-полуйским. Соответствует и цветовой набор единственной глазчатой бусины. Т.Н.Троицкая к моменту выхода публикации по кулайской культуре в Новосибирском Приобье отмечала наличие 125 бусин в 10 захоронениях для III-II вв. до н. э. и уже 340 бусин на 10 могил в I в. до н.э. - I в. н. ${ }^{75}$. Большинство из них представляли стеклянные и позолоченные изделия, служившие украшениями костюма и подвесками. Глиня-

67 Алексеева Е. М. Античные бусы Северного Причерноморья. С. 51, табл. 31: 37.

68 Щапова Ю. Л. Древнее стекло: Морфология, технология, химический состав. М., 1989.

69 Чемякин Ю.П. Барсова Гора. Очерки археологии Сургутского Приобья. Древность. С. 82, рис. 81.

70 Там же. Рис. 83, 86: 1-16.

71 Баранов М.Ю. Могильник кулайской культуры Сырой Аган 13 в Сургутском Приобье // Барсова Гора: древности таёжного Приобья. Екатеринбург; Сургут, 2008. Рис. 16: 4, 9, 16.

72 Борзунов В. А. Городища с бастионно-башенными фортификациями раннего железного века в лесном Зауралье. С. 103.

73 Перевалова Е. В., Карачаров К.Г. Река Аган и ее обитатели. Екатеринбург; Нижневартовск, 2006. C. 70 .

74 Чиндина Л. А. Древняя история Среднего Приобья в эпоху железа. С. 53.

75 Троицкая Т.Н. Кулайская культура в Новосибирском Приобье / отв. ред. В.И. Молодин. Новосибирск, 1979. С. 13, 23. 
ные подражания нигде не упоминаются. По мере продвижения к югу в комплексах саргатской культуры количество бус увеличивается, меняется и их видовой состав. Связи между саргатскими племенами и таежным населением не вызывают сомнений.

Источники же поступления бус к тому же саргатскому населению могли быть самые разные. Н. П. Довгалюк, с одной стороны, отмечала относительную стабильность в поставке бус из ремесленных центров с конца III в. до н.э. по IV в. н.э., с другой - сложность реконструкции путей поступления товаров, когда даже для условно близких районов Прииртышья и Притоболья наблюдалась существенная разница $^{76}$. В целом же бусы к населению саргатской культуры поступали из нескольких регионов: Египта, прибрежной Сирии, Китая, основным же поставщиком служили мастерские внутренних районов Передней Азии. Большое значение имело то, что набор поступавших в лесостепь и, вероятно, далее на север товаров формировался не в производственных мастерских, а на узловых торговых пунктах.

На Камских костищах гляденовского времени отмечено наличие большого числа изделий из египетского фаянса, значительная доля изделий с золотой фольгой, глазчатых синих бус ${ }^{77}$. Известны на Гляденово и крупные цилиндрические полихромные бусины с поперечным орнаментом. Большое количество аналогичных бус известно из погребений Ныргындинского I могильника, среди которых значительная доля принадлежит изделиям с золотой фольгой внутри и одноцветным гладким ${ }^{78}$. В Прикамье, таким образом, можно видеть более широкий ассортимент изделий, нежели тот, который встречен на Усть-Полуе. Все это позволяет предполагать схожую ситуацию, когда товарообменные связи с тем или иным населением шли через отдельные торговые фактории, формирующие ассортимент.

\section{Выводы}

Отмеченная массовость импортных изделий на севере Западной Сибири, в том числе в районах, прилежащих к Северному полярному кругу, исключает постановку вопроса об опосредованных обменных связях. Очевидно, что торговые связи были вполне налаженными, располагаясь по линии «Север - Юг», вдоль Оби - Иртыша, проходя из таежных и лесотундровых областей Западной Сибири в степные (лесостепные) ее регионы, а, возможно, и дальше - в Среднюю Азию и Причерноморье. На западе - в Приуралье и на востоке - в Томском Приобье подобные вещи (кроме бус), если и зафиксированы, то только единично. Такая массовость и однородность импортов может являться свидетельством личного участия северного населения в этой торговле - иначе трудно представить себе такую осведомленность «продавцов» в северных потребностях.

Бытование импортов в местной северной среде, которое отразилось в том числе и в создании копий и подражаний, недвусмысленно свидетельствует о том, что

76 Довгалюк Н.П. Происхождение стеклянных бус из могильников саргатской культуры // Вестник Омского университета. 1997. Вып. 1. С. 52.

77 Новокрещенных Н. Н. Гляденовское костище Пермской губернии на р. Каме Пермского уезда // Труды Пермской губернской ученой архивной комиссии. Пермь, 1914. Табл. XI: 87-95, 14-24.

78 Голдина Р.Д., Красноперов А.А. Ныргындинский I могильник II-III вв. на Средней Каме. Ижевск, 2012. 
эти изделия воспринимались не только как престижные, хотя и инокультурные, но осмысливались по-своему, находили место в системе культурных ценностей Севера, становились фактором местной социальной и духовной атрибутики. Таким образом, происходила реальная культурная трансляция новых элементов в среду Севера, к тому времени готовую эти трансляции воспринимать.

Дальнейшая судьба зафиксированных в виде импортов и подражаний им групп артефактов лишь показывает глубину и прочность внедрения этих культурных трансляций в северную среду. В эпоху Средневековья, вернее к концу I тыс. н.э., когда были восстановлены нарушенные в начале его торговые пути, в Западной Сибири, т. е. практически в том же регионе, опять появляется массовый импорт, в составе которого вновь металлическая посуда - медные котлы - и круглые бляхи, вызвавшие серию местных подражаний. Со времени появления здесь зеркал и блях «сарматского» типа они стали важным элементом статусного костюма, вернее, его украшений. К сожалению, у нас есть только один факт, подтверждающий этот вывод, - расположение круглой бляхи с циркульным орнаментом на груди погребенного в могильнике Барсов Городок. Вызывает сомнение массовый завоз зеркал для «нужд культа», тем более что все они имеют отверстие для подвешивания. Наличие же на зеркалах и бляхах местных рисунков-гравировок также не означает их культовый характер - его пока еще никто не доказал.

Авторы отдают себе отчет в необъятности заявленной темы и не претендуют на раскрытие всех ее аспектов в рамках одной статьи, за пределами которой остались еще многие вопросы. Но сама постановка этой проблемы нам кажется важной и своевременной.

\section{References}

Alekseeva E. M. Antichnye busy Severnogo Prichernomor'ia. Svod arkheologicheskikh istochnikov. Moscow, Nauka, 1975, iss. G1-12, vol. I, 118 p. (In Russian)

Alekseeva E. M. Antichnye busy Severnogo Prichernomor'ia. Svod arkheologicheskikh istochnikov. Moscow, Nauka, 1978, iss. G1-12, vol.II, 120 p. (In Russian)

Baranov M. Iu. Mogil'nik kulaiskoi kul'tury Syroi Agan 13 v Surgutskom Priob'e. Barsova Gora: drevnosti taezhnogo Priob'ia. Ekaterinburg, Surgut, Ural'skoe izdatel'stvo, 2008, pp. 219-238. (In Russian)

Baulo A.V. Drevniaia bronza iz etnograficheskikh kompleksov i sluchainykh sborov. Novosibirsk, Izd-vo IAET SO RAN, 2011.259 p. (In Russian)

Baulo A. V. "Starik sviashchennogo goroda": ikonografiia bozhestva v oblike medvedia po arkheologicheskim i etnograficheskim dannym. Arkheologiia, etnografiia i antropologiia Evrazii, 2016, no. 2, pp.118-128. (In Russian)

Bokovenko N. A. Tipologiia bronzovykh kotlov sarmatskogo vremeni v Vostochnoi Evrope. Sovetskaia arkheologiia, 1977, no. 4, pp. 228-235. (In Russian)

Borzunov V.A. Gorodishcha s bastionno-bashennymi fortifikatsiiami rannego zheleznogo veka v lesnom Zaural'e. Rossiiskaia arkheologiia, 2002, no. 3, pp.79-97. (In Russian)

Goldina R. D., Krasnoperov A. A. Nyrgyndinskii I mogil'nik II-III vv. na Srednei Kame. Izhevsk, Izd-vo Udm. un-ta, 2012. 364 p. (Materialy i issledovaniia Kamsko-Viatskoi arkheologicheskoi ekspeditsii. T.22). (In Russian)

Gusev An. V. Kollektsiia izdelii iz kosti i roga po materialam raskopok 1993-1995, 2006-2015 gg. Arkheologiia Arktiki, iss. 4. "Ust'-Polui: materialy i issledovaniia". Ekaterinburg, Izd-vo Delovaia pressa, 2017, vol. 2, pp.4-103. (In Russian)

Gusev An. V., Fedorova N. V. Drevnee sviatilishche Ust'-Polui: konstruktsii, deistviia, artefakty. Itogi issledovanii planigrafii i stratigrafii pamiatnika: 1935-2012 gg. Salekhard: GU IaNAO Severnoe izdatel'stvo, 2012. 60 p. (In Russian) 
Gusev An.V., Fedorova N.V. Morfologiia drevnego sakral'no-proizvodstvennogo tsentra Ust'-Polui. Arkheologiia Arktiki, iss. 4. “Ust'-Polui: materialy i issledovaniia”. Ekaterinburg, Izd-vo Delovaia pressa, 2017, vol. 1, pp. 19-63. (In Russian)

Dovgaliuk N.P. Proiskhozhdenie stekliannykh bus iz mogil'nikov sargatskoi kul'tury. Vestnik Omskogo universiteta, 1997, iss. 1, pp.51-55. (In Russian)

Zeimal' E. V. Medal'on s izobrazheniem parfianskogo tsaria. Sokrovishcha Priob'ia. St. Petrsburg, Izd-vo Formika, 1996, pp. 46-47. (In Russian)

Zeimal' E. V. Medal'on s izobrazheniem bogini-okhotnitsy. Sokrovishcha Priob'ia. St. Petersburg, Izd-vo Formika, 1996, pp. 48-49. (In Russian)

Ermolaev A. Ishimskaia kollektsiia. Opisanie kollektsii Krasnoiarskogo muzeia. Otdel arkheologicheskii. Krasnoiarsk, 1914, iss. 1, 18 p. (In Russian)

Karmanov V.N. Kharakteristika kamennogo inventaria sviatilishcha Ust'-Polui (po materialam raskopok 2006-2015 gg.) Arkheologiia Arktiki, iss. 4. "Ust'-Polui: materialy i issledovaniia. Ekaterinburg, Izd-vo Delovaia pressa, 2017, vol. 1, pp. 102-108. (In Russian)

Kosarev M. F. Drevnie kul'tury Tomsko-Narymskogo Priob'ia. Moscow, Izd-vo Nauka, 1974. 220 p. (In Russian)

Marshak B. I. Sokrovishcha Priob’ia. Sokrovishcha Priob’ia. St. Petersburg, Izd-vo Formika, 1996, pp. 6-44. (In Russian)

Molodin V.I., Bobrov V. V., Ravnushkin V.N. Aidashinskaia peshchera. Novosibirsk, Nauka, 1980, 208 p. (In Russian)

Moshinskaia V.I. Material'naia kul'tura i khoziaistvo Ust'-Poluia. Materialy $i$ issledovaniia po arkheologii SSSR. Moscow, Izd-vo AN SSSR, 1953, no. 35, pp.72-106. (In Russian)

Moshinskaia V. I. Arkheologicheskie pamiatniki severa Zapadnoi Sibiri. Svod arkheologicheskikh istochnikov. Moscow, Nauka, 1965, iss. D3-8. 88 p. (In Russian)

Nezabitovska-Vishnevska B. Zerkala iz Gornokniazevskogo klada (Iamalo-Nenetskii avtonomnyi okrug, Rossiia) - popytka interpretatsii. I Mezhdunarodnaia konferentsiia "Arkheologiia Arktiki". Tezisy dokladov 19-22 noiabria 2017 g. Ekaterinburg, Izd-vo Delovaia pressa, 2017, pp. 102-103. (In Russian)

Novokreshchennykh N.N. Gliadenovskoe kostishche Permskoi gubernii na r. Kame, Permskogo uezda. Trudy Permskoi gubernskoi uchenoi arkhivnoi komissii. Perm, 1914, 99 p. (In Russian)

Nyaksimvol. Otv. Red. Yakovlev. Tomsk - Chanty-Mansyisk: izd-vo Tomskogo universiteta, 2014. 2014. $200 \mathrm{c}$.

Perevalova E. V., Karacharov K. G. Reka Agan i ee obitateli. Ekaterinburg; Nizhnevartovsk, UrO RAN; studiia GRAFO, 2006, 352 p. (In Russian)

Podosenova Yu. A. Rezul'taty rentgeno-fluorestsentnogo analiza izdelii iz tsvetnogo metalla iz sviatilishcha Ust'-Polui. Arkheologiia Arktiki. Iss. 4. "Ust'-Polui: materialy i issledovaniia". Ekaterinburg, Izd-vo Delovaia pressa, 2017, vol. 1, pp. 127-133. (In Russian)

Pristupa O. I., Starodumov D. O., Iakovlev Ia. A. Okno v beskonechnost'. Bronzovye zerkala rannego zheleznogo veka. Khanty-Mansiisk: Izd-vo GalaPress, 2002, 88 p. (In Russian)

Savinov D. G. Vvedenie. Kul'turnye transliatsii i istoricheskii protsess (paleolit - srednevekov'e). St. Petersburg: [S.n.], 1994, pp. 3-7. (In Russian)

Troitskaia T.N. Kulaiskaia kul'tura v Novosibirskom Priobee. Ed by V.I. Molodin. Novosibirsk, Nauka SO, 1979, 123 p. (In Russian)

Fedorova N. V. Antropomorfnye obrazy Ust'-Poluia: tekhnologiia, ikonografiia, kompozitsiia stsen. Ural'skii istoricheskii vestnik. Ekaterinburg, Izd-vo UrO RAN, 2014, no. 2, pp. 63-71. (In Russian)

Fedorova N.V. Risunki na metalle: graficheskoe iskusstvo naseleniia severa Zapadnoi Sibiri i Predural'ia. Arkheologiia, etnografiia i antropologiia Evrazii. 2014, no. 1, pp.90-99. (In Russian)

Fedorova N.V., Gusev An. V., Podosenova Iu.A. Gornokniazevskii klad. Ed by. O. N. Korochkova. Kaliningrad, Izd-vo ROSDOAFK, 2016. 80 p. (In Russian)

Chernetsov V.N. Bronza ust'-poluiskogo vremeni. Materialy $i$ issledovaniia po arkheologii SSSR. Moscow, Izd-vo AN SSSR. 1953. no. 53, pp. 121-178. (In Russian)

Chindina L. A. Drevniaia istoriia Srednego Priob’ia v epokhu zheleza. Tomsk, Izd-vo Tom. un-ta, 1984, 256 p. (In Russian)

Shirin Yu. V. Import rubezha er v kompleksakh Zapadnoi Sibiri i ego znachenie dlia khronologii. Stratum Plus, 2016, no. 4, pp. 35-54. (In Russian)

Shirin Yu. V., Iakovlev Ia. A. Martirolog iugorskoi arkheologii. Khanty-mansiiskii avtonomnyi okrug v zerkale proshlogo. Tomsk, Khanty-Mansiisk, Izd-vo Tom. un-ta, 2010, iss. 8, pp.21-62. (In Russian) 
Shnirel'man V.A. Osvoenie Severa: iskonnye zemli ili ob"ekt kolonizatsii. Aktual'nye problemy drevne $i$ srednevekovoi istorii Sibiri. Ed by A. I. Bobrova. Tomsk, Tom. gos. un-t sis-m upravl. i radioel. 1997, pp.72-77. (In Russian)

Shul'ga P.I. Veroiatnye puti evoliutsii formy "vostochnykh" zerkal-pogremushek na territorii kulaiskoi obshchnosti. I Mezhdunarodnaia konferentsiia "Arkheologiia Arktiki. Tezisy dokladov. Ekaterinburg, Izd-vo Delovaia pressa, 2017, pp. 103-106. (In Russian)

Shul'ga P.I., Oborin Yu.V. Bronzovye diski iz Kazymskogo klada i “vostochnye" zerkala-pogremushki. Khanty-Mansiiskii avtonomnyi okrug v zerkale proshlogo. Tomsk, Khanty-Mansiisk, Izd-vo Tom. unta, 2017, iss. 15, pp. 84-123. (In Russian)

Shchapova Iu. L. Drevnee steklo: Morfologiia, tekhnologiia, khimicheskii sostav. Moscow, Izd-vo MGU, 1989, 96 p. (In Russian)

Shchukin M.B. Konkretno-istoricheskaia priroda transliatsii kul'tur epokhi Latena. Kul'turnye transliatsii i istoricheskii protsess (paleolit - srednevekov'e). St. Petersburg, [S.n.], 1994, pp. 99-119. (In Russian)

Статья поступила в редакцию 13 марта 2018 г.

Рекомендована в печать 12 марта 2019 г.

Received: March 13, 2018

Accepted: March 12, 2019 


\title{
Скандинавы среди первопоселенцев Новгорода по данным археологии
}

\author{
А.Е. Мусин, О. А. Тарабардина
}

Для цитирования: Мусин А. Е., Тарабардина О. А. Скандинавы среди первопоселенцев Новгорода по данным археологии // Вестник Санкт-Петербургского университета. История. 2019. T.64. Вып. 2. С.762-785. https://doi.org/10.21638/11701/spbu02.2019.218

Статья посвящена проблеме культурной и этнической характеристики первопоселенцев Новгорода и определению места скандинавов в жизни ранней городской общины. Дается критический обзор предшествующей историографии. Новое обращение к музейным коллекциям позволило увеличить количество скандинавских древностей и категорий находок из раннего культурного слоя, в то время как славянский компонент материальной культуры остается трудноуловимым. Скандинавы определенно присутствовали среди основателей первых усадеб города в 930-950-х гг. Распределение скандинавских артефактов на городской территории предполагает свободное расселение выходцев с севера и их престижные позиции в социальной топографии. Упомянутый в летописи «двор Поромонь» не может считаться местом компактного проживания варягов. Новгородские скандинавы однозначно сопоставимы с летописными варягами и отличались от руси как этносоциальной группы в Среднем Поднепровье, связанной с Рюриковичами. Закат скандинавского присутствия в Новгороде был обусловлен прекращением выплаты варяжской дани после смерти Ярослава Мудрого и находит отражение в данных археологии. Традиция российской науки недооценивать скандинавское присутствие в раннем Новгороде берет свои истоки в самоцензуре сталинской эпохи, превращаясь со временем в явление научной инерции.

Ключевые слова: Средние века, Новгород, первопоселенцы, урбанизация, археологические источники, материальная культура, славяне, скандинавы.

\section{The Scandinavians among the First Settlers of Novgorod on the Basis of Archaeological Evidence}

\section{A.E.Musin, O. N. Tarabardina}

For citation: Musin A.E., Tarabardina O.N. The Scandinavians among the First Settlers of Novgorod on the Basis of Archaeological Evidence. Vestnik of Saint Petersburg University. History, 2019, vol. 64, iss. 2, pp. 762-785. https://doi.org/10.21638/11701/spbu02.2019.218 (In Russian)

Александр Евгеньевич Мусин - д-р. ист. наук, вед. науч. сотр., Институт истории материальной культуры РАН, Российская Федерация, 191186, Санкт-Петербург, Дворцовая набережная, 18; aemusin64@gmail.com

Aleksandr E. Musin - Doctor in History, Senior Research Fellow, Institute for the History of Material Culture, Russian Academy of Sciences, 18, Dvortsovaya nab., St Petersburg, 191186, Russian Federation; aemusin64@gmail.com

Ольга Альбертовна Тарабардина - канд. ист. наук, заведующий Центром археологических исследований, Новгородский государственный объединенный музей-заповедник, Российская Федерация, 173000, Великий Новгород, ул. Ильина, 26; o.tarabardina@mail.ru

Olga N. Tarabardina - PhD in History, Director of the Archaeological Center, Novgorod State Museum, 26, ul. Ilina, Veliky Novgorod, 173000, Russian Federation; o.tarabardina@mail.ru

(c) Санкт-Петербургский государственный университет, 2019 
The article deals with the problem of the cultural and ethnic characteristics of first settlers of Novgorod. The previous historiography is reviewed. The revision of the archaeological collections enabled to increase the number and categories of Scandinavian objects, while the Slavonic component remains unclear. The Scandinavians must have been among the founders of Novgorod already in 930-950 A. D. The pattern of distribution of the Scandinavian objects suggests a free resettlement of Norsemen in the town. The "Poromon courtyard" mentioned in the Primary Rus' Chronicle cannot be regarded as a court of the overseas merchants. The Scandinavians in Novgorod were not directly connected to the ethno-social group of Rus'Rhôs linked to the Ryurikids. The archaeologically attested end of the Varangian presence in the town was caused by the cessation of payment of tributum pacis to the Varangians after the death of Prince Yaroslav the Wise. The tradition of the Russian historiography to underestimate the participation of the Scandinavians in the early development of Novgorod is stemmed from the "auto-censorship" of the Stalinist period, turning later into "scholarly inertia".

Keywords: Middle Ages, Novgorod, first settlers, urbanization, archaeological evidence, material culture, Slavs, Scandinavians.

Вопрос происхождения Новгорода в отечественной историографии неразрывно связан с дискуссией об этнической принадлежности его первопоселенцев и участии скандинавов в восточноевропейской истории. Составители летописи уже в начале XII в. стремились согласовать известное им предание об основании города Рюриком с памятью о славянском расселении в Восточной Европе, однако не смогли избежать противоречий. Согласно хронике, город был основан дважды: сначала славянами, первыми «насельниками» Новгорода, а потом князем ${ }^{1}$. Варяги оказывались в данной ситуации «находниками», вторичным элементом.

Отечественная историография интересовалась не столько разрешением этого противоречия, сколько поисками «старого города». В числе предшественников Новгорода назывались Рюриково Городище, поселения Ильменского Поозерья, Старая Ладога, Старая Русса и даже Киев ${ }^{2}$. Вероятно, топоним возник в связи со строительством укреплений на месте Детинца в 1044 г. ${ }^{3}$ В культурной памяти Руси это название было ретроспективно перенесено на первоначальные новгородские поселки и Городище второй половины IX - Х в. В сагах «доновгородский» Новгород также именовался своим поздним именем - Хольмгард ${ }^{4}$.

В одной из широко распространенных гипотез допускалось объединение в общегородской организм трех разноэтничных поселков словен, кривичей и мери, возникших к середине Х в. на месте будущих Людина, Неревского и Славенского концов $^{5}$ (рис. 1). Однако «этническая трехчленность» Новгорода не получила археологического подтверждения ${ }^{6}$ В результате возникло предположение, что здесь,

${ }^{1}$ Ипатьевская летопись. М., 2001 С. 5, 14; Лаврентьевская летопись. М., 2001. С. 6, 20; Новгородская первая летопись старшего и младшего изводов / ред. А.Н.Насонов. М.; Л., 1950. С. 106.

2 Обзор историографии см.: Носов Е. Н. Новгород и Новгородская округа IX-X вв. в свете новейших археологических данных // Новгородский исторический сборник. 1984. Вып. 2 (12). С. 3-7.

${ }^{3}$ Новгородская летопись. С. 181.

4 Джаксон Т. «Страна городов» и ее столица: Новгород в картине мира средневековых скандинавов // Slověne. 2015. № 1. С. 170-179.

5 Янин В.Л., Алешковский М.Х. Происхождение Новгорода (к постановке проблемы) // История СССР. 1971. № 2. С. 32-61. - Эта концепция, возможно, берет свои истоки в: Łowmiański H. Słoweni nadilmenscy i początki Nowogrodu // Zapiski Historyczne. 1966. T. XXXI. Z.2. S.7-41.

${ }^{6}$ Носов Е.Н. Новгород и Новгородская округа IX-X вв. в свете новейших археологических данных. С. 15. 


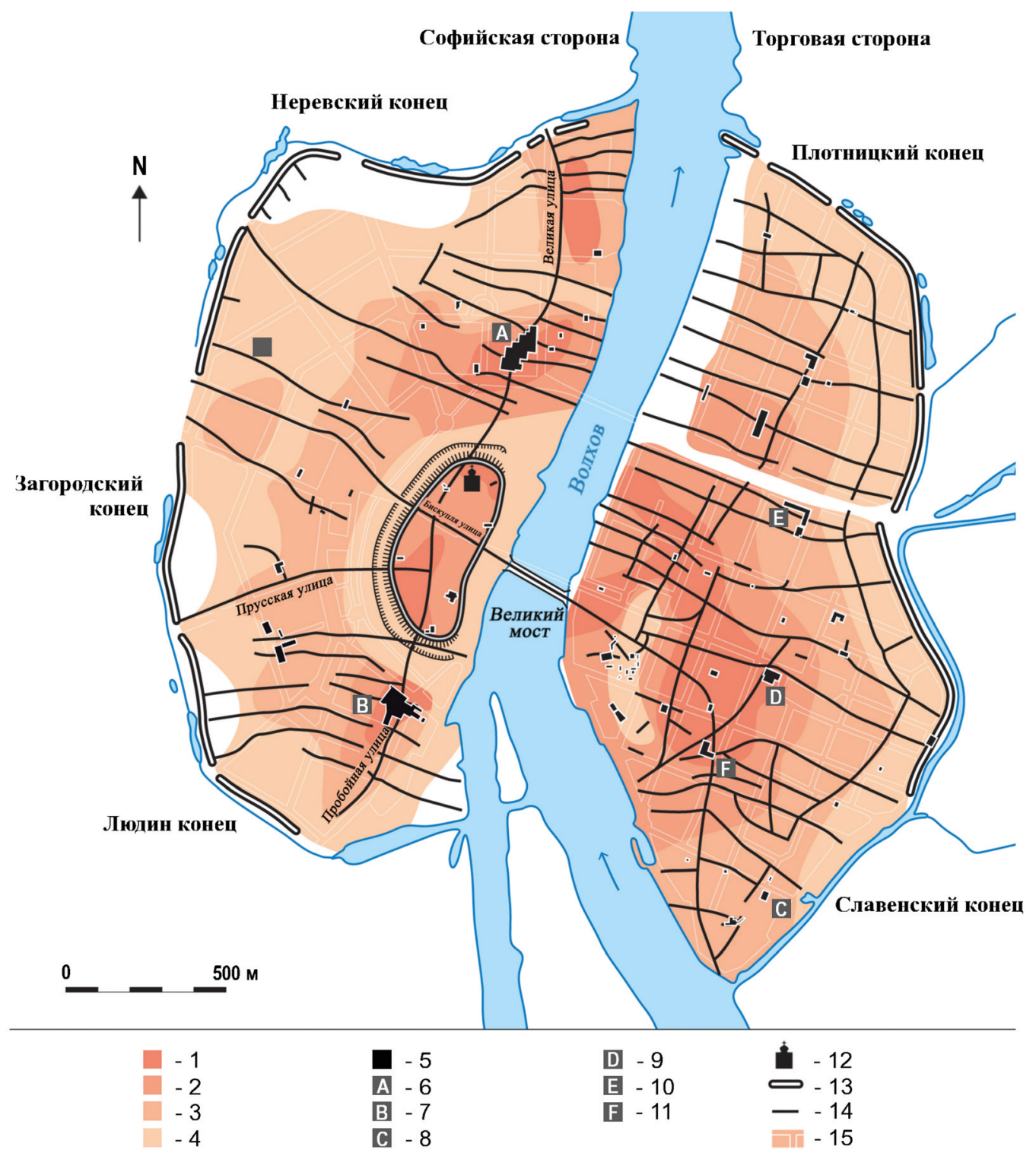

Puc. 1. План Новгорода с современными и средневековыми объектами. Мощность культурного слоя:

1 - более 6 м; 2 - от 4 до 6 м; 3 - от 2 до 4 м; 4 - менее 2 м; 5 - раскопы: 6 - Неревский; 7 - Троицкий; 8 - Посольский; $9-$ Ильинский; $10-$ Федоровский; $11-$ Нутный IV; $12-$ Софийский собор; 13 - вал окольного города; 14 - средневековые улицы; 15 - современные кварталы (рис. авторов)

в условиях вакуума княжеской власти, вызванного уходом Рюриковичей на юг, поселилась славянская племенная верхушка 7 . Преобразование поселков в городскую

7 Янин В. Л. 70 лет новгородской археологии. Итоги и перспективы // Новгородские археологические чтения - 2 / отв. ред. В. Л. Янин., А. С. Хорошев. Великий Новгород, 2004. С. 11. 
структуру в построениях исследователей совпадало с реформами княгини Ольги в 947 г. ${ }^{8}$ Альтернативные гипотезы отрицают элитарность Новгорода и его оппозицию княжеской власти ${ }^{9}$. Иногда в историографии можно почувствовать скепсис в отношении возможности прояснить происхождение Новгорода ${ }^{10}$.

На этом фоне хорошо видны особенности, присущие изучению роли скандинавов в истории Новгорода ${ }^{11}$ : приоритет количественного подхода, подчеркивающего малое число северных артефактов, генерализирующая тенденция, относящая предметы скандинавского происхождения к общебалтийским, избирательность выявления артефактов североевропейского происхождения, рассмотрение находок по технологически-функциональным категориям, недооценка интерпретационного значения предметов языческого культа. Скандинавские предметы из Новгорода противопоставляются находкам с Городища, где широко распространены кольцевидные булавки скандинавского мужского костюма, неизвестные в Новгороде ${ }^{12}$. Однако здесь же подчеркивается различие функций двух поселений, что должно было отразиться и в их материальной культуре. В результате принято считать, что археология лишь косвенно свидетельствует о слабовыраженных новгородскоскандинавских контактах ${ }^{13}$.

Для проверки этих положений стоит заново обратиться к выявлению и анализу этнокультурных маркеров в археологии Новгорода X-XI вв. Исследование роли скандинавов в истории города возможно лишь на основе методологии, преодолевающей описанные выше тенденции. Однако предварительно необходимо затронуть вопрос о датировке древнейших слоев Новгорода. Слои X в. обнаружены на Софийской стороне - в Неревском и Людином концах и в северной части новгородского Детинца, а на Торговой стороне - в центральной части Славенского конца (см. рис. 1). Первоначально древнейший 28-й ярус мостовой Козмодемьянской улицы Неревского раскопа был датирован Б. А. Колчиным с помощью дендрохронологического метода 953 г. ${ }^{14}$ В 1990-е гг. в ходе первой компьютерной обработки массовых данных дендрохронологического анализа для этого яруса была получена новая

8 Янин В.Л. Средневековый Новгород: очерки археологии и истории. М., 2004. С. 127-129.

9 Алексеев Ю. Г. «Черные люди» Новгорода и Пскова (к вопросу о социальной эволюции древнерусской городской общины) // Исторические записки. 1979. Т.103. С.242-279; Щавелев А.С. «Племена» восточных славян: этапы завоевания и степень зависимости от державы Рюриковичей в Х в. // Русь эпохи Владимира Великого: государство, церковь, культура / отв. ред. Н.А.Макаров, А. В. Назаренко. М.; Вологда, 2017. С. 24-48.

10 См.: Лукин П. В. Новгородское вече. М., 2014. С. 58-59.

11 Покровская Л.В. Металлические предметы скандинавского происхождения из раскопок на Троицком раскопе: топография // У истоков русской государственности / отв. ред. Е.Н.Носов, А. Е. Мусин. СПб., 2007. С. 280-284; Рыбина Е. А., Хвощинская Н. В. Еще раз о скандинавских находках из раскопок Новгорода // Диалог культур и народов средневековой Европы / отв. ред. Н. В. Хвощинская, А.Е. Мусин. СПб., 2010. С.66-78; Khvoshchinskaya N., Rybina E. Scandinavian objects from the excavations of Novgorod // Vers l'Orient et vers l'Occident. Regards croisés sur les dynamiques et les transferts culturels des Vikings à la Rous ancienne / dir. P. Bauduin, A. Musin. Caen, 2014. P. 245-256.

12 Рыбина Е.А., Хвощинская Н. В. Еще раз о скандинавских находках из раскопок Новгорода. С. 66; Ср.: Покровская Л. В. Металлические предметы скандинавского происхождения... С. 284.

13 Янсон И. Скандинавские находки IX-X вв. с Рюрикова городища // Великий Новгород в истории средневековой Европы / редкол. А. А. Гиппиус, Е.Н.Носов, А.С. Хорошев. М., 1999. С. 34; Ръцина Е. А. Торговля средневекового Новгорода. Великий Новгород, 2001. С. 95-96.

14 Колчин Б. А. Дендрохронология Новгорода // Труды Новгородской археологической экспедиции. Т. 3: Новые методы в археологии / отв. ред. А. В. Арциховский, Б. А. Колчин. М., 1963. С. 85, 90. 
дата - 932 г. $^{15}$ Дендродаты, полученные в 1970-2010-е гг. при изучении мостовых и построек Троицкого раскопа, свидетельствуют, что первые усадьбы и улицы Людина конца также возникают в 930 -е гг. ${ }^{16}$ Однако эти даты вступали в противоречие с официальными гипотезами о времени возникновения Новгорода и не закрепились в историографии. В северной части Детинца ранние комплексы датируются серединой Х в. и зафиксированы лишь на небольшой площади под остатками укреплений 1040-х гг. ${ }^{17}$ Несколько позднее происходит заселение Торговой стороны, где древнейшие напластования на Михайловском раскопе относятся к 970 -м гг. ${ }^{18}$ На этих датировках и строится хронология северных древностей Новгорода.

Непосредственное обращение к отчетам и коллекциям позволило авторам выявить новые скандинавской артефакты. В частности, это глиняные грузила для вертикального ткацкого станка ${ }^{19}$, традиционно рассматриваемые как свидетельство скандинавского присутствия ${ }^{20}$. Такие грузила известны на Рюриковом Городище, в Витебске, Старой Ладоге, Гнездове, Тимереве, Пскове, Чернигове и Шестовицах ${ }^{21}$. Количество находок на одной усадьбе не превышает 1-3 экз., тогда как набор грузил для вертикального станка мог составлять 20-30 шт. Ткани, изготовленные на вертикальном станке, также известны среди материалов Неревского раскопа 22. Совершенно новой категорией находок оказываются идолы и бытовые предметы с символами северогерманской традиции ${ }^{23}$. Их публикация и анализ имеют самостоятельную исследовательскую ценность.

Авторы считают необходимым вовлечь в исследование наблюдения коллег, которым удалось выявить в новгородских материалах серии скандинавских артефактов. Прежде всего речь должна идти об односторонних наборных гребнях с за-

15 Урьева А. Ф., Черных Н.Б. Дендрошкалы Новгорода: опыт компьютерной обработки // Новгород и Новгородская земля: история и археология. 1995. Вып. 9. С. 106-114.

16 Янин В. Л., Колчин Б. А., Миронова В. Г., Рыбина Е. А., Хорошев А. С. Новгородская экспедиция // Археологические открытия 1977 г. / отв. ред. Б. А. Рыбаков. М., 1978. С. 36-37; Фараджева Н. Н., Тарабардина О.А., Гайдуков П. Г. Усадьбы Ярышевой улицы Людина конца средневекового Новгорода в X в. (по материалам Троицкого раскопа) // Русь в IX-XII вв.: общество, государство, культура / отв. ред. Н. А. Макаров, А. Е. Леонтьев. М.; Вологда, 2014. С. 134-160.

17 Воронова М. А. Раскопки у Лихудова корпуса в Новгородском кремле // Новгород и Новгородская земля: история и археология. 1989. Вып. 1. С. 75.

18 Колчин Б. А., Хорошев А.С. Михайловский раскоп // Археологическое изучение Новгорода / отв. ред. Б. А. Колчин, В. Л. Янин. М., 1978. С. 145.

19 Ср.: Рьбина Е.А., Хвощинская Н. В. Еще раз о скандинавских находках из раскопок Новгорода. С. 70.

20 Штакельберг Ю. И. Глиняные диски из Старой Ладоги // Археологический сборник Государственного Эрмитажа. 1962. T.4. С.109-115; Staermose Nielsen K.-H. A Preliminary Classification of Shapes of Loomweights // Northern Archaeological Textiles. 2005. T. VII. P. 130.

${ }^{21}$ Носов Е. Н., Плохов А. В., Хвощинская Н. В. Рюриково Городище: новые исследования. СПб., 2017. С. 63-64; Казаков А., Черненко Е. Черниговский детинец IX-XIII вв. в свете новіх археологических материалов // Чернигов у середньовічній та ранньомодерній історії Центрально-Східної Європи / ред. О. Б. Коваленко. Чернігів, 2007. С. 120.

22 Нахлик А. Ткани Новгорода: опыт технологического анализа // Труды Новгородской археологической экспедиции. Т. 4 / отв. ред. А. В. Арциховский, Б. А. Колчин. М., 1963. С. 256-257, рис. 18, 19.

${ }^{23}$ Мусин А.Е., Тарабардина О.А., Кокуиа Л.В., Кубло Э.К. Предметы с христианской и языческой символикой из раскопок в Новгороде и Старой Руссе // Российский археологический ежегодник. 2016. Вып. 5-6. С. 163, рис. 6. Ср.: Дорофеева Т. С. О скандинавских культовых и магических предметах с Городища под Новгородом (по материалам раскопок разных лет) // Археология и история Пскова и Псковской земли. 2016. Вып. 31. С.227-239; Дорофеева Т. С. Скандинавские «символы бесконечности» с Рюрикова Городища и из новгородского Софийского собора // Российская археология. 2016. № 1. С. 107, 108, 109, рис. 1; 2, 1; 3, 4. 
клепками класса 1 («А») согласно Л. И.Смирновой (группа II по О.И.Давидан) ${ }^{24}$, которые связаны со скандинавской орнаментальной традицией и ремеслом. В Новгороде они датируются серединой X - XI в., однако их пик приходится на конец $\mathrm{X}$ в., что соответствует хронологии подобных находок повсеместно на периферии скандинавского мира ${ }^{25}$. А.А.Кудрявцев выявил в повседневной культуре города ключи и замки, характерные для северной Европы. Речь идет о навесных кубических замках типа «А» и плоских ключах к ним с прямоугольной лопастью ${ }^{26}$.

Однако анализ этнокультурных маркеров раннего Новгорода не должен основываться лишь на категориях отдельных находок. Нельзя не согласиться с Е. Н. Носовым: выявление этнической принадлежности населения городских районов возможно лишь на основе изучения целостных комплексов находок из отдельных усадеб, тогда как простое сопоставление раскопов по количеству этнически определимых вещей ничего само по себе не доказывает ${ }^{27}$. Наиболее целесообразным представляется исследование скандинавских древностей в границах конкретных городских усадеб в связи с их материальной культурой. В настоящее время такая задача представляется трудноосуществимой, поскольку полевое изучение Новгорода значительно опережает осмысление и издание открытых древностей. В этих условиях приоритетным представляется параллельный анализ топографии и хронологии артефактов северного и общебалтийского происхождения.

Комплексы скандинавских предметов были выявлены уже во время первых широкомасштабных археологических исследований Новгорода на Неревском раскопе, располагавшемся на территории средневекового Неревского конца. Так, на усадьбе «И», в слоях середины X - первой половины XI в. были обнаружены фрагменты двух грузил для вертикального ткацкого станка (рис. 2: И3, 5) 28 . Отсюда происходят фрагменты костей с рунами и руноподобными знакам (рис. 2: И2, 4) ${ }^{29}$. На этой же усадьбе был найден деревянный идол в головном уборе, несколько поодаль - еще один в позе адорации (рис. 2: И1) ${ }^{30}$. Обе фигурки могут быть связаны с северной изобразительной традицией ${ }^{31}$. Здесь же обнаружены оба кубических замка типа «А» Неревского раскопа и ключ к ним ${ }^{32}$.

24 Давидан О. И. Гребни Старой Ладоги // Археологический сборник Государственного Эрмитажа. 1962. Вып. 4. С. 95-108.

25 Smirnova L. Comb-Making in medieval Novgorod (950-1450). Oxford, 2005. P. 17-18, 35, 37, 55, $6878,89,93-105,189$, fig. $3.18 ; 3.46 ; 6.8$.

${ }^{26}$ Кудрявиев А. А. Замки и ключи в материальной культуре средневекового Новгорода: дис. ... канд. ист. наук. М., 2014. С. 80-82.

27 Носов Е.Н. Новгород и Новгородская округа IX-X вв. в свете новейших археологических данных. С. 12.

${ }^{28}$ H-58, Hep-XXIV-XXVE, 25/26-27-1620-№20, 21, НГМ НВ 20944 / Пр. к. А78-867, 868.

29 H-56, Нер-XVI, 25/28-1180-4, НГМ КП 39560-6/A6-35; Н-58, Нер-XIV, 25-1650; НГМ КП 39560-1/А6-30; Мельникова Е.А. Скандинавские рунические надписи. М., 1977. С.156-158, 271, № 141-142; Мельникова Е. А. Скандинавские рунические надписи: новые находки и интерпретации. M., 2001. C. 251, 451, № 7.3 .

30 Н-56, Нер-XVI, 28-1166-7; Н-59, Нер-XXVIII, 25-27-1520. См.: Колчин Б.А. Новгородские древности. Резное дерево. М., 1971. С. 43-44, № 230, 231, рис. 17: 2, 8.

${ }^{31}$ Kirpichnikov A. Early Ladoga during the Viking Age in the light of the international cultural transfer // Vers l'Orient et vers l'Occident. Regards croisés sur les dynamiques et les transferts culturels des Vikings à la Rous ancienne. Dir. P. Bauduin, A. Musin. Caen, 2014. P. 226-227. Fig. 9: 4.

32 H-58, Нер-XXIII, 25/26-1543; H-59, Нер-XXVIII, 24/27-1780; первая четверть XI в.; Н-60, НерXXX, 26/23-1962, конец X - начало XI в. 
Среди материалов усадьбы «Д» была найдена костяная проколка со скандинавским орнаментом в стиле Рингерике второй четверти - середины XI в. (рис. 2: Д2 $)^{33}$. В более ранних слоях обнаружена биллоновая привеска со стилизованным изображением подтреугольной фигуры с вогнутыми боками, иногда интерпретируемой как «молот Тора» (рис. 2: Д1). С этой же усадьбы происходит клад дирхемов (tpq 974/975 г.), обнаруженный в слоях 970-х гг. ${ }^{34}$

$\mathrm{C}$ усадьбы «Е» из слоя второй половины $\mathrm{X}$ в. происходит фрагмент луженой железной тордированной гривны с обломанными концами (рис. 2: Е2) ${ }^{35}$. В восточной части двора в постройке было найдено навершие с сидящим идолом с выраженными половыми признаками (рис. 2: Е3) ${ }^{36}$. Возможно, это изображение божества плодородия Фрейра. Фигурка выпадает в слой на рубеже X-XI в., т.е. вскоре после крещения Новгорода. С мостовой Великой улицы рядом с усадьбой происходит ажурная верхняя пластина двухскорлупной овальной фибулы с позолотой типа JP 51 (рис. 2: E1) ${ }^{37}$. На усадьбе «К» в слоях 930-950 гг. найдена еще одна круглая привеска с подтреугольным символом ${ }^{38}$, в напластованиях второй половины Х в. - деревянные конские путы (рис. 2: К1), аналогии которым известны в Швеции ${ }^{39}$.

Итак, на территории Неревского конца скандинавские вещи присутствуют в материалах усадеб, находящихся близь перекрестка Великой и Козмодемьянской улиц, ближайшему к Детинцу ядру городского квартала (см. рис. 6). Они выпадают в слой как в ранних горизонтах, так и на рубеже X/XI - в первой половине XI в. Наиболее насыщенным северными предметами оказывается 25-й ярус (1006-1025 гг.), с которыми связаны фигурка Фрейра, кости с руническими надписями, одна из круглых привесок и фибула. Сюда же можно отнести находки некоторых бытовых предметов: кубического замка и грузиков для вертикального ткацкого станка. Фрагменты тканей, изготовленных на вертикальном станке, могут быть связаны с усадьбами «Д», «Е» и «И», где известны находки скандинавского происхождения. Здесь же, согласно наблюдениям Л. И. Смирновой, в слоях середины X - середины XI в. наблюдается значительная концентрация односторонних

33 Н-62, Нер- XXXIII, 23-24/29-2161, НГМ КП 19300/А2-2. Отнесена к XII в. см.: Ръбина E. А., Хвощинская Н. В. Еще раз о скандинавских находках из раскопок Новгорода. С. 72, 75. Рис. 4: 12.

34 Янина С. А. Второй Неревский клад куфических монет Х в. // Труды Новгородской археологической экспедиции. Т. 3 / отв. ред. А. В. Арциховский, Б. А. Колчин. М., 1963. С. 288-331.

35 Н-57, Нер-ХІХ, 27/34-1375; ГИМ 100497. Оп. 1965/1994; См.: Седова М. В. Ювелирные изделия древнего Новгорода (X-XV вв.). М, 1981. С. 11, 22-23. Рис. 1:7.

36 Н-57, Нер-ХХ, 26 (25)/33-1402, НГМ КП 25293/А5-120. См.: Седова М. В. Ювелирные изделия древнего Новгорода (X-XV вв.). С. 177, 178. Рис. 78. Химический состав: Cu-94,9 \%, Zn - 4 \%, $\mathrm{Pb}-0,7 \%, \mathrm{Sn}-0,2 \%, \mathrm{Bi}-0,02 \%, \mathrm{Ag}-0,02 \%, \mathrm{Sb}-0,06 \%$, As - 0,04 \%, Fe - 0,03 \%, Ni - 0,006 \%, $\mathrm{Mn}-0,02$ \%, Au - 0,0001 \%. См.: Коновалов А. А., Ениосова Н. В., Митоян Р. А., Сарачева Т. Г. Цветные и драгоценные металлы и их сплавы на территории Восточной Европы в эпоху средневековья. M., 2008. C. 63, № 668. Cp.: Early Finnish art, from prehistory to the Middle Ages: photos by I. Rácz / eds. C. F. Meinander, P.-L. Lehtosalo. Helsinki, 1961. Fig. 127.

37 Н-57, Нер-ХІХ, 25-640, ГИМ 100497. Оп. 1965/1994, 1006-1025 гг. См.: Седова М. В. Ювелирные изделия древнего Новгорода (X-XV вв.). С. 39, 84. Рис. 13: 8; Рыбина Е. А., Хвощинская Н. В. Еще раз о скандинавских находках из раскопок Новгорода. С. 72, рис. $4: 1$.

38 Н-56, Нер-XVIII, 28/32-1281, ГИМ 100497. Оп. 1965/1984. См. Седова М. В. Ювелирные изделия древнего Новгорода (X-XV вв.). С. 37, 39, рис. 13: 5; Рьбина Е. А., Хвощинская Н. В. Еще раз о скандинавских находках из раскопок Новгорода. С. 69, 68, рис. 2: 3.

39 H-56, Нер-XVII, 27-28/31-1253, НГОМЗ КП 26507/А40-185. См.: Гринев А. М. Деревянные конские путы Х в. с Неревского раскопа // Археологические вести. 2017. Вып. 23. С. 250-253. 


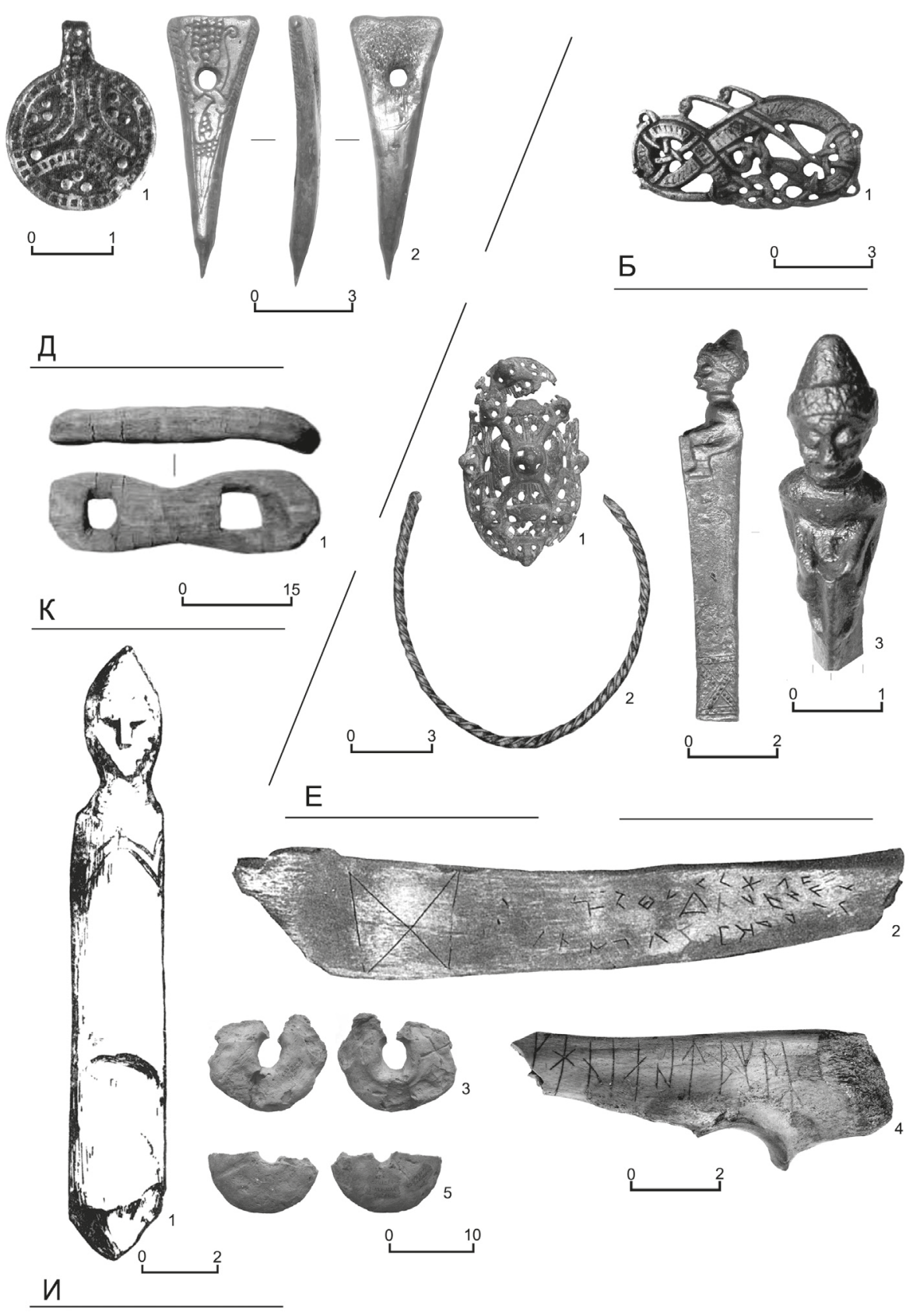

Puc. 2. Комплексы находок северного происхождения Неревского раскопа. Усадьба «Д»:

1 - подвеска; 2 - проколка (1 - [Седова, 1981, рис. 13: 5], 2 - фото С. Е. Торопова); усадьба «Б»: 1 - накладка ([Седова, 1981, рис. 13: 7]); усадьба «К»: 1 - путы ([Гринев, 2017, рис. 1]); усадьба «Е»: 1 - фибула; 2 - гривна; 3 - навершие с идолом (1 фото Н. И. Асташовой; 2 - [Седова, 1981, рис. 1: 7]; 3 - фото С. Е. Торопова); усадьба «И»: 1 - идол; 2, $4-$ кости с руническими надписями; 3, $5-$ грузила $(1-$ [Колчин, 1971, рис. 17: 8]; 2, 4- фото С.Е. Торопова; 3, 5 - фото авторов) 
наборных гребней класса 1 «А» (не менее 16 экз. на усадьбе «И», «К»-9, «Д»-19, $« \mathrm{E} »-21)^{40}$.

Интересно сравнить распространение скандинавских предметов на этих усадьбах с комплексами северной части раскопа. Так, на усадьбе «Б» зафиксировано не менее 25 односторонних гребней, в основном, второй половины Х в. Отсюда происходят клад куфических монет (tpq 971/972 г.), найденный в слоях 970-х гг. ${ }^{41}$, и не менее трех плоских ключей рубежа X-XI вв. ${ }^{42}$ Здесь же найдена бронзовая накладка (рис. 2: Б1) (1170-1190 гг.) ${ }^{43}$, которая, по мнению М.В.Седовой, выполнена в стиле Маммен $^{44}$, тогда как Е.А.Рыбина и Н. В.Хвощинская считают, что ее орнаментация напоминает изображения на поздних рунических камнях ${ }^{45}$.

Также есть сведения о находке на усадьбе «В» в предматериковом слое глиняного грузила для вертикального ткацкого станка ${ }^{46}$. Здесь же, в слоях первой половины XI в., обнаружен плоский ключ от кубического замка ${ }^{47}$ и некоторое количество односторонних гребней. Логично предположить, что материальная культура обитателей этих усадеб в XI в. демонстрирует распространение технологических инноваций (замки, ключи, гребни северной традиции) и связана с новым этапом славяно-скандинавского взаимодействия.

Гораздо более представительной выглядит коллекция скандинавских предметов на усадьбах Людина конца, исследованных на Троицком раскопе. На плане раскопа их границы показаны обобщенно (см. рис. 7). В Х в. они проходили несколько иначе ${ }^{48}$, и авторы соотносили находки с исторически существовавшими комплексами. Так, на усадьбе «А» в слоях 930-950 гг. были найдены фрагменты глиняных грузил для вертикального ткацкого станка (рис. 3: A1, 4) ${ }^{49}$, из слоев 980-1000-х гг. происходит ажурный наконечник ножен меча (рис. 3: A3) ${ }^{50}$, из слоев конца XI начала XII в. - игральная шашка из моржовой кости (рис. 3: A2) ${ }^{51}$. На мостовой Пробойной улицы рядом с усадьбой найден плоский ключ от кубического замка типа «А», датированный второй половиной X в. ${ }^{52}$ Дополнительно отметим находку двух плоских ключей к кубическим замкам второй половины Х в. на усадьбе «Б» 53 .

40 Smirnova L. Comb-Making in medieval Novgorod (950-1450). P.95-96.

41 Янина С. А. Неревский клад куфических монет Х в. // Труды Новгородской археологической экспедиции. Т. 1 / отв. ред. А. В. Арциховский, Б. А. Колчин. М., 1956. С. 180-207.

42 H-54, Hep-VII, 26/27-26-501; H-55, Hep-XIV, 25/26-28-1022; 25-26-1015.

43 Н-55, Нер-ХІV, 17/20-1008; ГИМ 100497. Оп. 1965/1969.

44 Седова М. В. Ювелирные изделия древнего Новгорода (X-XV вв.). С. 39, 163, рис. $13: 7$.

45 Рьбина Е. А., Хвощъинская Н. В. Еще раз о скандинавских находках из раскопок Новгорода. С. 68,69 , рис. $2: 1$.

46 H-53, Нер-IV, пл. 29. Ср.: Арииховский А. В. Отчет Новгородской археологической экспедиции за 1953 г. // Научный архив Института археологии РАН. Р-1. № 860. Л. 170.

47 H-53, Hep-V, 25-26-402.

48 Фараджева Н.Н., Тарабардина О.А., Гайдуков П. Г. Усадьбы Ярышевой улицы Людина конца средневекового Новгорода в Х в. (по материалам Троицкого раскопа). С. 138-142, рис. 4-8.

49 H-77, Tp-IV, 23-217, 23-235; НГМ НВ 19492 / Пр. к А57-584, 585.

50 Н-77, 21-208-5, КП 28080/А57-581. См.: Каинов С.Ю., Авдеенко Е.Е. Литые наконечники ножен мечей (по материалам Троицкого раскопа Новгорода Великого) // Археологические вести. 2012. Вып. 18. С. 148, рис. 1: 3.

51 H-82, Tp-VI, 16-400, НГМ КП 33560/A-96 №403.

52 H-83, Tp-VI, 27-426.

53 H-75, Tp-III, 21-151; H-78, Tp-IV, 25-273. 


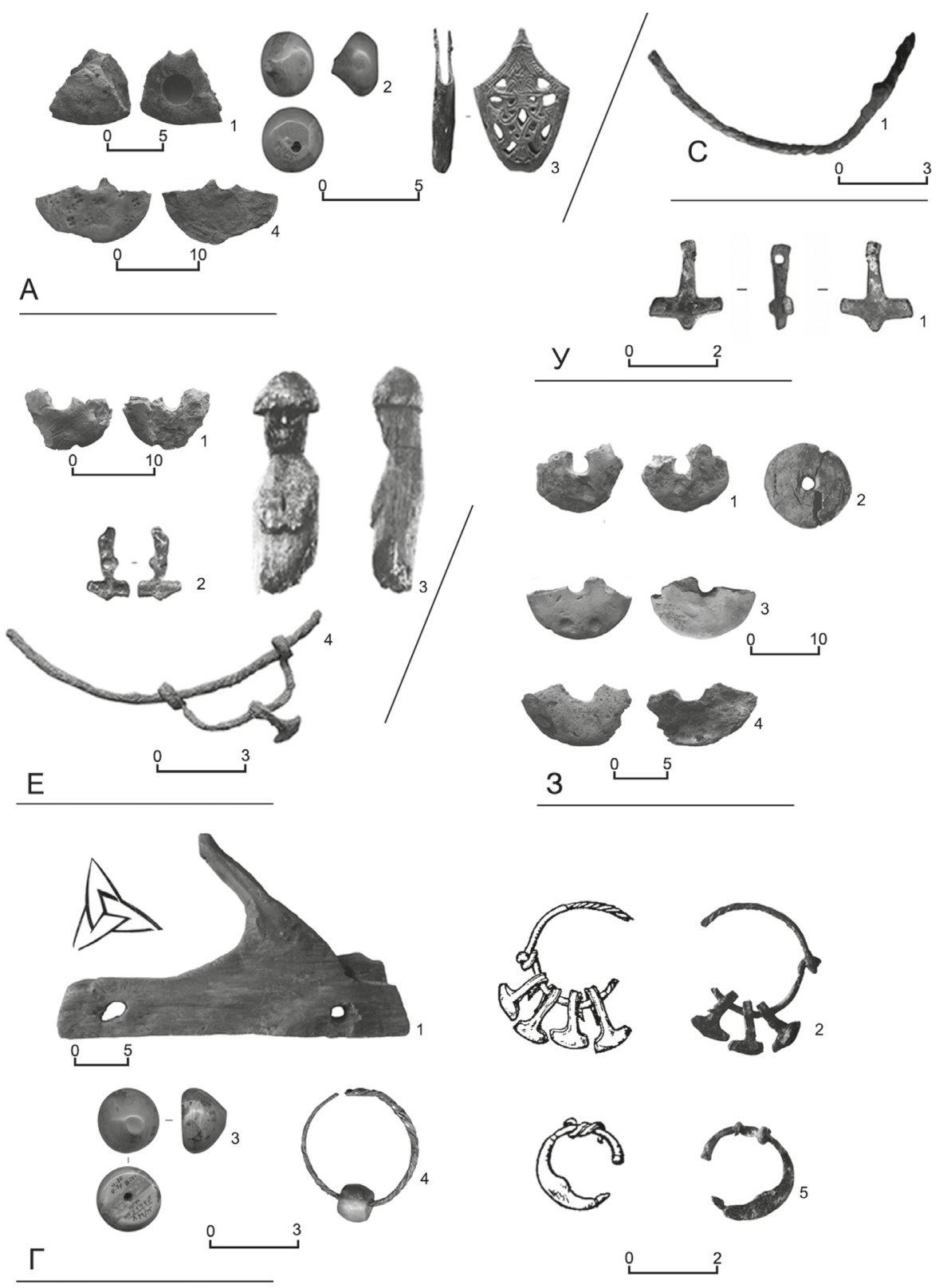

Puc. 3. Комплексы находок северного происхождения Троицкого раскопа.

Усадьба «А»: 1, 4 - грузила; 2 - игральная шашка; 3 - наконечник ножен меча (1, 4 - фото авторов, 2, 3 - фото С.Е. Торопова); усадьба «С»: 1 - гривна (фото С. А. Орлова); усадьба «У»: 1 - амулет-«молоточек Тора» (фото С. А. Орлова); усадьба «Е»: 1 грузило; 2 - амулет-«молоточек Тора»; 3 - идол; 4 - гривна с амулетами (1 - фото авторов, 2 - фото С.Е. Торопова, 3, 4 - фото С. А. Орлова); усадьба «3»: 1-4 - грузила $(1,3,4-$ фото авторов, $2-$ фото С. А. Орлова; усадьба «Г»: 1 - уключина; 2 - кольцоамулет с «молоточками Тора»; 3 - игральная шашка; 4 - кольцо с янтарной бусиной; 5 - гривнообразная привеска-амулет (1 - фото авторов, $2,5-$ фото С. А. Орлова, 3 , 4 - фото С. Е. Торопова) 
Культовые предметы, связанные с северным язычеством, найдены на усадьбе «Е»: подвеска - «молоточек Тора» на согнутой в виде скобы железной проволоке, подвешенной к фрагментированной железной тордированной гривне (рис. 3: E4), а также отливка (литейный брак?) свинцово-оловянистой подвески в виде «молоточка Тора» (рис. 3: Е2), происходящая из материковой ямы. Находки синхронны сооружениям 28-го яруса и датируются 940-960-ми гг. ${ }^{54}$ Также на усадьбе на уровне построек, датируемых первой четвертью XI в., найдено глиняное грузило от ткацкого станка (рис. 3: E1) 55 . Из постройки 1050-1070-е гг. происходит деревянная антропоморфная скульптура в позе адорации (рис. 3: Е3) ${ }^{56}$. Здесь известен кубический замок типа «А» первой половины XI в. ${ }^{57}$ К этой же усадьбе Л.В.Покровская относит фрагмент крученой железной гривны с обломанными концами, найденный в предматериковых слоях (рис. 3: C1) ${ }^{58}$, однако скорее всего она происходит с расположенной южнее усадьбы «С». Остается добавить, что на усадьбе «У» в предматериковых слоях 930-950-х гг. была найдена еще одна свинцово-оловянистая привеска в виде «молоточка Тора» (рис. 3: У1) ${ }^{59}$.

На усадьбе «Г» в предматериковом слое 930-950 гг. выявлено металлическое кольцо-амулет с четырьмя «молоточками Тора» (рис. 3: Г2) и имитирующей гривну подвеской (рис. 3: Г5) ${ }^{60}$. Уникальной является находка деревянной уключины с изображением трикветры в слоях 990-1010-х гг. (рис. 3: Г1) ${ }^{61}$. Здесь же в слоях последней четверти XI в. была найдена игральная полусферическая шашка из моржовой кости (рис. 3: Г3) ${ }^{62}$. С этой же усадьбы происходит амулет скандинавской традиции - кольцо из перекрученной четырехгранной железной проволоки с янтарной бусиной (рис. 3: Г4) из слоя 1080-1100-х гг. ${ }^{63}$, а из слоя второй половины XI в. плоский ключ к кубическому замку ${ }^{64}$.

На территории усадьбы «3», выходящей на Черницину улицу и расположенной к западу от усадьбы «Г», на различных раскопах, но в одном слое 930-950 гг.,

${ }^{54}$ H-00, Tp-XII, 23-1440; НГМ КП 43677/A197 - 1011; H-00, Tp-XII, В V - 1526; КП 43677 / А 197 - 1017. Ср.: Покровская Л. В. Металлические предметы скандинавского происхождения. С. 283; Рьбина Е.А., Хвощинская Н.В. Еще раз о скандинавских находках из раскопок Новгорода. С. 74, рис. 4: 6; Мусин А.Е. Скандинавское язычество на Востоке по данным археологии: общее и особенное // Российский археологический ежегодник. 2012. № 2. С.555-602, рис. 2: 1-3; Kvoshchinskaya N., Rybina E. Scandinavian objects from the excavations of Novgorod. P.252, 253, fig. 6: 2, 3.

55 H-00, Tp-XII, 18-1405, НГМ НВ 23292 / Пр.к A197-236.

${ }^{56} \mathrm{H}-99$, Tp-XII, 15-1466.

57 H-00, Tp-XII, 20-1416.

58 H-2000, Тр-ХII, 23-1560. См.: Янин В.Л., Хорошев А. С., Рыбина Е.А., Сорокин А.Н. Отчет Новгородской археологической экспедиции за 2000 г. // Научный архив Института археологии РАН. Р-1 № 23596. Л.107; № 23597. Рис.53: 1. Ср.: Покровская Л.В. Металлические предметы скандинавского происхождения... С. 281.

59 H-2009, Tp-XIII, предматерик, 1674-2. Kvoshchinskaya N., Rybina E. Scandinavian objects from the excavations of Novgorod. P. 253. Fig. 6: 4.

${ }^{60}$ H-87, Tp-VIII, 23-654/656. Предметы в музейных коллекциях не вывялены. См.: Янин В. Л., Рьбина Е. А., Хорочев А. С., Гайдуков П. Г., Сорокин А. Н. Отчет Новгородской археологической экспедиции за 1987 г. // Научный архив Института археологии РАН. Р-1. № 12455. Л. 101, № 12455А. Рис. 63.

61 Н-87, Tp-VIII, 19-688; НГМ КП 44/655. Передана в музей в 2008 г.

${ }^{62}$ H-1980, Tp -V, 16-317; НГМ КП 31490/A71-75.

${ }^{63}$ H-86, Tp-VIII, 13-703; НГМ КП 36697/A-109-372.

${ }^{64}$ H-87, Tp-VIII, 14-670. 
были найдены глиняные грузила от вертикального ткацкого станка (рис. 3: Г1-4) 65 и плоский ключ от кубического замка второй половины XI в. ${ }^{66}$ Здесь обнаружено наибольшее количество ткацких грузиков, известных на новгородских усадьбах.

Предметы скандинавского облика известны и на усадьбах Ярышевой улицы. Так, на усадьбе «Р» в предматериковых слоях 930-950-х гг. был найден фрагмент бутероли меча, относящийся к группе наконечников с фигурой птицы (рис. 4: P1) ${ }^{67}$. На расположенной к западу усадьбе «И» в слоях 950-970-х гг. обнаружен ажурный наконечник ножен меча (рис. 4: И3). Аналогичные наконечники представлены на территории расселения балтских племен и считаются импортом из Скандинавии ${ }^{68}$. Отсюда же происходит уникальная рукоять деревянного ковша с изображением трикветры (рис. 4: И1), найденная в слоях конца Х в. ${ }^{69}$, и еще оно железное кольцо с бусиной (рис. 4: И2) - в слоях 930-950 гг. ${ }^{70}$ (которое авторы предположительно относят к северным древностям), а в слоях первой половины XI в. обнаружен кубический замок типа «А» и плоские ключи к нему ${ }^{71}$.

К западу от нее находилась усадьба «П», где отмечена концентрация интересных деревянных предметов, культурная принадлежность которых дискуссионна. Однако, на наш взгляд, некоторые из них могут быть связаны с северной изобразительной традицией. Так, в жилой постройке в слоях 930-950-х гг. была найден идол (рис. 4: $\Pi 1)^{72}$, имеющий ближайшую аналогию в Шлезвиге, тогда как изображение находит параллели в германской традиции ${ }^{73}$, а южнее - антропофорное навершие (рис. 4: $\Pi 2)^{74}$. Здесь же, в слоях 940-960-х гг. найден чехол с авиморфными мотивами (рис. 4: П3), имеющим, по мнению некоторых исследователей, аналогии среди балтских древностей ${ }^{75}$, а также плоские ключи второй половины X - первой половины XI в. ${ }^{76}$

Исключительным выглядит комплекс находок с усадьбы «Ж», выходившей на Черницыну улицу. Еще в 1986 г. здесь в слоях второй половины Х в. был обнаружен фрагмент овальной фибулы JP $52^{77}$, которую первоначально отнесли к усадьбе «Е» и датировали XI в. (рис. 4: Ж1) ${ }^{78}$ Однако в 2014 г. при расширении площади рас-

65 H-87, Tp-VIII, 21-709 (2), НГМ КП 36697/A109-1708; H-87, Tp-VIII, 22-716, НГМ НВ 22081/ Пр. к А109-195; Н-94, Тр-Х, 19-1198, НГМ КП 41170/A170-54.

${ }_{66} \mathrm{H}-87$, Tp-VIII, 16-696.

67 Н-98, Тр-ХI, предматерик-1240, НГМ КП 43204/А190 - 384. Ср.: Каинов С. Ю., Авдеенко Е.Е. Литые наконечники ножен мечей (по материалам Троицкого раскопа Новгорода Великого). С. 146, рис. 1: 1.

68 H-98, Tp-XI , 19 (27)-1252, НГМ КП 43204/А190-372. См.: Каинов С. Ю., Авдеенко Е. Е. Там же. Рис. 1: 2.

${ }^{69}$ Н-98, Тр-ХI, 18-1237, НГМ КП 43204 / А13-1518. Ср.: Мусин А. Е. и др. Предметы с христианской и языческой символикой из раскопок в Новгороде и Старой Руссе. С. 163, рис. 6: 1.

${ }^{70}$ Н-98, Тр-XI, 20-1252; НГМ КП 43204/ А190-397.

71 H-93, Tp-X, 16-1093, 14-1059, 15-1063.

72 Н-94, Тр-Х, предматерик-30-1092, НГМ КП 41170 / А170-602.

73 Cр. мнение: Radtke Ch. Der Schleswig-Mann - ein „Hausgeist“ aus Novgorod? // Archäologische Nachrichten aus Schleswig-Holstein. 2010. Bd.16. S.92-95.

${ }_{74} \mathrm{H}-94, \mathrm{Tp}-\mathrm{X}$ 18-1157, НГМ КП 41170/А170-601.

75 H-94, Tp-X, 29-18-1128. НГМ КП. Ср.: Rybina E. A. Die Funde als Spiegel des Lebens. Alltag im mittelalterlichen Novgorod // Novgorod. Das mittelalterliche Zentrum und sein Umland im Norden Russlands / Hrsg. M. Müller-Wille, V. L. Janin, E. N. Nosov, E. A. Rybina. Neumünster, 2001. S. 200, 204, Abb. 5:1.

76 H-94, Tp-IX, 16-809; H-94, Tp-X, 16-1086.

77 H-86, Tp-VII, 19-602, НГМ КП 35697/A107-92.

78 См.: Покровская Л.В. Металлические предметы скандинавского происхождения... С.281, 282, рис. 2: 7. 

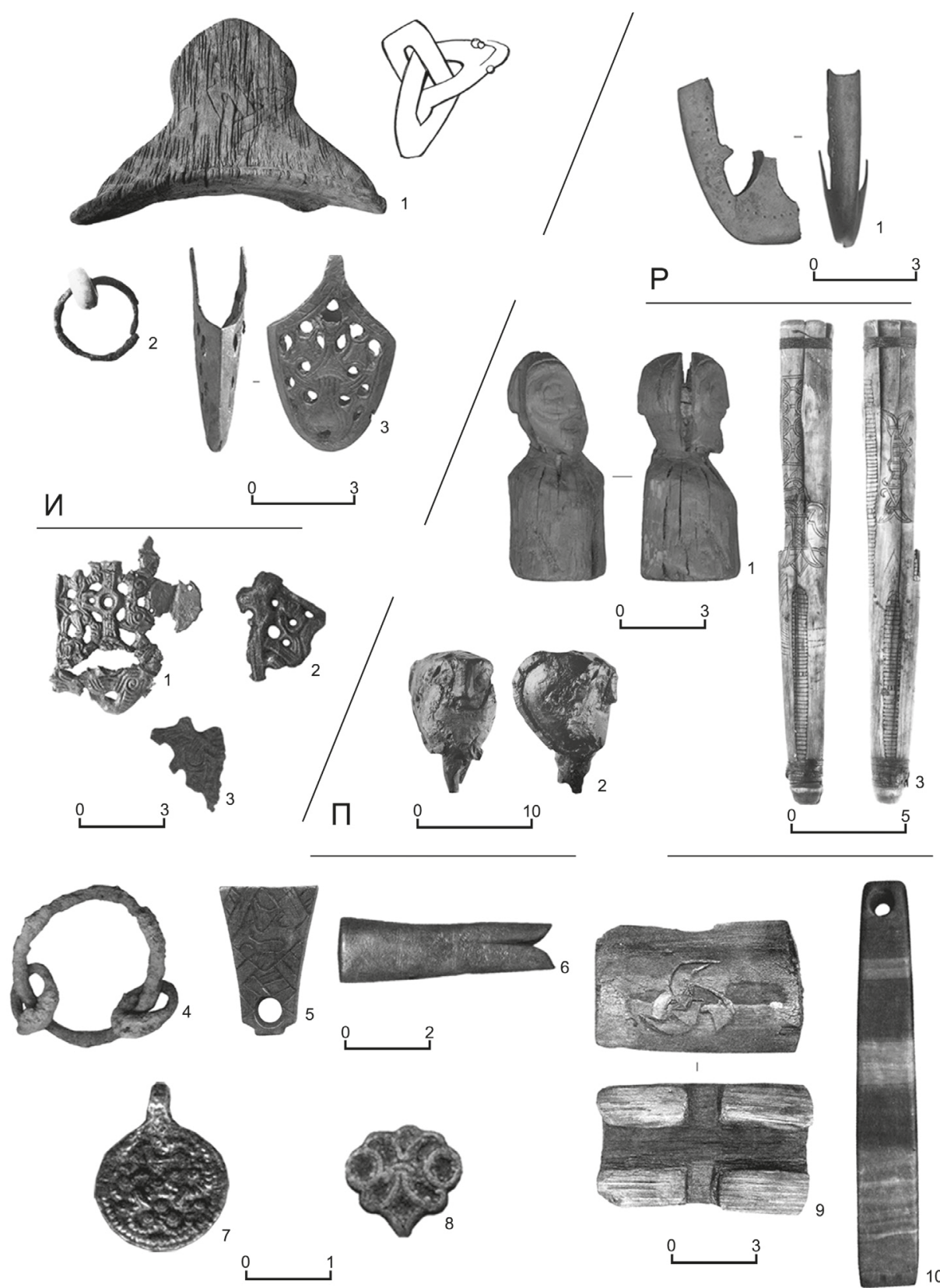

ж

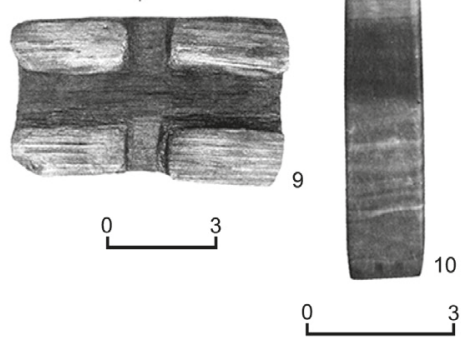

Puc. 4. Комплексы находок северного происхождения Троицкого раскопа. Усадьба «И»:

1 - рукоять ковша; 2 - кольцо с бусиной; 3 - наконечник ножен меча $(1,3-$ фото С.Е. Торопова, 2 - фото С.А. Орлова); усадьба «Р»: 1 - наконечник ножен меча (фото С.Е. Торопова); усадьба «П»: 1,2 - идолы; 3 - ножны $(1-$ фото С.Е. Торопова, 2, 3 фото С. А. Орлова); усадьба «Ж»: 1-3 - фрагменты фибулы; 4 - кольца-амулеты; 5 - булавка; 6 - подвеска в форме «рыбьего хвоста»; 7 - подвеска; 8 - накладка; 9 - цилиндр; 10 - оселок (1 - фото С.Е. Торопова, 2-10 - [Янин В. Л. и др., 2015, рис. 7, 9]) 
копа на юг удалось фактически полностью завершить исследование усадьбы «Ж»79 и не только обнаружить здесь фрагменты накладки на скорлупообразную фибулу (рис. 4: Ж2, 3) ${ }^{80}$, возможно, открытую ранее, но и выявить комплекс скандинавских вещей, которые авторы суммарно датируют второй половиной X - началом XI в. Из нижних слоев, синхронных постройкам 950-970-х гг., происходят уже упоминавшиеся фрагменты фибулы, поясные накладки в стиле Борре (рис.4: Ж8) ${ }^{81}$, железные кольца-амулеты (рис. 4: Ж4) ${ }^{82}$ и костяная орнаментированная булавка (рис. 4: Ж5) ${ }^{83}$. В более поздних горизонтах усадьбы, относящихся к концу X - началу XI в., найдена уникальная для Восточной Европы бронзовая привеска в форме «рыбьего хвоста» (рис.4: Ж6) ${ }^{84}$, характерная для культуры Готланда в конце Х в. (Kvie, Endre sn; Västös, Hall sn; Broe, Halla sn; Ire, Hellvi sn) ${ }^{85}$, амулет-оселок из полосатого сланца (рис. 4: Ж10) и фрагменты подобных оселков ${ }^{86}$, а также подвеска с волютообразным орнаментом (рис. 4: Ж9) ${ }^{87}$. С той же усадьбы происходят полусферическая игральная шашка из моржового клыка с плоским основанием, фрагмент наконечника ножен меча и ширококонечный браслет, тип которого известен в Балтийском регионе в X-XII вв. и представлен среди материалов Неревского (3 экз.) и Троицкого (4 экз.) раскопов ${ }^{88}$. Комплекс сопровождается находками большого количества деталей весов (4 экз.), гирек (12 экз.), восточных (14 экз.) и византийских (2 экз.) монет и односторонних гребней. Здесь же, в слоях второй половины $\mathrm{X}$ - первой половины XI в. известны и плоские ключи для кубических замков ${ }^{89}$. Следует отметить, что в 2013 г. в слоях второй половины XI в. усадьбы «Ж» найдена деревянная пломба-цилиндр со знаком, напоминающим трискелеон или трикветру (рис. 4: Ж9) 90 . Новые находки на усадьбе «Ж» почти вдовое увеличили число новгородских артефактов скандинавского происхождения.

79 Янин В. Л., Рыбина Е.А., Покровская Л.В., Сингх В.К., Степанов А. М., Тянина Е. А. Работы в Людином конце Великого Новгорода в 2014 г. // Новгород и Новгородская земля: история и археология. 2015. Вып. 29. С. 51-65.

${ }^{80}$ H-14, Tp-XIII, 17-1851; предматерик-1839. См.: Янин В.Л. и др. Работы в Людином конце Великого Новгорода в 2014 г. (Троицкие раскопы: XIII-Г, Г-1 и XV) // Новгород и Новгородская земля: история и археология. 2015. Вып. 29. С. 61, 63, рис. 9: 1-2.

${ }^{81}$ Н-14, Tp-XIII, 18-1803. Другие накладки встречены в позднейших слоях, напр.: Н-14, ТрXIII, 16-1845. См.: Янин В. Л. и др. Работы в Людином конце Великого Новгорода в 2014 г. Рис. 7: 3-4.

${ }^{82}$ H-14, Tp-XIII, 17-1848. См. Янин В.Л. и др. Работы в Людином конце Великого Новгорода в 2014 г. С. 61, рис. 9: 4.

${ }^{83}$ H-14, Tp-XIII, 16/17-1861. См.: Янин В. Л. и др. Работы в Людином конце Великого Новгорода в 2014 г. Рис. 9: 3.

${ }^{84}$ Н-14, Tp-XIII, 16-1860. См.: Янин В. Л. и др. Работы в Людином конце Великого Новгорода в 2014 г. С. 61, рис. 9: 5.

85 Thunmark-Nylén L. Die Wikingerzeit Gotlands. T.2. Typentafeln. Stockholm, 1998. Taf. 162: 1-11; Thunmark-Nylén L. Die Wikingerzeit Gotlands. T. 4: 1. Katalog. Stockholm, 2000. S. 142-143, 308, 344, 395.

${ }^{86}$ H-14, Tp-XIII, 15-1856. См.: Янин В. Л. и др. Работы в Людином конце Великого Новгорода в 2014 г. С. 61 , рис. 9: 6.

87 Н-14, Tp-XIII, 15-1857. См.: Янин В. Л. и др. Работы в Людином конце Великого Новгорода в 2014 г. С. 59 , рис. $7: 8$.

88 Седова М. В. Ювелирные изделия древнего Новгорода (X-XV вв.). С. 110, рис. 38: 5, 11.

89 H-86, Tp-VI, 18-599; H-14, Tp-XIII, 16-1840, 17-1845, 18-1809. См.: Янин В. Л. и др. Работы в Людином конце Великого Новгорода в 2014 г. С. 58, рис. 6: 3-5.

90 Янин В. Л., Рыбина Е.А., Покровская Л.В., Степанов А. М., Сингх В.К., Тянина Е. А. Работы в Людином конце Великого Новгорода в 2013 году // Новгород и Новгородская земля: история и археология. 2014. Вып. 28. С. 30, 31-32, рис. 9: 2. 
Подводя итог обзору северных артефактов Троицкого раскопа, отметим, что, так же как и на севере Новгорода, в его южной части усадьбы с элементами скандинавской культуры связаны с перекрестком главных магистралей - Пробойной и Чернициной улиц (см. рис.7). Если в Неревском конце скандинавские предметы известны на шести усадьбах из восьми, существовавших в середине $\mathrm{X}$ - первой половине XI в., то на Троицком раскопе это соотношение 11 : 14. Концентрация скандинавских находок здесь соответствует распространению односторонних наборных гребней X - первой половины XI в. Согласно наблюдениям Л. Смирновой, на усадьбе «А» гребней этого типа известно не менее 25 экз., на усадьбе «Е» - 49, на усадьбе «С» - 12, на усадьбе «Ж» - 10, на усадьбе «Г» - 35, на усадьбе «М» -25 , на усадьбе «Р» -6 , на усадьбе «И» -18 , на усадьбе «П» $-21^{91}$. В то же время число «троицких» находок уже значительно в 930-950-х гг., тогда как «неревские» относятся преимущественно к концу X - рубежу X-XI вв. Это позволяет предположить различные волны скандинавских мигрантов в Восточную Европу, неизменно поселявшихся в ключевых местах городских кварталов, что может свидетельствовать о привилегированной позиции пришельцев в местной иерархии.

Скандинавы определенно были среди первопоселенцев и основателей Новгорода, что подтверждается находками скандинавских амулетов 930-950 гг. Предметы культа, как и языческие символы на бытовых предметах, не могли попасть в Новгород в результате торговли и свидетельствуют о религиозных взглядах местных жителей ${ }^{92}$. Их происхождение из предматериковых слоев, предшествующих появлению жилых построек, имеет полные аналогии на поселениях эпохи викингов в Швеции, где такие депозиты рассматриваются как жертвоприношения, оберегающие жилое пространство ${ }^{93}$. Добавим, что амулеты из клыков кабана, известные в Новгороде, также стоит рассматривать в связи со скандинавским язычеством. Сокращение их количества в XI в. соотносится не только с христианизацией, но и сменой этнического состава горожан ${ }^{94}$.

Известные на Неревском раскопе кости с руническими и руноподобными знаками могут служить важным свидетельством межэтнического взаимодействия в Новгороде XI в. Новые находки кости с глаголическими и кириллическими буквами в Новгороде на усадьбе «Ж» Троицкого раскопа в слоях 1050-1080 гг. ${ }^{95}$ помещают эти предметы в более широкий контекст культурного трансфера и даже, возможно, взаимного обучения варягов и славян древне-северному и славянскому языкам ${ }^{96}$.

В целом археологически известное присутствие скандинавов в Новгороде сопоставимо с прочими поселениями Балтийского региона. Однако северные пред-

91 Smirnova L. Comb-Making in medieval Novgorod (950-1450). P. 97.

92 Мусин А. Е. Скандинавское язычество на Востоке по данным археологии: общее и особенное. C. 565-566.

93 Carlie A. Forntida byggnadskult: Tradition och regionalitet i södra Skandinavien. Stockholm, 2004. S. 176, 179-181, 251-252.

94 Тянина Е. А. Амулеты из зубов и костей животных средневекового Новгорода // Археологические вести. 2011. Вып. 17. С. 165.

95 Н-2013, Тр-XIII, 13-1823-59. См.: Михеев С. М., Сингх В.К. Глаголические и кириллические буквы на кости второй половины ХІ в. из Новгорода // Российская археология. 2016. № 1. С. 102. Рис. 4.

96 Ср.: Медведев А. Ф. Загадочная надпись начала ХІ в. из Новгорода // Славяне и Русь / отв. ред. Е.И. Крупнов. М., 1968. С. 439. 
меты более выразительны на фоне этнически нейтральной культуры обитателей других усадеб. Такие определенно славянские артефакты, как ромбощитковые кольца, формочки для изготовления трапециевидных подвесок и биконические керамические пряслица, чрезвычайно редки и датируются преимущественно концом $\mathrm{X}$ - XI вв. ${ }^{97}$ Это не позволяет говорить о «северной вуали» Рюрикова Городища и Новгорода ${ }^{98}$. Здесь исследователь имеет дело не со «скандинавской вуалью», а с культурой местных скандинавов. Различная репрезентативность скандинавских и славянских элементов в Новгороде может иметь свое объяснение. Если новоприбывшие скандинавы подчеркивали свой культурный статус, то славяне, уже аккультурировавшиеся в регионе, могли использовать иные средства выражения идентичности. При решении этого вопроса важно учитывать унифицирующий характер городской культуры.

Необходимо упомянуть и отдельные предметы северной традиции на территории Новгорода. Одной их последних находок культовых скандинавских предметов является набор бронзовых амулетов - «жезлов Вельвы» на завязанном характерным образом кольце ${ }^{99}$, происходящий из слоев XI в. Воздвиженского раскопа 2017 г. в южной части Людина конца, однако его анализ будет целесообразен после публикации материалов раскопок.

На Торговой стороне известны лишь отдельные находки скандинавского облика, относящиеся к XI-XII вв. Так, на Посольском раскопе на территории Славенского конца в 2008 г. была найдена круглая бронзовая фибула типа IJ II A 4 (II B-?), орнаментация которой характерна для конца X - середины XI в., что соответствует датировке предматерикового слоя, из которого она происходит. Возможно, речь должна идти о незаконченном изделии местного мастера, изготовленном на Рюриковом Городище (рис. 5: 1) ${ }^{100}$.

Результатом многократного тиражирования изделия в стиле Еллинг является литая круглая привеска из латуни с изображением двух переплетающихся драконов (рис. 5: 2) ${ }^{101}$. Предмет найден в северной части Славенского конца на усадьбе «А» Ильинского раскопа в слоях 1110-1130 гг. Ближайшими аналогиями ему являются парные подвески из Гнездовского клада 1867 г. (рис. 5: 3-4) ${ }^{102}$, подвеска из клада в Варбю в Швеции (Vårby, Huddinge sn, Södermanland, SHM 4516) (рис. 5: 5) ${ }^{103}$

97 Седова М. В. Ювелирные изделия древнего Новгорода (X-XV вв.). С. 9-10, рис. 1: 1, 2, 4; Янин В. Л., Хорошев А. С., Рыбина Е. А., Сорокин А. Н., Степанов А. М., Покровская Л. В. Работы в Людином конце Великого Новгорода // Новгород и Новгородская земля: история и археология. 2006. Вып. 20. C. 13 .

98 Носов Е.Н. Новгородская земля: Северное Приильменье и Поволховье // Русь в IX-X веках: археологическая панорама / отв. ред. Н. А. Макаров. М.; Вологда, 2012. С. 114.

99 Price N.S. The Viking Way: Religion and War in Late Iron Age Scandinavia. Uppsala, 2002. P. 202-203; Дорофеева Т.С. О скандинавских культовых и магических предметах с Городища под Новгородом (по материалам раскопок разных лет). С. 235-236, рис. 4: 4, 5.

100 Н-08, Посольский-2008, 9-8. Ср.: Рыбина Е. А., Хвощзинская Н. В. Еще раз о скандинавских находках из раскопок Новгорода. С. 72,73 , рис. 4: 4; Торопов С. Е. Случайные находки скандинавских предметов эпохи викингов в Приильменье // Археологические вести. 2014. Вып. 20. С.241, рис. 8: 9.

101 Н-64, Ил, 15-16/25-4, НГМ КП 18203/А99-78.

102 Гущиин А. С. Памятники художественного ремесла древней Руси X-XIII вв. М.; Л., 1936. С. 55, табл. 3: 2,4 .

${ }^{103}$ Hildebrand B.E., Hildebrand H. Teckningar ur svenska statens historiska museum. H.2. S. 6. Stockholm, 1878. Pl. 2. 
и музея университета Бергена, Норвегия (рис. 5: 6) ${ }^{104}$. Подобный сюжет представлен на оковке большого рога из погребения в кургане Черная Могила в Чернигове (рис. 5: 7) ${ }^{105}$.

На усадьбе «Е» Федоровского раскопа в южной части Плотницкого конца в напластованиях второй половины XI - середины 30-х гг. XII в. был найден ажурный шарообразный предмет со сквозным отверстием (навершие или «яблоко» церемониального посоха [?]). В орнаментации изделия присутствуют зооморфные элементы: переплетенные фигуры фантастических существ, имеющие скандинавские черты, близкие стилю Урнес (?) (рис. 5: 8) ${ }^{106}$.

В 2016 г. в предматериковых слоях Нутного IV раскопа второй четверти XI в. в центральной части Славенского конца был найден костяной предмет, наконечник или псалий (?) с антропоморфным и зооморфным рельефными изображениями (рис. 5: 9) ${ }^{107}$. В нижней части представлено изображение мужского лица с бородой и усами. Ближайшей аналогией антропоморфной маске является подвеска из Гнездовского клада 1867 г. определенно скандинавского происхождения (рис. 5: 10) ${ }^{108}$.

Итак, северные мигранты, появившиеся в Новгороде в момент его возникновения, оказываются типичными варягами ПВЛ, отличавшимися от руси Рюриковичей, возникшей в результате аккультурации скандинавов в славянской среде и в середине Х в. концентрировавшейся в Среднем Поднепровье. Часть новоприбывших варягов могла войти в эту русь, представленную княжеским гарнизоном на Городище. Другая же часть влилась в формирующееся население Новгорода, представленное свободными горожанами: торговцами и ремесленниками, поселившимися под защитой княжеской власти. Этим и объясняются неоднократно подчеркивавшиеся в историографии различия скандинавской материальной культуры Новгорода и Городища, социально-политическая оппозиция которых не прослеживается. Напротив, здесь имеет место поселенческий симбиоз и разделение функций между bellatores Городища, laboratores Новгорода и, позднее, oratores Детинца.

В дальнейшем урбанизация приводит к формированию в целом однородной общины «мужей новгородских». Это не исключало «конфликтов роста» и законодательных мер по их преодолению, уравнивавших в правах княжеского «русина» и новгородского «словенина» ${ }^{109}$. В связи с этим возникает вопрос о возможности компактного проживания скандинавов в Новгороде X - начала XI в., которое пытались увидеть на Торговой стороне или в Людином конце ${ }^{110}$. Одним из ключевых моментов является летописное известие о «дворе Поромоне», где в 1015 г. новго-

104 Корзухина Г. Ф. Турьи рога черниговских курганов // В камне и в бронзе / отв. ред. А.Е. Мусин. СПб., 2017. С. 620-634.

105 Рыбаков Б. А. Русское прикладное искусство Х-ХІІІ веков. Л., 1971. Рис. 3.

106 H-93, Фед-V, 12/13 5-18-389-21, НГМ ВХ 1976.

107 См.: URL: http://novgorodmuseum.ru/novosti/1394-priblizhayutsya-k-zaversheniyu-raboty-naraskope-nutnyj-iv.html (дата обращения: 16.04.2018); Петров М.И. Костяной предмет из раскопа Нутный-IV в Великом Новгороде // Археология Древней Руси: актуальные проблемы и открытия. Материалы междунар. конф., посвящ. 100-летию со дня рождения Д.А. Авдусина / ред. Е. А.Рыбина, Н. В.Ениосова. М., 2018. С. 107.

108 Гущзин А. С. Памятники художественного ремесла древней Руси X-XIII вв. С. 56, табл. 3: 6.

109 Правда Русская / отв. ред. Б. Д. Греков. Т. 1. М., 1940. С. 70, 79, 104.

110 Smirnova L. Comb-making in medieval Novgorod (950-1450). An industry in transition P. 35, 37, 78, 89, 95-97, 105, 317, 332; Рьєина Е. А., Хвощинская Н. В. Еще раз о скандинавских находках из раскопок Новгорода С. 76. 

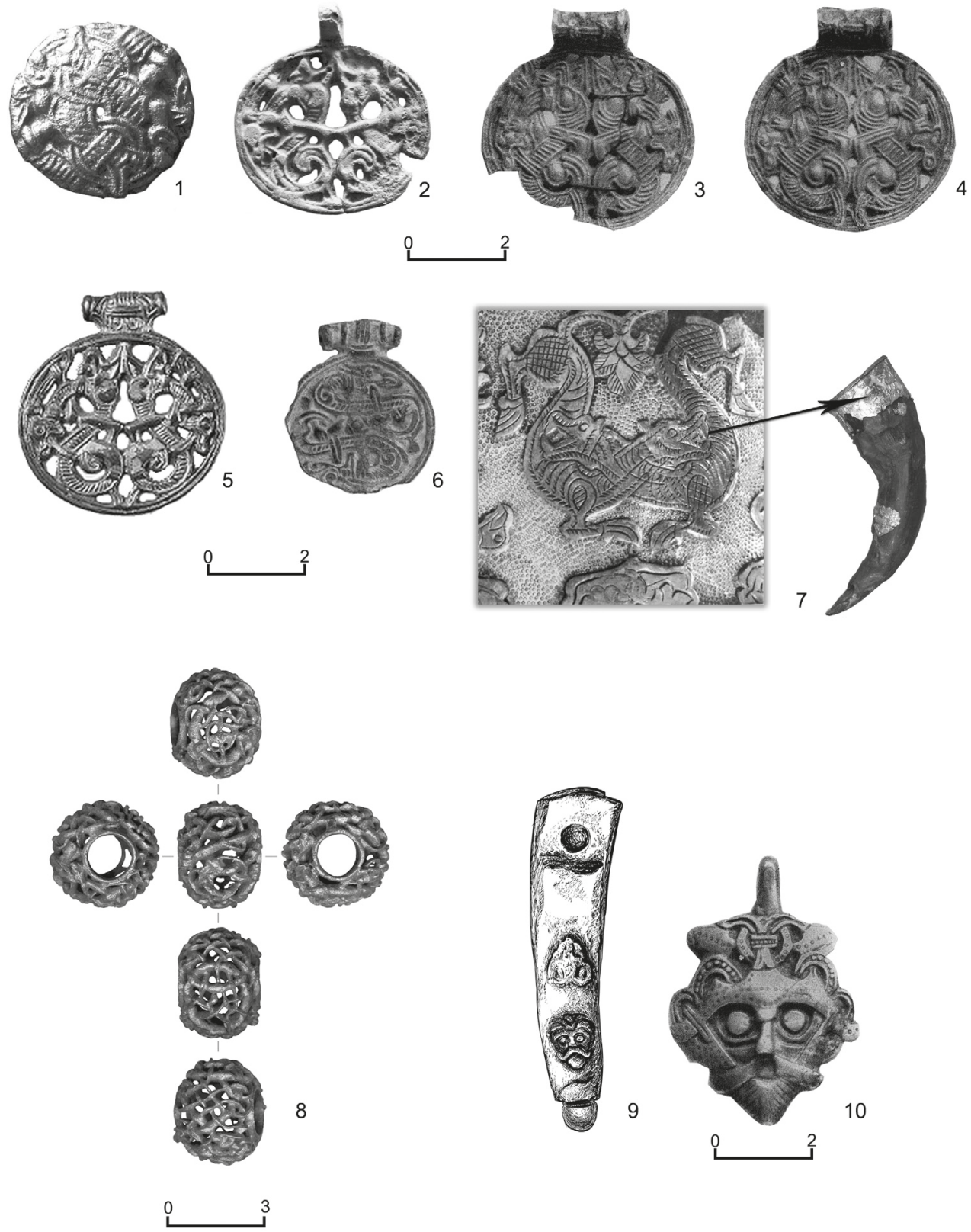

Puc. 5. Предметы северного происхождения с Торговый стороны и их аналогии:

1 - фибула, Посольский раскоп; 2 - подвеска, Ильинский раскоп; 3, 4, 10 - подвески, Гнездовский клад 1867 г.; 5 - подвеска, клад Варбю; 6 - подвеска, Берген; 7 - изображение на большом роге из кургана Черная Могила (увеличено, перевернуто); 8 шарообразный предмет в стиле Урнес (?), Федоровский раскоп; 9 - псалий (?) с антропоморфным и зооморфным изображениями, Нутный раскоп (1 - фото М.И.Петрова; 2, 8 - фото С. Е. Торопова; 3, 4, 10 - по [Гущин, 1936, табл. 3: 2, 4, 6]; 5 - [Hildebrand B. E., Hildebrand Н., 1878, pl. 2]; 6 - фото Университетского музея Бергена; 7 - по [Рыбаков, 1971, рис. 3]; 9 - авторская прорисовка по фото М.И. Петрова) 


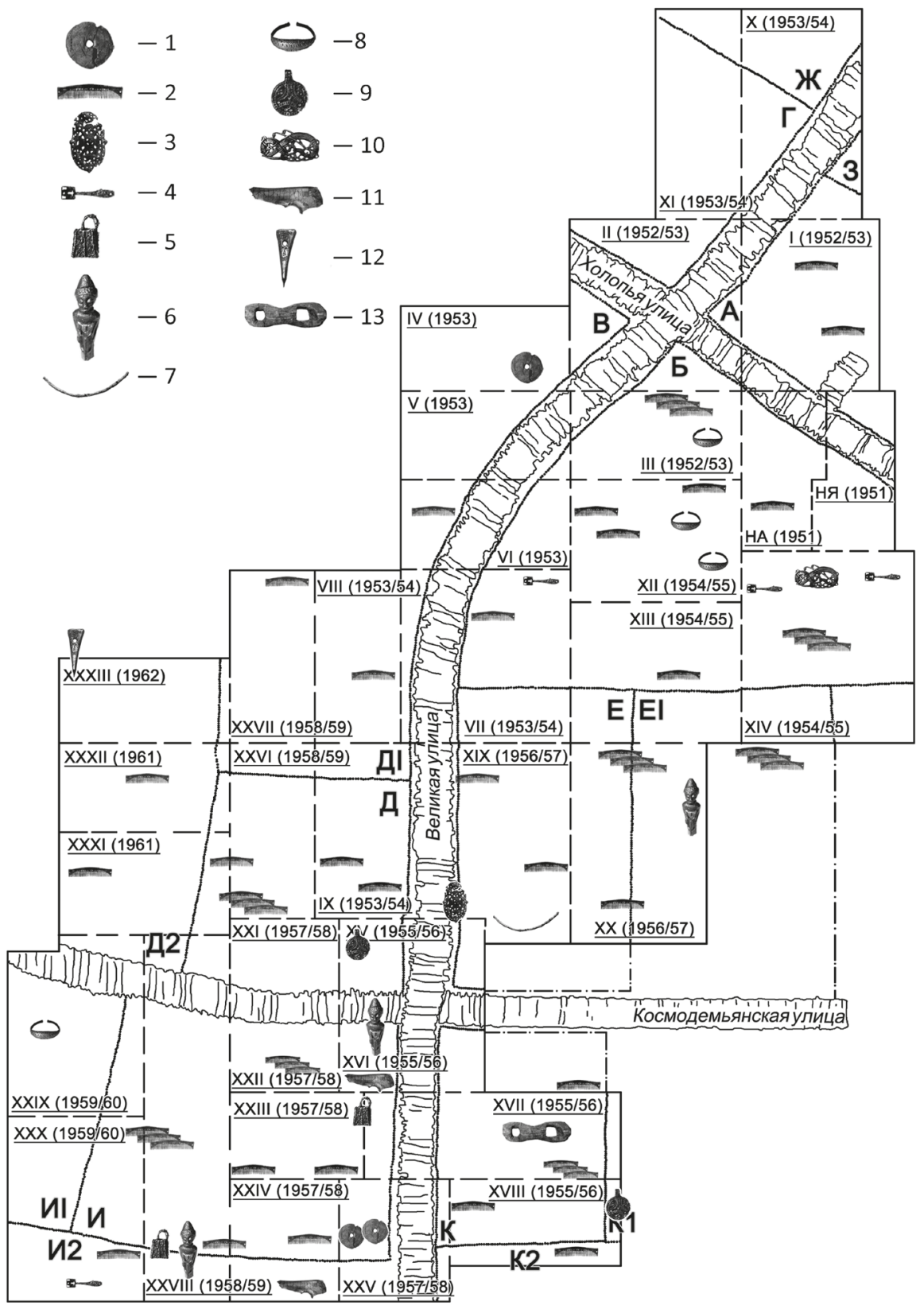

Puc. 6. Распределение предметов северного происхождения на Неревском раскопе:

1 - грузило ткацкого станка; 2 - гребень односторонний; 3 - фибула овальная; $4-$ ключ плоский; 5 - замок кубический; 6 - идол; 7 - гривна; 8 - браслет ширококонечный; 9 - подвеска круглая; 10 - накладка в стиле Маммен; 11 - кость с надписью; 12 - проколка в стиле Ренгерике; 13 - путы конские (рис. авторов) 

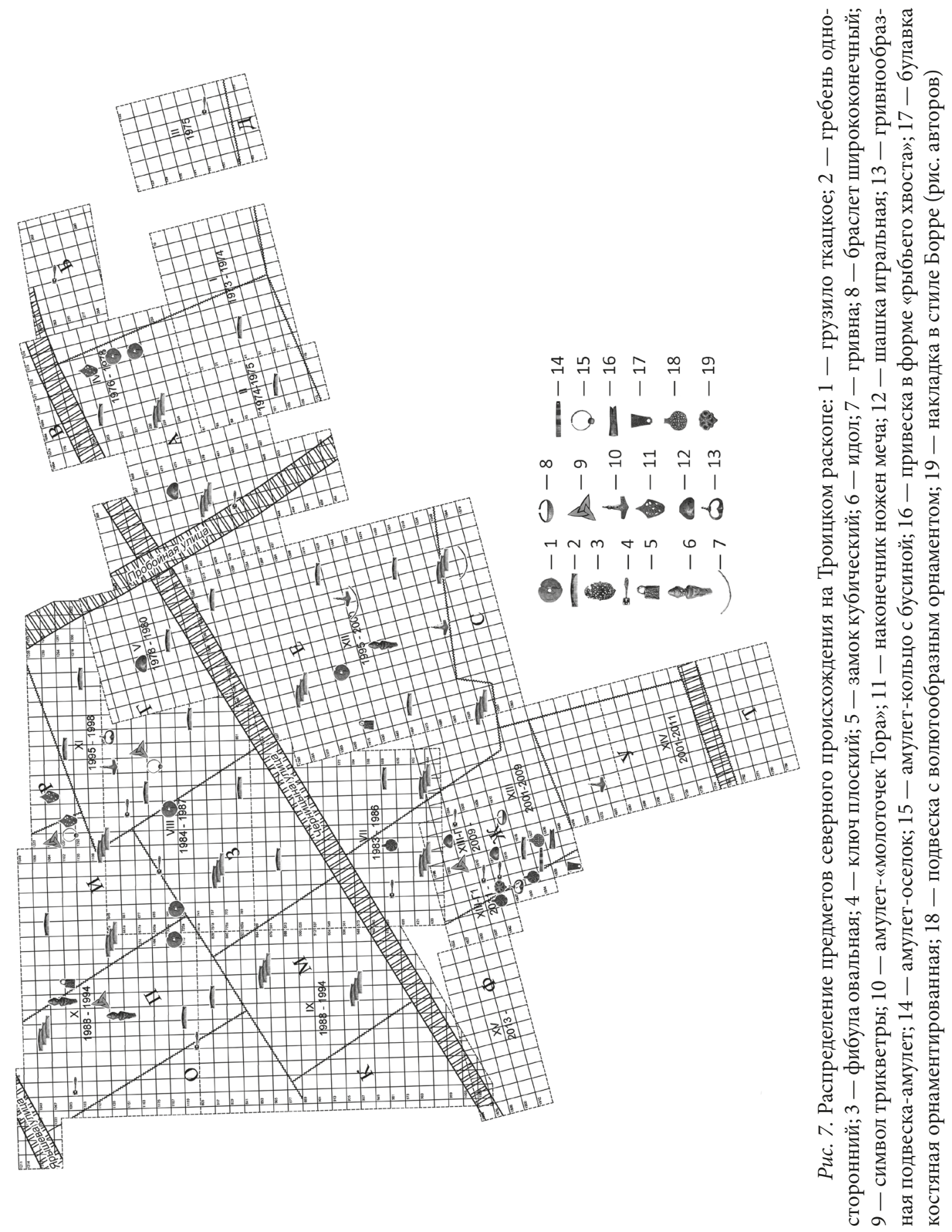
родцы избили насильников-варягов. Употребленное в летописи личное имя понималось некоторыми исследователями как искаженное древнесеверное слово Farmaðr - путешественник, или греческое $\pi \alpha \rho \alpha \mu \nu \alpha i$ - стражи, а сам двор представлялся им купеческой резиденцией или казармой ${ }^{111}$. Обе гипотезы были восприняты российской наукой ${ }^{112}$. Однако археология свидетельствует о свободном расселении скандинавов на территории города. Место избиения варягов оказывается скорее всего лишь двором, принадлежавшим некоему Парамону, а предлагаемая этимология необязательна ${ }^{113}$.

События 1015 г. не положили конец скандинавскому присутствию в Новгороде. Это произошло позднее, в результате социальных и политических изменений в жизни Восточной Европы. Известно, что Ипатьевская редакция «Повести временных лет» под 882 г. сообщает, что князь Олег возложил на Новгород варяжскую дань в 3000 гривен «мира деля»: 2000 из них шло в Киев, а 1000 раздавалась варягом непосредственно в городе. Такая практика сохранялась до смерти князя Ярослава Мудрого $^{114}$. Прекращение выплаты tributum pacis ${ }^{115}$ после 1054 г. стоит сопоставить с практически полным исчезновением скандинавских предметов из быта горожан во второй половине XI в. Отдельные северные артефакты этого времени известны в основном на периферии города. Именно в это время, но не ранее конца XI - начала XII в., используя образовавшуюся социальную нишу, в Новгороде мог появиться ладожский род Рогволдовичей скандинавского происхождения, который влился в городскую аристократию ${ }^{116}$, заняв усадьбы, где ранее могли проживать скандинавы.

В заключение коснемся причин невнимания историографии к скандинавскому компоненту в истории раннего Новгорода. В свое время Д. А. Авдусин вспоминал, что основатель Новгородской археологической экспедиции А. В.Арциховский не хотел признавать северный характер некоторых находок и боялся появления большого количества скандинавских древностей в ранних слоях города ${ }^{117}$. Такой страх стоит связать с самоцензурой сталинской эпохи. Позднее этот подход поддерживался историографической инерцией. В действительности присутствие скандинавов среди первых обитателей Новгорода не соответствует ни историографическим моделям, ни летописной версии. Оно отражает реальную историю города, сохраненную археологией.

111 Mikkola J.J. Fornry. Poromonĭ dvorŭ, fisl. Farmađr // Arkiv förnordisk filologi. 1907. T. 23 (3) (N. F. 19). S. 281; Ekblom R. Livvaktens gård i Jaroslav den Vises Novgorod // Kungliga Humanistiska Vetenskaps-Samfundets i Uppsala. 1952. S.21.

112 См. напр.: Мельникова Е. А. К предыстории Готского двора в Новгороде // Мельникова Е. А. Древняя Русь и Скандинавия. М., 2011. С. 373.

113 Подобным образом нормандская топонимика, связанная с именем Farmann, отражает, скорее всего, вторичное англо-скандинавское влияние, проявившееся не ранее XII в. (ср.: Beaurepaire de F. Les noms des communes et anciennes paroisses de la Manche. Paris, 1986. P.117; cp.: Adigard des Gautries J. Les noms de personnes scandinaves en Normandie de 911 à 1066. Lund, 1954. P.200-202, 361). Авторы благодарят Э. Ридель-Гранже (Университет Кан), за любезные консультации.

114 Ипатьевская летопись. С. 17, 114-115; Новгородская летопись. С. 107, 168.

115 Стефанович П.С. Загадочное известие летописи: древнейшая дань из Новгорода в Киев // Новгородский исторический сборник. 2010. № 12. С. 5-35.

116 Молчанов А. А. Новгородское боярство в X-XI вв.: славянский и скандинавский компоненты // Висы дружбы: сб. статей в честь Т. Н. Джаксон / под ред. Н. Ю. Гвоздецкой [и др.]. М., 2011. С. 269275.

117 Авдусин Д. А. Артемий Владимирович Арциховский и Новгород // Новгородские археологические чтения-1 / отв. ред. В. Л. Янин, П. Г. Гайдуков. Новгород, 1994. С. 29-30. 


\section{References}

Avdusin D. A. Artemii Vladimirovich Artsikhovskii i Novgorod. Novgorodskie arkheologicheskie chteniia 1. Eds V. L. Ianin, P. G. Gaidukov. Novgorod, Museum Publ., 1994, pp. 28-34. (In Russian)

Alekseev Iu. G. "Chernye liudi» Novgoroda i Pskova (k voprosu o sotsial'noi èvoliutsii drevnerusskoi gorodskoi obshchiny). Istoricheskie zapiski, 1979, vol. 103, pp. 242-279. (In Russian)

Beaurepaire de F. Les noms des communes et anciennes paroisses de la Manche. Paris, Picard, 1986. 253 p.

Carlie A. Forntida byggnadskult: Tradition och regionalitet i södra Skandinavien. Stockholm, Riksantikvarieambetets Forlag, 2004, 366 p.

Grinev A. M. Dereviannye konskie puty X v. s Nerevskogo raskopa. Arkheologicheskie vesti, 2017, iss.23, pp. 250-253. (In Russian)

Gushchin A.S. Pamiatniki khudozhestvennogo remesla drevnei Rusi X-XIII vv. Moscow, Leningrad, Gosudarstvennoe sotsial'no-èkonomicheskoe izdatel'stvo, 1936. 82 p. (In Russian)

Davidan O.I. Grebni Staroi Ladogi. Arkheologicheskii sbornik Gosudarstvennogo Ėrmitazha, 1962, iss.4, pp. 95-108. (In Russian)

Dzhakson T. "Strana gorodov" i ee stolitsa: Novgorod v kartine mira srednevekovykh skandinavov. Slověne, 2015, no. 1, pp. 170-179. (In Russian)

Dorofeeva T. S. O skandinavskikh kul'tovykh i magicheskikh predmetakh s Gorodishcha pod Novgorodom (po materialam raskopok raznykh let). Arkheologiia i istoriia Pskova i Pskovskoi zemli, 2016, iss.31, pp. 227-239. (In Russian)

Dorofeeva T. S. Skandinavskie "simvoly beskonechnosti" s Riurikova gorodishcha i iz novgorodskogo Sofiiskogo sobora. Rossiiskaia arkheologiia, 2016, no. 1, pp. 106-113. (In Russian)

Ekblom R. Livvaktens gård i Jaroslav den Vises Novgorod. Kungliga Humanistiska Vetenskaps-Samfundets i Uppsala, Årsbok 1952, pp. 17-31.

Hildebrand B.E., Hildebrand H. Teckningar ur svenska statens historiska museum. H.2. S.6. Stockholm, Samson \& Wallin, 1878. 12 p., $10 \mathrm{pl}$.

Faradzheva N.N., Tarabardina O. A., Gaidukov P. G. Usad'by Iaryshevoi ulitsy Liudina kontsa srednevekovogo Novgoroda v X v. (po materialam Troitskogo raskopa). Rus'v IX-XII vv.: obshchestvo, gosudarstvo, kul'tura. Eds N. A. Makarov, A. E. Leont'ev. Moscow, Vologda, Drevnosti Severa, 2014, pp. 134-160. (In Russian)

Kazakov A., Chernenko E. Chernigovskii detinets IX-XIII vv. v svete novikh arkheologicheskikh materialov. Chernigov u serednovichnii ta rannomodernii istorii TSentral'no-Skhidnoï Evropi. Ed. by O. B. Kovalenko. Chernigiv, Desnians'ka Pravda Publ., 2007, pp. 119-125. (In Russian)

Kainov S. Iu., Avdeenko E.E. Litye nakonechniki nozhen mechei (po materialam Troitskogo raskopa Novgoroda Velikogo). Arkheologicheskie vesti, 2012, iss. 18, pp. 145-151. (In Russian)

Kirpichnikov A. Early Ladoga during the Viking Age in the light of the international cultural. Vers l'Orient et vers l'Occident. Regards croisés sur les dynamiques et les transferts culturels des Vikings à la Rous ancienne. Dir. P. Bauduin, A. Musin. Caen, PUC, 2014, pp. 215-230.

Khvoshchinskaya N., Rybina E. Scandinavian objects from the excavations of Novgorod. Vers l'Orient et vers l'Occident. Regards croisés sur les dynamiques et les transferts culturels des Vikings à la Rous ancienne. Dir. P. Bauduin, A. Musin. Caen, PUC, 2014, pp. 245-256.

Kolchin B. A. Dendrokhronologiia Novgoroda. Trudy Novgorodskoi arkheologicheskoi èkspeditsii. Vol. 3. Eds A. V. Artsikhovskii, B. A. Kolchin. Materialy i issledovaniia po arkheologii SSSR. № 117. Moscow, AN SSSR Publ., 1963, pp. 5-103. (In Russian)

Kolchin B.A. Novgorodskie drevnosti. Reznoe derevo. Svod arkheologicheskikh istochnikov. Iss. E1-55. Moscow, Nauka Publ., 1971. 60 p.

Kolchin B. A., Xoroshev A.S. Mikhailovskii raskop. Arkheologicheskoe izuchenie Novgoroda. Eds B. A. Kolchin, V.L. Ianin. Moscow, Nauka Publ., 1978, pp.135-173. (In Russian)

Konovalov A. A., Eniosova N. V., Mitoian R. A., Saracheva T. G. Tsvetnye i dragotsennye metally i ikh splavy na territorii Vostochnoi Evropy v épokhu srednevekov'ia. Moscow, Vostochnaia literature Publ., 2008. 191 p. (In Russian)

Korzukhina G. F. Tur'i roga chernigovskikh kurganov. V kamne i v bronze. Sbornik statei v chest' A. Peskovoi. Eds A. E. Musin, O. A. Shcheglova. St. Petersburg, IIMK RAN Publ., 2017, pp. 620-634. (In Russian)

Kudriavtsev A. A. Zamki i kliuchi v material'noi kyl'ture Novgoroda. Diss. ... kand. ist. nauk.

Moscow, 2014. 253 p. (In Russian)

Łowmiański H. Słoweni nadilmenscy i początki Nowogrodu. Zapiski Historyczne, 1966, vol.XXXI, z.2, pp.7-41.

Lukin P. V. Novgorodskoe veche. Moscow, Indrik, 2014. 607 p. (In Russian) 
Medvedev A.F. Zagadochnaia nadpis' nachala XI v. iz Novgoroda. Slaviane i rus'. Ed. by E. I. Krupnov. Moscow, Nauka Publ, 1968, pp.437-439. (In Russian)

Mel'nikova E. A. Skandinavskie runicheskie nadpisi: teksty, perevod, kommentarii. Moscow, Nauka Publ., 1977. 276 p. (In Russian)

Mel'nikova E. A. Skandinavskie runicheskie nadpisi: novye nakhodki i interpretatsii. Teksty. Perevod. Kommentarii. Moscow, Vostochnaia literatura Publ., 2001. 495 p. (In Russian)

Mel'nikova E. A. K predystorii Gotskogo dvora v Novgorod. Mel'nikova E. A.Drevniaia Rus' i Skandinaviia: izbrannye trudy. Moscow, Universitet Dmitriia Pozharskogo Press, 2011, pp.371-395. (In Russian)

Mikheev S. M., Singkh V. K. Glagolicheskie i kirillicheskie bukvy na kosti vtoroi poloviny XI v. iz Novgoroda. Rossiiskaia arkheologiia, 2016, no. 1, pp.99-105. (In Russian)

Mikkola J. J. Fornry. Poromoni dvorŭ, fisl. Farmađr. Arkiv förnordisk filologi, 1907, t. 23 (3) (N. F. 19.), p. 281.

Molchanov A. A. Novgorodskoe boiarstvo v X-XI vv.: slavianskii i skandinavskii komponenty. Visy druzhby. Ed. by E. A. Mel'nikova. Moscow, Universitet Dmitriia Pozharskogo Press, 2011, pp. 269-275. (In Russian)

Musin A.E. Skandinavskoe iazychestvo na Vostoke po dannym arkheologii: obshchee i osobennoe. Rossiiskii arkheologicheskii ezhegodnik, 2012, no. 2, pp.555-602. (In Russian)

Musin A.E., Tarabardina O.A., Kokutsa L.V., Kublo Ė.K. Predmety s khristianskoi i iazycheskoi simvolikoi iz raskopok v Novgorode i Staroi Russe. Rossiiskii arkheologicheskii ezhegodnik, 2016, no. 5-6, pp. 157-170. (In Russian)

Nakhlik A. Tkani Novgoroda: opyt tekhnologicheskogo analiza. Trudy Novgorodskoi arkheologicheskoi èkspeditsii, vol.4. Eds A. V. Artsikhovskii, B. A. Kolchin. Materialy i issledovaniia po arkheologii SSSR, no. 123. Moscow, AN SSSR Publ., 1963, pp. 228-313. (In Russian)

Nosov E. N. Novgorod i Novgorodskaia okruga IX-X vv. v svete noveishikh arkheologicheskikh dannykh. Novgorodskii istoricheskii sbornik, 1984, no.2 (12), pp.3-38. (In Russian)

Nosov E. N. Novgorodskaia zemlia: Severnoe Priil'men'e i Povolkhov'e. Rus'v IX-X vekakh: arkheologicheskaia panorama. Ed. by N. A. Makarov. Moscow, Vologda, Drevnosti Severa, 2012, pp.93-121. (In Russian)

Nosov E. N., Plokhov A. V., Kvoshchinskaia N. V. Riurikovo Gorodishche: novye issledovaniia. St. Petersburg, Dmitrii Bulanin, 2017. 287 p. (In Russian)

Petrov M. I. Kostianoi predmet iz raskopa Nutnyi-IV v Velikom Novgorode. Arkheologiia Drevnei Rusi: aktual'nye problemy i otktytiia. Materialy mezhdunarodnoi konferentsii, posviashchennoi pamiati D.A.Avdusina. Eds E. A. Rybina, N. V. Eniosova. Moscow, State University Publ., 2018, p. 107. (In Russian)

Pokrovskaia L.V. Metallicheskie predmety skandinavskogo proiskhozhdeniia iz raskopok na Troitskom raskope: topografiia. $U$ istokov russkoi gosudarstvennosti: istoriko-arkheologicheskii sbornik. Eds E. N. Nosov, A.E. Musin. St. Petersburg, Dmitrii Bulanin, 2007, pp. 280-284. (In Russian)

Pokrovskaya L. Female costume from Early Novgorod and its ethno-cultural background: an essay of the reconstruction. Vers l'Orient et vers l'Occident. Regards croisés sur les dynamiques et les transferts culturels des Vikings à la Rous ancienne. Dir. P. Bauduin, A. Musin. Caen, PUC, 2014, pp. 101-112.

Price N.S. The Viking Way: Religion and War in Late Iron Age Scandinavia. Uppsala, Department of Archaeology, 2002. 435 p.

Radtke Ch. Der Schleswig-Mann - ein „Hausgeist“ aus Novgorod? Archäologische Nachrichten aus Schleswig-Holstein, 2010, Bd. 16, pp. 92-95.

Rybakov B. A. Russkoe prikladnoe iskusstvo X-XIII vekov. Leningrad, Avrora Publ., 1971. 128 p. (In Russian)

Rybina E. A. Die Funde als Spiegel des Lebens. Alltag im mittelalterlichen Novgorod. Novgorod. Das mittelalterliche Zentrum und sein Umland im Norden Ruslands. Hrsg. M. Müller-Wille, V. L. Janin, E. N. Nosov, E. A. Rybina. Neumünster, Wachholtz, 2001, pp. 197-224.

Rybina E. A. Torgovlia srednevekovogo Novgoroda. Istoriko-arkheologicheskie ocherki. Velikii Novgorod, Novgorod University Press, 2001. 389 p. (In Russian)

Rybina E. A., Khvoshchinskaia N.V. Eshche raz o skandinavskikh nakhodkakh iz raskopok Novgoroda. Dialog kul'tur i narodov srednevekovoi Evropy. Eds N. V. Kvoshchinskaia, A.E. Musin. St. Petersburg, Dmitrii Bulanin, 2010, pp. 66-78. (In Russian)

Sedova M. V. Iuvelirnye izdelija drevnego Novgoroda (X-XV vv.). Moscow, Nauka Publ., 1981. (In Russian)

Stefanovich P. S. Zagadochnoe izvestie letopisi: drevneishaia dan' iz Novgoroda v Kiev. Novgorodskii istoricheskii sbornik, 2010, no. 12, pp.5-35. (In Russian)

Shtakel'berg Iu. I. Glinianye diski iz Staroi Ladogi. Arkheologicheskii sbornik Gosudarstvennogo Ėrmitazha, 1962, vol. 4, pp. 109-115. (In Russian) 
Shchavelev A.S. „Plemena“ vostochnykh slavian: etapy zavoevaniia i stepen’ zavisimosti ot derzhavy Riurikovichei v X v. Rus' épokhi Vladimira Velikogo: gosudarstvo, tserkov', kul'tura. Ed. by N. A. Makarov, A. V. Nazarenko. Moscow, Vologda, Drevnosti Severa, 2017, pp. 24-48. (In Russian)

Smirnova L. Comb-making in medieval Novgorod (950-1450). An industry in transition. Oxford, Archaeopress, 2005. $334 \mathrm{p}$.

Staermose Nielsen K.-H. A Preliminary Classification of Shapes of Loomweights. Northern Archaeological Textiles, 2005, vol. VII, pp. 129-135.

Thunmark-Nylén L. Die Wikingerzeit Gotlands. T.2. Typentafeln. Stockholm, Kungliga vitterhets historie och antikvitets akademien, 1998. 17 p., $316 \mathrm{pl}$.

Thunmark-Nylén L. Die Wikingerzeit Gotlands. T. 4: 1. Katalog. Stockholm, Kungliga vitterhets historie och antikvitets akademien, 2000. $487 \mathrm{p}$.

Toropov S.E. Sluchainye nakhodki skandinavskikh predmetov épokhi vikingov v Priil'men'e: iz kollektsii Novgorodskogo muzeia. Arkheologicheskie vesti, 2014, iss. 20, pp. 225-252. (In Russian)

Tianina E. A. Amulety iz zubov i kostei zhivotnykh srednevekovogo Novgoroda. Arkheologicheskie vesti, 2011, iss. 17, pp. 159-168. (In Russian)

Ur'eva A.F., Chernykh N.B. Dendroshkaly Novgoroda: opyt komp'iuternoi obrabotki. Novgorod i Novgorodskaia zemlia: istoriia i arkheologiia, 1995, iss.9, pp. 106-114. (In Russian)

Voronova M. A. Raskopki u Likhudova korpusa v Novgorodskom kremle. Novgorod i Novgorodskaia zemlia: istoriia i arkheologiia, 1989, iss. 1, pp.73-75. (In Russian)

Yanin V.L. 70 let novgorodskoi arkheologii. Itogi i perspektivy. Novgorodskie arkheologicheskie chteniia 2. Eds V.L. Ianin, A. S.Xoroshev, E. A. Rybina. Velikii Novgorod: Museum Publ., 2004, pp. 10-13. (In Russian)

Yanin V. L. Srednevekovyi Novgorod: ocherki arkheologii i istorii. Moscow, Nauka Publ., 2004. 415 p. (In Russian)

Yanin V. L., Aleshkovskii M.X. Proiskhozhdenie Novgoroda (k postanovke problemy). Istoriia SSSR, 1971, no. 2, pp. 32-61. (In Russian)

Yanin V. L., Kolchin B. A., Mironova V. G., Rybina E. A., Xoroshev A. S. Novgorodskaia èkspeditsiia. Arkheologicheskie otkrytiia 1977. Ed. by B. A. Rybakov. Moscow, Nauka Publ., 1978, pp.36-37. (In Russian)

Yanin V.L., Xoroshev A.S., Rybina E. A., Sorokin A. N., Stepanov A. M., Pokrovskaia L. V. Raboty v Liudinom kontse Velikogo Novgoroda. Novgorod i Novgorodskaia zemlia: istoriia i arkheologiia, 2006, iss. 20, pp. 5-14. (In Russian)

Yanin V.L., Rybina E. A., Pokrovskaia L. V., Stepanov A. M., Singh V.K., Tianina E. A. Raboty v Liudinom kontse Velikogo Novgoroda v 2013 godu. Novgorod $i$ Novgorodskaia zemlia: istoriia $i$ arkheologiia, 2014, iss. 28, pp. 22-39. (In Russian)

Yanin V.L., Rybina E. A., Pokrovskaia L. V., Singh V.K., Stepanov A. M., Tianin E. A. Raboty v Liudinom kontse Velikogo Novgoroda v 2014 godu. Novgorod i Novgorodskaia zemlia: istoriia i arkheologiia, 2015, iss.29, pp. 51-65. (In Russian)

Yanina S. A. Nerevskii klad kuficheskikh monet X v. Trudy Novgorodskoi arkheologicheskoi èkspeditsii. Vol. 1. Eds A. V. Artsikhovskii, B. A. Kolchin. Materialy i issledovaniia po arkheologii SSSR, no. 55. Moscow, AN SSSR Publ., 1956, s. 180-207. (In Russian)

Yanina S. A. Vtoroi Nerevskii klad kuficheskikh monet X v. Trudy Novgorodskoi arkheologicheskoi èkspeditsii, vol.3. Eds A.V.Artsikhovskii, B. A. Kolchin. Materialy i issledovaniia po arkheologii SSSR, 1963, no. 117, Moscow, AN SSSR Publ., p. 288-331. (In Russian)

Yanson I. Skandinavskie nakhodki IX-X vv. s Riurikova gorodishcha. Velikii Novgorod v istorii srednevekovoi Evropy. Eds A. A. Gippius, E. N. Nosov, A. S. Xoroshev. Moscow, Russkie slovari Publ., 1999, pp. 18-38. (In Russian)

Статья поступила в редакцию 24 апреля 2018 г. Рекомендована в печать 12 марта 2019 г. Received: April 24, 2018 Accepted: March 12, 2019 


\title{
РЕЦЕНЗИИ
}

\section{Очередная биография первого русского царя}

\author{
B. В. Шапочник
}

Для цитирования: Шапошник В.В. Очередная биография первого русского царя // Вестник Санкт-Петербургского университета. История. 2019. Т. 64. Вып. 2. С. 786-794. https://doi.org/10.21638/11701/spbu02.2019.219

В 2018 г. в серии «Жизнь замечательных людей» вышла новая книга известного историка Д. М. Володихина, посвященная первому русскому царю - «Иван IV Грозный: Царьсирота». К сожалению, в работе много неточностей, некоторые положения автора недостаточно обоснованы, нарушается последовательность событий. Так, например, автор относит все московские пожары 1547 г. к одному месяцу - апрелю, путает ход боевых действий начального периода Ливонской войны, пишет о том, что сначала было Московское восстание, затем венчание Ивана IV на царство. Неубедительны выводы историка о добровольном пострижении великой княгини Соломонии Юрьевны Сабуровой, о стремлении представителей русской аристократии к престолу, о дипломатической деятельности Грозного. Вместе с тем в книге Д. М. Володихина есть интересные, удачные наблюдения и выводы. Среди них размышления исследователя о причинах Ливонской войны, о введении, целях и первоначальной направленности опричнины, о «заимствовании» жестокости к подлинным и мнимым политическим оппонентам из Западной Европы и др. Однако впечатление серьезно портят постоянные отсылки к «сиротству» и «артистизму», которые якобы и определяли действия царя Ивана. Все эти «красивости» уместны в художественной литературе, но не в историческом исследовании, биографии. Трудно отделаться и от впечатления, что книга готовилась наспех, отсюда и неточности. Особенно это касается нарушения последовательности событий. Тем не менее эта книга Д. М. Володихина найдет своих заинтересованных читателей, которые, ознакомившись с ней, захотят глубже вникнуть в тему и обратятся к другим исследованиям, посвященным интереснейшей эпохе правления первого русского царя. Ключевые слова: Иван Грозный, Д.М.Володихин, биография, сиротство, опричнина, венчание на царство.

Вячеслав Валентинович Шапошник - д-р ист. наук, проф., Санкт-Петербургский государственный университет, Российская Федерация, 199034, Санкт-Петербург, Университетская наб., 7-9; v.shaposhnik@spbu.ru

Vyacheslav V. Shaposhnik - Doctor in History, Professor, St. Petersburg State University, 7-9, Universitetskaya nab., St. Petersburg, 199034, Russian Federation; v.shaposhnik@spbu.ru

() Санкт-Петербургский государственный университет, 2019 


\section{V.Shaposhnik}

For citation: Shaposhnik V.V. Another Biography of the First Russian Tsar. Vestnik of Saint Petersburg University. History, 2019, vol. 64, issue 2, pp. 786-794.

https://doi.org/ 10.21638/11701/spbu02.2019.219 (In Russian)

In 2018, a new book by a famous historian D. M. Volodikhin dedicated to the first Russian Tsar - "Ivan IV the Terrible: Orphan Tsar" was published in the series "Life of Outstanding People". Unfortunately, the work contains a range of inaccuracies, some of the author's suggestions are not substantiated, a sequence of events is distorted. Thus, for example, the author dates all the fires in Moscow in 1547 by the same month - April; mixes up military activities of the initial period of Livonian War; states that Moscow Mutiny took place before the coronation of Ivan IV. Similarly, the historian's conclusions on the voluntary taking the veil by the Grand Princess Solomonia Saburova, on striving for the throne by some Russian noblemen, on diplomatic activity of Ivan the Terrible seem to be unconvincing. That said, the book by D. M. Volodikhin includes some interesting and proper observations and conclusions. However, the impression is significantly marred by persistent references to "orphanage" and "artistry". Such embellishments are appropriate in fiction, but not in a historical biography. Also, it's hard to escape the impression that the book was prepared in haste, which resulted in inaccuracies that can't benefit an academic research. Such mistakes could have easily been avoided by addressing primary sources. At the same time, we believe that this book by D. M. Volodikhin will find its audience who, having familiarized themselves with it, would like to go deeper into the subject and turn to other studies dedicated to a very interesting period of the reign of the first Russian Tsar.

Keywords: Ivan the Terrible, D. M. Volodikhin, biography, orphanage, oprichnina, coronation.

В 2018 г. вышла новая книга известного историка Д. М. Володихина, посвященная Ивану Грозному ${ }^{1}$. Необходимо отметить, что это далеко не первое обращение исследователя к фигуре первого русского царя. Можно вспомнить о том, что в последние годы ученый выпустил в свет несколько биографий этого правителя ${ }^{2}$. И для издательства «Молодая гвардия» и серии «Жизнь замечательных людей» царь Иван также не новый герой ${ }^{3}$. Сразу же оговоримся, что обращение автора к одному историческому деятелю в нескольких исторических работах является совершенно нормальным явлением, тем более к такому многогранному, как Иван Грозный, количество биографий которого огромно. Несколько смущает другое: для авторского стиля Д. М. Володихина, по крайней мере в данном случае, характерно наличие подзаголовков, что более полно определяет то, о чем или о ком рассказывается в книге. В случае с книгами Д. М. Володихина, посвященными первому русскому царю, подзаголовки, как легко убедиться, разные.

Поставим себя на место неискушенного в отечественной истории человека, который просто интересуется биографиями выдающихся исторических деятелей. Для такого читателя сразу же становится очевидным, что книга посвящена Ивану

1 Володихин Д. М. Иван IV Грозный: Царь-сирота. М., 2018.

2 См., например: Володихин Д. М. Иван Грозный: Бич Божий. М., 2006; Володихин Д. М. Грозный царь московитов: Артист на престоле. СПб., 2014.

3 Флоря Б. Н. Иван Грозный. М., 1999. 
Грозному. Однако дальше он видит: «Бич Божий», что скорее всего навеет ассоциации о жестокости русского монарха. Предположим далее, что этот же читатель обратится к следующей биографии царя Ивана и увидит подзаголовок «Артист на престоле», который, как представляется, может вызвать определенное недоумение, так как подзаголовки различные, хотя очевидно, что речь идет об одном и том же историческом деятеле и авторстве одного и того же исследователя. Но вот в руки любознательного читателя попадает и третья биография, где он читает: «Царьсирота», это уже третий вариант, отличающийся от двух первых случаев.

Итак, неискушенный читатель, держа в руках три книги одного автора, посвященные одному историческому персонажу, оказывается в некотором замешательстве. Если в первом случае, как можно предположить, основное внимание будет уделено жестокости и наказанию, то во втором речь пойдет об «артисте» и «артистизме». Для правителя это скорее нечто негативное, сходное с «фиглярством». Думаем, подобный подзаголовок подошел бы, например, к биографии римского императора Нерона. Хотя можно, конечно, вспомнить о том, что, по словам Шекспира, «весь мир - театр, а люди в нем актеры». Но в таком случае подобный подзаголовок можно дать любой биографии или, в более частном случае, любой биографии монарха - при шекспировском понимании каждый из них окажется «артистом на престоле». И наконец, «царь-сирота». Это уже совсем из другой «оперы». В двух первых случаях подзаголовок имел скорее негативный для героя повествования смысл, в третьем же - «сиротинушку» надо пожалеть, хоть он и царь, хоть он и Иван Грозный.

Итак, три книги одного автора об одном историческом деятеле с разными подзаголовками, подразумевающими еще до начала чтения различное отношение к герою повествования. Подобное способно только запутать читателя. Но оставим в стороне «Бич Божий» и «Артиста на престоле», поговорим о «Царе-сироте», выпущенном в свет в 2018 г.

Уже в первой главе, названной «Сиротский театр Московского царства» узнаем, что, скорее всего, если бы была возможность, то мы бы имели в книге два подзаголовка: и «сироту» и «артиста». Как же может быть иначе, если «на дне личности грозного правителя лежит тяжкое сиротство ... оно дотянулось холодными щупальцами из младенчества до возраста зрелости и заставило совершать поступки, гремевшие над Россией ...» (с. 7-8). Это о сиротстве. А об артистизме чуть дальше: Иван - это «Гамлет на троне», для которого «горячая кровь... выглядела киноварью... Блистательный артист... забывал о целях игры и выше ставил произведенное на публику впечатление, нежели практический результат». Для царя, оказывается, главным был не реальный эффект предпринятых действий, а «признание» и «внимание» (с.9-10). Как можно видеть, уже в самом начале своей книги Д.М. Володихин определяет мотивы действий Грозного - сиротство и артистизм. Что и говорить, написано красиво, остается только один вопрос, как историк выяснил, что именно это и определяло в основном действия царя? На основании чего он пришел к таким выводам? Остается только поверить на слово.

После первой главы начинается собственно повествование. Рассказывая о браке великого князя Василия Ивановича с Соломонией Сабуровой, историк пишет о том, что отсутствие прямого наследника угрожало России повторением событий $\mathrm{XV}$ в., когда в схватке за великокняжеский престол сошлись князья московского 
дома (с. 12). В этой связи замечу, что у Василия был наследник - младший брат удельный князь Юрий Иванович Дмитровский. В случае бездетной смерти великого князя престол переходил к нему. Очевидно, что «претенденты из служилой знати, в глазах которых Московский дом был не самым родовитым на Руси», ничего противопоставить князю Юрию не смогли бы. С другой стороны, именно рождение наследника у Василия III должно было привести к вспышке придворной борьбы в том случае, если бы великий князь умер до его зрелости. Надо ли упоминать о том, что в действительности, как известно, все так и произошло.

В истории с пострижением первой жены великого князя Василия Д. М. Володихин склонен доверять известиям официальных летописей о ее добровольном уходе в монастырь. Якобы Сабурова «знала об угрозе смуты, нависшей над Россией» (с. 14-15). Но дело в том, что никакой реальной угрозы смуты в действительности не было, а летописи... Что же могли писать официальные летописи? То, что великая княгиня пострижена насильно и, соответственно, незаконно? Что великий князь Иван IV, родившийся во втором браке, является, таким образом, бастардом? Очевидно, что официальные летописи будут писать то, что является официальной точкой зрения в момент их создания.

Склонившись к версии о добровольном пострижении Соломонии Сабуровой, Д.М.Володихину не удается вразумительно объяснить, с чем связано дело о «неплодстве» великой княгини. Историк приводит два аргумента в пользу своего предположения: во-первых, упоминавшиеся в деле «наговоренные составы от ворожей» были «ароматическими притираниями», с помощью которых женщина пыталась вернуть внимание мужа (с. 20). Но если великая княгиня постриглась добровольно, то зачем ей было возвращать «внимание мужа»? Второй аргумент исследователя более основателен. По его мнению, существовала влиятельная группировка знати, которая стремилась не допустить к власти Юрия Дмитровского, так как он привел бы на ведущие места в Москве своих приближенных, нарушив порядок, сложившийся при дворе. Это вполне возможно. Однако дальнейшие рассуждения автора книги о связи князя Юрия с крымскими татарами едва ли могут быть серьезно обоснованы (с.21). Можно видеть, что мнение ученого о добровольности пострижения Соломонии, о ее “самопожертвовании» не имеют доказательной силы. Даже если принять во внимание вполне вероятное наличие группы знатных лиц, стремившихся не допустить Юрия Ивановича к власти, нет оснований говорить о добровольном уходе великой княгини в монастырь. Причем странным образом автор несколькими страницами ниже пишет о «некрасивых обстоятельствах разводного процесса» (с. 27). Но если Сабурова постриглась добровольно, то о каких «некрасивых обстоятельствах» можно говорить?

В книге имеются и некоторые неточности. Так, перечисляя наиболее влиятельных княжат, которые «преобладали в Боярской думе и на воеводских постах в армии», Д. М. Володихин упоминает князей Звенигородских (с. 26-27). Но в исследовании А.А.Зимина показано, что в период правления Василия III и Елены Глинской Звенигородские не играли значительной роли ${ }^{4}$. Упоминая переговоры между Юрием Дмитровским и Андреем Михайловичем Шуйским, ученый зачем-то пишет о том, что «оба они могли считаться претендентами на престол». И если с князем

${ }^{4}$ Зимин А.А. Формирование боярской аристократии в России во второй половине XV первой трети XVI в. М., 1988. С. 56-58. 
Юрием все понятно, то А. М. Шуйский — «аристократ исключительной знатности» (c. 28). Проблема в том, что таких «исключительно знатных» аристократов при дворе было много, и при таком подходе придется считать чуть ли не каждого члена Думы «претендентом на престол», что доводит ситуацию до полного абсурда. При подавлении мятежа Андрея Старицкого, по словам Д. М. Володихина, были казнены «некоторые крупные фигуры» (с. 28). Интересно было бы узнать, о каких «крупных фигурах» идет речь. Как известно, повешены были тридцать новгородских помещиков, перешедших на сторону Старицкого 5 . Среди них не было особо «крупных фигур». Другое дело, что среди казненных находились некоторые представители знатных родов (Колычевы и князь Ярославский) ${ }^{6}$, но таких в России были сотни, если не тысячи. Те же, кого можно назвать «крупными фигурами», думцы князя Андрея, отделались торговой казнью и заключением, которое, впрочем, оказалось сравнительно кратким - они были освобождены в апреле 1538 г., после смерти Елены Глинской ${ }^{7}$.

Рассуждая об опасностях для власти Ивана IV после смерти великой княгини Елены, Д. М. Володихин упоминает о Старицких, причем «взрослый претендент на престол... это очень опасный конкурент» (с.31). Проблема в том, что из всех Старицких мужского пола в живых в то время был только князь Владимир Андреевич, двоюродный брат Ивана IV. Но он, во-первых, находился в заключении, а во-вторых, был еще младше великого князя ${ }^{8}$. Следовательно, никаким «взрослым претендентом на престол» он быть никак не мог.

Историк много рассуждает об опасностях, которые подстерегали маленького Ивана Васильевича. Получается, что вся русская аристократия того времени могла претендовать на престол. В таких страшных условиях, «мальчик Иван... удержал престол и не погиб только потому, что Бог не дал... высокородным господам составить альянс, да сменить его на кого-то из своих» (с. 33). Подобные умозаключения вызывают серьезные сомнения. Ивана IV реально не на кого было менять. Даже если и допустить, что все наши аристократы спали и видели себя на троне, то все равно - прав на трон, в обход московской княжеской семьи, у них не было. Серьезные сомнения вызывает заявление историка о том, что чем взрослее становился Иван, тем меньше «ценности» в нем было для боярских группировок (с. 34). Полагаю, что все происходило как раз наоборот: «ценность» великого князя для враждующих боярских кланов только возрастала с его взрослением. В самом деле, теперь можно было «понравиться» государю, получить его расположение и использовать его в придворной борьбе. Ведь это великий князь, хотя еще и не совсем полновластный.

Странным образом все московские пожары 1547 г. Д.М.Володихин относит к апрелю месяцу - 12, 20 и 21 числам. Соответственно, и восстание, получается, произошло в апреле (с. 48-49). Здесь необходимо отметить, что первые два пожара действительно были в апреле, но самый разрушительный, великий пожар, и последовавшее за ним восстание случились в июне 1547 г. ${ }^{9}$ Похожая ошибка есть и на

\footnotetext{
5 Полное собрание русских летописей (ПСРЛ). Т. 29. М., 2009. С. 30.

6 ПСРЛ. Т. 8. М., 2001. С. 295; Переписка Ивана Грозного с Андреем Курбским. Л., 1979. С. 27.

7 ПСРЛ. Т. 34. М., 1978. С. 26.

8 Там же. С. 25.

9 ПСРЛ. Т.29. С. 51.
} 
293 странице повествования. Оказывается, Псков был сдан королю Стефану Баторию князем В.И. Телятевским в 1579 г. Очевидно, речь должна идти о Полоцке, действительно захваченном Баторием в 1579 г. ${ }^{10}$ Касательно Избранной Рады исследователь отмечает, что Сильвестр и Адашев «представляли интересы крупных аристократических группировок», хотя и не входили в круг высокородной знати (с. 52). Но чуть ниже историк пишет о том, что Рада была «буфером» между царем, аристократами и Церковью. Здесь согласовывались позиции аристократических группировок (с.53). Но если, как пишет Д. М. Володихин, основные ее участники выражали интересы аристократии, то зачем этой самой аристократии нужен был «буфер»?

Рассказывая о начале Ливонской войны, исследователь пишет о том, что «первым пал Юрьев», а затем Нарва (с. 111). Но в действительности первым в мае 1558 г. взяли как раз Нарву, а Юрьев только в июле того же года ${ }^{11}$. Причем из дальнейшего изложения становится ясно, что историк знает, что Нарву взяли в мае. Но тогда ситуация совсем запутывается: если все таки, по мнению Д. М. Володихина, Юрьев взяли первым, то когда же это произошло? В феврале или марте? Взятие Полоцка русскими войсками под пером ученого становится поистине судьбоносным: в этот день Иван Васильевич навсегда избавился «от разрушительного сомнения, рожденного сиротской долей». Сомнения эти, как можно понять из текста книги, состояли в оценке собственных способностей к государственной деятельности (с. 127). Все это непонятно, на чем основано.

Слишком категоричным представляется утверждение о том, что «аристократические семейства... отнюдь не планировали изменить государственный строй России» (с. 139). В самом деле, русская аристократия была прекрасно осведомлена, например, о ситуации в Великом княжестве Литовском, где власть монарха была очень серьезно ограничена. К тому же некоторые представители русской знати были связаны родством с литовской великокняжеской династией и магнатами. Учитывая это, не стоит, видимо, однозначно утверждать, что у нашей отечественной аристократии не было планов по изменению государственного строя. Думается, что ситуация здесь была неоднозначной, сложной и нуждается в дальнейшем изучении.

Интересные размышления о причинах введения опричнины и ее направленности Д. М. Володихин завершает тирадой о «черном театре опричнины», «цареюроде с блистательным умом, обширной ученостью и холодным сердцем» (с. 153). В этом месте у нас действует «артист на престоле». Спустя несколько десятков страниц появляется сирота, который «выстроил вокруг себя причудливое здание. В стенах его сироту берегли пуще глаза, в стенах его сироту слушали с неослабным напряжением сил» (с. 173). Думаю, что все это может быть уместно в художественной литературе, но не в научной биографии. Что-то карикатурное появляется под пером автора при рассказе о дипломатической деятельности Ивана Грозного. Здесь мы снова встречаемся с «актером», даже скорее с «фигляром»: впечатление, произведенное царем на окружающих и соседние державы, значили для него не меньше (если не больше), чем успех переговоров. «Театральная поза, амбиция... вели его

10 Зимин А.А. В канун грозных потрясений: Предпосылки первой Крестьянской войны в России. М., 1986. С. 56.

${ }^{11}$ ПСРЛ. Т. 13. М., 2000. С. 295, 304. 
ум к выходкам и балаганным трюкам, но не позволяли проявить твердость в намерениях и действиях» (с. 211).

Удивление вызывает небрежность исследователя, которую нельзя объяснить. Так, возвращаясь к событиям 1547 г., он пишет, что в этом году был большой бунт, вызванный самовольством аристократии, после его подавления «последовали принятие царского титула и женитьба на Анастасии Захарьиной-Юрьевой» (с. 318). Получается, что сперва произошло восстание, а уже затем венчание на царство и свадьба с Анастасией. Но это далеко не так: венчание на царство произошло в январе 1547 г. $^{12}$, свадьба - в феврале ${ }^{13}$, а восстание в июне ${ }^{14}$.

Что касается замечаний Д. М. Володихина в мой адрес, то позволю себе его адресовать к своей книге, в которой подробно рассматриваются представления о власти царя в России XVI в. ${ }^{15}$ Сам исследователь пишет, что царь не связан законом и полновластен в отношении подданных. Однако, продолжает историк, если царь греховен, если он отступает от веры, то его «следует поменять на другого, лишенного этих недостатков» (С.45). Хочется спросить, а кто будет «менять» царя, кто из подданных возьмет на себя такую ответственность? Сам Д. М. Володихин, споря со мной, утверждает, что для правителей нравственность задается верой, а вера опирается на учение Церкви. Далее историк пишет о том, что опричнину Церковь не одобрила, митрополит Афанасий опричнину не поддержал, а митрополит Филипп публично требовал отменить ее (с.327). Замечу на это лишь следующее: я нигде не писал о том, что Церковь поддержала опричнину и многочисленные казни. Афанасий, скорее всего, действительно не поддерживал опричнину, но и не выступал против нее. Не случайно митрополит покинул свой престол не при ее введении, а спустя год с лишним, в мае 1566 г. ${ }^{16}$ Филипп (Колычев) же стал митрополитом уже во время опричнины, летом 1566 г., хотя отказывался какое-то время, настаивая на ее отмене. Тем не менее его удалось уговорить занять данный пост. Публично он выступил против казней спустя длительное время, в начале 1568 г. В результате его лишили сана, отправили в заключение, в котором он и погиб ${ }^{17}$. Осужден он был церковным собором. Можно спорить о характере этого собора и о том, насколько были запуганы или подкуплены его участники, но факт остается фактом. Кроме того, Церковь как организация в XVI в. не выступала против политики Ивана Грозного, не призывала «поменять» царя.

Безусловно, в новой книге Д.М.Володихина есть интересные, удачные наблюдения и выводы. Так, автор видит в опричнине военно-административную реформу, вызванную неудачами на театре военных действий (С. 150). Мнение автора представляется заслуживающим внимания, тем более что Д. М.Володихин специально занимался историей воеводского корпуса в период правления первого рус-

12 ПСРЛ. Т.29. С. 49

13 Там же. С. 51.

14 Там же. С. 54.

15 Шапошник В.В. Церковно-государственные отношения в России в 30-80-е годы XVI века. СПб., 2006. С. 433-540.

16 ПСРЛ. Т. 13. С. 401.

17 Колобков В.А. Митрополит Филипп и становление московского самодержавия: Опричнина Ивана Грозного. СПб., 2004. С. 263-349; Зимин А. А. Опричнина Ивана Грозного. М., 1964. С. 212-259; Скрынников Р. Г. Царство террора. СПб., 1992. С. 323-341. 
ского царя ${ }^{18}$. Причины Ливонской войны исследователь связывает с «продуманной, логически объяснимой стратегией», которая базировалась на слабости Ливонского ордена, стремлении получить земли с крестьянами, которые можно раздать в поместья, враждебной по отношению к России политикой самого Ордена и религиозными мотивами (с. 108-109). Построения историка вполне логичны, хотя в историографии существуют и другие мнения о причинах начала войны и первоначальных задачах русского правительства ${ }^{19}$. Интересными мне кажутся размышления автора о «заимствовании» жестокости к подлинным и мнимым политическим оппонентам из Западной Европы (с. 178-181). В самом деле, на Руси до Ивана Грозного не было столь масштабных репрессий ${ }^{20}$. Можно вспомнить и рассказ об испанской инквизиции, на который в свое время ссылался архиепископ Геннадий Новгородский ${ }^{21}$.

Однако впечатление серьезно портят постоянные отсылки к «сиротству» и «артистизму», которые якобы и определяли действия царя Ивана. Мы ведь в самом деле никогда точно не узнаем, в какой степени раннее сиротство повлияло на Грозного. То же относится и к артистизму его натуры. Трудно отделаться и от впечатления, что книга готовилась наспех, отсюда и неточности, которые не украшают исследование. Особенно это касается нарушения последовательности событий. От неточностей можно было бы избавиться, обратившись к историческим источникам. Думаю, что данная работа исследователя не является научной биографией, скорее это художественно-научное сочинение.

Вместе с тем считаю, эта книга Д. М. Володихина найдет своих заинтересованных читателей, некоторые из которых, ознакомившись с ней, захотят поглубже вникнуть в тему и обратятся к другим исследованиям, посвященным интереснейшей эпохе правления первого русского царя.

\section{References}

Alekseev A.I. Religioznye dvizheniia na Rusi poslednei treti XIV - nachala XVI v.: strigol'niki $i$ zhidovstvuyuschie. Moscow, Indrik, 2012, 560 p. (In Russian)

Veber D. I., Filyushkin A. I. “Ot ordena ostalos' tol'ko imya ...". Sud'ba i smert' nemetskikh rytsarei v Pribaltike. St. Petersburg, Nauka Publ., 2018, 247 p. (In Russian)

Volodikhin D. M. Groznyi tsar moskovitov: Artist na prestole. St. Petersburg, Amfora, 2014, 256 p. (In Russian)

Volodikhin D. M. Ivan IV Groznyi: Tsar-sirota. Moscow, Molodaia gvardiia, 2018, 341 p. (In Russian)

Volodikhin D. M. Ivan Groznyi: Bich Bozhii. Moscow, Veche, 2006, 384 p. (In Russian)

Volodikhin D. M. Sotsial'nyi sostav russkogo voevodskogo korpusa pri Ivane IV. St. Petersburg, Peterburgskoe Vostokovedenie, 2011, 296 p. (In Russian)

Zimin A. A. V kanun groznykh potriasenii: Predposylki pervoi Krest'ianskoi voiny v Rossii. Moscow, Mysl', 1986, 333 p. (In Russian)

Zimin A. A. Oprichnina Ivana Groznogo. Moscow, Mysl', 1964, 535 p. (In Russian)

Zimin A. A. Formirovanie boyarskoi aristokratii v Rossii vo vtoroi polovine XV - pervoi treti XVI v. Moscow, Nauka Publ., 1988, 350 p (In Russian) 2011.

18 Володихин Д. М. Социальный состав русского воеводского корпуса при Иване IV. СПб.,

19 Вебер Д. И., Филюшкин А. И. «От ордена осталось только имя...». Судьба и смерть немецких рыцарей в Прибалтике. СПб., 2018. С. 174, 217-226.

20 Рогов В.А. История уголовного права, террора и репрессий в Русском государстве XVXVII вв. М., 1995. С. 109-157.

21 Алексеев А.И. Религиозные движения на Руси последней трети XIV - начала XVI в.: стригольники и жидовствующие. М., 2012. С. 269-270. 
Kolobkov V.A. Mitropolit Filipp i stanovlenie moskovskogo samoderzhaviia: Oprichnina Ivana Groznogo. St. Petersburg, Aleteia, 2004, 640 p. (In Russian)

Rogov V. A. Istoriia ugolovnogo prava, terror i repressii v Russkom gosudarstve XV-XVII vv. Moscow, Yurist Publ., 1995, 288 p. (In Russian)

Skrynnikov R. G. Tsarstvo terrora. St. Petersburg, Nauka Publ., 1992, 573 p. (In Russian)

Florya B. N. Ivan Groznyi. Moscow, Molodaia gvardiia Publ., 1999, 403 p. (In Russian)

Shaposhnik V.V. Tserkovno-gosudarstvennye otnosheniia v Rossii v 30-80-e gody XVI veka. St. Petersburg, St. Petersburg University Press, 2006, 569 p. (In Russian)

Статья поступила в редакцию 22 июля 2018 г.

Рекомендована в печать 12 марта 2019 г.

Received: July 22, 2018

Accepted: March 12, 2019 


\title{
Новые приключения историка Георгия Вернадского
}

\author{
А. Ю. Дворниченко
}

Для цитирования: Дворниченко А.Ю. Новые приключения историка Георгия Вернадского // Вестник Санкт-Петербургского университета. История. 2019. Т.64. Вып. 2. С.795-812. https://doi.org/10.21638/11701/spbu02.2019.220

Жизнь и творчество выдающегося историка русского зарубежья Георгия Владимировича Вернадского - своего рода странствование сквозь время и пространство, события и эпохи, изобилующее драматическими коллизиями. Не менее напряженным оказался и процесс изучения его жизни и творчества, начавшийся в России только в начале 90-х гг. ХХ в. - до этого времени имя «младшего Вернадского» в СССР было фактически под запретом. Продолжается это изучение и в наши дни. В 80-е гг. XX в. единственным исследованием, посвященным жизни и творчеству Вернадского, была работа американского историка Чарльза Гальперина. Собственно, им было создано в те годы два труда: сравнительно небольшая статья и статья монографического формата. Эти работы составляют основу изучения жизни и творчества Г. В. Вернадского в американской историографии и ныне. Рецензия посвящена анализу перевода на русский язык и публикации работы Гальперина 1985 г. совместно с недавно вышедшей в свет статьей о современных достижениях в изучении Вернадского. Автор рецензии подверг критике качество перевода работы американского автора и остановился на ряде спорных проблем. На оценку творчества русского историка Гальпериным сильно повлияло отрицательное отношение к евразийству. Между тем, по мнению автора рецензии, евразийство Вернадского, не имея отношения к политической борьбе, отнюдь не принижает значения его концепции истории России, а, наоборот придает ей оригинальность и убедительность. Проявившаяся в последнее время тенденция в работах Гальперина более позитивной оценки творчества Вернадского должна получить дальнейшее развитие. Удивление вызывает его поддержка сомнительных рассуждений некоторых современных украинских авторов об украинской идентичности Георгия Вернадского. Вывод статьи таков: работа известного американского русиста, игравшая уникальную роль в изучении творчества Г. В. Вернадского в последней четверти XX - начале XXI в.,

Андрей Юрьевич Дворниченко - д-р ист. наук, проф., Институт истории, Санкт-Петербургский государственный университет, Российская Федерация, 199034, Санкт-Петербург, Университетская наб., 7-9; a.dvornichenko@spbu.ru

Andrey Yu. Dvornichenko - Doctor in History, Professor, Institute of History, St. Petersburg State University, 7-9, Universitetskaya nab., St. Petersburg, 199034, Russian Federation; a.dvornichenko@spbu.ru

Исследование выполнено в рамках гранта № 19-18-00073 «Национальная идентичность в имперской политике памяти: история Великого княжества Литовского и Польско-Литовского государства в историографии и общественной мысли XIX-XX вв.» Российского научного фонда.

This research was supported by the grant No. 19-18-00073 "National Identity in the Imperial Politics of Memory: History of The Grand Duchy of Lithuania and the Polish-Lithuanian State in Historiography and Social Thought of the $19^{\text {th }}-20^{\text {th }}$ Centuries" of the Russian Science Foundation.

(c) Санкт-Петербургский государственный университет, 2019 
будет полезна нашему читателю и сейчас. Она, будем надеяться, органично войдет в российский историографический контекст.

Ключевые слова: Георгий Вернадский, жизнь и творчество, Чарльз Гальперин, перевод, евразийство, украинская идентичность.

\section{The new Adventures of the Historian George Vernadsky}

\section{A. Yu.Dvornichenko}

For citation: Dvornichenko A. Yu. The new Adventures of the Historian George Vernadsky. Vestnik of Saint Petersburg University. History, 2019, vol. 64, issue 2, pp. 795-812. https://doi.org/10.21638/11701/spbu02.2019.220 (In Russian)

A study of Vernadsky's legacy is a very dramatic process. It is full of strange contradictions. In Russia, the research began only in the last decade of the previous century and is still in progress. In the USA, the life and scholarly works by George Vernadsky attracted the attention in the previous decade. It resulted in two articles, the best and the only outcome, written by the famous specialist in the Russian history and historiography Charles Halperin. This review is devoted to the publication of a translation of the biggest article by Halperin (1985), and a translation of his recent article from one of the Russian historical journals. The author of this review questions the quality of the translation and critically comments on it. According to the author, Halperin's perception of Vernadsky was influenced by his negative attitude to Eurasianism. But Vernadsky never was a participant of this political movement, moreover, he was against it. As for his scholarly ideas, it can be said that Eurasianism was one of the best explanation of the Russian historical process. Recently, Halperin's opinion about the significance of Vernadsky's legacy has been improved, and we hope that this trend will continue to strength. Surprisingly, however, Halperin supported some doubtful ideas by some Ukrainian authors who found a certain Ukrainian identity in Vernadsky. The author of review cannot see any trace of such connections between this statement and Vernadky's deep love for the Ukrainian history and culture. The author's conclusion is that the translation of the work by the famous American historian will be currently very useful to the Russian readers.

Keywords: George Vernadsky, life and scientific work, Charles Halperin, translation, Eurasianism, Ukrainian identity.

Есть явления жизни, науки и культуры, которые всегда будут привлекать к себе внимание людей. Более того, они, как выдержанное вино или старинные картины с их потемневшим красочным слоем, привлекают это самое внимание все больше и больше. Такой «монадой» (если пользоваться терминологией Г. В. Лейбница) является «Феномен Г. В. Вернадского». Здесь я хотел бы подчеркнуть именно историографическую сторону данного феномена, ибо изучение творчества историка - своего рода приключение, которое отражает столкновение многих научных трендов, завязанных, в свою очередь, на историю России и других стран ${ }^{1}$. Георгий всегда

1 А если к этому добавить долгие странствия ученого, то, может быть, станет понятно мое первоначальное решение назвать свою книгу о Г. Вернадском «Русский историк Георгий Вернадский. Необычайные путешествия и приключения в мире людей, идей и событий». Но в издательстве «Евразия» мне намекнули, что я - не Дефо, а мой герой - не Робинзон Крузо, за что я им очень признателен. Однако бренд «путешествий» все равно остался, и я потом обнаружил, что даже и не первый, кто так определял жизнь и творчество историка. 
становился объектом разного рода противоречий и конфликтов, почву которых понять бывает довольно трудно. Одно дело, когда это советская неприязнь к «белогвардейцу», совсем другое - какие-то, на первый взгляд непонятные, «наскоки» в США, в смысле которых исследователю (особенно россиянину) разобраться тяжело. Впрочем, в задачу данной рецензии не входит подробное изложение историографии, посвященной младшему Вернадскому, ведь данная работа посвящена конкретному сочинению ${ }^{2}$.

И все-таки от истории изучения вышеназванного феномена никуда не уйдешь. Тут заметна довольно четкая граница: до «перестройки» и после. Это когда о нашей стране рассуждаем. В «перестройку» наступил «настоящий взрыв интереса к русскому зарубежью» ${ }^{3}$ В вибрациях упомянутой «взрывной волны» вспыхнул интерес и к Георгию Вернадскому. Прежде всего ему старались найти место в привлекшем всеобщее внимание евразийстве. Выделили (на мой взгляд, довольно искусственно) и такую грань его феномена, как общественно-политические взгляды ${ }^{4}$. Особо отмечу работу Н.Е. Соничевой, которая написала на данную тему кандидатскую диссертацию, ряд статей и даже брошюру ${ }^{5}$ Это способный исследователь: создала довольно цельную и адекватную картину жизни и творчества ученого, используя примерно 20 \% тех материалов, которые можно привлечь для написания такой картины. Как видим, Георгий послужил благодатной темой для создания работ, которые один из моих учителей называл «пропуском в науку». Вообще это были первопроходцы!

В такой роли выступил и известный историк В.Н.Козляков, издавший «Русскую историографию» Вернадского, а также написавший к ней статью и (главное!) давший прекрасный обзор «американской коллекции» документов историка ${ }^{6}$. К сожалению, для него эта тема осталась проходной... Как, впрочем, и для других. Все мои попытки создать эдакий кружок по общим интересам и для этого по базам данных найти сведения о вышеупомянутых историках успехом не увенчались. Непонятно. Даже если допустить, что Соничева могла сменить фамилию, но куда пропал Бондарь? Впрочем, эпоха была смутная...

В 2005 г. в роли такого первопроходца выступил ушедший уже из жизни академик, специалист по российско-американским отношениям, Н. Н. Болховитинов. В небольшой книге он постарался осветить жизнь и творчество, а также влияние на американскую науку трех столпов российской эмигрантской исторической мысли: Г. В. Вернадского, М. М. Карповича и М. Т. Флоринского. Конечно, это только пусть и интересные, но «пролегомены», что понимал и сам академик. Он отметил, что «монографического исследования о Георгии Вернадском в России пока

2 Гальперин Ч. Русь и степь: Георгий Вернадский и евразийство. Воронеж, 2018.

3 Болховитинов Н. Н. Русские ученые-эмигранты (Г. В. Вернадский, М. М. Карпович, М. Т. Флоринский) и становление русистики в США. М., 2005. С.9.

4 Бондарь А.Ю. Общественно-политические взгляды и деятельность Г. В.Вернадского: дис. ... канд. ист. наук. М., 2001.

${ }^{5}$ Соничева Н.Е. Становление и развитие исторической концепции Г.В.Вернадского: дис. ... канд. ист. наук. М., 1994.

${ }^{6}$ Козляков В.Н. Обзор коллекции документов Г. В. Вернадского в Бахметевском архиве библиотеки Колумбийского университета в Нью-Йорке // Вернадский Г.В. Русская историография. М., 1998. С. 395-444. 
не опубликовано» ${ }^{7}$. Конечно, о русско-американском историке в том или ином контексте писали и другие. Вспомним содержательные работы Е.П.Аксеновой, А. В. Антощенко, Н. В. Ануфриевой, М. Г. Вандалковской, В. И. Дурновцева, О. И. Захарова, В.П. Корзун, М.Ю.Сорокиной, В.Т. Пашуто, Е.В.Петрова, И. В. Тункиной и др. Пусть простят меня остальные за это грубое и безликое «др.», но я еще раз повторяю, что задачу дать историографический обзор перед собой не ставил.

Интереснее сейчас вопрос о том, могла ли «молодая» «перестроечная» наука России опереться на труды американских историков? Значительной «вернадскианы» мы в американской науке (как, впрочем, и в европейской) не находим, но сразу замечаем труды Чарльза Гальперина. Собственно, было две публикации: одна статья и другая работа, которая вполне вписывается в монографический формат, хотя и была издана в известном западногерманском журнале ${ }^{8}$. Издание это была ведомо и нашим историкам: знал ее В. Н. Козляков, широко использовал Н. Н. Болховитинов, а Соничева (в моем сознании она постепенно превращается в эпического богатыря) даже полемизировала с заокеанским научным авторитетом. Однако определяющего воздействия на становление российского (поначалу еще советского) «вернадоведения» эта работа не оказала. Нам и сейчас легко представить далекий 1985 г.: «перестройка» еще только начиналась, вожделенный Бахметевский архив был по-прежнему весьма плохо досягаем, да и «Forschungen» не является настольным чтением для отечественного историка...

Для дальнейшего складного изложения мне необходимо сделать следующую экспозицию. Ко второму десятилетию нынешнего столетия автор этих строк увлекся жизнью и творчеством Георгия Вернадского. В книге я обыграл это в шуточной манере, но на самом деле интерес к творчеству историка проистекал из моей предшествующей жизни и работы. Даже непосредственно предшествующей: был написан труд о своего рода приключениях «демократической» идеи древнерусского политогенеза, ярким адептом которой был Вернадский․ Перейти от «путешествий» этой идеи к путешествиям историка было вполне логичным шагом. Интерес ознаменовался публикацией ряда моих статей и неопубликованных ранее произведений ученого ${ }^{10}$, и, наконец, книги ${ }^{11}$. Этот интерес так меня захватил, что, не будучи способным вырваться из его объятий, я сделал Георгия одним из героев еще одной книги ${ }^{12}$. И должен признаться, что, если бы не отличная работа Гальперина,

7 Болховитинов Н. Н. Русские ученые-эмигранты (Г. В. Вернадский, М. М. Карпович, М. Т. Флоринский) и становление русистики в США. С. 12.

${ }^{8}$ Halperin Ch.J. Russia and the Steppe: George Vernadsky and Eurasianism // Forschungen zur osteuropäischen Geschichte. Berlin, 1985. Otto Harrassowitz. Wiesbaden. Bd. 36. P. 55-194.

9 Дворниченко А.Ю. Зеркала и Химеры. О возникновении древнерусского государства. СПб.; M., 2014.

10 Дворниченко А. Ю.: 1) Г. В. Вернадский об Украине и украинском вопросе (к публикации статьи Г.В.Вернадского «Князь Трубецкой и украинский вопрос») // Вестник Санкт-Петербургского университета. Серия 2. История. 2015. Вып. 2. С. 57-79; 2) Георгий Вернадский о советской России (к публикации статьи Г.В.Вернадского «Парадоксы большевизма») // Новейшая история России. СПб., 2015. № 2(13). С.101-132; Дворниченко А. Ю., Белоусов М.С. Движение декабристов в творчестве Георгия Вернадского // Вестник Санкт-Петербургского университета. История. 2017. Т.62. Вып. 2. С. 358-374 и др.

11 Дворниченко А. Ю. Русский историк Георгий Вернадский. Путешествия в мире людей, идей и событий. СПб., 2017.

12 Дворниченко А. Ю. Прощание с Революцией. М., 2018. 
я, наверное, и до сих пор бы блуждал в потемках сложнейшей темы. Эту работу я знал уже чуть ли не наизусть. Несмотря на то что я мало с чем в ней соглашался, она была для меня прекрасным путеводителем, прежде всего по архивным материалам, хотя тут возникла неожиданная трудность, о которой я еще скажу. В общем, номер журнала стал для меня настольной книгой ${ }^{13}$.

В отличие от соотечественников, славный американский историк оказался вполне доступен, во всяком случае электронным способом. Он написал рецензию на мою монографию о Вернадском ${ }^{14}$ и дал ей очень высокую оценку. Поскольку не все смогут добраться до этого журнала, я приведу «Abstract» ${ }^{15}$. Конечно, в рецензии была и критика, о которой я, может, еще скажу. Меня как автора не могло не обрадовать, что подобная (может быть, менее комплиментарная и пространная) рецензия вышла и в России ${ }^{16}$. Не скрою - я был несколько удивлен, когда узнал, что в Воронеже переводится и готовится к изданию та самая работа Чарльза Гальперина, которую я только что воспевал. Я даже принял участие в ее оформлении, что читатель ясно увидит, взяв в руки книгу, выпущенную Издательско-полиграфическим центром «Научная книга» и украшенную на заднем форзаце еще и загадочным тавро: «Издательская группа Пояс Евразии». Меня даже поблагодарили. Что ж, согласно английской вежливости, «спасибо за спасибо», но остановиться на сем не могу. Книга, собственно, состоит из перевода мегастатьи Гальперина и его же статьи ${ }^{17}$, которая завершает текст. Все это предваряется небольшим предисловием редактора, а поскольку этот же редактор сопроводил книгу большим количеством «подвальных» ссылок под названием «Примечание редактора», то книга получилась достаточно пространной - 373 страницы. Кстати, по какому принципу редактор составлял данные «примечания», так и осталось для меня загадкой: некоторым деятелям науки и культуры отводится значительное место, а другим - нет. Причем, это вовсе не зависит от значимости той или иной фигуры.

Однако к этому у меня особых претензий нет, как нет претензий и к обложке книги, и к шрифту. Приятно также и то, что листы сшиты - книга будет жить долго. Впрочем, чтобы обеспечить ей жизнь не только долгую, но и приятную, редактору надо было приложить гораздо больше усилий, чем составить «примечания». Большие претензии возникают к переводу книги. Говорят, что когда грузинский поэт Симон Чиковани увидел свое стихотворение на русском языке, то он обра-

13 Пользуясь случаем, хочу поблагодарить почетного профессора нашего Университета С. Г. Кащенко за то, что он в свое время подарил историческому факультету комплект журнала за пару десятков лет, привезенный из-за границы, по-моему, из Голландии.

${ }^{14}$ Halperin Ch. J. (Re)Discovering George Vernadsky // Journal of modern Russian history and historiography. 2018. No.11. P. 134-157.

15 “Andrei Dvornichenko's impressive Russkii istorik. Georgii Vernadskii. Puteshestviia v mire liudei, idei $i$ sobytii is the first biography of the Russian émigré historian of Russia who was one of the founding fathers of the study of Russian history in the United States. Dvornichenko's book surveys Vernadsky's life and prodigious scholarly output in detail. It is now the standard work on the subject. Anyone interested in the Russian emigration, Russian historiography, or Russian history in general should read this monograph". Ibid. P. 134.

16 Китаев В.А. Одиссея Георгия Вернадского // Историческая экспертиза. Журнал рецензий. 2018. № 3 (16). С. 253-261. Рец. на: Дворниченко А. Ю. Русский историк Георгий Вернадский. Путешествия в мире людей, идей и событий. СПб.: Евразия, 2017. 724 с.

17 Halperin Ch.J. Recent research on George Vernadsky // Золотоордынская цивилизация. 2017. № 10. C. $455-470$. 
тился к переводчикам с горячей просьбой больше этого не делать ${ }^{18}$. Боюсь, что так может получиться и в этом случае. Если же искать ответ на сермяжный российский вопрос, то виновата не та неизвестная мне женщина, которая значится на обложке в качестве переводчика (хотя и она лепту внесла), а виноват редактор. Нет, я, конечно, понимаю, что среднестатистический российский преподаватель вуза изнывает под бременем взваленных на него проблем, но уж если живого классика русистики берешься переводить, то надо обязательно прочесть получившийся текст. Ты же редактор! Да и перевод-то не художественный, главное - точность. Тут же перевод грубый и неряшливый, порой смысл уходит. Слова и фразы просто неправильно поняты или переведены некорректно. Взять хотя бы главу «Евразийство». Вместо «примерно совпадала» - «точно совпадала», вместо «неверной культурной вестернизации Петра» появляется сам Петр, «упорствующий в своих заблуждениях», «межвоенный период» превращается в... «Гражданскую войну», вместо «евразийская история была наполнена фантазией» получаем «распространялась с выдумками». А ведь животики можно надорвать, когда читаешь такую фразу: «Евразийцы транслировали горестные повести о европейской развращенности и отклонялись от славянофилов и Данилевского». И тут же: «...реакцией на инспирированный Европой ужас мировой войны», хотя в оригинале «реакция против Европы, инспирированная ужасом Великой Войны»». Почувствуйте разницу! И тут же название до боли знакомого произведения «Закат Европы» переводится как «Отрицание Запада»... Места мне для примеров не хватит, пришлось бы весь номер журнала абонировать... И ведь не понимают, что смысл-то искажается. Например «...в разговоре по поводу университета Джона Хопкинса» ${ }^{19}$, а то был «talk» не «по поводу», а в самом этом университете. Или «попытался обезопасить от Советского Союза микрофильм» ${ }^{20}$, а он просто хотел его получить...

Текст попросту не вычитан, много ошибок в названиях и особенно в фамилиях. С последними особенно досадно. О, эта извечная англо-русская проблема: «а» или «у». И тогда «Батлеровская библиотека» оказывается «Бутлеровской», знаменитый историк «Крамми» легким движением руки вдруг превращается в «Крумми», а читатель думает-гадает над тем, как это «профессор работал в Колумбии»? Что он наркотрафиком, что ли, занимался? Проблемы не только с английским, но и с другими языками, например немецким. И тогда знаменитый славист Фасмер вдруг оказывается «Васмером», а знаменитый издатель де Гройтер - де Гюнтером. Но такие ошибки хоть понять можно, но вот как петербургская исследовательница Тункина превращается в «Туркину», а почтенная дама-историк Корзун в некоего «Козина», известный профессор Дурновцев вдруг оказывается «Дуровцевым». Как Анри Грегуар тут же может превращаться в «Аньюара»? А великий историк Грушевский временами трансформируется в некоего «Хрущевского». А видный польский историк-эмигрант О. Галецкий в некоего «Халеки»?! Также и со странами: Румыния вдруг стала Романией и т. д. Пишу это с болью, ведь Гальперин в своей рецензии на мою книгу отметил, что в ней количество типографских ошибок ничтожно ${ }^{21}$. Мне

18 Чуковский К. Высокое искусство. Принципы художественного перевода. СПб., 2015. С. 21.

19 Гальперин Ч. Русь и степь: Георгий Вернадский и евразийство. С. 311.

20 Там же. С. 79.

${ }^{21}$ Halperin Ch.J. (Re)Discovering George Vernadsky. Р. 144. Повод сказать искреннее «спасибо!» специалистам нашего славного Петрополя, работникам «Евразии». 
кажется, что своей безалаберностью воронежские деятели подводят почтенного американского автора, а данное в конце сообщение о том, что книга дается в авторской редакции и авторском наборе, выглядит просто издевкой. Особенно для того, кто знает необыкновенную скрупулезность Гальперина, связанную еще и с тем, что он прекрасный знаток компьютеров, программист и системный аналитик. К тому же в этом издании он хотел «исправить свои фактические ошибки и пропуски» ${ }^{22}$. Не могу не добавить, что порой горе-переводчики «подставляют» своего автора, так сказать, вдвойне. Редкий случай, когда Гальперин не справился с русской фамилией и под его пером появился соратник Николая Второго - «Uktinskii» ${ }^{23}$. Под пером же переводчиков вдруг появляется уже совсем загадочный «Уткинский» ${ }^{24}$, где, вообще-то, должен быть «Ухтомский» 25 .

Жаль, что приходится воронежскому редактору Ю. В. Селезневу объяснять такие очевидные вещи. Да это еще не все. Ведь очевидно, что если издается книга 1985 г., то редактор должен учесть то, что произошло за протекшие несколько десятков лет. То, что он мою книгу нигде не упомянул, хотя между подписанием в печать перевода и выходом моей книги прошло больше года, пусть просто остается на его совести, я человек не гордый, хотя делу такой подход вредит. Но ведь так во всем! Взять, например, систему ссылок на Бахметевский архив. Когда я до него добрался, то никак не мог понять, что за ссылки у Гальперина. Не могла мне помочь даже куратор архива славная Таня Чеботарефф. Наконец выяснилось, что за это время коллекция Вернадского была полностью переформатирована, и, как отметил сам Гальперин, его система ссылок теперь бесполезна ${ }^{26}$. Таки редактор должен был тут поработать и переделать сноски на архив.

Или вот, например, Гальперин в 1985 г. считал, что «Возражение» патриарха Никона, которое готовили к печати Г. В. и Валерия Туминс, так и не вышло в свет, а оно было опубликовано в 1982 г. $^{27}$ Для того чтобы исправить эту ошибку, вернее, просто дополнить сведения Гальперина, редактору стоило лишь заглянуть в мою книгу. На этом я прекращаю критику текста перевода работы Чарльза Гальперина. Как говорила устами своей героини великая Фаина Раневская: «Что выросло, то выросло». За десятилетия я почти изжил в себе юношеский максимализм - все или ничего. Книга будет полезна и в таком виде, так как плохой перевод все равно не понизит значения текста заслуженного американского автора. К тому же нынче у нас не так много переводят работ американских русистов. Тем более мне-то вообще повезло: я буду прикладывать к российскому переводу западногерманский оригинал, и такой симбиоз поможет избежать ляпов воронежских кудесников. Но еще раз хочу подчеркнуть, что Гальперин сделал все, что мог: в английский текст своей работы он даже внес кое-какие интересные дополнения!

Скажу еще об одном нюансе. В рецензии на мою работу Гальперин тонко почувствовал, что я обращаюсь именно к русскому читателю ${ }^{28}$. Зря только он придает этому слишком национальный, этнический оттенок. Для того, у кого значительная

22 Гальперин Ч. Русь и степь: Георгий Вернадский и евразийство. С. 335.

${ }^{23}$ Halperin Ch. J. Russia and the Steppe: George Vernadsky and Eurasianism. P. 167.

24 Гальперин Ч. Русь и степь: Георгий Вернадский и евразийство. С. 277.

25 Ухтомский Эспер Эсперович (1861-1921) - дипломат, ориенталист, публицист и др.

${ }^{26}$ Halperin Ch.J. (Re)Discovering George Vernadsky. P. 143.

27 Дворниченко А. Ю. Русский историк Георгий Вернадский. С. 288.

${ }^{28}$ Halperin Ch. J. (Re)Discovering George Vernadsky. P. 144. 
часть жизни прошла в СССР, русскими часто были все, кто говорил на русском языке. Кстати, и сейчас говорят, судя по телевизионным передачам и туристическим впечатлениям. Но мне действительно хотелось в первую очередь объяснить значение Вернадского именно русскоязычному читателю, особенно россиянину. Впрочем, Гальперин отметил, что по моей книге и западный специалист сможет переосмыслить жизнь и творчество историка. Сам же Гальперин, учитывая характер издания и тогдашнюю ситуацию, писал в основном для западного читателя. Тогда возникает очень приятная картина: то ни одной книги, посвященной Вернадскому не было, а теперь сразу две. Одна адресована всем русским и западным специалистам, а другая - первоначально западным специалистам и избранным русским. Теперь они обе обращаются к русскому читателю, и читатель может одну дополнять другой...

Кстати, с этим наблюдением Гальперина связано и еще одно его замечание: я слишком себя идентифицирую с героем своего повествования. Более того, Гальперин считает, что политический подтекст моей патриотической «преданности» (кавычки его. - A. Д.) Вернадскому ясен. Воспевание эмигранта, изгнанного из России и оклеветанного коммунистами, отражает отторжение советской историографии на почве возрождающегося (с 1991 г.) русского национализма ${ }^{29}$. На это обратил внимание и российский рецензент, правда, акцент сделал не на политике. Он предположил, что таким образом я стараюсь встать вровень с героем ${ }^{30}$. Хочу отвести от себя такие обвинения. К политике это никакого отношения не имеет, хотя, не скрою, мне приятно отнесение моей скромной фигуры к русскому национализму. Но ведь он в природе не особо водится, потому это все слова, а «вровень» ни с кем я давно уже вставать не хочу. Просто я всю информацию пропускаю через себя и, чувствуя духовное сродство со своим героем, не могу удержаться от реплик - результата в общем-то печального процесса накопления жизненного опыта и впечатлений.

Ну, что это я все о себе и о себе! Это ж все-таки рецензия! И поспорить с замечательным американским историком есть о чем. Впрочем, некоторые мои замечания были уже сделаны и вошли в мою книгу, к которой я и могу отослать читателя. К тому же вряд ли здесь целесообразно спорить по мелочам. В данной рецензии лучше остановиться на каких-то принципиальных моментах и на том, что проявилось в последнее время или не было замечено прежде. Пробежимся по страницам книги.

Что касается жизни нашего героя, то она хорошо изложена в книге. И хоть Гальперин считает, что моя трехсотстраничная проза (часть книги, посвященная биографии историка) значительно перекрывает его биографический очерк Вернадского, не могу не отметить добротность его очерка. Тем более что в новом издании есть и кое-какие уточнения и исправления. Меня, например, очень порадовало, что исчез с лица земли греческий профессор Лорензато и благодаря «щедрой помощи Николаоса Хризидиса» (дай Бог здоровья этому светлому человеку и Чарльзу Гальперину, который его нашел!) появился на свет Панагиотис Лоренцатос, с которым

29 Halperin Ch. J. (Re)Discovering George Vernadsky. P. 144-146.

30 Китаев В. А. Одиссея Георгия Вернадского. С. 254. 
Георгий дружил в Афинах 31 . Это один из немногих персонажей жизни историка, перед которым и я было спасовал - не мог найти о нем сведений.

Можно спорить о том, любил ли Георгий Иельский университет ${ }^{32}$. Тут прямых данных нет. Я думаю, что любил, но что касается отношений с родителями, тут я, как скала - не было никакого доминирования со стороны отца! Это был такой творческий союз, такие теплые и трогательные отношения в лучших традициях русской интеллигенции, что можно только завидовать... и все! Ну, какое может быть доминирование за тысячи верст, да и в детстве его не было, а были прекрасные и дружеские отношения... Очень хотелось бы этот креативный диалог отца и сына рассмотреть подробно, к чему призывает В. А. Китаев ${ }^{33}$, но это тема отдельной работы. К тому же у отца - гордости нашей науки и культуры, в отличие от сына, почерк был просто ужасный...

А вообще, тема «жизнь Георгия Вернадского» - совершенно неисчерпаемая, и я верю, что к ней будет обращаться не одно поколение специалистов-гуманитариев. В чем я не согласен с Чарльзом Гальпериным, так это в том, что он пытается навесить на Георгия какие-то политические ярлычки, которые во многом якобы и определяли его научную деятельность. Это порой выглядит так: «...Личностная эволюция В. не была завершена (перед приездом в США. - А.Д.): в дальнейшем к его запутанным кадетским и евразийским идеям неизбежно добавился ряд определенно американских ценностей» ${ }^{34}$. Как человек более 36 лет преподающий и изучающий русскую историографию, с полной ответственностью заявляю, что при всей политизированности мышления россиян, у русских историков ни политическое, ни национальное мышление (во всяком случае, до М. С. Грушевского) не было доминантой. Даже советская историческая наука, крайне в этом заинтересованная, пасовала перед тем, чтобы определить политические взгляды С. М.Соловьева или В.О.Ключевского и многих других. Еще в студенческие годы я представлял себе, как бы отреагировали те из русских историков, которых их советские коллеги относили, например, к «теории официальной народности». Концепция русской истории у наших историков редко завязана на политические воззрения, и в этом смысле нет оснований смешивать в одну кучу историографию и историософию. Последняя гораздо больше связана с политикой...

Эта тема, в свою очередь, близка к теме евразийства, характеристике которого посвящена вторая глава книги. Объективно говоря, этот очерк короток и уже несколько устарел, во всяком случае в историографической части: ведь литература по евразийству растет, как снежный ком. Но дело не в этом. Гальперин прекрасно знает и новую историографию ${ }^{35}$. Дело в оценке данного явления. Гальперин оценивает его негативно и прежде всего как политическое течение, своего рода «антидемократическое оправдание империализма и колониализма». Оно раздражает американского историка. Западные историки уже, как мне кажется, начинают демонизировать

31 Гальперин Ч. Русь и степь: Георгий Вернадский и евразийство. С. 335. - Это ценное уточнение Чарльз Гальперин сделал в статье, опубликованной первоначально в «Золотоордынском ежегоднике».

${ }^{32}$ Halperin Ch. J. (Re)Discovering George Vernadsky. P. 148.

33 Китаев В.А. Одиссея Георгия Вернадского. С. 260.

34 Там же. С. 68.

${ }^{35}$ Halperin Ch. J. Russia Faces East: Eurasianism Reconsidered // Russian History. 2016. No 43. P. 6980. 
это политическое учение, не находя даже предшественников для них в «русской истории идей» ${ }^{36}$. Наши историки также видят в евразийстве политическое течение $^{37}$. Но ведь тут, я уверен, надо четко отделять политику (а она всегда - «дело грязное»), к которой у Георгия всегда было примерно такое отношение, как у черта к ладану ${ }^{38}$, от широкого комплекса идей (может, и расплывчатых), которые он пытался положить в основу своей концепции русской истории. Его концепция русской истории - евразийская, а почему бы и нет?! Во всяком случае, мне близко то место Киевской Руси, которое ей отводится в российской истории евразийством. ${ }^{39} \mathrm{y}$ нас сейчас (после падения Берлинской стены) явная нехватка более или менее адекватных концепций российской истории. Вернадский такую концепцию дал - честь ему и хвала. Насколько она «полноценная и завершенная» ${ }^{40}$, можно спорить и, конечно, надо разбираться с тем, что такое «концепция» вообще. А то научный пуризм уже приводит к тому, что концепция Преснякова якобы состоит из каких-то обломков, а Ключевскому и вовсе отказывают в научной концепции ${ }^{41}$. Впрочем, о сложных отношениях Вернадского с евразийством пишет и сам Гальперин ${ }^{42}$.

В связи с работой Гальперина важнее другое - отношение к Вернадскому. Оценивая русского историка, Гальперин (по его собственному признанию) «не сдерживался в выражениях» ${ }^{43}$. Теперь он вроде прямо-таки по-русски «покаялся», как оказалось, тогда «допустил стратегическую ошибку», но «выражения-то» остались... А при ближайшем рассмотрения оказывается, что бо́льшая часть неприязни к Георгию Вернадскому связана с этим самым демонизируемым евразийством. Если его отбросить, то окажется, что довольно часто Гальперин даже хвалит нашего героя. И почему Гальперин так невзлюбил евразийство Вернадского?! Ведь с историографической точки зрения упрекать его в евразийстве - все равно что, например, упрекать Ивана Дмитриевича Беляева за том, что он «славянофил», или Ключевского за приверженность к государственной школе и т. д.

И вот, если двинуться дальше, то увидим, что во всем касающемся древности Гальперин признает заслуги Вернадского. Тот, оказывается, приобрел выдающуюся

36 Люкс Л. Краткие заметки к дискуссии о «неоевразийстве» Александра Дугина и о «классическом» евразийстве на сайте gerfter.ru // Журнал рецензий. 2018. № 3 (16). С. 206.

37 Фроянов И.Я. О зарождении евразийства в изучении русского средневековья // Сб. в честь В. К.Зиборова. Вып. 5: Опыты по источниковедению. СПб., 2017. С. 300.

38 Гальперин, вообще, зачастую видит политику там, где ее нет. Так, он упрекает меня в том, что я призвал Вернадского для того, чтобы оправдать присоединение Крыма к Российской Федерации (Halperin Ch.J. (Re)Discovering George Vernadsky. P. 148). А я ведь пишу только о том, что он находил русских в Крыму с древних времен! Хотя теперь не могу не отметить, что для Средневековья Вернадский всегда выступал за немедленную аннексию Крыма Россией. Ремарка же Гальперина о том, что нет сведений о протестах Вернадского в связи с передачей Крыма Украинской CCP (Ibid.), мне, вообще, непонятна. Неужели специалист в области истории России всерьез думает, что судьба того или иного российского региона может зависеть от поступка полоумного правителя?

39 Dvornichenko A. Yu. The place of the Kievan Rus in history // Вестник Санкт-Петербургского университета. Серия 2. История. 2016. Вып. 4. С. 5-16.

40 Китаев В. А. Одиссея Георгия Вернадского. С. 259.

41 Шаханов А.Н. Русская историческая наука второй половины XIX - начала XX века: Московский и Петербургский университеты. М., 2003.

42 Гальперин Ч. Русь и степь: Георгий Вернадский и евразийство. С. 58, 60.

43 Там же. С.328. Даже американские обозреватели признали негативизм по отношению к Вернадскому чрезмерным (Кeер J. Review of: Forschungen zur osteuropäischen Geschichte. Bd.36 // Canadian Slavonic Papers. 1985. No 27. P. 444). 
осведомленность в истории Азии ${ }^{44}$. Тут, пожалуй, и добавить нечего. Впрочем, есть. Я думаю, что Вернадский во многом заложил основы столь популярного сейчас сравнительного анализа империй. А насколько он идеализировал отношения Руси и степного азиатского моря? У Гальперина почему-то они вызывают ассоциации с американо-индейскими отношениями. Вот тут история поработала явно не на Гальперина: «наши» азиаты живут теперь в новых государствах, где русские, судя по всему, не на первых ролях. Где же государства американских индейцев? Кроме резерваций, никаких не наблюдаем.

Касательно «Происхождения Руси» я уже высказался в своей книге и взгляда своего не меняю. Прекрасная книжка - ее стоит перевести на русский язык (правда, воронежцев звать не будем). «Киевскую Русь» и сам Гальперин высоко оценивает. Его только удивляет, почему концепция Киевской Руси (в моей оценке) у Вернадского так близка к концепции И. Я. Фроянова, ведь Фроянов не евразиец ${ }^{45}$. Но дело в том, что Фроянов тут не одинок. В уже упоминавшейся работе я старался показать читателю всех предшественников теории петербургского историка - нашего современника ${ }^{46}$. В общем, глава о Киевской Руси на самом деле заканчивается заслуженным панегириком в адрес Вернадского за то, как он показал отношения Руси со Степью. Тут я совершенно согласен, только отмечу, что не считаю произведение С. Франклина и Дж. Шепарда лучшим обзором истории Киевской Руси на любом европейском языке. Я бы тут вспомнил недавнюю фундаментальную книгу И.Я. Фроянова ${ }^{47}$.

В связи с Фрояновым, обосновавшим в своих работах фактическое отсутствие феодализма в Древней Руси, не могу не вспомнить этот конструкт. В новом издании осталось прежнее высказывание Гальперина о наличии феодализма, который он готов был заменить неким «манориализмом» ${ }^{48}$. С этим трудно согласиться. В дополнение к прежним рассуждениям могу заметить, что феодализм очень плохо уживается с общинными городами-государствами ${ }^{49}$ и тем более - с племенными структурами ${ }^{50}$.

Глава, посвященная оценке Вернадским «монгольской проблемы», самая пространная в книге. Это и понятно, ведь известно, что сам Гальперин крупный специалист в области изучения русско-монгольских отношений. Опять же, если отбросить филиппики в адрес пресловутого евразийства, то окажется, что американский ученый высоко оценивает результаты исследования. Уже ранние взгляды историкf содержат «похвальные аксиомы» (с. 191); анализ Золотой Орды «весьма компетентен» (с. 136); изящное открытие (с. 137); обоснованные наблюдения о монгольском

44 Там же. С. 130.

45 Более того, выяснилось, что он, как и Гальперин, весьма не симпатизирует евразийству, правда, скорее больше современному. При этом значительные заслуги Вернадского (да и столпов евразийства) И. Я. Фроянов вполне признает и отличает их «от нынешних лакировщиков монголорусских отношений» (Фроянов И. Я. О зарождении евразийства в изучении русского средневековья. C. 328,333$)$.

46 Дворниченко А. Ю. Зеркала и Химеры.

47 Фроянов И. Я. Лекции по русской истории. Киевская Русь. СПб., 2015.

48 Гальперин Ч. Русь и степь. С. 180.

49 Дворниченко А.Ю. Эволюция городской общины и генезис феодализма на Руси // Вопросы истории. 1988. № 1. С. 58-73.

50 Дворниченко А.Ю. Племенные структуры и славянские политогенезы (Реплика) // Studia Slavica et Balcanica Petropolitana, 2015. № 2(18). C. 152-160. 
влиянии (С.220). Более того, Гальперин включает Вернадского в группу историков (в эту группу входят еще сам Гальперин и Дональд Островски), которая наиболее правильно трактует последствия монгольского нашествия ${ }^{51}$. Такие высокие оценки ${ }^{52}$ проистекают из того, что книга, будучи по виду евразийской, приходит к неевразийским и даже антиевразийским выводам. Учитывая то, что было мной только что сказано касательно этого несчастного (или счастливого) евразийства, можно далее подход Гальперина и не комментировать. Но отмечу, что я все-таки по-иному представляю себе заслуги Вернадского. Главное не то, что он видел смешанный характер монгольского влияния, а то, что он одним из первых показал, что действовало данное влияние, так сказать, с оттяжкой, что и привело в конце концов к изменению общественного строя Руси. Но был это не восточный деспотизм в духе Карла Виттфогеля (в привязанности к этой концепции Гальперин почемуто и меня уличил), а особый, уникальный государственно-крепостнический строй (ГКС), ставший своего рода российским брендом ${ }^{53}$.

Отдельную главу своей книги Чарльз Гальперин посвящает работам Вернадского о Московии и Украине. Что касается Московского государства, то я много писать не хочу, поскольку имел возможность полемизировать (в основном защищая своего героя от некоторых критических замечаний Гальперина) с первым изданием. Правда, тогда я так, видимо, увлекся, что не заметил восторженной оценки: Вернадский, оказывается, дал самое полное и исчерпывающее исследование реформ времен Ивана Грозного не только на английском языке, но, возможно, и вообще в историографии ${ }^{54}$. Да и формулировка, что текст, посвященный Ивану Грозному, «не более чем полезен», по-моему, скорее положительная, чем отрицательная оценка. Собственно, и здесь вся критика замыкается на этот столь (почему-то) несимпатичный Гальперину «евразинизм».

Об Украине надо сказать больше - ведь ясно, что, как и Крым, она воспринимается по-иному (если сравнивать с восьмидесятыми годами прошлого века), и сегодня эта тема стала гораздо более актуальной. Болезненное внимание, как и сон разума, порождает всякое.

Сам Гальперин подошел к проблеме «Вернадский и Украина», как всегда, спокойно, взвешенно и профессионально. Он отметил «амбивалентный характер» отношения Вернадского к украинскому вопросу, который отразился в двух его неопубликованных текстах ${ }^{55}$. Подчеркнул любовь Вернадского к Украине и украинской культуре, проанализировал популярную биографию знаменитого гетмана Хмельницкого, эпопею с изданием в США сочинения М.С.Грушевского, которого Георгию пришлось защищать от нападок местных коммунистов и т. д. Заключая свой обзор, он вновь делает вывод о «двойственности» позиции Вернадского, который и увлекался историей Украины, и был активным сторонником единения ее

${ }^{51}$ Halperin Ch.J. (Re)Discovering George Vernadsky. P. 152. - Заметим, что и еще один специалист по монголам - учитель Гальперина М. Чернявский - называл книгу Вернадского великой книгой.

52 В книге, конечно, есть и критика некоторых воззрений и методов Вернадского. Как без критики?! Идеальных построений не бывает, но для меня далеко не вся эта критика убедительна...

53 Дворниченко А. Ю. Российская история с древнейших времен до падения самодержавия. М., 2010

54 Гальперин Ч. Русь и степь: Георгий Вернадский и евразийство. С. 257-258.

55 Там же. С. 261. 
с Россией, неожиданно солидаризуясь в этом с позицией советских историков ${ }^{56}$. Остро встал вопрос о еврейских погромах во времена Хмельницкого: в работе о Хмельницком Вернадский не упомянул о них. В своей книге я это тоже отметил и отнюдь не поощрил историка, но попытался найти этому объяснение 57 . В рецензии на мой труд Гальперин придумывает еще одно объяснение, которое тоже может быть принято. Но далее он, опираясь на труды С. Глебова, М. Ларуэлль, М. Бассина, В. Шнирельмана, пытается обвинить в фашизме и евразийство, и «последнего евразийца» Л.Н. Гумилева ${ }^{58}$. Справедливости ради скажу, что Вернадский тут напрямую не упомянут, но, поскольку он восхищался Гумилевым ${ }^{59}$ и был евразийцем, тень падает и на него. Вот тут я категорически не согласен! Касательно «последнего евразийца» мне уже приходилось писать: никакого отношения к фашизму он не имел ${ }^{60}$. Но уж на Вернадского и подавно грешить не приходится. Этот светлый человек был начисто лишен каких-либо черт расизма, антисемитизма, фашизма и прочих гадостей. Однако вернусь к Украине.

Тут Гальперин также попал под дурное влияние. Дело в том, что за это время вышли статьи некоего современного «экспатрианта», внештатного и штатного сотрудника нескольких русских, украинских и европейских институтов (последний - в Швеции $)^{61}$ Игоря Торбакова ${ }^{62}$, который заинтересовался евразийством, а через него вышел на нашего героя. Сообщив общеизвестные сведения об историке и его творчестве, Торбаков неожиданно формулирует свою исследовательскую задачу: показать суть творчества Вернадского. Оказывается, суть эта определяется внутренними противоречиями, вызванными украинским происхождением и имперским Weltanschauung ${ }^{63}$. Торбаков обратил внимание на известный факт: главные евразийцы (П.Н. Савицкий) происходили или жили на территории Украины. В ход идет и то, что Н.С. Трубецкой - потомок Гедиминовичей. И вот надо же: украинские корни Вернадских тоже хорошо документированы. Впрочем, Торбаков признает, что само происхождение не определяет дальнейшее развитие человека, не могла тут сыграть определяющей роли и страстная любовь к Украине со стороны отца - Владимира Ивановича. Но, испытав страшные потрясения в России, Георгий оказался подготовлен к восприятию украинской идентичности, а своего рода переломом, точкой бифуркации тут стала долгожданная встреча с родителями в Праге в 1922 г. ${ }^{64}$ Вот так: ни много ни мало! Выйдя из транса, я стал читать дальше: пытаясь обрести украинскую идентичность, Георгий и писал свою «Историю». Другими словами, появлению «евразийской» истории России мы обязаны тем, что он искал свою украинскую идентичность! Доказывается этот неизвестный науке факт ссылками на сведения об интересе Вернадского к своим предкам, а также на

56 Гальперин Ч. Русь и степь. С. 268.

57 Дворниченко А. Ю. Русский историк Георгий Вернадский. С. 251.

58 Halperin Ch.J. (Re)Discovering George Vernadsky. P. 155-156.

59 Дворниченко А. Ю. Русский историк Георгий Вернадский. С. 298-300.

60 Дворниченко А. Ю. Зеркала и Химеры.

61 Гальперин Ч. Русь и степь. С. 335.

62 Хочу от всей души поблагодарить Чарльза Гальперина за то, что он не только указал мне на работы Торбакова, но даже их прислал.

63 Weltanschauung (нем.) - миропонимание.

${ }^{64}$ Torbakov I. Between Russia, Ukraine and Eurasia: George Vernadskii's Search for Identity. Empire De/Centered: New Spatial Histories of Russia and the Soviet Union / eds S. Turoma, M. Waldstein. Surrey, 2013. P.74. 
статью В.И. Вернадского «Украинский вопрос и русское общество». Да еще общеизвестными сведениями об учении евразийцев (Савицкого и Трубецкого). Почему для того, чтобы увидеть мультинациональность Российской Империи, Вернадскому надо было представить себя украинцем, автор не объясняет...

Как же реагировал на эту чушь наш уважаемый Чарльз Гальперин? С одной стороны, он разоблачил самоплагиат ученого ${ }^{65}$ и отметил, что без персональных свидетельств лучше воздержаться от приписывания Вернадскому некоей эмоциональности в трактовке русско-украинских отношений. Но с другой стороны, Гальперин считает, что наблюдение Торбакова об отношении историка к своему украинскому прошлому - значительный, оригинальный вклад в наше понимание интеллектуальной эволюции ученого ${ }^{66}$. Позволю себе не согласиться с уважаемым американским ученым: концепция сего экспатрианта, как говорится, высосана из пальца и выеденного яйца не стоит, никаких намеков, ни в каких источниках на «обнаруженные» Торбаковым «процессы» в психике и интеллекте Вернадского не выявлено. Я представляю, как Вернадский, убежденно писавший о крайнем вреде разделения церквей в России и Украине, был бы ошарашен ныне, узнав о «Томасе»...

Я тоже под горячую руку попал. Гальперин отмечает, что моя враждебная оценка украинской независимости обходит молчанием «имперское измерение в классическом евразийстве, а этот империалистический аспект, в свою очередь, дезавуирует классическое евразийство» ${ }^{67}$. Что тут скажешь? Чарльз Гальперин, видимо, пока не понял мою концепцию. Мне приходится вновь повторить свою идею об уникальном государственно-крепостническом строе, который не вписывается в ординарные представления об империи. И этим мне близок евразиец Вернадский. Как ученый я понимаю, что этот строй таит опасность распада «империи» на те или иные части, как человек я не вижу позитива в отдельном существовании России и Украины и считаю их распад делом сугубо политическим. Я помню, как, будучи еще студентом на военных сборах (1980 г.), до одурения спорил с одним самостийником (фамилию его, естественно, не называю, так как ныне он известный петербургский (sic!) ученый, правда, не историк). Взгляды мои с тех времен не изменились, и я был очень рад найти подобные воззрения у Вернадского.

Довольно странное впечатление производит статья Э.Гыйдела ${ }^{68}$. Выпускник Ужгородского университета издал несколько работ Вернадского и подумал над проблемой национальной идентичности Георгия. На основании одного (!) высказывания в личном письме он внес историка в «длинный и все еще продол-

65 Выяснилось, что практически то же самое ученый писал и в 2008 г. (Torbakov I. Rethinking the Nation: Imperial Collapse, Eurasianism, and George Vernadsky's Historical Scholarship // Kennan Institute Occasional Paper. No 302. 2008. P. 1-21) и в 2015 г. (Torbakov I. The Intellectual Odyssey of Georgii Vernadskii. Between Europe \& Asia: The Origins, Theories and Legacies of Russian Eurasianism / eds M. Bassin, S. Glebov, M. Laruelle. Pittsburgh, 2015. P. 113-136).

66 Halperin Ch. J. Russia Faces East: Eurasianism Reconsidered. P. 76.

67 Halperin Ch. J. (Re)Discovering George Vernadsky. P. 154.

68 Статья эта оставалась неизвестной и мне, и Чарльзу Гальперину. Ну, я не очень-то читаю экзотический журнал «Ab Imperio», а вот почему Гальперин не знал - не понимаю, ведь у него в этом же номере рецензия! Наверное, не прислали номер. Э. Гыйдел, видимо, не сам был в архиве, а получил документы от некоего Игоря Мартынюка. Как уж их получил сей человек - Бог ведает! 
жающийся список известных и неизвестных лиц с двойной (русско-украинской) идентичностью» ${ }^{69}$.

Ниже, однако, Гыйдел одумался и стал сам себя поправлять и, в конечном итоге, ту самую «двойную идентичность» Вернадского отменил. Зато ему бросились в глаза украинистические интересы историка. Ну и что? Причем тут идентичность? Украинская история живая и увлекательная, и заинтересоваться ею можно и без всякой украинской идентичности. Конечно, наличие какой-то кровной или еще какой другой связи с Украиной может этот интерес приумножить, но, опять же, идентичность тут ни при чем. Таких, как Георгий, у нас в России миллионы (в смысле русской, прежде всего, идентичности). Вот у меня, например, дедушка - украинец, читал и мне давал «Твори» Кобзаря, а его тесть - мой прадедушка, который был поляком, - читал А. Мицкевича. Повлияло ли это на мой интерес? Да, я всю жизнь интересуюсь и украинской, и польской историей. На идентичность же - никак: родился и помру русским. Когда смотришь из глубин России, то все те группы украинцев, о которых пишут вышеупомянутые авторы, кажутся надуманными. Есть украинцы, в дружеском соседстве и родстве с которыми русские жили веками, и есть бандеровцы, с которыми никакой дружбы не было и быть не может.

Но вернемся к книге Гальперина. Глава (вернее, часть главы), посвященная дореволюционной России, теперь выглядит несколько лапидарной, хотя мне и прежде, и теперь кажется, что Гальперин искусно вышел из сложной ситуации. Иногда призывают к «...более или менее полноценной реконструкции XIX - начала $\mathrm{XX}$ в. в истории России по Вернадскому» ${ }^{70}$. Но сделать это трудно, поскольку этим временем он так масштабно, как Средневековьем, не занимался. Гальперин собрал значительное число историографических фактов. Я только никогда не соглашусь с утверждением, что «евразийские обзоры русской имперской истории представляли собой грубо искаженную пропаганду» ${ }^{71}$. К тому же он противоречит сам себе, отмечая, что то, что написал Вернадский о «Новой истории России» (т.е. XVIIIXIX вв.), имеет больше всего смысла, когда помещено в контекст евразийства ${ }^{72}$.

Говоря о восприятии Гальпериным тех работ, которые Вернадский посвятил советскому периоду, в который раз приходится повторить свое наблюдение: что если бы не евразийство, то американский ученый был бы более милостив к русскому американцу. В этой части книги такая антиномия кажется еще заметнее ${ }^{73}$. Более того, в одном месте Гальперин заметил, что «евразийство Георгия Вернадского позволило ему быстрее других увидеть, как география Советского Союза укрепила его способность сопротивляться немцам» ${ }^{74}$. Так это же и есть то самое, о чем я толкую: без того или иного «евразийства» российскую историю просто адекватно не понять! Это-то и осознавал Вернадский. Да, похоже, к концу книги и Гальперин это

69 Гыйдел Э. Об «украинофильстве» Георгия Вернадского, или Вариация на тему национальных и государственных лояльностей // Ab Imperio. 2006. № 4. С. 339.

70 Китаев В.А. Одиссея Георгия Вернадского. С. 257.

71 Соответствующая глава в моей книге (Дворниченко А. Ю. Русский историк Георгий Вернадский...) и есть пространное возражение против такого подхода.

72 Гальперин Ч. Русь и степь. С. 291-292.

73 Кстати, приходится напомнить воронежским переводчикам, что «антиномия» — это совсем не то, что «антимония» (С. 356).

74 Гальперин Ч. Русь и степь. С. 303. 
понял. Во всяком случае высокая оценка концепции Советского Союза в ее «удивительно последовательных измерениях» ${ }^{75}$, как говорится, дорогого стоит.

Все сказанное в полной мере относится и к оценке наследия (legacy) ученого в целом, и прежде всего влияния его творчества на последующую науку. Оценка этого влияния Гальпериным, на мой взгляд, противоречива. С одной стороны, он отмечает, что историк стал связующей нитью между русской дореволюционной историографической традицией и находившейся в стадии становления русистикой в США; в любом исследовании об изучении истории России в США его имя будет присутствовать, что он стал образцом для подражания для нескольких поколений историков $^{76}$. С другой стороны, все то же, столь нелюбезное сердцу Гальперина евразийство сводит эту «репутацию» на нет, некоторые из его взглядов должны быть преданы забвению. Он поддерживает Соничеву в утверждении, что Вернадский не основал историческую школу в США и бо́льшая часть его гипотез и неоконченных идей не нашла резонанса ${ }^{77}$. Полагаю, что значение творчества Вернадского непосредственно связано со значением эмигрантской науки вообще - ведь он крупнейший историк русской эмиграции. Русская эмигрантская историография стала связующей нитью не только с историографией США, но и с исторической мыслью современной России. Гальперину как жителю одной из самых благополучных стран мира, наверное, все-таки трудно понять нашу страну с ее смутами (так, как Ленину, Трампу все равно не замутить!). Несколько десятков лет наша историческая мысль, хоть и развивалась, но была зажата жесткими идеологическими рамками. Эмигрантская историческая наука сильно влияла на западную русистику и в США, и в Европе. Вот тут я поддерживаю И. Торбакова, который пишет о том, что о силе концепции Вернадского говорили и Р.Пайпс, и А.Каппелер, и многие другие ${ }^{78}$. Мои уже имеющиеся наблюдения склоняют меня к такому же выводу ${ }^{79}$. Но теперь историческая наука русской (украинской, белорусской) эмиграции пришла и к нам. Она позволит нам восстановить «времен связующую нить», органически впишется в современную историографию, и, может быть, возобновится более или менее естественное развитие нашей исторической науки...

Перечитал рецензию. Вот результат: по-прежнему высоко оценил работу американского исследователя, со многим не соглашаясь, поругал отечественных издателей его труда за главный российский грех - разгильдяйство, а бывших соотечественников - за то, что тянут одеяло на себя. Вспомнились хрестоматийные слова летописца: «Оже се где буду описал или переписал или не дописал, чтите исправливая Бога деля, а не клените». Только вот книги «не ветшаны», а достаточно свежие. Ум же, хоть и не молод, но может до чего-то и не дошел... И еще раз спасибо

75 Гальперин Ч. Русь и степь. С. 313-314.

76 Там же. С. 318.

77 Там же. С. 359.

78 Torbakov I. Rethinking the Nation: Imperial Collapse, Eurasianism, and George Vernadsky's Historical Scholarship. P. 15, 21. - Гальперин как-то неубедительно пишет о том, что Пайпс не специалист (Halperin Ch.J. Russia Faces East: Eurasianism Reconsidered. P.75), что не мешало ему ссылаться на авторитет такого «специалиста» в Древней Руси, как Н. Н. Болховитинов (Гальперин Ч. Русь и степь: Георгий Вернадский и евразийство. С. 348). Я уверен, что в этом вопросе Пайпс точно специалист!

79 Дворниченко А.Ю.: 1) Древнерусский политогенез в германской историографии // Былые годы. 2014. № 34 (4). С.487-497; 2) Зеркала и химеры. С. 355-421. 
американскому историку Чарльзу Гальперину за такой стойкий и конструктивный интерес к нашим истории и историографии!

\section{References}

Bolkhovitinov N.N. Russkie uchenye-emigranty (G.V.Vernadskiy, M.M.Karpovich, M. T. Florinskii) $i$ stanovlenie rusistiki v SSHA. Moscow, Rossiiskaia politicheskaia entsiklopediia (ROSSPĖN), 2005, 144 p. (In Russian)

Bondar' A. Yu. Obshchestvenno-politicheskie vzgliady i deiatel'nost' G. V. Vernadskogo. Diss. ... kand. ist. nauk. Moscow, Rossiskii Universitet Druzhby Narodov, 2001, 210 p. (In Russian)

Chukovskii K. Vysokoe iskusstvo. Printsipy khudozhestvennogo perevoda. St. Petersburg, Azbuka, 2015, 416 p. (In Russian)

Dvornichenko A. Y. Evoliutsiia gorodskoi obshchiny i genezis feodalizma na Rusi. Voprosy istorii, 1988, no. 1, pp. 58-73. (In Russian)

Dvornichenko A. Yu. Rossiiskaia istoriia s drevneishikh vremen do padeniia samoderzhaviia. Moscow, Ves' Mir, 2010, 944 p. (In Russian)

Dvornichenko A.Yu. Zerkala i Khimery. O vozniknovenii drevnerusskogo gosudarstva. St. Petersburg, EVRAZIIA, Moscow, Klio, 2014, 560 p. (In Russian)

Dvornichenko A. Yu. Old Russian politogenesis in German historiography. Bylye Gody, 2014, no. 34 (4), pp. 487-497. (In Russian)

Dvornichenko A. Yu. G. V. Vernadsky ob Ukraine i ukrainskom voprose (k publikatsii stat'i G. V. Vernadskogo "Kniaz' Trubetskoi i ukrainskii vopros"). Vestnik of Saint Petersburg University. Seriia 2. History. 2015, vol. 2, pp. 57-79. (In Russian)

Dvornichenko A. Yu. George Vernadsky about Soviet Russia (for publication of the article by G. V. Vernadsky "Paradoxes of Bolshevism"), Modern History of Russia, 2015, no.2(13), pp. 101-132. (In Russian)

Dvornichenko A. Yu. Tribal structures and Slavic politogenesis (Some remarks). Studia Slavica et Balcanica Petropolitana, 2015, no. 2(18), pp. 152-160. (In Russian)

Dvornichenko A. Yu. The place of the Kievan Rus in history. Vestnik of Saint Petersburg University. History, 2016, vol. 4, pp. 5-16.

Dvornichenko A. Yu., Belousov M.S. Decembrist movement in the creativity of George Vernadsky. Vestnik of Saint Petersburg University. History, 2017, vol. 62, iss. 2, pp. 358-374. (In Russian)

Dvornichenko A. Yu. Russkii istorik Georgii Vernadskii. Puteshestviia v mire liudei, idei i sobytii. St. Petersburg, Evraziia, 2017, 724 p. (In Russian)

Dvornichenko A. Yu. Proshchanie s revoliutsiei. Moscow, Ves' Mir, 2018, 272 p. (In Russian)

Froianov I. Ya. Lektsii po russkoi istorii. Kievskaia Rus'. St. Petersburg, Russkaia kolletsiia, 2015, 1044 p. (In Russian)

Froianov I. Ya. O zarozhdenii evraziistva v izuchenii russkogo srednevekov'ia. Sbornikv chest' V. K. Ziborova. Iss. 5: Opyty po istochnikovedeniiu. St. Petersburg, Skriptorum, 2017, pp. 300-342. (In Russian)

Gyidel E. Ob "ukrainofil'stve" Georgiia Vernadskogo, ili variatsiia na temu natsional'nykh i gosudarstvennykh loial'nostei. Ab Imperio, 2006, no. 4, pp. 329-346. (In Russian)

Halperin Ch. J. Russia and the Steppe: George Vernadsky and Eurasianism. Forschungen zur osteuropäischen Geschichte. Berlin, 1985, Otto Harrassowitz. Wiesbaden, Bd.36, pp. 55-194.

Halperin Ch. J. Russia Faces East: Eurasianism Reconsidered. Russian History, 2016, no. 43, pp. 69-80.

Halperin Ch. J. Recent research on George Vernadsky. Zolotoordynskaia tsivilizatsiia, 2017, no. 10, pp.455470.

Halperin Ch.J. (Re)Discovering George Vernadsky. Journal of modern Russian history and historiography, 2018, no. 11, pp. 134-157.

Halperin Ch. J. Rus' i step': Georgii Vernadskii i evraziistvo. Ed. by Yu. V. Seleznev. Voronezh, Izdatel'skopoligraficheskii tsentr "Nauchnaia kniga", 2018, 373 p. (In Russian)

Keep J. Review of Forschungen zur osteuropäischen Geschichte. Bd.36. Canadian Slavonic Papers, 1985, no. 27, pp. 443-444.

Kitaev V.A. Odisseia Georgiia Vernadskogo. Istoricheskaia ekspertiza. Zhurnal retsenzii, 2018, no. 3 (16), pp. 253-261. Rets.: Dvornichenko A. Yu. Russkii istorik Georgii Vernadsky. Puteshestviia v mire liudei, idei i sobytii. St. Petersburg, Evraziia publ., 2017, 724 p. (In Russian)

Kozliakov V.N. Obzor kollektsii dokumentov G.V.Vernadskogo v Bakhmetevskom arkhive Biblioteki Kolumbiiskogo universiteta v N'iu-Iorke. Vernadskii G. V. Russkaia istoriografiia. Sost. i nauchn. konsul'tant k.i.n. V.N. Kozliakov. Moscow, Agraf publ., 1998, pp. 395-444. (In Russian) 
Liuks L. Kratkie zametki k diskussii o «neoevraziistve» Aleksandra Dugina i o "klassicheskom" evraziistve na saite gerfter.ru. Zhurnal retsenzii, 2018, no. 3 (16), pp. 204-208. (In Russian)

Sonicheva N.E. Stanovlenie i razvitie istoricheskoi kontseptsii G. V. Vernadskogo. Kand. diss. Moscow, Gosudarstvennaia Akademiia sfery byta i uslug publ., 1994, 250 p. (In Russian)

Shakhanov A. N. Russkaia istoricheskaia nauka vtoroi poloviny XIX - nachala XX veka: Moskovskii $i$ Peterburgskii universitety. Moscow, Nauka, 2003, 419 p. (In Russian)

Torbakov I. Rethinking the Nation: Imperial Collapse, Eurasianism, and George Vernadsky's Historical Scholarship. Kennan Institute Occasional Paper, 2008, no. 302, pp. 1-21.

Torbakov I. Between Russia, Ukraine and Eurasia: George Vernadsky's Search for Identity. Empire De/ Centered: New Spatial Histories of Russia and the Soviet Union. Eds S. Turoma, M. Waldstein. Surrey, Ashgate Publishing Limited, 2013, pp.61-83.

Torbakov I. The Intellectual Odyssey of Georgii Vernadsky. Between Europe \& Asia: The Origins, Theories and Legacies of Russian Eurasianism. Eds M. Bassin, S. Glebov, M. Laruelle. Pittsburgh, University of Pittsburgh Press, 2015, pp. 113-136.

Статья поступила в редакцию 14 декабря 2018 г.

Рекомендована в печать 12 марта 2019 г.

Received: December 14, 2018

Accepted: March 12, 2019 